DOE/OR/01-1175/V1

\title{
Final Report on the Background Soil Characterization Project at the Oak Ridge Reservation, Oak Ridge, Tennessee
}

\section{Volume 1-Results of Field Sampling Program}

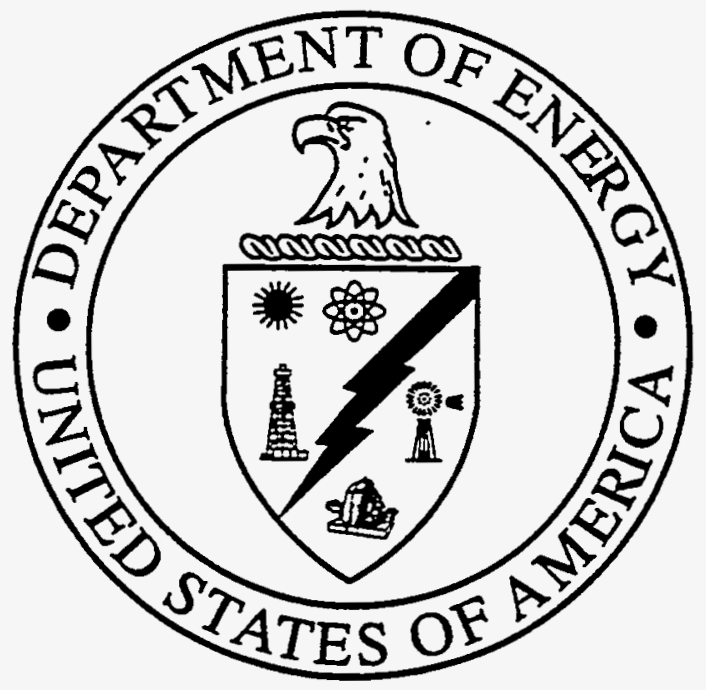




\section{DISCLAIMER}

This report was prepared as an account of work sponsored by an agency of the United States Government. Neither the United States Government nor any agency thereof, nor any of their employees, makes any warranty, express or implied, or assumes any legal liability or responsibility for the accuracy, completeness, or usefulness of any information, apparatus, product, or process disclosed, or represents that its use would not infringe privately owned rights. Reference herein to any specific commercial product, process, or service by trade name, trademark, manufacturer, or otherwise, does not necessarily constitute or imply its endorsement, recommendation, or favoring by the United States Government or any agency thereof. The views and opinions of authors expressed herein do not necessarily state or reflect those of the United States Government or any agency thereof.

This report has been reproduced directly from the best available copy.

Available to DOE and DOE contractors from the Office of Scientific and Technical Information, P.O. Box 62, Oak Ridge, TN 37831; prices available from 615-576-8401.

Available to the public from the National Technical Information Service, U.S. Department of Commerce, $\mathbf{5 2 8 5}$ Port Royal Rd., Springfield, VA 22161. 


\section{DISCLAIMER}

Portions of this document may be illegible in electronic image products. Images are produced from the best available original document. 
DOE/OR/01-1175/V1

ES/ER/TM-84/V1

\title{
Final Report on the Background Soil Characterization Project at the Oak Ridge Reservation, Oak Ridge, Tennessee \\ Volume 1-Results of Field Sampling Program
}

Environmental Restoration Division

P.O. Box 2003

Oak Ridge, Tennessee 37831-7298

Date Issued-October 1993

\author{
Prepared by \\ Environmental Sciences Division \\ Oak Ridge National Laboratory \\ ESD Publication 4144 \\ Prepared for \\ U.S. Department of Energy
}

Office of Environmental Restoration and Waste Management

under budget and reporting code EW 20

MARTIN MARIETTA ENERGY SYSTEMS, INC. managing the

Oak Ridge K-25 Site

Oak Ridge Y-12 Plant

Oak Ridge National Laboratory

under contract DE-AC05-84OR21400

for the

U.S. DEPARTMENT OF ENERGY 
Authors

D. R. Watkins

J. T. Ammons

J. L. Branson

B. B. Burgoa

P. L. Goddard

T. L. Hatmaker

L. A. Hook

B. L. Jackson

C. W. Kimbrough

S. Y. Lee

D. A. Lietzke

C. W. McGinn

B. D. Nourse

R. L. Schmoyer

S. E. Stinnette

J. Switek

\section{Author Affiliations}

D. R. Watkins (Project Manager), L. A. Hook, S. Y. Lee, and J. Switek are affiliated with the Environmental Sciences Division; B. L. Jackson is a member of the Computing Applications Division; P. L. Goddard is with the K-25 Site Program Office; T. L. Hatmaker is with the Measurement Applications and Development Group; C. W. McGinn, B. D. Nourse, and S. E. Stinnette are members of the Health Sciences Research Division; and R. L. Schmoyer is with the Engineering Physics and Mathematics Division, all part of the Oak Ridge National Laboratory. C. W. Kimbrough is manager of the Analytical Projects Office. All of these organizations are managed by Martin Marietta Energy Systems, Inc. J. T. Ammons, J. L. Branson, and B. B. Burgoa are with the Department of Plant and Soil Science at The University of Tennessee in Knoxville. D. A. Lietzke is a consultant. 
Final Report on the Background Soil Characterization Project at the Oak Ridge Reservation, Oak Ridge, Tennessee

(DOE/OR/01-1175)

APPROVALS

S. P.Riddle, Chief

Decontamination and Decommissioning Branch

DOE Oak Ridge Operations Office

D. M. Carden

Havid m. Cacelen

DOE Program Manager

DOE Oak Ridge Operations Office

David J. Bell

$10 / 25 / 93$

D. T. Bell

Date

ER Program Manager

Martin Marietta Energy Systems, Inc.

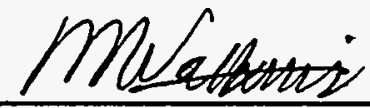

D. R. Watkins

BSCP Manager

Martin Marietta Energy Systems, Inc. 
- 


\title{
CONTENTS
}

\author{
VOLUME 1
}

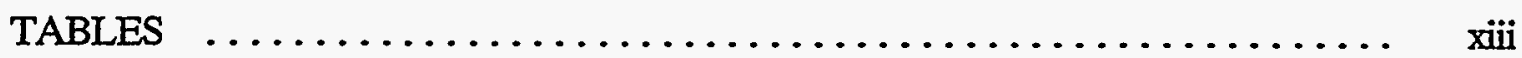

FIGURES $\ldots \ldots \ldots \ldots \ldots \ldots \ldots \ldots \ldots \ldots \ldots \ldots \ldots \ldots \ldots \ldots \ldots \ldots \ldots \ldots \ldots \ldots$

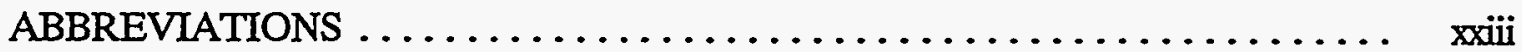

ACKNOWLEDGMENTS $\ldots \ldots \ldots \ldots \ldots \ldots \ldots \ldots \ldots \ldots \ldots \ldots \ldots \ldots \ldots \ldots \ldots \ldots \ldots$

EXECUTIVE SUMMARY $\ldots \ldots \ldots \ldots \ldots \ldots \ldots \ldots \ldots \ldots \ldots \ldots \ldots \ldots \ldots \ldots$

1. INTRODUCTION $\ldots \ldots \ldots \ldots \ldots \ldots \ldots \ldots \ldots \ldots \ldots \ldots \ldots \ldots \ldots \ldots \ldots \ldots, 1-1$

1.1 PROJECT OBJECTIVES AND APPROACH $\ldots \ldots \ldots \ldots \ldots \ldots \ldots, 1-1$

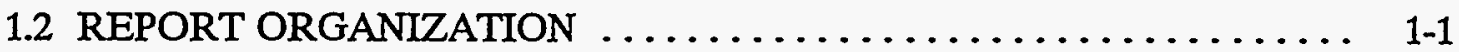

1.3 SAMPLE REFERENCE DESIGNATIONS $\ldots \ldots \ldots \ldots \ldots \ldots \ldots \ldots \ldots, 1-2$

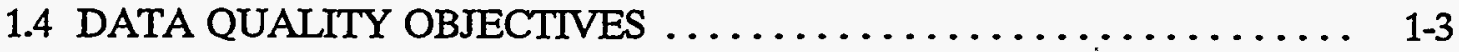

2. PROJECT BACKGROUND AND DATA USER INFORMATION $\ldots \ldots \ldots, 2-1$

2.1 SUMMARY OF PROJECT ORGANIZATION $\ldots \ldots \ldots \ldots \ldots \ldots \ldots, 2-1$

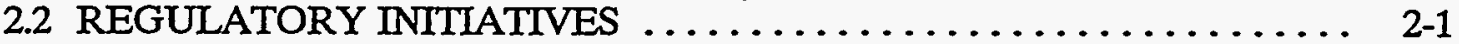

2.3 DATA MANAGEMENT AND VERIFICATION .............. 2-5

2.3.1 Responsibilities for Data Management and Verification $\ldots \ldots \ldots \ldots$ 2.5

2.3.2 Data Storage and Records Management ............... 2-5

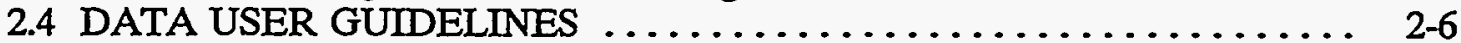

2.4.1 How To Use Data-A Field Perspective $\ldots \ldots \ldots \ldots \ldots \ldots \ldots, 2-6$

2.4.2 How To Use Data-An Analytical Perspective ............. 2-18

2.4.3 Statistical Guidelines for Users of Background Soil Data ........ 2-20

2.4.4 Data User Guidelines for Risk Assessments .............. 2-21

2.4.5 Data Access Considerations ........................ 2-23

2.5 EXAMPLE APPLICATIONS OF DATA USER GUIDELINES $\ldots \ldots \ldots 2-24$

3. FIELD INVESTIGATION, GAMMA SCREENING ANALYSES, AND

QUALITATIVE SITE EVALUATION $\ldots \ldots \ldots \ldots \ldots \ldots \ldots \ldots \ldots, 3-1$

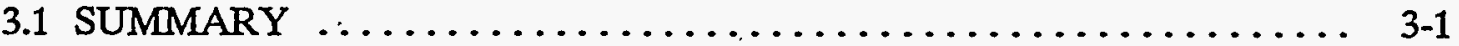

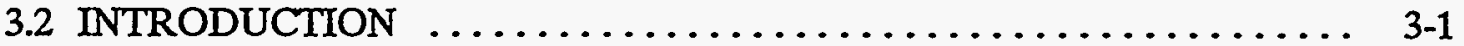

3.3 SAMPLING SITE SELECTION $\ldots \ldots \ldots \ldots \ldots \ldots \ldots \ldots \ldots \ldots \ldots, 3-2$

3.3.1 Site Evaluation $\ldots \ldots \ldots \ldots \ldots \ldots \ldots \ldots \ldots \ldots \ldots \ldots \ldots \ldots \ldots \ldots, 3-2$

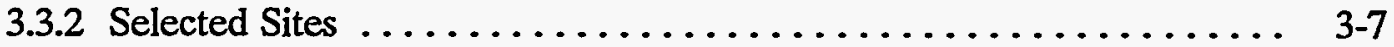

3.3.3 Composited Sample Sites $\ldots \ldots \ldots \ldots \ldots \ldots \ldots \ldots \ldots \ldots \ldots$ 3-7

3.3.4 Selection and Initial Evaluation of Off-Site Locations $\ldots \ldots \ldots \ldots \ldots$ 3-8

3.4 SITE AND SOIL DESCRIPTIONS $\ldots \ldots \ldots \ldots \ldots \ldots \ldots \ldots \ldots \ldots, 3-8$

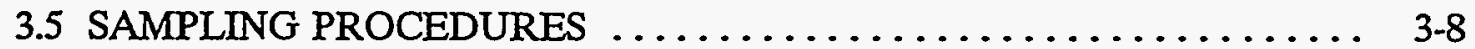

3.6 SOIL SAMPLING AND SAMPLE PREPARATION $\ldots \ldots \ldots \ldots \ldots \ldots .3-9$

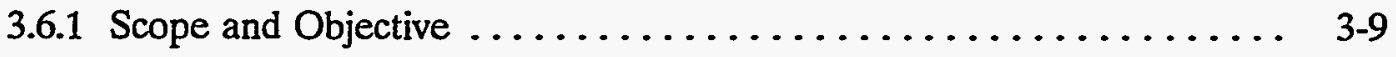


3.6.2 Materials ............................. 3-9

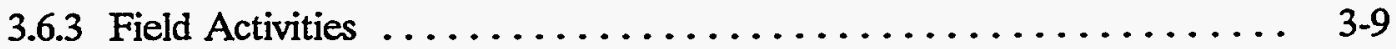

3.7 FIELD QUALITY CONTROL OBJECTIVES AND METHODS $\ldots \ldots \ldots$ 3-16

3.8 QUALITATIVE RESULTS OF GAMMA SPECTROSCOPY

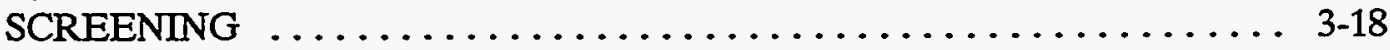

3.9 QUALITATIVE ANALYSIS OF OAK RIDGE

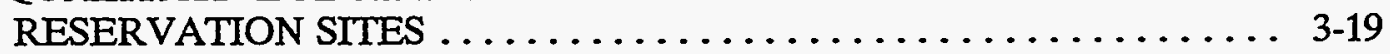

3.10 QUALITATIVE ANALYSIS OF ROANE COUNTY SITES ......... 3-35

3.11 QUALITATIVE ANALYSIS OF ANDERSON COUNTY SITES ..... $33-39$

4. ANALYTICAL LABORATORY ANALYSES

AND DATA VALIDATION $\ldots \ldots \ldots \ldots \ldots \ldots \ldots \ldots \ldots \ldots \ldots ., 4-1$

4.1 SUMMARY OF DATA VALIDATION $\ldots \ldots \ldots \ldots \ldots \ldots \ldots \ldots \ldots$ 4-1

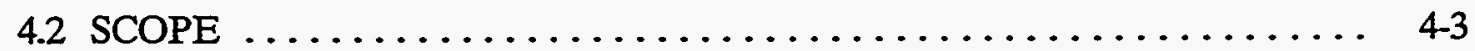

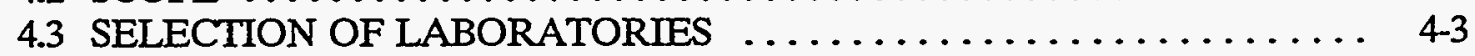

4.4 QUALITY ASSURANCE/QUALITY CONTROL AND

DATA VALIDATION $\ldots \ldots \ldots \ldots \ldots \ldots \ldots \ldots \ldots \ldots \ldots \ldots \ldots \ldots \ldots, 4$

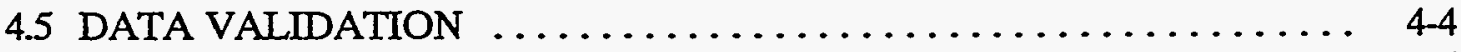

4.5.1 Organic Data Validation Results .................. 4-5

4.5.2 Inorganic Data Validation Results ................... 4-17

4.5.3 Radiochemical Data Validation Results . . . . . . . . . . . . 4-26

4.5.4 ICP/MS Data Validation Results .................. 4.35

4.5.5 Neutron Activation Analysis (NAA) Data Validation Results ....... 4-37

4.6 SCREENING ANALYSES FOR VOLATILE ORGANIC

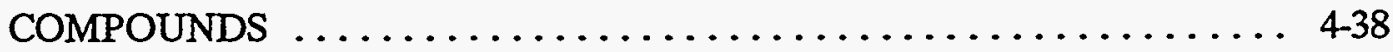

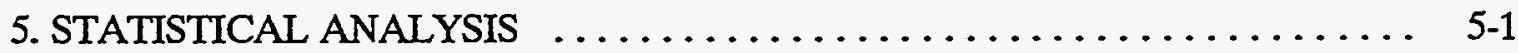

5.1 SUMMARY $\ldots \ldots \ldots \ldots \ldots \ldots \ldots \ldots \ldots \ldots \ldots \ldots \ldots \ldots \ldots \ldots \ldots \ldots \ldots, 1$

5.2 INTRODUCTION $\ldots \ldots \ldots \ldots \ldots \ldots \ldots \ldots \ldots \ldots \ldots \ldots \ldots \ldots \ldots, 5,1$

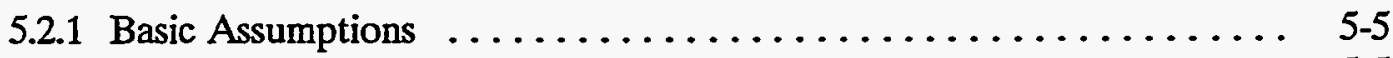

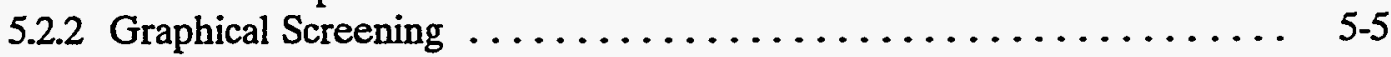

5.2.3 Comparison of Formation-Locations and Horizons $\ldots \ldots \ldots \ldots \ldots .5-12$

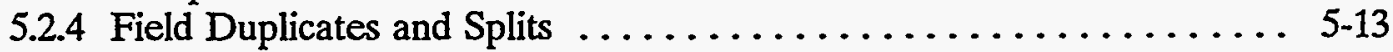

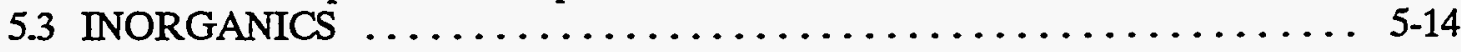

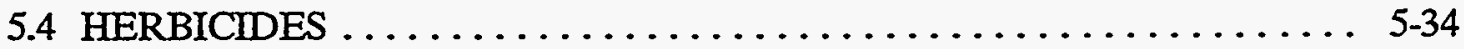

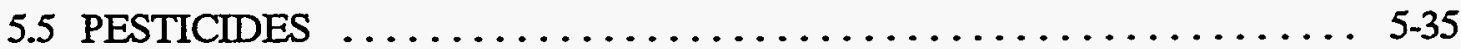

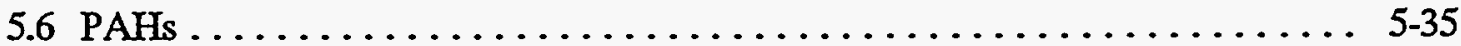

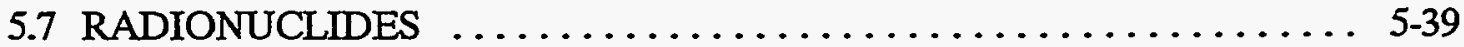

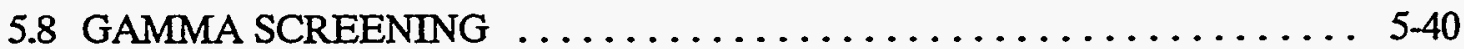

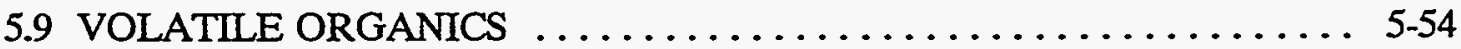

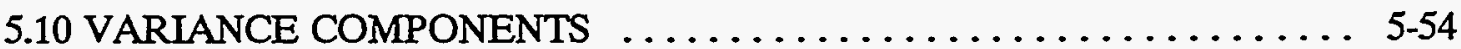

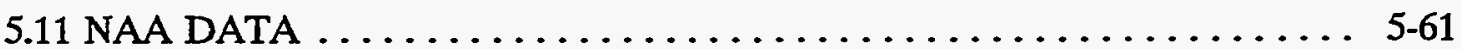

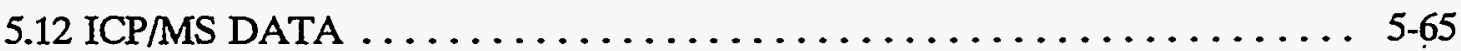

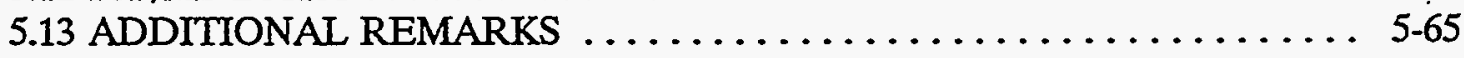

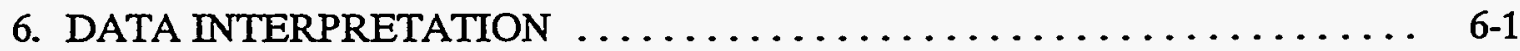

6.1 SUMMARY $\ldots \ldots \ldots \ldots \ldots \ldots \ldots \ldots \ldots \ldots \ldots \ldots \ldots \ldots \ldots \ldots \ldots \ldots \ldots \ldots, 6,1$ 
6.2 BASIC IDEAS AND CONCEPTS OF INTERPRETING

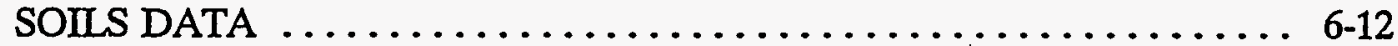

$\begin{aligned} \text { 6.2.1 Soil Extraction Factors That Can Affect } & \ldots\end{aligned}$

6.2.2 Landscape Factors That May Affect the Chemical

Content of Soils . . . . . . 6.14

6.2.3 Factors That Can Affect the Chemical

Contents of A, B, And C Soil Horizons ................ 6-14

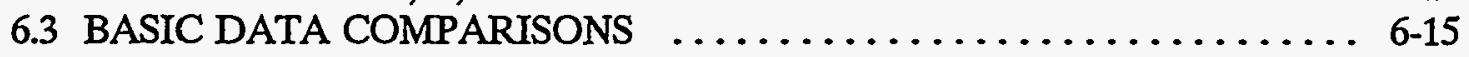

6.3.1 Site and Soil Factors That Must Be Considered in the Initial

Comparison of Results .................... 6-15

6.3.2 Comparisons Between Methods of Extraction and Analysis ....... 6-16

6.4 VALID DATA COMPARISONS $\ldots \ldots \ldots \ldots \ldots \ldots \ldots \ldots \ldots \ldots, 6-17$

6.4.1 Volatile Organic Compounds .................. $6-17$

6.4.2 Pesticides, Herbicides, and Polychlorinated Biphenyls ........ 6-17

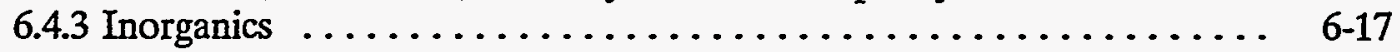

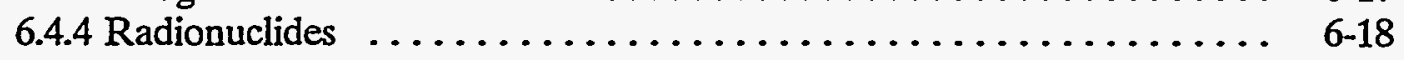

6.5 INTERPRETATION OF DATA BY INDIVIDUAL ELEMENT

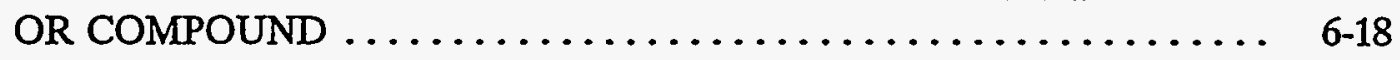

6.5 .1 Organic Compounds ...................... 6-19

6.5.2 Inorganic Compounds and Metals $\ldots \ldots \ldots \ldots \ldots \ldots \ldots \ldots, 6-20$

6.5.3 Summary of Inorganics $\ldots \ldots \ldots \ldots \ldots \ldots \ldots \ldots \ldots \ldots, 6-30$

6.5.4 Radionuclides ........................... 6-31

6.6 TRACE ELEMENTS ANALYZED BY NAA $\ldots \ldots \ldots \ldots \ldots \ldots \ldots 6-37$

7. BACKGROUND RISK EVALUATION $\ldots \ldots \ldots \ldots \ldots \ldots \ldots \ldots \ldots, 7-1$

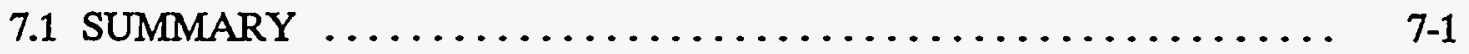

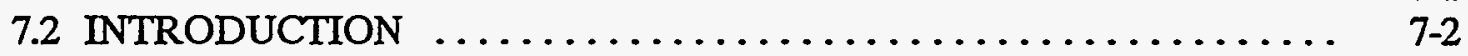

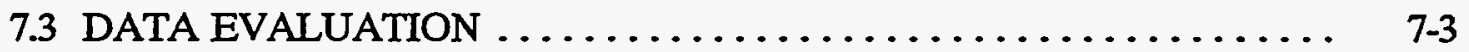

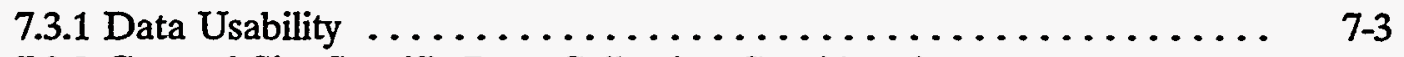

7.3.2 General Site-Specific Data Collection Considerations .......... 7-3

7.3.3 General Site-Specific Data Evaluation Considerations ......... 7-4

7.3.4 Identification of Constituents Included

in the Background Risk Evaluation $\ldots \ldots \ldots \ldots \ldots \ldots \ldots \ldots, 7-4$

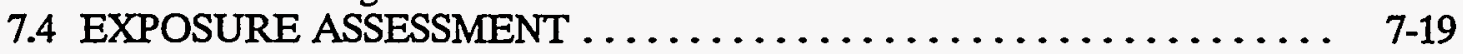

7.4.1 Characterization of Exposure Setting $\ldots \ldots \ldots \ldots \ldots \ldots \ldots \ldots$ 7-19

7.4.2 Identification of Exposure Pathways ................. 7-19

7.4.3 Quantification of Exposure $\ldots \ldots \ldots \ldots \ldots \ldots \ldots \ldots \ldots \ldots \ldots \ldots \ldots \ldots, 7-20$

7.5 TOXICITY ASSESSMENT $\ldots \ldots \ldots \ldots \ldots \ldots \ldots \ldots \ldots \ldots \ldots \ldots \ldots \ldots \ldots \ldots \ldots, 7-21$

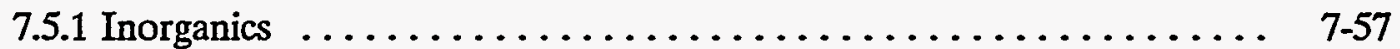

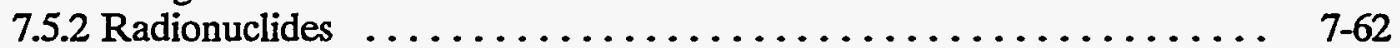

7.5.3 Polynuclear Aromatic Hydrocarbons $\ldots \ldots \ldots \ldots \ldots \ldots \ldots \ldots \ldots \ldots \ldots \ldots$

7.6 RISK CHARACTERIZATION $\ldots \ldots \ldots \ldots \ldots \ldots \ldots \ldots \ldots \ldots \ldots \ldots \ldots \ldots$

7.6.1 EPA Guidance-Carcinogens ................... 7-68

7.6.2 EPA Guidance-Noncarcinogens ................. 7-68

7.6.3 Background Risk and Hazard Index Comparisons

Between the ORR and Anderson and Roane Counties ........ 7-74

7.6.4 Background Risk Characterization for the ORR ............ 7-108 
7.7 UNCERTAINTIES AND ASSUMPTIONS $\ldots \ldots \ldots \ldots \ldots \ldots \ldots \ldots, 7-128$

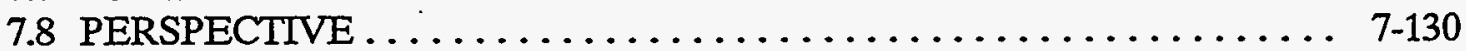

8. ASSESSMENT OF OVERALL DATA QUALITY OBJECTIVES $\ldots \ldots \ldots$ 8-1

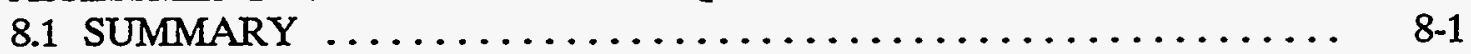

8.2 INTRODUCTION $\ldots \ldots \ldots \ldots \ldots \ldots \ldots \ldots \ldots \ldots \ldots \ldots \ldots, 8-1$

8.3 DATA QUALITY OBJECTIVES FOR FIELD
MEASUREMENT DATA $\ldots \ldots \ldots \ldots \ldots \ldots \ldots \ldots \ldots \ldots \ldots \ldots, 8-2$

8.4 DATA QUALITY OBJECTIVES FOR

LABORATORY MEASUREMENT DATA $\ldots \ldots \ldots \ldots \ldots \ldots \ldots, \quad 8-2$

8.5 ASSESSMENT OF COMPLIANCE

WTTH DATA QUALITY OBJECTIVES . . . . $\ldots \ldots \ldots \ldots \ldots \ldots . \quad 8-3$

8.5.1 Audits and Surveillances .................... 8-3

8.5.2 Data Quality Indicators for Field Measurement Data ........ 8-4

8.5.3 Data Quality Indicators for Analytical Laboratory

Measurement and Soil Preparation Laboratory Data ........ 8. 8-4

8.5.4 Training of Field and Soil Preparation Laboratory Personnel .... 8. 8-5

8.5.5 Field Data and Records Management $\ldots \ldots \ldots \ldots \ldots \ldots \ldots . \quad 8-6$

8.5 .6 Field Quality Program $\ldots \ldots \ldots \ldots \ldots \ldots \ldots \ldots \ldots \ldots \ldots \ldots \ldots \ldots$

8.5.7 Field Data Validation $\ldots \ldots \ldots \ldots \ldots \ldots \ldots \ldots \ldots \ldots . \quad 8.9 \ldots \ldots$

8.5.8 Assessment of Field Quality Control Methods and Procedures .... 8 8

8.5.9 Analytical Data Quality Assessment ............... 8-14

8.6 LESSONS LEARNED AND RECOMMENDATIONS . . . . . . . . $8-17$

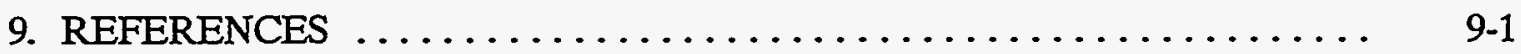

\section{VOLUME 2}

PREFACE TO VOLUME $2 \ldots \ldots \ldots \ldots \ldots \ldots \ldots \ldots \ldots \ldots \ldots \ldots \ldots \ldots \ldots$ vii

Appendix A. SITE DESCRIPTIONS, SOIL PROFILE DESCRIPTIONS, AND GENERAL ANALYSIS OF SITES $\ldots \ldots \ldots \ldots \ldots \ldots$ A-1

A.1 OAK RIDGE RESERVATION SITE DESCRIPTIONS $\ldots \ldots \ldots \ldots \ldots$ A-3

A.2 ROANE COUNTY SITE DESCRIPTIONS $\ldots \ldots \ldots \ldots \ldots \ldots \ldots$ A-17

A.3 ANDERSON COUNTY SITE DESCRIPTIONS .............. A-21

A.4 OAK RIDGE RESERVATION SOIL PROFILES $\ldots \ldots \ldots \ldots \ldots \ldots$ A-25

A.5 ROANE COUNTY SOIL PROFILES . . . . . . . . . . . . . . A

A.6 ANDERSON COUNTY SOIL PROFILES ................ A-121

A.7 SITE LOCATIONS $\ldots \ldots \ldots \ldots \ldots \ldots \ldots \ldots \ldots \ldots \ldots \ldots$ A A 145

A.7.1 Oak Ridge Reservation Site Locations $\ldots \ldots \ldots \ldots \ldots \ldots \ldots$ A-145

A.7.2 Latitudes and Longitudes for Roane and Anderson Counties ........................ A-146

Appendix B. SCREENING ANALYSIS DATA $\ldots \ldots \ldots \ldots \ldots \ldots \ldots \ldots$ B-1

Appendix C. ORGANIC ANALYSIS DATA $\ldots \ldots \ldots \ldots \ldots \ldots \ldots \ldots \ldots \ldots \ldots \ldots$ 
Appendix D. INORGANIC ANALYSIS DATA $\ldots \ldots \ldots \ldots \ldots \ldots \ldots \ldots$ D-1

Appendix E. RADIONUCLIDE ANALYSIS DATA $\ldots . . \ldots \ldots \ldots . . . . .6$ E-1

Appendix F. RELATION OF SAMPLE NUMBERS TO

LABORATORY SAMPLE DELIVERY GROUPS (SDGs) $\ldots \ldots \ldots$ F-1

Appendix G. SUMMARY OF STATISTICALLY TREATED DATA

AND THE SIGNIFICANCE LEVEL OF DIFFERENCES

IN THE DATA $\ldots \ldots \ldots \ldots \ldots \ldots \ldots \ldots \ldots \ldots \ldots \ldots$ G-1

Appendix H. NEUTRON ACTIVATION ANALYSIS (NAA) DATA . . . . . . . H-1

Appendix I. ICP/MS ANALYSIS DATA $\ldots \ldots \ldots \ldots \ldots \ldots \ldots \ldots \ldots \ldots \ldots \ldots \ldots \ldots$

Appendix J. OCCURRENCES OF REJECTED DATA $\ldots \ldots \ldots \ldots \ldots \ldots . \mathrm{J}-1$

VOLUME 3

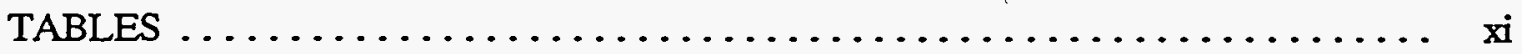

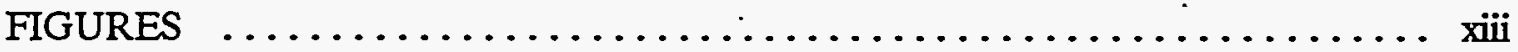

EXECUTTVE SUMMARY $\ldots \ldots \ldots \ldots \ldots \ldots \ldots \ldots \ldots \ldots \ldots \ldots \ldots \ldots \ldots \ldots \ldots$

1. INTRODUCTION $\ldots \ldots \ldots \ldots \ldots \ldots \ldots \ldots \ldots \ldots \ldots \ldots \ldots \ldots \ldots \ldots \ldots \ldots$

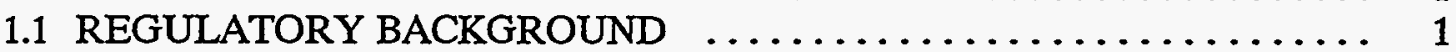

1.2 SCOPE OF THE BACKGROUND SOIL CHARACTERIZATION

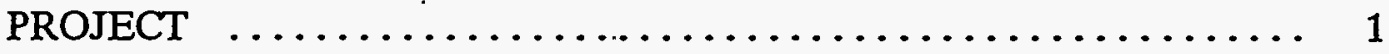

2. OBJECTIVES AND PROJECT ORGANIZATION $\ldots \ldots \ldots \ldots \ldots \ldots \ldots, 3$

2.1 OBJECTIVES AND APPROACH $\ldots \ldots \ldots \ldots \ldots \ldots \ldots \ldots \ldots \ldots \ldots \ldots \ldots$

2.2 ORGANIZATION OF THE BACKGROUND SOIL

CHARACTERIZATION PROJECT PLAN $\ldots \ldots \ldots \ldots \ldots \ldots \ldots \ldots, 3$

3. HISTORY AND CURRENT CONDITIONS $\ldots \ldots \ldots \ldots \ldots \ldots \ldots \ldots \ldots$

3.1 HISTORY OF THE OAK RIDGE FACILITIES $\ldots \ldots \ldots \ldots \ldots \ldots \ldots, 5$

3.2 GENERAL DESCRIPTION OF THE PLANT FACULITIES $\ldots \ldots \ldots \ldots \ldots, 5$

3.2.1 Oak Ridge National Laboratory $\ldots \ldots \ldots \ldots \ldots \ldots \ldots \ldots \ldots \ldots$

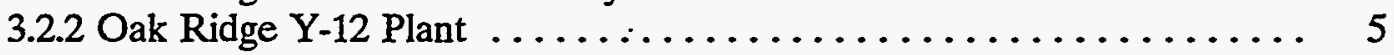

3.2.3 Oak Ridge K-25 Site $\ldots \ldots \ldots \ldots \ldots \ldots \ldots \ldots \ldots \ldots \ldots \ldots$

3.3 CONTAMINANT RELEASES BEYOND THE OAK

RIDGE RESERVATION $\ldots \ldots \ldots \ldots \ldots \ldots \ldots \ldots \ldots \ldots \ldots \ldots$

4. ENVIRONMENTAL SETTING $\ldots \ldots \ldots \ldots \ldots \ldots \ldots \ldots \ldots \ldots \ldots \ldots \ldots \ldots \ldots \ldots$

4.1 GEOGRAPHY OF THE OAK RIDGE RESERVATION $\ldots \ldots \ldots \ldots \ldots \quad 7$

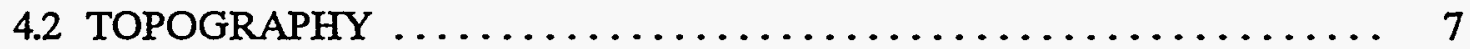


4.3 GEOLOGY $\ldots \ldots \ldots \ldots \ldots \ldots \ldots \ldots \ldots \ldots \ldots \ldots \ldots \ldots \ldots \ldots \ldots, 12$

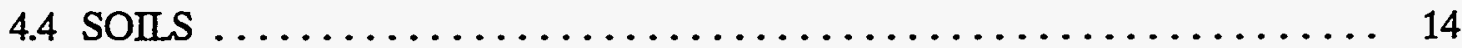

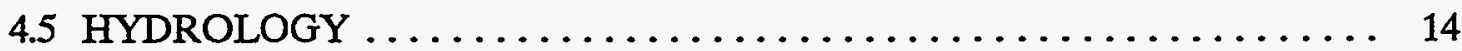

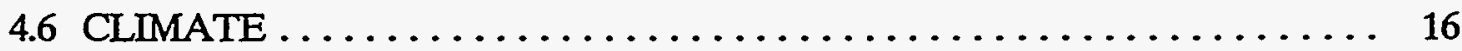

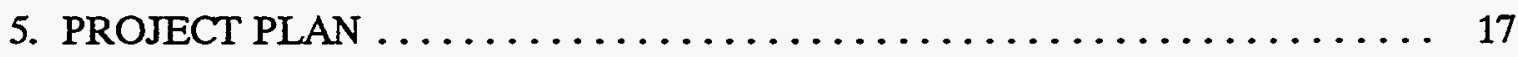

5.1 PROJECT ORGANIZATION AND MANAGEMENT ............. 17

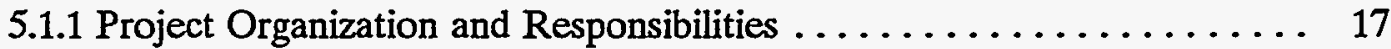

5.1.2 Project Schedule $\ldots \ldots \ldots \ldots \ldots \ldots \ldots \ldots \ldots \ldots \ldots \ldots \ldots \ldots \ldots \ldots \ldots \ldots, 21$

5.2 SITE SELECTION PLAN $\ldots \ldots \ldots \ldots \ldots \ldots \ldots \ldots \ldots \ldots \ldots \ldots \ldots \ldots \ldots \ldots \ldots, 23$

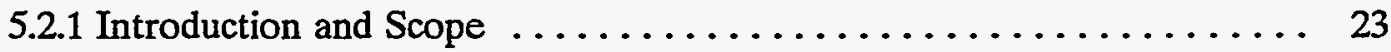

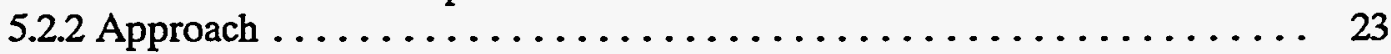

5.3 SOIL SAMPLING AND ANALYSIS PLAN . . . . . . . . . . . . 25

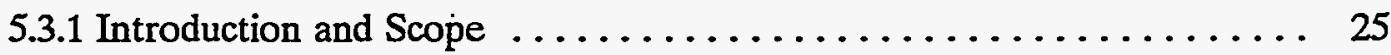

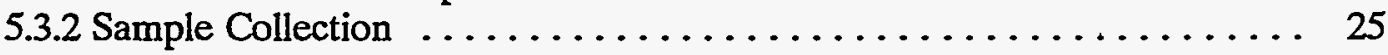

5.3 .3 Sample Analysis ........................... 31

5.4 SAMPLE TRACKING AND RECORDS MANAGEMENT 32

5.4 .1 Logbooks . . . . . . . . . . . . . . . . . . . 30

5.4.2 Sample Custody Documentation ................... 33

5.4.3 Data Management .............................. 33

5.5 STATISTICAL ANALYSIS PLAN $\ldots \ldots \ldots \ldots \ldots \ldots \ldots \ldots \ldots \ldots \ldots \ldots \ldots \ldots \ldots$

5.5 .1 Objectives of Statistical Analysis . . . . . . . . . . . . . . . . 33

5.5 .2 Statistical Methods ........................... 34

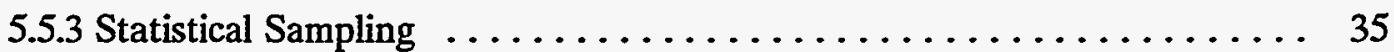

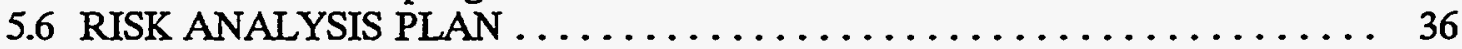

5.6.1 Determining Potential Contaminants of Concern ............ 37

5.6 .2 Calculation of Risks $\ldots \ldots \ldots \ldots \ldots \ldots \ldots \ldots \ldots \ldots \ldots \ldots \ldots \ldots \ldots$

6. QUALITY ASSURANCE PROJECT PLAN .................. 40

6.1 INTRODUCTION (including Approvals Statement) $\ldots \ldots \ldots \ldots \ldots \ldots \ldots 40$

6.2 PURPOSE ...................................... 40

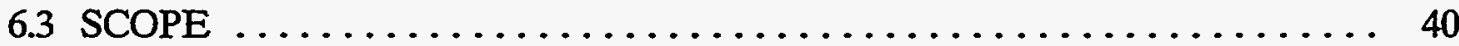

6.4 PROJECT DESCRIPTION AND TRAINING ................. 44

6.5 PROJECT ORGANIZATION AND QA RESPONSIBILITIES $\ldots \ldots \ldots \ldots 44$

6.6 DATA QUALITY OBJECTIVES .................... 47

6.6.1 Quality Assurance Objectives For Field Measurement Data ........ 49

6.6.2 Quality Assurance Objectives for Laboratory Measurement Data . . . . . 57

6.6.3 Data Reduction, Validation and Reporting .............. 63

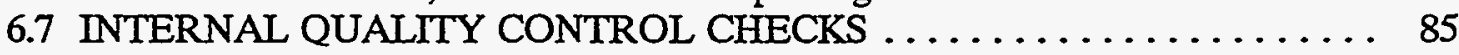

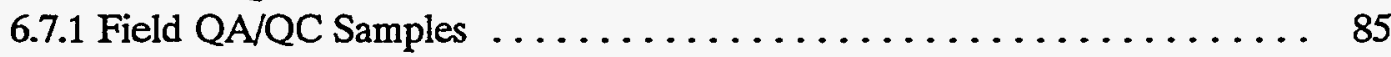

6.7 .2 Laboratory QA/QC Samples ..................... 85

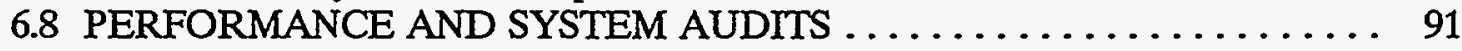

6.8 .1 Laboratory $\ldots \ldots \ldots \ldots \ldots \ldots \ldots \ldots \ldots \ldots \ldots \ldots \ldots \ldots \ldots \ldots \ldots \ldots$

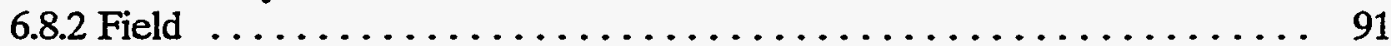

6.9 PREVENTIVE MAINTENANCE $\ldots \ldots \ldots \ldots \ldots \ldots \ldots \ldots \ldots \ldots . \ldots 2$

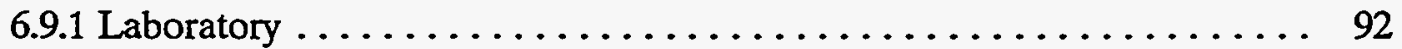

6.9 .2 Field $\ldots \ldots \ldots \ldots \ldots \ldots \ldots \ldots \ldots \ldots \ldots \ldots \ldots \ldots \ldots \ldots \ldots$ 
6.10 PROCEDURES TO ASSESS DATA PRECISION, ACCURACY

AND COMPLETENESS . ......................... 94

\$ 6.11 NONCONFORMANCES AND CORRECTIVE ACTIONS . . $3 . \ldots . . .94$

6.11 .1 Laboratory $\ldots \ldots \ldots \ldots \ldots \ldots \ldots \ldots \ldots \ldots \ldots \ldots \ldots \ldots \ldots \ldots$

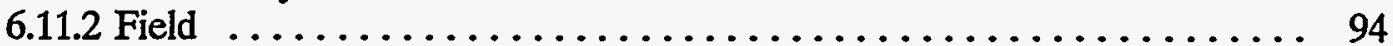

6.12 QUALITY ASSURANCE REPORTS TO MANAGEMENT . . . . . . . 94

6.12.1 Formal Written Reports .......................... 94

6.12 .2 Project Reports $\ldots \ldots \ldots \ldots \ldots \ldots \ldots \ldots \ldots \ldots \ldots \ldots \ldots \ldots$

6.13 RECORDS MANAGEMENT SYSTEM $\ldots \ldots \ldots \ldots \ldots \ldots \ldots \ldots .95$

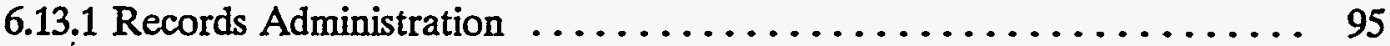

6.13 .2 Records Receipt ......................... 95

6.13.3 Storage, Preservation, and Safekeeping ............... 96

6.13.4 Retrieval and Final Disposition $\ldots \ldots \ldots \ldots \ldots \ldots \ldots \ldots \ldots .96$

6.14 DOCUMENT CONTROL . . . . . . . . . . . . . . . . . . . 96

6.15 PROCUREMENT DOCUMENT CONTROL $\ldots \ldots \ldots \ldots \ldots \ldots \ldots .96$

6.16 PURCHASED ITEMS AND SERVICES CONTROL $\ldots \ldots \ldots \ldots \ldots \ldots 97$

7. DATA MANAGEMENT PLAN $\ldots \ldots \ldots \ldots \ldots \ldots \ldots \ldots \ldots \ldots \ldots \ldots$

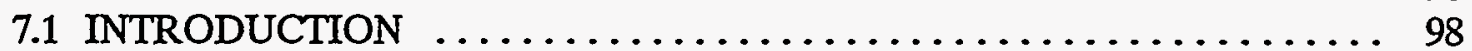

7.2 OBJECTIVES $\ldots \ldots \ldots \ldots \ldots \ldots \ldots \ldots \ldots \ldots \ldots \ldots \ldots \ldots \ldots \ldots, 98$

7.3 DATA MANAGEMENT $\ldots \ldots \ldots \ldots \ldots \ldots \ldots \ldots \ldots \ldots \ldots \ldots \ldots$

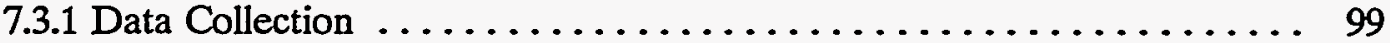

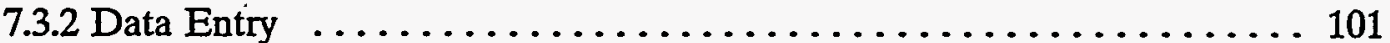

7.3.3 Data Encoding ............................... 101

7.3.4 Data Traceability ............................. 102

7.3.5 Quality Assurance/Quality Control ................... 102

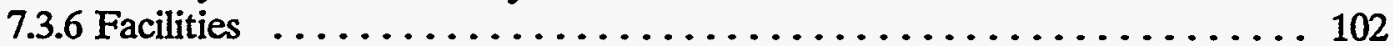

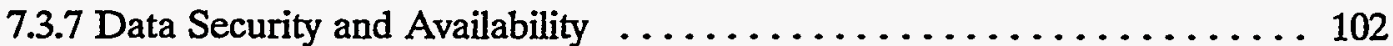

7.4 DOCUMENT CONTROL . . . . . . . . . . . . . . . . . . . . 102

7.5 RECORDS MANAGEMENT SYSTEM $\ldots \ldots \ldots \ldots \ldots \ldots \ldots \ldots \ldots \ldots$

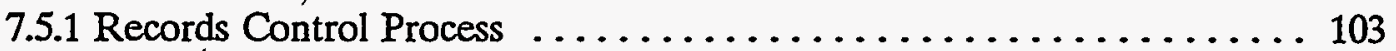

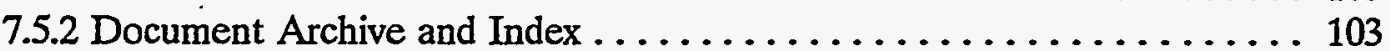

7.5.3 Document Accessibility .......................... 104

7.6 ADMINISTRATIVE RECORD $\ldots \ldots \ldots \ldots \ldots \ldots \ldots \ldots \ldots \ldots \ldots \ldots$

8. HEALTH AND SAFETY PLAN $\ldots \ldots \ldots \ldots \ldots \ldots \ldots \ldots \ldots \ldots \ldots \ldots \ldots \ldots \ldots \ldots$

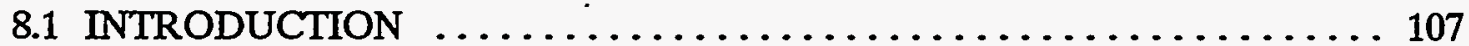

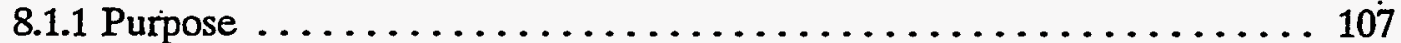

8.1.2 Applicability . . . . . . . . . . . . . . . . . . . . . . . 107

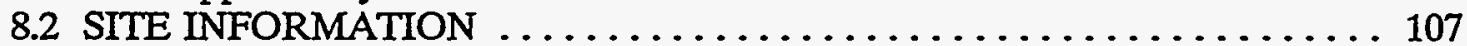

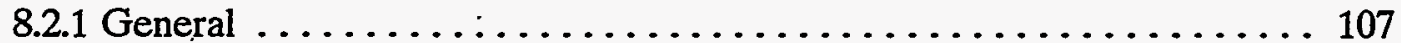

8.2.2 Physical Hazards .............................. 108

8.3 SITE TASK HAZARD ANALYSIS $\ldots \ldots \ldots \ldots \ldots \ldots \ldots \ldots \ldots \ldots \ldots$

8.3.1 Site Requirements ............................ 109

8.3.2 Suspected Contaminants . . . . . . . . . . . . . . . . . . . 110

8.3 .3 Hazard Evaluation.$\ldots \ldots \ldots \ldots \ldots \ldots \ldots \ldots \ldots \ldots \ldots \ldots \ldots \ldots \ldots \ldots \ldots$

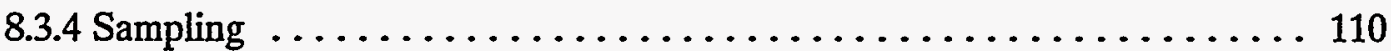

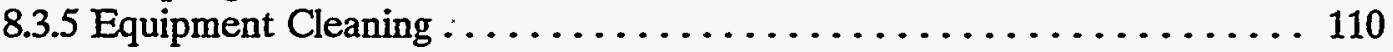


8.4 SPECIAL HAZARDS $\ldots \ldots \ldots \ldots \ldots \ldots \ldots \ldots \ldots \ldots \ldots \ldots \ldots \ldots \ldots \ldots \ldots \ldots$

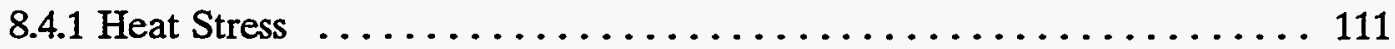

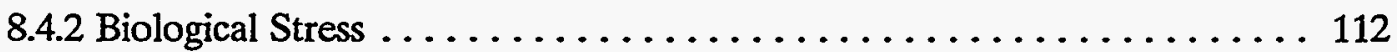

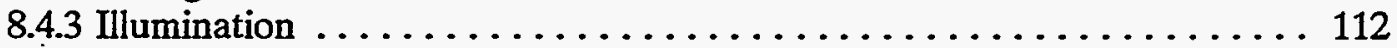

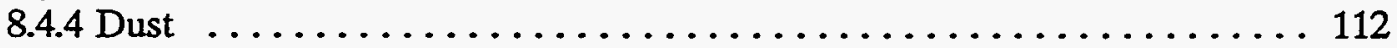

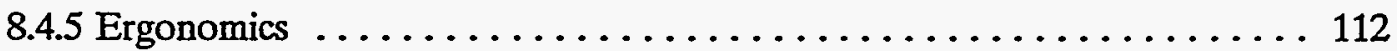

8.4.6 Physical Sampling Location Hazards . . . . . . . . . . . . . . 113

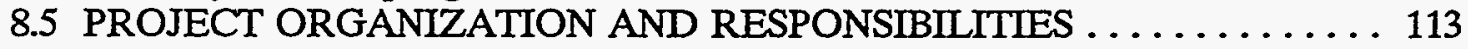

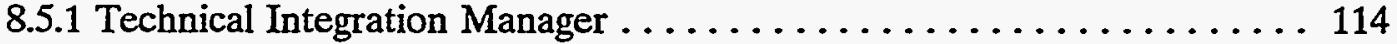

8.5.2 Project Manager ............................... 114

8.5.3 Technical Coordinator ........................... 114

8.5.4 Site Health Safety Officer/Project Personnel $\ldots \ldots \ldots \ldots \ldots \ldots \ldots . \ldots \ldots$

8.5.5 ORNL Industrial Hygiene (HAZWOPER) $\ldots \ldots \ldots \ldots \ldots \ldots \ldots \ldots$

8.5.6 ORNL Health Physics $\ldots \ldots \ldots \ldots \ldots \ldots \ldots \ldots \ldots \ldots \ldots \ldots \ldots \ldots \ldots$

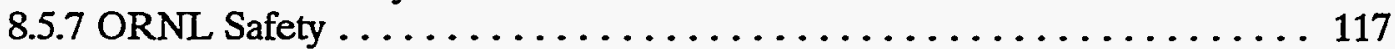

8.6 EMERGENCY PROCEDURES $\ldots \ldots \ldots \ldots \ldots \ldots \ldots \ldots \ldots \ldots \ldots \ldots \ldots \ldots$

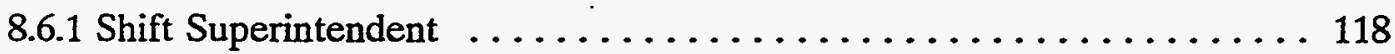

8.6 .2 Reporting an Emergency ................................ 119

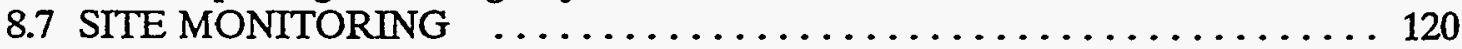

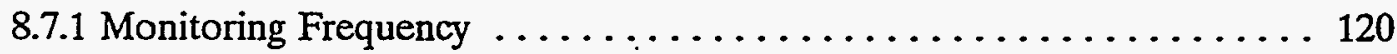

8.7.2 Instrument Calibration/Response Checks $\ldots \ldots \ldots \ldots \ldots \ldots \ldots \ldots \ldots$

8.7.3 Monitoring Equipment Action Limits ................... 120

8.8 SITE CONTROL MEASURES-SAMPLING AREA $\ldots \ldots \ldots \ldots \ldots \ldots$

8.9 HEALTH AND SAFETY TRAINING REQUIREMENTS $\ldots \ldots \ldots \ldots \ldots 122$

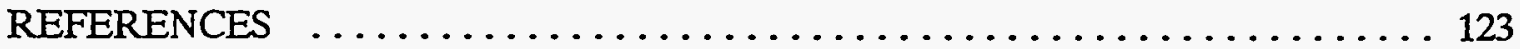

Appendix A. REFERENCE SOIL PROFILE DESCRIPTIONS $\ldots \ldots \ldots \ldots \ldots 127$

Appendix B. SAMPLING AND ANALYSIS PLAN SUPPLEMENT . . . . . . . 141

Appendix C. CHAIN-OF-CUSTODY FORMS FOR SOIL SAMPLES $\ldots \ldots \ldots 149$

Appendix D. STATISTICAL ASPECTS OF DQOS $\ldots \ldots \ldots \ldots \ldots \ldots \ldots \ldots$ 


\section{TABLES}

\section{VOLUME 1}

2.1 Soil horizons and sample designations for Phase $I$ and $I I \ldots \ldots \ldots \ldots \ldots$

4.1 Definition of data validation qualifiers $\ldots \ldots \ldots \ldots \ldots \ldots \ldots \ldots \ldots$

4.2 Summary distribution of pesticide/PCB data validation results . . . . . . . 4-9

4.3 Summary distribution of herbicide data validation results $\ldots \ldots \ldots \ldots \ldots$ 4-12

4.4 Summary distribution of polynuclear aromatic hydrocarbon

data validation results ....................... 4-17

4.5 Summary distribution of inorganic data validation results $\ldots \ldots \ldots \ldots$ 4-25

4.6 Summary distribution of radiochemical data validation results . . . . . . 4-36

4.7 Summary distribution of ICP/MS data validation results $\ldots \ldots \ldots \ldots \ldots$ 4-37

4.8 Summary distribution of neutron activation analysis data

validation results $\ldots \ldots \ldots \ldots \ldots \ldots \ldots \ldots \ldots \ldots \ldots \ldots \ldots . \ldots .49$

$5.1 \quad$ Summary statistics for inorganics $\ldots \ldots \ldots \ldots \ldots \ldots \ldots \ldots \ldots \ldots$

5.2 Additional summary statistics for inorganics with fewer than

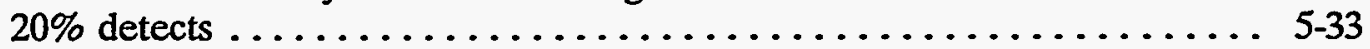

5.3 Herbicides-95\% UCBs for probabilities of detection or of exceeding the MAXDL ............................. 5-35

5.4 Pesticides-95\% UCBs for probabilities of detection or of exceeding maximum detection limit $\ldots \ldots \ldots \ldots \ldots \ldots \ldots \ldots \ldots \ldots . \ldots . . \ldots$

$5.5 \quad$ PAHs $-95 \%$ UCBs for detection probability $\ldots \ldots \ldots \ldots \ldots \ldots \ldots$

$5.6 \quad$ Additional summary statistics for PAHs $\ldots \ldots \ldots \ldots \ldots \ldots \ldots \ldots$

5.7 Summary statistics for radionuclides with fewer than $20 \%$ detects $\ldots \ldots \ldots 5-41$

5.8 Additional summary statistics for detected radionuclides by horizons $\ldots \ldots \ldots \ldots \ldots \ldots \ldots \ldots \ldots \ldots \ldots \ldots \ldots \ldots \ldots \ldots \ldots$

$5.9 \quad$ Overall results of gamma screening for cesium $-137 \ldots \ldots \ldots \ldots \ldots \ldots$

5.10a Standard deviation estimates for inorganics $\ldots \ldots \ldots \ldots \ldots \ldots \ldots$ 
$5.10 \mathrm{~b}$ Standard deviation estimates for PAHs $\ldots \ldots \ldots \ldots \ldots \ldots \ldots \ldots \ldots, 5-58$

$5.10 \mathrm{c}$ Standard deviation estimates for radionuclides $\ldots \ldots \ldots \ldots \ldots \ldots .59$

5.11a Correlation statistics for radionuclides $\ldots \ldots \ldots \ldots \ldots \ldots \ldots \ldots \ldots$. $5-62$

5.11b Correlation statistics for metals $\ldots \ldots \ldots \ldots \ldots \ldots \ldots \ldots \ldots \ldots$ 5 62

5.12a Regression statistics for radionuclides $\ldots \ldots \ldots \ldots \ldots \ldots \ldots \ldots \ldots, 5-65$

$5.12 \mathrm{~b} \quad$ Regression statistics for metals $\ldots \ldots \ldots \ldots \ldots \ldots \ldots \ldots \ldots \ldots .6 .65$

5.13 Correlation statistics for metals $\ldots \ldots \ldots \ldots \ldots \ldots \ldots \ldots \ldots \ldots, 5,67$

$5.14 \quad$ Regression statistics for metals $\ldots \ldots \ldots \ldots \ldots \ldots \ldots \ldots \ldots \ldots$ 5 67

6.1a Summary statistics for inorganics on the ORR by group $\ldots \ldots \ldots \ldots .6-3$

6.1b Summary statistics for selected radionuclides on the ORR by group ..... 6-9

6.1c Summary statistics by group for PAHs on the ORR $\ldots \ldots \ldots \ldots \ldots \ldots 6-13$

6.2 Ratios of radionuclides concentrations................... 6-34

7.1a Oak Ridge Reservation background soil analytes evaluated

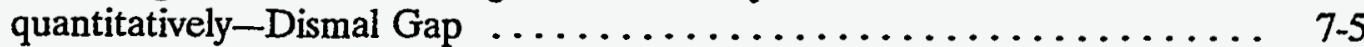

7.1b Oak Ridge Reservation background soil analytes evaluated

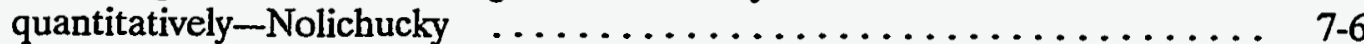

7.1c Oak Ridge Reservation background soil analytes evaluated

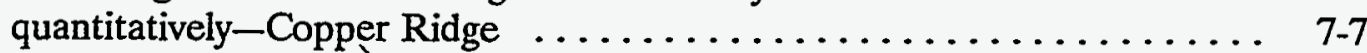

7.1d Oak Ridge Reservation background soil analytes evaluated

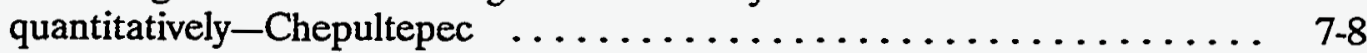

7.1e Oak Ridge Reservation background soil analytes evaluated quantitatively - Chickamauga (Bethel Valley) $\ldots \ldots \ldots \ldots \ldots \ldots \ldots$. 7-10

7.1f Oak Ridge Reservation background soil analytes evaluated

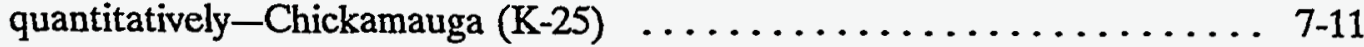

7.2a Oak Ridge Reservation background soil analytes evaluated qualitatively-Dismal Gap $\ldots \ldots \ldots \ldots \ldots \ldots \ldots \ldots \ldots \ldots \ldots . \ldots \ldots$

7.2b Oak Ridge Reservation background soil analytes evaluated qualitatively-Nolichucky 
7.2c Oak Ridge Reservation background soil analytes evaluated

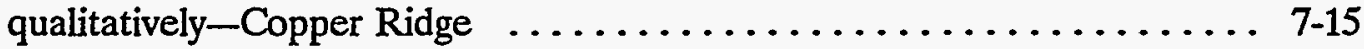

7.2d Oak Ridge Reservation background soil analytes evaluated qualitatively-Chepultepec

7.2e Oak Ridge Reservation background soil analytes evaluated qualitatively-Chickamauga (Bethel Valley)

7.2f Oak Ridge Reservation background soil analytes evaluated qualitatively-Chickamauga (K-25) $\ldots \ldots \ldots \ldots \ldots \ldots \ldots \ldots \ldots \ldots \ldots \ldots \ldots \ldots$

7.3 On-site resident exposure scenario $\ldots \ldots \ldots \ldots \ldots \ldots \ldots \ldots \ldots \ldots, 7-22$

7.4a Chronic daily intake of ORR background soil by the on-site

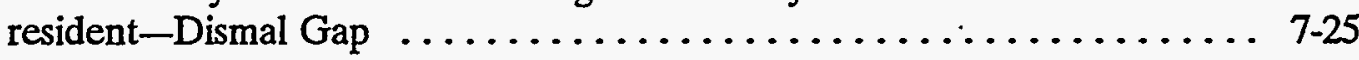

7.4b Chronic daily intake of ORR background soil by the on-site resident-Nolichucky

7.4c Chronic daily intake of ORR background soil by the on-site resident-Copper Ridge ......................... 7-29

7.4d Chronic daily intake of ORR background soil by the on-site resident-Chepultepec

7.4e Chronic daily intake of ORR background soil by the on-site resident-Chickamauga (Bethel Valley)

7.4f Chronic daily intake of ORR background soil by the on-site resident-Chickamauga (K-25)

7.5a Chronic daily intake of ORR background soil by the on-site resident-Dismal Gap

7.5b Chronic daily intake of ORR background soil by the on-site resident-Nolichucky

7.5c Chronic daily intake of ORR background soil by the on-site resident-Copper Ridge ........................ 7-45

7.5d Chronic daily intake of ORR background soil by the on-site

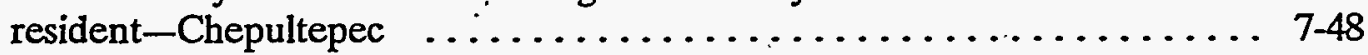

7.5e Chronic daily intake of ORR background soil by the on-site resident-Chickamauga (Bethel Valley) 
7.5f Chronic daily intake of ORR background soil by the on-site

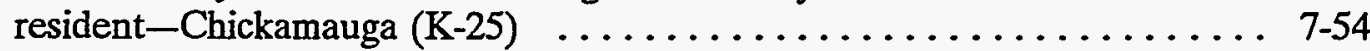

7.6 Toxicity information for carcinogenic potential analytes of

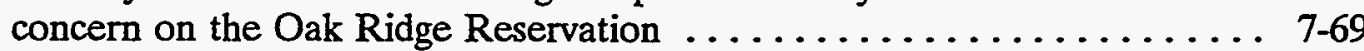

7.7 Toxicity information for polycyclic aromatic hydrocarbon analytes of potential concern on the Oak Ridge Reservation ............. 7-70

7.8 Toxicity information for external exposure to potential radionuclides of concern on the Oak Ridge Reservation ........... 7-71

7.9 Toxicity information for inorganic noncarcinogenic potential analytes of concern on the Oak Ridge Reservation $\ldots \ldots \ldots \ldots \ldots \ldots$ 7-72

7.10a Comparative background risk estimates from exposure to soil constituents from the Oak Ridge Reservation, Anderson County, and Roane County-Dismal Gap $\ldots \ldots \ldots \ldots \ldots \ldots \ldots \ldots \ldots . . . . .$.

7.10b Comparative background risk estimates from exposure to soil constituents from the Oak Ridge Reservation, Anderson County, and Roane County-Copper Ridge $\ldots \ldots \ldots \ldots \ldots \ldots \ldots \ldots \ldots$. 7-79

7.10c Comparative background risk estimates from exposure to soil constituents from the Oak Ridge Reservation-Chickamauga ...... 7-81

7.11a Comparative background hazard index estimates from exposure to soil constituents from the Oak Ridge Reservation, Anderson County, and Roane County-Dismal Gap ........... 7-85

7.11b Comparative background hazard index estimates from exposure to soil constituents from the Oak Ridge Reservation, Anderson County, and Roane County-Copper Ridge ......... 7-87

7.11c Comparative background hazard index estimates from exposure to soil constituents from the Oak Ridge Reservation (Bethel Valley and K-25)-Chickamauga ................. 7-89

7.12a Comparative background risk estimates from exposure to soil constituents on the Oak Ridge Reservation, Anderson County, and Roane County-Dismal Gap ............ 7-92

7.12b Comparative background risk estimates from exposure to soil constituents on the Oak Ridge Reservation, Anderson County, and Roane County-Copper Ridge .......... 7-94 
7.12c Comparative background risk estimates from exposure to soil constituents on the Oak Ridge Reservation,

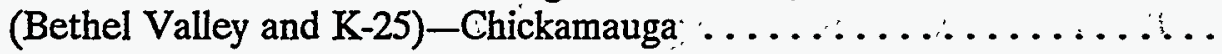

7.13a Comparative background risk estimates from exposure to soil constituents from the Oak Ridge Reservation-Nolichucky

7.13b Comparative background risk estimates from exposure to soil constituents from the Oak Ridge Reservation-Chepultepec ........ 7-100

7.14a Comparative background hazard index estimates from exposure to soil constituents from the Oak Ridge Reservation, Anderson County, and Roane County-Dismal Gap .................... 7-102

7.14b Comparative background hazard index estimates from exposure to soil constituents from the Oak Ridge Reservation, Anderson County, and Roane County-Cópper Ridge .................. 7-103

7.14c Comparative background hazard index estimates from exposure to soil constituents from the Oak Ridge Reservation (Bethel Valley

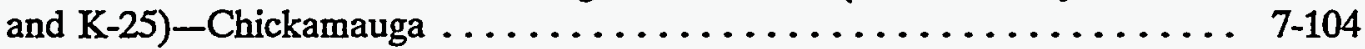

7.15a Comparative background hazard index estimates from exposure to soil constituents from the Oak Ridge Reservation-Nolichucky ...... 7-106

7.15b Comparative background hazard index estimates from exposure to soil constituents from the Oak Ridge Reservation-Chepultepec ..... 7-107

7.16a Background cancer risk estimates from exposure to Oak Ridge Reservation soil constituents-inorganics and organics/ingestion

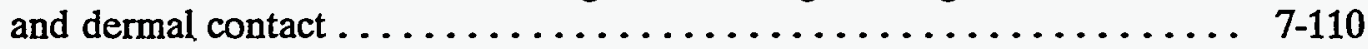

7.16b Background cancer risk estimates from exposure to Oak Ridge Reservation soil constituents-radionuclides/ingestion ........... 7-114

7.16c Background cancer risk estimates from exposure to Oak Ridge Reservation soil constituents-radionuclides/external exposure ...... 7-117

7.17a Background hazard index estimates for residents exposed to Oak Ridge Reservation soil constituents-ingestion ........... 7-120

7.17b Background hazard index estimates for residents exposed to Oak Ridge Reservation soil constituents-dermal contact ......... 7-124

7.18 General uncertainty factors in risk assessment $\ldots \ldots \ldots \ldots \ldots \ldots \ldots$ 7-129

8.1 Comparison of rinse water and source water for metals on the ORR $\ldots \quad 8-12$ 
8.2 Comparison of source water and rinse water for Anderson and Roane counties .................... 8-13

8.3 Distribution of data usability $\ldots \ldots \ldots \ldots \ldots \ldots \ldots \ldots \ldots \ldots$

\section{TABLES}

\section{VOLUME 2}

B.1 Volatile organic analysis results for soil samples $\ldots \ldots \ldots \ldots \ldots \ldots$

B.2 Weighted gamma screening results for soil samples $\ldots \ldots \ldots \ldots \ldots \ldots$ B-71

B.3 Unweighted gamma screening results for soil samples $\ldots \ldots \ldots \ldots \ldots \ldots$ B-91

C.1 Organic analysis results for soil samples $\ldots \ldots \ldots \ldots \ldots \ldots \ldots \ldots \ldots$

D.1 Inorganic analysis results for composite soil samples $\ldots \ldots \ldots \ldots \ldots$

E.1 Radionuclide analysis results for composite soil samples $\ldots \ldots \ldots \ldots \ldots$ E-3

E.2 Tritium analysis results for noncomposited soil samples $\ldots \ldots \ldots \ldots$ E-53

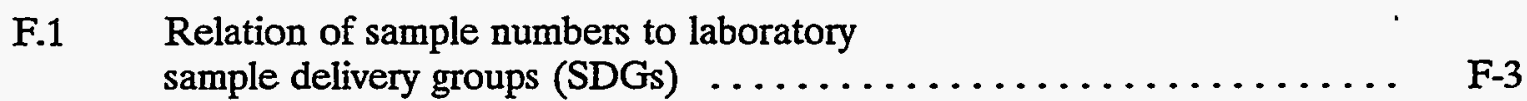

G.1 Summary statistics for NAA data $\ldots \ldots \ldots \ldots \ldots \ldots \ldots \ldots \ldots$

G.2 Summary statistics for ICP/MS data $\ldots \ldots \ldots \ldots \ldots \ldots \ldots \ldots$ G-20

G.3 Significance levels for comparing inorganics $\ldots \ldots \ldots \ldots \ldots \ldots \ldots$ G-28

G.4 Significance levels for comparing PAHs $\ldots \ldots \ldots \ldots \ldots \ldots \ldots \ldots$ G-30

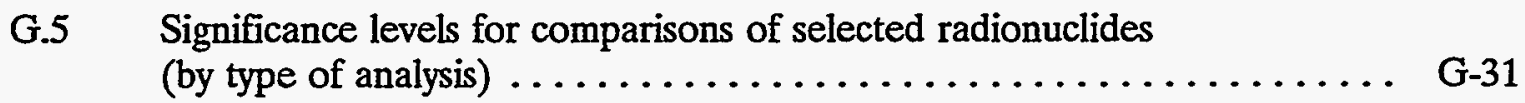

G.6 Comparisons of horizons for inorganics $\ldots \ldots \ldots \ldots \ldots \ldots \ldots$ G-32

G.7 Comparisons of horizons for selected radionuclides $\ldots \ldots \ldots \ldots \ldots \ldots$ G $\ldots$. 47

G.8 Summary statistics for ORR inorganics-overall $\ldots \ldots \ldots \ldots \ldots \ldots$ G-54

G.9 Summary statistics for ORR radionuclides-overall $\ldots \ldots \ldots \ldots \ldots \ldots$ G.57

G.10 Summary statistics for ORR PAHs-overall $\ldots \ldots \ldots \ldots \ldots \ldots \ldots$ G. . . . . . . 
H.1 NAA analysis results for composite soil samples $\ldots \ldots \ldots \ldots \ldots \ldots \ldots$ H-3

I.1 ICP/MS metals results for composite soil sàmples $\ldots \ldots \ldots \ldots \ldots \ldots$ I-3

J.1 Occurrences of rejected data $\ldots \ldots \ldots \ldots \ldots \ldots \ldots \ldots \ldots \ldots, \mathrm{J}-3$

\section{TABLES}

\section{VOLUME 3}

$5.1 \quad$ On-site resident exposure scenario $\ldots \ldots \ldots \ldots \ldots \ldots \ldots \ldots \ldots \ldots \ldots$

6.1 Modular profile and cross-reference of EPA QAMS-005/80 and

NQA-1 elements $\ldots \ldots \ldots \ldots \ldots \ldots \ldots \ldots \ldots \ldots \ldots \ldots \ldots \ldots \ldots \ldots . \ldots 4$

6.2 Functional responsibility chart for the BSCP $\ldots \ldots \ldots \ldots \ldots \ldots \ldots$

6.3 QA/QC levels to which BSCP measurement tasks have been assigned $\ldots \ldots 50$

6.4 Recommended sample containers, sample preservation, sample size, and sample holding time requirements for analytical samples $\ldots \ldots \ldots \ldots .53$

6.5 Analyte list for volatile organics by EPA-8240 using the target compound list $\ldots \ldots \ldots \ldots \ldots \ldots \ldots \ldots \ldots \ldots \ldots \ldots$

6.6 Analyte list for organochlorine pesticides/PCBs by EPA CLP SOW (3/90) . 60

$6.7 \quad$ Analyte list for herbicides by EPA-8150 ................ 61

$6.8 \quad$ Analyte list for polyaromatic hydrocarbons by EPA-8310 . . . . . . 62

$6.9 \quad$ Analyte list for atomic absorption of metals $\ldots \ldots \ldots \ldots \ldots \ldots \ldots$

6.10 Analyte list for inductively coupled plasma metals $\ldots \ldots \ldots \ldots \ldots \ldots \ldots$

6.11 Analyte list for inductively coupled plasma/mass spectrometry metals $\ldots . .66$

$6.12 \quad$ Analyte list for inorganic parameters $\ldots \ldots \ldots \ldots \ldots \ldots \ldots \ldots \ldots$

$6.13 \quad$ Analyte list for radionuclides $\ldots \ldots \ldots \ldots \ldots \ldots \ldots \ldots \ldots \ldots \ldots$

$6.14 \quad$ Deliverables for the BSCP $\ldots \ldots \ldots \ldots \ldots \ldots \ldots \ldots \ldots \ldots \ldots \ldots$

Analyte concentration equivalent (milligram per liter) arising
from interferants at $100 \mathrm{mg} / \mathrm{L} \ldots \ldots \ldots \ldots \ldots \ldots \ldots \ldots \ldots \ldots \ldots$

6.16 BSCP-1992 Schedule of surveillance activities $\ldots \ldots \ldots \ldots \ldots \ldots \ldots$ 
7.1 Records to be included in the BSCP DMA and the originating office.

8.1 Protective equipment for on-site activities $\ldots \ldots \ldots \ldots \ldots \ldots \ldots$

8.2 Safe working distances from electrical transmission lines

for drill rigs $\ldots \ldots \ldots \ldots \ldots \ldots \ldots \ldots \ldots \ldots \ldots \ldots \ldots \ldots \ldots \ldots \ldots$

8.3 Key BSCP personnel $\ldots \ldots \ldots \ldots \ldots \ldots \ldots \ldots \ldots \ldots \ldots \ldots \ldots \ldots \ldots$ 


\section{FIGURES}

VOLUME 1

$2.1 \quad$ Staff organization of the $\operatorname{BSCP} \ldots \ldots \ldots \ldots \ldots \ldots \ldots \ldots \ldots \ldots .2-2$

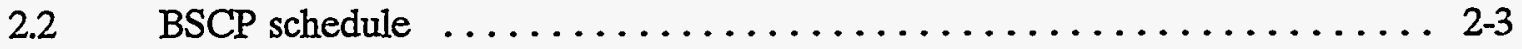

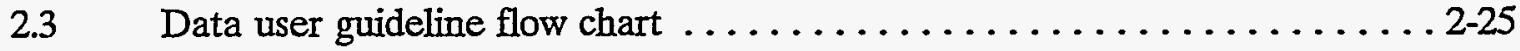

3.1 Approximate locations of BSCP sampling areas $\ldots \ldots \ldots \ldots \ldots \ldots .3-3$

3.2 Sampling site locations for the ORR $\ldots \ldots \ldots \ldots \ldots \ldots \ldots \ldots, 3-4$

3.3 Sampling sites in Roane County $\ldots \ldots \ldots \ldots \ldots \ldots \ldots \ldots \ldots . \ldots \ldots$

3.4 Sampling sites in Anderson County $\ldots \ldots \ldots \ldots \ldots \ldots \ldots \ldots \ldots \ldots \ldots \ldots$

$5.1 \quad$ Example of a plot to check for outliers $\ldots \ldots \ldots \ldots \ldots \ldots \ldots \ldots .5 .6$

5.2 Another plot to check for outliers; data are consistent $\ldots \ldots \ldots \ldots \ldots$ 5-7

5.3 Plot of observation logs by corresponding normal scores

5.4 Plot of observation logs by corresponding normal scores for pseudorandom lognormal data with means and variance the same as for the horizon $B$ aluminum data $\ldots \ldots \ldots \ldots \ldots \ldots \ldots \ldots \ldots .6 .10$

5.5 Plot similar to Fig 5.3 but based on product limit estimates for horizon A mercury data, which have nondetects .............. 5-11

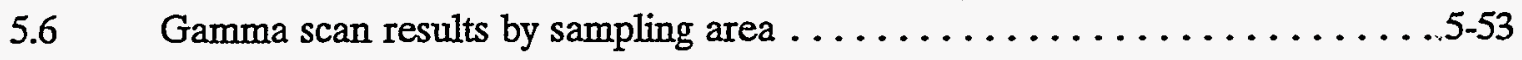

5.7 Example plot for potassium for comparing NAA with AA/ICP results . . . . . . . . . . . . . . . . . . . . .

5.8 Example comparison of NAA and gamma results for potassium- 40 . . . . 5-64

7.1 Comparison of total background cancer risks calculated from soil samples from the Dismal Gap Formation in Anderson County, Dismal Gap in Roane County, Dismal Gap on the ORR, and the Nolichucky Formation on the ORR 


\section{FIGURES}

\section{VOLUME 3}

4.1 Regional map showing location of the Oak Ridge Reservation $\ldots \ldots \ldots . .8$

4.2 General site map of the Oak Ridge Reservation $\ldots \ldots \ldots \ldots \ldots$

4.3 Location of communities near the Oak Ridge Reservation . . . . . . . 10

4.4 Schematic of ridge-valley province near Oak Ridge Reservation . . . . . . . 11

4.5 Distribution of geologic units on the Oak Ridge Reservation . . . . . . . 13

4.6 Location map of streams and rivers at the Oak Ridge Reservation ...... 15

$5.1 \quad$ BSCP staff organization $\ldots \ldots \ldots \ldots \ldots \ldots \ldots \ldots \ldots \ldots \ldots \ldots$

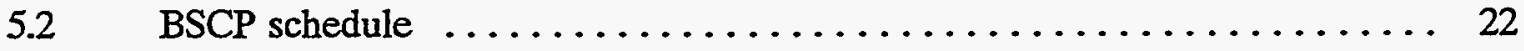

5.3 Location of candidate geology formations near the Oak Ridge Reservation . 24

5.4 Distribution of candidate soil series selected for background soil characterization project in the Oak Ridge Reservation . . . . . . . . 26

5.5 Approximate location of off-site background soil sampling areas in Roane County and Anderson County .................. 27

$5.6 \quad$ Selected soil sampling sites in Roane County $\ldots \ldots \ldots \ldots \ldots \ldots \ldots$

$5.7 \quad$ Selected soil sampling site in Anderson County $\ldots \ldots \ldots \ldots \ldots \ldots$

$6.1 \quad$ Field change request/variance form $\ldots \ldots \ldots \ldots \ldots \ldots \ldots \ldots \ldots$

7.1 Responsibility matrix and process flow of BSCP samples, data, and documents $\ldots \ldots \ldots \ldots \ldots \ldots \ldots \ldots \ldots \ldots \ldots \ldots . \ldots \ldots$ 


\section{ABBREVIATIONS}

$\begin{array}{ll}\text { AA } & \text { atomic absorption } \\ \text { AESG } & \text { Analytical Environmental Support Group at the Oak Ridge K-25 Site } \\ \text { AND } & \text { Anderson County } \\ \text { APO } & \text { Analytical Projects Office } \\ \text { BEIAS } & \text { Biomedical Environmental Information Analysis Section } \\ \text { BSCP } & \text { Background Soil Characterization Project } \\ \text { BV } & \text { Bethel Valley } \\ \text { CCB } & \text { continuing calibration blank } \\ \text { CCV } & \text { continuing calibration verification } \\ \text { CDI } & \text { chronic daily intake } \\ \text { CERCLA } & \text { Comprehensive Environmental Response, Compensation, and Liability } \\ & \text { Act (1980) } \\ \text { CHE } & \text { Chepultepec Formation } \\ \text { CHI } & \text { Chickamauga Formation } \\ \text { CLP } & \text { Contract Laboratory Program } \\ \text { COC } & \text { chain of custody } \\ \text { CR } & \text { Copper Ridge Formation } \\ \text { CRDL } & \text { contract required detection limit } \\ \text { CVAA } & \text { cold vapor atomic absorption } \\ \text { DG } & \text { Dismal Gap Formation } \\ \text { DOE } & \text { U.S. Department of Energy } \\ \text { DOE-ORO } & \text { DOE Oak Ridge Operations Office } \\ \text { DQ } & \text { data quality } \\ \text { DQO } & \text { data quality objective } \\ \text { ECD } & \text { electron capture detector } \\ \text { EPA } & \text { U.S. Environmental Protection Agency } \\ \text { ER } & \text { environmental restoration } \\ \text { ESD } & \text { Environmental Sciences Division of ORNL } \\ \text { FD } & \text { field duplicate } \\ \text { FL } & \text { formation-location } \\ \text { FLAA } & \text { flame atomic absorption } \\ \text { FWHM } & \text { full-width half-maximum } \\ \text { GC } & \text { gas chromatography } \\ \text { GC/ECD } & \text { gas chromatograph/electron capture detector } \\ \text { GFAA } & \text { graphite furnace atomic absorption } \\ \text { GI } & \text { gastrointestinal } \\ \text { GOF } & \text { goodness of fit } \\ \text { HEAST } & \text { Health Effects Assessment Summary Tables } \\ \text { HI } & \text { hazard index } \\ \text { HPLC } & \text { high performance liquid chromatography } \\ \text { HSWA } & \text { Hazardous and Solid Waste Amendments to RCRA (1984) } \\ \text { ICB } & \text { initial calibration blank } \\ \text { ICP } & \text { inductively coupled plasma } \\ \text { ICP/MS } & \text { inductively coupled plasma/mass spectroscopy } \\ \text { ICRP } & \text { International Commission on Radiological Protection } \\ & \end{array}$




\begin{tabular}{|c|c|}
\hline ICS & interference check sample \\
\hline ICV & initial calibration verification \\
\hline ID & identification number \\
\hline $\mathrm{IDL}$ & instrument detection limit \\
\hline IRIS & Integrated Risk Information System \\
\hline LCS & laboratory control sample \\
\hline LET & linear energy transfer \\
\hline LLWDDD & Low-Level Waste Disposal Development Demonstration \\
\hline LTB & lower tolerance bound \\
\hline MAD & Measurement Applications and Development Group \\
\hline MAXDL & maximum detection limit \\
\hline MDA & minimum detectable activity \\
\hline MDL & method detection limit \\
\hline MS & mass spectroscopy \\
\hline MSA & method of standard additions \\
\hline MSD & matrix spike duplicate \\
\hline MS/MSD & matrix spike/matrix spike duplicate \\
\hline NAA & neutron activation analysis \\
\hline ND & no data \\
\hline NEPA & National Environmental Policy Act (1968) \\
\hline NIST & National Institute for Standards and Testing \\
\hline NOL & Nolichucky Formation \\
\hline NPL & National Priorities List \\
\hline OREIS & Oak Ridge Environmental Information System \\
\hline ORNL & Oak Ridge National Laboratory \\
\hline ORR & Oak Ridge Reservation \\
\hline OSWER & Office of Solid Waste and Emergency Response \\
\hline OU & operable unit \\
\hline PAH & polynuclear aromatic hydrocarbon \\
\hline PARCC & precision, accuracy, representativeness, completeness, and comparability \\
\hline $\mathrm{PC}$ & personal computer \\
\hline PCB & polychlorinated biphenyl \\
\hline $\mathrm{PE}$ & performance evaluation \\
\hline PEM & performance evaluation mixture \\
\hline PQL & practical quantitation limit \\
\hline PSD & percent standard deviation \\
\hline QA/QC & quality assurance/quality control \\
\hline RAGS & Risk Assessment Guidance for Superfund \\
\hline RCRA & Resource Conservation and Recovery Act (1976) \\
\hline $\mathrm{RfD}$ & reference dose \\
\hline ROA & Roane County \\
\hline ROW & right of way \\
\hline RPD & relative percent difference \\
\hline RSD & relative standard deviation \\
\hline SARA & Superfund Amendments and Reauthorization Act (1986) \\
\hline SDG & sample delivery group \\
\hline SF & slope factor \\
\hline SOP & standard operating proc \\
\hline
\end{tabular}




$\begin{array}{ll}\text { SOW } & \text { statement of work } \\ \text { SPL } & \text { Soil Preparation Laboratory } \\ \text { SVOC } & \text { semi-volatile organic compound } \\ \text { SWMU } & \text { solid waste management unit } \\ \text { TIC } & \text { tentatively identified compound } \\ \text { TSD } & \text { treatment, storage, and disposal } \\ \text { TVA } & \text { Tennessee Valley Authority } \\ \text { UCB } & \text { upper confidence bound } \\ \text { UTK } & \text { The University of Tennessee-Knoxville } \\ \text { USDA } & \text { U.S. Department of Agriculture } \\ \text { VOA } & \text { volatile organic analysis } \\ \text { VOC } & \text { volatile organic compound } \\ \text { WAG } & \text { waste area grouping } \\ \text { WM } & \text { waste management }\end{array}$


-

- 


\section{ACKNOWLEDGMENTS}

The authors wish to express their thanks and appreciation to the many contributors who made this effort possible. Chief among these were D. M. Carden (DOE-ORO) and D. T. Bell of Program Integration and Administration for program management support for this project; P. L. Goddard, A. J. Kuhaida, and V. J. Brumback, the K-25, ORNL, and Y-12 Site Program Office representatives, respectively, for valuable suggestions in scoping the project; T. M. Koepp of the ER/Central quality organization for providing dedicated QA/QC oversight; F. F. Dyer and L. Robinson of the Analytical Chemistry Division at ORNL for performing and analyzing NAA data; I. L. Larsen of the Environmental Sciences Division at ORNL for conducting gamma screening analyses of soil samples; M. A. Cannon, T. M. French, and J. C. Wright of the Measurement Applications and Development Group for technical coordination of analytical laboratory activities; and B. Ladd, S. N. Burman, and D. C. Landguth of the Health Sciences Research Division for assisting in performing risk analyses and developing the BSCP Health and Safety Plan, respectively.

Special thanks are reserved for D. M. Carden and other reviewers at DOE-ORO; to R. J. Lewis of UTK, J. R. Stokely of the Analytical Chemistry Division, and R. R. Turner for review of this document; and for H. L. Boston, ORNL Site ER Manager, F. P. Baxter of the Office of Environmental Compliance and Documentation, L. K. Mann, and P. M. Jardine for very helpful technical reviews of other prominent documents in the BSCP; A. L. Harkey, P. L. Lund, and other members of the Publications Division for insightful suggestions to improve quality of the documents throughout this project; and M. J. Jenkins, T. P. McKenzie, and V. L. Lewis for their excellent word processing support on earlier project documents; those not specified are with the Environmental Sciences Division at ORNL. 
- 


\section{EXECUTIVE SUMMARY}

Many constituents of potential concern for human health occur naturally at low concentrations in undisturbed soils. The Background Soil Characterization Project (BSCP) was undertaken to provide background concentration data on potential contaminants (organic compounds, inorganics, and radionuclides) in relatively undisturbed soils on the Oak Ridge Reservation (ORR). The objectives of the BSCP are to provide (1) baseline data for contaminated site assessment and (2) estimates of potential human health risk associated with background concentrations of hazardous and other constituents in natural soils.

Background soil characterization data will be used for three purposes. The first application is in differentiating between naturally occurring constituents (including global or regional fallout) and site-related contamination. This is a very important step in risk assessment because, if sufficient background data are not available, no constituent known to be a contaminant can be eliminated from an assessment even if the sampled concentration is measured at a minimum level. The second use of background data is in calculating baseline risks against which site-specific contamination risks [i.e, those associated with waste area groupings (WAGs)] can be compared. The third application is in establishing corrective action (cleanup) levels for contaminated soils on the ORR.

To evaluate realistically the level of contamination (with implications for risk and remedial actions), it is necessary to know the background levels of contaminants that would be expected at a specific site. To understand the geologic soil environment, the BSCP addresses variability of concentration levels in terms of (1) taxonomical types (soil series) occurring in different geologic formations, (2) soil sampling depths (horizons) within a specific soil profile, and (3) natural areal variations in soils both on-site and off-site developed from the same geologic formations. Early in the project, soils from two on-site parent geologies were sampled and analyzed-the Nolichucky Shale and the Dismal Gap formations in the Conasauga Group, which are the dominant formations located at WAGs and operable units in imminent remedial projects on the ORR. One of these, the Dismal Gap Formation, was sampled off-site in two areas. Data on the remaining soil series were obtained later, including soils from the other representative groups (the Chickamauga and Knox groups) required to provide comprehensive, sitewide data. Rome Formation soils do not appear with regularity at contaminated sites on the ORR and for that reason have not been considered to date.

The BSCP data base is intended for unrestricted use, with recommendations provided on how to use the data for contaminated site assessment. In addition, the data can be used to provide estimates of any potential human health risks associated with background level concentrations of potentially hazardous constituents. All results were required to adhere to the highest, most rigorous Environmental Protection Agency protocols and requirements for analysis procedures, data validation, and data record documentation [U.S. Environmental Protection Agency (EPA) Level IV]. These procedures yield data that are both technically and legally defensible.

This report contains all analytical and field data obtained in the BSCP. It is organized in three volumes: Volume 1 is devoted to discussion of the results, Volume 2 contains the 
detailed tabulated data and supporting information, and Volume 3 presents the BSCP Plan that governed all project-related activities and established the basis for the project.

The primary conclusion drawn from analysis and interpretation of the data is that there is general consistency between most constituents of interest and in the levels of risk associated with background soil concentrations between sampling sites on the ORR and those located off-site in remote areas of both Roane and Anderson counties. All analytical laboratory results presented in this report have been fully validated and peer reviewed, and verified as being representative of and corresponding to the formations of interest. In addition, the resulting data have been organized in formats suitable for inclusion in the Oak Ridge Environmental Information System (OREIS) and for distribution through OREIS to data users. Statistical analyses to establish data validity in meeting project objectives and yielding summary statistical parameters necessary for application of the data to subsequent assessment of risk have been completed and are presented in this report. The report also contains discussion of technical interpretation of the field data integrated with analytical data to determine the meaning and implications of the results. Finally, the Final Report discusses assessment of the project data in meeting and complying with project data quality objectives. Key information is summarized at the beginning of each section.

Risks were estimated for exposure to background soil constituents on the ORR to provide a framework or reference for interpreting the magnitude and relative importance of risks evaluated at hazardous waste sites on the ORR and to provide a context for the discussion and comparison of risks associated with site-related contamination in future risk assessments. The results of the background evaluation have been discussed within the context of the Comprehensive Environmental Response, Compensation, and Liability Act, which uses the estimated potential risks from site-related contamination to determine if remedial action is necessary at a waste site. Most of the risk modeled from the exposure to background soil constituents discussed in this report is a subset of the unavoidable risk associated with exposure to natural radiation sources. EPA has determined that risks from exposure to hazardous waste sites are avoidable sources of exposure. The risk resulting from exposure to avoidable hazardous sources is referred to as incremental or excess cancer risk, because it is risk in addition to background, which is unavoidable. The information presented in this document should be used to differentiate between unavoidable (background) and avoidable risks and to ensure that risk management decisions are based on excess cancer risk associated with actual site contamination. Furthermore, the background risk results reported and discussed in this report are not indicative of concerns or actions that would be identified with similar potential risks from a contaminated site, and care should be taken not to misinterpret these results to pertain directly to remediation decisions. 


\section{INTRODUCTION}

\subsection{PROJECT OBJECTIVES AND APPROACH}

This report presents, evaluates, and documents data and results obtained in the Background Soil Characterization Project (BSCP). It is intended to be a stand-alone document for application and use in structuring and conducting remedial investigation and remedial action projects in the Environmental Restoration (ER) Program.

The objectives of the BSCP consist of the following:

- determine background concentrations of organics, metals, and radionuclides in natural soils that are key to environmental restoration projects;

- provide remediation projects with $100 \%$ validated data on background concentrations, which are technically and legally defensible; and

- quantify baseline risks from background constituents for comparison of risks associated with contaminated sites.

The approach detailed in the BSCP Plan (Energy Systems 1992, Volume 3) is summarized as follows:

- identification of the most important geologic formations underlying potentially contaminated sites on the Oak Ridge Reservation (ORR);

- identification of the dominant residuum soil type corresponding to each selected formation;

- randomized selection of candidate soil sampling sites on the ORR, in western Roane County, and in eastern Anderson County;

- field screening and soil sampling for site acceptability;

- chemical and radiological analyses by commercial analytical laboratories;

- data validation, verification, statistical analysis, and interpretation; and

- data transfer to the Oak Ridge Environmental Information System.

\subsection{REPORT ORGANIZATION}

The BSCP Final Report is organized in three volumes to provide a logical flow of information for the reader from relevant background through to the discussion of analytical data, results, and evaluations. Section 1 of Volume 1 presents the project objectives and approach and the regulatory background and data quality objectives (DQOs) that define the project environment in terms of uses and applicability of the data. Section 2 presents the project organization, the data management and storage and records management systems, and the data user guidelines. These systems are part of the analytical laboratory data repository and meet requirements for record content, data formats, electronic storage, and data access guidelines.

Section 3 of Volume 1 discusses field investigation activities and initial gamma screening operations and analyses, along with site selection criteria and requirements and descriptions of specific field site locations. Section 3 also includes a discussion of objectives and methods for soil sampling and field quality control (QC). 
Analytical laboratory analyses and data validation are discussed in Sect. 4. In this section, laboratory selection criteria employed by the Analytical Projects Office (APO) are discussed, along with U.S. Environmental Protection Agency (EPA) Level IV data requirements and documentation. The QA/QC and data validation subsection presents procedures and provides narrative on EPA Level IV data quality requirements. Finally, specific results are presented and described, and these include screening analyses [volatile organic compounds (VOCs) and gamma screening], organic compounds, inorganics (metals), and radionuclide constituents.

Section 5 of Volume 1 provides a summary of relevant statistical parameters, discusses the adequacy of the field sampling program, infers trends in natural variability versus system/sampling errors, and discusses the statistical procedures used to distinguish types of errors.

Sections 6,7 , and 8 present results of data interpretation, risk evaluation studies, and an evaluation of how well the project met the DQOs. Section 6 provides the summary of trends and background constituent concentration levels and assesses applicability of the data. Section 7 presents results of the risk evaluation based on statistical data. Section 8, an evaluation of DQOs, explores further applicability of the data to ER projects.

- Volume 2 presents detailed soil descriptive data and site screening data, as well as all validated results and associated statistical data. Volume 3 contains the project plan that governed all field operations and analytical laboratory activities.

\subsection{SAMPLE REFERENCE DESIGNATIONS}

In the BSCP Final Report, analytical results are compared and discussed with respect to (1) sampling areas, (2) geologic rock groups, (3) individual geologic formations within a group, (4) sampling sites within formations, and (5) A horizons vs B horizons vs $C$ horizons of soils within formations. A summary of such statistically treated data is presented in Appendix $G$. There are three distinct sampling areas in this project: the ORR, Roane County, and Anderson County. However, in part of the statistical treatment in Sect. 5, only two sampling areas are discussed: on-site (ORR) and off-site (Anderson and Roane counties together). There are three major geologic rock groups of interest: Conasauga, Knox, and Chickamauga. ORR samples were obtained from all three rock groups, but Roane and Anderson samples were only from the Conasauga and Knox. There are six geologic formations: the Dismal Gap and Nolichucky from the Conasauga Group, Copper Ridge and Chepultepec from the Knox Group, and two different sections, designated as Bethel Valley and K-25 (which includes several formations), from the Chickamauga Group.

The ORR is represented by samples from all six formations, but both Roane and Anderson are represented only by samples from the Dismal Gap Formation of the Conasauga Group and the Copper Ridge Formation of the Knox Group. Twelve sites were sampled for each formation. Several samples were collected from all A horizons for a variety of analytical procedures, but $B$ and $C$ horizons were sampled only for the analysis of inorganics and radionuclides. The following hierarchy summarizes the discussion that follows in this report regarding sampling from each category (i.e., sampling areas, groups, formations, and individual sites). 
$1-3$

\begin{tabular}{lrrr}
\hline Designation & On-site & Off-site \\
\hline Sampling areas & 1 & 2 \\
Geologic rock groups & 3 & 2 \\
Geologic formations & 6 & 2 \\
Individual sites & 72 & 48 \\
Soil horizons & 216 & 144 \\
\hline
\end{tabular}

\subsection{DATA QUALITY OBJECTIVES}

Determination of naturally occurring concentrations of constituents in soils in the Oak Ridge area necessitated a systematic investigation because there are several different underlying formations from which soils are derived, and because of the natural variability within different soils. To evaluate the ranges of concentrations of organics, metals, and radionuclides with high confidence levels, the project participants followed the steps described in this section for project planning found in the report Characterizing Heterogeneous Wastes: Methods and Recommendations (Rupp and Jones 1991). This section outlines the approach taken to establish DQOs for this project.

\section{State the Problem To Be Resolved}

The problem to be resolved by conducting the BSCP is to determine the ranges in concentration of naturally occurring organics, metals, and radionuclides in soils. Ranges of concentrations for these constituents are required because of the variability found in any naturally occurring substance and because of the varying soils resulting from different underlying geologic formations in the Oak Ridge area. The sample collection program was designed to account for some of this variability (Sect. 5.2, Energy Systems 1992) through the collection of field duplicates and splits.

\section{Identify the Decision To Be Made}

Decisions will be made with respect to the characterization of background concentrations of organics, inorganics (metals), and radionuclides found in nature. Standards for cleanup of potentially contaminated soils on the ORR will be based on the concentrations above those established as background in this project for typical constituents. If data from this project can be used to determine that levels of organics, metals, and radionuclides at a suspected contaminated site are no greater than those found in nature, then those constituents will not be considered contaminants of concern for that particular site. However, if the concentrations of these constituents are significantly greater than those found in nature, then appropriate remedial activities will be evaluated in site specific cleanup projects to reduce the elevated concentrations to those of naturally occurring levels or to technically feasible levels. 
Identify Inputs to the Decision

The approach taken to provide needed quantitative data on background concentration levels is based on collecting and analyzing samples from representative soil horizons. The determination that sample collection locations are representative was made by assimilating information from relevant disciplines. Those disciplines included site history, geology, soil science, statistics, and analytical chemistry. To ascertain that samples would reflect accurate background concentrations, the history of each sample collection site was determined to be unaffected by process and research operations of the ORR, and the site was determined to have the same underlying geologic units and soils as those underlying suspected and contaminated sites. To determine the probable ranges of background concentrations, a statistically based sample collection and analysis program was designed. To provide defensible laboratory analyses upon which to base statistical analysis and the resulting conclusions, analytical chemists determined that EPA Analytical Level IV QC and documentation were required.

\section{Narrow the Boundaries of the Study}

Upon defining the problem to be resolved and the decisions to be made from project data, the boundaries of the study were narrowed in three ways: (1) appropriate locations for sample collection were determined, (2) analytical parameters were agreed upon, and (3) statistical analytical procedures were designed. From these decisions, the appropriate levels of QA documentation required from field sampling and laboratory activities were established. The process for selecting sample collection sites is described in the BSCP Plan (Energy Systems 1992, Volume 3). Therein, the process is discussed in detail, as are the analytical parameters of interest for both the field and laboratory activities, the associated QA documentation requirements for each, and the statistical analysis techniques.

\section{Develop a Decision Rule}

Upon completion of sample collection and analysis according to the requirements discussed above, the results were statistically analyzed, compiled, and reported including the ranges of concentrations for each constituent. This information will be used to address the following statement: If concentrations of contaminants of concern at potentially contaminated sites are above those established as background, then appropriate remedial measures will be evaluated for application at that site.

\section{Develop Uncertainty Constraints}

The uncertainty of all results from this project must be as low as reasonably achievable or, in other words, the confidence level must be high, because the information developed in this study will be used as a basis upon which to make decisions in remedial projects that may cost millions of dollars and require several years to implement. It is important that resources be directed at sites that are truly contaminated. To achieve the lowest uncertainty in the statistical analysis conducted as a part of this project, proper field sampling program design and sampling/analytical methodologies were required. The project team decided that the analytical data required EPA Level IV quality control and documentation and $100 \%$ data validation to ensure high quality. Preliminary screening analyses were assigned EPA Analytical Level III quality control documentation. To ensure that sample collection and field observations were performed in a manner that ensured technically complete and accurate and 
legally defensible information, these activities were conducted according to procedures that had been reviewed and approved by technical experts, knowledgeable managers, and regulators, subject to appropriate QA oversight.

It is difficult, at best, to assign a simple uncertainty constraint to this or any environmental investigation. These types of investigations differ from other experiments where uncertainty constraints are commonly used, in that little is known about the sample population (background concentration) before the experiment. In many uses of uncertainty constraints, there is some knowledge of the sample population (such as the length of a manufactured item or a combination of poker hands) before the experiment. Furthermore, while uncertainty constraints can be calculated for the end result of the data acquisition effort (the analytical results), there are several controlling aspects of an environmental investigation that do not lend themselves to quantifiable uncertainties:

1. the certainty that the sample was collected within the geologic unit for which it was intended,

2. the certainty that the sample was collected within the soil horizon for which it was intended,

3. the certainty that the sample collection locations accurately reflect the actual constituent concentrations of areally distributed soil types, and

4. the certainty that sample analyses accurately reflect the actual concentrations in the sample.

Each of the above controlling factors is based on the best professional judgment of highly qualified individuals, but even then a numerical value on these factors would be difficult to calculate objectively. Consequently, uncertainty descriptors such as high, medium, and low are recommended for the DQO process.

The uncertainty constraints that can be calculated for the BSCP are described in Appendix D of the BSCP Plan. These include probability calculations on the laboratory analyses. The analyses upon which these calculations are based were the basis for the sampling program. This program was in turn based on examination of the available data; however, the available data came from an experiment that was much different from the BSCP. Those data were collected upgradient of a known contaminant source in the Resource Conservation and Recovery Act (RCRA) investigation of the K-1070-A Contaminated Burial Ground, which is in the Knox Group. BSCP data were collected from strata that included representative soil groups but were removed from any known contaminant sources.

The quantifiable uncertainty constraints that can be made in this experiment are based on two scenarios or combinations of them: (1) concentrations will be above the detection limits of laboratory instrumentation and (2) concentrations will be below the detection limits of laboratory instruments.

In the first scenario, where many or all analytical results are above the detection limit of the laboratory instrument, the distribution, standard deviation, mean, and median were computed. Upper confidence bounds of any percentile can be computed from this information, and for this experiment, the 95 th percentile was reported. The range of the 95 th percentile will vary according to the range of the analytical results. If the analytical results for a certain constituent vary only slightly, the spread between the median and the corresponding 
95th percentile will be small. On the other hand, if the analytical results for any constituent vary considerably, then the spread between the median value and the 95 th will be large.

In the second scenario, where all analytical results are below the detection limit of the laboratory instrument, confidence bounds for detection probabilities will be reported. As discussed in Appendix D of the BSCP Plan, when the sample size is 4, as is the case in this experiment where four composited soil samples are analyzed, the $90 \%$ lower confidence bound for the probability that another composited sample would also be less than the detection limit is 0.56 . If the composited samples from different geologic units and/or horizons were combined and all have concentrations less than detection limits, thereby increasing the sample size to 12 , for example, then the $90 \%$ confidence bound would be 0.83 . However, combining the sample populations to increase sample size needs to be evaluated for technical defensibility before statements on the probabilities of doing so can be made.

A detailed explanation of statistical implications can be found in Appendix D of the BSCP Plan (Energy Systems 1992, Volume 3).

\section{Optimize Design for Obtaining Data}

The data collection design for this project is described in the BSCP Plan (Sect. 5.3, Energy Systems 1992). This design was optimized to account for variability within soils by compositing soil samples. Additional optimization was achieved by conducting field screening analyses on soils to ensure that the site was not contaminated by unrecorded disposals or inadvertent releases. The field screening analyses were supplemented by laboratory analysis for man-made contaminants that would render a site unacceptable for determining natural background concentrations.

The sampling plan was further optimized by repeating the sample collection and statistical analyses obtained on the ORR at two separate remote areas in adjacent counties. These areas were selected to ensure the same underlying geologic formations and, consequently, similar soils. This repeat analysis technique was designed to verify the results of the analysis conducted on those samples collected within the boundaries of the ORR. 


\section{PROJECT BACKGROUND AND DATA USER INFORMATION}

\section{SUMOMARY OF PROJECT ORGANIZATION}

The Background Soil Characterization Project (BSCP) is under the management of the U.S. Department of Energy (DOE) and Martin Marietta Energy Systems for the Environmental Restoration (ER) Program at Oak Ridge. Project scope is discussed in detail in the BSCP Plan (Energy Systems 1992, Volume 3). The BSCP staff organization is summarized in Fig. 2.1. Functional responsibilities for individual participants in project activities are described in the BSCP Plan (Energy Systems 1992, Volume 3). The project schedule is presented in Fig. 2.2. Individual schedule elements have been discussed previously (see Energy Systems 1992 and DOE 1993).

\section{REGULATORY INITIATIVES}

The Oak Ridge Reservation (ORR) encompasses three major installations: the Oak Ridge National Laboratory (ORNL), the Oak Ridge Y-12 Plant weapons complex, and the Oak Ridge K-25 Site (formerly referred to as the Oak Ridge Gaseous Diffusion Plant). These installations were constructed in the early to mid $1940 \mathrm{~s}$ as research, development, and process facilities in support of the Manhattan Project. These installations, along with the Paducah Gaseous Diffusion Plant in Paducah, Kentucky, and the Portsmouth Gaseous Diffusion Plant in Piketon, Ohio, are currently administered by the DOE Oak Ridge Operations Office (DOE-ORO) in Oak Ridge, Tennessee, and are managed by Martin Marietta Energy Systems, Inc.

During the construction and operation of these research, development, and process facilities, the associated decontamination, maintenance, and fabrication processes resulted in the generation of various hazardous and radioactive waste by-products. Hazardous waste treatment, storage, and disposal (TSD) facilities were created at each of the DOE-ORO facilities to handle such by-products. Some of these facilities continue to receive hazardous wastes while others are inactive or surplus. The ER Program was established to reduce the risks to human health and the environment posed by these inactive and surplus sites and facilities. All facilities under the ER Program are subject to the requirements of several laws; the relationship of the BSCP to these laws is discussed here.

- Resource Conservation and Recovery Act (RCRA). RCRA was enacted in 1976 as a system for managing hazardous wastes. It requires that TSD facilities apply for permits and meet certain operating criteria to safeguard the environment (RCRA 1976). These TSD facilities are referred to as solid waste management units (SWMUs), which are defined as any "discernible waste management unit at a RCRA facility from which hazardous waste or hazardous constituents might migrate, irrespective of whether or not the unit was intended for the management of solid or hazardous waste." Such units include any area at a facility at which hazardous wastes or hazardous constituents have been routinely and systematically released (EPA 1989a). 


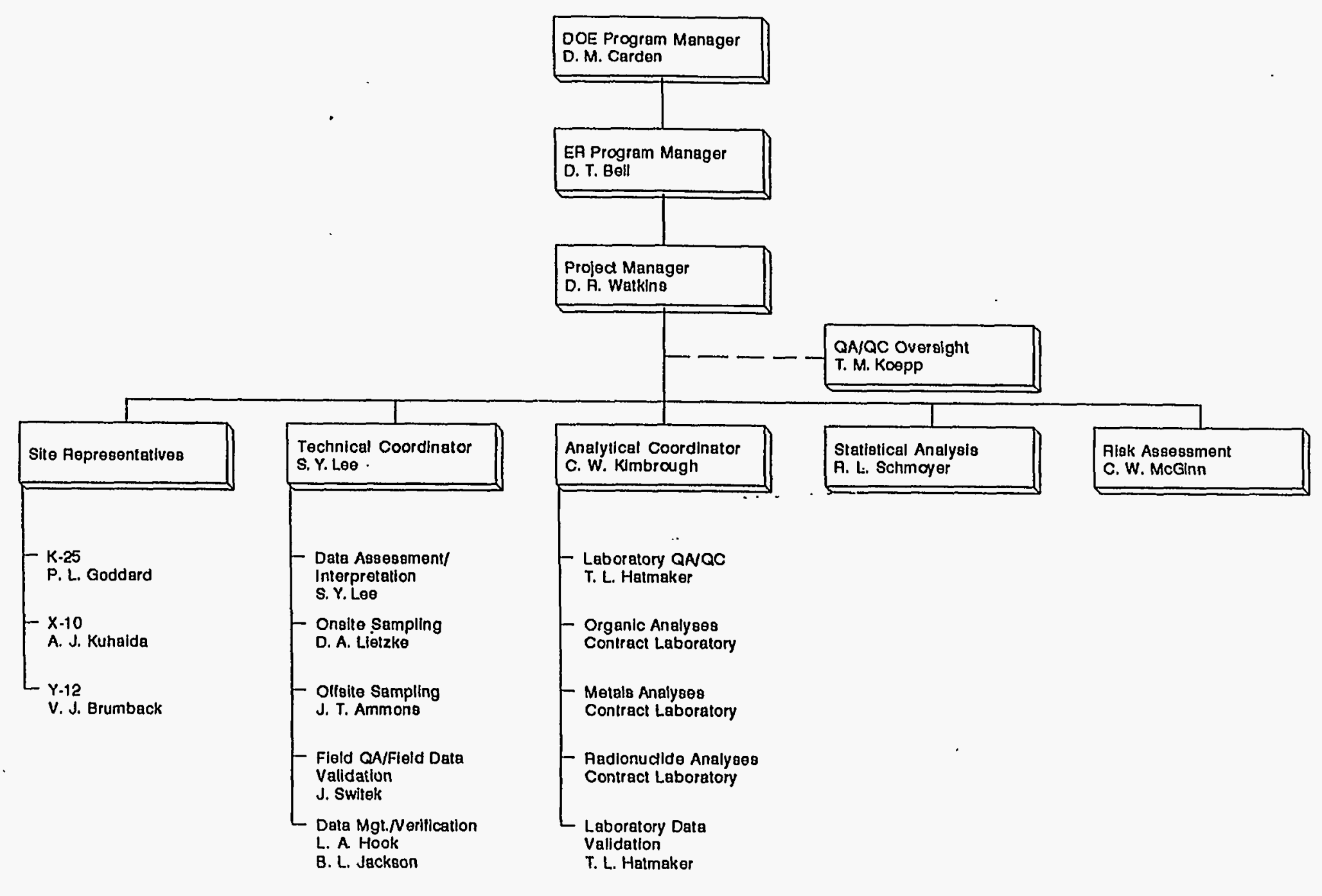

Fig. 2.1. Staff organization of the BSCP. 


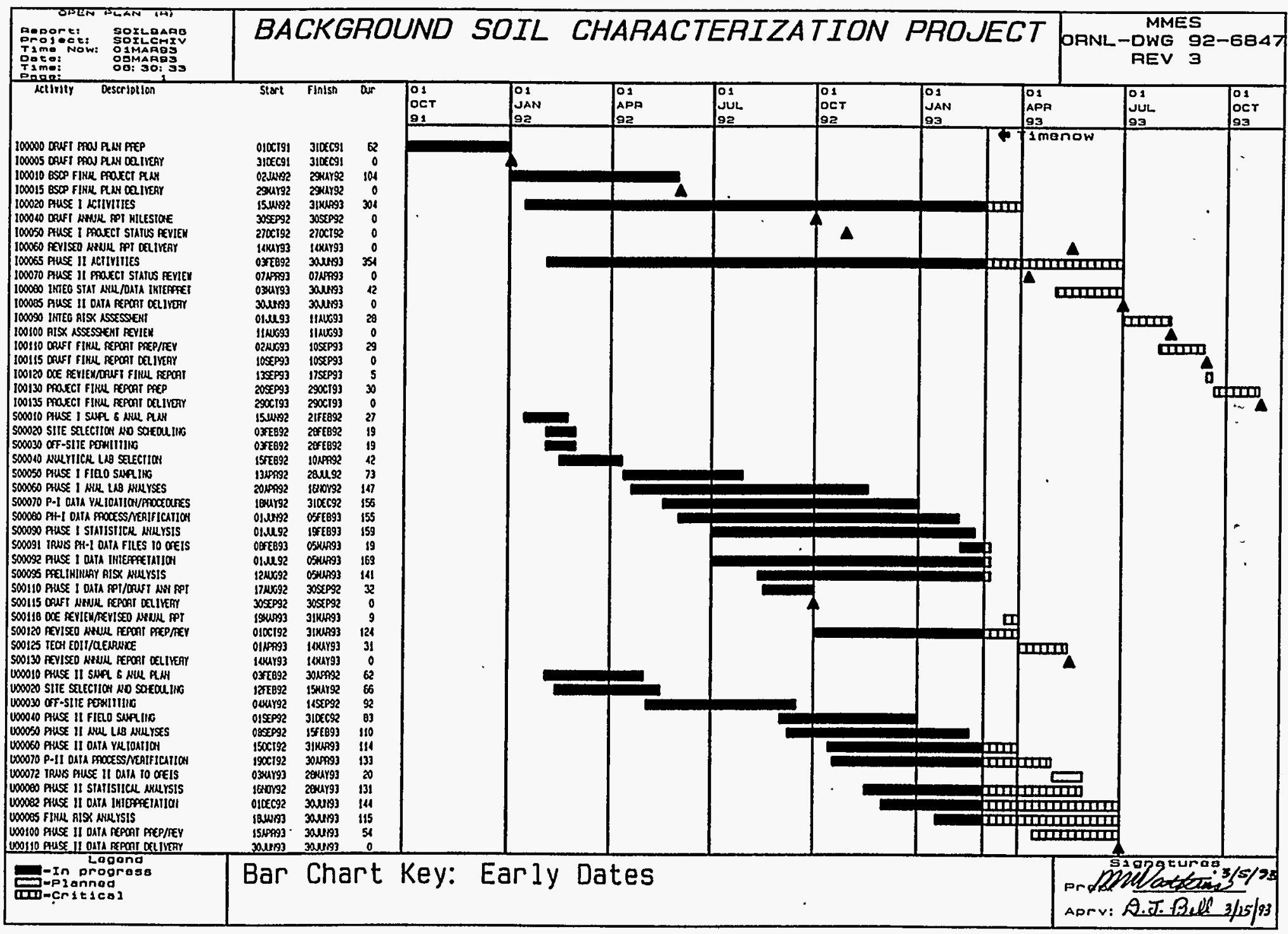

Fig. 2.2 BSCP schedule. 
- Hazardous and Solid Waste Amendments (HSWA). These amendments to RCRA were enacted in 1984 and provided the U.S. Environmental Protection Agency (EPA) with the authority to enforce corrective actions by broadening the scope of the RCRA Corrective Action Program. In addition to evaluating and correcting releases to the uppermost aquifer from regulated RCRA units, HSWA promotes the cleanup of continuing releases to any environmental media resulting from waste management units and practices at RCRA facilities (HSWA 1984). Among the most significant provisions of HSWA are the following:

1. Section 3004(u), Corrective Action for Continuing Releases. Section 3004(u) states that for permits issued after November 8, 1984, corrective action is required for releases of hazardous waste or constituents from any SWMU at any TSD facility seeking a permit for permanent operation, regardless of when waste was placed in the unit. Thus, corrective actions apply to current as well as past releases.

2. Section 3004(v), Corrective Action Beyond the Facility Boundary. Section 3004(v) authorizes EPA to require that corrective action be taken by the facility owner or operator for releases that have migrated off-site beyond the facility boundary. Such action should be taken where necessary to protect human health and the environment unless the owner/operator demonstrates to the satisfaction of the administrator that permission to undertake such action was denied.

- Comprehensive Environmental Response, Compensation, and Liability Act (CERCLA), also referred to as Superfund. Created in 1980, CERCLA established a program to identify sites (operable units) from which environmental releases of hazardous substances might occur or have occurred. At such sites, Superfund promotes the evaluation of damage to natural resources, ensures cleanup by the responsible party or the government, and creates a claims procedure for parties involved in site cleanup and natural resource reclamation. Sites identified by CERCLA are evaluated and then placed on the National Priorities List (NPL), if appropriate. The ORR was listed on the NPL in December 1989 in the Federal Register (54 FR 48184) (EPA 1989b).

- Superfund Amendments and Reauthorization Act (SARA). This act was created in 1986 as a 5-year extension of the Superfund/CERCLA program to clean up hazardous releases at uncontrolled or abandoned hazardous waste sites.

- National Environmental Policy Act (NEPA). Created in 1968, NEPA directs public officials to consider the impacts of their actions (e.g., construction, remediation) on the human environment as a part of all decision-making processes.

When the ORR was placed on the NPL, CERCLA became the primary regulatory driver for environmental studies and cleanup actions. Part of the requirements of CERCLA are that remedial actions be based on nine criteria: (1) overall protection of human health and the environment; (2) compliance with applicable, or relevant and appropriate requirements; (3) long-term effectiveness and permanence; (4) reduction of toxicity, mobility, or volume through treatment; (5) short-term effectiveness; (6) implementability; (7) cost; (8) state acceptance; and (9) community acceptance. To determine whether or not proposed remedial activities for contaminated sites can meet these criteria, the concentration of suspected contaminants must be compared with the concentrations of those same constituents in natural environments. The purpose of the BSCP is to determine the background concentrations of all key organics, 
inorganics (metals), and radionuclides in soils in the Oak Ridge area so that they could be used for comparing the concentrations found at contaminated sites undergoing remedial investigation under CERCLA. Key constituents are those that are of interest to ongoing, as well as anticipated, remedial actions and investigations.

\section{DATA MANAGEMENT AND VERIFICATION}

\subsection{Responsibilities for Data Management and Verification}

Records of data collection and analysis of samples for the BSCP are generated by field and laboratory personnel. The BSCP data base, using SAS ${ }^{1}$ software, has been established on a mainframe computer system at ORNL. The purpose of the data base is to provide retrievability, integrity, security, and organization of the data, according to the data management plan (Sect. 7) in the BSCP Plan (Energy Systems 1992). All project data have been verified to be correct and representative of the background soil sampling sites, validated against project requirements, and assessed for compliance with project data quality objectives. All validated project data packages from the contract laboratories were verified by data management personnel to be correct as input into the project data base and cross-checked with field records to corroborate the one-to-one correspondence of laboratory results with field sampling sites from where soil samples were originally obtained.

Field data were verified in two ways. First, field activities were subject to surveillances and were found to be satisfactory with regard to in-force standard operating procedures (SOPs). Early on the SOPs needed to be refined to ensure that all items specified in the BSCP Plan were accounted for. Second, this required that all field records for sampling be reviewed site-by-site and checked for completeness against the ESP-500 procedures, as called for in the BSCP Plan. These records were found to be complete but lacked an index or user's guide (see Sect. 2.3 of the BSCP Plan). Validation of analytical laboratory data is discussed fully in Sect. 4.5 .

Data summaries, statistical analysis, risk evaluation, and availability of data are discussed briefly in this section. Programs have been developed to provide working data reports to the technical coordinator, analytical coordinator, field operations personnel, and in-house laboratory personnel. These working reports are available throughout the project and facilitate accurate record keeping and status reporting of progress.

\subsubsection{Data Storage and Records Management}

The BSCP data base is cataloged and resides on a disk pool volume on the IBM 3090 computer system at ORNL. A partitioned data set of source programs is cataloged and resides on the disk pool volume. Read, write, execute, and delete accesses to these data sets are restricted. Daily and weekly backups are performed. Working data sets may be accessed on PC diskette, PC fixed disk, the STC10 VAX, or UNIX workstation. However, all data appear in final form in the SAS data base on the IBM 3090.

\footnotetext{
'SAS is the registered trademark of the SAS Institute, Inc., Cary, North Carolina.
} 
The following field data records and laboratory analysis records have been entered or transferred to the SAS data base:

- field sample tracking information entered from ORNL Environmental Sciences Division (ESD) and University of Tennessee sampling crew field sample logbooks and from sample compositing/sample processing laboratory logbooks;

- gamma sample laboratory parameter information, activity measurements, and concentration summaries transferred from diskettes provided by the ESD Radioanalytical Laboratory;

- volatile organic analysis screening results provided by the Y-12 Plant analytical laboratory, which were transferred to and included in the SAS data base;

- organic (pesticides, PCBs, herbicides, and PAHs) sample laboratory information and concentration levels entered from analysis data sheets provided by Lockheed Analytical Services;

- inorganic sample laboratory information and concentrations entered from analysis data sheets provided by Lockheed Analytical Services; and

- radionuclide sample laboratory parameter information, concentrations, and detection limits entered from analysis data sheets provided by Ecotek Laboratory Services, Inc.

Data sets of analytical laboratory results were provided to the statistical coordinator for conducting statistical analysis, generating data summaries, and performing data reduction. The statistical coordinator in turn provided data summaries to the risk evaluation coordinator. Baseline risk to human health was calculated for later use in comparison of risks associated with contaminated sites.

Validated and verified analytical data and field data will be transferred to the Oak Ridge Environmental Information System (OREIS) with the approval of the project manager. Other ER Division projects needing background soil concentration data may access data from OREIS.

The complete summary printout showing types of analyses (except gamma screening data) is provided in Table 2.1 .

\subsection{DATA USER GUIDELINES}

\subsubsection{How To Use Data-A Field Perspective}

The purpose of this section is to advise data users on how to use the BSCP data base. The BSCP Plan (Energy Systems 1992) discussed the approach for site selection and sampling requirements. Reading the plan will help in understanding the objectives and the scope of activities. If your intended use of background soils data is beyond the scope of the BSCP Plan, you must develop scientific rationale to justify such use. Users are advised to read the entire text of this report instead of just the data summaries appearing in Sect. 5 and Appendixes B through $\mathrm{G}$. 
Table 2.1. Soil horizons and sample designations for Phase I and II

\begin{tabular}{|c|c|c|c|c|c|c|c|c|c|c|c|c|c|c|c|}
\hline Site & Horizon & Phase & $\begin{array}{c}\text { Field } \\
\text { duplicate }\end{array}$ & $\begin{array}{l}\text { Lab } \\
\text { split }\end{array}$ & PAH & Herbicides & $\begin{array}{l}\text { Pesticides } \\
\text { PCBs }\end{array}$ & $\begin{array}{c}\text { ICP } \\
\text { metals }\end{array}$ & $\begin{array}{c}\mathrm{AA} \\
\text { metals }\end{array}$ & Sulfate & Cyanide & $\begin{array}{l}\text { Gamma } \\
\text { emitters }\end{array}$ & Tritium & $\begin{array}{l}\text { Alpha } \\
\text { emitters }\end{array}$ & $\begin{array}{c}\text { Beta } \\
\text { emitters }\end{array}$ \\
\hline & \multicolumn{13}{|c|}{ Location=AND; Formation=COPPER RIDGE } & \multicolumn{2}{|c|}{$\therefore$} \\
\hline 31 & $\mathbf{A}$ & 2 & & & 2257 & 2257 & 2257 & & & & & & & & \\
\hline $31,32,36$ & A & 2 & & & & & & 7057 & 7057 & 7057 & 7057 & 7058 & & 7058 & 7058 \\
\hline $31,32,36$ & B & 2 & & & & & & 7060 & 7060 & 7060 & 7060 & 7061 & & 7061 & 7061 \\
\hline $31,32,36$ & c & 2 & & & & & & 7063 & 7063 & 7063 & 7063 & 7064 & & 7064 & 7064 \\
\hline 32 & A & 2 & & & 2259 & 2259 & 2259 & & & & & & 2260 & \multicolumn{2}{|c|}{ - } \\
\hline 33 & A & 2 & & & 2262 & 2262 & 2262 & & & & & & 2263 & & 7084 \\
\hline $33,34,35$ & A & 2 & & Split 1 & & & & 7046 & 7046 & 7046 & 7046 & 7048 & & 7048 & 7048 \\
\hline $33,34,35$ & A & 2 & & Split 2 & & & & 7047 & 7047 & 7047 & 7047 & 7049 & & 7049 & 7049 \\
\hline $33,34,35$ & B & 2 & & & & & & 7051 & 7051 & 7051 & 7051 & 7052 & & 7052 & 7052 \\
\hline $33,34,35$ & C & 2 & & & & & & 7054 & 7054 & 7054 & 7054 & 7055 & & 7055 & 7055 \\
\hline 34 & A & 2 & & & 2265 & 2265 & 2265 & & & & & & 2266 & & 7085 \\
\hline 35 & $\mathbf{A}$ & 2 & & & 2268 & 2268 & 2268 & & & & & & 2269 & 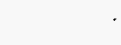 & \\
\hline 36 & A & 2 & & & 2271 & 2271 & 2271 & & & & & & & \multirow{2}{*}{\multicolumn{2}{|c|}{$\therefore$}} \\
\hline 37 & A & 2 & & & 2273 & 2273 & 2273 & & & & & & & & \\
\hline $37,38,41$ & $\mathbf{A}$ & 2 & & & & & & 7075 & 7075 & 7075 & 7075 & 7076 & & \multicolumn{2}{|c|}{$7076 \quad 7076$} \\
\hline $37,38,41$ & B & 2 & & & & & & 7078 & 7078 & 7078 & 7078 & 7079 & & \multicolumn{2}{|c|}{$7079 \quad 7079$} \\
\hline $37,38,41$ & C & 2 & & & & & & 7081 & 7081 & 7081 & 7081 & 7082 & & \multirow[t]{2}{*}{7082} & 7082 \\
\hline 38 & A & 2 & & & 2275 & 2275 & 2275 & & & & & & & & \\
\hline 39 & $\mathbf{A}$ & 2 & & & 2277 & 2277 & 2277 & & & & & . & & \multicolumn{2}{|c|}{$\therefore$} \\
\hline $39,40,42$ & A & 2 & & & & & & 7066 & 7066 & 7066 & 7066 & 7067 & & \multirow{3}{*}{\multicolumn{2}{|c|}{$\begin{array}{ll}7067 & 7067 \\
7070 & 7070 \\
7073 & 7073\end{array}$}} \\
\hline $39,40,42$ & B & 2 & & & & & & 7069 & 7069 & 7069 & 7069 & 7070 & & & \\
\hline $39,40,42$ & C & 2 & & & & & & 7072 & 7072 & 7072 & 7072 & 7073 & & & \\
\hline 40 & $\mathbf{A}$ & 2 & & & 2279 & 2279 & 2279 & & & & & & & 7073 & 7073 \\
\hline 41 & A & 2 & & & 2281 & 2281 & 2281 & & & & & & & \\
\hline 42 & A & 2 & & & 2283 & 2283 & 2283 & & & & & & & & \\
\hline
\end{tabular}


Table 2.1 (continued)

\begin{tabular}{|c|c|c|c|c|c|c|c|c|c|c|c|c|c|c|c|}
\hline Site & Horizon & Phase & $\begin{array}{c}\text { Field } \\
\text { duplicate }\end{array}$ & $\begin{array}{l}\text { Lab } \\
\text { split }\end{array}$ & PAH & Herbicides & $\begin{array}{c}\text { Pesticides } \\
\text { PCBs }\end{array}$ & $\begin{array}{c}\mathrm{ICP} \\
\text { metals }\end{array}$ & $\underset{\text { metals }}{\mathrm{AA}}$ & Sulfate & Cyanide & $\begin{array}{l}\text { Gamma } \\
\text { cmitters }\end{array}$ & Tritium & $\begin{array}{l}\text { Alpha } \\
\text { emitters }\end{array}$ & $\begin{array}{c}\text { Beta } \\
\text { emitters }\end{array}$ \\
\hline \multicolumn{16}{|c|}{ Location=AND; Fonmation=DISMAL GAP } \\
\hline 1 & A & 1 & & & 2157 & & 2157 & & & & & & & & \\
\hline $1,20,22$ & $\mathbf{A}$ & 1 & & & & & & 7028 & 7028 & 7028 & 7028 & 7029 & & 7029 & 7029 \\
\hline $1,20,22$ & B & 1 & & & & & & 7031 & 7031 & 7031 & 7031 & 7032 & & 7032 & 7032 \\
\hline $1,20,22$ & C & 1 & & & & & & 7034 & 7034 & 7034 & 7034 & 7035 & & 7035 & 7035 \\
\hline 10 & A & 1 & & & 2143 & & 2143 & & & & & & & & \\
\hline 11 & A & 1 & & & 2112 & & 2112 & & & & & & & & \\
\hline 12 & A & 1 & & & 2080 & & 2080 & & & & & & & & \\
\hline 19 & A & 1 & & & 2116 & & 2116 & & & & & & & & \\
\hline 19 & A & 1 & FD & & 2120 & & 2120 & & & & & & & & \\
\hline 20 & A & 1 & & & 2070 & & 2070 & & & & & & & & \\
\hline 21 & A & 1 & & & 2101 & & 2101 & & & & & & & & \\
\hline 22 & A & 1 & & & 2090 & & 2090 & & & & & & & & \\
\hline 3 & A & 1 & & & 2059 & & 2059 & & & & & & & & \\
\hline 3 & A & 2 & & 、 & & & & & & & & & & & 7087 \\
\hline $3,5,11$ & $\mathbf{A}$ & 1 & & & & & & 7010 & 7010 & 7010 & 7010 & 7011 & & 7011 & 7011 \\
\hline $3,5,11$ & B & 1 & & & & & & 7013 & 7013 & 7013 & 7013 & 7014 & & 7014 & 7014 \\
\hline $3,5,11$ & C & 1 & & & & & & 7016 & 7016 & 7016 & 7016 & 7017 & & 7017 & 7017 \\
\hline 4 & $A$ & 1 & & & 2039 & & 2039 & & & & & & & & \\
\hline 4 & A & 2 & & & & & & & & & & & & & 7088 \\
\hline 4 & A & 2 & FD & & & & & & & & & & & & 7089 \\
\hline $4,12,21$ & $A$ & 1 & & & & & & 7019 & 7019 & 7019 & 7019 & 7020 & & 7020 & 7020 \\
\hline $4,12,21$ & B & 1 & & & & & & 7022 & 7022 & 7022 & 7022 & 7023 & & 7023 & 7023 \\
\hline $4,12,21$ & C & 1 & & & & & & 7025 & 7025 & 7025 & 7025 & 7026 & & 7026 & 7026 \\
\hline 5 & A & 1 & & & 2149 & & 2149 & & & & & & & & \\
\hline 9 & $A$ & 1 & & & 2130 & & 2130 & & & & & & & & \\
\hline $9,10,19$ & A & 1 & & & & & & 7001 & 7001 & 7001 & 7001 & 7002 & & 7002 & 7002 \\
\hline $9,10,19$ & $A$ & 1 & $\mathbf{F}$ & & & & & 7037 & 7037 & 7037 & 7037 & 7038 & & 7038 & 7038 \\
\hline $9,10,19$ & B & 1 & & & & & & 7004 & 7004 & 7004 & 7004 & 7005 & & 7005 & 7005 \\
\hline $9,10,19$ & B & 1 & $F D$ & & & & & 7040 & 7040 & 7040 & 7040 & 7041 & & 7041 & 7041 \\
\hline $9,10,19$ & C & 1 & & & & & & 7007 & 7007 & 7007 & 7007 & 7008 & & 7008 & 7008 \\
\hline $9,10,19$ & $\mathrm{C}$ & 1 & FD & & & & & 7043 & 7043 & 7043 & 7043 & 7044 & & 7044 & 7044 \\
\hline
\end{tabular}


Table 2.1 (continued)

\begin{tabular}{|c|c|c|c|c|c|c|c|c|c|c|c|c|c|c|c|}
\hline Site & Horizon & Phase & $\begin{array}{c}\text { Field } \\
\text { duplicate }\end{array}$ & $\begin{array}{l}\text { Lab } \\
\text { split }\end{array}$ & PAH & Herbicides & $\begin{array}{l}\text { Pesticides } \\
\text { PCBs }\end{array}$ & $\begin{array}{c}\text { ICP } \\
\text { metals }\end{array}$ & $\begin{array}{c}\mathrm{AA} \\
\text { metals }\end{array}$ & Sulfate & Cyanide & $\begin{array}{l}\text { Gamma } \\
\text { emitters }\end{array}$ & Tritium & $\begin{array}{l}\text { Alpha } \\
\text { emitters }\end{array}$ & $\begin{array}{c}\text { Beta } \\
\text { emitters }\end{array}$ \\
\hline
\end{tabular}

Location=ORR; Formation=CHEPULTEPEC

50

$50,66,73$

$50,66,73$

$50,66,73$

$50,66,73$

$50,66,73$

$50,66,73$

$50,66,73$

$50,66,73$

$52,53,78$

$52,53,78$

$52,53,78$

53

66

68

$68,74,90$

$68,74,90$

$68,74,90$

$68,74,90$

73

74

$77,85,86$

$77,85,86$

$77,85,86$

$77,85,86$

$77,85,86$

$77,85,86$

78

85

86

\begin{tabular}{ll} 
A & 2 \\
A & 2 \\
A & 2 \\
A & 2 \\
A & 2 \\
B & 2 \\
B & 2 \\
C & 2 \\
C & 2 \\
A & 2 \\
B & 2 \\
C & 2 \\
A & 2 \\
A & 2 \\
A & 2 \\
A & 2 \\
A & 2 \\
B & 2 \\
C & 2 \\
A & 2 \\
A & 2 \\
A & 2 \\
A & 2 \\
A & 2 \\
B & 2 \\
B & 2 \\
C & 2 \\
C & 2 \\
A & 2 \\
A & 2 \\
A & 2 \\
A & 2 \\
A & 2 \\
& \\
\hline
\end{tabular}

1548

$\begin{array}{ll} & \text { Split 1 } \\ & \text { Split 2 } \\ \text { FD } & \text { Split 1 } \\ \text { FD } & \text { Split 2 }\end{array}$

FD

FD

FD

FD

FD

Split 1

Split 2

Split 1

Split 2

1744
1549

$\begin{array}{lllll}5165 & 5165 & 5165 & 5165 & 5167 \\ \mathbf{5 1 6 6} & 5166 & 5166 & 5166 & 5168 \\ 5173 & 5173 & 5173 & 5173 & 5175 \\ 5174 & 5174 & 5174 & 5174 & 5176 \\ 5170 & 5170 & 5170 & 5170 & 5171 \\ 5178 & 5178 & 5178 & 5178 & 5179 \\ 5181 & 5181 & 5181 & 5181 & 5182 \\ 5184 & 5184 & 5184 & 5184 & 5185 \\ 5127 & 5127 & 5127 & 5127 & 5128 \\ 5130 & 5130 & 5130 & 5130 & 5131 \\ 5133 & 5133 & 5133 & 5133 & 5134\end{array}$

$\begin{array}{ll}5167 & 5167 \\ 5168 & 5168 \\ 5175 & 5175 \\ 5176 & 5176 \\ 5171 & 5171 \\ 5179 & 5179 \\ 5182 & 5182 \\ 5185 & 5185 \\ 5128 & 5128 \\ 5131 & 5131 \\ 5134 & 5134\end{array}$

1739

$\begin{array}{lll}1738 & 1738 & 1738\end{array}$

$\begin{array}{lll}1741 & 1741 & 1741\end{array}$

$$
515
$$

$5154 \quad 5154,5154$

$5159 \quad 5159$

5159

5154

5155

5159

5156

5157

5160

5163

1744

1746

$\begin{array}{lllll}5136 & 5136 & 5136 & 5136 & 5137 \\ 5145 & 5145 & 5145 & 5145 & 5146 \\ 5139 & 5139 & 5139 & 5139 & 5140 \\ 5148 & 5148 & 5148 & 5148 & 5149 \\ 5142 & 5142 & 5142 & 5142 & 5143 \\ 5151 & 5151 & 5151 & 5151 & 5152\end{array}$

1747

$$
\begin{array}{ll} 
& 4272 \\
5156 & 5156
\end{array}
$$

-5157 5157

$5160 \quad 5160$

$5163 \quad 5163$

4273

$5137 \quad 4276$

$\begin{array}{ll}5137 & 5137 \\ 5146 & 5146\end{array}$

$5140 \quad 5140$

$5149 \quad 5149$

$5143 \quad 5143$

$5152+5152$

1607

4277

4278

4279 
Table 2.1 (continued)

\begin{tabular}{|c|c|c|c|c|c|c|c|c|c|c|c|c|c|c|c|}
\hline Site & Horizon & Phase & $\begin{array}{c}\text { Field } \\
\text { duplicate }\end{array}$ & $\begin{array}{l}\text { Lab } \\
\text { split }\end{array}$ & PAH & Herbicides & $\begin{array}{l}\text { Pesticides } \\
\text { PCBs }\end{array}$ & $\begin{array}{c}\text { ICP } \\
\text { metals }\end{array}$ & $\begin{array}{c}\text { AA } \\
\text { metals }\end{array}$ & Sulfate & Cyanide & $\begin{array}{l}\text { Gamma } \\
\text { emitters }\end{array}$ & Tritium & $\begin{array}{c}\text { Alpha } \\
\text { emitters }\end{array}$ & $\begin{array}{c}\text { Beta } \\
\text { emitters }\end{array}$ \\
\hline \multicolumn{16}{|c|}{ Location=ORR; Formation=CHICKAMAUGA Bethel V } \\
\hline 100 & A & 2 & & & 1906 & & 1906 & & & & & & 4218 & & \\
\hline 101 & A & 2 & & & 1897 & 1897 & 1897 & & & & & & 4219 & & \\
\hline 101 & $\mathbf{A}$ & 2 & & Split 1 & & & & & & & & & & & 4281 \\
\hline 101 & A & 2 & & Split 2 & & & & & & & & & & & 4282 \\
\hline $101,102,103$ & A & 2 & & & & & & 5196 & 5196 & 5196 & 5196 & 5197 & & 5197 & 5197 \\
\hline $101,102,103$ & B & 2 & & & & & & 5199 & 5199 & 5199 & 5199 & 5200 & & 5200 & \\
\hline $101,102,103$ & C & 2 & & & & & & 5202 & 5202 & 5202 & 5202 & 5203 & & 5203 & \\
\hline 102 & A & 2 & & & 1894 & & 1894 & & & & & & 4220 & & 4283 \\
\hline 103 & A & 2 & & & 1891 & 1891 & 1891 & & & & & & 4221 & & 4284 \\
\hline 104 & A & 2 & & & 1964 & 1964 & 1964 & & 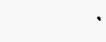 & & & & 1965 & & \\
\hline $104,108,110$ & A & 2 & & & & & & 5205 & 5205 & 5205 & 5205 & 5206 & & 5206 & 5206 \\
\hline $104,108,110$ & B & 2 & & & & & & 5208 & 5208 & 5208 & 5208 & 5209 & & 5209 & 5209 \\
\hline $104,108,110$ & C & 2 & & & & & & 5211 & 5211 & 5211 & 5211 & 5212 & & 5212 & 5212 \\
\hline 108 & A & 2 & & & 1967 & & 1967 & & & & & & 1968 & & \\
\hline 110 & A & 2 & & & 1970 & 1970 & 1970 & & & & & & 1971 & & \\
\hline 115 & A & 2 & & & 1973 & & 1973 & & & & & & 1974 & & \\
\hline $115,116,117$ & A & 2 & & Split 1 & & & & 5216 & 5216 & 5216 & 5216 & 5218 & & 5218 & 5218 \\
\hline $115,116,117$ & $A$ & 2 & & Split 2 & & & & 5217 & 5217 & 5217 & 5217 & 5219 & & 5219 & 5219 \\
\hline $115,116,117$ & B & 2 & & & & & & 5222 & 5222 & 5222 & 5222 & 5223 & & 5223 & 5223 \\
\hline $115,116,117$ & C & 2 & & & & & & 5225 & 5225 & 5225 & 5225 & 5226 & & 5226 & 5226 \\
\hline 116 & A & 2 & & & 1976 & 1976 & 1976 & & & & & & 1977 & & 4285 \\
\hline 117 & $A$ & 2 & & & 1979 & & 1979 & & & & & & 1980 & & 4286 \\
\hline 93 & A & 2 & & & 1900 & & 1900 & & & & & & 4216 & & \\
\hline $93,99,100$ & A & 2 & & & & & & 5187 & 5187 & 5187 & 5187 & 5188 & & 5188 & 5188 \\
\hline $93,99,100$ & B & 2 & & & & & & 5190 & 5190 & 5190 & 5190 & 5191 & & 5191 & 5191 \\
\hline $93,99,100$ & C & 2 & & & & & & 5193 & 5193 & 5193 & 5193 & 5194 & & 5194 & 5194 \\
\hline 99 & A & 2 & & & 1903 & 1903 & 1903 & & & & & & 4217 & & 4280 \\
\hline
\end{tabular}


Table 21 (continued)

\begin{tabular}{|c|c|c|c|c|c|c|c|c|c|c|c|c|c|c|c|}
\hline Site & Horizon & Phase & $\begin{array}{c}\text { Field } \\
\text { duplicate }\end{array}$ & $\begin{array}{l}\text { Lab } \\
\text { split }\end{array}$ & PAH & Herbicides & $\begin{array}{l}\text { Pesticides } \\
\text { PCBs }\end{array}$ & $\begin{array}{c}\text { ICP } \\
\text { metals }\end{array}$ & $\begin{array}{c}\text { AA } \\
\text { metals }\end{array}$ & Sulfate & Cyanide & $\begin{array}{l}\text { Gamma } \\
\text { emitters }\end{array}$ & Tritium & $\begin{array}{c}\text { Alpha } \\
\text { emitters }\end{array}$ & $\begin{array}{c}\text { Beta } \\
\text { emitters }\end{array}$ \\
\hline
\end{tabular}

Location=ORR; Formation=CHICKAMAUGA K-25

$\begin{array}{lll}118 & \text { A } & 2 \\ 118,122,124 & \text { A } & 2 \\ 118,122,124 & \text { A } & 2 \\ 118,122,124 & \text { B } & 2 \\ 118,122,124 & \text { C } & 2 \\ 119 & \text { A } & 2 \\ 119,123,127 & \text { A } & 2 \\ 119,123,127 & \text { A } & 2 \\ 119,123,127 & \text { B } & 2 \\ 119,123,127 & \text { C } & 2 \\ 120 & \text { A } & 2 \\ 120,126,129 & \text { A } & 2 \\ 120,126,129 & \text { A } & 2 \\ 120,126,129 & \text { B } & 2 \\ 120,126,129 & \text { C } & 2 \\ 121 & \text { A } & 2 \\ 121,125,128 & \text { A } & 2 \\ 121,125,128 & \text { A } & 2 \\ 121,125,128 & \text { B } & 2 \\ 121,125,128 & \text { C } & 2 \\ 122 & \text { A } & 2 \\ 123 & \text { A } & 2 \\ 124 & \text { A } & 2 \\ 125 & \text { A } & 2 \\ 126 & \text { A } & 2 \\ 127 & \text { A } & 2 \\ 128 & \text { A } & 2 \\ 129 & \text { A } & 2\end{array}$

$\begin{array}{llll} & 4095 & 4095 & 4095 \\ \text { Split 1 } & & & \\ \text { Split 2 } & & & \\ & & & \\ & & & \\ \text { Split 1 } & 4127 & & \\ \text { Split 2 } & & & \\ & & & \\ & & & \\ \text { Split 1 } & 4092 & 4092 & \\ \text { Split 2 } & & & \\ & & & \\ & & & \\ & 4129 & & 4129 \\ \text { Split 1 } & & & \\ \text { Split 2 } & & & \\ & & & \\ & & & \\ & & & \\ & 4105 & 4105 & 4105 \\ & 4131 & & 4131 \\ & 4115 & 4115 & 4115 \\ & 4133 & & 4133 \\ & 4089 & & 4089 \\ & 4135 & & 4135 \\ & 4137 & & 4137 \\ & 4086 & 4086 & 4086\end{array}$

4096

$\begin{array}{lll}5240 & 5240 & 5240 \\ 5241 & 5241 & 5241 \\ 5246 & 5246 & 4246 \\ 5249 & 5249 & 5249 \\ & & \\ 5252 & 5252 & 5252 \\ 5253 & 5253 & 5253 \\ 5257 & 5257 & 5257 \\ 5260 & 5260 & 5260 \\ & & \\ 5228 & 5228 & 5228 \\ 5229 & 5229 & 5229 \\ 5234 & 5234 & 5234 \\ 5237 & 5237 & 5237 \\ & & \\ 5263 & 5263 & 5263 \\ 5264 & 5264 & 5264 \\ 5268 & 5268 & 5268 \\ 5271 & 5271 & 5271\end{array}$

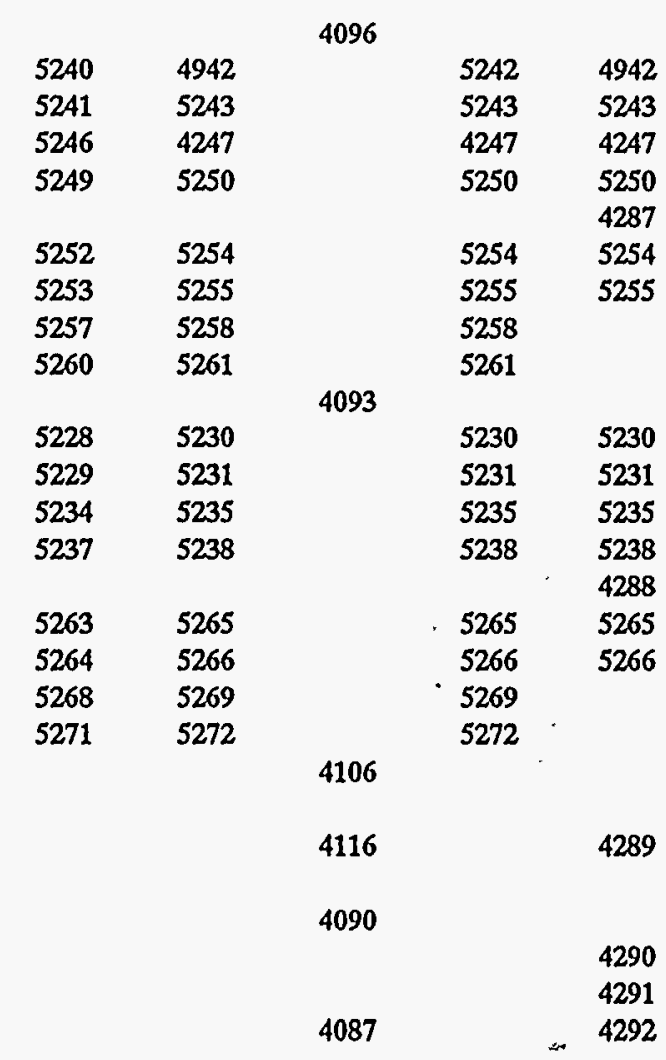


Table 2.1 (continued)

\begin{tabular}{|c|c|c|c|c|c|c|c|c|c|c|c|c|c|c|c|}
\hline Sile & Horizon & Phase & $\begin{array}{c}\text { Field } \\
\text { duplicate }\end{array}$ & $\begin{array}{l}\text { Lab } \\
\text { split }\end{array}$ & PAH & Herbicides & $\begin{array}{c}\text { Pesticides } \\
\text { PCBs }\end{array}$ & $\begin{array}{c}\text { ICP } \\
\text { metals }\end{array}$ & $\begin{array}{c}\text { AA } \\
\text { metals }\end{array}$ & Sulfate & Cyanide & $\begin{array}{l}\text { Gamma } \\
\text { emitters }\end{array}$ & Tritium & $\begin{array}{c}\text { Alpha } \\
\text { emitters }\end{array}$ & $\begin{array}{c}\text { Beta } \\
\text { emitters }\end{array}$ \\
\hline \multicolumn{16}{|c|}{ Location=ORR; Formation=COPPER RIDGE } \\
\hline 45 & A & 2 & & & 1544 & & & & & & & & & & \\
\hline $45,60,75$ & $A$ & 2 & & & & & & 5109 & 5109 & 5109 & 5109 & 5110 & & 5110 & 5110 \\
\hline $45,60,75$ & B & 2 & & & & & & 5112 & 5112 & 5112 & 5112 & 5113 & & 5113 & \\
\hline $45,60,75$ & $\mathrm{C}$ & 2 & & & & & & 5115 & 5115 & 5115 & & 5116 & & 5116 & \\
\hline 51 & $\mathbf{A}$ & 2 & & & 1546 & & & & & & & & & & 4267 \\
\hline $51,55,62$ & $\mathbf{A}$ & 2 & & & & & & 5100 & 5100 & 5100 & 5100 & 5101 & & 5101 & 5101 \\
\hline $51,55,62$ & B & 2 & & & & & & $5 i 04$ & 5104 & 5104 & 5104 & 5103 & & 5103 & 5103 \\
\hline $51,55,62$ & C & 2 & & & & & & 5106 & 5106 & 5106 & 5106 & 5107 & & 5107 & 5107 \\
\hline 54 & A & 2 & & & 1497 & & 1497 & & & & & & & & 4268 \\
\hline $54,64,83$ & A & 2 & & & & & & 5118 & 5118 & 5118 & 5118 & 5119 & & 5119 & 5119 \\
\hline $54,64,83$ & B & 2 & & & & & & 5121 & 5121 & 5121 & 5121 & 5122 & & 5122 & 5122 \\
\hline $54,64,83$ & C & 2 & & & & & & 5124 & 5124 & 5124 & 5124 & 5125 & & 5125 & 5125 \\
\hline 55 & $\mathbf{A}$ & 2 & & & 1495 & & 1495 & & & & & & & & \\
\hline 58 & A & 2 & & & 1542 & & & & & & & & & & \\
\hline $58,59,91$ & A & 2 & & & & & & 5091 & 5091 & 5091 & 5091 & 5092 & & 5092 & 5092 \\
\hline $58,59,91$ & B & 2 & & & & & & 5094 & 5094 & 5094 & 5094 & 5095 & & 5095 & 5095 \\
\hline $58,59,91$ & C & 2 & & & & & & 5097 & 5097 & 5097 & 5097 & 5098 & & 5098 & 5098 \\
\hline 59 & A & 2 & & & 1491 & & 1491 & & & & & & & & \\
\hline 60 & A & 2 & & & 1493 & & 1493 & & & & & & & & 4269 \\
\hline 62 & A & 2 & & & 1480 & & 1480 & & & & & & 1481 & & 4270 \\
\hline 64 & A & 2 & & & 1483 & & 1483 & & & & & & 1484 & & 4271 \\
\hline 74 & A & 2 & & & & & & & & & & & & & 4275 \\
\hline 75 & A & 2 & & & 1477 & & 1477 & & & & & & 1478 & & \\
\hline 83 & A & 2 & & & 1474 & & 1474 & & & & & & 1475 & & \\
\hline 91 & A & 2 & & & 1471 & & 1471 & & & & & & 1472 & & \\
\hline
\end{tabular}


Table 2.1 (continued)

\begin{tabular}{|c|c|c|c|c|c|c|c|c|c|c|c|c|c|c|c|}
\hline Site & Horizon & Phase & $\begin{array}{c}\text { Field } \\
\text { duplicate }\end{array}$ & $\begin{array}{l}\text { Lab } \\
\text { split }\end{array}$ & $\mathrm{PAH}$ & Herbicides & $\begin{array}{c}\text { Pesticides } \\
\text { PCBs }\end{array}$ & $\begin{array}{c}\text { ICP } \\
\text { metals }\end{array}$ & $\begin{array}{c}\text { AA } \\
\text { metals }\end{array}$ & Sulfate & Cyanide & $\begin{array}{l}\text { Gamma } \\
\text { emitters }\end{array}$ & Tritium & $\begin{array}{l}\text { Alpha } \\
\text { emitters }\end{array}$ & $\begin{array}{c}\text { Beta } \\
\text { emitters }\end{array}$ \\
\hline \multicolumn{16}{|c|}{ Location=ORR; Formation=DISMAL GAP } \\
\hline 10 & A & 1 & & & 1127 & 1127 & 1127 & & & & & & 1128 & & \\
\hline $10,33,35$ & A & 1 & & & & & & 5019 & 5019 & 5019 & 5019 & 5020 & & 5020 & 5020 \\
\hline $10,33,35$ & B & 1 & & & & & & 5022 & 5022 & 5022 & 5022 & 5023 & & 5023 & 5023 \\
\hline $10,33,35$ & C & 1 & & & & & & 5025 & 5025 & 5025 & 5025 & 5026 & & 5026 & 5026 \\
\hline 11 & A & 1 & $\therefore$ & & 1080 & 1080 & 1080 & & & & & & 1079 & & \\
\hline $11,27,41$ & A & 1 & & & & & & 5001 & 5001 & 5001 & 5001 & 5002 & & 5002 & 5002 \\
\hline $11,27,41$ & B & 1 & & & & & & 5004 & 5004 & 5004 & 5004 & 5005 & & 5005 & 5005 \\
\hline $11,27,41$ & C & 1 & & & & & & 5007 & 5007 & 5007 & 5007 & 5008 & & 5008 & 5008 \\
\hline 19 & A & 1 & & & 1099 & 1099 & 1099 & & & & & & 1122 & & \\
\hline $19,22,32$ & A & 1 & & & & & & 5010 & 5010 & & & 5011 & & 5011 & 5011 \\
\hline $19,22,32$ & B & 1 & & & & & & 5013 & 5013 & 5013 & 5013 & 5014 & & 5014 & 5014 \\
\hline $19,22,32$ & C & 1 & & & & & & 5016 & 5016 & 5016 & 5016 & 5017 & & 5017 & 5017 \\
\hline 2 & A & 1 & & & 1190 & 1190 & 1190 & & & & & & 1189 & & \\
\hline 2 & A & 1 & FD & & 1201 & 1201 & 1201 & & & & & & 1198 & & \\
\hline 2 & A & 2 & & & & & & & & & & & & & 4255 \\
\hline $2,26,43$ & A & 1 & & & & & & 5028 & 5028 & 5028 & 5028 & 5029 & & 5029 & 5029 \\
\hline $2,26,43$ & A & 1 & FD & & & & & 5037 & 5037 & 5037 & 5037 & 5038 & & 5038 & 5038 \\
\hline $2,26,43$. & B & 1 & & & & & & 5031 & 5031 & 5031 & 5031 & 5032 & & 5032 & 5032 \\
\hline $2,26,43$ & B & 1 & FD & & & & & 5040 & $=5040$ & 5040 & 5040 & 5041 & & 5041 & 5041 \\
\hline $2,26,43$. & C & 1 & & & & & & 5034 & 5034 & 5034 & 5034 & 5035 & & 5035 & 5035 \\
\hline $2,26,43$ & C & 1 & FD & & 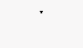 & & & 5043 & 5043 & 5043 & 5043 & 5044 & & 5044 & 5044 \\
\hline 22 & A & 1 & & & 1106 & 1106 & 1106 & & & & & & 1123 & & \\
\hline 26 & A & 1 & & & 1213 & 1213 & 1213 & & & & & & 1214 & & \\
\hline 26 & A & 2 & & & & & & & & & $\cdot$ & & & & 4260 \\
\hline 27 & A & 1 & & & 1072 & 1072 & 1072 & & & & & & 1071 & & \\
\hline 27 & A & 2 & & & & & & & & & & & & & 4261 \\
\hline 32 & A & 1 & & & 1107 & 1107 & 1107 & & & & & & 1124 & & \\
\hline 32 & A & 2 & & & & & & & . & & & & & & 4263 \\
\hline 33 & A & 1 & & & 1108 & 1108 & 1108 & & & & & & 1125 & & 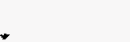 \\
\hline 33 & A & 2 & & & & & & & & & & & & & 4264 \\
\hline 35 & A & 1 & & & 1115 & 1115 & 1115 & & & & & & 1126 & & \\
\hline 41 & A & 1 & & & 1064 & 1064 & 1064 & & & & & & 1063 & & - \\
\hline 43 & A & 1 & & & 1231 & & 1231 & & & & & & & & \\
\hline 43 & A & 2 & & & & & & & & & & & & & 4265 \\
\hline
\end{tabular}


Table 2.1 (continued)

\begin{tabular}{|c|c|c|c|c|c|c|c|c|c|c|c|c|c|c|c|}
\hline Site & Horizon & Phase & $\begin{array}{c}\text { Field } \\
\text { duplicate }\end{array}$ & $\begin{array}{l}\text { Lab } \\
\text { split }\end{array}$ & PAH & Herbicides & $\begin{array}{c}\text { Pesticides } \\
\text { PCBs }\end{array}$ & $\begin{array}{c}\text { ICP } \\
\text { metals }\end{array}$ & $\begin{array}{c}\mathrm{AA} \\
\text { metals }\end{array}$ & Sulfate & Cyanide & $\begin{array}{l}\text { Gamma } \\
\text { emitters }\end{array}$ & Tritium & $\begin{array}{c}\text { Alpha } \\
\text { emitters }\end{array}$ & $\begin{array}{c}\text { Beta } \\
\text { emitters }\end{array}$ \\
\hline
\end{tabular}

Location=ORR; Formation=NOLICHUCKY

$\begin{array}{lll}13 & \text { A } & 1 \\ 13 & \text { A } & 2 \\ 15 & \text { A } & 1 \\ 15 & \text { A } & 2 \\ 15,23,25 & \text { A } & 1 \\ 15,23,25 & \text { B } & 1 \\ 15,23,25 & \text { C } & 1 \\ 16 & \text { A } & 1 \\ 16,28,42 & \text { A } & 1 \\ 16,28,42 & \text { B } & 1 \\ 16,28,42 & \text { C } & 1 \\ 21 & \text { A } & 1 \\ 21 & \text { A } & 2 \\ 23 & \text { A } & 1 \\ 24 & \text { A } & 1 \\ 24 & \text { A } & 2 \\ 24 & \text { A } & 2 \\ 25 & \text { A } & 1 \\ 28 & \text { A } & 1 \\ 28 & \text { A } & 2 \\ 3 & \text { A } & 1 \\ 3,13,24 & \text { A } & 1 \\ 3,13,24 & \text { B } & 1 \\ 3,13,24 & \text { C } & 1 \\ 31 & \text { A } & 1 \\ 42 & \text { A } & 1 \\ 5 & \text { A } & 1 \\ 5 & \text { A } & 2 \\ 5,21,31 & \text { A } & 1 \\ 5,21,31 & \text { B } & 1 \\ 5,21,31 & \text { C } & 1\end{array}$

1299

1300

1301

1296

1295

1294

Split 1

Split 2

$$
\begin{aligned}
& 1293 \\
& 1292 \\
& 1297 \\
& \\
& \\
& \\
& 1303 \\
& 1302 \\
& 1298
\end{aligned}
$$

$$
1299
$$

1300

1301

5058

5061

1301

$5064 \quad 5064$

$\begin{array}{rr}.5064 & 5064 \\ 5067 & 5067\end{array}$

$\begin{array}{ll}5067 & 5067 \\ 5070 & 5070\end{array}$

1296

1295

1294

1293

1292

1297

$\begin{array}{lllll}5082 & 5082 & 5082 & 5082 & 5083\end{array}$

$\begin{array}{lllll}5085 & 5085 & 5085 & 5085 & 5086 \\ 5088 & 5088 & 5088 & 5088 & 5089\end{array}$

1303

1302

1298
4254

4256

5056

5059

5062

5065

5068

5071

4257

$\stackrel{\stackrel{4}{A}}{\stackrel{4}{A}}$

4258

4259

4262

$5083 \quad 5083$

$5086 \quad 5086$

$5089 \quad 5089$

$\begin{array}{llllllll}5073 & 5073 & 5073 & 5073 & 5074 & & 4253 \\ 5076 & 5076 & 5076 & 5076 & 5077 & 5074 & 5074 \\ 5079 & 5079 & 5079 & 5079 & 5080 & 5077 & 5077 \\ & & & & & 5080 & 5080\end{array}$


Table 2.1 (continued)

\begin{tabular}{|c|c|c|c|c|c|c|c|c|c|c|c|c|c|c|c|}
\hline Site & Horizon & Phase & $\begin{array}{c}\text { Field } \\
\text { duplicate }\end{array}$ & $\begin{array}{l}\text { Lab } \\
\text { split }\end{array}$ & PAH & Herbicides & $\begin{array}{l}\text { Pesticides } \\
\text { PCBs }\end{array}$ & $\begin{array}{l}\text { ICP } \\
\text { metals }\end{array}$ & $\underset{\text { metals }}{\mathrm{AA}}$ & Sulfate & Cyanide & $\begin{array}{l}\text { Gamma } \\
\text { emitters }\end{array}$ & Tritium & $\begin{array}{l}\text { Alpha } \\
\text { emitters }\end{array}$ & $\begin{array}{c}\text { Beta } \\
\text { emitters }\end{array}$ \\
\hline
\end{tabular}

$\begin{array}{lll}33 & \text { A } & 2 \\ 33,35,44 & \text { A } & 2 \\ 33,35,44 & \text { B } & 2 \\ 33,35,44 & \text { C } & 2 \\ 34 & \text { A } & 2 \\ 34,39,41 & \text { A } & 2 \\ 34,39,41 & \text { A } & 2 \\ 34,39,41 & \text { B } & 2 \\ 34,39,41 & \text { C } & 2 \\ 35 & \text { A } & 2 \\ 39 & \text { A } & 2 \\ 40 & \text { A } & 2 \\ 40,42,43 & \text { A } & 2 \\ 40,42,43 & \text { B } & 2 \\ 40,42,43 & \text { C } & 2 \\ 41 & \text { A } & 2 \\ 42 & \text { A } & 2 \\ 43 & \text { A } & 2 \\ 43 & \text { A } & 2 \\ 44 & \text { A } & 2 \\ 45 & \text { A } & 2 \\ 45,46,47 & \text { A } & 2 \\ 45,46,47 & \text { A } & 2 \\ 45,46,47 & \text { B } & 2 \\ 45,46,47 & \text { B } & 2 \\ 45,46,47 & \text { C } & 2 \\ 45,46,47 & \text { C } & 2 \\ 46 & \text { A } & 2 \\ 47 & \text { A } & 2 \\ & & \end{array}$

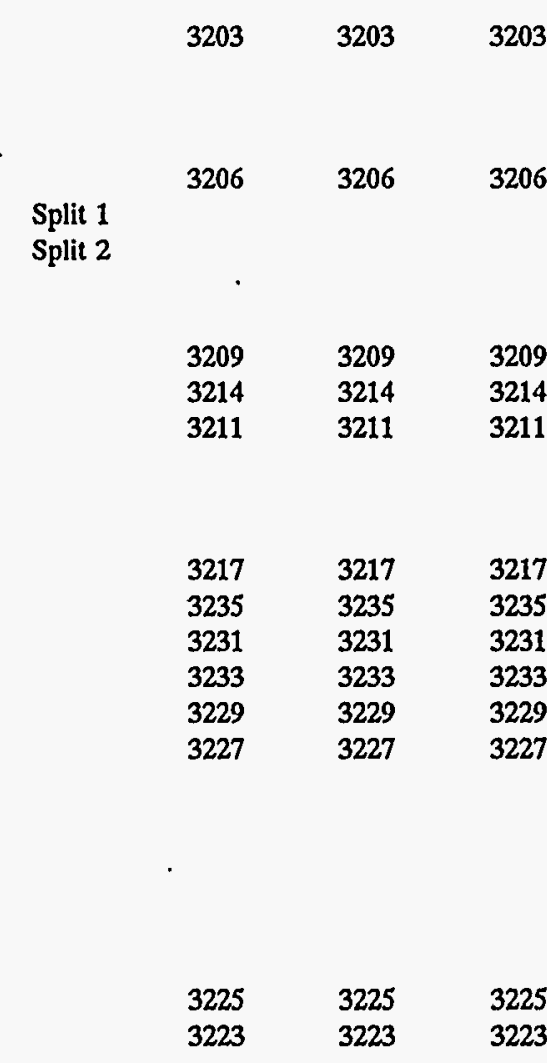


Table 2.1 (continued)

\begin{tabular}{|c|c|c|c|c|c|c|c|c|c|c|c|c|c|c|c|}
\hline Site & Horizon & Phase & $\begin{array}{c}\text { Field } \\
\text { duplicate }\end{array}$ & $\begin{array}{l}\text { Lab } \\
\text { split }\end{array}$ & PAH & Herbicides & $\begin{array}{l}\text { Pesticides } \\
\text { PCBs }\end{array}$ & $\begin{array}{c}\text { ICP } \\
\text { metals }\end{array}$ & $\begin{array}{c}\mathrm{AA} \\
\text { metals }\end{array}$ & Sulfate & Cyanide & $\begin{array}{l}\text { Gamma } \\
\text { emitters }\end{array}$ & Tritium & $\begin{array}{c}\text { Alpha } \\
\text { emitters }\end{array}$ & $\begin{array}{l}\text { Beta } \\
\text { emitters }\end{array}$ \\
\hline
\end{tabular}

\begin{tabular}{|c|c|c|c|c|c|c|c|c|c|c|c|c|c|c|}
\hline 10 & $A$ & 1 & & 3168 & & 3168 & & & & & & & & \\
\hline $10,13,14$ & A & 1 & & & & & 6028 & 6028 & 6028 & 6028 & 6029 & & 6029 & 6029 \\
\hline $10,13,14$ & A & 1 & FD & & & & 6037 & 6037 & 6037 & 6037 & 6038 & & 6038 & 6038 \\
\hline $10,13,14$ & B & 1 & & & & & 6031 & 6031 & 6031 & 6031 & 6032 & & 6032 & 6032 \\
\hline $10,13,14$ & B & 1 & FD & & & & 6040 & 6040 & 6040 & 6040 & 6041 & & 6041 & 6041 \\
\hline $10,13,14$ & $\mathrm{C}$ & 1 & & & & & 6034 & 6034 & 6034 & 6034 & 6035 & & 6035 & 6035 \\
\hline $10,13,14$ & $\mathrm{C}$ & 1 & FD & & & & 6043 & 6043 & 6043 & 6043 & 6044 & & 6044 & 6044 \\
\hline 13 & A & 1 & & 3127 & & 3127 & & & & & & & & \\
\hline 13 & $A$ & 1 & FD & 3139 & & 3139 & & & & & & & & \\
\hline 14 & A & 1 & & 3148 & & 3148 & & & & & & & & \\
\hline 17 & A & 1 & & 3018 & 3018 & 3018 & & & & & & 3016 & & \\
\hline 19 & A & 1 & & 3032 & 3032 & 3032 & & & & & & 3031 & & \\
\hline 19 & A & 2 & & & & & & & & & & & & 6096 \\
\hline 20 & $A$ & 1 & & 3046 & 3046 & 3046 & & & & & & 3045 & & \\
\hline 20 & A & 2 & & & & & & & & & & & & 6097 \\
\hline 21 & A & 1 & & 3113 & & 3113 & & & & & & & & \\
\hline 21 & A & 2 & & & & & & & & & & & & 6098 \\
\hline 22 & A & 1 & & 3058 & 3058 & 3058 & & & & & & 3057 & & \\
\hline 3 & A & 1 & & 3099 & 3099 & 3099 & & & & & & 3098 & & \\
\hline $3,7,21$ & A & 1 & & & & & 6019 & 6019 & 6019 & 6019 & 6020 & & 6020 & 6020 \\
\hline $3,7,21$ & B & 1 & & & & & 6022 & 6022 & 6022 & 6022 & 6023 & & 6023 & 6023 \\
\hline $3,7,21$ & C & 1 & & & & & 6025 & 6025 & 6025 & 6025 & 6026 & & 6026 & 6026 \\
\hline 7 & A & 1 & & 3085 & 3085 & 3085 & & & & & & 3084 & & \\
\hline 8 & A & 1 & & 3072 & 3072 & 3072 & & & & & & 3071 & & \\
\hline $8,20,22$ & A & 1 & & & & & 6010 & 6010 & 6010 & 6010 & 6011 & & 6011 & 6011 \\
\hline $8,20,22$ & B & 1 & & & & & 6013 & 6013 & 6013 & 6013 & 6014 & & 6014 & 6014 \\
\hline $8,20,22$ & C & 1 & & & & & 6016 & 6016 & 6016 & 6016 & 6017 & & 6017 & 6017 \\
\hline 9 & A & 1 & & 3003 & 3003 & 3003 & & & & & & 3004 & & \\
\hline $9,17,19$ & A & 1 & & & & & 6004 & 6004 & 6004 & 6004 & 6005 & & 6005 & 6005 \\
\hline $9,17,19$ & B & 1 & & & & & 6001 & 6001 & 6001 & 6001 & 6002 & & 6002 & 6002 \\
\hline $9,17,19$ & $\mathrm{C}$ & 1 & & & & & 6007 & 6007 & 6007 & 6007 & 6008 & & 6008 & 6008 \\
\hline
\end{tabular}


The following checklist of pertinent questions is provided to guide the prospective data user.

1. Do you know your site geological formations and soil characteristics? Have you read the BSCP sampling protocols? Will you be using a qualified soil scientist for identifying and collecting samples from $\mathrm{A}, \mathrm{B}$, and $\mathrm{C}$ horizons of the soil?

2. Did you compare your analytical methods with those contained in the BSCP Plan (Energy Systems 1992)? Were the samples analyzed according to the EPA methods and procedures referenced in BSCP Plan? Either extraction or total dissolution methods (as specified in this document) for metals, organics, and some radionuclides must be the same, only in terms of analyte specificity and similar analyte recovery efficiency, if results from contaminated sites are to be compared with results from this project. The use of neutron activation analysis data and mass spectroscopy analysis of EPA methods of soil dissolution or extraction to currently accepted EPA methods is compared and discussed in Sect. 6.

3. What geologic formation is beneath your soil sampling site? This question is important when contaminants, such as metals and radionuclides, occur naturally in soils and bedrock.

a. Rome Formation: Naturally occurring metal and radionuclide BSCP data may not be applicable. No sampling was performed, so there is no basis for comparison.

b. Conasauga Group: For Pumpkin Valley, Rutledge (Friendship), and Maynardville formations, BSCP data for metals and radionuclides may not be applicable. There was no sampling of these formations. The data may be applicable for the Dismal Gap (Maryville) and Nolichucky formations in the Melton Creek section, even though this section of the Conasauga was not sampled.

c. Knox Group: For the Copper Ridge and Chepultepec formations, the data are nearly all similar. For the Longview, Kingsport, and Mascot formations, which were not sampled, BSCP metals and radionuclides data should generally be applicable for the geologic group (see Tables 6.1a and 6.1b). The Melton Hill section of the Knox should be able to use the Knox Group values contained in Tables 6.1a and 6.1b.

d. If there is no significant difference between two formations in a group for a particular constituent, the group data may be applicable to other formations in the same group.

e. Chickamauga Group: For the Bethel Valley area, the Bethel Valley section BSCP data should be applicable although some geologic units $(A, B, C$, and $D)$ were not sampled. For the K-25 area, the K-25 section BSCP data should be applicable across all formations.

4. Was your sample collected from a ridgetop or upper side slope and from a residual soil? If your sample came from a floodplain or from a concave-shaped landform with alluvial-colluvial soils, then the data you obtain will probably vary. However, the applicable and comparable BSCP data will probably be on the conservative side. 
5. Was your sample collected from a forested mineral soil surface layer (A horizon or A plus $E$ horizons) or from an Ap horizon in a grassland field? You can use the appropriate values from the $\mathrm{A}$ horizon from the geologic formation that you checked above.

6. Was your sample collected from the surface of a site that has been disturbed or stripped of topsoil in the past 30 to 45 years? If so, then the B horizon data from the particular geologic formation will probably be the most appropriate for comparisons.

7. Was your sample collected from a depth of $3 \mathrm{ft}$ or more below the surface? You can compare your data with the median values for the $\mathrm{C}$ horizon for the geologic formation or geologic group that you checked above.

8. Was your sample collected from fill materials or cover above waste trenches? Can you identify the geologic formation source of those soil materials? If so, then you can compare your data with the appropriate $\mathrm{C}$ horizon data. If the geologic source of the cover or fill material cannot be identified according to its geologic origin, or if it was imported, do not compare your data with any BSCP data! If the fill came from Chestnut Ridge or from Melton Hill on the ORR, then you should be able to use the appropriate $\mathrm{C}$ horizon data from the Copper Ridge or Chepultepec formations or the Knox Group data of Tables $6.1 \mathrm{a}$ and $6.1 \mathrm{~b}$.

9. Are your results equal to or lower than the median value plus two sigma deviation units? If so, your sample is probably not contaminated. If your results are significantly higher than the mean plus two sigma units, then your sample may be contaminated. Note: The data user should keep in mind that some properties of natural soils are extremely variable and complex and that the BSCP data represent only a very small subset of soils on the ORR.

10. With respect to man-made organic compounds and radionuclides, these represent a separate issue and are not connected to geology. We do not want to limit the application of BSCP data because of these artificial soil constituents. We do want to base the analytic thresholds on instrument detection limits or on detection limits associated with method dilution factors. The presence of man-made chemical compounds and radionuclides above background should be interpreted as a sign of potential contamination.

11. Please use only the relevant numbers from Tables $6.1 \mathrm{a}$ and $6.1 \mathrm{~b}$ for most of your data comparisons. If the discussion for a particular element or compound in Sect. 6 indicates a significant difference by formation within a geologic group, then use the appropriate formation data by horizon from Sect. 5 . If $A, B$, and $C$ horizon data are significantly different, use the data for specific horizons from a specific formation. For some very broad uses, the data across all geologic groups have been merged but have limited usefulness as a result (see Tables G.8 and G.9).

\subsubsection{How To Use Data-An Analytical Perspective}

The data reported in this document have been collected, analyzed, and validated according to the guidelines and requirements detailed in the BSCP Plan (Energy Systems 1992). The data were analyzed according to methods detailed in Sect. 4.7 of this report, and 
the data were validated according to the criteria described in Sect. 4.4. For these data to be properly used by future users, the user must use similar data analysis methods as described in this report. In addition, the user must ensure that any deviation in protocols be considered during the planning stage.

To use these data properly, the user must understand the purpose of the data validation and the validation qualifiers used. The purpose of validation was to assess the quality of the data against EPA's nationally applicable criteria. The criteria followed for most of the chemical data were the EPA Contract Laboratory Program (CLP) Data Validation Criteria. The criteria used for the non-CLP chemical and radiological data were prepared according to the requirements provided in the BSCP Plan and the EPA CLP Data Validation Criteria. The validated data were given validation qualifiers that explain the overall judgment of the data validator as to the worthiness of the data points. Two types of qualifiers are provided in the data tables: laboratory qualifiers and validation qualifiers. The definitions of the contract laboratory qualifiers are found in Sects. 4.4.1 and 4.4.2. The data validation qualifiers used in this project are listed in Table 4.1.

Data with validation qualifiers J, UJ, UJN, UN, and JN in Table 4.1 can be used, but the data user must be aware that the data must be used with the limitations that the qualifier defines. An example would be that a project could use the data qualified as J, but it must be understood that they are using a data value that represents an estimated or approximate concentration of the analyte and not a true concentration.

The following questions are presented to provide additional guidance.

1. Did you compare your analytical methods with those contained in the BSCP Plan (Energy Systems 1992)?

2. Were the samples analyzed according to the EPA methods and procedures contained in the BSCP Plan (Energy Systems 1992)?

3. Did you follow the same sample preparation methods and requirements as those stated in the BSCP Plan (Energy Systems 1992)?

4. Did you use total dissolution methods [refer to HASL-300 methods in AEC (1972)] for radiological analyses?

5. Did you incorporate any deviations or modifications in the methods as described in the BSCP Plan (Energy Systems 1992) or in this report?

6. Is your data based on wet weight or dry weight?

7. Are the units associated with your data the same as those presented in this report?

8. Did you compare your detection limits with those contained in the BSCP Plan (Energy Systems 1992)? Are you using instrument detection limits, method detection limits, practical quantitation limits, or contract required detection limits? For explanation of terminology on detection limits, refer to EPA/SW-846 (2nd ed.) and to the EPA/CLP statement of work for organic and inorganic analyses. 
9. Did you use the data validation guidelines developed for the BSCP, and did you refer to the validation qualifiers (list of data validation qualifier definitions can be found in Sect. 4.4) for data in this report when evaluating your data?

\subsubsection{Statistical Guidelines for Users of Background Soil Data}

The scope of possible applications of the BSCP data is so broad that it is not feasible to elaborate on statistical methods appropriate for each possible application. The following is presented as a starting point.

\section{Is your goal}

1. to design a soil sampling program for which the BSCP is to be a reference? Refer to the BSCP Plan (Energy Systems 1992) and to Sect. 5 (particularly Sect. 5.10) of this report for discussions of laboratory and spatial variance and compositing.

2. to compare background levels in various formations or horizons? See Sect. 5.2 (particularly Sect. 5.2.3) and discussion on analytes of interest in Sects. 5 and 6 of this report.

3. to determine target values for remediation? See Sect. 5.2 for general discussion on the computation of confidence bounds, and Sects. 5.3-5.9 for particular analytes of interest.

- to obtain a target value that is within the normal background range? Use a lower tolerance bound for an upper percentile (e.g., the 95th).

- to obtain a target value that is near the mean (or median, see Sect. 5.2, Measures of Central Tendency) of normal background levels? Use a confidence bound for the mean. If you want to be confident that a target is no higher than the median, use a lower confidence bound. (Use an upper confidence bound for the median only if you want to be confident that the target is above the median.)

4. to determine if the detection of a PAH, pesticide, herbicide, or other normally absent substance is inconsistent with a practical definition of background (i.e., one for which some limited anthropogenic effects are admitted)? Refer to upper confidence bounds for detection probabilities, discussed in Sect. 5 (particularly Sect. 5.2), but note that some of these confidence bounds are not useful because overall sample sizes are small.

5. to determine if detected concentrations are within normal background levels? Refer to appropriate upper percentile estimates and lower tolerance bounds in Sect. 5 (Table 5.1 for inorganics, for example) and discussion in Sects. 5.2 and 5.10.

\section{Exclusions}

Certain applications will be sufficiently sensitive to warrant a close look at the background data and statistical methods of analysis. How well the lognormal and alternate models apply for the particular analytes of concern should be considered. Data already collected may not be automatically compared to BSCP data without further scrutiny and analysis-for example, if samples are not composited or if they are composited at significantly different levels other than three, or if they are biased, perhaps through the use of a 
nonrandomized sampling site selection process that results in the selection of hot spots. Alternatives for composites of other than three are discussed in Sect. 5.10. The statistical variability of new observations, which may be expressed, in means or percentiles from replicates, should be considered.

Confidence bounds and other statistics are intended to reasonably delineate states of knowledge. For some purposes, some of the BSCP data statistics may seem unreasonably high or low. In most cases the problem is not in the statistics but is rather in the actual uncertainty in the state of knowledge. If a statistic is questionable, the costs of getting additional information, for example, by additional sampling, should be weighed against the losses due to relying on values that may be too high or low. Practical considerations should go beyond statistical confidence and significance. For example, in light of risks, some background levels may be unnecessarily low remediation targets.

\subsection{Data User Guidelines for Risk Assessments}

The following questions are intended to focus attention on aspects of using BSCP data for risk assessments.

\section{What is risk assessment as it pertains to the BSCP?}

Risk assessment is used to evaluate potential risks to human health from exposure to constituents in background soils (from the ORR, Anderson County, and Roane County). There are two types of risk, carcinogenic risk and noncarcinogenic (systemic) risk. For carcinogens, risks are estimated as the incremental probability of an individual developing cancer over a lifetime as a result of exposure to the carcinogen. Cancer risk from the exposure to contamination is expressed as excess cancer risk; that is, cancer incurred in addition to normally expected rates of cancer development. An excess cancer risk of $1.0 \times$ $10^{-6}$ indicates one person in one million is predicted to incur cancer from exposure to this contamination level.

Noncarcinogenic effects are systemic toxic effects, that is, they are toxic effects to an organ or system which occur when a threshold dose is reached. Unlike carcinogenic risk, which is represented by a probability of incurring cancer over a lifetime, systemic risk is posed only if a threshold is exceeded.

What are the primary goals of this risk assessment?

The primary objectives of this BSCP risk assessment are to (1) evaluate the BSCP data in terms of potential adverse effects to human health (carcinogenic and systemic); (2) produce a comprehensive database for naturally occurring constituent concentrations in soils on the ORR; (3) provide the context for discussion of risks associated with ORR site related contamination (which includes identifying contaminants of concern); and (4) provide a comparison, based on risk, between soils collected from the sampling areas (ORR, Anderson County, and Roane County). 
How are risks and hazard indices determined?

To evaluate potential risk to human health from background constituents, EPA-approved dose/response information must be available-that is, slope factors (for carcinogenic risk analysis) and reference doses (for analysis of noncarcinogenic/systemic effects).

Carcinogenic effects are expressed in terms of risk. The risk is calculated by multiplying the daily intake of a constituent by the EPA-approved slope factor. There are three regions of concern according to EPA guidelines for contaminated sites: risk $<1.0 \times 10^{-6}$, no concern; risk between $1.0 \times 10^{-6}$ and $1.0 \times 10^{-4}$, range of concern; and risk $>1.0 \times 10^{-4}$, unacceptable. Risks due to background soil concentrations are reported in this manner, but the results are only for comparison with site-related risk; the results do not pertain to remediation goals.

Systemic risks are expressed in terms of a hazard index. The hazard index is calculated by determining the ratio of the daily intake of a constituent to the EPA-approved reference dose. If this ratio is less than 1.0, no adverse effects from exposure to this chemical are expected; if the hazard index is greater than 1.0, adverse systemic effects may possibly occur.

How are the calculated risk values to be used?

The most important aspect of the background soil data for risk assessment is in the selection of contaminants of potential concern. These background values can be used to attain an accurate assessment of the risk to human health posed by contaminants found at higher concentrations [two orders of magnitude above background concentrations according to the EPA (EPA 1990)] than naturally occurring background concentrations on the ORR. The total soil background risk reported in this document can be used to discuss site-related risk in the context of background risk.

Although background risk numbers are presented for Anderson and Roane counties in addition to the ORR, risk assessments conducted on the reservation are to employ the background risk numbers calculated for the ORR, as these data best represent background levels at an ORR site. The background risk numbers presented in Sect. 7 should be used in a baseline risk assessment or in a feasibility study for screening of alternatives on the ORR. In some cases (refer to Sect. 7), the background risk is unacceptable for an analyte in terms of EPA guidance (i.e, risk $>1 \times 10^{-4}$ ); this information should also be reported in the sitespecific risk assessment. Cleanup goals should not be below the reported background level.

The risk assessment in this report is subject to uncertainty pertaining to sampling and analysis, exposure estimation, and toxicological data. Several sources of uncertainty exist that are associated with site risk assessments. The following are examples of factors that may contribute to uncertainty in the risk assessment (Sect. 7).

- Assuming that risk doses within an exposure route are additive does not account for synergism or antagonism, which may overestimate or underestimate risks.

- Not all toxicity values represent the same degree of certainty. These values are subject to change as new evidence becomes available.

- Assuming exposures to be constant does not account for environmental fate, transport, or transfer that may alter concentrations. 
In addition, land use for this risk assessment was assumed to be residential. Although the assumption of residential land use is generally recommended when determining risk at a site (EPA 1989), risk numbers that result from the residential land use scenario are at the conservative end of the scale, when in fact residential use may not be the most likely future land use for the ORR. This assumption contributes to the uncertainty by possibly overestimating risks. Identifying these, and other, key site-related variables and assumptions that contribute to uncertainty will enable the risk estimates to be placed in proper perspective (EPA 1989).

\section{What are the uncertainties associated with the risk and hazard index numbers?}

Risk assessment, as a scientific activity, is subject to uncertainty. Although the methodology used in this risk assessment follows EPA guidelines, uncertainties pertaining to sampling and analysis, exposure estimation, and toxicological data still exist.

The major assumptions used in risk assessment are that (1) contaminant concentrations detected and reported by the analytical laboratory are representative of the analyte concentrations in the soil, (2) the intake rates and exposure parameters are representative of actual potentially exposed populations, and (3) all contaminant exposure and intakes are from the site-related exposure media.

Given these assumptions, there are other areas which can result in uncertainty. The toxicological data (slope factors and reference doses) are often updated and revised, which could alter risk values. Furthermore, these values are often extrapolations from animals to humans, which also induces uncertainties in toxicity values. In addition, not all of the detected background chemicals reported in this study currently have toxicity values; hence, this can underestimate total risk because quantitative assessment of such chemicals is currently not obtainable.

\subsection{Data Access Considerations}

BSCP analytical results are available from OREIS. Users wishing to access the data should refer to ER/C-P2702, Rev. 0, "Obtaining Access to Data in OREIS," and the "Oak Ridge Environmental Information System (OREIS) User Interface Manual for General Users, Version 1.0."

All data definitions are consistent within OREIS and are described in the OREIS documentation. Based upon user responses to the previous and the following guideline questions, the various fields can be queried to extract specific information.

Note: Additional considerations follow.

1. Does the user want to distinguish between data collected for screening purposes and those for higher quality analytical results? Attention must be given to qualifiers which indicate the original purpose for which the data were collected and then determine the appropriate use of the data.

2. Does the user want to distinguish among results for the same analyte but determined by different analytical methods? Users are cautioned to separate the results by method before calculating summary statistics. 
3. Does the user want to reproduce the risk calculations using alternate risk factors or exposure scenarios? The mean and upper $95 \%$ confidence bounds were calculated using a maximum likelihood estimation technique to appropriately account for values reported at their detection limit.

\section{EXAMPLE APPLICATIONS OF DATA USER GUIDELINES}

The process flow for applying the data user guidelines discussed in Sect. 2.4 is summarized in Fig. 2.3. This section presents two example cases to illustrate the suggested approach for applying the background soil characterization data in this report.

\section{EXERCISE IN USING BACKGROUND SOIL DATA}

Refer to the series of questions in Sect. 2.4.1 for guidance in determining applicability, both in general and for geological aspects in particular, of BSCP data to the two hypothetical situations under discussion here. Then refer specifically to Sect. 2.4 .2 when comparing contaminated site data directly with BSCP data. The central question is: Are the data comparable? Refer to Sect. 2.4.3 when determining whether the treatment of the contaminated site data has been statistically similar to the treatment of the BSCP data. Finally, refer to Sect. 2.4 .4 for data user guidelines relative to risk assessment.

The primary concern in this discussion is whether the contaminated site data are comparable or are even compatible with the BSCP data. If this is not the case, then obtain technical assistance.

\section{Case I - Hypothetical Situation}

A waste treatment facility has had two leaks from a pressurized line that runs through a wooded area to the injection well. One slow leak occurred at a joint in the above-ground part of the pipe. This leak spread a plume on the surface that reached out into the woods. The area was roped off, and samples were collected and analyzed to locate the extent of the contaminated area and to estimate the level of contamination. This preliminary analysis identified the following radionuclide analytes of concern in the plume: cesium-137, technetium-99, and tritium. Samples were collected from the upper $10 \mathrm{~cm}$ of soil. The other line leak occurred in a below-ground section of the pipe at a depth between 50 and $100 \mathrm{~cm}$. The same contaminants were found at this depth, too.

\section{Site Characteristics}

Geology: Use the provisional ORR geology map (ORNL/TM-12074), have a qualified geologist make a site determination of the geologic formation, or use the ORR soils map, which relates soils to the underlying geologic formations. The leaks were found to be underlain by the Nolichucky Formation of the Conasauga Group.

Soils: Use the ORR soils map to determine if the leaks occurred in residual soils or colluvial-alluvial soils, or have a qualified soil scientist make an on-site evaluation. The leaks were found to be underlain by residual soils of the Nolichucky Formation. 


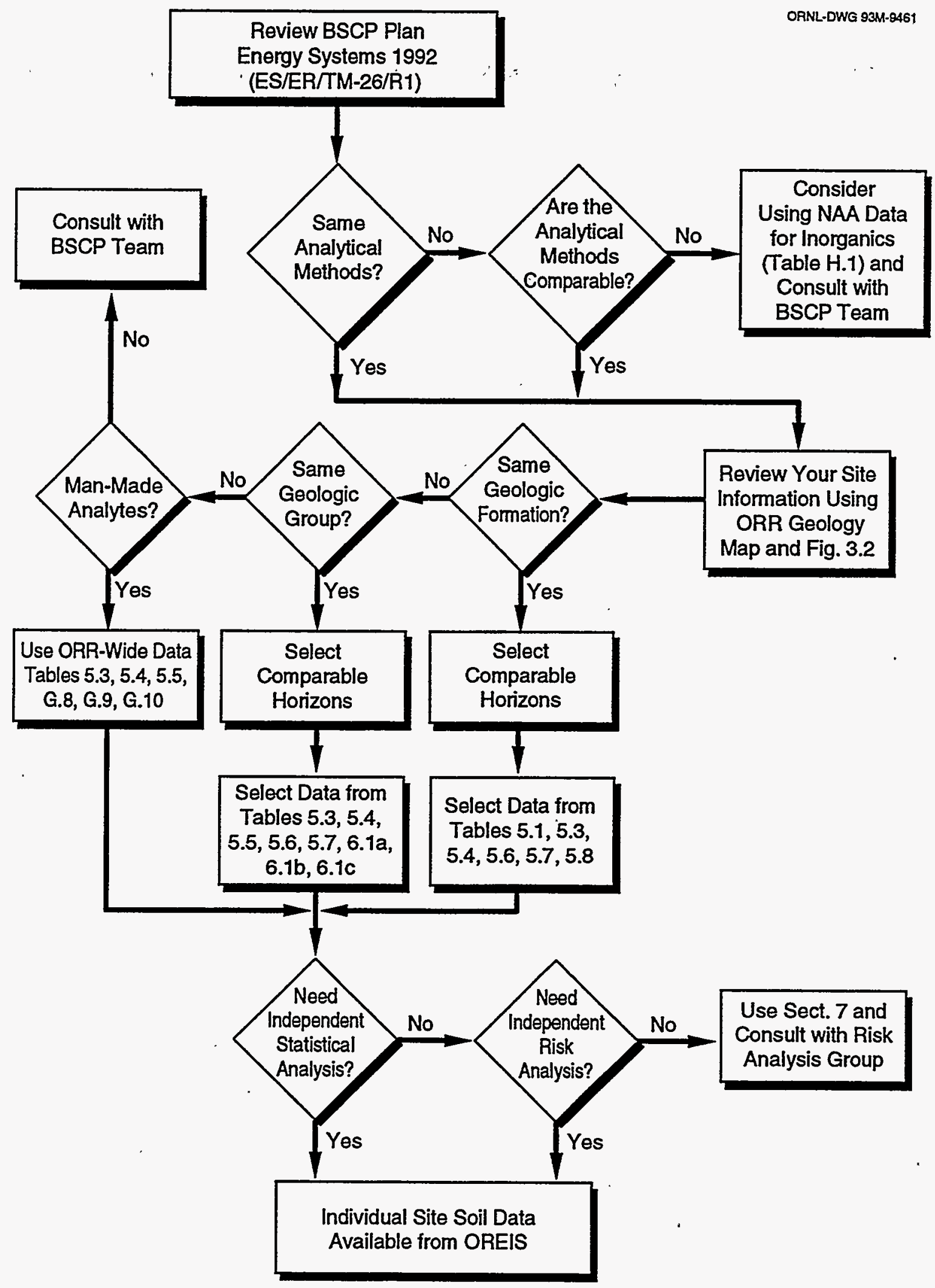

Fig. 23. Data user guideline flow chart. 
Landform: The above-ground leak is on a sideslope, and the below-ground leak is on a ridgetop landform.

Vegetation: The vegetation is mixed hardwoods and pines.

\section{Background Data Selection}

The surface (0 to $10 \mathrm{~cm}$ ) sampling depth is roughly equivalent to the A horizon of the soil profile, and the 50 to $100 \mathrm{~cm}$ depth is approximately equivalent to the $C$ horizon of the soil profile. Where formation data are available in Sect. 5 , they will be used; if formation data are not available, geologic group data from Sect. 6 will be used.

- Background data are available for cesium-137 from the A horizon for the Nolichucky Formation. See Table 5.8 for NOL-ORR A horizon data.

- Technetium-99 data are available for the Nolichucky A horizon. See Table 5.8.

- There are no tritium data available for the Nolichucky Formation; therefore, the Conasauga Group A horizon data for tritium from Table $6.1 \mathrm{~b}$ will be used.

- There are no cesium-137 detect data from the Nolichucky Formation for the $\mathrm{C}$ horizon; therefore, data from Table $6.1 \mathrm{~b}$ can be used for the $\mathrm{C}$ horizon, because the Nolichucky Formation belongs to the Conasauga Group.

- BSCP soil samples were not collected from $B$ and $C$ horizons for technetium and tritium; however, those data should be below the instrument detection limits (IDLs), and we can resort to use of the DLs in this case.

Data for 0 to $10 \mathrm{~cm}$ depth of contaminated soil samples (from Sect. 5)

\begin{tabular}{lccccc}
\hline Analyte & Units & Median & UCB95 & X95 & LTB9595 \\
\hline Cesium-137 & pCi/g & 0.53 & 1.26 & 2.99 & 1.18 \\
Tc-99 & pCi/g & 1.10 & 1.91 & 2.63 & 1.57 \\
Tritium & pCi/g & 0.32 & 0.43 & 0.70 & 0.05 \\
\hline
\end{tabular}

Data for 60 to $100 \mathrm{~cm}$ depth of contaminated soil samples (from Sect. 6)

\begin{tabular}{lccccc}
\hline Analyte & Units & Median & UCB95 & X95 & LTB9595 \\
\hline Cesium-137 & pCi/g & 0.0008 & 0.091 & 0.803 & 0.008 \\
Tc-99 & pCi/g & IDL & & & \\
Tritium & pCi/g & IDL & & & \\
\hline
\end{tabular}

Note that numerical rounding of data has been done for this exercise. For an explanation of the headings in the tables above, please see pages 5-15 of this report.

\section{Analytical Method Selection}

The analytical coordinator reviewed the following information to ensure that the analytical laboratory methods used were comparable. 
- Did you compare your analytical methods with those contained in the BSCP Plan (Energy Systems 1992, Volume 3)? Were the samples analyzed according to the EPA methods and procedures contained in the BSCP Plan?

- The methods used for this investigation were taken from the BSCP Plan. The coordinator referred to Tables 6.5 to 6.13 in the Plan and used the following methods:

- HASL 300 Method for technetium;

- EPA 901.1 for cesium, which is the gamma spectrometry method; and

- EPA 906.1 for tritium, which is the liquid scintillation method.

- Did you follow the same sample preparation methods and requirements as those stated in the BSCP Plan (Energy Systems 1992, Volume 3)?

- The laboratory used a distillation method to prepare the tritium sample, just as in the BSCP.

- The laboratory prepared the technetium sample using the HASL-300 method, which means that the laboratory did not ash the samples. This does not compromise the data, since the ashing step is only used to remove the organics that interfere with the analysis.

- Radiochemical preparation methods must be considered, because it is very important that the laboratory use a method employing total dissolution. Radiochemical preparation methods are not standardized, so individual laboratory.procedures should be evaluated. The BSCP used methods that provide for total dissolution.

- Did you use total dissolution methods for radiological analyses?

- Total dissolution methods were used.

- Did you incorporate any deviations or modifications in the methods, as described in the BSCP Plan or in this report?

- No deviations or modifications reported by BSCP were used for this investigation, since the laboratory adhered to the HASL-300 method for technetium-99 analysis.

- Are your data based on wet weight or dry weight?

- All weights were based on oven-dry-soil weight $\left(\sim 105^{\circ} \mathrm{C}\right)$, with percent moisture also reported.

- Are the units associated with your data the same as those presented in this report?

- All units were the same.

- Did you compare your detection limits with those specified in the BSCP Plan?

- In the decision process to arrive at appropriate analytical methods, the detection limits found in Tables 6.5 to 6.13 of the BSCP Plan were reviewed and determined to be sufficient for the investigation (cesium-137 $=3 \mathrm{pCi} / \mathrm{g}$, technetium-99 $=2 \mathrm{pCi} / \mathrm{g}$, tritium $=1 \mathrm{pCi} / \mathrm{g})$.

- Did you use the data validation guidelines developed for the BSCP, and did you refer to the validation qualifiers (list of data validation qualifier definitions appears in Sect. 4.4) for data in this report when evaluating your data?

- Data validation guidance was used consistent with BSCP definitions. 


\section{Statistical Methods}

From analytical considerations, it can be concluded that the data are compatible. The question of comparability is to determine if analyte levels at the site are within "normal" background ranges. Suppose that "normal" means below the 95th percentile. (Of course, other percentiles could be used instead.)

From Table 5.10c, essentially all of the variance in background A horizon cesium-137 measurements is due to laboratory variability (i.e., there is no spatial component). Therefore, compositing does not affect the variance of sample values, and the normal backgrond range is indicated by X95, the 95 th percentile estimate, and by tolerance bounds for that percentile. $\mathrm{X} 95$ for cesium-137 is $2.99 \mathrm{pCi} / \mathrm{g}$. LTB9595 for cesium-137 is 1.18 . An upper $95 \%$ tolerance bound (UTB9595) for X95 can be computed using the expression

$$
\text { UTB9595 }=\exp [2 * \ln (\mathrm{X95})-\ln (\mathrm{LTB} 9595)] \text {. }
$$

That value is 7.58. Thus, the true 95th percentile could be anywhere from LTB9595 $=1.18$ to UTB9595 = 7.58. Assuming that the laboratory variability for the site and background studies are about the same and under the assumptions made in the BSCP statistical analysis, we can be about $95 \%$ confident that site samples below 1.18 are normal and $95 \%$ confident that site samples above 7.58 are abnormal. Site samples between those two values may warrant additional consideration (e.g., of risks) or more sampling.

For $\mathrm{C}$ horizon cesium-137, there were no Nolichucky detects. There were, however, several $C$ horizon ORR-Dismal Gap detects, and there were also detects at Dismal Gap sites in Anderson County. The P-value (probability) for comparing Nolichucky and Dismal Gap sites (P-DGN in Table G.5) is 0.017. This suggests that the Dismal Gap and Nolichucky sites may differ for $\mathrm{C}$ horizon cesium-137. If so, combining Conasauga site data may not be justified. However, the significance level 0.017 is borderline (see discussion on significance levels in Sect. 5.5.3), and so we can consider the combined Conasauga data.

The values for Conasauga $C$ horizon cesium-137 in Table $6.1 \mathrm{~b}$ are median $=0.00078$, $\mathrm{UCB} 95=0.091, \mathrm{X} 95=0.803$, and LTB9595 $=0.0077$. The spatial variability of $\mathrm{C}$ horizon cesium-137 is appreciable: 2.20 base-ten- $\log \mathrm{pCi} / \mathrm{g}$ (from Table 5.10c). The laboratory standard deviation is $\mathbf{0 . 5 3 2}$. Therefore, the standard deviation for noncomposites is

$$
\left[(0.532)^{2}+(2.20)^{2}\right]^{1 / 2}=2.26 \text { and } 10^{\log (\text { median })+1.64 \cdot 2.26}=3.97,
$$

estimates the 95th percentile for noncomposites. If the variability of the variance estimate is ignored, substituting upper or lower confidence bounds for the median provides upper and lower tolerance bounds for the 95th percentile. These values are 0.000004 and 4.02 . The median and these tolerance bounds may be used as references for cesium-137 at Conasauga $\mathrm{C}$ horizon sites.

The degrees-of-freedom for $C$ horizon cesium-137 in Table 5.10c are 29 and 28. This suggests that the standard deviation estimates are fairly accurate. Nevertheless, the more detailed approach sketched in Sect. 5.10 could also be performed to account for the variability in variance estimates. 
As with A horizon cesium-137, the spatial component of variance for technetium-99 is negligible (see Table 5.10c). The technetium-99 samples were also noncomposites. Thus, the approach described for $\mathrm{A}$ horizon cesium-137 can be taken for technetium-99. The lower and upper tolerance bounds for the 95th percentile are 1.57 and $4.41 \mathrm{pCi} / \mathrm{g}$, respectively.

Tritium samples were also noncomposites, so lower and upper tolerance bounds for the 95th percentile are again calculated as for $\mathrm{A}$ horizon cesium-137. They are 0.045 and $0.100 \mathrm{pCi} / \mathrm{g}$, respectively.

\section{Case II - Hypothetical Situation}

The Y-12 Burial Ground in the Bear Creek Valley section of the ORR has suspect surface contamination of uranium dust and naphthalene at one of its disposal trenches. Samples were collected and analyzed to determine the extent and amount of contamination. The analytes of concern were identified as uranium-235, uranium-238, and naphthalene. Most of the contamination was found to be in the upper $30 \mathrm{~cm}$ of soil.

\section{Site Characteristics}

Geology: Use the provisional ORR geology map (ORNL/TM-12074) to obtain the location of the contaminated areas with respect to the underlying geology. The contaminated area was found to be underlain by the Pumpkin Valley Formation.

Soils: Soil mapping was purposely not done in burial grounds or in suspected contaminated areas behind fences, so no soil data are available in such areas. The trench was initially installed to a depth of $8 \mathrm{ft}$. After filling, the spoil taken from the trench was used as cover material. Contamination evidently occurred when an adjacent trench was being filled. The soil scientist confirmed that the cover materials above the trench consisted essentially of C horizon soil from the Pumpkin Valley Formation of the Conasauga Group, although recent covering of nearby trenches with red clayey soil from the Knox Group had occurred, and some red clay soil material had been pushed onto the outer edges of the contaminated area.

\section{Background Data Selection}

- BSCP data for the Pumpkin Valley Formation do not exist. Since the Pumpkin Valley Formation is part of the Conasauga Group, the Conasauga Group C horizon will be used for obtaining background uranium values. See Table $6.1 \mathrm{~b}$ for uranium-235 (alpha) and uranium-238 (alpha) data. (Use of the total uranium data shown in Table 6.1b is not recommended.)

- Data for naphthalene were collected only from the A horizons of undisturbed soils. There were no data determined for any Conasauga Group soils. For this man-made organic, data from overall ORR PAH analyses (Table G.10) are applicable to provide the required estimated values.

Data for Conasauga Group C horizon (from Sect. 6)

\begin{tabular}{llcccc}
\hline Analyte & Units & Median & UCB95 & X95 & LTB9595 \\
\hline Uranium-235 & pCi/g & 0.039 & 0.057 & 0.112 & 0.071 \\
Uranium-238 & $\mathrm{pCi} / \mathrm{g}$ & 0.864 & 1.03 & 1.44 & 1.16 \\
\hline
\end{tabular}


Data combined over sampling areas (from Table G)

\begin{tabular}{lccccc}
\hline Analyte & Units & Median & UCB95 & X95 & LTB9595 \\
\hline Naphthalene & $\mu \mathrm{g} / \mathrm{kg}$ & 4.79 & 7.27 & 31.30 & 17.10 \\
\hline
\end{tabular}

Please refer to page 5-15 for an explanation of the headings that appear in the tables above.

\section{Analytical Method Selection}

The analytical coordinator reviewed the following information to ensure that the methods were comparable.

- Did you compare your analytical methods with those contained in the BSCP Plan (Energy Systems 1992, Volume 3)? Were the samples analyzed according to the EPA methods and procedures contained in the BSCP Plan?

- The methods used for this investigation were taken from the BSCP Plan. The analyst referred to Tables 6.5 to 6.13 in the Plan for the methods:

- EPA 8310 for napthalene and

- EPA 907.0 for isotopic uranium by alpha spectrometry.

- Did you follow the same sample preparation methods and requirements as those stated in the BSCP Plan (Energy Systems 1992, Volume 3)?

- The laboratory used the same preparation methods as in the BSCP for napthalene, and the uranium method was based on an anion exchange column separation (HASL E-U-02-01). Radiochemical preparation methods must be considered, because it is very important that the laboratory use a method employing total dissolution. Radiochemical preparation methods are not standardized so individual laboratory procedures should be evaluated. The BSCP used methods that provided for total dissolution.

- Did you use total dissolution methods for radiological analyses?

- Total dissolution methods were used.

- Did you incorporate any deviations or modifications in the methods, as described in the BSCP Plan or in this report?

- No deviations or modifications to those reported by the BSCP were used for this investigation.

- Are your data based on wet weight or dry weight?

- All weights were based on oven-dry-weight (approximately $105^{\circ} \mathrm{C}$ ) with percent moisture also reported.

- Are the units associated with your data the same as those presented in this report?

- All units are the same. Napthalene was reported in $\mu \mathrm{g} / \mathrm{kg}$, and isotopic uranium was reported in $\mathrm{pCi} / \mathrm{g}$.

- Did you compare your detection limits with those contained in the BSCP Plan? 
- In the decision process to determine methods, the detection limits found in Tables 6.5 to 6.13 of the BSCP Plan were reviewed and determined to be sufficient for this case (naphthalene $=1206 \mu \mathrm{g} / \mathrm{kg}$, uranium-235 and -238 each $\doteq 0.1 \mathrm{pCi} / \mathrm{g}$ ).

- Did you use the data validation guidelines developed for the BSCP, and did you refer to the validation qualifiers (list of data validation qualifier definitions can be found in Sect. 4.4) for data in this report when evaluating your data?

- Data validation guidance was used consistent with BSCP definitions.

\section{Statistical Methods}

The issue is to determine whether analyte levels at the site are within "normal" background ranges. In Table G.5, the P-values for comparing the Dismal Gap and Nolichucky formations in the $C$. horizons are 0.62 for uranium-235 and 0.0018 for uranium-238. The significant difference in uranium-238 levels for the Dismal Gap and Nolichucky formations suggests that extrapolating from the BSCP data to the Pumpkin Valley Formation may not be justified, at least for uranium-238 values. Nevertheless, this can be done for both uranium235 and uranium-238; calculations such as those for the $C$ horizon cesium-137 are then appropriate.

In some cases a tolerance bound for a composite may be a more useful reference value than a tolerance bound for a noncomposite. The tolerance bounds for composites of three are straightforward: for uranium-235, the LTB9595 is 0.071, and UTB9595, calculated using equation 2.1, is 0.177. For uranium-238, the LTB9595 is 1.16, and the UTB9595 is 1.79.

When a noncomposited sample is analyzed, it could come from a localized area of elevated or higher concentration, but humans, due to their normal movements, are never exposed continuously to the upper end of the normal analyte distribution. If the analyte is sufficiently toxic, a person continuously exposed to these high concentrations might be affected. But, because of normal movements, the actual human exposure would always be closer to the mean concentration than to an upper percentile concentration. In such a case, the upper percentile would make an inappropriate refërence value, and a percentile (or tolerance bound) for a composite would be a more representative reference.

Because of analytical laboratory problems, the naphthalene data for the Conasauga Group were excluded from the statistical analysis presented in Sect. 5. However, it is reasonable to assume that the distribution of concentrations of naphthalene (a PAH) does not vary with formation. (See Table G.4. None of the tests comparing naphthalene concentrations was significant.) Thus, it is appropriate to consider statistics for the ORR as a whole (Table G.10): median $=4.790$, UCB95 $=7.27$, X95 $=31.30$, LTB9595 $=17.10$, all in $\mu \mathrm{g} / \mathrm{kg}$. These statistics may be combined as in Case I for technetium-99 or tritium, which, like naphthalene, were also sampled as noncomposites.

As the foregoing shows, consideration of the situation in the field and of the analytical procedures at the time of sampling can establish compatibility of the site data with BSCP data. Further analysis using statistical methods was needed to determine actual direct comparability of the results quantitatively. Thus, if results of field sampling and laboratory analyses indicate that concentrations of analytes of concern exceed pre-established criteria or threshold levels-perhaps by a factor of 2 or 5 times background (depending on confidence 
in the data)-then the site can be considered contaminated and in need of remediation, with appropriate realistic cleanup targets based on measured and validated background levels of the analytes of concern.

Refer to Sect. 2.4 .4 for guidance relative to the evaluation of risk due to background concentrations of soil constituents. 


\section{FIELD INVESTIGATION, GAMMA SCREENING ANALYSES, AND QUALITATIVE SITE EVALUATION}

\subsection{SUMMARY}

This section discusses pertinent aspects of obtaining soil samples for analysis according to project objectives. To this end, the section covers sampling site selection, sample preparation procedures, field quality control, and results of site screening activities. To meet sampling requirements, field operations were planned and executed as follows:

- In the first half of Phase I, the Dismal Gap Formation was sampled at 24 locations, both on-site (12 on the ORR) and off-site (12 in Roane County).

- In the second half of Phase I, 24 more sites were sampled (12 on the ORR in the Nolichucky and 12 in the Dismal Gap in Anderson County) for a total of 48 sites in Phase I. These operations were conducted during FY 1992.

- In Phase II activities, 12 Copper Ridge sites and 12 Chepultepec sites were sampled on the Oak Ridge Reservation's (ORR's) Chestnut Ridge plus 12 Chickamauga sites in Bethel Valley and 12 Chickamauga sites in the East Fork (designated as K-25) area of the ORR. In addition, 12 Copper Ridge sites were sampled in Roane County and 12 Copper Ridge sites were sampled in Anderson County during Phase II.

\subsection{INTRODUCTION}

The Oak Ridge Reservation (ORR) lies in an area characterized by elongated ridges and broad-to-narrow valleys which run northeast to southwest. The hydrologic system on the ORR, including both surface water and groundwater, is controlled regionally by the Clinch River. The climate of the area is generally temperate with warm, humid summers and cool winters, and the average annual rainfall in the Oak Ridge area is approximately $136 \mathrm{~cm}$.

Geologically, the area is characterized by three principal rock groups (the Conasauga, Knox, and Chickamauga). There are two major categories of soils: residual soils developed from in-place weathered residuum of the geologic groups and soils developed in partially sorted colluvial and alluvial soil materials. Within the first of these residual soil groups, only the major formations of the area are considered in this investigation, because they represent the dominant soils at waste area groupings and operable units in imminent remedial action projects on the ORR. These formations are Dismal Gap and Nolichucky of the Conasauga Group, Copper Ridge and Chepultepec of the Knox Group, and deeply weathered soils of the Chickamauga Group. Soils formed in the Knox and Chickamauga groups were sampled and analyzed in the Phase II activities of this project. Soils from the Rome Formation, which is not one of the three major rock groups, do not appear with regularity at contaminated sites on the ORR and, for that reason, were not addressed in this project.

Early soil sampling activities were restricted to residual soils of the two most representative Conasauga Group geologic formations of six: the Dismal Gap Formation (formerly Maryville Limestone) and Nolichucky Formation within the Bear Creek Valley section. Three areas within this geologic section were chosen. The ORR area extended from the Clinch River on the west to the west end of the Y-12 Plant burial grounds on the east. 
Two off-site areas in the same geologic strike zone were located to the southwest in Roane County and to the northeast in Anderson County (Fig. 3.1). Only residual soils of the Dismal Gap and Copper Ridge formations were sampled at both on-site ORR and off-site locations. Three geographic areas within the Chestnut Ridge section of this formation were chosen. The ORR area extended from the Clinch River on the west to the Roane County-Anderson County boundary on the east. Two off-site areas in the same geologic strike zone were located to the southwest in Roane County and to the northeast in Anderson County (Fig. 3.1). In addition, the Chepultepec Formation was sampled on the ORR, as were Chickamauga sites located both in Bethel Valley and in the East Fork (K-25 Site) area of the ORR. Several Bethel Valley Chickamauga sites were located in Anderson County. The selection of which parent materials to sample in each sampling area reflected the availability of limited resources and the goal of maximizing project effectiveness, in addition to considering technical factors, such as site accessibility and the availability of suitable sampling sites that fit the selection criteria discussed in Sect. 3.3.

\subsection{SAMPLING SITE SELECTION}

Sampling sites on the ORR were confined mostly to the Roane County portion, but some ORR Bethel Valley Chickamauga sites were located in Anderson County (Fig. 3.2). Recent digitized soil maps (available from the Oak Ridge Environmental Information System), where residual soils had been related to the underlying geologic formations, provided the base map for generating most potential ORR sites. A statistical program was used to randomly select grid coordinates that fell on predetermined soil map delineations of those soils of greatest extent. No two sites were to be less than $250 \mathrm{ft}$ apart. This methodology resulted in the generation of a base map with potential sampling locations for the Dismal Gap, Nolichucky, Copper Ridge, Chepultepec and some of the Bethel Valley Chickamauga soils. Each ORR potential sampling site was assigned a unique number. In addition, the statistical program determined primary and secondary sampling sites. Secondary sites are alternate site locations in case the primary sites were unacceptable in terms of the selection criteria discussed below. In several cases on the ORR, both primary and secondary sites were unacceptable, resulting in the soil scientist looking nearby for enough potential sites that would meet the criteria. The majority of ORR Chickamauga sites were selected by the soil scientist because of the extreme soil variability. Potential sites in southwestern Roane (Fig. 3.3) and northeastern Anderson (Fig. 3.4) counties were selected somewhat differently because of ownership, vegetation (Figs. 3.1-3.4), and past disturbance constraints. Anderson County and Roane County sites are located within the shaded remote site areas, as shown in Fig. 3.1. In these off-site locations, more than 48 potential sites were located in the field. Those sites eventually chosen were located along the entire distance of the evaluated area and had to meet the vegetation and disturbance requirements discussed below.

\subsubsection{Site Evaluation}

Individual site evaluation used the following criteria.

Vegetation and disturbance. The site had to be in forest that had not been disturbed for at least the past $40 \pm 5$ years. Forest was either hardwoods, mixed old-field successional pines-cedars and hardwoods, or older planted loblolly pine plantations. Recently replanted pine plantations were rejected because the surface had been disturbed too recently. Each site was located by relating the map grid point to the actual soil map unit delineation and then 
ORNL-DWG 91Z-14221R

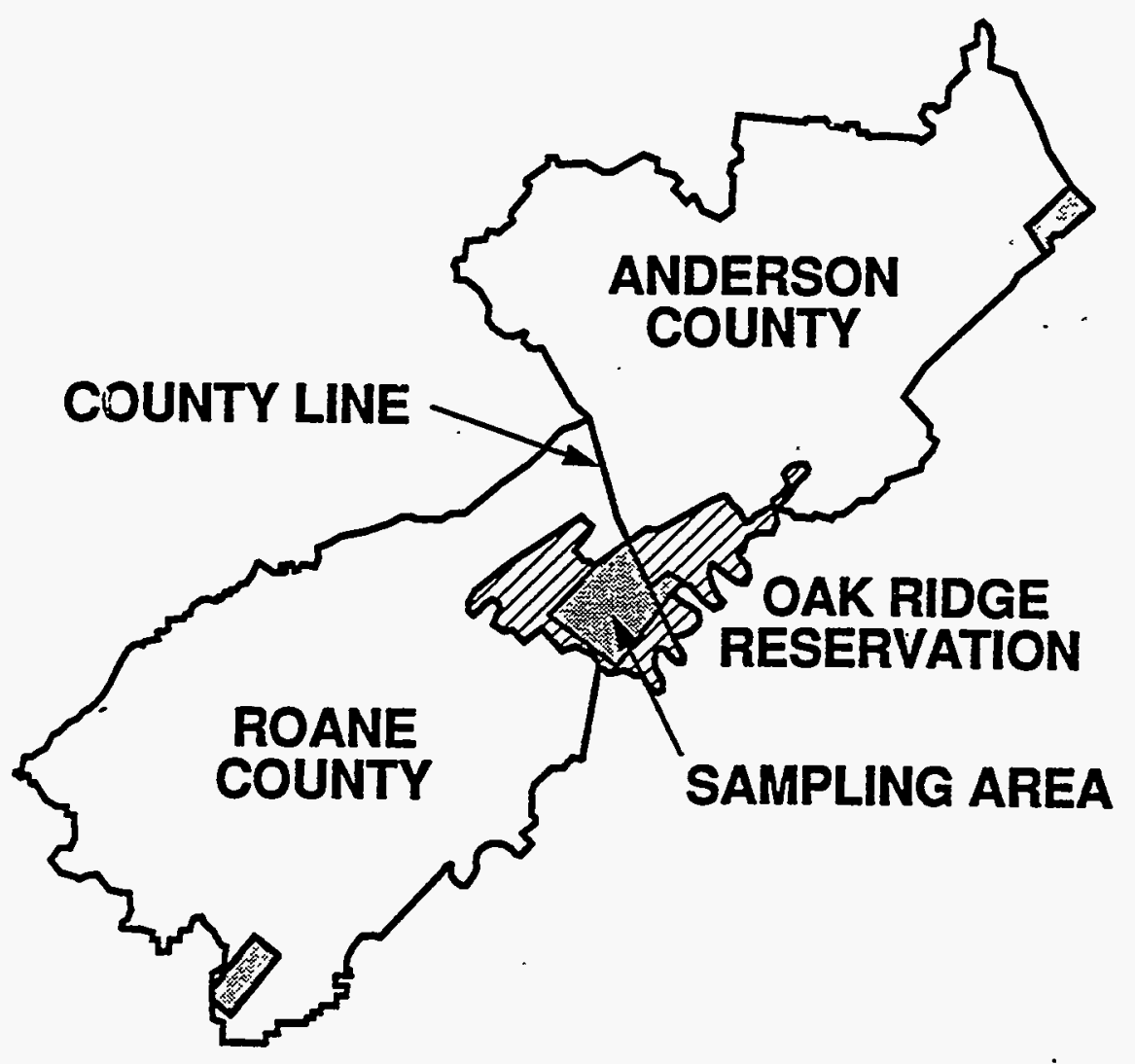

Fig. 3.1. Approximate locations of BSCP sampling areas. 
ORNL-DWG 93M-9338

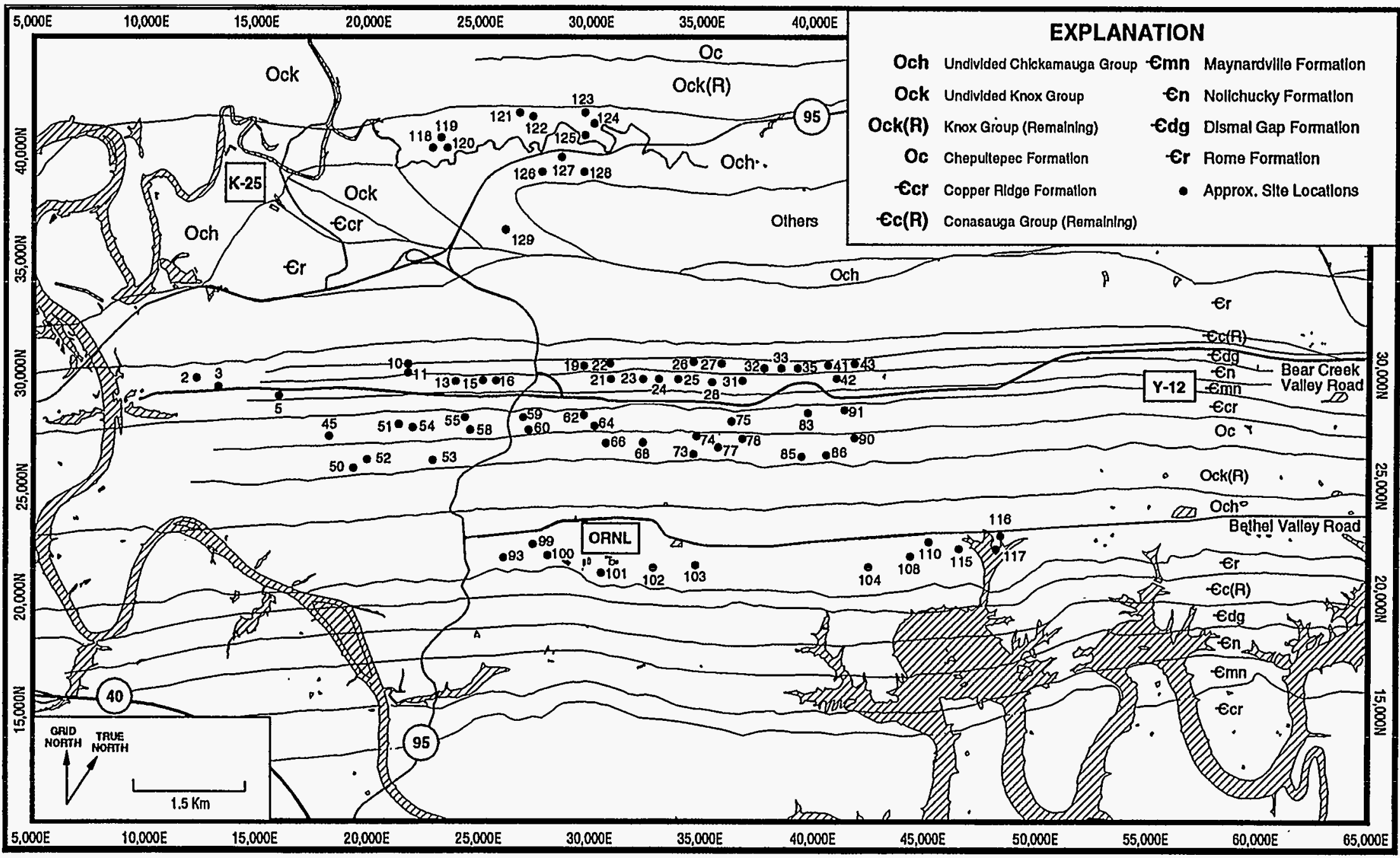

Fig. 3.2. A part of the ORR showing sampling site locations. 
ORNL DWG 93M-1364R2

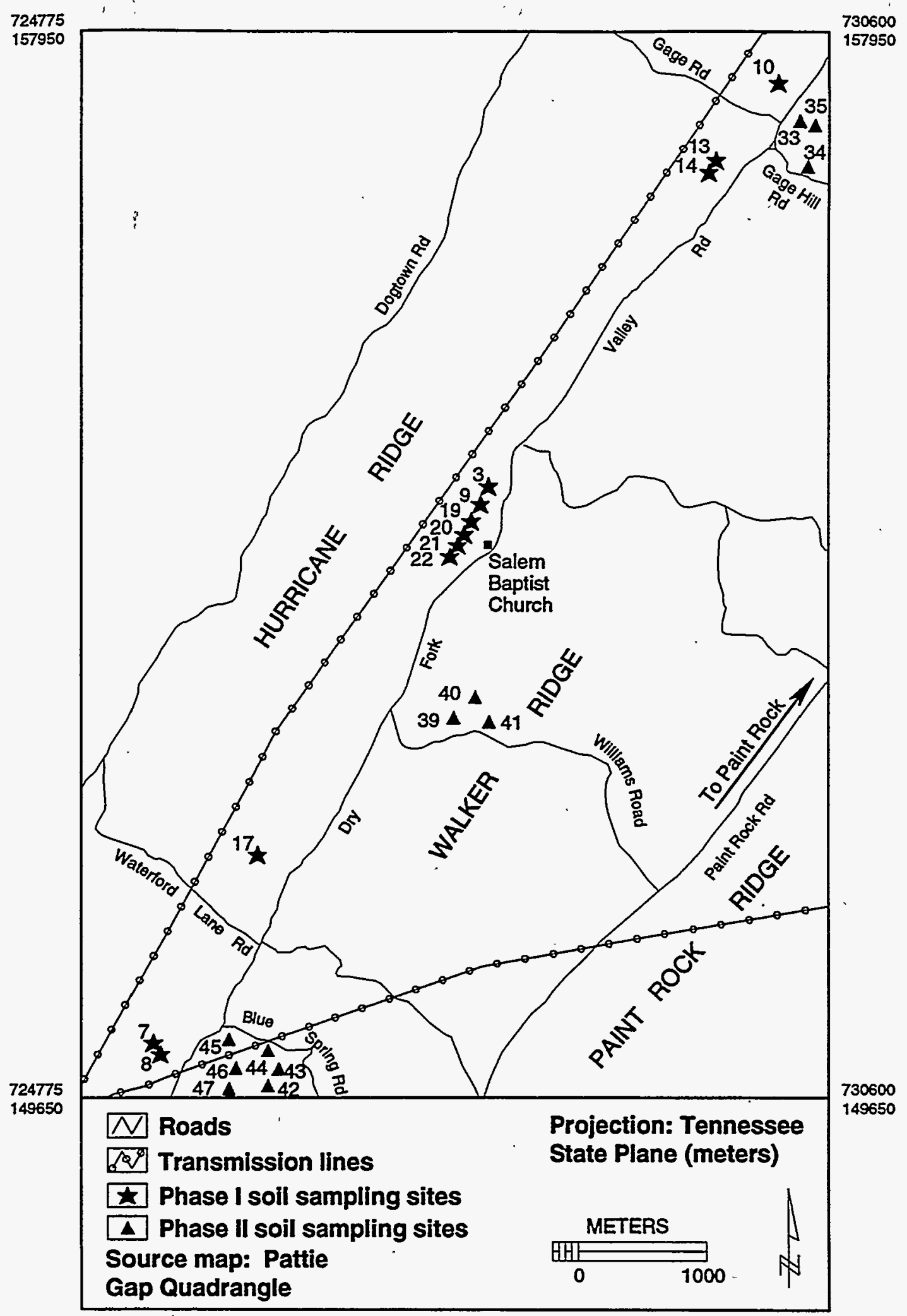

Fig. 3.3. Sampling sites in Roane County. 


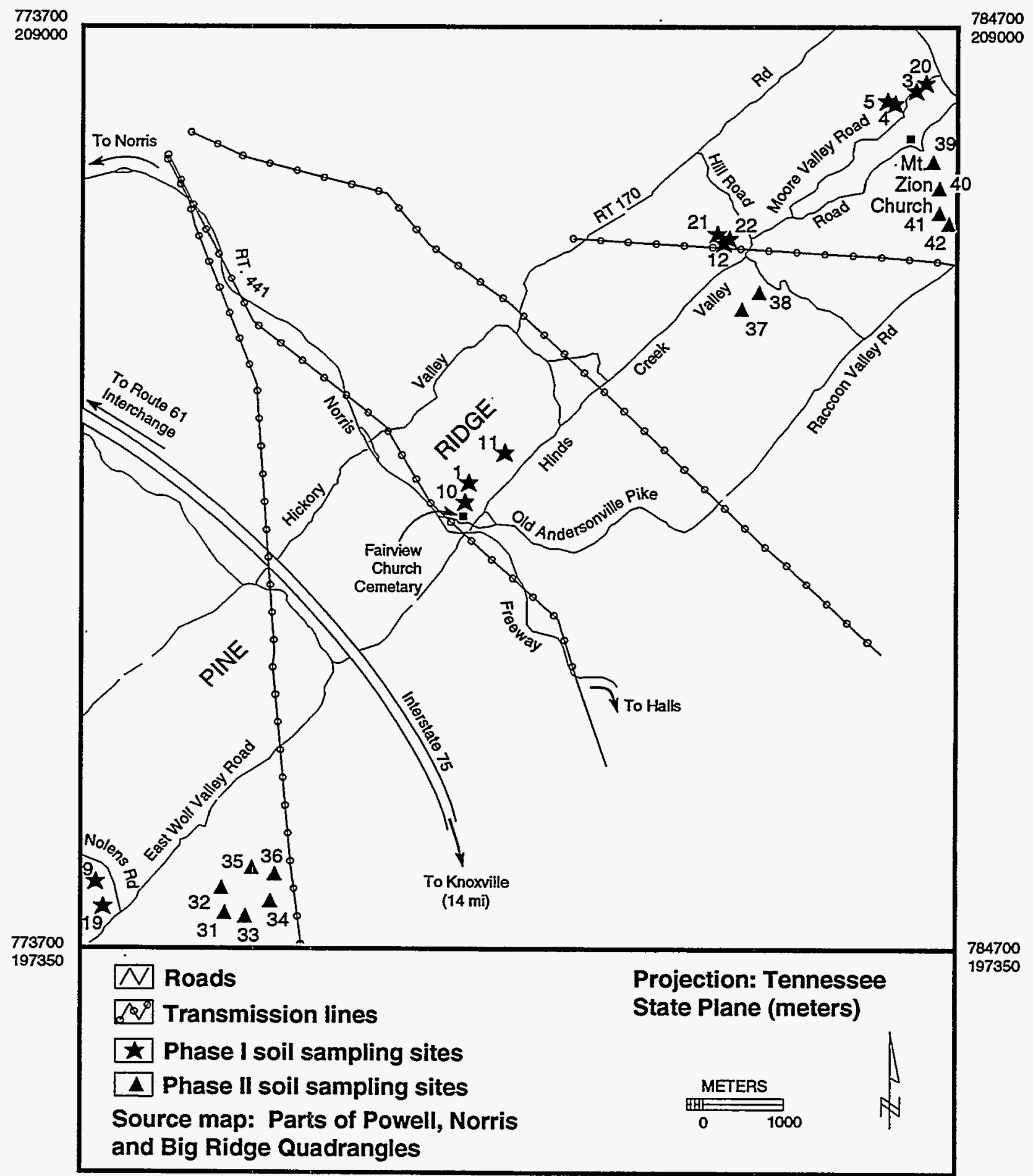

Fig. 3.4. Sampling sites in Anderson County. 
to the actual landform in the woods. If the vegetation parameter was met, then the next evaluation parameter was considered.

Initial soil evaluation. Several soil evaluations were made in an area surrounding the potential 3- by 3-m sampling site to determine whether the soil there was entirely of residual origin and not colluvium, or of a thin capping of colluvium over residuum, which was considered to be an acceptable site. The center of the actual sampling site was then located, and plastic ribbon was tied around one or more trees. The closest route in from the nearest point of access was also flagged so that the site could be located again some time after the initial evaluation.

\subsubsection{Selected Sites}

After the initial vegetation and soil screenings were finished for all of the potential sites, the following ORR sites were found to be suitable:

- Dismal Gap/primary: $11,22,26,32,33$, and 41 ;

- Dismal Gap/secondary: $1,2,4,10,19,27,35$, and 43;

- Nolichucky/primary: $15,23,24,25$, and 31 ;

- Nolichucky/secondary: $3,5,13,16,21,28$, and 42 ;

- Copper Ridge/primary: $45,55,60,62,64,75,83$, and 91 ;

- Copper Ridge/secondary: 51, 54, 58, and 59;

- Chepultepec/primary: $50,52,66,68,73,74,77,78,85,86$, and 90 ;

- Chepultepec/secondary: 53;

- Chickamauga: No primary or secondary sites were designated. Twenty of the 24 were selected by the soil scientist using criteria described elsewhere in this section. Field variance procedures were also used for the Bethel Valley part of the Chickamauga sampling and site grouping procedures.

\subsubsection{Composited Sample Sites}

After 12 sites were chosen for each formation, a randomizing process was used to determine the grouping of threes for the compositing procedure specified in the sampling plan in Sect. 5.3 of the Background Soil Characterization Project (BSCP) Plan (Energy Systems 1992).

Following are the groupings for the ORR sites:

- Dismal Gap: [27 41 11] [ [22 19 32] [ [33 10 35] [ [2 43 26],

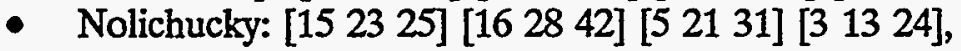

- Copper Ridge: [91 59 58] [62 51 55] [75 60 45] [83 54 64],

- Chepultepec: [53 78 52] [85 86 77] [74 68 90] [66 50 73],

- Chickamauga-Bethel Valley: [93 99 100] [101 102 103] [104 108 110] [115 116 117] (The Bethel Valley groupings were not randomly generated because of a systematic distribution of cesium-137 but were instead cluster grouped to determine whether other anthropogenic compounds had a similar nonrandom distribution.), and

- Chickamauga-K-25: [120 129 126] [118 124 122] [ [119'127 123] [125 128 121].

The exact sequence of sampling a site within any. particular sampling group was not important. 


\subsubsection{Selection and Initial Evaluation of Off-Site Locations}

Conventional U.S. Geological Survey topographic maps were used to locate potential sampling areas in southwest Roane County and in northeast Anderson County, so that these potential areas were in the same strike belt Conasauga Group section and Copper Ridge section as the ORR Dismal Gap and Copper Ridge sites. The University of Tennessee sampling crew made the potential site selection by using the same vegetation and soil parameters described elsewhere in this section. Independent confirmation was obtained that, of the Roane County sites, 12 were in the Dismal Gap Formation and 12 in the Copper Ridge Section. Because of both present and past land uses off-site, the potential number of sampling areas was severely limited, but no two adjacent sampling sites could be closer than $250 \mathrm{ft}$. Twenty four sampling sites that met the vegetation, soils, and past land use criteria were selected in Roane County and 24 in Anderson County (12 in the Dismal Gap and 12 in the Copper Ridge). A radiation scan was not performed for any off-site sampling location.

After the Roane and Anderson sites were selected, a random drawing process was used to generate combinations of sites for compositing purposes. Following are the combinations that were generated:

- Roane County/Dismal Gap: [9 17 19] [3 7 21] [8 20 22] [10 13 14],

- Anderson County/Dismal Gap: [21 4 12] [19 9 10] [3 5 11] [22 1 20],

- Roane County/Copper Ridge: [33 35 44] [40 42 43] [46 47 45] [34 39 41], and

- Anderson County/Copper Ridge: [31 32 36] [34 35 33] [39 42 40] [41 37 38].

\subsection{SITE AND SOIL DESCRIPTIONS}

The site and soil narrative descriptions are presented in Appendix A for on-site ORR locations and off-site locations in Roane and Anderson counties. Also included in Appendix A are tables giving the approximate coordinates of each site. Each site is described in numerical order within any location. In the appendix, ORR sampling sites are described first, followed by descriptions of the Roane County and Anderson County sites.

\subsection{SAMPLING PROCEDURES}

Field operations and sample handling were governed by the following procedures developed specifically for this project:

- Background Soil Characterization Project, Procedure BSCP-SOP-01, Rev. 1, May 23, 1992; and

- Background Soil Characterization Project, Procedure BSCP-SOP-02, Rev. 0, August 6, 1992.

These procedures were developed based on the following references: EPA (1980, 1987a, 1987b, and 1991a); ANSI/ASTM (1980); and Kimbrough et al. (1988).

A performance-based training plan was initiated for all personnel involved with soil sampling activities. The technical coordinator tested the team sampling leader in all aspects of sampling and sample management in which he/she was involved. Only those actually doing 
the soil sampling and signing chain-of-custody forms received performance-based training and testing. Technicians received on-the-job training for those activities in which they were involved and were supervised in these activities, either by the technical coordinator or by the sampling team leader.

\subsection{SOIL SAMPLING AND SAMPLE PREPARATION}

\subsubsection{Scope and Objective}

Procedure BSCP-SOP-01, Rev. 1 describes the siting of soil sampling locations and soil sampling methodology. The objectives of the procedure are to (1) select representative sampling sites and (2) obtain representative soil samples for characterization. This procedure was prepared to meet the project quality assurance/quality control and health and safety objectives (BSCP Plan, Energy Systems 1992).

\subsubsection{Materials}

Required equipment for field sampling operations is described in Procedure BSCP-SOP-01, Rev. 1.

\subsubsection{Field Activities}

\subsubsection{Locating sampling sites}

The soil scientist located potential sampling sites based on location of grid nodes on site location maps (Figs. 3.2 through 3.4). At selected sites, the following stepwise assessment was made before sampling based on the following criteria:

1. Field evidence must substantiate that the present forest vegetation had not been disturbed for the last $40 \pm 5$ years. Young pine plantations were not considered. Only old hardwood forest, old field forest regrowth, and old pine plantation areas were considered as potential sampling sites. If a primary site was unsuitable because of recent surface disturbance, it was rejected with an explanatory note in the soil scientist's logbook, and the secondary site was evaluated for its potential suitability. If this process did not provide sufficient primary and secondary sites selected by random procedures, the soil scientist made additional selections.

2. If a site was deemed to have potential based on vegetation cover, the first soil observed near the grid point that qualified for sampling marked one corner of the proposed sample site. This was one way of reducing soil scientist bias. After one corner of the sample site had been located; additional soil observations were made within a 4-m radius of the located grid point to determine whether the proposed site was uniform enough for sampling or for additional sampling in the future. Proposed sampling areas were located on the most stable part of the landform with the intent that there would have been minimal overland runoff and removal of surface soil materials over the past 40 or so years or recent deposition. The purpose of the additional soil observations was to determine that most of the site was composed of residual soils, not of thick colluvium or a thin (50- to $100-\mathrm{cm}$ ) colluvial capping. However, because of several constraints of 
locating enough suitable sites, soils with a thin colluvial or alluvial capping less than $50 \mathrm{~cm}$ thick were considered suitable for sampling.

3. If the soils and vegetation cover were suitable, then an area approximately 3 by $3 \mathrm{~m}$ was selected and located by flagging around nearby trees. Soil observations were made at the four corners of this square area, and brief soil evaluations were made. Disturbance within the square was kept to a minimum. Soil from these limited observations was not placed within the 3-by-3-m area. The site number was painted on at least one marker stake. This stake was driven into the ground at one corner of the sampling square. Other stakes were placed at the other three corners. These stakes remained in place until all sampling had been completed. Care was taken to minimize surface disturbance of the sampling area when digging pits. On a sloping site, the sampling pit was always located at the lowest point, and the upslope face, if suitable, was sampled. Often, in a forested area, filled-in stump holes were exposed in digging the pit, and another pit face had to be selected. In situations where there was highly variable depth to rock, a pit face other than the upslope face had to be sampled. Soil removed from the pit was placed outside the 3-by-3-m site.

4. The most feasible route from the sampling site to the road was flagged so that the site could be easily relocated.

5. All ORR sites were scanned before any sampling using a hand-held radiation detector. An air reading and a ground-level reading were obtained. If the ground-level radiation reading was higher than $100 \mathrm{cpm}$, then the site was considered contaminated. Where ground-level readings were above 80 counts per minute (cpm), a reading was taken in the top of the auger hole to determine whether a higher level of radioactivity existed in the upper mineral soil. Off-reservation sites in Roane and Anderson counties were not scanned with the detector. Volatile organic compound (VOC) emissions from selected sites were monitored by an industrial hygienist during sampling (only $25 \%$ of ORR sites).

6. After all sampling had been completed, a permanent, steel-marker fence post, suitably labeled, was placed at the center of each site (only ORR sites), so that the site could be relocated.

\subsubsection{Sampling methods}

After arriving at or near the sampling site, all equipment to be used for sampling (which had been precleaned, rinsed, and wrapped in aluminum foil in the laboratory) was thoroughly rinsed with deionized water and then rewrapped with aluminum foil. A small pit was dug in a topographically lower part of the sampling square, so that the area above the pit was not disturbed. Soil horizons were evaluated in this small pit. If the soil exposure was suitable, the pit width was enlarged, so that enough soil area was exposed to acquire the volume needed for the sample. Initial pit excavation was done with a steel shovel or spade. The soil profile was described from the pit face to be sampled before collecting Environmental Sciences Division (ESD) composite samples of $A, B$, and $C$ horizons. The newly exposed pit face was cut back about 1-2 cm with stainless steel soil sampling equipment to expose a fresh face. The forest litter layer was removed down to the mineral surface. If a pit had been opened previously for other sampling, the old pit face was cut back at least $18 \mathrm{~cm}$, exposing a fresh face to obtain undisturbed samples. A fresh, precleaned, and field-rinsed stainless steel sampling tool was used for sampling each soil horizon. Soil contaminated sampling tools were 
not reused in the field until they had been thoroughly cleaned back at the Soil Preparation Laboratory (SPL).

Surface horizon sampling. At least two conditions could be encountered in sampling the surface layer. First, the site could be located in an area that had never been plowed. The horizonation would usually be an $\mathrm{O}$ horizon followed by an $\mathrm{A}$ horizon. This $\mathrm{A}$ horizon, usually thin, is less than $10 \mathrm{~cm}$ thick unless there has been recent deposition, and is underlain by an $\mathrm{E}$ horizon. Second, the site could be located in an old field with naturally regenerated forest or in a pine plantation with trees at least 40 years old. Here the soil would usually have an $\mathrm{O}$ horizon of forest litter followed by a dark-colored $\mathrm{A}$ horizon that is $2 \mathrm{~cm}$ to about 5 or $6 \mathrm{~cm}$ thick. Beneath this horizon is a lighter colored old Ap horizon that typically extends to a depth of 15 to $18 \mathrm{~cm}$. This particular horizon may not always be recognized as an old Ap horizon but instead as an $\mathrm{E}$ horizon. In the event of old fields that have been abandoned to forest 40 to 50 years ago, the surficial organic $O$ horizon and the uppermost $A$ horizon have reformed since the last disturbance. The upper organic enriched mineral horizons, designated as $A$ or Ap, were sampled and labeled A horizon. At some sites, there was no $A$ horizon or only an $A$ horizon less than $2 \mathrm{~cm}$ thick. In this situation, the thin $A$ horizon and the underlying $\mathrm{E}$ horizon were sampled. At all forested sites, sampling usually required the removal of tree roots. As poison ivy grows nearly everywhere, care was taken by samplers to protect against it. A small stainless steel trowel or spatula was used to push soil into the mouth of the sample jar. If any soil went past the mouth of the jar and came into contact with the sampler's hand, the soil was discarded. All sampling was done in this manner, where the soil that was collected came into contact only with the stainless steel sampling tool. The only exception was for gamma screening samples where, because of the geometry of the sampling container, the soil was packed into the lower part of the container using a clean tool, which conformed to QC Level II.

Three different soil samples were collected from the surface. A horizon soil. Noncomposited A horizon samples were collected for (1) VOC analysis in a 250-mL amber glass bottle, (2) tritium analysis in a $1000-\mathrm{mL}$ clear glass bottle, and (3) organic compound (such as PAHs, pesticides, and herbicides) analyses in a 1000-mL amber bottle. Bottles were capped, labeled, and sealed with a custody seal. One additional A horizon sample was collected in a 2-L bottle and labeled, "ESD A Horizon Composite." All A horizon samples were placed in a chilled ice chest in the field and then placed into a refrigerator maintained at $4^{\circ} \pm 4^{\circ} \mathrm{C}$.

Each soil sample had an attached label to uniquely identify that sample. If an A horizon field duplicate sample was obtained for VOC, organics, or tritium analysis, it was identified by the letters "FD" after the sample identification number. The choice of site from which to obtain an A horizon duplicate was at the discretion of the soil scientist. Any used gloves were discarded into a trash bag.

Subsoil (B horizon) sampling. The subsoil, either a Bt horizon or a Bw horizon, was sampled at all sites but only for compositing purposes. Only horizons $8 \mathrm{~cm}$ thick or thicker were sampled individually. Thin subsoil horizons were grouped so that a minimum $15-\mathrm{cm}$ thickness was sampled. The surface of the subsoil horizon was exposed by removing any soil horizons above it. Final removal of overlying soil was done using stainless steel equipment. At least $1.5 \mathrm{~kg}$ of the subsoil samples were collected at a designated depth determined from the field description using stainless steel sampling equipment and placed into a suitably labeled glass 2-L container or into three or four 1-L jars if field splits were to be generated 
in the SPL. If the Bt or Bw horizon was less than $15 \mathrm{~cm}$ thick, its entire thickness was sampled. Otherwise, only the upper $15 \mathrm{~cm}$ was sampled. Samplers wore suitable gloves as needed for the hand work, and the presence of poison ivy roots necessitated protection at some sites. B horizon samples were all labeled, "ESD B Horizon Composite."

C horizon or substratum sampling. Soils having a shallow depth to the $\mathrm{C}$ or $\mathrm{Cr}$ horizon were sampled with manual digging equipment. This included soils in the Dismal Gap and Nolichucky formations and some soils in the Chickamauga. Soils in the Copper Ridge and Chepultepec formations required hand augering equipment to penetrate deep enough to reach such soil materials. The $C$ horizon or substratum is defined as that depth in the soil where there is minimal evidence of translocated clay and where there is minimal expression of pedogenic soil structure. The $\mathrm{C}$ horizon of soils varied; in some, it was composed of mostly saprolite; in some, saprolitic materials; and in some, clayey materials lying directly on bedrock. Depth to the soil layer to be sampled was established by the project soil scientist at each site as sampling was done. However, earlier observations assisted in determining the approximate depth of sampling. At least $1.5 \mathrm{~kg}$ of $\mathrm{C}$ horizon soil samples were collected from depths predetermined from field description using clean stainless steel equipment; placed in glass jars, and labeled, "ESD C Horizon Composite."

Duplicate samples and composited SPL splits. Duplicate soil samples from A, B, and C horizons were collected from at least one composited group per geologic formation for the ORR, Roane, and Anderson locations. The practice of collecting field duplicates for compositing purposes required that a set of $\mathrm{A}, \mathrm{B}$, and $\mathrm{C}$ horizon samples be collected from one face of the soil pit. Then, the field duplicate set was obtained from a side face of the same soil pit to expedite field operations, rather than digging another soil pit. Field duplicates for compositing purposes were identified by the letters "FD" after the sample number. The primary set and the field duplicate set were treated as completely different during SPL compositing procedures.

Field splits were generated in the following manner. Enough additional sample from each of the three horizons to be composited was collected in the field. After the SPL compositing was done; the thoroughly mixed sample was divided into two parts. The first part was placed into a precleaned sample jar and labeled, for example, "metals, A horizon." Another jar, filled with the second part, would have the same designation but a different number and would be listed as a composited split in the laboratory notebook. The contract laboratory was not informed in advance that there were splits. Field duplicates were obtained periodically during BSCP sampling activities. Composited field splits were generated only during the latter part of sampling activities.

Gamma screening samples. Six 5-cm-deep increment samples were collected from a 10by $10-\mathrm{cm}$ area in special plastic containers for cesium-137 determination by gamma spectroscopy. Detailed steps for collecting ESD gamma soil samples follow.

1. After a site had been located and preliminary observations made, including a radiation scan, a pit was dug to a depth of 50 to $60 \mathrm{~cm}$ at one corner of the 3- by $3-\mathrm{m}$ site.

2. Surface litter and organic matter layers were removed to expose the mineral soil surface in an area larger than that to be sampled (about $500 \mathrm{~cm}^{2}$ ). 
3. A $10 \mathrm{~cm} \times 10 \mathrm{~cm} \times 5 \mathrm{~cm}$-deep stainless steel frame was laid on the soil surface and carefully hammered into the soil to its $5-\mathrm{cm}$ depth.

4. Soil from three sides of the frame was removed. A knife or a spatula was used to sever roots and soil from beneath the frame. All soil was removed from the outer sides of the frame before it was placed onto aluminum foil.

5. The soil inside the frame was packed into a 500-mL marinelli beaker. The label was filled out after packing and cross-checked with the field book entry. Large roots ( $>1 \mathrm{~cm}$ diam) were not put into the container. When samples had a considerable number of coarse fragments-for example, soils in the Knox Group-fine earth was packed into the container first, and the coarse fragments were added on top. The container lid was placed, taped, and custody sealed.

6. The sampling frame and equipment were wiped clean of soil using paper towels and a brass wire brush before the next 5-cm increment was collected.

7. The soil from the sampling area was removed down to the top of the next depth in an area larger than that to be sampled. The clean stainless steel frame was placed on the soil and driven into its full $5-\mathrm{cm}$ depth. The soil was removed and packed following the previously described procedure.

8. This procedure was repeated at $5-\mathrm{cm}$ increments to a depth of $30 \mathrm{~cm}$.

3.6.3.3 Preparation of composited soil samples in the SPL

The following steps were employed in preparing soil samples for analysis.

1. Composite samples (to be composited) of $A, B$, and $C$ horizons brought from sampling sites were refrigerated until soil sampling of all three sites in the predetermined group was completed.

2. Individual composite samples were placed on clean blotting paper to partially dry before sieving. All of the samples were passed through a $4.75-\mathrm{mm}$ stainless steel sieve in the laboratory. The coarse fragments $(>4.75 \mathrm{~mm}$ ) were discarded after determination of the weight contribution to the whole soil sample. An equal amount (about $1 \mathrm{~kg}$ or more) of three equivalent horizon samples (passed through the $4.75-\mathrm{mm}$ sieve) was composited by through mixing in stainless steel containers. Mixing involved pouring the sample from one stainless steel container into another several times while the pouring container was rotated. If a sample splitter was used, it produced a mixed composited sample sooner, but care had to be taken not to raise excess dust. One-third of each composited sample was stored in a precleaned glass jar for metal analyses, one-third in a polypropylene bottle for radionuclide analyses, and the remaining one-third (labeled "extra") in a glass bottle for use in measurement of soil properties, such as $\mathrm{pH}$, and for neutron activation analysis (NAA). Additional samples and jars were required if composited splits were generated. The compositing procedure resulted in the destruction of the original field composite $A$, $B$, and $C$ horizon soil samples. New sample numbers were assigned to all SPL composited soil samples, and a new chain-of-custody form was completed. The sampling time (and date) for composited samples corresponded to the original field composite sample with the earliest sampling date. 
3. The composited $B$ and $C$ horizon soil samples and noncomposited $A$ horizon soil samples were preserved in the SPL refrigerator until packed for shipment. Samples were shipped to the designated contract laboratories through the Analytical Projects Office according to Procedure BSCP-SOP-02, Rev. 0.

\section{Additionally, note that}

- Soil profile descriptions were recorded in the field sampling notebook. Soil profile descriptions were not made until the soil pit was dug to the depth required for sampling $\mathrm{B}$ and $\mathrm{C}$ horizons. Any horizons that were field grouped for sampling because of thinness were noted in the field book.

- A variance form was used where field conditions necessitated a change in sampling procedure (none were needed in Phase I, but more than one were executed in ORR Phase II activities). It was intended that the sampling and compositing procedures would be the same for all sites underlain by a particular geologic formation(s).

\subsubsection{NAA samples}

Composited samples of all A, B, and C horizons that had been labeled "extra" and preserved in a refrigerator were subsampled for NAA A 40-mL precleaned glass sample jar with a teflon seal was filled with soil from a large clear glass "extra" jar. A small sampling device was used to obtain a vertical cross-section sample from the large glass jar. Sampling was done in this manner until the $40-\mathrm{mL}$ jar was filled. The small sample jar was given the same "extra" composited sample number but was designated "NAA." A laboratory chain-of-custody form was completed, and the samples were transferred to the Analytical Chemistry Division at ORNL. After the samples had been returned to the SPL, the moisture content of each was determined. Consistent with other CLP method requirements, the moisture content was used to convert all NAA results to an oven-dry-soil basis.

\subsubsection{Cleaning sample containers and sampling tools}

Precleaned glass jar sample containers used by field sampling teams were obtained from a commercial supplier. Analytical results of the last rinse water for the lot were provided by the supplier. Stainless steel sampling devices were cleaned by field sampling teams in the SPL using Method ESP-900 (Environmental Surveillance Procedures, Kimbrough et al. 1988). Soil-contaminated tools were brought into the soils laboratory. They were first washed in tap water and a detergent, then thoroughly rinsed with warm tap water. The tools were then carefully rinsed with SPL distilled water for a total of five rinses. The tools were given another five rinses with deionized distilled water and then wrapped while wet in one or more thicknesses of aluminum foil and placed in a cardboard box ready for transport to the field. An acid rinse and a solvent rinse called for in the above ESP-900 procedure were not applied to stainless steel field and laboratory equipment. A final deionized water rinse of the sampling devices was performed in the field before sampling. The effectiveness of the equipment cleaning and any potential contamination during sampling trips was monitored by submitting rinse water samples for analysis (five times by on-site and off-site sampling teams). The quality of the deionized and organic-free water used was monitored by collecting samples (once from on-site and off-site water sources) in standard precleaned sample containers and submitting them to the analytical laboratory for analysis. 
3.6.3.6 Maintenance and calibration of SPL balances, oven, refrigerator, and other equipment used in soil preparation activities

The SPL balance was used to weigh soil for compositing, to obtain the weight of coarse fragments, and to determine moisture contents of soil samples. The electronic balance is recalibrated every 6 months. In use, the balance was zeroed before anything was placed on the pan. The weight was recorded after the balance stabilized and an "OK" appeared in the display window. The accuracy of the balance was verified using a standard weight. In addition, a set of brass weights ranging from $1 \mathrm{~g}$ to $2000 \mathrm{~g}$ was used to determine both accuracy and precision. This information was recorded in the BSCP laboratory notebook.

Periodic temperature monitoring was conducted of the refrigerator, the ice chests used to cool soil samples in the field, and the ice chests used in the transfer to analytical laboratories. Temperature measurements made with a max/min thermometer indicated that a temperature range of $4^{\circ} \pm 4^{\circ} \mathrm{C}$ was maintained most of the time. However, the EPA standard is $4^{\circ} \pm 2^{\circ} \mathrm{C}$. The addition of several relatively warm samples could raise the temperature above $8^{\circ} \mathrm{C}$ for a short time. There were a few instances where a VOC trip blank was taken to the field with too much ice, resulting in partial freezing of the trip blank before warmer soil samples were added to the ice chest. Temperature data were recorded in the laboratory and field notebooks where appropriate.

The oven in the SPL was monitored periodically to ensure that the drying temperature was maintained between $100^{\circ}$ and $104^{\circ} \mathrm{C}$. These monitoring data were recorded in the laboratory notebook.

The deionized water used for sampling equipment rinsing was monitored periodically for conductivity. This information was put in the laboratory notebook.

\subsubsection{Maintenance and transfer of records}

Original records were maintained in the SPL (Building 1505, Room 375 at ORNL) for all BSCP ORR sampling activities. For University of Tennessee sampling activities, some original documents were kept there, and copies were kept in Room 375. Records were kept in a file cabinet with a list of contents. After each phase of the project had been completed and the data verified, copies were made of each document, and the originals were transferred to archived storage. Transfer was accomplished by a chain-of-custody procedure, where the original documents to be transferred were listed individually. Copies remain in the SPL for reference and review.

\subsubsection{Management of noncontaminated waste in the SPL}

Waste generated in the SPL consisted of emptied glass jars, excess soil beyond what was needed for compositing purposes, soil in gamma scan containers, soil in VOC sample bottles returned from the Y-12 Plant VOC analytical laboratory, and blotting paper. Because none of the these waste materials contained any hazardous metals, organics, or radionuclides, disposal was done as follows. The plastic lids and teflon seals were removed from the glass jars and placed into a suitable trash container at the rear of Building 1505. The glass jars were placed in the glass dumpster at the rear of Building 1505. Blotting paper was placed into the waste container in Room 375 for removal by cleaning personnel. Excess soil was returned to the woods close to its origin and spread on the forest floor in a thin layer. 
If the SPL should have any contaminated samples, they would be disposed of under laboratory standard operating procedures.

\subsection{FIELD QUALITY CONTROL OBJECTIVES AND METHODS}

There were three major objectives for achieving field quality control:

1. selection of representative sampling sites undisturbed by recent activities, including ORR facility activities or off-site activities, such as farming operations or recreational uses, that resulted in surface soil disturbance;

2. collection of representative samples and transfer of these samples to analytical laboratories; and

3. prevention of cross-contamination at any site and between sites, which included maintaining a complete chain of custody and detailed records of all field and laboratory compositing activities.

Any sign of recent (in the past 40 to 50 years) land disturbance or the presence of man-made organic compounds or radionuclides above global fallout levels would immediately result in a site being rejected. Potential sites were initially chosen on the basis of the lack of any recent land disturbance which, for most sites, was the presence of old-field successional forest. Nearly all of the sites had been cultivated and severely eroded before being abandoned or planted in pine trees on the ORR or allowed to revert back to forest on private lands.

Site screening on ORR sites included the following:

1. Sites were scanned for radiation. Any ground-level reading above $100 \mathrm{cpm}$ resulted in a site being rejected. However, no potential sampling sites were rejected for this reason.

2. Selected ORR sites were monitored for organics by an industrial hygienist while a sampling pit was opened, either for the first time or when the pit was reopened to collect additional samples.

3. Samples of each A horizon were collected for VOC analysis at all sites. Site screening at Roane County and Anderson County sites consisted of collecting VOA samples from all A horizons. The BSCP Plan stated that VOC analyses would be done according to EPA Analytical Level II. Analytical laboratory data in the BSCP adhere to EPA Level IV methods, procedures, and documentation requirements. The Y-12 Plant Laboratory used Level IV methodology and procedures in determining VOC levels but, because the results were to be used only for screening purposes to reject unacceptable sampling sites (by preactivity), these results were required to be reported and documented only to Level II, because more rigorous requirements were unnecessary.

Field quality levels ranged from data quality (DQ) Level II to DQ Level IV. However, in practice, DQ Level IV was adhered to throughout all field sampling activities, including screening samples for VOCs, where samples were placed into precleaned glass containers. Field quality control procedures are listed in Sects. 6.6.1.3 to 6.6.1.9 of the BSCP Plan 
(Energy Systems 1992). The following discussion covers the procedures followed in collecting samples.

Before going to the field, all stainless steel sampling equipment was thoroughly washed with soap and water followed by a prescribed number of distilled water rinses. After the final rinse, the equipment was wrapped with aluminum foil: The sampling equipment was taken to the field in the back of a pickup truck. At or near the site, the sampling equipment was unwrapped and given a field rinse, then immediately rewrapped until it was used. Some sites were located a considerable distance from the closest point of access. In these instances, rinsing was done at the truck and the equipment was wrapped in aluminum foil, placed into a backpack, and carried to the site. A small pit was dug with a steel shovel deep enough to place the sample jar below the soil horizon to be sampled. A sampling tool was unwrapped and used to remove soil from the pit face directly into the jar. At no time did fingers touch a soil sample placed into a precleaned glass sample container. Soil pushed by the sampling tool beyond the mouth of the jar was discarded. The only exception to this rule was placing soil into the ESD gamma poly containers. Placing the entire volume of soil into the gamma poly container required that the soil be packed into the lower restricted space either with fingers or with a freshly cut stick of a convenient diameter. After each soil horizon was sampled, a new sampling tool was used to collect samples from the next soil horizon. All soilcontaminated stainless steel sampling tools were returned to the laboratory for standard cleaning, rinsing, and wrapping in aluminum foil. Shovels used to open and fill pits were thoroughly cleaned between sites to prevent any cross-contamination. In addition, soil removed from pits was placed outside the 3- by 3-m sample area.

Each sample was given its own identification number in the field. This number and the description of each sample were first recorded in the field logbook. From the field logbook, sample container labels were completed and placed on glass sample jars, after the jar was filled. Each sample logged into the field logbook then was transcribed onto a field chain-of-custody form which was signed by all personnel involved in the sampling operation.

SPL operations after compositing consisted of placing soil samples in a refrigerator, preparing laboratory chain-of-custody forms, packing samples into ice chests, and taking them to shipping or, in the case of the UT SPL, bringing them to the ESD SPL at ORNL for storage until they were sent for analysis. In the latter half of Phase I and all of Phase II activities, preparation of laboratory chain-of-custody forms and new container labels, the packing, and the shipping were done by MAD/APO personnel, according to Procedure BSCP_SOP-02, Rev. 0.

The compositing process resulted in the destruction of the individual site A horizon, B horizon, and $C$ horizon samples and the creation of new composited samples. All of these activities were recorded in the ESD soils laboratory logbook. New sample numbers were first recorded in the laboratory logbook, then transcribed onto container labels and the appropriate chain-of-custody form.

The field change/variance system '(Sect. 6.6.1.9 of the BSCP Plan, Energy Systems 1992, Volume 3) was not utilized in any Phase I activities, but it was used in certain ORR Phase II activities, primarily to make changes in implementing cluster compositing of the Bethel Valley Chickamauga sites (see Sect. 5.2.1). The clustering procedure grouped each set of three adjacent site samples for compositing purposes. 


\subsection{QUALITATIVE RESULTS OF GAMMA SPECTROSCOPY SCREENING}

The objective of gamma screening was to determine whether any of the sites had been affected by ORR facility or off-site activities in the past or had been subjected to recent erosion or deposition. Gamma spectroscopy shows the activities of several radionuclides in soils. There are several important natural radionuclides such as potassium-40, thorium, and radon-226, and there can be several anthropogenic radionuclides including cesium- 137 . Cesium-137 activities in the upper $30 \mathrm{~cm}$ of soil profiles at each site were used as a screening parameter. If the potential site had a cesium-137 radioactivity level caused by local sources that was much higher than regional background fallout level, it could be rejected as a sampling site, if there was no obvious explanation from the site description. The presence of any other anthropogenic radionuclide would also have resulted in rejection of a sampling site. The average background level of cesium-137 for the southeastern United States is now about $8.5 \mathrm{pCi} / \mathrm{cm}^{2}$. However, soils located in areas that received deposition from higher areas could have up to $14 \mathrm{pCi} / \mathrm{cm}^{2}$, and soils from erosional landforms could have much lower values. Soils located on a stable landform would be ideal for the BSCP. However, it was necessary to use some sites that were less desirable than the ideal, but which, in fact, represent the real world better, as there are no ideal sites.

The gamma screening samples were counted on a high-resolution, solid state, coaxial, intrinsic, germanium detector coupled to an ND9900 multichannel analyzer with 4096 channels. The gamma system had previously been calibrated with a laboratory control sample (National Bureau of Standards SRM 4353 Rocky Flats Soil) in the geometry used to contain the soil samples. The documentation of analytical results was prepared at DQ Level II, but the analytical procedure used for the soil samples was DQ Level IV. For example, the laboratory control sample, laboratory blank; and duplicate counts were performed within a batch of 20 or fewer samples and documented. In addition, sources were counted on a weekly or daily schedule to verify that the detectors remained in calibration.

Cesium-137 values in picocuries per square centimeter were summed for the upper $30 \mathrm{~cm}$ of the soil profile (see Appendix B). In another part of Appendix B, the gamma screening data have been converted to picocuries per gram after moisture content analysis, and the dry weight of each scanned sample was determined. Statistical analysis shows that there are significant differences between ORR, Anderson, and Roane Dismal Gap sites, but no differences exist between Copper Ridge sites. Roane County sites have lower mean values, but this can be accounted for by present and recent past land use practices causing localized erosion in Roane County. One Roane County site, No. 13, had a total cesium-137 value of $1.98 \mathrm{pCi} / \mathrm{cm}^{2}$. The soil profile description for this site (Appendix A) strongly indicates that this severely eroded site has only very recently become stabilized with a forest litter layer, thus reducing surface erosion. Two Roane County sites had high cesium-137 values compared with the expected average background level of approximately $8.5 \mathrm{pCi} / \mathrm{cm}^{2}$. Both sites had a surface capping of either colluvium or alluvium, a situation where there is lateral water and sediment movement and localized transport and deposition from higher areas. Note that a global source of cesium-137 exists via atmospheric deposition over the entire region of the ORR and Roane and Anderson counties. In addition, the ORR has superimposed on it, at least in certain locations, the contribution of cesium from sources within the ORR. No transport or movement of cesium or other soil constituents is postulated or implied from these results between on-site and off-site sampling areas. Two Anderson County sites had the highest values: $A N D-19$, with a value of $14.42 \mathrm{pCi} / \mathrm{cm}^{2}$, and $A N D-41$, with a value of $14.31 \mathrm{pCi} / \mathrm{cm}^{2}$. The first site; AND-19, located on the lower part of a convex slope, has an overthickened 
surface horizon with about $13 \mathrm{~cm}$ of modern sediment overwash that contains considerable cesium-137, while AND-41 also has an overthickened A horizon. The ORR Dismal Gap data are slightly higher than the Anderson County and Roane County Dismal Gap data because of higher minimum values, which indicates a longer period of minimal disturbance for the ORR sites. The Nolichucky data have the highest mean values and also the highest minimum values. This is most likely caused by the more gentle slope gradients which resulted in less lateral transport of particles downslope. The ORR Dismal Gap sites were significantly different from the Roane and Anderson county sites. There were no differences between the ORR, AND and ROA Copper Ridge sites. The gamma scan results for some of the ORR-Bethel Valley sites indicate that a localized cesium-137 source exists. A characteristic bell-shaped curve of cesium-137 distribution occurs with the highest value from ORR-101 of $22.89 \mathrm{pCi} / \mathrm{cm}^{2}$. This ORR-101 site is located just east of the new water treatment plan and at the west end of Building 4500. The adjacent two sites 100 and 102 (on either side of 101), also have elevated cesium-137 levels. Background levels are reached at ORR-104, which is located just east of the HFIR road. The ORR K-25 Chickamauga sites had typical cesium-137 background values that were slightly lower than the ORR Copper Ridge mean value, but this is to be expected because the Chickamauga soils tend to be more erosive. In conclusion, most variations in the cesium-137 gamma screening data could be accounted for by past land use and by landform variability. The cesium-137 data from ORR sites 101, 102, and 103 were not used for statistical analysis and for risk assessment because there was possible local contamination with cesium-137 at these sites. Tritium data from ORR sites 101, 102, and 103 were also deleted because of suspected local contamination.

\subsection{QUALITATIVE ANALYSIS OF OAK RIDGE RESERVATION SITES}

ORR Site 2. This site, based on both geologic information and soil survey data, is situated within the Dismal Gap Formation. The soils are typical of ORR Dismal Gap soils in that they possess a very high degree of spatial variability. No visual field evidence existed of any recent surface disturbance, nor had the site ever been plowed. The A horizon sample consisted of $A$ and $E$ horizon soil material. The $B$ horizon sample consisted of the entire argillic horizon, and the $\mathrm{C}$ horizon consisted of transition horizons between the argillic horizon and the $\mathrm{Cr}$ horizon. The VOA sample 1257 contained chloroform. This is considered to be caused by instrument contamination. The related water trip blank did not contain chloroform. Two sets of A horizon samples were collected for tritium analysis (samples 1189 and 1198). No tritium was detected in either sample, but the reported detection limits were different. Two sets of A horizon samples were collected for organics analysis (samples 1190 and 1201). Most of the reported numbers, below detection limits, are similar, but statistical analysis would be needed to determine whether any of the reported results are different. The ESD gamma scan analysis for cesium-137 gave a value of $8.33 \mathrm{pCi} / \mathrm{cm}^{2}$, a typical value for cesium in the upper $30 \mathrm{~cm}$ of the soil on a sloping site.

ORR Site 3. This site is located on the Nolichucky Formation and within $50 \mathrm{ft}$ of the north edge of the cutslope above Bear Creek Road. This site is in old-field successional woods, and no field evidence existed of recent surface disturbance. The A horizon soil sample consisted of a thin A horizon and the old Ap horizon beneath. The B horizon sample consisted entirely of argillic horizon soil material, and the $C$ horizon sample was collected entirely of $\mathrm{C}$ horizon material between the $\mathrm{B}$ horizon above and the $\mathrm{Cr}$ horizon beneath. Acetone from instrument contamination was detected in VOA sample 1271, but the reported value is lower than for other samples that have a " $U$ " qualifier. The organics analysis 
indicated no detects. The ESD gamma scanning results gave a cesium-137 value of $8.47 \mathrm{pCi} / \mathrm{cm}^{2}$ in the upper $30 \mathrm{~cm}$ of the soil profile.

ORR Site 5. This site is located in the Nolichucky Formation. This site is located behind the security fence of the Central Training Facility and about $50 \mathrm{ft}$ south of Bear Creek Road. The vegetation is old-field successional forest dominated by pines. This site had a layer of pine needles and mosses $5 \mathrm{~cm}$ thick and differed from many other sites in this respect. The A horizon sample consisted of an old Ap horizon. The B horizon sample consisted of the entire argillic horizon, and the $C$ horizon consisted of a mixture of $C$ and $\mathrm{Cr}$ horizon materials because of the steeply dipping strata. VOA sample 1272 contained acetone (from sporadic, accidental instrument contamination). All organics were below detection limits. ESD gamma scanning results gave a cesium-137 value of $9.03 \mathrm{pCi} / \mathrm{cm}^{2}$ in the upper $30 \mathrm{~cm}$ of the soil profile, a typical value of a stable site where no recent erosion has occurred.

ORR Site 10. This site is situated in the transition zone between the Dismal Gap Formation and the Rogersville Formation. Vegetation includes hardwoods, indicating that this site had reverted from agricultural activities well before other sites because of very severe erosion before abandonment. The $A$ horizon sample consisted entirely of $A$ horizon materials, the $B$ horizon consisted of cambic materials, and the $C$ horizon consisted of $C$ and Cr materials, an example of a fairly typical Dismal Gap soil. VOA sample 1258 contained acetone (instrument contamination). The tritium result was rejected (refer to Sect. 4.5.3.10 for explanation). All organic results were below detection limits. ESD gamma scanning results gave a cesium- 137 value of $10.97 \mathrm{pCi} / \mathrm{cm}^{2}$ in the upper $30 \mathrm{~cm}$ of the soil profile, an indication that this site was stable even though the slope was about $20 \%$, and evidence indicates that the site had once been severely eroded before global fallout started. The slightly higher than normal value indicates that there has been 1 to $2 \mathrm{~cm}$ of recent deposition.

ORR Site 11. This site is located about $400 \mathrm{ft}$ downslope from ORR Site 10. This site is located in the Dismal Gap Formation. Vegetation consisted of old-field successional forest, indicating that this site was open when abandoned in 1942-43. The A horizon sample consisted of the old Ap horizon, the B horizon sample consisted of the entire thickness of the argillic horizon, and the $C$ horizon sample consisted mostly of $C$ materials. Because ORR Site 10 and ORR Site 11 are close together, the results should be closely comparable, except for the differences in past land use, surface stability, and present vegetation. VOA analysis (sample 1259) shows nothing above detection limits, except for acetone (instrument contamination). No tritium was detected. All organic results were below detection limits. ESD gamma scanning results gave a cesium- 137 value of $7.26 \mathrm{pCi} / \mathrm{cm}^{2}$ in the upper $30 \mathrm{~cm}$ of the soil profile, considerably lower than that for ORR Site 10 , indicating that some soil erosion has occurred since global fallout started.

ORR Site 13. This site is located in an abandoned farm yard. The soil had a thick, dark surface layer, indicating that it had formed beneath grass vegetation. This site, in the Nolichucky Formation, is underlain by a brecciated zone having higher porosity than is typical. VOA sample 1273 showed acetone as an instrument contaminant. Organics results indicated the estimated " $\mathrm{J}$ " presence of a PAH, benzo[b]fluoranthene. All other data were below detection limits. Recent pine harvesting and replanting activity near this site might have caused this PAH to be in the soil. ESD cesium-137 gamma scanning results gave a value of $8.94 \mathrm{pCi} / \mathrm{cm}^{2}$ in the upper $30 \mathrm{~cm}$ of the soil, indicating that this site has been stable. 
ORR Site 15 and ORR Site 16. These sites are located about $250 \mathrm{ft}$ apart on the Nolichucky Formation. They have similar vegetation of 40 - to 50-year-old planted loblolly pines. The major difference is that one site, ORR Site 15 ; is located on a nearly level landform, and ORR Site 16 is located on a sideslope with $10 \%$ slope gradient and was severely eroded before abandonment. Except for acetone caused by instrument contamination, there were no VOAs above detection limits. The organic results were also very similar to all results below detection limits except for " $\mathrm{J}$ ". estimates of benzo[a]pyrene, benzo[b]fluoranthene, and benzo[b]fluoranthene at very low levels at ORR Site 16. ESD gamma scanning results from ORR Site 15 gave a median value of $8.08 \mathrm{pCi} / \mathrm{cm}^{2}$ in the upper $30 \mathrm{~cm}$ of the soil, indicating that this site has been stable. ESD cesium-137 gamma results for ORR Site 16 gave a value of $9.93 \mathrm{pCi} / \mathrm{cm}^{2}$ in the upper $30 \mathrm{~cm}$ of the soil profile, indicating that this site has also been stable since global fallout began.

ORR Site 19. This site is located on the Dismal Gap Formation. It is in an old field with old-field successional forest dominated by pines. All samples were collected from appropriate soil horizons. Except for acetone resulting from instrument contamination, there were no VOAs above detection limits. Tritium was not found at this site, but the results were rejected because of analytical laboratory problems. The organic results were all below detection limits, except for fluorene which has a "J" qualifier. ESD cesium-137 gamma scanning results from ORR Site 19 gave a value of $9.01 \mathrm{pCi} / \mathrm{cm}^{2}$ in the upper $30 \mathrm{~cm}$ of the soil, indicating that this site has been stable.

ORR Site 21. This site is underlain by the Nolichucky Formation. Present vegetation is old-field successional forest once dominated by pines. This site is situated on a bench landform below an upper convex slope and had been severely eroded before abandonment. All VOA results were below detection limits except for acetone caused by instrument contamination. All organics results were below detection limits. ESD cesium-137 gamma scanning results from ORR Site 21 gave a value of $11.46 \mathrm{pCi} / \mathrm{cm}^{2}$ in the upper $30 \mathrm{~cm}$ of the soil, indicating that this site has probably received some soil deposition from higher areas since global fallout began.

ORR Site 22. This site is in the transition zone between the Dismal Gap Formation and the Rogersville Formation. It is situated on a high point in the landscape. The site is in an old field. The present forest vegetation is old-field successional dominated by pines. The A horizon sample consists of a recently formed A horizon and the old Ap horizon beneath. The $\mathrm{B}$ horizon consists of the entire thickness of the argillic horizon, and the $\mathrm{C}$ horizon sample consists of a mixture of the $\mathrm{C}$ and $\mathrm{Cr}$ soil materials. The soil is very typical of the geology and landform location. The VOA data show no detects except for acetone, which is the result of instrument contamination. Tritium was detected at this site (sample 1123) (refer to Sect. 4.5.3.10 for explanation). All organics were below detection limits. ESD gamma scanning results for cesium-137 gave a value of $9.63 \mathrm{pCi} / \mathrm{cm}^{2}$, indicating that this site has been stable since global fallout began, and that little cesium had been removed by erosion.

ORR Site 23, ORR Site 24, and ORR Site 25. These three sites are closely related in terms of their geology, landscape position, vegetation, and past land use. They are all underlain by the Nolichucky Formation, and all are in forest dominated by old-field successional pines. All three sites have similar soil morphology with a superficial layer of organic materials. The A horizon samples consisted of a thin $A$ horizon and the old Ap horizon beneath. The $B$ horizon samples consisted of a mixture of the argillic and cambic horizons, and the $\mathrm{C}$ horizon samples were a mixture of $\mathrm{C}$ and $\mathrm{Cr}$ soil materials. Duplicate 
samples were collected for VOA analysis from two of the three sites. The results were all below detection except for acetone caused by instrument contamination. The organic results were also very similar for all three sites, except for "J" estimates of acenapthene in ORR Site 23 and pyrene in ORR Site 24. The results for benzoanthrene, chrysene, and fluoranthene were all rejected (discussed in Sect. 4.5.1.3). ESD cesium-137 gamma scanning results are similar for ORR Site 23 and ORR Site $24,9.17$ and $10.49 \mathrm{pCi} / \mathrm{cm}^{2}$, respectively, indicating site stability. ORR Site 25 had a result of $7.69 \mathrm{pCi} / \mathrm{cm}^{2}$, indicating that some erosion had occurred since global fallout started.

ORR Site 26 and ORR Site 27. These sites are also close together. Both are underlain by the Dismal Gap Formation, have similar forest vegetation and past land use, and are separated by a quite deeply incised drainageway. Both sites are in old fields that were abandoned well before 1942-43. The early successional pines on both sites had all been replaced by hardwoods. The A horizon samples consisted of a recently formed $A$ horizon and the older Ap horizon beneath. The B horizon samples consisted of the entire thickness of the argillic horizon, and the $\mathrm{C}$ horizons consisted of a mixture of $\mathrm{C}$ and $\mathrm{Cr}$ horizon materials. VOA results were all non-detects except for acetone and 2-butanone, which are caused by instrument contamination. ORR Site 26 contained "J" estimated tritium, while ORR Site 27 did not. The organic results for both sites were below detection limits. ESD gamma scanning data for cesium-137 indicated a normal result of 8.59 for ORR Site 26 and $6.35 \mathrm{pCi} / \mathrm{cm}^{2}$ for ORR Site 27, an indication of recent erosion from this site. ORR Site 26 is on a steeper slope gradient than ORR Site 27 but appears to be more stable. One cannot rule out a forest fire on ORR Site 27 that could have led to some soil erosion.

ORR Site 28. This site is located a short distance south of ORR Site 26 and ORR Site 27. ORR Site 28 is underlain by the Nolichucky Formation and is in a dense stand of young pines with some scattered hardwoods. The old-field successional pines had already been harvested from this site or had died and fallen over. The soil profile is typical of Nolichucky soils. The A horizon sample consisted of a thin, recently formed A horizon and the older Ap horizon beneath. The B horizon sample consisted entirely of the argillic horizon, and the $\mathrm{C}$ horizon sample consisted of mostly $\mathrm{C}$ horizon materials. Two samples were sent for VOA analysis. There were no detects in the VOA results exception for an acetone "J" value caused by instrument contamination. All organics were below detection limits, with two PAHs rejected. ESD gamma scan results for cesium-137 showed a value of $9.69 \mathrm{pCi} / \mathrm{cm}^{2}$, indicating that this site had not been subjected to erosion since global fallout started, even though this site had been severely eroded before abandonment.

ORR Site 31. This site is underlain by the Nolichucky Formation, but the upper $61 \mathrm{~cm}$ consisted of colluvium. Most of the old-field successional pines had been harvested in the past 10 to 15 years, and there was evidence that the larger area around this site had been disturbed, but the site did not show any evidence of disturbance. This site was considered marginal in terms of site quality during the site selection process, but, with the difficulty of locating suitable Nolichucky sites, it was sampled. Two samples were collected for VOA analysis. One result showed the presence of trichlorofluoromethane, but the other sample did not. Both samples had acetone, and one had 2-butanone, which is considered to be caused by instrument contamination. The organic results had a " $J$ " estimate for benzo[b]fluoranthene, and the result for fluoranthene was rejected. All other organics were below detection limits: ESD gamma scanning data showed a value of $11.14 \mathrm{pCi} / \mathrm{cm}^{2}$ for cesium-137, a value slightly higher than predicted. This site is on the lower part of a long side slope and had received 
some deposition of soil from higher on the slope. Specific data for this site do not indicate that it should be rejected.

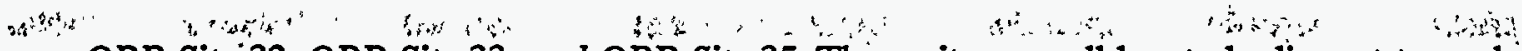

ORR Site 32, ORR Site 33, and ORR Site 35. These sites are all located adjacent to each other and are separated by about 250 to $300 \mathrm{ft}$. All three sites are underlain by the Dismal Gap Formation and have had similar old-field successional forest dominated by pines. Most of the pines have recently died and fallen over, releasing a dense understory of brush, small pines, and small hardwoods. All three sites had similar soil morphology. The A horizon sample consisted of a thin, recently formed A horizon and the older Ap horizon beneath. The $B$ horizon sample consisted of the entire thickness of the argillic horizon, and the $C$ horizon sample consisted of a mixture of $\mathrm{C}$ and $\mathrm{Cr}$ materials. Acetone was found in all VOA samples, but it is considered to be caused by instrument contamination. All three sites have detectable tritium. All organics were below detection limits. Data from ESD cesium-137 gamma scanning had some spread, indicating that one site (ORR Site 35) was more subject to erosion than the other two sites. ORR Site 32 had a value of 7.88, ORR Site 33 had a value of 9.38 , and ORR Site 35 had a value of $5.87 \mathrm{pCi} / \mathrm{cm}^{2}$. These differences cannot be explained in terms of soil morphology, slope gradient, vegetation, or landscape position but are the result of micro erosion and deposition on hill slopes.

ORR Site 41, ORR Site 42, and ORR Site 43. These sites are located near the west end of the Y-12 burial grounds. ORR Site 41 and ORR Site 43 are underlain by the Dismal Gap Formation, while ORR Site 42 is underlain by the Nolichucky Formation. All sites had typical soils of their geologic formation and had similar morphology. Except for acetone, all A horizon VOA analytes were below detection limits. Tritium was not detected in ORR Site 41, and the other sites were not analyzed. No organics registered above detection limits in ORR Site 41 and ORR Site 43 . Benzo[b]fluoranthene and pyrene were estimated at very low levels in ORR Site 42. The results of some PAHs for these sites were rejected. ESD cesium-137 gamma scan data for two of the three sites showed that minimal surface instability had occurred since global fallout started. ORR Site 41 had a value of $10.89 \mathrm{pCi} / \mathrm{cm}^{2}$ in the upper $30 \mathrm{~cm}$ of soil, ORR Site 42 had a value of 6.75 , indicating erosion, and ORR Site 43 had a value of 8.48. Soil morphology for ORR Site 42 shows that this site had been somewhat less stable than the sites on either side.

ORR Site 45. This site is located within the Copper Ridge Formation. Vegetation is oldgrowth hardwoods that have been cut several times. The most recent logging near this site was done 15 to 25 years ago. An access road was cut nearby, about 100 to $150 \mathrm{ft}$ away, to allow access for well drilling. The soil surface was leaf-covered. The A horizon samples were collected from a thin A horizon and the E1 horizon immediately beneath. There were no VOA detects, but there were one or more PAHs. These PAH compounds were found at every Copper Ridge and Chepultepec site on the ORR. ESD gamma scanning results gave a cesium-137 value of $8.00 \mathrm{pCi} / \mathrm{cm}^{2}$ indicating a stable site. Based on all screening data, this site was considered suitable and representative.

ORR Site 50. This site is located within the Chepultepec Formation. Vegetation is old-field successional forest, where most of the early pines have died and fallen over. The soil surface was covered both by leaves and by an underlying $\mathrm{Oa}$ horizon. The $\mathrm{A}$ horizon samples were collected wholly from the A horizon. Because of the thickness of the subsoil Bt horizon, the $C$ horizon sample (at a depth of 140 to $160 \mathrm{~cm}$ ) was sampled in the lower Bt horizon. Both acetone and butanone were detected in the VOA analysis, but the presence of these compounds is considered to be caused by instrument contamination. There were detects for 
several PAHs. After examination of the data, these PAHs were considered to be natural background. ESD gamma scan results gave a cesium-137 value of $8.39 \mathrm{pCi} / \mathrm{cm}^{2}$ indicating a stable site. Based on all site parameters and screening tests, this site was considered suitable and representative.

ORR Site 51. This site is located in the Copper Ridge Formation. Vegetation is old-field successional forest, but most of the original pines have died and fallen over, releasing poplar, red maple, and sugar maple. This site is near an area that was recently cleared and planted in loblolly pines and is within $80 \mathrm{ft}$ of a bulldozed road to allow access for drilling wells. Both acetone and butanone were detected in the VOA analysis, but these compounds were caused by instrument contamination. One or more PAHs were detected, but these occur at all Copper Ridge and Chepultepec sites. ESD gamma scanning results gave a cesium-137 value of $8.30 \mathrm{pCi} / \mathrm{cm}^{2}$ indicating a stable site. Based on site selection criteria and screening criteria, this site was considered suitable and representative.

ORR Site 52. This site is located in the Chepultepec Formation. Vegetation is old-field successional, but most of the original pines have died and fallen over. The soil surface is leafcovered. The A horizon sample was collected from the regenerated forest soil A horizon and the older Ap (plowed) horizon beneath. The C horizon sample, obtained from a depth of 140 to $170 \mathrm{~cm}$, consisted of clay-plugged saprolitic materials. Both acetone and butanone were detected in the VOA analysis, but these compounds are caused by instrument contamination. Data for PAHs are missing, but, based on all other Copper Ridge and Chepultepec data, these compounds can be presumed to be present. ESD gamma scan results for cesium-137 gave a value of $10.14 \mathrm{pCi} / \mathrm{cm}^{2}$, indicating that this site has received some recent deposition. Based on site selection criteria and screening analysis, this site was considered suitable.

ORR Site 53. This site is located on the Chepultepec Formation. Vegetation is old-field successional forest, but the field had been abandoned to woods well before 1940. Present forest is dominated by white oak. The soil on this site has a layer of local cherty colluvium that is $36 \mathrm{~cm}$ thick. The soil surface was leaf-covered. The A horizon sampled was collected from the regenerated forest soil A horizon and the underlying old Ap horizon. The B and C horizons were sampled in the underlying residuum. The $C$ horizon sample, obtained at a depth of 140 to $160 \mathrm{~cm}$, consisted of clay-plugged saprolitic materials. There were no VOA detects, but there were one or more detects for PAHs. The ESD gamma scan results gave a value of $6.23 \mathrm{pCi} / \mathrm{cm}^{2}$ indicating some recent erosion. Based on site selection criteria and screening analysis, this site was considered suitable and representative.

ORR Site 54. This site is located in the Copper Ridge Formation. The vegetation is older but cutover forest. Most of the large trees are chestnut oak along with smaller red maple. The soil surface was leaf-covered. The A horizon sample consisted of a thin A horizon and part of the $E$ horizon beneath. The $C$ horizon sample, obtained from a depth of 155 to $165 \mathrm{~cm}$, consisted of clay-plugged saprolitic materials. VOA data are missing for this site. One to several PAHs were detected at this site. ESD gamma scan results gave a value of $7.76 \mathrm{pCi} / \mathrm{cm}^{2}$, indicating a stable site. Based on site selection criteria and screening analysis, this site was considered suitable and representative.

ORR Site 55. This site is located in the Copper Ridge Formation. Present vegetation consisted of cut-over forest. This site did not appear to have ever been plowed. Large trees are mostly chestnut oak along with mid-level sugar maple and poplar. The ground surface was leaf-covered. The A horizon sample consisted of a thin A horizon and the thin horizon 
immediately beneath. The A horizon sample was obtained from the colluvium, but the B horizon sample was obtained from residuum. The $C$ horizon sample, obtained from a depth of 140 to $165, \mathrm{~cm}$, consisted of high-clay-content subsoil materials. VOA data for this site are missing, and there were one or more detects for PAHs. ESD gamma scan results for cesium-137 gave a value of 8.33 indicating a stable site. Based on site selection criteria and screening analysis, this site was considered suitable and representative.

ORR Site 58. This site is located in the Copper Ridge Formation. Present forest vegetation is old-field successional, but the early pines have been succeeded by red oak, sugar maple, and some poplar. The ground surface was leaf-covered. The A horizon samples consisted of a thin, regenerated forest soil A horizon and the old Ap horizon beneath. The $C$ horizon sample, obtained from a depth of 140 to $173 \mathrm{~cm}$, consisted of high-clay-content subsoil materials. Both acetone and butanone were detected at this site, but these compounds are the result of instrument contamination. There were one or more PAH detects. ESD gamma scan results for cesium-137 gave a value of $7.01 \mathrm{pCi} / \mathrm{cm}^{2}$, indicating that there has been slight erosion. Based on site selection criteria and screening analysis, this site was considered suitable and representative.

ORR Site 59. This site is located in the Copper Ridge Formation. Present forest vegetation is old-field successional. There are mature short-leaf pine and mature white oak with an understory of dogwood, beech, red maple, and sassafras. There were sparse blueberry shrubs and a few hickory sprouts, and the forest floor was leaf-covered. The A horizon sample consisted of a thin.A horizon and the $E$ horizon beneath. The $C$ horizon sample, obtained at a depth of 140 to $165 \mathrm{~cm}$, consisted of clay-plugged saprolitic materials. Results from VOA analysis are missing, but there were one or more detects for PAHs. ESD gamma scanning results gave a value for cesium- 137 of $7.71 \mathrm{pCi} / \mathrm{cm}^{2}$, indicating that this site has been fairly stable. Based on site selection criteria and screening analysis, this site was considered suitable and representạtive.

ORR Site 60. This site is located in the Copper Ridge Formation. This site was once a severely eroded agricultural field. Present forest vegetation is old-field successional. The early pine have either died and fallen over or were harvested. Present canopy trees are oaks and red maple with a few white pine and a regrowth of Virginia pine. There were a few blueberry shrubs along with tree sprouts on the leaf-covered forest floor. The $A$ horizon sample consisted of a thin A horizon and the old Ap horizon beneath. The $\mathrm{C}$ horizon sample, obtained from a depth of 145 to $175 \mathrm{~cm}$, consisted of partially clay-plugged saprolitic materials. Results of the VOA analysis are missing, but there were one or more detects for PAHs. ESD gamma scan results for cesium-137 gave a value of $6.23 \mathrm{pCi} / \mathrm{cm}^{2}$, an indication of erosion. Based on site selection criteria and screening analysis, this site was considered suitable and representative.

ORR Site 62. This site is located in the Copper Ridge Formation. Present vegetation consists of old-field successional forest. Most of the early pines have died and fallen over, allowing oak and hickory to become dominant in the canopy. The forest floor is leaf-covered. This site is located within 75 to $80 \mathrm{ft}$ of an area that was clear cut and replanted to loblolly pine. The VOA results are missing, but there were one or more detects for PAHs. The A horizon sample consisted of a thin A horizon and the old Ap horizon beneath. The $C$ horizon, obtained at a depth of 140 to $163 \mathrm{~cm}$, consisted of highly mottled lower subsoil materials. ESD gamma scan results for cesium-137 gave a value of $10.45 \mathrm{pCi} / \mathrm{cm}^{2}$, indicating 
that there has been a slight amount of sediment deposition. Based on site selection criteria and screening analysis, this site was considered suitable and representative.

ORR Site 64. This site is located in the Copper Ridge Formation. Present vegetation is old-field successional forest. The early pines have all disappeared, leaving oaks and poplar. The forest floor is leaf-covered. The A horizon sample consisted of a thin $A$ horizon and the old Ap horizon beneath. The $C$ horizon sample, obtained at a depth of 150 to $160 \mathrm{~cm}$, was composed of saprolite. The VOA data is missing, but there were one or more detects for PAHs. ESD gamma scan results for cesium-137 gave a value of $8.76 \mathrm{pCi} / \mathrm{cm}^{2}$, indicating that this site has been stable. Based on site selection criteria and screening analysis, this site was considered suitable and representative.

ORR Site 66. This site is located in the Chepultepec Formation. Present vegetation is old-field successional with many of the early pines still standing. There are few poplar and red maple along with many red maple saplings and dogwood. The site was in a dense stand of ferns. The A horizon sample consisted of the old Ap horizon. The $\mathrm{C}$ horizon, obtained at a depth of 150 to $173 \mathrm{~cm}$, was composed of highly clay-plugged saprolitic materials. There were no VOA detects and one or more detects for PAHs. The herbicide 2-4-D was detected at this site, but, given the remoteness of this site and no close access to a road, this particular detect is highly questionable and most likely caused by contamination after the sample left the ORR or by analytical instrument contamination. ESD gamma scan results for cesium-137 gave a value of $5.53 \mathrm{pCi} / \mathrm{cm}^{2}$ indicating recent erosion. Based on site selection criteria and screening analysis, this site was considered suitable and representative.

ORR-68. This site is located in the Chepultepec Formation. Vegetation is old forest where periodic logging has occurred. Present large trees are oaks and hickories. The forest floor is leaf-covered. The upper 40 to $50 \mathrm{~cm}$ of the soil consists of local cherty colluvium. The A horizon soil sample consisted entirely of the A horizon. The B horizon sample was collected in the residuum beneath the surficial colluvium. The $C$ horizon soil sample, obtained from a depth of 150 to $175 \mathrm{~cm}$, consisted of clayey subsoil material. Acetone was detected, but this compound is caused by instrument contamination. One or more PAHs were detected. ESD gamma scan results for cesium-137 on samples collected from colluvium gave a value of $10.33 \mathrm{pCi} / \mathrm{cm}^{2}$ indicating some recent deposition. Based on site selection criteria and screening analysis, this site was considered suitable. The presence of the colluvium makes this site slightly less desirable in representing residual soils.

ORR Site 73. This site is located in the Chepultepec Formation. Vegetation on this site is old-growth forest that has been periodically logged. Stumps were close to the pit. Indeed, the pit face cut through an old stump hole. Present canopy trees are poplar, oak, and red maple. There is a thick sapling stand of red maple, oak cherry, and cedar. The ground surface is leaf-covered. Soil samples were obtained away from the filled-in stump hole. The A horizon soil sample consisted of the $A$ horizon. The $C$ horizon soil sample, obtained at a depth of 145 to $160 \mathrm{~cm}$, consisted of saprolite. ESD gamma scan results for cesium-137 gave a value of $12.87 \mathrm{pCi} / \mathrm{cm}^{2}$ indicating recent deposition. There are recent tree throw mounds above this site which could have contributed sediments. Based on site selection criteria and screening analysis, this site was considered to be suitable and representative.

ORR Site 74. This site is located in the Chepultepec Formation. Present vegetation is old-field successional forest. The site is located close to an old fence row. Barb wire was embedded in several trees. Older trees in the fence row are red oak and white oak. Younger 
trees in the old field area are black gum, sweet gum, oak and red maple. The ground surface is leaf-covered. The A horizon soil sample consisted of the A horizon and part of the $E$ horizon immediately beneath. The $C$ horizon soil sample, obtained from a depth of 140 to 160 $\mathrm{cm}$, consisted of very cherty saprolitic materials. Acetone was detected, but its presence is caused by instrument contamination. From one to several PAHs were detected. ESD gamma scan results for cesium-137 gave a value of $7.15 \mathrm{pCi} / \mathrm{cm}^{2}$ indicating relative stability. Based on the site selection criteria and screening analysis, this site was considered suitable and representative.

ORR Site 75. This site is located in the Copper Ridge Formation. Present vegetation is old-field successional forest. The original pines are in the process of being replaced by a thick stand of seedling pines along with poplar, black gum, sourwood, and dogwood. The ground surface is covered by leaves, needles, and fallen pine trees. The A horizon soil sample consisted of the thin regenerated $A$ horizon and the old Ap horizon beneath. The $C$ horizon soil sample, obtained from a depth of 150 to $160 \mathrm{~cm}$, consisted of the lower clayey subsoil. The VOA analysis data is missing, but there were one or more detects for PAHs. ESD gamma scan results for cesium-137 gave a value of $10.04 \mathrm{pCi} / \mathrm{cm}^{2}$ indicating relative stability. Based on the site selection criteria and screening analysis, this site was considered suitable and representative.

ORR Site 77. This site is located in the Chepultepec Formation. Vegetation is old-field successional forest. A few of the early pines are still standing, but the dominant canopy trees are hardwoods. The ground surface is leaf-covered. The A horizon soil sample consisted of a thin, regenerated $A$ horizon and the old Ap horizon beneath. The $C$ horizon soil sample, obtained from a depth of 140 to $160 \mathrm{~cm}$, consisted of saprolitic materials that contained considerable manganese oxide. There were no VOA detects. The PAH data are missing, but, based on the widespread presence of one or more PAHs in all other sites, these compounds should be present at this site. ESD gamma scan results for cesium-137 gave a value of $11.76 \mathrm{pCi} / \mathrm{cm}^{2}$ indicating slight recent deposition. Based on site selection criteria and screening analysis, this site was considered suitable and representative.

ORR Site 78. This site is located in the Chepultepec Formation. The soil has a layer of ancient colluvium that is about 36-cm-thick. Vegetation is old-field successional forest. Most of the early pines have died and fallen over, and the present forest is dominated by hardwoods. The forest floor is leaf-covered. The A horizon soil sample consisted of the thin, regenerated A horizon and the old Ap horizon beneath. The B horizon soil sample was obtained from the clayey subsoil of the residuum beneath the colluvial capping. The $C$ horizon soil sample, obtained from a depth of 140 to $150 \mathrm{~cm}$, consisted of clay-plugged saprolitic materials. There were no VOA detects, and the organic data are missing. Based on the widespread presence of one or more PAHs in all other sites, these compounds should be present at this site. ESD gamma scan results for cesium-137 gave a value of 8.56 indicating stability. Based on site selection criteria and screening analysis, this site was considered suitable and representative.

ORR Site 83. This site is located in the Copper Ridge Formation. Vegetation is old-field successional forest. Most of the early pines have died and fallen over. The forest canopy is now dominated by hardwoods, but some pines are present. The forest floor is leaf-covered. The A horizon soil sample consisted of a thin A horizon and the old Ap horizon beneath. The $C$ horizon soil sample, obtained from a depth of 100 to $170 \mathrm{~cm}$, consisted of very cherty clay-plugged saprolitic materials. This site required two deep auger holes to collect enough 
sample, because of the high chert content. The VOA data are missing. One or more PAHs were detected at this site. ESD gamma scan results for cesium-137 gave a value of $9.01 \mathrm{pCi} / \mathrm{cm}^{2}$ indicating stability. Based on site selection criteria and screening analysis, this site was considered suitable and representative.

ORR Site 85. This site is located in the Chepultepec Formation. The present forest is cutover old-growth. Because of the site steepness, it does not appear that the soil has ever been plowed. Present canopy trees are red oak, sugar maple, white pine, and umbrella magnolia. The soil at this site has a layer of creep-derived colluvium that is about 42-cm-thick. The soil also has a thick, dark surface layer because of the northerly aspect. The A horizon soil sample consisted of the upper $15 \mathrm{~cm}$ of the $23-\mathrm{cm}$-thick A horizon. The B horizon was sampled from the clayey residuum. The $C$ horizon soil sample, obtained from a depth of 140 to $160 \mathrm{~cm}$, consisted of saprolitic materials. Acetone was a detect in the VOA analysis, but the presence of this compound is the result of instrument contamination. The data for PAHs are missing. Based on the widespread presence of one or more PAHs in all other sites, these compounds should be present at this site. All ESD gamma scan samples were collected from the surficial colluvium. The value of $8.32 \mathrm{pCi} / \mathrm{cm}^{2}$ indicated stability. Based on site selection criteria and screening analysis, this site was considered suitable and representative of soils on steeper slopes on the ORR.

ORR Site 86. This site is located in the Chepultepec Formation. Vegetation is old-grawth forest. Dominant canopy trees are chestnut oak and hickory. There are smaller red maple and sassafras. The ground surface was leaf-covered. The soil at this site had an extremely cherty lag-gravel surface layer. Because of the slope steepness, this site had never been plowed. The A horizon soil sample was obtained from the very thin A horizon and part of the E horizon beneath to a depth of $15 \mathrm{~cm}$. The $B$ horizon soil sample was obtained from the clayey residual subsoil beneath the creep capping. The $C$ horizon soil sample, obtained from a depth of 140 to $155 \mathrm{~cm}$, consisted of clayey saprolitic materials. There were no VOA detects, and the organics data are missing. Based on the widespread presence of one or more PAHs in all other sites, these compounds should be present at this site. ESD gamma scan results for cesium-137 gave a value of $7.89 \mathrm{pCi} / \mathrm{cm}^{2}$ indicating stability. Based on site selection criteria and screening analysis, this site was considered suitable and representative of soils on steeper slopes.

ORR Site 90. This site is located in the Chepultepec Formation. Vegetation is a 30- to 40-year-old stand of planted loblolly pine. The understory is red maple, poplar, and seedling pines. The ground is covered by honeysuckle, roses, and blackberry briars. The ground surface is covered by pine needles and leaves. This site is located about $60 \mathrm{ft}$ north of Chestnut Ridge Road. This is a heavily traveled road with a limestone gravel surface. As a result, calcium content of the surface may be higher than in areas farther from the road. The A horizon soil sample was obtained from the entire thickness of the Ap horizon. The $\mathrm{C}$ horizon soil sample, obtained from a depth of 140 to $160 \mathrm{~cm}$, consisted of clay-plugged saprolitic materials. Acetone was detected in the VOA analysis, but this compound is caused by instrument contamination. One or more PAHs were detected at this site. The closeness of the road to this site evidently did not contribute to higher VOA or organics levels than at more remote sites. ESD gamma scan results for cesium-137 gave a value of $9.88 \mathrm{pCi} / \mathrm{cm}^{2}$ indicating stability. Based on site selection criteria and screening analysis, this site was considered suitable and representative. 
ORR Site 91. This site is located in the Copper Ridge Formation. Vegetation is oldgrowth woods. Several chestnut stumps are located nearby, and barb wire is embedded in nearby trees, an indication of an old fence row. Dominant canopy trees are poplar, cherry, post oak, and white oak. One chestnut sprout occurred close to the soil pit. The ground surface was leaf- covered. The A horizon soil sample consisted of a thin A horizon and the entire thickness of the $E$ horizon beneath. The $C$ horizon sample, obtained from a depth of 135 to $155 \mathrm{~cm}$, consisted of the lower part of the clayey argillic horizon. The VOA data are missing. One or more PAHs were detected. ESD gamma scan results for cesium-137 gave a value of $10.85 \mathrm{pCi} / \mathrm{cm}^{2}$ indicating a slight amount of recent deposition. Based on site selection criteria and screening analysis, this site was considered suitable and representative.

The following sites (ORR Site 93 through ORR Site 117) were sampled in the Bethel Valley area of the ORR. Site screening with a hand-held radiation detector revealed higherthan-background levels of radiation, but no sites were rejected, because all site readings were less than $100 \mathrm{cpm}$. A decision was made to continue sampling to determine whether other elevated levels of metals or organics could be related to the higher cesium-137 levels.

ORR Site 93. This site is located within the Moccasin Formation of the Chickamauga Group of the Bethel Valley section. Vegetation is old-field successional. The old field had been severely eroded before abandonment. The canopy is now dominated by hardwoods, but a few large pines and cedars remain. The ground surface is leaf-covered. The A horizon soil sample consisted of a very thin, regenerated $A$ horizon and the old Ap horizon beneath. The C horizon soil sample, obtained from a depth of 65 to $80 \mathrm{~cm}$, consisted of clayey lower subsoil. Rock was encountered at a depth of $85 \mathrm{~cm}$. This site, located at the west end of the Bethel Valley sampling area, had a cesium-137 level slightly elevated above background. Because this site is not in a concave landform position, the elevated cesium is interpreted to be of local ORNL origin. Tritium was below detection limit at this site. No other elevated levels of metals or radionuclides were associated with the elevated cesium. Acetone was a detect in the VOA analysis, but this compound is caused by instrument contamination. One or more PAHs were detected. The ESD gamma scan results for cesium-137 gave a value of $10.4 \mathrm{pCi} / \mathrm{cm}^{2}$, indicating relative stability or perhaps a slight amount of contamination. Based on site selection criteria and screening analysis, this site was considered suitable and representative.

ORR Site 99. This site is located in the Bethel Valley section of the Chickamauga Group Moccasin Formation. This site was a very severely eroded field before abandonment. Vegetation is old-field successional forest. Most of the original pines are still standing. The ground surface was about $70 \%$ covered by mosses and the remainder, by pine needles and leaves. The A horizon soil sample consisted of a very thin A horizon and the old Ap horizon beneath. The $C$ horizon soil sample, obtained from a depth of 98 to $113 \mathrm{~cm}$, consisted of clayey saprolitic materials with abundant manganese. Depth to limestone at this site was more than $1.5 \mathrm{~m}$. Both acetone and butanone were VOA detects, but these two compounds are the result of instrument contamination. There were one or more PAHs detects. Technetium-99 was detected at this site. Cesium-137 from the ESD gamma scan was slightly elevated above background $\left(12.5 \mathrm{pCi} / \mathrm{cm}^{2}\right)$ and is interpreted to be caused by local ORNL input. Tritium was below detection limits. However, no other metals or radionuclides were elevated at this site except for the higher than normal cesium. Based on site selection criteria and screening analysis, this site was considered suitable and representative. 
ORR Site 100. This site is in the Bethel Valley section of the Chickamauga Group (Unit G). Vegetation is old-growth woods that had been partially cut over and pastured before abandonment. The present open forest stand has large oaks, some white pine, and sugar maple. There are low bush blueberry plants, and the ground surface is leaf-covered. This site, located southwest of Bldg. 1505, has the third highest level of cesium-137 (18.4 $\left.\mathrm{pCi} / \mathrm{cm}^{2}\right)$ and second highest level of tritium $(0.14 \mathrm{pCi} / \mathrm{g})$. These elevated levels are interpreted to be caused by local ORNL emissions. There were no elevated levels of other metals or radionuclides. The A horizon soil sample was obtained from the entire thickness of the old Ap horizon. The C horizon soil sample, obtained from a depth of 55 to $70 \mathrm{~cm}$, consisted of saprolite. There was a paralithic $\mathrm{Cr}$ horizon at a depth of $85 \mathrm{~cm}$. Acetone was detected in the VOA analysis, but this compound is caused by instrument contamination. One or more PAHs were detected. Based on site selection criteria and screening analysis, this site was considered suitable and representative except for cesium and tritium.

ORR Site 101. This site is in the Bethel Valley section of the Chickamauga Group Moccasin Formation. Vegetation consists of mature oaks, cedars, and american beech with saplings of beech, sugar maple, and dogwood. This site was severely eroded before abandonment and was probably a woods pasture. The forest floor was leaf-covered. This site had the highest elevated level of cesium-137 $\left(22.9 \mathrm{pCi} / \mathrm{cm}^{2}\right)$ and the third highest level of tritium $(0.12 \mathrm{pCi} / \mathrm{g})$. Both of these elements are interpreted to be caused by local contamination from ORNL. There were no other elevated levels of organics, metals, or radionuclides. The A horizon soil sample consisted of a 12-cm-thick A horizon. An old stump infilling occurred in part of the pit face but was avoided in sampling. The $C$ horizon soil sample, obtained from a depth of 60 to $70 \mathrm{~cm}$, consisted of clayey saprolitic materials. Depth to rock was highly irregular in the soil pit. Rock was at a depth of $70 \mathrm{~cm}$ in the section of the pit face that was sampled. Acetone was detected in the VOA analysis, but this compound is caused by instrument contamination. One or more PAHs were detected. Based on site selection criteria and screening analysis, this site was considered suitable and representative except for cesium and tritium.

ORR Site 102. This site is in the Bethel Valley section of the Chickamauga Group Moccasin Formation. This site was evidently the front yard or back yard of a farmstead. Vegetation is an open stand of large, mature oaks and pines. Poison ivy was very abundant. The ground surface was covered with leaves and pine needles. This site had an elevated level of cesium-137 $\left(17.3 \mathrm{pCi} / \mathrm{cm}^{2}\right)$ and the highest level of tritium $(0.22 \mathrm{pCi} / \mathrm{g})$. This site and ORR Site 101 are on either side of Bldg. 4500. However, no other elevated levels of organics, metals, or radionuclides were associated with either the cesium or tritium. The elevated levels are interpreted to be caused by local input from ORNL. The A horizon soil sample was collected in the upper $10 \mathrm{~cm}$ of the A horizon. The C horizon, obtained from a depth of 90 to $101 \mathrm{~cm}$, consisted of saprolitic materials. Rock ledges were encountered at a depth of $101 \mathrm{~cm}$ in the vertical section of the soil pit that was sampled. Depth to rock in the soil pit varied from $34 \mathrm{~cm}$ to $101 \mathrm{~cm}$. Acetone was a detect in the VOA analysis, but this compound is caused by instrument contamination. One or more PAHs were detected. Based on site selection criteria and screening analysis, this site was considered suitable and representative except for the elevated levels of cesium-137 and tritium.

ORR Site 103. This site is in the Bethel Valley section of the Chickamauga Group Moccasin Formation. Vegetation is old-field successional forest. This site was severely eroded before abandonment. Some of the early pines and cedars remain along with a few large oaks. Smaller trees are american beech, dogwood, black gum, and cedars. This site had elevated 
levels of cesium-137 (14.0 $\left.\mathrm{pCi} / \mathrm{cm}^{2}\right)$ and tritium $(0.20 \mathrm{pCi} / \mathrm{g})$. These higher levels are interpreted to be caused by local input from ORNL. There were no other elevated levels of organics, metals or radionuclides at this site when compared to all of the Bethel.Valley sites. The A horizon soil sample was collected from a 4-cm-thick A horizon. The A horizon was mostly composed of Rome colluvium that had moved downslope. The $C$ horizon soil sample, obtained from a depth of 90 to $100 \mathrm{~cm}$, consisted of saprolitic materials. Acetone was detected in the VOA analysis, but this compound is caused by instrument contamination. One or more PAHs were detected. Based on site selection criteria and screening analysis, however, this site was considered suitable and representative, even though it exhibited elevated levels of cesium-137 and tritium.

ORR Site 104. This site is in the Bethel Valley Section of the Chickamauga Group Moccasin Formation. Vegetation is old-field successional forest. The early pines and cedars have mostly been replaced by hardwoods dominated by oaks, red maple, and hickory. There are low-bush blueberries, and the forest floor is leaf-covered. Levels of cesium-137 $\left(10.2 \mathrm{pCi} / \mathrm{cm}^{2}\right)$ and tritium were at background and below-detection limits, respectively. There were no other elevated levels of metals or other radionuclides. The A horizon soil sample consisted of a reformed $\mathrm{E}$ horizon and the old Ap horizon beneath. The $\mathrm{C}$ horizon sample, obtained at a depth of 75 to $95 \mathrm{~cm}$, consisted of saprolitic materials. No rock was encountered within a depth of $100 \mathrm{~cm}$. There were no VOA detects, but there were one or more detects for PAHs. Based on site selection criteria and screening analysis, this site was considered suitable and representative.

ORR Site 108. This site is in the Bethel Valley section of the Chickamauga Group. Vegetation is old-field successional. There are still many older pines and cedars. The forest floor was mostly leaf-covered, but there were patches of mosses. There were no elevated levels of either cesium $-137\left(8.5 \mathrm{pCi} / \mathrm{cm}^{2}\right)$ or tritium, nor of any other metals or radionuclides. The A horizon soil sample consisted of the old Ap horizon. The $\mathrm{C}$ horizon, obtained from a depth of 80 to $90 \mathrm{~cm}$, consisted of highly clay-plugged saprolitic materials. Depth to rock was variable in the soil pit, ranging from 53 to $95 \mathrm{~cm}$. The vertical section of soil sampled was in the deepest part of the pit. Butanone was detected in the VOA analysis, but this compound is caused by instrument contamination. One or more PAHs were detected. Based on site selection criteria and screening analysis, this site was considered suitable and representative.

ORR Site 110. This site is underlain by the Bethel Valley section of the Chickamauga Group. Vegetation is old-field successional forest with pines, cedars, and oaks. The understory consists of beech and hickory sprouts along with weeds and honeysuckle. The forest floor is leaf-covered. This site had been severely eroded before abandonment. There were no elevated levels of cesium-137 $\left(7.9 \mathrm{pCi} / \mathrm{cm}^{2}\right)$ or tritium, although there was a reading of $90 \mathrm{cpm}$ in the top of the auger hole from the hand-held radiation detector used in site screening. There were apparent elevated levels of $\mathrm{Pa}-234$ and $\mathrm{Np}-237$ that might have caused this higher than normal instrument reading. The A horizon soil sample consisted of the 3-cm-thick reformed A horizon. The $\mathrm{C}$ horizon, obtained from a depth of 75 to $85 \mathrm{~cm}$, consisted of clayey saprolitic materials. There were thin rock ledges at several depths in the pit face. Based on site selection criteria and screening analysis, this site was considered suitable and representative.

ORR Site 115. This site is underlain by the Bethel Valley section of the Chickamauga. Vegetation is old-field successional forest of Virginia pine, cedar, oak, hickory, ash, and dogwood. The ground was covered with poison ivy, honeysuckle, and leaves. This site did not 
appear to have been plowed, but evidently was a woods pasture. There were no elevated levels of cesium-137 $\left(9.5 \mathrm{pCi} / \mathrm{cm}^{2}\right)$ nor tritium. The $A$ horizon soil sample consisted of the $A$ horizon and the transitional EB horizon beneath. The $\mathrm{C}$ horizon sample, obtained from a depth of 60 to $75 \mathrm{~cm}$, consisted of saprolitic materials. Depth to rock was mostly 25 to $45 \mathrm{~cm}$, except in the deep part of the pit that was sampled. There, rock occurred at a depth of $75 \mathrm{~cm}$. Acetone was a detect in the VOA analysis, but this compound is caused by instrument contamination. One or more PAHs were detected. This site had an apparent higher level of Pa-234 than most other Bethel Valley sites. Based on site selection criteria and screening analysis, this site was considered suitable and representative.

ORR Site 116. This site is underlain by the Bethel Valley section of the Chickamauga Group. Vegetation is a planted loblolly pine plantation. The trees appear to be about 40 years old. The site is within 50 to $60 \mathrm{ft}$ of an old house or barn (disturbed area). There were no elevated levels of cesium-137 $\left(7.8 \mathrm{pCi} / \mathrm{cm}^{2}\right)$, nor of tritium, nor of any other radionuclides or metals. The A horizon soil sample consisted of a thin, reformed A horizon and the old Ap horizon beneath. The $C$ horizon, obtained from a depth of 70 to $85 \mathrm{~cm}$, consisted of saprolitic materials. No rock was encountered within a depth of $100 \mathrm{~cm}$. Both acetone and butanone were detected in the VOA analysis, but these two compounds are caused by instrument contamination. One or more PAHs were detected. Technetium-99 was also detected in this sample. This site also had an elevated level of $\mathrm{Pa}-234$ when compared with most other Bethel Valley sites. Based on site selection criteria and screening analysis, this site was considered suitable and representative.

ORR Site 117. This site is underlain by the Bethel Valley section of the Chickamauga Group. The soils are formed in residuum, but the presence of rounded river gravels indicates that this site had been covered with alluvium in the past. Vegetation is a loblolly pine plantation. The trees appear to be about 40 years old. There were no elevated levels of cesium-137 $\left(8.9 \mathrm{pCi} / \mathrm{cm}^{2}\right)$, nor of tritium, nor of any other radionuclides or metals. The A horizon soil sample consisted of a thin, reformed A horizon and the old Ap horizon beneath. The $\mathrm{C}$ horizon soil sample, obtained from a depth of 85 to $95 \mathrm{~cm}$, consisted of clayey saprolitic materials. Limestone rock was encountered at a depth of $106 \mathrm{~cm}$. Butanone was a detect in the VOA analysis, but this is caused by instrument contamination. One or more PAHs were detected. This site had a higher level of Pa-234 than most of the other Bethel Valley sites. Based on site selection criteria and screening analysis, this site was considered suitable and representative.

ORR Site 118. This site is underlain by the East Fork (K-25 Site) section of the Chickamauga Group. Vegetation is old-growth hardwood forest dominated by large white oaks, American beech, cherry, and sugar maple. There were no elevated levels of cesium-137 $\left(9.64 \mathrm{pCi} / \mathrm{cm}^{2}\right)$ nor of tritium. No VOAs were detected, but there were one or more detects for PAHs. The A horizon soil sample consisted of the 5-cm-thick, reformed A horizon. The C horizon soil sample, obtained from a depth of 70 to $80 \mathrm{~cm}$, consisted of saprolitic materials. No rock was encountered within a depth of $100 \mathrm{~cm}$. Based on site selection criteria and screening analysis, this site was considered suitable and representative.

ORR Site 119. This site is underlain by the East Fork (K-25 Site) section of the Chickamauga Group. Vegetation is cut-over old woods. Present large trees are cedars, oak, and ash. There were no elevated levels of cesium-137 $\left(7.79 \mathrm{pCi} / \mathrm{cm}^{2}\right)$ nor of tritium, but there was a detect for technetium-99. There were no VOA detects, but there were one or more detects for PAHs. The A horizon soil sample consisted of a thin A1 horizon and the A2 
horizon beneath. The $\mathrm{C}$ horizon soil sample, obtained from a depth of 75 to $88 \mathrm{~cm}$, consisted of the transitional horizon beneath the Bt horizon and limestone bedrock. Depth to rock in the soil pit varied from $30 \mathrm{~cm}$ to more than $100 \mathrm{~cm}$. Based on, site selection criteria and screening analysis, this site was considered suitable and representative.

ORR Site 120. This site is underlain by the East Fork (K-25 Site) section of the Chickamauga Group. The soil had a thin layer of alluvium, 27-cm-thick over the residuum. Vegetation is old-growth hardwoods dominated by large American beech. There were no elevated levels of cesium-137 $\left(9.01 \mathrm{pCi} / \mathrm{cm}^{2}\right)$ or tritium. There were no VOA detects, but there were one or more detects for PAHs. The A horizon sample was obtained from the upper $10 \mathrm{~cm}$ of the soil. The $B$ horizon sample was collected from the residuum beneath the surficial alluvium. The $C$ horizon soil sample, obtained from a depth of 85 to $100 \mathrm{~cm}$, consisted of saprolitic materials. No rock was encountered within a depth of $100 \mathrm{~cm}$. Based on site selection criteria and screening analysis, this site was considered suitable and representative.

ORR Site 121. This site is underlain by the East Fork (K-25 Site) section of the Chickamauga Group. Vegetation is old-field successional forest dominated by Virginia pine with an understory of gum, red maple, and beech. There were no elevated levels of cesium-137 nor of tritium, but technetium- 99 was detected. Butanone was a VOA detect, but this compound is caused by instrument contamination. There were one or more detects for PAHs. Of special interest is a detect for chlordane. This site is close to an old farm building site, so it may be a real detect and not caused by instrument contamination. The A horizon soil sample consisted of a thin, reformed A horizon and the old Ap horizon beneath. The $C$ horizon soil sample, obtained from a depth of 70 to $90 \mathrm{~cm}$, consisted of saprolitic material. No rock was encountered within a depth of $100 \mathrm{~cm}$. ESD gamma scan results for cesium-137 gave a value of $6.36 \mathrm{pCi} / \mathrm{cm}^{2}$, an indication of recent erosion. Based on site selection criteria and screening analysis, this site was considered suitable and representative.

ORR Site 122. This site is underlain by the East Fork (K-25 Site) section of the Chickamauga Group. Vegetation is a planted loblolly pine plantation with trees more than 40 years old. There are abundant honeysuckle and briars on the needle-covered forest floor. There were no elevated levels of cesium-137 nor of tritium. There were no VOA detects, but there were one or more detects for PAHs. The A horizon soil sample consisted of the entire thickness of the old Ap horizon. The $C$ horizon soil sample, obtained from a depth of 70 to $80 \mathrm{~cm}$, consisted of saprolitic materials. No rock was encountered within a depth of $100 \mathrm{~cm}$. Based on site selection criteria and screening analysis, this site was considered suitable and representative.

ORR Site 123. This site is underlain by the East Fork (K-25 Site) section of the Chickamauga Group. Vegetation is a planted loblolly pine plantation with trees more than 40 years old. There are abundant honeysuckle and briars on the needle-covered forest floor. There were no elevated levels of cesium-137 or tritium. Acetone was a detect in the VOA analysis, but this compound is caused by instrument contamination. One or more PAHs were detected. The A horizon soil sample was obtained from a depth of 0 to $3 \mathrm{~cm}$. The $\mathrm{C}$ horizon soil sample, obtained from a depth of 80 to $90 \mathrm{~cm}$, consisted of saprolitic materials. No rock was encountered within a depth of $100 \mathrm{~cm}$. ESD gamma scan results for cesium-137 gave a value of $7.30 \mathrm{pCi} / \mathrm{cm}^{2}$, an indication of recent erosion. Based on site selection criteria and screening analysis, this site was considered suitable and representative. 
ORR Site 124. This site is underlain by the East Fork (K-25 Site) section of the Chickamauga Group. Vegetation is a planted loblolly pine plantation with trees more than 40 years old. There are abundant honeysuckle and briars on the needle-covered forest floor. The actual site is at the very edge of the plantation and close to a rock escarpment overlooking East Fork of Poplar Creek. There were no elevated levels of cesium-137 $\left(8.09 \mathrm{pCi} / \mathrm{cm}^{2}\right)$ nor of tritium, but technetium-99 was detected. There were no VOA detects for VOAs, but there were one or more detects for PAHs. The A horizon soil sample, obtained from a depth of $10 \mathrm{~cm}$, consisted of a thin, reformed A horizon and part of the old Ap horizon beneath. The C horizon soil sample, obtained from a depth of 80 to $90 \mathrm{~cm}$, consisted of saprolitic materials. Rock was encountered in the soil pit from very close to the surface at one end to more than $100 \mathrm{~cm}$ at the other end, about $3 \mathrm{ft}$ away. Based on site selection criteria and screening analysis, this site was considered suitable and representative.

ORR Site 125. This site is underlain by the East Fork (K-25 Site) section of the Chickamauga Group. Vegetation is a planted loblolly pine plantation with trees more than 40 years old. There are abundant honeysuckle and briars on the needle-covered forest floor. There were no elevated levels of cesium-137 or tritium. Acetone was a detect in the VOA analysis, but this compound is caused by instrument contamination. There were one or more detects for PAHs. The A horizon soil sample consisted of the very thin, reformed A horizon and part of the older Ap horizon beneath. The $C$ horizon soil sample, obtained from a depth of 70 to $90 \mathrm{~cm}$, consisted of clayey saprolitic materials. No rock was encountered in the soil pit within a depth of $100 \mathrm{~cm}$. ESD gamma scan results for cesium-137 gave a value of $7.50 \mathrm{pCi} / \mathrm{cm}^{2}$, an indication of relative stability. Based on site selection criteria and screening analysis, this site was considered suitable and representative.

ORR Site 126. This site is underlain by the East Fork (K-25 Site) section of the Chickamauga Group. Vegetation is old-field successional forest dominated by Virginia pine and hardwoods. Poison ivy, honeysuckle, and mosses were abundant on the ground surface. There were no elevated levels of cesium-137 $\left(9.31 \mathrm{pCi} / \mathrm{cm}^{2}\right)$ nor of tritium. Acetone was a VOA detect, but this compound is caused by instrument contamination. There were one or more detects for PAHs. The A horizon soil sample consisted of a thin, reformed A horizon and the old Ap horizon beneath. The $C$ horizon soil sample, obtained from a depth of 80 to $90 \mathrm{~cm}$, consisted of saprolitic materials. No rock was encountered in the soil pit within a depth of $100 \mathrm{~cm}$. Based on site selection criteria and screening analysis, this site was considered suitable and representative.

ORR Site 127. This site is underlain by the East Fork (K-25 Site) section of the Chickamauga Group. Vegetation is old-field successional forest dominated by Virginia pine, cedars, and hardwoods. There were abundant poison ivy and honeysuckle on the ground surface. There were no elevated levels of cesium-137 $\left(9.62 \mathrm{pCi} / \mathrm{cm}^{2}\right)$ nor of tritium. There were no VOA detects, but there were one or more detects for PAHs. The A horizon soil sample consisted of a thin, reformed $A$ horizon. The $C$ horizon soil sample, obtained from a depth of 65 to $75 \mathrm{~cm}$, consisted of clayey saprolitic materials. No rock was encountered in the soil pit within a depth of $100 \mathrm{~cm}$. Based on site selection criteria and screening analysis, this site was considered suitable and representative.

ORR Site 128. This site is underlain by the East Fork (K-25 Site) section of the Chickamauga Group. Vegetation is old-field successional forest dominated by Virginia pine, cedars, and hardwoods along with some dogwood and red maple. Poison ivy and honeysuckle were abundant on the ground surface. There were no elevated levels of cesium-137 
$\left(8.89 \mathrm{pCi} / \mathrm{cm}^{2}\right)$ nor of tritium. Both acetone and butanone were VOA detects, but these compounds are caused by instrument contamination. One or more PAHs were detected. The A horizon soil sample consisted of a thin, reformed A horizon and the old Ap horizon beneath. The $C$ horizon soil sample, obtained from a depth of 70 to $90 \mathrm{~cm}$, consisted of saprolitic materials. No rock was encountered in the soil pit within a depth of $100 \mathrm{~cm}$. Based on site selection criteria and screening analysis, this site was considered suitable and representative.

ORR Site 129. This site is underlain by the East Fork (K-25 Site) section of the Chickamauga Group. Vegetation is old-field successional forest. The site was probably an open woods pasture. There are a few large oaks. White pine is now invading and rapidly reproducing. There are a few holly trees, along with red maple and oak sprouts. There were no elevated levels of cesium-137 $\left(8.96 \mathrm{pCi} / \mathrm{cm}^{2}\right)$ nor of tritium. Butanone was a VOA detect, but this compound is caused by instrument contamination. One or more PAHs were detected. The A horizon soil sample consisted of a thin, reformed A horizon and the old Ap horizon beneath. The $C$ horizon soil sample, obtained from a depth of 100 to $116 \mathrm{~cm}$, consisted of saprolitic materials. No rock was encountered in the soil pit within a depth of $100 \mathrm{~cm}$. Based on site selection criteria and screening analysis, this site was considered suitable and representative.

\subsection{QUALITATIVE ANALYSIS OF ROANE COUNTY SITES}

ROA Site 3, ROA Site 9, ROA Site 19, ROA Site 20, ROA Site 21, and ROA Site 22. These sites are located close together in the central part of the.sampling transect. All of these sites had old-field successional forest of pines and hardwoods.

ROA Site 3. This site is located in a toeslope position. The entire soil profile consists of colluvium/alluvium derived from soils of Conasauga Group rocks rather than residuum from the Dismal Gap Formation. Acetone and 2-butanone were "J" estimates in the VOA analysis, but these are caused by instrument contamination. There were no other VOA analytes above detection limits. No tritium was detected in the A horizon sample from this site. In the organics analysis, only naphthalene was estimated to be present. All other organics were below detection limits. ESD cesium-137 gamma scan analysis for this site showed a median value of $5.63 \mathrm{pCi} / \mathrm{cm}^{2}$, a low value, indicating that this site has experienced erosion since the start of global fallout.

ROA Site 7 and ROA Site 8. These sites are close together. ROA Site 7 and ROA Site 8 are on a lower sideslope. The upper $44 \mathrm{~cm}$ of the ROA Site 7 and the ROA Site 8 soil profiles are formed in colluvium. The soil beneath is residuum of the Dismal Gap Formation. Present forest is old-field successional dominated by pines. This site is in a group of trees surrounded by cattle pasture, and the site is open to cattle grazing. Except for acetone, no VOAs were detected and no tritium was detected. Benzo[b]anthracene was an estimated "J" detect, but no other organics were detected. ESD cesium-137 gamma scan results gave a value of $6.64 \mathrm{pCi} / \mathrm{cm}^{2}$ for ROA Site 7, indicating that this site has been eroding since global fallout started. The corresponding value for ROA Site 8 is $11.93 \mathrm{pCi} / \mathrm{cm}^{2}$, indicating that there has been some deposition on this site.

ROA Site 9. This site is located in a toeslope position. The upper $52 \mathrm{~cm}$ of the soil profile is in colluvium. The A horizon and the B horizon samples are colluvial materials, while 
the $\mathrm{C}$ horizon sample consists of $\mathrm{Cr}$ materials from the Dismal Gap Formation. No VOAs were detected, no tritium was detected, and no organics were detected. ESD cesium-137 gamma scan showed a value of $10.15 \mathrm{pCi} / \mathrm{cm}^{2}$ for the upper $30 \mathrm{~cm}$ of the soil profile, an . indication of some recent deposition.

ROA Site 10. This site is located at the north end of the Roane County transect. This site is surrounded by an open field, and cattle have access to this site. The upper $18 \mathrm{~cm}$ of the soil formed in alluvium, but the lower part formed in residuum of the Dismal Gap Formation. Present forest is old-field successional with both pines and hardwoods. Except for acetone, no VOAs or organics were detected. ESD cesium-137 gamma scan results gave a value of $8.56 \mathrm{pCi} / \mathrm{cm}^{2}$, indicating that this site has been relatively stable.

ROA Site 13 and ROA Site 14. These sites are close together. The soil at ROA Site 13 formed in residuum of the Dismal Gap Formation. Present forest is old-field successional dominated by pines on ROA Site 13. The site is at the base of a long slope. Except for acetone and 2-butanone, no VOAs were detected. Benzo[b]fluoranthene was an estimated " $J$ " detect. No other organics were detected. ESD cesium-137 gamma scan results gave a value of $1.98 \mathrm{pCi} / \mathrm{cm}^{2}$, a very low value, indicating that this site has been actively eroding. ROA Site 14 occurs on a convex sideslope. The upper $41 \mathrm{~cm}$ of the soil profile formed in colluvium. Below $41 \mathrm{~cm}$, the soil formed in the transition zone between the Dismal Gap and Rogersville formations. Present forest is old-field successional dominated by red maple, poplar, dogwood, and poison ivy. Except for acetone, no VOAs were detected. Benzo[a]pyrene was an estimated "J" detect, but no other organics were detected. ESD gamma scan results gave a value of $8.20 \mathrm{pCi} / \mathrm{cm}^{2}$ for this site, an indication of relative stability.

ROA Site 17. This site is isolated. The soil on this site is residuum of the Dismal Gap Formation. Present forest vegetation is old-field successional dominated by pines. The site is open to cattle. Exception for acetone and 2-butanone resulting from instrument contamination, no other VOAs were detected, no tritium was detected, and no organics were detected. ESD cesium-137 gamma scan results gave a value of $9.61 \mathrm{pCi} / \mathrm{cm}^{2}$, indicating that this site has not been eroding.

ROA Site 19. This site is located in a toeslope position. The upper $47 \mathrm{~cm}$ of the soil profile is formed in colluvium. The A horizon and B horizon samples came from this soil material. The $\mathrm{C}$ horizon sample came from residuum of the Dismal Gap Formation. No VOAs were detected, no tritium was detected, and no organics were detected in the A horizon sample. ESD cesium-137 gamma scan results showed a median value of $4.16 \mathrm{pCi} / \mathrm{cm}^{2}$, an indication that this site has been eroding since the start of global fallout.

$R O A$ Site 20. This site is located in a toeslope position. The soil is derived from residuum of the Dismal Gap Formation. No VOAs were detected, no tritium was detect, but fluorene was a "J" estimated detect in the A horizon. No other organics were detected. ESD cesium-137 gamma scan results gave a value of $6.11 \mathrm{pCi} / \mathrm{cm}^{2}$, indicating that some soil erosion has occurred since global fallout started.

ROA Site 21. This site is located in a midslope position. The upper $74 \mathrm{~cm}$ of the soil profile formed in colluvium from the Dismal Gap Formation. The $2 \mathrm{Cr}$ horizon beneath is residuum of the Dismal Gap. Present forest is old-field successional dominated by pines. No VOAs were detected, and no organics were detected. The ESD cesium-137 gamma scan data 
results show a value of $5.40 \mathrm{pCi} / \mathrm{cm}^{2}$, an indication that this site has been eroding since global fallout started.

$R O A$ Site 22. This site is located on a bench landform. The upper $45 \mathrm{~cm}$ of the soil profile is colluvium. Below is residuum of the Dismal Gap Formation. Present forest is old-field successional, but it is now dominated by hardwoods. No VOAs were detected, no tritium was detected, but there was an estimated "J" detect for naphthalene in A horizon samples. ESD cesium-137 gamma scan results gave a value of $4.16 \mathrm{pCi} / \mathrm{cm}^{2}$ to a depth of $30 \mathrm{~cm}$ for this site, indicating that erosion has occurred since global fallout started.

ROA Site 33. This site is underlain by the Copper Ridge Formation of the Knox Group. This site is about $400 \mathrm{ft}$ away from an old quarry. The surface of the site was covered with carbonate fragments up to boulder size. These were the result of blasting operations. Vegetation is old-field successional forest. The pines have all been replaced by hardwoods. Acetone was a VOA detect, but this compound is caused by instrument contamination. A pesticide product, 4-4' DDT was detected. One or more PAHs were detected. This site had a slightly elevated cesium-137 level, but this is considered within the norm. Based on site selection criteria and screening analysis, this site was considered to be typical and representative.

ROA Site 34. This site is underlain by the Copper Ridge Formation of the Knox Group. Vegetation is old-field successional forest with some of the early pines still remaining, but most of the trees are now hardwoods. Acetone was a VOA detect, but this compound is caused by instrument contamination. One or more PAHs were detected. This site had an elevated cesium-137 level. The soil profile description indicated that there had been about $4 \mathrm{~cm}$ of recent overwash, which would explain the higher-than-normal level. Based on site selection criteria and screening analysis, this site was considered to be typical and representative.

ROA Site 35. This site is underlain by the Copper Ridge Formation of the Knox Group. Vegetation is old-field successional forest with all of the early pines having been replaced by hardwoods dominated by oaks. No VOAs were detected, but there were one or more PAHs. This site had an elevated cesium-137 level. The soil profile description indicated that there had been some recent overwash, resulting in an over-thickened $A$ horizon, which would explain the higher-than-normal level. Based on site selection criteria and screening analysis, this site was considered to be typical and representative.

$R O A$ Site 39. This site is underlain by the Copper Ridge Formation of the Knox Group, but the upper $95 \mathrm{~cm}$ of the soil consisted of local colluvium. Vegetation is old-field successional forest, but the early pines have been replaced by oaks. No VOAs were detected, but there were one or more PAHs. This site had a slightly elevated cesium-137 accumulation, an indication that some local sediment accumulation has occurred. Because of the excessive thickness of the colluvium, this site is not considered to be representative of residual soils, but would be representative of local cherty colluvial soils of the Copper Ridge Formation.

ROA Site 40. This site is underlain by the Copper Ridge Formation of the Knox Group, but the upper $52 \mathrm{~cm}$ of the soil consisted of local cherty colluvium. Vegetation is old-field successional forest, but most of the early pines have been replaced by oaks and hickories. Acetone was a detect in the VOA analysis, but this compound is caused by instrument contamination. One or more PAHs were detected. Cesium-137 accumulation of $8.7 \mathrm{pCi} / \mathrm{cm}^{2}$ 
was within the normal (average) background range of about 8.7. The slightly excessive thickness of colluvium is borderline to consider this site to be representative of Copper Ridge residual soils.

ROA Site 41. This site is underlain by the Copper Ridge Formation of the Knox Group. Vegetation is old-field successional forest, but most of the early pines have been replaced by oaks. No VOAs were detected, but there were one or more detects for PAHs. Cesium-137 accumulation of $9.1 \mathrm{pCi} / \mathrm{cm}^{2}$ was within the normal background range of about 8.7 . Based on site selection criteria and screening analysis, this site was considered to be typical and representative.

ROA Site 42. This site is underlain by the Copper Ridge Formation of the Knox Group. Vegetation is old-field successional forest. Most of the early pines have been replaced by oaks, red maple, and sumac. Acetone was a VOA detect, but this compound is the result of instrument contamination. One or more PAHs were detected. Cesium-137 accumulation of $6.7 \mathrm{pCi} / \mathrm{cm}^{2}$ was the below background range of about 8.7 , an indication that some surficial erosion has occurred at this site. The soil profile description does not indicate the presence of any A horizon. Based on site selection criteria and screening analysis, this site was considered to be typical and representative, except for the slight amount of erosion ( 1 to $2 \mathrm{~cm}$ ).

ROA Site 43. This site is underlain by the Copper Ridge Formation of the Knox Group, but the upper $72 \mathrm{~cm}$ of the soil consisted of local cherty colluvium. Vegetation is old-field successional forest. Present vegetation is chestnut oak, dogwood, sumac, and sassafras. Acetone was a VOA detect, but this compound is the result of instrument contamination. One or more PAHs were detected. Cesium-137 accumulation of $11.1 \mathrm{pCi} / \mathrm{cm}^{2}$ was above normal background range of about 8.7, an indication that there has been some surficial deposition on this site, although the presence of any recent deposition was not described in the soil profile description. Because of the excessive thickness of the colluvium, this site is not considered to be representative of residual soils, but would be representative of local cherty colluvial soils of the Copper Ridge Formation. The second problem is the recent deposition on this site, but sediment accumulation of about $2 \mathrm{~cm}$ would account for the higher cesium-137 value.

ROA Site 44. This site is underlain by the Copper Ridge Formation of the Knox Group, but the upper $88 \mathrm{~cm}$ of the soil consisted of local cherty colluvium. Vegetation is old-field successional forest. Most of the early pines have been replaced by oaks, red maple, poplar, and dogwood. Acetone was a VOA detect, but this compound is the result of instrument contamination. One or more PAHs were detected. Cesium-137 accumulation of $5.8 \mathrm{pCi} / \mathrm{cm}^{2}$ was considerably below the normal background range of about 8.7, a strong indication that this site has been eroding since radioactive cesium deposition began. Because of the excessive thickness of the colluvium, this site is not considered to be representative of residual soils, but it would be representative of local cherty colluvial soils of the Copper Ridge Formation. The second problem is the recent erosion from this site.

ROA Site 45. This site is underlain by the Copper Ridge Formation of the Knox Group, but the upper $33 \mathrm{~cm}$ of the soil consisted of local cherty colluvium. Vegetation is old-field successional forest. Most of the early pines have been replaced by sassafras, oaks, hickories, and dogwood. Acetone was a VOA detect, but this compound is the result of instrument contamination. One or more PAHs were detected. Cesium-137 accumulation of $8.4 \mathrm{pCi} / \mathrm{cm}^{2}$ 
was very close to the normal background range of about 8.7. Based on site selection criteria and screening analysis, this site was considered to be typical and representative.

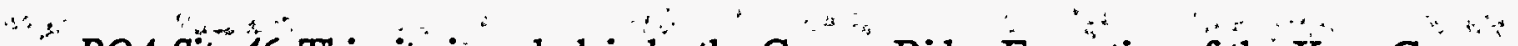

ROA Site 46. This site is underlain by the Copper Ridge Formation of the Knox Group, but the upper $64 \mathrm{~cm}$ of the soil consisted of local ancient alluvium. Vegetation is old-field successional forest. Most of the early pines have been replaced by red maple and dogwood. Acetone was a VOA detect, but this compound is the result of instrument contamination. One or more PAHs were detected. Cesium-137 accumulation of $7.7 \mathrm{pCi} / \mathrm{cm}^{2}$ was within the normal background.range of about 8.7. Because of the excessive thickness of the ancient alluvium, this site is not considered to be representative of residual soils.

ROA Site 47. This site is underlain by the Copper Ridge Formation of the Knox Group, but the upper $43 \mathrm{~cm}$ of the soil consisted of local cherty colluvium: Vegetation is old-field successional forest. Most of the early pines have been replaced by poplar, red maple, and dogwood. Acetone was a VOA detect, but this compound is the result of instrument contamination. One or more PAHs were detected. Cesium-137 accumulation of $4.3 \mathrm{pCi} / \mathrm{cm}^{2}$ was well below the normal background range of about 8.7, an indication that there has been considerable erosion. Because of the thickness of colluvium, this site is marginally representative of residual soils. The second problem is the recent erosion from this site.

\subsection{QUALITATIVE ANALYSIS OF ANDERSON COUNTY SITES}

AND Site 1, AND Site 10, and AND Site 11. These sites are located close together. AND Site 1 is located in Dismal Gap residuum and is situated in a woodlot that is also used for cattle pasture. The A horizon sample consisted of an old Ap horizon, the B horizon sample consisted of the entire thickness of the argillic horizon, and the $C$ horizon samples of $\mathrm{Cr}$ horizon materials. This site is also on a $30 \%$ slope and subject to accelerated soil erosion. No VOAs registered above detection limits, but several organics were detected. The results from ESD cesium-137 gamma scanning gave a value of $6.58 \mathrm{pCi} / \mathrm{cm}^{2}$ in the upper $30 \mathrm{~cm}$ of soil. This value indicates that this site has been, and perhaps still is, eroding, although at a very slow rate. AND Site 10 occurs in an old field with old-field successional forest dominated by pines. This site is on a nearly level ridge top. The A horizon sample consisted of an A horizon, the $B$ horizon sample consisted of the entire thickness of the argillic horizon, and the $\mathrm{C}$ horizon sample consisted of $\mathrm{Cr}$ materials. Except for acetone, all VOA analytes were below detection limits, but several organics were estimated. All were PAHs. In addition, there were several organic rejects. ESD cesium-137 gamma scanning results gave a median value of $9.39 \mathrm{pCi} / \mathrm{cm}^{2}$, which agrees with the soil morphology indication of surface stability. AND Site 11 occurs in a stand of hardwoods that was once an old field. The soil morphology is typical of a more strongly weathered and developed soil from the Dismal Gap Formation than what is generally typical. Except for acetone, no VOA analytes registered above detection limits. There were several "J" estimated organics. The ESD cesium-137 gamma scanning results gave a median value of $10.27 \mathrm{pCi} / \mathrm{cm}^{2}$ for the upper $30 \mathrm{~cm}$ of the soil profile. This value indicates that this site has not been eroding, but may have received 1 to $2 \mathrm{~cm}$ of recent deposition.

AND Site 3, AND Site 4, AND Site 5, and AND Site 20. These four sites are clustered close together. They are all under the same ownership and have a similar old-field successional forest dominated by pines. The underlying geology is the Dismal Gap Formation. AND Site 3 was formed wholly in residuum. AND Site 4 was formed in $53 \mathrm{~cm}$ of colluvium 
and the underlying residuum. AND Site 5 was formed in $70 \mathrm{~cm}$ of colluvium and the underlying residuum. AND Site 20 was formed in $21 \mathrm{~cm}$ of colluvium and the underlying residuum. Except for acetone resulting from instrument contamination, no VOA analytes registered above detection limits. All sites showed estimated "J" amounts of several PAHs. ESD cesium-137 gamma scan results indicated that AND Site 3, with a value of $4.73 \mathrm{pCi} / \mathrm{cm}^{2}$, had been quite eroded. AND Site 20 , with a value of $7.03 \mathrm{pCi} / \mathrm{cm}^{2}$, had been eroded to some extent, but AND Site 4, with a value of $9.97 \mathrm{pCi} / \mathrm{cm}^{2}$, had not experienced any erosion.

AND Site 9 and AND Site 19. These sites are located close together, separated by about $300 \mathrm{ft}$. Both sites have typical soils that formed in Dismal Gap residuum. AND Site 9 occurs on a convex sideslope, while AND Site 19 occurs on the lower part of a sideslope. Except for acetone, no VOA analytes registered above detection limits for either site. However, there were several. "J" estimated organics, mostly PAHs, for both sites. ESD cesium-137 gamma scan results for AND Site 9 show a value of $8.95 \mathrm{pCi} / \mathrm{cm}^{2}$ in the upper $30 \mathrm{~cm}$ of the soil profile, while AND Site 19 shows a value of 14.42 . The soil profile description indicates that there has been some soil deposition at this site.

AND Site 12, AND Site 21, and AND Site 22. These sites are underlain by the Dismal Gap Formation, and the soils are typical of Dismal Gap residual soils. They exhibit similar old-field successional forest dominated by pines but have slightly differing landscape positions. Cattle are allowed to graze on AND Site 12 and Site 21 but not on AND Site 22. Except for acetone, no VOA analytes registered above detection limits. All sites contain estimated "J" PAHs. AND Site 12 also contains Aroclor 1242 above detection limits. ESD cesium-137 gamma scan data show a value of $7.31 \mathrm{pCi} / \mathrm{cm}^{2}$, a lower-than-normal value, indicating that there has been some soil erosion from AND Site 12. The value for AND Site 21 is 6.35, also a lower- than-normal value, indicating that there has been soil erosion from this site. In addition, AND Site 22 has a value of $3.80 \mathrm{pCi} / \mathrm{cm}^{2}$, an indication of considerable erosion.

AND Site 31. This site is underlain by the Copper Ridge Formation, but the upper $61 \mathrm{~cm}$ of the soil profile consisted of local cherty colluvium. Vegetation is old-field successional forest and is now dominated by Virginia pine, sassafras, and oaks. Both acetone and butanone were VOA detects, but these compounds are the result of instrument contamination. One or more PAHs were detected. Cesium-137 accumulation of $8.6 \mathrm{pCi} / \mathrm{cm}^{2}$ was well within normal background range of about 8.5. Because of the excessive thickness of the colluvium, this site is not considered to be representative of residual soils but would be representative of local cherty colluvial soils of the Copper Ridge Formation.

AND Site 32. This site is underlain by the Copper Ridge Formation, but the upper $45 \mathrm{~cm}$ of the soil profile consisted of local cherty colluvium. Vegetation is old-field successional forest and is now dominated by oaks, hickories, and sassafras. Both acetone and butanone were VOA detects, but these compounds are the result of instrument contamination. One or more PAHs were detected. Cesium-137 accumulation of $7.1 \mathrm{pCi} / \mathrm{cm}^{2}$ was slightly below the normal background of about 8.5 , an indication that some erosion has occurred at this site. Because of the thickness of colluvium, this site is marginally representative of residual soils.

AND Site 33. This site is underlain by the Copper Ridge Formation, but the upper $46 \mathrm{~cm}$ of the soil profile consisted of local cherty colluvium. Vegetation is old-field successional forest and is now dominated by hickories, oaks, dogwood, and sassafras. No VOAs were detected. One or more PAHs were detected. The herbicide aldrin was detected. Cesium-137 
accumulation of $8.5 \mathrm{pCi} / \mathrm{cm}^{2}$ was the same as the normal background range of about 8.5 . Because of the thickness of colluvium, this site is marginally representative of residual soils.

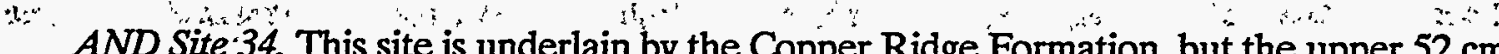

AND Site 34 . This site is underlain by the Copper Ridge Formation, but the upper $52 \mathrm{~cm}$ of the soil profile consisted of local cherty colluvium. Vegetation is old-field successional forest which is now dominated by chestnut oaks, sassafras, dogwoods, and red maple. No VOAs were detected. One or more PAHs were detected. Technetium-99 was detected at this site. Cesium-137 accumulation of $11.4 \mathrm{pCi} / \mathrm{cm}^{2}$ was above the normal background of about 8.5 , an indication that some sediment accumulation has occurred on this site. Because of the thickness of colluvium, this site is marginally representative of residual soils. The abovenormal cesium level indicating deposition also makes this site less representative of stable sites.

AND Site 35. This site is underlain by the Copper Ridge Formation, but the upper $62 \mathrm{~cm}$ of the soil profile consisted of local cherty colluvium. Vegetation is old-field successional forest and is now dominated by oaks, sassafras, and red maple. Both acetone and butanone were VOA detects, but these compounds are the result of instrument contamination. One or more PAHs were detected. Cesium-137 accumulation of $7.5 \mathrm{pCi} / \mathrm{cm}^{2}$ was slightly below the normal background of about 8.5, an indication that some erosion has occurred at this site. Because of the thickness of colluvium, this site is not considered to be representative of residual soils but is very representative of the associated colluvial soils.

AND Site 36. This site is underlain by the Copper Ridge Formation, but more than $90 \mathrm{~cm}$ of the soil profile consisted of local cherty colluvium. Vegetation is poplar, white oak, red oak, and hickory. Both acetone and butanone were VOA detects, but these compounds are the result of instrument contamination. One or more PAHs were detected. Cesium-137 accumulation of $5.1 \mathrm{pCi} / \mathrm{cm}^{2}$ was well below normal background range of about 8.5 , an indication that erosion has occurred at this site. Because of the thickness of colluvium, this site is not representative of residual soils but is representative of adjacent colluvial soils. The second problem with this site is the amount of erosion that has occurred.

AND Site 37. This site is underlain by the Copper Ridge Formation. Vegetation is old-field successional forest and is now dominated by cedar, red maple, and oak. No VOAs were detected. One or more PAHs were detected. Cesium-137 accumulation of $12.8 \mathrm{pCi} / \mathrm{cm}^{2}$ was well above the normal background of about 8.5, an indication that some sedimentation has occurred on this site. Based on site selection criteria, this site would appear to be representative, but the high cesium-137 value, an indication of sediment deposition, makes this site marginally suitable.

AND Site 38. This site is underlain by the Copper Ridge. Formation, but the upper $40 \mathrm{~cm}$ of the soil consisted of local cherty colluvium. Vegetation is old-field successional forest and is now dominated by cedar, privet, red maple, and oak. No VOAs were detected. One or more PAHs were detected. Cesium-137 accumulation of $10.5 \mathrm{pCi} / \mathrm{cm}^{2}$ was above the normal background range of about 8.5 , an indication that some sedimentation has occurred on this site. Based on site selection criteria, this site would appear to be representative, but the colluvial capping and the higher than normal cesium-137 value would make this site marginally representative.

AND Site 39. This site is underlain by the Copper Ridge Formation, but the upper $34 \mathrm{~cm}$ of the soil consisted of local ancient alluvium. Vegetation is old-field successional forest and 
is now dominated by oaks, hickories, and red maple. No VOAs were detected. One or more PAHs were detected. Cesium-137 accumulation of $6.8 \mathrm{pCi} / \mathrm{cm}^{2}$ was below the normal background range of about 8.5 , an indication that some erosion has occurred at this site. Based on site selection criteria, this site would appear to be representative, but the thin alluvial capping and the lower than normal cesium-137 value would make this site marginally representative.

AND Site 40. This site is underlain by the Copper Ridge Formation, but the upper $36 \mathrm{~cm}$ of the soil consisted of local cherty colluvium or alluvium. Vegetation is old-field successional forest and is now dominated by Virginia pine and red maple with a ground cover of ferns. Acetone was a VOA detect, but this compound is the result of instrument contamination. One or more PAHs were detected. Cesium-137 accumulation of $7.3 \mathrm{pCi} / \mathrm{cm}^{2}$ was slightly below the normal background of about 8.5, an indication that some erosion has occurred on this site. Based on site selection criteria, this site is considered to be representative.

AND Site 41. This site is underlain by the Copper Ridge Formation, but the upper $38 \mathrm{~cm}$ of the soil consisted of local cherty colluvium. Vegetation is old-field successional forest and is now dominated by red maple, dogwoods, and Virginia pine with a ground cover of ferns. There were no VOA detects. One or more PAHs were detected. Both alpha chlordane and endosulfon- 1 were pesticide detects. Cesium- 137 accumulation of $14.3 \mathrm{pCi} / \mathrm{cm}^{2}$ was well above the normal background of about 8.5, an indication that considerable sedimentation has occurred on this site. Based on site selection criteria, this site would appear to be representative, but much higher than normal cesium-137 value would make this site marginally representative.

AND Site 42. This site is underlain by the Copper Ridge Formation, but the upper $53 \mathrm{~cm}$ of the soil consisted of local cherty colluvium. Vegetation is old-field successional forest and is now dominated by Virginia pine and red maple with a ground cover of ferns. Acetone was a VOA detect, but this compound is the result of instrument contamination. One or more PAHs were detected. Cesium-137 accumulation of $7.1 \mathrm{pCi} / \mathrm{cm}^{2}$ was slightly below the normal background of about 8.5 , an indication that some erosion has occurred at this site. Based on site selection criteria, this site would not be representative of residual soils, but would be representative of adjacent colluvial soils. 


\section{ANALYTICAL LABORATORY ANALYSES AND DATA VALIDATION}

\subsection{SUMMARY OF DATA VALIDATION}

The data generated in the Background Soil Characterization Project (BSCP) were validated according to project-specific validation guidelines. These guidelines were prepared according to the U.S. Environmental Protection Agency (EPA) Contract Laboratory Program (CLP) Validation Functional Guidelines and the BSCP Project Plan (Energy Systems 1992). A total of 55 data packages was received for, the BSCP Project, 23 chemical and 32 radiological. (Please note that the number of chemical packages from the Phase I annual report was incorrect; the report stated 35 data packages and there were only 12 data packages, which is the reason for the decrease in the number of chemical packages). The laboratories reported 22,370 results, with only a total of 1715 results $(8.0 \%)$ being rejected by data validation and 6,947 results $(31 \%)$ being estimated (J) or (UJ) (Table 4.1). Occurrences of rejected data appear in Appendix H. The quality control (QC) problems observed in the chemical data validation consisted of (1) calibration problems; (2) blank spike, matrix spike (MS), and surrogate recoveries outside QC limits; and (3) coelution ${ }^{1}$ problems. The major concern in the chemical data centered on the analysis of polynuclear aromatic hydrocarbons (PAHs). The analytical laboratory had problems related to the method, with only $75 \%$ of the data being usable. There were minor problems with herbicides and metals; $31 \%$ of the dalapon results and $87 \%$ of the osmium results were rejected. The problems encountered in the radiological data ranged from calibration problems to blank spike and MS recoveries outside of QC limits. Usability was lowest for two isotopes-curium-244 and neptunium-237-for which only $43 \%$ of the curium-244 and $70 \%$ of the neptunium-237 were usable. The curium-244 data were rejected because the laboratory was unable to recover blank spikes, matrix spikes, or duplicates due to interferences. The neptunium-237 results were rejected because of calibration errors and calculation errors in matrix spike/matrix spike duplicate (MS/MSD) and blank spike recoveries that, upon correction, yielded recoveries that were outside limits. Lists of sample numbers belonging to each sample delivery group (SDG) are presented in Appendix F. Information on numbers of samples involved in these summary percentages is provided in Tables 4.2 through 4.6.

Lessons learned during the course of this project can benefit future Environmental Restoration (ER) projects. The initial planning process focused on sampling, with a general idea of what analyses were required. Upon review of $Q C$ requirements and analytical methods required, the project had to re-evaluate the schedule and budget to address analytical needs. In addition, the BSCP was the first ER project to utilize fully the new Analytical Projects Office (APO). The laboratories performing the work - the first large project they had received from Energy Systems-required a period of adjustment to Energy Systems requirements and needs. Many of the concerns that surfaced during early validation activities may be attributed to this learning period; however, there were some problems that Energy Systems might have been able to avert. A project-specific preaudit [with reference to the BSCP Project Plan (Energy Systems 1992, Volume 3) and the APO Statement of Work] of the laboratories, including review of the laboratories' procedures and quality assurance (QA) review process,

\footnotetext{
${ }^{1}$ Coelution is defined as the condition of insufficient separation of two compounds during the chromatographic process.
} 
Table 4.1. Definition of data validation qualifiers

\begin{tabular}{ll}
\hline Qualifier & Definition \\
\hline U & The analyte was analyzed for but was not detected above the \\
reported sample quantitation limit. \\
The analyte was positively identified; the associated numerical \\
value is the approximate concentration of the analyte in the \\
sample. \\
The analysis indicates the presence of an analyte for which there is \\
presumptive evidence to make a tentative identification. \\
JN \\
The analysis indicates the presence of an analyte that has been \\
tentatively identified, and the associated numerical value represents \\
its approximate concentration. \\
The analyte was not detected above the reported sample \\
quantitation limit. However, the reported quantitation limit is \\
approximate and may or may not represent the actual limit of \\
quantitation necessary to accurately and precisely measure the \\
analyte in the sample. \\
The sample results are rejected because of serious deficiencies in \\
the ability to analyze the sample and meet quality control criteria. \\
The presence or absence of the analyte cannot be verified. \\
The laboratory did not register this compound, but there was \\
presumptive evidence of a compound that was within the retention \\
time window but was not reported. No other qualification of the \\
data was made.
\end{tabular}

would have been helpful. In addition, sending performance evaluation samples to the laboratory for each of the methods requested would have indicated the types of data packages each laboratory can provide and demonstrated the laboratory's ability to perform the requested analyses. For example, during validation of the technetium-99 data, a copy of the laboratory's procedure for analyzing technetium was requested, and it was discovered that the laboratory furnaced the samples at $500^{\circ} \mathrm{C}$. This temperature caused the rejection of the technetium data. A preaudit would have revealed the furnacing step of the procedure before the samples were shipped. Because no preaudit was performed, project personnel had to study and evaluate the effects of muffle furnacing at high temperatures on the volatility of 
technetium in order to determine the acceptability and usefulness of the data. Follow up and results are discussed in Sect. 4.4.

\subsection{SCOPE}

The objective of the analytical program was to determine the background concentration levels of selected metals, organics, and radionuclides in natural soil samples.

The assumptions used to select the analytical parameters follow.

- Background concentrations of naturally occurring inorganic, organic, and radiological parameters or analytes of interest to be determined are those normally found in soils and sediments of natural origin that indicate contamination when found above natural background. These include heavy metals, organic compounds, and radionuclides that are used in or generated by industrial, agricultural, and research activities associated with the Oak Ridge Reservation (ORR).

- The parameters or analytes not occurring naturally were assumed to have an a priori concentration equivalent to zero background, which would be below the analytical detection limits. Some of these include manmade compounds such as volatile organics and some semivolatile organics. Radionuclides were an exception due to nuclear activation and fission products that may have been added to the natural background by natural processes, such as atmospheric deposition.

The analytical methodologies used for this project are those consistent with EPA's analytical Level $\mathrm{TV}$. The EPA CLP procedures were used where appropriate and SW-846 methods were used for the non-CLP parameters. Due to the nature of the project, the contract-required detection limits were too high, so the laboratory adapted the SW- 846 detection limits to their procedures.

\subsection{SELECTION OF LABORATORIES}

The laboratories selected to perform the analyses were

- evaluated, selected, and approved by the APO,

- capable of performing the requested analyses as stated in the work plan, and

- the lowest in cost.

The laboratories selected for the BSCP were Lockheed Analytical Services (chemical) and EcoTek LSI (radiological). These laboratories were chosen by comparing the responses of four laboratories to the issued statement of work [consisting of the Project Sampling and Analysis Plan and the Quality Assurance Plan contained in the BSCP Plan (Energy Systems 1992, Volume 3)]. All the laboratories did not submit prices for each analyte required for this project, so common analytes were selected and a price comparison was performed for evaluation purposes. Of the laboratories submitting prices for the chemical portion of the project, only Lockheed provided pricing and availability for all requested parameters. An analysis of the submitted prices also indicated that Lockheed had the overall lowest cost of the laboratories responding. 
Only two laboratories submitted responses to the statement of work for the radiological analyses. A comparison of the responses indicated that EcoTek was capable of performing the analyses at the lowest cost.

\subsection{QUALITY ASSURANCE/QUALITY CONTROL AND DATA VALIDATION}

The QA and QC of this project was conducted according to the requirements of the EPA CLP. The Analytical Level as defined by the EPA Data Quality Objectives document is Level IV. This level is characterized by rigorous QA/QC protocols and documentation. The pesticide/PCB analyses were performed according to the EPA CLP March 1990 Organics Statement of Work. The metals analyses (except osmium). were performed according to the EPA CLP March 1990 Inorganics Statement of Work. All other analyses were analyzed under "CLP-like" procedures with the minimum QC outlined in the project plan.

During this project there were some modifications to the analytical program. The following lists the modifications and how they affected the project.

- The method for the volatile organic analysis was changed from EPA Method 8240 to EPA Method 8260 , because the laboratory was using a gas chromatographic system that utilized a capillary column for separation instead of a column packed with graphitized carbon coated with carbowax (which method 8240 uses). This change did not affect the detection limits specified by the work plan.

- The analysis of nitrate was removed from the analytical program because of the 24-h holding time. Due to the compositing of samples, the samples were not shipped for 2 to 5 days after sample collection, which meant that the nitrate holding time was already exceeded. Therefore, analyzing for nitrate would be futile.

- The work plan indicates that EPA 200.7 CLP-M was to be used for the preparation and analysis of silicon. However, silicon was prepared according to EPA Method 3050 and analyzed according to EPA 200.7 CLP-M. This change does affect the recovery of silicon, since the preferred method is to use a hydrogen fluoride digestion.

- Since it was found that the laboratory was muffle-furnacing technetium-99 samples, a method was needed to remove organic matter but not volatilize the technetium. EcoTek LSI performed an in-house study of the effects of furnace temperatures and detrmined that there was no appreciable loss of technetium at $400^{\circ} \mathrm{C}$ or less. Because of this finding, we resampled for technetium and reanalyzed using the lower furnace temperature. As an additional precaution, we had the laboratory spike the samples before furnacing and determine recovery efficiency before carrying out the technetium-99 method analysis. Using this technique, it was found that the technetium was quantitatively recovered, and the results were usable for the BSCP.

\subsection{DATA VALIDATION}

The data validation for this project was conducted by the K-25 Analytical Environmental Support Group (AESG), the ORNL Measurement Applications and Development Group (MAD), and the ORNL Biomedical Environmental Information Analysis Section (BEIAS). 
All sample data were delivered to the ORNL/MAD Analytical Coordinator who had ultimate responsibility for the data throughout the validation process. ORNL/MAD screened the data packages to ensure contract compliance and that project deliverables were provided, and $\mathrm{K}-25$ AESG performed the technical review of the data.

The criteria for the data validation are outlined in the BSCP Plan (Energy Systems 1992, Volume 3). However, the project plan did not provide detailed requirements; therefore, the K-25 Site AESG personnel developed project-specific criteria. They were prepared consistent with the EPA CLP Validation Functional Guidelines, as well as the validation guidelines outlined in the BSCP Plan.

The quality of the data validation process was ensured by a defined and documented process. Initially, the data package was screened for completeness of project deliverables. Secondly, the data were reviewed and evaluated against the project-specific data validation criteria. This evaluation was then assessed by a peer review that examined the qualified data, checked the rationale of the professional judgments, and evaluated the reasonableness of the findings in light of the data quality objectives. The peer-reviewed data package was then reviewed by a third individual who concentrated on the rationale and reasonableness of the qualifications. This extensive review and oversight process was designed to ensure that consistency was maintained throughout the process. Upon completion of the validation, a report was issued; a summary of the findings is presented below.

\subsubsection{Organic Data Validation Results}

\subsubsection{Pesticide/PCB validation results}

The analysis of pesticide/PCB samples was performed according to the USEPA Contract Laboratory Program Statement of Work for Organic Analysis, Multi-media, Multi-Concentration, March 1990. There were 118 samples analyzed for the pesticide/PCB compounds listed in the statement of work.

Holding Times. Holding times were met for both the extraction and analysis for all samples except samples in SDGs 0514260 and 0727260 . Samples in SDG 0514260 were re-extracted outside of the extraction holding time, thus qualifying the data as estimated (J). The extraction holding time for samples in SDG 0727260 was exceeded by one day, so the data was qualified as estimated (J).

Gas chromatograph/electron capture detector (GC/ECD) Instrument Performance. The frequency and sequence of the resolution check mixture and the performance evaluation mixtures were evaluated.

1. A resolution check mixture was analyzed at the beginning of every initial calibration sequence, on each GC column and instrument used for analysis.

2. The depth of the valleys between two adjacent compounds (dieldrin and DDE) in the resolution check mixture could not be verified as being $\geq 60 \%$ of the height of the shorter peak.

- Dieldrin and DDE were qualified as estimated (J) for positive results and estimated nondetect (UJ) for nondetects in SDGs 0523260, 0508260, 0511260, 042260, $0424260,0430260,0514260$, and 0519260. 
3. A performance evaluation mixture (PEM) was analyzed at the beginning and end of each initial calibration sequence and at the beginning of every other 12-h analytical sequence.

4. Adjacent peaks in the PEM were reviewed and appeared to be $100 \%$ resolved for all compounds except beta-BHC and gamma-BHC on one column. Retention times were within the specified retention time windows.

- Beta-BHC and gamma-BHC were qualified as estimated (J) for positive results and estimated nondetect (UJ) for nondetects for SDGs 0523260, 0508260, 0511260, 0430260,0514260 , and 0519260.

5. The relative percent difference (RPD) between the calculated amount and the true amount for each of the single component pesticides and surrogates in the PEMs was $\leq 25 \%$ for all target compounds except the following:

- 4,4'-DDT was qualified as estimated (J) for positive results and estimated nondetect (UJ) for nondetects in SDG 0523260;

- beta-BHC was qualified as estimated $(J)$ for positive results and estimated nondetect (UJ) for nondetects in SDG 0508260;

- beta-BHC and methoxychlor in sample 3072 of SDG 0511260 were qualified as estimated (J) for positive results and estimated nondetect (UJ) for nondetects;

- alpha-BHC was qualified as estimated (J) for positive results and estimated nondetect (UJ) for nondetects in samples 1064, 1072, 1080, and 3003 of SDG 042260;

- beta-BHC and methoxychlor were qualified as estimated ( $(J)$ for positive results and estimated nondetect (UJ) for nondetects in sample 3018 of SDG 042260;

- alpha-BHC was qualified as estimated (J) for positive results and estimated nondetect (UJ) for nondetects in samples 1099 and 1106 of SDG 0424260;

- beta-BHC and methoxychlor were qualified as estimated (J) for positive results and estimated nondetect (UJ) for nondetects in samples 1107, 1108, and 1115 of SDG 0424260;

- beta-BHC and methoxychlor were qualified as estimated (J) for positive results and estimated nondetect (UJ) for nondetects in samples 1127 and 3032 of SDG 0430260;

- 4,4'-DDT was qualified as estimated (J) for positive results and estimated nondetect (UJ) for nondetects for SDG 0722260;

- beta-BHC was qualified as estimated $(J)$ for positive results and estimated nondetect (UJ) for nondetects in SDG 0727260; and

- beta-BHC was qualified as estimated (J) for positive results and estimated nondetect (UJ) for nondetects in SDG 0803260.

Initial and Verification Calibration. Results on initial calibration and calibration verification forms were examined to ensure that reported results met required QC criteria.

1. Individual standard mixtures $A$ and $B$ contained all of the single component compounds and surrogates and were analyzed at low, midpoint, and high concentrations during the initial calibration on each GC column and instrument used for analysis.

2. Adjacent peaks in the individual standard mixtures were reviewed and appeared to be at least $90 \%$ resolved for all target compounds.

3. Retention times reviewed were within the specified retention time windows.

- Endosulfan I and alpha-BHC had almost the same retention time window that qualified the data as estimated (J) for positive results and estimated nondetect (UJ) for nondetects in SDG 0508260. 
4. All percent standard deviation (\%RSD) results for the calibration factors met the QC criterion of $\leq 20 \%$ for target compounds, with the exception of the following:

- alpha-BHC was qualified as estimated (J) for positive results and estimated nondetect (UJ) for nondetects in SDGs 0803260 and 0727260 ;

- 4,4'-DDT was qualified as estimated (J) for positive results and estimated nondetect (UJ) for nondetects in SDG 0722260;

- alpha-BHC, delta-BHC, 4,4'-DDD and 4,4'-DDE were qualified as estimated (J) for positive results and estimated nondetect (UJ) for nondetects in SDGs 0519260 and 0508260;

- alpha-BHC, 4,4'-DDD and 4,4'-DDE were qualified as estimated (J) for positive results and estimated nondetect (UJ) for nondetects in SDG 0430260 and sample 3072 of SDG 0511260;

- alpha-BHC and endrin aldehyde were qualified as estimated (J) for positive results and estimated nondetect (UJ) for nondetects in samples 1099 and 1106 of SDG 0424260 and samples 1064, 1072, 1080, and 3003 of SDG 042260;

- alpha-BHC, 4,4'DDE, 4,4'-DDD, and 4,4'-DDT were qualified as estimated (J) for positive results and estimated nondetect (UJ) for nondetects in samples 1107, 1108, and 1115 of SDG 0424260 and sample 3018 of SDG 042260 ;

- alpha-BHC, delta-BHC, gamma-BHC, $4,4^{\prime}-\mathrm{DDD}$ and $4,4^{\prime}-\mathrm{DDE}$ were qualified as estimated $(J)$ for positive results and estimated nondetect (UJ) for nondetects in samples 3058, 3099, and 3085 of SDG 0511260; and

- alpha-BHC, gamma-BHC, 4,4'-DDD, 4,4'-DDT, and endrin aldehyde were qualified as estimated (J) for positive results and estimated nondetect (UJ) for nondetects in SDG 0523260.

5. Surrogates met the criterion of $\leq 30 \%$ RSD.

6. A single concentration calibration standard was analyzed for multi-component compounds.

7. All RPDs between calculated and nominal amounts for each target compound and surrogate in the midpoint continuing calibration concentrations met the QC criterion of $\leq 25 \%$, with the exception of the following:

- aldrin, which was qualified as estimated (J) in SDG 0430260; and

- delta-BHC, heptachlor, and 4,4'-DDD, which were qualified as estimated (J) in SDG 0523260.

Laboratory Blanks. Samples were extracted with a method blank, and an instrument blank was run immediately prior to analysis of either a PEM or an individual continuing calibration midpoint standard mixture. The was no significant contamination found in the blanks, with the exception of PBBLK02 of SDG 0514260. PBBLK02 was found to contain Aroclor 1242, which was also identified in two of the samples. Therefore, samples 3046 and 3148 were qualified as non-detected $(U)$ since the concentration of the samples was less than five times the concentration found in the associated blanks.

Surrogates. All surrogates were within the 60 to $150 \%$ QC limits with the following exceptions:

- sample 3058 of SDG 0511260, all target compounds in this sample were qualified as estimated (J); 
- sample 3018 of SDG 042260, no qualification was necessary because all surrogates were outside the limits on the high side and no target compounds were detected;

- sample 3113 of. SDG 0514260 , all target compounds in this sample were qualified as estimated (J);

- some surrogates for SDG 0722260 were outside the QC limits. Sample 2130 showed a TCMX recovery of $175 \%$. Samples 2090 and 2143 showed one recovery of DCB below the minimum QC criterion of $60 \%$ and sample 2149 showed DCB recoveries less than the QC criterion of $60 \%$ on both columns; therefore, late eluters (those eluting within $10 \mathrm{~min}$ of the DCB surrogate) were qualified as estimated (J) in sample 2149;

- samples 2179 and 1462 of SDG 0727260 showed recoveries of DCB of less than QC criterion of $60 \%$ on both columns; therefore, late eluters (those eluting within $10 \mathrm{~min}$ of the DCB surrogate) were qualified as estimated (J) in samples 1462 and 2179; and

- SDG 0727260 showed recovery of DCB less than the QC criterion of $60 \%$ on both columns; therefore, late eluters (those eluting within $10 \mathrm{~min}$ of the $\mathrm{DCB}$ surrogate) were qualified as estimated (J) in this SDG.

Matrix Spike/Matrix Spike Duplicates. Results were checked to ensure that reported results met the required QC criteria. MS and MSD data are not used to qualify data alone. All MS and MSD recoveries were within QC limits with the exception of the following:

- MS and MSD recoveries in SDGs 0727260 and 0803260 exceeded the QC limit of $150 \%$. However, there was no qualification of the data because no target compounds were found in the samples.

- Endrin failed to be recovered in the MS of SDG 0523260 and was poorly recovered in the MSD. However, since there were no problems with recovery and breakdown of endrin in the standards and PEMs, there was no qualification of the data.

Overall Assessment. The laboratory did not always adhere to CLP protocol.

- Extract volumes were condensed to $4 \mathrm{~mL}$ instead of $10 \mathrm{~mL}$.

- Only $1 \mathrm{~mL}$ of matrix spike and matrix spike duplicate solutions were added to samples instead of the required $2 \mathrm{~mL}$.

- Chromatograms for standards were non-compliant (less than $10 \%$ full scale for single component compounds and less than $25 \%$ full scale for multi-component compounds).

- The Florisil cartridge check and cleanup were not performed as required.

- Target compounds were detected on both columns above the detection limit, but below the contract required quantitation limit; however, they were not reported on Form 1s.

A summary of the pesticide/PCB data validation results is presented in Table 4.2.

\subsubsection{Chlorinated herbicide validation results}

The analysis of chlorinated herbicide samples was performed according to the USEPA $S W-846$ Method 8150, Second Edition with the QC performed in a "CLP-like" manner. There were 58 samples analyzed for the chlorinated herbicide compounds. 
Table 4.2 Summary distribution of pesticide/PCB data validation results

\begin{tabular}{|c|c|c|c|c|c|c|c|c|}
\hline$\therefore \quad$ Compound & $\begin{array}{c}\text { No } \\
\text { qualifier }\end{array}$ & U. & UJ & $\mathbf{P}$ & $\mathbf{J}$ & $\mathbf{R}$ & SUM & \% usable \\
\hline alpha-BHC & & 27 & 90 & & & 1 & $\dot{118}$ & 99 \\
\hline beta-BHC & & 60 & 57 & & & 1 & 118 & 99 \\
\hline delta-BHC & & 45 & 72 & & & 1 & 118 & 99 \\
\hline gamma-BHC(Lindane) & & 27 & 90 & & & 1 & 118 & 99 \\
\hline Heptachlor & & 57 & 60 & & & 1 & 118 & 99 \\
\hline Aldrin & 1 & 77 & 39 & & & 1 & 118 & 99 \\
\hline Heptachlor epoxide & & 96 & 21 & & & 1 & 118 & 99 \\
\hline Endosulfan I & & 89 & 25 & 1 & 1 & 2 & 118 & 98 \\
\hline Dieldrin & & 49 & 68 & & & 1 & 118 & 99 \\
\hline 4,4'-DDE & & 46 & 71 & & & 1 & 118 & 99 \\
\hline Endrin & & 96 & 21 & & & 1 & 118 & 99 \\
\hline Endosulfan II & & 95 & 22 & & & 1 & 118 & 99 \\
\hline $4,4^{\prime}-\mathrm{DDD}$ & & 53 & 64 & & & 1 & 118 & 99 \\
\hline Endosulfan sulfate & & 94 & 22 & & & 1 & 117 & 99 \\
\hline 4,4'-DDT & & 24 & 91 & & 2 & 1 & 118 & 99 \\
\hline Methoxychlor & & 88 & 29 & & & 1 & 118 & 99 \\
\hline Endrin ketone & & 94 & 23 & & & 1 & 118 & 99 \\
\hline Endrin aldehyde & & 87 & 29 & & & 1 & 117 & 99 \\
\hline alpha-Chlordane & 1 & 91 & 24 & & 1 & 1 & 118 & 99 \\
\hline gamma-Chlordane & & 96 & 21 & & & 1 & 118 & 99 \\
\hline Toxaphene & & 96 & 21 & & & 1 & 118 & 99 \\
\hline Aroclor-1016 & & 96 & 21 & & & 1 & 118 & 99 \\
\hline Aroclor-1221 & & 96 & 21 & & & 1 & 118 & 99 \\
\hline Aroclor-1232 & & 96 & 21 & & & 1 & 118 & 99 \\
\hline Aroclor-1242 & 2 & 93 & 21 & 1 & & 1 & 118 & 99 \\
\hline Aroclor-1248 & & 96 & 21 & & & 1 & 118 & 99 \\
\hline Aroclor-1254 & & 96 & 21 & & & 1 & 118 & 99 \\
\hline Aroclor-1260 & & 95 & 21 & & 1 & 1 & 118 & 99 \\
\hline
\end{tabular}

Holding Times. All holding times fell within the specified range, except for the following:

- All samples in SDGs 1204260,1209260 and 1211260 exceeded holding times by greater than two times the limit. All non-detects were flagged unusable (R) and detects were flagged estimated (J).

- Sample 3359 in SDGs 1118260,1120260 and 1124260 was three days outside holding time limit and was flagged estimated non-detect (UJ) for nondetects and estimated (J) for detects.

- Sample 1734 in SDGs 1015260, 1016260, 1020260, and 1023260 exceeded holding time limits by one day and was qualified estimated non-detect (UJ) for nondetects and estimated $(J)$ for detects.

- All samples in SDGs 1204260, 1209260, and 1211260 were re-extracted, exceeding holding time greater than two times the holding time limit. They were qualified as unusable (R) and estimated (J). 
Initial and Verification Calibration. Some of the chlorinated herbicides were found to be outside the QC limits $\left(r^{2} \geq 0.990\right)$. The data was qualified by reviewing the exceedance of the $\mathrm{QC}$ limits in regard to other problems encountered during the validation.

- In SDGs 0508260 and 0511260 , the data were qualified as non-detected (U) because dalapon, dichloroprop, dinoseb, and the surrogate 2,4 dichlorophenylmethylacetate were outside QC limits, but there were no compounds detected in the samples and the second column values were within QC limits (with the exception of dalapon). Since dalapon failed the QC criteria on both columns, this compound was qualified as estimated nondetected (UJ) for all samples except 1213.

- In SDGs 0803260 and $0727260 / 0728260 / 0729260$, the data were qualified as non-detected (U) because 2,4-DB was outside the QC limits on one column while dinoseb and the surrogate 2,4 dichlorophenylmethylacetate were outside the limits on the second column. Since no compounds were detected in the samples and since the compounds met the QC criteria on at least one column, the data was qualified nondetected.

- The data in SDG 0430260 were qualified because dalapon, MCPA, and 2,4-dichlorophenyl-methylacetate were outside QC limits on both columns and 2,4-DB was outside on one column, and dichloroprop was outside on the other column. Another initial calibration should have been run due to the failure of the surrogate on both columns. Therefore, all data is qualified estimated non-detected (UJ), because the surrogate value was not within the $\mathrm{QC}$ limits. Dalapon was rejected $(\mathrm{R})$ due to it gross failure of the QC criteria.

- Dalapon in SDG 0424260 was rejected because it was found to be significantly outside the QC limits.

- All calibration verifications were run under the initial calibration, with the exceptions of SDGs 042260 and 0424260. Dalapon was rejected (R) in SDG 042260, because it failed the QC limit (\%D $\leq 15 \%$ ), while dichloroprop, dinoseb, and 2,4-DB were qualified estimated nondetected (UJ).

- Dicamba, MCPP and 2,4-D were qualified estimated non-detected (UJ) because they were found outside the QC limits (\%D $\leq 15 \%$ ).

- In SDGs 1204260,1209260 , and 1211260, dalapon on column RTX-35 and dalapon on column RTX-5 were outside the $20 \%$ RSD limit. All results qualified as estimated non-detects (UJ) and estimated detects (J).

- Calibration factor \%RSD for SDGs 1015260, 1016260, 1020260, and 1023260 was exceeded. The compounds dalapon, dichloroprop, MCPP, and MCPA were qualified UJ for nondetects and $J$ for detects.

- MCPP and MCPA in SDGs 0828260 and 0827260 exceeded QC limits. Dalapon, 2,4-D, 2,4-DB, silvex and dinoseb were qualified $U J$ for nondetects and $J$ for detects because initial calibration exceeded $20 \%$.

Laboratory Blanks. There were no significant contamination problems found except for the following:

- SDG 0430260, where the laboratory experienced a contamination problem and diluted all the samples and QC samples by a factor of $1: 10$ and

- SDGs 1204260, 1209260, and 1211260, where the surrogate recovery for the blank AB6960MB was outside the 50 to $150 \%$ established range. All results for samples 1964 , 
1970, and 1976 were qualified UJ for nondetects and J for detects. Samples associated with $A B 6960$ from both columns qualified as $R$ because holding times were greater than two times, the limit.

Surrogates. All surrogate recoveries were found within the QC criteria of 50 to $150 \%$, with the exception of some samples within SDGs $0430260(1064,1080,1127$, and 3032), 0424260 $(1099,1106,1107$, and 1115), 0511260 (3046 and 3072), and 0508260 (1201-FD). Samples that had surrogate recoveries outside the QC limits on both columns and no detects reported were qualified as estimated nondetected (UJ). However, if surrogate recoveries were less than $10 \%$ on both columns, the data was rejected (R).

Laboratory Control Samples. All samples met requirements for laboratory control sample (LCS) recoveries except for the following:

- Silvex and 2, 4, 5-T had LCS recoveries slightly outside the QC limits; therefore, data for SDGs 0508260 and 0511260 were qualified as estimated (J);

- all samples of SDG 0424260 were qualified estimated nondetected (UJ) because the LCS recoveries were outside QC limits;

- all data in SDGs 0803260 and $0727260 / 0728260 / 0729260$ were qualified estimated nondetected (UJ) because no LCS was analyzed;

- in SDGs 1015260, 1016260, 1020260, and 1023260, the recovery of 2,4-D, silvex, 2,2,5-T exceeded the acceptable range, and the data were qualified (J); and

- samples in SDGs 1204260,1209260 , and 11211260 had low surrogate recoveries; nondetects were qualified $\mathrm{R}$ and detects $\mathrm{J}$.

Overall Assessment. The overall performance of the laboratory was acceptable, but the following problems were noted:

- initial calibration information was not provided for SDG 0424260;

- there were contamination problems with some of the SDGs, and the laboratory had to dilute some samples at a factor of $1: 20$;

- improper amounts of soil were used. The proper amount was $50 \mathrm{~g}$, but the laboratory used $25 \mathrm{~g}$ in some of the SDGs; and

- verification of practical quantitation limits was not possible, because the information was not provided.

A summary of the chlorinated herbicide data validation results is presented in Table 4.3.

\subsubsection{Polynuclear aromatic hydrocarbons}

The analysis of PAH samples was performed according to the USEPA SW-846 Method 8310, Second Edition, with the QC performed in a "CLP-like" manner. There were 131 samples analyzed for the PAH compounds.

The PAH data generated from the Phase II (1993 sampling) sampling effort had more detected values than the data results in Phase I. The reason for this cannot be definitively determined, but a review of the validation results indicates that the laboratory had more 
Table 4.3. Summary distribution of herbicide data validation results

\begin{tabular}{|c|c|c|c|c|c|c|c|c|}
\hline Compound & No qualifier & $\mathbf{U}$ & UJ & $\mathrm{P}^{*}$ & $\mathrm{~J}$ & $\mathbf{R}$ & SUM & \% usable \\
\hline Dalapon & & 8 & 32 & & & 18 & 58 & 69 \\
\hline Dicamba & & 33 & 19 & & & 6 & 58 & 90 \\
\hline Dichloroprop & & 21 & 31 & & & 6 & 58 & 90 \\
\hline Dinoseb & & 21 & 31 & & & 6 & 58 & 90 \\
\hline MCPA & & 14 & 37 & 1 & & 6 & 58 & 90 \\
\hline MCPP & & 17 & 35 & & & 6 & 58 & 90 \\
\hline Silvex & & 15 & 37 & & & 6 & 58 & 90 \\
\hline 2,4-D & & 18 & 33 & & 1 & 6 & 58 & 90 \\
\hline 2,4-DB & & 20 & 32 & & & 6 & 58 & 90 \\
\hline $2,4,5-\mathrm{T}$ & & .24 & 28 & & & 6 & 58 & 90 \\
\hline
\end{tabular}

* Qualifier $\mathrm{P}$ is a laboratory data qualifier defined in the preface to Volume 2.

problems with contamination in Phase I than in Phase II. This contamination problem could be the cause of the larger number of detected results in Phase II data.

Holding Times. All samples met established holding times, except for those associated with SDG 0722260 . These samples were re-extracted 14 days outside of the extraction holding times. Therefore, all detected results were estimated (J), and nondetected results were qualified estimated nondetected (UJ).

Initial and Verification Calibration. The initial calibration is assessed by the review of the data against the correlation coefficient. The QC limit for the correlation coefficient is $r^{2} \geq 0.990$.

- Benzo[a]anthracene and chrysene for SDGs 0422260, 0424260, 0430260, 0508260, $0511260,0514260,0519260,0722260$, and $0722260 / 0723260$ were found to coelute and were qualified as unusable $(R)$ for all positive hits, because it was impossible to distinguish one from the other and nondetected $(U)$ for results less than reporting limits.

- Anthracene and acenaphthene for SDGs 0422260 and 0424260 exceeded the initial calibration QC limits and were qualified estimated (J) for positive hits and estimated nondetected (UJ) for nondetects.

- Pyrene and decafluorobiphenyl (the surrogate) for SDGs 0508260 and 0511260 exceeded the initial calibration QC limits, so all pyrene data were flagged as estimated (J) for detects and estimated nondetected (UJ) for nondetects. All other data must be estimated (J) because of the coelution of the surrogate with a target compound.

- The surrogate decafluorobiphenyl and fluoranthene coelute. Therefore, detected fluoranthene results in SDG 0511260 were qualified as unusable (R). All other data must be estimated $(\mathrm{J})$ because of the coelution of the surrogate with a target compound.

- Positive hits for fluoranthene were qualified unusable (R), because decafluorobiphenyl and fluoranthene coelute. All other data must be estimated $(J)$ because of the coelution of the surrogate with a target compound.

- Decafluorobiphenyl and benzo[a]anthracene/chrysene for SDG 0523260 exceeded the initial calibration QC limits. All data were estimated (J) for detected compounds and estimated nondetected for nondetected compounds. 
- Benzo[ghi]perylene coelutes with dibenzo[ah]anthracene, therefore, results for SDGs 0727260,0727260 and 0803260 for these two compounds must be qualified as unusable (R), because the laboratory could not quantify the MS/MSD and LCS recoveries for dibenzo[ah]anthracene.

- Anthracene, benzo[k]fluoranthene, benzo[a]pyrene, and benzo[ghi]perylene/ dibenzo[ah]anthracene for SDG 0727260 exceeded initial calibration QC limits, so detected results for anthracene and benzo[ $k]$ fluoranthene were qualified as estimated (J) and estimated nondetects for nondetected results of these compounds. Because benzo[ $a]$ pyrene is only slightly below criteria (0.9891) it was not qualified.

- Anthracene, benzo[k]fluoranthene, benzo[a]pyrene, and benzo[ghi]perylene/ dibenzo[ah]anthracene for samples 1458, and 1464 of SDG 0803260 exceeded initial calibration QC limits, so detected results for anthracene and benzo[ $k]$ fluoranthene were qualified as estimated $(\mathrm{J})$ and estimated nondetects for nondetected results of these compounds. Because benzo[a]pyrene is only slightly below criteria $(0.9303)$ it was not qualified.

- Benzo[b]fluoranthene and benzo[ghi]perylene in SDG $1216260 / 1016260 / 1020260$ / 1023260 were qualified as estimated $(\mathrm{J})$, because the chromatograms for these samples indicated the presence of these analytes even though they were not reported.

The verification of the calibration was assessed by determining the percent difference of the verification calibration result sample to the initial calibration result. All verification analyses were within the QC criteria (\%D $\leq 15 \%)$ except the following:

- Benzo[k]fluoranthene, indeno[123-cd]pyrene, benzo[ $a$ ]pyrene, and benzo[ghi]perylenefor samples 1099, 1106, 1107, 1108, 1115, and 3018 of SDG 0422260 exceeded QC limits, and detected compounds were qualified as estimated $(\mathbf{J})$, and non-detected compounds were qualified as estimated non-detect (UJ).

- Naphthalene, acenaphthalene, fluorene, phenanthrene, fluoranthene, indeno[123-cd]pyrene, benzo[ $k]$ fluoranthene, and benzo[ghi]perylene for SDGs 0430260 , 0508260 , and 0511260 exceeded QC limits, and detected compounds were qualified as estimated (J), and nondetected compounds were qualified as estimated nondetect (UJ).

- Naphthalene, acenaphthalene, fluorene, phenanthrene, fluoranthene, indeno[123-cd]pyrene, benzo[ $k]$ fluoranthene, anthracene, pyrene, benzo[ghi]perylene, and benzo[a]pyrene for SDGs 0514260 and 0519260 exceeded QC limits, and detected compounds were qualified as estimated (J), and nondetected compounds were qualified as estimated nondetect (UJ).

- Naphthalene, acenaphthalene, fluorene, phenanthrene, fluoranthene, indeno[123-cd]pyrene, benzo[k]fluoranthene, anthracene, pyrene, benzo[ $a]$ anthracene/chrysene, and benzo $[a]$ pyrene for SDG 0523260 exceeded QC limits, and detected compounds were qualified as estimated (J), and nondetected compounds were qualified as estimated nondetect (UJ).

- Benzo[k]fluoranthene for SDG 0722260 exceeded QC limits, and detected compounds were qualified as estimated $(\mathrm{J})$, and nondetected compounds were qualified as estimated nondetect (UJ).

- Benzo[k]fluoranthene, dibenzo[ $a h]$ anthracene, and benzo[ghi]perylene forSDGs 0727260 and 0803260 were qualified as estimated $(\mathrm{J})$, and nondetected compounds were qualified as estimated nondetect (UJ). 
- Pyrene exceeded QC criteria in SDG 0828260, therefore, detected values of pyrene were qualified as estimated (J), and nondetected values were qualified estimated nondetects (UJ).

Laboratory Blanks. The laboratory experienced some laboratory blank contamination during the course of this project. The laboratory experienced a contamination problem in the samples of SDGs 0422260 and 0424260 . The laboratory had to dilute all the samples and QC samples by a factor of $1: 100$ and $1: 10$, respectively. Due to this problem, all the samples were estimated (J) for detected compounds and estimated nondetect (UJ) for nondetected compounds.

Sample concentrations of the analytes listed below that were greater than or equal to the maximum detection limit (MDL) but less than five times the highest concentration found in any blank were qualified as nondetected $(U)$. Sample concentrations of the analytes listed below that were found to be below the MDL were qualified as nondetected (U), while sample concentrations greater than five times the highest concentration found in any blank were not qualified.

- For SDG 0828260, acenapthalene, phenanthrene, fluoranthene, benzo[a]anthracene, chrysene, and indeno[123-cd]pyrene were found in the blank.

- For SDG 0924260/1002260/1009260, phenanthrene and fluoranthene were found in the laboratory blank.

- For SDG 1015260/1016260/1020260/1023260, fluorene was found in the laboratory blank.

- For SDG 1118260/1120260/1124260, phenanthrene, fluoranthene, and pyrene were found in the laboratory blank.

- For SDG 1204260/1209260/1211260, napthalene, phenanthrene, anthracene, fluoranthene, pyrene, benzo[ $a]$ anthracene, and benzo[ghi]fluoranthene were found in the laboratory blank.

- For SDG $1216260 / 1217260 / 1218260$, phenanthrene, pyrene, benzo[a]anthracene, benzo[ghi]perylene, and indeno[123-cd]pyrene were found in the blank.

- For SDG 1204260/1209260/121126, gross contamination of anthracene, pyrene, benzo[ $a]$ anthracene, and benzo[ghi]perylene was found in the laboratory blank. This gross contamination caused these analytes to be qualified unusable (R) in this SDG.

Surrogates. All surrogate recoveries were found within the QC criteria of 50 to $150 \%$ with the exception of the following:

- Surrogate recoveries were below $10 \%$ for SDG 0422260 , therefore, all positive results were qualified as estimated (J), and all nondetected compounds were qualified as estimated nondetect (UJ).

- Surrogate recoveries were reported outside the QC limits for all samples except sample 1099 of SDG 0424260. All results except for sample 1099 were qualified as NJ for detected compounds and UNJ for nondetected compounds. The $\mathrm{N}$ qualification was added because of the laboratory's inability to properly integrate the surrogate peak.

- Decafluorobiphenyl had a 0\% recovery for sample 1213 in SDG 0508260 , so all nondetects were rejected (R), and all positive results were estimated (J). 
- Decafluorobiphenyl had extremely high values for samples 1190 and 1201 of SDG 0508260 , so all positive results were estimated $(J)$ and all nondetects were estimated

$\therefore$ nondetects (UJ).

- All results for SDG 0511260 were qualified as J (detects) and UJ (nondetects) and nondetect results for sample 3099 were qualified unusable (R), because a surrogate recovery of $0 \%$ was reported.

- Surrogate recoveries were outside of QC limits for SDG 0514260 , so all positive results were estimated (J), and all nondetects were estimated nondetects (UJ).

- Surrogate recoveries were outside of QC limits for samples 3148 and 3168 of SDG 0519260 , so all positive results were estimated (J), and all nondetects were estimated nondetects (UJ).

- Surrogate recoveries were outside of QC limits for all samples of SDG 0523260 except samples $1293,1295,1300$, and 1301, so all positive results of the samples outside of QC limits were estimated (J), and all nondetects were estimated nondetects (UJ).

- Surrogate recoveries were outside of QC limits for samples 2039, 2143, 2130, and 2059 of SDG 0722260 , so all positive results were estimated (J), and all nondetects were estimated nondetects (UJ).

- All samples in SDG 0722260/0723260 exceeded the surrogate QC limits, therefore, all positive results of the samples outside of $Q C$ limits were estimated $(J)$, and all nondetects were estimated nondetects (UJ). Sample 2080 had a surrogate recovery below $10 \%$, so all positive results were estimated (J), and nondetects were rejected (R).

- Compounds quantitated off the fluorescence detector were qualified estimated for detected compounds and unusable (R) for nondetects for the following SDGs: $1204260 / 1209260 / 1211260$, 1216260/1217260/1218260 (with acenapthalene and indeno[123-cd]pyrene qualified as estimated for detects and estimated nondetects for nondetects in samples 1964, 1967, 1970, and 1973), 0924260/1002260/1009260, and 0828260 (samples 3223, 3227, 3229, 3231 and 3233-FD).

- For SDG 1015260/1016260/1020260/1023260, sample 1744 had surrogate recoveries of $322 \%$, so detects were qualified as estimated (J), and nondetects were not qualified. Samples 1738 and 1741 had no surrogate recovery, so detects were qualified as J and nondetects as $\mathrm{R}$.

- For SDG 0828260 , samples 3227 and 3229 had no recovery off the UV/Vis detector, so detects were qualified as J, and nondetects as R. Samples 3233-FD and 3235 had surrogate recoveries exceeding $150 \%$, so detects qualified as $\mathrm{J}$, and nondetects as UJ. Sample 3223 had a surrogate recovery less than $50 \%$ but greater than $10 \%$, so qualified detects as $\mathrm{J}$ and nondetects as UJ.

Matrix Spike/Matrix Spike Duplicates. Reported results were checked to ensure that they met the required QC criteria. MS and MSD data are not used to qualify data alone. All MS and MSD recoveries were within QC limits, with the exception of the following:

- SDGs 0422260 and 0424260 had $\cdot M S$ recoveries for naphthalene and acenaphthalene of $0 \%$.

- SDGs 0508260 and 0511260 had MS recoveries for naphthalene, acenaphthalene, phenanthrene, fluorene, and acenaphthene of $0 \%$. 
- SDG 0514260 had MS recoveries for fluorene of $0 \%$. Naphthalene was reported at twice the amount spiked.

- SDG 0523260 had MS recoveries for naphthalene, acenaphthalene, fluorene, and acenaphthene (MSD) of $0 \%$.

- All results for dibenzo[ah]anthracene and benzo[ghi]perylene of SDG 0722260 were rejected $(R)$ because these two compounds coelute.

- SDGs 0727260 and 0803260 had MS recoveries for anthracene and dibenzo[ah] anthracene (MS/MSD) of $0 \%$.

- SDG $1204260 / 1209260 / 1211260$ was grossly contaminated with pyrene and anthracene.

Laboratory Control Samples. All samples met requirements for LCS recoveries except for the following:

- An LCS was not provided in SDG 0422260, therefore, all the data was qualified as estimated (detects) and UJ (nondetects).

- The LCS for SDG 0424260 was diluted 1:10, indicating a problem. Because of this, samples in this SDG were estimated J (detects) or UJ (nondetects).

- Fluorene results for SDG 0511260 were estimated J (detects) or UJ (nondetects) because LCS recoveries for fluorene were outside QC limits (D-142\%).

- Acenaphthalene results for SDG 0523260 were estimated J (detects) or rejected R (nondetects) because a $0 \%$ LCS recovery was reported.

- SDG $1204260 / 1209260 / 1211260$ was grossly contaminated with pyrene and anthracene, so pyrene and anthracene were qualified as unusable (R).

Overall Assessment. There were three major problems identified with the PAHs: coelution, compound identification, and reporting of diluted and undiluted samples.

The conditions used by the laboratory for method 8310 resulted in coelution problems. Initially the laboratory was using decafluorobiphenyl as a surrogate, which coeluted with fluoranthene. The laboratory also experienced coelution problems with benzo[ $a]$ anthracene and chrysene under these conditions. A change of conditions took place after June 1, 1992, including a change of surrogates to 2-fluorobiphenyl. Coelution problems were resolved for the surrogate and fluoranthene and for benzo[a]anthracene and chrysene; however, this led to a coelution problem between benzo[ghi]perylene and dibenzo[ah]anthracene.

There were several identification problems with the PAHs. The laboratory's method of determining retention time windows and their criteria for determining whether a compound is within or outside the retention time window is not consistent. For samples experiencing this problem, the compounds were qualified as $\mathrm{N}$, because there was presumptive evidence of the compound.

The laboratory does not consistently perform dilutions when a compound exceeds the initial calibration linear range. When dilutions are performed, the laboratory reports both the diluted and undiluted samples on the same Form 1s. The laboratory was found to report sample results at the practical quantitation limit (PQL) even though a positive hit was found in the undiluted sample while it was not found in the diluted sample. The $N$ qualifier was 
again used in these cases, because the validator felt that there was presumptive evidence of a compound.

A summary of the PAH data validation results is presented in Table 4.4.

Table 4.4. Summary distribution of polynuclear aromatic hydrocarbon data validation results

\begin{tabular}{lccccccccccc}
\hline Compound & $\begin{array}{c}\text { No } \\
\text { Qual. }\end{array}$ & U & UJ & J & JN & R & RN & UN & UJN & SUM & $\begin{array}{c}\% \\
\text { usable }\end{array}$ \\
\hline Acenaphthene & & 12 & 28 & 27 & 5 & 48 & & & 11 & 131 & 63 \\
Acenaphthylene & 2 & 42 & 46 & 8 & & 19 & 2 & & 12 & 131 & 84 \\
Anthracene & 2 & 3 & 36 & 42 & 1 & 34 & 2 & & 11 & 131 & 73 \\
Benzo[a]anthracene & 2 & 3 & 12 & 65 & 5 & 34 & & & 10 & 131 & 74 \\
Benzo[a]pyrene & 2 & & 25 & 74 & 6 & 10 & & & 14 & 131 & 92 \\
Benzo[b]fluoranthene & 3 & 4 & 28 & 58 & 6 & 21 & & & 11 & 131 & 84 \\
Benzo[ghi]perylene & 4 & 1 & 24 & 51 & & 38 & 1 & & 12 & 131 & 70 \\
Benzo[k]fluoranthene & 2 & & 28 & 65 & & 19 & 1 & 1 & 15 & 131 & 85 \\
Chrysene & 2 & 12 & 24 & 21 & & 61 & 1 & & 10 & 131 & 53 \\
Dibenzo[ah]anthracene & & 6 & 26 & 29 & & 60 & & & 10 & 131 & 54 \\
Fluoranthene & 7 & & 8 & 55 & & 57 & 1 & & 3 & 131 & 56 \\
Fluorene & & 8 & 34 & 24 & 4 & 48 & 2 & & 11 & 131. & 62 \\
Indeno[123-cd]pyrene & 11 & 20 & 52 & 18 & & 18 & 2 & & 10 & 131 & 85 \\
Naphthalene & & 7 & 39 & 27 & & 46 & 1 & & 11 & 131 & 64 \\
Phenanthrene & 4 & & 23 & 76 & 11 & 4 & & & 13 & 131 & 97 \\
Pyrene & 6 & 1 & 20 & 67 & 1 & 16 & & & 20 & 131 & 88 \\
\hline
\end{tabular}

\subsubsection{Inorganic Data Validation Results}

The analysis of inorganic species was performed according to the USEPA Contract Laboratory Program Statement of Work for Inorganic Analysis, Multi-media, Multi -Concentration, August 1987. The analytes that are not governed under this statement of work were osmium and sulfate, which were done using a CLP-like SW-846 method with a QC protocol similar to CLP. There were 158 samples analyzed for all analytes listed in the BSCP work plan, except for the following. There were 157 samples analyzed for boron, lithium, and strontium. There were 159 samples analyzed for cadmium, 153 samples analyzed for chromium, 152 samples analyzed for cyanide, 139 samples analyzed for sodium, and 154 samples analyzed for sulfate. These data results are missing because of laboratory inconsistencies in data reporting. The low number of sodium samples is due to the laboratory inconsistently reporting an analyte that was not requested.

Holding Times. All holding times were within the specified times, except for the following:

- Mercury and sulfate were analyzed outside of their specified holding times for samples 5001, 5004, and 5007. Sample 5010 also had the holding time exceeded for sulfate. In addition, sample 3144 (water sample) had a pH of 5 upon receipt at the laboratory. The required $\mathrm{pH}$ under CLP is 2. 
- Soil samples 6046,6049 , and 6052 of SDG 0909260/0915260 exceeded the cyanide technical holding time of 14 days by 5 days. Cyanide results for these samples were qualified as "J" for detects and "UJ" for nondetects.

- Soil samples $6064,6067,6070,6073,6076$, and 6079 of SDG 1015260/1020260/1023260 exceeded the cyanide technical holding time of 14 days by 1 day. Cyanide results for these samples were qualified as " $J$ " for detects and "UJ" for nondetects.

- Soil samples 6082,6084 , and 6090 of SDG $1118260 / 1120260 / 1124260$ exceeded the cyanide technical holding time of 14 days by 5 days. Cyanide results for these samples were qualified as " $\mathrm{J}$ " for detects and "UJ" for nondetects.

- Soil samples 5205, 5208, and 5211 of SDG $1204260 / 1209260 / 1211260$ exceeded the cyanide technical holding time of 14 days by 3 days. Cyanide results for these samples were qualified as "J" for detects and "UJ" for nondetects.

Initial Calibration and Calibration Verification. The calibrations for the SDGs for graphite furnace atomic absorption met all the requirements, or the deviations did not warrant any action by the validator.

The calibration for ICP analyses met all requirements except for the following SDGs: $042260,0430260,0508260,0511260,0514260$, and 0519260 . The calibration for ICP analyses of these SDG did not comply with the CLP criteria or the manufacturers' criteria. In addition, there were three SDGs where the calibration did not comply for the ICP analytes of boron, lithium, osmium, and silicon. These three SDGs are 0722260, 0723260, and 0803260. In each case, the laboratory used the update function of the instrument instead of the calibration called for in the CLP statement of work. Also, an update slope function was used in conjunction with the update function. The update slope determines percent correction factors to be used by the instrument to "recalibrate" the instrument. This, too, is a deviation from CLP. The laboratory did not use the proper manufacturer's guidance in applying this correction. The laboratory allowed percent corrections to exceed manufacturer criteria for recalibration without performing a recalibration. The technical judgment was to not qualify the data as estimated ( $\mathrm{J}$ ) because of acceptable initial calibration verification (ICV) and continuing calibration verifications (CCVs), but it may be necessary to consider the added uncertainty for certain uses of the data, as well as regulatory and defensibility concerns.

The cyanide results were qualified estimated $(\mathrm{J})$ or estimated nondetect, because there was no evidence that the middle standard or ICV was distilled as specified by CLP.

The osmium CCV samples (CCV-3, $-4,-5$, and -6) for SDG 0722260/0723260 were outside the criteria at $110.9,113.0,112.1$, and 111.4 , respectively. This would qualify the osmium data as estimated ( $\mathrm{J}$ ), but the MS recovery finding supersedes this qualification because it qualifies the data as unusable (R).

Samples 5216 and 5217 of SDG 1204260/1209260/1211260 were assayed for lead and found to be over the calibration limit of the instrument. The samples were diluted and reanalyzed, but the dilution was not taken. into account when recalculating the dry concentration; thus, the results for lead were qualified as unusable (R).

(Note: The laboratory used SDG numbers for some of the data packages which were a combination of individual SDGs when they had to combine several SDGs for one analysis. 
The laboratory used slash marks to separate the combined SDGs from individual SDGs. This nomenclature was not carried through consistently in every case.)

Laboratory Blank Results. The analysis of laboratory blanks provides a means of assessing the existence of contamination in the analytical method. Blanks did not show evidence of significant contamination except for the analytes discussed below.

- For SDG 0422260, the level of selenium in the preparation blank was comparable to that found in some of the samples, so those samples were qualified as nondetect (U).

- Sample 6004 of SDG 0430260 was qualified as nondetect for lithium, because the sample result was less than five times the value of the associated $\mathrm{CCV}$.

- The lithium result for sample 6010 (SDG 0511260) was also qualified as nondetect, because the result was less than 5 times the associated CCV. In addition, calcium and selenium were qualified as nondetects, because the results of the preparation blank were comparable to the sample results.

- The preparation blanks for SDG 0514260 contained levels of calcium and thallium comparable to that found in the samples; therefore, these samples were qualified as nondetect.

- Thallium results for SDG 0519260 were qualified nondetect, because the preparation blank results were comparable to those found in the samples.

- Boron and silicon results for SDG 0727260/0728260/0729260 were qualified as estimated nondetects (UJ), because the continuing calibration blank (CCB) before or between which they were determined had values approaching the negative reporting limit and well beyond the negative instrument detection limit (IDL). Calcium results were qualified nondetect when the calcium sample results were less than 5 times the concentration in the preparation blank.

- Antimony data for SDG $0722260 / 0723260$ was qualified nondetect when sample results were less than 5 times the concentration found in the preparation blanks.

- The boron and silicon results in SDG 0803260 were qualified as estimated nondetected (UJ) and estimated (J), respectively. The bor̃on result was qualified estimated nondetected because the CCBs between which it was determined had values approaching the negative reporting limit and well beyond the negative IDL. Silicon results were qualified estimated (J), because the CCBs between which the sample was analyzed had values exceeding the negative reporting limit.

- Overall, the laboratory did not comply with the sample analysis order for CCBs and CCVs. The laboratory analyzed the $C C B$ before the $C C V$, which is against the specifications of the CLP statement of work. In addition, in some cases the laboratory analyzed a rinse blank before the CCB. By doing so, the evaluation of the CCBs does not provide information regarding carryover contamination.

- Boron results were above the IDL and above "negative" sample results; therefore, all boron results for SDG 0909260/0915260 were qualified as unusable (R).

- Lithium had an absolute value greater than IDL in SDG 1118260/1120260/1124260; all lithium data were qualified estimated (J).

- Copper results for samples $6055,5118,5127,5136,5145,6076$, and 6079 of SDGs $0909260 / 0915260$ and $1015260 / 1020260 / 1023260$ were qualified $U$, because the sample results were less than five times the blank result. 
- Cobalt results for samples 5094, 5097, 5104, 5115, 6061, 6058, 6052, 6049, 5121, 5124, $5130,5133,5139,6064,6076,6079$, and 6084 of SDGs $0909260 / 0915260,0924260 /$ $1002260 / 1009260,1015260 / 1020260 / 1023260$, and $1118260 / 1120260 / 1124260$ were qualified $U$ because the sample results were less than five times the blank result.

- $\quad$ Nickel results for samples $6061,6058,6055,6046,5118,5127,5130,5136,6076$, and 6079 of SDGs 0909260/0915260 and 1015260/1020260/1023260 were qualified U, because the sample results were less than five times the blank result.

- Strontium results for samples $5094,5097,5106,5115$, and 7057 of SDGs $0924260 /$ $1002260 / 1009260$ and $1204260 / 1209260 / 1211260$ were qualified $U$, because the sample results were less than five times the blank result.

- Chromium results for samples 1735 and 5145 of SDG 1015260/1020260/1023260 were qualified $U$, because the sample results were less than five times the blank result.

- Beryllium results for samples 5118, 5121, 5124, 5127, 5130, 5133, 5136, 5139, 5142, 5145, 5148,6076 , and 6079 of SDG $1015260 / 1020260 / 1023260$ were qualified $U$, because the sample results were less than five times the blank result.

- Sodium results for sample 5118 of SDG $1015260 / 1020260 / 1023260$ were qualified as U, because the sample results were less than five times the blank result.

- Calcium results for sample 5124 of SDG $1015260 / 1020260 / 1023260$ were qualified U, because the sample results were less than five times the blank result.

- Cadmium results for samples 5133 of SDG 1015260/1020260/1023260 were qualified U, because the sample results were less than five times the blank result.

- Potassium results for samples 5127, 5136, 5145, and 6076 of SDG 1015260/1020260/ 1023260 were qualified $U$, because the sample results were less than five times the blank result.

- All osmium results were qualified $U$, because of soil preparation blank results in SDG $1118260 / 1120260 / 1124260$.

- Nickel results for sample 7057 of SDG $1204260 / 1209260 / 1211260$ was qualified UJ, because the sample results were less than five times the blank result.

- All silicon results less than the IDL were qualified as estimated (J), due to consistently reported negative values in SDG 1216260/1217260/1218260.

Interference Check Sample. The analysis of an interference check sample (ICS) was to verify the interelement and background correction factors. All ICS results were acceptable except for the following:

- Vanadium was outside the criteria on both the initial and final ICS; therefore, all vanadium data was qualified estimated (J) in SDGs 0514260 and 0519260.

- Zinc consistently had results over the contact required detection limit (CRDL) when supposedly no analyte was present. Due to this, zinc results in all samples of SDG $1015260 / 1020260 / 1023260$ were qualified as estimated $(J)$ when the reported value was greater than the CRDL.

- Silicon and osmium were qualified as estimated (J) in all samples, due to an ICS recovery greater than $120 \%$ and because the results in all samples exceeded the IDL, with the exception of sample 6082 for osmium. The osmium result for sample 6082 was less than IDL; therefore, osmium for sample 6082 was qualified $U$ in SDG 1118260/1120260/ 1124260 . 
- Samples $6082,6084,6087$, and 6090 for potassium had results below the CRDL and were qualified as unusable (R), because the ICS was $-808 \mu \mathrm{g} / \mathrm{L}$ and the results were false

$\therefore$. negatives:in SDG 1.118260/1120260/1124260: $\cdots$

- Strontium, manganese, vanadium, zinc, and molybdenum all had results over the CRDL when supposedly no analyte was present. All strontium results were qualified $\mathrm{J}$ if over CRDL and UJ if under CRDL, due to the possibility of negative interference. All manganese, vanadium, zinc, and molybdenum results were qualified $J$ if over CRDL and UJ if under CRDL, due to the possibility of false positives in SDG 1204260/1209260/ 1211260.

- All potassium, silicon and boron results less than the IDL were qualified as estimated (J), due to consistently negative results that could be of greater magnitude than the IDL. All associated results for these analytes may be false negatives in SDG 1216260/1217260/ 1218260.

- All manganese, vanadium, zinc, and molybdenum results greater than the IDL were qualified as estimated, since the results were consistently greater than the IDL when no analytes were present, and all associated samples may be affected by false positives in SDG $1216260 / 1217260 / 1218260$.

Matrix Spikes. The spiking levels and analytes did not agree with CLP requirements, so it was difficult to apply CLP criteria for Phase I data. However, the laboratory did bring spiking levels to CLP requirements in analyzing Phase II samples. In addition, post-digestion spikes were also not performed as specified by CLP. The data was qualified because MS samples were outside criteria, as follows.

- Magnesium and potassium .results for SDG 0422260 were qualified estimated (J). Osmium results were qualified as estimated nondetects, because the predigestion spike was outside criteria.

- The results for SDGs 0422260 and $0430260 / 0508260 / 0511260$ for silicon were qualified as estimated (J), because the spike recovery was below the lower limit.

- Osmium results for SDGs 0430260,0508260 , and 0511260 were qualified as estimated nondetect, because predigestion spike was outside criteria.

- Silver results for SDG 0727260/0728260/0729260 were qualified as estimated nondetected (UJ), because of low predigestion spike recoveries. Silicon was qualified as estimated (J), because of low recoveries, while osmium results were rejected $(R)$ because of very low recoveries.

- Antimony and silver results for SDG 0722260/0723260 were qualified as estimated nondetected (UJ), because spike recovery was low. Magnesium and potassium results were qualified estimated (J), because the predigestion spike results were outside criteria, greater than $125 \%$. All osmium results were rejected (R), because the spike recovery was outside criteria at $2.2 \%$ (criteria 75 to $125 \%$ ).

- Silicon and cadmium results for SDG 0803260 were qualified estimated (J) because of low spike recoveries. Sulfate was qualified as estimated (J) because the postdigestion spike recovery was very low.

- All osmium results for SDGs 0909260/0915260 and 0924260/1002260/1009260 were qualified as unusable $(\mathrm{R})$ due to $0 \%$ spike recovery. 
- All silicon results for SDGs $0909260 / 0915260$ and $0924260 / 1002260 / 1009260$ were qualified as unusable $(R)$ because spike recovery was reported $<0 \%$.

- Lead results for samples 6052 and 6061 were qualified as estimated (J) due to spike recoveries outside the established range of 85 to $115 \%$ for SDG $0909260 / 0915260$.

- All cadmium results for SDG 0909260/0915260 reported above the CRDL were qualified as estimated (J) due to spike recovery out of acceptable limits.

- All manganese results above the CRDL for SDG 0924260/1002260/1009260 were qualified as estimated $(\mathrm{J})$ due to spike recovery out of acceptable limits.

- All antimony and mercury results greater than the CRDL were qualified estimated (J) due to the spike recoveries out of acceptable criteria in SDG 1015260/1020260/1023260.

- All silicon results reported as detected were qualified estimated (J) and nondetects qualified (UJ) due to the spike recovery out of acceptable criteria in SDG 1015260/ $1020260 / 1023260$.

- Cadmium samples 6070 and 5151 of SDG $1015260 / 1020260 / 1023260$ were qualified as estimated (UJ for nondetects) due to high postdigestion spike recovery.

- Selenium samples 5124, 5127, 5136, 5139, 5142, 5145, 5148, and 5151 of SDG 1015260/ $1020260 / 1023260$ were qualified as estimated ( $\mathrm{J}$ for detects and UJ for nondetects) due to low postdigestion spike recovery.

- All results for arsenic and lead less than the IDL were not qualified; however, due to the MS recovery exceeding criteria, all results for arsenic and lead above the IDL were qualified estimated (J) in SDG 1118260/1120260/1124260.

- All results for antimony, cadmium, manganese, and cyanide were qualified $J$ if over CRDL and UJ if under CRDL, due to low MS recoveries in SDG 1118260/1120260/ 1124260.

- All results for barium, lithium, molybdenum, silicon, strontium, and osmium were qualified as unusable (R) due to the lack of a predigestion spike in SDG 1118260/ $1120260 / 1124260$.

- All results for antimony and silicon were qualified J if over CRDL and UJ if under CRDL, due to low MS recoveries in SDG 1204260/1209260/1211260.

- All results for osmium were qualified as unusable (R), due to MS recovery near zero in SDG 1204260/1209260/1211260.

- Arsenic results were qualified estimated (J), due to poor MS recovery and omission of method of standard additions for this analyte in SDG 1204260/1209260/1211260.

- All antimony results were qualified as UJ if less than the CRDL due to low spike recovery in SDG 1216260/1217260/1218260.

- All lead results were qualified as estimated (J) if greater than the CRDL, due to high spike recovery in SDG 1216260/1217260/1218260.

- All osmium results were qualified as unusable (R) due to spike recovery of approximately zero in SDG 1216260/1217260/1218260.

- Arsenic results for samples 7066, 7072, and 7075 (SDG 1216260/1217260/1218260) were qualified as estimated $(\mathrm{J})$ due to spike recovery outside control limits.

- Selenium results for samples 5240 and 5268 (SDG 1216260/1217260/1218260) were qualified as estimated $(\mathrm{J})$, due to spike recovery outside control limits. 
- Thallium results for sample 5241 (SDG $1216260 / 1217260 / 1218260$ ) were qualified as estimated (J) due to spike recovery outside control limits.

- Lead resúlts for samples 7078 and 7081 (SDG 1216260/1217260/1218260) wère qualified as estimated (J) due to spike recovery outside control limits.

Duplicates. All laboratory duplicates were within the QC limits, except for the following:

- Copper, iron, boron, and sulfate results for SDGs 0422260, 0430260, 0508260, and 0511260 were qualified as estimated (J), because the duplicate results exceeded criteria.

- Chromium results for SDG 0803260 were qualified estimated (J), because the duplicate results exceeded criteria.

- All results for chromium, iron, vanadium, and sulfate were qualified as estimated (J) for SDG 0909260/0915260, due to the RPD exceeding criteria in the soil duplicates.

- All results for arsenic, iron, manganese, selenium, and vanadium were qualified as estimated (J) for SDG 0924260/1002260/1009260, due to the RPD exceeding criteria in the soil duplicates.

- Chromium and zinc soil analysis results were qualified as estimated (J), due to duplicate spike recoveries exceeding the maximum RPD for soils in SDG 1118260/1120260/ 1124260.

Laboratory Control Samples. An aqueous LCS was used. The CLP statement of work specifies that a solid LCS be used when analyzing solid samples. The results from the aqueous LCS may not be indicative of analyte recovery, making the evaluation difficult. Aqueous control samples are being used with more frequency becuase of the difficulty in finding comparable matrix material. Sand or pure silica has been used by some laboratories, but it still does not provide the matrix related effects.

Osmium results in SDGs $042260,0430260,0508260$, and 0511260 were qualified estimated (J) or estimated nondetected (UJ), because LCS recoveries were outside of criteria. Osmium results for SDGs 0514260,0519260 , and 0803260 were rejected $(\mathrm{R})$ because of very poor recovery.

All results for cadmium greater than the IDL were qualified as estimated (J), because the LCS recovery was outside criteria in SDG 0909260/0915260.

All results for osmium were qualified as unusable (R), because the LCS recovery was outside criteria in SDG 1015260/1020260/1023260.

The aqueous LCS was not spiked with osmium according to the case narrative accompanying package 1118260/1120260/1124260; therefore, the results for aqueous samples were qualified $\mathrm{UJ}$ for nondetects and $\mathrm{J}$ for detects.

Method of Standard Additions. The method of standard additions (MSA) was performed on the following samples. Lead samples 5031, 5034, 5040, 6028, 6034, 6040, 5079, 5088, 1468, and 1468D had MSAs performed with no problems, except that the spiking levels used in sample 5079 and 5088 were not adapted well to the concentration of the samples. Chromium samples 7034, 7037-FD, 7040-FD, 7043-FD, and 1468 had MSAs performed with no problems. 
Serial Dilutions. The serial dilution results for SDG $0422260 / 0430260 / 0508260 / 0511260$ for silicon exceeded the acceptance criteria; therefore, all silicon data was qualified as estimated (J).

Silicon results for SDG 0727260/0728260/0729260 were qualified estimated (J) because the serial dilution exceeded acceptance criteria.

Silicon and zinc serial dilution results exceeded acceptance criteria for SDG 0803260.

Chromium and lead for SDG 1015260/1020260/1023260 did not meet the percent difference requirements; therefore, all associated chromium and lead data were qualified as estimated (J).

The percent difference for zinc was reported in excess of $10 \%$ with a concentration of fifty times the CRDL. Data were qualified $\mathrm{J}$ if results were over CRDL and UJ if under CRDL in SDG 1204260/1209260/1211260.

Results for chromium, lead, and zinc were qualified as estimated (J), because they exceeded limits for ICP serial dilution.

Other Laboratory $Q C$. Accompanying the soil samples were equipment water rinsates. The equipment rinsates for samples collected during Phase I were taken after the completion of sampling, whereas potential contamination of samples is normally identified from rinsates taken before samples are collected. Association of rinsates with particular samples was not identified, so specific qualification of data could not be performed.

- SDG 0422260: Antimony analytical spike recoveries were below limits, so those results were qualified as estimated (J).

- SDG 0430260: Antimony graphite furnace atomic absorption (GFAA) analytical spike recovery is based on a spike concentration of $20 \mathrm{mg} / \mathrm{L}$. The laboratory qualified sample 6001 with a "W"; all antimony results should have been so qualified, since the values of the analytical spike ranged from 73 to $80 \%$. On this basis, all antimony results were qualified as estimated nondetects.

- SDG 0508260: Antimony GFAA results for sample 5019, 5022, and 5010 were qualified as estimated nondetected because the analytical spike recovery was low.

- SDG 0519260: Antimony GFAA results were qualified as estimated nondetected (UJ) because of low analytical spike recoveries.

- SDG 0727260/0728260/0729260: The arsenic results for sample 5070 was qualified estimated nondetected (UJ), because the analytical spike results exceeded limits.

- SDG 0722260/0723260: Antimony GFAA results were qualified as estimated nondetected (UJ) because of low recoveries for the analytical spike.

Overall Assessment. There were numerous deviations from CLP protocol that could affect data comparability and create increased uncertainty in the quality of the data. Some of the deviations were

- calibration of the Leeman ICP did not follow CLP or manufacturer's instructions; 
- $\quad$ spiking levels for matrix spikes, postdigestion spikes, and GFAA analytical spikes were inconsistent with CLP, and the analytes in the matrix spike were not in agreement with

- the CLP;

- preparation volumes were noncompliant;

- the laboratory analyzed postdigestion spikes when they were not called for;

- matrix spikes for GFAA were analyzed with an analytical spike added, which is not called for in CLP;

- reanalysis when the blank exceeded the absolute value of the CRDL or reporting limit was not performed; and

- aqueous rather than solid LCSs were analyzed with soil samples.

A summary of the inorganic data validation results is presented in Table 4.5.

Table 4.5. Summary distribution of inorganic data validation results

\begin{tabular}{|c|c|c|c|c|c|c|c|c|}
\hline Compound & No qualifier & $\mathrm{B}^{*}$ & $\mathrm{U}$ & UJ & $\mathrm{J}$ & $\mathbf{R}$ & SUM & \% usable \\
\hline Aluminum & 150 & 3 & 5 & 0 & 0 & 0 & 158 & 100 \\
\hline Antimony & 1 & 9 & 68 & 76 & 4 & 0 & 158 & 100 \\
\hline Arsenic & 85 & 23 & 12 & 2 & 36 & 0 & 158 & 100 \\
\hline Barium & 115 & 34 & 9 & 0 & 0 & 0 & 158 & 100 \\
\hline Beryllium & 32 & 104 & 22 & 0 & 0 & 0 & 158 & 100 \\
\hline Boron & 12 & 5 & 79 & 33 & 13 & 15 & 157 & 90 \\
\hline Cadmium & 1 & 0 & 142 & 13 & 2 & 1 & 159 & 99 \\
\hline Calcium & 45 & 84 & 29 & 0 & 0 & 0 & 158 & 100 \\
\hline Chromium & 79 & 0 & 10 & 1 & 63 & 0 & 153 & 100 \\
\hline Cobalt & 73 & 47 & 26 & 3 & 9 & 0 & 158 & 100 \\
\hline Copper & 121 & 3 & 18 & 0 & 16 & 0 & 158 & 100 \\
\hline Cyanide & 4 & 0 & 19 & 105 & 12 & 12 & 152 & 92 \\
\hline Iron & 104 & 2 & 4 & 0 & 48 & 0 & 158 & 100 \\
\hline Lead & 106 & 15 & 10 & 1 & 24 & 2 & 158 & 99 \\
\hline Lithium & 61 & 57 & 21 & 0 & 8 & 10 & 157 & 94 \\
\hline Magnesium & 66 & 65 & 9 & 0 & 18 & 0 & 158 & 100 \\
\hline Manganese & 94 & 3 & 6 & 0 & 55 & 0 & 158 & 100 \\
\hline Mercury & 74 & 1 & 65 & 0 & 18 & 0 & 158 & 100 \\
\hline Molybdenum & 1 & 26 & 118 & 0 & 3 & 10 & 158 & 94 \\
\hline Nickel & 117 & 10 & 31 & 0 & 0 & 0 & 158 & 100 \\
\hline Osmium & 0 & 0 & 3 & 18 & 0 & 136 & 157 & 13 \\
\hline Potassium & 72 & 39 & 13 & 6 & 23 & 5 & 158 & 98 \\
\hline Selenium & 3 & 46 & 13 & 6 & 80 & 10 & 158 & 94 \\
\hline Silicon & 49 & 0 & 2 & 2 & 80 & 25 & 158 & 84 \\
\hline Silver & 1 & 0 & 130 & 27 & 0 & 0 & 158 & 100 \\
\hline Sodium & 42 & 89 & 8 & 0 & 0 & 0 & 139 & 100 \\
\hline Strontium & 59 & 45 & 25 & 0 & 18 & 10 & 157 & 94 \\
\hline Sulfate & 125 & 2 & 7 & 0 & 20 & 0 & 154 & 100 \\
\hline Thallium & 1 & 16 & 127 & 2 & 0 & 12 & 158 & 92 \\
\hline Vanadium & 64 & 1 & 9 & 0 & 84 & 0 & 158 & 100 \\
\hline Zinc & 73 & 4 & 3 & 1 & 77 & 0 & 158 & 100 \\
\hline
\end{tabular}

"Qualifier B is a laboratory data qualifier defined in the preface to Volume 2. 


\subsubsection{Radiochemical Data Validation Results}

Iodine-129 was initially considered as an analyte of concern, but the unavailability of qualified laboratories capable of analyzing for this radionuclide caused the project team to drop it from the analyte list.

\subsubsection{Thorium isotopic validation results}

One hundred fifty samples were analyzed for isotopic thorium by the alpha spectrometry technique.

Holding times. The holding times for isotopic thorium were met.

Calibration. The laboratory was unable to provide information on the standard used for the initial energy and efficiency calibration. The laboratory included the daily full-width half maximum information, centroid information, and efficiency information. Background information pertaining to these samples was acceptable, except for SDGs 21262, 21232, 21123, $21058,21081,21383,21328,21377$, and 30044 . Either the background information was not provided at all or it was not provided for the detectors of interest. Without the correct information, the data must be qualified estimated $(J)$ for results greater than minimum detectable activity (MDA) and (UJ) for results less than MDA

Incorrect monthly calibration information was provided for SDGs $2658,2419,2423$, 21262, 21232, 21299, 21345, 21247, 2878, 21081, 21383, 2847, 21169, 2924, 21328, and 21377. The information that they provided was not for the detectors of interest. Also, no monthly calibration was provided for SDGs $21046,2970,21034,21123,21003,21058,21205$, and 30044. Without the correct information, the data must be qualified estimated (J) for results greater than the MDA and (UJ) for results less than MDA.

The laboratory did not provide daily calibration information for SDGs $2633,2638,21383$, 21169 , and $21345-10,11$, so it is impossible to determine the behavior of the instrument on the day of the analysis. All results greater than MDA were qualified as (J), and all results less than MDA were qualified as (UJ).

Laboratory blank results. All laboratory blank results were either less than the MDA or the lowest sample activity was 5 times greater than the blank activity and deemed acceptable.

Tracer results. Thorium-229 was used as the tracer for this analysis. All tracer recoveries were within the QC limits ( 15 to 125\%), except for SDGs 2419, 2423, and 2633. These SDGs were qualified estimated $(J)$ for results greater than MDA and unusable (R) for results less than MDA. An outdated tracer solution was used for Phase $I$, and all results greater than MDA were estimated (J), and all results less than MDA were rejected (R) for SDGs.

Matrix spike/matrix spike duplicates. Thorium-230 was the spike used in the MS/MSD. All MS/MSD results were within the QC limits (75-125\%), except for SDGs 21262 and 21232. RPDs between the MS/MSD were all within QC limits ( $\leq 50 \%$ maximum).

Duplicates. The RPD acceptance criterion was $\pm 35 \%$ for samples with values greater than or equal to 5 times the MDA. All duplicate results met this criterion. 
Blank Spike. The spike was thorium-230. All blank spike results were within QC limits (75-125\%).

Chemical separation specificity. No energy spectra or library matches were provided to check the chemical separation specificity of the isotope. All results were qualified as estimated (J) for results greater than the MDA and (UJ) for results less than MDA.

Overall assessment. All the data were estimated (J) or (UJ) because the laboratory was unable to provide information on the standard used for the initial energy and efficiency calibration, an outdated tracer was used, and no energy spectra and library matches were provided to assess the chemical separation specificity. Also, there was a failure to run a daily calibration on SDGs 21383, 21169, 21345-10,11.

\subsubsection{Uranium isotopic validation results}

One hundred forty-eight samples were analyzed for isotopic uranium by the alpha spectrometry technique.

Holding times. The holding times for isotopic uranium were met.

Calibration. Sample 6038 of SDG 2423 was qualified estimated (J) for results greater than MDA and estimated nondetect (UJ) for results less than MDA. The laboratory was unable to provide information on the standard used for the initial energy and efficiency calibration. The laboratory included the daily full-width half maximum information, centroid information, and efficiency information. Background information pertaining to these samples was acceptable, except for SDGs 21383, 21046, 2970, 21003, 21034, 21366, 21081, 21377, and 21377. Either the background information was not provided or it was not provided for the detectors of interest. Without the correct information, the data must be qualified estimated (J) for results greater than MDA and (UJ) for results less than MDA.

Incorrect monthly calibration information was provided for SDGs 21123, 21299, 21247, 21328,21377 , and 21169 . The information that they provided was not for the detectors of interest. Also, no monthly calibration was provided for SDGs 21383, 2924, 21046, 2970, 21003, $21058,21205,2847,21345,2878,21034,21366,21081,30044,21262$, and 21232. Without the correct information, the data must be qualified estimated $(J)$ for results greater than the MDA and (UJ) for results less than MDA.

The laboratory did not provide daily calibration information for SDGs 21046, 21034, 30044 , and 21383-06A, so it is impossible to determine the behavior of the instrument on the day of the analysis. All results greater than MDA were qualified as (J), and all results less than MDA were qualified as (UJ).

Laboratory blank results. All laboratory blank results were either less than the MDA or the lowest sample activity was 5 times greater than the blank activity and deemed acceptable. There were no detected activities found above the MDA, except for SDGs 2391 and 2658.

- Uranium-238 was found in the laboratory blank of SDG 2391 above the MDA, but it was less than $10 \%$ of the sample activity. 
- Uranium-234, -235 , and -238 were found in the laboratory blank of SDG 2658 above the MDA. All the samples had positive results greater than the MDA, but less than 5 times the blank value. Therefore, all results less than 5 times the blank were qualified $U$.

Tracer results. All tracer recoveries were within the QC limits (15-125\%), except for sample 6038 of SDG 2423, which had tracer recoveries below the QC limits. Results above the MDA were qualified $\mathrm{J}$, and results below the MDA were rejected (R).

Matrix spike/matrix spike duplicates. All MS/MSSD recoveries were within the QC limits (75-125\%), with the exception of SDGs 2419, 2423, 2878, and 2847. RPDs between the MS/MSD were all within QC limits ( $\leq 50 \%$ maximum).

Duplicates. The RPD acceptance criterion was $\pm 35 \%$ for samples with values greater than or equal to 5 times the MDA All duplicate RPDs were within QC limits, except for uranium-235 of SDGs 2684, 2970, 21046, 2847, 21003, 21058, 21205, and 2924. All data associated with these SDGs were qualified $(J)$ for results greater than the MDA.

Blank Spike. All the blank spike results were within QC limits (75-125\%), with the exception of SDGs 21046, 21034, and 2924.

Chemical separation specificity. No energy spectra or library matches were provided to check the chemical separation specificity of the isotope. All results were qualified as estimated (J) for results greater than the MDA and (UJ) for results less than MDA.

Overall assessment. All the data was estimated (J) or (UJ) because the laboratory was unable to provide information on the standard used for the initial energy and efficiency calibration and no energy spectra and library matches were provided to assess the chemical separation specificity. Also, there was a failure to run a daily calibration on SDGs 21046, 21034, 30044, and 21383-06A. Samples in SDG 2423 were qualified estimated $(J)$ because of the failure of the MS to meet acceptance criteria.

\subsubsection{Plutonium isotopic validation results}

Sixty-three samples were analyzed for plutonium-238 and 56 samples for plutonium-239/240 by the alpha spectrometry technique.

Holding times. The holding times for isotopic plutonium were met.

Calibration. The laboratory was unable to provide information on the standard used for the initial energy and efficiency calibration. The laboratory included the daily full-width half maximum information, centroid information, and efficiency information. Background information pertaining to these samples was acceptable, except for SDGs 21232, 21003, 21299, 21366, 2970, 2847, and 21046. Sample 5029 of SDG 2419 was qualified estimated (J) for results greater than $\mathrm{MDA}$ and UJ for results less than MDA because no background information was provided. Data in SDG 2633 was qualified $J$ for results greater than MDA and UJ for results less than MDA, because daily calibration information was not provided, so it was impossible to determine instrument behavior at the time of analysis. 
Incorrect monthly calibration information was provided for SDGs $21169,30044,21377$, and 2847. The information that they provided was not for the detectors of interest. Also, no monthly calibration was provided for SDGs 21081, 21232, 2924, 21328, 21383, 21058, 21003, $21123,21345,21299,21366,2970,2847,21034$, and 21046. Without the correct information, the data must be qualified estimated (J) for results greater than the MDA and (UJ) for results less than MDA.

The laboratory did not provide daily calibration information for SDGs 21232,2970 , and 21046, so it is impossible to determine the behavior of the instrument on the day of the analysis. All results greater than MDA were qualified as (J), and all results less than MDA were qualified as (UJ).

Laboratory blank results. All laboratory blank results were either less than the MDA or the lowest sample activity was 5 times greater than the blank activity and deemed acceptable.

Tracer results. All tracer recoveries were within the QC limits (15-125\%), with the exception of SDGs 2684 and 2391 and 2878. The data in SDGs 2684 and 2391 was J for results above the MDA and $\mathrm{R}$ for results less than MDA because of the use of an outdated tracer solution. The tracer could not be recovered in samples of SDG 2878.

Matrix spike/matrix spike duplicates. All MS/MSD recoveries were within the QC limits (75-125\%). RPDs between the MS/MSD were all within QC limits ( $\leq 50 \%$ maximum).

Duplicates. The RPD acceptance criterion was $\pm 35 \%$ for samples with values greater than or equal to 5 times the MDA All duplicate RPDs were within QC limits ( $\leq 50 \%$ maximum), except for SDGs 21058, 21081, and 2924, which had several isotopes (Pu-238 and Pu-239/240) outside QC limits. Also, the following SDGs had just Pu-238 RPD outside QC limits: 2970, $21366,21299,21345,21003,21262,21383,21328,21232,21377,30044$, and 21169. SDG 21123 and SDG 2878 had only Pu-239/240 outside QC limits. All data associated with these SDGs were qualified $(J)$ for results greater than the MDA.

Blank Spike. All the blank spike results were within QC limits (75-125\%), with the exception of SDG 2878, for which a blank spike could not be calculated, because the tracer activity could not be recovered. Samples in this SDG were qualified unusable (R).

Chemical separation specificity. No energy spectra or library matches were provided to check the chemical separation specificity of the isotope. The preparation notes mention the presence of iron hydroxide precipitate at the time of plating, suggesting the presence of uranium, which would interfere with the plutonium. All results were qualified as estimated (J) for results greater than the MDA and (UJ) for results less than MDA.

Overall assessment. All the data were estimated (J) or (UJ) [with the exception of the samples in SDGs 2684,2391 , and 2878, which were qualified (R)], because the laboratory was unable to provide information on the standard used for the initial energy and efficiency calibration and no energy spectra and library matches were provided to assess the chemical separation specificity. Also, no daily calibration was run on SDGs 21232, 2970, and 21046.

Plutonium-239/240 are isotopes that are analyzed by alpha spectrometry. In this procedure, the $\mathrm{Pu}-239 / 240$ isotopes are not separated out by this method. Therefore, these two isotopes should be reported as one. However, during the Phase I analyses of Pu-239/240, the 
laboratory reported some samples individually. There were $7 \mathrm{Pu}-239$ samples and $6 \mathrm{Pu}-240$ samples reported in this way. The reasons for this are not clear, so caution must be used when using these data.

\subsubsection{Neptunium-237 validation results}

Sixty-four samples were analyzed for neptunium-237 by alpha spectrometry technique.

Holding Times. All technical holding times were met.

Calibration. The tracer (neptunium-239) for this analysis was run by gas proportional counter, and determination of neptunium-237 was done by alpha spectrometry; therefore, calibration information was needed for each instrument. The laboratory was unable to provide information on the standard used for the initial energy and efficiency calibration. The laboratory included the daily full-width half maximum information, centroid information, and efficiency information. Background information on these samples was acceptable, except for SDGs 21262 and 21232. Either the background information was not provided or it was not provided for the detectors of interest. Without the correct information, the data must be qualified estimated (J) for results greater than MDA and (UJ) for results less than MDA.

Incorrect monthly calibration information was provided for SDGs $21299,21169,21123$, $21345,30044,21377,2924,21328$, and 21383 . The information provided was not for the detectors of interest. Also, no monthly calibration was provided for SDGs 21262, 21232, $21081,21034,21003,21366,21046$, and 2970 . Without the correct information, the data must be qualified estimated $(J)$ for results greater than MDA and (UJ) for results less than MDA.

The laboratory did not provide daily calibration information for SDGs 21123,21345 , and 21299, so it is impossible to determine the behavior of the instrument on the day of the analysis. All results greater than MDA were qualified as (J), and all results less than MDA were qualified as (UJ).

Calibration information for the gas proportional counter contained self-absorption curves with all raw data and the beta plateau curves. The crosstalk information was present, but raw data counts were not provided. Gas proportional counter calibration met all criteria.

Laboratory blank results. All laboratory blank results were less than the MDA, except for SDGs 21262 and 21232. Blank activities exceeded the MDA; therefore, possible blank contamination exists, and all data above the MDA were estimated (J). No laboratory blank data was provided for SDG 2684, so all data above the MDA was $\mathrm{J}$.

Tracer results. All tracer recoveries were within the QC limits (15-125\%).

Matrix spike/matrix spike duplicate. MS/MSD recoveries were within the QC limits (75-125\%) for SDGs 2391, 21232, 21262, and 21169, but all other SDGs were outside QC limits. The laboratory used an incorrect activity value, which changed their MS/MSD results. The data were qualified estimated $(\mathrm{J})$ for results greater than the MDA because of the failure to meet QC criteria.

Duplicates. The RPD acceptance criterion was $\pm 35 \%$ for samples with values greater than or equal to 5 times the MDA. All duplicate RPDs were within QC limits of ( $\leq 50 \%$ 
maximum) except for SDGs 21299, 21345, 21058, 21034, 2878, 21081, 21383, 21328, 2924, 21377,30044 , and 2847. All data associated with these SDGs were qualified (J) for results greater than the MDA.

Blank spike results. All blank spike recoveries were within QC limits (75-125\%) except for SDGs 2970, 21046, 21366, 21299, 21345, 21003, 21058, 21034, 2878, 21081, 21383, 21328, $2924,21377,30044$, and 2847. All results greater than the MDA were qualified estimated (J), while all results less than the MDA were rejected $(R)$. There were six results less than the MDA that should have been rejected, but professional judgment was used to determine that only one of the six should be rejected (R). The other results had blank spike recoveries above $70 \%$. The sample that was rejected was 6074 of SDG 21034.

Chemical separation specificity. No energy spectra or library matches were provided to check the chemical separation specificity of the isotope. All results were qualified as estimated (J) for results greater than the MDA and (UJ) for results less than MDA.

Overall assessment. All the data were estimated (J) or (UJ) [with the exception of the sample in SDG 21034, which was qualified (R)], because the laboratory was unable to provide information on the standard used for the initial energy and efficiency calibration and no energy spectra and library matches were provided to assess the chemical separation specificity. Also, there was a failure to run a daily calibration on SDGs 21123, 21345, and 21299. Data in SDGs 2419 and 2391 were rejected, because there was no self-absorption information to assess calibration.

\subsubsection{Curium-244 validation results}

Sixty-one samples were analyzed for curium-244 by alpha spectrometry technique.

Holding times. All technical holding times were met for curium-244.

Calibration. The laboratory was unable to provide information on the standard used for the initial energy and efficiency calibration. The laboratory included the daily full-width half maximum information, centroid information, and efficiency information. Background information pertaining to these samples was acceptable except for SDG 2847. Either the background information was not provided or it was not provided for the detectors of interest. Without the correct information, the data must be qualified estimated (J) for results greater than MDA and (UJ) for results less than MDA.

Incorrect monthly calibration information was provided for SDGs $21366,21299,21345$, $21328,21377,30044$, and 2847 . The information that they provided was not for the detectors of interest. Also, no monthly calibration was provided for SDG 21383. Without the correct information, the data must be qualified estimated (J) for results greater than the MDA and (UJ) for results less than MDA.

The laboratory did not provide daily calibration information for SDGs 21366, 21299, $21345,21383,21328,21377,30044$, and 2847 , so it is impossible to determine the behavior of the instrument on the day of the analysis. All results greater than MDA were qualified as (J), and all results less than MDA were qualified as (UJ). 
Laboratory blank results. All laboratory blank results were either less than the MDA or the lowest sample activity was 5 times greater than the blank activity and deemed acceptable.

Tracer results. All tracer recoveries were within the QC limits (15-125\%).

Matrix spike/matrix spike duplicate. MS/MSD recoveries were all within the QC limits (75-125\%) except for SDGs 21046, 21123, 21003, 21058, 21034, 2878, 21081, 2924, 21169, 21262,21232 , and 2970 . There was no recovery of the duplicate sample or the unspiked sample. Therefore, neither a duplicate nor a matrix spike could be calculated. All of these SDGs with no recovery were qualified as unusable (R).

Duplicates. The RPD acceptance criterion was $\pm 35 \%$ for samples with values greater than or equal to 5 times the MDA. All duplicate RPDs were within QC limits of ( $\leq 50 \%$ maximum) except for SDGs 21046, 21123, 21003, 21058, 21034, 2878, 21081, 2924, 21169, 21262,21232 , and 2970 . There was no recovery of the duplicate sample or the unspiked sample. Therefore, neither a duplicate nor a matrix spike could be calculated. All of these SDGs with no recovery were qualified as unusable (R).

Blank spike results. All blank spike recoveries were within QC limits (75-125\%).

Chemical separation specificity. No energy spectra or library matches were provided to check the chemical separation specificity of the isotope. All results were qualified as estimated (J) for results greater than the MDA and (UJ) for results less than MDA.

Overall assessment. The data were estimated (J) or (UJ) because the laboratory was unable to provide information on the standard used for the initial energy and efficiency calibration, and no energy spectra and library matches were provided to assess the chemical separation specificity. Also, there was a failure to run a daily calibration on SDGs 21366, 21299, 21345, $21383,21328,21377,30044$; and 2847. The following SDGs were all qualified unusable (R), because there was no recovery of the duplicate sample or the unspiked sample. Therefore, neither a duplicate nor a matrix spike could be calculated SDGs 21046, 21123, 21003, 21058, 21034, 2878, 21081, 2924, 21169, 21262, 21232, and 2970.

\subsubsection{Strontium-90 validation results}

Fifty-four samples were analyzed for strontium-90 by gas flow proportional counting.

Holding times. All technical holding times were met for strontium-90.

Calibration. All calibration criteria were met for strontium-90.

Laboratory blank results. There were no detected activities found above the MDA.

Matrix spike/matrix spike duplicates. All MS/MSD recoveries were within the QC limits (75-125\%) with the exception of SDGs $2633,2638,2658,21046$, and 21034, which had MS recoveries below the QC limits.

Duplicates. The RPD acceptance criterion was $\pm 35 \%$ for samples with values greater than or equal to 5 times the MDA. All duplicate results met this criterion except for SDGs 21299 and 21328 . 
Blank spike results. All blank spike recoveries were within the QC limits (75-125\%) except for SDGs 21058 and 21081.

Overall Assessment. The data for strontium-90 were qualified as usable. All detects had no qualifiers and all nondetects had $(\mathrm{U})$ qualifiers.

\subsubsection{Gamma spectrometry validation results}

One hundred forty-eight samples were analyzed by gamma spectrometry.

Holding times. All technical holding times were met.

Calibration. All calibration criteria were met for all samples and were within the upper and lower ranges.

Laboratory blank results. No analytical laboratory blank samples were analyzed.

Duplicates. The RPD acceptance criterion was $\pm 35 \%$ for samples with values greater than or equal to 5 times the MDA. All duplicate RPDs were within QC limits of ( $\leq 50 \%$ maximum) except for SDGs 2419, 2423, 21345 and 21247, which had RPD results outside the QC limits.

Overall Assessment. The data were qualified as usable for all analytes except europium-155. All detects had no qualifiers and all nondetects had estimated $(U)$ qualifiers. Europium-155 data were qualified unusable $(R)$ because the laboratory incorrectly identified a thorium $x$-ray line as europium- 155 .

\subsubsection{Total uranium validation results}

Sixty-one samples were analyzed for total uranium by pulsed laser phosphorimetry. This technique provided results on a mass basis, which the laboratory converted to activity by multiplying by an activity conversion factor $(0.679 \mathrm{pCi} / \mu \mathrm{g})$. This conversion factor was based on the specific activities and natural distribution of uranium-234, uranium-235, and uranium-238. The natural distribution of uranium isotopes was $0.0055 \%$ uranium-234, $0.72 \%$ uranium-235, and $99.27 \%$ uranium-238. The specific activities used for the conversion were $6.13 \mathrm{E}+3 \mathrm{pCi} / \mu \mathrm{g}$ for uranium-234, $2.14 \mathrm{pCi} / \mu \mathrm{g}$ for uranium-235, and $0.33 \mathrm{pCi} / \mu \mathrm{g}$ for uranium-238.

Holding times. All technical holding times were met.

Calibration. All calibration criteria were met except for the SDGs $2423,2684,2658,2638$, and 2633. These SDGs had correlation coefficients outside criteria for the high and low standards; therefore, detects were $\mathrm{J}$ and nondetects were UJ.

Laboratory blank results. All laboratory blank results were either less than the MDA or the lowest sample activity was 5 times greater than the blank activity and deemed acceptable.

Matrix spike/matrix spike duplicates. All MS/MSD recoveries were within the QC limits (75-125\%) with the exception of SDGs 21123, 21058, 21081, 2924, 21169, 21262, and 21232. The percent RPDs were within the QC limits. 
Duplicates. The RPD acceptance criterion was $\pm 35 \%$ for samples with values greater than or equal to 5 times the MDA. All duplicate RPDs were within QC limits of ( $\leq 50 \%$ maximum), except for SDG 2878.

Blank spike results. All blank spike recoveries were within QC limits (75-125\%).

Overall assessment. The data for total uranium were estimated (J) or (UJ) because the laboratory was unable to provide information on the amount of spiking compound used and the amount of tracer used, since the laboratory was putting the spike and tracer in the same aliquot or because of spike recoveries. However, later the laboratory began to separate the spike from the tracer, and the amounts were able to be determined. The following SDGs have no qualifiers, because of this change: $21383,30044,2847,21328$, and 2878.

\subsubsection{Technetium-99 validation results}

Fifty-one samples were analyzed for technetium-99 by liquid scintillation. These samples were obtained from the resampling discussed in Sect. 4.4.

Technetium-99 data met all necessary criteria, and it was determined that the data is usable, and there were no validation qualifiers assessed to the data. Therefore, all detects have no qualifiers and all nondetects are qualified estimated (U).

\subsubsection{Tritium validation results}

Sixty-one samples were analyzed for tritium by liquid scintillation.

Holding times. All technical holding times were met.

Calibration. The liquid scintillation counter was calibrated with NIST traceable quench standards; however, this information was not verifiable according to the information submitted. The carbon-14 daily standard check did not include a radioactive source report. There is no information to relate the raw data for the quench curve to the standard used, and there is no preparation information for the quench curve. Also, the daily standard information and the control charts used to monitor the daily standard checks were not present, and there is no way to verify whether the standard checks passed or failed.

Due to the laboratory's failure to include proper documentation for the carbon-14 standard and the exclusion of the daily standard information, including control charts used to monitor the daily standard and background checks, all of the data must be qualified as estimated (J) for detects and (UJ) for nondetects.

Laboratory blank results. There were no detected activities found above the MDA.

Matrix spike/matrix spike duplicates. All MS/MSD recoveries were within the QC limits (75-125\%), except SDG 2369, 2391, 2970.

Duplicates. The RPD acceptance criterion was $\pm 35 \%$ for samples with values greater than or equal to 5 times the MDA. All duplicate RPDs were within QC limits of ( $\leq 50 \%$ maximum), except for SDG 2391. This qualifies SDG 2391 as J for results above the MDA and UJ for results below the MDA. 
Blank spike results. All blank spike recoveries were within QC limits (75-125\%) except for SDG 21345.

Overall assessment. Data for these soil samples (Table 4.6) were qualified as estimated due to the laboratory's failure to include all relevant information for calibration. Therefore, all detects are (J) and all nondetects (UJ). However, there is one sample, 21205-05, that is qualified unusable $(R)$, because the laboratory reported it at a point outside of the quench curve that makes it invalid.

\subsubsection{ICP/MS Data Validation Results}

Of the 150 samples collected for ICP/MS analysis, 144 were analyzed. The remaining six samples were not analyzed, because sample volume was depleted before ICP/MS analysis could take place.

Holding times. There were no holding time requirements for the soil samples in this case.

Initial calibration and calibration verification. Four runs of tuning solution with \%RSD $<10 \%$ were shown. The spectra for mass calibration and resolution checks for the 12/28/92 run were nearly illegible, hence, the factors could not be verified. A mass calibration report did not accompany the graphical representation of the scans. The \%R for ICV and CCV were within limits, and true values were verified.

Laboratory blank results. The analysis of laboratory blanks provides a means of assessing the existence of contamination in the analytical method. Blanks did not show evidence of significant contamination.

Interference check samples. The analysis of an ICS was to verify the interelement and background correction factors. ICS samples were run. The laboratory used 6020 CLP-M Version 8.1 and adhered to recommended values in Table 4.7, except for those recommended values that were higher than the linear range of the instrument. Solution $A$ indicates no barium, copper, nickel, or zinc, but low levels of these elements were found.

Matrix spike. Spiking levels did not agree exactly with CLP. The spike for antimony was outside $\mathrm{QC}$ limits and was rerun, as required.

Duplicates. All duplicate \%RSD were acceptable, except for selenium (40.2\%). The selenium data will be qualified as estimated $(J)$ due to this finding.

Laboratory control samples. The LCS was identified in the laboratory response, and true values and recoveries are correct.

Serial dilutions. Serial dilutions would be required for barium, chromium, lead, and zinc. All $\% \mathrm{D}$ values were acceptable except for zinc. The results of the diluted samples were higher than the original sample for zinc; therefore, all zinc data were qualified as estimated (J). 
Table 4.6. Summary distribution of radiochemical data validation results

\begin{tabular}{|c|c|c|c|c|c|c|c|}
\hline Analyte & $\begin{array}{c}\text { No } \\
\text { Qualifier }\end{array}$ & $\mathrm{U}$ & $\mathbf{J}$ & UJ & $\mathbf{R}$ & SUM & $\begin{array}{c}\% \\
\text { usable }\end{array}$ \\
\hline Americium-241 & 1 & 147 & & & & 148 & 100 \\
\hline Barium-133 & & 148 & & & & 148 & 100 \\
\hline Cesium-137 & 80 & 68 & & & & 148 & 100 \\
\hline Chromium-51 & & 148 & & & & 148 & 100 \\
\hline Cobalt-57 & & 148 & & & & 148 & 100 \\
\hline Cobalt -60 & & 148 & & & & 148 & 100 \\
\hline Curium-243 & & 61 & & & & 61 & 100 \\
\hline Curium-244 & & & & 24 & 32 & 56 & 43 \\
\hline Curium-245 & & 61 & & & & 61 & 100 \\
\hline Curium-247 & 2 & 59 & & & & 61 & 100 \\
\hline Europium-152 & & 148 & & & & 148 & 100 \\
\hline Europium-154 & & 148 & & & & 148 & 100 \\
\hline Europium-155 & & & & & 148 & 148 & 0 \\
\hline Hafnium-181 & & 136 & & & & 136 & 100 \\
\hline Iridium-192 & & 136 & & & & 136 & 100 \\
\hline Neptunium-237 & & & 35 & 10 & 19 & 64 & 70 \\
\hline Neptunium Gamma & & 90 & & & & 90 & 100 \\
\hline Niobium & & 134 & & & & 134 & 100 \\
\hline Plutonium-238 & & & 28 & 33 & 2 & 63 & 97 \\
\hline Plutonium-239/240 & & & 16 & 39 & 1 & 56 & 98 \\
\hline Potassium-40 & 139 & 9 & & & & 148 & 100 \\
\hline Radium-226 & 147 & 3 & & & & 150 & 100 \\
\hline Ruthenium-103 & 1 & 147 & & & & 148 & 100 \\
\hline Strontium-90 & 2 & 52 & & & & 54 & 100 \\
\hline Technetium-99 & 10 & 41 & & & & 51 & 100 \\
\hline Thorium-228 & & & 148 & 2 & & 150 & 100 \\
\hline Thorium-230 & & & 149 & 1 & & 150 & 100 \\
\hline Thorium-232 & & & 150 & & & 150 & 100 \\
\hline Thorium-234 & 51 & 1 & 18 & 59 & & 129 & 100 \\
\hline Thorium-234 Gamma & 7 & 8 & & & & 15 & 100 \\
\hline Total Uranium & 9 & & 51 & 1 & & 61 & 100 \\
\hline Tritium & & & 18 & 39 & 4 & 61 & 93 \\
\hline Uranium-233/234 & & & 136 & 12 & & 148 & 100 \\
\hline Uranium-235 & & & 107 & 41 & & 148 & 100 \\
\hline Uranium-235 Gamma & 59 & 89 & & & & 148 & 100 \\
\hline Uranium-236 & & & 6 & 142 & & 148 & 100 \\
\hline Uranium-238 & & & 136 & 12 & & 148 & 100 \\
\hline Zinc- 65 & & 148 & & & & 148 & 100 \\
\hline Zirconium-95 & & 148 & & & & 148 & 100 \\
\hline
\end{tabular}


Table 4.7. Summary distribution of ICP/MS data validation results

\begin{tabular}{|c|c|c|c|c|c|c|c|c|}
\hline Compound & No qualifier & $\mathrm{B}^{-}$ & $U$ & UJ & $\mathrm{J}$ & $\mathbf{R}$ & SUM & $\%$ usable \\
\hline Aluminum & 143 & & & & & & 143 & 100 \\
\hline Antimony & & 3 & 140 & & & & 143 & 100 \\
\hline Arsenic & 140 & 3 & & & & & 143 & 100 \\
\hline Barium & 106 & 37 & & & & & 143 & 100 \\
\hline Beryllium & 25 & 113 & 5 & & & & 143 & 100 \\
\hline Cadmium & & & 143 & & & & 143 & 100 \\
\hline Chromium & 143 & & & & & & 143 & 100 \\
\hline Cobalt & 79 & 64 & & & & & 143 & 100 \\
\hline Copper & 137 & 6 & & & & & 143 & 100 \\
\hline Lead & 143 & & & & & & 143 & 100 \\
\hline Manganese & 142 & 1 & & & & & 143 & 100 \\
\hline Nickel & 111 & 32 & & & & & 143 & 100 \\
\hline Selenium & & & & 14 & 56 & & 70 & 100 \\
\hline Silver & & & 143 & & & & 143 & 100 \\
\hline Thallium & & 71 & 72 & & & & 143 & 100 \\
\hline Zinc & & & & & 143 & & 143 & 100 \\
\hline
\end{tabular}

\subsubsection{Neutron Activation Analysis (NAA) Data Validation Results}

The method of NAA was used to determine 34 trace elements in the samples according to procedures given in Standard Analytical Method ORNL-AC-MM-222003. There were a total of 143 samples analyzed. They were broken down into seven different batches.

Holding Times. All holding times fell within the specified range.

Initial calibration and calibration verification. There is no information provided about the energy calibration of the detectors, but inspection of peak searches for standards shows peak energies at the expected locations. Efficiency information was provided, and all other criteria for calibration was met. The laboratory performed three different counts: long counts (20-day decay), medium counts (4-day decay), and short counts (20-min decay). In the long and medium counts, all standards were counted in the same geometry, and the same efficiency files were applied to all. For these longer-lived nuclides, decay corrections were not necessary. The short counts for the standards were counted in different geometries. Exact efficiencies were provided for the standards, and decay corrections were implemented.

Laboratory blank results. The procedure states that the blank is acceptable if the activity in each peak of interest is less than $5 \%$ of analyte level. However, no activities are given for the blank values in milligrams per kilogram. Comparison of the milligrams per kilogram values from the blank with those of sample 5030 shows that the blank is less than $5 \%$ of the analyte levels, except for hafnium. The blank level for hafnium was a significant fraction $(>10 \%)$ of most sample values. Hafnium will be qualified as $\mathrm{J}$.

Laboratory control samples (LCS). The percent recovery limits for the LCS were 80 to $120 \%$. Based on the LCS results, the following elements are qualified J: silver, barium, cerium, 
chromium, iron, hafnium, lutetium, and samarium. The following elements are qualified $\mathrm{R}$ : cadmium, selenium, and zinc. The laboratory felt that the zinc results for this batch were anomalous, but upon review it was determined that only batches 1 and 5 should be $R$.

Matrix spike recoveries. The percent recovery could not be calculated with the information given in the table. Upon speaking with the laboratory, it was determined that all values should be converted to mass rather than concentration. Tabular results can be produced in this way. However, spike recovery limits do not apply for analytes with concentrations more than 4 times the spike amount. This was the case for hafnium, iron, magnesium, manganese, potassium, scandium, and sodium. Therefore, even though some of these were out of the control limits, no qualifier was applied. The following elements were qualified estimated (J) due to out-of-control-limit recoveries: arsenic, cadmium, cerium, cobalt, chromium, gallium, lanthanum, samarium, and thorium. These elements are qualified rejected $(R)$ : tungsten and zinc. Note: Cobalt batches 4 and 5 had no qualifier.

Duplicates. For values that are undetected $(U)$, control limits do not apply. The laboratory applied limits of $\pm 35 \%$ and indicated that the out-of-limits elements for the duplicate samples are antimony, arsenic, gallium, terbium, and uranium. However, EPA control limits for soils are very wide (only \%RPD $>100 \%$ are estimated). Thus, no elements required qualification.

Continuing calibration verification (CCV). The following guidelines were used to qualify the data: $90-110 \%$ no qualifier; $89-75 \%$ and $111-125 \%$ are J; all others will be $R$. The following elements are out of limits: lutetium and yttrium are qualified $\mathrm{J}$; and cadmium, samarium, and zinc are qualified $\mathrm{R}$.

Overall Assessment. The final validation qualifiers for the NAA data are as follows: arsenic, barium, cerium, chromium, gallium, hafnium, iron, lanthanum, lutetium, silver, and thorium are all qualified estimated $\mathrm{J}$. Cobalt is also qualified $\mathrm{J}$, but only for batches $1,2,3,6$, and 7 . The following elements are qualified unusable R: cadmium, samarium, selenium, and tungsten. Zinc batches 1 and 5 were also qualified R. Note: all " 0 " concentrations are to be interpreted as MISSING DATA. Information cannot be retrieved. In contrast, cadmium, selenium, and zinc data obtained by ICP analyses were $99 \%, 94 \%$, and $100 \%$ usable, respectively.

\subsection{SCREENING ANALYSES FOR VOLATILE ORGANIC COMPOUNDS}

The analyses of volatile organic compounds were performed on non-composited surface soil samples. This analysis was conducted as a screen to determine whether there was any disposal of wastes at the site or evidence of contamination of groundwater plumes under the site. Since this analysis was being performed as a screen, the analytical level was set at II, which provided quantitative data with less rigorous $Q A / Q C$ and documentation.

The results of most volatile organic screens were that no volatile organic compounds were detected. However, there were some samples found with detectable quantities of compounds found typically associated as laboratory contaminates (acetone and 2-butanone). Sixty-seven samples showed acetone; 8 samples showed 2-butanone; 2 samples showed trichloroethylene; 17 samples showed both acetone and 2-butanone; 3 samples showed acetone, 2-butanone, and trichloroethylene; 1 sample showed acetone and trichloroethene; and 1 sample showed acetone, 2-butanone, and toluene as contaminants. In addition, there were two samples that showed a compound other than these two contaminants. One sample 
showed detectable quantities of trichlorofluoromethane, and the other sample showed detectable quantities of chloroform. Each of these compounds was found in low concentration and could conceivably be associated with the laboratory performing the analysis.

Table 4.8. Summary distribution of neutron activation analysis data validation results

\begin{tabular}{|c|c|c|c|c|c|c|}
\hline Analyte & No qualifier & $\mathbf{J}$ & UJ & $\mathbf{R}$ & Sum & \% Usable \\
\hline Aluminum & 143 & & & & 143 & $100 \%$ \\
\hline Antimony & 143 & & & & 143 & $100 \%$ \\
\hline Arsenic & & 143 & & & 143 & $100 \%$ \\
\hline Barium & & 143 & & & 143 & $100 \%$ \\
\hline Cadmium & & & & 143 & 143 & $0 \%$ \\
\hline Cerium & & 143 & & & 143 & $100 \%$ \\
\hline Cesium & 143 & & & & 143 & $100 \%$ \\
\hline Chromium & & 143 & & & 143 & $100 \%$ \\
\hline Cobalt & 40 & 103 & & & 143 & $100 \%$ \\
\hline Europium & 143 & & & & 143 & $100 \%$ \\
\hline Gallium & & 143 & & & 143 & $100 \%$ \\
\hline Gold & 143 & & & & 143 & $100 \%$ \\
\hline Hafnium & & 143 & & & 143 & $100 \%$ \\
\hline Iron & & 143 & & & 143 & $100 \%$ \\
\hline Lanthanum & & 143 & & & 143 & $100 \%$ \\
\hline Lutetium & & 143 & & & 143 & $100 \%$ \\
\hline Magnesium & 143 & & & 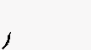 & 143 & $100 \%$ \\
\hline Manganese & 143 & & & & 143 & $100 \%$ \\
\hline Mercury & 143 & & & & 143 & $100 \%$ \\
\hline Potassium & 143 & & & & 143 & $100 \%$ \\
\hline Rubidium & 143 & & & & 143 & $100 \%$ \\
\hline Samarium & & & & 143 & 143 & $0 \%$ \\
\hline Scandium & 143 & & & & 143 & $100 \%$ \\
\hline Selenium & & & & 143 & 143 & $0 \%$ \\
\hline Silver & & 143 & & & 143 & $100 \%$ \\
\hline Sodium & 143 & & & & 143 & $100 \%$ \\
\hline Terbium & 143 & & . & & 143 & $100 \%$ \\
\hline Thorium & & 143 & & & 143 & $100 \%$ \\
\hline Titanium & 143 & & & & 143 & $100 \%$ \\
\hline Tungsten & & & & 143 & 143 & $0 \%$ \\
\hline Uranium & 143 & & & & 143 & $100 \%$ \\
\hline Vanadium & 143 & & & & 143 & $100 \%$ \\
\hline Ytterbium & 143 & & & & 143 & $100 \%$ \\
\hline Zinc & 103 & & & 40 & 143 & $72 \%$ \\
\hline
\end{tabular}




\section{STATISTICAL ANALYSIS}

\subsection{SUMMARY}

This section contains data summary statistics for the Background Soil Characterization Project (BSCP), which include detection frequencies, median estimates as measures of central tendency, upper 95th quantile estimates as measures of the upper ends of the normal background range, and confidence bounds for these estimates. Detection probability confidence bounds are given for the data that were primarily "nondetects." The statistical methodology for "detect" data assumes that data follow the lognormal distribution, with possibly different means but the same variance in each formation-location (FL). The statistical methodology incorporates each nondetect as "between zero and the detection limit" without resorting to approximation, such as setting its value to the detection limit.

All data were examined graphically to assess the lognormal assumption and to check for outliers. With the exception of a few outliers, the data appear to be consistent with the assumptions. However, sample size limitations precluded thorough statistical testing of these assumptions. Comparisons were made across FLs and horizons, and some significant differences were determined. These differences include differences among the Oak Ridge Reservation (ORR) and Anderson County and Roane County FLs (see Sect. 6). Laboratory and spatial variances were estimated and compared. On the basis of these estimates and the relative costs of laboratory and field sampling, the advantage of using composited soil samples was demonstrated.

\subsection{INTRODUCTION}

The purpose of this section is to provide a statistical overview of the BSCP data and to demonstrate statistical methodology. The data are either "detects" or "nondetects," depending on whether they exceed detection limits. Each nondetect was considered "censored," that is, known only to be less than the detection limit. Data qualified as "unusable" were rejected a priori.

Statistical analyses were performed to

1. assess the data graphically-that is, to screen for statistical outliers and to make preliminary decisions about the statistical distributions of the soil constituents;

2. compute summary statistics: means, medians, confidence bounds, and tolerance bounds for soil concentration levels, and estimates and confidence bounds for detection probabilities;

3. resolve and estimate laboratory and field components of variance;

4. compare, to a limited extent, the three soil horizons and the geologic formations in three different sampling areas: the Dismal Gap and Copper Ridge formations on the ORR and in Anderson and Roane counties, the Nolichucky and the Chepultepec formations on the ORR, and the Chickamauga formations in Bethel Valley and K-25 on the ORR;

5. compare NAA and ICP/MS results with the AA/ICP inorganics and with alpha, beta, and gamma radionuclide results; and 
6. uncover, through the above five steps, data problems not revealed earlier by data validation and verification.

Different analytes tend to have different statistical distributions, variance properties, patterns of detection, and patterns of missing or rejected data. For many of the analytes, the statistical analysis is premised on the assumption that the data arise from lognormal distributions with equal variances but possibly different means in different FLs. These assumptions are discussed further in Sect. 5.2.1. How appropriate these assumptions are varies with the analyte. Available time and budget constraints precluded the tailoring of individual statistical analysis for each analyte.

However, special attention may be warranted in certain cases, especially for analytes whose background levels are near levels of risk concern. In such cases, the discussion in this section may provide useful guidance, but the users of the background data should perform their own analysis.

All results were plotted to check for outliers and other anomalies. For those soil constituents that were mostly detected, which includes most of the inorganics and PAHs and some of the radionuclides, the same plots were used to decide whether a parametric statistical distribution (e.g., normal or lognormal) was appropriate for modeling the data or whether the statistical scatter in the data was similar over the different FLs. On the basis of this visual assessment, the decision was made that the lognormal distribution and homogeneity-ofvariance (equal scatter) assumptions were adequate for the data analyses considered here. Graphical data assessment is discussed further in Sect. 5.2.2.

For the mostly detected constituents, the usual array of means, standard errors, and confidence bounds were computed using the SAS Lifereg procedure and the method of maximum likelihood with lognormal errors and homogeneity of variance (SAS 1990). This is described further below.

The nondetects were entered as censored data using the Lifereg procedure. The method of analysis used to handle nondetects (the method of maximum likelihood) makes full use of the data, without "imputing" them or resorting to other compromises, such as setting them to zero, to the detection limit, or to half the detection limit.

Maximum likelihood estimation for censored lognormal data is discussed in Lawless (1982, Sect. 5.2). For the mostly detected constituents, separate means are estimated for the lognormal analyte distributions for each formation and horizon, but results for all formations contribute to a single variance estimate. In this way the data were pooled over formations, thus reducing the statistical noise in the estimates and making confidence limits tighter. Results cannot, in the same way, be pooled across horizons because of the statistical dependence of the results from different horizons at the same individual site.

Summary statistics are given in Sects. 5.3-5.9 for inorganics, herbicides, pesticides/PCBs, PAHs, radionuclides, volatile organics, and gamma screening data. These statistics can ordinarily be computed when there are detects. There are exceptions, however (e.g., when each FL having a detect, has just one, and it is less than the detection limits for nondetects from that FL). Exceptions also occur in a few cases for numerical reasons (e.g., the computing algorithm may fail to converge because of a nonrobust starting value). In such cases these estimates are indicated as missing with the symbol ".". 
Means and confidence bounds for means are computed as standard procedure. However, focusing exclusively on means skirts the issue of data scatter and the question of how large a constituent level has to be before it can reasonably be assumed to exceed background. To address this question, tolerance bounds are used: If a background distribution percentile is known exactly, it would be logical to assume that a particular sample exceeds background if it exceeds some particular upper percentile of the background distribution, selected as a reasonable bound on the usual background range. For example, if the sample result exceeds the 95th percentile, then either (1) contamination is present, or (2) it is an unusual (1-in-20) background sample. As the percentile level is increased, statement (1) becomes ever more and (2) ever less tenable. While background percentiles are not known exactly, they can be estimated from background data. Tolerance bounds, which are just confidence bounds for percentiles, account for estimation error; lower tolerance bounds for upper percentiles are of particular interest. If a sample value is below such a lower tolerance bound, then one can be confident that it does not exceed the corresponding percentile. If the sample percentile level is not too high, then one can be confident that the sample level is within the usual background range. For the same reason, a lower tolerance bound for an upper percentile would be a reasonable candidate for a remediation target (particularly a tolerance bound for a single noncomposite sample).

For analyses with sufficiently many detects, tolerance bounds along with their corresponding percentile estimates and the mean estimates and upper confidence bounds (UCBs) provide a good assessment of the statistical accuracy of the results. When the vast majority of the results are nondetects, as with herbicides and pesticides, the usual statistics cannot be computed, and only detection probabilities are estimated. UCBs for detection probabilities (binomial probability distributions) are discussed in Owen (1962). Similar UCBs are also computed for probabilities of exceeding the maximum detection limit (MAXDL) of the nondetects.

UCBs for detection probabilities can be used as follows: If there is confidence that the true background detection probability is less than the UCB, if that UCB is small enough and if the detection limits do not change much in the future, then any future detect would suggest contamination. For example, if the detection probability is less than 0.05 , then a detect indicates either a 1-in-20 chance background event or else contamination.

To be useful, the detection probability UCBs should be around 0.05 or less. To achieve this, sample sizes need to be 50 or more, and data must be combined over FLs. Similar use can be made of UCBs for probabilities of exceeding MAXDLs. Of course, the probability of detection depends on the laboratory and can change in future surveys.

Comparisons of results for different FLs and horizons are discussed in Sects. 5.2.3 and 5.3-5.9. Comparisons are of interest because of their implications on (1) combining FLs for data analysis (e.g., to increase degrees of freedom for error estimates) and (2) extrapolations to other sampling areas, formations, locations, and sites not sampled in the BSCP. Possible differences in background values among areas for which there are data may require using caution in extrapolating to other areas.

Gamma screening and volatile organic results are discussed in Sects. 5.8 and 5.9, and NAA and ICP/MS results are presented in Sects. 5.11 and 5.12. 


\section{- Composite Sample Data}

BSCP herbicide, pesticide, PAH, and volatile organic samples were not composited, but the inorganics and radionuclide samples were. For most of the inorganics and radionuclides, there are sufficient numbers of detects to make estimating medians and computing tolerance bounds the primary approach to statistical analysis. But some inorganics and, especially, some radionuclides were mostly undetected. In such cases, detection probabilities are given for composites of three.

When a contaminant or unusual constituent is detected in composites, the individual samples are sometimes analyzed separately to determine the original site or sites that it came from. This procedure was not pursued in the BSCP. Therefore, detection probabilities for single (noncomposite) samples cannot be estimated directly for the inorganics and radionuclides. A bound for these probabilities can be found as follows: Suppose $\mathrm{X}$, an observation from a composite of three, is $\left[\left(x_{1}+x_{2}+x_{3}\right) / 3\right] \cdot e$, where $e$ is laboratory error, and $x_{1}, x_{2}$ and $x_{3}$ represent the true concentrations in the individual composited samples. The random variable $X_{1}=x_{1}$. e has the same statistical distribution as an observation from a single noncomposite sample. For any $x, P(X>x) \geq P\left(x_{1} \cdot e>3 \cdot x\right)$. Thus, a UCB for $\mathrm{P}(\mathrm{X}>\mathrm{x})$ is a conservative $U C B$ for $\mathrm{P}\left(\mathrm{X}_{1}>3 \cdot \mathrm{x}\right)$, and a $U C B$ for the detection probability for composites is a conservative UCB for the detection probability of noncomposites with detection limits tripled.

BSCP results for composites can be compared to results for noncomposites, though in some cases it will be necessary to account for the smaller variance of the composite results. To do this, variance components (i.e., field and laboratory) must be estimated. This is discussed in Sect. 5.10, where the advantage of compositing is also demonstrated for the background data. Variance component estimates can also be used in planning future surveys. Variance component estimates require replicate observations at the same site. Replicates in the BSCP, which are in the form of duplicates and splits, are discussed in Sect. 5.2.4.

\section{Measures of Central Tendency}

Analysis of lognormal data is generally accomplished by analyzing the logs of the data, that is by computing means, standard errors, etc. of the logs. A problem arises when the results are transformed back to the original scale, because the mean of the logs is not the same as the log of the means. However, the median (50th percentile) of the logs is the log of the median. Other percentiles transform in the same way, as do confidence bounds for them. For this reason, in this section attention is restricted mostly to medians and other percentiles, instead of means. But, medians are usually considered to be more appropriate measures of central tendency for skewed distributions, such as the lognormal.

\section{Rejected Data}

Many of the background results are nondetects (designated by validation codes "U," "UJ"); the results given in the background data sets are then detection limits. Data designated with the validation code " $R$ " (rejected) were not used in the following analyses but, with a few exceptions, the remaining data were used, including data designated "J" (estimated). The exceptions, which are discussed in the following sections, were usually obvious outliers and, at the suggestion of soil scientists, were deleted from further statistical analyses. For most of the analyses, some data were assigned the validation code "R." It is assumed here that the 
assignment of $\mathrm{Rs}$ was not based on the detection status of results. In particular, results of the same analyses should not be differentially rejected because they are nondetects.

\subsubsection{Basic Assumptions}

Residual soils that are underlain by a particular formation are represented as the union of numerous small disjoint regions. For each BSCP formation, a subset of that union, suitable as background and within particular property boundaries, defines a targeted area for the BSCP (e.g., ORR Dismal Gap). As described in the BSCP Plan (Volume 3, Energy Systems 1992), to the extent feasible, targeted areas were sampled randomly. For composites, samples were partitioned randomly into sets of three and composited. (Note, however, one procedural variance discussed at the end of Sect. 3.7). Therefore, to the extent that sites are sampled randomly, the data, both composites and noncomposites, are simple random samples. A close approximation to random sampling was achieved for ORR sites. Access limitations were more severe off-site, and so the approximation is not as good there. Nevertheless, on the basis of graphical inspection, on-site and off-site data seem to have similar distributions, and it is reasonable to assume that the goal of simple random sample site selection was met. Certain applications, however, may warrant closer scrutiny of these assumptions.

For those analytes that were mostly undetected, spatial distribution assumptions play no role in the analysis. For many of the inorganics and radionuclides, however, there are detects. For these analyses, on the basis of data plots, the decision was made to model the data as lognormal with equal variances (but possibly different means) within FLs. Separate analyses are made for each horizon. By using the same statistical model for all of the detected analytes, the analysis is greatly simplified. This is consistent with the goal of providing a statistical overview. Furthermore, more formal assessment of the model assumptions, [e.g., using goodness-of-fit (GOF) tests] is difficult (because of small numbers of observations in each area, nondetects, etc.) and fraught with logical problems (failing to reject a model may be due only to weakness of the GOF test, which is itself very complicated to assess). GOF tests are discussed in Lawless (1982, Chapter 9), where the lack of procedures appropriate for this setting is made clear. Nevertheless, the lognormal and equal variance assumptions may be less appropriate for some analytes than others, and closer scrutiny may be warranted in applications different from this. A graphical approach to assessing these assumptions is discussed in the next section.

\subsection{Graphical Screening}

All results, whether detects or nondetects, were plotted to check for outliers, homogeneity of variance, and deviations from lognormality, which, for these data with so few observations for each formation, amounts to checking for outliers. The large number of graphs precludes presenting them all here. An example is the horizon $A$ aluminum plot in Fig. 5.1. In this example, the highest Dismal Gap-ORR result is suspect, especially since there is another observation at the same site that is much lower. Such discrepancies were resolved by BSCP soil scientists. By contrast, the horizon B aluminum results in Fig. 5.2 are more consistent. Major outliers and anomalous results are noted in Sects. 5.3-5.9.

For each analysis and horizon, a graphical assessment of the fundamental assumptionthat the analyte concentrations have lognormal distributions with the same variance but means that may depend on FL-can be made as follows: 


\section{INORGANIC ANALYSES}

ANALYSIS=Aluminum Horizon=A

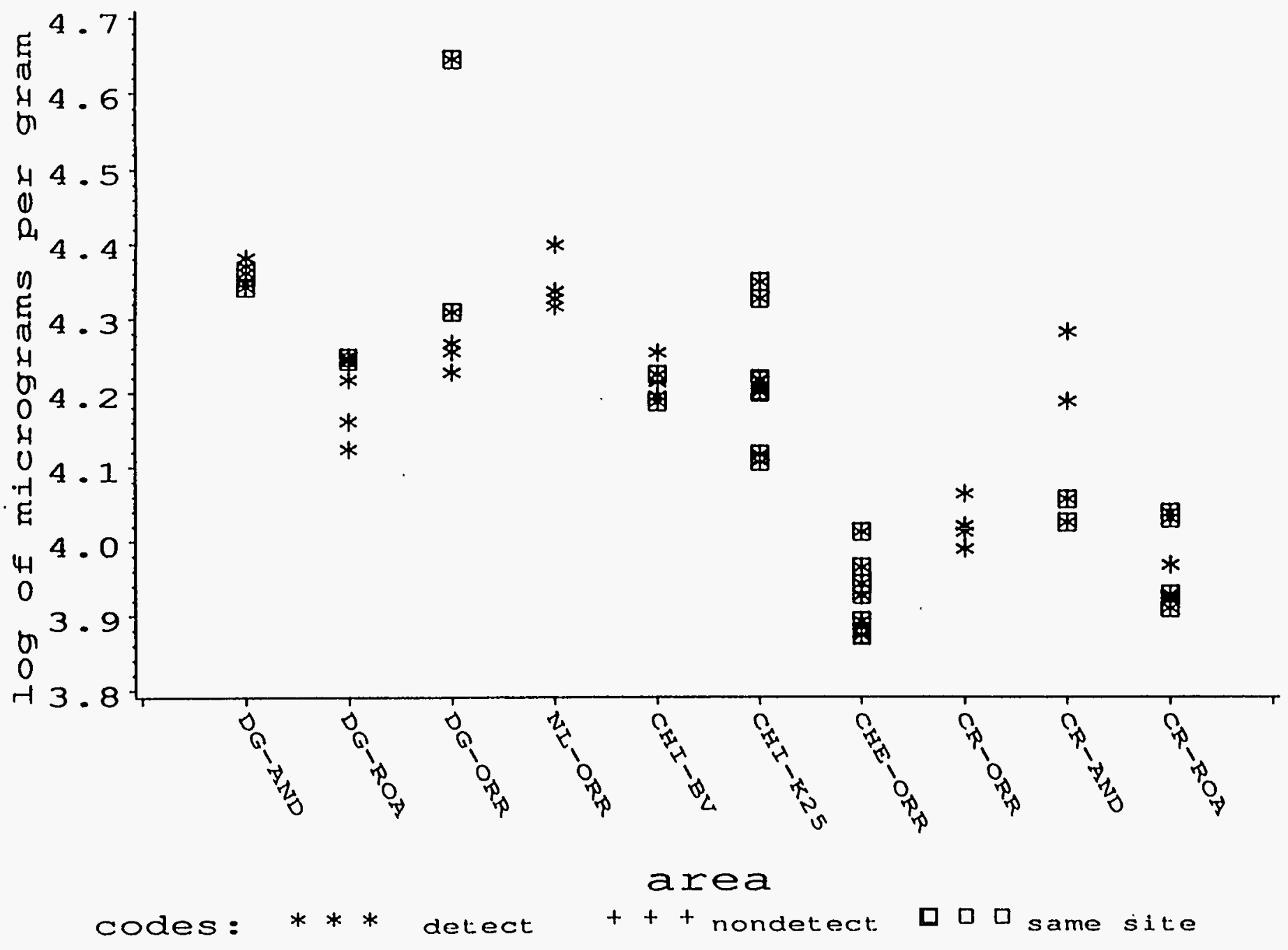

Fig. 5.1. Example of a plot to chock for outliers. The ORR Dismal Gap duplicates are suspicious. 


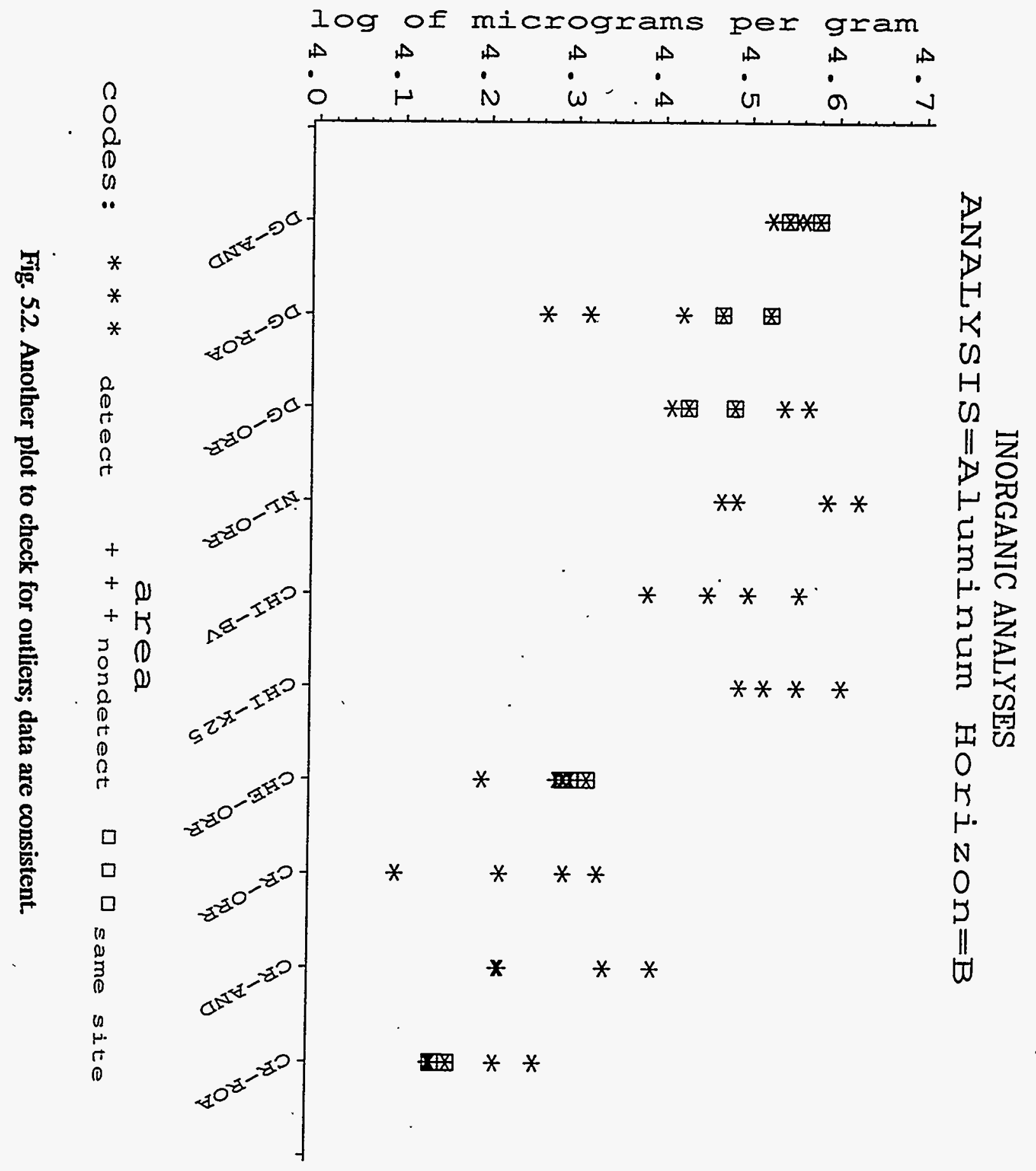


1. For each FL, convert the observations-denoted as $x_{1}, x_{2}, \ldots, x_{n}$-to $\operatorname{logs}, y_{1}=\log \left(x_{1}\right)$, $\ldots, y_{n}=\log \left(x_{n}\right)$ (y is simply the logarithm of the observations).

2. For the data in each FL, depending on whether or not there are nondetects, compute either the empirical distribution function or the product limit estimate of the distribution. $F_{n}(y)$, the empirical distribution function of (uncensored) observations, $y_{1}, y_{2}, \ldots, y_{n}$, is the proportion of $i$ with $y_{i} \leq y$. The product-limit estimate is analogous but adjusts for nondetects (see Lawless (1982), Sects. 2.3.1 and 9.1.1).

3. Compute the normal scores, $G\left[F_{n}(y)\right]$, where $G$ is the inverse of the standard normal distribution function.

4. For all FLs plot the y values by the normal scores using symbols that distinguish FLs.

Under the lognormal model these GOF plots should be roughly linear with the same slope, that is, parallel lines. In fact, it can be shown that the intercepts of the lines should be approximately the means and that the slopes should be approximately the pooled standard deviation from the analysis of variance of the log concentrations. The word "roughly" is operative because there are only a few observations for each FL, and so the distribution function estimates tend to be noisy. One can get an idea about how such data should behave by performing this procedure with simulated (pseudorandom) lognormal data.

Figure 5.3 is a GOF plot of normal scores for aluminum in horizon B. Figure 5.4 is a GOF plot with the same medians and scale, but simulated lognormal data. Thus, the horizon B aluminum data seem to be consistent with the lognormal assumption. All of the data are detects. Figure 5.5 is a plot of normal scores computed from the product-limit estimates of the logs of the data for mercury in horizon $A$, which had numerous nondetects. (A plot analogous to Fig. 5.4 for mercury could also be made, but to properly account for nondetection would require detection limits for all observations, including the detects. Then the ith simulated concentration would become a nondetect, if it happens to fall below the ith detection limit.)

This graphical GOF procedure could be turned into a more. formal test as follows: compute a GOF statistic-say a sum of squares-that measures the deviations of the plotted values (i.e., logs by normal scores, as in Fig. 5.3) from the fitted lines having slope equal to the overall standard deviation and intercepts equal to the means. Next, simulate pseudorandom normal data having those means and that standard deviation. Figure 5.4 is one realization of such a simulation. Then compute the GOF statistic for the simulated data. Repeat the simulation many times (e.g., 1000), and recompute the GOF statistic for each repetition. Then, see where the original GOF statistic (computed from the original plotted data) lies in the range of simulated ones. An original value that is unusually large relative to the range of simulated values suggests that the lognormal model does not hold. Note, however, that this is still not a formal GOF test (it is a "bootstrap" test).

The GOF plots reported do not support the lognormal assumption for every analyte and horizon. For example, there is an outlier in the horizon A aluminum data plot. These deficiencies were not pursued, because the purpose of this section is to provide an overview and to demonstrate methods. Nevertheless, the GOF plots could be used to assess lognormality in each case. 


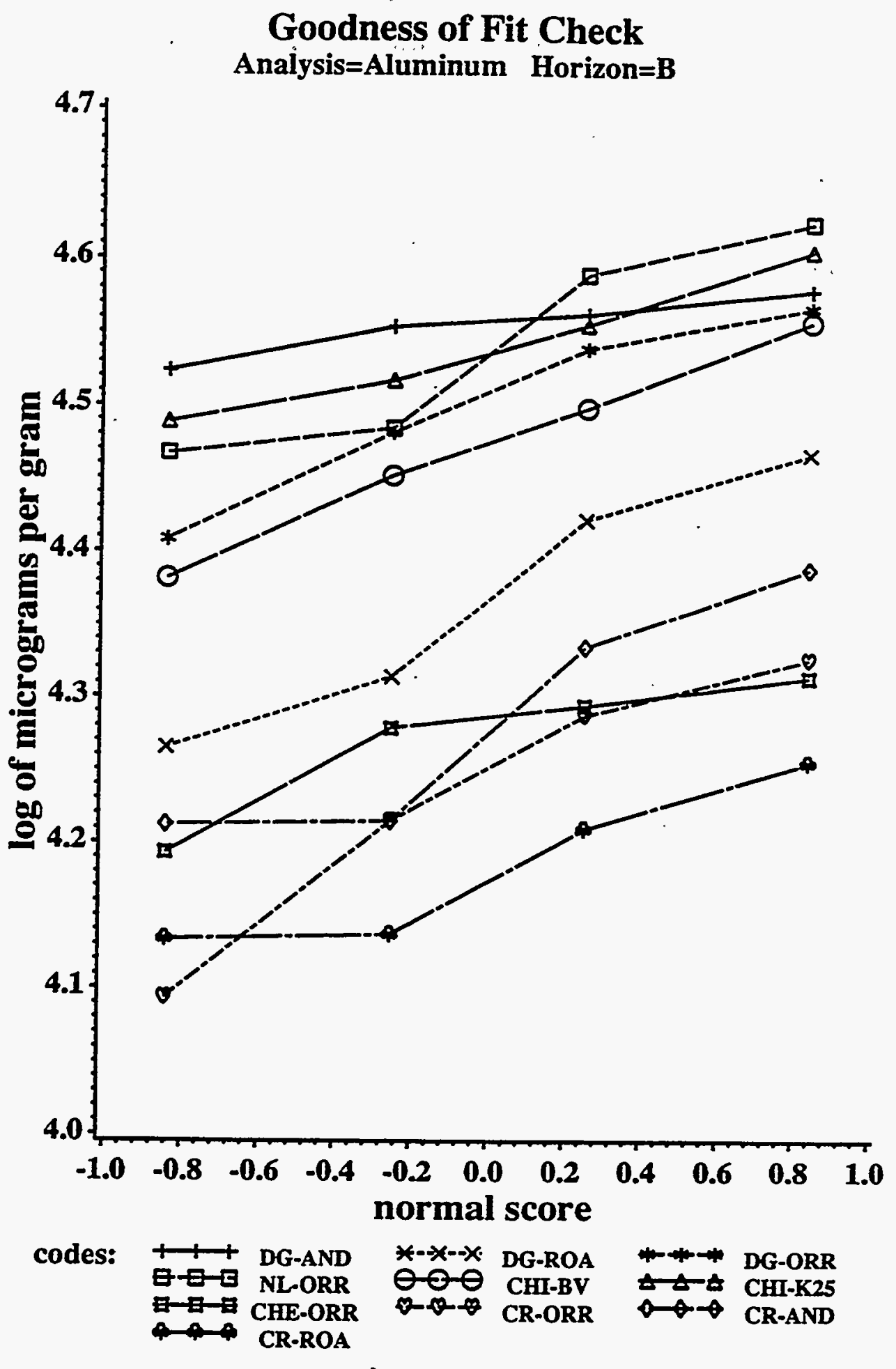

Fig. 5.3. Plot of observation logs by corresponding normal scores for horizon B aluminum. In the absence of statistical variation, the curves should be parallel lines-if the lognormal, equal-variance model holds. 


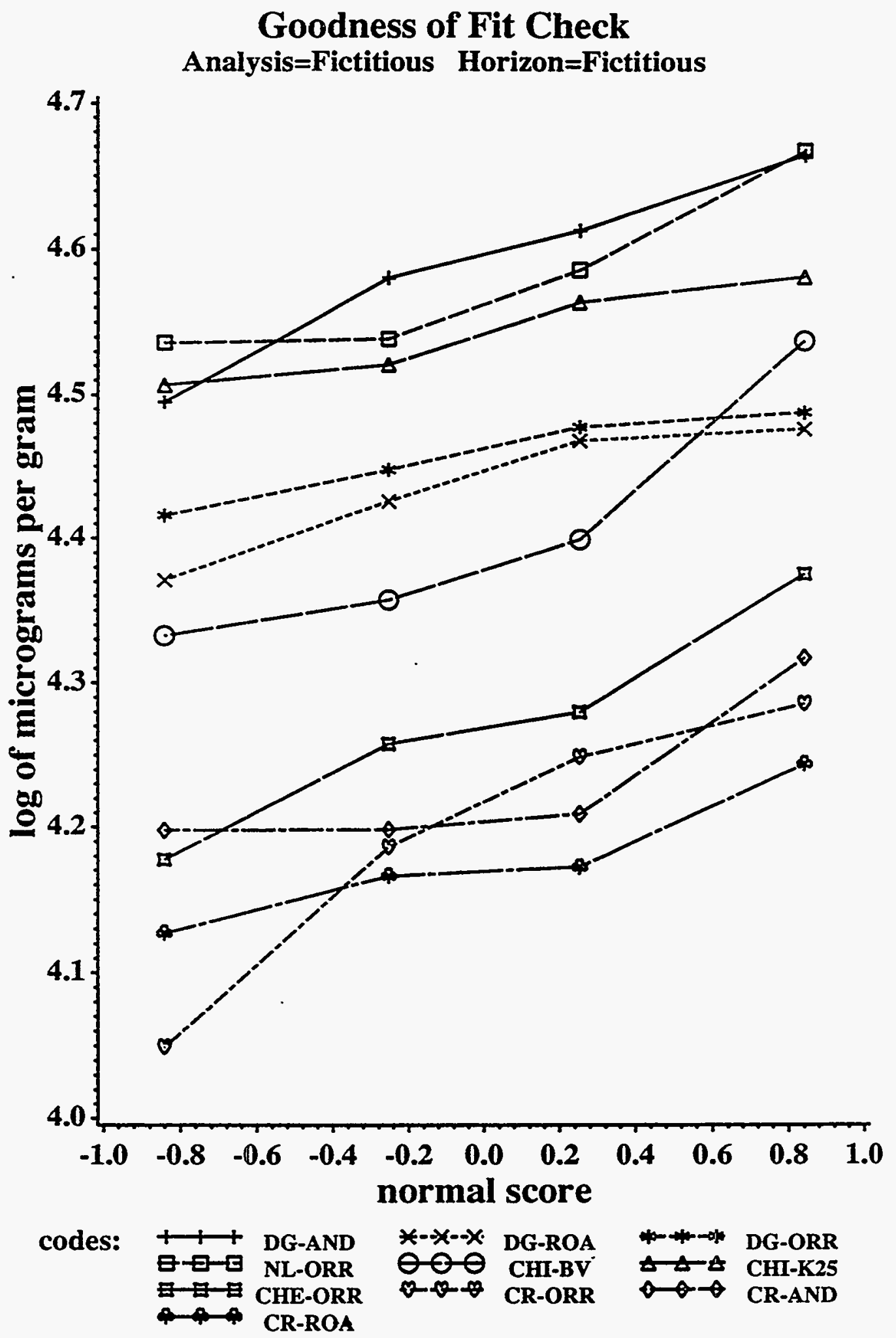

Fig. 5.4. Plot of observation logs by corresponding normal scores for pseudorandom lognormal data with means and variance the same as for the horizon B aluminum data. This illustrates the departure from ideal parallel lines due to ordinary statistical variation, as also illustrated in Fig. 5.3. 


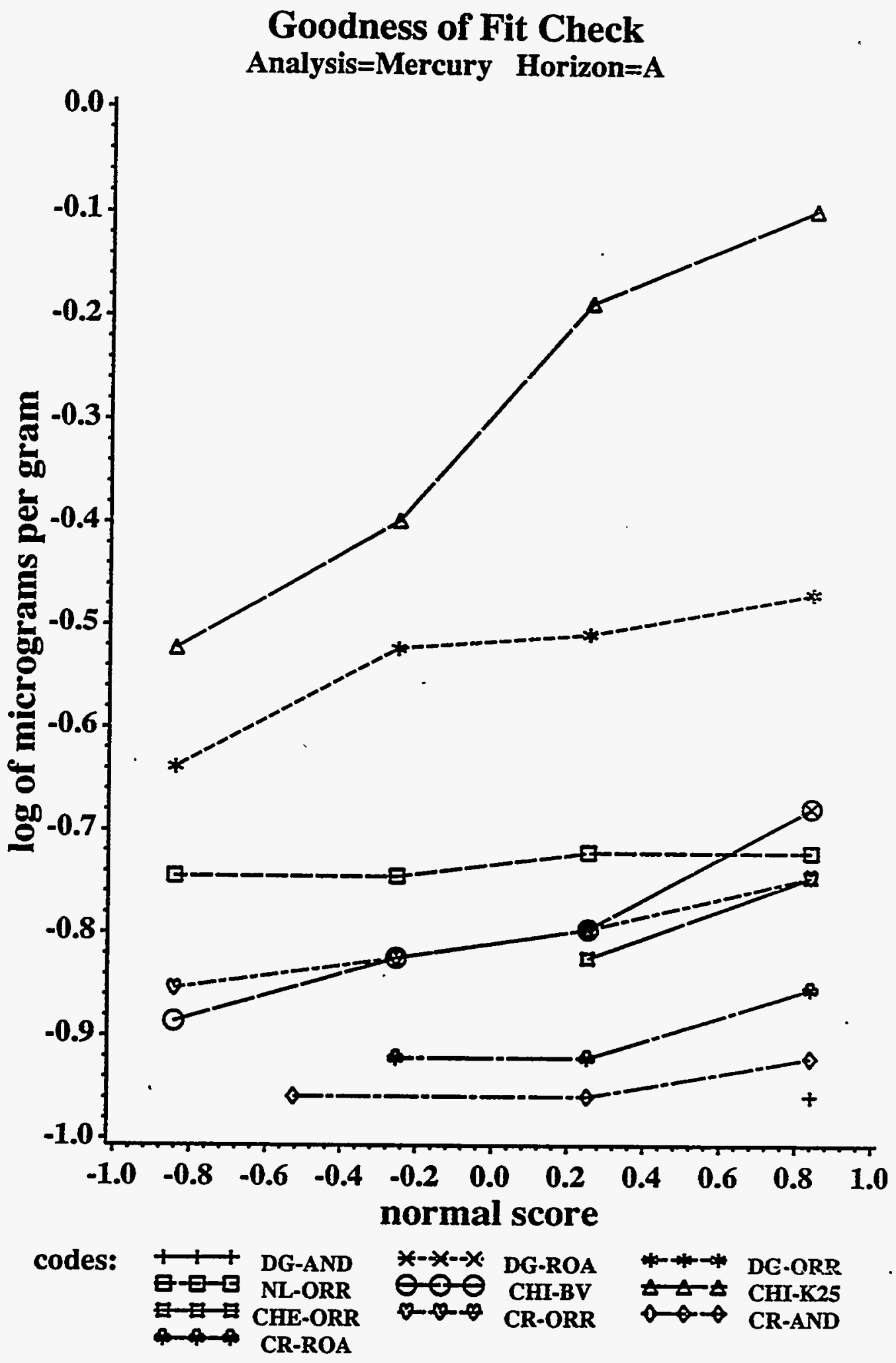

Fig. 5.5. Plot similar to Fig. 5.3 but based on product limit estimates for horizon A mercury data, which have nondetects. 


\subsection{Comparison of Formation-Locations and Horizons}

Comparisons of FLs and horizons are discussed briefly here. The intent is to sketch a method by which these comparisons can be made, rather than to give a detailed discussion of the nature of the differences among FLs or horizons for each analyte. These differences are discussed further in Sect. 6.

Comparisons of FLs can be made by using chi-square likelihood ratio (LR) tests (Lawless 1982, pp. 524-525). This can be done using the SAS Proc Lifereg and the lognormal equal variance model, even when there are nondetects. The tests involve computing likelihoods under two (null and alternative) models, their LR, and then comparing the likelihoods using $-2 \ln (\mathrm{LR})$, which, under the null model, has approximately a chi-square distribution. This is essentially a one-way analysis of variance, but nondetects are admitted into the analysis. When there are no nondetects, FLs can also be compared using F-tests or t-tests, for example, with SAS Proc GLM (SAS 1990). This is the usual one-way analysis of variance-a standard statistical procedure.

When there are no nondetects, the LR and F-test significance levels are the same asymptotically (i.e., in theory for large sample sizes). In practice, as with the BSCP sample sizes, the LR significance levels are generally smaller. [The LR and F-tests actually coincide in this case (Wilks 1962, Chapter 13). The approximation incurred in the LR test is only through using the chi-square to approximate the F-distribution.] For the majority of analytes, there are some nondetects. To be consistent for both these and the all-detect cases, the LR test was used to make all comparisons. But since the corresponding significance levels tend to be smaller (and especially since many comparisons are being made), the 0.01 significance-level cut-off is likely to be better than the usual 0.05 for declaring differences to be significant.

When FLs differ significantly, the question becomes how they differ (comparison of means). Unlike the SAS Proc GLM, the software in Proc Lifereg has not been developed to answer this question easily. Under project constraints, pursuing that question fully for each analyte and horizon was not feasible. Nevertheless, tests were performed to compare (1) all FLs in general, (2) Dismal Gap locations, (3) Copper Ridge locations, (4) ORR FLs, (5) Chickamauga locations, (6) ORR Dismal Gap with Nolichucky FLs, (7) ORR Copper Ridge with Chepultepec FLs, and (8) groups on the ORR-the Chickamauga, Conasauga (Dismal Gap and Nolichucky formations), and Knox (Copper Ridge and Chepultepec formations).

Formal comparisons can also be made of detection frequencies (using a different chi-square test). Here, frequencies are the focus only when there are few or no detects, and in such cases frequency comparisons are almost always negative.

By virtue of the sampling, BSCP soil samples are statistically independent for each horizon. They are not, however, independent across horizons, as observations for the three horizons come in triples for each site or (in the case of composites) combination of sites. When there is no censoring, this dependence can be accounted for by analyzing differences between results at different horizons: $B$ from $A, C$ from $B$, and $C$ from $A$. When there is censoring, these differences are themselves censored. For example, if a horizon A observation is a nondetect with detection limit 10 and the corresponding horizon B observation is a 
detect, say 15, then the A-B difference is interval censored: between $0-15=-15$ and $10-15=-5$.

The censored differences between horizons can also be analyzed using the SAS Lifereg procedure. For this section, these differences are assumed to arise from approximately normal distributions. Horizon comparisons are made for inorganics and radionuclides (Sects. 5.3 and 5.7). The differences are first compared to check for differences (in the differences) between FLs. Generally, the FL does seem to play a role in horizon differences, and the differences are examined for each FL.

\subsection{Field Duplicates and Splits}

BSCP results include two kinds of replication at the same site: (1) field splits-separate subsamples from one original (possibly composited) sample and (2) field duplicates-samples (possibly composited) from the same general sites (e.g., holes) but taken a small distance (or distances) apart. In the BSCP, the distance was unspecified but was generally about $3 \mathrm{ft}$. Field splits can be used to estimate laboratory error along with any error associated with sample granularity. Field duplicates measure both of these errors plus small-scale spatial variability.

How to combine replicates into the data analysis is not straightforward. A duplicate or split does not represent new independent information because it is from a site already sampled, and so these replicates should not be treated as independent observations. On the other hand, replicates, having been measured more than once, represent more information than an ordinary, single sample.

For data that are uncensored (all detects), duplicates and splits can be handled using variance components models (see, for example, Searle 1971, Chapter 9). Sites-within-FLs can be modeled as a random effect, but even then approximation is necessary. How to compute exact confidence intervals for the spatial variance estimates is unknown.) For most BSCP analytes, however, there are nondetects. Unfortunately, software is not readily available for analogous analyses with nondetects. Therefore, our approach to replication at the same site is as follows.

For analyses with primarily nondetects, only one member of each replicate pair, triple, etc. was included in the data analysis. In most cases that means simply that one nondetect was included in the analysis and that additional nondetects at the same site were dropped.

For analyses with more than just a few detects, replicates at a site were averaged. This may cause a slight downward bias in variance estimates, but the alternative of not using replicates ignores useful information, and the alternative of modeling the replicates-a random effects model with censored data-is not feasible under project cost and time constraints. When all are detects, this is straightforward. When there are nondetects (which are left-censored), the averages are either left-censored or interval-censored. For example, if at the same site there are two splits, one a nondetect with detection limit 1 and the other a detect at level $d$, then the average is interval-censored, between $1 / 2$ and $(d+1) / 2$. If both splits are nondetects with limits $l_{1}$ and $l_{2}$, then the average is a nondetect, between 0 and $\left(l_{1}+l_{2}\right) / 2$. Notice that these averages are computed BEFORE taking logs. If the averaging was done after taking logs, because the log of zero is minus infinity, the average for replicates with even a single nondetect would be a nondetect regardless of the number of detects among the replicates. 
Variance components are discussed in Sect. 5.10. In order to increase the frequency of data that can be used to estimate variance components, duplicates and splits are treated the same-as replicates.

\subsection{INORGANICS}

Inorganics include metals, cyanide, and sulfates. For several of these, some or all values are nondetects, but most results are detects. Data screening reveals that many of the ORR A horizon composite results for sites 2, 26, and 43 are much higher than the other values for the ORR A horizon, including the field duplicate, which also happens to be from sites 2, 26, and 43. Figure 5.1 illustrates this for aluminum. It is also true for nickel, vanadium, and zinc, and to a lesser extent for barium, beryllium, cobalt, copper, iron, lithium, magnesium, potassium, and strontium. The duplicates are consistently high, suggesting the possibility of laboratory error.

There is an unusually high nondetect among the Roane County, Copper Ridge, horizon $\mathrm{C}$ results for antimony. There are four detects (of four composites) for antimony in Nolichucky horizons B and C, but there were very few detects elsewhere in horizon C. An ORR, Dismal Gap, horizon C cadmium nondetect is suspiciously high. There is an extremely low horizon C, Dismal Gap, ORR mercury value. There is an extremely high horizon A, Anderson County, Copper Ridge selenium value.

There are in horizons A and B of the Nolichucky, arsenic, chromium, and lead values that are extremely low, and single high values of arsenic for ORR Copper Ridge in each of horizons $\mathrm{B}$ and $\mathrm{C}$. These were all deleted (though not validation rejects). All nondetects for calcium were deleted. There are extremely low values of copper and vanadium for ORR Dismal Gap horizon B; they were deleted.

Some of the cyanide results are negative. The negative results were set to zero for the statistical analysis, but this still remains a problem because a zero value implies that the cyanide detection limit is zero.

Summary statistics for inorganics that have sufficiently many detects are given in Table 5.1. They include estimates of the medians, made under the assumption that the data are lognormal with equal variances across FLs. The estimates are based on all of the data, whether detects or not. Results for field duplicates and originals were averaged. The percentile estimate and lower tolerance bounds are for composites of three.

For each analyte, horizon, and formation, Table 5.1 also shows UCB95, a 95\% UCB for the median, X95, an estimate of the 95th percentile of the analyte's distribution, and LTB9595, the $95 \%$ lower tolerance bound for the 95th percentile. $N$, the number of samples, $\mathrm{D}$, the number of true detects (single detects or all-detect averages), and $\mathrm{I}$, the number of interval-censored averages, are also given. The information contained in Table 5.1 can be applied directly in utilization of the data, as discussed in Sect. 2.4.3. The estimates and confidence bounds are computed using the Lifereg procedure in SAS, which gives standard errors of percentile estimates in addition to the estimates themselves. The standard errors are used to compute confidence bounds, with the estimates assumed to be approximately normal. 
Table 5.1. Summary statistics for inorganics"

(Estimates and confidence bounds are in milligrams per kilogram.)

\begin{tabular}{|c|c|c|c|c|c|c|c|c|}
\hline Horizon & $\begin{array}{l}\text { Formation- } \\
\text { location }\end{array}$ & $\mathrm{N}$ & I & D & Median & UCB95 & X95 & LTB9595 \\
\hline \multicolumn{9}{|c|}{ Aluminum } \\
\hline A & DG-AND & 4 & 0 & 4 & 23100 & 26000 & 29200 & 25800 \\
\hline A & DG-ROA & 4 & 0 & 4 & 15400 & 17300 & 19500 & 17200 \\
\hline A & DG-ORR & 4 & 0 & 4 & 20700 & 23200 & 26200 & 23100 \\
\hline A & NL-ORR & 4 & 0 & 4 & 22200 & 25000 & 28100 & 24800 \\
\hline$A^{\prime}$ & CHI-BV & 4 & 0 & 4 & 16500 & 18600 & 20900 & 18500 \\
\hline A & CHI-K25 & 4 & 0 & 4 & 16500 & 18600 & 20900 & 18500 \\
\hline A & CHE-ORR & 4 & 0 & 4 & 8450 & 9510 & 10700 & 9440 \\
\hline A & CR-ORR & 4 & 0 & 4 & 10500 & 11800 & 13300 & 11800 \\
\hline A & CR-AND & 4 & 0 & 4 & 13600 & 15300 & 17200 & 15200 \\
\hline A & CR-ROA & 4 & 0 & 4 & 9150 & 10300 & 11600 & 10200 \\
\hline$B$ & DG-AND & 4 & 0 & 4 & 35500 & 40100 & 45200 & 39800 \\
\hline B & DG-ROA & 4 & 0 & 4 & 23700 & 26700 & 30100 & 26500 \\
\hline B & DG-ORR & 4 & 0 & 4 & 31100 & 35100 & 39600 & 34800 \\
\hline B & NL-ORR & 4 & 0 & 4 & 34800 & 39200 & 44300 & 38900 \\
\hline B & CHI-BV & 4 & 0 & 4 & 29700 & 33500 & 37800 & 33200 \\
\hline B & CHI-K25 & 4 & 0 & 4 & 34800 & 39300 & 44300 & 39000 \\
\hline B & CHE-ORR & 4 & 0 & 4 & 18400 & 20800 & 23500 & 20700 \\
\hline B & CR-ORR & 4 & 0 & 4 & 17000 & 19200 & 21700 & 19000 \\
\hline B & CR-AND & 4 & 0 & 4 & 19400 & 21900 & 24700 & 21700 \\
\hline B & CR-ROA & 4 & 0 & 4 & 15400 & 17300 & 19600 & 17200 \\
\hline C & DG-AND & 4 & 0 & 4 & 38900 & 44000 & 49900 & 43700 \\
\hline $\mathrm{C}$ & DG-ROA & 4 & 0 & 4 & 25100 & 28500 & 32200 & 28200 \\
\hline C & DG-ORR & 4 & 0 & 4 & 39000 & 44200 & 50100 & 43900 \\
\hline C & NL-ORR & 4 & 0 & 4 & 37900 & 42900 & 48600 & 42600 \\
\hline C & CHI-BV & 4 & 0 & 4 & 33300 & 37800 & 42800 & 37500 \\
\hline C & CHI-K25 & 4 & 0 & 4 & 34300 & 38900 & 44000 & 38600 \\
\hline C & CHE-ORR & 4 & 0 & 4 & 17600 & 20000 & 22600 & 19800 \\
\hline C & CR-ORR & 4 & 0 & 4 & 17800 & 20200 & 22900 & 20000 \\
\hline C & CR-AND & 4 & 0 & 4 & 20900 & 23700 & 26900 & 23500 \\
\hline C & CR-ROA & 4 & 0 & 4 & 16800 & 19100 & 21600 & 18900 \\
\hline \multicolumn{9}{|c|}{ Antimony } \\
\hline A & DG-AND & 4 & 0 & 1 & 0.885 & 0.929 & 0.936 & 0.882 \\
\hline A & NL-ORR & 4 & 0 & 1 & 0.463 & 0.485 & 0.490 & 0.470 \\
\hline A & REMAINDER & 32 & 0 & 0 & - & - & - & - \\
\hline B & DG-AND & 4 & 0 & 1 & 0.663 & 1.000 & 1.200 & 0.780 \\
\hline B & NL-ORR & 4 & 0 & 4 & 0.717 & 0.965 & 1.300 & 0.838 \\
\hline B & REMAINDER & 32 & 0 & 0 & 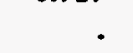 & - & - & . \\
\hline C & DG-AND & 4 & 0 & 1 & 0.710 & 1.090 & 1.310 & 0.847 \\
\hline $\mathrm{C}$ & NL-ORR & 4 & 0 & 4 & 0.673 & 0.914 & 1.240 & 0.808 \\
\hline C & CHI-BV & 4 & $0^{-}$ & 1 & 0.328 & 0.512 & 0.606 & 0.393 \\
\hline C & REMAINDER & 28 & 0 & 0 & & . & . & 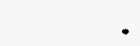 \\
\hline
\end{tabular}


Table 5.1 (continued)

\begin{tabular}{|c|c|c|c|c|c|c|c|c|}
\hline Horizon & $\begin{array}{l}\text { Formation- } \\
\text { location }\end{array}$ & $\mathbf{N}$ & I & $\mathrm{D}$ & Median & UCB95 & $\mathrm{X} 95$ & LTB9595 \\
\hline \multicolumn{9}{|c|}{ Arsenic } \\
\hline A & DG-AND & 4 & 0 & 4 & 4.35 & 5.56 & 7.10 & 5.47 \\
\hline A & DG-ROA & 4 & 0 & 4 & 5.86 & 7.49 & 9.56 & 7.36 \\
\hline A & DG-ORR & 4 & 0 & 4 & 6.24 & 7.97 & 10.20 & 7.84 \\
\hline A & NL-ORR & 3 & 0 & 3 & 6.16 & 8.18 & 10.10 & 7.47 \\
\hline A & CHI-BV & 4 & 0 & 4 & 6.25 & 7.99 & 10.20 & 7.86 \\
\hline A & CHI-K25 & 4 & 0 & 4 & 7.61 & 9.73 & 12.40 & 9.57 \\
\hline A & CHE-ORR & 4 & 0 & 4 & 11.30 & 14.40 & 18.40 & 14.20 \\
\hline A & CR-ORR & 4 & 0 & 4 & 24.10 & 30.70 & 39.30 & 30.20 \\
\hline A & CR-AND & 4 & 0 & 4 & 12.10 & 15.50 & 19.80 & 15.20 \\
\hline A & CR-ROA & 4 & 0 & 4 & 9.22 & 11.80 & 15.00 & 11.60 \\
\hline B & DG-AND & 4 & 0 & 3 & 4.04 & 5.42 & 7.18 & 5.27 \\
\hline B & DG-ROA & 4 & 0 & 4 & 7.03 & 9.37 & 12.50 & 9.18 \\
\hline B & DG-ORR & 4 & 0 & 4 & 7.77 & 10.40 & 13.80 & 10.10 \\
\hline B & NL-ORR & 3 & 0 & 3 & 6.45 & 8.99 & 11.50 & 8.08 \\
\hline B & CHI-BV & 4 & 0 & 4 & 7.05 & 9.40 & 12.50 & 9.21 \\
\hline B & $\mathrm{CHI}-\mathrm{K} 25$ & 4 & 0 & 4 & 7.41 & 9.87 & 13.20 & 9.67 \\
\hline B & CHE-ORR & 4 & 0 & 4 & 21.20 & 28.30 & 37.70 & 27.70 \\
\hline B & CR-ORR & 3 & 0 & 3 & 42.50 & 59.20 & 75.50 & 53.20 \\
\hline B & CR-AND & 4 & $\mathbf{0}$ & 4 & 20.60 & 27.50 & 36.60 & 26.90 \\
\hline B & CR-ROA & 4 & 0 & 4 & 16.70 & 22.30 & 29.70 & 21.80 \\
\hline $\mathrm{C}$ & DG-AND & 4 & 0 & 3 & 3.80 & 5.69 & 8.34 & 5.45 \\
\hline C & DG-ROA & 4 & 0 & 4 & 7.43 & 11.00 & 16.30 & 10.70 \\
\hline C & DG-ORR & 4 & 0 & 4 & 12.60 & 18.70 & 27.70 & 18.20 \\
\hline C & NL-ORR & 4 & 0 & 3 & 6.63 & 9.96 & 14.60 & 9.48 \\
\hline C & CHI-BV & 4 & 0 & 4 & 6.24 & 9.25 & 13.70 & 9.00 \\
\hline c & CHI-K25 & 4 & 0 & 4 & 6.79 & 10.10 & 14.90 & 9.79 \\
\hline c & CHE-ORR & 4 & 0 & 4 & 32.90 & 48.80 & 72.30 & 47.40 \\
\hline C & CR-ORR & 3 & 0 & 3 & 68.40 & 108.00 & 150.00 & 93.10 \\
\hline C & CR-AND & 4 & 0 & 4 & 26.10 & 38.60 & 57.30 & 37.60 \\
\hline C & CR-ROA & 4 & 0 & 4 & 29.30 & 43.40 & 64.40 & 42.20 \\
\hline \multicolumn{9}{|c|}{ Barium } \\
\hline A & DG-AND & 4 & 0 & 4 & 80.7 & 105.0 & 136.0 & 103.0 \\
\hline A & DG-ROA & 4 & 0 & 4 & 87.9 & 114.0 & 148.0 & 112.0 \\
\hline A & DG-ORR & 4 & 0 & 4 & 99.1 & 129.0 & 167.0 & 126.0 \\
\hline$A$ & NL-ORR & 4 & 0 & 4 & 75.4 & 97.8 & 127.0 & 96.2 \\
\hline A & CHI-BV & 4 & 0 & 4 & 79.6 & 103.0 & 134.0 & 102.0 \\
\hline A & CHI-K25 & 4 & 0 & 4 & 76.7 & 99.6 & 129.0 & 97.9 \\
\hline $\mathrm{A}$ & CHE-ORR & 4 & 0 & 4 & 53.6 & 69.5 & 90.3 & 68.4 \\
\hline A & CR-ORR & 4 & 0 & 4 & 71.8 & 93.2 & 121.0 & 91.6 \\
\hline A & CR-AND & 4 & 0 & 4 & 116.0 & 151.0 & 196.0 & 148.0 \\
\hline A & CR-ROA & 4 & 0 & 4 & 61.3 & 79.6 & 103.0 & 78.2 \\
\hline B & DG-AND & 4 & 0 & 4 & 76.0 & 89.3 & 105.0 & 88.4 \\
\hline B & DG-ROA & 4 & 0 & 4 & 69.4 & 81.7 & 96.1 & 80.8 \\
\hline B & DG-ORR & 4 & 0 & 4 & 96.7 & 114.0 & 134.0 & 113.0 \\
\hline B & NL-ORR & 4 & 0 & 4 & 86.2 & 101.0 & 119.0 & 100.0 \\
\hline B & CHI-BV & 4 & 0 & 4 & 113.0 & 133.0 & 156.0 & 131.0 \\
\hline B & CHI-K25 & 4 & 0 & 4 & 89.4 & 105.0 & 124.0 & 104.0 \\
\hline B & CHE-ORR & 4 & 0 & 4 & 35.6 & 41.9 & 49.3 & 41.4 \\
\hline
\end{tabular}


Table 5.1 (continued)

\begin{tabular}{|c|c|c|c|c|c|c|c|c|}
\hline Horizon & $\begin{array}{c}\text { Formation- } \\
\text { location }\end{array}$ & $\mathrm{N}$ & I & D & Median & UCB95 & X95 & LTB9595 \\
\hline B & CR-ORR & 4 & 0 & 4 & 39.8 & 46.8 & 55.0 & 46.3 \\
\hline $\mathbf{B}$ & CR-AND & 4 & 0 & 4 & 46.9 & 55.2 & 64.9 & 54.6 \\
\hline B & CR-ROA & 4 & 0 & 4 & 36.1 & 42.4 & 49.9 & 42.0 \\
\hline $\mathrm{C}$ & DG-AND & 4 & 0 & 4 & 83.2 & 115.0 & 158.0 & 112.0 \\
\hline $\mathrm{C}$ & DG-ROA & 4 & 0 & 4 & 73.0 & 101.0 & 139.0 & 98.6 \\
\hline $\mathrm{C}$ & DG-ORR & 4 & 0 & 4 & 109.0 & 150.0 & 207.0 & 147.0 \\
\hline C & NL-ORR & 4 & 0 & 4 & 80.9 & 112.0 & 154.0 & 109.0 \\
\hline C & CHI-BV & 4 & 0 & 4 & 145.0 & 200.0 & 276.0 & 196.0 \\
\hline C & CHI-K25 & 4 & 0 & 4 & 79.0 & 109.0 & 150.0 & 107.0 \\
\hline $\mathrm{C}$ & CHE-ORR & 4 & 0 & 4 & 26.3 & 36.3 & 50.1 & 35.6 \\
\hline $\mathrm{C}$ & CR-ORR & 4 & 0 & 4 & 11.6 & 16.0 & 22.1 & 15.7 \\
\hline C & CR-AND & 4 & 0 & 4 & 26.9 & 37.1 & 51.1 & 36.3 \\
\hline C & CR-ROA & 4 & 0 & 4 & 16.0 & 221 & 30.4 & 21.6 \\
\hline \multicolumn{9}{|c|}{ Beryllium } \\
\hline A & DG-AND & 4 & 0 & 4 & 0.833 & 1.020 & 1.250 & 1.010 \\
\hline A & DG-ROA & 4 & 0 & 4 & 0.647 & 0.793 & 0.973 & 0.782 \\
\hline A & DG-ORR & 4 & 0 & 4 & 0.781 & 0.957 & 1.170 & 0.944 \\
\hline A & NL-ORR & 4 & 0 & 4 & 0.786 & 0.964 & 1.180 & 0.950 \\
\hline A & CHI-BV & 4 & 0 & 4 & 1.020 & 1.250 & 1.530 & 1.230 \\
\hline A & CHII-K25 & 4 & 0 & 4 & 0.912 & 1.120 & 1.370 & 1.100 \\
\hline A & CHE-ORR & 4 & 0 & 2 & 0.350 & 0.460 & 0.526 & 0.397 \\
\hline A & CR-ORR & 4 & 0 & 3 & 0.511 & 0.634 & 0.768 & 0.613 \\
\hline A & CR-AND & 4 & 0 & 4 & 0.743 & 0.911 & 1.120 & 0.898 \\
\hline A & CR-ROA & 4 & 0 & 4 & 0.455 & 0.558 & 0.684 & 0.550 \\
\hline $\mathbf{B}$ & DG-AND & 4 & 0 & 4 & 0.962 & 1.230 & 1.580 & 1.210 \\
\hline B & DG-ROA & 4 & 0 & 4 & 0.628 & 0.805 & 1.030 & 0.791 \\
\hline B & DG-ORR & 4 & 0 & 4 & 0.728 & 0.934 & 1.200 & 0.917 \\
\hline B & NL-ORR & 4 & 0 & 4 & 1.000 & 1.290 & 1.650 & 1.260 \\
\hline B & CHII-BV & 4 & 0 & 4 & 1.450 & 1.850 & 2.380 & 1.820 \\
\hline B & $\mathrm{CHI}-\mathrm{K} 25$ & 4 & 0 & 4 & 1.440 & 1.840 & 2360 & 1.810 \\
\hline B & CHE-ORR & 4 & 0 & 2 & 0.503 & 0.693 & 0.828 & 0.596 \\
\hline B & CR-ORR & 4 & 0 & 3 & 0.544 & 0.715 & 0.895 & 0.673 \\
\hline B & CR-AND & 4 & 0 & 4 & 0.656 & 0.841 & 1.080 & 0.826 \\
\hline B & CR-ROA & 4 & 1 & 3 & 0.428 & 0.554 & 0.704 & 0.537 \\
\hline C & DG-AND & 4 & 0 & 4 & 1.170 & 1.470 & 1.840 & 1.450 \\
\hline C & DG-ROA & 4 & 0 & 4 & 0.825 & 1.030 & 1.300 & 1.020 \\
\hline C & DG-ORR & 4 & 0 & 4 & 1.020 & 1.270 & 1.600 & 1.250 \\
\hline C & NL-ORR & 4 & 0 & 4 & 1.170 & 1.460 & 1.830 & 1.440 \\
\hline C & CHI-BV & 4 & 0 & 4 & 1.910 & 2.390 & 3.000 & 2360 \\
\hline C & $\mathrm{CHI}-\mathrm{K} 25$ & 4 & 0 & 4 & 1.420 & 1.770 & 2.220 & 1.750 \\
\hline C & CHE-ORR & 4 & 0 & 2 & 0.548 & 0.738 & 0.860 & 0.633 \\
\hline C & CR-ORR & 4 & 0 & 3 & 0.753 & 0.960 & 1.180 & 0.918 \\
\hline C & CR-AND & 4 & 0 & 4 & 0.682 & 0.855 & 1.070 & 0.842 \\
\hline C & CR-ROA & 4 & 0 & 4 & 0.555 & 0.695 & 0.871 & 0.684 \\
\hline
\end{tabular}


Table 5.1 (continued)

\begin{tabular}{|c|c|c|c|c|c|c|c|c|}
\hline Horizon & $\begin{array}{c}\text { Formation- } \\
\text { location }\end{array}$ & $\mathbf{N}$ & I & D & Median & UCB95 & X95 & LTB9595 \\
\hline & \multicolumn{8}{|c|}{ Boron } \\
\hline $\mathbf{A}$ & DG-ROA & 4 & 1 & 3 & 26.00 & 38.10 & 55.80 & 33.80 \\
\hline A & DG-ORR & 3 & 1 & 1 & 13.70 & 22.70 & 29.50 & 16.80 \\
\hline A & CHE-ORR & 4 & 1 & 0 & 2.38 & 4.87 & 5.12 & 2.50 \\
\hline A & REMAINDER & 23 & 0 & $\mathbf{0}$ & - & - & - & - \\
\hline B & DG-ROA & 4 & 0 & 3 & 15.20 & 25.60 & 41.80 & 21.80 \\
\hline B & DG-ORR & 4 & 1 & 3 & 21.40 & 35.60 & 58.90 & 30.20 \\
\hline B & CHE-ORR & 4 & 0 & 1 & 3.49 & 6.99 & 9.61 & 4.88 \\
\hline B & REMAINDER & 24 & 0 & 0 & - & - & - & - \\
\hline C & DG-ROA & 4 & $\mathbf{0}$ & 4 & 23.40 & 32.50 & 45.00 & 29.90 \\
\hline C & DG-ORR & 4 & 0 & 4 & 27.40 & 37.90 & 52.50 & 34.90 \\
\hline $\mathrm{C}$ & CHE-ORR & 4 & 1 & 1 & 4.82 & 7.09 & 9.25 & 6.15 \\
\hline $\mathrm{C}$ & REMAINDER & 23 & 0 & 0 & - & - & - & - \\
\hline
\end{tabular}

Cadmium
A REMAINDER $40 \quad 0 \quad 0$
$\begin{array}{llccc}\text { B } & \text { CR-ROA } & 4 & 1 & 0 \\ \text { B } & \text { REMAINDER } & 36 & 0 & 0\end{array}$
C REMAINDER $40 \quad 0 \quad-0$

Calcium

$\begin{array}{rlrrrrrrr}\text { A } & \text { DG-AND } & 4 & 0 & 4 & 1350 & 1860 & 2570 & 1820 \\ \text { A } & \text { DG-ROA } & 2 & 0 & 2 & 1310 & 2070 & 2490 & 1560 \\ \text { A } & \text { DG-ORR } & 3 & 0 & 3 & 1250 & 1810 & 2370 & 1600 \\ \text { A } & \text { NL-ORR } & 2 & 0 & 2 & 689 & 1080 & 1310 & 817 \\ \text { A } & \text { CHI-BV } & 4 & 0 & 4 & 1860 & 2560 & 3530 & 2500 \\ \text { A } & \text { CHI-K25 } & 4 & 0 & 4 & 1360 & 1880 & 2590 & 1830 \\ \text { A } & \text { CHE-ORR } & 4 & 0 & 4 & 443 & 611 & 843 & 597 \\ \text { A } & \text { CR-ORR } & 4 & 0 & 4 & 505 & 696 & 960 & 679 \\ \text { A } & \text { CR-AND } & 4 & 0 & 4 & 899 & 1240 & 1710 & 1210 \\ \text { A } & \text { CR-ROA } & 4 & 0 & 4 & 547 & 755 & 1040 & 737 \\ & & & & & & & & \\ \text { B } & \text { DG-AND } & 4 & 0 & 4 & 764 & 1080 & 1520 & 1050 \\ \text { B } & \text { DG-ROA } & 1 & 0 & 1 & 779 & 1550 & 1550 & 769 \\ \text { B } & \text { DG-ORR } & 2 & 0 & 2 & 886 & 1440 & 1760 & 1060 \\ \text { B } & \text { NL-ORR } & 3 & 0 & 3 & 768 & 1140 & 1530 & 1000 \\ \text { B } & \text { CHI-BV } & 4 & 0 & 4 & 2210 & 3110 & 4390 & 3030 \\ \text { B } & \text { CHI-K25 } & 4 & 0 & 4 & 1190 & 1680 & 2370 & 1640 \\ \text { B } & \text { CHE-ORR } & 4 & 0 & 4 & 484 & 682 & 961 & 664 \\ \text { B } & \text { CR-ORR } & 4 & 0 & 4 & 312 & 439 & 619 & 428 \\ \text { B } & \text { CR-AND } & 4 & 0 & 4 & 415 & 585 & 825 & 570 \\ \text { B } & \text { CR-ROA } & 4 & 0 & 4 & 305 & 430 & 607 & 419 \\ & & & & & & & & \\ \text { C } & \text { DG-AND } & 4 & 0 & 4 & 383 & 563 & 828 & 547 \\ \text { C } & \text { DG-ROA } & 1 & 0 & 1 & 594 & 1280 & 1280 & 585 \\ \text { C } & \text { DG-ORR } & 4 & 0 & 4 & 898 & 1320 & 1940 & 1280 \\ \text { C } & \text { NL-ORR } & 2 & 0 & 2 & 1240 & 2130 & 2680 & 1520 \\ \text { C } & \text { CHI-BV } & 4 & 0 & 4 & 4590 & 6760 & 9930 & 6560\end{array}$


Table 5.1 (continued)

\begin{tabular}{llrrrrrrr}
\hline Horizon & $\begin{array}{c}\text { Formation- } \\
\text { location }\end{array}$ & N & I & D & Median & UCB95 & X95 & LTB9595 \\
\hline C & CHI-K25 & 4 & 0 & 4 & 1210 & 1780 & 2620 & 1730 \\
C & CHE-ORR & 4 & 0 & 4 & 251 & 369 & 543 & 359 \\
C & CR-ORR & 3 & 0 & 3 & 172 & 269 & 372 & 232 \\
C & CR-AND & 4 & 0 & 4 & 364 & 536 & 788 & 520 \\
C & CR-ROA & 4 & 0 & 4 & 244 & 358 & 527 & 348
\end{tabular}

Crromium

$\begin{array}{lllllllll}\text { A } & \text { DG-AND } & 4 & 0 & 4 & 28.1 & 33.3 & 39.5 & 32.9 \\ \text { A } & \text { DG-ROA } & 4 & 0 & 4 & 27.3 & 32.3 & 38.3 . & 31.9 \\ \text { A } & \text { DG-ORR } & 4 & 0 & 4 & 24.7 & 29.2 & 34.6 & 28.9 \\ \text { A } & \text { NL-ORR } & 3 & 0 & 3 & 28.0 & 34.0 & 39.2 & 31.9 \\ \text { A } & \text { CHI-BV } & 4 & 0 & 4 & 34.0 & 40.2 & 47.7 & 39.8 \\ \text { A } & \text { CHI-K25 } & 4 & 0 & 4 & -32.5 & 38.5 & 45.6 & 38.1 \\ \text { A } & \text { CHE-ORR } & 4 & 1 & 3 & 14.6 & 17.4 & 20.5 & 17.1 \\ \text { A } & \text { CR-ORR } & 4 & 0 & 4 & 15.4 & 18.3 & 21.6 & 18.1 \\ \text { A } & \text { CR-AND } & 4 & 0 & 4 & 20.2 & 23.9 & 28.3 & 23.6 \\ \text { A } & \text { CR-ROA } & 4 & 0 & 4 & 12.7 & 15.0 & 17.8 & 14.8 \\ & & & & & & & & \\ \text { B } & \text { DG-AND } & 4 & 0 & 4 & 35.0 & 41.3 & 48.7 & 40.8 \\ \text { B } & \text { DG-ROA } & 4 & 0 & 4 & 38.1 & 44.9 & 52.9 & 44.4 \\ \text { B } & \text { DG-ORR } & 4 & 0 & 4 & 37.4 & 44.1 & 52.0 & 43.6 \\ \text { B } & \text { NL-ORR } & 3 & 0 & 3 & 37.1 & 44.9 & 51.5 & 42.2 \\ \text { B } & \text { CHI-BV } & 4 & 0 & 4 & 34.1 & 40.2 & 47.3 & 39.7 \\ \text { B } & \text { CHI-K25 } & 4 & 0 & 4 & 34.2 & 40.3 & 47.5 & 39.9 \\ \text { B } & \text { CHE-ORR } & 4 & 0 & 4 & 29.7 & 35.0 & 41.2 & 34.6 \\ \text { B } & \text { CR-ORR } & 4 & 0 & 4 & 29.3 & 34.6 & 40.7 & 34.2 \\ \text { B } & \text { CR-AND } & 4 & 0 & 4 & 30.1 & 35.5 & 41.8 & 35.1 \\ \text { B } & \text { CR-ROA } & 4 & 0 & 4 & 24.6 & 29.0 & 34.2 & 28.7 \\ & & & & & & & & \\ \text { C } & \text { DG-AND } & 4 & 0 & 4 & 37.7 & 45.0 & 53.7 & 44.4 \\ \text { C } & \text { DG-ROA } & 4 & 0 & 4 & 38.7 & 46.2 & 55.2 & 45.7 \\ \text { C } & \text { DG-ORR } & 4 & 0 & 4 & 46.0 & 54.9 & 65.5 & 54.3 \\ \text { C } & \text { NL-ORR } & 4 & 0 & 4 & 54.4 & 64.9 & 77.4 & 64.1 \\ \text { C } & \text { CHI-BV } & 4 & 0 & 4 & 33.1 & 39.5 & 47.2 & 39.1 \\ \text { C } & \text { CHI-K25 } & 4 & 0 & 4 & 29.3 & 34.9 & 41.7 & 34.5 \\ \text { C } & \text { CHE-ORR } & 4 & 0 & 4 & 27.0 & 32.2 & 38.4 & 31.8 \\ \text { C } & \text { CR-ORR } & 4 & 0 & 4 & 28.9 & 34.5 & 41.2 & 34.1 \\ \text { C } & \text { CR-AND } & 4 & 0 & 4 & 32.7 & 39.0 & 46.5 & 38.5 \\ \text { C } & \text { CR-ROA } & 4 & 0 & 4 & 35.4 & 42.3 & 50.4 & 41.8\end{array}$

Cobalt

$\begin{array}{lllllrrrr}\text { A } & \text { DG-AND } & 4 & 0 & 4 & 12.40 & 16.50 & 21.90 & 16.20 \\ \text { A } & \text { DG-ROA } & 4 & 0 & 4 & 21.40 & 28.40 & 37.70 & 27.90 \\ \text { A } & \text { DG-ORR } & 4 & 0 & 4 & 14.50 & 19.30 & 25.60 & 18.90 \\ \text { A } & \text { NL-ORR } & 4 & 0 & 4 & 14.40 & 19.20 & 25.40 & 18.80 \\ \text { A } & \text { CHI-BV } & 4 & 0 & 4 & 18.50 & 24.50 & 32.50 & 24.10 \\ \text { A } & \text { CHI-K25 } & 4 & 0 & 4 & 19.50 & 25.90 & 34.40 & 25.40 \\ \text { A } & \text { CHE-ORR } & 4 & 0 & 4 & 11.50 & 15.30 & 20.30 & 15.00 \\ \text { A } & \text { CR-ORR } & 4 & 0 & 4 & 7.76 & 10.30 & 13.70 & 10.10 \\ \text { A } & \text { CR-AND } & 4 & 0 & 4 & 15.90 & 21.10 & 28.00 & 20.70 \\ \text { A } & \text { CR-ROA } & 4 & 1 & 2 & 5.16 & 7.02 & 9.09 & 6.60\end{array}$


Table 5.1 (continued)

\begin{tabular}{|c|c|c|c|c|c|c|c|c|}
\hline Horizon & $\begin{array}{l}\text { Formation- } \\
\text { location }\end{array}$ & $\mathbf{N}$ & I & D & Median & UCB95 & X95 & LTB9595 \\
\hline B & DG-AND & 4 & 0 & 4 & 12.20 & 19.20 & 30.20 & 18.50 \\
\hline B & DG-ROA & 4 & 0 & 4 & 9.80 & 15.40 & 24.30 & 14.90 \\
\hline B & DG-ORR & 4 & 0 & 4 & 8.92 & 14.10 & 22.10 & 13.60 \\
\hline B & NL-ORR & 4 & 0 & 4 & 13.40 & 21.10 & 33.30 & 20.40 \\
\hline B & CHI-BV & 4 & 0 & 4 & 13.50 & 21.20 & 33.40 & 20.50 \\
\hline B & CHI-K25 & 4 & 0 & 4 & 12.70 & 20.00 & 31.50 & 19.30 \\
\hline B & CHE-ORR & 4 & 1 & 1 & 2.29 & 3.94 & 5.69 & 3.26 \\
\hline $\mathbf{B}$ & CR-ORR & 4 & 0 & 1 & 1.70 & 3.16 & 4.22 & 2.26 \\
\hline B & CR-AND & 4 & 0 & 4 & 9.62 & 15.20 & 23.90 & 14.60 \\
\hline B & CR-ROA & 4 & 1 & 1 & 2.26 & 3.94 & 5.61 & 3.17 \\
\hline $\mathrm{C}$ & DG-AND & 4 & 0 & 4 & 14.60 & 27.80 & 53.10 & 26.40 \\
\hline C & DG-ROA & 4 & 0 & 4 & 10.10 & 19.30 & 36.90 & 18.30 \\
\hline $\mathrm{C}$ & DG-ORR & 4 & 0 & 4 & 12.00 & 22.90 & 43.60 & 21.70 \\
\hline C & NL-ORR & 4 & 0 & 4 & 14.50 & 27.70 & 52.90 & 26.30 \\
\hline $\mathrm{C}$ & CHI-BV & 4 & 0 & 4 & 23.00 & 43.90 & 83.80 & 41.70 \\
\hline C & CHI-K25 & 4 & 0 & 4 & 14.30 & 27.20 & 51.90 & 25.80 \\
\hline $\mathrm{C}$ & CHE-ORR & 4 & 0 & 3 & 6.79 & 13.10 & 24.70 & 12.30 \\
\hline $\mathrm{C}$ & CR-ORR & 4 & 0 & 1 & 151 & 3.54 & 5.50 & 2.36 \\
\hline C & CR-AND & 4 & 0 & 4 & 6.30 & 12.00 & 22.90 & 11.40 \\
\hline C & CR-ROA & 4 & 0 & 1 & 0.97 & 237 & 3.53 & 1.45 \\
\hline \multicolumn{9}{|c|}{ Copper } \\
\hline A & DG-AND & 4 & 0 & 4 & 14.90 & 18.90 & 24.00 & 18.60 \\
\hline A & DG-ROA & 4 & 0 & 4 & 11.00 & 14.00 & 17.80 & 13.80 \\
\hline A & DG-ORR & 4 & 0 & 4 & 16.10 & 20.50 & 26.10 & 20.10 \\
\hline A & NL-ORR & 4 & 0 & 4 & 11.70 & 14.90 & 18.90 & 14.60 \\
\hline A & CHII-BV & 4 & 0 & 4 & 16.20 & 20.60 & 26.20 & 20.20 \\
\hline A & $\mathrm{CHI}-\mathrm{K} 25$ & 4 & 0 & 4 & 11.40 & 14.50 & $18: 50$ & 14.30 \\
\hline A & CHE-ORR & 4 & 1 & 1 & 3.92 & 5.26 & 6.33 & 4.68 \\
\hline A & CR-ORR & 4 & 0 & 3 & 6.25 & 8.19 & 10.10 & 7.59 \\
\hline A & CR-AND & 4 & 0 & 4 & 9.15 & 11.60 & 14.80 & 11.40 \\
\hline A & CR-ROA & 4 & 1 & 2 & 5.76 & 7.41 & 9.30 & 7.15 \\
\hline B & DG-AND & 4 & 0 & 4 & 19.00 & 23.50 & 29.00 & 23.10 \\
\hline B & DG-ROA & 4 & 0 & 4 & 13.70 & 16.90 & 20.90 & 16.70 \\
\hline B & DG-ORR & 3 & 0 & 3 & 20.60 & 26.20 & 31.30 & 24.20 \\
\hline B & NL-ORR & 4 & 0 & 4 & 19.30 & 23.80 & 29.40 & 23.50 \\
\hline B & CHI-BV & 4 & 0 & 4 & 23.60 & 29.20 & 36.00 & 28.70 \\
\hline $\mathbf{B}$ & CHI-K25 & 4 & 0 & 4 & 17.90 & 22.10 & 27.30 & 21.80 \\
\hline B & CHE-ORR & 4 & 0 & 4 & 16.80 & 20.70 & 25.50 & 20.40 \\
\hline B & CR-ORR & 4 & 0 & 4 & 18.60 & 23.00 & 28.40 & 22.60 \\
\hline B & CR-AND & 4 & 0 & 4 & 22.40 & 27.60 & 34.10 & 27.20 \\
\hline B & CR-ROA & 4 & 1 & 3 & 12.20 & 15.10 & 18.60 & 14.80 \\
\hline C & DG-AND & 4 & 0 & 4 & 27.30 & 33.90 & 42.10 & 33.40 \\
\hline C & DG-ROA & 4 & 0 & 4 & 23.80 & 29.60 & 36.70 & 29.20 \\
\hline C & DG-ORR & 4 & 0 & 4 & 28.70 & 35.70 & 44.30 & 35.10 \\
\hline C & NL-ORR & 4 & 0 & 4 & 24.90 & 30.90 & 38.40 & 30.50 \\
\hline C & CHI-BV & 4 & 0 & 4 & 29.00 & 36.00 & 44.70 & 35.50 \\
\hline $\mathrm{C}$ & $\mathrm{CHI}-\mathrm{K} 25$ & 4 & 0 & 4 & 19.00 & 23.60 & 29.30 & 23.30 \\
\hline C & CHE-ORR & 4 & 0 & 3 & 21.40 & 27.10 & 32.90 & 25.70 \\
\hline $\mathrm{C}$ & CR-ORR & 4 & 0 & 4 & 30.80 & 38.30 & 47.50 & 37.70 \\
\hline
\end{tabular}


Table 5.1 (continued)

\begin{tabular}{|c|c|c|c|c|c|c|c|c|}
\hline Horizon & $\begin{array}{l}\text { Formation- } \\
\text { location }\end{array}$ & $\mathrm{N}$ & $\mathrm{I}$ & D & Median & UCB95 & $\mathrm{X} 95$ & LTB9595 \\
\hline C & CR-AND & 4 & 0 & 4 & 30.00 & 37.20 & 46.20 & 36.70 \\
\hline C & CR-ROA & 4 & 0 & 4 & 16.50 & 20.50 & 25.50 & 20.20 \\
\hline \multicolumn{9}{|c|}{ Cyanide } \\
\hline A & DG-AND & 4 & 1 & 1 & 0.1340 & 0.253 & 0.410 & 0.195 \\
\hline A & DG-ROA & 4 & 1 & 2 & 0.3190 & 0.583 & 0.979 & 0.447 \\
\hline A & DG-ORR & 3 & 0 & 1 & 0.1300 & 0.281 & 0.398 & 0.177 \\
\hline A & REMAINDER & 26 & 0 & 0 & - & - & - & . \\
\hline B & DG-AND & 4 & 0 & 1 & 0.0688 & 0.210 & 0.291 & 0.102 \\
\hline B & DG-ORR & 4 & 0 & 2 & 0.2460 & 0.594 & 1.040 & 0.292 \\
\hline B & REMAINDER & 30 & 0 & 0 & - & 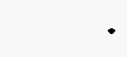 & 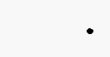 & • \\
\hline C & DG-ORR & 4 & 0 & 2 & 0.2660 & 0.760 & 1.450 & 0.278 \\
\hline C & REMAINDER & 33 & 0 & 0 & - & - & - & • \\
\hline \multicolumn{9}{|c|}{ Iron } \\
\hline A & DG-AND & 4 & 0 & 4 & 25600 & 29700 & 34600 & 29400 \\
\hline A & DG-ROA & 4 & 0 & 4 & 25400 & 29600 & 34400 & 29300 \\
\hline A & DG-ORR & 4 & 0 & 4 & 29400 & 34200 & 39800 & 33900 \\
\hline A & NL-ORR & 4 & 0 & 4 & 27900 & 32400 & 37700 & 32100 \\
\hline A & CHI-BV & 4 & 0 & 4 & 36000 & 41800 & 48600 & 41400 \\
\hline A & CHI-K25 & 4 & 0 & 4 & 31000 & 36000 & 41800 & 35600 \\
\hline A & CHE-ORR & 4 & 0 & 4 & 14200 & 16500 & 19200 & 16400 \\
\hline A & CR-ORR & 4 & 0 & 4 & 12000 & 13900 & 16200 & 13800 \\
\hline A & CR-AND & 4 & 0 & 4 & 15300 & 17800 & 20700 & 17600 \\
\hline A & CR-ROA & 4 & 0 & 4 & 11600 & 13400 & 15600 & 13300 \\
\hline B & DG-AND & 4 & 0 & 4 & 39400 & 44500 & 50200 & 44100 \\
\hline B & DG-ROA & 4 & 0 & 4 & 32600 & 36800 & 41600 & 36500 \\
\hline B & DG-ORR & 4 & $\mathbf{0}$ & 4 & 37300 & 42100 & 47600 & 41800 \\
\hline B & NL-ORR & 4 & 0 & 4 & 42400 & 47900 & 54100 & 47500 \\
\hline B & CHI-BV & 4 & 0 & 4 & 48900 & 55200 & 62400 & 54800 \\
\hline B & CHI-K25 & 4 & 0 & 4 & 55100 & 62300 & 70300 & 61800 \\
\hline B & CHE-ORR & 4 & 0 & 4 & .33500 & 37800 & 42700 & 37500 \\
\hline B & CR-ORR & 4 & $\mathbf{0}$ & 4 & 32700 & 36900 & 41700 & 36600 \\
\hline B & CR-AND & 4 & 0 & 4 & 29400 & 33200 & 37500 & 33000 \\
\hline$\dot{\mathbf{B}}$ & CR-ROA & 4 & 0 & 4 & 23000 & 26000 & 29300 & 25700 \\
\hline C & DG-AND & 4 & 0 & 4 & 42700 & 47100 & 52000 & 46800 \\
\hline C & DG-ROA & 4 & 0 & 4 & 38800 & 42900 & 47300 & 42600 \\
\hline C & DG-ORR & 4 & 0 & 4 & 43000 & 47400 & 52300 & 47100 \\
\hline C & NL-ORR & 4 & 0 & 4 & 41700 & 46000 & 50800 & 45700 \\
\hline C & CHI-BV & 4 & 0 & 4 & 52800 & 58200 & 64300 & 57900 \\
\hline C & CHI-K25 & 4 & 0 & 4 & 53700 & 59200 & 65400 & 58800 \\
\hline C & CHE-ORR & 4 & 0 & 4 & 34500 & 38100 & 42000 & 37800 \\
\hline C & CR-ORR & 4 & 0 & 4 & 41200 & 45500 & 50200 & 45200 \\
\hline C & CR-AND & 4 & 0 & 4 & 33800 & 37300 & 41100 & 37000 \\
\hline C & CR-ROA & 4 & 0 & 4 & 37900 & 41900 & 46200 & 41600 \\
\hline
\end{tabular}


Table 5.1 (continued)

\begin{tabular}{|c|c|c|c|c|c|c|c|c|}
\hline Horizon & $\begin{array}{l}\text { Formation- } \\
\text { location }\end{array}$ & $\mathrm{N}$ & I & D & Median & UCB95 & X95 & LTB9595 \\
\hline \multicolumn{9}{|c|}{ Lead } \\
\hline A & DG-AND & 4 & 0 & 4 & 28.6 & 39.1 & 53.4 & 38.3 \\
\hline A & DG-ROA & 4 & 0 & 4 & 23.6 & 32.2 & 44.0 & 31.5 \\
\hline A & DG-ORR & 4 & 0 & 4 & 20.3 & 27.7 & 37.9 & 27.2 \\
\hline A & NL-ORR & 3 & 0 & 3 & 17.5 & 25.1 & 32.7 & 22.4 \\
\hline A & CHI-BV & 3 & 0 & 3 & 35.7 & 51.1 & 66.5 & 45.5 \\
\hline A & CHI-K25 & 4 & $\mathbf{0}$ & 4 & 31.6 & 43.2 & 59.0 & 42.2 \\
\hline A & CHE-ORR & 4 & 0 & 4 & 18.0 & 24.6 & 33.6 & 24.1 \\
\hline A & CR-ORR & 4 & 0 & 4 & 38.2 & 52.2 & 71.3 & 51.1 \\
\hline A & CR-AND & 4 & $\mathbf{0}$ & 4 & 33.1 & 45.2 & 61.7 & 44.2 \\
\hline A & CR-ROA & 4 & 0 & 4 & 19.8 & 27.0 & 36.9 & 26.4 \\
\hline B & DG-AND & 4 & 0 & 4 & 18.8 & 25.9 & 35.6 & 25.3 \\
\hline B & DG-ROA & 4 & $\mathbf{0}$ & 4 & 12.8 & 17.6 & 24.2 & 17.2 \\
\hline B & DG-ORR & 4 & 0 & 4 & 11.8 & 16.2 & 22.3 & 15.8 \\
\hline B & NL-ORR & 3 & 0 & 3 & 11.8 & 17.1 & 22.4 & 15.2 \\
\hline B & CHI-BV & 4 & 0 & 4 & 20.1 & 27.7 & 38.0 & 27.1 \\
\hline B & CHI-K25 & 4 & 0 & 4 & 16.7 & 22.9 & 31.5 & 22.4 \\
\hline B & CHE-ORR & 4 & 0 & 4 & 10.0 & 13.8 & 19.0 & 13.5 \\
\hline B & CR-ORR & 4 & 0 & 4 & 18.5 & 25.4 & 35.0 & 24.9 \\
\hline B & CR-AND & 4 & 0 & 4 & 23.5 & 32.3 & 44.5 & 31.7 \\
\hline B & CR-ROA & 4 & 0 & 4 & 10.9 & 15.0 & 20.7 & 14.7 \\
\hline C & DG-AND & 3 & 0 & 3 & 21.3 & 34.3 & 48.7 & 29.5 \\
\hline C & DG-ROA & 4 & 0 & 4 & 15.7 & 23.8 & 36.0 & 23.1 \\
\hline C & DG-ORR & 4 & 0 & 4 & 14.7 & 22.2 & 33.6 & 21.6 \\
\hline C & NL-ORR & 4 & 0 & 4 & 23.7 & 35.9 & 54.2 & 34.9 \\
\hline C & CHI-BV & 4 & 0 & 4 & 40.0 & 60.5 & 91.5 & 58.9 \\
\hline C & CHI-K25 & 4 & 0 & 4 & 16.7 & 25.3 & 38.2 & 24.6 \\
\hline C & CHE-ORR & 4 & 0 & 4 & 20.9 & 31.5 & 47.7 & 30.7 \\
\hline C & CR-ORR & 4 & $\mathbf{0}$ & 4 & 33.9 & 51.2 & 77.4 & 49.8 \\
\hline C & CR-AND & 4 & 0 & 4 & 17.5 & 26.5 & 40.0 & 25.7 \\
\hline C & CR-ROA & 4 & 0 & 4 & 15.7 & 23.7 & 35.9 & 23.1 \\
\hline \multicolumn{9}{|c|}{ Lithium } \\
\hline A & DG-AND & 4 & 0 & 4 & 10.40 & 13.30 & 16.90 & 13.00 \\
\hline A & DG-ROA & 4 & 0 & 2 & 10.50 & 14.10 & 17.10 & 12.60 \\
\hline A & DG-ORR & 3 & 0 & 3 & 16.20 & 21.40 & 26.40 & 19.50 \\
\hline A & NL-ORR & 4 & 0 & 4 & 10.90 & 14.00 & 17.80 & 13.70 \\
\hline A & CHI-BV & 2 & 0 & 2 & 11.30 & 16.00 & 18.40 & 12.80 \\
\hline A & CHI-K25 & 4 & 0 & 4 & 13.70 & 17.40 & 22.30 & 17.10 \\
\hline A & CHE-ORR & 4 & 1 & 1 & 3.85 & 4.99 & 6.28 & 4.78 \\
\hline A & CR-ORR & 4 & 0 & 2 & 2.60 & 3.48 & 4.24 & 3.15 \\
\hline A & CR-AND & 4 & 0 & 4 & 7.18 & 9.17 & 11.70 & 8.98 \\
\hline A & CR-ROA & 3 & 0 & 3 & 3.51 & 4.66 & 5.74 & 4.24 \\
\hline B & DG-AND & 4 & 0 & 4 & 19.20 & 24.60 & 31.60 & 24.20 \\
\hline B & DG-ROA & 4 & 0 & 4 & 19.20 & 24.60 & 31.50 & 24.10 \\
\hline B & DG-ORR & 4 & 0 & 4 & 22.10 & 28.40 & 36.40 & 27.80 \\
\hline B & NL-ORR & 4 & 0 & 4 & 23.80 & 30.50 & 39.20 & 30.00 \\
\hline B & CHI-BV & 2 & 0 & 2 & 29.00 & 41.20 & 47.70 & 33.10 \\
\hline B & CHI-K25 & 4 & 0 & 4 & 32.60 & 41.80 & 53.60 & 41.10 \\
\hline
\end{tabular}


Table 5.1 (continued)

\begin{tabular}{clrrrrrrr}
\hline Horizon & $\begin{array}{c}\text { Formation- } \\
\text { location }\end{array}$ & N & I & D & Median & UCB95 & X95 & LTB9595 \\
\hline B & CHE-ORR & 4 & 0 & 3 & 10.60 & 13.90 & 17.40 & 13.00 \\
B & CR-ORR & 4 & 0 & 4 & 6.33 & 8.12 & 10.40 & 7.97 \\
B & CR-AND & 4 & 0 & 4 & 12.10 & 15.60 & 20.00 & 15.30 \\
B & CR-ROA & 3 & 0 & 3 & 8.76 & 11.70 & 14.40 & 10.60 \\
& & & & & & & & \\
C & DG-AND & 4 & 0 & 4 & 20.70 & 27.30 & 35.90 & 26.70 \\
C & DG-ROA & 4 & 0 & 4 & 24.60 & 32.30 & 42.50 & 31.60 \\
C & DG-ORR & 4 & 0 & 4 & 27.60 & 36.30 & 47.70 & 35.50 \\
C & NL-ORR & 4 & 0 & 4 & 23.40 & 30.80 & 40.50 & 30.20 \\
C & CHI-BV & 2 & 0 & 2 & 37.10 & 54.60 & 64.10 & 42.90 \\
C & CHI-K25 & 4 & 0 & 4 & 36.00 & 47.30 & 62.30 & 46.40 \\
C & CHE-ORR & 4 & 1 & 2 & 11.40 & 15.60 & 19.70 & 14.20 \\
C & CR-ORR & 4 & 0 & 3 & 4.09 & 5.40 & 7.07 & 5.26 \\
C & CR-AND & 4 & 0 & 4 & 12.80 & 16.80 & 22.10 & 16.50 \\
C & CR-ROA & 3 & 0 & 3 & 9.88 & 13.60 & 17.10 & 12.20
\end{tabular}

Magnesium

$\begin{array}{llrlrrrrr}\text { A } & \text { DG-AND } & 4 & 0 & 4 & 2690 & 3230 & 3880 & 3190 \\ \text { A } & \text { DG-ROA } & 4 & 0 & 4 & 1580 & 1900 & 2290 & 1880 \\ \text { A } & \text { DG-ORR } & 4 & 0 & 4 & 2850 & 3420 & 4110 & 3380 \\ \text { A } & \text { NL-ORR } & 4 & 0 & 4 & 2010 & 2410 & 2900 & 2380 \\ \text { A } & \text { CHI-BV } & 4 & 0 & 4 & 1380 & 1660 & 2000 & 1640 \\ \text { A } & \text { CHI-K25 } & 4 & 0 & 4 & 1080 & 1300 & 1570 & 1290 \\ \text { A } & \text { CHE-ORR } & 4 & 0 & 4 & 369 & 443 & 533 & 438 \\ \text { A } & \text { CR-ORR } & 4 & 0 & 4 & 463 & 557 & 669 & 550 \\ \text { A } & \text { CR-AND } & 4 & 0 & 4 & 680 & 817 & 982 & 807 \\ \text { A } & \text { CR-ROA } & 4 & 0 & 4 & 411 & 494 & 594 & 488 \\ & & & & & & & & \\ \text { B } & \text { DG-AND } & 4 & 0 & 4 & 2890 & 3370 & 3930 & 3340 \\ \text { B } & \text { DG-ROA } & 4 & 0 & 4 & 1980 & 2320 & 2700 & 2290 \\ \text { B } & \text { DG-ORR } & 4 & 0 & 4 & 3280 & 3820 & 4460 & 3790 \\ \text { B } & \text { NL-ORR } & 4 & 0 & 4 & 2720 & 3180 & 3710 & 3150 \\ \text { B } & \text { CHI-BV } & 4 & 0 & 4 & 2330 & 2720 & 3170 & 2690 \\ \text { B } & \text { CHI-K25 } & 4 & 0 & 4 & 2310 & 2690 & 3140 & 2660 \\ \text { B } & \text { CHE-ORR } & 4 & 0 & 4 & 813 & 949 & 1110 & 940 \\ \text { B } & \text { CR-ORR } & 4 & 0 & 4 & 569 & 664 & 776 & 658 \\ \text { B } & \text { CR-AND } & 4 & 0 & 4 & 869 & 1010 & 1180 & 1000 \\ \text { B } & \text { CR-ROA } & 4 & 0 & 4 & 556 & 648 & 757 & 642 \\ & & & & & & & & \\ \text { C } & \text { DG-AND } & 4 & 0 & 4 & 3560 & 4260 & 5080 & 4210 \\ \text { C } & \text { DG-ROA } & 4 & 0 & 4 & 3010 & 3590 & 4290 & 3550 \\ \text { C } & \text { DG-ORR } & 4 & 0 & 4 & 4370 & 5210 & 6230 & 5150 \\ \text { C } & \text { NL-ORR } & 4 & 0 & 4 & 3380 & 4040 & 4820 & 3990 \\ \text { C } & \text { CHI-BV } & 4 & 0 & 4 & 3230 & 3860 & 4610 & 3820 \\ \text { C } & \text { CHI-K25 } & 4 & 0 & 4 & 2290 & 2740 & 3270 & 2710 \\ \text { C } & \text { CHE-ORR } & 4 & 0 & 4 & 735 & 877 & 1050 & 867 \\ \text { C } & \text { CR-ORR } & 4 & 0 & 4 & 451 & 539 & 644 & 533 \\ \text { C } & \text { CR-AND } & 4 & 0 & 4 & 859 & 1030 & 1230 & 1010 \\ \text { C } & \text { CR-ROA } & 4 & 0 & 4 & 449 & 536 & 640 & 530\end{array}$


Table 5.1 (continued)

\begin{tabular}{|c|c|c|c|c|c|c|c|c|c|}
\hline Horizon & $\begin{array}{c}\text { Formation- } \\
\text { location }\end{array}$ & & $\mathbf{N}$ & I & D & Median & UCB95 & X95 & LTB9595 \\
\hline \multicolumn{10}{|c|}{ Manganese } \\
\hline A & DG-AND & & 4 & 0 & 4 & 708.0 & 970 & 1330 & 950 \\
\hline A & DG-ROA & & 4 & 0 & 4 & 1720.0 & 2360 & 3230 & 2310 \\
\hline A & DG-ORR & & 4 & 0 & 4 & 997.0 & 1370 & 1870 & 1340 \\
\hline A & NL-ORR & & 4 & 0 & 4 & 653.0 & 895 & 1230 & 877 \\
\hline A & CHI-BV & & 4 & 0 & 4 & 1050.0 & 1440 & 1980 & 1410 \\
\hline A & CHI-K25 & & 4 & $\mathbf{0}$ & 4 & 1670.0 & 2290 & 3130 & 2240 \\
\hline A & CHE-ORR & & 4 . & 0 & 4 & 921.0 & 1260 & 1730 & 1240 \\
\hline A & CR-ORR & & 4 & 0 & 4 & 1070.0 & 1460 & 2000 & 1430 \\
\hline A & CR-AND & & 4 & 0 & 4 & 2230.0 & 3060 & 4190 & 3000 \\
\hline A & CR-ROA & & 4 & 0 & 4 & 853.0 & 1170 & 1600 & 1140 \\
\hline B & DG-AND & & 4 & 0 & 4 & 279.0 & 484 & 841 & 467 \\
\hline B & DG-ROA & & 4 & 0 & 4 & 341.0 & 593 & 1030 & 572 \\
\hline B & DG-ORR & & 4 & 0 & 4 & 279.0 & 484 & 842 & 467 \\
\hline B & NL-ORR & & 4 & 0 & 4 & 265.0 & 460 & 799 & 444 \\
\hline B & CHI-BV & & 4 & 0 & 4 & 378.0 & 656 & 1140 & 633 \\
\hline B & CHII-K25 & & 4 & 0 & 4. & 328.0 & 571 & 992 & 550 \\
\hline B & CHE-ORR & & 4 & 0 & 4 & 114.0 & 197 & 343 & 190 \\
\hline B & CR-ORR & & 4 & 0 & 4 & 139.0 & 242 & 421 & 233 \\
\hline B & CR-AND & & 4 & 0 & 4 & 519.0 & 902 & 1570 & 870 \\
\hline B & CR-ROA & & 4 & 0 & 4 & 123.0 & 214 & 372 & 206 \\
\hline C & DG-AND & & 4 & 0 & 4 & 535.0 & 1080 & 2180 & 1030 \\
\hline C & DG-ROA & & 4 & 0 & 4 & 265.0 & 535 & 1080 & 511 \\
\hline $\mathrm{C}$ & DG-ORR & & 4 & 0 & 4 & 344.0 & 693 & 1400 & 662 \\
\hline C & NL-ORR & 1 & 4 & 0 & 4 & 321.0 & 648 & 1310 & 619 \\
\hline $\mathrm{C}$ & CHI-BV & & 4 & 0 & 4 & 675.0 & 1360 & 2740 & 1300 \\
\hline C & CHI-K25 & & 4 & 0 & 4 & 370.0 & 747 & 1510 & 713 \\
\hline $\mathrm{C}$ & CHE-ORR & & 4 & 0 & 4 & 206.0 & 415 & 838 & 397 \\
\hline $\mathrm{C}$ & CR-ORR & & 4 & 0 & 4 & 92.5 & 186 & 376 & 178 \\
\hline $\mathrm{C}$ & CR-AND & & 4 & 0 & 4 & 326.0 & 658 & 1330 & 629 \\
\hline $\mathrm{C}$ & CR-ROA & & 4 & 0 & 4 & 67.9 & 137 & 276 & 131 \\
\hline \multicolumn{10}{|c|}{ Mercury } \\
\hline A & DG-AND & & 4 & 0 & 1 & 0.095 & 0.1180 & 0.1310 & 0.1050 \\
\hline A & DG-ROA & & 4 & 0 & 2 & 0.154 & 0.1840 & 0.2120 & 0.1770 \\
\hline A & DG-ORR & & 4 & 0 & 4 & 0.316 & 0.3700 & 0.4340 & 0.3650 \\
\hline A & NL-ORR & & 4 & 0 & 4 & 0.185 & 0.2170 & 0.2540 & 0.2140 \\
\hline A & CHI-BV & & 4 & 0 & 4 & 0.160 & 0.1880 & 0.2200 & 0.1850 \\
\hline A & $\mathrm{CHI}-\mathrm{K} 25$ & & 4 & 0 & 4 & 0.494 & 0.5790 & 0.6780 & 0.5710 \\
\hline A & CHE-ORR & & 4 & 1 & 2 & 0.129 & 0.1530 & 0.1770 & 0.1490 \\
\hline A & CR-ORR & & 4 & 0 & 4 & 0.157 & 0.1840 & 0.2150 & 0.1810 \\
\hline A & CR-AND & & 4 & 1 & 3 & 0.110 & 0.1300 & 0.1500 & 0.1260 \\
\hline A & CR-ROA & & 4 & 0 & 3 & 0.118 & 0.1390 & 0.1620 & 0.1360 \\
\hline B & DG-ROA & & 4 & $\mathbf{0}$ & 1 & 0.136 & 0.1660 & 0.1850 & 0.1520 \\
\hline B & DG-ORR & & 4 & 0 & 2 & 0.151 & 0.1800 & 0.2060 & 0.1710 \\
\hline B & CHI-K25 & & 4 & 0 & 3 & 0.117 & 0.1370 & 0.1590 & 0.1330 \\
\hline B & CHE-ORR & & 4 & 0 & 3 & 0.104 & 0.1220 & 0.1410 & 0.1180 \\
\hline B & CR-ORR & & 4 & 0 & 4 & 0.107 & 0.1250 & 0.1460 & 0.1220 \\
\hline B & CR-AND & & 4 & 0 & 4 & 0.131 & 0.1530 & 0.1790 & 0.1500 \\
\hline
\end{tabular}


Table 5.1 (continued)

\begin{tabular}{|c|c|c|c|c|c|c|c|c|}
\hline Horizon & $\begin{array}{l}\text { Formation- } \\
\text { location }\end{array}$ & $\mathbf{N}$ & I & $\mathrm{D}$ & Median & UCB95 & $\mathrm{x} 95$ & LTB9595 \\
\hline B & CR-ROA & 4 & 1 & 3 & 0.145 & 0.1690 & 0.1970 & 0.1650 \\
\hline B & REMAINDER & 12 & 0 & 0 & - & - & & . \\
\hline C & DG-ROA & 4 & $\mathbf{0}$ & 1 & 0.126 & 0.1570 & 0.1760 & 0.1410 \\
\hline C & DG-ORR & 4 & 0 & 1 & 0.060 & 0.0838 & 0.0838 & 0.0594 \\
\hline C & CHI-BV & 4 & 0 & 2 & 0.098 & 0.1180 & 0.1370 & 0.1130 \\
\hline C & CHI-K25 & 4 & 0 & 4 & 0.135 & 0.1590 & 0.1880 & 0.1560 \\
\hline C & CHE-ORR & 4 & $\mathbf{0}$ & 4 & 0.161 & 0.1900 & 0.2250 & 0.1870 \\
\hline C & CR-ORR & 4 & 0 & 4 & 0.248 & 0.2930 & 0.3460 & 0.2880 \\
\hline C & CR-AND & 4 & 0 & 4 & 0.179 & 0.2110 & 0.2500 & 0.2070 \\
\hline C & CR-ROA & 4 & 0 & 4 & 0.232 & 0.2740 & 0.3240 & 0.2690 \\
\hline C & REMAINDER & 8 & 0 & 0 & - & . & - & - \\
\hline \multicolumn{9}{|c|}{ Molybdenum } \\
\hline A & DG-AND & 4 & 1 & $\mathbf{0}$ & 1.28 & 1.72 & 1.69 & 1.24 \\
\hline A & CR-ORR & 4 & 0 & 1 & 1.41 & 1.75 & 1.87 & 1.48 \\
\hline A & REMAINDER & 29 & 0 & 0 & $\cdot$ & - & - & . \\
\hline B & DG-AND & 4 & 1 & 1 & 1.32 & 1.89 & 2.37 & 1.62 \\
\hline B & NL-ORR & 4 & $\mathbf{0}$ & 1 & 1.31 & 1.95 & 2.35 & 1.59 \\
\hline B & CHI-BV & 2 & $\mathbf{0}$ & 1 & 2.33 & 3.74 & 4.19 & 2.56 \\
\hline B & CHI-K25 & 4 & $\mathbf{0}$ & 1 & 2.13 & 3.20 & 3.82 & 2.56 \\
\hline B & CHE-ORR & 4 & $\mathbf{0}$ & 1 & 2.03 & 3.05 & 3.64 & 2.43 \\
\hline B & CR-ORR & 4 & 0 & 3 & 3.03 & 4.08 & 5.43 & 3.82 \\
\hline B & CR-AND & 4 & $\mathbf{0}$ & 2 & 2.66 & 3.70 & 4.78 & 3.35 \\
\hline B & CR-ROA & 3 & 0 & 1 & 1.47 & 2.30 & 2.64 & 1.68 \\
\hline B & REMAINDER & 8 & 0 & 0 & 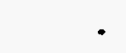 & - & - & 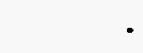 \\
\hline C & DG-AND & 4 & 0 & 2 & 1.57 & 2.02 & 2.44 & 1.86 \\
\hline C & CHE-ORR & 4 & 1 & 1 & 2.21 & 2.96 & 3.45 & 256 \\
\hline C & CR-ORR & 4 & 0 & 4 & 3.80 & 4.74 & 5.93 & 4.53 \\
\hline C & CR-AND & 4 & 0 & 2 & 2.71 & 3.48 & 4.22 & 3.23 \\
\hline C & CR-ROA & 3 & 1 & 2 & 2.62 & 3.44 & 4.08 & 3.01 \\
\hline C & REMAINDER & 18 & 0 & $\mathbf{0}$ & & . & . & \\
\hline
\end{tabular}

Nictel

$\begin{array}{llrlrrrrr}\text { A } & \text { DG-AND } & 4 & 0 & 4 & 20.80 & 25.80 & 32.00 & 25.40 \\ \text { A } & \text { DG-ROA } & 4 & 0 & 4 & 16.70 & 20.80 & 25.80 & 20.40 \\ \text { A } & \text { DG-ORR } & 4 & 0 & 4 & 23.50 & 29.10 & 36.10 & 28.60 \\ \text { A } & \text { NL-ORR } & 4 & 0 & 4 & 17.30 & 21.40 & 26.60 & 21.10 \\ \text { A } & \text { CHI-BV } & 4 & 0 & 4 & 13.50 & 16.70 & 20.70 & 16.40 \\ \text { A } & \text { CHI-K25 } & 4 & 0 & 4 & 17.20 & 21.30 & 26.50 & 21.00 \\ \text { A } & \text { CHE-ORR } & 4 & 1 & 0 & 5.74 & 7.65 & 8.83 & 6.62 \\ \text { A } & \text { CR-ORR } & 4 & 0 & 3 & 7.65 & 9.71 & 11.80 & 9.15 \\ \text { A } & \text { CR-AND } & 4 & 0 & 3 & .8 .64 & 10.70 & 13.30 & 10.50 \\ \text { A } & \text { CR-ROA } & 4 & 2 & 0 & 4.29 & 6.06 & 6.59 & 4.63 \\ & & & & & & & & \\ \text { B } & \text { DG-AND } & 4 & 0 & 4 & 24.30 & 30.40 & 38.00 & 29.80 \\ \text { B } & \text { DG-ROA } & 4 & 0 & 4 & 17.90 & 22.40 & 28.00 & 22.00 \\ \text { B } & \text { DG-ORR } & 4 & 0 & 4 & 22.90 & 28.60 & 35.70 & 28.10 \\ \text { B } & \text { NL-ORR } & 4 & 0 & 4 & 20.80 & 26.10 & 32.60 & 25.60 \\ \text { B } & \text { CHI-BV } & 4 & 0 & 4 & 22.60 & 28.20 & 35.30 & 27.70 \\ \text { B } & \text { CHI-K25 } & 4 & 0 & 4 & 21.70 & 27.10 & 33.90 & 26.60\end{array}$


Table 5.1 (continued)

\begin{tabular}{|c|c|c|c|c|c|c|c|c|}
\hline Horizon & $\begin{array}{c}\text { Formation- } \\
\text { location }\end{array}$ & $\mathrm{N}$ & I & $\mathrm{D}$ & Median & UCB95 & X95 & LTB9595 \\
\hline B & CHE-ORR & 4 & 0 & 1 & 10.50 & 13.80 & 16.50 & 12.60 \\
\hline $\mathbf{B}$ & CR-ORR & 4 & 0 & 4 & 11.50 & 14.30 & 17.90 & 14.10 \\
\hline $\mathbf{B}$ & CR-AND & 4 & 0 & 4 & 14.30 & 17.80 & 22.30 & 17.50 \\
\hline B & CR-ROA & 4 & 1 & 2 & 8.44 & 10.70 & 13.20 & 10.30 \\
\hline $\mathrm{C}$ & DG-AND & 4 & 0 & 4 & 29.20 & 37.30 & 47.80 & 36.70 \\
\hline $\mathrm{C}$ & DG-ROA & 4 & 0 & 4 & 26.90 & 34.40 & 44.10 & 33.80 \\
\hline $\mathrm{C}$ & DG-ORR & 4 & 0 & 4 & 28.80 & 36.90 & 47.30 & 36.30 \\
\hline C & NL-ORR & 4 & 0 & 4 & 24.30 & 31.10 & 39.90 & 30.60 \\
\hline $\mathrm{C}$ & CHI-BV & 4 & 0 & 4 & 31.90 & 40.90 & 52.30 & 40.20 \\
\hline $\mathrm{C}$ & CHI-K25 & 4 & 0 & 4 & 22.90 & 29.40 & 37.60 & 28.90 \\
\hline $\mathrm{C}$ & CHE-ORR & 4 & 0 & 3 & 19.90 & 25.60 & 32.70 & 25.10 \\
\hline $\mathrm{C}$ & CR-ORR & 4 & $\mathbf{0}$ & 4 & 15.80 & 20.20 & 25.90 & 19.90 \\
\hline $\mathrm{C}$ & CR-AND & 4 & 0 & 4 & 16.00 & 20.60 & 26.30 & 20.20 \\
\hline C & CR-ROA & 4 & 0 & 3 & 10.90 & 14.00 & 17.90 & 13.70 \\
\hline \multicolumn{9}{|c|}{ Osmium } \\
\hline A & REMAINDER & 4 & 0 & 0 & - & - & $\cdot$ & - \\
\hline B & REMANNDER & 5 & 0 & 0 & - & - & - & - \\
\hline C & REMAINDER & 5 & 0 & 0 & • & - & $\cdot$ & - \\
\hline \multicolumn{9}{|c|}{ Potassium } \\
\hline A & DG-AND & 4 & 0 & 4 & 3890 & 4740 & 5770 & 4670 \\
\hline A & DG-ROA & 4 & 0 & 4 & 1300 & 1590 & 1940 & 1570 \\
\hline$A$ & DG-ORR & 4 & 0 & 4 & 2300 & 2800 & 3410 & 2760 \\
\hline$A$ & NL-ORR & 4 & 0 & 4 & 2950 & 3590 & 4380 & 3540 \\
\hline A & CHI-BV & 4 & 0 & 4 & 1550 & 1890 & 2300 & 1860 \\
\hline A & CHI-K25 & 4 & 0 & 4 & 1690 & 2060 & 2510 & 2030 \\
\hline A & CR-ORR & 4 & 0 & 4 & 370 & 451 & 549 & 444 \\
\hline A & CR-AND & 4 & 0 & 4 & 505 & 615 & 749 & 606 \\
\hline A & CR-ROA & 3 & 1 & 2 & 290 & 370 & 430 & 335 \\
\hline A & REMAINDER & 4 & 0 & 0 &. & - & - & • \\
\hline B & DG-AND & 4 & 0 & 4 & 3850 & 4540 & 5350 & 4490 \\
\hline B & DG-ROA & 4 & 0 & 4 & 1730 & 2040 & 2410 & 2020 \\
\hline B & DG-ORR & 4 & 0 & 4 & 2590 & 3050 & 3590 & 3010 \\
\hline B & NL-ORR & 4 & 0 & 4 & 3690 & 4350 & 5130 & 4300 \\
\hline B & CHI-BV & 4 & 0 & 4 & 2400 & 2830 & 3330 & 2800 \\
\hline B & CHI-K25 & 4 & 0 & 4 & 3860 & 4550 & 5360 & 4500 \\
\hline B & CHE-ORR & 4 & 0 & 4 & 1100 & 1300 & 1530 & 1280 \\
\hline B & CR-ORR & 4 & 0 & 4 & 597 & 703 & 829 & 696 \\
\hline B & CR-AND & 4 & 0 & 4 & 854 & 1010 & 1190 & 996 \\
\hline B & CR-ROA & 3 & 0 & 3 & 479 & 578 & 664 & 545 \\
\hline C & DG-AND & 4 & 0 & 4 & 4460 & 5180 & 6020 & 5130 \\
\hline $\mathrm{C}$ & DG-ROA & 4 & 0 & 4 & 2490 & 2890 & 3360 & 2860 \\
\hline C & DG-ORR & 4 & 0 & 4 & 3130 & 3630 & 4220 & 3600 \\
\hline C & NL-ORR & 4 & 0 & 4 & 5020 & 5830 & 6770 & 5770 \\
\hline C & CHI-BV & 4 & 0 & 4 & 2470 & 2870 & 3330 & 2840 \\
\hline $\mathrm{C}$ & $\mathrm{CHI}-\mathrm{K} 25$ & 4 & 0 & 4 & 3810 & 4420 & 5140 & 4380 \\
\hline $\mathrm{C}$ & CHE-ORR & 4 & 0 & 4 & 1210 & 1410 & 1640 & 1390 \\
\hline
\end{tabular}


Table 5.1 (continued)

\begin{tabular}{|c|c|c|c|c|c|c|c|c|}
\hline Horizon & $\begin{array}{l}\text { Formation- } \\
\text { focation }\end{array}$ & $\mathbf{N}$ & I & D & Median & UCB95 & $\mathrm{x} 95$ & LTB9595 \\
\hline C & CR-ORR & 4 & 0 & 4 & 798 & 927 & 1080 & 918 \\
\hline C & CR-AND & 4 & 0 & 4 & 1010 & 1170 & 1360 & 1160 \\
\hline C & CR-ROA & 3 & 0 & 3 & 500 & 595 & 675 & 563 \\
\hline \multicolumn{9}{|c|}{ Selenium } \\
\hline A & DG-AND & 4 & 0 & 4 & 0.746 & 0.940 & 1.190 & 0.919 \\
\hline A & DG-ROA & 4 & 0 & 1 & 0.723 & 0.996 & 1.150 & 0.833 \\
\hline A & NL-ORR & 4 & 0 & 3 & 0.565 & 0.718 & 0.898 & 0.695 \\
\hline A & CHI-BV & 4 & 0 & 4 & 0.739 & 0.931 & 1.170 & 0.911 \\
\hline A & CHI-K25 & 4 & 0 & 4 & 0.763 & 0.962 & 1.210 & 0.940 \\
\hline A & CHE-ORR & 2 & 1 & 1 & 0.440 & 0.625 & 0.699 & 0.486 \\
\hline A & CR-ORR & 4 & 0 & 4 & 0.637 & 0.803 & 1.010 & 0.785 \\
\hline A & CR-AND & 4 & $\mathbf{0}$ & 4 & 1.040 & 1.310 & 1.650 & 1.280 \\
\hline A & CR-ROA & 4 & 0 & 2 & 0.483 & 0.621 & 0.767 & 0.591 \\
\hline A & REMAINDER & 4 & 0 & 0 & - & - & - & \\
\hline B & DG-AND & 4 & 0 & 4 & 0.676 & 0.809 & 0.967 & 0.795 \\
\hline B & DG-ROA & 4 & 0 & 1 & 0.429 & 0.595 & 0.613 & 0.440 \\
\hline B & NL-ORR & 4 & 0 & 3 & 0.649 & 0.779 & 0.928 & 0.763 \\
\hline B & CHI-BV & 4 & 0 & 4 & 0.785 & 0.938 & 1.120 & 0.922 \\
\hline B & CHI-K25 & 4 & 0 & 3 & 0.721 & 0.877 & 1.030 & 0.838 \\
\hline B & CHE-ORR & 3 & 0 & 2 & 0.474 & 0.592 & 0.677 & 0.537 \\
\hline B & CR-ORR & 4 & 0 & 4 & 0.813 & 0.971 & 1.160 & 0.955 \\
\hline B & CR-AND & 4 & 0 & 4 & 0.622 & 0.744 & 0.889 & 0.731 \\
\hline B & CR-ROA & 4 & 0 & 3 & 0.588 & 0.706 & 0.841 & 0.691 \\
\hline B & REMAINDER & 4 & 0 & 0 & • & & - & • \\
\hline C & DG-AND & 4 & 1 & 3 & 0.495 & 0.637 & 0.804 & 0.612 \\
\hline C & NL-ORR & 4 & 0 & 3 & 0.817 & 1.050 & 1.330 & 1.020 \\
\hline C & CHI-BV & 4 & 0 & 2 & 0.612 & 0.792 & 0.994 & 0.758 \\
\hline C & CHI-K25 & 4 & 0 & 3 & 0.530 & 0.681 & 0.861 & 0.658 \\
\hline C & CHE-ORR & 3 & 0 & 2 & 0.531 & 0.709 & 0.862 & 0.635 \\
\hline C & CR-ORR & 4 & 0 & 4 & 0.880 & 1.120 & 1.430 & 1.090 \\
\hline C & CR-AND & 4 & 0 & 4 & 0.646 & 0.824 & 1.050 & 0.802 \\
\hline C & CR-ROA & 4 & 0 & 4 & 0.651 & 0.830 & 1.060 & 0.808 \\
\hline C & REMAINDER & 8 & 0 & 0 & • & - & - & \\
\hline \multicolumn{9}{|c|}{ Silicon } \\
\hline A & DG-AND & 4 & 0 & 4 & 221 & 243 & 267 & 241 \\
\hline A & DG-ROA & 4 & 0 & 4 & 484 & 532 & 585 & 528 \\
\hline A & DG-ORR & 4 & 0 & 4 & 506 & 556 & 611 & 552 \\
\hline A & NL-ORR & 4 & 0 & 4 & 245 & 269 & 295 & 267 \\
\hline A & CHI-BV & 2 & 0 & 2 & 510 & 583 & 616 & 536 \\
\hline A & CHI-K25 & 4 & 0 & 4 & 636 & 699 & 769 & 694 \\
\hline A & CHE-ORR & 4 & 0 & 4 & 541 & 595 & 653 & 590 \\
\hline A & CR-ORR & 1 & 0 & 1 & 633 & 764 & 764 & 631 \\
\hline A & CR-AND & 4 & 0 & 4 & 451 & 49.6 & 545 & 492 \\
\hline$A$ & CR-ROA & 1 & 0 & 1 & 580 & 700 & 700 & 577 \\
\hline B & DG-AND & 4 & 0 & 4 & 239 & 268 & 299 & 265 \\
\hline B & DG-ROA & 4 & 0 & 4 & 519 & 580 & 649 & 575 \\
\hline B & DG-ORR & 4 & 0 & 4 & 491 & 549 & 613 & 544 \\
\hline
\end{tabular}


Table 5.1 (continued)

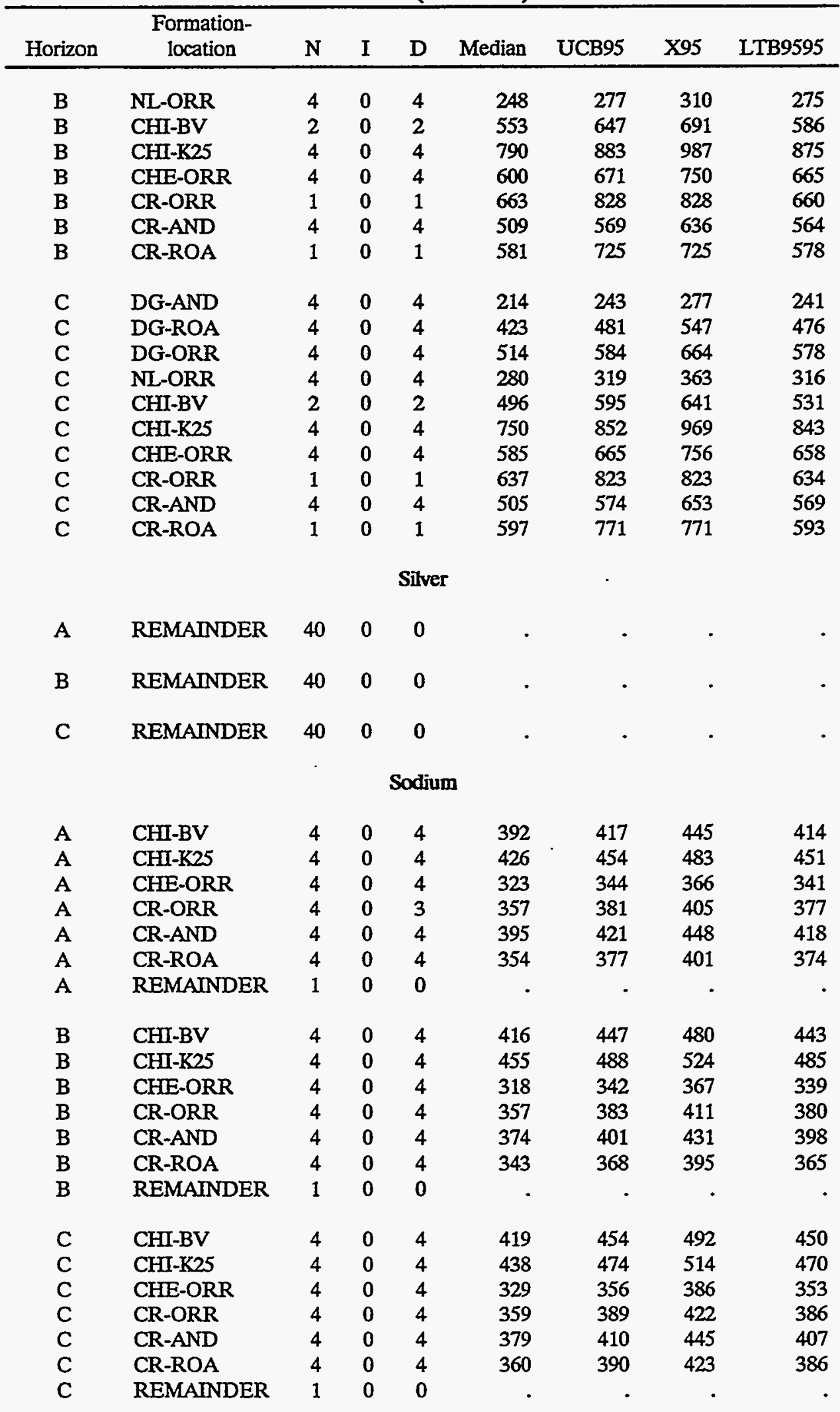


Table 5.1 (continued)

\begin{tabular}{|c|c|c|c|c|c|c|c|c|}
\hline Horizon & $\begin{array}{l}\text { Formation- } \\
\text { location }\end{array}$ & $\mathbf{N}$ & I & D & Median & UCB95 & $\mathrm{X95}$ & LTB9595 \\
\hline \multicolumn{9}{|c|}{ Strontium } \\
\hline A & DG-AND & 4 & 0 & 4 & 6.180 & 8.480 & 11.60 & 8.270 \\
\hline $\mathbf{A}$ & DG-ROA & 4 & 0 & 4 & 4.970 & 6.820 & 9.35 & 6.650 \\
\hline A & DG-ORR & 3 & 0 & 3 & 7.930 & 11.400 & 14.90 & 10.100 \\
\hline A & NL-ORR & 4 & 0 & 4 & 4.550 & 6.250 & 8.57 & 6.090 \\
\hline A & CHI-BV & 2 & 0 & 2 & 5.520 & 8.640 & 10.40 & 6.530 \\
\hline A & CHI-K25 & 4 & 0 & 4 & 11.700 & 16.000 & 2200 & 15.600 \\
\hline A & CHE-ORR & 4 & 0 & 2 & 2.360 & 3.330 & 4.45 & 3.120 \\
\hline A & CR-ORR & 4 & 0 & 4 & 3.510 & 4.810 & 6.60 & 4.700 \\
\hline A & CR-AND & 4 & 0 & 4 & 5.590 & 7.680 & 10.50 & 7.490 \\
\hline A & CR-ROA & 3. & 0 & 3 & 3.480 & 5.020 & 6.56 & 4.460 \\
\hline B & DG-AND & 4 & 0 & 4 & 4.320 & 6.340 & 9.32 & 6.150 \\
\hline B & DG-ROA & 4 & 0 & 4 & 4.630 & 6.810 & 10.00 & 6.600 \\
\hline B & DG-ORR & 4 & 0 & 4 & 7.520 & 11.100 & 16.20 & 10.700 \\
\hline B & NL-ORR & 4 & 0 & 4 & 5.520 & 8.100 & 11.90 & 7.860 \\
\hline B & CHII-BV & $2^{\prime}$ & 0 & 2 & 6.900 & 11.900 & 14.90 & 8.450 \\
\hline B & $\mathrm{CHI}-\mathrm{K} 25$ & 4 & 0 & 4 & 14.400 & 21.200 & 31.10 & 20.500 \\
\hline B & CHE-ORR & 4 & 0 & 2 & 2.830 & 4.300 & 6.11 & 3.970 \\
\hline B & CR-ORR & 4 & 0 & 3 & 1.910 & 2.840 & 4.13 & 2.710 \\
\hline B & CR-AND & 4 & 0 & 4 & 2.890 & 4.250 & 6.24 & 4.120 \\
\hline B & CR-ROA & 3 & 0 & 3 & 2.380 & 3.710 & 5.14 & 3.210 \\
\hline $\mathrm{C}$ & DG-AND & 4 & 0 & 4 & 3.760 & 5.900 & 9.26 & 5.670 \\
\hline $\mathrm{C}$ & DG-ROA & 4 & 0 & 4 & 4.170 & $6.55 ़ 0$ & 10.30 & 6.290 \\
\hline C & DG-ORR & 4 & 0 & 4 & 8.970 & 14.100 & 22.10 & 13.600 \\
\hline $\mathrm{C}$ & NL-ORR & 4 & 0 & 4 & 5.190 & 8.150 & 12.80 & 7.840 \\
\hline $\mathrm{C}$ & CHI-BV & 2 & 0 & 2 & 13.200 & 25.100 & $32.70^{\circ}$ & 16.800 \\
\hline $\mathrm{C}$ & CHI-K25 & 4 & 0 & 4 & 12.800 & 20.000 & 31.50 & 19.300 \\
\hline $\mathrm{C}$ & CHE-ORR & 4 & 0 & 2 & 0.596 & 0.962 & 1.47 & 0.893 \\
\hline C & CR-AND & 4 & 0 & 4 & 1.860 & 2.930 & 4.60 & 2.820 \\
\hline $\mathrm{C}$ & CR-ROA & 3 & 0 & 3 & 1.480 & 2.490 & 3.65 & 2.090 \\
\hline $\mathrm{C}$ & REMAINDER & 4 & 0 & 0 & - & • & - & . \\
\hline
\end{tabular}

Sulfate

$\begin{array}{lllllrrrr}\text { A } & \text { DG-AND } & 4 & 0 & 4 & 14.10 & 19.6 & 27.4 & 19.2 \\ \text { A } & \text { DG-ROA } & 4 & 0 & 4 & 69.90 & 97.5 & 136.0 & 95.3 \\ \text { A } & \text { DG-ORR } & 3 & 0 & 3 & 86.70 & 127.0 & 169.0 & 113.0 \\ \text { A } & \text { NL-ORR } & 4 & 0 & 4 & 18.70 & 26.0 & 36.3 & 25.5 \\ \text { A } & \text { CHI-BV } & 4 & 0 & 4 & 94.70 & 132.0 & 184.0 & 129.0 \\ \text { A } & \text { CHI-K25 } & 4 & 0 & 4 & 178.00 & 248.0 & 346.0 & 243.0 \\ \text { A } & \text { CHE-ORR } & 4 & 0 & 4 & 73.70 & 103.0 & 143.0 & 101.0 \\ \text { A } & \text { CR-ORR } & 4 & 0 & 4 & 63.20 & 88.2 & 123.0 & 86.3 \\ \text { A } & \text { CR-AND } & 4 & 0 & 4 & 104.00 & 146.0 & 203.0 & 142.0 \\ \text { A } & \text { CR-ROA } & 4 & 0 & 4 & 54.90 & 76.6 & 107.0 & 74.9 \\ & & & & & & & & \\ \text { B } & \text { DG-AND } & 4 & 0 & 4 & 41.80 & 58.2 & 81.0 & 56.9 \\ \text { B } & \text { DG-ROA } & 4 & 0 & 4 & 134.00 & 187.0 & 260.0 & 183.0 \\ \text { B } & \text { DG-ORR } & 4 & 0 & 4 & 103.00 & 143.0 & 199.0 & 140.0 \\ \text { B } & \text { NL-ORR } & 4 & 0 & 4 & 79.00 & 110.0 & 153.0 & 108.0 \\ \text { B } & \text { CHI-BV } & 4 & 0 & 4 & 79.40 & 111.0 & 154.0 & 108.0 \\ \text { B } & \text { CHI-K25 } & 4 & 0 & 4 & 137.00 & 191.0 & 266.0 & 187.0 \\ \text { B } & \text { CHE-ORR } & 4 & 0 & 4 & 46.00 & 64.1 & 89.3 & 62.7\end{array}$


Table 5.1 (continued)

\begin{tabular}{llrrrrrrr}
\hline Horizon & $\begin{array}{c}\text { Formation- } \\
\text { location }\end{array}$ & N & I & D & Median & UCB95 & \multicolumn{1}{rc}{ X95 } & LTB9595 \\
\hline B & CR-ORR & 4 & 0 & 4 & 44.90 & 62.6 & 87.2 & 61.3 \\
B & CR-AND & 4 & 0 & 4 & 55.40 & 77.1 & 107.0 & 75.4 \\
B & CR-ROA & 4 & 0 & 4 & 57.60 & 80.2 & 112.0 & 78.5 \\
& & & & & & & & \\
C & DG-AND & 4 & 0 & 4 & 16.00 & 24.7 & 37.9 & 23.9 \\
C & DG-ROA & 4 & 0 & 4 & 47.20 & 72.5 & 112.0 & 70.2 \\
C & DG-ORR & 4 & 0 & 4 & 129.00 & 199.0 & 306.0 & 192.0 \\
C & NL-ORR & 4 & 0 & 4 & 38.30 & 58.9 & 90.6 & 57.0 \\
C & CHI-BV & 4 & 0 & 4 & 36.70 & 56.5 & 86.8 & 54.7 \\
C & CHI-K25 & 4 & 0 & 4 & 43.70 & 67.3 & 103.0 & 65.2 \\
C & CHE-ORR & 4 & 1 & 2 & 13.50 & 21.3 & 32.0 & 19.9 \\
C & CR-ORR & 4 & 0 & 2 & 9.83 & 16.1 & 23.3 & 14.1 \\
C & CR-AND & 4 & 0 & 4 & 35.80 & 55.1 & 84.7 & 53.3 \\
C & CR-ROA & 4 & 0 & 3 & 10.80 & 17.1 & 25.7 & 16.0 \\
& & & & & & & & \\
& & & & Thallium & & & & \\
A & DG-ROA & 4 & 0 & 1 & 0.105 & 0.387 & 0.523 & 0.154 \\
A & DG-ORR & 4 & 0 & 1 & 0.165 & 0.556 & 0.818 & 0.257 \\
A & CR-AND & 4 & 1 & 0 & 0.394 & 1.370 & 1.950 & 0.605 \\
A & REMAINDER & 26 & 0 & 0 &. &. &. & \\
& & & & & & &. & \\
B & DG-ROA & 4 & 0 & 1 & 0.232 & 0.405 & 0.496 & 0.286 \\
B & DG-ORR & 4 & 0 & 2 & 0.326 & 0.500 & 0.696 & 0.414 \\
B & NL-ORR & 4 & 0 & 1 & 0.343 & 0.597 & 0.732 & 0.430 \\
B & CR-ORR & 4 & 0 & 1 & 0.273 & 0.486 & 0.583 & 0.335 \\
B & REMAINDER & 22 & 0 & 0 &. &. &. & \\
& & & & & & & \\
C & DG-ROA & 4 & 0 & 1 & 0.269 & 0.394 & 0.489 & 0.335 \\
C & DG-ORR & 4 & 0 & 2 & 0.345 & 0.485 & 0.626 & 0.430 \\
C & NL-ORR & 4 & 0 & 4 & 0.576 & 0.777 & 1.050 & 0.712 \\
C & CHE-ORR & 2 & 1 & 0 & 0.313 & 0.542 & 0.569 & 0.321 \\
C & CR-AND & 4 & 0 & 1 & 0.463 & 0.710 & 0.840 & 0.553 \\
C & REMAINDER & 20 & 0 & 0 &. &. &. &. \\
& & & & & & & &
\end{tabular}

\section{Vanadium}

\begin{tabular}{|c|c|c|c|c|c|c|c|c|}
\hline A & DG-AND & 4 & 0 & 4 & 30.3 & 34.8 & 39.8 & 34.5 \\
\hline A & DG-ROA & 4 & 0 & 4 & 32.2 & 36.9 & 42.3 & 36.6 \\
\hline A & DG-ORR & 4 & 0 & 4 & 34.2 & 39.1 & 44.8 & 38.8 \\
\hline A & NL-ORR & 4 & 0 & 4 & 32.4 & 37.1 & 42.5 & 36.8 \\
\hline A & CHI-BV & 4 & 0 & 4 & 36.5 & 41.9 & 48.0 & 41.5 \\
\hline A & CHI-K25 & 4 & 0 & 4 & 36.6 & 42.0 & 48.1 & 41.6 \\
\hline A & CHE-ORR & 4 & 0 & 4 & 30.0 & 34.3 & 39.3 & 34.0 \\
\hline A & CR-ORR & 4 & 0 & 4 & 26.4 & 30.3 & 34.7 & 30.0 \\
\hline A & CR-AND & 4 & 0 & 4 & 34.4 & 39.4 & 45.1 & 39.0 \\
\hline A & CR-ROA & 4 & 0 & 4 & 23.0 & 26.4 & 30.2 & 26.1 \\
\hline B & DG-AND & 4 & 0 & 4 & 44.8 & 50.7 & 57.5 & 50.3 \\
\hline B & DG-ROA & 4 & 0 & 4 & 39.1 & 44.3 & 50.2 & 43.9 \\
\hline B & DG-ORR & 3 & 0 & 3 & 39.8 & 45.9 & 51.0 & 43.9 \\
\hline B & NL-ORR & 4 & 0 & 4 & 45.9 & 52.0 & 58.9 & 51.5 \\
\hline B & CHI-BV & 4 & 0 & 4 & 44.1 & 50.0 & 56.6 & 49.6 \\
\hline B & CHI-K25 & 4 & 0 & 4 & 52.7 & 59.7 & 67.6 & 59.2 \\
\hline B & CHE-ORR & 4 & 0 & 4 & 61.7 & 69.9 & 79.2 & 69.3 \\
\hline
\end{tabular}


Table 5.1 (continued)

\begin{tabular}{|c|c|c|c|c|c|c|c|c|}
\hline Horizon & $\begin{array}{l}\text { Formation- } \\
\text { location }\end{array}$ & $N$ & I & $\mathrm{D}$ & Median & UCB95 & X95 & LTB9595 \\
\hline B & CR-ORR & 4 & 0 & 4 & 63.4 & 71.8 & 81.3 & 71.2 \\
\hline B & CR-AND & 4 & 0 & 4 & 57.5 & 65.2 & 73.8 & 64.6 \\
\hline B & CR-ROA & 4 & 0 & 4 & 49.3 & 55.8 & 63.3 & 55.4 \\
\hline C & DG-AND & 4 & 0 & 4 & 42.6 & 47.6 & 53.2 & 47.3 \\
\hline C & DG-ROA & 4 & 0 & 4 & 35.0 & 39.1 & 43.7 & 38.8 \\
\hline C & DG-ORR & 4 & 0 & 4 & 46.6 & 52.1 & 58.2 & 51.7 \\
\hline C & NL-ORR & 4 & 0 & 4 & 41.4 & 46.2 & 51.6 & 45.9 \\
\hline C & CHI-BV & 4 & 0 & 4 & 42.1 & 47.0 & 52.5 & 46.7 \\
\hline C & CHI-K25 & 4 & 0 & 4 & 45.8 & 51.2 & 57.1 & 50.8 \\
\hline C & CHE-ORR & 4 & 0 & 4 & 57.9 & 64.6 & 72.2 & 64.2 \\
\hline C & CR-ORR & 4 & 0 & 4 & 78.3 & 87.4 & 97.6 & 86.8 \\
\hline C & CR-AND & 4 & 0 & 4 & 63.6 & 71.0 & 79.2 & 70.5 \\
\hline C & CR-ROA & 4 & 0 & 4 & 81.1 & 90.5 & 101.0 & 89.9 \\
\hline \multicolumn{9}{|c|}{ Zine } \\
\hline A & DG-AND & 4 & 0 & 4 & 49.7 & 61.4 & 75.9 & 60.6 \\
\hline A & DG-ROA & 4 & 0 & 4 & 40.7 & 50.3 & 62.1 & 49.6 \\
\hline A & DG-ORR & 4 & 0 & 4 & 50.6 & 62.6 & 77.4 & 61.7 \\
\hline A & NL-ORR & 4 & 0 & 4 & 37.9 & 46.8 & 57.9 & 46.2 \\
\hline A & CHI-BV & 4 & 0 & 4 & 44.9 & 55.5 & 68.6 & 54.8 \\
\hline A & CHI-K25 & 4 & 0 & 4 & 46.0 & 56.9 & 70.4 & 56.1 \\
\hline A & CHE-ORR & 4 & 0 & 4 & 39.3 & 48.6 & 60.1 & 47.9 \\
\hline A & CR-ORR & 4 & 0 & 4 & 34.9 & 43.2 & 53.4 & 42.6 \\
\hline A & CR-AND & 4 & 0 & 4 & 44.1 & 54.5 & 67.3 & 53.7 \\
\hline A & CR-ROA & 4 & 0 & 4 & 39.4 & 48.7 & 60.2 & 48.0 \\
\hline B & DG-AND & 4 & 0 & 4 & 51.0 & 66.2 & 86.0 & 65.1 \\
\hline B & DG-ROA & 4 & 0 & 4 & 41.1 & 53.4 & 69.4 & 52.5 \\
\hline B & DG-ORR & 4 & 0 & 4 & 51.5 & 66.9 & 86.9 & 65.8 \\
\hline B & NL-ORR & 4 & 0 & 4 & 44.5 & 57.8 & 75.0 & 56.8 \\
\hline B & CHI-BV & 4 & 0 & 4 & 58.9 & 76.5 & 99.4 & 75.2 \\
\hline B & CHII-K25 & 4 & 0 & 4 & 71.0 & 92.2 & 120.0 & 90.6 \\
\hline B & CHE-ORR & 4 & 0 & 4 & 116.0 & 151.0 & 196.0 & 149.0 \\
\hline B & CR-ORR & 4 & 0 & 4 & 76.7 & 99.6 & 129.0 & 97.9 \\
\hline B & CR-AND & 4 & 0 & 4 & 73.3 & 95.2 & 124.0 & 93.6 \\
\hline B & CR-ROA & 4 & 0 & 4 & 43.5 & 56.5 & 73.4 & 55.6 \\
\hline c & DG-AND & 4 & 0 & 4 & 59.5 & 79.0 & 105.0 & 77.5 \\
\hline C & DG-ROA & 4 & 0 & 4 & 51.1 & 67.8 & 90.0 & 66.5 \\
\hline C & DG-ORR & 4 & 0 & 4 & 61.5 & 81.6 & 108.0 & 80.1 \\
\hline$c$ & NL-ORR & 4 & 0 & 4 & 44.6 & 59.3 & 78.7 & 58.1 \\
\hline C & CHI-BV & 4 & 0 & 4 & 82.9 & 110.0 & 146.0 & 108.0 \\
\hline $\mathrm{C}$ & CHII-K25 & 4 & 0 & 4 & 65.4 & 86.8 & 115.0 & 85.2 \\
\hline C & CHE-ORR & 4 & 0 & 4 & 171.0 & 227.0 & 302.0 & 223.0 \\
\hline C & CR-ORR & 4 & 0 & 3 & 129.0 & 173.0 & 227.0 & 166.0 \\
\hline C & CR-AND & 4 & 0 & 4 & 82.8 & 110.0 & 146.0 & 108.0 \\
\hline C & CR-ROA & 4 & 0 & 4 & 55.2 & 73.2 & 97.2 & 71.9 \\
\hline
\end{tabular}

${ }^{\circ} \mathrm{N}=$ number of observations, possibly averages over replicates at sites; $\mathrm{I}=$ number of interval censored observations (see text); $D=$ number of true detects (see text); UCB95 $=95 \%$ upper confidence bound for median; X95 = estimate of 95th percentile; LTB9595 = 95\% lower confidence bound for 95th percentile; REMAINDER refers to the remaining observations-no detects. 


\begin{tabular}{||c|l||}
\hline \hline Abbreviation & \multicolumn{1}{|c|}{ Definition } \\
\hline DG-AND & Dismal Gap-Anderson County \\
DG-ROA & Dismal Gap-Roane County \\
DG-ORR & Dismal Gap-Oak Ridge Reservation \\
NL-ORR & Nolichucky-Oak Ridge Reservation \\
CHI-BV & Chickamauga-Bethel Valley \\
CHI-K25 & Chickamauga-K-25 Area \\
CHE-ORR & Chepultepec-Oak Ridge Reservation \\
CR-ORR & Copper Ridge-Oak Ridge Reservation \\
CR-AND & Copper Ridge-Anderson County \\
CR-ROA & Copper Ridge-Roane County \\
\hline
\end{tabular}

The statistical accuracy of the results can be assessed by comparing the estimates to their corresponding confidence bounds: the median to the UCB95 and the percentile X95 (for composites of three) to the lower tolerance bound LTB9595, and by comparing the two confidence bounds. Consider, for example, the beryllium, A horizon of the ORR Dismal Gap row in Table 5.1. The median and 95th percentile estimates are 0.78 and $1.17 \mathrm{mg} / \mathrm{kg}$ per gram. But, as indicated, we can be $95 \%$ confident only that the median is less than 0.96 , and $95 \%$ confident that the 95th percentile exceeds $0.94 \mathrm{mg} / \mathrm{kg}$. On the basis of these data and statistical arguments, and given a beryllium measurement of a composite of three from a new test location, one could not rule out beryllium contamination at the new location, unless the level there was less than about 0.94 . Since it is $95 \%$ certain only that the background median is less than 0.96 , one cannot be confident of not getting future beryllium samples for which contamination would not be ruled out-even in uncontaminated areas-on the basis of these data. This is an unavoidable consequence of the study's small sample sizes. Of course, in practice, on the basis of risk arguments, EPA guidelines, etc., levels much higher than this might be needed to trigger an alarm. Nevertheless, on a purely statistical basis, the results are inadequate. To increase statistical precision, further combining of data may be necessary, or it may simply be necessary to collect more data.

An example of further data combination is presented in Table 6.1a, which is like Table 5.1 except that the breakdown is by ORR groups rather than formations. The groups are the Conasauga (Dismal Gap and Nolichucky formations), Knox (Copper Ridge and Chepultepec formations), and Chickamauga soils group, represented by the two ORR Chickamauga sampling locations. The UCB95 statistics tend to be lower than the LTB9595s in Table 6.1a, a reflection of the combination of data (over formations) for each group. Of course, combining data as in Table 6.1a should be justified. To this end, tests to compare areas within groups are discussed here and in Sect. 6.

The usual summary statistics are not meaningful when nearly all of the observations are nondetects. For those inorganics, Table 5.2 presents an alternative. Table 5.2 contains $95 \%$ UCBs for the probabilities of detection or exceeding the MAXDL for those analytes having fewer than $20 \%$ detects. Field duplicates and splits were dropped. (Consequently, there may be a few discrepancies between number of detects in Tables 5.1 and 5.2.) The MAXDLs are only for the nondetects. When the UCBs in Table 5.2 are less than 0.05 or perhaps 0.10 , the observation of a new detect in a similar area suggests that the background values may have been compromised. 
Table 5.2 Additional summary statistics for inorganics with fewer than $20 \%$ detects (Data have been combined over sampling areas.)

\begin{tabular}{|c|c|c|c|c|c|c|c|}
\hline Analysis & Horizon & $\mathbf{N}$ & $\begin{array}{l}\text { MAXDL } \\
(\mathrm{mg} / \mathrm{kg})\end{array}$ & $\begin{array}{l}\text { Number of } \\
\text { detects }\end{array}$ & $\begin{array}{l}\text { 95\% UCB for } \\
\text { detection } \\
\text { probability }\end{array}$ & $\begin{array}{l}\text { Number } \\
\text { exceeding } \\
\text { MAXDL }\end{array}$ & $\begin{array}{l}\text { 95\% UCB for } \\
\text { prob. > MAXDL }\end{array}$ \\
\hline Antimony & A & 40 & 1.40 & 2 & 0.15 & 0 & 0.07 \\
\hline Antimony & B & 40 & 1.40 & 5 & 0.25 & 0 & 0.07 \\
\hline Antimony & C & 40 & 2.20 & 6 & 0.27 & 0 & 0.07 \\
\hline Boron & A & 34 & 19.80 & 6 & 0.32 & 4 & 0.25 \\
\hline Boron & B & 36 & $: 10.20$ & 7 & 0.33 & 6 & 0.30 \\
\hline Cadmium & A & 40 & 0.25 & 0 & 0.07 & 0 & 0.07 \\
\hline Cadmium & $\mathrm{B}^{\prime}$ & 40 & 0.24 & 1 & 0.11 & 0 & 0.07 \\
\hline Cadmium & $\mathrm{C}$ & 40 & 0.31 & 0 & 0.07 & 0 & 0.07 \\
\hline Cyanide & A & 37 & 1.30 & 5 & 0.26 & 0 & 0.08 \\
\hline Cyanide & B & 38 & 1.10 & 3 & 0.19 & 0 & 0.08 \\
\hline Cyanide & $\mathrm{C}$ & 37 & 1.10 & 2 & 0.16 & $\mathbf{0}$ & 0.08 \\
\hline Molybdenum & $A$ & 37 & 9.80 & 2 & 0.16 & 0 & 0.08 \\
\hline Osmium & A & 4 & 14.80 & 0 & 0.53 & 0 & 0.53 \\
\hline Osmium & B & 5 & 15.20 & 0 & 0.45 & 0 & 0.45 \\
\hline Osmium & $\mathrm{C}$ & 5 & 19.90 & 0 & 0.45 & 0 & 0.45 \\
\hline Silver & A & 40 & 2.10 & 0 & 0.07 & 0 & 0.07 \\
\hline Silver & B & 40 & 2.20 & 0 & 0.07 & 0 & 0.07 \\
\hline Silver & C & 40 & 2.80 & 0 & 0.07 & 0 & 0.07 \\
\hline Thallium & A & 38 & 0.78 & 2 & 0.16 & 1 & 0.12 \\
\hline Thallium & B & 38 & 0.67 & 5 & 0.26 & 0 & 0.08 \\
\hline
\end{tabular}

${ }^{a}$ Composited samples-95\% UCBs for probabilities of detection or of exceding the MAXDL. $N=$ number of observations, duplicates and splits not included. $\mathrm{MAXDL}=$ maximum detection limit for nondetects.

Some of the UCBs in Table 5.2 are above 0.10 . Results in the table have been combined over all BSCP FLs to increase the sample sizes. Reducing the UCBs further would require additional sampling from the same or new areas.

Tests for differences between FLs and between horizons are discussed in Sect. 5.2.3 and in Appendix G. Significance levels for tests for FL differences in inorganics are presented in Table G.5. Cadmium, boron, cyanide, osmium, silver, and horizon $\mathrm{A}$ antimony and molybdenum were not analyzed for FL differences because of little detection of these analytes. Neither were horizon B and $C$ antimony, which have almost no detects, except in the Nolichucky Formation, where there were four.

To see how to use Table G.3, consider, for example, horizon A arsenic. It shows significant differences among all FLs in general ( $\mathrm{p}<0.0001)$, among Copper Ridge locations $(\mathrm{p}=0.0002)$, among ORR FLs $(\mathrm{p}<0.0001)$, between the ORR Copper Ridge and the Chepultepec FLs ( $p=0.0008)$, and among the three groups $(\mathrm{p}<0.0001)$, but not among Dismal Gap locations $(p=0.20)$, or between the two ORR Chickamauga locations $(p=0.35)$, or between the ORR Dismal Gap and Nolichucky formations $(p=0.96)$.

FL comparisons are discussed further in Sect. 6. The differences can be further explored using other LR tests; for analysis-horizon combinations without censoring, using F-tests and 
t-tests; and, less formally, using Table 5.1 or graphical techniques. For example, horizon B aluminum, which shows significant differences among FLs overall, among Dismal Gap locations, and among ORR FLs, does not show differences among Copper Ridge locations. This is illustrated in Fig. 5.2. From the figure and Table 5.1, it is clear that horizon B aluminum is lowest in the Copper Ridge and Chepultepec formations, and, among Dismal Gap locations, slightly lower in Roane County.

Differences between horizons for the inorganics are analyzed first to see if the FL makes a difference in the horizon differences (it does seem to) and then to estimate the average differences for the various FLs. Significance levels for these comparisons are presented in Table G.6. For example, for aluminum, the FL has a significant effect on the horizon A-B differences $(p=0.0002)$. The average differences in aluminum concentrations $(\mathrm{mg} / \mathrm{kg})$ between horizons $\mathrm{A}$ and $\mathrm{B}$ by FL are

\begin{tabular}{lc}
\hline $\begin{array}{c}\text { Formation- } \\
\text { location }\end{array}$ & $\begin{array}{c}\text { Average difference } \\
\text { (mg/kg) }\end{array}$ \\
\hline DG-AND & -12425 \\
DG-ROA & -8700 \\
DG-ORR & -9975 \\
NOL-ORR & -12925 \\
CHI-BV & -13450 \\
CHI-K25 & -18150 \\
CHE-ORR & -10037 \\
CR-ORR & -6805 \\
CR-AND & -5675 \\
CR-ROA & -6249 \\
\hline awith standard error 2071.
\end{tabular}

Athough these differences vary significantly with FL, each is also highly significant ( $p \leq 0.0061$ in each case): in each FL, there is significantly more aluminum in horizon B than in A. Horizon differences for inorganics are discussed further in Sect. 6.

\subsection{HERBICIDES}

All results for herbicides are horizon A noncomposites. There are two detects, one on the ORR (2,4-D in the Chepultepec FL) and one in Roane County (MCPA in the Copper Ridge). Graphical examination reveals that the field duplicates and originals are generally in extremely close agreement for the herbicides. This suggests that perhaps the designation " $U$ " for nondetect may have been applied too conservatively. Of course, these data are nevertheless handled here as nondetects. Table 5.3 parallels Table 5.2 for the inorganics. For a fixed $N$ (number of samples), as long as the number of detects is fixed (e.g., at 0 ), the UCB is the same.

These UCBs are useful because they are small enough that we can be confident that a detect in a background area is a low-probability event. Thus, statistically, a detect suggests a departure from background. 
Table 5.3. Herbicides-95\% UCBs for probabilities of detection or of esceeding the MAXDL" (Horizon A data have been combined over sampling areas.)

\begin{tabular}{lcrcccc}
\hline \multicolumn{1}{c}{ Analysis } & N & $\begin{array}{c}\text { MAXDL } \\
(\mu \mathrm{g} / \mathrm{kg})\end{array}$ & $\begin{array}{c}\text { Number of } \\
\text { detects }\end{array}$ & $\begin{array}{c}\text { UCB for } \\
\text { detection } \\
\text { probability }\end{array}$ & $\begin{array}{c}\text { Number } \\
\text { exceeding } \\
\text { MAXDL }\end{array}$ & $\begin{array}{c}\text { UCB for } \\
\text { prob. }> \\
\text { MAXDL }\end{array}$ \\
\hline 2,4,5-T & 50 & 316.0 & 0 & 0.06 & 0 & 0.06 \\
2,4-D & 50 & 1894.0 & 1 & 0.09 & 0 & 0.06 \\
2,4-DB & 50 & 1421.0 & 0 & 0.06 & 0 & 0.06 \\
Dalapon & 38 & 5527.2 & 0 & 0.08 & 0 & 0.08 \\
Dicamba & 50 & 421.0 & 0 & 0.06 & 0 & 0.06 \\
Dichlorprop & 50 & 1052.0 & 0 & 0.06 & 0 & 0.06 \\
Dinoseb & 50 & 221.0 & 0 & 0.06 & 0 & 0.06 \\
MCPA & 50 & 394685.0 & 1 & 0.09 & 0 & 0.06 \\
MCPP & 50 & 299961.0 & 0 & 0.06 & 0 & 0.06 \\
Silvex & 50 & 263.0 & 0 & 0.06 & 0 & 0.06 \\
& & & & & 0 & 0.06 \\
\hline
\end{tabular}

${ }^{a} \mathrm{~N}=$ number of observations, duplicates and splits not included. MAXDL = maximum detection limit for nondetects.

\subsection{PESTICIDES}

All pesticide results are A horizon noncomposites. There are no statistical outliers. As with the herbicides, field duplicates and original results are all very close. After excluding duplicates, there were either 108 or 109 samples for each pesticide. Of these there were eight detects-four in Anderson County, two in Roane County, and two on the ORR. These results are discussed in Sect. 6. Table 5.4 for pesticides is analogous to Tables 5.2 and 5.3.

In spite of the detects, like the herbicide UCBs, the pesticide UCBs are useful because they are small enough that we can be confident that a detect in a background area is a low-probability event.

\subsection{PAHs}

All PAH results are $A$ horizon noncomposites. Many results have the validation designation " $R$ "'and are thus not used in the statistical analysis. (All of the originals in the original-reanalysis pairs are so designated.) There are no statistical outliers. However, most of the results for the Dismal Gap and Nolichucky formations are designated as nondetects (even though the PAH field duplicate and original results are nearly identical for all of the PAH samples from these areas and are exactly equal for most). However, most of the results for the other formations are detects, sometimes lower than the detection limits for the Dismal Gap and Nolichucky data. This is due to analytical laboratory contamination problems in the samples (see Sect. 4). Therefore, the results of those samples were excluded from the statistical analysis discussed in this section.

Table 5.5 gives UCBs for detection probabilities. Table 5.6 gives summary statistics for those PAHs having one or more detects. Tables 5.5 and 5.6 parallel Tables 5.1 and 5.2 for the inorganics. 
Table 5.4. Pesticides-95\% UCBs for probabilities of

detection or of exceeding maximum detection limit ${ }^{2}$

(Horizon A data have been combined over sampling areas.)

\begin{tabular}{|c|c|c|c|c|c|c|}
\hline Analysis & $\mathrm{N}$ & $\begin{array}{c}\text { MAXDL } \\
(\mu \mathrm{g} / \mathrm{kg})\end{array}$ & $\begin{array}{l}\text { Number of } \\
\text { detects }\end{array}$ & $\begin{array}{l}\text { UCB for } \\
\text { detection } \\
\text { probability }\end{array}$ & $\begin{array}{l}\text { Number } \\
\text { exceeding } \\
\text { MAXDI }\end{array}$ & $\begin{array}{c}\text { UCB for prob. } \\
\text { > MAXDL }\end{array}$ \\
\hline 4,4'-DDD & 109 & 13.0 & $\mathbf{0}$ & 0.03 & 0 & 0.03 \\
\hline 4,4'-DDE & 109 & 13.0 & $\mathbf{0}$ & 0.03 & $\mathbf{0}$ & 0.03 \\
\hline 4,4'-DDT & 109 & 13.0 & 2 & 0.06 & 1 & 0.04 \\
\hline Aldrin & 109 & 6.3 & 1 & 0.04 & $\mathbf{0}$ & 0.03 \\
\hline Aroclor 1016 & 109 & 130.0 & $\mathbf{0}$ & 0.03 & 0 & 0.03 \\
\hline Aroclor 1221 & 109 & 254.0 & $\mathbf{0}$ & 0.03 & $\mathbf{0}$ & 0.03 \\
\hline Aroclor 1232 & 109 & 130.0 & $\mathbf{0}$ & 0.03 & 0 & 0.03 \\
\hline Aroclor 1242 & 109 & 130.0 & 1 & 0.04 & 1 & 0.04 \\
\hline Aroclor 1248 & 109 & 130.0 & $\mathbf{0}$ & 0.03 & $\mathbf{0}$ & 0.03 \\
\hline Aroclor 1254 & 109 & 130.0 & $\mathbf{0}$ & 0.03 & 0 & 0.03 \\
\hline Aroclor 1260 & 109 & 130.0 & $\mathbf{0}$ & 0.03 & $\mathbf{0}$ & 0.03 \\
\hline Dieldrin & 109 & 13.0 & $\mathbf{0}$ & 0.03 & 0 & 0.03 \\
\hline Endosulfan I & 108 & 6.3 & 2 & 0.06 & 0 & 0.03 \\
\hline Endosulfan II & 109 & 13.0 & $\mathbf{0}$ & 0.03 & $\mathbf{0}$ & 0.03 \\
\hline Endosulfan sulfate & 109 & 23.5 & $\mathbf{0}$ & 0.03 & 0 & 0.03 \\
\hline Endrin & 109 & 13.0 & 0 & 0.03 & 0 & 0.03 \\
\hline Endrin aldehyde & 109 & 13.0 & $\mathbf{0}$ & 0.03 & $\mathbf{0}$ & 0.03 \\
\hline Endrin ketone & 109 & 13.0 & $\mathbf{0}$ & 0.03 & 0 & 0.03 \\
\hline Heptachlor & 109 & 6.3 & $\mathbf{0}$ & 0.03 & 0 & 0.03 \\
\hline Heptachlor epoxide & 109 & 6.3 & $\mathbf{0}$ & 0.03 & $\mathbf{0}$ & 0.03 \\
\hline Methoxychlor & 109 & 63.0 & $\mathbf{0}$ & 0.03 & 0 & 0.03 \\
\hline Toxaphene & 109 & 630.0 & $\mathbf{0}$ & 0.03 & $\mathbf{0}$ & 0.03 \\
\hline alpha-BHC & 109 & 6.3 & $\mathbf{0}$ & 0.03 & 0 & 0.03 \\
\hline alpha-Chlordane & 109 & 235.0 & 2 & 0.06 & 0 & 0.03 \\
\hline beta-BHC & 109 & 6.3 & $\mathbf{0}$ & 0.03 & $\mathbf{0}$ & 0.03 \\
\hline delta-BHC & 109 & 6.3 & $\mathbf{0}$ & 0.03 & 0 & 0.03 \\
\hline gamma-BHC (Lindane) & 109 & 6.3 & $\mathbf{0}$ & 0.03 & $\mathbf{0}$ & 0.03 \\
\hline gamma-Chlordane & 109 & 46.0 & $\mathbf{0}$ & 0.03 & $\mathbf{0}$ & 0.03 \\
\hline
\end{tabular}

${ }^{a} \mathrm{~N}=$ number of observations, duplicates and splits not included. $\mathrm{MAXDL}=$ maximum detection limit for nondetects.

Significance levels for comparisons of PAHs by FL are in Table G.4. Many of the PAHs do exhibit some significant differences.

Table 5.5. PAHs-95\% UCBs for detection probability (Horizon A data has been combined over sampling areas.)

\begin{tabular}{lcccccc}
\hline \multicolumn{1}{c}{ Analysis } & $\mathrm{N}$ & $\begin{array}{c}\text { MAXDL } \\
(\mu \mathrm{g} / \mathrm{kg})\end{array}$ & $\begin{array}{c}\text { Number of } \\
\text { detects }\end{array}$ & $\begin{array}{c}\text { UCB for } \\
\text { detection } \\
\text { probability }\end{array}$ & $\begin{array}{c}\text { Number } \\
\text { exceeding } \\
\text { MAXDL }\end{array}$ & $\begin{array}{c}\text { UCB for } \\
\text { prob. > } \\
\text { MAXDL }\end{array}$ \\
\hline Acenaphthene & 25 & 4.7 & 11 & 0.62 & 0 & 0.11 \\
Acenaphthylene & 61 & 236.7 & 5 & 0.16 & 2 & 0.10 \\
Anthracene & 44 & 4.7 & 39 & 0.95 & 3 & 0.17 \\
Benzo[b]fluoranthene & 52 & 4.7 & 47 & 0.96 & 12 & 0.35 \\
Chrysene & 36 & 4.7 & 23 & 0.77 & 11 & 0.45 \\
Dibenzo[a,h]anthracene & 33 & 4.7 & 27 & 0.92 & 1 & 0.14 \\
Fluorene & 34 & 4.7 & 20 & 0.73 & 1 & 0.13 \\
Indeno[1,2,3-c,d]pyrene & 64 & 45.2 & 27 & 0.53 & 1 & 0.07 \\
Naphthalene & 32 & 23.7 & 19 & 0.74 & 2 & 0.18 \\
\hline
\end{tabular}

${ }^{a} \mathrm{~N}=$ number of observations, duplicates and splits not included. $\mathrm{MAXDL}=$ maximum detection limit for nondetects. Note: Dismal Gap and Nolichucky (Phase I) data were excluded (see text of this section). 


\section{5-37}

Table 5.6. Additional summary statistics for PAHs

(Estimates and confidence bounds are in micrograms per kilogram.)

\begin{tabular}{|c|c|c|c|c|c|c|c|}
\hline $\begin{array}{l}\text { Formation- } \\
\text { location }\end{array}$ & $\mathbf{N}$ & I & D & Median & UCB95 & X95 & LTB9595 \\
\hline \multicolumn{8}{|c|}{ Acenaphthene } \\
\hline CHI-BV & 1 & $\mathbf{0}$ & 1 & 3.50 & 5.96 & 5.96 & 3.390 \\
\hline CHI-K25 & 3 & 0 & 3 & 1.33 & 1.82 & 2.27 & 1.590 \\
\hline CHE-ORR & 4 & $\mathbf{0}$ & 1 & 0.80 & 1.36 & 1.36 & 0.775 \\
\hline CR-ORR & 6 & $\mathbf{0}$ & 3 & 1.42 & 1.93 & 2.42 & 1.700 \\
\hline CR-AND & 2 & 0 & 2 & 1.20 & 1.74 & 2.04 & 1.340 \\
\hline CR-RÓA & 9 & 0 & 1 & 0.80 & 1.36 & 1.36 & 0.775 \\
\hline \multicolumn{8}{|c|}{ Acenaphthylene } \\
\hline CR-ORR & 10 & 0 & 4 & 57.6 & 240 & 1580 & 306.0 \\
\hline CR-ROA & 8 & 0 & 1 & 13.6 & 151 & 372 & 50.7 \\
\hline REMAINDER & 43 & 0 & 0 & . & - & - & $\cdot$ \\
\hline \multicolumn{8}{|c|}{ Anthracene } \\
\hline CHI-BV & 5 & 0 & 5 & 0.623 & 1.15 & 2.44 & 1.260 \\
\hline CHI-K25 & 10 & 0 & 10 & 1.240 & 1.91 & 4.85 & 2.950 \\
\hline CHE-ORR & 4 & 0 & 2 & 0.398 & 1.04 & 1.56 & 0.581 \\
\hline CR-ORR & 8 & 0 & 8 & 0.880 & 1.42 & 3.44 & 2000 \\
\hline CR-AND & 7 & 0 & 7 & 1.340 & 2.25 & 5.26 & 2960 \\
\hline CR-ROA & 10 & 0 & 7 & 1.410 & 2.30 & 5.52 & 3.240 \\
\hline \multicolumn{8}{|c|}{ Benzo $[a]$ anthracene } \\
\hline CHI-BV & 6 & 0 & 6 & 4.30 & 6.42 & 11.50 & 7.49 \\
\hline CHI-K25 & 12 & $\mathbf{0}$ & 12 & 5.65 & 7.51 & 15.10 & 11.00 \\
\hline CHE-ORR & 7 & 0 & 7 & 1.70 & 2.46 & 4.54 & 3.04 \\
\hline CR-ORR & 12 & 0 & 12 & 2.01 & 2.67 & 5.38 & 3.91 \\
\hline CR-AND & 11 & 0 & 11 & 2.13 & 2.87 & 5.70 & 4.10 \\
\hline CR-ROA & 12 & 0 & 12 & 3.22 & 4.28 & 8.62 & 6.26 \\
\hline \multicolumn{8}{|c|}{ Benzo[a]pyrene } \\
\hline CHI-BV & 12 & 0 & 12 & 3.78 & 4.92 & 9.42 & 7.00 \\
\hline CHI-K25 & 12 & $\mathbf{0}$ & 12 & 5.19 & 6.75 & 12.90 & 9.60 \\
\hline CHE-ORR & 5 & 0 & 5 & 3.28 & 4.93 & 8.17 & 5.31 \\
\hline CR-ORR & 10 & 0 & 10 & 2.66 & 3.54 & 6.61 & 4.81 \\
\hline CR-AND & 10 & $\mathbf{0}$ & 10 & 1.70 & 2.26 & 4.22 & 3.07 \\
\hline CR-ROA & 12 & 0 & 11 & 1.21 & 1.59 & 3.01 & 2.22 \\
\hline \multicolumn{8}{|c|}{ Benzo[b]fluoranthene } \\
\hline CHI-BV & 8 & $\mathbf{0}$ & 8 & 4.45 & 6.30 & 11.90 & 8.10 \\
\hline CHI-K25 & 12 & $\mathbf{0}$ & 12 & 4.58 & 6.09 & 12.30 & 8.83 \\
\hline CHE-ORR & 4 & 0 & 2 & 2.97 & 5.28 & 7.96 & 4.44 \\
\hline CR-ORR & 8 & 0 & 8 & 2.19 & 3.11 & 5.87 & 4.00 \\
\hline CR-AND & 8 & 0 & 8 & 2.66 & 3.77 & 7.12 & 4.85 \\
\hline CR-ROA & 12 & 0 & 9 & 1.79 & 246 & 4.80 & 3.38 \\
\hline \multicolumn{8}{|c|}{ Benzo[ghi]perylene } \\
\hline CHI-BV & 5 & $\mathbf{0}$ & 5 & 3.46 & 5.13 & 8.35 & 5.49 \\
\hline CHI-K25 & 12 & 0 & 12 & 4.78 & 6.16 & 11.50 & 8.62 \\
\hline CHE-ORR & 6 & 0 & 6 & 2.57 & 3.68 & 6.20 & 4.21 \\
\hline CR-ORR & 9 & 0 & 9 & 2.85 & 3.82 & 6.87 & 4.96 \\
\hline CR-AND & 10 & 0 & 10 & 231 & 3.05 & 5.57 & 4.07 \\
\hline CR-ROA & 11 & 0 & 10 & 1.90 & 2.51 & 4.59 & 3.37 \\
\hline
\end{tabular}


Table 5.6 (continued)

\begin{tabular}{|c|c|c|c|c|c|c|c|}
\hline $\begin{array}{l}\text { Formation- } \\
\text { location }\end{array}$ & $\mathbf{N}$ & I & $\mathbf{D}$ & Median & UCB95 & X95 & LTB9595 \\
\hline \multicolumn{8}{|c|}{ Benzo[k]fiuoranthene } \\
\hline CHII-BV & 12 & 0 & 12 & 2.270 & 2.91 & 5.34 & 4.04 \\
\hline CHI-K25 & 12 & 0 & 12 & 2.910 & 3.72 & 6.84 & 5.18 \\
\hline CHE-ORंR & 5 & 0 & 5 & 1.570 & 2.29 & 3.68 & 2.46 \\
\hline CR-ORR & 11 & 0 & 11 & 1.400 & 1.81 & 3.29 & 2.47 \\
\hline CR-AND & 9 & 0 & 9 & 1.360 & 1.81 & 3.19 & 2.34 \\
\hline CR-ROA & 12 & 0 & 12 & 0.943 & 1.21 & 2.22 & 1.68 \\
\hline \multicolumn{8}{|c|}{ Chrysene } \\
\hline CHI-BV & 5 & 0 & 4 & 4.98 & 7.82 & 13.20 & 8.02 \\
\hline $\mathrm{CHI}-\mathrm{K} 25$ & 6 & 0 & 4 & 5.31 & 8.01 & 14.10 & 8.92 \\
\hline CR-ORR & 9 & 0 & 9 & 3.93 & 5.45 & 10.40 & 6.98 \\
\hline CR-AND & 1 & 0 & 1 & 4.30 & 11.40 & 11.40 & 4.18 \\
\hline CR-ROA & 12 & 0 & 5 & 2.13 & 3.09 & 5.66 & 3.83 \\
\hline REMAINDER & 3 & 0 & 0 & - & - & - & - \\
\hline \multicolumn{8}{|c|}{ Dibenzo $[a, h]$ anthracene } \\
\hline CHI-BV & 3 & 0 & 2 & 0.597 & 1.42 & 2.05 & 0.83 \\
\hline CHI-K25 & 3 & 0 & 3 & 0.765 & 1.56 & 2.62 & 1.23 \\
\hline CHE-ORR & 5 & 0 & 3 & 1.030 & 2.03 & 3.51 & 1.70 \\
\hline CR-ORR & 8 & 0 & 8 & 1.030 & 1.59 & 3.53 & 2.12 \\
\hline CR-AND & 2 & $\mathbf{0}$ & 2 & 1.310 & 3.12 & 4.48 & 1.80 \\
\hline CR-ROA & 12 & $\mathbf{0}$ & 9 & 0.960 & 1.44 & 3.29 & 2.04 \\
\hline \multicolumn{8}{|c|}{ Fuoranthene } \\
\hline CHI-BV & 8 & 0 & 8 & 4.95 & 7.26 & 14.60 & 9.61 \\
\hline CHI-K25 & 11 & $\mathbf{0}$ & 11 & 6.82 & 9.45 & 20.10 & 13.90 \\
\hline CHE-ORR & 7 & 0 & 7 & 3.09 & 4.64 & 9.09 & 5.85 \\
\hline CR-ORR & 12 & $\mathbf{0}$ & 12 & 5.95 & 8.12 & 17.50 & 12.30 \\
\hline CR-AND & 6 & 0 & 6 & 2.85 & 4.42 & 8.39 & 5.23 \\
\hline CR-ROA & 12 & 0 & 12 & 4.38 & 5.99 & 12.90 & 9.06 \\
\hline \multicolumn{8}{|c|}{ Fluorene } \\
\hline CHI-BV & 2 & $\mathbf{0}$ & 2 & 2.600 & 5.540 & 7.58 & 3.400 \\
\hline CHI-K25 & 7 & 0 & 7 & 1.410 & 2.110 & 4.12 & 2.540 \\
\hline CHE-ORR & 6 & 0 & 2 & 0.365 & 0.726 & 1.07 & 0.523 \\
\hline CR-ORR & 6 & 0 & 3 & 0.873 & 1.590 & 2.55 & 1.340 \\
\hline CR-AND & 3 & 0 & 3 & 2.160 & 4.010 & 6.30 & 3.220 \\
\hline CR-ROA & 10 & 0 & 3 & 0.935 & 1.660 & 2.73 & 1.480 \\
\hline \multicolumn{8}{|c|}{ Indeno $[1,2,3-c, d]$ pyrene } \\
\hline CHI-BV & 11 & 0 & 8 & 11.20 & 16.2 & 34.1 & 22.4 \\
\hline CHII-K25 & 12 & 0 & 7 & 9.48 & 13.6 & 28.8 & 19.4 \\
\hline CHE-ORR & 7 & 0 & 1 & 7.85 & 15.9 & 23.9 & 12.0 \\
\hline CR-AND & 12 & 0 & 8 & 8.99 & 12.8 & 27.3 & 18.3 \\
\hline CR-ROA & 10 & 1 & 3 & 13.10 & 20.4 & 39.8 & 25.2 \\
\hline REMAINDER & 12 & 0 & 0 & - & - & - & - \\
\hline \multicolumn{8}{|c|}{ Naphthalene } \\
\hline CHI-BV & 7 & 0 & 7 & 6.20 & 10.90 & 27.70 & 13.90 \\
\hline CHI-K25 & 6 & 0 & 6 & 1.88 & 3.46 & 8.39 & 4.06 \\
\hline CHE-ORR & 4 & 0 & 3 & 9.50 & 21.50 & 42.40 & 17.50 \\
\hline CR-ORR & 7 & 0 & 3 & 8.05 & 16.50 & 35.90 & 17.00 \\
\hline REMAINDER & 8 & 0 & 0 & - & - & - & - \\
\hline
\end{tabular}


Table 5.6 (continued)

\begin{tabular}{|c|c|c|c|c|c|c|c|}
\hline $\begin{array}{l}\text { Formation- } \\
\text { location }\end{array}$ & $\mathbf{N}$ & I & D & Median & UCB95 & $\mathbf{X} 95$ & LTB9595 \\
\hline \multicolumn{8}{|c|}{ Phenanthrene } \\
\hline CHI-BV & 12 & 0 & 12 & 6.63 & 8.79 & 17.70 & 12.90 \\
\hline CHI-K25 & 12 & $\mathbf{0}$ & 12 & 7.16 & 9.50 & 19.10 & 13.90 \\
\hline CHE-ORR & 7 & 0 & 7 & 3.12 & 4.52 & 8.31 & 5.59 \\
\hline CR-ORR & 12 & 0 & 12 & 4.06 & 5.39 & 10.80 & 7.90 \\
\hline CR-AND & 12 & $\mathbf{0}$ & 12 & 3.63 & 4.81 & 9.67 & 7.05 \\
\hline CR-ROA & 12 & 0 & 12 & 3.17 . & 4.21 & 8.45 & 6.16 \\
\hline \multicolumn{8}{|c|}{ Pyrene } \\
\hline CHI-BV & 6 & 0 & 6 & 7.84 & 12.50 & 24.80 & 15.00 \\
\hline CHI-K25 & 12 & 0 & 12 & 10.90 & 15.30 & 34.60 & 23.80 \\
\hline CHE-ORR & 7 & 0 & 7 & 3.42 & 5.28 & 10.80 & 6.76 \\
\hline CR-ORR & 12 & 0 & 12 & 5.04 & 7.02 & 15.90 & 10.90 \\
\hline CR-AND & 10 & 0 & 10 & 3.07 & 4.42 & 9.70 & 6.48 \\
\hline CR-ROA & 12 & 0 & 12 & 2.12 & 2.96 & 6.71 & 4.61 \\
\hline
\end{tabular}

${ }^{a} \mathrm{~N}=$ number of observations, possibly averages over replicates at sites; $\mathrm{I}=$ number of interval censored observations (see text); $D=$ number of true detects (see text); UCB95 $=95 \%$ upper confidence bound for median; X95 = estimate of 95 th percentile; LTB9595 = 95\% lower confidence bound for 95th percentile; REMAINDER refers to the remaining observations-no detects.

\subsection{RADIONUCLIDES}

Many of the radionuclide soil results are validation rejects, and in general, the missing data structures for radionuclides vary considerably with analyte. There are no usable data for europium-155. There are substantial proportions of missing data for various sampling areas, formations, and horizons for isotopes of curium, hafnium, iridium, neptunium, niobium, plutonium, ruthenium, and zirconium.

Upon graphical analysis, several radionuclide results (including detection limits) seemed anomalous. One of the plutonium-239/240 results for horizon A Copper Ridge in Roane County is extremely high. A uranium-236 detect in the Chickamauga-K-25 area is much lower than all other uranium-236 reported values, almost all of which are nondetects. For several analytes (e.g., americium-241 and barium-133), the detection limits for Dismal Gap and Nolichucky samples from on- and off-site were almost all higher than the remaining formations.

Uranium-233/234 and uranium-238 were not detected in the Nolichucky Formation but were detected in all other formations. Uranium-235 was also not detected in the Nolichucky Formation but was detected at most other formations. For the statistical analyses discussed in this section and for the Nolichucky Formation, NAA uranium-238 data were substituted for alpha uranium-238 data, as well as for uranium-233/234 data. NAA uranium-235 data were also substituted for the alpha uranium-235 data. For the alpha detects, the uranium-233/234 to uranium-238 ratio is $0.984 \pm 0.032$, very close to the theoretical value of 1 . This motivates using uranium-238 data for uranium-233/234. The relationship of NAA data to alpha uranium results is discussed in Sects. 5.11 and 6.6.4.

One of the niobium-95 detection limits $(82,000 \mathrm{pCi} / \mathrm{g})$ is clearly due to laboratory error and was dropped. The potassium-40 nondetects were also dropped. 
After the data deletions and substitutions, with the exceptions of potassium-40, thorium-232, uranium-233/234, and uranium-238, all of the radionuclides have one or more nondetects. Results for the mostly undetected analytes are summarized in Table 5.7. Results for the detected analytes are summarized in Table 5.8. Statistics are also given for tritium in Table 5.7, computed from all BSCP data except data from ORR Copper Ridge, ORR Dismal Gap, and Bethel Valley, where tritium contamination appears likely (see Table 5.8).

Summary statistics for radionuclides by group are presented in Table 6.1b. Significance levels for comparisons of radionuclides by FLs in Table G.5. The radionuclides do not exhibit as many significant differences across FLs as the inorganics, but there are differences. Thorium-232, for example, shows differences and seems to be elevated in horizon $A$ in the Nolichucky Formation ( $p=0.0045$ for the Dismal Gap comparisons, $p<0.0001$ for the ORR comparisons, $p=0.0001$ for the comparison of Nolichucky with ORR Dismal Gap locations, and see Table 5.8).

Similarly, although there are horizon differences, there seem to be fewer for radionuclides than for inorganics. For example, thorium-232 horizon A-B differences are not affected significantly by FL ( $p=0.34)$ :

\begin{tabular}{lccc}
\hline $\begin{array}{l}\text { Formation- } \\
\text { location }\end{array}$ & $\begin{array}{c}\text { Difference } \\
\text { estimate } \\
\text { (pCi/g) }\end{array}$ & $\begin{array}{c}\text { Standard } \\
\text { error } \\
\text { (pCi/g) }\end{array}$ & $\begin{array}{c}\text { Significance } \\
\text { level }\end{array}$ \\
\hline DG-AND & -0.06 & 0.24 & 0.8160 \\
DG-ROA & -0.32 & 0.24 & 0.1707 \\
DG-ORR & -0.64 & 0.24 & 0.0072 \\
NL-ORR & -0.03 & 0.24 & 0.9158 \\
CHI-BV & -0.14 & 0.24 & 0.5501 \\
CHI-K25 & -0.71 & 0.24 & 0.0027 \\
CHE-ORR & -0.54 & 0.24 & 0.0234 \\
CR-ORR & -0.55 & 0.24 & 0.0207 \\
CR-AND & -0.41 & 0.24 & 0.0829 \\
CR-ROA & -0.47 & 0.24 & 0.0475 \\
\hline
\end{tabular}

NOTE: Table G.9 contains this table and similar ones for other radionuclides.

To further explore the nature of the differences, see Table 5.8 for the data. For data with all detects, formal comparisons can also be made using an analysis of variance (Proc GLM). For example, by that approach, horizon A thorium-232 levels are significantly different in the Dismal Gap areas $(p=0.02)$ and on the ORR $(p<0.0001)$. FL and horizon differences for radionuclides are also discussed in Sect. 6.

\subsection{GAMMA SCREENING}

The primary purpose of the gamma screening is to affirm that background cesium- 137 levels are not higher than normal for the southeastern United States. (about $10 \mathrm{pCi} / \mathrm{cm}^{2}$ ).

The Nolichucky-ORR and Dismal Gap-Roane County data differ very slightly from those in the Phase I report (DOE/OR/01-1136), because of some minor discrepancies in dates and sample IDs, which are accounted for in Table 5.9. The data are also illustrated in Fig. 5.6. 
Table 5.7. Summary statistics for radionuclides with fewer than $20 \%$ detects (Data have been combined over sampling areas.)

\begin{tabular}{|c|c|c|c|c|c|c|c|}
\hline Analysis & Horizon & $N$ & MAXDL & $\begin{array}{c}\text { Number } \\
\text { of } \\
\text { detects }\end{array}$ & $\begin{array}{l}\text { UCB for } \\
\text { detection } \\
\text { probability }\end{array}$ & $\begin{array}{l}\text { Number } \\
\text { exceeding } \\
\text { MAXDL }\end{array}$ & $\begin{array}{l}\text { UCB for } \\
\text { prob. > } \\
\text { MAXDL }\end{array}$ \\
\hline \multicolumn{8}{|c|}{ Alpha } \\
\hline Curium-244 & $A$ & 15 & 7.540 & 0 & 0.18 & 0 & 0.18 \\
\hline Curium-244 & B & 1 & 0.830 & $\mathbf{0}$ & 0.95 & 0 & 0.95 \\
\hline Neptunium-237 & B & 1 & 2.600 & $\mathbf{0}$ & 0.95 & $\mathbf{0}$ & 0.95 \\
\hline Plutonium-238 & C & 3 & 0.095 & 0 & 0.63 & 0 & 0.63 \\
\hline Uranium-236 & A & 40 & 0.084 & 3 & 0.18 & 0 & 0.07 \\
\hline Uranium-236 & B & 39 & 0.058 & 1 & 0.12 & 1 & 0.12 \\
\hline Uranium-236 & C & 40 & 0.110 & 2 & 0.15 & 0 & 0.07 \\
\hline \multicolumn{8}{|c|}{ Beta } \\
\hline Hafnium-181 & A & 12 & 0.0120 & 0 & 0.22 & 0 & 0.22 \\
\hline Hafnium-181 & B & 11 & 0.0110 & 0 & 0.24 & $\mathbf{0}$ & 0.24 \\
\hline Hafnium-181 & C & 11 & 0.0110 & 0 & 0.24 & 0 & 0.24 \\
\hline Iridium-192 & $A$ & 12 & 0.0100 & 0 & 0.22 & 0 & 0.22 \\
\hline Iridium-192 & B & 11 & 0.0080 & $\mathbf{0}$ & 0.24 & 0 & 0.24 \\
\hline Iridium-192 & C & 11 & 0.0088 & 0 & 0.24 & $\mathbf{0}$ & 0.24 \\
\hline Niobium-95 & A & 12 & 0.0140 & $\mathbf{0}$ & 0.22 & $\mathbf{0}$ & 0.22 \\
\hline Niobium-95 & B & 10 & 0.0120 & $\mathbf{0}$ & 0.26 & 0 & 0.26 \\
\hline Niobium-95 & C & 10 & 0.0260 & 0 & 0.26 & 0 & 0.26 \\
\hline Ruthenium-103 & A & 16 & 0.1100 & 0 & 0.17 & 0 & 0.17 \\
\hline Ruthenium-103 & B & 15 & 0.0100 & 0 & 0.18 & 0 & 0.18 \\
\hline Ruthenium-103 & C & 15 & 0.0100 & 1 & 0.28 & $\mathbf{0}$ & 0.18 \\
\hline Strontium-90 & A & 36 & 4.2000 & 2 & 0.16 & 0 & 0.08 \\
\hline Zirconium-95 & A & 16 & 0.0240 & $\mathbf{0}$ & 0.17 & $\mathbf{0}$ & 0.17 \\
\hline Zirconium-95 & B & 15 & 0.0220 & $\mathbf{0}$ & 0.18 & 0 & 0.18 \\
\hline Zirconium-95 & C & 15 & 0.0200 & o & 0.18 & $\mathbf{0}$ & 0.18 \\
\hline \multicolumn{8}{|c|}{ Gamma } \\
\hline Americium-241 & A & 40 & 0.1160 & 0 & 0.07 & $\mathbf{0}$ & 0.07 \\
\hline Americium-241 & B & 39 & 0.3420 & $\mathbf{0}$ & 0.07 & $\mathbf{0}$ & 0.07 \\
\hline Americium-241 & C & 39 & 0.1960 & 0 & 0.07 & o & 0.07 \\
\hline Barium-133 & A & 40 & 0.0426 & $\mathbf{0}$ & 0.07 & 0 & 0.07 \\
\hline Barium-133 & B & 39 & 0.1310 & 0 & 0.07 & $\mathbf{0}$ & 0.07 \\
\hline Barium-133 & C & 39 & 0.0957 & 0 & 0.07 & $\mathbf{0}$ & 0.07 \\
\hline Cesium-137 & C & 39 & 0.0944 & 5 & 0.25 & 2 & 0.15 \\
\hline Chromium-51 & A & 40 & 1.0700 & 0 & 0.07 & 0 & 0.07 \\
\hline Chromium-51 & B & 39 & 0.8680 & 0 & 0.07 & 0 & 0.07 \\
\hline Chromium-51 & C & 39 & 0.7680 & 0 & 0.07 & 0 & 0.07 \\
\hline Cobalt-57 & A & 40 & 0.0239 & 0 & 0.07 & 0 & 0.07 \\
\hline Cobalt-57 & B & 39 & 0.0719 & 0 & 0.07 & $\mathbf{0}$ & 0.07 \\
\hline Cobalt-57 & $\tilde{C}$ & 39 & 0.0501 & 0 & 0.07 & 0 & 0.07 \\
\hline Cobalt-60 & A & 40 & 0.0431 & 0 & 0.07 & 0 & 0.07 \\
\hline Cobalt-60 & B & 39 & 0.1130 & 0 & 0.07 & 0 & 0.07 \\
\hline Cobalt-60 & C & 39 & 0.1950 & 0 & 0.07 & 0 & 0.07 \\
\hline Curium-243 & A & 36 & 0.2350 & 0 & 0.08 & 0 & 0.08 \\
\hline Curium-243 & B & 4 & 0.0686 & 0 & 0.53 & 0 & 0.53 \\
\hline Curium-243 & C & 4 & 0.0680 & 0 & 0.53 & 0 & 0.53 \\
\hline Curium-245 & A & 36 & 0.2900 & 0 & 0.08 & 0 & 0.08 \\
\hline Curium-245 & B & 4 & 0.1100 & 0 & 0.53 & 0 & 0.53 \\
\hline
\end{tabular}


Table 5.7 (continued)

\begin{tabular}{|c|c|c|c|c|c|c|c|}
\hline Analysis & Horizon & $\mathbf{N}$ & MAXDL & $\begin{array}{c}\text { Number } \\
\text { of } \\
\text { detects }\end{array}$ & $\begin{array}{l}\text { UCB for } \\
\text { detection } \\
\text { probability }\end{array}$ & $\begin{array}{l}\text { Number } \\
\text { exceeding } \\
\text { MAXDL }\end{array}$ & $\begin{array}{l}\text { UCB for } \\
\text { prob. }> \\
\text { MAXDL }\end{array}$ \\
\hline Curium-245 & C & 4 & 0.1100 & 0 & 0.53 & 0 & 0.53 \\
\hline Curium-247 & A & 36 & 0.2720 & 2 & 0.16 & 0 & 0.08 \\
\hline Curium-247 & B & 4 & 0.0114 & 0 & 0.53 & 0 & 0.53 \\
\hline Curium-247 & C & 4 & 0.0110 & $\mathbf{0}$ & 0.53 & $\mathbf{0}$ & 0.53 \\
\hline Europium-152 & A & 40 & 0.2360 & 0 & 0.07 & 0 & 0.07 \\
\hline Europium-152 & B & 39 & 0.7520 & 0 & 0.07 & $\mathbf{0}$ & 0.07 \\
\hline Europium-152 & C & 39 & 0.5000 & $\mathbf{0}$ & 0.07 & $\mathbf{0}$ & 0.07 \\
\hline Europium-154 & A & 40 & 0.0466 & 0 & 0.07 & 0 & 0.07 \\
\hline Europium-154 & B & 39 & 0.1400 & 0 & 0.07 & 0 & 0.07 \\
\hline Europium-154 & C & 39 & 0.3160 & 0 & 0.07 & 0 & 0.07 \\
\hline Hafnium-181 & A & 24 & 0.0877 & 0 & 0.12 & 0 & 0.12 \\
\hline Hafnium-181 & B & 24 & 0.1990 & 0 & 0.12 & 0 & 0.12 \\
\hline Hafnium-181 & C & 24 & 0.1760 & 0 & 0.12 & 0 & 0.12 \\
\hline Iridium-192 & A & 24 & 0.0440 & 0 & 0.12 & $\mathbf{0}$ & 0.12 \\
\hline Iridium-192 & B & 24 & 0.1990 & 0 & 0.12 & 0 & 0.12 \\
\hline Iridium-192 & C & 24 & 0.1020 & $\mathbf{0}$ & 0.12 & $\mathbf{0}$ & 0.12 \\
\hline Neptunium-237 & A & 23 & 4.6800 & 0 & 0.12 & 0 & 0.12 \\
\hline Neptunium-237 & B & 24 & 13.7000 & 0 & 0.12 & 0 & 0.12 \\
\hline Neptunium-237 & $\mathrm{C}$ & 24 & 9.9100 & 0 & 0.12 & 0 & 0.12 \\
\hline Niobium-95 & A & 24 & 0.1190 & 0 & 0.12 & 0 & 0.12 \\
\hline Niobium-95 & B & 24 & 3.0300 & 0 & 0.12 & 0 & 0.12 \\
\hline Niobium-95 & C & 24 & 0.2450 & $\mathbf{0}$ & 0.12 & 0 & 0.12 \\
\hline Ruthenium-103 & $\mathbf{A}$ & 24 & 0.0860 & 0 & 0.12 & 0 & 0.12 \\
\hline Ruthenium-103 & B & 24 & 0.2070 & 0 & 0.12 & 0 & 0.12 \\
\hline Ruthenium-103 & C & 24 & 0.1780 & $\mathbf{0}$ & 0.12 & 0 & 0.12 \\
\hline Uranium-238 & A & 24 & 26.7000 & $\mathbf{0}$ & 0.12 & 0 & 0.12 \\
\hline Uranium-238 & B & 24 & 74.8000 & 0 & 0.12 & 0 & 0.12 \\
\hline Uranium-238 & C & 24 & 28.3000 & 1 & 0.18 & 1 & 0.18 \\
\hline Zinc-65 & A & 40 & 0.0991 & $\mathbf{0}$ & 0.07 & $\mathbf{0}$ & 0.07 \\
\hline Zinc-65 & B & 39 & 0.2890 & 0 & 0.07 & 0 & 0.07 \\
\hline Zinc-65 & $\mathrm{C}$ & 39 & 0.2310 & 0 & 0.07 & 0 & 0.07 \\
\hline Zirconium-95 & A & 24 & 0.1140 & $\mathbf{0}$ & 0.12 & 0 & 0.12 \\
\hline Zirconium-95 & B & 24 & 0.3320 & 0 & 0.12 & 0 & 0.12 \\
\hline Zirconium-95 & C & 24 & 0.2690 & 0 & 0.12 & 0 & 0.12 \\
\hline \multicolumn{8}{|c|}{ Tritium } \\
\hline Tritium $^{b}$ & A & 24 & 0.3 & $\mathbf{0}$ & 0.12 & 0 & 0.12 \\
\hline
\end{tabular}

${ }^{\circ}$ Composited samples-95\% UCBs for probabilities of detection or of exceeding the MAXDL. $N=$ number of observations, duplicates and splits not included. MAXDL = maximum detection limit for nondetects.

${ }^{b}$ Excluding ORR Copper Ridge, Dismal Gap, and Bethel Valley data. 
Table 5.8. Additional summary statistics for detected radionuclides by horizons (Estimates and confidence bounds are in picocuries per gram.)

\begin{tabular}{|c|c|c|c|c|c|c|c|c|}
\hline Horizon & $\begin{array}{c}\text { Formation- } \\
\text { location }\end{array}$ & $\mathbf{N}$ & I & D & Median & UCB95 & $\mathrm{X} 95$ & LTB9595 \\
\hline \multicolumn{9}{|c|}{ Cesium-137 (Gamma) } \\
\hline A & DG-AND & 4 & 0 & 3 & 0.12700 & 0.3060 & 0.723 & 0.2850 \\
\hline A & DG-ROA & 4 & 0 & 3 & 0.29700 & 0.7130 & 1.690 & 0.6650 \\
\hline A & DG-ORR & 4 & 0 & 4 & 0.59800 & 1.4300 & 3.400 & 1.3400 \\
\hline A & NL-ORR & 4 & 0 & 4 & 0.52700 & 1.2600 & 2.990 & 1.1800 \\
\hline A & CHII-BV & 3 & 0 & 3 & 1.17000 & 3.1900 & 6.640 & 2.3000 \\
\hline A & CHI-K25 & 4 & 0 & 4 & 1.09000 & 2.5900 & 6.170 & 2.4300 \\
\hline A & CHE-ORR & 4 & 0 & 4 & 0.99900 & 23800 & 5.670 & 2.2300 \\
\hline$A$ & CR-ORR & 4 & 0 & 4 & 0.84200 & 2.0100 & 4.780 & 1.8800 \\
\hline A & CR-AND & 4 & 1 & 3 & 0.63300 & 1.5100 & 3.590 & 1.4100 \\
\hline $\mathbf{A}$ & CR-RỌA & 4 & 0 & 4 & 0.95000 & 2.2600 & 5.400 & 2.1200 \\
\hline B & -DG-AND & 4 & 0 & 4 & 0.06190 & 0.2500 & 1.010 & 0.1940 \\
\hline $\mathbf{B}$ & DG-ROA & 4 & 0 & 4 & 0.00935 & 0.0378 & 0.153 & 0.0292 \\
\hline $\mathbf{B}$ & DG-ORR & 3 & 0 & 2 & 0.03740 & 0.2000 & 0.611 & 0.0979 \\
\hline B & NL-ORR & 4 & 0 & 3 & 0.00762 & 0.0329 & 0.125 & 0.0239 \\
\hline $\mathbf{B}$ & CR-ORR & 4 & 0 & 1 & 0.00625 & 0.0436 & 0.102 & 0.0150 \\
\hline $\mathbf{B}$ & CR-AND & 4 & 0 & 1 & 0.02320 & 0.1290 & 0.379 & 0.0684 \\
\hline B & REMAINDER & 15 & 0 & 0 & - & - & - & - \\
\hline $\mathrm{C}$ & DG-AND & 4 & 1 & 2 & 0.02730 & 0.2280 & 1.600 & 0.0896 \\
\hline C & DG-ORR & 3 & 0 & 2 & 0.03450 & 0.4180 & 2.010 & 0.0920 \\
\hline $\mathrm{C}$ & REMAINDER & 31 & 0 & $\mathbf{0}$ & $\cdot$ & $\cdot$ & $\cdot$ & $\cdot$ \\
\hline \multicolumn{9}{|c|}{ Curium-247 (Gamma) } \\
\hline A & NL-ORR & 4 & 0 & 2 & .00552 & .00649 & .00716 & .00578 \\
\hline A & REMAINDER & 32 & 0 & 0 & $\cdot$ & $\cdot$ & $\cdot$ & - \\
\hline B & REMAINDER & 4 & 0 & 0 & - & - & - & - \\
\hline $\mathrm{C}$ & REMAINDER & 4 & 0 & 0 & - & - & - & - \\
\hline \multicolumn{9}{|c|}{ Neptunium-237 (Alpha) } \\
\hline A & DG-AND & 4 & 0 & 4 & 0.0877 & 0.1130 & 0.1450 & 0.1100 \\
\hline A & NL-ORR & 2 & 0 & 2 & 0.1330 & 0.1900 & 0.2200 & 0.1510 \\
\hline A & CHI-BV & 3 & 0 & 3 & 0.0934 & 0.1250 & 0.1550 & 0.1130 \\
\hline A & CHI-K25 & 4 & 1 & 3 & 0.0928 & 0.1200 & 0.1540 & 0.1160 \\
\hline A & CHE-ORR & 4 & 1 & 2 & 0.0672 & 0.0891 & 0.1110 & 0.0824 \\
\hline A & CR-ORR & 4 & 0 & 4 & 0.0841 & 0.1080 & 0.1390 & 0.1050 \\
\hline A & CR-AND & 4 & 1 & 2 & 0.0601 & 0.0793 & 0.0995 & 0.0744 \\
\hline A & CR-ROA & 4 & 0 & 3 & 0.0526 & 0.0682 & 0.0870 & 0.0659 \\
\hline $\mathbf{B}$ & REMAINDER & 1 & 0 & 0 & - & - & - & - \\
\hline \multicolumn{9}{|c|}{ Plutonium-238 (Alpha) } \\
\hline A & DG-AND & 4 & 1 & 0 & 0.0209 & 0.0443 & 0.0508 & 0.0239 \\
\hline A & DG-ROA & 4 & 1 & 2 & 0.1040 & 0.1660 & 0.2530 & 0.1520 \\
\hline A & DG-ORR & 4 & 1 & 0 & 0.0413 & 0.0825 & 0.1010 & 0.0503 \\
\hline A & CHI-BV & 3 & 1 & 1 & 0.0739 & 0.1290 & 0.1800 & 0.1000 \\
\hline
\end{tabular}


Table 5.8 (continued)

\begin{tabular}{|c|c|c|c|c|c|c|c|c|}
\hline Horizon & $\begin{array}{c}\text { Formation- } \\
\text { location }\end{array}$ & $N$ & I & D & Median & UCB95 & X95 & LTB9595 \\
\hline A & CHII-K25 & 4 & 3 & 1 & 0.0725 & 0.1150 & 0.1770 & 0.1050 \\
\hline A & CHE-ORR & 4 & 2 & 1 & 0.0802 & 0.1310 & 0.1960 & 0.1150 \\
\hline A & CR-ORR & 4 & 0 & 3 & 0.0232 & 0.0382 & 0.0566 & 0.0329 \\
\hline A & CR-AND & 4 & 0 & 1 & 0.0865 & 0.1530 & 0.2110 & 0.1190 \\
\hline A & CR-ROA & 3 & 2 & 0 & 0.1110 & 0.1980 & 0.2720 & 0.1510 \\
\hline A & REMAINDER & 4 & 0 & $\mathbf{0}$ & . & . & . & . \\
\hline B & DG-ROA & 1 & 0 & 1 & 0.0980 & 0.1160 & 0.1160 & 0.0946 \\
\hline B & DG-ORR & 2 & 0 & 2 & 0.0853 & 0.0964 & 0.1010 & 0.0857 \\
\hline C & REMAINDER & 3 & 0 & $\mathbf{0}$ & . & . & . & . \\
\hline \multicolumn{9}{|c|}{ Plutonium-239/240 (Alpha) } \\
\hline $\mathbf{A}$ & DG-ORR & 4 & 0 & 1 & 0.0135 & 0.0371 & 0.0555 & 0.0205 \\
\hline A & CHI-BV & 3 & 1 & 1 & 0.0320 & 0.0806 & 0.1320 & 0.0482 \\
\hline A & CHI-K25 & 4 & 2 & 1 & 0.0237 & 0.0505 & 0.0975 & 0.0408 \\
\hline A & CHE-ORR & 4 & 2 & 0 & 0.0172 & 0.0452 & 0.0707 & 0.0251 \\
\hline A & CR-ORR & 4 & 0 & 3 & 0.0191 & 0.0397 & 0.0787 & 0.0337 \\
\hline A & CR-ROA & 3 & 0 & 1 & 0.0671 & 0.1650 & 0.2760 & 0.1080 \\
\hline A & REMAINDER & 16 & 0 & $\mathbf{0}$ & . & . & . & . \\
\hline B & DG-ORR & 2 & 0 & 1 & . & . & . & . \\
\hline B & REMAINDER & 1 & 0 & 0 & - & . & . & . \\
\hline c & DG-ROA & 1 & 0 & 1 & . & . & . & . \\
\hline C & REMAINDER & 2 & 0 & 0 & . & . & . & . \\
\hline \multicolumn{9}{|c|}{ Potassium-40 (Gamma) } \\
\hline A & DG-AND & 4 & 0 & 4 & 19.30 & 23.40 & 28.50 & 23.20 \\
\hline A & DG-ROA & 4 & 0 & 4 & 11.10 & 13.50 & 16.30 & 13.30 \\
\hline A & DG-ORR & 4 & 0 & 4 & 16.30 & 19.80 & 24.10 & 19.60 \\
\hline A & NL-ORR & 4 & 0 & 4 & 15.20 & 18.40 & 22.40 & 18.20 \\
\hline A & CHI-BV & 4 & 0 & 4 & 15.20 & 18.40 & 22.30 & 18.20 \\
\hline A & $\mathrm{CHI}-\mathrm{K} 25$ & 4 & 0 & 4 & 9.70 & 11.80 & 14.30 & 11.60 \\
\hline A & CHE-ORR & 4 & 0 & 4 & 3.15 & 3.82 & 4.64 & 3.77 \\
\hline A & CR-ORR & 4 & 0 & 4 & 4.10 & 4.97 & 6.04 & 4.91 \\
\hline A & CR-AND & 4 & 0 & 4 & 3.37 & 4.09 & 4.97 & 4.04 \\
\hline$A$ & CR-ROA & 4 & 0 & 4 & 2.74 & 3.33 & 4.04 & 3.29 \\
\hline B & DG-AND & 4 & 0 & 4 & 26.20 & 34.90 & 46.40 & 34.20 \\
\hline B & DG-ROA & 4 & 0 & 4 & 18.20 & 24.20 & 32.20 & 23.70 \\
\hline B & DG-ORR & 2 & 0 & 2 & 19.90 & 29.80 & 35.20 & 23.20 \\
\hline B & NL-ORR & 4 & 0 & 4 & 16.60 & 22.10 & 29.40 & 21.70 \\
\hline B & CHI-BV & 4 & 0 & 4 & 22.60 & 30.10 & 40.00 & 29.50 \\
\hline B & CHI-K25 & 4 & 0 & 4 & 22.80 & 30.30 & 40.20 & 29.60 \\
\hline B & CHE-ORR & 3 & 0 & 3 & 10.10 & 14.10 & 17.90 & 12.70 \\
\hline B & CR-ORR & 4 & 0 & 4 & 6.58 & 8.75 & 11.60 & 8.57 \\
\hline B & CR-AND & 4 & 0 & 4 & 6.07 & 8.07 & 10.70 & 7.90 \\
\hline B & CR-ROA & 3 & 0 & 3 & 7.16 & 9.95 & 12.70 & 8.95 \\
\hline C & DG-AND & 4 & 0 & 4 & 22.30 & 29.80 & 39.80 & 29.20 \\
\hline C & DG-ROA & 4 & 0 & 4 & 23.40 & 31.20 & 41.70 & 30.60 \\
\hline C & DG-ORR & 3 & 0 & 3 & 19.50 & 27.20 & 34.70 & 24.40 \\
\hline
\end{tabular}


Table 5.8 (continued)

\begin{tabular}{|c|c|c|c|c|c|c|c|c|}
\hline Horizon & $\begin{array}{l}\text { Formation- } \\
\text { location }\end{array}$ & $\mathbf{N}$ & I & D & Median & UCB95 & $\mathrm{X} 95$ & LTB9595 \\
\hline C & NL-ORR & 4 & 0 & 4 & 25.20 & 33.60 & 44.80 & 32.90 \\
\hline C & CHI-BV & 4 & 0 & 4 & .14 .50 & 19.30 & 25.70 & 18.90 \\
\hline C & CHI-K25 & 3 & 0 & 3 & 34.40 & 48.00 & 61.30 & 43.10 \\
\hline C & CHE-ORR & 2 & 0 & 2 & 10.90 & 16.50 & 19.50 & 12.80 \\
\hline C & CR-ORR & 4 & 0 & 4 & 6.83 & 9.11 & 12.20 & 8.93 \\
\hline C & CR-AND & 4 & 0 & 4 & 5.23 & 6.98 & 9.32 & 6.84 \\
\hline C & CR-ROA & 4 & 0 & 4 & 3.75 & 5.00 & 6.68 & 4.90 \\
\hline \multicolumn{9}{|c|}{ Radium-226 (Alpha) } \\
\hline A & DG-AND & 4 & 0 & 4 & 1.820 & 2.640 & 3.84 & 2.570 \\
\hline A & DG-ROA & 4 & 0 & 4 & 0.833 & 1.210 & 1.76 & 1.180 \\
\hline A & DG-ORR & 4 & 0 & 4 & 0.786 & 1.140 & 1.66 & 1.110 \\
\hline$A$ & NL-ORR & 4 & 0 & 4 & 0.740 & 1.080 & 1.57 & 1.050 \\
\hline A & CHI-BV & 4 & 0 & 4 & 1.080 & 1.570 & 2.28 & 1.530 \\
\hline A & CHI-K25 & 4 & 0 & 4 & 0.931 & 1.350 & 1.97 & 1.320 \\
\hline A & CHE-ORR & 4 & 1 & 3 & 0.870 & 1.270 & 1.84 & 1.230 \\
\hline A & CR-ORR & 4 & 0 & 4 & 1.220 & 1.780 & 2.58 & 1.730 \\
\hline A & CR-AND & 4 & 0 & 3 & 0.573 & 0.834 & 1.21 & 0.813 \\
\hline A & CR-ROA & 4 & 0 & 4 & 0.911 & 1.330 & 1.93 & 1.290 \\
\hline B & DG-AND & 4 & 0 & 4 & 1.710 & 2.250 & 2.97 & 2.210 \\
\hline B & DG-ROA & 4 & 0 & 4 & 0.865 & 1.140 & 1.50 & 1.120 \\
\hline B & DG-ORR & 4 & 0 & 3 & 0.747 & 1.010 & 1.30 & 0.947 \\
\hline B & NL-ORR & 4 & 0 & 4 & 0.880 & 1.160 & 1.53 & 1.140 \\
\hline B & CHI-BV & 4 & 0 & 4 & 1.070 & 1.410 & 1.86 & 1.390 \\
\hline B & CHI-K25 & 4 & 0 & 4 & 0.950 & 1.250 & 1.65 & 1.230 \\
\hline B & CHE-ORR & 4 & 0 & 4 & 1.580 & 2.080 & 2.74 & 2.040 \\
\hline B & CR-ORR & 4 & 0 & 4 & 1.490 & 1.970 & 2.59 & 1.930 \\
\hline B & CR-AND & 4 & 0. & 4 & 1.340 & 1.760 & 2.32 & 1.730 \\
\hline B & CR-ROA & 4 & 0 & 4 & 1.120 & 1.470 & 1.94 & 1.440 \\
\hline C & DG-AND & 4 & 0 & 4 & 1.670 & 2.180 & 2.84 & 2.140 \\
\hline C & DG-ROA & 4 & 0 & 4 & 0.786 & 1.030 & 1.34 & 1.010 \\
\hline C & DG-ORR & 4 & 0 & 4 & 0.763 & 0.995 & 1.30 & 0.977 \\
\hline C & NL-ORR & 4 & 0 & 4 & 0.970 & 1.260 & 1.65 & 1.240 \\
\hline C & CHI-BV & 4 & 0 & 4 & 1.200 & 1.570 & 204 & 1.540 \\
\hline $\mathrm{C}$ & CHI-K25 & 4 & 0 & 4 & 1.190 & 1.550 & 2.02 & 1.520 \\
\hline C. & CHE-ORR & 4 & 0 & 4 & 1.290 & 1.680 & 2.19 & 1.650 \\
\hline C & CR-ORR & 4 & 0 & 4 & 1.610 & 2.110 & 2.75 & 2.070 \\
\hline C & CR-AND & 4 & 0 & 4 & 1.270 & 1.660 & 2.17 & 1.630 \\
\hline C & CR-ROA & 4 & 0 & 4 & 1.370 & 1.790 & 233 & 1.760 \\
\hline \multicolumn{9}{|c|}{ Strontium-90 (Beta) } \\
\hline A & DG-ORR & 3 & 0 & 1 & 0.701 & 1.38 & 1.56 & 0.762 \\
\hline A & CR-ROA & 4 & 1 & 0 & 0.647 & 1.25 & 1.44 & 0.762 \\
\hline$A$ & REMAINDER & 29 & 0 & 0 & . & $\cdot$ & - & $\cdot$ \\
\hline \multicolumn{9}{|c|}{ Technetium-99 (Beta) } \\
\hline A & DG-AND & 2 & 1 & 1 & 3.99 & 7.39 & 9.53 & 4.67 \\
\hline A & NL-ORR & 6 & 0 & 1 & 1.10 & 1.91 & 2.63 & 1.57 \\
\hline A & CHI-BV & 6 & $\mathbf{0}$ & 2 & 1.26 & 1.98 & 3.00 & 1.87 \\
\hline
\end{tabular}


Table 5.8 (continued)

\begin{tabular}{|c|c|c|c|c|c|c|c|c|}
\hline Horizon & $\begin{array}{c}\text { Formation- } \\
\text { location }\end{array}$ & $\mathbf{N}$ & I & $\mathrm{D}$ & Median & UCB95 & X95 & LTB9595 \\
\hline A & CHI-K25 & 6 & 0 & 3 & 1.11 & 1.67 & 2.65 & 1.66 \\
\hline A & CR-AND & 3 & 0 & 2 & 2.26 & 3.82 & 5.41 & 2.96 \\
\hline A & REMANNDER & 23 & 0 & 0 & . & . & . & - \\
\hline \multicolumn{9}{|c|}{ Thorium-228 (Alpha) } \\
\hline A & DG-AND & 4 & 0 & 4 & 1.200 & 1.710 & 2.430 & 1.670 \\
\hline A & DG-ROA & 4 & 0 & 4 & 0.988 & 1.410 & 2.010 & 1.370 \\
\hline A & DG-ORR & 4 & 0 & 4 & 0.713 & 1.020 & 1.450 & 0.992 \\
\hline A & NL-ORR & 4 & 0 & 4 & 1.510 & 2.150 & 3.060 & 2.100 \\
\hline A & CHI-BV & 4 & 0 & 4 & 1.290 & 1.840 & 2.620 & 1.790 \\
\hline A & CHI-K25 & 4 & 0 & 4 & 1.130 & 1.610 & 2.290 & 1.570 \\
\hline A & CHE-ORR & 4 & 0 & 4 & 0.606 & 0.863 & 1.230 & 0.842 \\
\hline A & CR-ORR & $4^{\circ}$ & 0 & 3 & 0.339 & 0.484 & 0.688 & 0.472 \\
\hline A & CR-AND & 4 & 0 & 4 & 0.845 & 1.200 & 1.720 & 1.170 \\
\hline A & CR-ROA & 4 & 0 & 4 & 0.615 & 0.877 & 1.250 & 0.856 \\
\hline B & DG-AND & 4 & 0 & 4 & 1.010 & 1.380 & 1.900 & 1.360 \\
\hline B & DG-ROA & 4 & 0 & 4 & 0.733 & 1.010 & 1.380 & 0.985 \\
\hline B & DG-ORR & 4 & 0 & 4 & 1.030 & 1.410 & 1.940 & 1.380 \\
\hline B & NL-ORR & 4 & 0 & 4 & 1.590 & 2.190 & 3.000 & 2.140 \\
\hline B & CHI-BV & 4 & 0 & 4 & 1.500 & 2.060 & 2.830 & 2.020 \\
\hline B & CHI-K25 & 4 & 0 & 4 & 1.530 & 2.100 & 2.880 & 2.060 \\
\hline B & CHE-ORR & 4 & 0 & 4 & 1.070 & 1.470 & 2.020 & 1.440 \\
\hline B & CR-ORR & 4 & 0 & 4 & 1.160 & 1.600 & 2.190 & 1.570 \\
\hline B & CR-AND & 4 & 0 & 4 & 1.200 & 1.640 & 2.250 & 1.610 \\
\hline B & CR-ROA & 4 & 0 & 4 & 1.090 & 1.490 & 2.050 & 1.460 \\
\hline C & DG-AND & 4 & 0 & 4 & 1.090 & 1.590 & 2.340 & 1.550 \\
\hline C & DG-ROA & 4 & 0 & 4 & 0.712 & 1.040 & 1.530 & 1.020 \\
\hline C & DG-ORR & 4 & 0 & 3 & 0.629 & 0.924 & 1.350 & 0.899 \\
\hline $\mathrm{C}$ & NL-ORR & 4 & 0 & 4 & 1.570 & 2.300 & 3.370 & 2.240 \\
\hline C & CHI-BV & 4 & 0 & 4 & 1.410 & 2.060 & 3.020 & 2.010 \\
\hline C & CHI-K25 & 4 & 0 & 4 & 2.000 & 2.930 & 4.290 & 2.850 \\
\hline $\mathrm{C}$ & CHE-ORR & 4 & 0 & 4 & 1.190 & 1.750 & 2.560 & 1.700 \\
\hline $\mathrm{C}$ & CR-ORR & 4 & 0 & 4 & 1.260 & 1.840 & 2.700 & 1.800 \\
\hline C & CR-AND & 4 & 0 & 4 & 1.190 & 1.740 & 2.550 & 1.700 \\
\hline C & CR-ROA & 4 & 0 & 4 & 1.250 & 1.830 & 2.680 & 1.780 \\
\hline
\end{tabular}

Thorium-230 (Alpha)

$\begin{array}{lllllllll}\text { A } & \text { DG-AND } & 4 & 0 & 4 & 0.912 & 1.090 & 1.310 & 1.080 \\ \text { A } & \text { DG-ROA } & 4 & 0 & 4 & 0.746 & 0.894 & 1.070 & 0.884 \\ \text { A } & \text { DG-ORR } & 4 & 0 & 4 & 0.565 & 0.677 & 0.812 & 0.669 \\ \text { A } & \text { NL-ORR } & 4 & 0 & 4 & 0.966 & 1.160 & 1.390 & 1.140 \\ \text { A } & \text { CHI-BV } & 4 & 0 & 4 & 1.060 & 1.270 & 1.520 & 1.250 \\ \text { A } & \text { CHI-K25 } & 4 & 0 & 4 & 1.040 & 1.240 & 1.490 & 1.230 \\ \text { A } & \text { CHE-ORR } & 4 & 0 & 4 & 0.774 & 0.927 & 1.110 & 0.916 \\ \text { A } & \text { CR-ORR } & 4 & 0 & 4 & 1.110 & 1.330 & 1.590 & 1.310 \\ \text { A } & \text { CR-AND } & 4 & 0 & 4 & 1.090 & 1.310 & 1.570 & 1.300 \\ \text { A } & \text { CR-ROA } & 4 & 0 & 4 & 0.864 & 1.040 & 1.240 & 1.020 \\ & & & & & & & & \\ \text { B } & \text { DG-AND } & 4 & 0 & 4 & 0.958 & 1.230 & 1.570 & 1.210 \\ \text { B } & \text { DG-ROA } & 4 & 0 & 4 & 0.868 & 1.110 & 1.430 & 1.090\end{array}$


Table 5.8 (continued)

\begin{tabular}{|c|c|c|c|c|c|c|c|c|}
\hline Horizon & $\begin{array}{c}\text { Formation- } \\
\text { location }\end{array}$ & $\mathbf{N}$ & $I$ & $\mathrm{D}$ & Median & UCB95 & X95 & LTB9595 \\
\hline B & DG-ORR & 4 & 0 & 4 & 0.727 & 0.931 & 1.190 & 0.916 \\
\hline B & NL-ORR & 4 & 0 & 4 & 1.000 & 1.290 & 1.650 & 1.260 \\
\hline B & CHI-BV & 4 & 0 & 4 & 1.070 & 1.370 & 1.750 & 1.350 \\
\hline B & $\mathrm{CHI}-\mathrm{K} 25$ & 4 & 0 & 3 & 1.060 & 1.390 & 1.740 & 1.310 \\
\hline B & CHE-ORR & 4 & 0 & 4 & 1.220 & 1.570 & 2.010 & 1.540 \\
\hline B & CR-ORR & 4 & 0 & 4 & 1.550 & 1.990 & 2.550 & 1.960 \\
\hline B & CR-AND & 4 & 0 & 4 & 1.510 & 1.940 & 2.480 & 1.910 \\
\hline B & CR-ROA & 4 & 0 & 4 & 1.050 & 1.350 & 1.720 & 1.320 \\
\hline C & DG-AND & 4 & 0 & 4 & 0.833 & 1.070 & 1.380 & 1.050 \\
\hline C & DG-ROA & 4 & 0 & 4 & 0.508 & 0.654 & 0.841 & 0.643 \\
\hline C & DG-ORR & 4 & 0 & 4 & 0.571 & 0.735 & 0.945 & 0.723 \\
\hline C & NL-ORR & 4 & 0 & 4 & 0.877 & 1.130 & 1.450 & 1.110 \\
\hline $\mathrm{C}$ & CHI-BV & 4 & 0 & 4 & 1.080 & 1.390 & 1.790 & 1.370 \\
\hline $\mathrm{C}$ & CHI-K25 & 4 & 0 & 4 & 1.250 & 1.610 & 2.060 & 1.580 \\
\hline $\mathrm{C}$ & CHE-ORR & 4 & 0 & 4 & 1.440 & 1.850 & 2.380 & 1.820 \\
\hline C & CR-ORR & 4 & 0 & 4 & 1.640 & 2.110 & 2.710 & 2.080 \\
\hline $\mathrm{C}$ & CR-AND & 4 & 0 & 4 & 1.620 & 2.080 & 2.670 & 2.040 \\
\hline $\mathrm{C}$ & CR-ROA & 4 & 0 & 4 & 1.380 & 1.770 & 2.280 & 1.740 \\
\hline \multicolumn{9}{|c|}{ Thorium-232 (Alpha) } \\
\hline A & DG-AND & 4 & 0 & 4 & 1.060 & 1.230 & 1.430 & 1.220 \\
\hline A & DG-ROA & 4 & 0 & 4 & 0.945 & 1.100 & 1.280 & 1.090 \\
\hline A & DG-ORR & 4 & 0 & 4 & 0.683 & 0.794 & 0.923 & 0.786 \\
\hline A & NL-ORR & 4 & 0 & 4 & 1.490 & 1.740 & 2.020 & 1.720 \\
\hline A & CHI-BV & 4 & 0 & 4 & 1.250 & 1.450 & 1.690 & 1.440 \\
\hline A & CHI-K25 & 4 & 0 & 4 & 1.100 & 1.280 & 1.490 & 1.270 \\
\hline$A$ & CHIE-ORR & 4 & 0 & 4 & 0.622 & 0.722 & 0.840 & 0.715 \\
\hline A & CR-ORR & 4 & 0 & 4 & 0.679 & 0.789 & 0.917 & 0.781 \\
\hline A & CR-AND & 4 & 0 & 4 & 0.784 & 0.912 & 1.060 & 0.903 \\
\hline$A$ & CR-ROA & 4 & 0 & .4 & 0.544 & 0.632 & 0.735 & 0.626 \\
\hline $\mathbf{B}$ & DG-AND & 4 & 0 & 4 & 1.100 & 1.400 & 1.780 & 1.380 \\
\hline B & DG-ROA & 4 & 0 & 4 & 1.280 & $1.630^{\circ}$ & 2.070 & 1.600 \\
\hline B & DG-ORR & 4 & 0 & 4 & 1.020 & 1.300 & 1.650 & 1.280 \\
\hline B & NL-ORR & 4 & 0 & 4 & 1.500 & 1.900 & 2.410 & 1.870 \\
\hline B & CHI-BV & 4 & 0 & 4 & 1.380 & 1.760 & 2.230 & 1.730 \\
\hline $\mathbf{B}$ & $\mathrm{CHI}-\mathrm{K} 25$ & 4 & 0 & 4 & 1.770 & 2.240 & 2850 & 2.210 \\
\hline B & CHE-ORR & 4 & 0 & 4 & 1.150 & 1.470 & 1.860 & 1.440 \\
\hline B & CR-ORR & 4 & 0 & 4 & 1.220 & 1.550 & 1.970 & 1.530 \\
\hline B & CR-AND & 4 & 0 & 4 & 1.200 & 1.530 & 1.940 & 1.500 \\
\hline $\mathbf{B}$ & CR-ROA & 4 & 0 & 4 & 0.949 & 1.210 & 1.530 & 1.190 \\
\hline C & DG-AND & 4 & 0 & 4 & 1.070 & 1.460 & 2.000 & 1.440 \\
\hline C & DG-ROA & 4 & 0 & 4 & 0.680 & 0.930 & 1.270 & 0.911 \\
\hline C & DG-ORR. & 4 & 0 & 4 & 0.841 & 1.150 & 1.580 & 1.130 \\
\hline C & NL-ORR & 4 & 0 & 4 & 1.370 & 1.870 & 2.560 & 1.830 \\
\hline C & CHI-BV & 4 & 0 & 4 & 1.430 & 1.960 & 2.690 & 1.920 \\
\hline C & CHI-K25 & 4 & 0 & 4 & 1.640 & 2.250 & 3.080 & 2.200 \\
\hline C & CHE-ORR & 4 & 0 & 4 & 1.210 & 1.660 & 2.270 & 1.630 \\
\hline C & CR-ORR & 4 & 0 & 4 & 1.250 & 1.710 & 2340 & 1.670 \\
\hline C & CR-AND & 4 & 0 & 4 & 1.120 & 1.530 & 2.090 & 1.500 \\
\hline C & CR-ROA & 4 & 0 & 4 & 1.240 & 1.700 & 2.320 & 1.660 \\
\hline
\end{tabular}


Table 5.8 (continued)

\begin{tabular}{|c|c|c|c|c|c|c|c|c|}
\hline Horizon & $\begin{array}{l}\text { Formation- } \\
\text { location }\end{array}$ & $N$ & I & $\mathrm{D}$ & Median & UCB95 & $\mathrm{X} 95$ & LTB9595 \\
\hline \multicolumn{9}{|c|}{ Thorium-234 (Beta) } \\
\hline A & DG-AND & 4 & 0 & 4 & 1.060 & 1.230 & 1.410 & 1.200 \\
\hline A & DG-ROA & 3 & 0 & 3 & 1.430 & 1.680 & 1.890 & 1.580 \\
\hline A & DG-ORR & 4 & 0 & 4 & 1.630 & 1.880 & 2.170 & 1.850 \\
\hline A & NL-ORR & 4 & 0 & 4 & 1.420 & 1.640 & 1.890 & 1.610 \\
\hline A & $\mathrm{CH}-\mathrm{K} 25$ & 2 & 1 & 0 & 0.945 & 1.200 & 1.250 & 0.974 \\
\hline A & CHE-ORR & 4 & 1 & 0 & 0.616 & 0.761 & 0.817 & 0.657 \\
\hline A & CR-ORR & 3 & 0 & 2 & 1.560 & 1.840 & 2.070 & 1.730 \\
\hline A & CR-AND & 4 & 1 & 0 & 0.703 & 0.932 & 0.933 & 0.701 \\
\hline A & REMAINDER & 6 & $\mathbf{0}$ & 0 & . & - & . & - \\
\hline B & DG-AND & 4 & 0 & 4 & 1.050 & 1.520 & 2.220 & 1.450 \\
\hline B & DG-ROA & 3 & 0 & 3 & 1.290 & 1.990 & 2.730 & 1.690 \\
\hline B & DG-ORR & 4 & 0 & 3 & 0.757 & 1.110 & 1.600 & 1.050 \\
\hline B & NL-ORR & 4 & 0 & 4 & 1.100 & 1.600 & 2.330 & 1.520 \\
\hline B & CHE-ORR & 4 & 1 & 0 & 0.725 & 1.200 & 1.530 & 0.926 \\
\hline B & CR-ORR & 3 & 0 & 2 & 1.640 & 2.590 & 3.470 & 2.130 \\
\hline B & CR-AND & 4 & 0 & 3 & 1.920 & 2.810 & 4.050 & 2.660 \\
\hline B & REMAINDER & 8 & 0 & 0 & . & . & - & . \\
\hline $\mathrm{C}$ & DG-AND & 4 & 0 & 4 & 1.020 & 1.440 & 2.040 & 1.370 \\
\hline $\mathrm{C}$ & DG-ROA & 3 & 0 & 3 & 1.350 & 2.000 & 2680 & 1.710 \\
\hline C & DG-ORR & 4 & 0 & 4 & 1.160 & 1.640 & 2.310 & 1.550 \\
\hline C & NL-ORR & 4 & 0 & 4 & 1.070 & 1.510 & 2.120 & 1.420 \\
\hline C & CHE-ORR & 4 & 1 & 0 & 0.720 & 1.140 & 1.430 & 0.910 \\
\hline C & CR-AND & 4 & 0 & 1 & 0.886 & 1.350 & 1.760 & 1.160 \\
\hline $\mathrm{C}$ & CR-ROA & 3 & 0 & 1 & 1.050 & 1.630 & 2.090 & 1.330 \\
\hline C & REMAINDER & 8 & 0 & 0 & . & . & . & . \\
\hline \multicolumn{9}{|c|}{ Thorium-234 (Gamma) } \\
\hline$A$ & CHI-BV & 1 & 0 & 1 & . & . & . & . \\
\hline A & CR-ROA & 1 & 0 & 1 & . & . & . & . \\
\hline$A$ & REMAINDER . & 2 & 0 & 0 & . & . & . & . \\
\hline B & CHII-BV & 1 & 0 & 1 & . & - & . & . \\
\hline B & CR-ROA & 1 & 0 & 1 & . & . & . & . \\
\hline B & REMAINDER & 2 & 0 & 0 & . & . & . & . \\
\hline $\mathrm{C}$ & CHI-BV & 1 & 0 & 1 & . & . & . & . \\
\hline C & CR-ROA & 1 & 0 & 1 & . & . & . & . \\
\hline C & REMAINDER & 2 & 0 & 0 & - & - & - & - \\
\hline \multicolumn{9}{|c|}{ Total Uranium (Alpha) } \\
\hline A & DG-AND & 4 & 0 & 4 & 0.999 & 1.730 & 299 & 1.660 \\
\hline A & DG-ROA & 4 & 0 & 3 & 0.670 & 1.160 & 2.01 & 1.120 \\
\hline A & DG-ORR & 4 & 0 & 4 & 1.310 & 2.270 & 3.93 & 2.180 \\
\hline A & NL-ORR & 4 & 0 & 4 & 1.150 & 1.990 & 3.44 & 1.910 \\
\hline A & CHI-BV & 3 & 0 & 3 & 1.250 & 2.350 & 3.73 & 1.910 \\
\hline A & CHI-K25 & 4 & 0 & 4 & 0.923 & 1.600 & 2.77 & 1.540 \\
\hline A & CHE-ORR & 3 & 0 & 3 & 1.920 & 3.630 & 5.76 & 2.960 \\
\hline A & CR-ORR & 4 & 0 & 4 & 2.710 & 4.690 & 8.12 & 4.510 \\
\hline A & CR-AND & 4 & 0 & 4 & 1.040 & 1.810 & 3.13 & 1.740 \\
\hline
\end{tabular}


Table 5.8 (continued)

\begin{tabular}{|c|c|c|c|c|c|c|c|c|}
\hline Horizon & $\begin{array}{c}\text { Formation- } \\
\text { location }\end{array}$ & $\mathbf{N}$ & $I$ & $\mathbf{D}$ & Median & UCB95 & $\mathrm{X} 95$ & LTB9595 \\
\hline A & CR-ROA & 4 & 0 & 4 & 1.920 & 3.320 & 5.75 & 3.190 \\
\hline B & DG-ROA & 1 & 0 & 1 & 0.450 & 1.650 & 1.65 & 0.345 \\
\hline B & DG-ORR & 2 & 0 & 2 & 0.316 & 0.791 & 1.16 & 0.326 \\
\hline C & DG-ROA & 1 & 0 & 1 & 1.300 & 9.340 & 9.34 & 0.869 \\
\hline C & DG-ORR & 2 & 0 & 2 & 0.299 & 1.210 & 2.15 & 0.315 \\
\hline \multicolumn{9}{|c|}{ Tritium (Tritium) } \\
\hline A & DG-ORR & 9 & 0 & 5 & 0.0324 & 0.0421 & 0.0653 & 0.0476 \\
\hline A & CHI-BV & 9 & 3 & 0 & 0.0776 & 0.1080 & 0.1560 & 0.1110 \\
\hline A & CR-ORR & 5 & 0 & 4 & 0.0166 & 0.0231 & 0.0335 & 0.0226 \\
\hline A & REMAINDER & 24 & 0 & $\mathbf{0}$ & - & - & - & - \\
\hline \multicolumn{9}{|c|}{ Uranium-233/234 (Alpha) } \\
\hline A & DG-AND & 4 & 0 & 4 & 0.925 & 1.120 & 1.350 & 1.100 \\
\hline A & DG-ROA & 4 & 0 & 4 & 0.934 & 1.130 & 1.360 & 1.120 \\
\hline A & DG-ORR & 4 & 0 & 4 & 0.937 & 1.130 & 1.370 & 1.120 \\
\hline$A$ & NL-ORR & 4 & 0 & 4 & 1.280 & 1.550 & 1.870 & 1.530 \\
\hline A & CHI-BV & 4 & 0 & 4 & 1.010 & 1.220 & 1.480 & 1.210 \\
\hline A & CHII-K25 & 4 & 0 & 4 & 1.220 & 1.470 & 1.780 & 1.450 \\
\hline A & CHE-ORR & 4 & 0 & 4 & 1.100 & 1.340 & 1.610 & 1.320 \\
\hline A & CR-ORR & 4 & 0 & 4 & 1.450 & 1.750 & 2.120 & 1.730 \\
\hline A & CR-AND & 4 & 0 & 4 & 1.170 & 1.420 & 1.710 & 1.400 \\
\hline A & CR-ROA & 4 & 0 & 4 & 1.230 & 1.490 & 1.800 & 1.470 \\
\hline B & DG-AND & 4 & 0 & 4 & 0.916 & 1.150 & 1.430 & 1.130 \\
\hline $\mathrm{B}$ & DG-ROA & 4 & 0 & 4 & 0.766 & 0.957 & 1.200 & 0.943 \\
\hline B & DG-ORR & 4 & 0 & 4 & 1.110 & 1.390 & 1.740 & 1.370 \\
\hline B & NL-ORR & 4 & 0 & 4 & 1.050 & 1.320 & 1.640 & 1.300 \\
\hline B & CHI-BV & 4 & 0 & 4 & 0.893 & 1.120 & 1.390 & 1.100 \\
\hline B & CHI-K25 & 4 & 0 & 4 & 1.200 & 1.490 & 1.870 & 1.470 \\
\hline B & CHE-ORR & 4 & 0 & 4 & 1.320 & 1.650 & 2.060 & 1.620 \\
\hline B & CR-ORR & 4 & 0 & 4 & 1.740 & 2.180 & 2720 & 2.140 \\
\hline B & CR-AND & 4 & 0 & 4 & 1.630 & 2.040 & 2.550 & 2.010 \\
\hline B & CR-ROA & 3 & 0 & 3 & 0.897 & 1.160 & 1.400 & 1.070 \\
\hline C & DG-AND & 4 & 0 & 4 & 0.871 & 1.040 & 1.250 & 1.030 \\
\hline C & DG-ROA & 4 & 0 & 4 & 0.671 & 0.804 & 0.964 & 0.795 \\
\hline C & DG-ORR & 4 & 0 & 4 & 0.663 & 0.795 & 0.953 & 0.785 \\
\hline C & NL-ORR & 4 & 0 & 4 & 1.120 & 1.340 & 1.610 & 1.330 \\
\hline $\mathrm{C}$ & CHI-BV & 4 & 0 & 4 & 1.050 & 1.260 & 1.510 & 1.250 \\
\hline C & CHI-K25 & 4 & 0 & 4 & 1.160 & 1.390 & 1.670 & 1.370 \\
\hline C & CHE-ORR & 4 & 0 & 4 & 1.290 & 1.540 & 1.850 & 1.520 \\
\hline C & CR-ORR & 4 & 0 & 4 & 1.910 & 2.290 & 2.750 & 2.270 \\
\hline $\mathrm{C}$ & CR-AND & 4 & 0 & 4 & 1.490 & 1.790 & 2.140 & 1.770 \\
\hline C & CR-ROA & 4 & 0 & 4 & 1.180 & 1.420 & 1.700 & 1.400 \\
\hline \multicolumn{9}{|c|}{ Uranium-235 (Alpha) } \\
\hline A & DG-AND & 4 & 1 & 0 & 0.0355 & 0.0579 & 0.0708 & 0.0434 \\
\hline A & DG-ROA & 4 & 1 & 3 & 0.0542 & 0.0777 & 0.1080 & 0.0738 \\
\hline A & DG-ORR & 4 & 1 & 2 & 0.0541 & 0.0779 & 0.1080 & 0.0737 \\
\hline A & NL-ORR & 4 & 0 & 4 & 0.0548 & 0.0774 & 0.1090 & 0.0753 \\
\hline
\end{tabular}


Table 5.8 (continued)

\begin{tabular}{|c|c|c|c|c|c|c|c|c|}
\hline Horizon & $\begin{array}{c}\text { Formation- } \\
\text { location }\end{array}$ & $\mathbf{N}$ & $\mathbf{I}$ & D & Median & UCB95 & X95 & LTB9595 \\
\hline A & CHI-BV & 4 & 0 & 4 & 0.0930 & 0.1310 & 0.1860 & 0.1280 \\
\hline A & CHI-K25 & 4 & 1 & 3 & 0.0583 & 0.0824 & 0.1160 & 0.0802 \\
\hline A & CHE-ORR & 4 & 1 & 2 & 0.0721 & 0.1040 & 0.1440 & 0.0978 \\
\hline A & CR-ORR & 4 & 0 & 4 & 0.1250 & 0.1770 & 0.2500 & 0.1720 \\
\hline A & CR-AND & 4 & 0 & 4 & 0.0741 & 0.1050 & 0.1480 & 0.1020 \\
\hline A & CR-ROA & 4 & 1 & 3 & 0.0352 & 0.0501 & 0.0702 & 0.0482 \\
\hline B & DG-AND & 4 & 1 & 2 & 0.0366 & 0.0747 & 0.1430 & 0.0677 \\
\hline B & DG-ROA & 4 & 1 & 2 & 0.0311 & 0.0645 & 0.1220 & 0.0567 \\
\hline B & DG-ORR & 4 & 1 & 2 & 0.0643 & 0.1330 & 0.2520 & 0.1180 \\
\hline B & NL-ORR & 4 & 0 & 4 & 0.0477 & 0.0944 & 0.1870 & 0.0896 \\
\hline B & CHI-BV & 4 & 0 & 4 & 0.0860 & 0.1700 & 0.3370 & 0.1620 \\
\hline B & CHI-K25 & 4 & 0 & 4 & 0.1040 & 0.2060 & 0.4080 & 0.1960 \\
\hline B & CHE-ORR & 4 & 0 & 3 & 0.2920 & 0.5870 & 1.1400 & 0.5470 \\
\hline B & CR-ORR & 4 & 0 & 4 & 0.1770 & 0.3500 & 0.6920 & 0.3320 \\
\hline B & CR-AND & 4 & 0 & 4 & 0.1550 & 0.3070 & 0.6080 & 0.2920 \\
\hline B & CR-ROA & 3 & 0 & 3 & 0.0633 & 0.1390 & 0.2480 & 0.1080 \\
\hline $\mathrm{C}$ & DG-AND & 4 & 1 & 2 & 0.0348 & 0.0664 & 0.1180 & 0.0596 \\
\hline $\mathrm{C}$ & DG-ROA & 4 & 1 & 0 & 0.0329 & 0.0732 & 0.1110 & 0.0502 \\
\hline $\mathrm{C}$ & DG-ORR & 4 & 1 & 2 & 0.0337 & 0.0644 & 0.1140 & 0.0575 \\
\hline $\mathrm{C}$ & NL-ORR & 4 & 0 & 4 & 0.0440 & 0.0810 & 0.1490 & 0.0769 \\
\hline $\mathrm{C}$ & CHI-BV & 4 & 0 & 4 & 0.1210 & 0.2230 & 0.4100 & 0.2110 \\
\hline $\mathrm{C}$ & $\mathrm{CHI}-\mathrm{K} 25$ & 4 & 0 & 4 & 0.0759 & 0.1400 & 0.2570 & 0.1320 \\
\hline C & CHE-ORR & 4 & 0 & 3 & 0.0728 & 0.1360 & 0.2460 & 0.1260 \\
\hline C & CR-ORR & 4 & 0 & 4 & 0.1950 & 0.3590 & 0.6610 & 0.3410 \\
\hline $\mathrm{C}$ & CR-AND & 4 & 0 & 3 & 0.1110 & 0.2070 & 0.3760 & 0.1940 \\
\hline $\mathrm{C}$ & CR-ROA & 4 & 0 & 3 & 0.0738 & 0.1380 & 0.2490 & 0.1280 \\
\hline \multicolumn{9}{|c|}{ Uranium-235 (Gamma) } \\
\hline A & DG-AND & 4 & 0 & 4 & 0.0606 & 0.0727 & 0.0872 & 0.0706 \\
\hline A & DG-ROA & 4 & 0 & 4 & 0.0768 & 0.0922 & 0.1110 & 0.0896 \\
\hline A & DG-ORR & 4 & 0 & 4 & 0.0792 & 0.0950 & 0.1140 & 0.0923 \\
\hline A & NL-ORR & 4 & 0 & 4 & 0.0713 & 0.0855 & 0.1030 & 0.0831 \\
\hline A & REMAINDER & 23 & 0 & 0 & . & . & - & . \\
\hline $\mathbf{B}$ & DG-AND & 4 & 0 & 4 & 0.0537 & 0.0733 & 0.1000 & 0.0696 \\
\hline B & DG-ROA & 4 & 0 & 4 & 0.0639 & 0.0873 & 0.1190 & 0.0829 \\
\hline $\mathbf{B}$ & DG-ORR & 3 & 0 & 3 & 0.0700 & 0.1000 & 0.1310 & 0.0870 \\
\hline B & NL-ORR & 4 & 0 & 4 & 0.0412 & 0.0563 & 0.0769 & 0.0534 \\
\hline $\mathbf{B}$ & REMANNDER & 24 & 0 & 0 & - & - & - & - \\
\hline $\mathrm{C}$ & DG-AND & 4 & 0 & 4 & 0.0345 & 0.0447 & 0.0578 & 0.0430 \\
\hline $\mathrm{C}$ & DG-ROA & 4 & 0 & 4 & 0.0626 & 0.0810 & 0.1050 & 0.0781 \\
\hline $\mathrm{C}$ & DG-ORR & 4 & 0 & 4 & 0.0433 & 0.0560 & 0.0725 & 0.0540 \\
\hline $\mathrm{C}$ & NL-ORR & 4 & 0 & 4 & 0.0473 & 0.0612 & 0.0792 & 0.0589 \\
\hline $\mathrm{C}$ & CR-ORR & 4 & 0 & 1 & 0.1620 & 0.2270 & 0.2720 & 0.1950 \\
\hline $\mathrm{C}$ & CR-ROA & 4 & 0 & 1 & 0.0918 & 0.1320 & 0.1540 & 0.1080 \\
\hline $\mathrm{C}$ & REMAINDER & 16 & 0 & 0 & . & . & . & - \\
\hline
\end{tabular}


Table 5.8 (continued)

\begin{tabular}{|c|c|c|c|c|c|c|c|c|}
\hline Horizon & $\begin{array}{c}\text { Formation- } \\
\text { location }\end{array}$ & $\mathbf{N}$ & $I$ & $\mathbf{D}$ & Median & UCB95 & X95 & LTB9595 \\
\hline \multicolumn{9}{|c|}{ Uranium-236 (Alpha) } \\
\hline $\mathbf{A}$ & DG-ORR & 4 & 0 & 1 & 0.0165 & 0.0292 & 0.0325 & 0.0185 \\
\hline $\mathbf{A}$ & CHI-K25 & 4 & 1 & 0 & 0.0103 & 0.0180 & 0.0204 & 0.0113 \\
\hline $\mathbf{A}$ & CR-ORR & 4 & 0 & 1 & 0.0107 & 0.0174 & 0.0210 & 0.0126 \\
\hline A & REMAINDER & 28 & 0 & 0 & - & - & - & - \\
\hline B & DG-ORR & 4 & 0 & 1 & 0.0111 & 0.3290 & 0.3110 & 0.0156 \\
\hline B & REMAINDER & 35 & $\mathbf{0}$ & $\mathbf{0}$ & • & - & - & - \\
\hline C & $\mathrm{CHI}-\mathrm{K} 25$ & 4 & 0 & 1 & - & • & - & - \\
\hline C & CR-ROA & 4 & 1 & $\mathbf{0}$ & - & - & - & - \\
\hline C & REMAINDER & 32 & 0 & 0 & - & - & - & - \\
\hline \multicolumn{9}{|c|}{ Uranium-238 (Alpha) } \\
\hline $\mathbf{A}$ & DG-AND & 4 & 0 & 4 & 0.890 & 0.996 & 1.11 & 0.988 \\
\hline A & DG-ROA & 4 & 0 & 4 & 0.992 & 1.110 & 1.24 & 1.100 \\
\hline A & DG-ORR & 4 & 0 & 4 & 1.020 & 1.150 & 1.28 & 1.140 \\
\hline A & NL-ORR & 4 & 0 & 4 & 1.280 & 1.430 & 1.60 & 1.420 \\
\hline $\mathbf{A}$ & CHI-BV & 4 & 0 & 4 & 1.060 & 1.190 & 1.33 & 1.180 \\
\hline $\mathbf{A}$ & CHII-K25 & 4 & 0 & 4 & 1.220 & 1.360 & 1.52 & 1.350 \\
\hline A & CHE-ORR & 4 & 0 & 4 & 1.120 & 1.260 & 1.40 & 1.250 \\
\hline A & CR-ORR & 4 & 0 & 4 & 1.380 & 1.540 & 1.73 & 1.530 \\
\hline $\mathbf{A}$ & CR-AND & 4 & 0 & 4 & 1.360 & 1.520 & 1.70 & 1.510 \\
\hline A & CR-ROA & 4 & 0 & 4 & 0.836 & 0.935 & 1.05 & 0.928 \\
\hline B & DG-AND & 4 & 0 & 4 & 0.966 & 1.170 & 1.42 & 1.160 \\
\hline B & DG-ROA & 4 & 0 & 4 & 0.825 & 1.000 & 1.21 & 0.987 \\
\hline B & DG-ORR & 4 & 0 & 4 & 1.120 & 1.350 & 1.64 & 1.340 \\
\hline B & NL-ORR & 4 & 0 & 4 & 1.050 & 1.280 & 1.55 & 1.260 \\
\hline B & CHI-BV & 4 & $\mathbf{0}$ & 4 & 1.050 & 1.280 & $1.55^{\circ}$ & 1.260 \\
\hline B & CHI-K25 & 4 & 0 & 4 & 1.260 & 1.520 & 1.85 & 1.500 \\
\hline B & CHE-ORR & 4 & 0 & 4 & 1.540 & 1.870 & 2.26 & 1.840 \\
\hline B & CR-ORR & 4 & 0 & 4 & 1.840 & 2.230 & 2.70 & 2.200 \\
\hline B . & CR-AND & 4 & 0 & 4 & 1.760 & 2.140 & 2.59. & 2.110 \\
\hline B. & CR-ROA & 3 & 0 & 3 & 0.940 & 1.170 & 1.38 & 1.090 \\
\hline C & DG-AND & 4 & 0 & 4 & 0.871 & 1.050 & 1.25 & 1.030 \\
\hline C & DG-ROA & 4 & 0 & 4 & 0.743 & 0.892 & 1.07 & 0.881 \\
\hline C & DG-ORR & 4 & 0 & 4 & 0.666 & 0.800 & 0.96 & 0.790 \\
\hline C & NL-ORR & 4 & 0 & 4 & 1.120 & 1.350 & 1.62 & 1.330 \\
\hline C & CHI-BV & 4 & 0 & 4 & 1.040 & 1.250 & 1.50 & 1.240 \\
\hline $\mathrm{C}$ & CHII-K25 & 4 & 0 & 4 & 1.250 & 1.500 & 1.80 & 1.480 \\
\hline C & CHE-ORR & 4 & 0 & 4 & 1.300 & 1.560 & 1.87 & 1.540 \\
\hline C & CR-ORR & 4 & 0 & 4 & 2.100 & 2.520 & 3.03 & 2.490 \\
\hline C & CR-AND & 4 & 0 & 4 & 1.490 & 1.790 & 2.15 & 1.770 \\
\hline C & CR-ROA & 4 & 0 & 4 & 1.420 & 1.710 & 2.05 & 1.690 \\
\hline
\end{tabular}


Table 5.8 (continued)

\begin{tabular}{|c|c|c|c|c|c|c|c|c|}
\hline Horizon & $\begin{array}{c}\text { Formation- } \\
\text { location }\end{array}$ & $\mathrm{N}$ & I & D & Median & UCB95 & X95 & LTB9595 \\
\hline \multicolumn{9}{|c|}{ Uranium-238 (Gamma) } \\
\hline A & REMAINDER & 24 & $\mathbf{0}$ & 0 & - & . & - & . \\
\hline B & REMAINDER & 24 & $\mathbf{0}$ & 0 & - & . & . & - \\
\hline C & CHI-BV & 4 & 0 & 1 & 3.42 & 86.4 & 92.2 & 4.91 \\
\hline C & REMAINDER & 20 & 0 & 0 & . & . & . & . \\
\hline
\end{tabular}

${ }^{a} \mathrm{~N}=$ number of observations, possibly averages over replicates at sites; 1 = number of interval censored observations (see text); $D=$ number of true detects (see text); UCB95 = 95\% upper confidence bound for median; X95 = estimate of 95th percentile; LTB9595 = 95\% lower confidence bound for 95th percentile; REMAINDER refers to the remaining observations-no detects.

Table 5.9. Overall results of gamma screening for cesium-137 (Values are in picocuries per square centimeter.)

\begin{tabular}{lccrccr}
\hline Formation & Location & N & \multicolumn{1}{c}{ Mean } & Std Dev & Min & Max \\
\hline Chepultepec & ORR & 12 & 8.931 & 2.190 & 5.534 & 12.819 \\
Chickamauga & ORR-BV & 12 & 11.502 & 4.602 & 7.631 & 22.975 \\
Chickamauga & ORR-K25 & 12 & 8.586 & 0.946 & 7.103 & 9.730 \\
Copper Ridge & AND & 12 & 8.952 & 2.722 & 5.611 & 14.516 \\
Copper Ridge & ORR & 12 & 8.619 & 1.380 & 6.233 & 10.977 \\
Copper Ridge & ROA & 12 & 9.105 & 2.410 & 4.956 & 13.182 \\
Dismal Gap & AND & 12 & 7.870 & 3.007 & 3.775 & 14.424 \\
Dismal Gap & ORR & 12 & 8.541 & 1.525 & 6.024 & 11.053 \\
Dismal Gap & ROA & 12 & 6.577 & 2.923 & 1.975 & 11.937 \\
Nolichucky & ORR & 12 & 9.128 & 1.537 & 6.760 & 11.842 \\
\hline
\end{tabular}

The very low result ( $<3 \mathrm{pCi} / \mathrm{cm}^{2}$ ) in the Dismal Gap Formation of Roane County is from a severely eroded site; the several very high results $\left(>14 \mathrm{pCi} / \mathrm{cm}^{2}\right)$ are from sediment deposition sites.

All of the gamma scan cesium data are detects, and so they were analyzed using the usual F-tests (Proc GLM). Probably because they arise as counts, the data seem to be modeled more appropriately using the square-root rather than the log transformation. Therefore, the square-root transformation was used to statistically analyze the gamma screening data. This is a departure from the general lognormal approach. However, both transformations as well as no-transformation were investigated, and the following conclusions about differences across areas are not materially affected by the choice. The conclusions are also essentially the same if data greater than $14 \mathrm{pCi} / \mathrm{cm}^{2}$ or less than $3 \mathrm{pCi} / \mathrm{cm}^{2}$ are discarded.

There are some significant differences between FLs $(p=0.003)$ : the ChickamaugaBethel Valley cesium-137 levels are significantly higher than levels in the two off-site Dismal Gap locations. The on-site FLs have significantly higher levels than the off-site $(p=0.008)$, but that could result from formation differences. The significance level for the comparison of Copper Ridge to Dismal Gap levels is $\mathbf{0 . 0 2}$. 


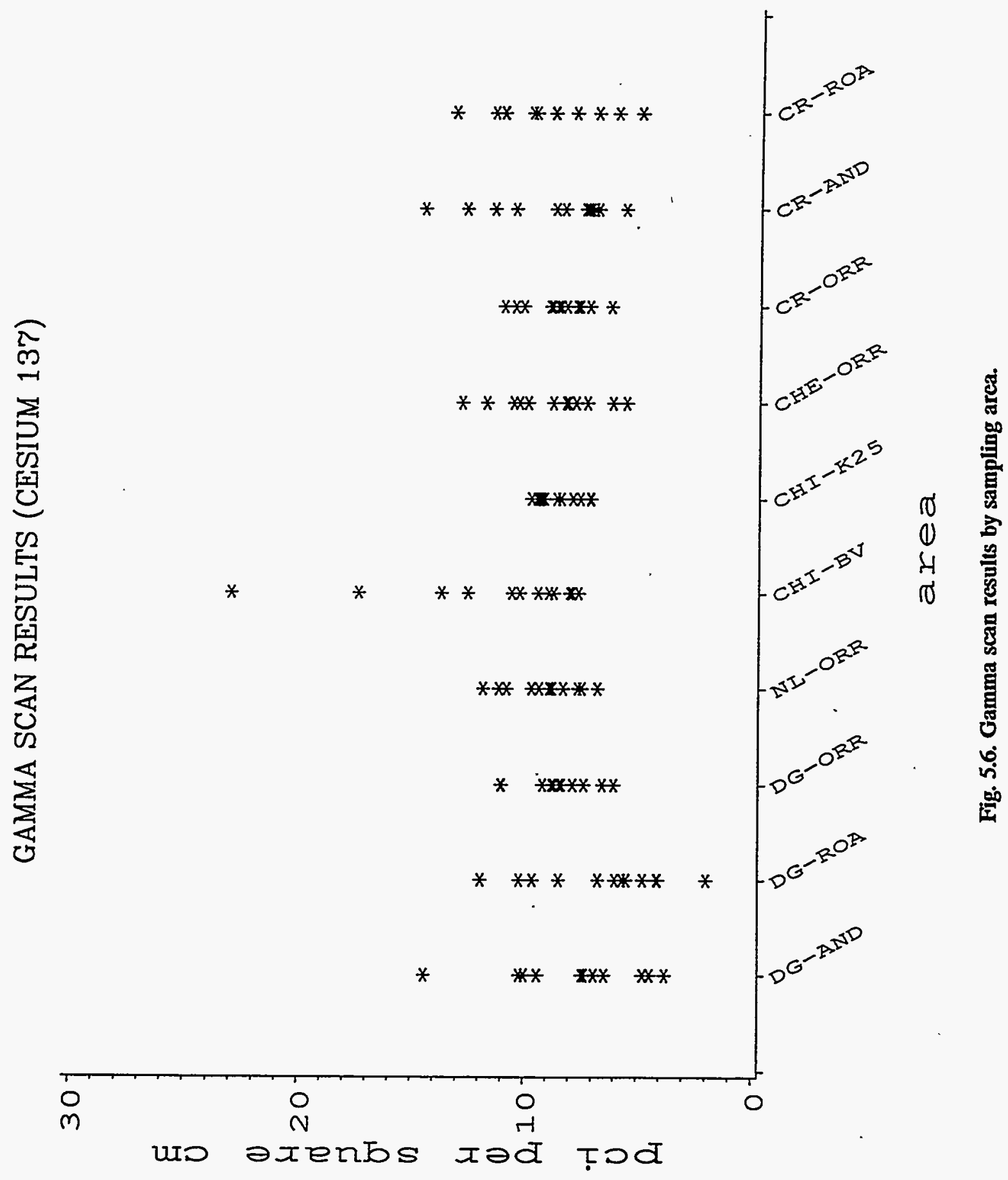




\subsection{VOLATHE ORGANICS}

No statistical analyses were performed on the volatile organics data. The purpose of these analyses was to screen for volatile organics-ideally to confirm that, since sampling is from background areas, volatile organics are absent. Although there are a few exceptions, this is generally true. The exceptions are discussed in Sect. 6.

\subsection{VARIANCE COMPONENTS}

The term "variance components" refers to the contributions to an overall variance or standard deviation by individual sources of error. Here there are two main sources, the field (spatial error) and the laboratory. In this section estimates of the standard deviations for these separate components are given. These standard deviation estimates can be used to compute tolerance bounds for composites of other than three. They can also be used in sample size calculations for future surveys, and to assess the advantage of compositing. These applications are discussed further here.

For radionuclides (except tritium and technetium-99) and inorganics, the variable LTB9595 is a tolerance bound for composites of three. Tolerance bounds for noncomposites or composites of other than three can also be computed from the BSCP data, but to do this, estimates of laboratory and spatial standard deviations are needed. Tolerance bounds for composites of other than three are useful as references for new composites of that same order. Tolerance bounds for noncomposites may also be useful as references for remediation.

BSCP data inherently exhibit a component of randomness due to laboratory and sampling errors. The variance of each observation satisfies

$$
\mathrm{V}=\mathrm{L}+\mathrm{S} / \mathrm{k},
$$

where $L$ is the variance of laboratory error, $S$ is the spatial variance of single (noncomposited) samples, and $\mathrm{k}$ is the level of compositing. $\mathrm{S}$ is the hypothetical variance of single samples measured without error. Strictly speaking, equation (5.1) applies to untransformed data, but it also holds approximately for log-transformed data. (To see this consider the equation $\mathrm{X}=$ $\left(x_{1}+\ldots+x_{k}\right) \cdot e / k$, where $X$ is the observation, $e$ represents laboratory error, and $x_{1}, \ldots, x_{k}$ represent the contributions of the $k$ individual samples to the overall composite. Note that expectation (E) satisfies $E\left[\left(x_{1}+\ldots+x_{k}\right) / k\right]=E\left(x_{1}\right)$, and the variance (Var) (distinct from V) satisfies

$$
\operatorname{Var}\left[\left(\mathrm{x}_{1}+\ldots+\mathrm{x}_{\mathrm{k}}\right) / \mathrm{k}\right]=\operatorname{Var}\left(\mathrm{x}_{1}\right) / \mathrm{k}
$$

From the variance approximation, $\operatorname{Var}[\log (\mathrm{Y})] \approx \operatorname{Var}(\mathrm{Y}) /[\mathrm{E}(\mathrm{Y})]^{2}$, it follows that $\operatorname{Var}[\log (\mathrm{X})] \approx \operatorname{Var}[\log (\mathrm{e})]+\operatorname{Var}\left[\log \left(\mathrm{x}_{1}\right)\right] / k$, which is equation (5.1) for the log-transformed data.) We will assume that equation (5.1) holds on the log scale for the log-transformed data.

For the lognormal model, computing a tolerance bound for a composite of $\mathrm{k}$ requires an estimate of $\mathrm{V}$. For composites of three, the quantity $\mathrm{V}$ can be estimated simply by computing the maximum likelihood estimate of the pooled standard deviation of individual (composited) BSCP observations using Proc Lifereg. L can be estimated from field duplicate and split 
differences, using data from all horizons. $S$ can then be estimated using equation (5.1) with $\mathrm{k}=3$.

Tables 5.10a through 5.10c contain standard deviation estimates for base-ten log concentrations of inorganics, PAHs, and radionuclides. Each standard deviation is the square root of the corresponding variance, $\mathrm{V}, \mathrm{L}$, or $\mathrm{S}$, of the log-transformed observations. A degree-of-freedom adjustment has been made so that the standard deviations coincide with the usual unbiased standard deviations when there are no nondetects. The degrees of freedom for the overall variance estimate is the number of observations, possibly averages, less the number of FLs for which there are observations.

As in the estimation analysis discussed above, results for this error analysis were averaged over sites so that the two analyses would be consistent. Because there is not much replication, this should not substantially affect the error estimates.

The degrees of freedom for laboratory error in Tables $5.10 \mathrm{a}-5.10 \mathrm{c}$ is the number of observations that are replicates less the number of sites for which there are replicates. Here degrees of freedom refers to both detects and nondetects. The quantity $\mathrm{D}$ is the number of true detects among the observation averages, which were used to compute the estimates and confidence bounds in Tables 5.1-5.8. Both degrees of freedom show that the standard deviation estimates are based on data that are combined over FLs (to increase precision). Standard deviations of the estimates of standard deviations are also given in the Proc Lifereg output.

For a number of horizons and analyses, the spatial standard deviation is missing (.), which indicates that the best estimate is actually zero. In particular, this happens when there is a relatively small overall standard deviation (of composites) and relatively large laboratory standard deviation. It can be a consequence of the noise inherent in these small-sample-size standard deviations or of anomalous discrepancies between field duplicates, as in Fig. 5.1. It may also be due to bias in the laboratory and spatial standard deviations, a consequence of imperfect replication: in addition to laboratory error, field duplicates reflect small-scale spatial variability, and both duplicates and splits reflect variability due to granularity of subsamples. These additional sources of variation may cause the laboratory standard deviations to be upwardly biased, which can in turn lead, via equation (5.1), to negative estimates of the spatial standard deviation.

The standard deviation estimates might be improved by basing the laboratory standard deviations solely on field splits rather than on both splits and duplicates. Then, however, the statistical imprecision would increase because of smaller sample sizes (i.e., $\mathrm{df}$ for the laboratory standard deviation). The standard deviation would most likely be improved with additional data based on standards (e.g., NIST-traceable) or replicates from homogeneous samples (with negligible granularity). This is also a good quality control procedure.

Means of untransformed observations do not depend on the degree of compositing, and the same holds approximately for their logs. Thus, estimates of and confidence bounds for the mean of BSCP composites-of-three are estimates and confidence bounds for other background observations, whatever the degree of compositing. 
Table 5.10a. Standard deviation estimates for inorganics

\begin{tabular}{|c|c|c|c|c|c|c|c|c|c|}
\hline Analysis & Horizon & $\begin{array}{l}\text { Number of } \\
\text { areas }\end{array}$ & $\mathbf{N}$ & Detect & $\begin{array}{c}\text { Std dev for } \\
\text { composites } \\
\text { (log of } \mathrm{mg} / \mathrm{kg} \text { ) }\end{array}$ & df & $\begin{array}{c}\text { Std dev for } \\
\text { laboratory } \\
\text { (log of } \mathrm{mg} / \mathrm{kg} \text { ) }\end{array}$ & df & $\begin{array}{c}\text { Spatial } \\
\text { std dev } \\
\text { (log of } \mathrm{mg} / \mathrm{kg} \text { ) }\end{array}$ \\
\hline Aluminum & A & 10 & 40 & 40 & 0.07200 & 30 & 0.05086 & 28 & 0.08827 \\
\hline Aluminum & B & 10 & 40 & 40 & 0.07389 & 30 & 0.05086 & 28 & 0.09283 \\
\hline Aluminum & C & 10 & 40 & 40 & 0.07602 & 30 & 0.05086 & 28 & 0.09785 \\
\hline Antimony & A & 10 & 40 & 2 & 0.01716 & 30 & 0.00018 & 28 & 0.02972 \\
\hline Antimony & B & 10 & 40 & 5 & 0.18080 & 30 & 0.00018 & 28 & 0.31315 \\
\hline Antimony & C & 10 & 40 & 6 & 0.18723 & 30 & 0.00018 & 28 & 0.32429 \\
\hline Arsenic & A & 10 & 39 & 39 & 0.15001 & 29 & 0.13435 & 28 & 0.11555 \\
\hline Arsenic & B & 10 & 38 & 37 & 0.17662 & 28 & 0.13435 & 28 & 0.19856 \\
\hline Arsenic & C & 10 & 39 & 37 & 0.24104 & 29 & 0.13435 & 28 & 0.34662 \\
\hline Barium & A & 10 & 40 & 40 & 0.15906 & 30 & 0.07471 & 28 & 0.24323 \\
\hline Barium & B & 10 & 40 & 40 & 0.09891 & 30 & 0.07471 & 28 & 0.11228 \\
\hline Barium & $\mathrm{C}$ & 10 & 40 & 40 & 0.19613 & 30 & 0.07471 & 28 & 0.31410 \\
\hline Beryllium & A & 10 & 40 & 37 & 0.12431 & 30 & 0.07061 & 28 & 0.17720 \\
\hline Beryllium & B & 10 & 40 & 36 & 0.14932 & 30 & 0.07061 & 28 & 0.22788 \\
\hline Beryllium & C & 10 & 40 & 37 & 0.13762 & 30 & 0.07061 & 28 & 0.20458 \\
\hline Boron & A & 10 & 34 & 7 & 0.25692 & 24 & 0.17883 & 27 & 0.31949 \\
\hline Boron & B & 10 & 36 & 8 & 0.26000 & 26 & 0.17883 & 27 & 0.32688 \\
\hline Boron & C & 10 & 35 & 10 & 0.20537 & 25 & 0.17883 & 27 & 0.17488 \\
\hline Calcium & A & 10 & 35 & 35 & 0.20090 & 25 & 0.04110 & 25 & 0.34061 \\
\hline Calcium & B & 10 & 34 & 34 & 0.21585 & 24 & 0.04110 & 25 & 0.36703 \\
\hline Calcium & C & 10 & 34 & 34 & 0.24230 & 24 & 0.04110 & 25 & 0.41360 \\
\hline Chromium & A & 10 & 39 & 39 & 0.09722 & 29 & 0.09812 & 28 & . \\
\hline Chromium & B & 10 & 39 & 39 & 0.10045 & 29 & 0.09812 & 28 & 0.03720 \\
\hline Chromium & C & 10 & 40 & 40 & 0.10780 & 30 & 0.09812 & 28 & 0.07731 \\
\hline Cobalt & A & 10 & 40 & 39 & 0.17417 & 30 & 0.14833 & 28 & 0.15811 \\
\hline Cobalt & B & 10 & 40 & 33 & 0.26813 & 30 & 0.14833 & 28 & 0.38687 \\
\hline Cobalt & C & 10 & 40 & 33 & 0.39403 & 30 & 0.14833 & 28 & 0.63228 \\
\hline Copper & A & 10 & 40 & 36 & 0.14634 & 30 & 0.08647 & 28 & 0.20448 \\
\hline Copper & B & 10 & 39 & 38 & 0.12734 & 29 & 0.08647 & 28 & 0.16190 \\
\hline Copper & C & 10 & 40 & 39 & 0.13172 & 30 & 0.08647 & 28 & 0.17209 \\
\hline Cyanide & A & 10 & 37 & 6 & 0.41034 & 27 & 0.65423 & 22 & . \\
\hline Cyanide & B & 10 & 38 & 3 & 0.44352 & 28 & 0.65423 & 22 & . \\
\hline Cyanide & C & 10 & 37 & 2 & 0.52389 & 27 & 0.65423 & 22 & \\
\hline Iron & A & 10 & 40 & 40 & 0.09175 & 30 & 0.09009 & 28 & 0.03010 \\
\hline Iron & B & 10 & 40 & 40 & 0.07428 & 30 & 0.09009 & 28 & . \\
\hline Iron & C & 10 & 40 & 40 & 0.06003 & 30 & 0.09009 & 28 & . \\
\hline Lead & A & 10 & 38 & 38 & 0.19194 & 28 & 0.15899 & 27 & 0.18625 \\
\hline Lead & B & 10 & 39 & 39 & 0.19485 & 29 & 0.15899 & 27 & 0.19508 \\
\hline Lead & C & 10 & 39 & 39 & 0.25300 & 29 & 0.15899 & 27 & 0.34088 \\
\hline Lithium & A & 10 & 36 & 29 & 0.15474 & 26 & 0.09431 & 27 & 0.21248 \\
\hline Lithium & B & 10 & 37 & 36 & 0.15403 & 27 & 0.09431 & 27 & 0.21093 \\
\hline Lithium & C & 10 & 37 & 34 & 0.16763 & 27 & 0.09431 & 27 & 0.24002 \\
\hline Magnesium & A & 10 & 40 & 40 & 0.11218 & 30 & 0.05647 & 28 & 0.16789 \\
\hline Magnesium & B & 10 & 40 & 40 & 0.09429 & 30 & 0.05647 & 28 & 0.13078 \\
\hline Magnesium & C & 10 & 40 & 40 & 0.10823 & 30 & 0.05647 & 28 & 0.15992 \\
\hline Manganese & A & 10 & 40 & 40 & 0.19166 & 30 & 0.14480 & 28 & 0.21748 \\
\hline Manganese & B & 10 & 40 & 40 & 0.33699 & 30 & 0.14480 & 28 & 0.52705 \\
\hline Manganese & C & 10 & 40 & 40 & 0.42776 & 30 & 0.14480 & 28 & 0.69717 \\
\hline Mercury & A & 10 & 40 & 32 & 0.09395 & 30 & 0.06908 & 28 & 0.11029 \\
\hline Mercury & B & 10 & 40 & 21 & 0.08383 & 30 & 0.06908 & 28 & 0.08226 \\
\hline Mercury & C & 10 & 40 & 24 & 0.10199 & 30 & 0.06908 & 28 & 0.12996 \\
\hline Molybdenum & A & 10 & 37 & 2 & 0.13156 & 27 & 0.07594 & 27 & 0.18608 \\
\hline Molybdenum & B & 10 & 37 & 12 & 0.18852 & 27 & 0.07594 & 27 & 0.29887 \\
\hline
\end{tabular}


Table 5.10a (continued)

\begin{tabular}{|c|c|c|c|c|c|c|c|c|c|}
\hline Analysis & Horizon & $\begin{array}{c}\text { Number of } \\
\text { areas }\end{array}$ & $\mathbf{N}$ & Detect & $\begin{array}{l}\text { Std dev for } \\
\text { composites - } \\
\text { (log of } \mathrm{mg} / \mathrm{kg})\end{array}$ & df & $\begin{array}{c}\text { Std dev for } \\
\text { laboratory } \\
\text { (log of } \mathrm{mg} / \mathrm{kg})\end{array}$ & - df & $\begin{array}{c}\text { Spatial } \\
\text { std dev } \\
(\log \text { of } \mathrm{mg} / \mathrm{kg})\end{array}$ \\
\hline Molybdenum & $\mathrm{C}$ & 10 & 37 & 13 & 0.14134 & 27 & 0.07594 & 27 & 0.20647 \\
\hline Nickel & A & 10 & 40 & 32 & 0.13026 & 30 & 0.07374 & 28 & 0.18598 \\
\hline Nickel & B & 10 & 40 & 35 & 0.13349 & 30 & 0.07374 & 28 & 0.19273 \\
\hline Nickel & C & 10 & 40 & 38 & 0.15103 & 30 & 0.07374 & 28 & 0.22828 \\
\hline Potassium & A & 10 & 39 & 35 & 0.12090 & 29 & 0.07729 & 26 & 0.16101 \\
\hline Potassium & B & 10 & 39 & 39 & 0.10031 & 29 & 0.07729 & 26 & 0.11074 \\
\hline Potassium & C & 10 & 39 & 39 & 0.09202 & 29 & 0.07729 & 26 & 0.08650 \\
\hline Selenium & A & 10 & 38 & 28 & 0.14337 & 28 & 0.16249 & 22 & - \\
\hline Selenium & B & 10 & 39 & 28 & 0.10935 & 29 & 0.16249 & 22 & - \\
\hline Selenium & C & 10 & 39 & 26 & 0.14860 & 29 & 0.16249 & 22 & - \\
\hline Silicon & A & 10 & 32 & 32 & 0.06008 & 22 & 0.05260 & 27 & 0.05029 \\
\hline Silicon & B & 10 & 32 & 32 & 0.07088 & 22 & 0.05260 & 27 & 0.08228 \\
\hline Silicon & $\mathrm{C}$ & 10 & 32 & 32 & 0.08176 & 22 & 0.05260 & 27 & 0.10841 \\
\hline Sodium & A & 7 & 25 & 23 & 0.03937 & 18 & 0.02680 & 19 & 0.04996 \\
\hline Sodium & B & 7 & 25 & 24 & 0.04408 & 18 & 0.02680 & 19 & 0.06061 \\
\hline Sodium & $\mathrm{C}$ & 7 & 25 & 24 & 0.05022 & 18 & 0.02680 & 19 & 0.07357 \\
\hline Strontium & A & 10 & 36 & 34 & 0.19646 & 26 & 0.09055 & 27 & 0.30197 \\
\hline Strontium & B & 10 & 37 & 34 & 0.23779 & 27 & 0.09055 & 27 & 0.38084 \\
\hline Strontium & C & 10 & 37 & 31 & 0.27897 & 27 & 0.09055 & 27 & 0.45703 \\
\hline Sulfate & A & 10 & 39 & 39 & 0.20390 & 29 & 0.15394 & 28 & 0.23159 \\
\hline Sulfate & $\mathbf{B}$ & 10 & 40 & 40 & 0.20194 & 30 & 0.15394 & 28 & 0.22638 \\
\hline Sulfate & C & 10 & 40 & 36 & 0.26151 & 30 & 0.15394 & 28 & 0.36616 \\
\hline Thallium & A & 10 & 38 & 3 & 0.49763 & 28 & 0.49717 & 22 & 0.03688 \\
\hline Thallium & B & 10 & 38 & 5 & 0.23344 & 28 & 0.49717 & 22 & . \\
\hline Thallium & C & 10 & 38 & 9 & 0.19571 & 28 & 0.49717 & 22 & - \\
\hline Vanadium & A & 10 & 40 & 40 & 0.08288 & 30 & 0.08567 & 28 & - \\
\hline Vanadium & B & 10 & 39 & 39 & 0.07638 & 29 & 0.08567 & 28 & - \\
\hline Vanadium & $\mathrm{C}$ & 10 & 40 & 40 & 0.06723 & 30 & 0.08567 & 28 & - \\
\hline Zinc & A & 10 & 40 & 40 & 0.12926 & 30 & 0.06856 & 28 & 0.18979 \\
\hline Zinc & B & 10 & 40 & 40 & 0.15942 & 30 & 0.06856 & 28 & 0.24928 \\
\hline Zinc & C & 10 & 40 & 39 & 0.17288 & 30 & 0.06856 & 28 & 0.27488 \\
\hline
\end{tabular}

aAll results are for base-ten log concentrations. $N=$ number of sites having observations. The degrees of freedom (df) for "std dev for composites" is the number of observations, possibly averages, less the number of areas for which there are observations. The degrees of freedom for "std dev for laboratory" is the number of observations that are replicates less the number of sites for which there are replicates. See text for descriptions of the standard deviations.

For a general composite of $\mathrm{k}^{\prime}$ an estimate $\hat{\mathrm{V}}^{\prime}$ of its variance $\mathrm{V}^{\prime}$ can be computed using Table 5.10 and equation (5.1). These estimates can be used in planning future surveys. If the laboratory variance $L$ changes, new estimates can be substituted for the laboratory standard deviation estimates in Table 5.10 .

For example, let $\mu$ denote the mean on the log scale of an analyte constituent in some area. On the log scale, with an estimate $\hat{\mu}$ of $\mu$, a percentile estimate can be computed as $\hat{\mu}+A\left(\hat{V}^{\prime}\right)^{1 / 2}$, where $A$ is a percentile of the normal distribution (e.g., $A=1.64$ for the 95 th percentile). To obtain a tolerance bound (i.e., confidence bound for the percentile), there is a need to estimate the standard error of this percentile estimate. The following two paragraphs present a sketch of how this can be done. Tolerance bounds can then be computed from the standard errors in the usual (normal theory) way. Estimates and tolerance bounds on the original (antilog) scale can then be obtained by taking antilogs. 
Table 5.10b. Standard deviation estimates for PAHs (All results for A horizon are noncomposites.)

\begin{tabular}{lcrrrrrrc}
\hline \multicolumn{1}{c}{ Analysis } & $\begin{array}{c}\text { Number of } \\
\text { areas }\end{array}$ & $\mathrm{N}$ & Detect & $\begin{array}{c}\text { Std dev } \\
\text { (log of } \\
\mu \mathrm{g} / \mathrm{kg})\end{array}$ & df & $\begin{array}{c}\text { Laboratory } \\
\text { std dev (log } \\
\text { of } \mu \mathrm{g} / \mathrm{kg})\end{array}$ & df & $\begin{array}{c}\text { Spatial std dev } \\
\text { (log of } \mu \mathrm{g} / \mathrm{kg})\end{array}$ \\
\hline Acenaphthene & 10 & 69 & 20 & 0.34213 & 59 & 0.12120 & 3 & 0.31995 \\
Acenaphthylene & 10 & 103 & 6 & 0.87895 & 93 & 0.00223 & 4 & 0.87895 \\
Anthracene & 10 & 86 & 39 & 0.38305 & 76 & 0.24522 & 4 & 0.29428 \\
Benzo[a]anthracene & 10 & 94 & 70 & 0.27652 & 84 & 0.39868 & 3 &. \\
Benzo[a]pyrene & 10 & 106 & 69 & 0.24590 & 96 & 0.05568 & 4 & 0.23951 \\
Benzo[b]fluoranthene & 10 & 94 & 53 & 0.25815 & 84 & 0.77358 & 4 & \\
Benzo[ghi]perylene & 10 & 88 & 53 & 0.24457 & 78 & 0.08351 & 3 & 0.22987 \\
Benzo[k]fluoranthene & 10 & 103 & 62 & 0.23387 & 93 & 0.21286 & 4 & 0.09688 \\
Chrysene & 10 & 67 & 23 & 0.27935 & 57 & 0.00000 & 2 & 0.27935 \\
Dibenzo[ah]anthracene & 9 & 67 & 27 & 0.34946 & 58 & 0.72932 & 3 & \\
Fiuoranthene & 9 & 68 & 58 & 0.32783 & 59 & 0.23984 & 2 & 0.22349 \\
Fluorene & 10 & 77 & 26 & 0.42111 & 67 & 0.04101 & 3 & 0.41911 \\
Indeno[1,2,3-c,d]pyrene & 10 & 106 & 28 & 0.31407 & 96 & 0.31941 & 4 & \\
Naphthalene & 9 & 75 & 21 & 0.41301 & 66 & 0.00174 & 3 & 0.41301 \\
Phenanthrene & 10 & 112 & 78 & 0.30720 & 102 & 0.17278 & 4 & 0.25401 \\
Pyrene & 10 & 102 & 63 & 0.33395 & 92 & 0.03737 & 4 & 0.33185 \\
\hline
\end{tabular}

${ }^{a}$ All results are for base-ten $\log$ concentrations. $N=$ number of sites having observations. The degrees of freedom (df) for "std dev for composites" is the number of observations, possibly averages, less the number of areas for which there are observations. The degrees of freedom for "std dev for laboratory" is the number of observations that are replicates less the number of sites for which there are replicates. See text for descriptions of the standard deviations.

The variance $V^{\prime}$ is $L+S / k^{\prime}$, and $S=k(V-L)$. Therefore $V^{\prime}=\left(1-k / k^{\prime}\right) L+\left(k / k^{\prime}\right) V$, and the 'percentile for the new composite of $\mathrm{k}^{\prime}$ is $\mu+\mathrm{A}\left[\left(1-\mathrm{k} / \mathrm{k}^{\prime}\right) \mathrm{L}+\left(\mathrm{k} / \mathrm{k}^{\prime}\right) \mathrm{V}\right]^{1 / 2}$. $\mathrm{V}^{\prime}$ can be estimated either by substituting estimates $\hat{S}$ and $\hat{L}$ of $S$ and $L$ into $L+S / k^{\prime}$ [i.e., using equation (5.1) with $\mathbf{k}=\mathbf{k}^{\prime}$ ], or equivalently, by substituting estimates of $\mathrm{V}$ and $\mathrm{L}$ into $\left(1-\mathrm{k} / \mathrm{k}^{\prime}\right) \mathrm{L}+\left(\mathrm{k} / \mathrm{k}^{\prime}\right) \mathrm{V}$. Estimates $\hat{\mu}$ and $\hat{\mathrm{V}}$ of $\mu$ and $\mathrm{V}$ and their approximate variances and covariances can be obtained from the Proc Lifereg output. Likewise, $\hat{L}$ and its approximate variance can be obtained from a Lifereg analysis of replicates.

It is well known that for uncensored lognormal data, the sample mean and variance of the logs are statistically independent. Because field splits and duplicates from the same site are usually quite homogeneous, the mean of their logs is usually quite close to the log of their mean. Therefore, the sample variance of the logs and the log of the mean are approximately independent. It can be assumed that this approximation holds and that it continues to hold even with limited censoring. Then, the covariance of $\hat{\mathrm{L}}$ with either $\hat{\mu}$ or $\hat{\mathrm{V}}$ is approximately zero, and, using $\hat{\mu}, \hat{\mathrm{L}}$, and $\hat{\mathrm{V}}$ and their approximate variances and covariances, an approximate standard error for $\hat{\mu}+A\left(\hat{V}^{\prime}\right)^{1 / 2}$ can be obtained (with a first-order Taylor-expansion of $\mu+\mathrm{A}\left[\left(1-\mathrm{k} / \mathrm{k}^{\prime}\right) \mathrm{L}+\left(\mathrm{k} / \mathrm{k}^{\prime}\right) \mathrm{V}\right]^{1 / 2}$ in $\mu, \mathrm{V}$, and $\left.\mathrm{L}\right)$.

Because the laboratory standard deviations are biased up and the spatial standard deviations are biased down, the ratio, $\mathrm{R}$, of spatial-to-laboratory standard deviations is biased down. This ratio is of interest because, as can be shown, the degree of compositing $k$ that minimizes the overall variance for a fixed total cost is given by $R(A / F)^{1 / 2}$, where $F$ is the cost 
Table 5.10c. Standard deviation estimates for radionuclides ${ }^{a}$

\begin{tabular}{|c|c|c|c|c|c|c|c|c|c|}
\hline Analysis & Horizon & $\begin{array}{l}\text { Number of } \\
\text { areas }\end{array}$ & $\mathbf{N}$ & $\mathrm{D}$ & $\begin{array}{l}\text { Std dev for } \\
\text { composites } \\
\text { (log of pCi/g) }\end{array}$ & df & $\begin{array}{c}\text { Std dev for } \\
\text { laboratory } \\
(\log \text { of } \mathrm{pCi} / \mathrm{g})\end{array}$ & df & $\begin{array}{c}\text { Spatial std } \\
\text { dev (log of } \\
\text { pCi/g) }\end{array}$ \\
\hline \multicolumn{10}{|c|}{ Alpha } \\
\hline Neptunium-237 & A & 8 & 29 & 26 & 0.15728 & 21 & 0.13623 & 12 & 0.13612 \\
\hline Plutonium-238 & A & 10 & 38 & 16 & 0.19954 & 28 & 0.39234 & 16 & . \\
\hline Plutonium-239/240 & A & 10 & 38 & 10 & 0.51850 & 28 & 0.58490 & 15 & . : \\
\hline Radium-226 & A & 10 & 40 & 39 & 0.22688 & 30 & 0.19687 & 28 & 0.19529 \\
\hline Radium-226 & B & 10 & 40 & 39 & 0.16870 & 30 & 0.19687 & 28 & . \\
\hline Radium-226 & $\mathrm{C}$ & 10 & 40 & 40 & 0.16180 & 30 & 0.19687 & 28 & . \\
\hline Thorium-228 & A & 10 & 40 & 39 & 0.21591 & 30 & 0.08428 & 28 & 0.34430 \\
\hline Thorium-228 & B & 10 & 40 & 40 & 0.19299 & 30 & 0.08428 & 28 & $0.30070^{3}$ \\
\hline Thorium-228 & C & 10 & 40 & 39 & 0.23313 & 30 & 0.08428 & 28 & 0.37647 \\
\hline Thorium-230 & A & 10 & 40 & 40 & 0.11044 & 30 & 0.10342 & 28 & 0.06711 \\
\hline Thorium-230 & B & 10 & 40 & 39 & 0.15119 & 30 & 0.10342 & 28 & 0.19101 \\
\hline Thorium-230 & $\mathrm{C}$ & 10 & 40 & 40 & 0.15336 & 30 & 0.10342 & 28 & 0.19613 \\
\hline Thorium-232 & A & 10 & 40 & 40 & 0.09172 & 30 & 0.09469 & 28 & . \\
\hline Thorium-232 & B & 10 & 40 & 40 & 0.14587 & 30 & 0.09469 & 28 & 0.19219 \\
\hline Thorium-232 & $\mathrm{C}$ & 10 & 40 & 40 & 0.19136 & 30 & 0.09469 & 28 & 0.28803 \\
\hline Total uranium & A & 10 & 38 & 37 & 0.33747 & 28 & 0.32526 & 15 & 0.15580 \\
\hline Uranium-233/234 & A & 10 & 40 & 40 & 0.11548 & 30 & 0.06742 & 27 & 0.16239 \\
\hline Uranium-233/234 & B & 10 & 39 & 39 & 0.13642 & 29 & 0.06742 & 27 & 0.20541 \\
\hline Uranium-233/234 & $\mathrm{C}$ & 10 & 40 & 40 & 0.11070 & 30 & 0.06742 & 27 . & 0.15208 \\
\hline Uranium-235 & A & 10 & 40 & 33 & 0.19423 & 30 & 0.27946 & 27 & . \\
\hline Uranium-235 & B & 10 & 39 & 32 & 0.41693 & 29 & 0.27946 & 27 & 0.53589 \\
\hline Uranium-235 & $\mathrm{C}$ & 10 & 40 & 31 & 0.37560 & 30 & 0.27946 & 27 & 0.43466 \\
\hline Uranium-236 & A & 10 & 40 & 3 & 0.24580 & 30 & 0.30884 & 27 & - \\
\hline Uranium-236 & $\mathrm{B}$ & 10 & 39 & 1 & 1.02053 & 29 & 0.30884 & 27 & 1.68473 \\
\hline Uranium-236 & $\mathrm{C}$ & 10 & 40 & 1 & 0.17440 & 30 & 0.30884 & 27 & . \\
\hline
\end{tabular}


Table 5.10c (continued)

\begin{tabular}{|c|c|c|c|c|c|c|c|c|c|}
\hline Analysis & Horizon & $\begin{array}{c}\text { Number of } \\
\text { areas }\end{array}$ & $\mathrm{N}$ & $\mathrm{D}$ & $\begin{array}{c}\text { Std dev for } \\
\text { composites } \\
\text { (log of } \mathrm{pCi} / \mathrm{g} \text { ) }\end{array}$ & df & $\begin{array}{c}\text { Std dev for } \\
\text { laboratory } \\
\text { (log of } p \mathrm{i} / \mathrm{g} \text { ) }\end{array}$ & df & $\begin{array}{c}\text { Spatial std } \\
\text { dev (log of } \\
\text { pCi/g) }\end{array}$ \\
\hline Uranium-238 & A & 10 & 40 & 40 & 0.06817 & 30 & 0.06118 & 27 & 0.05208 \\
\hline Uranium-238 & B & 10 & 39 & 39 & 0.11781 & 29 & 0.06118 & 27 & 0.17438 \\
\hline Uranium-238 & C & 10 & 40 & $\begin{array}{c}40 \\
\text { Beta }\end{array}$ & 0.11134 & 30 & 0.06118 & 27 & 0.16113 \\
\hline Strontium-90 & A & 10 & 36 & 2 & 0.12755 & 26 & 0.47729 & 16 & . \\
\hline Technetium-99 & A & 10 & 46 & 10 & 0.25012 & 36 & 1.00549 & 4 & . \\
\hline Thorium-234 & A & 10 & 34 & 20 & 0.09083 & 24 & 0.23733 & 25 & . \\
\hline Thorium-234 & B & 10 & 34 & 20 & 0.23650 & 24 & 0.23733 & 25 & . \\
\hline Thorium-234 & $\mathrm{C}$ & 10 & 34 & $\begin{array}{c}18 \\
\text { Gamma }\end{array}$ & 0.21492 & 24 & 0.23733 & 25 & . \\
\hline Cesium-137 & A & 10 & 40 & 38 & 0.52601 & 30 & 0.53234 & 28 & . \\
\hline Cesium-137 & B & 10 & 39 & 16 & 0.83589 & 29 & 0.53234 & 28 & 1.11625 \\
\hline Cesium-137 & $\mathrm{C}$ & 10 & 39 & 5 & 1.37535 & 29 & 0.53234 & 28 & 2.19649 \\
\hline Curium-247 & A & 10 & 36 & 2 & 0.08058 & 26 & 0.00558 & 15 & 0.13924 \\
\hline Potassium-40 & A & 10 & 40 & 40 & 0.11814 & 30 & 0.07937 & 25 & 0.15156 \\
\hline Potassium-40 & B & 10 & 36 & 36 & 0.17712 & 26 & 0.07937 & 25 & 0.27426 \\
\hline Potassium-40 & $\mathrm{C}$ & 10 & 36 & 36 & 0.17937 & 26 & 0.07937 & 25 & 0.27862 \\
\hline Uranium-235 & A & 10 & 39 & 16 & 0.11140 & 29 & 0.10418 & 28 & 0.06831 \\
\hline Uranium-235 & B & 10 & 39 & 15 & 0.19108 & 29 & 0.10418 & 28 & 0.27744 \\
\hline Uranium-235 & $\mathrm{C}$ & 10 & 40 & 18 & 0.15724 & 30 & 0.10418 & 28 & 0.20398 \\
\hline Uranium-238 & $\mathrm{C}$ & 6 & 24 & $\begin{array}{c}1 \\
\text { Tritium }\end{array}$ & 1.00470 & 18 & 0.00096 & 19 & 1.74018 \\
\hline Tritium $^{b}$ & A & 8 & 50 & 15 & 0.32199 & 42 & 0.29663 & 7 & 0.12524 \\
\hline
\end{tabular}

${ }^{a}$ All results are for base-ten log concentrations. $N=$ number of sites having observations. The degrees of freedom (df) for "std dev for composites" is the number of observations, possibly averages, less the number of areas for which there are observations. The degrees of freedom for "std dev for laboratory" is the number of observations that are replicates less the number of sites for which there are replicates. See text for descriptions of the standard deviation.

noncomposites 
per field sample and $A$ is the cost per sample sent to the laboratory. [Using Lagrange multipliers, minimize $(\mathrm{L}+\mathrm{S} / \mathrm{k}) / \mathrm{N}$ subject to $\mathrm{NA}+\mathrm{NkF}=\mathrm{C}$, where $\mathrm{N}$ is the number of laboratory samples and $C$ is the fixed total cost.] Note that $A$ includes the costs of data entry, verification, and validation.

In 1992, costs to the BSCP for laboratory analysis, data entry, and validation were about 4.5 times the cost of field sampling. Because field samples were composited, this implies that $\mathrm{A} / \mathrm{F}>4.5$, and thus $(\mathrm{A} / \mathrm{F})^{1 / 2}>2.1$. Thus, the optimal $\mathrm{k}$ exceeds $2.1 \mathrm{R}$. From Tables 5.10a and $5.10 \mathrm{c}$, values of $\mathrm{R}$ (which are biased down) are in the vicinity of 2-3.5 for arsenic, beryllium, and lead, 4 for thorium-228, $0.5-4.5$ for total uranium, 0.6-2.6 for uranium-235 (gamma), and 60 for thorium. For these analytes, the optimal $\mathbf{k}$ is at least 1 , and often greater than 4. Although it is difficult to quantify the cost of statistical variability, compositing translates to direct savings to the project.

\subsection{NAA DATA}

The primary purpose of analyzing BSCP samples by NAA was to investigate the relationship between NAA and corresponding AA/ICP, alpha, beta, and gamma results. The NAA results serve, secondarily, as background data in their own right. The statistical analysis of the NAA data is the same as for the other methods, but, in addition, the relationship of NAA and corresponding results through (1) graphics, (2) correlation, and (3) regression is considered.

Summary statistics for NAA data are given in Table G.1. The relationship between NAA and corresponding results was investigated graphically using data plots, such as Fig. 5.7 and Fig. 5.8.

Correlations between NAA and corresponding other BSCP data are not straightforward, because there can be nondetects in either the NAA or corresponding data. For each relationship, a correlation statistic was computed that is a simple analog of the Kendall's tau statistic (Lehmann 1975, p. 316). This statistic, also called the "coefficient of concordance," is computed by examining all possible pairs of ordered pairs $(x, y)$ of data. Here $x$ refers to an NAA result and $y$ to the corresponding result from AA/ICP, alpha. A pair of pairs, $\left(x_{1}, y_{1}\right)$ and $\left(x_{2}, y_{2}\right)$ are said to be concordant if either $x_{1}<x_{2}$ and $y_{1}<y_{2}$ or else $x_{1}>x_{2}$ and $y_{1}>$ $y_{2}$. They are said to be discordant if either $x_{1}<x_{2}$ and $y_{1}>y_{2}$ or else $x_{1}>x_{2}$ and $y_{1}<y_{2}$. (Various modifications have been considered for ties-that is, when either $x_{1}=x_{2}$ or $y_{1}=y_{2}$ ) Kendall's tau is the ratio of "score" to "possible," where "score" is the number of concordant pairs less the number of discordant pairs, and "possible" is the total number of pairs compared. Kendall's tau is one in the case of perfect concordance, minus one in the case of perfect discordance, and otherwise between minus one and one.

Modifying Kendall's tau to accommodate nondetects is straightforward: for certain pairs, because of either censoring or ties, concordancy or discordancy is indeterminate. Those pairs are excluded from the total possible considered and the correlation statistic is computed on the basis of determinate pairs only. These correlation statistics are given in Tables 5.11a and 5.11b.

Unfortunately, computing significance levels for these correlations is not straightforward, and that task is not pursued further. 
Table 5.11a. Correlation statistics for radionuclides ${ }^{a}$ (NAA with alpha or gamma)

\begin{tabular}{lrccc}
\hline \multicolumn{1}{c}{ Analysis } & N & Score & Possible & Corr \\
\hline Potassium-40 & 89 & 2961 & 3901 & 0.76 \\
Thorium-232 & 102 & 2564 & 5100 & 0.50 \\
Uranium-235 & 100 & 1494 & 4462 & 0.33 \\
Uranium-238 & 97 & 2142 & 4608 & 0.46 \\
\hline
\end{tabular}

"See text for definitions of "score" and "possible."

Table 5.11b. Correlation statistics for metals ${ }^{a}$ (NAA with AA/ICP)

\begin{tabular}{lrrrr}
\hline \multicolumn{1}{c}{ Analysis } & N & Score & Possible & Corr \\
\hline Aluminum & 101 & 3180 & 5018 & 0.63 \\
Antimony & 99 & -362 & 554 & -0.65 \\
Arsenic & 95 & 2524 & 4436 & 0.57 \\
Barium & 102 & 1890 & 5138 & 0.37 \\
Chromium & 100 & 2608 & 4934 & 0.53 \\
Cobalt & 102 & 3643 & 4817 & 0.76 \\
Iron & 102 & 3792 & 5136 & 0.74 \\
Magnesium & 101 & 2933 & 4977 & 0.59 \\
Manganese & 102 & 3877 & 5139 & 0.75 \\
Potassium & 95 & 3461 & 4425 & 0.78 \\
Sodium & 78 & 1174 & 2946 & 0.40 \\
Vanadium & 100 & 2457 & 4937 & 0.50 \\
Zinc & 71 & 1769 & 2417 & 0.73 \\
& & & & \\
\hline
\end{tabular}

aSee text for definitions of "score" and "possible."

Ideally, the most straightforward way to compare NAA and corresponding results would be by regression of the corresponding results on the NAA. Again, this process is complicated by the nondetects: The lognormal-model SAS Lifereg procedure can accommodate censoring in dependent variables but not in independent variables. Fortunately, most of the NAA analytes having corresponding results for AA/ICP have either no censoring or very little. In those cases, regressions are appropriate. Regression results are summarized in Tables 5.12a and 5.12b.

For example, the intercept and slope for the uranium-235 regression of the log alpha results on the log NAA results has intercept $1.03 \pm 0.48$ and slope $1.75 \pm 0.39$. In theory these values should be 0 and 1 . By contrast, the intercept and slope for the uranium-238 regression are $-0.15 \pm 0.06$ and $1.10 \pm 0.31$, much closer to the ideal. 


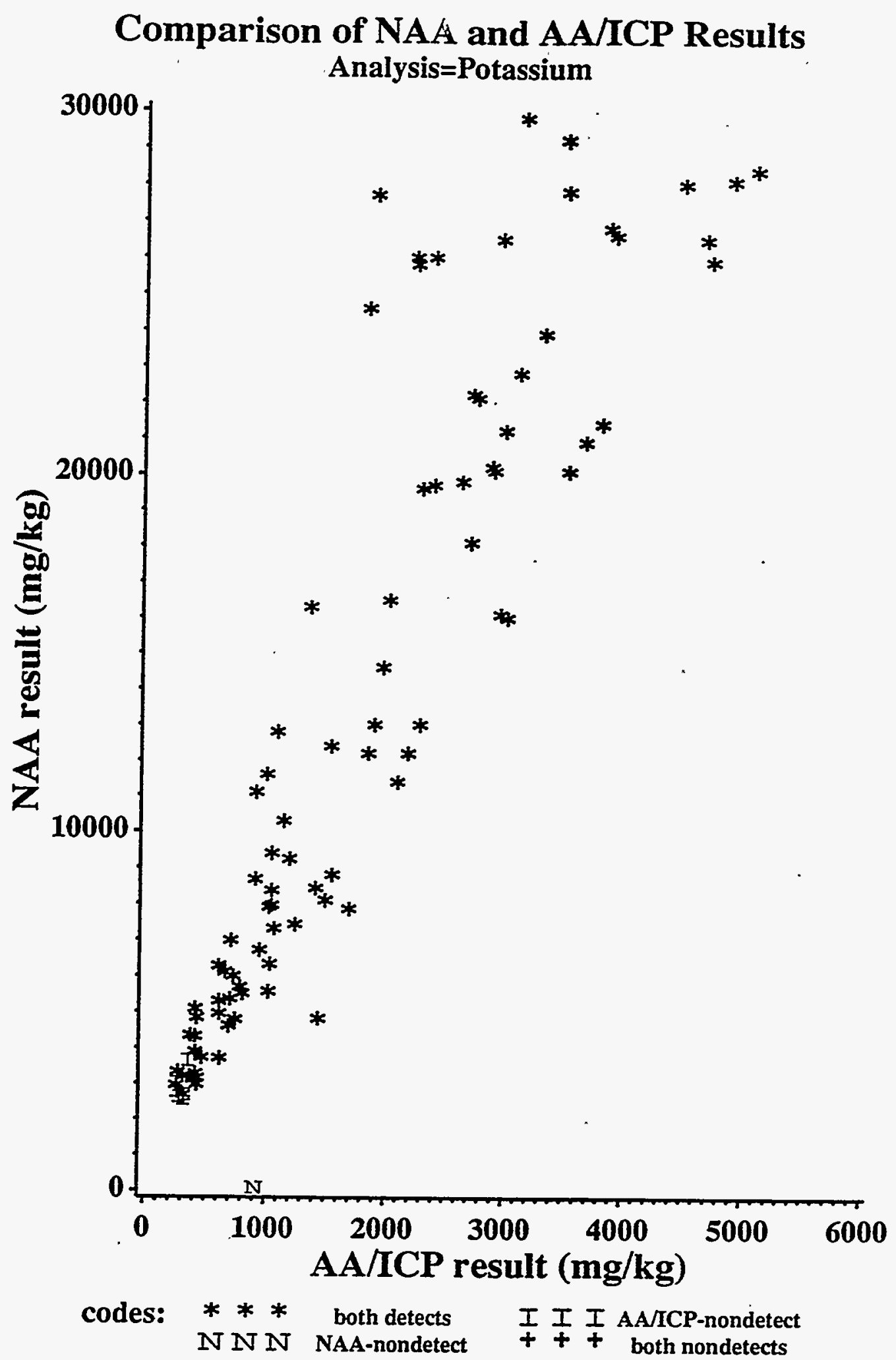

Fig. 5.7. Example plot for potassium for comparing NAA with AA/ICP results. 
Comparison of NAA and Gamma Radionuclide Results Analysis $=$ POTASSIUM -40

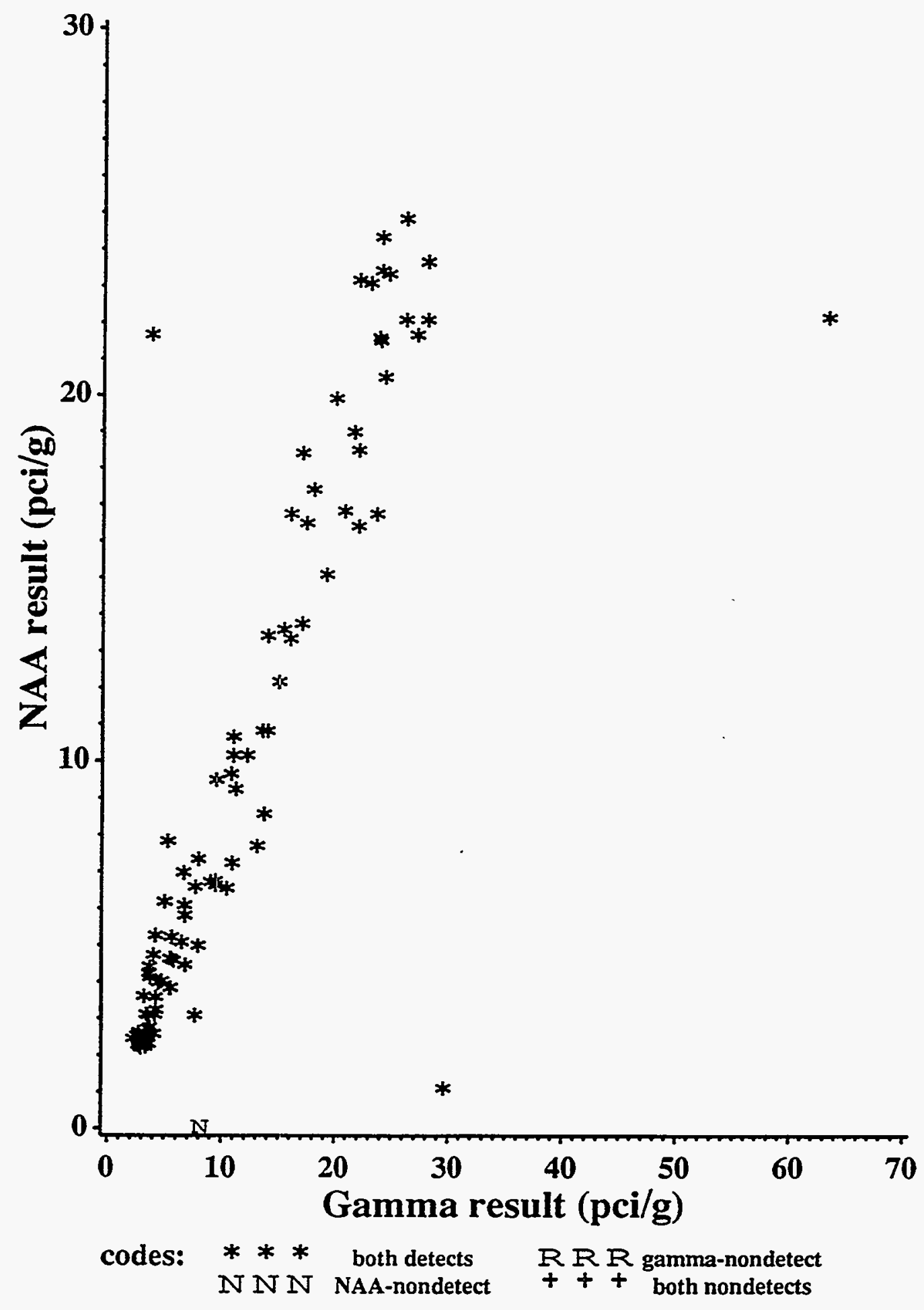

Fig. 5.8. Example comparison of NAA and gamma results for potassium-40. 
Table 5.12a Regression statistics for radionulides ${ }^{a}$ (NAA with alpha or gamma)

\begin{tabular}{rrrrr}
\hline Analysis & Intercept & Std Err & Slope & Std Err \\
\hline & & & & \\
Potassium-40 & 0.387 & 0.057 & 0.662 & 0.061 \\
Thorium-232 & -0.004 & 0.016 & 0.711 & 0.100 \\
Uranium-235 & 1.031 & 0.479 & 1.754 & 0.391 \\
Uranium-238 & -0.152 & 0.057 & 1.108 & 0.312 \\
\hline
\end{tabular}

antercepts and their standard errors are in picocuries per gram. Slopes and their standard errors are unitless.

Table 5.12b. Regression statistics for metals ${ }^{2}$ (NAA with AA/ICP)

\begin{tabular}{lrrrr}
\hline \multicolumn{1}{c}{ Analysis } & Intercept & Std Err & Slope & Std Err \\
\hline & & & & \\
Aluminum & 3.285 & 0.146 & 0.214 & 0.031 \\
Antimony & -1.459 & 0.435 & -0.928 & 0.634 \\
Arsenic & 0.216 & 0.078 & 0.811 & 0.068 \\
Barium & 1.372 & 0.100 & 0.153 & 0.038 \\
Chromium & 0.226 & 0.123 & 0.701 & 0.070 \\
Cobalt & -0.390 & 0.072 & 1.275 & 0.067 \\
Iron & 0.673 & 0.213 & 0.848 & 0.047 \\
Magnesium & 1.310 & 0.222 & 0.486 & 0.062 \\
Manganese & 1.399 & 0.154 & 0.480 & 0.060 \\
Potassium & -0.353 & 0.219 & 0.866 & 0.055 \\
Sodium & 2.383 & 0.034 & 0.071 & 0.013 \\
Vanadium & 1.454 & 0.056 & 0.109 & 0.030 \\
Zinc & 0.041 & 0.108 & 0.880 & 0.053 \\
& & & & \\
\hline
\end{tabular}

\footnotetext{
${ }^{a}$ Intercepts and their standard errors are in picocuries per gram. Slopes and their standard errors are unitless.
}

\subsection{ICP/MS DATA}

Analysis of the ICP/MS data parallels the NAA analysis, except that it is for metals only. Summary statistics of ICP/MS data are presented in Table G.2. Correlation statistics of ICP/MS with AA/ICP appear in Table 5.13 and regression statistics in Table 5.14.

\subsection{ADDITIONAL REMARKS}

Many of the results need further consideration, particularly the large discrepancies between some field duplicate and original results for some of the inorganics, and a few 
severely high detection limits for some of the radionuclides. In contrast to the inorganics, the duplicate and original results for the organics are very close. Perhaps the designation " $U$ " for nondetect has been applied too conservatively for the organics. In this background study, the use of unnecessarily high detection limits is not conservative because it tends to obscure how low background values actually may be.

Statistics presented in this section may be biased upwards (too high) because of the assignment of validation codes on the basis of detect-nondetect status. Again, because this is a background study, upward bias is nonconservative.

Because many analytes do differ significantly by FL and by horizon, many that do not probably would if sample sizes were larger or statistical variability were smaller. In cases where no significant difference was found, confidence limits for the true differences, or minimum detectable differences should be considered. In many cases the minimum detectable differences may themselves be of practical importance. This would indicate a need for further sampling (or more powerful statistical methods).

Field duplicates can be analyzed to assess small-scale spatial variability. This was not considered in the BSCP Plan, and has not been pursued here. Some of the BSCP data are field splits. The splits cannot be used to assess small-scale variability, but they provide a much better assessment of laboratory error than field duplicates, for the very reason that splits do not differ because of small-scale spatial differences. As indicated in Sects. 5.2 and 5.10, the estimation of laboratory variability is crucial here. In providing an assessment of laboratory error, field splits also offer a method of validation that depends only on the simple statistical comparisons of results and not on expensive and time-consuming reviews of paperwork.

Some of the analyses are inherently noisy. This is seen in the wide departure of the confidence bounds from their corresponding median or percentile estimates. In certain cases risk arguments may demonstrate that the results are adequate (or more than adequate) despite the noise. In other cases the noise problem might be approached by pooling results, for example over formations within groups (as in Table G.1), if such pooling can be justified. The noise might also be mitigated by some method of statistical analysis that is more complicated than the lognormal model used here (e.g., a multivariate analysis using vectors of measurements over horizons). It is likely, however, that in many cases the only viable way to reduce the noise, which is an unavoidable consequence of the survey's limited sample sizes, may be to obtain additional data. 
Table 5.13. Correlation statistics for metals ${ }^{a}$. (ICP/MS with AA/ICP)

\begin{tabular}{lrrrr}
\hline Analysis & N & Score & Possible & Corr \\
\hline & 99 & 3307 & 4813 & 0.69 \\
Aluminum & 95 & 2932 & 4412 & 0.66 \\
Arsenic & 99 & 3928 & 4840 & 0.81 \\
Barium & 99 & 2871 & 4011 & 0.72 \\
Beryllium & 97 & 2890 & 4634 & 0.62 \\
Chromium & 99 & 3522 & 4514 & 0.78 \\
Cobalt & 99 & 3672 & 4676 & 0.79 \\
Copper & 96 & 3014 & 4536 & 0.66 \\
Lead & 99 & 3892 & 4840 & 0.80 \\
Manganese & 99 & 3666 & 4516 & 0.81 \\
Nickel & 36 & 79 & 311 & 0.25 \\
Selenium & 90 & 135 & 417 & 0.32 \\
Thallium & 99 & 3765 & 4759 & 0.79 \\
Zinc & &
\end{tabular}

"See Sect. 5.11 for definitions of "score" and "possible."

Table 5.14. Regression statistics for metals ${ }^{2}$ (ICP/MS with AA/ICP)

\begin{tabular}{lrrrr}
\hline Analysis & Intercept & Std Err & Slope & Std Err \\
\hline & & & & \\
Aluminum & 0.908 & 0.179 & 0.792 & 0.042 \\
Antimony & 0.179 & 1.260 & 1.946 & 2.024 \\
Arsenic & 0.295 & 0.058 & 0.859 & 0.057 \\
Barium & 0.307 & 0.053 & 0.842 & 0.030 \\
Beryllium & 0.028 & 0.013 & 0.656 & 0.038 \\
Cadmium & -0.422 & 0.591 & 0.496 & 0.911 \\
Chromium & 0.119 & 0.083 & 0.911 & 0.056 \\
Cobalt & -0.074 & 0.052 & 1.029 & 0.049 \\
Copper & 0.011 & 0.042 & 0.974 & 0.034 \\
Lead & 0.040 & 0.096 & 0.945 & 0.072 \\
Manganese & 0.232 & 0.096 & 0.920 & 0.037 \\
Nickel & 0.142 & 0.047 & 0.901 & 0.040 \\
Selenium & -0.217 & 0.068 & 0.340 & 0.205 \\
Thallium & -0.114 & 0.250 & 0.891 & 0.451 \\
Zinc & 0.294 & 0.051 & 0.880 & 0.030 \\
\hline
\end{tabular}

${ }^{2}$ Intercepts and their standard errors are in milligrams per kilogram. Slopes and their standard errors are unitless. 
6-1

\section{DATA INTERPRETATION}

\subsection{SUMMARY}

This section fulfills the need for technical evaluation of the project data so as to maximize usefulness for other Environmental Restoration projects and field investigations.

Chemical compounds, minerals, elements, and radionuclides in soils can have several sources. Current U.S. Environmental Protection Agency (EPA) extraction procedures remove differing amounts of various soil constituents. The location of the soil in the landscape can also affect the data. Interpretation of these data, then, must be done very carefully. Please review the user.guidelines in Sect. 2.4 for precautions regarding data usage.

Screening of sites on the Oak Ridge Reservation (ORR) by a hand-held radiation detector, plus gamma screening and analysis of volatile organic compounds (VOCs) for all sites, did not reveal any gross contamination. Most of the ORR sites, along with Roane County and Anderson County sites, had some detects for other organic contaminants, particularly polynuclear aromatic hydrocarbons (PAHs). Sampling of A horizons of soils with analysis by current volatile organic analysis (VOA) and organics analytical techniques can be used elsewhere on the ORR without restriction as to site properties or soil conditions. The screening data indicate that any VOC detects in suspected contaminated sites should be taken as a sign of contamination. Some VOCs (at very low levels) may be due to soil microbial respiration, but most VOCs reported in this study are suspected to be due to instrument contamination in the laboratory.

Inorganic compounds in soils present a much more complex situation regarding interpretation. Some inorganics are definitely inherited from the underlying geologic formations. Others have both an anthropogenic source from either global fallout or from local and regional sources and a geologic source. For example, lead and arsenic can have both geologic and anthropogenic sources, while nearly all mercury can be considered a surface anthropogenic contaminant because of elevated levels in the A horizon. Several metallic elements, including $\mathrm{Cd}, \mathrm{Os}$, and $\mathrm{Ag}$, were not detected in any BSCP soil samples. The presence of any of these in the $A$ horizon at higher levels than in the $B$ or $C$ horizon beneath could be considered an indicator of possible contamination. Some small amounts of these elements may be inherited from the rock beneath.

Higher concentrations of inorganic compounds or metals in the A horizon than the B or $\mathrm{C}$ horizons or in the on-site than off-site locations are an indicator of anthropogenic contamination of the ORR soils and false background levels. An exception to this statement may be biocycled elements that are used by plants and become concentrated in the A horizon. In general, anthropogenic metals (heavy metals) were not detected in the A horizon, or their levels were not significantly different than in off-site areas, or their levels were not significantly higher than in $\mathrm{B}$ and $\mathrm{C}$ horizons. See Table 6.1a for valid inorganic data to use for comparison purposes.

Selected metals were analyzed by the current EPA-mandated atomic absorption (AA) spectroscopy method and inductively coupled plasma (ICP) method and compared with 
ICP/mass spectroscopy (ICP/MS). The ICP/MS analytical method exhibited lower instrumental detection limits than the AA and ICP sweep (AA/ICP). Correlations between ICP/MS and AA/ICP were fairly consistent for all metals, except for thallium and selenium, suggesting that analytical methods did not bias the results as long as the soil sample was extracted by the same procedure.

The neutron activation analysis (NAA) method is a whole soil analytical technique in contrast to the AA/ICP and ICP/MS analytical techniques, where an acid extract of the soil is analyzed. The levels measured by $\mathrm{AA} / \mathrm{ICP}$ methods were not different from those from NAA when the compounds were very acid soluble or were on soil clay or organic matter exchange sites. NAA levels were higher than AA/ICP when the elements are part of the soil mineral or were more resistant to dissolution.

Many radionuclides have two primary sources: the underlying geology plus both global and regional anthropogenic sources. However, a third possible source of certain radionuclides $\left({ }^{247} \mathrm{Cm},{ }^{3} \mathrm{H},{ }^{99} \mathrm{Tc},{ }^{137} \mathrm{Cs}\right.$, and $\left.{ }^{90} \mathrm{Sr}\right)$ on the ORR cannot be ignored, although part of the tritium may be from naturally occurring sources. The presence on the ORR of these isotopes above background can be interpreted as a sign of local contamination. Uranium isotopes can have a local source as well as a geologic source. Some important radionuclides, such as thorium isotopes and ${ }^{40} \mathrm{~K}$, have a total geologic source. Concentrations of these local source radionuclides above background levels should be taken as indications of potential contamination from local sources. See Table $6.1 \mathrm{~b}$ for valid radionuclide data to use for comparisons.

Several trace and rare earth elements that were analyzed are not important in risk assessment, but they can be important in geochemistry investigations and in tracing sediments to their source geologic formation. Cerium, europium, and terbium had higher concentrations in the Chickamauga Group than in the Conasauga or Knox Group. Several trace elements were highly depleted in the Knox Group. These included Hf, La, Lu, and Sc. Titanium and ytterbium were fairly evenly distributed across all geologic groups.

Some PAHs were generally uniformly distributed across most sites or else were randomly distributed throughout all the sampling sites. The presence of PAHs, then, is considered as background for purposes of data comparison with contaminated sites. Values of PAHs can be obtained from Sect. 5 for geologic formations of interest. In addition, see Table 6.1c for valid PAH data to use for comparisons. Some PAHs may have a soil origin, but with the presence of the Rockwood Coking operation and two TVA coal-fired steam generating power plants, most PAHs probably are from these sources.

In summary, none of the ORR sites exhibited any indication of disturbance in the past $\sim 50$ years. For this reason, the data presented in this report can be considered "background" level and used as a basis of comparison with similar areas on the ORR where contamination is known or suspected. A qualitative assessment of each sampling site is presented in Sects. 3.9, 3.10, and 3.11 for the ORR, Roane County, and Anderson County sampling areas, respectively. 
Table 6.1a. Summary statistics for inorganics on the ORR by group (Estimates and confidence bounds are in milligrams per kilogram.)

\begin{tabular}{|c|c|c|c|c|c|c|c|c|}
\hline Hórizon & Group & $N$ & $I$ & $\bar{D}$ & Median & UCB95 & X95 & LTB959 \\
\hline & \multicolumn{8}{|c|}{ Aluminum } \\
\hline $\begin{array}{l}\text { A } \\
\text { A } \\
\text { A } \\
\text { B } \\
\text { B } \\
\text { B } \\
\text { C } \\
\text { C } \\
\text { C }\end{array}$ & $\begin{array}{l}\text { Conasauga } \\
\text { Chickamauga } \\
\text { Knox } \\
\text { Conasauga } \\
\text { Chickamauga } \\
\text { Knox } \\
\text { Conasauga } \\
\text { Chickamauga } \\
\text { Knox }\end{array}$ & $\begin{array}{l}8 \\
8 \\
8 \\
8 \\
8 \\
8 \\
8 \\
8 \\
8\end{array}$ & $\begin{array}{l}0 \\
0 \\
0 \\
0 \\
0 \\
0 \\
0 \\
0 \\
0\end{array}$ & $\begin{array}{l}8 \\
8 \\
8 \\
8 \\
8 \\
8 \\
8 \\
8 \\
8\end{array}$ & $\begin{array}{r}21400 \\
16500 \\
9430 \\
32900 \\
32100 \\
17700 \\
38500 \\
33800 \\
17700\end{array}$ & $\begin{array}{l}23500 \\
18100 \\
10300 \\
36000 \\
35200 \\
19400 \\
41500 \\
36500 \\
19200\end{array}$ & $\begin{array}{l}27800 \\
21400 \\
12200 \\
42700 \\
41700 \\
23000 \\
47800 \\
42000 \\
22000\end{array}$ & $\begin{array}{l}24800 \\
19200 \\
10900 \\
38200 \\
37300 \\
20600 \\
43600 \\
38300 \\
20100\end{array}$ \\
\hline
\end{tabular}

Antimony

$\begin{array}{llrllllll}\text { A } & \text { Conasauga } & 8 & 0 & 1 & 0.0846 & 0.684 & 0.486 & 0.158 \\ \text { A } & \text { REMAINDER } & 16 & 0 & 0 & . & 0 & . & 0.535 \\ \text { B } & \text { COnasauga } & 8 & 0 & 4 & 0.2750 & 0.582 & 1.550 & 0.535 \\ \text { B } & \text { REMAINDER } & 16 & 0 & 0 & . & 0 & . & . \\ \text { C } & \text { COnasauga } & 8 & 0 & 4 & 0.3000 & 0.541 & 1.210 & 0.545 \\ \text { C } & \text { Chickamauga } & 8 & 0 & 1 & 0.1490 & 0.421 & 0.601 & 0.265 \\ \text { C } & \text { REMAINDER } & 8 & 0 & 0 & - & - & . & .\end{array}$

Arsenic

$\begin{array}{llrlrrrrr}\text { A } & \text { Conasauga } & 7 & 0 & 7 & 6.21 & 8.03 & 12.3 & 9.03 \\ \text { A } & \text { Chickamauga } & 8 & 0 & 8 & 6.90 & 8.78 & 13.6 & 10.20 \\ \text { A } & \text { Knox } & 8 & 0 & 8 & 16.50 & 20.90 & 32.5 & 24.30 \\ \text { B } & \text { Conasauga } & 7 & 0 & 7 & 7.18 & 9.20 & 13.8 & 10.30 \\ \text { B } & \text { Chickamauga } & 8 & 0 & 8 & 7.23 & 9.11 & 13.9 & 10.50 \\ \text { B } & \text { Knox } & 7 & 0 & 7 & 28.60 & 36.60 & 55.1 & 40.90 \\ \text { C } & \text { Conasauga } & 8 & 0 & 7 & 9.08 & 13.30 & 26.5 & 16.70 \\ \text { C } & \text { Chickamauga } & 8 & 0 & 8 & 6.51 & .9 .50 & 19.0 & 11.90 \\ \text { C } & \text { Knox } & 7 & 0 & 7 & 45.00 & 67.50 & 131.0 & 80.90\end{array}$

\section{Barium}

$\begin{array}{rlrlrrrrr}\text { A } & \text { Conasauga } & 8 & 0 & 8 & 86.4 & 104.0 & 145.0 & 116.0 \\ \text { A } & \text { Chickamauga } & 8 & 0 & 8 & 78.1 & 93.8 & 131.0 & 105.0 \\ \text { A } & \text { Knox } & 8 & 0 & 8 & 62.0 & 74.5 & 104.0 & 83.5 \\ \text { B } & \text { Conasauga } & 8 & 0 & 8 & 91.3 & 102.0 & 126.0 & 110.0 \\ \text { B } & \text { Chickamauga } & 8 & 0 & 8 & 100.0 & 113.0 & 139.0 & 121.0 \\ \text { B } & \text { Knox } & 8 & 0 & 8 & 37.6 & 42.2 & 52.1 & 45.4 \\ \text { C } & \text { Conasauga } & 8 & 0 & 8 & 93.8 & 129.0 & 231.0 & 157.0 \\ \text { C } & \text { Chickamauga } & 8 & 0 & 8 & 107.0 & 147.0 & 264.0 & 180.0 \\ \text { C } & \text { Knox } & 8 & 0 & 8 & 17.5 & 24.0 & 43.0 & 29.3\end{array}$

Beryllium

$\begin{array}{lllllllll}\text { A } & \text { Conasauga } & 8 & 0 & 8 & 0.783 & 0.911 & 1.200 & 0.997 \\ \text { A } & \text { Chickamauga } & 8 & 0 & 8 & 0.964 & 1.120 & 1.480 & 1.230 \\ \text { A } & \text { Knox } & 8 & 0 & 5 & 0.437 & 0.521 & 0.670 & 0.550 \\ \text { B } & \text { Conasauga } & 8 & 0 & 8 & 0.854 & 1.010 & 1.370 & 1.120 \\ \text { B } & \text { Chickamauga } & 8 & 0 & 8 & 1.440 & 1.700 & 2.310 & 1.880 \\ \text { B } & \text { Knox } & 8 & 0 & 5 & 0.528 & 0.644 & 0.847 & 0.679 \\ \text { C } & \text { Conasauga } & 8 & 0 & 8 & 1.090 & 1.270 & 1.670 & 1.390 \\ \text { C } & \text { Chickamauga } & 8 & 0 & 8 & 1.640 & 1.910 & 2.520 & 2.100 \\ \text { C } & \text { Knox } & 8 & 0 & 5 & 0.662 & 0.792 & 1.020 & 0.832\end{array}$


6-4

Table 6.1a (continued)

\begin{tabular}{|c|c|c|c|c|c|c|c|c|}
\hline Horizon & Group & $N$ & I & $\mathrm{D}$ & Median & UCB95 & X95 & LTB95S \\
\hline \multicolumn{9}{|c|}{ Boron } \\
\hline $\begin{array}{l}A \\
A \\
A \\
B \\
B \\
B \\
C \\
C \\
C\end{array}$ & $\begin{array}{l}\text { Conasauga } \\
\text { Knox } \\
\text { REMAINDER } \\
\text { Conasauga } \\
\text { Knox } \\
\text { REMAINDER } \\
\text { Conasauga } \\
\text { Knox } \\
\text { REMAIHDER }\end{array}$ & $\begin{array}{l}7 \\
8 \\
6 \\
8 \\
8 \\
6 \\
8 \\
8 \\
6\end{array}$ & $\begin{array}{l}1 \\
1 \\
0 \\
1 \\
0 \\
0 \\
0 \\
1 \\
0\end{array}$ & $\begin{array}{l}1 \\
0 \\
0 \\
3 \\
1 \\
0 \\
4 \\
1 \\
0\end{array}$ & $\begin{array}{c}8.26 \\
2.12 \\
10.10 \\
1.80 \\
12.20 \\
2.57 \\
.\end{array}$ & $\begin{array}{c}12.90 \\
4.27 \\
19.30 \\
5.35 \\
21.70 \\
5.64 \\
.\end{array}$ & $\begin{array}{c}17.90 \\
4.58 \\
45.70 \\
8.10 \\
49.20 \\
10.40 \\
.\end{array}$ & $\begin{array}{c}11.30 \\
2.45 \\
. \\
19.40 \\
3.45 \\
23.10 \\
4.96 \\
.\end{array}$ \\
\hline
\end{tabular}

Cadmium

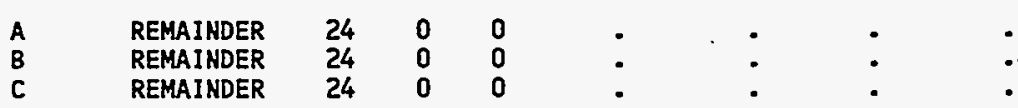

\section{Calcium}

$\begin{array}{llrrrrrrr}\text { A } & \text { Conasauga } & 5 & 0 & 5 & 983 & 1330 & 1930 & 1370 \\ \text { A } & \text { Chickamauga } & 8 & 0 & 8 & 1590 & 2020 & 3130 & 2330 \\ \text { A } & \text { Knox } & 8 & 0 & 8 & 473 & 601 & 930 & 693 \\ \text { B } & \text { Conasauga } & 5 & 0 & 5 & 813 & 1180 & 1880 & 1220 \\ \text { B } & \text { Chickamauga } & 8 & 0 & 8 & 1620 & 2180 & 3750 & 2600 \\ \text { B } & \text { Knox } & 8 & 0 & 8 & 388 & 522 & 896 & 623 \\ \text { C } & \text { Conasauga } & 6 & 0 & 6 & 999 & 1560 & 2960 & 1760 \\ \text { C } & \text { Chickanauga } & 8 & 0 & 8 & 2360 & 3470 & 6990 & 4360 \\ \text { C } & \text { Knox } & 7 & 0 & 7 & 214 & 322 & 633 & 386\end{array}$

\section{Chromium}

$\begin{array}{lllllllll}\text { A } & \text { Conasauga } & 7 & 0 & 7 & 26.0 & 30.2 & 38.7 & 32.3 \\ \text { A } & \text { Chickamauga } & 8 & 0 & 8 & 33.2 & 38.2 & 49.5 & 41.6 \\ \text { A } & \text { Knox } & 8 & 1 & 7 & 15.0 & 17.3 & 22.3 & 18.8 \\ \text { B } & \text { Conasauga } & 7 & 0 & 7 & 37.3 & 41.3 & 48.9 & 43.3 \\ \text { B } & \text { Chickamauga } & 8 & 0 & 8 & 34.2 & 37.6 & 44.7 & 39.9 \\ \text { B } & \text { Knox } & 8 & 0 & -8 & 29.5 & 32.5 & 38.6 & 34.4 \\ \text { C } & \text { Conasauga } & 8 & 0 & 8 & 50.0 & 56.3 & 69.8 & 60.6 \\ \text { C } & \text { Chickamauga } & 8 & 0 & 8 & 31.1 & 35.0 & 43.5 & 37.7 \\ \text { C } & \text { Knox } & 8 & 0 & 8 & 27.9 & 31.4 & 39.0 & 33.8\end{array}$

\section{Cobalt}

$\begin{array}{llrlrrrrr}\text { A } & \text { Conasauga } & 8 & 0 & 8 & 14.50 & 17.30 & 24.10 & 19.4 \\ \text { A } & \text { Chickamauga } & 8 & 0 & 8 & 19.00 & 22.70 & 31.60 & 25.4 \\ \text { A } & \text { Knox } & 8 & 0 & 8 & 9.45 & 11.30 & 15.70 & 12.6 \\ \text { B } & \text { Conasauga } & 8 & 0 & 8 & 10.90 & 14.90 & 26.20 & 17.7 \\ \text { B } & \text { Chickamauga } & 8 & 0 & 8 & 13.10 & 17.80 & 31.20 & 21.2 \\ \text { B } & \text { Knox } & 8 & 1 & 2 & 2.03 & 3.01 & 4.85 & 3.2 \\ \text { C } & \text { Conasauga } & 8 & 0 & 8 & 13.20 & 22.80 & 62.10 & 31.2 \\ \text { C } & \text { Chickamauga } & 8 & 0 & 8 & 18.10 & 31.30 & 85.30 & 42.8 \\ \text { C } & \text { Knox } & 8 & 0 & 4 & 3.38 & 6.17 & 15.90 & 8.2\end{array}$


Table 6.1a (continued)

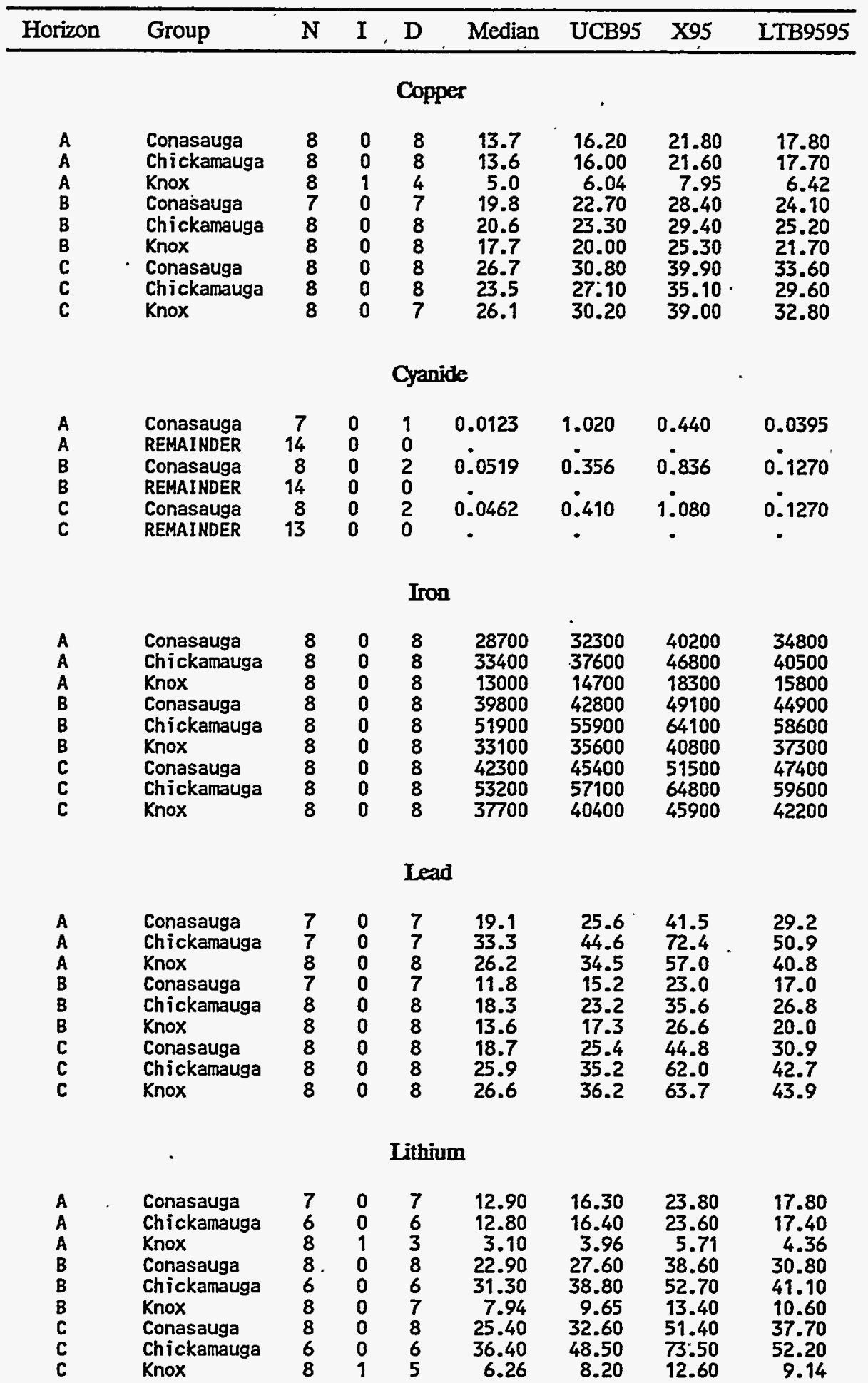


6-6

Table 6.1a (continued)

\begin{tabular}{|c|c|c|c|c|c|c|c|c|}
\hline Horizon & Group & $\mathbf{N}$ & I & $\mathrm{D}$ & Median & UCB95 & X95 & LTB9595 \\
\hline \multicolumn{9}{|c|}{ Magnesium } \\
\hline $\begin{array}{l}A \\
A \\
A \\
B \\
B \\
B \\
C \\
C \\
C\end{array}$ & $\begin{array}{l}\text { Conasauga } \\
\text { Chickamauga } \\
\text { Knox } \\
\text { Conasauga } \\
\text { Chickamauga } \\
\text { Knox } \\
\text { Conasauga } \\
\text { Chickamauga } \\
\text { Knox }\end{array}$ & $\begin{array}{l}8 \\
8 \\
8 \\
8 \\
8 \\
8 \\
8 \\
8 \\
8\end{array}$ & $\begin{array}{l}0 \\
0 \\
0 \\
0 \\
0 \\
0 \\
0 \\
0 \\
0\end{array}$ & $\begin{array}{l}8 \\
8 \\
8 \\
8 \\
8 \\
8 \\
8 \\
8 \\
8\end{array}$ & $\begin{array}{r}2390 \\
1220 \\
413 \\
2990 \\
2320 \\
680 \\
3840 \\
2720 \\
576\end{array}$ & $\begin{array}{r}2780 \\
1430 \\
481 \\
3400 \\
2640 \\
775 \\
4510 \\
3200 \\
677\end{array}$ & $\begin{array}{r}3670 \\
1880 \\
635 \\
4320 \\
3350 \\
983 \\
6070 \\
4300 \\
910\end{array}$ & $\begin{array}{r}3060 \\
1570 \\
529 \\
3690 \\
2860 \\
840 \\
4990 \\
3540 \\
749\end{array}$ \\
\hline \multicolumn{9}{|c|}{ Manganese } \\
\hline $\begin{array}{l}A \\
A \\
A \\
B \\
B \\
B \\
C \\
C \\
C\end{array}$ & $\begin{array}{l}\text { Conasauga } \\
\text { Chickamauga } \\
\text { Knox } \\
\text { Conasauga } \\
\text { Chickamauga } \\
\text { Knox } \\
\text { Conasauga } \\
\text { Chickamauga } \\
\text { Knox }\end{array}$ & $\begin{array}{l}8 \\
8 \\
8 \\
8 \\
8 \\
8 \\
8 \\
8 \\
8\end{array}$ & $\begin{array}{l}0 \\
0 \\
0 \\
0 \\
0 \\
0 \\
0 \\
0 \\
0\end{array}$ & $\begin{array}{l}8 \\
8 \\
8 \\
8 \\
8 \\
8 \\
8 \\
8 \\
8\end{array}$ & $\begin{array}{r}807 \\
1330 \\
992 \\
272 \\
352 \\
126 \\
332 \\
500 \\
138\end{array}$ & $\begin{array}{r}1020 \\
1680 \\
1250 \\
377 \\
488 \\
174 \\
572 \\
860 \\
237\end{array}$ & $\begin{array}{r}1560 \\
2570 \\
1920 \\
685 \\
888 \\
317 \\
1540 \\
2320 \\
641\end{array}$ & $\begin{array}{r}1180 \\
1940 \\
1450 \\
462 \\
599 \\
214 \\
802 \\
1210 \\
333\end{array}$ \\
\hline \multicolumn{9}{|c|}{ Mercury } \\
\hline $\begin{array}{l}A \\
A \\
A \\
B \\
B \\
B \\
C \\
C \\
C\end{array}$ & $\begin{array}{l}\text { Conasauga } \\
\text { Chickamauga } \\
\text { Knox } \\
\text { Conasauga } \\
\text { Chickamauga } \\
\text { Knox } \\
\text { Conasauga } \\
\text { Chickamauga } \\
\text { Knox }\end{array}$ & $\begin{array}{l}8 \\
8 \\
8 \\
8 \\
8 \\
8 \\
8 \\
8 \\
8\end{array}$ & $\begin{array}{l}0 \\
0 \\
1 \\
0 \\
0 \\
0 \\
0 \\
0 \\
0\end{array}$ & $\begin{array}{l}8 \\
8 \\
6 \\
2 \\
3 \\
7 \\
1 \\
6 \\
8\end{array}$ & $\begin{array}{l}0.2420 \\
0.2810 \\
0.1360 \\
0.1140 \\
0.0982 \\
0.1050 \\
0.0573 \\
0.1140 \\
0.2000\end{array}$ & $\begin{array}{l}0.3120 \\
0.3620 \\
0.1770 \\
0.1370 \\
0.1160 \\
0.1210 \\
0.0869 \\
0.1360 \\
0.2360\end{array}$ & $\begin{array}{l}0.4960 \\
0.5770 \\
0.2800 \\
0.1680 \\
0.1450 \\
0.1550 \\
0.0925 \\
0.1850 \\
0.3220\end{array}$ & $\begin{array}{l}0.3630 \\
0.4220 \\
0.2060 \\
0.1390 \\
0.1210 \\
0.1280 \\
0.0607 \\
0.1490 \\
0.2580\end{array}$ \\
\hline
\end{tabular}

\section{Molybdenum}

$\begin{array}{llrllcccc}\text { A } & \text { KnOX } & 8 & 0 & 1 & 1.33 & 1.94 & 2.00 & 1.38 \\ \text { A } & \text { REMAINDER } & 14 & 0 & 0 & . & . & . & . \\ \text { B } & \text { Conasauga } & 8 & 0 & 1 & 1.23 & 2.02 & 2.47 & 1.53 \\ \text { B } & \text { Chickamauga } & 6 & 0 & 2 & 2.10 & 3.09 & 4.21 & 2.83 \\ \text { B } & \text { KnOX } & 8 & 0 & 4 & 2.50 & 3.34 & 5.03 & 3.50 \\ \text { C } & \text { KnOX } & 8 & 1 & 5 & 2.93 & 3.75 & 5.55 & 3.87 \\ \text { C } & \text { REMAINDER } & 14 & 0 & 0 & \cdot & . & . & .\end{array}$

Nickel

$\begin{array}{lllllrrrr}\text { A } & \text { Conasauga } & 8 & 0 & 8 & 20.10 & 23.60 & 31.7 & 25.90 \\ \text { A } & \text { Chickamauga } & 8 & 0 & 8 & 15.20 & 17.90 & 23.9 & 19.60 \\ \text { A } & \text { Knox } & 8 & 1 & 3 & 6.71 & 8.11 & 10.6 & 8.57 \\ \text { B } & \text { Conasauga } & 8 & 0 & 8 & 21.80 & 25.00 & 32.1 & 27.10 \\ \text { B } & \text { Chickamauga } & 8 & 0 & 8 & 22.10 & 25.40 & 32.5 & 27.50 \\ \text { B } & \text { Knox } & 8 & 0 & 5 & 11.20 & 13.00 & 16.5 & 14.00 \\ \text { C } & \text { Conasauga } & 8 & 0 & 8 & 26.40 & 31.70 & 44.1 & 35.40 \\ \text { C } & \text { Chickamauga } & 8 & 0 & 8 & 27.00 & 32.40 & 45.1 & 36.20 \\ \text { C } & \text { Knox } & 8 & 0 & 7 & 17.70 & 21.20 & 29.5 & 23.70\end{array}$

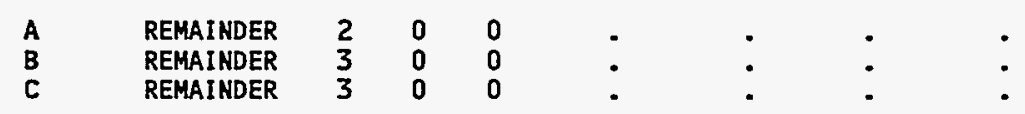


Table 6.1a (continued)

\begin{tabular}{|c|c|c|c|c|c|c|c|c|}
\hline Horizon & Group & $\mathbf{N}$ & $I$ & $\mathrm{D}$ & Median & UCB95 & X95 & LTB9595 \\
\hline \multicolumn{9}{|c|}{ Potassium } \\
\hline $\begin{array}{l}A \\
A \\
A \\
B \\
B \\
B \\
C \\
C \\
C\end{array}$ & $\begin{array}{l}\text { Conasauga } \\
\text { Chickamauga } \\
\text { Knox } \\
\text { Conasauga } \\
\text { Chickamauga } \\
\text { Knox } \\
\text { Conasauga } \\
\text { Chickamauga } \\
\text { Knox }\end{array}$ & $\begin{array}{l}8 \\
8 \\
8 \\
8 \\
8 \\
8 \\
8 \\
8 \\
8\end{array}$ & $\begin{array}{l}0 \\
0 \\
0 \\
0 \\
0 \\
0 \\
0 \\
0 \\
0\end{array}$ & $\begin{array}{l}8 \\
8 \\
4 \\
8 \\
8 \\
8 \\
8 \\
8 \\
8\end{array}$ & $\begin{array}{r}2600 \\
1620 \\
301 \\
3090 \\
3050 \\
811 \\
3960 \\
3060 \\
983\end{array}$ & $\begin{array}{r}3040 \\
1890 \\
358 \\
3670 \\
3620 \\
963 \\
4650 \\
3600 \\
1150\end{array}$ & $\begin{array}{r}4030 \\
2500 \\
465 \\
5030 \\
4960 \\
1320 \\
6230 \\
4820 \\
1550\end{array}$ & $\begin{array}{r}3320 \\
2060 \\
385 \\
4090 \\
4030 \\
1070 \\
5140 \\
3970 \\
1270\end{array}$ \\
\hline \multicolumn{9}{|c|}{ Selenium } \\
\hline $\begin{array}{l}A \\
A \\
A \\
B \\
B \\
B \\
C \\
C \\
C\end{array}$ & $\begin{array}{l}\text { Conasauga } \\
\text { Chickamauga } \\
\text { Knox } \\
\text { Conasauga } \\
\text { Chickamauga } \\
\text { Knox } \\
\text { Conasauga } \\
\text { Chickamauga } \\
\text { Knox }\end{array}$ & $\begin{array}{l}8 \\
8 \\
6 \\
8 \\
8 \\
7 \\
8 \\
8 \\
7\end{array}$ & $\begin{array}{l}0 \\
0 \\
1 \\
0 \\
0 \\
0 \\
0 \\
0 \\
0\end{array}$ & $\begin{array}{l}3 \\
8 \\
5 \\
3 \\
7 \\
6 \\
3 \\
5 \\
6\end{array}$ & $\begin{array}{l}0.491 \\
0.751 \\
0.571 \\
0.498 \\
0.747 \\
0.645 \\
0.416 \\
0.508 \\
0.689\end{array}$ & $\begin{array}{l}0.587 \\
0.865 \\
0.675 \\
0.635 \\
0.913 \\
0.797 \\
0.653 \\
0.760 \\
1.030\end{array}$ & $\begin{array}{l}0.733 \\
1.120 \\
0.853 \\
0.863 \\
1.290 \\
1.120 \\
1.190 \\
1.450 \\
1.970\end{array}$ & $\begin{array}{l}0.604 \\
0.932 \\
0.698 \\
0.664 \\
1.000 \\
0.861 \\
0.728 \\
0.894 \\
1.170\end{array}$ \\
\hline \multicolumn{9}{|c|}{ Silicon } \\
\hline $\begin{array}{l}A \\
A \\
A \\
B \\
B \\
B \\
C \\
C \\
C\end{array}$ & $\begin{array}{l}\text { Conasauga } \\
\text { Chickamauga } \\
\text { Knox } \\
\text { Conasauga } \\
\text { Chickamauga } \\
\text { Knox } \\
\text { Conasauga } \\
\text { Chickamauga } \\
\text { Knox }\end{array}$ & $\begin{array}{l}8 \\
6 \\
5 \\
8 \\
6 \\
5 \\
8 \\
6 \\
5\end{array}$ & $\begin{array}{l}0 \\
0 \\
0 \\
0 \\
0 \\
0 \\
0 \\
0 \\
0\end{array}$ & $\begin{array}{l}8 \\
6 \\
5 \\
8 \\
6 \\
5 \\
8 \\
6 \\
5\end{array}$ & $\begin{array}{l}352 \\
591 \\
558 \\
349 \\
701 \\
612 \\
380 \\
653 \\
595\end{array}$ & $\begin{array}{l}413 \\
712 \\
685 \\
411 \\
849 \\
755 \\
449 \\
793 \\
736\end{array}$ & $\begin{array}{r}555 \\
933 \\
881 \\
556 \\
1120 \\
977 \\
610 \\
1050 \\
956\end{array}$ & $\begin{array}{l}454 \\
747 \\
695 \\
452 \\
891 \\
766 \\
495 \\
833 \\
747\end{array}$ \\
\hline \multicolumn{9}{|c|}{ Silver } \\
\hline $\begin{array}{l}A \\
B \\
C\end{array}$ & $\begin{array}{l}\text { REMAINDER } \\
\text { REMAINDER } \\
\text { REMAINDER }\end{array}$ & $\begin{array}{l}24 \\
24 \\
24\end{array}$ & $\begin{array}{l}0 \\
0 \\
0\end{array}$ & $\begin{array}{l}0 \\
0 \\
0\end{array}$ & : & : & : & $\dot{.}$ \\
\hline \multicolumn{9}{|c|}{ Sodium } \\
\hline $\begin{array}{l}A \\
A \\
B \\
B \\
C \\
C\end{array}$ & $\begin{array}{l}\text { Chickamauga } \\
\text { Knox } \\
\text { Chickamauga } \\
\text { Knox } \\
\text { Chickamauga } \\
\text { Knox }\end{array}$ & $\begin{array}{l}8 \\
8 \\
8 \\
8 \\
8 \\
8\end{array}$ & $\begin{array}{l}0 \\
0 \\
0 \\
0 \\
0 \\
0\end{array}$ & $\begin{array}{l}8 \\
7 \\
8 \\
8 \\
8 \\
8\end{array}$ & $\begin{array}{l}409 \\
338 \\
435 \\
337 \\
428 \\
344\end{array}$ & $\begin{array}{l}428 \\
355 \\
456 \\
353 \\
451 \\
362\end{array}$ & $\begin{array}{l}466 \\
386 \\
495 \\
384 \\
496 \\
398\end{array}$ & $\begin{array}{l}439 \\
363 \\
467 \\
362 \\
464 \\
372\end{array}$ \\
\hline \multicolumn{9}{|c|}{ Strontium } \\
\hline $\begin{array}{l}A \\
A \\
A \\
B \\
B \\
B \\
C \\
C \\
C\end{array}$ & $\begin{array}{l}\text { Conasauga } \\
\text { Chickamauga } \\
\text { Knox } \\
\text { Conasauga } \\
\text { Chickamauga } \\
\text { Knox } \\
\text { Conasauga } \\
\text { Chickamauga } \\
\text { Knox }\end{array}$ & $\begin{array}{l}7 \\
6 \\
8 \\
8 \\
6 \\
8 \\
8 \\
6 \\
8\end{array}$ & $\begin{array}{l}0 \\
0 \\
0 \\
0 \\
0 \\
0 \\
0 \\
0 \\
0\end{array}$ & $\begin{array}{l}7 \\
6 \\
6 \\
8 \\
6 \\
5 \\
8 \\
6 \\
2\end{array}$ & $\begin{array}{r}5.780 \\
9.090 \\
2.840 \\
6.440 \\
11.300 \\
2.190 \\
6.830 \\
12.900 \\
0.331\end{array}$ & $\begin{array}{r}7.960 \\
12.900 \\
3.880 \\
9.240 \\
17.100 \\
3.230 \\
10.500 \\
21.200 \\
0.577\end{array}$ & $\begin{array}{r}13.50 \\
21.20 \\
6.64 \\
17.90 \\
31.20 \\
6.06 \\
22.80 \\
43.20 \\
1.11\end{array}$ & $\begin{array}{r}9.090 \\
14.000 \\
4.590 \\
11.300 \\
19.000 \\
3.890 \\
13.000 \\
23.400 \\
0.639\end{array}$ \\
\hline
\end{tabular}


$6-8$

Table 6.1a (continued)

\begin{tabular}{|c|c|c|c|c|c|c|c|c|}
\hline Horizon & Group & $\mathbf{N}$ & I & D & Median & UCB95 & X95 & LTB9595 \\
\hline \multicolumn{9}{|c|}{ Sulfate } \\
\hline $\begin{array}{l}\text { A } \\
\text { A } \\
\text { A } \\
\text { B } \\
\text { B } \\
\text { B } \\
\text { C } \\
\text { C } \\
\text { C }\end{array}$ & $\begin{array}{l}\text { Conasauga } \\
\text { Chickamauga } \\
\text { Knox } \\
\text { Conasauga } \\
\text { Chickamauga } \\
\text { Knox } \\
\text { Conasauga } \\
\text { Chickamauga } \\
\text { Knox }\end{array}$ & $\begin{array}{l}7 \\
8 \\
8 \\
8 \\
8 \\
8 \\
8 \\
8 \\
8\end{array}$ & $\begin{array}{l}0 \\
0 \\
0 \\
0 \\
0 \\
0 \\
0 \\
0 \\
1\end{array}$ & $\begin{array}{l}7 \\
8 \\
8 \\
8 \\
8 \\
8 \\
8 \\
8 \\
4\end{array}$ & $\begin{array}{r}36.0 \\
130.0 \\
68.3 \\
90.1 \\
104.0 \\
45.5 \\
70.3 \\
40.1 \\
10.9\end{array}$ & $\begin{array}{r}53.2 \\
187.0 \\
98.2 \\
121.0 \\
140.0 \\
61.1 \\
106.0 \\
60.7 \\
17.1\end{array}$ & $\begin{array}{r}101.0 \\
363.0 \\
191.0 \\
207.0 \\
240.0 \\
105.0 \\
227.0 \\
130.0 \\
35.2\end{array}$ & $\begin{array}{r}63.5 \\
233.0 \\
123.0 \\
145.0 \\
169.0 \\
73.4 \\
136.0 \\
77.6 \\
21.2\end{array}$ \\
\hline \multicolumn{9}{|c|}{ Thallium } \\
\hline $\begin{array}{l}\text { A } \\
\text { A } \\
B \\
B \\
B \\
C \\
C \\
C\end{array}$ & $\begin{array}{l}\text { Conasauga } \\
\text { REMAIIIDER } \\
\text { Conasauga } \\
\text { Knox } \\
\text { REMAIIIDER } \\
\text { Conasauga } \\
\text { Knox } \\
\text { REMAIHDER }\end{array}$ & $\begin{array}{r}8 \\
14 \\
8 \\
6 \\
8 \\
8 \\
6 \\
8\end{array}$ & $\begin{array}{l}0 \\
0 \\
0 \\
0 \\
0 \\
0 \\
1 \\
0\end{array}$ & $\begin{array}{l}1 \\
0 \\
3 \\
1 \\
0 \\
6 \\
0 \\
0\end{array}$ & $\begin{array}{c}0.0642 \\
0.3350 \\
0.2500 \\
0.4580 \\
0.2650 \\
.\end{array}$ & $\begin{array}{l}1.350 \\
0.480 \\
0.441 \\
0.563 \\
0.410 \\
.\end{array}$ & $\begin{array}{l}0.748 \\
0.701 \\
0.523 \\
0.804 \\
0.466 \\
.\end{array}$ & $\begin{array}{l}0.158 \\
0.461 \\
0.324 \\
0.594 \\
0.308 \\
.\end{array}$ \\
\hline \multicolumn{9}{|c|}{ Vanadium } \\
\hline $\begin{array}{l}A \\
A \\
A \\
B \\
B \\
B \\
C \\
C \\
C\end{array}$ & $\begin{array}{l}\text { Conasauga } \\
\text { Chickamauga } \\
\text { Knox } \\
\text { Conasauga } \\
\text { Chickamauga } \\
\text { Knox } \\
\text { Conasauga } \\
\text { Chickamauga } \\
\text { Knox }\end{array}$ & $\begin{array}{l}8 \\
8 \\
8 \\
7 \\
8 \\
8 \\
8 \\
8 \\
8\end{array}$ & $\begin{array}{l}0 \\
0 \\
0 \\
0 \\
0 \\
0 \\
0 \\
0 \\
0\end{array}$ & $\begin{array}{l}8 \\
8 \\
8 \\
7 \\
8 \\
8 \\
8 \\
8 \\
8\end{array}$ & $\begin{array}{l}33.3 \\
36.6 \\
28.1 \\
43.1 \\
48.2 \\
62.5 \\
43.9 \\
43.9 \\
67.3\end{array}$ & $\begin{array}{l}37.0 \\
40.7 \\
31.3 \\
47.8 \\
53.1 \\
68.9 \\
48.6 \\
48.5 \\
74.4\end{array}$ & $\begin{array}{l}45.1 \\
49.6 \\
38.1 \\
56.7 \\
63.4 \\
82.2 \\
58.3 \\
58.3 \\
89.3\end{array}$ & $\begin{array}{l}39.6 \\
43.6 \\
33.5 \\
50.2 \\
56.4 \\
73.1 \\
51.7 \\
51.7 \\
79.2\end{array}$ \\
\hline \multicolumn{9}{|c|}{ Zinc } \\
\hline $\begin{array}{l}A \\
A \\
A \\
B \\
B \\
B \\
C \\
C \\
C\end{array}$ & $\begin{array}{l}\text { Conasauga } \\
\text { Chickamauga } \\
\text { Knox } \\
\text { Conasauga } \\
\text { Chickamauga } \\
\text { Knox } \\
\text { Conasauga } \\
\text { Chickamauga } \\
\text { Knox } \\
\end{array}$ & $\begin{array}{l}8 \\
8 \\
8 \\
8 \\
8 \\
8 \\
8 \\
8 \\
8 \\
\end{array}$ & $\begin{array}{l}0 \\
0 \\
0 \\
0 \\
0 \\
0 \\
0 \\
0 \\
0 \\
\end{array}$ & $\begin{array}{l}8 \\
8 \\
8 \\
8 \\
8 \\
8 \\
8 \\
8 \\
7 \\
\end{array}$ & $\begin{array}{r}43.8 \\
45.5 \\
37.1 \\
47.9 \\
64.7 \\
94.5 \\
52.4 \\
73.6 \\
149.0 \\
\end{array}$ & $\begin{array}{r}51.9 \\
53.8 \\
43.9 \\
57.4 \\
77.6 \\
113.0 \\
63.8 \\
89.7 \\
182.0 \\
\end{array}$ & $\begin{array}{r}70.6 \\
73.3 \\
59.8 \\
80.1 \\
108.0 \\
158.0 \\
91.4 \\
129.0 \\
261.0 \\
\end{array}$ & $\begin{array}{r}57.6 \\
59.8 \\
48.8 \\
64.3 \\
86.9 \\
127.0 \\
72.0 \\
101.0 \\
205.0 \\
\end{array}$ \\
\hline
\end{tabular}

${ }^{a} \mathrm{~N}=$ number of observations, possibly averages over replicates at sites; $\mathrm{I}=$ number of interval censored observations (see text); $\mathrm{D}=$ number of true detects (see text); UCB95 = 95\% upper confidence bound for median; X95 = estimate of 95th percentile; LTB9595 = 95\% lower confidence bound for 95th percentile; REMAINDER refers to the remaining observations-no detects. 
Table 6.1b. Summary statistics for selected radionuclides on the ORR by group

(Estimates and confidence bounds are in picocuries per gram.)

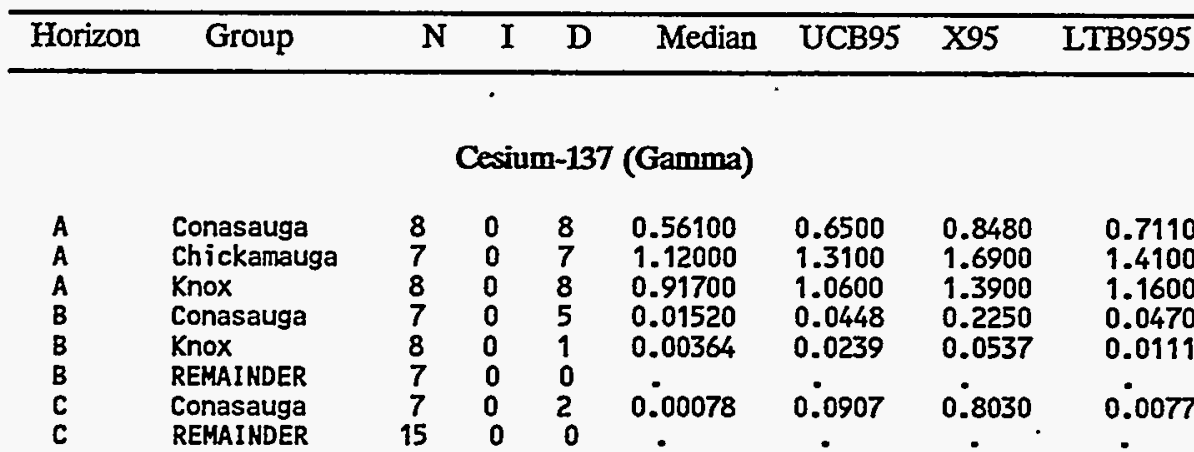

Curium-247 (Gamma)

$\begin{array}{llrllllll}\text { A } & \text { Conasauga } & 8 & 0 & 2 & .00552 & .00649 & .00716 & .00579 \\ \text { A } & \text { REMAINDER } & 15 & 0 & 0 & : & : & : & : \\ \text { B } & \text { REMAINDER } & 3 & 0 & 0 & : & : & : & : \\ \text { C } & \text { REMAINDER } & 3 & 0 & 0 & : & : & :\end{array}$

Neptunium-237 (Alpha)

$\begin{array}{lllllllll}\text { A } & \text { Conasauga } & 2 & 0 & 2 & 0.1330 & 0.1870 & 0.216 & 0.1490 \\ \text { A } & \text { Chickamauga } & 7 & 1 & 6 & 0.0931 & 0.1120 & 0.151 & 0.1200 \\ \text { A } & \text { Knox } & 8 & 1 & 6 & 0.0761 & 0.0911 & 0.123 & 0.0989 \\ \text { B } & \text { REMAINDER } & 1 & 0 & 0 & . & . & . & .\end{array}$

Plutonium-238 (Alpha)

$\begin{array}{lllllllll}\text { A } & \text { Conasauga } & 8 & 1 & 0 & 0.0138 & 0.0587 & 0.0753 & 0.0426 \\ \text { A } & \text { Chickamauga } & 7 & 4 & 2 & 0.0288 & 0.1020 & 0.1690 & 0.1120 \\ \text { A } & \text { Knox } & 8 & 2 & 4 & 0.0201 & 0.0591 & 0.0979 & 0.0651 \\ \text { B } & \text { Conasauga } & 2 & 0 & 2 & 0.0853 & 0.0991 & 0.1050 & 0.0838 \\ \text { C } & \text { REMAINDER } & 2 & 0 & 0 & . & . & . & .\end{array}$

Plutonium-239/240 (Alpha)

$\begin{array}{lllllllll}\text { A } & \text { Conasauga } & 8 & 0 & 1 & 0.0138 & 0.0231 & 0.0298 & 0.0182 \\ \text { A } & \text { Chickamauga } & 7 & 3 & 2 & 0.0288 & 0.0402 & 0.0620 & 0.0408 \\ \text { A } & \text { Knox } & 8 & 2 & 3 & 0.0201 & 0.0280 & 0.0432 & 0.0286 \\ \text { B } & \text { Conasauga } & 2 & 0 & 1 & \cdot & : & : & . \\ \text { C } & \text { REMAINDER } & 2 & 0 & 0 & : & : & : & \text {. }\end{array}$

Potassium-40 (Gamma)

$\begin{array}{llrlrrrrr}\text { A } & \text { Conasauga } & 8 & 0 & 8 & 15.80 & 18.10 & 23.50 & 19.80 \\ \text { A } & \text { Chickamauga } & 8 & 0 & 8 & 12.10 & 14.00 & 18.00 & 15.20 \\ \text { A } & \text { Knox } & 8 & 0 & 8 & 3.59 & 4.13 & 5.35 & 4.51 \\ \text { B } & \text { Conasauga } & 6 & 0 & 6 & 17.70 & 20.30 & 24.70 & 21.00 \\ \text { B } & \text { Chickamauga } & 8 & 0 & 8 & 22.70 & 25.60 & 31.70 & 27.40 \\ \text { B } & \text { Knox } & 7 & 0 & 7 & 7.91 & 8.98 & 11.10 & 9.50 \\ \text { C } & \text { Conasauga } & 7 & 0 & 7 & 22.60 & 31.20 & 53.20 & 35.90 \\ \text { C } & \text { Chickamauga } & 7 & 0 & 7 & 21.00 & 29.00 & 49.50 & 33.40 \\ \text { C } & \text { Knox } & 6 & 0 & 6 & 7.99 & 11.30 & 18.90 & 12.40\end{array}$


Table 6.1b (continued)

\begin{tabular}{|c|c|c|c|c|c|c|c|c|}
\hline Horizon & Group & $\mathbf{N}$ & $\mathbf{I}$ & D & Median & UCB95 & X95 & LTB9595 \\
\hline \multicolumn{9}{|c|}{ Radium-226 (Alpha) } \\
\hline $\begin{array}{l}\text { A } \\
\text { A } \\
\text { A } \\
B \\
B \\
B \\
C \\
C \\
C\end{array}$ & $\begin{array}{l}\text { Conasauga } \\
\text { Chickamauga } \\
\text { Knox } \\
\text { Conasauga } \\
\text { Chickamauga } \\
\text { Knox } \\
\text { Conasauga } \\
\text { Chickamauga } \\
\text { Knox }\end{array}$ & $\begin{array}{l}8 \\
8 \\
8 \\
8 \\
8 \\
8 \\
8 \\
8 \\
8\end{array}$ & $\begin{array}{l}0 \\
0 \\
1 \\
0 \\
0 \\
0 \\
0 \\
0 \\
0\end{array}$ & $\begin{array}{l}8 \\
8 \\
7 \\
7 \\
8 \\
8 \\
8 \\
8 \\
8\end{array}$ & $\begin{array}{l}0.763 \\
1.000 \\
1.030 \\
0.814 \\
1.010 \\
1.530 \\
0.860 \\
1.190 \\
1.440\end{array}$ & $\begin{array}{l}0.905 \\
1.190 \\
1.220 \\
1.020 \\
1.250 \\
1.900 \\
1.060 \\
1.470 \\
1.770\end{array}$ & $\begin{array}{l}1.24 \\
1.62 \\
1.67 \\
1.50 \\
1.86 \\
2.83 \\
1.53 \\
2.13 \\
2.57\end{array}$ & $\begin{array}{l}1.01 \\
1.32 \\
1.36 \\
1.15 \\
1.43 \\
2.18 \\
1.20 \\
1.67 \\
2.01\end{array}$ \\
\hline \multicolumn{9}{|c|}{ Strontium-90 (Beta) } \\
\hline A & $\begin{array}{l}\text { Conasauga } \\
\text { REMAINDER }\end{array}$ & $\begin{array}{r}7 \\
15\end{array}$ & $\begin{array}{l}0 \\
0\end{array}$ & $\begin{array}{l}1 \\
0\end{array}$ & 0.391 & $\begin{array}{l}1.36 \\
.\end{array}$ & 1.12 & 0.548 \\
\hline \multicolumn{9}{|c|}{ Technetium-99 (Beta) } \\
\hline $\begin{array}{l}A \\
A \\
A\end{array}$ & $\begin{array}{l}\text { Conasauga } \\
\text { Chickamauga } \\
\text { REMAINDER }\end{array}$ & $\begin{array}{l}12 \\
12 \\
11\end{array}$ & $\begin{array}{l}0 \\
0 \\
0\end{array}$ & $\begin{array}{l}1 \\
5 \\
0\end{array}$ & $\begin{array}{l}0.961 \\
1.180 \\
.\end{array}$ & $\begin{array}{l}1.74 \\
1.64 \\
.\end{array}$ & $\begin{array}{r}2.25 \\
2.77 \\
. \quad .\end{array}$ & $\begin{array}{l}1.46 \\
1.84 \\
.\end{array}$ \\
\hline \multicolumn{9}{|c|}{ Thorium-228 (Alpha) } \\
\hline $\begin{array}{l}A \\
A \\
A \\
B \\
B \\
B \\
C \\
C \\
C\end{array}$ & $\begin{array}{l}\text { Conasauga } \\
\text { Chickamauga } \\
\text { Knox } \\
\text { Conasauga } \\
\text { Chickamauga } \\
\text { Knox } \\
\text { Conasauga } \\
\text { Chickamauga } \\
\text { Knox }\end{array}$ & $\begin{array}{l}8 \\
8 \\
8 \\
8 \\
8 \\
8 \\
8 \\
8 \\
8\end{array}$ & $\begin{array}{l}0 \\
0 \\
0 \\
0 \\
0 \\
0 \\
0 \\
0 \\
0\end{array}$ & $\begin{array}{l}8 \\
8 \\
7 \\
8 \\
8 \\
8 \\
7 \\
8 \\
8\end{array}$ & $\begin{array}{l}1.040 \\
1.210 \\
0.450 \\
1.280 \\
1.510 \\
1.120 \\
0.987 \\
1.680 \\
1.220\end{array}$ & $\begin{array}{l}1.48 \\
1.71 \\
0.64 \\
1.55 \\
1.83 \\
1.35 \\
1.44 \\
2.44 \\
1.78\end{array}$ & $\begin{array}{l}2.81 \\
3.27 \\
1.22 \\
2.19 \\
2.59 \\
1.91 \\
2.85 \\
4.84 \\
3.53\end{array}$ & $\begin{array}{l}1.830 \\
2.120 \\
0.796 \\
1.740 \\
2.060 \\
1.520 \\
1.810 \\
3.060 \\
2.240\end{array}$ \\
\hline
\end{tabular}

Thorium-230 (Alpha)

$\begin{array}{lllllllll}\text { A } & \text { Conasauga } & 8 & 0 & 8 & 0.739 & 0.862 & 1.14 & 0.949 \\ \text { A } & \text { Chickamauga } & 8 & 0 & 8 & 1.050 & 1.220 & 1.62 & 1.350 \\ \text { A } & \text { Knox } & 8 & 0 & 8 & 0.926 & 1.080 & 1.43 & 1.190 \\ \text { B } & \text { Conasauga } & 8 & 0 & 8 & 0.854 & 1.030 & 1.47 & 1.160 \\ \text { B } & \text { Chickamauga } & 8 & 0 & 7 & 1.060 & 1.290 & 1.82 & 1.440 \\ \text { B } & \text { Knox } & 8 & 0 & 8 & 1.380 & 1.670 & 2.37 & 1.880 \\ \text { C } & \text { Conasauga } & 8 & 0 & 8 & 0.708 & 0.855 & 1.21 & 0.962 \\ \text { C } & \text { Chickamauga } & 8 & 0 & 8 & 1.160 & 1.400 & 1.98 & 1.580 \\ \text { C } & \text { Knox } & 8 & 0 & 8 & 1.540 & 1.860 & 2.63 & 2.090\end{array}$

Thorium-232 (Alpha)

$\begin{array}{lllllllll}\text { A } & \text { Conasauga } & 8 & 0 & 8 & 1.010 & 1.210 & 1.66 & 1.350 \\ \text { A } & \text { Chickamauga } & 8 & 0 & 8 & 1.170 & 1.400 & 1.93 & 1.560 \\ \text { A } & \text { Knox } & 8 & 0 & 8 & 0.649 & 0.775 & 1.07 & 0.865 \\ \text { B } & \text { Conasauga } & 8 & 0 & 8 & 1.240 & 1.520 & 2.21 & 1.730 \\ \text { B } & \text { Chickamauga } & 8 & 0 & 8 & 1.560 & 1.920 & 2.80 & 2.180 \\ \text { B } & \text { Knox } & 8 & 0 & 8 & 1.190 & 1.460 & 2.13 & 1.660 \\ \text { C } & \text { Conasauga } & 8 & 0 & 8 & 1.070 & 1.400 & 2.27 & 1.650 \\ \text { C } & \text { Chickamauga } & 8 & 0 & 8 & 1.540 & 2.000 & 3.25 & 2.360 \\ \text { C } & \text { Knox } & 8 & 0 & 8 & 1.230 & 1.600 & 2.61 & 1.890\end{array}$


Table 6.1b (continued)

\begin{tabular}{|c|c|c|c|c|c|c|c|c|}
\hline Horizon & Group & $\mathbf{N}$ & I & $D$ & Median & UCB95 & X95 & LTB95 \\
\hline \multicolumn{9}{|c|}{ Thorium-234 (Beta) } \\
\hline $\begin{array}{l}A \\
A \\
A \\
B \\
B \\
B \\
C \\
C \\
C\end{array}$ & $\begin{array}{l}\text { Conasauga } \\
\text { Chickamauga } \\
\text { Knox } \\
\text { Conasauga } \\
\text { KnoX } \\
\text { REMAINDER } \\
\text { Conasauga } \\
\text { KnoX } \\
\text { REMAINDER }\end{array}$ & $\begin{array}{l}8 \\
5 \\
7 \\
8 \\
7 \\
5 \\
8 \\
7 \\
5\end{array}$ & $\begin{array}{l}0 \\
1 \\
1 \\
0 \\
1 \\
0 \\
0 \\
1 \\
0\end{array}$ & $\begin{array}{l}8 \\
0 \\
2 \\
7 \\
2 \\
0 \\
8 \\
0 \\
0\end{array}$ & $\begin{array}{l}1.520 \\
0.702 \\
0.915 \\
0.905 \\
0.993 \\
1.110 \\
0.892\end{array}$ & $\begin{array}{l}1.90 \\
1.08 \\
1.21 \\
1.30 \\
1.57 \\
1.20 \\
1.03 \\
.\end{array}$ & $\begin{array}{l}2.86 \\
1.31 \\
1.71 \\
2.48 \\
2.72 \\
1.39 \\
1.12 \\
.\end{array}$ & $\begin{array}{l}2.080 \\
0.870 \\
1.260 \\
1.470 \\
1.640 \\
1.230 \\
0.964\end{array}$ \\
\hline
\end{tabular}

Thorium-234 (Gamma)

$\begin{array}{lllllllll}\text { A } & \text { Chickamauga } & 3 & 0 & 1 & 0.909 & 1.68 & 1.76 & 0.893 \\ \text { B } & \text { Chickamauga } & 3 & 0 & 1 & 0.739 & 1.20 & 1.24 & 0.728 \\ \text { C } & \text { Chickamauga } & 3 & 0 & 1 & 1.010 & 2.27 & 2.49 & 0.989\end{array}$

Total Uranium (Alpha)

$\begin{array}{lllllllll}\text { A } & \text { Conasauga } & 8 & 0 & 8 & 1.230 & 1.710 & 3.12 & 2.090 \\ \text { A } & \text { Chickamauga } & 7 & 0 & 7 & 1.050 & 1.490 & 2.67 & 1.750 \\ \text { A } & \text { Knox } & 7 & 0 & 7 & 2.340 & 3.330 & 5.96 & 3.900 \\ \text { B } & \text { Conasauga } & 2 & 0 & 2 & 0.316 & 0.972 & 1.55 & 0.276 \\ \text { C } & \text { Conasauga } & 2 & 0 & 2 & 0.299 & 1.650 & 3.35 & 0.244\end{array}$

Tritium (Tritium)

$\begin{array}{llrllllll}\text { A } & \text { Conasauga } & 9 & 0 & 5 & 0.0318 & 0.0427 & 0.0697 & 0.0487 \\ \text { A } & \text { Chickamauga } & 15 & 3 & 0 & 0.0556 & 0.0779 & 0.1220 & 0.0884 \\ \text { A } & \text { Knox } & 9 & 0 & 4 & 0.0165 & 0.0238 & 0.0361 & 0.0232\end{array}$

Uranium-233/234 (Alpha)

$\begin{array}{lllllllll}\text { A } & \text { Conasauga } & 8 & 0 & 8 & 1.100 & 1.24 & 1.54 & 1.33 \\ \text { A } & \text { Chickamauga } & 8 & 0 & 8 & 1.110 & 1.25 & 1.56 & 1.35 \\ \text { A } & \text { Knox } & 8 & 0 & 8 & 1.270 & 1.43 & 1.77 & 1.54 \\ \text { B } & \text { Conasauga } & 8 & 0 & 8 & 1.080 & 1.30 & 1.83 & 1.46 \\ \text { B } & \text { Chickamauga } & 8 & 0 & 8 & 1.030 & 1.24 & 1.74 & 1.40 \\ \text { B } & \text { Knox } & 8 & 0 & 8 & 1.520 & 1.82 & 2.56 & 2.05 \\ \text { C } & \text { Conasauga } & 8 & 0 & 8 & 0.862 & 1.02 & 1.38 & 1.13 \\ \text { C } & \text { Chickamauga } & 8 & 0 & 8 & 1.100 & 1.30 & 1.76 & 1.44 \\ \text { C } & \text { Knox } & 8 & 0 & 8 & 1.570 & 1.85 & 2.50 & 2.05\end{array}$

Uranium-235 (Alpha)

$\begin{array}{lllllllll}\text { A } & \text { Conasauga } & 8 & 1 & 6 & 0.0540 & 0.0727 & 0.122 & 0.0860 \\ \text { A } & \text { Chickamauga } & 8 & 1 & 7 & 0.0736 & 0.0983 & 0.167 & 0.1170 \\ \text { A } & \text { Knox } & 8 & 1 & 6 & 0.0955 & 0.1280 & 0.216 & 0.1520 \\ \text { B } & \text { Conasauga } & 8 & 1 & 6 & 0.0540 & 0.0979 & 0.277 & 0.1360 \\ \text { B } & \text { Chickamauga } & 8 & 0 & 8 & 0.0946 & 0.1690 & 0.485 & 0.2390 \\ \text { B } & \text { Knox } & 8 & 0 & 7 & 0.2220 & 0.4000 & 1.140 & 0.5660 \\ \text { C } & \text { Conasauga } & 8 & 1 & 6 & 0.0392 & 0.0574 & 0.112 & 0.0711 \\ \text { C } & \text { Chickamauga } & 8 & 0 & 8 & 0.0959 & 0.1390 & 0.274 & 0.1740 \\ \text { C } & \text { Knox } & 8 & 0 & 7 & 0.1220 & 0.1770 & 0.348 & 0.2220\end{array}$


$6-12$

Table 6.1b (continued)

\begin{tabular}{|c|c|c|c|c|c|c|c|c|}
\hline Horizon & Group & $\mathbf{N}$ & $\mathbf{I}$ & D & Median & UCB95 & X95 & LTB9595 \\
\hline \multicolumn{9}{|c|}{ Uranium-235 (Gamma) } \\
\hline $\begin{array}{l}A \\
A \\
B \\
B \\
C \\
C \\
C\end{array}$ & $\begin{array}{l}\text { Conasauga } \\
\text { REMAINDER } \\
\text { Conasauga } \\
\text { REMAINDER } \\
\text { Conasauga } \\
\text { KnOX } \\
\text { REMAIHDER }\end{array}$ & $\begin{array}{r}8 \\
15 \\
7 \\
16 \\
8 \\
8 \\
8\end{array}$ & $\begin{array}{l}0 \\
0 \\
0 \\
0 \\
0 \\
0 \\
0\end{array}$ & $\begin{array}{l}8 \\
0 \\
7 \\
0 \\
8 \\
1 \\
0\end{array}$ & $\begin{array}{l}0.0751 \\
0.0517 \\
0.0452 \\
0.1100 \\
.\end{array}$ & $\begin{array}{l}0.0895 \\
0.0699 \\
0.0567 \\
0.1620 \\
.\end{array}$ & $\begin{array}{l}0.1230 \\
0.1150 \\
0.0858 \\
0.2090 \\
.\end{array}$ & $\begin{array}{l}0.0942 \\
0.0723 \\
0.0608 \\
0.1490 \\
.\end{array}$ \\
\hline \multicolumn{9}{|c|}{ Uranium-236 (Alpha) } \\
\hline $\begin{array}{l}A \\
A \\
A \\
B \\
B \\
C \\
C\end{array}$ & $\begin{array}{l}\text { Conasauga } \\
\text { Chickamauga } \\
\text { Knox } \\
\text { Conasauga } \\
\text { REMAINDER } \\
\text { Chickamauga } \\
\text { REMAINDER }\end{array}$ & $\begin{array}{r}8 \\
8 \\
8 \\
8 \\
16 \\
8 \\
16\end{array}$ & $\begin{array}{l}0 \\
1 \\
0 \\
0 \\
0 \\
0 \\
0\end{array}$ & $\begin{array}{l}1 \\
0 \\
1 \\
1 \\
0 \\
1 \\
0\end{array}$ & $\begin{array}{l}.009810 \\
.006310 \\
.009260 \\
.000586 \\
: \\
:\end{array}$ & $\begin{array}{l}0.0197 \\
0.0126 \\
0.0182 \\
0.6130 \\
\vdots \\
:\end{array}$ & $\begin{array}{l}0.0240 \\
0.0154 \\
0.0226 \\
0.1430 \\
\vdots \\
:\end{array}$ & $\begin{array}{l}0.01340 \\
0.00882 \\
0.01240 \\
0.00445 \\
. \\
.\end{array}$ \\
\hline
\end{tabular}

Uranium-238 (Alpha)

$\begin{array}{lllllllll}\text { A } & \text { Conasauga } & 8 & 0 & 8 & 1.150 & 1.27 & 1.52 & 1.35 \\ \text { A } & \text { Chickamauga } & 8 & 0 & 8 & 1.140 & 1.26 & 1.51 & 1.34 \\ \text { A } & \text { Knox } & 8 & 0 & 8 & 1.250 & 1.38 & 1.65 & 1.47 \\ \text { B } & \text { Conasauga } & 8 & 0 & 8 & 1.080 & 1.26 & 1.66 & 1.38 \\ \text { B } & \text { Chickamauga } & 8 & 0 & 8 & 1.150 & 1.34 & 1.76 & 1.47 \\ \text { B } & \text { Knox } & 8 & 0 & 8 & 1.680 & 1.95 & 2.57 & 2.14 \\ \text { C } & \text { Conasauga } & 8 & 0 & 8 & 0.864 & 1.03 & 1.44 & 1.16 \\ \text { C } & \text { Chickamauga } & 8 & 0 & 8 & 1.140 & 1.37 & 1.90 & 1.53 \\ \text { C } & \text { Knox } & 8 & 0 & 8 & 1.650 & 1.98 & 2.75 & 2.21\end{array}$

Uranium-238 (Gamma)

\begin{tabular}{|c|c|c|c|c|c|c|c|c|}
\hline $\begin{array}{l}A \\
B \\
C \\
C\end{array}$ & $\begin{array}{l}\text { REMAINDER } \\
\text { REMAINDER } \\
\text { Chickamauga } \\
\text { REMAINDER }\end{array}$ & $\begin{array}{r}16 \\
16 \\
8 \\
8\end{array}$ & $\begin{array}{l}0 \\
0 \\
0 \\
0\end{array}$ & $\begin{array}{l}1 \\
0\end{array}$ & 0.9 & 100 & 43.4 & 3.7 \\
\hline
\end{tabular}

${ }^{a} \mathrm{~N}=$ number of observations, possibly averages over replicates at sites; I = number of interval censored observations (see text); $\mathrm{D}=$ number of true detects (see text); UCB95 = 95\% upper confidence bound for median; X95 = estimate of 95 th percentile; LTB9595 = 95\% lower confidence bound for 95th percentile; REMAINDER refers to the remaining observations-no detects.

\subsection{BASIC IDEAS AND CONCEPTS OF INTERPRETING SOILS DATA}

The original intent of the BSCP data interpretation was to partition the soil analysis data according to three sources: (1) the inherited geologic source, (2) the worldwide or regional atmospheric depositional source, and (3) that introduced by local sources. This has been done where there was sufficient reason to do so. The following discussion covers the difficulties of trying to partition soils data into these three components. 
Table 6.1c. Summary statistics by group for PAHs on the ORR ${ }^{a}$ (A horizon, noncomposited samples. Phase I Conasauga sites have been deleted. Estimates and confidence bounds are in micrograms per kilogram. May be inappropriate when areas have different median analyte concentrations.)

\begin{tabular}{|c|c|c|c|c|c|c|c|c|}
\hline Analysis & Group & $\mathbf{N}$ & I & D & Median & UCB95 & $\mathrm{X} 95$ & LTB9595 \\
\hline $\begin{array}{l}\text { Acenaphthene } \\
\text { Acenaphthene }\end{array}$ & $\begin{array}{l}\text { Chickamauga } \\
\text { Knox }\end{array}$ & $\begin{array}{r}4 \\
10\end{array}$ & $\begin{array}{l}0 \\
0\end{array}$ & $\begin{array}{l}4 \\
4\end{array}$ & $\begin{array}{l}1.700 \\
1.210\end{array}$ & $\begin{array}{l}2.560 \\
1.800\end{array}$ & $\begin{array}{l}3.87 \\
2.76\end{array}$ & $\begin{array}{l}2.30 \\
1.70\end{array}$ \\
\hline $\begin{array}{l}\text { Acenaphthylene } \\
\text { Acenaphthylene }\end{array}$ & $\begin{array}{l}\text { Chickamauga } \\
\text { Knox }\end{array}$ & $\begin{array}{l}24 \\
17\end{array}$ & $\begin{array}{l}0 \\
0\end{array}$ & $\begin{array}{l}0 \\
4\end{array}$ & 11.300 & 103.000 & 1000.00 & 154.00 \\
\hline $\begin{array}{l}\text { Anthracene } \\
\text { Anthracene }\end{array}$ & $\begin{array}{l}\text { Chickamauga } \\
\text { Knox }\end{array}$ & $\begin{array}{l}15 \\
12\end{array}$ & $\begin{array}{l}0 \\
0\end{array}$ & $\begin{array}{l}15 \\
10\end{array}$ & $\begin{array}{l}0.986 \\
0.746\end{array}$ & $\begin{array}{l}1.400 \\
1.150\end{array}$ & $\begin{array}{l}3.87 \\
2.93\end{array}$ & $\begin{array}{l}2.41 \\
1.73\end{array}$ \\
\hline $\begin{array}{l}\text { Benzo [a] anthracene } \\
\text { Benzo [a] anthracene }\end{array}$ & $\begin{array}{l}\text { Chickamauga } \\
\text { Knox }\end{array}$ & $\begin{array}{l}18 \\
19\end{array}$ & $\begin{array}{l}0 \\
0\end{array}$ & $\begin{array}{l}18 \\
19\end{array}$ & $\begin{array}{l}5.160 \\
1.890\end{array}$ & $\begin{array}{l}6.710 \\
2.440\end{array}$ & $\begin{array}{l}15.7 \\
5.76\end{array}$ & $\begin{array}{r}11.20 \\
4.13\end{array}$ \\
\hline $\begin{array}{l}\text { Benzo [a] pyrene } \\
\text { Benzo [a] pyrene }\end{array}$ & $\begin{array}{l}\text { Chickamauga } \\
\text { Knox }\end{array}$ & $\begin{array}{l}24 \\
15\end{array}$ & $\begin{array}{l}0 \\
0\end{array}$ & $\begin{array}{l}24 \\
15\end{array}$ & $\begin{array}{l}4.430 \\
2.850\end{array}$ & $\begin{array}{l}5.430 \\
3.680\end{array}$ & $\begin{array}{l}12.0 \\
7.70\end{array}$ & $\begin{array}{l}9.09 \\
5.61\end{array}$ \\
\hline $\begin{array}{l}\text { Benzo [b] f luoranthene } \\
\text { Benzo [b] fluoranthene }\end{array}$ & $\begin{array}{l}\text { Chickamauga } \\
\text { Knox }\end{array}$ & $\begin{array}{l}20 \\
12\end{array}$ & $\begin{array}{l}0 \\
0\end{array}$ & $\begin{array}{l}20 \\
10\end{array}$ & $\begin{array}{l}4.530 \\
2.350\end{array}$ & $\begin{array}{l}5.800 \\
3.300\end{array}$ & $\begin{array}{l}13.7 \\
7.15\end{array}$ & $\begin{array}{l}9.77 \\
4.79\end{array}$ \\
\hline $\begin{array}{l}\text { Benzo }[g, h, i] \text { perylene } \\
\text { Benzo[g, } h, i] \text { perylene }\end{array}$ & $\begin{array}{l}\text { Chickamauga } \\
\text { Knox }\end{array}$ & $\begin{array}{l}17 \\
15\end{array}$ & $\begin{array}{l}0 \\
0\end{array}$ & $\begin{array}{l}17 \\
15\end{array}$ & $\begin{array}{l}4.350 \\
2.730\end{array}$ & $\begin{array}{l}5.600 \\
3.580\end{array}$ & $\begin{array}{l}12.3 \\
7.75\end{array}$ & $\begin{array}{l}8.85 \\
5.50\end{array}$ \\
\hline $\begin{array}{l}\text { Benzo [k] fluoranthene } \\
\text { Benzo [k] fluoranthene }\end{array}$ & $\begin{array}{l}\text { Chickamauga } \\
\text { Knox }\end{array}$ & $\begin{array}{l}24 \\
16\end{array}$ & $\begin{array}{l}0 \\
0\end{array}$ & $\begin{array}{l}24 \\
16\end{array}$ & $\begin{array}{l}2.570 \\
1.450\end{array}$ & $\begin{array}{l}3.140 \\
1.850\end{array}$ & $\begin{array}{l}6.84 \\
3.86\end{array}$ & $\begin{array}{l}5.23 \\
2.85\end{array}$ \\
\hline $\begin{array}{l}\text { Chrysene } \\
\text { Chrysene }\end{array}$ & $\begin{array}{l}\text { Chickamauga } \\
\text { Knox }\end{array}$ & $\begin{array}{l}11 \\
12\end{array}$ & $\begin{array}{l}0 \\
0\end{array}$ & $\begin{array}{l}8 \\
9\end{array}$ & $\begin{array}{l}5.030 \\
3.400\end{array}$ & $\begin{array}{l}7.260 \\
4.880\end{array}$ & $\begin{array}{l}16.2 \\
11.0\end{array}$ & $\begin{array}{r}10.10 \\
6.89\end{array}$ \\
\hline $\begin{array}{l}\text { Dibenzo }[a, h] \text { anthracene } \\
\text { Dibenzo }[a, h] \text { anthracene }\end{array}$ & $\begin{array}{l}\text { Chickamauga } \\
\text { Knox }\end{array}$ & $\begin{array}{r}6 \\
13\end{array}$ & $\begin{array}{l}0 \\
0\end{array}$ & $\begin{array}{r}5 \\
11\end{array}$ & $\begin{array}{l}0.693 \\
1.030\end{array}$ & $\begin{array}{l}1.190 \\
1.480\end{array}$ & $\begin{array}{l}2.32 \\
3.45\end{array}$ & $\begin{array}{l}1.23 \\
2.11\end{array}$ \\
\hline $\begin{array}{l}\text { Fluoranthene } \\
\text { Fluoranthene }\end{array}$ & $\begin{array}{l}\text { Chickamauga } \\
\text { Knox }\end{array}$ & $\begin{array}{l}19 \\
19\end{array}$ & $\begin{array}{l}0 \\
0\end{array}$ & $\begin{array}{l}19 \\
19\end{array}$ & $\begin{array}{l}5.960 \\
4.670\end{array}$ & $\begin{array}{l}8.080 \\
6.330\end{array}$ & $\begin{array}{l}22.4 \\
17.5\end{array}$ & $\begin{array}{l}15.10 \\
11.80\end{array}$ \\
\hline $\begin{array}{l}\text { Fluorene } \\
\text { Fluorene }\end{array}$ & $\begin{array}{l}\text { Chickamauga } \\
\text { Knox }\end{array}$ & $\begin{array}{r}9 \\
12\end{array}$ & $\begin{array}{l}0 \\
0\end{array}$ & $\begin{array}{l}9 \\
5\end{array}$ & $\begin{array}{l}1.620 \\
0.555\end{array}$ & $\begin{array}{l}2.500 \\
0.943\end{array}$ & $\begin{array}{l}5.96 \\
2.05\end{array}$ & $\begin{array}{l}3.32 \\
1.12\end{array}$ \\
\hline $\begin{array}{l}\text { Indeno }[1,2,3-c, d] \text { pyrene } \\
\text { Indeno }[1,2,3-c, d] \text { pyrene }\end{array}$ & $\begin{array}{l}\text { Chickamauga } \\
\text { Knox }\end{array}$ & $\begin{array}{l}23 \\
19\end{array}$ & $\begin{array}{l}0 \\
0\end{array}$ & $\begin{array}{r}15 \\
1\end{array}$ & $\begin{array}{r}10.200 \\
5.650\end{array}$ & $\begin{array}{l}13.400 \\
11.000\end{array}$ & $\begin{array}{l}31.7 \\
17.5\end{array}$ & $\begin{array}{r}22.00 \\
9.86\end{array}$ \\
\hline $\begin{array}{l}\text { Naphthalene } \\
\text { Naphthalene }\end{array}$ & $\begin{array}{l}\text { Chickamauga } \\
\text { Knox }\end{array}$ & $\begin{array}{l}13 \\
11\end{array}$ & $\begin{array}{l}0 \\
0\end{array}$ & $\begin{array}{r}13 \\
6\end{array}$ & $\begin{array}{l}3.570 \\
8.200\end{array}$ & $\begin{array}{r}5.710 \\
15.000\end{array}$ & $\begin{array}{l}19.4 \\
44.5\end{array}$ & $\begin{array}{l}10.20 \\
22.60\end{array}$ \\
\hline $\begin{array}{l}\text { Phenanthrene } \\
\text { Phenanthrene }\end{array}$ & $\begin{array}{l}\text { Chickamauga } \\
\text { Knox }\end{array}$ & $\begin{array}{l}24 \\
19\end{array}$ & $\begin{array}{l}0 \\
0\end{array}$ & $\begin{array}{l}24 \\
19\end{array}$ & $\begin{array}{l}6.890 \\
3.680\end{array}$ & $\begin{array}{l}8.300 \\
4.550\end{array}$ & $\begin{array}{l}17.2 \\
9.21\end{array}$ & $\begin{array}{r}13.40 \\
7.06\end{array}$ \\
\hline $\begin{array}{l}\text { Pyrene } \\
\text { Pyrene }\end{array}$ & $\begin{array}{l}\text { Chickamauga } \\
\text { Knox }\end{array}$ & $\begin{array}{l}18 \\
19\end{array}$ & $\begin{array}{l}0 \\
0\end{array}$ & $\begin{array}{l}18 \\
19\end{array}$ & $\begin{array}{l}9.800 \\
4.370\end{array}$ & $\begin{array}{r}13.100 \\
5.790\end{array}$ & $\begin{array}{l}33.6 \\
15.0\end{array}$ & $\begin{array}{l}23.10 \\
10.40\end{array}$ \\
\hline
\end{tabular}

${ }^{a} \mathrm{~N}=$ number of observations, possibly averages over replicates at sites; $\mathrm{I}=$ number of interval censored observations (see text); D = number of true detects (see text); UCB95 = 95\% upper confidence bound for median; X95 = estimate of 95 th percentile; LTB9595 = 95\% lower confidence bound for 95th percentile; REMAINDER refers to the remaining observations-no detects.

\subsubsection{Soil Extraction Factors That Can Affect the Measured Chemical Content of Soils}

The interpretation of analytical results of data from a soil environment can often be an exercise in both frustration and uncertainty. The chemical extraction of inorganic soil components is also fraught with great uncertainties. The $\mathrm{pH}$ of unbuffered soil extractants can change from sample to sample, resulting in the extraction of differing amounts of what is to be measured. Differing extracting methods and procedures result in differing amounts of what is measured. The scientific literature refers to differing methods for extracting soil 
components. This report also contains a discussion of a whole soil analysis technique (NAA) with the results from the current EPA extraction and analytical methods for metals.

The soil system is dynamic in both time and space. Included is a very dynamic biotic component. For example, some inorganic ions are quite immobile, but if transformed into organic compounds, they can be come very mobile and potentially hazardous. Methyl mercury is a prime example. Biotic compounds of arsenic and lead behave similarly. Therefore, the interpretation of results must be based on a knowledge of what goes on at various depths in a soil system and how the whole soil system reacts and interacts. In this BSCP activity, samples were collected from specific soil horizons rather than from prescribed depths. The only exceptions were the gamma screening samples. Gamma screening was done primarily to determine the atmospheric input of ${ }^{137} \mathrm{Cs}$, so the upper $30 \mathrm{~cm}$ of the soil profile was sampled in 5-cm increments.

\subsubsection{Landscape Factors That May Affect the Chemical Content of Soils}

Several soil-landscape variables can affect what is measured. Some variables can act independently, whereas other variables interact in unpredictable ways. One major variable that can affect results and interpretation of those results is the location of the soil in the landscape. A soil can be affected by the adjacent soils, especially those soils at higher elevations. Rainfall can infiltrate or run off from higher soils. Rainfall that has infiltrated soil at higher elevations can then move laterally below the surface to affect soils downslope. The primary objective of BSCP was to sample soils that were (1) geomorphically stable, (2) located in the highest part of the landform so that there would be minimal effects from the immediate adjacent soils, (3) not disturbed in the past 50 years or more and had a hardwood forest, (4) not eroded, and (5) formed in residuum. However, reality dictated that some chosen sites were on side slopes, some had a thin capping of either old colluvium or old alluvium, and some were located in older loblolly pine plantations or in old-field successional mixed pine and hardwood forests. The background levels of contaminants in colluvial or floodplain soils or more recently disturbed soils can either be higher or lower than the background levels measured in this project but still may be considered to be background for those specific sites. The data presented in this report represent part of the entire ORR. There are many soils and several geologic formations that have not yet been sampled.

\subsection{Factors That Can Affect the Chemical Contents of A, B, and C Soil Horizons}

Samples were obtained from (1) the A horizon of the soil, (2) the B horizon of the soil, and (3) the "C" horizon (including either the lower $B$ horizon, a transitional $B C$ or $C B$ horizon, the $\mathrm{C}$ horizon or the upper part of a paralithic $\mathrm{Cr}$ horizon.) The $\mathrm{A}$ horizon contains the most organic carbon and also the highest biotic activity. Here, soil fauna can decompose or transform one compound into another, or inorganic compounds can be transformed into more mobile organic compounds. Both aerobic and anaerobic respiration can occur in this surface mineral horizon of the soil.

The B horizon of most soils, commonly known as the upper subsoil, is the soil zone in which there is a net accumulation of soil clay minerals and iron oxides. Here, soil fauna tend to degrade organic compounds that have been translocated from the A horizon above, releasing metal ions from an organic form to an inorganic form. Respiration in this part of the soil tends to be aerobic on ped surfaces and along root channels and anaerobic within peds. Dissolved organic carbon moves into and through this soil horizon. Whether it is 
degraded and releases any metal ions depends on its rate of movement and time of residence. Saturated flow will tend to move dissolved organic carbon compounds and other ions rapidly through larger flow zones so that the soil fauna never come into contact with it. Another process that often occurs in this upper subsoil zone results in the destruction of clay minerals and the release of both silica and alumina ions and their lateral or downward translocation.

The $\mathrm{C}$ horizon occurs at a highly variable depth in the soil. It begins at the upper zone, where saprolite or saprolitic material with its geologic strike and dip can be recognized or where pedogenic soil structure becomes minor. Here, soil processes are minimal, but there is often some biotic component, especially the soil fauna associated with roots and dissolved organic carbon that move downward along ped surfaces and along fracture and joint surfaces. Soil moisture remains nearly constant, and most soil fauna respiration is anaerobic, except along cracks and pores open to the surface. Where $C$ horizons occur close to the surface (less than $50 \mathrm{~cm}$ to about $100 \mathrm{~cm}$ ) as in most Dismal Gap and Nolichucky soils, there is a much higher organic component than in the " $C$ " horizon of the ORR Copper Ridge and Chepultepec soils that were sampled below a depth of 140 to $160 \mathrm{~cm}$. The C horizon zone of the soil tends to be the location where there is deposition of ions translocated through the horizons above. Here, manganese and other ions with similar chemistry are often found in higher zones of concentration although the total manganese content is lower than in the $A$ horizon above. In this part of the soil, water movement becomes increasingly channelized into well-defined flow zones. Flow zones in this part of the soil usually have a rather intense reduction potential because the oxygen partial pressure is very low. Here, some ions that are generally quite immobile are transformed into more mobile forms. For example, manganese oxides are reduced, resulting in greater mobility. The same happens with iron oxides that are transformed from ferric to ferrous forms and acquire a layer of oriented hydration water or hydroxyl groups. Other ions having similar geochemical properties can also become mobile in this zone.

\subsection{BASIC DATA COMPARISONS}

\subsubsection{Site and Soil Factors That Must Be Considered in the Initial Comparison of Results}

When making a comparison with a new site, the best interpretation of results involves having a set of data from the $A, B$, and $C$ horizons of a particular site under similar vegetation to observe trends of those ions in question. For example, contamination via surface deposition on a grassy slope should be confined to the surface if ions are immobile because of the shallow rooting of grasses. In a forest, contamination via surface deposition is a different situation. Here, stem flow can deliver contaminants deeply into the soil through root flow zones and rapidly into shallow water tables. Tree drip can produce zones where the level of contamination may be higher. A high degree of spatial variability is normal in a forested soil. The data from an $\mathrm{A}$ horizon at one site should not be compared with the $\mathrm{B}$ or $\mathrm{C}$ horizon data from another site. In principle, inorganic and natural radionuclide data from the soils of one formation should not be used as background data for soils of another formation because soils from different geologic formations can have different levels of inherited metals and natural radionuclides unless the statistical interpretation would indicate otherwise. Inorganic data from residual soils should not be compared with data from alluvial or colluvial soils without making sure that the same standard operating procedures were adhered to and whether the statistical analysis would indicate that such comparisons would be valid. 


\subsubsection{Comparisons Between Methods of Extraction and Analysis}

\subsubsection{Comparison between AA/ICP and ICP/MS analysis}

Sixteen metals were analyzed by using AA/ICP and ICP/MS methods, and the results were compared. The metals in which the measured concentration was the same between both methods were $\mathrm{Al}, \mathrm{Ba}, \mathrm{Be}, \mathrm{Cr}, \mathrm{Co}, \mathrm{Cu}, \mathrm{Pb}, \mathrm{Mn}$, and $\mathrm{Ni}$ (9 out of 16 ). Antimony concentrations were below detection limits for both methods, but more detects were observed with $\mathrm{AA} / \mathrm{ICP}$. Cadmium concentrations were equally below detection limits for both methods. Arsenic, beryllium, and zinc concentrations determined by AA/ICP were larger than those determined with ICP/MS. Selenium results were scattered, and no difference between the methods can be observed. These results did not show an advantage in using ICP/MS over AA/ICP.

\subsubsection{Comparison between AA/ICP and NAA analysis}

Fifteen metals were analyzed by using AA/ICP and NAA methods, and the results were compared. The metals in which the measured concentration was the same between the methods were: As, $\mathrm{Co}, \mathrm{Fe}$, and $\mathrm{Mn}$. The metals for which measured concentrations with NAA were higher than with $\mathrm{AA} / \mathrm{CCP}$ were $\mathrm{Al}, \mathrm{Cr}, \mathrm{Mg}, \mathrm{K}, \mathrm{V}$, and $\mathrm{Zn}$. Antimony, barium, and silver were only detected using the NAA method. Mercury was detected using AA/ICP but not the NAA method. Sodium concentration did not show a relationship between the methods. The limiting factor in the determination of metal concentrations in soil is not the instrument but the extraction procedure. The acid extraction procedure for metal determination represents only a part of the total amount of the metal in the soil structure. Metal concentrations measured by NAA represents the total element concentration in soils.

\subsubsection{Comparison between electrostatic discharge gamma scanning and contract laboratory results for radionuclides}

The electrostatic discharge gamma scanning technique uses a much larger sample (400 to $900 \mathrm{~g}$ ) compared to the contract laboratory sample size of $1 \mathrm{~g}$. Problems in comparison are mainly related to analytical techniques and the time of counting. The contract laboratory uses a more sensitive analytical technique and detection instruments and a longer counting time. The electrostatic discharge analytical technique uses a less sensitive analytical instrument and a shorter counting time for soil samples between depths of 0 and $25 \mathrm{~cm}$. The $25-$ to $30-\mathrm{cm}$ depth section uses a longer counting time, and the results from this increment are probably more accurate than those from the contract laboratory. The primary problem with any comparisons of data is that the sample sizes are so different and the depths are not comparable. The electrostatic discharge gamma scanning technique via the methodology in the BSCP Plan (Energy Systems 1992, Volume 3) can be used anywhere and for all conditions for sample/site screening purposes based on ${ }^{137} \mathrm{Cs}$ activity levels. This procedure requires that a standard cross-sectional area be sampled. Obtaining a series of samples to a depth of at least $30 \mathrm{~cm}$ ensures that all ${ }^{137} \mathrm{Cs}$ has been found for upland residual soils. However, cesium levels for alluvial and colluvial soils can be much different. Colluvial soils usually have higher levels of ${ }^{137} \mathrm{Cs}$ because of surface and subsurface transport from soils higher in the landscape. In floodplain and low-terrace landscapes, it will often be necessary to sample deeper, where modern deposition of sediments has occurred, because the products of airborne deposition can be buried below a depth of $30 \mathrm{~cm}$. The other possibility is that the ${ }^{137} \mathrm{Cs}$ and other associated contaminants may have been removed from the site by surface erosion. 
The gamma scanning error term must be considered in attaching significance to any data. The error term for some elements is very low $(<10 \%)$, whereas the error terms for other elements, namely ${ }^{235} \mathrm{U}$ and ${ }^{238} \mathrm{U}$, tend to be large $(>50 \%)$. Uranium screening data are reported but should not be used for risk assessment because the contract laboratory and Neutron Activation Laboratory used more sensitive analytical methods. The tolerance bounds or confidence limits for all elements and compounds that were analyzed in this project must be recognized and incorporated into any kind of data comparison and interpretation.

\subsection{VALID DATA COMPARISONS}

\subsubsection{Volatile Organic Compounds}

VOC analysis can be done at any site on the ORR. Some precautions must be considered in interpreting results. Certain organic compounds, such as acetone, butanone, and other laboratory-induced compounds, commonly show up in the results. These are mostly the result of contamination of the analytical apparatus. The interpretation of other results must be based on the life of such volatile compounds in an aerobic surface soil environment. The data, presented elsewhere, are only from the A horizon of the soil.

\subsubsection{Pesticides, Herbicides, and Polychlorinated Biphenyls}

The analysis for these compounds is done on field moist soil samples. The surface leaf litter in a forest soil is removed, and a sample is immediately collected. For bare or grass-covered soil, a sample is collected from the upper 5 to $10 \mathrm{~cm}$ of the soil. Additional samples can be collected at depth to determine the extent of downward migration. If an upwelling plume is suspected, a sample or samples can be collected at depth to confirm or reject the hypothesis. The interpretation of results must be based on the life of such compounds in a soil environment. Some compounds have a very long half-life, whereas others are readily decomposed by the indigenous soil fauna. Most of the compounds that were analyzed for BSCP have a very long half-life, or the daughter products still have undesirable biochemical properties. Therefore, it is helpful in interpretation if the time when the suspected contamination occurred is known.

\subsubsection{Inorganics}

Inorganics occur as cations and anions, as well as in the mineral fraction. Some cations are relatively mobile, whereas others are not. Most anions are mobile because there are very few anion retention sites in soils, the notable exceptions being the organic carbon component of the surface soil layer (A horizon) and oxides that coat ped surfaces in the subsoil ( $\mathrm{B}$ horizon) or fracture faces in the $\mathrm{C}$ horizon.

Many cations of metals, such as aluminum and iron, are dominant components of all mineral soils and are not diagnostic of any contamination. Some metals are inherited from the underlying geology. If the distribution of these metals remains the same throughout the various sampling depths or increases with depth, they usually have a geologic origin, especially if they are not mobile in a soil environment. Results must be interpreted carefully so that anthropogenic contamination can be distinguished from geologically inherited inorganics. Some metals can be introduced by the use of sampling equipment. A comparison of ORR source water with the ORR inorganics field rinse water showed that the rinse water contained 
higher amounts of $\mathrm{Al}, \mathrm{Fe}, \mathrm{Mn}, \mathrm{Si}, \mathrm{Sr}$, and $\mathrm{Cu}$. The scratches and wear on the sampling stainless steel equipment are a likely source of the added components in the rinse water. Geologic inherited inorganics must be determined from the particular geologic formation because different geologic formations have differing levels of rare earths and heavy metals. One must also be aware that sedimentation conditions vary within any geologic formation.

Another complicating factor in interpreting results is the past land use of a site. Past fertilizer and lime applications can result in increased amounts of heavy metals and rare earths in the surface soil, especially if rock phosphate was used. The widespread use of certain fungicides and pesticides, such as copper sulfate or lead arsenate, can also affect interpretations. Comparisons of inorganic results should be confined to the same geologic formation or section of that formation. However, the data tend to indicate that the results from the Dismal Gap and Nolichucky in the Bear Creek Conasauga section should be applicable to the Melton Creek section of the Conasauga. Likewise, most of the data between the Bethel Valley section of the Chickamauga and the East Fork (designated at K-25) section of the Chickamauga are quite similar, but with some departures. Where the statistical analysis indicates that there are no significant differences, most of the trace metals between soils in a geologic group would suggest that the applicable BSCP data could be applied as background values for other similar formations within the group (see Sect. 2).

\subsubsection{Radionuclides}

The presence of certain nuclides, such as ${ }^{137} \mathrm{Cs},{ }^{99} \mathrm{Tc},{ }^{247} \mathrm{Cm},{ }^{239240} \mathrm{Pu}$, and ${ }^{3} \mathrm{H}$, is nearly always the result of airborne deposition, whereas other nuclides could be inherited from the underlying rock. Uranium isotopes $\left({ }^{235} \mathrm{U}\right.$ and $\left.{ }^{238} \mathrm{U}\right)$ present special problems in interpretation because part of these isotopes are inherited from the underlying rock and part are the result of airborne dust deposition. Therefore, a critical source evaluation is essential before any comparisons are made. For example, where is the radionuclide located in soil and core samples, and what is the isotopic ratio of ${ }^{235} \mathrm{U}$ to ${ }^{238} \mathrm{U}$ ? If most of the uranium is in the $A$ horizon and the values are much higher than in the $\mathrm{B}$ and $\mathrm{C}$ horizons, then the higher amounts in the A horizon are most likely due to airborne dust deposition, while the values in the $\mathrm{C}$ horizon are most likely that part inherited from the geology. If the isotopic ratio is off, then there is both a geologic source and an airborne source.

\subsection{INTERPRETATION OF DATA BY INDIVIDUAL ELEMENT OR COMPOUND}

Detailed analytical results of the soil chemical analyses for organics, inorganics, and radionuclides are given in Appendixes $\mathrm{C}, \mathrm{D}$, and $\mathrm{E}$, respectively. The analytical procedures are referenced to the EPA Contract Laboratory Program Statement of Work (EPA 1990a and $b$ ). Additional analytical results were obtained from ICP/MS analysis for selected metals (Appendix I) and from NAA (Appendix $\mathrm{H}$ ) for most inorganic soil components. The interpretation and comparison of results for $\mathrm{A}, \mathrm{B}$, and $\mathrm{C}$ soil horizons, individual geologic formations, geologic groups, and locations (Roane County, Anderson County, and the ORR) were made, with a few exceptions, from Contract Laboratory Program (CLP) data. The two non-CLP analyses (ICP/MS and NAA) were conducted in order to compare analytical techniques. The ICP/MS method of analysis was expected to have a lower instrumental detection limit for most metals. The NAA method is a nondestructive total elemental analysis method rather than the EPA acid extractable inorganic elemental analysis method (CLP-AA). 
The NAA method provides additional data for analytes such as rare earth elements and actinides. The actinides include ${ }^{232} \mathrm{Th},{ }^{235} \mathrm{U}$, and ${ }^{238} \mathrm{U}$.

In this section, analytical results are compared and discussed, including differences among (1) sampling areas, (2) geologic rock groups, (3) individual geologic formations within a group, (4) sites within formations, and (5) A horizons vs B horizons vs C horizons of soils within formations. A summary of statistically treated data is presented in Appendix G. There are three sampling areas-the ORR, Roane County, and Anderson County. However, in part of the statistical treatment, only two sampling areas are mentioned: on-site (ORR) and off-site (Anderson and Roane). There are three geologic rock groups: Conasauga, Knox, and Chickamauga. The ORR has samples from all three rock groups, but Roane and Anderson have samples only from the Conasauga and Knox. There are six geologic formations: Dismal Gap and Nolichucky from the Conasauga Group; Copper Ridge and Chepultepec from the Knox Group; and two different sections, Bethel Valley and K-25 (which includes several formations), from the Chickamauga Group. The ORR is represented by samples from all six formations, but both Roane and Anderson are represented only by samples from the Dismal Gap Formation of the Conasauga Group and the Copper Ridge Formation of the Knox Group. Twelve sites in each sampling area were sampled from each formation. Several samples were collected from all A horizons for different analytical procedures, but only B and $\mathrm{C}$ horizons were sampled for the analysis of inorganics and radionuclides. The following is a summary of the designations used for soil samples from sampling areas, groups, and formations.

\begin{tabular}{lccc} 
Sample Origin Designations & & $\begin{array}{c}\text { Numbers } \\
\text { on-site }\end{array}$ & $\begin{array}{c}\text { Numbers } \\
\text { off-site }\end{array}$ \\
\cline { 1 - 1 } Sampling area & & 1 & 2 \\
Geologic rock groups & 3 & 2 \\
Geologic formations & 72 & 2 \\
Individual sites & & 68 \\
Soil horizons & & & 144
\end{tabular}

\subsubsection{Organic Compounds}

Screening analysis for VOCs was negative except for the following sites. Site ROA-8 in Roane County contained 1,1,1-trichloroethane. Site ORR-31 on the Reservation had trichlorofluoromethane, but the field duplicate for this site did not contain any contaminants. Both of these may be due to instrument contamination in the laboratory. The presence of detectable VOCs' for any potentially contaminated ORR site can be taken as a sign of probable contamination. Some VOCs, in very small amounts, may be due to microbial respiration.

The analyses of pesticides, herbicides, and PAHs were performed only on surface A horizon soil samples. There were a very limited number of estimated detects for pesticides. Two sites had alpha-chlordane (ORR-121 and AND-41), one site had aldrin (AND-33), and one site had Aroclor 1260 (ROA-43). However, the primary sample did not contain this compound, but the field duplicate did. One site had Aroclor 1242 (ROA-14), two sites had Endosulfan I (AND-41 and ORR-83), and two sites had 4,4'-DDT (ROA-8 and ROA-33). 
One site (ORR-66) had an estimated detect for 2,4-D. However, this is a remote site. The estimated result is highly suspect. The culprit is most likely instrument contamination.

In the early part of the project (Dismal Gap and Nolichucky sites), PAHs were nearly all below detection limits, with only a few that were slightly above detection limits with a "J" qualifier. Later, a change in laboratory procedure or analytical instrument resulted in many detects as well as many "J" estimates for the Copper Ridge, Chepultepec, and Chickamauga sites. This later analysis indicated that PAHs were ubiquitous at all sites. Phenanthrene, pyrene, benzo[ $a]$ anthracene, fluoranthene, and benzo $[k]$ anthracene were detected at all of the Copper Ridge, Chepultepec, and Chickamauga sites and can be presumed to be at all Dismal Gap and Nolichucky sites as well. Some PAHs were more common in the A horizons of some soils than in others, and some soils had lower amounts. The ORR Chepultepec sites had significantly lower amounts of fluorine, benzo[a]anthrene, and phenanthrene than all other sites. In contrast, the Chickamauga sites at the K-25 Site had significantly higher amounts of phenanthrene, pyrene, and benzo[a]pyrene than all other sites. The Roane Copper Ridge sites had significantly lower amounts of benzo[ghi]perylene, benzo[k]fluoranthene, and benzo[b]fluoranthene than all other sites.

The presence of organic compounds can be taken as a sign of probable contamination on the ORR. However, some organic compounds were detected more often off-site than on-site, suggesting that the presence of the organic compounds on the ORR is not related to Department of Energy (DOE) activity. Because of the widespread occurrence of PAHs both on the ORR and in Anderson and Roane counties, the values given in Appendix C should be considered as background. On the ORR the distribution of acenapthene, acenapthylene, benzo[ $a]$ anthracene, benzo[ $a]$ pyrene, benzo[b]fluoranthene, benzo $[k]$ fluoranthene, fluorene, indeno[1,2,3-cd]pyrene, phenanthrene, and pyrene is significantly related to individual geologic groups. Individual background values from tables in Sect. 5 for each geologic formation should be used in any comparison. The presence of the Rockwood coking ovens plus two TVA coal-fired steam generating power plants would most likely represent major local sources of PAHs near the ORR.

For certain users of this data, grand median values by horizon across all Geologic Groups have been computed. These are in Table G.8. However, the data must be used with great caution. Following is a list of organics where there are no significant differences among groups: anthracene, chrysene, dibenzo[ah]anthracene, and indeno[1,2,3-cd]pyrene. The following list of organics is significantly different between the $1 \%$ to $10 \%$ level: acenaphthene, benzo $[a]$ pyrene, benzo $[b]$ fluoranthene, benzo[ghi]perylene, fluoranthene, and naphthalene. All the other organics are significantly different and the data for these in Table G.8 should not be used, but the data in Sect. 5 should be used instead.

\subsubsection{Inorganic Compounds and Metals}

Inorganics and metals were analyzed using five analytical techniques. The acid extraction method, however, causes considerable laboratory variability; and some elements discussed here are more susceptible to extraction by acid than others, depending on the natural soil $\mathrm{pH}$ and the nature of the compound. Acid extraction data will not be comparable to NAA data, to total analysis data, or to cation-anion exchangeable data. Some of the data distribution by soil horizon reflects the translocation of certain constituents, while other data indicate the surface addition of contaminants (e.g., lead and mercury), and still other data indicate a geologic 
origin. Several metals were usually below detection limits, including $\mathrm{Cd}$, Os, and Ag. The following discussion uses median values determined from statistical analysis.

inot $\quad \because \cdots, \quad$ :

The primary sources of the following information are Rankama and Sahama (1950); Page, Miller, and Keeney (1982); and Kabata-Pendias and Pendias (1984).

Aluminum. Aluminum is a natural constituent of all inorganic soils. During the weathering of parent material, aluminum hydroxides of variable charge and composition are formed; and they become part of the clay's structure. The total aluminum content of soil is inherited from the parent material, and only a fraction of the aluminum will be easily mobile and exchangeable. Acid extraction removes large quantities of aluminum from soils.

Aluminum levels from on- and off-site sampling areas were significantly different in all horizons of the Dismal Gap and only for the A horizon of Copper Ridge soils. The aluminum levels between geological groups were significantly different, but they were not significantly different within groups. Aluminum levels of ORR formations were significantly lower in the A horizon because the clay content is lower than in the higher clay-enriched subsoil $B$ horizons and in $\mathrm{C}$ horizons. The aluminum content was not significantly different between $\mathrm{B}$ and $\mathrm{C}$ horizons with the exception of the ORR Dismal Gap Formation.

Antimony. The abundance of antimony is very low in rocks. Antimony may be highly mobile in the environment and is associated with iron hydroxides. The total antimony concentration in U.S. surface soils ranges between 0.25 and $0.6 \mathrm{mg} / \mathrm{kg}$ (Kabata-Pendias and Pendias 1984). Antimony is likely to be a pollutant in an industrial environment.

Antimony was detected in less than $15 \%$ of the collected samples. Antimony was detected (A horizon) in one sample of the Anderson County (AND) Dismal Gap Formation and ORR Nolichucky Formation. Antimony concentration was higher in AND than ORR locations. Not enough data were collected to do a statistical analysis for comparisons between sampling areas and geological groups.

Arsenic. Arsenic is distributed uniformly in major types of rocks. Some arsenic minerals and compounds are very soluble in certain weathering environments. Arsenic can occur in the soil in the following valance states: $-3,0,+3$, and +5 , and in compounds that have varying solubility and dissociation constants. These compounds can be translocated within the soil on fine clay particles. Biologic processes can transform inorganic forms to volatile organic forms that are readily taken up by plants. Arsenic mobility is often reduced because it has a very high affinity for clays, hydroxides, and organic matter. The range in U.S. surface soils of total arsenic is between $<0.1$ to $69 \mathrm{mg} / \mathrm{kg}$, with a grand mean of 6.7 . Anthropogenic sources of arsenic are related to industrial activities, such as metal processing or coal-fired power plants, and as fungicides in agriculture (fruit trees).

Arsenic levels between on- and off-site sampling areas were significantly different only for the Dismal Gap C horizons and Copper Ridge A and B horizons. Arsenic levels in ORR soils were significantly different between geological groups but not within groups (except A and $B$ horizons from the Knox Group). Arsenic levels were not significantly different between $A$ and $B$ horizons with the exception of ORR Chepultepec and Copper Ridge. The arsenic content was not significantly different between $B$ and $C$ horizons with the exception of the ORR Chepultepec Formation. 
Arsenic levels on the ORR are not considered to be a contaminant because no difference was found between $A$ and $B$ horizons nor were levels different between on- and off-site sampling areas.

Barium. Barium commonly occurs in igneous rock. In geochemical processes, barium is associated with alkali feldspars and biotite. During weathering, barium is easily precipitated with sulfates and carbonates. It is strongly sorbed by clays, and in a soil environment is concentrated in manganese and phosphate concretions and minerals. The mean total barium concentration in U.S. surface soils ranges from 265 to $835 \mathrm{mg} / \mathrm{kg}$. The source of most barium in soils is from geologic origin.

Barium levels between on- and off-site sampling areas were not significantly different. Barium levels for the ORR were significantly different between geological groups but not within groups. Barium levels within ORR formations were not significantly different between $A$ and $B$ horizons with the exception of ORR Chickamauga (Bethel Valley). The barium content of ORR formations was not significantly different between $B$ and $C$ horizons with the exception of ORR Chickamauga-Bethel Valley and Copper Ridge.

Beryllium. Beryllium is widely distributed and is likely to be concentrated in acid igneous rock, argillaceous sediments, and shales. Beryllium is present in soils primarily in oxide-bonded forms. Beryllium is closely associated with aluminum, where it can be substituted for aluminum in the lattice structures of clay minerals. Beryllium is easily bound to organic matter and accumulates in organic soil horizons and coals. The total beryllium concentration in U.S. topsoil ranges from $<1$ to $15 \mathrm{mg} / \mathrm{kg}$. Anthropogenic sources of beryllium are related to rocket fuels and coal combustion.

Beryllium levels between on- and off-site sampling areas were not significantly different. Beryllium levels for the ORR were significantly different between geological groups but not within groups. Beryllium levels in ORR formations were significantly lower in the A horizon of soils than in the B horizon with the exception of ORR Dismal Gap, Chepultepec, and Copper Ridge formations. Beryllium content was not significantly different between B and $\mathrm{C}$ horizons, with the exception of the ORR Dismal Gap and Chickamauga-Bethel Valley formations.

Beryllium levels on the ORR are not considered to be a contaminant because no difference was found between on- and off-site sampling areas and because the levels were lower in the A than B horizon.

Boron. Boron is not uniformly distributed, and it is concentrated in acidic igneous rocks and in the clay fraction of some sedimentary rocks. Its geochemistry is characterized by an abnormally large variation in the boron content of rocks. Boron is likely to be retained by illitic clays, sesquioxides, and organic matter. Some boron, from volcanic eruptions, is deposited on the soil surface and then subjected to biologic uptake or to downward translocation. Boron is very mobile in soil. The mean total boron level in U.S. surface soils ranges from 20 to $55 \mathrm{mg} / \mathrm{kg}$.

Boron was detected in only $32 \%$ of the collected soil samples. Boron was only detected in some Dismal Gap and Chepultepec soils. Boron was detected in three sites (A horizon only) in ROA Dismal Gap Formation and one site in ORR Dismal Gap Formation. The boron concentrations were higher at Roane County sites compared with ORR locations. Not 
enough data were collected to do a statistical analysis for comparisons between sampling areas and geologic groups.

n.........

Cadmium. There was no detectable cadmium at any BSCP site.

Calcium. One must keep in mind that an acid extraction for determination of calcium is of questionable validity. Calcium levels between the on- and off-site sampling areas were not significantly different in the Dismal Gap and Copper Ridge soils. Calcium levels from the ORR were significantly different between geological groups but not within groups (except in the $\mathrm{C}$ horizon of both Chickamauga). The calcium levels in ORR formations were not significantly different between $A$ and $B$ horizons. Calcium levels were not significantly different between $B$ and $C$ horizons with exception of the ORR Chickamauga-Bethel Valley.

Chromium. Chromium is associated with ultramafic and mafic rocks, and upon oxidation and weathering forms complexes with anions and cations. Chromium $(3+)$ resembles iron and aluminum in ionic size and geochemical properties. After weathering, most of the chromium is associated with mineral lattice structures or else is sorbed by clays and hydrous oxides. The grand mean for total chromium content is $54 \mathrm{mg} / \mathrm{kg}$ for U.S. topsoils. Anthropogenic sources of chromium are industrial waste and municipal sewage sludge. Another source of chromium in soils is a flyash contaminant from coal-powered electric generating plants.

Chromium levels between on- and off-site sampling areas were not significantly different. Chromium levels on the ORR were significantly different between groups but not within groups. Chromium levels were significantly lower in A horizons than B horizons for ORR formations, except for the ORR Chickamauga (Bethel Valley and K-25). Chromium content was not significantly different between $B$ and $C$ horizons, with the exception of the ORR Nolichucky Formation.

Chromium levels on the ORR are not considered to be a contaminant because no difference was found between on- and off-site sampling areas and because the levels were lower in the A than B horizon. Chickamauga may be an exception.

Cobalt. A high concentration of cobalt occurs in ultramafic rocks. The concentration in sedimentary rocks is lower and is associated with clay minerals and organic matter. Cobalt geochemical behavior is similar to that of iron and manganese. During weathering, cobalt is immobilized by iron and manganese oxides and by clay minerals. The cobalt concentration in soils depends on the parent material. The grand mean for total cobalt is $8.2 \mathrm{mg} / \mathrm{kg}$ in U.S. topsoil. Cobalt occurs as a contaminant from the flyash of coal-powered electric generating plants. Roadside soils are often contaminated by cobalt.

Cobalt levels between on- and off-site sampling areas in the Dismal Gap Formation were not significantly different but were significantly different for the Copper Ridge Formation. Cobalt levels on the ORR were significantly different between geological groups but not within groups (except between formations of the Knox Group). Cobalt levels were not significantly different between $A$ and $B$ horizons for ORR soils. Cobalt content was not significantly different between $B$ and $C$ horizons, with the exception of the ORR Chepultepec Formation.

Copper. Copper is abundant in mafic and intermediate igneous rocks and deficient in carbonate rocks. During weathering, copper reacts with clay minerals and organic matter; and 
it may also be precipitated as a sulfide, carbonate, or hydroxide. Copper occurs in soils in $\mathrm{Cu}^{+2}$ and $\mathrm{Cu}^{+3}$ compounds with varying solubilities and dissociation constants. Copper can be biologically translocated in the soil as well as being translocated downward attached to clay minerals. Copper is rather immobile in soil, and it is not accumulated in the soil profile. The mean levels in the U.S. topsoils for total copper ranged from 6 to $60 \mathrm{mg} / \mathrm{kg}$, depending on the parent material. Anthropogenic sources of copper in soils are from fertilizers, pesticides, municipal waste, and industrial emissions.

Copper levels between on- and off-site sampling areas were not significantly different for the Dismal Gap Formation but were significantly different ( $B$ and $C$ horizons) in the Copper Ridge Formation. Cobalt levels on the ORR were significantly different between groups but not different within groups (except between formations of the Knox Group). Copper levels were significantly lower in A than B horizons for ORR formations with the exception of the ORR Dismal Gap Formation. Copper content was not significantly different between B and $C$ horizons of ORR formations, with the exception of the ORR Copper Ridge Formation.

Some of the copper reported in this study may have come from the stainless steel sampling equipment, as it became abraded and worn during sampling of the Copper Ridge and Chepultepec $C$ horizons. A comparison of the ORR rinse water with the source water indicated that rinsate copper levels were higher than in the source water.

Cyanide. Cyanide was detected in less than $11 \%$ of the sites. Cyanide was detected in a few A horizons in the Dismal Gap Formation. Cyanide concentration (close to analytical detection limits) was higher at ROA than at AND or ORR locations. Not enough data were collected to performed a statistical analysis for comparisons between sampling areas and geological groups. The presence of higher cyanide levels in any soil would be a sign of potential contamination.

Iron. Iron is an important component of most well-drained upland soils, and large amounts are readily extracted by an acid extraction procedure. Extractable iron levels are usually associated with the clay content. Reduced iron $\left(\mathrm{Fe}^{+2}\right)$ is quite soluble, moving both laterally and downward with soil water, while $\mathrm{Fe}^{+3}$ is immobile.

Iron levels between on- and off-site sampling areas were not significantly different for the Dismal Gap Formation, but iron levels in B horizons were significantly different for the Copper Ridge Formation. Iron levels on the ORR were significantly different between geological groups but not within groups. Iron levels were significantly lower in A than B horizons for ORR formations. Iron content was not significantly different between $B$ and $C$ horizons of all ORR formations with the exception of the ORR Copper Ridge Formation.

Iron levels are always lower in the A horizons of soils because of various soil processes that result in the translocation of iron compounds from $A$ and $E$ soil horizons to subsoil $B$ horizons. Acid-extractable iron cannot be considered diagnostic of any soil contamination.

Lead. Lead is concentrated in the igneous rocks and in argillaceous sediments. During weathering, lead forms carbonates and is sorbed by clay minerals, iron oxides, manganese oxides, and organic matter. Lead replaces $\mathrm{K}, \mathrm{Ba}, \mathrm{Sr}$, and $\mathrm{Ca}$ from sorption sites. The total mean lead content in the surface of U.S. soils is $20 \mathrm{mg} / \mathrm{kg}$. Anthropogenic sources of lead in soils are mining, metal processing industry, sludges, and automobile exhaust. 
Lead levels between on- and off-site sampling areas were not significantly different. Lead levels between and within groups on the ORR were not significantly different. Lead levels were not significantly different between $A$ and $B$ horizons with the exception of the ORR Copper Ridge Formation. Lead content were significantly lower in $\mathrm{B}$ than in $\mathrm{C}$ horizons with the exception of ORR Dismal Gap and Chickamauga K-25.

Some of the lead data from the ORR Nolichucky Formation appears to have a laboratory problem. Samples 5064 and 5067 (A and B horizons) have nondetected lead levels, while sample 5070 from the $C$ horizon has a value above detection and is not estimated. In contrast, all other ORR Nolichucky A and B horizons have detectable levels of lead. The lack of data for the $A$ and $B$ horizon results in median values being much lower.

Lithium. Lithium is widely distributed, but it is concentrated in acidic igneous rocks and sedimentary aluminosilicates. Lithium distribution in soils is controlled more by soil formation factors than by parent materials. Lithium competes for clay mineral sorption sites with calcium and magnesium. The grand mean for total lithium concentration is $23 \mathrm{mg} / \mathrm{kg}$ for U.S. topsoils.

Lithium levels between on- and off-site sampling areas were not significantly different for the Dismal Gap Formation but were significantly different in only the A and $C$ horizons of the Copper Ridge Formation. Lithium levels on the ORR were not significantly different between geological groups or within groups (except with formations of the Knox Group). Lithium levels were significantly lower in A than in B horizons for ORR formations with the exception of ORR Dismal Gap and Copper Ridge. Lithium content was not significantly different between $\mathrm{B}$ and $\mathrm{C}$ horizons with the exception of the ORR Chickamauga Bethel Valley.

High levels of lithium in the soil surface over levels found in lower B and C horizons would indicate a possibility of surface contamination.

Magnesium. Sources of magnesium include agricultural lime plus that inherited from underlying rock. Very high concentrations in A horizons would indicate that a site had been limed in the past.

Magnesium levels between on- and off-site sampling areas were significantly different for A and B horizons of the Dismal Gap Formation and for all horizons of the Copper Ridge Formation. Magnesium levels on the ORR were significantly different between and within geological groups. Magnesium levels were significantly lower in A than in B horizons for ORR formations with the exception of the ORR Dismal Gap, Chepultepec, and Copper Ridge formations. Magnesium content was significantly lower in $\mathrm{B}$ than in $\mathrm{C}$ horizons with the exception of the ORR Chickamauga $\mathrm{K}-25$, Chepultepec, and Copper Ridge formations.

Magnesium levels are higher in $\mathrm{C}$ horizons than in $\mathrm{A}$ and $\mathrm{B}$ horizons. This distribution results from the usually net downward movement of this element. Some surface A horizons can have slightly higher levels of both magnesium and calcium, a result of biologic uptake. Past additions of agricultural lime can also result in higher levels of surface magnesium. The ORR Nolichucky soils have less magnesium than the ORR Dismal Gap soils, a reflection of the lower carbonate content of the Nolichucky Formation.

Manganese. Manganese in soils has several valance states, with some compounds having quite high solubility and others being quite insoluble. Most soil manganese compounds have 
a valance of $+2,+3$, and +4 . Most soil manganese occurs in the oxide form $(+4)$, which has a very low solubility. Manganese along with iron compounds in the soil is involved with oxidation-reduction processes as either an electron donor or acceptor. Many soils are deficient in plant usable manganese. Manganese is of interest in soils because of its association with other trace and potentially toxic metals.

Manganese levels between on- and off-site sampling areas were significantly different for the A horizons of the Dismal Gap Formation and the B horizon of the Copper Ridge Formation. Manganese levels on the ORR were not significantly different between and within geological groups. Manganese content was significantly lower in B than in A horizons with the exception of the ORR Nolichucky Formation.

Manganese levels on the ORR are not considered to be a contaminant because no difference was found between on- and off-site sampling areas.

Mercury. Mercury was detected at some BSCP sites. Mercury was detected in on- and off-site sampling areas in the A horizon of the Dismal Gap and Copper Ridge formations. Significantly higher mercury concentrations in the $\mathrm{A}$ horizon than in the $\mathrm{B}$ and $\mathrm{C}$ horizons were observed for the ORR Dismal Gap Formation and the ORR Chickamauga K-25 sites. Some of these sites may have been contaminated with mercury.

The presence of mercury in the A horizon of soils can be taken as an indicator of airborne deposition, especially if none is detected in the B and C horizons. Some mercury, however, may be inherited from the underlying rock.

Molybdenum. Molybdenum was detected at only 3\% of the sites and only in the A horizon. Molybdenum was detected (A horizon) in one site at the ORR Copper Ridge Formation, but the concentration was at the analytical detection limit, which makes the data questionable. Not enough data were collected to perform a statistical analysis for comparisons between locations and geological groups.

The presence of molybdenum in A horizon samples in greater amounts than in B and $\mathrm{C}$ horizons above detection can probably be taken as a sign that there is probably surface contamination.

Nickel. Nickel contents are highest in ultramafic rocks..Sedimentary rocks contain nickel, with the highest range being for argillaceous rocks and the lowest for sandstone. Nickel occurs primarily in sulfides and arsenides, and most of it is in ferromagnesian minerals, replacing iron. Nickel is also associated with carbonates, phosphates, and silicates. Nickel is easily mobilized during weathering and then is coprecipitated mainly with iron and manganese oxides. In surface soil horizons, nickel appears to occur mainly in organically bound forms. Nickel distribution in soil profiles is related either to organic matter or to amorphous oxides and clay fractions, depending on soil conditions. Nickel status in soils is highly dependent on the nickel content of the parent material and on soil-forming processes. Total nickel content in U.S. topsoils ranges from $<5$ to $200 \mathrm{mg} / \mathrm{kg}$. The highest nickel contents are always in clayey and loamy soils, in soils over basic and volcanic rocks, and in organic-rich soils. Nickel is released into the environment from metal processing operations and from the increasing combustion of coal and oil (automobile exhaust or from oil-burning power plants). The application of sludges and certain phosphate fertilizers may be an important source of nickel. 
Nickel levels between on- and off-site sampling areas were not significantly different. Nickel levels on the ORR were significantly different between groups (except $C$ horizons) but not within groups. Nickel levels were significantly lower in A than in B horizons only for the ORR Chickamauga Bethel Valley. Nickel content was significantly lower in B than in C horizons with the exception of the ORR Nolichucky, Chickamauga K-25, and Copper Ridge formations.

The level of nickel is the lowest in the soil surface and highest in the $\mathrm{C}$ horizon, indicating a dominant geologic source. If nickel is highest in the surface horizon, it would be considered to be associated with contamination.

Osmium. Osmium was not detected at any site. Its presence, in greater amounts in A than in $\mathrm{B}$ or $\mathrm{C}$ horizons, could be taken as a sign of contamination.

Potassium. Potassium is an important element in all soils. Its natural occurrence in soils is of geologic origin. Potassium, being an important plant nutrient that is nearly always limiting, is added to soils in fertilizer.

Potassium levels between on- and off-site sampling areas were significantly different for the Dismal Gap Formation, but only the B and C horizons were significantly different in the Copper Ridge. Potassium levels were significantly different both between and within groups on the ORR. Potassium levels were significantly lower in A than in B horizons for ORR formations with the exception of the Dismal Gap and Copper Ridge formations. Potassium content was not significantly different between $B$ and $C$ horizons with the exception of the ORR Dismal Gap and Nolichucky formations.

The use of potassium fertilizer in this study cannot be ruled out, but potassium distributions by soil horizon and by location indicate that very little potassium fertilizer was ever applied to the sampled sites. ORR Nolichucky soils, having a higher clay mineral content and also a higher mica content, have quite high potassium levels, especially in the $\mathrm{C}$ horizon. Potassium levels in soils cannot be taken as an indicator of any contamination.

Selenium. Selenium occurs in nearly all materials of the earth's crust. In sedimentary rocks, selenium is associated with the clay fraction, and thus the smallest quantities of selenium are in sandstone and limestone. Selenite ions $\left(\mathrm{SeO}_{3}{ }^{2-}\right)$ resulting from oxidation processes are stable and able to migrate until they are adsorbed on mineral or organic particles. The solubility of selenium in most soils is rather low. Soils heavily amended with sewage sludge or flyash will have a higher selenium content. The grand mean of total selenium in topsoils is $0.4 \mathrm{mg} / \mathrm{kg}$. A considerable input of selenium to the soil surface takes place through precipitation from volcanic exhalation and industrial emissions, in particular, the combustion of coals.

Selenium levels between on- and off-site sampling areas were significantly different only for the A horizon of the Copper Ridge Formation and were not detected in the ORR Dismal Gap Formation. Selenium levels of ORR A and B horizons were significantly different between groups but were not significantly different within groups. Selenium data are doubtful, based on the low number of detects.

The presence of selenium in greater amounts in $A$ than in $B$ or $C$ horizons above detection can probably be taken as an indication of probable surface contamination. 
Silicon. Silica is a dominant component of all inorganic soils. However, since the acid-extractable silica does not represent total silica content, it does not reflect the actual amount of silica in the soil.

Silicon levels between on- and off-site sampling areas were significantly different for the Dismal Gap Formation but not for the Copper Ridge Formation. Silicon levels on the ORR were significantly different between geological groups. Silicon levels were significantly different for formations within the Chickamauga and the Conasauga Group. Silicon levels within the Knox Group were not significantly different. Silicon levels were not significantly different between $A$ and $B$ horizons of ORR formations with the exception of the ORR Chickamauga K-25. Silicon levels were not significantly different between B and C horizons.

Silver. Silver was not detected at any site. Its presence in greater amounts in A horizon than in $\mathrm{B}$ or $\mathrm{C}$ horizons above detection can be considered a probable sign of potential surface contamination.

Sodium. Sodium was not analyzed in the Dismal Gap and Nolichucky formations. Sodium levels between the on- and off-site sampling areas for the Copper Ridge Formation were not significantly different. Sodium levels for the ORR were significantly different between geological groups but not within the groups. Sodium levels were not. significantly different between $\mathrm{A}$ and $\mathrm{B}$ horizons or between $\mathrm{B}$ and $\mathrm{C}$ horizons for ORR formations.

Because sodium ions are so mobile, the presence of sodium, unless in very high amounts from road salt contamination, cannot be used as a sign of probable contamination.

Strontium. Strontium is likely to be concentrated in intermediate igneous rocks and in carbonate sediments. Strontium is very often associated with calcium because of its similar geochemical and biochemical characteristics. Strontium is easily mobilized during weathering, and it is incorporated in clay minerals and strongly fixed by organic matter. Strontium content in soil is highly controlled by parent material and climate. Mean contents of strontium for U.S. topsoils range from 110 to $445 \mathrm{mg} / \mathrm{kg}$. Strontium distribution in soils follows the general trends of soil biocycling. Anthropogenic sources of strontium are most likely from coal flyash deposition.

Strontium levels between on- and off-site sampling areas were not significantly different for $\mathrm{A}$ and $\mathrm{B}$ horizons of the Dismal Gap and Copper Ridge formations. Strontium was not detected in the $\mathrm{C}$ horizon of the ORR Copper Ridge Formation. Strontium levels on the ORR were significantly different between and within groups. Strontium levels were not significantly different between $A$ and $B$ horizons of ORR formations with the exception of the ORR Chickamauga K-25. Strontium levels were not significantly different between $B$ and C horizons with the exception of the ORR Chickamauga K-25 and Bethel Valley formations.

Sulfate. Sulfate levels between on- and off-site sampling areas were significantly different for the Dismal Gap Formation, but sulfate levels for A and B horizons were not significantly different for the Copper Ridge Formation. Sulfate levels on the ORR were significantly different between groups but not within groups with the exception of the Conasauga Group.

Sulfate levels were not significantly different between A and B horizons for ORR formations with the exception of the ORR Nolichucky Formation. Sulfate levels were not significantly different between $B$ and $C$ horizons with the exception of the ORR Chickamauga K-25 sites. 
The most likely source of sulfate anions found in the surface horizons of soils is deposition from coal- and oil-fired electric power plants. Some sulfate can be inherited from the underlying geology where pyritic compounds weather. The Dismal Gap Formation, at least on the ORR, is known to contain pyritic materials.

Thallium. Thallium concentration seems to increase with the increasing acidity of igneous rocks and with the increasing clay content of sedimentary rocks. The cation Th + is highly associated with potassium and boron and also with several other cations and is incorporated into various minerals, mainly sulfides. During weathering, thallium is readily mobilized and transported together with alkaline metals. Thallium is most often fixed in situ by clays and by manganese and iron oxides. Thallium concentration in U.S. surface soils ranges from 0.02 to $2.9 \mathrm{mg} / \mathrm{kg}$. The largest anthropogenic sources of thallium are related to coal combustion, but also heavy metal smelting and refining processes may release some amounts of thallium into the environment.

Thallium was detected in only $13 \%$ of the collected samples. Thallium was detected (A horizon) at one site of the ROA Dismal Gap Formation and ORR Dismal Gap Formation, both with similar concentrations and below the analytical detection limit. No significant differences were observed between on- and off-site sampling areas, groups, and formations.

Vanadium. This metal is concentrated mainly in mafic rocks and in shales within the common range of 100 to $250 \mathrm{mg} / \mathrm{kg}$. It usually does not form its own mineral but rather replaces other metals $(\mathrm{Fe}, \mathrm{Pt}, \mathrm{Al})$ in crystal structures. Vanadium tends to be associated with organic matter. Much of the soil vanadium, mainly the vanadyl cation, is mobilized as complexes with humic acids. In general, vanadium is distributed in soil profiles rather uniformly, and the variation in vanadium content of the soil is inherited from parent materials. The average vanadium content of soils is $84 \mathrm{mg} / \mathrm{kg}$ for U.S. soils. The industrial processing of certain mineral ores and burning of coals and oils will increase the deposition of vanadium in soils. Combustion of fuel oil is an especially serious source of vanadium in soils.

Overall, vanadium levels in A horizons were not significantly different between on- and off-site sampling areas. Vanadium levels for $\mathrm{A}, \mathrm{B}$, and $\mathrm{C}$ horizons from on- and off-site Dismal Gap soils were not significantly different. Vanadium levels for the A horizon of the Copper Ridge Formation were significantly different in on- versus off-site areas. Vanadium levels on the ORR were significantly different between groups but not within groups with the exception of the Knox Group. Vanadium levels were significantly lower in A than in B horizons for ORR formations with the exception of the ORR Dismal Gap and Chickamauga Bethel Valley. Vanadium levels were not significantly different between B and C horizons with the exception of the ORR Copper Ridge Formation.

Vanadium levels on the ORR are not considered to be a contaminant because no difference was found between on- and off-site sampling areas and because vanadium levels were lower in the $A$ than in the $B$ horizon.

Zinc. Zinc occurs chiefly as a sulfide ( $\mathrm{ZnS})$ but is also known to substitute for magnesium in silicates. The solubility of zinc minerals during weathering produces $\mathrm{Zn}+2$, especially in acidic, oxidizing environments. Also, zinc is easily adsorbed by minerals and organic components, and thus, in most soil types, its accumulation in the surface horizon is observed. Mean total zinc content in surface soils of different countries and the U.S. ranges from 17 to $125 \mathrm{mg} / \mathrm{kg}$. The atmospheric input of this metal exceeds its output because of both leaching 
and the production of biomass. The anthropogenic sources of zinc are related, first of all, to the nonferric metal industry and then to agriculture practices.

Overall, zinc levels in the A horizon were significantly different between on- and off-site sampling areas. Zinc levels in A, B, and C horizons of on- and off-site Dismal Gap formations were not significantly different. Zinc levels between on- and off-site sampling areas were significantly different only in the $\mathrm{C}$ horizon of Copper Ridge Formation soils. Zinc levels in $B$ and $C$ horizons on the ORR were significantly different between groups. Zinc levels were not significantly different between $A$ and $B$ horizons for ORR formations with the exception of ORR Chepultepec and Copper Ridge. Zinc levels were not significantly different between $B$ and $C$ horizons with the exception of the ORR Chickamauga Bethel Valley, Chepultepec, and Copper Ridge formations.

\subsubsection{Summary of Inorganics}

For certain users of this data, grand median values by horizon across all geologic groups have been computed. These are in Table G.8. However, the data must be used with great caution. Following is a list of inorganics where there are no significant differences among groups: barium, A horizon; chromium, B horizon; copper, B horizon; molybdenum, A and B horizon; thallium, A and B horizon; and zinc, A horizon. The following list of inorganics is significantly different between the $1 \%$ to $10 \%$ level: cobalt, $A$ horizon; copper, $C$ horizon; lead, $\mathrm{A}, \mathrm{B}$, and $\mathrm{C}$ horizon; manganese, $\mathrm{A}, \mathrm{B}$, and $\mathrm{C}$ horizon; nickel, $\mathrm{C}$ horizon; selenium, $\mathrm{A}$ horizon; sodium, $\mathrm{C}$ horizon; thallium, $\mathrm{C}$ horizon; vanadium, $\mathrm{A}$ horizon. All the other inorganics are significantly different and the data for these in Table G.8 should not be used.

\subsubsection{Comparisons by horizons}

Atmospheric deposition of contaminants will be detected by a significantly higher concentration in the A horizon compared with the underlying $\mathrm{B}$ and $\mathrm{C}$ horizons. Another reason for the accumulation of metals in the A horizon is biocycling (e.g., nutrients deposited by plants).

The concentration of the following inorganic compounds or metals were significantly higher in the $\mathrm{A}$ than in $\mathrm{B}$ horizons: mercury and manganese. Manganese is a plant nutrient that accumulates in the A horizon. Mercury may be a contaminant in this area. The $A$ horizon concentration of all other elements was lower than or similar to the B horizon.

\subsubsection{Comparisons by geologic groups}

In general, significant differences in metal concentrations were observed among geologic groups and not within the groups. The data for those elements can be obtained from Table 6.1a.

The median concentration of most of the inorganic compounds and metals were not significantly different between Chickamauga Bethel Valley and K-25 with the exception of: calcium in the $\mathrm{C}$ horizon, mercury in the $\mathrm{A}$ horizon, potassium in both $\mathrm{B}$ and $\mathrm{C}$ horizons, and silicon in both $\mathrm{B}$ and $\mathrm{C}$ horizons. The data for these elements can be obtained from Sect. 5 .

The median concentrations of most of the inorganic compounds and metals in the Dismal Gap and Nolichucky formations can be used as background data for other Conasauga Group 
soils with the exception of mercury in the $\mathrm{A}$ horizon; potassium in the $\mathrm{C}$ horizon; selenium in both $B$ and $C$ horizons; silicon in the $A, B$, and $C$ horizons; and sulfate in both the $A$ and $\mathrm{C}$ horizons. The data for these elements can be obtained from Sect. 5.

The median concentrations of most of the inorganic compounds and metals in the Copper Ridge and Chepultepec formations can be used as background data for other soils in the Knox Group, with the exception of arsenic in the A horizon, barium in the $\mathrm{C}$ horizon, lead in the $A$ horizon, lithium in the $C$ horizon, magnesium in the $C$ horizon, potassium in both the $A$ and $B$ horizons, selenium in the $A$ horizon, strontium in the $C$ horizon, and vanadium in the $C$ horizon. The data for these elements can be obtained from Sect. 5 .

\subsubsection{Interpretation by sampling areas}

Two formations were used to compare the background levels on the ORR against surrounding counties. Anderson and Roane counties were sampled following the same procedures as at the ORR. The Dismal Gap (Conasauga Group) and Copper Ridge (Knox Group) formations were sampled.

Inorganic compounds and metals that had concentrations very close to the AA/ICP detection limits were not compared statistically ( $\mathrm{Sb}, \mathrm{Cd}, \mathrm{Os}, \mathrm{Ag}$, and cyanide). Other extraction methods will be needed to compare those elements. Twenty-four inorganic compounds and metals were used to compare between on- and off-site sampling areas.

The following metal concentrations were significantly higher in the ORR Dismal Gap Formation than the off-site sampling areas: arsenic in the $\mathrm{C}$ horizon, mercury in the $\mathrm{A}$ horizon, silicon in the $\mathrm{C}$ horizon, and sulfate in the $\mathrm{C}$ horizon. The following metal concentrations were significantly higher in the ORR Copper Ridge than the off-site sampling areas: arsenic in both $\mathrm{A}$ and $\mathrm{B}$ horizons and zinc in the $\mathrm{C}$ horizon.

\subsubsection{Radionuclides}

Radionuclides in soils originate from three major sources: (1) those naturally occurring in soils and bedrock; (2) those resulting from global fallout after atmospheric bomb tests and nuclear reactor accidents in the former Soviet Union; and (3) those originating from uranium enrichment, isotope production, reactor operation, and reprocessing activities. This project tried to include all radionuclides that have been or could be detected on any known contaminated areas of the ORR.

Radionuclides from global fallout and local sources are expected to be associated mainly with surface soils (A horizon), and radionuclides from natural sources are expected to be present in both surface and subsurface soils ( $\mathrm{B}$ and $\mathrm{C}$ horizons). The following radionuclides, including ${ }^{238} \mathrm{Pu},{ }^{239240} \mathrm{Pu},{ }^{237} \mathrm{~Np},{ }^{90} \mathrm{Sr},{ }^{99} \mathrm{Tc},{ }^{243,}{ }^{244,}{ }^{247} \mathrm{Cm}$, and tritium, were analyzed in all A horizon soil samples but were not analyzed in all $\mathrm{B}$ and $\mathrm{C}$ horizon soils. This decision was made based on the observed absence of gamma-producing radionuclides, such as ${ }^{137} \mathrm{Cs}$ and ${ }^{241} \mathrm{Am}$ from nonnatural sources in $\mathrm{B}$ and $\mathrm{C}$ horizons.

A total of 34 isotopes was analyzed. In most cases, the majority of radionuclides was not detected above the reported detection limit (qualifier UJ), or the analytical results were rejected because of serious deficiencies in the ability to analyze the sample and meet quality control criteria (qualifier R). The detection limit is approximate and may or may not 
represent the actual limit of quantification necessary to accurately and precisely measure the analyte in the samples, but it could be used as an upper bound of background concentration. On the other hand, analytical results having data validation qualifier " $R$ " are not reported because the presence or absence of the analyte cannot be verified. Summary statistics for radionuclides with fewer than $20 \%$ detects are presented in Table 5.7 after combining over sampling areas. The contract laboratory for radionuclide analyses reported ${ }^{155} \mathrm{Eu}$ values as a detect by gamma spectroscopy, but the data interpretation team rejected the data because of possible interference with the gamma spectra of other naturally occurring radionuclides in soils. Therefore, statistics for ${ }^{155} \mathrm{Eu}$ were not included in Table 5.7. Summary statistics of ${ }^{155} \mathrm{Eu}$ expect to be similar to ${ }^{152} \mathrm{Eu}$ or ${ }^{154} \mathrm{Eu}$, because the europium isotopes were in a similar gamma energy range and were all determined to be nondetects by gamma spectroscopy.

Radionuclides detected (see Table 5.8 ) are ${ }^{137} \mathrm{Cs} ;{ }^{247} \mathrm{Cm} ;{ }^{237} \mathrm{~Np} ;{ }^{40} \mathrm{~K} ;{ }^{238} \mathrm{Pu}$ and ${ }^{239240} \mathrm{Pu}$; ${ }^{226} \mathrm{Ra}$; ${ }^{228} \mathrm{Th},{ }^{230} \mathrm{Th},{ }^{232} \mathrm{Th}$, and ${ }^{234} \mathrm{Th}$; and ${ }^{233234} \mathrm{U},{ }^{235} \mathrm{U}$, and ${ }^{238} \mathrm{U}$. Uranium-235 and uranium-238 along with thorium-232 were also determined by the NAA method and have been substituted for the ICP extraction method. In the following discussion, interpretations are limited to those radionuclides that were positively identified in most soil samples. Additional information is presented in Sect. 5 for other radionuclides that were produced during nuclear material testing, reactor spent fuel reprocessing, and isotope production. Most of these particular radionuclides were below detection limits. Only those radionuclides with several detects are discussed below.

Cesium-137. The major source of this radionuclide is global fallout. Analytical results showed that both Dismal Gap and Nolichucky Formation A horizon soils on the ORR have a higher concentration than Dismal Gap Formation soils in Anderson and Roane counties. This is most likely the result of greater off-site soil erosion. In addition to the global fallout of ${ }^{137} \mathrm{Cs}$, there is an additional local source contribution to some of the Bethel Valley Chickamauga soils. This was first noticed from the electrostatic discharge gamma scanning of the upper $30 \mathrm{~cm}$ of individual sites (see Sect. 3). The amount of the radionuclide decreased rapidly with depth in $B$ and $C$ horizons at all sites and sampling areas. The presence of elevated ${ }^{137} \mathrm{Cs}$ levels in some of the Chickamauga-Bethel Valley section soils is the only location on the ORR where past operations of Oak Ridge X-10 facilities may be a contributing factor for the higher levels of ${ }^{137} \mathrm{Cs}$ in these Bethel Valley soils. Recent additional work, however, immediately east of the HFIR facility located in Melton Valley tends to indicate another localized source. Any background risk assessment on the ORR for ${ }^{137} \mathrm{Cs}$ should, therefore, use ORR values by geologic formation rather than any overall median value.

Curium-247. Curium-247 is produced at Oak Ridge National Laboratory (ORNL) as a part of isotope production activities. Therefore, some of sediments/soils and wastes contain curium isotopes. The analyte was positively identified in only two soil samples from Nolichucky ORR. The concentrations were below the detection limits for all other soil samples. The location of the two samples with detects are too far away from possible sources. Therefore, the detection limit should be used as a possible maximum background level.

Neptunium-237. Neptunium-237 is a global fallout and/or decay product of other actinides. A considerable number of A horizon soil samples had detectable amounts of ${ }^{237} \mathrm{~Np}$. On-site soils appear to have higher amounts than off-site soils. The Copper Ridge soils in Roane County had much lower amounts. Nolichucky soils on the ORR appear to have higher amounts of ${ }^{237} \mathrm{~Np}$ than other soils. However, the overall differences are relatively too 
small to differentiate local input from global fallout. Soil samples from subsurface horizons were not analyzed. Statistical analyses show no significant differences among the formations 'and sampling areas. For their data comparison and assessment, data users should use appropriate values from Table $6.1 \mathrm{~b}$.

Plutonium-238 and -239/240. Plutonium isotopes originate from global fallout and/or reactor fuel processing. Both isotopes were positively identified in less than $25 \%$ of $\mathrm{A}$ horizon samples. The presence of these radionuclides at both on-site and off-site sampling areas and without any noticeable distribution trend suggests that there is no additional ORR source contribution to the global fallout source. However, if the global source is the sole source of the plutonium isotopes, the activity ratio of ${ }^{238} \mathrm{Pu}$ to ${ }^{239240} \mathrm{Pu}$ should be similar to the known ratio, about 0.04, for the northern hemisphere (Perkins and Thomas 1980). The observed values are at least ten times higher than the known ratio. Furthermore, the frequency of detects ( $\mathrm{J}$ qualifier) of ${ }^{238} \mathrm{Pu}$ were about a factor of 2 higher than that of ${ }^{238240} \mathrm{Pu}$. Considering the low frequency of detects, low activities, and the high 238 to 239/240 activity ratios, any generalization of the available data is difficult to assess.

Although the statistical analyses indicate that the differences among the formations are significant, data users should be careful in using this plutonium data for their applications. The ${ }^{239238} \mathrm{Pu}$ data could be used as an upper concentration level of background plutonium concentration for the study area but should not be used as a tool for source determination. For a better understanding and to answer the source term questions, additional plutonium data should be acquired.

Potassium-40. Potassium-40 is the most abundant naturally occurring isotope in soils. In most cases, variability of ${ }^{40} \mathrm{~K}$ is related to amounts of micaceous minerals and organic matter in the soils. Dismal Gap and Nolichucky soils have a higher ${ }^{40} \mathrm{~K}$ concentration than Copper Ridge and Chepultepec soils regardless of location. The results reflect the mineralogical composition of these'soils. Potassium-bearing clay minerals are abundant in the Conasauga Group, but potassium-free kaolinite is the major clay mineral in Knox Group soils. Chickamauga soils had similar ${ }^{40} \mathrm{~K}$ levels as Dismal Gap soils. In general, A horizon soil samples had lower ${ }^{40} \mathrm{~K}$ values than $\mathrm{B}$ and $\mathrm{C}$ horizon samples. The degree of soil weathering also influences both total and radioactive potassium contents in soils. Therefore, data users should compare their data with equivalent geologic groups and soil horizons. For independent evaluation of analytical methods, the ${ }^{40} \mathrm{~K}$ activities of the soils were calculated from the total nonradioactive potassium $\left({ }^{39} \mathrm{~K}\right.$ ) values (NAA results) using the natural abundance of ${ }^{40} \mathrm{~K}$ to total potassium $(0.01167 \%)$. The scatter diagram indicated that the gamma spectroscopy method has a reasonably good correlation with the NAA method (Table 6.2).

The above generalizations are also supported by statistical analyses. The ${ }^{40} \mathrm{~K}$ contents in A horizons of Nolichucky, Chickamauga K-25, and Dismal Gap at Roane County were significantly different from $\mathrm{B}$ and $\mathrm{C}$ horizons. The Chickamauga $\mathrm{B}$ horizons also have significantly different ${ }^{40} \mathrm{~K}$ concentrations than $\mathrm{C}$ horizons. Furthermore, all formations are different for ${ }^{40} \mathrm{~K}$. Therefore, data users should try to match equivalent geologic formations before using this data base (see Sect. 5 for data by formation-location and soil horizon). 
Table 6.2. Ratios of radionuclide concentrations ${ }^{a}$

\begin{tabular}{lrrrrc}
\hline \multicolumn{1}{c}{ Description } & N & Mean & Std dev & Minimum & Maximum \\
\hline K-40 NAA/ K-40 Gamma & 122 & 0.938 & 0.518 & 0.038 & 5.826 \\
Th-228 Alpha/Th-232 Alpha & 148 & 1.024 & 0.180 & 0.121 & 2.000 \\
Th-232 NAA/Th-232 Alpha & 136 & 1.214 & 0.746 & 0.321 & 7.400 \\
Pu-238 Alpha/Pu-239, 240 Alpha & 8 & 1.891 & 1.104 & 0.677 & 3.464 \\
U-235 Alpha/U-238 Alpha & 107 & 0.143 & 0.526 & 0.025 & 5.437 \\
U-235 NAA/U-238 NAA & 139 & 0.047 & 0.010 & 0.018 & 0.102 \\
U-238 NAA/U-238 Alpha & 120 & 1.140 & 0.334 & 0.352 & 2.136 \\
U-233, 234 Alpha/U-238 Alpha & 136 & 0.984 & 0.368 & 0.753 & 5.039 \\
Th-234 Alpha/U-238 Alpha & 60 & 1.418 & 0.459 & 0.833 & 2.754 \\
Total U/Sum U-234, 235, 238 & 55 & 0.695 & 0.456 & 0.0333 & 2.133 \\
\hline
\end{tabular}

'Nondetects not included, except for Sum U-234, 235, 238, for which one-half of the U-235 detection limit is used for U-235 nondetects. (Contribution of U-235 to the sum is negligible, however.)

Radium-226. Radium-226 is a naturally occurring radionuclide in soils and one of the decay products of ${ }^{238} \mathrm{U}$. Analytical results show that $\mathrm{A}$ horizons from AND Dismal Gap have significantly higher amounts of ${ }^{226} \mathrm{Ra}$ than in $\mathrm{B}$ and $\mathrm{C}$ horizons, but this trend did not hold for other soils for all other locations. Dismal Gap soils from Anderson County were relatively higher in ${ }^{226} \mathrm{Ra}$ levels than other soils, including the ROA Dismal Gap and ORR soils. On the other hand, ORR Copper Ridge soils had higher ${ }^{226} \mathrm{Ra}$ levels than the AND and ROA Copper Ridge soils. The median value of the A horizon from AND Copper Ridge soils was lower than that of other soils because of the presence of one nondetect value in the data set.

Statistical analyses do not show noticeable trends or differences in the distribution of ${ }^{226} \mathrm{Ra}$ between horizons except in the Chepultepec on the ORR and the Copper Ridge in Roane County. There are some significant differences among geologic groups at ORR and Dismal Gap soils at different locations. Therefore, the average values for each geologic group should be applied for environmental risk and contaminated site assessments. See Table 6.1b.

Strontium-90. Strontium-90, like ${ }^{137} \mathrm{Cs}$, is a man-made fission product. Global and local fallout would be the major sources in soils. The analytical results showed one detect from the ORR Dismal Gap and one detect from Copper Ridge soils in Anderson County. The location of the detect soils and low frequency of the detects suggests that the overall detection limit should be applied as background level of ${ }^{90} \mathrm{Sr}$.

Technetium-99. Technetium-99 is one of the fission products that is introduced to the environment by the reprocessing of spent fuel, by the uranium enrichment process, or from global fallout. Technetium-99 is present in the contaminated areas of the three plant sites. However, repeated sampling and analyses did not show any noticeable elevated background at the ORR. Technetium-99 was detected from a few on-site samples as well as from off-site soil samples. The Dismal Gap and Copper Ridge soils from Anderson County have a higher level of ${ }^{99} \mathrm{Tc}$ than on-site soil samples. 
There were no significant differences of ${ }^{99} \mathrm{Tc}$ concentrations among formations on the ORR. The results suggest that there was no significant contribution of ${ }^{99} \mathrm{Tc}$ from local sources. Therefore, the background level of ${ }^{99} \mathrm{Tc}$ should be estimated from detect values of both on- and off-sites. See Table $6.1 \mathrm{~b}$ for appropriate values.

Thorium-228, -230, -232, and -234. Thorium isotopes occur naturally in soils and are important for health risk assessment if elevated levels occur in soils. Thorium-232 is a primary isotope of the thorium series, and the others are products of uranium or thorium decay. Thorium-228 is a decay product of thorium-232. In the AND Dismal Gap soils, the level of ${ }^{228} \mathrm{Th}$ was relatively higher than in the same Dismal Gap soils of Roane County and the ORR. The A horizon of soils from the Copper Ridge had fairly low levels compared to all other horizons sampled in this project. The B and C horizons of Copper Ridge soils were not significantly different from other soils. The median value from the A horizon in the K-25 Chickamauga was significantly higher than other A horizons. Nolichucky soils also had a higher ${ }^{228} \mathrm{Th}$ level than other sites. Thorium-232 had a distribution pattern similar to that of thorium-228, and their overall concentration ratio was close to 1 (1.024). Thorium-230 and -234 are decay products of uranium-238. Uranium-238 decays to thorium-234 and then to uranium-234. Uranium-234 decays to thorium-230. Therefore, the ${ }^{230} \mathrm{Th}$ and ${ }^{234} \mathrm{Th}$ distributions should relate to uranium distribution in soils. Copper Ridge soils had relatively higher ${ }^{230} \mathrm{Th}$ levels than Dismal Gap soils for both on- and off-site locations. In general, ${ }^{230} \mathrm{Th}$ levels of Copper Ridge soils increased with depth. There was no observable trend between on-site and off-site locations. Thorium-234 data have some inconsistency; that is, a considerable number of samples were nondetects. Therefore, the results were not interpreted because the results should have the same trend as ${ }^{234} U$ and ${ }^{238} U$. Thorium-232 in soils was also analyzed by the NAA method, and the results were compared with the alpha spectroscopy results. A scatter plot of the results showed a reasonably good correlation between the two methods (Table 6.2).

Overall, statistical analysis of ${ }^{228} \mathrm{Th}$ and ${ }^{232} \mathrm{Th}$ show that $\mathrm{A}$ horizons of all ORR soils from each formation were significantly different from all others; and all of the geologic groups at the ORR location were significantly different from all others. Other horizons did not show such differences. For ${ }^{230} \mathrm{Th}$ in $\mathrm{C}$ horizons, each formation and geological group at the ORR was significantly different from other formations and groups at the ORR. Data for comparisons must be obtained by horizon and formation in Sect. 5 .

Tritium. Although tritium forms naturally in the atmosphere, this source is not usually a significant one. Tritium has been used in many different projects at ORNL, resulting in a considerable amount of discharge to waste steams. Natural rain water contains 100 to $300 \mathrm{pCi} / \mathrm{L}$ (EPA 1991). Tritium was detected in soils of these formations on the ORR, including Chickamauga-Bethel Valley, Copper Ridge, and Dismal Gap. Chickamauga-Bethel Valley soils had significantly higher levels, indicating a local source area near ORNL Building 4500 . Cesium-137 was also higher in the Chickamauga-Bethel Valley soils, but levels of other radionuclides and inorganic components were not elevated. Off-site soils did not have detectable levels of tritium. The cesium and tritium results indicate that some ORR soils were contaminated by local sources. Therefore, data users should be careful about using Chickamauga-Bethel Valley tritium and ${ }^{137} \mathrm{Cs}$ data. For example, if the user wants the background level of tritium, the user should use the maximum detection level calculated from nondetects. 
Uranium-233/234, -235 , and -238 . Uranium was quantified by three different isotopic analysis methods: alpha spectroscopy for all isotopes, NAA, and gamma spectroscopy for ${ }^{235} \mathrm{U}$ and ${ }^{238} \mathrm{U}$. Uranium-233 is not a naturally occurring isotope, and uranium-234 is a decay product of ${ }^{238} \mathrm{U}$. However, alpha spectroscopic analysis could not distinguish the two isotopes, ${ }^{233} \mathrm{U}$ and ${ }^{234} \mathrm{U}$. Therefore, this report designated these two isotopes as ${ }^{233 / 234} \mathrm{U}$, even though all activity was contributed by ${ }^{234} \mathrm{U}$. In theory, activity ratios should be unity among ${ }^{234} \mathrm{U},{ }^{238} \mathrm{U}$, and ${ }^{234} \mathrm{Th}$ at equilibrium. Actual ratios of observations were reasonably close (Table 6.2). If ${ }^{235} U$ was not enriched nor depleted, the natural activity ratio of ${ }^{235} U$ to ${ }^{238} U$ should be 0.046 . Alpha spectroscopy results had a ratio of 0.143 , and the NAA result had a ratio of 0.047 . The scatter plot of NAA vs alpha spectroscopy results showed excellent agreement with the isotopic ratio 1.214 (Table 6.2). The results suggest that (1) soils had natural isotopic ratios for uranium, (2) ${ }^{235} \mathrm{U}$ results analyzed by alpha method were not as good as the results analyzed by the NAA, and (3) interpretation of uranium isotope distribution can be done as a group instead of on an individual isotope basis.

Most of the uranium isotope series occurs naturally in soils, but the ORR soils were expected to have additional inputs from local sources, such as Oak Ridge K-25 Site and Oak Ridge Y-12 Plant operations. However, the analytical results of background soils do not confirm such speculation. Uranium data show that A horizon soils have relatively lower levels than do the B and C horizons. Dismal Gap soils have relatively lower values than soils of other formations regardless of location. Copper Ridge soils, except the Roane County area, have higher uranium values than other formation soils. Therefore, the depth of soil, geologic formation, and location are all important factors for uranium distribution. For ORR Nolichucky soils, uranium data analyzed by alpha spectroscopy were not usable and were replaced with NAA data.

General statistical analyses also indicated that ${ }^{233 / 234} U$ and ${ }^{238} U$ levels in $C$ horizon soils were significantly different among the formations and groups at the ORR. Data users should follow the general data user guidelines in Sect. 2 and use appropriate values for horizons and formation-locations in Sect. 5 .

Total Uranium Total uranium concentration was determined by pulsed laser phosphorimetry. The mass-based analytical results $(\mathrm{mg} / \mathrm{kg}$ ) were converted to activity units (pCi/g) using natural isotopic ratios of uranium (see Sect. 4.5.3.8). To evaluate the total uranium data, regression analysis of laser phosphorimetry results with alpha spectroscopy results was conducted. Total uranium activities of the alpha spectroscopy were calculated by summing the individual isotope $\left({ }^{233 / 234} \mathrm{U},{ }^{235} \mathrm{U}\right.$, and ${ }^{238} \mathrm{U}$ ) activities. Linear regression analysis shows 2.02 for the intercept, 1.17 for the slope, and 0.16 for the correlation coefficient in a scatter plot of the sum of the isotopes vs total uranium. These results suggest that the total uranium data, as determined by the laser phosphorimetry method, may not be as accurate as determined by the alpha spectroscopy method. With the exception of some of the ${ }^{235} \mathrm{U}$ data, the alpha spectroscopy isotopic analysis results showed excellent agreement with NAA results. Furthermore, the activity ratio of ${ }^{233234} \mathrm{U}$ vs ${ }^{238} \mathrm{U}$ analyzed by alpha spectroscopy was in agreement with the theoretical value. Therefore, even though total uranium data are presented in the data tables, these data are not recommended to be used as background data. Waste management and environmental restoration projects including risk assessment activities need to use isotopic uranium data rather than total uranium data.

Note: Uranium-236 was detected in three soil samples: one from K-25 Chickamauga soils and two from Dismal Gap soils on the ORR. The source of this contamination is not known. 


\section{Summary of Statistical Analysis}

For certain users of this data, grand median valuès by horizon across all geologic groups have been computed. These are in Table G.9. However, the data must be used with great caution. Following is a list of radionuclides where there are no significant differences among groups: ${ }^{235} \mathrm{U}$ gamma, $\mathrm{A}, \mathrm{B}$, and $\mathrm{C}$ horizon; ${ }^{237} \mathrm{~Np}$, A horizon; ${ }^{226} \mathrm{Ra}$, A horizon; ${ }^{228} \mathrm{Th}$ alpha, $\mathrm{B}$ horizon; total $\mathrm{U}$ alpha, $\mathrm{A}, \mathrm{B}$, and $\mathrm{C}$ horizon; and ${ }^{233 / 234} \mathrm{U}$ alpha, $\mathrm{A}$ horizon. The following list of radionuclides is significantly different between $1 \%$ to $10 \%$ level; ${ }^{235} \mathrm{U}$ alpha, $\mathrm{A}, \mathrm{B}$, and $\mathrm{C}$ horizon; ${ }^{238} \mathrm{U}$ alpha, $\mathrm{A}$ and $\mathrm{B}$ horizon; ${ }^{230} \mathrm{Th}$ alpha, A horizon; and ${ }^{233234} \mathrm{U}, \mathrm{B}$ horizon. All the other radionuclides are significantly different and the data for these in Table G.9 should not be used.

\subsection{TRACE ELEMENTS ANALYZED BY NAA}

The following trace elements were analyzed by the NAA method: $\mathrm{Ce}, \mathrm{Eu}, \mathrm{Ga}, \mathrm{Au}, \mathrm{Hf}$, $\mathrm{La}, \mathrm{Lu}, \mathrm{Rb}, \mathrm{Sc}, \mathrm{Tb}, \mathrm{Ti}$, and $\mathrm{Yb}$. Because these elements occur in small quantities, conventional analytical methods are not sensitive enough to detect them. The NAA method can detect small amounts. Most of these elements are not considered to be important in any risk analysis, but they can be important in tracing sediments to their source geologic formation.

Gold, gallium, hafnium, rubidium, scandium, and titanium are not part of either the actinide or lanthanide series of elements; but they do occur in trace amounts. Elements in the actinide series have differing geochemistry than those rare earth elements in the lanthanum series. All of the actinide series have radioactive isotopes. In this project they include $\mathrm{Np}, \mathrm{Th}$, $\mathrm{U}, \mathrm{Pu}, \mathrm{Am}, \mathrm{Cm}$, and $\mathrm{Pa}$. All of these, except cerium, were analyzed; and the results, if there were any detects, are discussed in Sect. 6.4.3. The analysis for lanthanides included $\mathrm{Ce}, \mathrm{Eu}$, $\mathrm{La}, \mathrm{Lu}, \mathrm{Tb}$, and $\mathrm{Yb}$.

The lanthanides have a geochemical behavior that makes them well qualified for geochemical studies (Brookins 1989). Most lanthanides are large cations with a valance of +3 . The only exceptions are cerium with a valance of +4 and europium with a valance of +2 . The large ionic radius tends to segregate them from other metal ions. Many lanthanides form complexes as fluorides, phosphates, and carbonates. Cerium, for example, tends to form complexes with manganese compounds as oxides. Many lanthanides become more concentrated in shales. Many lanthanides also tend to move quite readily in aqueous solutions and become more concentrated in carbonates.

Cerium. Cerium is found in significantly lower levels in soils of the Knox Group than in all other groups and in all horizons. Cerium is found in higher levels in soils of the Chickamauga Group.

Europium. Levels of europium are nearly the same for all $\mathrm{A}$ horizons that were sampled, but europium levels in the B and $\mathrm{C}$ horizons of the Knox Group soils were much lower than for all other groups. Chickamauga $\mathrm{B}$ and $\mathrm{C}$ horizons had higher levels than all other groups. Europium tends to become concentrated in shales.

Gallium Gallium has a fairly uniform distribution across all geologic groups. 
Gold. Gold was detected only in some of the ORR and Roane Copper Ridge soils and in some ORR Chepultepec soils (5 of 12 detects).

Hafnium. Hafnium was detected in nearly all samples. Hafnium and titanium are closely related and should have a similar distribution in soils. The $\mathrm{C}$ horizons of Knox Group soils at all locations had lower levels than all other groups.

Lanthanum. Lanthanum was detected in all but one sample. Lanthanum levels were similar in all A horizons and all B and C horizons except those of the Knox Group soils, which were significantly different.

Lutetium. Lutetium was detected in nearly all samples. Levels in all A, B, and C horizon samples were all nearly the same.

Rubidium. Rubidium was detected in only three samples. Two of the three were confined to the Bethel Valley section of the Chickamauga Group. Rubidium and cesium are nearly always associated with potassium minerals. Rubidium is more abundant than cesium, but cesium was detected in all samples. In the absence of potassium, both cesium and rubidium are toxic to animals.

Scandium. Scandium was detected in all samples. Scandium has many similarities to other lanthanides, except for its smaller ionic radius. Scandium occurs only in very small amounts in carbonate rocks. All Knox Group soils had lower levels of this element in A, B, and C horizons than all other soils, which bears this out. The Roane Copper Ridge had the lowest levels among soils of the Copper Ridge Formation. The Conasauga and Chickamauga groups had very similar levels.

Terbium. Terbium was detected in nearly all soils except for the $C$ horizons of Copper Ridge soils. Chickamauga A, B, and C horizons had higher levels than all other soils. Conasauga and Knox soils had similar levels.

Titanium. Titanium is a very common element in soils and geomedia and commonly associated with iron minerals. This element was detected in all soils and was nearly evenly distributed among the $\mathrm{A}, \mathrm{B}$, and $\mathrm{C}$ horizons.

Ytterbium. Ytterbium was detected in nearly all samples. The lowest levels were in the Copper Ridge $\mathrm{C}$ horizons for off-site locations in Roane and Anderson Counties.

Cerium, europium, and terbium were higher in the $A, B$, and $C$ horizons of the Chickamauga Group than in all other formations. Cerium, europium, and gallium were lower in the $\mathrm{C}$ horizon of Knox Group soils. Hafnium, lanthanum, lutetium, and scandium were lower in the Knox Group than in all other groups. Titanium and ytterbium were quite evenly distributed throughout all horizons of all formations. 


\section{BACKGROUND RISK EVALUATION}

\subsection{SUMMARY}

The background soil data, collected from A horizon soils of the Dismal Gap (DG), Nolichucky (NOL), Copper Ridge (CR), Chepultepec (CHE), and Chickamauga (CHI) formations on the Oak Ridge Reservation (ORR) and from Anderson (AND) and Roane (ROA) counties, were evaluated in terms of potential adverse effects to human health. This background risk evaluation provides a context for the discussion and comparison of risks associated with site-related contamination and for determining contaminants of potential concern (COPC) for that site.

Three primary pathways of exposure were evaluated, for inorganic, organic and radionuclide analytes, which include (1) direct ingestion of soil, (2) dermal contact with soil, and (3) external exposure to radionuclides in the soil. Background risks for individual analytes, total pathway risk estimates (i.e., the sum of the background risks of all analytes within a pathway), and cumulative risk estimates (i.e., the sum of the total pathway risks) were determined.

The constituents detected in the uncontaminated background soil samples were evaluated within the context of EPA-approved guidelines for contaminated soils in which there are three regions of carcinogenic risk (risk $<1.0 \mathrm{e}-06$, no concern; risk between 1.0e-06 and $1.0 \mathrm{e}-04$, range of concern; and risk $>1.0 \mathrm{e}-04$, unacceptable) and two areas of systemic toxicity (hazard index <1.0, no concern; and hazard index $>1.0$, concern). The background risks are reported in this manner, but the results are only for comparison with risks determined for contaminated sites; the results do not pertain to remediation decisions.

In summary, with a few exceptions, the carcinogenic-risk and noncarcinogenic-hazard indices determined for individual analytes (found in the A horizon of the Dismal Gap and Copper Ridge formations) were similar for the three sampling areas (ORR, Anderson and Roane counties). The cumulative pathway background risks (i.e., risks from ingestion of soil plus risks from dermal contact with soil plus risks from external exposure to radionuclides in the soil) for the Dismal Gap Formation are 6.4e-04, 9.4e-04, and 5.8e-04, for ORR, AND, and ROA, respectively; the cumulative risks for Copper Ridge are 7.0e-04, 6.4e-04, and $6.4 \mathrm{e}-04$, respectively. The main contributors to the risk for the both the ingestion and dermal contact pathways are beryllium and all nine detected polynuclear aromatic hydrocarbons. Cesium-137, potassium-40, radium-226, and thorium-228 are the main contributors to risk for the external exposure pathway.

The total pathway hazard indices for ingestion of soil in the Dismal Gap Formation are $0.69,0.55$, and 0.76 for ORR, AND and ROA counties, respectively; the pathway hazard indices for dermal exposure to Dismal Gap soil are $0.10,0.09$, and 0.12 , respectively. For the Copper Ridge Formation, the total pathway hazard indices for ingestion of soil are 1.7, 1.2, and 0.77 for ORR, AND, and ROA, respectively; the total pathway hazard indices for dermal exposure to Copper Ridge soil are $0.10,0.15$, and 0.07 , respectively. Arsenic and manganese are the major contributors to the hazard indices for the ingestion pathway, and the main contributors for the dermal exposure pathway are manganese and vanadium. 
These background risk estimates should be considered only in the context of comparison with site-related risk. The EPA action level for remediation, of $1.0 \mathrm{e}-04$, refers to risks related to hazardous waste sites. The background risk results themselves are not indicative of concerns or actions that would be identified with similar potential risks from a contaminated site, and care should be taken not to misinterpret these results as pertaining directly to remediation decisions.

\subsection{INTRODUCTION}

A primary goal of producing a comprehensive data base for - naturally occurring concentrations of soil constituents on the ORR is to support the need (for human health risk assessment) to differentiate contamination from naturally occurring constituents. The overall objective of this section is to evaluate the BSCP data relative to risk. The human health risk assessment methodology in this study is based on the RiskAssessment Guidance for Superfund (RAGS) (EPA 1989c), so that these risk results for exposure to background soil constituents will be comparable to future site-related risk evaluations. A quantitative analysis of the inorganic (metals), organic [polynuclear aromatic hydrocarbons (PAHs)], and radionuclide analytes found in undisturbed soil will characterize the unavoidable potential risks to human health associated with exposure to these naturally occurring constituents.

Specific objectives of this section are to (1) evaluate the potential risks from exposure to constituents in background soils on the ORR in order to provide a context for the discussion of risks associated with site-related contamination in future risk assessments, (2) support the selection of COPC in future site-related risk assessments, and (3) provide a comparison based on background risk between the soils collected at the three sampling areas (Anderson and Roane counties and the ORR). Because remedial investigation (RI) activities will use soil data specific to the ORR to meet background needs, this evaluation focuses primarily on background risks associated with ORR soils. Accordingly, the results of each step of the background risk evaluation are presented in full for the ORR soils. In addition, the same background risk evaluation process has been applied to the Dismal Gap Formation and Copper Ridge Formation soil data from Anderson and Roane counties; however, only the total risk and hazard indices are presented for these locations as part of the comparison of background risks associated with the three sampling areas.

A human health risk evaluation of background soils samples from the DG, NOL, CR, $\mathrm{CHE}$, and $\mathrm{CHI}$ formations is presented in this report. The first step involves evaluating the data from a risk assessment perspective and identifying those soil constituents that will be considered in the assessment. This process parallels the selection of COPC at a contaminated site. Next is an assessment of the exposure potential and the identification of exposure pathways. Subsequently, exposure is estimated, and the toxicity of the soil constituents is appraised. The results of the exposure and toxicity assessments are brought together in the background risk characterization section, which includes a comparison of background risks among the three sampling areas (ORR, AND and ROA counties) and a more detailed description of the ORR soils background risk evaluation.

The following sections describe the methodology used in evaluating site analytical data, physical characteristics, potential pathways, and receptors in quantifying the potential risk to human health from background soil constituents. 


\subsection{DATA EVALUATION}

\subsubsection{Data Usability}

Many natural soil constituents also occur as site related contaminants; therefore, the major use of background soil characterization information is to support the selection of COPC at contaminated ORR sites. The COPC are identified early in the risk assessment process as those contaminants related to site operations for which adverse health effects will be evaluated. An accurate assessment of the potential risk to human health posed by contaminants found at higher concentrations than naturally occurring background concentrations is the basis for risk management decisions. Data collected during the site investigation of specific hazardous waste sites should be compared to the background data in this report in order to identify COPC. In most cases, it is assumed that an analyte found to be at a greater concentration than the concentration for that constituent in background soil is related to site activities and is therefore a COPC. Guidance from the EPA suggests that a concentration of two orders of magnitude above the background concentration is indicative of a COPC (EPA/540/G-90/008, October 1990). The Risk Assessment Council is producing guidance on the selection of COPC. This guidance will include specific details on the application of this background soil information to the COPC selection process.

Of secondary importance, is the application and comparison of the background risk estimates included in this report to contaminated site risk estimates. Future site-specific investigations of risk to human health posed by soil contamination at the ORR, can be compared to the background risk associated with each analyte in this section of the BSCP. In addition, the total soil background risk reported here can be used to discuss site-related risk in the context of background risk. The risk evaluation of background soils on the ORR is to provide a context for the discussion of risks associated with site-related contamination in future risk assessments. To meet this objective, the background constituents detected in uncontaminated soils were evaluated by the same methods typically used to assess the potential risks resulting from exposure to contaminated soil. Similarly, the results of this background risk evaluation have been discussed within the context of the Comprehensive Environmental Response, Compensation, and Liability Act (CERCLA) framework; CERCLA uses the potential risks estimated from site-related contamination to determine if remedial action is necessary at a waste site. Although reported in this manner, the background risk results are not indicative of concerns or warrant remedial actions. Care should be taken not to misinterpret these results to pertain to remediation decisions.

\subsection{General Site-Specific Data Collection Considerations}

General guidance for collecting soil samples is given in the Project Plan for the BSCP on the ORR in Oak Ridge, Tennessee (Energy Systems 1992). Guidance for soil sampling is also included in the EPA publication Preparation of Soil Sampling Protocol, Techniques and Strategies (EPA 1983). Standard procedures were also followed for the collection of samples (Kimbrough et al. 1988) and the Engineering Support Branch Standard Operation Procedures and Quality Assurance Manual (EPA 1991a). Sample site selection and data collection are discussed in Sects. 3.2 and 3.4 of this report. 


\subsubsection{General Site-Specific Data Evaluation Considerations}

The validated data included in this study consist of organic, inorganic, and radionuclide analyses of soils from five formations (Dismal Gap, Nolichucky, Copper Ridge, Chepultepec, and Chickamauga), three horizons (A, B, and C), and three sampling areas (Roane County, Anderson County, and the ORR. Note: (i) for the Chepultepec and Nolichucky formations, soil samples were taken from the ORR only; (ii) for the Copper Ridge and Dismal Gap formations, soil samples were taken from Anderson County, Roane County and the ORR; and (iii) for the Chickamauga Formation, soil samples were taken from two separate places on the ORR. For complete statistical analysis of the data, refer to Sect. 5 . In this risk evaluation, both background cancer risk and background systemic [hazard index (HI)] effects posed to a child and an adult in a hypothetical on-site residential scenario will be determined for the ORR soil samples taken from the A horizon. Comparisons of total risk (child + adult) and total HI (child + adult) for the three sampling areas (Roane and Anderson counties and the ORR) for the Dismal Gap and Copper Ridge formations will be made.

The analytes detected in horizon A for the ORR, AND and ROA sampling areas will be divided into six horizon A data sets (i.e., DG, NOL, CR, CHE, CHI-BV, and CHI-K25); most tables throughout this text (Sect. 7) will be separated into parts a through $f$ to correspond with these five formations (and the two ORR-Chickamauga sampling locations, i.e., CHI-K25 and CHI-BV). ORR soil data are reported as (i) DG-ORR, (ii) NOL-ORR, (iii) CR-ORR, (iv) CHE-ORR, (v) CHI-BV, and (vi) CHI-K25; therefore, although both CHI-K25 and CHI-BV soil data are associated with the Oak Ridge Reservation soil, they will be listed and evaluated separately in this section (Sect. 7)

In this BSCP study, soil samples taken from undisturbed locations on the ORR (from the A horizon of the DG, NOL, CR, CHE, and CHI formations) best represent the background constituents found on the reservation and, therefore, best represent the background risk associated with these analytes.

\subsection{Identification of Constituents Included in the Background Risk Evaluation}

The identification of specific inorganic, organic and radionuclide soil constituents included in the assessment of background soil risk is based on methodology from Sect. 5 of RAGS (EPA 1989c). The number of constituents that can be quantitatively evaluated in the risk evaluation is limited by the availability of chemical-specific EPA-approved dose/response information. In addition, analytes which were not found above detection limits (undetected) were not included in the risk evaluation. The detected constituents considered in the quantitative assessment of risk and noncarcinogenic effects from background soil are listed in Table 7.1. Note: (i) beryllium is the only inorganic analyte found in the background soil samples for which an EPA-approved slope factor is available; (ii) for the Nolichucky Formation, problems were found in the alpha spectrometry data for uranium-233/234 and uranium-238, hence, these data have been replaced with neutron activation analysis (NAA) data (refer to Sects. 4 and 5); (iii) the technetium-99, tritium, and all organic analyte data are based on noncomposited samples (refer to Sects. 3 and 4); and (iv) no organic constituents were detected above the analytical detection limits in the Phase I sampling of the DG and NOL formations, hence, no organic data are reported for these lithologies (refer to Sect. 4.4). 
Table 7.1a. Oak Ridge Reservation background soil analytes evaluated quantitatively Dismal Gap

\begin{tabular}{|c|c|c|c|c|c|c|}
\hline Analyte & $\begin{array}{c}\text { Frequency } \\
\text { of } \\
\text { detection }\end{array}$ & $\begin{array}{c}\text { Minimum } \\
\text { detected } \\
\text { concentration }\end{array}$ & $\begin{array}{l}\text { Maximum } \\
\text { detected } \\
\text { concentration }\end{array}$ & $\begin{array}{c}\text { Lower } 95 \% \\
\text { confidence } \\
\text { bound on } \\
\text { median }\end{array}$ & $\begin{array}{c}\text { Median } \\
\text { concentration }\end{array}$ & $\begin{array}{c}\text { Upper } 95 \% \\
\text { confidence } \\
\text { bound on } \\
\text { median }\end{array}$ \\
\hline \multicolumn{7}{|c|}{ Inorganics (mg/kg) } \\
\hline Arsenic & $4 / 4$ & $5.30 \mathrm{E}+00$ & $7.30 \mathrm{E}+00$ & $4.88 \mathrm{E}+00$ & $6.24 E+00$ & $7.97 \mathrm{E}+00$ \\
\hline Barium & $4 / 4$ & $7.72 E+01$ & $212 E+02$ & $7.63 E+01$ & $9.91 E+01$ & $1.29 \mathrm{E}+02$ \\
\hline Beryllium & $4 / 4$ & $5.50 \mathrm{E}-01$ & $220 \mathrm{E}+00$ & $6.37 \mathrm{E}-01$ & 7.81E-01 & 9.57E-01 \\
\hline Boron & $1 / 3$ & $1.64 \mathrm{E}+01$ & $211 \mathrm{E}+01$ & $8.29 \mathrm{E}+00$ & $1.37 \mathrm{E}+01$ & $227 \mathrm{E}+01$ \\
\hline Chromium VI & $4 / 4$ & $1.94 E+01$ & $3.21 E+01$ & $208 \mathrm{E}+01$ & $247 E+01$ & $292 \mathrm{E}+01$ \\
\hline Cyanide & $1 \beta$ & $4.40 \mathrm{E}-01$ & 4.40E-01 & $6.01 \mathrm{E}-02$ & $1.30 \mathrm{E}-01$ & 282E-01 \\
\hline Manganese & $4 / 4$ & $7.68 \mathrm{E}+02$ & $222 E+03$ & $7.28 \mathrm{E}+02$ & $9.97 \mathrm{E}+02$ & $1.37 \mathrm{E}+03$ \\
\hline Mercury & $4 / 4$ & 230E-01 & $4.00 \mathrm{E}-01$ & $270 \mathrm{E}-01$ & $3.16 \mathrm{E}-01$ & $3.70 \mathrm{E}-01$ \\
\hline Mercury (salts) & $4 / 4$ & 230E-01 & $4.00 \mathrm{E}-01$ & 270E-01 & $3.16 \mathrm{E}-01$ & $3.70 \mathrm{E}-01$ \\
\hline Nickel & $4 / 4$ & $1.95 E+01$ & 5.67E+01 & $1.89 E+01$ & $235 \mathrm{E}+01$ & $291 E+01$ \\
\hline Nickel (salts) & $4 / 4$ & $1.95 E+0 I$ & $5.67 \mathrm{E}+01$ & $1.89 E+01$ & $235 E+01$ & $291 E+01$ \\
\hline Strontium & $3 \beta$ & $6.10 \mathrm{E}+00$ & $1.68 \mathrm{E}+01$ & $5.51 E+\infty 0$ & $7.93 \mathrm{E}+00$ & $1.14 \mathrm{E}+01$ \\
\hline Vanadium & $4 / 4$ & $279 \mathrm{E}+01$ & $5.40 E+01$ & $298 \mathrm{E}+01$ & $3.42 \mathrm{E}+01$ & $3.91 \mathrm{E}+01$ \\
\hline Zinc & $4 / 4$ & $4.23 \mathrm{E}+01$ & $1.08 \mathrm{E}+02$ & $4.10 \mathrm{E}+01$ & $5.06 \mathrm{E}+01$ & $6.26 \mathrm{E}+01$ \\
\hline \multicolumn{7}{|c|}{ Radionuclides (pCI/g) } \\
\hline Cesium-137 & $4 / 4$ & $210 \mathrm{E}-02$ & $9.00 \mathrm{E}-01$ & 253E-01 & $5.98 \mathrm{E}-01$ & $1.41 E+\infty 0$ \\
\hline Plutonium-239/240 & $1 / 4$ & 290E-02 & $290 \mathrm{E}-02$ & $5.50 \mathrm{E}-03$ & $1.42 E-02$ & $3.66 \mathrm{E}-02$ \\
\hline Potassium -40 & $4 / 4$ & $1.40 \mathrm{E}+01$ & $220 \mathrm{E}+01$ & $1.35 \mathrm{E}+01$ & $1.63 E+01$ & $1.98 \mathrm{E}+01$ \\
\hline Radium-226 & $.4 / 4$ & $7.00 \mathrm{E}-01$ & $8.60 \mathrm{E}-01$ & 5.41E-01 & 7.87E-01 & $1.14 E+\infty 0$ \\
\hline Strontium-90 & $1 / 3$ & $1.10 E+00$ & $1.10 E+00$ & 3.55E-01 & 7.01E-01 & $1.38 \mathrm{E}+\infty 0$ \\
\hline Thorium-228 & $4 / 4$ & $5.00 \mathrm{E}-01$ & $9.40 \mathrm{E}-01$ & $5.01 \mathrm{E}-01$ & 7.13E-01 & $1.02 E+00$ \\
\hline Thorium-230 & $4 / 4$ & $3.10 \mathrm{E}-01$ & $8.30 \mathrm{E}-01$ & 4.72E-0I & 5.65E-01 & $6.77 E-01$ \\
\hline Thorium-232 & $4 / 4$ & $4.10 \mathrm{E}-01$ & $9.70 \mathrm{E}-01$ & $5.88 \mathrm{E}-01$ & $6.83 \mathrm{E}-01$ & 7.94E-01 \\
\hline Thorium-234 & $4 / 4$ & $1.50 E+00$ & $1.90 \mathrm{E}+00$ & $1.42 E+00$ & $1.63 E+00$ & $1.88 \mathrm{E}+00$ \\
\hline Tritium $^{a}$ & $5 / 9$ & $3.60 \mathrm{E}-02$ & $6.20 \mathrm{E}-02$ & $200 \mathrm{E}-02$ & $298 \mathrm{E}-02$ & 4.43E-02 \\
\hline Uranium-233/234 & $4 / 4$ & $6.10 \mathrm{E}-01$ & $1.40 \mathrm{E}+00$ & $7.76 \mathrm{E}-01$ & 9.3TE-01 & $1.13 E+00$ \\
\hline Uranium-235 & $4 / 4$ & $5.69 \mathrm{E}-02$ & $1.20 \mathrm{E}-01$ & $6.60 \mathrm{E}-02$ & 7.92E-02 & $9.50 \mathrm{E}-02$ \\
\hline Uranium-236 & $1 / 4$ & $200 \mathrm{E}-02$ & $200 \mathrm{E}-02$ & $930 \mathrm{E}-03$ & $1.65 \mathrm{E}-02$ & 292E-02 \\
\hline Uranium-238 & $4 / 4$ & 7.50E-01 & $1.70 E+00$ & $9.16 \mathrm{E}-01$ & $1.02 \mathrm{E}+00$ & $1.15 E+00$ \\
\hline
\end{tabular}

\footnotetext{
${ }^{\circ}$ Data are based on noncomposited samples.
} 
Table 7.1b. Oak Ridge Reservation background soil analytes evaluated quantitatively Nolichucky

\begin{tabular}{|c|c|c|c|c|c|c|}
\hline Analyte & $\begin{array}{c}\text { Frequency } \\
\text { of } \\
\text { detection }\end{array}$ & $\begin{array}{c}\text { Minimum } \\
\text { detected } \\
\text { concentration }\end{array}$ & $\begin{array}{l}\text { Maximum } \\
\text { detected } \\
\text { concentration }\end{array}$ & $\begin{array}{c}\text { Lower } 95 \% \\
\text { confidence } \\
\text { bound on } \\
\text { median }\end{array}$ & $\begin{array}{c}\text { Median } \\
\text { concentration }\end{array}$ & $\begin{array}{c}\text { Upper } 95 \% \\
\text { confidence } \\
\text { bound on } \\
\text { median }\end{array}$ \\
\hline \multicolumn{7}{|c|}{ Inorganics (mg/kg) } \\
\hline Antimony & $1 / 4$ & $4.90 \mathrm{E}-01$ & $4.90 \mathrm{E}-01$ & $4.43 \mathrm{E}-01$ & 4.63E-01 & $4.85 \mathrm{E}-01$ \\
\hline Arsenic & $3 / 3$ & $5.80 \mathrm{E}+\infty 0$ & $6.40 \mathrm{E}+00$ & $4.64 E+00$ & $6.16 \mathrm{E}+00$ & $8.18 \mathrm{E}+00$ \\
\hline Barium & $4 / 4$ & $5.97 \mathrm{E}+01$ & $1.06 \mathrm{E}+02$ & $5.81 E+01$ & $7.54 \mathrm{E}+01$ & $9.78 \mathrm{E}+01$ \\
\hline Beryllium & $4 / 4$ & $7.30 \mathrm{E}-01$ & $8.50 \mathrm{E}-01$ & $6.41 \mathrm{E}-01$ & $7.86 \mathrm{E}-01$ & $9.64 \mathrm{E}-01$ \\
\hline Chromium VI & $3 / 3$ & $264 \mathrm{E}+01$ & $299 E+01$ & $230 E+01$ & $280 E+01$ & $3.40 \mathrm{E}+01$ \\
\hline Manganese & $4 / 4$ & $4.05 E+02$ & $9.35 E+02$ & $4.77 \mathrm{E}+02$ & $6.53 E+02$ & $8.95 E+02$ \\
\hline Mercury & $4 / 4$ & $1.80 \mathrm{E}-01$ & $1.90 \mathrm{E}-01$ & $1.58 \mathrm{E}-01$ & $1.85 \mathrm{E}-01$ & $217 E-01$ \\
\hline Mercury (salts) & $4 / 4$ & $1.80 \mathrm{E}-01$ & $1.90 \mathrm{E}-01$ & $1.58 \mathrm{E}-01$ & $1.85 \mathrm{E}-01$ & $217 \mathrm{E}-01$ \\
\hline Nickel & $4 / 4$ & $1.52 \mathrm{E}+01$ & $200 E+01$ & $1.39 \mathrm{E}+01$ & $1.73 E \div 01$ & $214 E+01$ \\
\hline Nickel (salts) & $4 / 4$ & $1.52 E+01$ & $200 \mathrm{E}+01$ & $1.39 \mathrm{E}+01$ & $1.73 E+01$ & $214 E+01$ \\
\hline Selenium & $3 / 4$ & $5.60 \mathrm{E}-01$ & $7.40 \mathrm{E}-01$ & $4.45 \mathrm{E}-01$ & $5.65 \mathrm{E}-01$ & $7.18 \mathrm{E}-01$ \\
\hline Strontium & $4 / 4$ & $3.20 \mathrm{E}+00$ & $6.10 \mathrm{E}+00$ & $3.32 \mathrm{E}+00$ & $4.55 \mathrm{E}+00$ & $6.25 \mathrm{E}+\infty 0$ \\
\hline Vanadium & $4 / 4$ & $294 \mathrm{E}+01$ & $3.52 \mathrm{E}+01$ & $283 E+01$ & $3.24 \mathrm{E}+01$ & $3.71 \mathrm{E}+01$ \\
\hline Zine & $4 / 4$ & $3.39 E+01$ & $4.07 \mathrm{E}+01$ & $3.07 \mathrm{E}+01$ & $3.79 \mathrm{E}+01$ & $4.68 \mathrm{E}+01$ \\
\hline \multicolumn{7}{|c|}{ Radionuclides (pCi/g) } \\
\hline Cesium-137 & $4 / 4$ & $3.80 \mathrm{E}-01$ & 7.10E-01 & $223 \mathrm{E}-01$ & $5.27 \mathrm{E}-01$ & $1.24 \mathrm{E}+00$ \\
\hline Curium-247 & $2 / 4$ & $5.30 \mathrm{E}-03$ & $7.00 \mathrm{E}-03$ & $4.70 \mathrm{E}-03$ & $5.50 \mathrm{E}-03$ & $6.50 \mathrm{E}-03$ \\
\hline Neptunium-237 & 22 & $7.70 E-02$ & 230E-01 & $9.32 E-02$ & $1.33 \mathrm{E}-01$ & $1.90 \mathrm{E}-01$ \\
\hline Potassium- 40 & $4 / 4$ & $1.40 \mathrm{E}+01$ & $1.70 \mathrm{E}+01$ & $1.25 E+01$ & $1.52 E+01$ & $1.84 \mathrm{E}+01$ \\
\hline Radium-226 & $4 / 4$ & $3.90 \mathrm{E}-01$ & $1.40 \mathrm{E}+00$ & $5.09 \mathrm{E}-01$ & $7.40 \mathrm{E}-01$ & $1.08 \mathrm{E}+00$ \\
\hline Technetium-99 & $1 / 6$ & $279 E+\infty 0$ & $279 E+00$ & $6.30 \mathrm{E}-01$ & $1.10 \mathrm{E}+00$ & $1.91 \mathrm{E}+00$ \\
\hline Thorium-228 & $4 / 4$ & $1.20 \mathrm{E}+00$ & $220 \mathrm{E}+\infty 0$ & $1.06 \mathrm{E}+00$ & $1.51 \mathrm{E}+00$ & $215 E+00$ \\
\hline Thorium-230 & $4 / 4$ & $8.50 \mathrm{E}-01$ & $1.20 \mathrm{E}+\infty 0$ & $8.06 \mathrm{E}-01$ & 9.67E-01 & $1.16 \mathrm{E}+00$ \\
\hline Thorium-232 & $4 / 4$ & $1.20 \mathrm{E}+00$ & $200 E+\infty$ & $1.29 \mathrm{E}+00$ & $1.49 \mathrm{E}+00$ & $1.74 E+\infty 0$ \\
\hline Thorium-234 & $4 / 4$ & $1.30 \mathrm{E}+00$ & $1.50 \mathrm{E}+\infty 0$ & $1.24 \mathrm{E}+00$ & $1.42 \mathrm{E}+00$ & $1.64 \mathrm{E}+\infty 0$ \\
\hline Uranium-233/234 & $4 / 4$ & $1.04 \mathrm{E}+00$ & $1.51 E+00$ & $1.06 \mathrm{E}+00$ & $1.28 \mathrm{E}+00$ & $1.55 \mathrm{E}+00$ \\
\hline Uranium-235 & $4 / 4$ & 4.32E-02 & 9.69E-02 & $5.94 \mathrm{E}-02$ & $7.13 \mathrm{E}-02$ & $8.55 \mathrm{E}-02$ \\
\hline Uranium-238 ${ }^{b}$ & $4 / 4$ & $1.04 E+00$ & $1.51 \mathrm{E}+\infty 0$ & $1.15 E+00$ & $1.28 E+\infty 0$ & $1.43 E+\infty 0$ \\
\hline
\end{tabular}

Data are based on noncomposited samples.

${ }^{b}$ Data are from Neutron Activation Analysis (NAA). 
Table 7.1c. Oak Ridge Reservation background soil analytes evaluated quantitatively Copper Ridge

\begin{tabular}{|c|c|c|c|c|c|c|}
\hline Analyte & $\begin{array}{c}\text { Frequency } \\
\text { of } \\
\text { detection }\end{array}$ & $\begin{array}{l}\text { Minimum } \\
\text { detected } \\
\text { concentration }\end{array}$ & $\begin{array}{c}\text { Maximum } \\
\text { detected } \\
\text { concentration }\end{array}$ & $\begin{array}{c}\text { Lower 95\% } \\
\text { confidence } \\
\text { boind on } \\
\text { median }\end{array}$ & $\begin{array}{c}\text { Median } \\
\text { concentration }\end{array}$ & $\begin{array}{c}\text { Upper 95\% } \\
\text { confidence } \\
\text { bound on } \\
\text { median }\end{array}$ \\
\hline & \multicolumn{4}{|c|}{ Inorganics (mg/kg) } & & \\
\hline Arsenic & $4 / 4$ & $1.13 E+01$ & $6.71 E+01$ & $1.88 \mathrm{E}+01$ & $241 E+01$ & 3.07E+01 \\
\hline Batium & $4 / 4$ & $6.29 \mathrm{E}+01$ & $7.99 \mathrm{E}+01$ & $5.53 \mathrm{E}+01$ & $7.18 \mathrm{E}+01$ & $9.32 E+01$ \\
\hline Beryllium & $3 / 4$ & $5.10 \mathrm{E}-01$ & $5.70 \mathrm{E}-01$ & 4.12E-01 & 5.11E-01 & $6.34 \mathrm{E}-01$ \\
\hline Chromium VI & $4 / 4$ & $1.05 E+01$ & $239 \mathrm{E}+01$ & $1.30 \mathrm{E}+01$ & $1.54 \mathrm{E}+01$ & $1.83 \mathrm{E}+01$ \\
\hline Manganese & $4 / 4$ & $9.40 E+02$ & $1.53 \mathrm{E}+03$ & $7.80 \mathrm{E}+02$ & $1.07 \mathrm{E}+03$ & $1.46 \mathrm{E}+03$ \\
\hline Mercury & $4 / 4$ & $1.40 \mathrm{E}-01$ & $1.80 \mathrm{E}-01$ & 1.34E-01 & $1.57 \mathrm{E}-01$ & $1.84 \mathrm{E}-01$ \\
\hline Mercury (salts) & $4 / 4$ & $1.40 \mathrm{E}-01$ & $1.80 \mathrm{E}-01$ & 1.34E-01 & 1.57E-01 & $1.84 \mathrm{E}-01$ \\
\hline Molybdenum & $1 / 4$ & $1.80 \mathrm{E}+00$ & $1.80 \mathrm{E}+00$ & $1.14 \mathrm{E}+00$ & $1.41 \mathrm{E}+00$ & $1.75 E+00$ \\
\hline Nickel & $3 / 4$ & $7.40 \mathrm{E}+00$ & $8.10 \mathrm{E}+00$ & $6.03 E+00$ & $7.65 \mathrm{E}+00$ & $9.71 E+00$ \\
\hline Nickel (salts) & $3 / 4$ & $7.40 \mathrm{E}+00$ & $8.10 \mathrm{E}+00$ & $6.03 E+00$ & $7.65 \mathrm{E}+00$ & $9.71 E+00$ \\
\hline Selenium & $4 / 4$ & $5.60 \mathrm{E}-01$ & 7.00E-01 & $5.05 E-01$ & 6.37E-01 & 8.03E-01 \\
\hline Strontium & $4 / 4$ & $270 E+00$ & $4.10 \mathrm{E}+00$ & $256 \mathrm{E}+00$ & $3.51 E+00$ & $4.81 E+00$ \\
\hline Vanadium & $4 / 4$ & 2.17E+01 & $3.11 E+01$ & $231 E+01$ & $264 E+01$ & $3.03 \mathrm{E}+01$ \\
\hline \multirow[t]{2}{*}{ Zine } & $4 / 4$ & $292 E+01$ & $4.13 E+01$ & $283 E+01$ & $3.49 E+01$ & $4.32 E+01$ \\
\hline & \multicolumn{4}{|c|}{ Organics (mg/kg) } & & \\
\hline Acenaphthene & $3 / 6$ & $8.00 \mathrm{E}-01$ & $240 E+00$ & $1.05 \mathrm{E}+00$ & $1.42 \mathrm{E}+00$ & $1.93 E+00$ \\
\hline Anthracene & $8 / 8$ & $4.00 \mathrm{E}-01$ & $1.46 \mathrm{E}+01$ & 5.43E- 01 & $8.80 \mathrm{E}-01$ & $1.42 E+00$ \\
\hline Benzo(a)anthracene & $12 / 12$ & 4.00E-01 & $7.50 \mathrm{E}+00$ & $1.52 \mathrm{E}+\infty 0$ & $201 E+\infty$ & $267 \mathrm{E}+00$ \\
\hline Benzo(a)pyrene & $10 / 10$ & $8.00 \mathrm{E}-01$ & $1.13 E+01$ & $1.99 \mathrm{E}+00$ & $266 \mathrm{E}+00$ & $3.54 \mathrm{E}+00$ \\
\hline Benzo(b)fluoranthene & $8 / 8$ & $4.00 \mathrm{E}-01$ & $9.40 \mathrm{E}+00$ & $1.55 \mathrm{E}+00$ & $2.19 E+00$ & $3.11 E+00$ \\
\hline Benzo(gh,i)perylene & $9 / 9$ & $4.00 \mathrm{E}-01$ & $1.01 \mathrm{E}+01$ & $212 E+00$ & $285 \mathrm{E}+00$ & $3.82 \mathrm{E}+00$ \\
\hline Benzo(k)fluoranthene & $11 / 11$ & $4.00 \mathrm{E}-01$ & $6.00 \mathrm{E}+00$ & $1.08 \mathrm{E}+00$ & $1.40 \mathrm{E}+00$ & $1.81 E+00$ \\
\hline Chrysene & $9 / 9$ & $1.20 \mathrm{E}+00$ & $1.20 \mathrm{E}+01$ & $284 E+\infty 0$ & $3.93 \mathrm{E}+00$ & $5.45 \mathrm{E}+00$ \\
\hline Dibenz $(2, h)$ anthracene & $8 / 8$ & $4.00 \mathrm{E}-01$ & $3.80 \mathrm{E}+00$ & 6.67E-01 & $1.03 E+00$ & $1.59 \mathrm{E}+00$ \\
\hline Fluoranthene & $12 \pi 2$ & $1.50 \mathrm{E}+\infty 0$ & $289 \mathrm{E}+01$ & $4.35 E+00$ & $5.95 \mathrm{E}+00$ & $8.12 E+00$ \\
\hline Fluorene & $3 / 6$ & $4.00 \mathrm{E}-01$ & $220 \mathrm{E}+\infty 0$ & $4.80 \mathrm{E}-01$ & 8.73E-01 & $1.59 \mathrm{E}+00$ \\
\hline Naphthalene & $3 \pi$ & $7.50 E \div 00$ & $203 E+01$ & $3.93 E+00$ & $8.05 E+00$ & $1.65 \mathrm{E}+01$ \\
\hline Phenanthrene & $12 / 12$ & $1.50 \mathrm{E}+\infty 00$ & $1.91 E+01$ & $3.06 \mathrm{E}+00$ & $4.06 \mathrm{E}+00$ & $5.39 E+\infty 0$ \\
\hline \multirow[t]{2}{*}{ Pyrene } & $12 / 12$ & $4.00 \mathrm{E}-01$ & $263 E+01$ & $3.61 E+\infty 0$ & $5.04 E+\infty 0$ & $7.02 E+\infty 0$ \\
\hline & \multicolumn{5}{|c|}{ Radionuciides (pCi/g) } & \\
\hline Cesium-137 & $4 / 4$ & $6.59 \mathrm{E}-01$ & $1.10 \mathrm{E}+\infty$ & $3.57 \mathrm{E}-01$ & $8.42 \mathrm{E}-01$ & $1.99 \mathrm{E}+00$ \\
\hline Neptunium-237 & $4 / 4$ & $6.72 \mathrm{E}-02$ & 1.11E-01 & $6.54 \mathrm{E}-02$ & 8.41E-02 & 1.08E-01 \\
\hline
\end{tabular}




\section{7-8}

Table 7.1c (continued)

\begin{tabular}{lcccccc}
\hline & $\begin{array}{c}\text { Frequency } \\
\text { of } \\
\text { detection }\end{array}$ & $\begin{array}{c}\text { Minimum } \\
\text { detected } \\
\text { concentration }\end{array}$ & $\begin{array}{c}\text { Maximum } \\
\text { detected } \\
\text { concentration }\end{array}$ & $\begin{array}{c}\text { Lower } 95 \% \\
\text { confidence } \\
\text { bound on } \\
\text { median }\end{array}$ & $\begin{array}{c}\text { Median } \\
\text { concentration }\end{array}$ & $\begin{array}{c}\text { Upper 95\% } \\
\text { confidence } \\
\text { bound on } \\
\text { median }\end{array}$ \\
\hline Plutyte & $3 / 4$ & $1.68 \mathrm{E}-02$ & $298 \mathrm{E}-02$ & $1.41 \mathrm{E}-02$ & $232 \mathrm{E}-02$ & $3.82 \mathrm{E}-02$ \\
Plutonium-239/240 & $3 / 3$ & $210 \mathrm{E}-02$ & $3.97 \mathrm{E}-02$ & $1.30 \mathrm{E}-02$ & $279 \mathrm{E}-02$ & $5.98 \mathrm{E}-02$ \\
Potassium-40 & $4 / 4$ & $3.74 \mathrm{E}+00$ & $4.29 \mathrm{E}+00$ & $3.38 \mathrm{E}+00$ & $4.10 \mathrm{E}+00$ & $4.97 \mathrm{E}+00$ \\
Radium-226 & $4 / 4$ & $1.12 \mathrm{E}+00$ & $1.37 \mathrm{E}+00$ & $8.40 \mathrm{E}-01$ & $1.22 \mathrm{E}+00$ & $1.78 \mathrm{E}+00$ \\
Thorium-228 & $3 / 4$ & $6.09 \mathrm{E}-01$ & $7.86 \mathrm{E}-01$ & $237 \mathrm{E}-01$ & $3.39 \mathrm{E}-01$ & $4.84 \mathrm{E}-01$ \\
Thorium-230 & $4 / 4$ & $9.11 \mathrm{E}-01$ & $1.47 \mathrm{E}+00$ & $9.24 \mathrm{E}-01$ & $1.11 \mathrm{E}+00$ & $1.33 \mathrm{E}+00$ \\
Thorium-232 & $4 / 4$ & $6.25 \mathrm{E}-01$ & $7.73 \mathrm{E}-01$ & $5.84 \mathrm{E}-01$ & $6.79 \mathrm{E}-01$ & $7.89 \mathrm{E}-01$ \\
Thorium-234 & $2 / 3$ & $1.86 \mathrm{E}+00$ & $218 \mathrm{E}+00$ & $1.32 \mathrm{E}+00$ & $1.56 \mathrm{E}+00$ & $1.84 \mathrm{E}+00$ \\
Tritium ${ }^{a}$ & $4 / 5$ & $1.20 \mathrm{E}-02$ & $240 \mathrm{E}-02$ & $9.70 \mathrm{E}-03$ & $1.60 \mathrm{E}-02$ & $264 \mathrm{E}-02$ \\
Uranium-233/234 & $4 / 4$ & $1.17 \mathrm{E}+00$ & $1.86 \mathrm{E}+00$ & $1.20 \mathrm{E}+00$ & $1.45 \mathrm{E}+00$ & $1.75 \mathrm{E}+00$ \\
Uranium-235 & $4 / 4$ & $5.62 \mathrm{E}-02$ & $1.93 \mathrm{E}-01$ & $8.86 \mathrm{E}-02$ & $1.25 \mathrm{E}-01$ & $1.77 \mathrm{E}-01$ \\
Uranium-236 & $1 / 4$ & $218 \mathrm{E}-02$ & $218 \mathrm{E}-02$ & $6.60 \mathrm{E}-03$ & $1.07 \mathrm{E}-02$ & $1.74 \mathrm{E}-02$ \\
Uranium-238 & $4 / 4$ & $1.10 \mathrm{E}+00$ & $1.57 \mathrm{E}+00$ & $1.23 \mathrm{E}+00$ & $1.38 \mathrm{E}+00$ & $1.54 \mathrm{E}+00$ \\
\hline
\end{tabular}

Data are based on noncomposited samples.

Table 7.1d. Oak Ridge Reservation background soil analytes evaluated quantitatively Chepultepec

\begin{tabular}{|c|c|c|c|c|c|c|}
\hline Analyte & $\begin{array}{c}\text { Frequency } \\
\text { of } \\
\text { detection }\end{array}$ & $\begin{array}{c}\text { Minimum } \\
\text { detected } \\
\text { concentration }\end{array}$ & $\begin{array}{c}\text { Marimum } \\
\text { detected } \\
\text { concentration }\end{array}$ & $\begin{array}{c}\text { Lower } 95 \% \\
\text { confidence } \\
\text { bound on } \\
\text { median }\end{array}$ & $\begin{array}{c}\text { Median } \\
\text { concentration }\end{array}$ & $\begin{array}{c}\text { Upper } 95 \% \\
\text { confidence } \\
\text { bound on } \\
\text { median }\end{array}$ \\
\hline \multicolumn{7}{|c|}{ Inorganics (mg/kg) } \\
\hline Arsenic & $4 / 4$ & $4.40 E+00$ & $3.12 E+01$ & $8.82 \mathrm{E}+00$ & $1.13 E+01$ & $1.44 \mathrm{E}+01$ \\
\hline Barium & $4 / 4$ & $3.16 \mathrm{E}+01$ & $1.51 E+02$ & $4.13 E+01$ & $5.36 \mathrm{E}+01$ & $6.95 \mathrm{E}+01$ \\
\hline Beryllium & $2 / 4$ & $280 \mathrm{E}-01$ & $5.50 \mathrm{E}-01$ & $266 \mathrm{E}-01$ & $3.50 \mathrm{E}-01$ & 4.60E-01 \\
\hline Chromium VI & $3 / 4$ & 1.17E+01 & $3.38 \mathrm{E}+01$ & $1.23 E+01$ & $1.46 \mathrm{E}+01$ & $1.74 \mathrm{E}+01$ \\
\hline Manganese & $4 / 4$ & $3.86 \mathrm{E}+02$ & $243 E+03$ & $6.72 \mathrm{E}+02$ & $9.21 E+02$ & $1.26 \mathrm{E}+03$ \\
\hline Mercury & $2 / 4$ & $1.00 \mathrm{E}-01$ & $200 \mathrm{E}-01$ & $1.09 \mathrm{E}-01$ & $1.29 \mathrm{E}-01$ & $1.53 \mathrm{E}-01$ \\
\hline Mercury (salts) & $2 / 4$ & $1.00 \mathrm{E}-01$ & 200E-01 & $1.09 \mathrm{E}-01$ & $1.29 \mathrm{E}-01$ & $1.53 \mathrm{E}-01$ \\
\hline Selenium & $1 / 2$ & $5.00 \mathrm{E}-01$ & $5.60 \mathrm{E}-01$ & $3.09 \mathrm{E}-01$ & 4.40E-01 & $6.25 \mathrm{E}-01$ \\
\hline Strontium & $2 / 4$ & $290 \mathrm{E}+00$ & $4.80 \mathrm{E}+00$ & $1.68 \mathrm{E}+00$ & $236 \mathrm{E}+00$ & $3.33 E+00$ \\
\hline Vanadium & $4 / 4$ & $1.88 \mathrm{E}+01$ & $6.12 E+01$ & $262 E+01$ & $3.00 \mathrm{E}+01$ & $3.43 E+01$ \\
\hline Zinc & $4 / 4$ & $214 E+01$ & $9.92 E+01$ & $3.18 \mathrm{E}+01$ & $3.93 E+01$ & $4.86 \mathrm{E}+01$ \\
\hline
\end{tabular}


Table 7.1d (continued)

\begin{tabular}{|c|c|c|c|c|c|c|}
\hline Analyte & $\begin{array}{c}\text { Frequency } \\
\text { of } \\
\text { detection }\end{array}$ & $\begin{array}{l}\text { Minimum } \\
\text { detected } \\
\text { concentration }\end{array}$ & $\begin{array}{l}\text { Maximum } \\
\text { detected } \\
\text { concentration }\end{array}$ & $\begin{array}{c}\text { Lower } 95 \% \\
\text { confidence } \\
\text { bound on } \\
\text { median }\end{array}$ & $\begin{array}{c}\text { Median } \\
\text { concentration }\end{array}$ & $\begin{array}{c}\text { Upper } 95 \% \\
\text { confidence } \\
\text { bound on } \\
\text { median }\end{array}$ \\
\hline \multicolumn{7}{|c|}{ Organics (mg/kg) } \\
\hline Acenaphthene & $1 / 4$ & $8.00 \mathrm{E}-01$ & $8.00 \mathrm{E}-01$ & $4.70 \mathrm{E}-01$ & $8.00 \mathrm{E}-01$ & $1.36 \mathrm{E}+00$ \\
\hline Anthracene & $2 / 4$ & 4.00E-01 & 4.00E-01 & $1.53 \mathrm{E}-01$ & $3.98 \mathrm{E}-01$ & $1.04 \mathrm{E}+00$ \\
\hline Benzo(a)anthracene & $7 n$ & 4.00E-01 & $4.50 E+00$ & $1.17 \mathrm{E}+00$ & $1.70 \mathrm{E}+\infty 0$ & $246 E+00$ \\
\hline Benzo(a)pyrene & $5 / 5$ & $260 E+00$ & $5.30 \mathrm{E}+00$ & $218 E+\infty 0$ & $3.28 \mathrm{E}+00$ & $4.93 E+00$ \\
\hline Benzo(b)fluoranthene & $2 / 4$ & $3.40 \mathrm{E}+00$ & $4.50 \mathrm{E}+00$ & $1.67 \mathrm{E}+00$ & $297 \mathrm{E}+00$ & $5.28 \mathrm{E}+00$ \\
\hline Benzo(gh,i)perylene & $6 / 6$ & $1.60 \mathrm{E}+00$ & $3.80 \mathrm{E}+00$ & $1.79 \mathrm{E}+00$ & $257 \mathrm{E}+00$ & $3.68 \mathrm{E}+00$ \\
\hline Benzo(k)fluoranthene & $5 / 5$ & $1.10 \mathrm{E}+00$ & $250 \mathrm{E}+00$ & $1.07 \mathrm{E}+00$ & $1.57 \mathrm{E}+00$ & $229 \mathrm{E}+00$ \\
\hline Dibenz(a,h)anthracene & $3 / 5$ & $4.00 \mathrm{E}-01$ & $3.70 \mathrm{E}+00$ & $5.18 \mathrm{E}-01$ & $1.03 \mathrm{E}+00$ & $203 E+00$ \\
\hline Fluoranthene & $7 \pi$ & 4.00E-01 & $8.90 E+00$ & $205 E+00$ & $3.09 \mathrm{E}+00$ & $4.64 \mathrm{E}+00$ \\
\hline Fluorene & $2 / 6$ & $200 \mathrm{E}-01$ & $8.00 \mathrm{E}-01$ & $1.84 \mathrm{E}-01$ & $3.65 \mathrm{E}-01$ & $7.26 \mathrm{E}-01$ \\
\hline Indeno(1,23-cd)pyrene & $1 \pi$ & $1.64 \mathrm{E}+01$ & $1.64 \mathrm{E}+01$ & $3.87 \mathrm{E}+00$ & $7.85 E+00$ & $1.59 \mathrm{E}+01$ \\
\hline Naphthalene & $3 / 4$ & $4.70 E+00$ & $4.84 \mathrm{E}+01$ & $4.20 \mathrm{E}+00$ & $9.50 \mathrm{E}+00$ & $2.15 E+01$ \\
\hline Phenantbrene & $7 \pi$ & $1.50 \mathrm{E}+00$ & $5.30 \mathrm{E}+00$ & $215 E+\infty 0$ & $3.12 E+00$ & $4.52 E+00$ \\
\hline Pyrene & $7 \pi$ & $1.20 \mathrm{E}+00$ & 8.00E+00 & $221 E+\infty$ & $3.42 \mathrm{E}+00$ & $5.28 \mathrm{E}+00$ \\
\hline \multicolumn{7}{|c|}{ Radionuciides (pCi/g) } \\
\hline Cesium-137 & $4 / 4$ & $8.30 \mathrm{E}-01$ & $1.20 \mathrm{E}+00$ & 4.23E-01 & $9.99 \mathrm{E}-01$ & $236 \mathrm{E}+\infty 0$ \\
\hline Neptunium-237 & $2 / 4$ & 3.21E-02 & 8.63E-02 & 5.07E-02 & $6.72 \mathrm{E}-02$ & $8.91 E-02$ \\
\hline Plutonium-238 & $1 / 4$ & 5.13E-02 & $1.84 \mathrm{E}-01$ & 4.93E-02 & $8.02 \mathrm{E}-02$ & $1.31 \mathrm{E}-01$ \\
\hline Potassium -40 & $4 / 4$ & $205 E+00$ & $4.34 \mathrm{E}+00$ & $259 E+\infty 0$ & $3.15 E+00$ & $3.82 E+00$ \\
\hline Radium-226 & $3 / 4$ & $8.40 \mathrm{E}-01$ & $1.25 \mathrm{E}+00$ & $5.99 E-01$ & 8.71E-01 & $1.27 \mathrm{E}+00$ \\
\hline Thorium-228 & $4 / 4$ & 4.07E-01 & 8.99E-01 & 4.25E-01 & $6.06 \mathrm{E}-01$ & 8.63E-01 \\
\hline Thorium-230 & $4 / 4$ & 6.67E-01 & $1.09 \mathrm{E}+00$ & $6.46 \mathrm{E}-01$ & $7.74 \mathrm{E}-01$ & $9.27 \mathrm{E}-01$ \\
\hline Thorium-232 & $4 / 4$ & 4.87E- 01 & $1.31 \mathrm{E}+\infty 0$ & 5.35E-01 & $6.22 \mathrm{E}-01$ & 7.22E-01 \\
\hline Uranium-233/234 & $4 / 4$ & $8.68 \mathrm{E}-01$ & $1.23 E+00$ & $9.14 E-01$ & $1.10 \mathrm{E}+00$ & $1.34 E+00$ \\
\hline Uranium-235 & $2 / 4$ & $5.74 \mathrm{E}-02$ & 2.1TE-01 & 4.99E-02 & 7.21E-02 & $1.04 \mathrm{E}-01$ \\
\hline Uranium-238 & $4 / 4$ & $9.39 \mathrm{E}-01$ & $1.35 E+\infty$ & $1.00 \mathrm{E}+00$ & $1.12 \mathrm{E}+00$ & $1.26 \mathrm{E}+00$ \\
\hline
\end{tabular}

a Data are based on noncomposited samples. 
Table 7.1e. Oak Ridge Reservation background soil analytes evaluated quantitatively Chickamauga (Bethel Valley)

\begin{tabular}{|c|c|c|c|c|c|c|}
\hline Analyte & $\begin{array}{l}\text { Frequency } \\
\text { of } \\
\text { detection }\end{array}$ & $\begin{array}{l}\text { Minimum } \\
\text { detected } \\
\text { concentration }\end{array}$ & $\begin{array}{l}\text { Maximum } \\
\text { detected } \\
\text { concentration }\end{array}$ & $\begin{array}{c}\text { Lower } 95 \% \\
\text { confidence } \\
\text { bound on } \\
\text { median }\end{array}$ & $\begin{array}{c}\text { Median } \\
\text { concentration }\end{array}$ & $\begin{array}{c}\text { Upper } 95 \% \\
\text { confidence } \\
\text { bound on } \\
\text { median }\end{array}$ \\
\hline \multicolumn{7}{|c|}{ Inorganics (mg/kg) } \\
\hline Arsenic & $4 / 4$ & $5.70 E+00$ & $7.00 \mathrm{E}+00$ & $4.89 \mathrm{E}+00$ & $6.25 \mathrm{E}+00$ & $7.99 \mathrm{E}+00$ \\
\hline Barium & $4 / 4$ & $7.06 \mathrm{E}+01$ & $1.03 \mathrm{E}+02$ & $6.13 \mathrm{E}+01$ & $7.96 \mathrm{E}+01$ & $1.03 E+02$ \\
\hline Beryllium & $4 / 4$ & $7.80 \mathrm{E}-01$ & $1.20 \mathrm{E}+00$ & $8.30 \mathrm{E}-01$ & $1.02 \mathrm{E}+00$ & $1.25 E+00$ \\
\hline Chromium VI & $4 / 4$ & $234 E+01$ & $4.47 \mathrm{E}+01$ & $287 \mathrm{E}+01$ & $3.40 \mathrm{E}+01$ & $4.02 E+01$ \\
\hline Manganese & $4 / 4$ & $7.40 \mathrm{E}+02$ & $1.51 E+03$ & $7.69 E+02$ & $1.05 \mathrm{E}+03$ & $1.44 E+03$ \\
\hline Mercury & $4 / 4$ & $1.30 \mathrm{E}-01$ & $210 \mathrm{E}-01$ & $1.37 \mathrm{E}-01$ & $1.60 \mathrm{E}-01$ & $1.88 \mathrm{E}-01$ \\
\hline Mercury (salts) & $4 / 4$ & $1.30 \mathrm{E}-01$ & 210E-01 & $1.37 \mathrm{E}-01$ & $1.60 \mathrm{E}-01$ & $1.88 \mathrm{E}-01$ \\
\hline Nickel & $4 / 4$ & $1.00 \mathrm{E}+01$ & $1.85 \mathrm{E}+01$ & $1.08 \mathrm{E}+01$ & $1.35 \mathrm{E}+01$ & $1.67 \mathrm{E}+01$ \\
\hline Nickel (salts) & $4 / 4$ & $1.00 \mathrm{E} \div 01$ & $1.85 \mathrm{E}+01$ & $1.08 \mathrm{E}+01$ & $1.35 \mathrm{E}+01$ & $1.67 \mathrm{E}+01$ \\
\hline Selenium & $4 / 4$ & $5.50 \mathrm{E}-01$ & $1.00 \mathrm{E}+00$ & $5.86 \mathrm{E}-01$ & $7.39 \mathrm{E}-01$ & $9.31 \mathrm{E}-01$ \\
\hline Strontium & $2 / 2$ & $5.30 \mathrm{E}+00$ & $5.60 \mathrm{E}+00$ & $3.53 E+\infty 0$ & $5.52 \mathrm{E}+00$ & $8.64 \mathrm{E}+\infty 0$ \\
\hline Vanadium & $4 / 4$ & $286 \mathrm{E}+01$ & $4.80 \mathrm{E}+01$ & $3.19 E+01$ & $3.65 \mathrm{E}+01$ & $4.19 \mathrm{E}+01$ \\
\hline Zinc & $4 / 4$ & $3.77 \mathrm{E}+01$ & $5.23 E+01$ & $3.63 E+01$ & $4.49 \mathrm{E}+01$ & $5.55 \mathrm{E}+01$ \\
\hline \multicolumn{7}{|c|}{ Organics (mg/kg) } \\
\hline Acenaphthene & $1 / 1$ & $3.50 \mathrm{E}+00$ & $3.50 \mathrm{E}+00$ & $205 E+00$ & $3.50 \mathrm{E}+00$ & $5.96 \mathrm{E}+00$ \\
\hline Anthracene & $5 / 5$ & 4.00E-01 & $1.30 \mathrm{E}+00$ & $3.38 \mathrm{E}-01$ & $6.23 \mathrm{E}-01$ & $1.15 E+00$ \\
\hline Benzo(2)anthracene & $6 / 6$ & $250 E+00$ & $7.50 \mathrm{E}+00$ & $288 \mathrm{E}+00$ & $4.30 \mathrm{E}+00$ & $6.42 \mathrm{E}+00$ \\
\hline Benzo(a)pyrene & $12 \pi 2$ & $9.00 \mathrm{E}-01$ & $7.50 \mathrm{E}+00$ & $291 E+00$ & $3.78 \mathrm{E}+00$ & $4.92 \mathrm{E}+00$ \\
\hline Benzo(b)fluoranthene & $8 / 8$ & $210 E+00$ & $7.10 \mathrm{E}+\infty 0$ & $3.14 E+\infty$ & $4.45 E+\infty 0$ & $6.30 \mathrm{E}+00$ \\
\hline Benzo(g,h,i)perylene & $5 / 5$ & $2.10 E+\infty 0$ & $4.70 \mathrm{E}+00$ & $233 E+00$ & $3.46 \mathrm{E}+\infty 0$ & $5.13 E+00$ \\
\hline Benzo(k)fluoranthene & $12 / 12$ & $9.00 \mathrm{E}-01$ & $4.40 \mathrm{E}+00$ & $1.78 \mathrm{E}+00$ & $227 \mathrm{E}+00$ & $291 E+00$ \\
\hline Chrysene & $4 / 5$ & $3.40 \mathrm{E}+00$ & $8.60 \mathrm{E}+00$ & $3.17 E+00$ & $4.98 \mathrm{E}+00$ & $7.82 E+00$ \\
\hline Dibenz(a,b)anthracene & $2 / 3$ & $4.00 \mathrm{E}-01$ & $9.00 \mathrm{E}-01$ & 252E-01 & $5.97 \mathrm{E}-01$ & $1.42 E+00$ \\
\hline Fluoranthene & $8 / 8$ & $1.30 \mathrm{E}+00$ & $1.25 \mathrm{E}+01$ & $3.38 \mathrm{E}+00$ & $4.95 \mathrm{E}+00$ & $7.26 \mathrm{E}+00$ \\
\hline Fluorene & 22 & $1.30 \mathrm{E}+00$ & $5.20 \mathrm{E}+00$ & $1.22 \mathrm{E}+00$ & $260 \mathrm{E}+00$ & $5.54 \mathrm{E}+00$ \\
\hline Indeno(1,2,3-cd)pyrene & $8 / 11$ & $5.30 E+00$ & $5.66 \mathrm{E}+01$ & $7.77 \mathrm{E}+00$ & $1.12 E+01$ & $1.62 \mathrm{E}+01$ \\
\hline Naphthalene & $7 n$ & $8.00 \mathrm{E}-01$ & $250 \mathrm{E}+01$ & $3.52 \mathrm{E}+00$ & $6.21 E+\infty$ & $1.09 \mathrm{E}+01$ \\
\hline Phenanthrene & $12 / 12$ & $3.50 \mathrm{E}+\infty 0$ & $208 \mathrm{E}+01$ & $4.99 \mathrm{E}+00$ & $6.63 E+00$ & $8.79 \mathrm{E}+00$ \\
\hline Pyrene & $6 / 6$ & $4.70 E+00$ & $1.10 \mathrm{E}+01$ & $4.90 \mathrm{E}+00$ & $7.84 \mathrm{E}+\infty 0$ & $1.25 \mathrm{E}+01$ \\
\hline
\end{tabular}




\section{7-11}

Table 7.1e (continued)

\begin{tabular}{|c|c|c|c|c|c|c|}
\hline Analyte & $\begin{array}{c}\text { Frequency } \\
\text { of } \\
\text { detection }\end{array}$ & $\begin{array}{c}\text { Minimum } \\
\text { detected } \\
\text { concentration }\end{array}$ & $\begin{array}{c}\text { Maximum } \\
\text { detected } \\
\text { concentration }\end{array}$ & $\begin{array}{c}\text { Lower 95\% } \\
\text { confidence } \\
\text { bound on } \\
\text { median }\end{array}$ & $\begin{array}{c}\text { Median } \\
\text { concentration }\end{array}$ & $\begin{array}{c}\text { Upper } 95 \% \\
\text { confidence } \\
\text { bound on } \\
\text { median }\end{array}$ \\
\hline \multicolumn{7}{|c|}{ Radionuclides (pCi/g) } \\
\hline Cesium-137 & $4 / 4$ & $8.98 \mathrm{E}-01$ & $209 \mathrm{E}+00$ & $5.72 \mathrm{E}-01$ & $1.35 \mathrm{E}+00$ & $3.19 \mathrm{E}+00$ \\
\hline Neptunium-237 & $3 / 3$ & $6.72 \mathrm{E}-02$ & 1.41E-01 & $6.98 \mathrm{E}-02$ & $9.34 \mathrm{E}-02$ & $1.25 \mathrm{E}-01$ \\
\hline Plutonium-238 & $1 / 3$ & $1.03 \mathrm{E}-01$ & $1.33 \mathrm{E}-01$ & $4.24 \mathrm{E}-02$ & $7.39 \mathrm{E}-02$ & $1.29 \mathrm{E}-01$ \\
\hline Plutonium-239/240 & $1 / 3$ & 289E-02 & $7.65 \mathrm{E}-02$ & $1.37 \mathrm{E}-02$ & $3.25 \mathrm{E}-02$ & $7.72 \mathrm{E}-02$ \\
\hline Potassium- 40 & $4 / 4$ & $1.02 \mathrm{E} \div 01$ & $239 \mathrm{E}+01$ & $1.25 \mathrm{E}+01$ & $1.52 \mathrm{E}+01$ & $1.84 \mathrm{E}+01$ \\
\hline Radium-226 & $4 / 4$ & 7.47E-01 & $1.98 \mathrm{E}+00$ & 7.41E-01 & $1.08 \mathrm{E}+00$ & $1.57 \mathrm{E}+00$ \\
\hline Technetium-99 & $2 / 6$ & $203 E+\infty 0$ & $256 \dot{\mathrm{E}}+00$ & $7.95 \mathrm{E}-01$ & $1.26 \mathrm{E}+00$ & $1.98 \mathrm{E}+00$ \\
\hline Thotium-228 & $4 / 4$ & $1.14 \mathrm{E}+\infty 0$ & $1.58 \mathrm{E}+00$ & $9.04 \mathrm{E}-01$ & $1.29 \mathrm{E}+00$ & $1.84 E+00$ \\
\hline Thorium-230 & $4 / 4$ & $9.98 \mathrm{E}-01$ & $1.19 E+00$ & 8.82E-01 & $1.06 \mathrm{E}+00$ & $1.27 \mathrm{E}+00$ \\
\hline Thorium-232 & $4 / 4$ & $1.04 \mathrm{E}+00$ & $1.56 \mathrm{E}+00$ & $1.07 \mathrm{E}+00$ & $1.25 \mathrm{E}+00$ & $1.45 \mathrm{E}+00$ \\
\hline Tritium ${ }^{a}$ & $3 / 12$ & $1.20 \mathrm{E}-01$ & 8.50E-01 & $7.89 \mathrm{E}-02$ & $1.13 \mathrm{E}-01$ & $1.62 \mathrm{E}-01^{\circ}$ \\
\hline Uranium-233/234 & $4 / 4$ & 9.17E-01 & $1.14 E+00$ & $8.38 \mathrm{E}-01$ & $1.01 E+00$ & $1.22 \mathrm{E}+00$ \\
\hline Uranium-235 & $4 / 4$ & $3.38 \mathrm{E}-02$ & 1.43E- 01 & $6.58 \mathrm{E}-02$ & $9.30 \mathrm{E}-02$ & $1.32 \mathrm{E}-01$ \\
\hline Uranium-238 & $4 / 4$ & $9.51 \mathrm{E}-01$ & $1.19 E+00$ & $9.50 \mathrm{E}-01$ & $1.06 \mathrm{E}+\infty 0$ & $1.19 \mathrm{E}+00$ \\
\hline
\end{tabular}

${ }^{a}$ Data are based on noncomposited samples.

Table 7.1f. Oak Ridge Reservation background soil analytes evaluated quantitatively Chickamauga (K-25)

\begin{tabular}{lcccccc}
\hline & $\begin{array}{c}\text { Frequency } \\
\text { of } \\
\text { detection }\end{array}$ & $\begin{array}{c}\text { Medium } \\
\text { detected } \\
\text { concentration }\end{array}$ & $\begin{array}{c}\text { Maximum } \\
\text { detected } \\
\text { concentration }\end{array}$ & $\begin{array}{c}\text { Lower 95\% } \\
\text { confidence } \\
\text { bound on } \\
\text { median }\end{array}$ & $\begin{array}{c}\text { Median } \\
\text { concentration }\end{array}$ & $\begin{array}{c}\text { Upper 95\% } \\
\text { confidence } \\
\text { bound on } \\
\text { median }\end{array}$ \\
\hline & & & Inorganics (mg/kg) & & & $9.73 \mathrm{E}+00$ \\
Arsenic & $4 / 4$ & $5.40 \mathrm{E}+00$ & $9.80 \mathrm{E}+00$ & $5.96 \mathrm{E}+00$ & $7.61 \mathrm{E}+00$ & $9.96 \mathrm{E}+01$ \\
Barium & $4 / 4$ & $5.10 \mathrm{E}+01$ & $9.97 \mathrm{E}+01$ & $5.91 \mathrm{E}+01$ & $7.67 \mathrm{E}+01$ & $1.12 \mathrm{E}+00$ \\
Beryllium & $4 / 4$ & $6.50 \mathrm{E}-01$ & $1.40 \mathrm{E}+00$ & $7.44 \mathrm{E}-01$ & $9.13 \mathrm{E}-01$ & $3.85 \mathrm{E}+01$ \\
Chromium VI & $4 / 4$ & $1.88 \mathrm{E}+01$ & $4.46 \mathrm{E}+01$ & $274 \mathrm{E}+01$ & $3.25 \mathrm{E}+01$ & $2.29 \mathrm{E}+03$ \\
Manganese & $4 / 4$ & $1.19 \mathrm{E}+03$ & $2.35 \mathrm{E}+03$ & $1.22 \mathrm{E}+03$ & $1.67 \mathrm{E}+03$ & $5.79 \mathrm{E}-01$ \\
Mercury & $4 / 4$ & $3.00 \mathrm{E}-01$ & $8.00 \mathrm{E}-01$ & $4.21 \mathrm{E}-01$ & $4.94 \mathrm{E}-01$ & $5.79 \mathrm{E}-01$ \\
Mercury (salts) & $4 / 4$ & $3.00 \mathrm{E}-01$ & $8.00 \mathrm{E}-01$ & $4.21 \mathrm{E}-01$ & $4.94 \mathrm{E}-01$ & $213 \mathrm{E}+01$ \\
Nickel & $4 / 4$ & $1.02 \mathrm{E}+01$ & $261 \mathrm{E}+01$ & $1.39 \mathrm{E}+01$ & $1.72 \mathrm{E}+01$ & $2.13 \mathrm{E}+01$ \\
Nickel (salts) & $4 / 4$ & $1.02 \mathrm{E}+01$ & $2.61 \mathrm{E}+01$ & $1.39 \mathrm{E}+01$ & $1.72 \mathrm{E}+01$ & $9.62 \mathrm{E}-01$ \\
Selenium & $4 / 4$ & $5.70 \mathrm{E}-01$ & $1.10 \mathrm{E}+00$ & $6.05 \mathrm{E}-01$ & $7.63 \mathrm{E}-01$ &
\end{tabular}


Table 7.1f (continued)

\begin{tabular}{|c|c|c|c|c|c|c|}
\hline Analyte & $\begin{array}{c}\text { Frequency } \\
\text { of } \\
\text { detection }\end{array}$ & $\begin{array}{c}\text { Medium } \\
\text { detected } \\
\text { concentration }\end{array}$ & $\begin{array}{c}\text { Maximum } \\
\text { detected } \\
\text { concentration }\end{array}$ & $\begin{array}{l}\text { Lower } 95 \% \\
\text { confidence } \\
\text { bound on } \\
\text { median }\end{array}$ & $\begin{array}{c}\text { Median } \\
\text { concentration }\end{array}$ & $\begin{array}{c}\text { Upper } 95 \% \\
\text { confidence } \\
\text { bound on } \\
\text { median }\end{array}$ \\
\hline Strontium & $4 / 4$ & $4.70 \mathrm{E}+00$ & $4.08 \mathrm{E}+01$ & $8.50 E+00$ & $1.17 \mathrm{E}+01$ & $1.60 \mathrm{E}+01$ \\
\hline Vanadium & $4 / 4$ & $232 E+01$ & $4.32 E+01$ & $3.20 \mathrm{E}+01$ & $3.66 \mathrm{E}+01$ & $4.20 \mathrm{E}+01$ \\
\hline Zinc & $4 / 4$ & $3.35 \mathrm{E}+01$ & $6.57 \mathrm{E}+01$ & $3.73 E+01$ & $4.60 \mathrm{E}+01$ & $5.69 \mathrm{E}+01$ \\
\hline \multicolumn{7}{|c|}{ Organics (mg/kg) } \\
\hline Acenaphthene & $3 / 3$ & $9.00 \mathrm{E}-01$ & $240 E+00$ & 9.81E-01 & $1.33 \mathrm{E}+00$ & $1.82 E+00$ \\
\hline Anthracene & $10 / 10$ & $4.00 \mathrm{E}-01$ & $240 E+00$ & $8.06 \mathrm{E}-01$ & $1.24 \mathrm{E}+00$ & $1.91 E+00$ \\
\hline Benzo(a)anthracene & $12 / 12$ & $1.20 \mathrm{E}+00$ & 1.STE+01 & $4.26 \mathrm{E}+00$ & $5.65 \mathrm{E}+00$ & $7.51 E+00$ \\
\hline Benzo(a)pyrene & $12 / 12$ & $1.90 \mathrm{E}+00$ & $1.14 \mathrm{E}+01$ & $3.99 E+00$ & $5.19 E+00$ & $6.75 \mathrm{E}+00$ \\
\hline Benzo(b)fluoranthene & $12 / 12$ & $1.70 \mathrm{E}+\infty 0$ & $1.27 \mathrm{E}+01$ & $3.45 E+00$ & $4.58 \mathrm{E}+00$ & $6.09 E+00$ \\
\hline Benzo( $(g, h, i)$ perylene & $12 / 12$ & $210 \mathrm{E}+\infty$ & $1.11 E+01$ & $3.71 E+00$ & $4.78 \mathrm{E}+00$ & $6.16 \mathrm{E}+00$ \\
\hline Benzo(k)fluoranthene & $12 / 12$ & $1.00 \mathrm{E}+00$ & $8.70 \mathrm{E}+00$ & $227 \mathrm{E}+00$ & $291 E+00$ & $3.72 E+00$ \\
\hline Chrysene & $4 / 6$ & 4.70E+00 & $1.52 E+01$ & $3.52 \mathrm{E}+00$ & $5.31 E+00$ & $8.01 E+00$ \\
\hline Dibenz $(2, h)$ anthracene & $3 / 3$ & $7.00 \mathrm{E}-01$ & $8.00 \mathrm{E}-01$ & $3.76 \mathrm{E}-01$ & $7.65 \mathrm{E}-01$ & $1.56 \mathrm{E}+00$ \\
\hline Fluoranthene & $11 / 11$ & $3.30 \mathrm{E}+00$ & $222 \mathrm{E}+01$ & $4.92 E+00$ & $6.82 E+00$ & $9.45 E+\infty 0$ \\
\hline Fluorene & $7 \pi$ & $4.00 \mathrm{E}-01$ & $4.60 \mathrm{E}+\infty 0$ & $9.41 \mathrm{E}-01$ & $1.41 E+00$ & $211 E+00$ \\
\hline Indeno(1,2,3-cd)pyrene & $7 / 12$ & $4.40 \mathrm{E}+00$ & $3.41 E+01$ & $6.63 E+00$ & $9.48 \mathrm{E}+00$ & $1.36 \mathrm{E}+01$ \\
\hline Naphthalene & $6 / 6$ & $7.00 \mathrm{E}-01$ & $5.40 E+00$ & $1.02 E+00$ & $1.88 \mathrm{E}+00$ & $3.46 \mathrm{E}+00$ \\
\hline Phenanthrene & $12 / 12$ & $290 E+00$ & $1.65 \mathrm{E}+01$ & $5.39 \mathrm{E}+00$ & $7.16 \mathrm{E}+00$ & $9.50 \mathrm{E}+00$ \\
\hline Pyrene & $12 / 12$ & $3.90 \mathrm{E}+00$ & $268 E+01$ & $7.85 \mathrm{E}+00$ & $1.09 \mathrm{E}+01$ & $1.53 \mathrm{E}+01$ \\
\hline \multicolumn{7}{|c|}{ Radionuciides (pCi/g) } \\
\hline Cesium-137 & $4 / 4$ & $5.78 \mathrm{E}-01$ & $1.72 \mathrm{E}+00$ & $4.60 \mathrm{E}-01$ & $1.09 \mathrm{E}+00$ & $256 \mathrm{E}+00$ \\
\hline Neptunium-237 & $3 / 4$ & $7.21 \mathrm{E}-02$ & $1.47 \mathrm{E}-01$ & $7.18 E-02$ & $9.28 \mathrm{E}-02$ & $1.20 \mathrm{E}-01$ \\
\hline Plutonium-238 & $1 / 4$ & $5.98 \mathrm{E}-02$ & 203E-01 & 4.57E-02 & $7.25 \mathrm{E}-02$ & $1.15 \mathrm{E}-01$ \\
\hline Plutonium-239/240 & $1 / 4$ & 3.17E-02 & $4.06 \mathrm{E}-02$ & $1.18 \mathrm{E}-02$ & $240 \mathrm{E}-02$ & 4.87E-02 \\
\hline Potassium-40 & $4 / 4$ & $6.72 E+00$ & $1.38 \mathrm{E}+01$ & $7.99 \mathrm{E}+00$ & $9.70 \mathrm{E}+00$ & $1.18 \mathrm{E}+01$ \\
\hline Radium-226 & $4 / 4$ & $7.42 E-01$ & $9.92 \mathrm{E}-01$ & $6.40 \mathrm{E}-01$ & $9.31 \mathrm{E}-01$ & $1.35 \mathrm{E}+00$ \\
\hline Technetium-99 & $3 / 6$ & $1.39 E+\infty 0$ & $1.93 \mathrm{E}+00$ & $7.36 \mathrm{E}-01$ & $1.11 E+00$ & $1.67 \mathrm{E}+00$ \\
\hline Thorium-228 & $4 / 4$ & $6.05 \mathrm{E}-01$ & $1.72 E+00$ & $7.92 \mathrm{E}-01$ & $1.13 \mathrm{E}+\infty$ & $1.61 E+\infty 0$ \\
\hline Thorium-230 & $4 / 4$ & $8.18 E-01$ & $1.26 E+00$ & $8.66 \mathrm{E}-01$ & $1.04 \mathrm{E}+\infty 0$ & $1.24 \mathrm{E}+00$ \\
\hline Thorium-232 & $4 / 4$ & $5.86 \mathrm{E}-01$ & $1.49 \mathrm{E}+00$ & $9.50 \mathrm{E}-01$ & $1.10 \mathrm{E}+00$ & $1.28 \mathrm{E}+00$ \\
\hline Uranium-233/234 & $4 / 4$ & $8.38 \mathrm{E}-01$ & $1.49 \mathrm{E}+00$ & $1.01 \mathrm{E}+00$ & $1.22 \mathrm{E}+00$ & $1.47 \mathrm{E}+00$ \\
\hline Uranium-235 & $3 / 4$ & $4.38 \mathrm{E}-02$ & $1.78 \mathrm{E}-01$ & $4.12 E-02$ & $5.83 \mathrm{E}-02$ & $8.24 \mathrm{E}-02$ \\
\hline Uranium-238 & $4 / 4$ & 8.67E-01 & $1.43 E+\infty 0$ & $1.09 \mathrm{E}+00$ & $1.22 \mathrm{E}+00$ & $1.36 \mathrm{E}+00$ \\
\hline
\end{tabular}

${ }^{a}$ Data are based on noncomposited samples. 
The risk from exposure to some constituents detected in soil can not be quantified because there are no current EPA-approved slope factors (SF) or reference doses (RfDs) available. Therefore, exposure to these constituents can only be evaluated qualitatively (Table 7.2); a quantitative assessment of these soil constituents is not performed as part of this risk evaluation.

Table 7.2a. Oak Ridge Reservation background soil analytes evaluated qualitatively Dismal Gap

\begin{tabular}{|c|c|c|c|c|c|c|}
\hline Analyte & $\begin{array}{c}\text { Frequency } \\
\text { of } \\
\text { detection }\end{array}$ & $\begin{array}{c}\text { Minimum } \\
\text { detected } \\
\text { concentration }\end{array}$ & $\begin{array}{l}\text { Maximum } \\
\text { detected } \\
\text { concentration }\end{array}$ & $\begin{array}{c}\text { Lower } 95 \% \\
\text { confidence } \\
\text { bound on } \\
\text { median }\end{array}$ & $\begin{array}{c}\text { Median } \\
\text { concentration }\end{array}$ & $\begin{array}{c}\text { Upper } 95 \% \\
\text { confidence } \\
\text { bound on } \\
\text { median }\end{array}$ \\
\hline \multicolumn{7}{|c|}{ Inorganics (mg/kg) } \\
\hline Aluminum & $4 / 4$ & $1.69 \mathrm{E}+04$ & $4.43 E+04$ & $1.84 \mathrm{E}+04$ & 2.07E+04 & $2.32 E+04$ \\
\hline Calcium & $3 \beta$ & $9.91 \mathrm{E}+02$ & $1.86 \mathrm{E}+03$ & $8.60 E+02$ & $1.25 E+03$ & $1.81 E+03$ \\
\hline Chromium & $4 / 4$ & $1.94 \mathrm{E}+01$ & $3.21 \mathrm{E}+01$ & $2.08 \mathrm{E}+01$ & $2.47 \mathrm{E}+01$ & $292 E+01$ \\
\hline Cobalt & $4 / 4$ & $1.13 E+01$ & $3.67 \mathrm{E}+01$ & $1.09 E+01$ & $1.45 \mathrm{E}+01$ & $1.93 E+01$ \\
\hline Copper & $4 / 4$ & $1.24 \mathrm{E}+01$ & $3.01 \mathrm{E}+01$ & $1.27 \mathrm{E}+01$ & $1.61 \mathrm{E}+01$ & $2.05 E+01$ \\
\hline Iron & $4 / 4$ & $2.38 \mathrm{E}+04$ & $4.90 \mathrm{E}+0.4$ & $253 E+04$ & $294 E+04$ & $3.42 \mathrm{E}+04$ \\
\hline Lead & $4 / 4$ & $1.46 \mathrm{E}+01$ & $3.54 \mathrm{E}+01$ & $1.49 E+01$ & $2.03 E+01$ & 2.77E+01 \\
\hline Lithium & $3 / 3$ & $1.27 \mathrm{E}+01$ & $2.70 E+01$ & $1.22 \mathrm{E}+01$ & $1.62 E+01$ & $2.14 \mathrm{E}+01$ \\
\hline Magnesium & $4 / 4$ & $2.09 \mathrm{E}+03$ & $7.43 E+03$ & $237 \mathrm{E}+03$ & $285 E+03$ & $3.42 E+03$ \\
\hline Potassium & $4 / 4$ & $1.89 \mathrm{E}+03$ & $5.39 \mathrm{E}+03$ & $1.89 E+03$ & $2.30 \mathrm{E}+03$ & $2.80 E+03$ \\
\hline Silicon & $4 / 4$ & $4.61 E+02$ & $6.97 \mathrm{E}+02$ & $4.60 \mathrm{E}+02$ & $5.06 \mathrm{E}+02$ & $5.56 \mathrm{E}+02$ \\
\hline Sulfate & $3 / 3$ & $2.80 \mathrm{E}+01$ & $1.63 \mathrm{E}+02$ & $5.91 E+01$ & $8.67 \mathrm{E}+01$ & $1.27 \mathrm{E}+02$ \\
\hline Thallium & $1 / 4$ & $7.90 \mathrm{E}-01$ & $7.90 \mathrm{E}-01$ & $4.90 \mathrm{E}-02$ & $1.65 \mathrm{E}-01$ & $5.56 \mathrm{E}-01$ \\
\hline \multicolumn{7}{|c|}{ Radionuclides (pCi/g) } \\
\hline Total Uranium & $4 / 4$ & $2.30 \mathrm{E}-01$ & $6.50 \mathrm{E}+00$ & $7.58 \mathrm{E}-01$ & $1.31 E+00$ & $2.27 \mathrm{E}+00$ \\
\hline
\end{tabular}




\section{7-14}

Table 7.2b. Oak Ridge Reservation background soil analytes evaluated qualitatively Nolichucky

\begin{tabular}{lcccccc}
\hline & $\begin{array}{c}\text { Frequency } \\
\text { of } \\
\text { detection }\end{array}$ & $\begin{array}{c}\text { Minimum } \\
\text { detected } \\
\text { concentration }\end{array}$ & $\begin{array}{c}\text { Maximum } \\
\text { detected } \\
\text { concentration }\end{array}$ & $\begin{array}{c}\text { Lower 95\% } \\
\text { confidence } \\
\text { bound on } \\
\text { median }\end{array}$ & $\begin{array}{c}\text { Median } \\
\text { concentration }\end{array}$ & $\begin{array}{c}\text { Upper 95\% } \\
\text { confidence } \\
\text { bound on } \\
\text { median }\end{array}$ \\
\hline \multicolumn{7}{c}{ Inorganics (mg/kg) } \\
Aluminum & $4 / 4$ & $2.08 \mathrm{E}+04$ & $2.51 \mathrm{E}+04$ & $1.97 \mathrm{E}+04$ & $2.22 \mathrm{E}+04$ & $2.50 \mathrm{E}+04$ \\
Calcium & $2 / 2$ & $4.98 \mathrm{E}+02$ & $9.52 \mathrm{E}+02$ & $4.37 \mathrm{E}+02$ & $6.89 \mathrm{E}+02$ & $1.08 \mathrm{E}+03$ \\
Chromium & $3 / 3$ & $2.64 \mathrm{E}+01$ & $2.99 \mathrm{E}+01$ & $2.30 \mathrm{E}+01$ & $2.80 \mathrm{E}+01$ & $3.40 \mathrm{E}+01$ \\
Cobalt & $4 / 4$ & $1.11 \mathrm{E}+01$ & $1.75 \mathrm{E}+01$ & $1.09 \mathrm{E}+01$ & $1.44 \mathrm{E}+01$ & $1.92 \mathrm{E}+01$ \\
Copper & $4 / 4$ & $1.10 \mathrm{E}+01$ & $1.27 \mathrm{E}+01$ & $9.21 \mathrm{E}+00$ & $1.17 \mathrm{E}+01$ & $1.49 \mathrm{E}+01$ \\
Iron & $4 / 4$ & $2.30 \mathrm{E}+04$ & $3.21 \mathrm{E}+04$ & $2.40 \mathrm{E}+04$ & $2.79 \mathrm{E}+04$ & $3.24 \mathrm{E}+04$ \\
Lead & $3 / 3$ & $1.53 \mathrm{E}+01$ & $2.04 \mathrm{E}+01$ & $1.22 \mathrm{E}+01$ & $1.75 \mathrm{E}+01$ & $2.51 \mathrm{E}+01$ \\
Lithium & $4 / 4$ & $7.60 \mathrm{E}+00$ & $1.55 \mathrm{E}+01$ & $8.55 \mathrm{E}+00$ & $1.09 \mathrm{E}+01$ & $1.40 \mathrm{E}+01$ \\
Magnesium & $4 / 4$ & $1.73 \mathrm{E}+03$ & $2.41 \mathrm{E}+03$ & $1.67 \mathrm{E}+03$ & $2.01 \mathrm{E}+03$ & $2.41 \mathrm{E}+03$ \\
Potassium & $4 / 4$ & $2.64 \mathrm{E}+03$ & $3.23 \mathrm{E}+03$ & $2.42 \mathrm{E}+03$ & $2.95 \mathrm{E}+03$ & $3.59 \mathrm{E}+03$ \\
Silicon & $4 / 4$ & $1.85 \mathrm{E}+02$ & $3.28 \mathrm{E}+02$ & $2.23 \mathrm{E}+02$ & $2.45 \mathrm{E}+02$ & $2.69 \mathrm{E}+02$ \\
Sulfate & $4 / 4$ & $1.41 \mathrm{E}+01$ & $2.54 \mathrm{E}+01$ & $1.34 \mathrm{E}+01$ & $1.87 \mathrm{E}+01$ & $2.60 \mathrm{E}+01$ \\
& & \multicolumn{7}{c}{ Radionuclides (pCi/g) } & & \\
Total Uranium & $4 / 4$ & $7.50 \mathrm{E}-01$ & $1.50 \mathrm{E}+00$ & $6.63 \mathrm{E}-01$ & $1.15 \mathrm{E}+00$ & $1.99 \mathrm{E}+00$ \\
\hline & & & & & &
\end{tabular}


Table 7.2c. Oak Ridge Reservation background soil analytes evaluated qualitatively Copper Ridge

\begin{tabular}{|c|c|c|c|c|c|c|}
\hline Analyte & $\begin{array}{l}\text { Frequency } \\
\text { of } \\
\text { detection }\end{array}$ & $\begin{array}{c}\text { Minimum } \\
\text { detected } \\
\text { concentration }\end{array}$ & $\begin{array}{l}\text { Maximum } \\
\text { detected } \\
\text { concentration }\end{array}$ & $\begin{array}{c}\text { Lower } 95 \% \\
\text { confidence } \\
\text { bound on } \\
\text { median }\end{array}$ & $\begin{array}{c}\text { Median } \\
\text { concentration }\end{array}$ & $\begin{array}{c}\text { Upper 95\% } \\
\text { confidence } \\
\text { bound on } \\
\text { median }\end{array}$ \\
\hline \multicolumn{7}{|c|}{ Inorganics (mg/kg) } \\
\hline Aluminum & $4 / 4$ & $9.78 \mathrm{E}+03$ & $1.16 \mathrm{E}+04$ & $9.35 \mathrm{E}+03$ & $1.05 \mathrm{E}+04$ & $1.18 \mathrm{E}+04$ \\
\hline Calcium & $4 / 4$ & $3.98 \mathrm{E}+02$ & $5.94 \mathrm{E}+02$ & $3.66 \mathrm{E}+02$ & $5.05 \mathrm{E}+02$ & $6.96 \mathrm{E}+02$ \\
\hline Chromium & $4 / 4$ & $1.05 \mathrm{E}+01$ & $2.39 \mathrm{E}+01$ & $1.30 \mathrm{E}+01$ & $1.54 \mathrm{E}+01$ & $1.83 \mathrm{E}+01$ \\
\hline Cobalt & $4 / 4$ & $5.40 \mathrm{E}+00$ & $1.91 \mathrm{E} \div 01$ & $5.85 \mathrm{E}+00$ & $7.76 \mathrm{E}+00$ & $1.03 \mathrm{E}+01$ \\
\hline Copper & $3 / 4$ & $5.40 \mathrm{E}+00$ & $7.80 \mathrm{E}+00$ & $4.76 \mathrm{E}+00$ & $6.25 \mathrm{E}+00$ & $8.19 \mathrm{E}+00$ \\
\hline Iron & $4 / 4$ & $9.70 E+03$ & $1.39 \mathrm{E}+04$ & $1.03 E+04$ & $1.20 \mathrm{E}+04$ & $1.39 \mathrm{E}+04$ \\
\hline Lead & $4 / 4$ & $1.82 \mathrm{E}+01$ & $1.65 \mathrm{E}+02$ & $2.79 \mathrm{E}+01$ & $3.82 \mathrm{E}+01$ & $5.22 \mathrm{E}+01$ \\
\hline Lithium & $2 / 4$ & $2.80 \mathrm{E}+00$ & $3.10 \mathrm{E}+00$ & $1.94 \mathrm{E}+00$ & $2.60 \mathrm{E}+00$ & $3.48 \mathrm{E}+00$ \\
\hline Magnesium & $4 / 4$ & $4.11 E+02$ & $5.17 \mathrm{E}+02$ & $3.85 \mathrm{E}+02$ & $4.63 E+02$ & $5.57 \mathrm{E}+02$ \\
\hline Potassium & $4 / 4$ & $2.74 \mathrm{E}+02$ & $4.16 \mathrm{E}+02$ & $3.04 \mathrm{E}+02$ & $3.70 \mathrm{E}+02$ & $4.51 \mathrm{E}+02$ \\
\hline Silicon & $1 / 1$ & $6.33 E+02$ & $6.33 E+02$ & $5.24 \mathrm{E}+02$ & $6.33 E+02$ & $7.64 \mathrm{E}+02$ \\
\hline Sodium & $3 / 4$ & $3.52 \mathrm{E}+02$ & $3.79 E+02$ & $3.34 \mathrm{E}+02$ & $3.57 \mathrm{E}+02$ & $3.81 \mathrm{E}+02$ \\
\hline Sulfate & $4 / 4$ & $4.42 E+01$ & $1.32 \mathrm{E}+02$ & $4.53 \mathrm{E}+01$ & $6.32 E+01$ & $8.82 \mathrm{E}+01$ \\
\hline \multicolumn{7}{|c|}{ Organics (mg/kg) } \\
\hline Acenaphthylene $^{a}$ & $4 / 10$ & $2.84 \mathrm{E}+01$ & $4.29 \mathrm{E}+03$ & $1.39 E+01$ & $5.76 \mathrm{E}+01$ & $240 \mathrm{E}+02$ \\
\hline \multicolumn{7}{|c|}{ Radionuclides (pCi/g) } \\
\hline Total Uranium & $4 / 4$ & $2.26 \mathrm{E}+00$ & $3.30 \mathrm{E}+00$ & $1.57 \mathrm{E}+00$ & $2.71 E+00$ & $4.69 \mathrm{E}+00$ \\
\hline
\end{tabular}

${ }^{a}$ Data based on noncomposited samples. 
Table 7.2d. Oak Ridge Reservation background soil analytes evaluated qualitatively Chepultepec

\begin{tabular}{|c|c|c|c|c|c|c|}
\hline Analyte & $\begin{array}{c}\text { Frequency } \\
\text { of } \\
\text { detection }\end{array}$ & $\begin{array}{c}\text { Minimum } \\
\text { detected } \\
\text { concentration }\end{array}$ & $\begin{array}{c}\text { Maximum } \\
\text { detected } \\
\text { concentration }\end{array}$ & $\begin{array}{l}\text { Lower } 95 \% \\
\text { confidence } \\
\text { bound on } \\
\text { median }\end{array}$ & $\begin{array}{c}\text { Median } \\
\text { concentration }\end{array}$ & $\begin{array}{l}\text { Upper } 95 \% \\
\text { confidence } \\
\text { bound on } \\
\text { median }\end{array}$ \\
\hline \multicolumn{7}{|c|}{ Inorganics (mg/kg) } \\
\hline Aluminum & $4 / 4$ & $7.45 E+03$ & $1.03 E+04$ & $7.51 E+03$ & $8.45 E+03$ & $9.51 E+03$ \\
\hline Calcium & $4 / 4$ & $3.38 \mathrm{E}+02$ & $6.80 E+02$ & 321.4124443. & 3078611. & $4.32 \mathrm{E}+03$ \\
\hline Chromium & $3 / 4$ & $1.17 \mathrm{E}+01$ & $3.38 \mathrm{E}+01$ & $1.23 E+01$ & $1.46 \mathrm{E}+01$ & $1.74 E+01$ \\
\hline Cobalt & $4 / 4$ & $7.50 \mathrm{E}+00$ & $1.69 E+01$ & $8.67 \mathrm{E}+00$ & $1.15 \mathrm{E}+01$ & $1.53 E+01$ \\
\hline Copper & $1 / 4$ & $4.10 \mathrm{E}+00$ & $7.80 \mathrm{E}+00$ & $2.92 \mathrm{E}+00$ & $3.92 E+00$ & $5.26 \mathrm{E}+00$ \\
\hline Iron & $4 / 4$ & $8.50 \mathrm{E}+03$ & $3.00 E+04$ & $1.22 \mathrm{E}+04$ & $1.42 E+04$ & $1.65 \mathrm{E}+04$ \\
\hline Lead & $4 / 4$ & $1.06 \mathrm{E}+01$ & $2.98 \mathrm{E}+01$ & $1.32 \mathrm{E}+01$ & $1.80 \mathrm{E}+01$ & $2.46 \mathrm{E}+01$ \\
\hline Lithium & $1 / 4$ & $4.40 \mathrm{E}+00$ & $1.21 \mathrm{E}+01$ & $2.96 \mathrm{E}+00$ & $3.85 \mathrm{E}+00$ & $4.99 \mathrm{E}+00$ \\
\hline Magnesium & $4 / 4$ & $2.80 \mathrm{E}+02$ & $5.13 E+02$ & $3.07 \mathrm{E}+02$ & $3.69 \mathrm{E}+02$ & $4.43 \mathrm{E}+02$ \\
\hline Silicon & $4 / 4$ & $4.83 E+02$ & $6.49 \mathrm{E}+02$ & $4.92 \mathrm{E}+02$ & $5.41 \mathrm{E}+02$ & $5.95 E+02$ \\
\hline Sodium & $4 / 4$ & $2.86 \mathrm{E}+02$ & $3.57 \mathrm{E}+02$ & $3.03 E+02$ & $3.23 \mathrm{E}+02$ & $3.44 \mathrm{E}+02$ \\
\hline Sulfate & $4 / 4$ & $6.05 \mathrm{E}+01$ & $9.14 \mathrm{E}+01$ & $5.28 \mathrm{E}+01$ & $7.37 \mathrm{E}+01$ & $1.03 E+02$ \\
\hline \multicolumn{7}{|c|}{ Radionuclides (pCi/g) } \\
\hline Total Uranium & $3 / 3$ & $9.04 \mathrm{E}-01$ & $5.56 \mathrm{E}+00$ & $1.02 E+00$ & $1.92 E+00$ & $3.63 E+00$ \\
\hline
\end{tabular}


Table 7.2e. Oak Ridge Reservation background soil analytes evaluated qualitatively Chickamauga (Bethel Valley)

\begin{tabular}{|c|c|c|c|c|c|c|}
\hline Analyte & $\begin{array}{c}\text { Frequency } \\
\text { of } \\
\text { detection }\end{array}$ & $\begin{array}{c}\text { Minimum } \\
\text { detected } \\
\text { concentration }\end{array}$ & $\begin{array}{c}\text { Maximum } \\
\text { detected } \\
\text { concentration }\end{array}$ & $\begin{array}{c}\text { Lower 95\% } \\
\text { confidence } \\
\text { bound on } \\
\text { median }\end{array}$ & $\begin{array}{c}\text { Median } \\
\text { concentration }\end{array}$ & $\begin{array}{c}\text { Upper } 95 \% \\
\text { confidence } \\
\text { bound on } \\
\text { median }\end{array}$ \\
\hline \multicolumn{7}{|c|}{ Inorganics (mg/kg) } \\
\hline Aluminum & $4 / 4$ & $1.54 \mathrm{E}+04$ & $1.80 \mathrm{E}+04$ & $1.47 \mathrm{E}+04$ & $1.65 \mathrm{E}+04$ & $1.86 \mathrm{E}+04$ \\
\hline Calcium & $4 / 4$ & $1.00 \mathrm{E}+03$ & $3.50 \mathrm{E}+03$ & $1.34 \mathrm{E}+03$ & $1.86 \mathrm{E}+03$ & $2.56 \mathrm{E}+03$ \\
\hline Chromium & $4 / 4$ & $2.34 \mathrm{E}+01$ & 4.47E+01 & $2.87 E+01$ & $3.40 \mathrm{E}+01$ & $4.02 \mathrm{E}+01$ \\
\hline Cobalt & $4 / 4$ & $1.52 \mathrm{E}+01$ & $221 E+01$ & $1.39 \mathrm{E}+01$ & $1.85 \mathrm{E}+01$ & $245 E+01$ \\
\hline Copper & $4 / 4$ & $1.11 E+01$ & $2.17 \mathrm{E}+01$ & $1.28 \mathrm{E}+01$ & $1.62 E+01$ & $2.06 \mathrm{E}+01$ \\
\hline Iron & $4 / 4$ & $3.10 E+04$ & $4.30 E+04$ & $3.09 \mathrm{E}+04$ & $3.60 \mathrm{E}+04$ & $4.18 \mathrm{E}+04$ \\
\hline Lead & $3 B$ & $3.24 \mathrm{E}+01$ & $4.20 E+01$ & $2.49 \mathrm{E}+01$ & $3.57 \mathrm{E}+01$ & $5.11 E+01$ \\
\hline Lithium & $2 / 2$ & $1.02 E+01$ & $1.26 \mathrm{E}+01$ & $7.99 \mathrm{E}+00$ & $1.13 E+01$ & $1.60 \mathrm{E}+01$ \\
\hline Magnesium & $4 / 4$ & $1.12 \mathrm{E}+03$ & $2.20 \mathrm{E}+03$ & $1.15 \mathrm{E}+03$ & $1.38 \mathrm{E}+03$ & $1.66 \mathrm{E}+03$ \\
\hline Potassium & $4 / 4$ & $1.14 \mathrm{E}+03$ & $2.22 \mathrm{E}+03$ & $1.27 \mathrm{E}+03$ & $1.55 \mathrm{E}+03$ & $1.89 E+03$ \\
\hline Silicon & $2 / 2$ & $4.71 E+02$ & $5.45 \mathrm{E}+02$ & $4.46 \mathrm{E}+02$ & $5.10 \mathrm{E}+02$ & $5.83 E+02$ \\
\hline Sodium & $4 / 4$ & $3.77 \mathrm{E}+02$ & $4.14 \mathrm{E}+02$ & $3.68 \mathrm{E}+02$ & $3.92 \mathrm{E}+02$ & 4.17E+02 \\
\hline Sulfate & $4 / 4$ & $6.40 \mathrm{E}+01$ & $1.81 E+02$ & $6.79 \mathrm{E}+01$ & $9.47 \mathrm{E}+01$ & $1.32 \mathrm{E}+02$ \\
\hline \multicolumn{7}{|c|}{ Radionuclides (pCi/g) } \\
\hline Total Uranium & $3 / 3$ & 2.69E-01 & $2.02 \mathrm{E}+00$ & $6.61 E-01$ & $1.25 \mathrm{E}+00$ & $235 \mathrm{E}+00$ \\
\hline
\end{tabular}


Table 7.2f. Oak Ridge Reservation background soil anałytes evaluated qualitatively Chickamagua $(K-25)$

\begin{tabular}{|c|c|c|c|c|c|c|}
\hline Analyte & $\begin{array}{l}\text { Frequency } \\
\text { of } \\
\text { detection }\end{array}$ & $\begin{array}{c}\text { Minimum } \\
\text { detected } \\
\text { concentration }\end{array}$ & $\begin{array}{c}\text { Maximum } \\
\text { detected } \\
\text { concentration }\end{array}$ & $\begin{array}{c}\text { Lower } 95 \% \\
\text { confidence } \\
\text { bound on } \\
\text { median }\end{array}$ & $\begin{array}{c}\text { Median } \\
\text { concentration }\end{array}$ & $\begin{array}{c}\text { Upper } 95 \% \\
\text { confidence } \\
\text { bound on } \\
\text { median }\end{array}$ \\
\hline \multicolumn{7}{|c|}{ Inorganics (mg/kg) } \\
\hline Aluminum & $4 / 4$ & $1.28 \mathrm{E}+04$ & $2.24 \mathrm{E}+04$ & 1.47E+04 & $1.65 E+04$ & $1.86 \mathrm{E}+04$ \\
\hline Calcium & $4 / 4$ & $8.08 \mathrm{E}+02$ & $3.54 \mathrm{E}+03$ & $9.87 \mathrm{E}+02$ & $1.36 \mathrm{E}+03$ & $1.88 \mathrm{E}+03$ \\
\hline Chromium & $4 / 4$ & $1.88 \mathrm{E}+01$ & $4.46 \mathrm{E}+01$ & $2.74 \mathrm{E}+01$ & $3.25 E+01$ & $3.85 \mathrm{E}+01$ \\
\hline Cobalt & $4 / 4$ & $1.67 \mathrm{E}+01$ & $2.36 \mathrm{E}+01$ & $1.47 \mathrm{E}+01$ & $1.95 \mathrm{E}+01$ & $2.59 \mathrm{E}+01$ \\
\hline Copper & $4 / 4$ & $7.80 \mathrm{E}+00$ & $1.97 \mathrm{E}+01$ & $8.99 \mathrm{E}+00$ & $1.14 \mathrm{E}+01$ & $1.45 E+01$ \\
\hline Iron & $4 / 4$ & $2.23 E+04$ & $4.23 E+04$ & $2.66 \mathrm{E}+04$ & $3.10 E+04$ & $3.60 \mathrm{E}+04$ \\
\hline Lead & $4 / 4$ & $1.98 \mathrm{E}+01$ & $3.94 \mathrm{E}+01$ & $2.31 E+01$ & $3.16 \mathrm{E}+01$ & $4.32 \mathrm{E}+01$ \\
\hline Lithium & $4 / 4$ & $9.10 \mathrm{E}+00$ & $2.11 E+01$ & $1.07 \mathrm{E}+01$ & $1.37 \mathrm{E}+01$ & $1.74 \mathrm{E}+01$ \\
\hline Magnesium & $4 / 4$ & $7.94 \mathrm{E}+02$ & $1.39 \mathrm{E}+03$ & $9.03 E+02$ & $1.08 \mathrm{E}+03$ & $1.30 E+03$ \\
\hline Potassium & $4 / 4$ & $1.05 E+03$ & $2.32 E+03$ & $1.39 E+03$ & $1.69 \mathrm{E}+03$ & $2.06 \mathrm{E}+03$ \\
\hline Silicon & $4 / 4$ & $5.46 \mathrm{E}+02$ & $7.32 \mathrm{E}+02$ & $5.79 \mathrm{E}+02$ & $6.36 \mathrm{E}+02$ & $6.99 \mathrm{E}+02$ \\
\hline Sodium & $4 / 4$ & $3.78 \mathrm{E}+02$ & $5.02 \mathrm{E}+02$ & $4.00 \mathrm{E}+02$ & $4.26 \mathrm{E}+02$ & $4.54 \mathrm{E}+02$ \\
\hline Sulfate & $4 / 4$ & $5.70 E+01$ & $3.95 E+02$ & $1.27 \mathrm{E}+02$ & $1.78 \mathrm{E}+02$ & $2.48 E+02$ \\
\hline \multicolumn{7}{|c|}{ Radionuclides (pCi/g) } \\
\hline Total Uranium & $4 / 4$ & $1.60 \mathrm{e}-01$ & $2.22 \mathrm{E}+00$ & $5.33 e-01$ & $9.23 e-01$ & $1.60 \mathrm{E}+00$ \\
\hline
\end{tabular}




\subsection{EXPOSURE ASSESSMENT}

An exposure assessment combines information about site characteristics and constituent data with the exposure assumptions used by the risk assessor. The objectives of the exposure assessment are to determine or estimate the magnitude, frequency, and duration of present and future pathways of potential human exposure to site-contaminants by:

- characterizing the exposure setting,

- identifying exposure pathways, and

- quantifying exposures.

\subsubsection{Characterization of Exposure Setting}

Characterization of the exposure setting involves identifying the general physical characteristics of the site (e.g., climate and vegetation) and the characteristics of the populations on or near the site. This characterization ensures that all potential constituent migration pathways and potential receptors are evaluated in the risk assessment. Details of the physical and environmental characteristics of the ORR and Anderson and Roane counties have already been discussed in Sect. 4 of the Project Plan for the BSCP (Energy Systems 1992).

To estimate human health risk for background soil, the soil sampling areas were selected from areas with minimal soil erosion and deposition, minimal groundwater discharge, and minimal influence of past and present DOE activities (on-site) and agricultural practices (off-site). A hypothetical on-site resident scenario will be used to determine human health risk associated with background soils; this scenario uses conservatively based calculations, as an accepted default scenario by EPA, and is unlikely to underestimate the exposure to background constituents for individuals residing on or in the vicinity of the ORR.

\subsubsection{Identification of Exposure Pathways}

The identification of exposure pathways of concern is determined by evaluating all of the components (source, transport medium, exposure point, potential receptors, and routes of exposure) necessary to complete the potential exposure pathway. For an exposure pathway to be considered complete, each of these components must be identified and linked to each of the other components. Routes of exposure (ingestion, inhalation, dermal absorption, and external exposure to radiation) and potential receptors are crucial in identifying the validity of an exposure pathway. For example, an exposure scenario that includes dermal absorption of subsurface soil contaminants would not be valid for general personnel (industrial) receptors. However, for excavation workers, dermal absorption of subsurface soil contaminants could be possible, and such a scenario would be valid.

In this assessment, potential health effects from background soils are considered for the A horizon surface soil in Roane and Anderson counties and from the ORR. Because soil samples taken on the ORR are the most representative of the background concentrations on the reservation, a detailed background risk analysis will use only the ORR soil data, and general comparisons will be made with the background risk determinations and results for Anderson and Roane counties. The following discussion evaluates the potential pathways related to the on-site resident scenario resulting from exposure to constituents in the soil. 
A hypothetical residential exposure scenario is used to assess the risk from soil because it is protective of human health and is typically employed in the evaluation of risk from the exposure to contamination on the ORR. If we assume that concentrations in the soil are constant, the potential pathways affecting the on-site resident would include direct exposure to soil as well as exposure to constituents in the soil transferred to the air. The direct exposure to soil would involve the ingestion and dermal contact routes of intake, and external exposure to radionuclides. Because of the uncertainty of modeling the air pathway, only direct exposure pathways (ingestion, dermal, and external exposure to radionuclides) are addressed here.

\subsubsection{Quantification of Exposure}

Exposure, in the context of human health risk, is defined as the direct contact of a person with a chemical or physical agent. To quantify exposure, one must determine exposure concentrations and calculate chemical intakes for the various exposure pathways identified for the site. The potential exposure pathways at background soil sampling areas are considered quantitatively in the following section.

This section follows the procedure involved in developing the chronic daily intake (CDI) of a constituent (also termed "intake" or "dose" for external exposure to radionuclides). The $\mathrm{CDI}$ is the amount of a constituent an individual takes into one's body per day via ingestion or dermal contact. The first consideration in deriving the CDI is the methodology employed in the development of an exposure concentration, which is the amount of each constituent in the various media to which receptors are exposed. To calculate the CDI, one evaluates the exposure concentration in the context of the scenario, exposure pathway, and constituent-specific exposure variables, such as duration of exposure and intake rate. The quantification of exposure and calculation of the CDI for the resident are discussed in Sects. 7.4.3.1 and 7.4.3.2.

\subsubsection{Derivation of representative exposure concentrations}

This section and Sect. 7.4.3.2 address methods used in calculating the exposure concentrations for the hypothetical on-site residential exposure scenario and pathways evaluated in this background risk assessment. EPA guidance requires evaluation using the on-site residential scenario, which is the most conservative. This typically requires determination of risks associated with adult residents, as well as young children (especially with respect to dermal contact and ingestion of soil). As a result of the statistical data evaluation process described in Sect. 5 , the set of background soil concentration data used in this background risk assessment were compiled. The results are summarized in Tables 7.1 and 7.2 and include the frequency of detection, the minimum and maximum detected concentrations of each analyte, the lower 95\% confidence bound (LCB95), the analyte median concentration, as well as the upper $95 \%$ confidence bound (UCB95) on the median.

The UCB95 is assumed to be representative of the analyte concentration and is used in the calculations of the CDI, dose, risk and hazard index. This upper confidence bound is used to ensure that the exposure concentrations are not underestimated. Refer to Sect. 5 for a complete statistical evaluation of the data and the list of analytes reported as nondetects. The nondetected analytes are not evaluated in this risk assessment. 


\subsubsection{Exposure to residents}

$\therefore$... The potential exposure pathways associated with the on-site residential land use scenario are direct ingestion of soil, dermal contact with soil, and external exposure to the radionuclides in the soil. The representative concentrations (UCB95) of constituents in sampling area soils in Table 7.1 are the concentrations used to quantify exposures via soil-related pathways.

Table 7.3 lists the exposure variables associated with each exposure route considered for the on-site resident. The variables used in each exposure equation have been derived from standard intake rates, skin surface areas, and adherence factors (EPA 1991e). It was assumed that the resident would be exposed to soil constituents for $350 \mathrm{~d} /$ year for 30 years. All pathways were divided into two parts. First, a 6-year exposure duration was evaluated for young children, which accounts for receptors with high intake rates relative to body weight. Second, a 24-year exposure duration was assumed for adults. For example, for the soil ingestion pathway, a child ingestion rate $(200 \mathrm{mg} /$ day) and body weight (15 kg) was assumed for 6 years, while an adult ingestion rate $(100 \mathrm{mg} /$ day $)$ and body weight $(70 \mathrm{~kg})$ was assumed for 24 years.

CDIs, for ingestion and dermal contact, and doses, for radionuclide external exposure, for the background soil samples are listed in Tables 7.4 and 7.5; these tables are separated (i.e, tables a through $\mathrm{f}$ ) by formation. Listed in Table 7.4 are the CDIs (and doses) for constituents for which a background risk and/or $\mathrm{HI}$ could be calculated (i.e., if a SF and/or $\mathrm{RfD}$ were available). This information can be used to re-calculate the background risks for constituents, if (i) the SF and/or RfD changes in the future, and if (ii) background risk information is desired using other exposure parameters, i.e., other land use assumptions. In the cases where toxicity information (SF and/or $\mathrm{RfD}$ ) is currently not available (Table 7.5), CDIs (and doses) are given so that when SFs and RfDs become available in the future, a background risk or HI can be calculated for the constituents present in this BSCP study.

\subsection{TOXICITY ASSESSMENT}

The purpose of any toxicity assessment is to evaluate the potential for constituents to cause adverse health effects in exposed individuals. This usually consists of an evaluation of the relationship between the extent of exposure to a particular constituent and the increased likelihood or severity of adverse health effects as a result of that exposure relative to a baseline. The toxicity assessment generally involves two steps. The first step comprises determining whether exposure to an agent can cause an increase in the incidence of a particular health effect and whether that health effect will occur in humans. The second step involves characterizing the relationship between the received dose of the constituent and the incidence of adverse health effects in exposed populations.

The constituent-specific information in Sects. 7.5.1, 7.5.2, and 7.5.3 provides general information as well as constituent-specific discussion about health effects related to those constituents of concern evaluated in the risk assessment for the background soil. Carcinogenic and noncarcinogenic health effects are considered. Data used in this section are from human and laboratory animal research and from occupational studies to characterize likely health 
Table 7.3. On-site resident exposure scenario

\begin{tabular}{|c|c|c|c|c|}
\hline \multicolumn{3}{|c|}{ Variable } & Value used & Explanation/source \\
\hline \multicolumn{5}{|c|}{ Residential ingestion scenario } \\
\hline \multicolumn{5}{|c|}{ Chronic daily intake $(\mathrm{mg} / \mathrm{kg}$ per day $)=\mathrm{CS} \times \mathrm{IR} \times \mathrm{FI} \times \mathrm{EF} \times \mathrm{ED}$} \\
\hline \multicolumn{5}{|c|}{$\mathrm{BW} \times \mathrm{AT}$} \\
\hline \multicolumn{5}{|c|}{ Intake $(\mathrm{pCi})=\mathrm{CS} \times \mathrm{CF} \times \mathrm{IR} \times \mathrm{EF} \times \mathrm{ED}$} \\
\hline CS & $=$ & $\begin{array}{l}\text { Concentration in } \\
\text { soil }\end{array}$ & $\begin{array}{l}\text { Chemical-specific (mg/kg; } \\
\mathrm{pCi} / \mathrm{g})\end{array}$ & $\begin{array}{l}\text { Concentration is obtained } \\
\text { from the data in Tables } 7.1 \\
\text { and } 7.2\end{array}$ \\
\hline \multirow[t]{2}{*}{ IR } & $=$ & Ingestion rate & $0.0002 \mathrm{~kg} /$ day & $\begin{array}{l}\text { Child rate (Sect. 6, RAGS, } \\
\text { EPA 1989c) }\end{array}$ \\
\hline & & & $0.0001 \mathrm{~kg} /$ day & $\begin{array}{l}\text { Adult rate (Sect. 6, RAGS, } \\
\text { EPA 1989c) }\end{array}$ \\
\hline $\mathrm{CF}$ & $=$ & Conversion factor & $10^{3} \mathrm{~g} / \mathrm{kg}$ & $\begin{array}{l}\text { Necessary to convert to } \\
\text { appropriate units. }\end{array}$ \\
\hline FI & $=$ & Fraction ingested & 1 (unitless) & $\begin{array}{l}\text { Maximum value used; } \\
\text { equivalent to } 100 \%\end{array}$ \\
\hline $\mathrm{EF}$ & $=$ & Exposure frequency & $350 \mathrm{~d} /$ year & $\begin{array}{l}\text { OSWER Directive } \\
\text { 9285.6-03 (EPA 1991e) }\end{array}$ \\
\hline \multicolumn{2}{|c|}{$\mathrm{ED}=$} & Exposure duration & $\begin{array}{l}6 \text { years } \\
24 \text { years }\end{array}$ & $\begin{array}{l}\text { Two-part (child and adult) } \\
\text { residential exposure for a } \\
\text { 30-year duration (OSWER } \\
\text { Directive, EPA 1991e) }\end{array}$ \\
\hline \multirow{2}{*}{\multicolumn{2}{|c|}{$\mathrm{BW}=$}} & Body weight & $15 \mathrm{~kg}$ & $\begin{array}{l}\text { Child (OSWER Directive, } \\
\text { EPA 1991e) }\end{array}$ \\
\hline & & & $70 \mathrm{~kg}$ & $\begin{array}{l}\text { Adult (Sect. 6, RAGS, EPA } \\
\text { 1989c) }\end{array}$ \\
\hline \multirow{2}{*}{\multicolumn{2}{|c|}{$\mathrm{AT}=$}} & Averaging time & $365 \mathrm{~d} \times \mathrm{ED}$ & $\begin{array}{l}\text { Averaging time } \\
\text { for noncarcinogens }\end{array}$ \\
\hline & & & $365 \mathrm{~d} /$ year $\times 70$ years & $\begin{array}{l}\text { Averaging time } \\
\text { for carcinogens }\end{array}$ \\
\hline
\end{tabular}


Table 7.3 (continued)

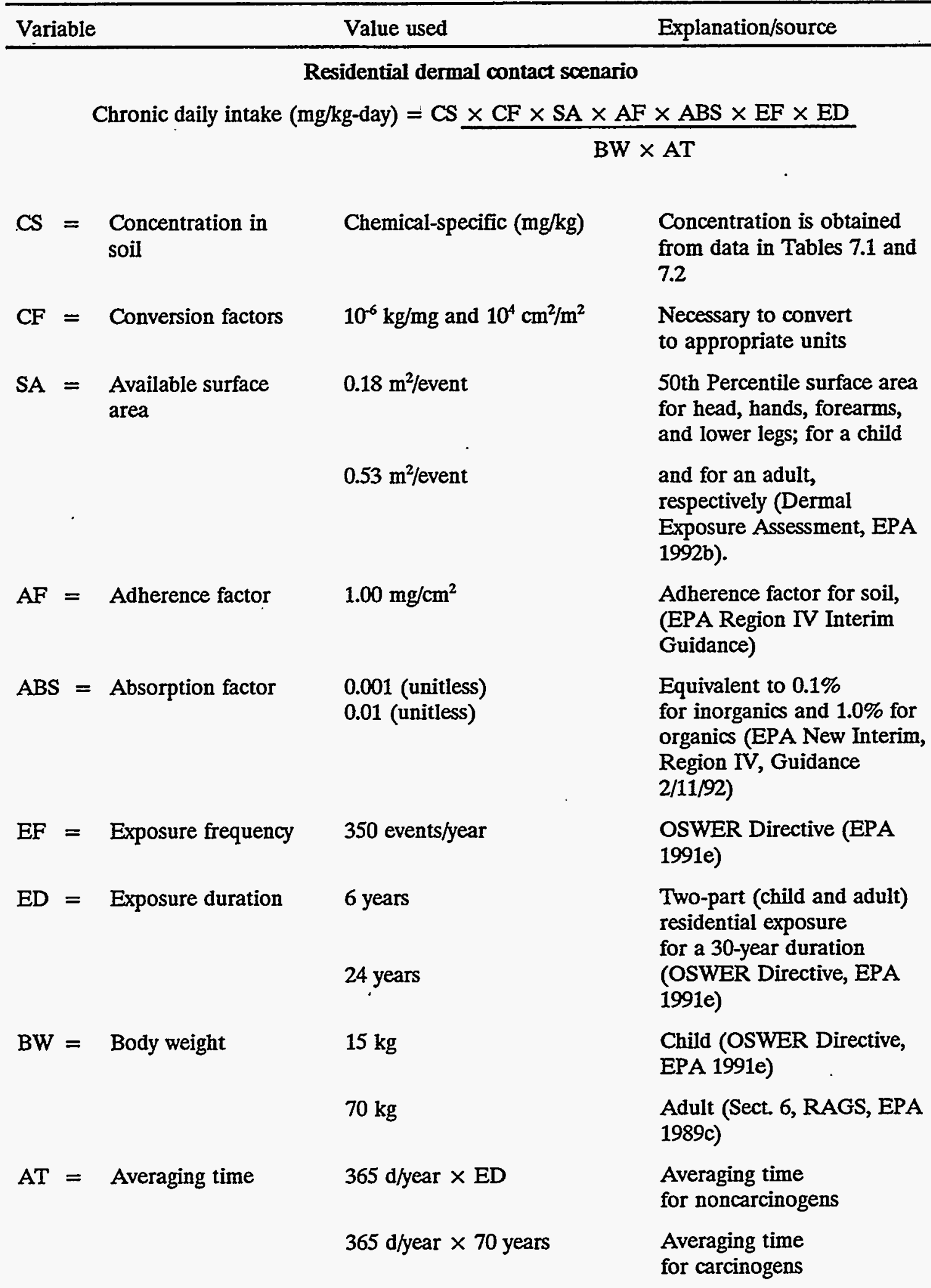


Table 7.3 (continued)

\begin{tabular}{|c|c|c|c|c|}
\hline \multicolumn{2}{|c|}{ Variable } & & Value used & Explanation/source \\
\hline \multicolumn{5}{|c|}{ Residential external exposure scenario } \\
\hline \multicolumn{5}{|c|}{ Dose $(\mathrm{pCi}-\mathrm{yr} / \mathrm{g})=\mathrm{CS} \times \mathrm{ED} \times(1-\mathrm{Se}) \times \mathrm{Te}$} \\
\hline CS & $=$ & $\begin{array}{l}\text { Concentration } \\
\text { in soil }\end{array}$ & Chemical-specific (pCi/g) & $\begin{array}{l}\text { Concentration is obtained } \\
\text { from the data in Tables } 7.1 \\
\text { and } 7.2\end{array}$ \\
\hline $\mathrm{ED}$ & $=$ & Exposure duration & $\begin{array}{l}6 \text { years } \\
24 \text { years }\end{array}$ & $\begin{array}{l}\text { Two-part (child and adult) } \\
\text { residential exposure } \\
\text { for a 30-year duration } \\
\text { (OSWER Directive, EPA } \\
\text { 1991e) }\end{array}$ \\
\hline Se & $=$ & $\begin{array}{l}\text { Gamma shielding } \\
\text { factor (unitless) }\end{array}$ & 0.2 & $\begin{array}{l}\text { RAGS-part B, EPA 1991; } \\
\text { sect. 4.1.2 (default value) }\end{array}$ \\
\hline $\mathrm{Te}$ & $=$ & $\begin{array}{l}\text { Gamma exposure } \\
\text { time factor (unitless) }\end{array}$ & 1.0 & $\begin{array}{l}\text { RAGS-part B, EPA 1991; } \\
\text { sect. } 4.1 .2 \text { (default value, } \\
24 \mathrm{~h} / 24 \mathrm{~h} \text { ) }\end{array}$ \\
\hline
\end{tabular}


Table 7.4a. Chronic daily intake of ORR background soil by the on-site resident-Dismal Gapa (for constituents for which a risk and/or hazard index could be calculated)

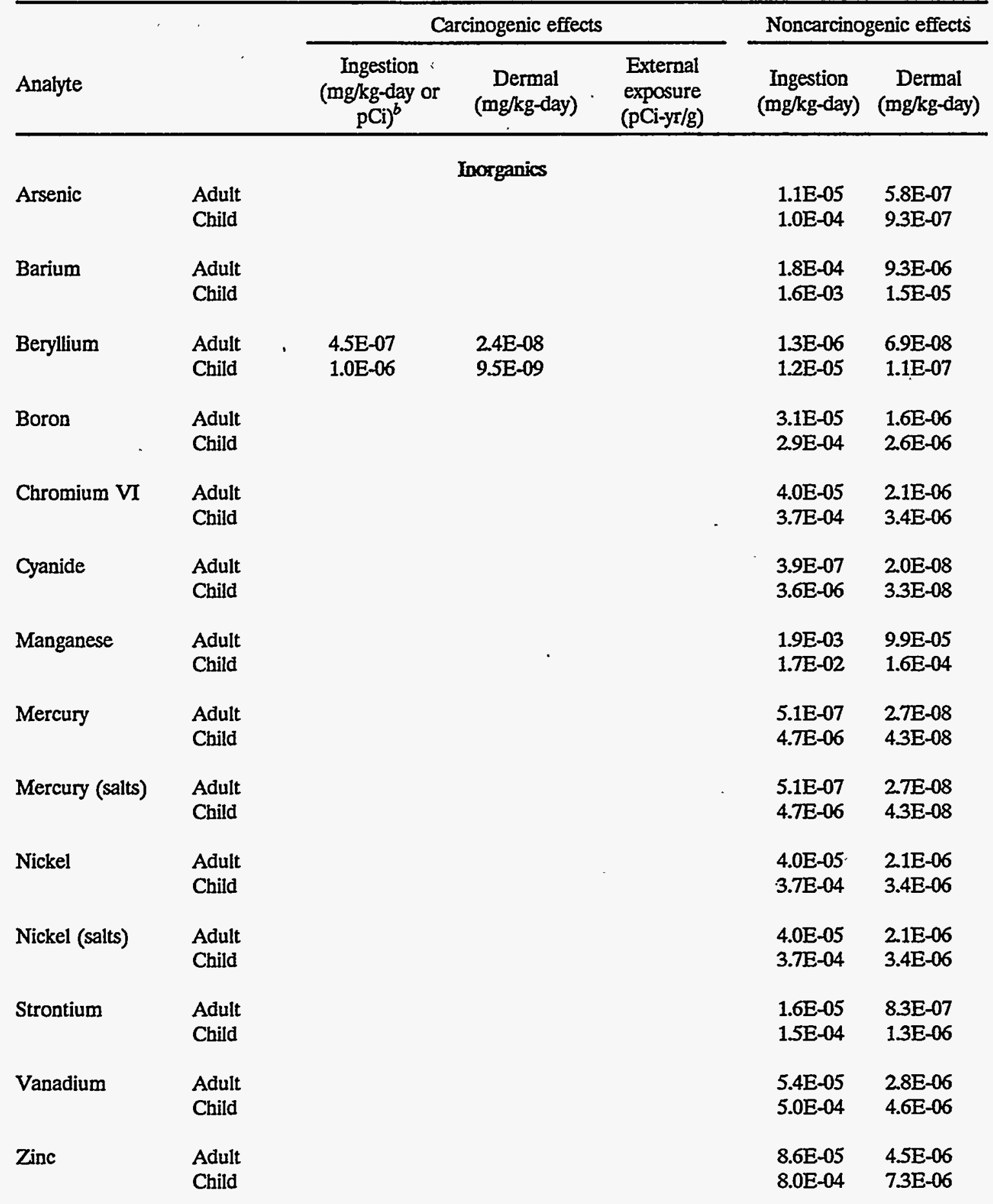


Table 7.4a (continued)

\begin{tabular}{|c|c|c|c|c|c|c|}
\hline \multirow[b]{2}{*}{ Analyte } & & \multicolumn{3}{|c|}{ Carcinogenic effects } & \multicolumn{2}{|c|}{ Noncarcinogenic effects } \\
\hline & & $\begin{array}{c}\text { Ingestion } \\
\text { (mg/kg-day or } \\
\text { pCi) }\end{array}$ & $\begin{array}{c}\text { Dermal } \\
\text { (mg/kg-day) }\end{array}$ & $\begin{array}{l}\text { External } \\
\text { exposure } \\
\text { (pCi-yr/g) }\end{array}$ & $\begin{array}{c}\text { Ingestion } \\
\text { (mg/kg-day) }\end{array}$ & $\begin{array}{c}\text { Dermal } \\
\text { (mg/kg-day) }\end{array}$ \\
\hline \multicolumn{7}{|c|}{ Radionuctides } \\
\hline \multirow[t]{2}{*}{ Cesium-137 } & Adult & $1.2 \mathrm{E}+03$ & & $2.7 E+01$ & . & \\
\hline & Child & $5.9 \mathrm{E}+02$ & & $6.8 \mathrm{E}+00$ & $\cdot$ & \\
\hline \multirow[t]{2}{*}{ Plutonium-239/240 } & Adult & $3.1 E+01$ & & $7.0 \mathrm{E}-01$ & & \\
\hline & Child & $1.5 \mathrm{E}+01$ & & $1.8 \mathrm{E}-01$ & & \\
\hline \multirow[t]{2}{*}{ Potassium-40 } & Adult & 1.7E+04 & & $3.8 \mathrm{E}+02$ & & \\
\hline & Child & $8.3 E+03$ & & $9.5 \mathrm{E}+01$ & & \\
\hline \multirow[t]{2}{*}{ Radium-226 } & Adult & $9.6 \mathrm{E}+02$ & & $2.2 E+01$ & & \\
\hline & Child & $4.8 \mathrm{E}+02$ & & $5.5 E+00$ & & \\
\hline \multirow[t]{2}{*}{ Strontium-90 } & Adult & $1.2 E+03$ & & $2.7 E+01$ & & \\
\hline & Child & $5.8 \mathrm{E}+02$ & & $6.6 \mathrm{E}+00$ & & \\
\hline \multirow[t]{2}{*}{ Thorium-228 } & Adult & $8.5 \mathrm{E}+02$ & & $2.0 \mathrm{E}+01$ & & \\
\hline & Child & $4.3 E+02$ & & $4.9 \mathrm{E}+00$ & & \\
\hline \multirow[t]{2}{*}{ Thorium-230 } & Adult & $5.7 \mathrm{E}+02$ & & $1.3 E+01$ & & \\
\hline & Child & $2.8 \mathrm{E}+02$ & & $3.3 E+\infty 0$ & & \\
\hline \multirow[t]{2}{*}{ Thorium-232 } & Adult & $6.7 \mathrm{E}+02$ & & $1.5 \mathrm{E}+01$ & & \\
\hline & Child & $3.3 E+02$ & & $3.8 \mathrm{E}+00$ & & \\
\hline \multirow[t]{2}{*}{ Thorium-234 } & Adult & $1.6 E+03$ & & $3.6 \mathrm{E}+01$ & & \\
\hline & Child & $7.9 \mathrm{E}+02$ & & $9.0 \mathrm{E}+00$ & & \\
\hline \multirow[t]{2}{*}{ Tritium } & Adult & $3.7 E+01$ & & $8.5 \mathrm{E}-01$ & & \\
\hline & Child & $1.9 \mathrm{E}+01$ & & $2.1 \mathrm{E}-01$ & & \\
\hline \multirow[t]{2}{*}{ Uranium-233/234 } & Adult & $9.5 E+02$ & & $2.2 \mathrm{E}+01$ & & \\
\hline & Child & $4.8 \mathrm{E}+02$ & & $5.4 \mathrm{E}+00$ & & \\
\hline \multirow[t]{2}{*}{ Uranium-235 } & Adult & $8.0 \mathrm{E}+01$ & & $1.8 \mathrm{E}+00$ & & \\
\hline & Child & $4.0 \mathrm{E}+01$ & & $4.6 \mathrm{E}-01$ & & \\
\hline \multirow[t]{2}{*}{ Uranium-236 } & Aduit & $2.4 \mathrm{E}+01$ & & $5.6 \mathrm{E}-01$ & & \\
\hline & Child & $1.2 E+01$ & & $1.4 \mathrm{E}-01$ & & \\
\hline \multirow[t]{2}{*}{ Uranium-238 } & Adult & $9.6 \mathrm{E}+02$ & & $2.2 \mathrm{E}+01$ & & \\
\hline & Child & $4.8 E+02$ & v & $5.5 E+00$ & & \\
\hline
\end{tabular}

The upper 95\% confidence bound on the median is used as the representative concentration in all calculations.

${ }^{b}$ For carcinogenic effects/ingestion pathway: units are $\mathrm{mg} / \mathrm{kg}$-day for inorganics and $\mathrm{pCi}$ for radionuclides. 
Table 7.4b. Chronic daily intake of ORR background soil by the on-site resident-Nolichucky" (for constituents for which a risk and/or hazard index could be calculated)

\begin{tabular}{|c|c|c|c|c|c|c|}
\hline \multirow[b]{2}{*}{ Analyte } & & \multicolumn{3}{|c|}{ Carcinogenic effects } & \multicolumn{2}{|c|}{ Noncarcinogénic effects } \\
\hline & & $\begin{array}{c}\text { Ingestion } \\
\text { (mg/kg-day or } \\
\text { pCi })^{b}\end{array}$ & $\begin{array}{c}\text { Dermal } \\
\text { (mg/kg-day) }\end{array}$ & $\begin{array}{l}\text { External } \\
\text { exposure } \\
\text { (pCi-yr/g) }\end{array}$ & $\begin{array}{l}\text { Ingestion } \\
\text { (mg/kg-day) }\end{array}$ & $\begin{array}{c}\text { Dermal } \\
\text { (mg/kg-day) }\end{array}$ \\
\hline \multicolumn{7}{|c|}{ Inorganics } \\
\hline \multirow[t]{2}{*}{ Antimony } & Adult & & & & $6.6 \mathrm{E}-07$ & $3.5 \mathrm{E}-08$ \\
\hline & Child & & & & $6.2 \mathrm{E}-06$ & $5.6 \mathrm{E}-08$ \\
\hline \multirow[t]{2}{*}{ Arsenic } & Adult & & & & $1.1 \mathrm{E}-05$ & $5.9 \mathrm{E}-07$ \\
\hline & Child & & & & $1.0 \mathrm{E}-04$ & 9.5E-07 \\
\hline \multirow{2}{*}{ Barium } & Adult & & & & $1.3 \mathrm{E}-04$ & 7.1E-06 \\
\hline & Child & & & & $1.3 \mathrm{E}-03$ & $1.1 \mathrm{E}-05$ \\
\hline \multirow{2}{*}{ Beryllium } & Adult & $4.5 \mathrm{E}-07$ & $2.4 \mathrm{E}-08$ & & $1.3 E-06$ & $7.0 \mathrm{E}-08^{\circ}$ \\
\hline & Child & $1.1 \mathrm{E}-06$ & $9.6 \mathrm{E}-09$ & & $1.2 \mathrm{E}-05$ & $1.1 \mathrm{E}-07$ \\
\hline \multirow{2}{*}{ Chromium VI } & Adult & & & & 4.7E-05 & 2.5E-06 \\
\hline & Child & & & & 4.3E-04 & $4.0 \mathrm{E}-06$ \\
\hline \multirow[t]{2}{*}{ Manganese } & Adult & & & & $1.2 \mathrm{E}-03$ & $6.5 \mathrm{E}-05$ \\
\hline & Child & & & & $1.1 E-02$ & $1.0 \mathrm{E}-04$ \\
\hline \multirow[t]{2}{*}{ Mercury } & Adult & & & & $3.0 \mathrm{E}-07$ & $1.6 \mathrm{E}-08$ \\
\hline & Child & & & & $2.8 \mathrm{E}-06$ & $2.5 \mathrm{E}-08$ \\
\hline \multirow[t]{2}{*}{ Mercury (salts) } & Adult & & & & $3.0 \mathrm{E}-07$ & $1.6 \mathrm{E}-08$ \\
\hline & Child & & & & $2.8 \mathrm{E}-06$ & $2.5 \mathrm{E}-08$ \\
\hline \multirow[t]{2}{*}{ Nickel } & Adult & & & & $2.9 \mathrm{E}-05$ & $1.6 \mathrm{E}-06$ \\
\hline & Child & & & & 2.7E-04 & $2.5 \mathrm{E}-06$ \\
\hline \multirow[t]{2}{*}{ Nickel (salts) } & Adult & & & & $2.9 \mathrm{E}-05$ & $1.6 \mathrm{E}-06$ \\
\hline & Child & & & & $27 \mathrm{E}-04$ & $2.5 E-06$ \\
\hline \multirow{2}{*}{ Selenium } & Adult & & & & $9.8 \mathrm{E}-07$ & $5.2 \mathrm{E}-08$ \\
\hline & Child & & & & $9.2 \mathrm{E}-06$ & 8.3E-08 \\
\hline \multirow[t]{2}{*}{ Strontium } & Adult & & & & $8.6 \mathrm{E}-06$ & $4.5 \mathrm{E}-07$ \\
\hline & Child & & . & & 8.0E-05 & $7.3 E-07$ \\
\hline \multirow[t]{2}{*}{ Vanadium } & Adult & & & & $5.1 \mathrm{E}-05$ & 2.7E-06 \\
\hline & Child & & & & 4.7E-04 & 4.3E-06 \\
\hline \multirow[t]{2}{*}{ Zinc } & Adult & & & & $6.4 \mathrm{E}-05$ & $3.4 \mathrm{E}-06$ \\
\hline & Child & & & & $6.0 \mathrm{E}-04$ & $5.4 \mathrm{E}-06$ \\
\hline
\end{tabular}


7-28

Table 7.4b (continued)

\begin{tabular}{|c|c|c|c|c|c|c|}
\hline \multirow[b]{2}{*}{ Analyte } & & \multicolumn{3}{|c|}{ Carcinogenic effects } & \multicolumn{2}{|c|}{ Noncarcinogenic effects } \\
\hline & & $\begin{array}{c}\text { Ingestion } \\
(\mathrm{mg} / \mathrm{kg} \text {-day or } \\
\text { pCi })^{b}\end{array}$ & $\begin{array}{c}\text { Dermal } \\
\text { (mg/kg-day) }\end{array}$ & $\begin{array}{l}\text { External } \\
\text { exposure } \\
\text { (pCi-yr/g) }\end{array}$ & $\begin{array}{l}\text { Ingestion } \\
\text { (mg/kg-day) }\end{array}$ & $\begin{array}{c}\text { Dermal } \\
\text { (mg/kg-day) }\end{array}$ \\
\hline \multicolumn{7}{|c|}{ Radionuclides } \\
\hline Cesium-137 & Adult & $1.0 \mathrm{E}+03$ & & $2.4 \mathrm{E}+01$ & & \\
\hline \multirow[t]{2}{*}{ Curium-247 } & Adult & $5.5 \mathrm{E}+00$ & & $1.2 \mathrm{E}-01$ & & \\
\hline & Child & $2.7 \mathrm{E}+00$ & & $3.1 \mathrm{E}-02$ & & \\
\hline \multirow[t]{2}{*}{ Neptunium-237 } & Adult & $1.6 \mathrm{E}+02$ & & $3.6 \mathrm{E}+00$ & & \\
\hline & Child & $8.0 \mathrm{E}+01$ & & $9.1 \mathrm{E}-01$ & & \\
\hline \multirow[t]{2}{*}{ Potassium-40 } & Adult & $1.5 E+04$ & & $3.5 \mathrm{E}+02$ & & \\
\hline & Child & $7.7 E+03$ & & $8.9 \mathrm{E}+01$ & & \\
\hline \multirow[t]{2}{*}{ Radium-226 } & Adult & $9.0 \mathrm{E}+02$ & & $2.1 \mathrm{E}+01$ & & \\
\hline & Child & $4.5 E+02$ & & $5.2 \mathrm{E}+00$ & & \\
\hline \multirow[t]{2}{*}{ Technetium-99 } & Adult & $1.6 E+03$ & & $3.7 E+01$ & & \\
\hline & Child & $8.0 E+02$ & & $9.2 \mathrm{E}+00$ & & \\
\hline \multirow[t]{2}{*}{ Thorium-228 } & Adult & $1.8 E+03$ & & $4.1 \mathrm{E}+01$ & & \\
\hline & Child & $9.0 \mathrm{E}+02$ & & $1.0 \mathrm{E}+01$ & & \\
\hline \multirow[t]{2}{*}{ Thorium-230 } & Adult & $9.7 \mathrm{E}+02$ & & 2.2E+01 & & \\
\hline & Child & $4.9 E+02$ & & $5.6 \mathrm{E}+00$ & & \\
\hline \multirow[t]{2}{*}{ Thorium-232 } & Adult & $1.5 E+03$ & & $3.3 \mathrm{E}+01$ & & \\
\hline & Child & $7.3 E+02$ & & $8.3 E+00$ & & \\
\hline \multirow[t]{2}{*}{ Thorium-234 } & Aduit & $1.4 \mathrm{E}+03$ & & $3.1 \mathrm{E}+01$ & & \\
\hline & Child & $6.9 \mathrm{E}+02$ & & $7.9 E+00$ & & \\
\hline \multirow[t]{2}{*}{ Uranium-233/234 } & Adult & $1.3 E+03$ & & $3.0 \mathrm{E}+01$ & & \\
\hline & Child & $6.5 E+02$ & & $7.4 \mathrm{E}+00$ & & \\
\hline \multirow[t]{2}{*}{ Uranium-235 } & Adult & $7.2 \mathrm{E}+01$ & & $1.6 \mathrm{E}+00$ & & \\
\hline & Child & $3.6 \mathrm{E}+01$ & & 4.1E-01 & & \\
\hline \multirow[t]{2}{*}{ Uranium-238 } & Adult & $1.2 \mathrm{E}+03$ & & $2.8 \mathrm{E}+01$ & & \\
\hline & Child & $6.0 \mathrm{E}+02$ & & $6.9 E+\infty 0$ & & \\
\hline
\end{tabular}

The upper $95 \%$ confidence bound on the median is used as the representative concentration in all calculations. ${ }^{b}$ For carcinogenic effects/ingestion pathway: units are $\mathrm{mg} / \mathrm{kg}$-day for inorganics and $\mathrm{pCi}$ for radionuclides. 


\section{7-29}

Table 7.4c. Chronic daily intake of background soil by the on-site resident-Copper Ridge (for constituents for which a risk and/or hazard index could be calculated)

\begin{tabular}{|c|c|c|c|c|c|c|}
\hline \multirow[b]{2}{*}{ Analyte } & & \multicolumn{3}{|c|}{ Carcinogenic effects } & \multicolumn{2}{|c|}{ Noncarcinogenic effects } \\
\hline & . & $\begin{array}{c}\text { Ingestion } \\
\text { (mg/kg-day or } \\
\text { pCi }{ }^{b}\end{array}$ & $\begin{array}{c}\text { Dermal } \\
\text { (mg/kg-day) }\end{array}$ & $\begin{array}{r}\text { External } \\
\text { exposure } \\
\text { (pCi-yr/g) } \\
\end{array}$ & $\begin{array}{l}\text { Ingestion } \\
\text { (mg/kg-day) }\end{array}$ & $\begin{array}{c}\text { Dermal } \\
\text { (mg/kg-day) }\end{array}$ \\
\hline \multicolumn{7}{|c|}{ Inorganics } \\
\hline \multirow[t]{2}{*}{ Arsenic } & Adult & & & & 4.2E-05 & 2.2E-06 \\
\hline & Cnila & & & & $3.9 \mathrm{E}-04$ & $3.6 \mathrm{E}-16$ \\
\hline \multirow[t]{2}{*}{ Barium } & Adult & & & & $1.3 E-04$ & $6.8 \mathrm{E}-06$ \\
\hline & Child & & & & $1.2 E-03$ & $1.1 \mathrm{E}-05$ \\
\hline \multirow[t]{2}{*}{ Beryllium } & Adult & $3.0 \mathrm{E}-07$ & $1.6 \mathrm{E}-08$ & & $8.7 \mathrm{E}-07$ & 4.6E-08 \\
\hline & Child & $6.9 \mathrm{E}-07$ & $6.3 \mathrm{E}-09$ & & 8.1E-06 & $7.4 \mathrm{E}-08$ \\
\hline \multirow[t]{2}{*}{ Chromium VI } & Adult & & & & $2.5 \mathrm{E}-05$ & $1.3 \mathrm{E}-06$ \\
\hline & Child & & & & 2.3E-04 & $2.1 \mathrm{E}-06$ \\
\hline \multirow[t]{2}{*}{ Manganese } & Adult & & & & $2.0 \mathrm{E}-03$ & $1.1 \mathrm{E}-04$ \\
\hline & Child & & & & $1.9 \mathrm{E}-02$ & $1.7 \mathrm{E}-04$ \\
\hline \multirow[t]{2}{*}{ Mercury } & Adult & & & & $2.5 \mathrm{E}-07$ & $1.3 \mathrm{E}-08$ \\
\hline & Child & & & & $2.4 \mathrm{E}-06$ & $2.1 \mathrm{E}-08$ \\
\hline \multirow[t]{2}{*}{ Mercury (salts) } & Adult & & & & 2.5E-07 & $1.3 \mathrm{E}-08$ \\
\hline & Child & & . & & $2.4 \mathrm{E}-06$ & 2.1E-08 \\
\hline \multirow[t]{2}{*}{ Molybdenum } & Adult & & & & $2.4 \mathrm{E}-06$ & $1.3 \mathrm{E}-07$ \\
\hline & Child & & & & $2.2 \mathrm{E}-05$ & $2.0 \mathrm{E}-07$ \\
\hline \multirow[t]{2}{*}{ Nickel } & Adult & & & & $1.3 E-05$ & 7.1E-07 \\
\hline & Child & & & & $1.2 \mathrm{E}-04$ & $1.1 \mathrm{E}-06$ \\
\hline \multirow[t]{2}{*}{ Nickel (salts) } & Adult & & & & $1.3 \mathrm{E}-05$ & 7.1E-07 \\
\hline & Child & & & & $1.2 \mathrm{E}-04$ & $1.1 \mathrm{E}-06$ \\
\hline \multirow[t]{2}{*}{ Selenium } & Adult & & & & $1.1 \mathrm{E}-06$ & $5.8 \mathrm{E}-08$ \\
\hline & Child & & & & $1.0 \mathrm{E}-05$ & $9.3 \mathrm{E}-08$ \\
\hline \multirow[t]{2}{*}{ Strontium } & Adult & & & & $6.6 \mathrm{E}-06$ & $3.5 \mathrm{E}-07$ \\
\hline & Child & & & & $6.2 \mathrm{E}-05$ & $5.6 \mathrm{E}-07$ \\
\hline \multirow[t]{2}{*}{ Vanadium } & Adult & & & & 4.1E-05 & $2.2 E-06$ \\
\hline & Child & & & & $3.9 \mathrm{E}-04$ & $3.5 \mathrm{E}-06$ \\
\hline \multirow[t]{2}{*}{ Zinc } & Adult & & & & $5.9 \mathrm{E}-05$ & $3.1 \mathrm{E}-06$ \\
\hline & Child & & & & $5.5 \mathrm{E}-04$ & $5.0 \mathrm{E}-06$ \\
\hline
\end{tabular}


7-30

Table 7.4c (continued)

\begin{tabular}{|c|c|c|c|c|c|c|}
\hline \multirow[b]{2}{*}{ Analyte } & & \multicolumn{3}{|c|}{ Carcinogenic effects } & \multicolumn{2}{|c|}{ Noncarcinogenic effects } \\
\hline & & $\begin{array}{c}\text { Ingestion } \\
(\mathrm{mg} / \mathrm{kg} \text {-day or } \\
\mathrm{pCi})^{b}\end{array}$ & $\begin{array}{c}\text { Dermal } \\
\text { (mg/kg-day) }\end{array}$ & $\begin{array}{l}\text { External } \\
\text { exposure } \\
\text { (pCi-yr/g) }\end{array}$ & $\begin{array}{l}\text { Ingestion } \\
\text { (mg/kg-day) }\end{array}$ & $\begin{array}{c}\text { Dermal } \\
\text { (mg/kg-day) }\end{array}$ \\
\hline \multicolumn{7}{|c|}{ Organics } \\
\hline \multirow[t]{2}{*}{ Acenaphthene } & Adult & & & & $2.6 \mathrm{E}-06$ & $1.4 \mathrm{E}-06$ \\
\hline & Child & & & & $2.5 \mathrm{E}-05$ & $2.2 \mathrm{E}-06$ \\
\hline \multirow[t]{2}{*}{ Anthracene } & Adult & & & & $2.0 \mathrm{E}-06$ & $1.0 \mathrm{E}-06$ \\
\hline & Child & & & & $1.8 \mathrm{E}-05$ & $1.7 \mathrm{E}-06$ \\
\hline \multirow[t]{2}{*}{ Benzo(a)anthracene } & Adult & $1.3 E-06$ & $6.7 \mathrm{E}-07$ & & & \\
\hline & Child & $2.9 \mathrm{E}-06$ & $2.7 \mathrm{E}-07$ & & & \\
\hline \multirow{2}{*}{ Benzo(a)pyrene } & Adult & 1.7E-06 & $8.8 \mathrm{E}-07$ & & & \\
\hline & Child & $3.9 \mathrm{E}-06$ & $3.5 \mathrm{E}-07$ & & & \\
\hline \multirow[t]{2}{*}{ Benzo(b)fluoranthene } & Adult & $1.5 \mathrm{E}-06$ & 7.7E-07 & & & \\
\hline & Child & $3.4 \mathrm{E}-06$ & $3.1 \mathrm{E}-07$ & & & \\
\hline \multirow[t]{2}{*}{ Benzo(g,h,i)perylene } & Adult & $1.8 \mathrm{E}-06$ & $9.5 \mathrm{E}-07$ & & & \\
\hline & Child & $4.2 \mathrm{E}-06$ & $3.8 \mathrm{E}-07$ & & & \\
\hline \multirow[t]{2}{*}{ Benzo(k)fluoranthene } & Adult & $8.5 \mathrm{E}-07$ & $4.5 \mathrm{E}-07$ & & & \\
\hline & Child & $2.0 \mathrm{E}-06$ & $1.8 \mathrm{E}-07$ & & & \\
\hline \multirow[t]{2}{*}{ Chrysene } & Adult & $2.6 \mathrm{E}-06$ & $1.4 \mathrm{E}-06$ & & & \\
\hline & Child & $6.0 \mathrm{E}-06$ & $5.4 \mathrm{E}-07$ & & & \\
\hline \multirow[t]{2}{*}{ Dibenz $(a, h)$ anthracene } & Adult & $7.5 \mathrm{E}-07$ & 4.0E-07 & & & \\
\hline & Child & $1.7 \mathrm{E}-06$ & $1.6 \mathrm{E}-07$ & & & \\
\hline \multirow[t]{2}{*}{ Fluoranthene } & Aduit & & & & $1.1 \mathrm{E}-05$ & $5.9 \mathrm{E}-06$ \\
\hline & Child & & & & $1.0 \mathrm{E}-04$ & $9.5 \mathrm{E}-06$ \\
\hline \multirow[t]{2}{*}{ Fluorene } & Adult & & & & $2.2 \mathrm{E}-06$ & $1.2 \mathrm{E}-06$ \\
\hline & Child & & & & $2.0 \mathrm{E}-05$ & $1.8 \mathrm{E}-06$ \\
\hline \multirow[t]{2}{*}{ Naphthalene } & Adult & & & & 23E-05 & $1.2 \mathrm{E}-05$ \\
\hline & Child & & & & 2.1E-04 & $1.9 \mathrm{E}-05$ \\
\hline \multirow[t]{2}{*}{ Phenanthrene } & Adult & $2.5 \mathrm{E}-06$ & $1.3 E-06$ & & & \\
\hline & Child & $5.9 \mathrm{E}-06$ & $5.4 \mathrm{E}-07$ & & & \\
\hline \multirow[t]{2}{*}{ Pyrene } & Adult & & & & $9.6 \mathrm{E}-06$ & $5.1 \mathrm{E}-06$ \\
\hline & Child & & & & $9.0 \mathrm{E}-05$ & $8.2 \mathrm{E}-06$ \\
\hline
\end{tabular}




\section{$7-31$}

Table 7.4c (continued)

\begin{tabular}{|c|c|c|c|c|c|c|}
\hline \multirow[b]{2}{*}{ Analyte } & & \multicolumn{3}{|c|}{ Carcinogenic effects } & \multicolumn{2}{|c|}{ Noncarcinogenic effects } \\
\hline & & $\begin{array}{c}\text { Ingestion } \\
\text { (mg/kg-day or } \\
\text { pCi })^{b}\end{array}$ & $\begin{array}{c}\text { Dermal } \\
\text { (mg/kg-day) }\end{array}$ & $\begin{array}{l}\text { External } \\
\text { exposure } \\
\text { (pCi-yr/g) }\end{array}$ & $\begin{array}{l}\text { Ingestion } \\
\text { (mg/kg-day) }\end{array}$ & $\begin{array}{c}\text { Dermal } \\
\text { (mg/kg-day) }\end{array}$ \\
\hline \multicolumn{7}{|c|}{ Radionuclides } \\
\hline Cesium-137 & $\begin{array}{l}\text { Adult } \\
\text { Child }\end{array}$ & $\begin{array}{l}1.7 \mathrm{E}+03 \\
8.4 \mathrm{E}+02\end{array}$ & & $\begin{array}{l}3.8 \mathrm{E}+01 \\
9.5 \mathrm{E}+00\end{array}$ & & \\
\hline Neptunium-237 & $\begin{array}{l}\text { Adult } \\
\text { Child }\end{array}$ & $\begin{array}{l}9.1 \mathrm{E}+01 \\
4.5 \mathrm{E}+01\end{array}$ & & $\begin{array}{l}2.1 E+00 \\
5.2 E-01\end{array}$ & & \\
\hline Plutonium-238 & $\begin{array}{l}\text { Adult } \\
\text { Child }\end{array}$ & $\begin{array}{l}3.2 \mathrm{E}+01 \\
1.6 \mathrm{E}+01\end{array}$ & - & $\begin{array}{l}7.3 \mathrm{E}-01 \\
1.8 \mathrm{E}-01\end{array}$ & & \\
\hline Plutonium-239/240 & $\begin{array}{l}\text { Adult } \\
\text { Child }\end{array}$ & $\begin{array}{l}5.0 \mathrm{E}+01 \\
2.5 \mathrm{E}+01\end{array}$ & & $\begin{array}{l}1.1 \mathrm{E}+00 \\
2.9 \mathrm{E}-01\end{array}$ & & \\
\hline Potassium -40 & $\begin{array}{l}\text { Adult } \\
\text { Child }\end{array}$ & $\begin{array}{l}4.2 E+03 \\
2.1 E+03\end{array}$ & & $\begin{array}{l}9.5 \mathrm{E}+01 \\
2.4 \mathrm{E}+01\end{array}$ & & \\
\hline Radium-226 & $\begin{array}{l}\text { Adult } \\
\text { Child }\end{array}$ & $\begin{array}{l}1.5 E+03 \\
7.5 E+02\end{array}$ & & $\begin{array}{l}3.4 E+01 \\
8.5 E+00\end{array}$ & & \\
\hline Thorium-228 & $\begin{array}{l}\text { Aduit } \\
\text { Child }\end{array}$ & $\begin{array}{l}4.1 \mathrm{E}+02 \\
2.0 \mathrm{E}+02\end{array}$ & & $\begin{array}{l}9.3 E+00 \\
2.3 E+00\end{array}$ & & \\
\hline Thorium-230 & $\begin{array}{l}\text { Aduit } \\
\text { Child }\end{array}$ & $\begin{array}{l}1.1 \mathrm{E}+03 \\
5.6 \mathrm{E}+02\end{array}$ & & $\begin{array}{l}2.5 E+01 \\
6.4 E+00\end{array}$ & & \\
\hline Thorium-232 & $\begin{array}{l}\text { Adult } \\
\text { Child }\end{array}$ & $\begin{array}{l}6.6 E+02 \\
3.3 E+02\end{array}$ & & $\begin{array}{l}1.5 \mathrm{E}+01 \\
3.8 \mathrm{E}+00\end{array}$ & & \\
\hline Thorium-234 & $\begin{array}{l}\text { Adult } \\
\text { Child }\end{array}$ & $\begin{array}{l}1.5 E+03 \\
7.7 E+02\end{array}$ & & $\begin{array}{l}3.5 E+01 \\
8.8 E+00\end{array}$ & & \\
\hline Tritium & $\begin{array}{l}\text { Adult } \\
\text { Child }\end{array}$ & $\begin{array}{l}2.2 \mathrm{E}+01 \\
1.1 \mathrm{E}+01\end{array}$ & & $\begin{array}{l}5.1 \mathrm{E}-01 \\
1.3 \mathrm{E}-01\end{array}$ & & \\
\hline Uranium-233/234 & $\begin{array}{l}\text { Adult } \\
\text { Child }\end{array}$ & $\begin{array}{l}1.5 E+03 \\
7.4 E+02\end{array}$ & & $\begin{array}{l}3.4 \mathrm{E}+01 \\
8.4 \mathrm{E}+00\end{array}$ & & \\
\hline Uranium-235 & $\begin{array}{l}\text { Adult } \\
\text { Child }\end{array}$ & $\begin{array}{l}1.5 \mathrm{E}+02 \\
7.4 \mathrm{E}+01\end{array}$ & & $\begin{array}{l}3.4 \mathrm{E}+00 \\
8.5 \mathrm{E}-01\end{array}$ & & \\
\hline Uranium-236 & $\begin{array}{l}\text { Adult } \\
\text { Child } \\
\text { Adult } \\
\text { Child } \\
\end{array}$ & $\begin{array}{l}1.5 \mathrm{E}+01 \\
7.3 \mathrm{E}+00 \\
1.3 \mathrm{E}+03 \\
6.5 \mathrm{E}+02 \\
\end{array}$ & & $\begin{array}{l}3.3 \mathrm{E}-01 \\
8.3 \mathrm{E}-02 \\
3.0 \mathrm{E}+01 \\
7.4 \mathrm{E}+00 \\
\end{array}$ & & \\
\hline
\end{tabular}

${ }^{a}$ The upper $95 \%$ confidence bound on the median is used as the representative concentration in all calculations.

${ }^{b}$ For carcinogenic effects/ingestion pathway: units are $\mathrm{mg} / \mathrm{kg}$-day for inorganics and organics, and $\mathrm{pCi}$ for radionuclides. 
Table 7.4d. Chronic daily intake of ORR background soil by the on-site resident-Chepultepec (for constituents for which a risk and/or hazard index could be calculated)

\begin{tabular}{|c|c|c|c|c|c|c|}
\hline \multirow[b]{2}{*}{ Analyte } & & \multicolumn{3}{|c|}{ Carcinogenic effects } & \multicolumn{2}{|c|}{ Noncarcinogenic effects } \\
\hline & & $\begin{array}{c}\text { Ingestion } \\
(\mathrm{mg} / \mathrm{kg} \text {-day or } \\
\mathrm{pCi})^{b}\end{array}$ & $\underset{\text { (mg/kg-day) }}{\text { Dermal }}$ & $\begin{array}{l}\text { External } \\
\text { exposure } \\
\text { (pCi-yr/g) }\end{array}$ & $\begin{array}{l}\text { Ingestion } \\
\text { (mg/kg-day) }\end{array}$ & $\begin{array}{c}\text { Dermal } \\
\text { (mg/kg-day) }\end{array}$ \\
\hline & & & Inorganics & & & \\
\hline Arsenic & $\begin{array}{l}\text { Adult } \\
\text { Child }\end{array}$ & & & & $\begin{array}{l}2.0 \mathrm{E}-05 \\
1.8 \mathrm{E}-04\end{array}$ & $\begin{array}{l}1.0 \mathrm{E}-06 \\
1.7 \mathrm{E}-06\end{array}$ \\
\hline Barium & $\begin{array}{l}\text { Adult } \\
\text { Child }\end{array}$ & & & & $\begin{array}{l}9.5 \mathrm{E}-05 \\
8.9 \mathrm{E}-04\end{array}$ & $\begin{array}{l}5.0 \mathrm{E}-06 \\
8.1 \mathrm{E}-06\end{array}$ \\
\hline Beryllium & $\begin{array}{l}\text { Adult } \\
\text { Child }\end{array}$ & $\begin{array}{l}2.2 \mathrm{E}-07 \\
5.0 \mathrm{E}-07\end{array}$ & $\begin{array}{l}1.1 \mathrm{E}-08 \\
4.6 \mathrm{E}-09\end{array}$ & & $\begin{array}{l}6.3 \mathrm{E}-07 \\
5.9 \mathrm{E}-06\end{array}$ & $\begin{array}{l}3.3 \mathrm{E}-08 \\
5.3 \mathrm{E}-08\end{array}$ \\
\hline Chromium VI & $\begin{array}{l}\text { Adult } \\
\text { Child }\end{array}$ & & & & $\begin{array}{l}2.4 \mathrm{E}-05 \\
2.2 \mathrm{E}-04\end{array}$ & $\begin{array}{l}1.3 \mathrm{E}-06 \\
2.0 \mathrm{E}-06\end{array}$ \\
\hline Manganese & $\begin{array}{l}\text { Adult } \\
\text { Child }\end{array}$ & & & & $\begin{array}{l}1.7 \mathrm{E}-03 \\
1.6 \mathrm{E}-02\end{array}$ & $\begin{array}{l}9.2 \mathrm{E}-05 \\
1.5 \mathrm{E}-04\end{array}$ \\
\hline Mercury & $\begin{array}{l}\text { Adult } \\
\text { Child }\end{array}$ & & & & $\begin{array}{l}2.1 \mathrm{E}-07 \\
2.0 \mathrm{E}-06\end{array}$ & $\begin{array}{l}1.1 \mathrm{E}-08 \\
1.8 \mathrm{E}-08\end{array}$ \\
\hline Mercury (salts) & $\begin{array}{l}\text { Adult } \\
\text { Child }\end{array}$ & & & & $\begin{array}{l}2.1 \mathrm{E}-07 \\
2.0 \mathrm{E}-06\end{array}$ & $\begin{array}{l}1.1 \mathrm{E}-08 \\
1.8 \mathrm{E}-08\end{array}$ \\
\hline Selenium & $\begin{array}{l}\text { Aduit } \\
\text { Child }\end{array}$ & & & & $\begin{array}{l}8.6 \mathrm{E}-07 \\
8.0 \mathrm{E}-06\end{array}$ & $\begin{array}{l}4.5 \mathrm{E}-08 \\
7.3 \mathrm{E}-08\end{array}$ \\
\hline Strontium & $\begin{array}{l}\text { Adult } \\
\text { Child }\end{array}$ & & & & $\begin{array}{l}4.6 \mathrm{E}-06 \\
4.3 \mathrm{E}-05\end{array}$ & $\begin{array}{l}2.4 \mathrm{E}-07 \\
3.9 \mathrm{E}-07\end{array}$ \\
\hline Vanadium & $\begin{array}{l}\text { Adult } \\
\text { Child }\end{array}$ & & & & $\begin{array}{l}4.7 \mathrm{E}-05 \\
4.4 \mathrm{E}-04\end{array}$ & $\begin{array}{l}2.5 \mathrm{E}-06 \\
4.0 \mathrm{E}-06\end{array}$ \\
\hline Zinc & $\begin{array}{l}\text { Adult } \\
\text { Child }\end{array}$ & & & & $\begin{array}{l}6.7 \mathrm{E}-05 \\
6.2 \mathrm{E}-04\end{array}$ & $\begin{array}{l}3.5 \mathrm{E}-06 \\
5.7 \mathrm{E}-06\end{array}$ \\
\hline & & & Organics & & & \\
\hline Acenaphthene & $\begin{array}{l}\text { Adult } \\
\text { Child }\end{array}$ & & & & $\begin{array}{l}1.9 \mathrm{E}-06 \\
1.7 \mathrm{E}-05\end{array}$ & $\begin{array}{l}9.9 \mathrm{E}-07 \\
1.6 \mathrm{E}-06\end{array}$ \\
\hline Anthracene & $\begin{array}{l}\text { Adult } \\
\text { Child }\end{array}$ & & & & $\begin{array}{l}1.4 \mathrm{E}-06 \\
1.3 \mathrm{E}-05\end{array}$ & $\begin{array}{l}7.5 \mathrm{E}-07 \\
1.2 \mathrm{E}-06\end{array}$ \\
\hline Benzo(a)anthracene & $\begin{array}{l}\text { Adult } \\
\text { Child }\end{array}$ & $\begin{array}{l}1.2 \mathrm{E}-06 \\
2.7 \mathrm{E}-06\end{array}$ & $\begin{array}{l}6.1 \mathrm{E}-07 \\
2.5 \mathrm{E}-07\end{array}$ & & & \\
\hline
\end{tabular}


Table 7.4d (continued)

\begin{tabular}{|c|c|c|c|c|c|c|}
\hline \multirow[b]{2}{*}{ Analyte } & & \multicolumn{3}{|c|}{ Carcinogenic effects } & \multicolumn{2}{|c|}{ Noncarcinogenic effects } \\
\hline & & $\begin{array}{c}\text { Ingestion } \\
(\mathrm{mg} / \mathrm{kg} \text {-day or } \\
\mathrm{pCi})^{b}\end{array}$ & $\begin{array}{c}\text { Dermal } \\
\text { (mg/kg-day) }\end{array}$ & $\begin{array}{l}\text { External } \\
\text { exposure } \\
\text { (pCi-yr/g) }\end{array}$ & $\begin{array}{c}\text { Ingestion } \\
\text { (mg/kg-day) }\end{array}$ & $\begin{array}{c}\text { Dermal } \\
\text { (mg/kg-day) }\end{array}$ \\
\hline \multicolumn{7}{|c|}{ Organics (continued) } \\
\hline Benzo(a)pyrene & $\begin{array}{l}\text { Adult } \\
\text { Child }\end{array}$ & $\begin{array}{l}2.3 \mathrm{E}-06 \\
5.4 \mathrm{E}-06\end{array}$ & $\begin{array}{l}1.2 \mathrm{E}-06 \\
4.9 \mathrm{E}-07\end{array}$ & & & \\
\hline Benzo(b)fluoranthene & $\begin{array}{l}\text { Aduit } \\
\text { Child }\end{array}$ & $\begin{array}{l}2.5 \mathrm{E}-06 \\
5.8 \mathrm{E}-06\end{array}$ & $\begin{array}{l}1.3 \mathrm{E}-06 \\
5.3 \mathrm{E}-07\end{array}$ & & & \\
\hline Benzo(g,h,i)perylene & $\begin{array}{l}\text { Adult } \\
\text { Child }\end{array}$ & $\begin{array}{l}1.7 \mathrm{E}-06 \\
4.0 \mathrm{E}-06\end{array}$ & $\begin{array}{l}9.2 \mathrm{E}-07 \\
3.7 \mathrm{E}-07\end{array}$ & & & \\
\hline Benzo(k)fluoranthene & $\begin{array}{l}\text { Adult } \\
\text { Child }\end{array}$ & $\begin{array}{l}1.1 \mathrm{E}-06 \\
2.5 \mathrm{E}-06\end{array}$ & $\begin{array}{l}5.7 \mathrm{E}-07 \\
2.3 \mathrm{E}-07\end{array}$ & & & \\
\hline Dibenz(a,h)anthracene & $\begin{array}{l}\text { Adult } \\
\text { Child }\end{array}$ & $\begin{array}{l}9.5 \mathrm{E}-07 \\
2.2 \mathrm{E}-06\end{array}$ & $\begin{array}{l}5.1 \mathrm{E}-07 \\
2.0 \mathrm{E}-07\end{array}$ & & & \\
\hline Fluoranthene & $\begin{array}{l}\text { Adult } \\
\text { Child }\end{array}$ & & & & $\begin{array}{l}6.4 \mathrm{E}-06 \\
5.9 \mathrm{E}-05\end{array}$ & $\begin{array}{l}3.4 \mathrm{E}-06 \\
5.4 \mathrm{E}-06\end{array}$ \\
\hline Fluorene & $\begin{array}{l}\text { Adult } \\
\text { Child }\end{array}$ & & & & $\begin{array}{l}9.9 \mathrm{E}-07 \\
9.3 \mathrm{E}-06\end{array}$ & $\begin{array}{l}5.3 \mathrm{E}-07 \\
8.4 \mathrm{E}-07\end{array}$ \\
\hline Indeno $(1,2,3-c d)$ pyrene & $\begin{array}{l}\text { Adult } \\
\text { Child }\end{array}$ & $\begin{array}{l}7.5 \mathrm{E}-06 \\
1.7 \mathrm{E}-05\end{array}$ & $\begin{array}{l}4.0 \mathrm{E}-06 \\
1.6 \mathrm{E}-06\end{array}$ & & & \\
\hline Naphthalene & $\begin{array}{l}\text { Adult } \\
\text { Child }\end{array}$ & & & & $\begin{array}{l}2.9 \mathrm{E}-05 \\
2.7 \mathrm{E}-04\end{array}$ & $\begin{array}{l}1.6 \mathrm{E}-05 \\
2.5 \mathrm{E}-05\end{array}$ \\
\hline Phenanthrene & $\begin{array}{l}\text { Adult } \\
\text { Child }\end{array}$ & $\begin{array}{l}2.1 \mathrm{E}-06 \\
4.9 \mathrm{E}-06\end{array}$ & $\begin{array}{l}1.1 \mathrm{E}-06 \\
4.5 \mathrm{E}-07\end{array}$ & & & \\
\hline Pyrene & $\begin{array}{l}\text { Adult } \\
\text { Child }\end{array}$ & & & & $\begin{array}{l}7.2 \mathrm{E}-06 \\
6.8 \mathrm{E}-05\end{array}$ & $\begin{array}{l}3.8 \mathrm{E}-06 \\
6.1 \mathrm{E}-06\end{array}$ \\
\hline \multicolumn{7}{|c|}{ Radionucides } \\
\hline Cesium-137 & $\begin{array}{l}\text { Adult } \\
\text { Child }\end{array}$ & $\begin{array}{l}2.0 \mathrm{E}+03 \\
9.9 \mathrm{E}+02\end{array}$ & & $\begin{array}{l}4.5 \mathrm{E}+01 \\
1.1 \mathrm{E}+01\end{array}$ & & \\
\hline Neptunium-237 & $\begin{array}{l}\text { Adult } \\
\text { Child }\end{array}$ & $\begin{array}{l}7.5 \mathrm{E}+01 \\
3.7 \mathrm{E}+01\end{array}$ & & $\begin{array}{c}1.7 \mathrm{E}+00 \\
4.3 \mathrm{E}-01\end{array}$ & & \\
\hline Plutonium-238 & $\begin{array}{l}\text { Adult } \\
\text { Child }\end{array}$ & $\begin{array}{l}1.1 \mathrm{E}+02 \\
5.5 \mathrm{E}+01\end{array}$ & - & $\begin{array}{c}2.5 \mathrm{E}+00 \\
6.3 \mathrm{E}-01\end{array}$ & & \\
\hline
\end{tabular}




\section{$7-34$}

Table 7.4d (continued)

\begin{tabular}{|c|c|c|c|c|c|c|}
\hline \multirow[b]{2}{*}{ Analyte } & & \multicolumn{3}{|c|}{ Carcinogenic effects } & \multicolumn{2}{|c|}{ Noncarcinogenic effects } \\
\hline & & $\begin{array}{c}\text { Ingestion } \\
(\mathrm{mg} / \mathrm{kg} \text {-day or } \\
\mathrm{pCi})^{b}\end{array}$ & $\begin{array}{c}\text { Dermal } \\
\text { (mg/kg-day) }\end{array}$ & $\begin{array}{l}\text { External } \\
\text { exposure } \\
\text { (pCi-yr/g) }\end{array}$ & $\begin{array}{l}\text { Ingestion } \\
\text { (mg/kg-day) }\end{array}$ & $\begin{array}{c}\text { Dermal } \\
\text { (mg/kg-day) }\end{array}$ \\
\hline \multicolumn{7}{|c|}{ Radionuclides (continued) } \\
\hline Potassium-40 & $\begin{array}{l}\text { Adult } \\
\text { Child }\end{array}$ & $\begin{array}{l}3.2 E+03 \\
1.6 E+03\end{array}$ & & $\begin{array}{l}7.3 \mathrm{E}+01 \\
1.8 \mathrm{E}+01\end{array}$ & & \\
\hline Radium-226 & $\begin{array}{l}\text { Adult } \\
\text { Child }\end{array}$ & $\begin{array}{l}1.1 E+03 \\
5.3 E+02\end{array}$ & & $\begin{array}{l}2.4 \mathrm{E}+01 \\
6.1 \mathrm{E}+00\end{array}$ & & \\
\hline Thorium-228 & $\begin{array}{l}\text { Adult } \\
\text { Child }\end{array}$ & $\begin{array}{l}7.2 \mathrm{E}+02 \\
3.6 \mathrm{E}+02\end{array}$ & & $\begin{array}{l}1.7 \mathrm{E}+01 \\
4.1 \mathrm{E}+00\end{array}$ & & \\
\hline Thorium-230 & $\begin{array}{l}\text { Aduit } \\
\text { Child }\end{array}$ & $\begin{array}{l}7.8 \mathrm{E}+02 \\
3.9 \mathrm{E}+02\end{array}$ & & $\begin{array}{l}1.8 \mathrm{E}+01 \\
4.5 \mathrm{E}+00\end{array}$ & & \\
\hline Thorium-232 & $\begin{array}{l}\text { Adult } \\
\text { Child }\end{array}$ & $\begin{array}{l}6.1 \mathrm{E}+02 \\
3.0 \mathrm{E}+02\end{array}$ & & $\begin{array}{l}1.4 \mathrm{E}+01 \\
3.5 \mathrm{E}+00\end{array}$ & & \\
\hline Uranium-233/234 & $\begin{array}{l}\text { Adult } \\
\text { Child }\end{array}$ & $\begin{array}{l}1.1 \mathrm{E}+03 \\
5.6 \mathrm{E}+02\end{array}$ & & $\begin{array}{l}2.6 \mathrm{E}+01 \\
6.4 \mathrm{E}+00\end{array}$ & & \\
\hline Uranium-235 & $\begin{array}{l}\text { Adult } \\
\text { Child }\end{array}$ & $\begin{array}{l}8.8 E+01 \\
4.4 E+01\end{array}$ & & $\begin{array}{c}2.0 \mathrm{E}+00 \\
5.0 \mathrm{E}-01\end{array}$ & & \\
\hline Uranium-238 & $\begin{array}{l}\text { Adult } \\
\text { Child }\end{array}$ & $\begin{array}{l}1.1 E+03 \\
5.3 E+02\end{array}$ & & $\begin{array}{l}2.4 \mathrm{E}+01 \\
6.0 \mathrm{E}+00\end{array}$ & & \\
\hline
\end{tabular}

The upper $95 \%$ confidence bound on the median is used as the representative concentration in all calculations.

${ }^{b}$ For carcinogenic effects/ingestion pathway: units are $\mathrm{mg} / \mathrm{kg}$-day for inorganies and organics, and $\mathrm{pCi}$ for radionuclides. 
Table 7.4e. Chronic daily intake of ORR background soil by the on-site resident-Chickamauga (Bethel Valleg) ${ }^{a}$

(for constituents for which a risk and/or hazard index could be calculated)

\begin{tabular}{|c|c|c|c|c|c|c|}
\hline \multirow[b]{2}{*}{ Analyte } & & \multicolumn{3}{|c|}{ Carcinogenic effects } & \multicolumn{2}{|c|}{ Noncarcinogenic effects } \\
\hline & & $\begin{array}{c}\text { Ingestion } \\
\text { (mg/kg-day or } \\
\text { pCi })^{b}\end{array}$ & $\begin{array}{c}\text { Dermal } \\
\text { (mg/kg-day) }\end{array}$ & $\begin{array}{l}\text { External } \\
\text { exposure } \\
\text { (pCi-yr/g) }\end{array}$ & $\begin{array}{c}\text { Ingestion } \\
\text { (mg/kg-day) }\end{array}$ & $\begin{array}{c}\text { Dermal } \\
\text { (mg/kg-day) }\end{array}$ \\
\hline \multicolumn{7}{|c|}{ Inorganics } \\
\hline \multirow[t]{2}{*}{ Arsenic } & Adult & & & & $1.1 \mathrm{E}-05$ & $5.8 \mathrm{E}-07$ \\
\hline & Child & & & & $1.0 \mathrm{E}-04$ & 9.3E-07 \\
\hline \multirow[t]{2}{*}{ Barium } & Adult & & & & $1.4 E-04$ & $75 \mathrm{E}-06$ \\
\hline & Child & & & & $1.3 \mathrm{E}-03$ & $1.2 \mathrm{E}-05$ \\
\hline \multirow[t]{2}{*}{ Beryllium } & Adult & $5.9 \mathrm{E}-07$ & $3.1 \mathrm{E}-08$ & & 1.7E-06 & $9.1 \mathrm{E}-08$ \\
\hline & Child & $1.4 \mathrm{E}-06$ & $1.2 \mathrm{E}-08$ & & $1.6 \mathrm{E}-05$ & $1.5 \mathrm{E}-07$ \\
\hline \multirow[t]{2}{*}{ Chromium VI } & Aduit & & & & $5.5 \mathrm{E}-05$ & $2.9 \mathrm{E}-06$ \\
\hline & Child & & & & 5.1E-04 & 4.7E-06 \\
\hline \multirow[t]{2}{*}{ Manganese } & Adult & & & & $2.0 \mathrm{E}-03$ & $1.0 \mathrm{E}-04$ \\
\hline & Child & & & & $1.8 \mathrm{E}-02$ & $1.7 \mathrm{E}-04$ \\
\hline \multirow[t]{2}{*}{ Mercury } & Adult & & & & 2.6E-07 & $1.4 \mathrm{E}-08$ \\
\hline & Child & & & & $2.4 \mathrm{E}-06$ & $2.2 \mathrm{E}-08$ \\
\hline \multirow[t]{2}{*}{ Mercury (salts) } & Adult & & & & $2.6-07$ & $1.4 \mathrm{E}-08$ \\
\hline & Child & & & & $2.4 \mathrm{E}-06$ & $2.2 \mathrm{E}-08$ \\
\hline \multirow[t]{2}{*}{ Nickel } & Adult & & & & $2.3 \mathrm{E}-05$ & $1.2 \mathrm{E}-06$ \\
\hline & Child & & & & $2.1 \mathrm{E}-04$ & $1.9 \mathrm{E}-06$ \\
\hline \multirow[t]{2}{*}{ Nickel (salts) } & Adult & & & & 2.3E-05 & $1.2 \mathrm{E}-06$ \\
\hline & Child & & & & 2.1E-04 & $1.9 E-06$ \\
\hline \multirow[t]{2}{*}{ Selenium } & Adult & & & & $1.3 \mathrm{E}-06$ & $6.8 \mathrm{E}-08$ \\
\hline & Child & & & & $1.2 \mathrm{E}-05$ & $1.1 \mathrm{E}-07$ \\
\hline \multirow[t]{2}{*}{ Strontium } & Aduit & & & & $1.2 \mathrm{E}-05$ & $6.3 \mathrm{E}-07$ \\
\hline & Child & & & & $1.1 \mathrm{E}-04$ & $1.0 \mathrm{E}-06$ \\
\hline \multirow[t]{2}{*}{ Vanadium } & Adult & & & & 5.7E-05 & $3.0 \mathrm{E}-06$ \\
\hline & Child & . & & & $5.4 \mathrm{E}-04$ & $4.9 \mathrm{E}-06$ \\
\hline \multirow[t]{2}{*}{ Zinc } & Adult & & & & $7.6 \mathrm{E}-05$ & $4.0 \mathrm{E}-06$ \\
\hline & Child & & & & 7.1E-04 & $6.5 \mathrm{E}-06$ \\
\hline
\end{tabular}


7-36

Table 7.4e (continued)

\begin{tabular}{|c|c|c|c|c|c|c|}
\hline \multirow[b]{2}{*}{ Analyte } & & \multicolumn{3}{|c|}{ Carcinogenic effects } & \multicolumn{2}{|c|}{ Noncarcinogenic effects } \\
\hline & & $\begin{array}{c}\text { Ingestion } \\
(\mathrm{mg} / \mathrm{kg} \text {-day or } \\
\mathrm{pCi})^{b}\end{array}$ & $\begin{array}{c}\text { Dermal } \\
\text { (mg/kg-day) }\end{array}$ & $\begin{array}{l}\text { External } \\
\text { exposure } \\
\text { (pCi-yr/g) }\end{array}$ & $\begin{array}{l}\text { Ingestion } \\
\text { (mg/kg-day) }\end{array}$ & $\begin{array}{c}\text { Dermal } \\
\text { (mg/kg-day) }\end{array}$ \\
\hline & & & Drganics & & & \\
\hline Acenaphthene & $\begin{array}{l}\text { Aduit } \\
\text { Child }\end{array}$ & & & & $\begin{array}{l}8.2 \mathrm{E}-06 \\
7.6 \mathrm{E}-05\end{array}$ & $\begin{array}{l}4.3 \mathrm{E}-06 \\
6.9 \mathrm{E}-06\end{array}$ \\
\hline Anthracene & $\begin{array}{l}\text { Adult } \\
\text { Child }\end{array}$ & & & & $\begin{array}{l}1.6 \mathrm{E}-06 \\
1.5 \mathrm{E}-05\end{array}$ & $\begin{array}{l}8.3 \mathrm{E}-07 \\
1.3 \mathrm{E}-06\end{array}$ \\
\hline Benzo(a)anthracene & $\begin{array}{l}\text { Adult } \\
\text { Child }\end{array}$ & $\begin{array}{l}3.0 \mathrm{E}-06 \\
7.0 \mathrm{E}-06\end{array}$ & $\begin{array}{l}1.6 \mathrm{E}-06 \\
6.4 \mathrm{E}-07\end{array}$ & & & \\
\hline Benzo(a)pyrene & $\begin{array}{l}\text { Aduit } \\
\text { Child }\end{array}$ & $\begin{array}{l}2.3 \mathrm{E}-06 \\
5.4 \mathrm{E}-06\end{array}$ & $\begin{array}{l}1.2 \mathrm{E}-06 \\
4.9 \mathrm{E}-07\end{array}$ & & & \\
\hline Benzo(b)fluoranthene & $\begin{array}{l}\text { Adult } \\
\text { Child }\end{array}$ & $\begin{array}{l}3.0 \mathrm{E}-06 \\
6.9 \mathrm{E}-06\end{array}$ & $\begin{array}{l}1.6 \mathrm{E}-06 \\
6.3 \mathrm{E}-07\end{array}$ & & & \\
\hline Benzo(g,h,i)perylene & $\begin{array}{l}\text { Adult } \\
\text { Child }\end{array}$ & $\begin{array}{l}2.4 \mathrm{E}-06 \\
5.6 \mathrm{E}-06\end{array}$ & $\begin{array}{l}1.3 \mathrm{E}-06 \\
5.1 \mathrm{E}-07\end{array}$ & & & \\
\hline Benzo(k)fluoranthene & $\begin{array}{l}\text { Adult } \\
\text { Child }\end{array}$ & $\begin{array}{l}1.4 \mathrm{E}-06 \\
3.2 \mathrm{E}-06\end{array}$ & $\begin{array}{l}7.2 \mathrm{E}-07 \\
2.9 \mathrm{E}-07\end{array}$ & & & \\
\hline Chrysene & $\begin{array}{l}\text { Adult } \\
\text { Child }\end{array}$ & $\begin{array}{l}3.7 \mathrm{E}-06 \\
8.6 \mathrm{E}-06\end{array}$ & $\begin{array}{l}1.9 \mathrm{E}-06 \\
7.8 \mathrm{E}-07\end{array}$ & & & \\
\hline Dibenz(a,h)anthracene & $\begin{array}{l}\text { Adult } \\
\text { Child }\end{array}$ & $\begin{array}{l}6.7 \mathrm{E}-07 \\
1.6 \mathrm{E}-06\end{array}$ & $\begin{array}{l}3.5 \mathrm{E}-07 \\
1.4 \mathrm{E}-07\end{array}$ & & & \\
\hline Fuoranthene & $\begin{array}{l}\text { Adult } \\
\text { Child }\end{array}$ & & & & $\begin{array}{l}9.9 \mathrm{E}-06 \\
9.3 \mathrm{E}-05\end{array}$ & $\begin{array}{l}5.3 E-06 \\
8.4 E-06\end{array}$ \\
\hline Fluorene & $\begin{array}{l}\text { Adult } \\
\text { Child }\end{array}$ & & & & $\begin{array}{l}7.6 \mathrm{E}-06 \\
7.1 \mathrm{E}-05\end{array}$ & $\begin{array}{l}4.0 \mathrm{E}-06 \\
6.4 \mathrm{E}-06\end{array}$ \\
\hline Indeno(1,2,3-cd)pyrene & $\begin{array}{l}\text { Adult } \\
\text { Child }\end{array}$ & $\begin{array}{l}7.6 \mathrm{E}-06 \\
1.8 \mathrm{E}-05\end{array}$ & $\begin{array}{l}4.0 \mathrm{E}-06 \\
1.6 \mathrm{E}-06\end{array}$ & & & \\
\hline Naphthalene & $\begin{array}{l}\text { Adult } \\
\text { Child }\end{array}$ & & . & & $\begin{array}{l}1.5 \mathrm{E}-05 \\
1.4 \mathrm{E}-04\end{array}$ & $\begin{array}{l}7.9 \mathrm{E}-06 \\
1.3 \mathrm{E}-05\end{array}$ \\
\hline Phenanthrene & $\begin{array}{l}\text { Adult } \\
\text { Child }\end{array}$ & $\begin{array}{l}4.1 \mathrm{E}-06 \\
9.6 \mathrm{E}-06\end{array}$ & $\begin{array}{l}2.2 \mathrm{E}-06 \\
8.8 \mathrm{E}-07\end{array}$ & & & \\
\hline Pyrene & $\begin{array}{l}\text { Aduit } \\
\text { Child }\end{array}$ & & & & $\begin{array}{l}1.7 \mathrm{E}-05 \\
1.6 \mathrm{E}-04\end{array}$ & $\begin{array}{l}9.1 \mathrm{E}-06 \\
1.5 \mathrm{E}-05\end{array}$ \\
\hline
\end{tabular}


Table 7.4e (continued)

\begin{tabular}{|c|c|c|c|c|c|c|}
\hline \multirow[b]{2}{*}{ Analyte } & & \multicolumn{3}{|c|}{ Carcinogenic effects } & \multicolumn{2}{|c|}{ Noncarcinogenic effects } \\
\hline & & 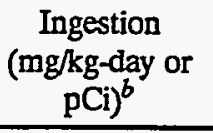 & $\begin{array}{c}\text { Dermal } \\
\text { (mg/kg-day) }\end{array}$ & $\begin{array}{c}\text { External } \\
\text { exposure } \\
\text { (pCi-yr/g) } \\
\end{array}$ & $\begin{array}{l}\text { Ingestion } \\
\text { (mg/kg-day) }\end{array}$ & $\begin{array}{c}\text { Dermal } \\
\text { (mg/kg-day) }\end{array}$ \\
\hline \multicolumn{7}{|c|}{ Radionuclides } \\
\hline Cesium-137 & $\begin{array}{l}\text { Adult } \\
\text { Child }\end{array}$ & $\begin{array}{l}2.7 E+03 \\
1.3 E+03\end{array}$ & & $\begin{array}{l}6.1 \mathrm{E}+01 \\
1.5 \mathrm{E}+01\end{array}$ & & \\
\hline Neptunium-237 & $\begin{array}{l}\text { Adult } \\
\text { Child }\end{array}$ & $\begin{array}{l}1.0 \mathrm{E}+02 \\
5.2 \mathrm{E}+01\end{array}$ & & $\begin{array}{l}2.4 \mathrm{E}+00 \\
6.0 \mathrm{E}-01\end{array}$ & & \\
\hline Plutonium-238 & $\begin{array}{l}\text { Adult } \\
\text { Child }\end{array}$ & $\begin{array}{l}1.1 \mathrm{E}+02 \\
5.4 \mathrm{E}+01\end{array}$ & & $\begin{array}{l}2.5 \mathrm{E}+00 \\
6.2 \mathrm{E}-01\end{array}$ & & \\
\hline Plutonium-239/240 & $\begin{array}{l}\text { Adult } \\
\text { Child }\end{array}$ & $\begin{array}{l}6.5 \mathrm{E}+01 \\
3.2 \mathrm{E}+01\end{array}$ & & $\begin{array}{l}1.5 \mathrm{E}+00 \\
3.7 \mathrm{E}-01\end{array}$ & & \\
\hline Potassium -40 & $\begin{array}{l}\text { Aduit } \\
\text { Child }\end{array}$ & $\begin{array}{l}1.5 E+04 \\
7.7 E+03\end{array}$ & & $\begin{array}{l}3.5 \mathrm{E}+02 \\
8.8 \mathrm{E}+01\end{array}$ & & \\
\hline Radium-226 & $\begin{array}{l}\text { Adult } \\
\text { Child }\end{array}$ & $\begin{array}{l}1.3 \mathrm{E}+03 \\
6.6 \mathrm{E}+02\end{array}$ & & $\begin{array}{l}3.0 \mathrm{E}+01 \\
7.5 \mathrm{E}+00\end{array}$ & & \\
\hline Technetium-99 & $\begin{array}{l}\text { Adult } \\
\text { Child }\end{array}$ & $\begin{array}{l}1.7 E+03 \\
8.3 E+02\end{array}$ & & $\begin{array}{l}3.8 E+01 \\
9.5 E+00\end{array}$ & & \\
\hline Thorium-228 & $\begin{array}{l}\text { Adult } \\
\text { Child }\end{array}$ & $\begin{array}{l}1.5 E+03 \\
7.7 E+02\end{array}$ & & $\begin{array}{l}3.5 \mathrm{E}+01 \\
8.8 \mathrm{E}+00\end{array}$ & & \\
\hline Thorium-230 & $\begin{array}{l}\text { Adult } \\
\text { Child }\end{array}$ & $\begin{array}{l}1.1 \mathrm{E}+03 \\
5.3 \mathrm{E}+02\end{array}$ & & $\begin{array}{l}24 \mathrm{E}+01 \\
6.1 \mathrm{E}+00\end{array}$ & & \\
\hline Thorium-232 & $\begin{array}{l}\text { Adult } \\
\text { Child }\end{array}$ & $\begin{array}{l}1.2 \mathrm{E}+03 \\
6.1 \mathrm{E}+02\end{array}$ & & $\begin{array}{l}2.8 \mathrm{E}+01 \\
7.0 \mathrm{E}+00\end{array}$ & & \\
\hline Tritium & $\begin{array}{l}\text { Adult } \\
\text { Child }\end{array}$ & $\begin{array}{l}1.4 \mathrm{E}+02 \\
6.8 \mathrm{E}+01\end{array}$ & & $\begin{array}{l}3.1 \mathrm{E}+00 \\
7.8 \mathrm{E}-01\end{array}$ & & \\
\hline Uranium-233/234 & $\begin{array}{l}\text { Adult } \\
\text { Child }\end{array}$ & $\begin{array}{l}1.0 \mathrm{E}+03 \\
5.1 \mathrm{E}+02\end{array}$ & & $\begin{array}{l}2.3 \mathrm{E}+01 \\
5.9 \mathrm{E}+00\end{array}$ & & \\
\hline Uranium-235 & $\begin{array}{l}\text { Aduit } \\
\text { Child }\end{array}$ & $\begin{array}{l}1.1 \mathrm{E}+02 \\
5.5 \mathrm{E}+01\end{array}$ & & $\begin{array}{l}2.5 \mathrm{E}+00 \\
6.3 \mathrm{E}-01\end{array}$ & & \\
\hline Uranium-238 & $\begin{array}{l}\text { Adult } \\
\text { Child }\end{array}$ & $\begin{array}{l}1.0 \mathrm{E}+03 \\
5.0 \mathrm{E}+02\end{array}$ & & $\begin{array}{l}2.3 \mathrm{E}+01 \\
5.7 \mathrm{E}+00\end{array}$ & & \\
\hline
\end{tabular}

"The upper $95 \%$ confidence bound on the median is used as the representative concentration in all calculations.

${ }^{b}$ For carcinogenic effects/ingestion pathway: units are $\mathrm{mg} / \mathrm{kg}$-day for inorganics and organics, and $\mathrm{pCi}$ for radionuclides. 
Table 7.4f. Chronic daily intake of ORR background soil by the on-site resident-Chickamauga (K-25)

(for constituents for which a risk and/or hazard index could be calculated)

\begin{tabular}{|c|c|c|c|c|c|c|}
\hline \multirow[b]{2}{*}{ Analyte } & & \multicolumn{3}{|c|}{ Carcinogenic effects } & \multicolumn{2}{|c|}{ Noncarcinogenic effects } \\
\hline & & $\begin{array}{c}\text { Ingestion } \\
\text { (mg/kg-day or } \\
\text { pCi })^{b}\end{array}$ & $\begin{array}{c}\text { Dermal } \\
\text { (mg/kg-day) }\end{array}$ & $\begin{array}{l}\text { External } \\
\text { exposure } \\
\text { (pCi-yr/g) }\end{array}$ & $\begin{array}{l}\text { Ingestion } \\
\text { (mg/kg-day) }\end{array}$ & $\begin{array}{c}\text { Dermal } \\
\text { (mg/kg-day) }\end{array}$ \\
\hline & & & Inorganics & & & \\
\hline \multirow[t]{2}{*}{ Arsenic } & Adult & & & & $1.3 E-05$ & 7.1E-07 \\
\hline & Child & & & & $1.2 E-04$ & $1.1 \mathrm{E}-06$ \\
\hline \multirow[t]{2}{*}{ Barium } & Adult & & & & $1.4 \mathrm{E}-04$ & 7.2E-06 \\
\hline & Child & & & & $1.3 \mathrm{E}-03$ & $1.2 \mathrm{E}-05$ \\
\hline \multirow[t]{2}{*}{ Beryllium } & Adult & 5.3E-07 & $2.8 \mathrm{E}-08$ & & $1.5 \mathrm{E}-06$ & 8.1E-08 \\
\hline & Child & $1.2 \mathrm{E}-06$ & $1.1 \mathrm{E}-08$ & & $1.4 \mathrm{E}-05$ & $1.3 E-07$ \\
\hline \multirow[t]{2}{*}{ Chromium VI } & Adult & & & & $5.3 \mathrm{E}-05$ & $2.8 \mathrm{E}-06$ \\
\hline & Child & & & & $4.9 \mathrm{E}-04$ & $4.5 \mathrm{E}-06$ \\
\hline \multirow[t]{2}{*}{ Manganese } & Aduit & & & & 3.1E-03 & $1.7 \mathrm{E}-04$ \\
\hline & Child & & & & $2.9 \mathrm{E}-02$ & 2.7E-04 \\
\hline \multirow[t]{2}{*}{ Mercury } & Adult & & & & $7.9 \mathrm{E}-07$ & 4.2E-08 \\
\hline & Child & & & & 7.4E-06 & $6.7 \mathrm{E}-08$ \\
\hline \multirow[t]{2}{*}{ Mercury (saits) } & Adult & & - & & 7.9E-07 & $4.2 \mathrm{E}-08$ \\
\hline & Child & & & & 7.4E-06 & $6.7 \mathrm{E}-08$ \\
\hline \multirow[t]{2}{*}{ Nickel } & Adult & & & & $2.9 \mathrm{E}-05$ & $1.5 \mathrm{E}-06$ \\
\hline & Child & & & & 2.7E-04 & $2.5 \mathrm{E}-06$ \\
\hline \multirow[t]{2}{*}{ Nickel (salts) } & Adult & & & & $2.9 \mathrm{E}-05$ & $1.5 \mathrm{E}-06$ \\
\hline & Child & & & & 2.7E-04 & $2.5 \mathrm{E}-06$ \\
\hline \multirow[t]{2}{*}{ Selenium } & Adult & & & & $1.3 \mathrm{E}-06$ & 7.0E-08 \\
\hline & Child & & & & $1.2 \mathrm{E}-05$ & $1.1 \mathrm{E}-07$ \\
\hline \multirow[t]{2}{*}{ Strontium } & Adult & & & & $2.2 \mathrm{E}-05$ & $1.2 \mathrm{E}-06$ \\
\hline & Child & & & & $2.0 \mathrm{E}-04$ & $1.9 \mathrm{E}-06$ \\
\hline \multirow[t]{2}{*}{ Vanadium } & Adult & & & & $5.7 \mathrm{E}-05$ & $3.0 \mathrm{E}-06$ \\
\hline & Child & & & & $5.4 \mathrm{E}-04$ & 4.9E-06 \\
\hline \multirow[t]{2}{*}{ Zinc } & Adult & & & & $7.8 \mathrm{E}-05$ & 4.1E-06 \\
\hline & Child & & & & 7.3E-04 & $6.6 \mathrm{E}-06$ \\
\hline
\end{tabular}


Table 7.4f (continued)

\begin{tabular}{|c|c|c|c|c|c|c|}
\hline \multirow{2}{*}{ Analyte } & & \multicolumn{3}{|c|}{ Carcinogenic effects } & \multicolumn{2}{|c|}{ Noncarcinogenic effects } \\
\hline & & $\begin{array}{c}\text { Ingestion } \\
(\mathrm{mg} / \mathrm{kg} \text {-day or } \\
\mathrm{pCi})^{b}\end{array}$ & $\begin{array}{c}\text { Dermal } \\
\text { (mg/kg-day) }\end{array}$ & $\begin{array}{l}\text { External } \\
\text { exposure } \\
\text { (pCi-yr/g) }\end{array}$ & $\begin{array}{l}\text { Ingestion } \\
\text { (mg/kg-day) }\end{array}$ & $\begin{array}{c}\text { Dermal } \\
\text { (mg/kg-day) }\end{array}$ \\
\hline & & & Organics & & & \\
\hline Acenaphthene & Adult & & & & 2.5E-06 & $1.3 \mathrm{E}-06$ \\
\hline Anthracene & $\begin{array}{l}\text { Adult } \\
\text { Child }\end{array}$ & & & & $\begin{array}{l}2.6 \mathrm{E}-06 \\
2.4 \mathrm{E}-05\end{array}$ & $\begin{array}{l}1.4 \mathrm{E}-06 \\
2.2 \mathrm{E}-06\end{array}$ \\
\hline Benzo(a)anthracene & $\begin{array}{l}\text { Aduit } \\
\text { Child }\end{array}$ & $\begin{array}{l}3.5 \mathrm{E}-06 \\
8.2 \mathrm{E}-06\end{array}$ & $\begin{array}{l}1.9 \mathrm{E}-06 \\
7.5 \mathrm{E}-07\end{array}$ & & & \\
\hline Benzo(a)pyrene & $\begin{array}{l}\text { Adult } \\
\text { Child }\end{array}$ & $\begin{array}{l}3.2 \mathrm{E}-06 \\
7.4 \mathrm{E}-06\end{array}$ & $\begin{array}{l}1.7 \mathrm{E}-06 \\
6.7 \mathrm{E}-07\end{array}$ & & & \\
\hline Benzo(b)fluoranthene & $\begin{array}{l}\text { Adult } \\
\text { Child }\end{array}$ & $\begin{array}{l}2.9 \mathrm{E}-06 \\
6.7 \mathrm{E}-06\end{array}$ & $\begin{array}{l}1.5 \mathrm{E}-06 \\
6.1 \mathrm{E}-07\end{array}$ & & & . \\
\hline Benzo $(g, h, i)$ perylene & $\begin{array}{l}\text { Adult } \\
\text { Child }\end{array}$ & $\begin{array}{l}2.9 \mathrm{E}-06 \\
6.8 \mathrm{E}-06\end{array}$ & $\begin{array}{l}1.5 \mathrm{E}-06 \\
6.1 \mathrm{E}-07\end{array}$ & & & \\
\hline Benzo(k)fluoranthene & $\begin{array}{l}\text { Adult } \\
\text { Child }\end{array}$ & $\begin{array}{l}\text { 1.7E-06 } \\
4.1 \mathrm{E}-06\end{array}$ & $\begin{array}{l}9.3 \mathrm{E}-07 \\
3.7 \mathrm{E}-07\end{array}$ & . & & \\
\hline Chrysene & $\begin{array}{l}\text { Adult } \\
\text { Child }\end{array}$ & $\begin{array}{l}3.8 \mathrm{E}-06 \\
8.8 \mathrm{E}-06\end{array}$ & $\begin{array}{l}2.0 \mathrm{E}-06 \\
8.0 \mathrm{E}-07\end{array}$ & & & \\
\hline Dibenz $(a, h)$ anthracene & $\begin{array}{l}\text { Adult } \\
\text { Child }\end{array}$ & $\begin{array}{l}\text { 7.3E-07 } \\
1.7 \mathrm{E}-06\end{array}$ & $\begin{array}{l}3.9 \mathrm{E}-07 \\
1.6 \mathrm{E}-07\end{array}$ & & & \\
\hline Fluoranthene & $\begin{array}{l}\text { Adult } \\
\text { Child }\end{array}$ & & & & $\begin{array}{l}1.3 \mathrm{E}-05 \\
1.2 \mathrm{E}-04\end{array}$ & $\begin{array}{l}6.9 \mathrm{E}-06 \\
1.1 \mathrm{E}-05\end{array}$ \\
\hline Fluorene & $\begin{array}{l}\text { Adult } \\
\text { Child }\end{array}$ & & & & $\begin{array}{l}2.9 \mathrm{E}-06 \\
2.7 \mathrm{E}-05\end{array}$ & $\begin{array}{l}1.5 \mathrm{E}-06 \\
2.5 \mathrm{E}-06\end{array}$ \\
\hline Indeno(1,2,3-cd)pyrene & $\begin{array}{l}\text { Adult } \\
\text { Child }\end{array}$ & $\begin{array}{l}6.4 \mathrm{E}-06 \\
1.5 \mathrm{E}-05\end{array}$ & $\begin{array}{l}3.4 \mathrm{E}-06 \\
1.4 \mathrm{E}-06\end{array}$ & & & \\
\hline Naphthalene & $\begin{array}{l}\text { Adult } \\
\text { Child }\end{array}$ & & & & $\begin{array}{l}\text { 4.7E-06 } \\
4.4 \mathrm{E}-05\end{array}$ & $\begin{array}{l}2.5 \mathrm{E}-06 \\
4.0 \mathrm{E}-06\end{array}$ \\
\hline Phenanthrene & $\begin{array}{l}\text { Adult } \\
\text { Child }\end{array}$ & $\begin{array}{l}4.5 \mathrm{E}-06 \\
1.0 \mathrm{E}-05\end{array}$ & $\begin{array}{l}2.4 \mathrm{E}-06 \\
9.5 \mathrm{E}-07\end{array}$ & & & \\
\hline Pyrene & $\begin{array}{l}\text { Aduit } \\
\text { Child }\end{array}$ & & & & $\begin{array}{l}2.1 \mathrm{E}-05 \\
2.0 \mathrm{E}-04\end{array}$ & $\begin{array}{l}1.1 \mathrm{E}-05 \\
1.8 \mathrm{E}-05\end{array}$ \\
\hline
\end{tabular}


Table 7.4f (continued)

\begin{tabular}{|c|c|c|c|c|c|c|}
\hline \multirow[b]{2}{*}{ Analyte } & & \multicolumn{3}{|c|}{ Carcinogenic effects } & \multicolumn{2}{|c|}{ Noncarcinogenic effects } \\
\hline & & $\begin{array}{c}\text { Ingestion } \\
(\mathrm{mg} / \mathrm{kg} \text {-day or } \\
\text { pCi })^{b}\end{array}$ & $\begin{array}{c}\text { Dermal } \\
\text { (mg/kg-day) }\end{array}$ & $\begin{array}{l}\text { External } \\
\text { exposure } \\
\text { (pCi-yr/g) }\end{array}$ & $\begin{array}{l}\text { Ingestion } \\
\text { (mg/kg-day) }\end{array}$ & $\begin{array}{c}\text { Dermal } \\
\text { (mg/kg-day) }\end{array}$ \\
\hline \multicolumn{7}{|c|}{ Radionuctides } \\
\hline \multirow[t]{2}{*}{ Cesium-137 } & Adult & $2.2 E+03$ & & $4.9 \mathrm{E}+01$ & & \\
\hline & Child & $1.1 E+03$ & & $1.2 E+01$ & & \\
\hline \multirow[t]{2}{*}{ Neptunium-237 } & Adult & $1.0 \mathrm{E}+02$ & & $2.3 E+\infty 0$ & & \\
\hline & Child & $5.0 \mathrm{E}+01$ & & $5.8 \mathrm{E}-01$ & & \\
\hline \multirow[t]{2}{*}{ Plutonium-238 } & Adult & $9.7 \mathrm{E}+01$ & & $2.2 \mathrm{E}+00$ & & \\
\hline & Child & $4.8 \mathrm{E}+01$ & & $5.5 \mathrm{E}-01$ & & \\
\hline \multirow[t]{2}{*}{ Plutonium-239/240 } & Aduit & 4.1E+01 & & $9.3 E-01$ & & \\
\hline & Child & $2.0 \mathrm{E}+01$ & & 2.3E-01 & & \\
\hline \multirow[t]{2}{*}{ Potassium -40} & Adult & $9.9 E+03$ & & $2.3 E+02$ & & \\
\hline & Child & $4.9 \mathrm{E}+03$ & & $5.6 \mathrm{E}+01$ & & \\
\hline \multirow[t]{2}{*}{ Radium-226 } & Adult & $1.1 \mathrm{E}+03$ & & $2.6 \mathrm{E}+01$ & & \\
\hline & Child & $5.7 \mathrm{E}+02$ & & $6.5 \mathrm{E}+00$ & & \\
\hline \multirow[t]{2}{*}{ Technetium-99 } & Adult & $1.4 \mathrm{E}+03$ & & $3.2 \mathrm{E}+01$ & & \\
\hline & Child & $7.0 \mathrm{E}+02$ & & $8.0 \mathrm{E}+00$ & & \\
\hline \multirow[t]{2}{*}{ Thorium-228 } & Adult & $1.4 \mathrm{E}+03$ & & $3.1 E+01$ & & \\
\hline & Child & $6.8 \mathrm{E}+02$ & & 7.7E+00 & & \\
\hline \multirow[t]{2}{*}{ Thorium-230 } & Adult & $1.0 E+03$ & & $2.4 E+01$ & & \\
\hline & Child & $5.2 E+02$ & & $6.0 \mathrm{E}+\infty 0$ & & \\
\hline \multirow[t]{2}{*}{ Thorium-232 } & Adult & $1.1 \mathrm{E}+03$ & & $2.5 E+01$ & & \\
\hline & Child & $5.4 E+02$ & & $6.2 \mathrm{E}+00$ & & \\
\hline \multirow[t]{2}{*}{ Uranium-233/234 } & Adult & $1.2 \mathrm{E}+03$ & & $2.8 \mathrm{E}+01$ & & \\
\hline & Child & $6.2 E+02$ & & $7.1 \mathrm{E}+00$ & & \\
\hline \multirow[t]{2}{*}{ Uranium-235 } & Adult & $6.9 \mathrm{E}+01$ & & $1.6 \mathrm{E}+00$ & & \\
\hline & Child & $3.5 E+01$ & & 4.0E-01 & & \\
\hline \multirow[t]{2}{*}{ Uranium-238 } & Adult & $1.1 \mathrm{E}+03$ & & $2.6 \mathrm{E}+01$ & & \\
\hline & Child & $5.7 E+02$ & & $6.5 \mathrm{E}+00$ & & \\
\hline
\end{tabular}

The upper $95 \%$ confidence bound on the median is used as the representative concentration in all calculations.

${ }^{b}$ For carcinogenic effects/ingestion pathway: units are $\mathrm{mg} / \mathrm{kg}$-day for inorganics and organics, and $\mathrm{pCi}$ for radionuclides. 
Table 7.5a. Chronic daily intake of ORR background soil by the on-site resident-Dismal Gapa (for constituents for which a risk and/or hazard index could not be calculated)

\begin{tabular}{|c|c|c|c|c|c|c|}
\hline \multirow[b]{2}{*}{ Analyte } & & \multicolumn{3}{|c|}{ Carcinogenic effects } & \multicolumn{2}{|c|}{ Noncarcinogenic effects } \\
\hline & & $\begin{array}{c}\text { Ingestion } \\
(\mathrm{mg} / \mathrm{kg}-\text { day or } \\
\mathrm{pCi})^{b}\end{array}$ & $\begin{array}{c}\text { Dermal } \\
\text { (mg/kg-day) }\end{array}$ & $\begin{array}{c}\text { External } \\
\text { exposure } \\
\text { (pCi-yr/g) }\end{array}$ & $\begin{array}{l}\text { Ingestion } \\
\text { (mg/kg-day) }\end{array}$ & $\begin{array}{c}\text { Dermal } \\
\text { (mg/kg-day) }\end{array}$ \\
\hline \multicolumn{7}{|c|}{ Inorganics } \\
\hline Aluminum & $\begin{array}{l}\text { Adult } \\
\text { Child }\end{array}$ & $\begin{array}{l}1.1 \mathrm{E}-02 \\
2.5 \mathrm{E}-02\end{array}$ & $\begin{array}{l}5.8 \mathrm{E}-04 \\
2.3 \mathrm{E}-04\end{array}$ & & $\begin{array}{l}3.2 \mathrm{E}-02 \\
3.0 \mathrm{E}-01\end{array}$ & $\begin{array}{l}1.7 \mathrm{E}-03 \\
2.7 \mathrm{E}-03\end{array}$ \\
\hline Arsenic & $\begin{array}{l}\text { Adult } \\
\text { Child }\end{array}$ & $\begin{array}{l}3.7 \mathrm{E}-06 \\
8.7 \mathrm{E}-06\end{array}$ & $\begin{array}{l}2.0 \mathrm{E}-07 \\
7.9 \mathrm{E}-08\end{array}$ & $=$ & & \\
\hline Barium & $\begin{array}{l}\text { Adult } \\
\text { Child }\end{array}$ & $\begin{array}{l}6.0 \mathrm{E}-05 \\
1.4 \mathrm{E}-04\end{array}$ & $\begin{array}{l}3.2 \mathrm{E}-06 \\
1.3 \mathrm{E}-06\end{array}$ & & & \\
\hline Boron & $\begin{array}{l}\text { Adult } \\
\text { Child }\end{array}$ & $\begin{array}{l}1.1 \mathrm{E}-05 \\
2.5 \mathrm{E}-05\end{array}$ & $\begin{array}{l}5.6 \mathrm{E}-07 \\
2.3 \mathrm{E}-07\end{array}$ & & & \\
\hline Calcium & $\begin{array}{l}\text { Adult } \\
\text { Child }\end{array}$ & $\begin{array}{l}8.5 \mathrm{E}-04 \\
2.0 \mathrm{E}-03\end{array}$ & $\begin{array}{l}4.5 \mathrm{E}-05 \\
1.8 \mathrm{E}-05\end{array}$ & & $\begin{array}{l}2.5 \mathrm{E}-03 \\
2.3 \mathrm{E}-02\end{array}$ & $\begin{array}{l}1.3 \mathrm{E}-04 \\
2.1 \mathrm{E}-04\end{array}$ \\
\hline Chromium & $\begin{array}{l}\text { Adult } \\
\text { Child }\end{array}$ & $\begin{array}{l}1.4 \mathrm{E}-05 \\
3.2 \mathrm{E}-05\end{array}$ & $\begin{array}{l}7.3 E-07 \\
2.9 E-07\end{array}$ & & $\begin{array}{l}4.0 \mathrm{E}-05 \\
3.7 \mathrm{E}-04\end{array}$ & $\begin{array}{l}2.1 \mathrm{E}-06 \\
3.4 \mathrm{E}-06\end{array}$ \\
\hline Chromium VI & $\begin{array}{l}\text { Adult } \\
\text { Child }\end{array}$ & $\begin{array}{l}1.4 \mathrm{E}-05 \\
3.2 \mathrm{E}-05\end{array}$ & $\begin{array}{l}7.3 \mathrm{E}-07 \\
2.9 \mathrm{E}-07\end{array}$ & . & & \\
\hline Cobalt & $\begin{array}{l}\text { Adult } \\
\text { Child }\end{array}$ & $\begin{array}{l}9.1 \mathrm{E}-06 \\
2.1 \mathrm{E}-05\end{array}$ & $\begin{array}{l}4.8 \mathrm{E}-07 \\
1.9 \mathrm{E}-07\end{array}$ & & $\begin{array}{l}2.6 \mathrm{E}-05 \\
2.5 \mathrm{E}-04\end{array}$ & $\begin{array}{l}1.4 \mathrm{E}-06 \\
2.2 \mathrm{E}-06\end{array}$ \\
\hline Copper & $\begin{array}{l}\text { Adult } \\
\text { Child }\end{array}$ & $\begin{array}{l}9.6 \mathrm{E}-06 \\
2.2 \mathrm{E}-05\end{array}$ & $\begin{array}{l}5.1 \mathrm{E}-07 \\
2.0 \mathrm{E}-07\end{array}$ & & $\begin{array}{l}2.8 \mathrm{E}-05 \\
2.6 \mathrm{E}-04\end{array}$ & $\begin{array}{l}1.5 E-06 \\
2.4 E-06\end{array}$ \\
\hline Cyanide & $\begin{array}{l}\text { Adult } \\
\text { Child }\end{array}$ & $\begin{array}{l}1.3 \mathrm{E}-07 \\
3.1 \mathrm{E}-07\end{array}$ & $\begin{array}{l}7.0 \mathrm{E}-09 \\
2.8 \mathrm{E}-09\end{array}$ & & & $\cdot$ \\
\hline Iron & $\begin{array}{l}\text { Adult } \\
\text { Child }\end{array}$ & $\begin{array}{l}1.6 \mathrm{E}-02 \\
3.7 \mathrm{E}-02\end{array}$ & $\begin{array}{l}8.5 \mathrm{E}-04 \\
3.4 \mathrm{E}-04\end{array}$ & & $\begin{array}{l}4.7 \mathrm{E}-02 \\
4.4 \mathrm{E}-01\end{array}$ & $\begin{array}{l}2.5 \mathrm{E}-03 \\
4.0 \mathrm{E}-03\end{array}$ \\
\hline Lead & $\begin{array}{l}\text { Adult } \\
\text { Child }\end{array}$ & $\begin{array}{l}1.3 \mathrm{E}-05 \\
3.0 \mathrm{E}-05\end{array}$ & $\begin{array}{l}6.9 \mathrm{E}-07 \\
2.8 \mathrm{E}-07\end{array}$ & & $\begin{array}{l}3.8 \mathrm{E}-05 \\
3: 5 \mathrm{E}-04\end{array}$ & $\begin{array}{l}2.0 \mathrm{E}-06 \\
3.2 \mathrm{E}-06\end{array}$ \\
\hline Lithium & $\begin{array}{l}\text { Adult } \\
\text { Child }\end{array}$ & $\begin{array}{l}1.0 \mathrm{E}-05 \\
2.4 \mathrm{E}-05\end{array}$ & $\begin{array}{l}5.3 \mathrm{E}-07 \\
2.1 \mathrm{E}-07\end{array}$ & & $\begin{array}{l}2.9 \mathrm{E}-05 \\
2.7 \mathrm{E}-04\end{array}$ & $\begin{array}{l}1.6 \mathrm{E}-06 \\
2.5 \mathrm{E}-06\end{array}$ \\
\hline Magnesium & $\begin{array}{l}\text { Aduit } \\
\text { Child }\end{array}$ & $\begin{array}{l}1.6 \mathrm{E}-03 \\
3.7 \mathrm{E}-03\end{array}$ & $\begin{array}{l}8.5 \mathrm{E}-05 \\
3.4 \mathrm{E}-05\end{array}$ & & $\begin{array}{l}4.7 \mathrm{E}-03 \\
4.4 \mathrm{E}-02\end{array}$ & $\begin{array}{l}2.5 \mathrm{E}-04 \\
4.0 \mathrm{E}-04\end{array}$ \\
\hline Manganese & $\begin{array}{l}\text { Adult } \\
\text { Child }\end{array}$ & $\begin{array}{l}6.4 \mathrm{E}-04 \\
1.5 \mathrm{E}-03\end{array}$ & $\begin{array}{l}3.4 \mathrm{E}-05 \\
1.4 \mathrm{E}-05\end{array}$ & & & \\
\hline
\end{tabular}


Table 7.5a (continued)

\begin{tabular}{|c|c|c|c|c|c|c|}
\hline \multirow[b]{2}{*}{ Analyte } & & \multicolumn{3}{|c|}{ Carcinogenic effects } & \multicolumn{2}{|c|}{ Noncarcinogenic effects } \\
\hline & & $\begin{array}{c}\text { Ingestion } \\
(\mathrm{mg} / \mathrm{kg} \text {-day or } \\
\text { pCi) }\end{array}$ & $\begin{array}{c}\text { Dermal } \\
\text { (mg/kg-day) }\end{array}$ & $\begin{array}{c}\text { External } \\
\text { exposure } \\
\text { (pCi-yr/g) }\end{array}$ & $\begin{array}{l}\text { Ingestion } \\
\text { (mg/kg-day) }\end{array}$ & $\begin{array}{c}\text { Dermal } \\
\text { (mg/kg-day) }\end{array}$ \\
\hline \multicolumn{7}{|c|}{ Inorganics (continued) } \\
\hline \multirow[t]{2}{*}{ Mercury } & Adult & 1.7E-07 & 9.2E-09 & & & \\
\hline & Child & $4.1 \mathrm{E}-07$ & 3.7E-09 & & & \\
\hline \multirow[t]{2}{*}{ Mercury (salts) } & Adult & $1.7 \mathrm{E}-07$ & $9.2 \mathrm{E}-09$ & & & \\
\hline & Child & $4.1 \mathrm{E}-07$ & 3.7E-09 & & & \\
\hline \multirow[t]{2}{*}{ Nickel } & Adult & $1.4 \mathrm{E}-05$ & $7.2 \mathrm{E}-07$ & & & \\
\hline & Child & $3.2 \mathrm{E}-05$ & $2.9 \mathrm{E}-07$ & & & \\
\hline \multirow[t]{2}{*}{ Nickel (salts) } & Adult & $1.4 \mathrm{E}-05$ & $7.2 \mathrm{E}-07$ & & & \\
\hline & Child & $3.2 \mathrm{E}-05$ & $2.9 \mathrm{E}-07$ & & & \\
\hline \multirow[t]{2}{*}{ Potassium } & Adult & $1.3 E-03$ & $7.0 \mathrm{E}-05$ & & $3.8 \mathrm{E}-03$ & $2.0 \mathrm{E}-04$ \\
\hline & Child & $3.1 \mathrm{E}-03$ & $2.8 \mathrm{E}-05$ & & $3.6 \mathrm{E}-02$ & 3.3E-04 \\
\hline \multirow[t]{2}{*}{ Silicon } & Adult & 2.6E-04 & $1.4 \mathrm{E}-05$ & & 7.6E-04 & 4.0E-05 \\
\hline & Child & $6.1 \mathrm{E}-04$ & $5.5 \mathrm{E}-06$ & & $7.1 \mathrm{E}-03$ & $6.5 \mathrm{E}-05$ \\
\hline \multirow[t]{2}{*}{ Strontium } & Adult & $5.4 \mathrm{E}-06$ & $2.8 \mathrm{E}-07$ & & & \\
\hline & Child & 1.3E-05 & $1.1 \mathrm{E}-07$ & & & \\
\hline \multirow[t]{2}{*}{ Sulfate } & Adult & $6.0 \mathrm{E}-05$ & $3.2 \mathrm{E}-06$ & & $1.7 \mathrm{E}-04$ & $9.2 \mathrm{E}-06$ \\
\hline & Child & 1.4E-04 & $1.3 E-06$ & & $1.6 \mathrm{E}-03$ & $1.5 \mathrm{E}-05$ \\
\hline \multirow[t]{2}{*}{ Thallium } & Adult & $2.6 \mathrm{E}-07$ & $1.4 \mathrm{E}-08$ & & $7.6 \mathrm{E}-07$ & 4.0E-08 \\
\hline & Child & $6.1 \mathrm{E}-07$ & $5.5 \mathrm{E}-09$ & & 7.1E-06 & $6.5 \mathrm{E}-08$ \\
\hline \multirow[t]{2}{*}{ Vanadium } & Adult & $1.8 \mathrm{E}-05$ & 9.7E-07 & & & \\
\hline & Child & $4.3 E-05$ & $3.9 E-07$ & & & \\
\hline \multirow[t]{2}{*}{ Zinc } & Adult & $2.9 \mathrm{E}-05$ & $1.6 \mathrm{E}-06$ & & & \\
\hline & Child & $6.9 \mathrm{E}-05$ & $6.2 E-07$ & & & \\
\hline \multicolumn{7}{|c|}{ Radionuclides } \\
\hline \multirow[t]{2}{*}{ Total Uranium } & Adult & $1.9 \mathrm{E}+03$ & & $4.4 \mathrm{E}+01$ & & \\
\hline & Child & $9.5 \mathrm{E}+02$ & & $1.1 \mathrm{E}+01$ & & \\
\hline
\end{tabular}

'The upper $95 \%$ confidence bound on the median is used as the representative concentration in all calculations.

${ }^{b}$ For carcinogenic effects/ingestion pathway: units are $\mathrm{mg} / \mathrm{kg}$-day for inorganics and $\mathrm{pCi}$ for radionuclides. 
Table 7.5b. Chronic daily intake of ORR background soil by the on-site resident-Nolichacky" (for constituents for which a risk and/or hazard index could not be calculated)

\begin{tabular}{|c|c|c|c|c|c|c|}
\hline \multirow[b]{2}{*}{ Analyte } & & \multicolumn{3}{|c|}{ Carcinogenic effects } & \multicolumn{2}{|c|}{ Noncarcinogenic effects } \\
\hline & & $\begin{array}{c}\begin{array}{c}\text { Ingestion } \\
(\mathrm{mg} / \mathrm{kg} \text {-day or } \\
\mathrm{pCi})^{b}\end{array} \\
\end{array}$ & $\begin{array}{c}\text { Dermal } \\
\text { (mg/kg-day) }\end{array}$ & $\begin{array}{l}\text { External } \\
\text { exposure } \\
\text { (pCi-yr/g) }\end{array}$ & $\begin{array}{l}\text { Ingestion } \\
\text { (mg/kg-day) }\end{array}$ & $\begin{array}{c}\text { Dermal } \\
\text { (mg/kg-day) }\end{array}$ \\
\hline & & & Inorganics & & & \\
\hline Aluminum & $\begin{array}{l}\text { Adult } \\
\text { Child }\end{array}$ & $\begin{array}{l}1.2 \mathrm{E}-02 \\
2.7 \mathrm{E}-02\end{array}$ & $\begin{array}{l}6.2 \mathrm{E}-04 \\
2.5 \mathrm{E}-04\end{array}$ & & $\begin{array}{l}3.4 \mathrm{E}-02 \\
3.2 \mathrm{E}-01\end{array}$ & $\begin{array}{l}1.8 \mathrm{E}-03 \\
2.9 \mathrm{E}-03\end{array}$ \\
\hline Antimony & $\begin{array}{l}\text { Adult } \\
\text { Child }\end{array}$ & $\begin{array}{l}2.3 E-07 \\
5.3 E-07\end{array}$ & $\begin{array}{l}1.2 \mathrm{E}-08 \\
4.8 \mathrm{E}-09\end{array}$ & & & \\
\hline Arsenic & $\begin{array}{l}\text { Adult } \\
\text { Child }\end{array}$ & $\begin{array}{l}3.8 \mathrm{E}-06 \\
9.0 \mathrm{E}-06\end{array}$ & $\begin{array}{l}2.0 \mathrm{E}-07 \\
8.2 \mathrm{E}-08\end{array}$ & & & \\
\hline Barium & $\begin{array}{l}\text { Adult } \\
\text { Child }\end{array}$ & $\begin{array}{l}4.6 \mathrm{E}-05 \\
1.1 \mathrm{E}-04\end{array}$ & $\begin{array}{l}2.4 \mathrm{E}-06 \\
9.8 \mathrm{E}-07\end{array}$ & & & \\
\hline Calcium & $\begin{array}{l}\text { Adult } \\
\text { Child }\end{array}$ & $\begin{array}{l}5.1 \mathrm{E}-04 \\
1.2 \mathrm{E}-03\end{array}$ & $\begin{array}{l}2.7 \mathrm{E}-05 \\
1.1 \mathrm{E}-05\end{array}$ & & $\begin{array}{l}1.5 \mathrm{E}-03 \\
1.4 \mathrm{E}-02\end{array}$ & $\begin{array}{l}7.9 \mathrm{E}-05 \\
1.3 \mathrm{E}-04\end{array}$ \\
\hline Chromium & $\begin{array}{l}\text { Adult } \\
\text { Child }\end{array}$ & $\begin{array}{l}\text { 1.6E-05 } \\
3.7 \mathrm{E}-05\end{array}$ & $\begin{array}{l}8.5 \mathrm{E}-07 \\
3.4 \mathrm{E}-07\end{array}$ & & $\begin{array}{l}4.7 \mathrm{E}-05 \\
4.3 \mathrm{E}-04\end{array}$ & $\begin{array}{l}2.5 \mathrm{E}-06 \\
4.0 \mathrm{E}-06\end{array}$ \\
\hline Chromium VI & $\begin{array}{l}\text { Adult } \\
\text { Child }\end{array}$ & $\begin{array}{l}1.6 \mathrm{E}-05 \\
3.7 \mathrm{E}-05\end{array}$ & $\begin{array}{l}8.5 \mathrm{E}-07 \\
3.4 \mathrm{E}-07\end{array}$ & & & \\
\hline Cobalt & $\begin{array}{l}\text { Adult } \\
\text { Child }\end{array}$ & $\begin{array}{l}9.0 \mathrm{E}-06 \\
2.1 \mathrm{E}-05\end{array}$ & $\begin{array}{l}4.8 \mathrm{E}-07 \\
1.9 \mathrm{E}-07\end{array}$ & & $\begin{array}{l}2.6 \mathrm{E}-05 \\
2.5 \mathrm{E}-04\end{array}$ & $\begin{array}{l}1.4 \mathrm{E}-06 \\
2.2 \mathrm{E}-06\end{array}$ \\
\hline Copper & $\begin{array}{l}\text { Adult } \\
\text { Child }\end{array}$ & $\begin{array}{l}7.0 \mathrm{E}-06 \\
1.6 \mathrm{E}-05\end{array}$ & $\begin{array}{l}3.7 \mathrm{E}-07 \\
1.5 \mathrm{E}-07\end{array}$ & & $\begin{array}{l}2.0 \mathrm{E}-05 \\
1.9 \mathrm{E}-04\end{array}$ & $\begin{array}{l}1.1 \mathrm{E}-06 \\
1.7 \mathrm{E}-06\end{array}$ \\
\hline Iron & $\begin{array}{l}\text { Aduit } \\
\text { Child }\end{array}$ & $\begin{array}{l}1.5 \mathrm{E}-02 \\
3.6 \mathrm{E}-02\end{array}$ & $\begin{array}{l}8.1 \mathrm{E}-04 \\
3.2 \mathrm{E}-04\end{array}$ & & $\begin{array}{l}4.4 \mathrm{E}-02 \\
4.1 \mathrm{E}-01\end{array}$ & $\begin{array}{l}2.4 \mathrm{E}-03 \\
3.8 \mathrm{E}-03\end{array}$ \\
\hline Lead & $\begin{array}{l}\text { Aduit } \\
\text { Child }\end{array}$ & $\begin{array}{l}1.2 \mathrm{E}-05 \\
2.8 \mathrm{E}-05\end{array}$ & $\begin{array}{l}6.2 \mathrm{E}-07 \\
2.5 \mathrm{E}-07\end{array}$ & & $\begin{array}{l}3.4 \mathrm{E}-05 \\
3.2 \mathrm{E}-04\end{array}$ & $\begin{array}{l}1.8 \mathrm{E}-06 \\
2.9 \mathrm{E}-06\end{array}$ \\
\hline Lithium & $\begin{array}{l}\text { Adult } \\
\text { Child }\end{array}$ & $\begin{array}{l}6.6 \mathrm{E}-06 \\
1.5 \mathrm{E}-05\end{array}$ & $\begin{array}{l}3.5 \mathrm{E}-07 \\
1.4 \mathrm{E}-07\end{array}$ & & $\begin{array}{l}1.9 \mathrm{E}-05 \\
1.8 \mathrm{E}-04\end{array}$ & $\begin{array}{l}1.0 \mathrm{E}-06 \\
1.6 \mathrm{E}-06\end{array}$ \\
\hline Magnesium & $\begin{array}{l}\text { Adult } \\
\text { Child }\end{array}$ & $\begin{array}{l}1.1 \mathrm{E}-03 \\
2.6 \mathrm{E}-03\end{array}$ & $\begin{array}{l}6.0 \mathrm{E}-05 \\
2.4 \mathrm{E}-05\end{array}$ & & $\begin{array}{l}3.3 \mathrm{E}-03 \\
3.1 \mathrm{E}-02\end{array}$ & $\begin{array}{l}1.8 \mathrm{E}-04 \\
2.8 \mathrm{E}-04\end{array}$ \\
\hline Manganese & $\begin{array}{l}\text { Adult } \\
\text { Child }\end{array}$ & $\begin{array}{l}4.2 \mathrm{E}-04 \\
9.8 \mathrm{E}-04\end{array}$ & $\begin{array}{l}2.2 \mathrm{E}-05 \\
8.9 \mathrm{E}-06\end{array}$ & & & \\
\hline Mercury & $\begin{array}{l}\text { Adult } \\
\text { Child }\end{array}$ & $\begin{array}{l}1.0 \mathrm{E}-07 \\
2.4 \mathrm{E}-07\end{array}$ & $\begin{array}{l}5.4 \mathrm{E}-09 \\
2.2 \mathrm{E}-09\end{array}$ & & & \\
\hline
\end{tabular}




\section{$7-44$}

Table 7.5b (continued)

\begin{tabular}{|c|c|c|c|c|c|c|}
\hline \multirow[b]{2}{*}{ Anaiyte } & & \multicolumn{3}{|c|}{ Carcinogenic effects } & \multicolumn{2}{|c|}{ Noncarcinogenic effects } \\
\hline & & $\begin{array}{c}\text { Ingestion } \\
(\mathrm{mg} / \mathrm{kg}-\text { day or } \\
\mathrm{pCi})^{b}\end{array}$ & $\begin{array}{c}\text { Dermal } \\
\text { (mg/kg-day) }\end{array}$ & $\begin{array}{l}\text { External } \\
\text { exposure } \\
\text { (pCi-yr/g) }\end{array}$ & $\begin{array}{l}\text { Ingestion } \\
\text { (mg/kg-day) }\end{array}$ & $\begin{array}{c}\text { Dermal } \\
\text { (mg/kg-day) }\end{array}$ \\
\hline \multicolumn{7}{|c|}{ Inorganics (continued) } \\
\hline \multirow[t]{2}{*}{ Mercury (salts) } & Adult & $1.0 \mathrm{E}-0.7$ & $5.4 \mathrm{E}-09$ & & & \\
\hline & Child & $2.4 \mathrm{E}-07$ & $2.2 \mathrm{E}-09$ & & & \\
\hline \multirow[t]{2}{*}{ Nickel } & Adult & $1.0 \mathrm{E}-05$ & 5.3E-07 & & & \\
\hline & Child & 2.3E-05 & 2.1E-07 & & & \\
\hline \multirow[t]{2}{*}{ Nickel (salts) } & Adult & $1.0 \mathrm{E}-05$ & 5.3E-07 & & & \\
\hline & Child & $2.3 \mathrm{E}-05$ & $2.1 \mathrm{E}-07$ & & & \\
\hline \multirow{2}{*}{ Potassium } & Adult & $1.7 \mathrm{E}-03$ & $8.9 \mathrm{E}-05$ & & $4.9 \mathrm{E}-03$ & $2.6 \mathrm{E}-04$ \\
\hline & Child & $3.9 \mathrm{E}-03$ & $3.6 \mathrm{E}-05$ & & 4.6E-02 & 4.2E-04 \\
\hline \multirow[t]{2}{*}{ Selenium } & Adult & $3.4 \mathrm{E}-07$ & $1.8 \mathrm{E}-08$ & & & \\
\hline & Child & $7.9 \mathrm{E}-07$ & $7.2 \mathrm{E}-09$ & & & \\
\hline \multirow[t]{2}{*}{ Silicon } & Adult & $1.3 E-04$ & $6.7 \mathrm{E}-06$ & & 3.7E-04 & $2.0 \mathrm{E}-05$ \\
\hline & Child & $2.9 \mathrm{E}-04$ & $2.7 \mathrm{E}-06$ & & $3.4 \mathrm{E}-03$ & 3.1E-05 \\
\hline \multirow[t]{2}{*}{ Strontium } & Adult & $2.9 \mathrm{E}-06$ & $1.6 \mathrm{E}-07$ & & & \\
\hline & Child & $6.8 \mathrm{E}-06$ & $6.2 \mathrm{E}-08$ & & & \\
\hline \multirow[t]{2}{*}{ Sulfate } & Adult & 1.2E-05 & $6.5 \mathrm{E}-07$ & & 3.6E-05 & $1.9 \mathrm{E}-06$ \\
\hline & Child & $2.9 \mathrm{E}-05$ & $2.6 \mathrm{E}-07$ & & 3.3E-04 & $3.0 \mathrm{E}-06$ \\
\hline \multirow[t]{2}{*}{ Vanadium } & Adult & $1.7 \mathrm{E}-05$ & 9.2E-07 & & & \\
\hline & Child & 4.1E-05 & 3.7E-07 & & & \\
\hline \multirow[t]{2}{*}{ Zinc } & Adult & $2.2 \mathrm{E}-05$ & $1.2 \mathrm{E}-06$ & & & \\
\hline & Child & 5.1E-05 & 4.7E-07 & & & \\
\hline \multicolumn{7}{|c|}{ Radionuclides } \\
\hline \multirow[t]{2}{*}{ Total Uranium } & Adult & $1.7 \mathrm{E}+03$ & & $3.8 \mathrm{E}+01$ & & \\
\hline & Child & $8.3 E+02$ & & $9.5 E+00$ & & \\
\hline
\end{tabular}

The upper $95 \%$ confidence bound on the median is used as the representative concentration in all calculations.

${ }^{b}$ For carcinogenic effects/ingestion pathway: units are $\mathrm{mg} / \mathrm{kg}$-day for inorganics and $\mathrm{pCi}$ for radionuclides. 
Table 7.5c. Chronic daily intake of ORR background soil by the on-site resident-Copper Ridge (for constituents for which a risk and/or hazard index could not be calculated)

\begin{tabular}{|c|c|c|c|c|c|c|}
\hline \multirow[b]{2}{*}{ Analyte } & & \multicolumn{3}{|c|}{ Carcinogenic effects } & \multicolumn{2}{|c|}{ Noncarcinogenic effects } \\
\hline & & $\begin{array}{c}\text { Ingestion } \\
\text { (mg/kg-day or } \\
\text { pCi) }\end{array}$ & $\begin{array}{c}\text { Dermal } \\
\text { (mg/kg-day) }\end{array}$ & $\begin{array}{r}\text { External } \\
\text { exposure } \\
\text { (pCi-yr/g) }\end{array}$ & $\begin{array}{l}\text { Ingestion } \\
\text { (mg/kg-day) }\end{array}$ & $\begin{array}{c}\text { Dermal } \\
\text { (mg/kg-day) }\end{array}$ \\
\hline \multicolumn{7}{|c|}{ Inorganics } \\
\hline \multirow[t]{2}{*}{ Aluminum } & Adult & $5.6 \mathrm{E}-03$ & $2.9 \mathrm{E}-04$ & & $1.6 \mathrm{E}-02$ & $8.6 \mathrm{E}-04$ \\
\hline & Child & $1.3 \mathrm{E}-02$ & $1.2 \mathrm{E}-04$ & & $1.5 \mathrm{E}-01$ & $1.4 \mathrm{E}-03$ \\
\hline \multirow[t]{2}{*}{ Arsenic } & Adult & $1.4 \mathrm{E}-05$ & 7.7E-07 & & & \\
\hline & Child & $3.4 \mathrm{E}-05$ & 3.1E-07 & & & \\
\hline \multirow[t]{2}{*}{ Barium } & Adult & 4.4E-05 & 2.3E-06 & & & \\
\hline & Child & $1.0 \mathrm{E}-04$ & 9.3E-07 & & & \\
\hline \multirow[t]{2}{*}{ Calcium } & Adult & $3.3 \mathrm{E}-04$ & 1.7E-05 & & $9.5 \mathrm{E}-04$ & $5.1 \mathrm{E}-05$ \\
\hline & Child & $7.6 \mathrm{E}-04$ & $6.9 \mathrm{E}-06$ & & $8.9 \mathrm{E}-03$ & 8.1E-05 \\
\hline \multirow[t]{2}{*}{ Chromium } & Adult & $8.6 \mathrm{E}-06$ & 4.5E-07 & & 2.5E-05 & $1.3 \mathrm{E}-06$ \\
\hline & Child & $2.0 \mathrm{E}-05$ & $1.8 \mathrm{E}-07$ & & 2.3E-04 & 2.1E-06 \\
\hline \multirow[t]{2}{*}{ Chromium VI } & Adult & $8.6 \mathrm{E}-06$ & $4.5 \mathrm{E}-07$ & . & - & \\
\hline & Child & $2.0 \mathrm{E}-05$ & $1.8 \mathrm{E}-07$ & & & \\
\hline \multirow[t]{2}{*}{ Cobalt } & Adult & $4.8 \mathrm{E}-06$ & $2.6 \mathrm{E}-07$ & & $1.4 \mathrm{E}-05$ & 7.5E-07 \\
\hline & Child & $1.1 \mathrm{E}-05$ & $1.0 \mathrm{E}-07$ & & $1.3 E-04$ & $1.2 \mathrm{E}-06$ \\
\hline \multirow[t]{2}{*}{ Copper } & Adult & $3.8 \mathrm{E}-06$ & $2.0 \mathrm{E}-07$ & & $1.1 \mathrm{E}-05$ & $5.9 \mathrm{E}-07$ \\
\hline & Child & $9.0 \mathrm{E}-06$ & $8.2 \mathrm{E}-08$ & & $1.0 \mathrm{E}-04$ & $9.5 \mathrm{E}-07$ \\
\hline \multirow[t]{2}{*}{ Iron } & Adult & $6.5 \mathrm{E}-03$ & $3.5 \mathrm{E}-04$ & & $1.9 \mathrm{E}-02$ & $1.0 \mathrm{E}-03$ \\
\hline & Child & $1.5 \mathrm{E}-02$ & $1.4 \mathrm{E}-04$ & & $1.8 \mathrm{E}-01$ & $1.6 \mathrm{E}-03$ \\
\hline \multirow[t]{2}{*}{ Lead } & Adult & $2.4 \mathrm{E}-05$ & $1.3 E-06$ & & 7.1E-05 & $3.8 \mathrm{E}-06$ \\
\hline & Child & $5.7 \mathrm{E}-05$ & $5.2 \mathrm{E}-07$ & & $6.7 \mathrm{E}-04$ & $6.1 E-06$ \\
\hline \multirow[t]{2}{*}{ Lithium } & Adult & $1.6 \mathrm{E}-06$ & 8.7E-08 & & $4.8 \mathrm{E}-06$ & $2.5 \mathrm{E}-07$ \\
\hline & Child & $3.8 \mathrm{E}-06$ & $3.5 \mathrm{E}-08$ & & $4.4 \mathrm{E}-05$ & $4.0 \mathrm{E}-07$ \\
\hline \multirow[t]{2}{*}{ Magnesium } & Aduit & $2.6 \mathrm{E}-04$ & $1.4 \mathrm{E}-05$ & & 7.6E-04 & $4.0 \mathrm{E}-05$ \\
\hline & Child & $6.1 E-04$ & $5.6 \mathrm{E}-06$ & & 7.1E-03 & $6.5 \mathrm{E}-05$ \\
\hline \multirow[t]{2}{*}{ Manganese } & Adult & $6.9 \mathrm{E}-04$ & $3.6 \mathrm{E}-05$ & & & \\
\hline & Child & $1.6 \mathrm{E}-03$ & $1.5 \mathrm{E}-05$ & & & \\
\hline \multirow[t]{2}{*}{ Mercury } & Adult & $8.6 \mathrm{E}-08$ & $4.6 \mathrm{E}-09$ & & & \\
\hline & Child & $2.0 E-07$ & $1.8 \mathrm{E}-09$ & & & \\
\hline \multirow[t]{2}{*}{ Mercury (salts) } & Adult & 8.6E-08 & 4.6E-09 & & & \\
\hline & Child & $2.0 \mathrm{E}-07$ & $1.8 \mathrm{E}-09$ & & & \\
\hline
\end{tabular}


Table 7.5c (continued)

\begin{tabular}{|c|c|c|c|c|c|c|}
\hline \multirow[b]{2}{*}{ Analyte } & & \multicolumn{3}{|c|}{ Carcinogenic effects } & \multicolumn{2}{|c|}{ Noncarcinogenic effects } \\
\hline & & $\begin{array}{c}\text { Ingestion } \\
(\mathrm{mg} / \mathrm{kg} \text {-day or } \\
\mathrm{pCi})^{b}\end{array}$ & $\underset{\text { (mg/kg-day) }}{\text { Dermal }}$ & $\begin{array}{l}\text { External } \\
\text { exposure } \\
\text { (pCi-yr/g) }\end{array}$ & $\begin{array}{l}\text { Ingestion } \\
\text { (mg/kg-day) }\end{array}$ & $\begin{array}{c}\text { Dermal } \\
(\mathrm{mg} / \mathrm{kg} \text {-day })\end{array}$ \\
\hline \multicolumn{7}{|c|}{ Inorganics (continued) } \\
\hline \multirow[t]{2}{*}{ Molybdenum } & Adult & $8.2 \mathrm{E}-07$ & $4.4 \mathrm{E}-08$ & & & \\
\hline & Child & $1.9 \mathrm{E}-06$ & $1.7 \mathrm{E}-08$ & & & \\
\hline \multirow[t]{2}{*}{ Nickel } & Adult & $4.6 \mathrm{E}-06$ & 2.4E-07 & & & \\
\hline & Child & 1.1E-05 & 9.7E-08 & & & \\
\hline \multirow{2}{*}{ Nickel (salts) } & Adult & $4.6 \mathrm{E}-06$ & 2.4E-07 & & & \\
\hline & Child & $1.1 \mathrm{E}-05$ & $9.7 \mathrm{E}-08$ & & & \\
\hline \multirow{2}{*}{ Potassium } & Adult & 2.1E-04 & $1.1 \mathrm{E}-05$ & & $6.2 \mathrm{E}-04$ & 3.3E-05 \\
\hline & Child & $4.9 \mathrm{E}-04$ & $4.5 \mathrm{E}-06$ & & $5.8 \mathrm{E}-03$ & 5.2E-05 \\
\hline \multirow[t]{2}{*}{ Selenium } & Adult & 3.8E-07 & $2.0 \mathrm{E}-08$ & & & \\
\hline & Child & $8.8 \mathrm{E}-07$ & $8.0 \mathrm{E}-09$ & & & \\
\hline \multirow[t]{2}{*}{ Silicon } & Adult & $3.6 \mathrm{E}-04$ & $1.9 \mathrm{E}-05$ & & $1.0 \mathrm{E}-03$ & $5.6 \mathrm{E}-05$ \\
\hline & Child & $8.4 \mathrm{E}-04$ & $7.6 \mathrm{E}-06$ & & $9.8 \mathrm{E}-03$ & $8.9 \mathrm{E}-05$ \\
\hline \multirow[t]{2}{*}{ Sodium } & Adult & $1.8 \mathrm{E}-04$ & $9.5 \mathrm{E}-06$ & & $5.2 \mathrm{E}-04$ & $2.8 \mathrm{E}-05$ \\
\hline & Child & 4.2E-04 & $3.8 \mathrm{E}-06$ & & $4.9 \mathrm{E}-03$ & 4.4E-05 \\
\hline \multirow{2}{*}{ Strontium } & Adult & $2.3 \mathrm{E}-06$ & $1.2 \mathrm{E}-07$ & & & \\
\hline & Child & 5.3E-06 & $4.8 \mathrm{E}-08$ & & & \\
\hline \multirow[t]{2}{*}{ Sulfate } & Adult & 4.1E-05 & $2.2 \mathrm{E}-06$ & & $1.2 \mathrm{E}-04$ & 6.4E-06 \\
\hline & Child & 9.7E-05 & $8.8 \mathrm{E}-07$ & & $1.1 \mathrm{E}-03$ & $1.0 \mathrm{E}-05$ \\
\hline \multirow[t]{2}{*}{ Vanadium } & Adult & $1.4 \mathrm{E}-05$ & $7.5 \mathrm{E}-07$ & & & \\
\hline & Child & 3.3E-05 & $3.0 \mathrm{E}-07$ & & & \\
\hline \multirow[t]{3}{*}{ Zinc } & Adult & $2.0 \mathrm{E}-05$ & $1.1 \mathrm{E}-06$ & & & \\
\hline & Child & 4.7E-05 & 4.3E-07 & & & \\
\hline & & & Organics & & & . \\
\hline \multirow[t]{2}{*}{ Acenaphthene } & Adult & $9.1 \mathrm{E}-07$ & $4.8 \mathrm{E}-07$ & & & \\
\hline & Child & $2.1 \mathrm{E}-06$ & $1.9 \mathrm{E}-07$ & & & \\
\hline \multirow[t]{2}{*}{ Acenaphthylene } & Adult & $1.1 \mathrm{E}-04$ & $6.0 \mathrm{E}-05$ & & $3.3 \mathrm{E}-04$ & 1.7E-04 \\
\hline & Child & $2.6 \mathrm{E}-04$ & $2.4 \mathrm{E}-05$ & & 3.1E-03 & $2.8 \mathrm{E}-04$ \\
\hline \multirow[t]{2}{*}{ Anthracene } & Adult & 6.7E-07 & $3.5 \mathrm{E}-07$ & & & \\
\hline & Child & $1.6 \mathrm{E}-06$ & $1.4 \mathrm{E}-07$ & & & \\
\hline
\end{tabular}


Table 7.5c (continued)

\begin{tabular}{|c|c|c|c|c|c|c|}
\hline \multirow[b]{2}{*}{ Analyte } & & \multicolumn{3}{|c|}{ Carcinogenic effects } & \multicolumn{2}{|c|}{ Noncarcinogenic effects } \\
\hline & & $\begin{array}{c}\text { Ingestion } \\
(\mathrm{mg} / \mathrm{kg} \text {-day or } \\
\text { pCi })^{b}\end{array}$ & $\underset{\text { (mg/kg-day) }}{\text { Dermal }}$ & $\begin{array}{r}\text { External } \\
\text { exposure } \\
\text { (pCi-yr/g) }\end{array}$ & $\begin{array}{l}\text { Ingestion } \\
\text { (mg/kg-day) }\end{array}$ & $\begin{array}{c}\text { Dermal } \\
\text { (mg/kg-day) }\end{array}$ \\
\hline \multicolumn{7}{|c|}{ Organics (continued) } \\
\hline Benzo(a)anthracene & $\begin{array}{l}\text { Adult } \\
\text { Child }\end{array}$ & & & & $\begin{array}{l}3.7 \mathrm{E}-06 \\
3.4 \mathrm{E}-05\end{array}$ & $\begin{array}{l}1.9 \mathrm{E}-06 \\
3.1 \mathrm{E}-06\end{array}$ \\
\hline Benzo(a)pyrene & $\begin{array}{l}\text { Adult } \\
\text { Child }\end{array}$ & & & & $\begin{array}{l}4.9 \mathrm{E}-06 \\
4.5 \mathrm{E}-05\end{array}$ & $\begin{array}{l}2.6 \mathrm{E}-06 \\
4.1 \mathrm{E}-06\end{array}$ \\
\hline Benzo(b)fluoranthene & $\begin{array}{l}\text { Adult } \\
\text { Child }\end{array}$ & & & & $\begin{array}{l}4.3 \mathrm{E}-06 \\
4.0 \mathrm{E}-05\end{array}$ & $\begin{array}{l}2.3 \mathrm{E}-06 \\
3.6 \mathrm{E}-06\end{array}$ \\
\hline Benzo(g,h,i)perylene & $\begin{array}{l}\text { Adult } \\
\text { Child }\end{array}$ & & & & $\begin{array}{l}5.2 \mathrm{E}-06 \\
4.9 \mathrm{E}-05\end{array}$ & $\begin{array}{l}2.8 \mathrm{E}-06 \\
4.4 \mathrm{E}-06\end{array}$ \\
\hline Benzo(k)fluoranthene & $\begin{array}{l}\text { Adult } \\
\text { Child }\end{array}$ & & & & $\begin{array}{l}2.5 \mathrm{E}-06 \\
2.3 \mathrm{E}-05\end{array}$ & $\begin{array}{l}1.3 \mathrm{E}-06 \\
2.1 \mathrm{E}-06\end{array}$ \\
\hline Chrysene & $\begin{array}{l}\text { Adult } \\
\text { Child }\end{array}$ & & & & $\begin{array}{l}7.5 \mathrm{E}-06 \\
7.0 \mathrm{E}-05\end{array}$ & $\begin{array}{l}4.0 \mathrm{E}-06 \\
6.3 \mathrm{E}-06\end{array}$ \\
\hline Dibenz(a,h)anthracene & $\begin{array}{l}\text { Adult } \\
\text { Child }\end{array}$ & & & & $\begin{array}{l}2.2 E-06 \\
2.0 E-05\end{array}$ & $\begin{array}{l}1.2 \mathrm{E}-06 \\
1.9 \mathrm{E}-06\end{array}$ \\
\hline Fluoranthene & $\begin{array}{l}\text { Adult } \\
\text { Child }\end{array}$ & $\begin{array}{l}3.8 \mathrm{E}-06 \\
8.9 \mathrm{E}-06\end{array}$ & $\begin{array}{l}2.0 \mathrm{E}-06 \\
8.1 \mathrm{E}-07\end{array}$ & & & \\
\hline Fiuorene & $\begin{array}{l}\text { Adult } \\
\text { Child }\end{array}$ & $\begin{array}{l}7.5 \mathrm{E}-07 \\
1.7 \mathrm{E}-06\end{array}$ & $\begin{array}{l}4.0 \mathrm{E}-07 \\
1.6 \mathrm{E}-07\end{array}$ & & & \\
\hline Naphthalene & $\begin{array}{l}\text { Adult } \\
\text { Child }\end{array}$ & $\begin{array}{l}7.7 \mathrm{E}-06 \\
1.8 \mathrm{E}-05\end{array}$ & $\begin{array}{l}4.1 \mathrm{E}-06 \\
1.6 \mathrm{E}-06\end{array}$ & & & \\
\hline Phenanthrene & $\begin{array}{l}\text { Aduit } \\
\text { Child }\end{array}$ & & & . & $\begin{array}{l}\text { 7.4E-06 } \\
6.9 \mathrm{E}-05\end{array}$ & $\begin{array}{l}3.9 \mathrm{E}-06 \\
6.3 \mathrm{E}-06\end{array}$ \\
\hline Pyrene & $\begin{array}{l}\text { Adult } \\
\text { Child }\end{array}$ & $\begin{array}{l}3.3 \mathrm{E}-06 \\
7.7 \mathrm{E}-06\end{array}$ & $\begin{array}{l}1.7 \mathrm{E}-06 \\
7.0 \mathrm{E}-07\end{array}$ & & & . \\
\hline & & & adionuclides & & & \\
\hline Total Uranium & $\begin{array}{l}\text { Adult } \\
\text { Child }\end{array}$ & $\begin{array}{l}3.9 \mathrm{E}+03 \\
2.0 \mathrm{E}+03\end{array}$ & & $\begin{array}{l}9.0 E+01 \\
2.3 E+01\end{array}$ & & \\
\hline
\end{tabular}

a The upper $95 \%$ confidence bound on the median is used as the representative concentration in all calculations.

${ }^{b}$ For carcinogenic effects/ingestion pathway: units are $\mathrm{mg} / \mathrm{kg}$-day for inorganics and organics, and pCi for radionuclides. 


\section{$7-48$}

Table 7.5d. Chronic daily intake of ORR background soil by the on-site resident-Chepultepec (for constituents for which a risk and/or hazard index could not be calculated)

\begin{tabular}{|c|c|c|c|c|c|c|}
\hline \multirow[b]{2}{*}{ Analyte } & & \multicolumn{3}{|c|}{ Carcinogenic effects } & \multicolumn{2}{|c|}{ Noncarcinogenic effects } \\
\hline & & $\begin{array}{c}\text { Ingestion } \\
\text { (mg/kg-day or } \\
\text { pCi })^{b}\end{array}$ & $\begin{array}{c}\text { Dermal } \\
\text { (mg/kg-day) }\end{array}$ & $\begin{array}{l}\text { External } \\
\text { exposure } \\
\text { (pCi-yr/g) }\end{array}$ & $\begin{array}{l}\text { Ingestion } \\
\text { (mg/kg-day) }\end{array}$ & $\begin{array}{c}\text { Dermal } \\
\text { (mg/kg-day) }\end{array}$ \\
\hline & & & inorganics & & & \\
\hline Aluminum & $\begin{array}{l}\text { Adult } \\
\text { Child }\end{array}$ & $\begin{array}{l}4.5 \mathrm{E}-03 \\
1.0 \mathrm{E}-02\end{array}$ & $\begin{array}{l}2.4 E-04 \\
9.5 E-05\end{array}$ & & $\begin{array}{l}1.3 \mathrm{E}-02 \\
1.2 \mathrm{E}-01\end{array}$ & $\begin{array}{l}6.9 \mathrm{E}-04 \\
1.1 \mathrm{E}-03\end{array}$ \\
\hline Arsenic & $\begin{array}{l}\text { Adult } \\
\text { Child. }\end{array}$ & $\begin{array}{l}6.8 \mathrm{E}-06 \\
1.6 \mathrm{E}-05\end{array}$ & $\begin{array}{l}3.6 \mathrm{E}-07 \\
1.4 \mathrm{E}-07\end{array}$ & & & \\
\hline Barium & $\begin{array}{l}\text { Adult } \\
\text { Child }\end{array}$ & $\begin{array}{l}3.3 \mathrm{E}-05 \\
7.6 \mathrm{E}-05\end{array}$ & $\begin{array}{l}1.7 E-06 \\
6.9 E-07\end{array}$ & & & \\
\hline Calcium & $\begin{array}{l}\text { Adult } \\
\text { Child }\end{array}$ & $\begin{array}{l}2.9 \mathrm{E}-04 \\
6.7 \mathrm{E}-04\end{array}$ & $\begin{array}{l}1.5 E-05 \\
6.1 E-06\end{array}$ & & $\begin{array}{l}8.4 \mathrm{E}-04 \\
7.8 \mathrm{E}-03\end{array}$ & $\begin{array}{l}4.4 E-05 \\
7.1 E-05\end{array}$ \\
\hline Chromium & $\begin{array}{l}\text { Adult } \\
\text { Child }\end{array}$ & $\begin{array}{l}8.2 E-06 \\
1.9 E-05\end{array}$ & $\begin{array}{l}4.3 \mathrm{E}-07 \\
1.7 \mathrm{E}-07\end{array}$ & & $\begin{array}{l}2.4 E-05 \\
2.2 E-04\end{array}$ & $\begin{array}{l}1.3 \mathrm{E}-06 \\
2.0 \mathrm{E}-06\end{array}$ \\
\hline Chromium VI & $\begin{array}{l}\text { Adult } \\
\text { Child }\end{array}$ & $\begin{array}{l}8.2 \mathrm{E}-06 \\
1.9 \mathrm{E}-05\end{array}$ & $\begin{array}{l}4.3 \mathrm{E}-07 \\
1.7 \mathrm{E}-07\end{array}$ & & & \\
\hline Cobalt & $\begin{array}{l}\text { Adult } \\
\text { Child }\end{array}$ & $\begin{array}{l}7.2 \mathrm{E}-06 \\
1.7 \mathrm{E}-05\end{array}$ & $\begin{array}{l}3.8 \mathrm{E}-07 \\
1.5 \mathrm{E}-07\end{array}$ & & $\begin{array}{l}2.1 \mathrm{E}-05 \\
2.0 \mathrm{E}-04\end{array}$ & $\begin{array}{l}1.1 \mathrm{E}-06 \\
1.8 \mathrm{E}-06\end{array}$ \\
\hline Copper & $\begin{array}{l}\text { Adult } \\
\text { Child }\end{array}$ & $\begin{array}{l}2.5 \mathrm{E}-06 \\
5.8 \mathrm{E}-06\end{array}$ & $\begin{array}{l}1.3 \mathrm{E}-07 \\
5.2 \mathrm{E}-08\end{array}$ & & $\begin{array}{l}7.2 \mathrm{E}-06 \\
6.7 \mathrm{E}-05\end{array}$ & $\begin{array}{l}3.8 \mathrm{E}-07 \\
6.1 \mathrm{E}-07\end{array}$ \\
\hline Iron & $\begin{array}{l}\text { Adult } \\
\text { Child }\end{array}$ & $\begin{array}{l}7.8 \mathrm{E}-03 \\
1.8 \mathrm{E}-02\end{array}$ & $\begin{array}{l}4.1 \mathrm{E}-04 \\
1.6 \mathrm{E}-04\end{array}$ & & $\begin{array}{l}2.3 E-02 \\
2.1 E-01\end{array}$ & $\begin{array}{l}1.2 \mathrm{E}-03 \\
1.9 \mathrm{E}-03\end{array}$ \\
\hline Lead & $\begin{array}{l}\text { Adult } \\
\text { Child }\end{array}$ & $\begin{array}{l}1.2 \mathrm{E}-05 \\
2.7 \mathrm{E}-05\end{array}$ & $\begin{array}{l}6.1 \mathrm{E}-07 \\
2.5 \mathrm{E}-07\end{array}$ & & $\begin{array}{l}3.4 \mathrm{E}-05 \\
3.1 \mathrm{E}-04\end{array}$ & $\begin{array}{l}1.8 E-06 \\
2.9 E-06\end{array}$ \\
\hline Lithium & $\begin{array}{l}\text { Adult } \\
\text { Child }\end{array}$ & $\begin{array}{l}2.3 \mathrm{E}-06 \\
5.5 \mathrm{E}-06\end{array}$ & $\begin{array}{l}1.2 \mathrm{E}-07 \\
5.0 \mathrm{E}-08\end{array}$ & & $\begin{array}{l}6.8 \mathrm{E}-06 \\
6.4 \mathrm{E}-05\end{array}$ & $\begin{array}{l}3.6 \mathrm{E}-07 \\
5.8 \mathrm{E}-07\end{array}$ \\
\hline Magnesium & $\begin{array}{l}\text { Adult } \\
\text { Child }\end{array}$ & $\begin{array}{l}2.1 \mathrm{E}-04 \\
4.9 \mathrm{E}-04\end{array}$ & $\begin{array}{l}1.1 \mathrm{E}-05 \\
4.4 \mathrm{E}-06\end{array}$ & & $\begin{array}{l}6.1 \mathrm{E}-04 \\
5.7 \mathrm{E}-03\end{array}$ & $\begin{array}{l}3.2 E-05 \\
5.2 E-05\end{array}$ \\
\hline Manganese & $\begin{array}{l}\text { Adult } \\
\text { Child }\end{array}$ & $\begin{array}{l}5.9 \mathrm{E}-04 \\
1.4 \mathrm{E}-03\end{array}$ & $\begin{array}{l}3.1 \mathrm{E}-05 \\
1.3 \mathrm{E}-05\end{array}$ & & & \\
\hline Mercury & $\begin{array}{l}\text { Adult } \\
\text { Child }\end{array}$ & $\begin{array}{l}7.2 \mathrm{E}-08 \\
1.7 \mathrm{E}-07\end{array}$ & $\begin{array}{l}3.8 \mathrm{E}-09 \\
1.5 \mathrm{E}-09\end{array}$ & & & \\
\hline Mercury (salts) & $\begin{array}{l}\text { Adult } \\
\text { Child }\end{array}$ & $\begin{array}{l}7.2 \mathrm{E}-08 \\
1.7 \mathrm{E}-07\end{array}$ & $\begin{array}{l}3.8 E-09 \\
1.5 E-09\end{array}$ & & & \\
\hline
\end{tabular}


Table 7.5d (continued)

\begin{tabular}{|c|c|c|c|c|c|c|}
\hline \multirow[b]{2}{*}{ Analyte } & & \multicolumn{3}{|c|}{ Carcinogenic effects } & \multicolumn{2}{|c|}{ Noncarcinogenic effects } \\
\hline & & $\begin{array}{c}\text { Ingestion } \\
(\mathrm{mg} / \mathrm{kg} \text {-day or } \\
\mathrm{pCi})^{b}\end{array}$ & $\begin{array}{c}\text { Dermal } \\
\text { (mg/kg-day) }\end{array}$ & $\begin{array}{l}\text { External } \\
\text { exposure } \\
\text { (pCi-yr/g) } \\
\end{array}$ & $\begin{array}{l}\text { Ingestion } \\
\text { (mg/kg-day) }\end{array}$ & $\begin{array}{c}\text { Dermal } \\
\text { (mg/kg-day) }\end{array}$ \\
\hline \multicolumn{7}{|c|}{ Inorganics (continued) } \\
\hline Selenium & $\begin{array}{l}\text { Adult } \\
\text { Child }\end{array}$ & $\begin{array}{l}2.9 \mathrm{E}-07 \\
6.9 \mathrm{E}-07\end{array}$ & $\begin{array}{l}1.6 \mathrm{E}-08 \\
6.2 \mathrm{E}-09\end{array}$ & & & \\
\hline Silicon & $\begin{array}{l}\text { Adult } \\
\text { Child }\end{array}$ & $\begin{array}{l}2.8 \mathrm{E}-04 \\
6.5 \mathrm{E}-04\end{array}$ & $\begin{array}{l}1.5 \mathrm{E}-05 \\
5.9 \mathrm{E}-06\end{array}$ & & $\begin{array}{l}8.1 \mathrm{E}-04 \\
7.6 \mathrm{E}-03\end{array}$ & $\begin{array}{l}4.3 \mathrm{E}-05 \\
6.9 \mathrm{E}-05\end{array}$ \\
\hline Sodium & $\begin{array}{l}\text { Adult } \\
\text { Child }\end{array}$ & $\begin{array}{l}1.6 \mathrm{E}-04 \\
3.8 \mathrm{E}-04\end{array}$ & $\begin{array}{l}8.6 \mathrm{E}-06 \\
3.4 \mathrm{E}-06\end{array}$ & & $\begin{array}{l}\text { 4.7E-04 } \\
4.4 \mathrm{E}-03\end{array}$ & $\begin{array}{l}2.5 \mathrm{E}-05 \\
4.0 \mathrm{E}-05\end{array}$ \\
\hline Strontium & $\begin{array}{l}\text { Adult } \\
\text { Child }\end{array}$ & $\begin{array}{l}1.6 \mathrm{E}-06 \\
3.6 \mathrm{E}-06\end{array}$ & $\begin{array}{l}\text { 8.3E-08 } \\
3.3 \mathrm{E}-08\end{array}$ & & & \\
\hline Sulfate & $\begin{array}{l}\text { Adult } \\
\text { Child }\end{array}$ & $\begin{array}{l}4.8 \mathrm{E}-05 \\
1.1 \mathrm{E}-04\end{array}$ & $\begin{array}{l}2.6 \mathrm{E}-06 \\
1.0 \mathrm{E}-06\end{array}$ & & $\begin{array}{l}1.4 \mathrm{E}-04 \\
1.3 \mathrm{E}-03\end{array}$ & $\begin{array}{l}7.5 \mathrm{E}-06 \\
1.2 \mathrm{E}-05\end{array}$ \\
\hline Vanadium & $\begin{array}{l}\text { Adult } \\
\text { Child }\end{array}$ & $\begin{array}{l}1.6 \mathrm{E}-05 \\
3.8 \mathrm{E}-05\end{array}$ & $\begin{array}{l}8.5 \mathrm{E}-07 \\
3.4 \mathrm{E}-07\end{array}$ & & & \\
\hline Zinc & $\begin{array}{l}\text { Adult } \\
\text { Child }\end{array}$ & $\begin{array}{l}2.3 \mathrm{E}-05 \\
5.3 \mathrm{E}-05\end{array}$ & $\begin{array}{l}1.2 \mathrm{E}-06 \\
4.8 \mathrm{E}-07\end{array}$ & & & \\
\hline & & & Organics & & & $\cdot$ \\
\hline Acenaphthene & $\begin{array}{l}\text { Adult } \\
\text { Child }\end{array}$ & $\begin{array}{l}6.4 \mathrm{E}-07 \\
1.5 \mathrm{E}-06\end{array}$ & $\begin{array}{l}3.4 \mathrm{E}-07 \\
1.4 \mathrm{E}-07\end{array}$ & & & \\
\hline Anthracene & $\begin{array}{l}\text { Adult } \\
\text { Child }\end{array}$ & $\begin{array}{l}4.9 \mathrm{E}-07 \\
1.1 \mathrm{E}-06\end{array}$ & $\begin{array}{l}2.6 \mathrm{E}-07 \\
1.0 \mathrm{E}-07\end{array}$ & & - & \\
\hline Benzo(a)anthracene & $\begin{array}{l}\text { Adult } \\
\text { Child }\end{array}$ & & & & $\begin{array}{l}3.4 \mathrm{E}-06 \\
3.1 \mathrm{E}-05\end{array}$ & $\begin{array}{l}1.8 \mathrm{E}-06 \\
2.9 \mathrm{E}-06\end{array}$ \\
\hline Benzo(a)pyrene & $\begin{array}{l}\text { Adult } \\
\text { Child }\end{array}$ & & & $\cdot$ & $\begin{array}{l}6.8 \mathrm{E}-06 \\
6.3 \mathrm{E}-05\end{array}$ & $\begin{array}{l}3.6 \mathrm{E}-06 \\
5.7 \mathrm{E}-06\end{array}$ \\
\hline Benzo(b)fluoranthene & $\begin{array}{l}\text { Adult } \\
\text { Child }\end{array}$ & & & & $\begin{array}{l}7.2 \mathrm{E}-06 \\
6.7 \mathrm{E}-05\end{array}$ & $\begin{array}{l}3.8 \mathrm{E}-06 \\
6.1 \mathrm{E}-06\end{array}$ \\
\hline Benzo(g,h,i)perylene & $\begin{array}{l}\text { Adult } \\
\text { Child }\end{array}$ & & & & $\begin{array}{l}5.0 \mathrm{E}-06 \\
4.7 \mathrm{E}-05\end{array}$ & $\begin{array}{l}2.7 \mathrm{E}-06 \\
4.3 \mathrm{E}-06\end{array}$ \\
\hline Benzo(k)fluoranthene & $\begin{array}{l}\text { Adult } \\
\text { Child }\end{array}$ & & & & $\begin{array}{l}3.1 E-06 \\
2.9 E-05\end{array}$ & $\begin{array}{l}\text { 1.7E-06 } \\
2.7 E-06\end{array}$ \\
\hline
\end{tabular}


Table 7.5d (continued)

\begin{tabular}{|c|c|c|c|c|c|c|}
\hline \multirow[b]{2}{*}{ Analyte } & & \multicolumn{3}{|c|}{ Carcinogenic effects } & \multicolumn{2}{|c|}{ Noncarcinogenic effects } \\
\hline & & $\begin{array}{c}\text { Ingestion } \\
\text { (mg/kg-day or } \\
\text { pCi })^{b}\end{array}$ & $\begin{array}{c}\text { Dermal } \\
\text { (mg/kg-day) }\end{array}$ & $\begin{array}{l}\text { External } \\
\text { exposure } \\
\text { (pCi-yr/g) }\end{array}$ & $\begin{array}{l}\text { Ingestion } \\
\text { (mg/kg-day) }\end{array}$ & $\begin{array}{c}\text { Dermal } \\
\text { (mg/kg-day) }\end{array}$ \\
\hline \multicolumn{7}{|c|}{ Organies (continued) } \\
\hline Dibenz $(a, h)$ anthracene & $\begin{array}{l}\text { Adult } \\
\text { Child }\end{array}$ & & & & $\begin{array}{l}2.8 \mathrm{E}-06 \\
2.6 \mathrm{E}-05\end{array}$ & $\begin{array}{l}1.5 \mathrm{E}-06 \\
2.4 \mathrm{E}-06\end{array}$ \\
\hline Fluoranthene & $\begin{array}{l}\text { Adult } \\
\text { Child }\end{array}$ & $\begin{array}{l}2.2 \mathrm{E}-06 \\
5.1 \mathrm{E}-06\end{array}$ & $\begin{array}{l}1.2 \mathrm{E}-06 \\
4.6 \mathrm{E}-07\end{array}$ & & & \\
\hline Fuorene & $\begin{array}{l}\text { Adult } \\
\text { Child }\end{array}$ & $\begin{array}{l}3.4 \mathrm{E}-07 \\
8.0 \mathrm{E}-07\end{array}$ & $\begin{array}{l}1.8 \mathrm{E}-07 \\
7.2 \mathrm{E}-08\end{array}$ & & . & \\
\hline Indeno(1,2,3-cd)pyrene & $\begin{array}{l}\text { Adult } \\
\text { Child }\end{array}$ & & & & $\begin{array}{l}2.2 \mathrm{E}-05 \\
2.0 \mathrm{E}-04\end{array}$ & $\begin{array}{l}1.2 \mathrm{E}-05 \\
1.9 \mathrm{E}-05\end{array}$ \\
\hline Naphthalene & $\begin{array}{l}\text { Adult } \\
\text { Child }\end{array}$ & $\begin{array}{l}1.0 \mathrm{E}-05 \\
2.4 \mathrm{E}-05\end{array}$ & $\begin{array}{l}5.3 \mathrm{E}-06 \\
2.1 \mathrm{E}-06\end{array}$ & & & \\
\hline Phenanthrene & $\begin{array}{l}\text { Adult } \\
\text { Child }\end{array}$ & & & & $\begin{array}{l}6.2 \mathrm{E}-06 \\
5.8 \mathrm{E}-05\end{array}$ & $\begin{array}{l}3.3 \mathrm{E}-06 \\
5.3 \mathrm{E}-06\end{array}$ \\
\hline Pyrene & $\begin{array}{l}\text { Adult } \\
\text { Child }\end{array}$ & $\begin{array}{l}2.5 \mathrm{E}-06 \\
5.8 \mathrm{E}-06\end{array}$ & $\begin{array}{l}1.3 E-06 \\
5.3 E-07\end{array}$ & & & \\
\hline & & & adionuctides & & & \\
\hline Total Uranium & $\begin{array}{l}\text { Adult } \\
\text { Child }\end{array}$ & $\begin{array}{l}3.0 E+03 \\
1.5 E+03\end{array}$ & & $\begin{array}{l}7.0 \mathrm{E}+01 \\
1.7 \mathrm{E}+01\end{array}$ & & \\
\hline
\end{tabular}

'The upper $95 \%$ confidence bound on the median is used as the representative concentration in all calculations.

${ }^{b}$ For carcinogenic effects/ingestion pathway: units are $\mathrm{mg} / \mathrm{kg}$-day for inorganics and organics, and $\mathrm{pCi}$ for radionuclides. 
Table 7.5e. Chronic daily intake of ORR background soil by the on-site resident-Chickamauga (Bethel Valley) ${ }^{a}$

(for constituents for which a risk and/or hazard index could not be calculated)

\begin{tabular}{|c|c|c|c|c|c|c|}
\hline \multirow[b]{2}{*}{ Analyte } & & \multicolumn{3}{|c|}{ Carcinogenic effects } & \multicolumn{2}{|c|}{ Noncarcinogenic effects } \\
\hline & & $\begin{array}{l}\text { Ingestion } \\
\text { (mg/kg-day } \\
\text { or pCi })^{b}\end{array}$ & $\begin{array}{c}\text { Dermal } \\
\text { (mg/kg-day) }\end{array}$ & $\begin{array}{l}\text { External } \\
\text { exposure } \\
\text { (pCi-yr/g) }\end{array}$ & $\begin{array}{c}\text { Ingestion } \\
\text { (mg/kg-day) }\end{array}$ & $\begin{array}{c}\text { Dermal } \\
\text { (mg/kg-day) }\end{array}$ \\
\hline & & & Inorganics & & & \\
\hline Aluminum & $\begin{array}{l}\text { Adult } \\
\text { Child }\end{array}$ & $\begin{array}{l}8.7 \mathrm{E}-03 \\
2.0 \mathrm{E}-02\end{array}$ & $\begin{array}{l}4.6 \mathrm{E}-04 \\
1.9 \mathrm{E}-04\end{array}$ & & $\begin{array}{l}2.5 \mathrm{E}-02 \\
2.4 \mathrm{E}-01\end{array}$ & $\begin{array}{l}1.4 \mathrm{E}-03 \\
2.2 \mathrm{E}-03\end{array}$ \\
\hline Arsenic & $\begin{array}{l}\text { Adult } \\
\text { Child }\end{array}$ & $\begin{array}{l}3.8 \mathrm{E}-06 \\
8.8 \mathrm{E}-06\end{array}$ & $\begin{array}{l}2.0 \mathrm{E}-07 \\
8.0 \mathrm{E}-08\end{array}$ & & & \\
\hline Barium & $\begin{array}{l}\text { Adult } \\
\text { Child }\end{array}$ & $\begin{array}{l}4.9 \mathrm{E}-05 \\
1.1 \mathrm{E}-04\end{array}$ & $\begin{array}{l}2.6 \mathrm{E}-06 \\
1.0 \mathrm{E}-06\end{array}$ & & & \\
\hline Calcium & $\begin{array}{l}\text { Adult } \\
\text { Child }\end{array}$ & $\begin{array}{l}1.2 \mathrm{E}-03 \\
2.8 \mathrm{E}-03\end{array}$ & $\begin{array}{l}6.4 E-05 \\
2.6 E-05\end{array}$ & & $\begin{array}{l}3.5 \mathrm{E}-03 \\
3.3 \mathrm{E}-02\end{array}$ & $\begin{array}{l}1.9 \mathrm{E}-04 \\
3.0 \mathrm{E}-04\end{array}$ \\
\hline Chromium & $\begin{array}{l}\text { Adult } \\
\text { Child }\end{array}$ & $\begin{array}{l}1.9 \mathrm{E}-05 \\
4.4 \mathrm{E}-05\end{array}$ & $\begin{array}{l}1.0 \mathrm{E}-06 \\
4.0 \mathrm{E}-07\end{array}$ & & $\begin{array}{l}5.5 \mathrm{E}-05 \\
5.1 \mathrm{E}-04\end{array}$ & $\begin{array}{l}2.9 \mathrm{E}-06 \\
4.7 \mathrm{E}-06\end{array}$ \\
\hline Chromium VI & $\begin{array}{l}\text { Adult } \\
\text { Child }\end{array}$ & $\begin{array}{l}1.9 \mathrm{E}-05 \\
4.4 \mathrm{E}-05\end{array}$ & $\begin{array}{l}1.0 \mathrm{E}-06 \\
4.0 \mathrm{E}-07\end{array}$ & & & \\
\hline Cobalt & $\begin{array}{l}\text { Adult } \\
\text { Child }\end{array}$ & $\begin{array}{l}1.2 \mathrm{E}-05 \\
2.7 \mathrm{E}-05\end{array}$ & $\begin{array}{l}6.1 \mathrm{E}-07 \\
24 \mathrm{E}-07\end{array}$ & & $\begin{array}{l}3.4 E-05 \\
3.1 E-04\end{array}$ & $\begin{array}{l}1.8 \mathrm{E}-06 \\
2.9 \mathrm{E}-06\end{array}$ \\
\hline Copper & $\begin{array}{l}\text { Adult } \\
\text { Child }\end{array}$ & $\begin{array}{l}9.7 \mathrm{E}-06 \\
2.3 \mathrm{E}-05\end{array}$ & $\begin{array}{l}5.1 \mathrm{E}-07 \\
2.1 \mathrm{E}-07\end{array}$ & & $\begin{array}{l}2.8 \mathrm{E}-05 \\
2.6 \mathrm{E}-04\end{array}$ & $\begin{array}{l}1.5 \mathrm{E}-06 \\
2.4 \mathrm{E}-06\end{array}$ \\
\hline Iron & $\begin{array}{l}\text { Adult } \\
\text { Child }\end{array}$ & $\begin{array}{l}2.0 \mathrm{E}-02 \\
4.6 \mathrm{E}-02\end{array}$ & $\begin{array}{l}1.0 \mathrm{E}-03 \\
4.2 \mathrm{E}-04\end{array}$ & & $\begin{array}{l}5.7 \mathrm{E}-02 \\
5.3 \mathrm{E}-01\end{array}$ & $\begin{array}{l}3.0 \mathrm{E}-03 \\
4.9 \mathrm{E}-03\end{array}$ \\
\hline Lead & $\begin{array}{l}\text { Adult } \\
\text { Child }\end{array}$ & $\begin{array}{l}2.4 \mathrm{E}-05 \\
5.6 \mathrm{E}-05\end{array}$ & $\begin{array}{l}1.3 \mathrm{E}-06 \\
5.1 \mathrm{E}-07\end{array}$ & & $\begin{array}{l}7.0 \mathrm{E}-05 \\
6.5 \mathrm{E}-04\end{array}$ & $\begin{array}{l}3.7 \mathrm{E}-06 \\
5.9 \mathrm{E}-06\end{array}$ \\
\hline Lithium & $\begin{array}{l}\text { Adult } \\
\text { Child }\end{array}$ & $\begin{array}{l}7.5 \mathrm{E}-06 \\
1.7 \mathrm{E}-05\end{array}$ & $\begin{array}{l}4.0 \mathrm{E}-07 \\
1.6 \mathrm{E}-07\end{array}$ & & $\begin{array}{l}2.2 \mathrm{E}-05 \\
2.0 \mathrm{E}-04\end{array}$ & $\begin{array}{l}1.2 \mathrm{E}-06 \\
1.9 \mathrm{E}-06\end{array}$ \\
\hline Magnesium & $\begin{array}{l}\text { Adult } \\
\text { Child }\end{array}$ & $\begin{array}{l}7.8 \mathrm{E}-04 \\
1.8 \mathrm{E}-03\end{array}$ & $\begin{array}{l}4.1 \mathrm{E}-05 \\
1.7 \mathrm{E}-05\end{array}$ & & $\begin{array}{l}2.3 E-03 \\
2.1 E-02\end{array}$ & $\begin{array}{l}1.2 \mathrm{E}-04 \\
1.9 \mathrm{E}-04\end{array}$ \\
\hline Manganese & $\begin{array}{l}\text { Adult } \\
\text { Child }\end{array}$ & $\begin{array}{l}6.8 \mathrm{E}-04 \\
1.6 \mathrm{E}-03\end{array}$ & $\begin{array}{l}3.6 \mathrm{E}-05 \\
1.4 \mathrm{E}-05\end{array}$ & & & \\
\hline Mercury & $\begin{array}{l}\text { Adult } \\
\text { Child }\end{array}$ & $\begin{array}{l}8.8 \mathrm{E}-08 \\
2.1 \mathrm{E}-07\end{array}$ & $\begin{array}{l}4.7 \mathrm{E}-09 \\
1.9 \mathrm{E}-09\end{array}$ & & & \\
\hline Mercury (salts) & $\begin{array}{l}\text { Adult } \\
\text { Child }\end{array}$ & $\begin{array}{l}8.8 \mathrm{E}-08 \\
2.1 \mathrm{E}-07\end{array}$ & $\begin{array}{l}4.7 \mathrm{E}-09 \\
1.9 \mathrm{E}-09\end{array}$ & & & \\
\hline
\end{tabular}




\section{$7-52$}

Table 7.5e (continued)

\begin{tabular}{|c|c|c|c|c|c|c|}
\hline \multirow[b]{2}{*}{ Analyte } & & \multicolumn{3}{|c|}{ Carcinogenic effects } & \multicolumn{2}{|c|}{ Noncarcinogenic effects } \\
\hline & & $\begin{array}{l}\text { Ingestion } \\
\text { (mg/kg-day } \\
\text { or pCi })^{b}\end{array}$ & $\begin{array}{c}\text { Dermal } \\
\text { (mg/kg-day) }\end{array}$ & $\begin{array}{r}\text { External } \\
\text { exposure } \\
\text { (pCi-yr/g) }\end{array}$ & $\begin{array}{l}\text { Ingestion } \\
\text { (mg/kg-day) }\end{array}$ & $\begin{array}{c}\text { Dermal } \\
\text { (mg/kg-day) }\end{array}$ \\
\hline \multicolumn{7}{|c|}{ Inorganies (continued) } \\
\hline \multirow[t]{2}{*}{ Nickel } & Adult & $7.8 \mathrm{E}-06$ & $4.2 \mathrm{E}-07$ & & & \\
\hline & Child & $1.8 \mathrm{E}-05$ & $1.7 \mathrm{E}-07$ & & & \\
\hline \multirow[t]{2}{*}{ Nickel (salts) } & Adult & $7.8 \mathrm{E}-06$ & $4.2 \mathrm{E}-07$ & & & \\
\hline & Child & $1.8 \mathrm{E}-05$ & $1.7 \mathrm{E}-07$ & & & \\
\hline \multirow[t]{2}{*}{ Potassium } & Adult & $8.9 \mathrm{E}-04$ & 4.7E-05 & & $2.6 \mathrm{E}-03$ & $1.4 \mathrm{E}-04$ \\
\hline & Child & 2.1E-03 & $1.9 \mathrm{E}-05$ & & 2.4E-02 & 2.2E-04 \\
\hline \multirow[t]{2}{*}{ Selenium } & Adult & 4.4E-07 & 2.3E-08 & & & \\
\hline & Child & $1.0 \mathrm{E}-06$ & $9.3 \mathrm{E}-09$ & & & \\
\hline \multirow[t]{2}{*}{ Silicon } & Adult & 2.7E-04 & $1.5 \mathrm{E}-05$ & & 8.0E-04 & $4.2 \mathrm{E}-05$ \\
\hline & Child & $6.4 \mathrm{E}-04$ & $5.8 \mathrm{E}-06$ & & $7.5 \mathrm{E}-03$ & $6.8 \mathrm{E}-05$ \\
\hline \multirow[t]{2}{*}{ Sodium } & Adult & $2.0 \mathrm{E}-04$ & $1.0 \mathrm{E}-05$ & & 5.7E-04 & $3.0 \mathrm{E}-05$ \\
\hline & Child & $4.6 \mathrm{E}-04$ & $4.2 \mathrm{E}-06$ & & $5.3 \mathrm{E}-03$ & $4.9 \mathrm{E}-05$ \\
\hline \multirow[t]{2}{*}{ Strontium } & Adult & 4.1E-06 & $2.2 \mathrm{E}-07$ & & & \\
\hline & Child & $9.5 \mathrm{E}-06$ & $8.6 \mathrm{E}-08$ & & & \\
\hline \multirow[t]{2}{*}{ Sulfate } & Adult & $6.2 E-05$ & $3.3 \mathrm{E}-06$ & & $1.8 \mathrm{E}-04$ & $9.6 \mathrm{E}-06$ \\
\hline & Child & $1.4 \mathrm{E}-04$ & $1.3 \mathrm{E}-06$ & & $1.7 \mathrm{E}-03$ & $1.5 \mathrm{E}-05$ \\
\hline \multirow[t]{2}{*}{ Vanadium } & Adult & 2.0E-05 & $1.0 \mathrm{E}-06$ & & & \\
\hline & Child & 4.6E-05 & 4.2E-07 & & & \\
\hline \multirow[t]{3}{*}{ Zinc } & Adult & $2.6 \mathrm{E}-05$ & $1.4 \mathrm{E}-06$ & & & \\
\hline & Child & $6.1 \mathrm{E}-05$ & $5.5 \mathrm{E}-07$ & & & \\
\hline & & & Organics & & & \\
\hline \multirow[t]{2}{*}{ Acenaphthene } & Adult & $2.8 \mathrm{E}-06$ & $1.5 \mathrm{E}-06$ & & & \\
\hline & Child & $6.5 \mathrm{E}-06$ & $5.9 \mathrm{E}-07$ & & & \\
\hline \multirow[t]{2}{*}{ Anthracene } & Adult & $5.4 \mathrm{E}-07$ & $2.9 \mathrm{E}-07$ & & & \\
\hline & Child & $1.3 \mathrm{E}-06$ & $1.1 \mathrm{E}-07$ & & & \\
\hline \multirow[t]{2}{*}{ Benzo(a)anthracene } & Adult & & & & $8.8 \mathrm{E}-06$ & 4.7E-06 \\
\hline & Child & & & & $8.2 \mathrm{E}-05$ & $7.5 \mathrm{E}-06$ \\
\hline \multirow[t]{2}{*}{ Benzo(a)pyrene } & Adult & & & & $6.7 \mathrm{E}-06$ & $3.6 \mathrm{E}-06$ \\
\hline & Child & & & & $6.3 E-05$ & $5.7 \mathrm{E}-06$ \\
\hline
\end{tabular}


Table 7.5e (continued)

\begin{tabular}{|c|c|c|c|c|c|c|}
\hline \multirow[b]{2}{*}{ Analyte } & & \multicolumn{3}{|c|}{ Carcinogenic effects } & \multicolumn{2}{|c|}{ Noncarcinogenic effects } \\
\hline & & $\begin{array}{l}\text { Ingestion } \\
\text { (mg/kg-day } \\
\text { or pCi) }\end{array}$ & $\begin{array}{c}\text { Dermal } \\
\text { (mg/kg-day) }\end{array}$ & $\begin{array}{l}\text { External } \\
\text { exposure } \\
\text { (pCi-yr/g) }\end{array}$ & $\begin{array}{l}\text { Ingestion } \\
\text { (mg/kg-day) }\end{array}$ & $\begin{array}{c}\text { Dermal } \\
\text { (mg/kg-day) }\end{array}$ \\
\hline \multicolumn{7}{|c|}{ Organies (continued) } \\
\hline Benzo(b)fluoranthene & $\begin{array}{l}\text { Adult } \\
\text { Child }\end{array}$ & & . & & $\begin{array}{l}8.6 \mathrm{E}-06 \\
8.1 \mathrm{E}-05\end{array}$ & $\begin{array}{l}4.6 \mathrm{E}-06 \\
7.3 \mathrm{E}-06\end{array}$ \\
\hline Benzo(g,h,i)perylene & $\begin{array}{l}\text { Adult } \\
\text { Child }\end{array}$ & & & & $\begin{array}{l}7.0 \mathrm{E}-06 \\
6.6 \mathrm{E}-05\end{array}$ & $\begin{array}{l}3.7 \mathrm{E}-06 \\
6.0 \mathrm{E}-06\end{array}$ \\
\hline Benzo(k)fluoranthene & $\begin{array}{l}\text { Adult } \\
\text { Child }\end{array}$ & & & & $\begin{array}{l}4.0 \mathrm{E}-06 \\
3.7 \mathrm{E}-05\end{array}$ & $\begin{array}{l}2.1 \mathrm{E}-06 \\
3.4 \mathrm{E}-06\end{array}$ \\
\hline Chrysene & $\begin{array}{l}\text { Adult } \\
\text { Child }\end{array}$ & & & & $\begin{array}{l}1.1 \mathrm{E}-05 \\
1.0 \mathrm{E}-04\end{array}$ & $\begin{array}{l}5.7 \mathrm{E}-06 \\
9.1 \mathrm{E}-06\end{array}$ \\
\hline Dibenz $(a, h)$ anthracene & $\begin{array}{l}\text { Adult } \\
\text { Child }\end{array}$ & & & & $\begin{array}{l}1.9 \mathrm{E}-06 \\
1.8 \mathrm{E}-05\end{array}$ & $\begin{array}{l}1.0 \mathrm{E}-06 \\
1.6 \mathrm{E}-06\end{array}$ \\
\hline Fluoranthene & $\begin{array}{l}\text { Adult } \\
\text { Child }\end{array}$ & $\begin{array}{l}3.4 \mathrm{E}-06 \\
8.0 \mathrm{E}-06\end{array}$ & $\begin{array}{l}1.8 \mathrm{E}-06 \\
7.2 \mathrm{E}-07\end{array}$ & & & \\
\hline Fluorene & $\begin{array}{l}\text { Adult } \\
\text { Child }\end{array}$ & $\begin{array}{l}2.6 \mathrm{E}-06 \\
6.1 \mathrm{E}-06\end{array}$ & $\begin{array}{l}1.4 \mathrm{E}-06 \\
5.5 \mathrm{E}-07\end{array}$ & & & \\
\hline Indeno(1,2,3-cd)pyrene & $\begin{array}{l}\text { Adult } \\
\text { Child }\end{array}$ & & & & $\begin{array}{l}2.2 \mathrm{E}-05 \\
2.1 \mathrm{E}-04\end{array}$ & $\begin{array}{l}1.2 \mathrm{E}-05 \\
1.9 \mathrm{E}-05\end{array}$ \\
\hline Naphthalene & $\begin{array}{l}\text { Adult } \\
\text { Child }\end{array}$ & $\begin{array}{l}5.1 \mathrm{E}-06 \\
1.2 \mathrm{E}-05\end{array}$ & $\begin{array}{l}27 \mathrm{E}-06 \\
1.1 \mathrm{E}-06\end{array}$ & & & \\
\hline Phenanthrene & $\begin{array}{l}\text { Adult } \\
\text { Child }\end{array}$ & & & & $\begin{array}{l}1.2 \mathrm{E}-05 \\
1.1 \mathrm{E}-04\end{array}$ & $\begin{array}{l}6.4 \mathrm{E}-06 \\
1.0 \mathrm{E}-05\end{array}$ \\
\hline Pyrene & $\begin{array}{l}\text { Adult } \\
\text { Child }\end{array}$ & $\begin{array}{l}5.9 \mathrm{E}-06 \\
1.4 \mathrm{E}-05\end{array}$ & $\begin{array}{l}3.1 E-06 \\
1.3 E-06\end{array}$ & & & \\
\hline \multicolumn{7}{|c|}{ Radionuclides } \\
\hline Total Uranium & $\begin{array}{l}\text { Adult } \\
\text { Child }\end{array}$ & $\begin{array}{l}2.0 E+03 \\
9.9 E+02\end{array}$ & & $\begin{array}{l}4.5 \mathrm{E}+01 \\
1.1 \mathrm{E}+01\end{array}$ & & \\
\hline
\end{tabular}

${ }^{a}$ The upper $95 \%$ confidence bound on the median is used as the representative concentration in all calculations.

${ }^{b}$ For carcinogenic effects/ingestion pathway: units are $\mathrm{mg} / \mathrm{kg}$-day for inorganics and organics, and $\mathrm{pCi}$ for radionuclides. 


\section{$7-54$}

Table 7.5f. Chronic daily intake of ORR background soil by the on-site resident-Chictamauga (K-25) ${ }^{a}$

(for constituents for which a risk and/or hazard index could not be calculated)

\begin{tabular}{|c|c|c|c|c|c|c|}
\hline \multirow[b]{2}{*}{ Analyte } & & \multicolumn{3}{|c|}{ Carcinogenic effects } & \multicolumn{2}{|c|}{ Noncarcinogenic effects } \\
\hline & & $\begin{array}{l}\text { Ingestion } \\
(\mathrm{mg} / \mathrm{kg} \text {-day } \\
\text { or pCi })^{b}\end{array}$ & $\begin{array}{c}\text { Dermal } \\
\text { (mg/kg-day) }\end{array}$ & $\begin{array}{l}\text { External } \\
\text { exposure } \\
\text { (pCi-yr/g) }\end{array}$ & $\begin{array}{l}\text { Ingestion } \\
\text { (mg/kg-day) }\end{array}$ & $\begin{array}{c}\text { Dermal } \\
\text { (mg/kg-day) }\end{array}$ \\
\hline & & & Inorganics & & & \\
\hline Aluminum & Adult & 8.7E-03 & 4.6E-04 & & $\begin{array}{l}25 \mathrm{E}-02 \\
24 \mathrm{E}-01\end{array}$ & $\begin{array}{l}1.4 \mathrm{E}-03 \\
2.2 \mathrm{E}-03\end{array}$ \\
\hline Arsenic & $\begin{array}{l}\text { Adult } \\
\text { Child }\end{array}$ & $\begin{array}{l}4.6 \mathrm{E}-06 \\
1.1 \mathrm{E}-05\end{array}$ & $\begin{array}{l}2.4 \mathrm{E}-07 \\
9.7 \mathrm{E}-08\end{array}$ & & & \\
\hline Barium & $\begin{array}{l}\text { Adult } \\
\text { Child }\end{array}$ & $\begin{array}{l}\text { 4.7E-05 } \\
1.1 E-04\end{array}$ & $\begin{array}{l}2.5 \mathrm{E}-06 \\
9.9 \mathrm{E}-07\end{array}$ & & & \\
\hline Calcium & $\begin{array}{l}\text { Adult } \\
\text { Child }\end{array}$ & $\begin{array}{l}8.8 \mathrm{E}-04 \\
2.1 \mathrm{E}-03\end{array}$ & $\begin{array}{l}\text { 4.7E-05 } \\
1.9 \mathrm{E}-05\end{array}$ & & $\begin{array}{l}2.6 \mathrm{E}-03 \\
2.4 \mathrm{E}-02\end{array}$ & $\begin{array}{l}1.4 \mathrm{E}-04 \\
2.2 \mathrm{E}-04\end{array}$ \\
\hline Chromium & $\begin{array}{l}\text { Adult } \\
\text { Child }\end{array}$ & $\begin{array}{l}1.8 \mathrm{E}-05 \\
4.2 \mathrm{E}-05\end{array}$ & $\begin{array}{l}9.6 \mathrm{E}-07 \\
3.8 \mathrm{E}-07\end{array}$ & & $\begin{array}{l}5.3 \mathrm{E}-05 \\
4.9 \mathrm{E}-04\end{array}$ & $\begin{array}{l}2.8 \mathrm{E}-06 \\
4.5 \mathrm{E}-06\end{array}$ \\
\hline Chromium VI & $\begin{array}{l}\text { Adult } \\
\text { Child }\end{array}$ & $\begin{array}{l}1.8 \mathrm{E}-05 \\
4.2 \mathrm{E}-05\end{array}$ & $\begin{array}{l}9.6 \mathrm{E}-07 \\
3.8 \mathrm{E}-07\end{array}$ & & & \\
\hline Cobalt & $\begin{array}{l}\text { Adult } \\
\text { Child }\end{array}$ & $\begin{array}{l}1.2 \mathrm{E}-05 \\
2.8 \mathrm{E}-05\end{array}$ & $\begin{array}{l}6.5 \mathrm{E}-07 \\
2.6 \mathrm{E}-07\end{array}$ & & $\begin{array}{l}3.6 \mathrm{E}-05 \\
3.3 \mathrm{E}-04\end{array}$ & $\begin{array}{l}1.9 \mathrm{E}-06 \\
3.0 \mathrm{E}-06\end{array}$ \\
\hline Copper & $\begin{array}{l}\text { Adult } \\
\text { Child }\end{array}$ & $\begin{array}{l}6.8 \mathrm{E}-06 \\
1.6 \mathrm{E}-05\end{array}$ & $\begin{array}{l}3.6 \mathrm{E}-07 \\
1.4 \mathrm{E}-07\end{array}$ & & $\begin{array}{l}2.0 \mathrm{E}-05 \\
1.9 \mathrm{E}-04\end{array}$ & $\begin{array}{l}1.1 \mathrm{E}-06 \\
1.7 \mathrm{E}-06\end{array}$ \\
\hline Iron & $\begin{array}{l}\text { Adult } \\
\text { Child }\end{array}$ & $\begin{array}{l}1.7 \mathrm{E}-02 \\
3.9 \mathrm{E}-02\end{array}$ & $\begin{array}{l}9.0 \mathrm{E}-04 \\
3.6 \mathrm{E}-04\end{array}$ & & $\begin{array}{l}4.9 \mathrm{E}-02 \\
4.6 \mathrm{E}-01\end{array}$ & $\begin{array}{l}2.6 \mathrm{E}-03 \\
4.2 \mathrm{E}-03\end{array}$ \\
\hline Lead & $\begin{array}{l}\text { Adult } \\
\text { Child }\end{array}$ & $\begin{array}{l}2.0 \mathrm{E}-05 \\
4.7 \mathrm{E}-05\end{array}$ & $\begin{array}{l}1.1 \mathrm{E}-06 \\
4.3 \mathrm{E}-07\end{array}$ & & $\begin{array}{l}5.9 \mathrm{E}-05 \\
5.5 \mathrm{E}-04\end{array}$ & $\begin{array}{l}3.1 \mathrm{E}-06 \\
5.0 \mathrm{E}-06\end{array}$ \\
\hline Lithium & $\begin{array}{l}\text { Adult } \\
\text { Child }\end{array}$ & $\begin{array}{l}8.2 \mathrm{E}-06 \\
1.9 \mathrm{E}-05\end{array}$ & $\begin{array}{l}4.3 \mathrm{E}-07 \\
1.7 \mathrm{E}-07\end{array}$ & & $\begin{array}{l}2.4 \mathrm{E}-05 \\
2.2 \mathrm{E}-04\end{array}$ & $\begin{array}{l}1.3 \mathrm{E}-06 \\
2.0 \mathrm{E}-06\end{array}$ \\
\hline Magnesium & $\begin{array}{l}\text { Adult } \\
\text { Child }\end{array}$ & $\begin{array}{l}6.1 \mathrm{E}-04 \\
1.4 \mathrm{E}-03\end{array}$ & $\begin{array}{l}3.2 \mathrm{E}-05 \\
1.3 \mathrm{E}-05\end{array}$ & & $\begin{array}{l}1.8 \mathrm{E}-03 \\
1.7 \mathrm{E}-02\end{array}$ & $\begin{array}{l}9.5 \mathrm{E}-05 \\
1.5 \mathrm{E}-04\end{array}$ \\
\hline Manganese & $\begin{array}{l}\text { Adult } \\
\text { Child }\end{array}$ & $\begin{array}{l}1.1 \mathrm{E}-03 \\
2.5 \mathrm{E}-03\end{array}$ & $\begin{array}{l}5.7 \mathrm{E}-05 \\
2.3 \mathrm{E}-05\end{array}$ & & & \\
\hline Mercury & $\begin{array}{l}\text { Adult } \\
\text { Child }\end{array}$ & $\begin{array}{l}2.7 \mathrm{E}-07 \\
6.3 \mathrm{E}-07\end{array}$ & $\begin{array}{l}1.4 \mathrm{E}-08 \\
5.8 \mathrm{E}-09\end{array}$ & & & \\
\hline Mercury (salts) & $\begin{array}{l}\text { Adult } \\
\text { Child }\end{array}$ & $\begin{array}{l}2.7 \mathrm{E}-07 \\
6.3 \mathrm{E}-07\end{array}$ & $\begin{array}{l}1.4 \mathrm{E}-08 \\
5.8 \mathrm{E}-09\end{array}$ & & & \\
\hline
\end{tabular}


Table 7.5f (continued)

\begin{tabular}{|c|c|c|c|c|c|c|}
\hline \multirow{2}{*}{$\begin{array}{c}. \\
\text { Analyte }\end{array}$} & & \multicolumn{3}{|c|}{ Carcinogenic effects } & \multicolumn{2}{|c|}{ Noncarcinogenic effects } \\
\hline & & $\begin{array}{l}\text { Ingestion } \\
(\mathrm{mg} / \mathrm{kg} \text {-day } \\
\text { or pCi) }\end{array}$ & $\begin{array}{c}\text { Dermal } \\
\text { (mg/kg-day) }\end{array}$ & $\begin{array}{l}\text { External } \\
\text { exposure } \\
\text { (pCi-yr/g) }\end{array}$ & $\begin{array}{l}\text { Ingestion } \\
\text { (mg/kg-day) }\end{array}$ & $\begin{array}{c}\text { Dermal } \\
\text { (mg/kg-day) }\end{array}$ \\
\hline \multicolumn{7}{|c|}{ Inorganics (continued) } \\
\hline \multirow[t]{2}{*}{ Nickel } & Adult & $1.0 \mathrm{E}-05$ & 5.3E-07 & & & \\
\hline & Child & 2.3E-05 & 2.1E-07 & & & \\
\hline \multirow[t]{2}{*}{ Nickel (salts) } & Adult & 1.0E-05 & $5.3 E-07$ & & & \\
\hline & Child & $2.3 \mathrm{E}-05$ & 2.1E-07 & & & \\
\hline \multirow[t]{2}{*}{ Potassium } & Adult & $9.7 \mathrm{E}-04$ & $5.1 \mathrm{E}-05$ & & $2.8 \mathrm{E}-03$ & $1.5 \mathrm{E}-04$ \\
\hline & Child & $2.3 \mathrm{E}-03$ & 2.1E-05 & & $2.6 \mathrm{E}-02$ & $2.4 \mathrm{E}-04$ \\
\hline \multirow[t]{2}{*}{ Selenium } & Adult & $4.5 \mathrm{E}-07$ & 2.4E-08 & & & \\
\hline & Child & $1.1 \mathrm{E}-06$ & $9.6 \mathrm{E}-09$ & & & \\
\hline \multirow{2}{*}{ Silicon } & Adult & $3.3 \mathrm{E}-04$ & $1.7 \mathrm{E}-05$ & & $9.6 \mathrm{E}-04$ & 5.1E-05 \\
\hline & Child & 7.7E-04 & $7.0 \mathrm{E}-06$ & & $8.9 \mathrm{E}-03$ & 8.1E-05 \\
\hline \multirow[t]{2}{*}{ Sodium } & Adult & $2.1 \mathrm{E}-04$ & $1.1 \mathrm{E}-05$ & & $6.2 \mathrm{E}-04$ & 3.3E-05 \\
\hline & Child & $5.0 \mathrm{E}-04$ & $4.5 \mathrm{E}-06$ & & $5.8 \mathrm{E}-03$ & 5.3E-05 \\
\hline \multirow[t]{2}{*}{ Strontium } & Adult & $7.5 \mathrm{E}-06$ & 4.0E-07 & & & \\
\hline & Child & $1.8 \mathrm{E}-05$ & $1.6 \mathrm{E}-07$ & & & \\
\hline \multirow[t]{2}{*}{ Sulfate } & Adult & $1.2 \mathrm{E}-04$ & $6.2 \mathrm{E}-06$ & & $3.4 \mathrm{E}-04$ & $1.8 \mathrm{E}-05$ \\
\hline & Child & 2.7E-04 & $2.5 \mathrm{E}-06$ & & $3.2 \mathrm{E}-03$ & 2.9E-05 \\
\hline \multirow[t]{2}{*}{ Vanadium } & Adult & $2.0 \mathrm{E}-05$ & $1.0 \mathrm{E}-06$ & & & \\
\hline & - Child & $4.6 \mathrm{E}-05$ & $4.2 \mathrm{E}-07$ & & & \\
\hline \multirow[t]{3}{*}{ Zinc } & Adult & 2.7E-05 & $1.4 \mathrm{E}-06$ & & & \\
\hline & Child & $6.2 \mathrm{E}-05$ & 5.7E-07 & & & \\
\hline & & & Organics & & & \\
\hline \multirow[t]{2}{*}{ Acenaphthene } & Adult & $8.5 \mathrm{E}-07$ & $4.5 \mathrm{E}-07$ & & & \\
\hline & Child & $2.0 \mathrm{E}-06$ & $1.8 \mathrm{E}-07$ & & & \\
\hline \multirow[t]{2}{*}{ Anthracene } & Adult & $9.0 \mathrm{E}-07$ & $4.8 \mathrm{E}-07$ & & & \\
\hline & Child & $2.1 E-06$ & $1.9 \mathrm{E}-07$ & & & \\
\hline \multirow{2}{*}{ Benzo(a)anthracene } & Adult & & & & $1.0 \mathrm{E}-05$ & $5.5 \mathrm{E}-06$ \\
\hline & Child & & & & $9.6 \mathrm{E}-05$ & 8.7E-06 \\
\hline \multirow[t]{2}{*}{ Benzo(a)pyrene } & Adult & & & & $9.2 \mathrm{E}-06$ & $4.9 \mathrm{E}-06$ \\
\hline & Child & & & & $8.6 \mathrm{E}-05$ & $7.9 E-06$ \\
\hline
\end{tabular}




\section{$7-56$}

Table 7.5f (continued)

\begin{tabular}{|c|c|c|c|c|c|c|}
\hline \multirow[b]{2}{*}{ Anaiyte } & & \multicolumn{3}{|c|}{ Carcinogenic effects } & \multicolumn{2}{|c|}{ Noncarcinogenic effects } \\
\hline & & $\begin{array}{l}\text { Ingestion } \\
\text { (mg/kg-day } \\
\text { or pCi) }\end{array}$ & $\begin{array}{c}\text { Dermal } \\
\text { (mg/kg-day) }\end{array}$ & $\begin{array}{l}\text { External } \\
\text { exposure } \\
\text { (pCi-yr/g) }\end{array}$ & $\begin{array}{l}\text { Ingestion } \\
\text { (mg/kg-day) }\end{array}$ & $\begin{array}{c}\text { Dermal } \\
\text { (mg/kg-day) }\end{array}$ \\
\hline \multicolumn{7}{|c|}{ Organics (continued) } \\
\hline Benzo(b)fluoranthene & $\begin{array}{l}\text { Adult } \\
\text { Child }\end{array}$ & & & & $\begin{array}{l}8.3 \mathrm{E}-06 \\
7.8 \mathrm{E}-05\end{array}$ & $\begin{array}{l}4.4 E-06 \\
7.1 E-06\end{array}$ \\
\hline Benzo(g,h,i)perylene & $\begin{array}{l}\text { Adult } \\
\text { Child }\end{array}$ & & & & $\begin{array}{l}8.4 \mathrm{E}-06 \\
7.9 \mathrm{E}-05\end{array}$ & $\begin{array}{l}4.5 E-06 \\
7.2 E-06\end{array}$ \\
\hline Benzo(k)fluoranthene & $\begin{array}{l}\text { Adult } \\
\text { Child }\end{array}$ & & & & $\begin{array}{l}5.1 E-06 \\
4.8 E-05\end{array}$ & $\begin{array}{l}2.7 E-06 \\
4.3 E-06\end{array}$ \\
\hline Chrysene & $\begin{array}{l}\text { Adult } \\
\text { Child }\end{array}$ & & & & $\begin{array}{l}1.1 \mathrm{E}-05 \\
1.0 \mathrm{E}-04\end{array}$ & $\begin{array}{l}5.8 \mathrm{E}-06 \\
9.3 \mathrm{E}-06\end{array}$ \\
\hline Dibenz(a,h)anthracene & $\begin{array}{l}\text { Adult } \\
\text { Child }\end{array}$ & & & & $\begin{array}{l}2.1 \mathrm{E}-06 \\
2.0 \mathrm{E}-05\end{array}$ & $\begin{array}{l}1.1 E-06 \\
1.8 E-06\end{array}$ \\
\hline Fluoranthene & $\begin{array}{l}\text { Adult } \\
\text { Child }\end{array}$ & $\begin{array}{l}4.4 E-06 \\
1.0 E-05\end{array}$ & $\begin{array}{l}2.4 \mathrm{E}-06 \\
9.4 \mathrm{E}-07\end{array}$ & & & \\
\hline Fluorene & $\begin{array}{l}\text { Adult } \\
\text { Child }\end{array}$ & $\begin{array}{l}9.9 \mathrm{E}-07 \\
2.3 \mathrm{E}-06\end{array}$ & $\begin{array}{l}5.3 E-07 \\
2.1 E-07\end{array}$ & & & \\
\hline Indeno(1,2,3-cd)pyrene & $\begin{array}{l}\text { Adult } \\
\text { Child }\end{array}$ & & & & $\begin{array}{l}1.9 E-05 \\
1.7 E-04\end{array}$ & $\begin{array}{l}9.9 \mathrm{E}-06 \\
1.6 \mathrm{E}-05\end{array}$ \\
\hline Naphthalene & $\begin{array}{l}\text { Adult } \\
\text { Child }\end{array}$ & $\begin{array}{l}1.6 \mathrm{E}-06 \\
3.8 \mathrm{E}-06\end{array}$ & $\begin{array}{l}8.6 \mathrm{E}-07 \\
3.4 \mathrm{E}-07\end{array}$ & & - & \\
\hline Phenanthrene & $\begin{array}{l}\text { Adult } \\
\text { Child }\end{array}$ & & & - & $\begin{array}{l}1.3 E-05 \\
1.2 E-04\end{array}$ & $\begin{array}{l}6.9 \mathrm{E}-06 \\
1.1 \mathrm{E}-05\end{array}$ \\
\hline Pyrene & $\begin{array}{l}\text { Adult } \\
\text { Child }\end{array}$ & $\begin{array}{l}7.2 \mathrm{E}-06 \\
1.7 \mathrm{E}-05\end{array}$ & $\begin{array}{l}3.8 \mathrm{E}-06 \\
1.5 \mathrm{E}-06\end{array}$ & & & \\
\hline & & & Radionucides & & & \\
\hline Total Uranium & $\begin{array}{l}\text { Adult } \\
\text { Child }\end{array}$ & $\begin{array}{l}1.3 E+03 \\
6.7 E+02\end{array}$ & & $\begin{array}{l}3.1 \mathrm{E}+01 \\
7.7 \mathrm{E}+00\end{array}$ & & \\
\hline
\end{tabular}

-The upper $95 \%$ confidence bound on the median is used as the representative concentration in all calculations.

${ }^{b}$ For carcinogenic effects/ingestion pathway: units are $\mathrm{mg} / \mathrm{kg}$-day for inorganics and organics, and $\mathrm{pCi}$ for radionuclides. 
effects resulting from exposure to the constituents of potential concern. Refer to the ORNL/HASRD/BELAS Toxicity Profiles report for further information regarding specific constituents. Tables 7.6 through 7.9 summarize toxicity information for the constituents. The health effects described in this section are conservative and may not necessarily represent the actual health effects incurred by exposure to constituent levels presented in this background soil evaluation.

\subsubsection{Inorganics}

\subsubsection{Antimony}

Antimony is a naturally occurring metal that is used in metallurgical processes, paints and enamels, various textiles, rubber, and fire retardants (antimony trioxide). Antimony is a common urban air pollutant, occurring at an average concentration of $0.001 \mu \mathrm{g} / \mathrm{m}^{3}$. Exposure to the element may occur via inhalation and ingestion of contaminated foods. In addition, some antimonials, such as potassium antimony tartrate, have been used medicinally as parasiticides (BELAS 1993).

Antimony is only slowly absorbed from the gastrointestinal tract. Based on animal data, gastrointestinal absorption of antimony was estimated to be 2 to $7 \%$. Antimony has been detected in the blood of occupationally exposed individuals; however, it is uncertain whether this was caused by pulmonary absorption or ingestion following mucociliary transport from the upper respiratory tract. Urinary excretion of antimony has been documented for workers exposed to antimony fumes. Acute poisoning has occurred as a result of accidental or suicidal ingestion of antimonials with death ensuing within several hours. Symptoms of severe antimony poisoning include vomiting, diarrhea, collapse, irregular respiration, and hypothermia. Oral exposure data are inconclusive concerning subchronic and chronic toxicity of antimony. Occupational inhalation exposure to antimonials may result in respiratory effects, including pneumoconiosis and chronic bronchitis. Dermal exposure to antimony may cause dermatitis, although no acute or chronic toxicity information is available. In addition, no information is available regarding the carcinogenicity of antimony in humans, and no evidence shows increased cancer incidence as a result of inhalation exposure (BEIAS 1993).

\subsubsection{Arsenic}

Arsenic is a metallic, steel-gray, crystalline, brittle, trivalent and pentavalent, solid, poisonous element. It is commonly used in pesticides. Trivalent compounds are generally more toxic and more likely to have systemic effects than the less soluble compounds which are more likely to cause chronic pulmonary effects if inhaled.

Water soluble inorganic arsenic compounds are absorbed through the gastrointestinal tract and lungs. Symptoms of acute inorganic arsenic poisoning in humans are nausea, anorexia, vomiting, epigastric and abdominal pain, and diarrhea. In addition, dermatitis, muscle cramps, cardiac abnormalities, hepatoxicity, bone marrow suppression and hematologic abnormalities, vascular lesions, and peripheral neuropathy have also been reported. Severe exposures can result in acute encephalopathy, congestive heart failure, stupor, convulsions, paralysis, coma, and death. Occupational exposure studies show a clear correlation between exposure to arsenic and lung cancer mortality (BELAS 1993). 


\subsubsection{Barium}

Barium is a divalent alkaline-earth metal found only in combination with other elements in nature. The most important of these combinations are the peroxide, chloride, sulfate, carbonate, nitrate, and chlorate. The most likely source of barium in the atmosphere is from industrial emissions. Because of the element's tendency to form salts with limited solubility in soil and water, it is expected to have a residence time of hundreds of years and is not expected to be very mobile. Trace amounts of barium have been found in more than $99 \%$ of surface waters and finished drinking water samples (average values of $43 \mu \mathrm{g} / \mathrm{L}$ and $28.6 \mu \mathrm{g} / \mathrm{L}$, respectively) across the United States (BELAS 1993).

The soluble salts of barium are toxic to mammalian systems. They are absorbed rapidly from the gastrointestinal tract and are deposited in the muscles, lungs, and bone. At low doses, barium acts as a muscle stimulant and at higher doses affects the nervous system eventually leading to paralysis. Subchronic and chronic oral or inhalation exposure primarily affects the cardiovascular system resulting in elevated blood pressure. Subchronic and chronic inhalation exposure of human populations to barium-containing dust can result in a benign pneumoconiosis called baritosis, which is a condition often accompanied by an elevated blood pressure but does not usually result in a pulmonary function change. Although the effects of barium on laboratory rats have been documented and include elevated blood pressure, decreased body weight, birth defects, and increased infant mortality, these effects have not been substantiated in humans. In addition, barium has not been evaluated by the United States Environmental Protection Agency (EPA) for evidence of human carcinogenicity (BEIAS 1993).

\subsubsection{Beryllium}

Pure beryllium is a hard, grayish metal. Beryllium compounds are present in the earth's crust. It can be found in emissions from coal combustion; in surface water and soil; and in house dust, food, drinking water, and cigarette smoke. Industry employs beryllium in several ways, including in brake systems for airplanes, for neutron monochromatization, as window material for x-ray tubes, and in radiation detectors. Additionally, beryllium compounds are used in manufacturing ceramics and refractories, chemical reagents, and gas mantle hardeners. The highest risk for exposure to beryllium occurs among workers employed in beryllium manufacturing, fabricating, or reclaiming industries. However, people who live near these industries and who are sensitive to extremely low concentrations of beryllium in the air are also at risk. In addition, smokers inhale unusually high concentrations of beryllium, depending on the source of tobacco.

A limited amount of data indicates that the oral toxicity of beryllium is low; however, the inhaled toxicity of beryllium is well documented. Humans inhaling massive doses of beryllium compounds may develop acute berylliosis. Additionally, beryllium and its compounds are presumed to have cancer-causing potential in the human lung when inhaled. The cancer-causing ability has been investigated in workers exposed to beryllium. The degree of harm depends on the amount and duration of exposure. Short-term exposure to beryllium may cause noncarcinogenic health effects, such as acute pneumonitis berylliosis, while long-term exposure may cause lung cancer (BEIAS 1993). 


\subsubsection{Chromium and Chromium VI}

Elemental chromium does not occur in nature but is present in ores-primarily chromite. Chromium exhibits several oxidation states, but the most prominent of these is Chromium VI and Chromium III. Chromium VI in the environment is manmade as a result of industrial emissions; in solution, Chromium VI exists as hydrochromate, chromate, and dichromate ionic species and reacts over time to form Chromium III. Chromium VI is much more mobile and toxic than is Chromium III. Chromium is useful in glucose and cholesterol metabolism and therefore is an essential element to humans and animals. Nonoccupational exposure to the metal occurs via the ingestion of chromium-containing food and water, whereas occupational exposure occurs via inhalation. Workers are exposed to chromium during its use in the production of dichromate; the chemical, stainless steel, refractory, and chromium-plating industries; and the production and use of alloys (ATSDR 1988; BEIAS 1993).

Chromium enters the body through the lungs, gastrointestinal tract, and, to a lesser extent, the skin. Inhalation is the most important route for occupational exposure. Workers exposed to chromium have developed nasal irritation, nasal ulcers, perforation of the nasal septum, and hypersensitivity reactions and "chrome holes" of the skin. Among the general population, contact dermatitis has been associated with the use of bleaches and detergents. Inhalation of chromium compounds has been associated with the development of cancer in workers in the chromate industry. Evidence also suggests an increased risk in developing nasal, pharyngeal, and gastrointestinal carcinomas. Based on sufficient evidence reporting that humans and animals are at risk of developing cancer, Chromium VI has been assigned an EPA weight-of-evidence classification of A, human carcinogen (BEIAS 1993).

\subsubsection{Manganese}

Manganese makes up about $0.10 \%$ of the earth's crust and is the 12th most abundant element. It can exist in oxidation states from -3 to +7 , the most common being +4 in the chemical form of manganese dioxide. The oxides and peroxides are used in industry as oxidizers, and the metal is used for manufacturing metal alloys to increase hardness and corrosion resistance. Manganese is an essential trace element in humans, which can elicit a variety of serious toxic responses upon prolonged exposure to elevated concentrations either orally or by inhalation. The central nervous system is the primary target (BEIAS 1993).

Initial symptoms of manganese exposure are insomnia, disorientation, anxiety, lethargy, and memory loss. These symptoms will progress with prolonged exposure and will eventually include motor disturbances, tremors, and walking difficulties similar to Parkinsonism. Effects on reproduction (decreased fertility, impotence) have been observed in humans with inhalation exposure and in animals with oral exposure at the same or similar doses that initiate the central nervous system effects. Data on possible carcinogenesis following injections in mice are inconclusive; however, the EPA weight-of-evidence classification is D, not classifiable as to human carcinogenicity based on no evidence in humans and inconclusive evidence in animals (BEIAS 1993).

\subsubsection{Mercury and Mercury Salts}

Mercury is a naturally occurring element that may exist in elemental, inorganic, or organic forms and in various oxidation states. Mercury is used in a wide variety of products 
and processes, including pressure sensitive devices (thermometers, barometers), electrical apparatus (wiring, switches, batteries), paints, pharmaceuticals, and in the production of various chemicals. The oxidation state and chemical form of mercury are important in determining its toxicity, with mercurous salts being less toxic than mercuric salts. Organic materials such as methyl mercury are highly toxic. In the environment, mercury may undergo transformations among the various oxidation states and chemical forms. Both environmental and occupational exposure are relevant to mercury and its compounds, although environmental exposure is unimportant for mercury vapor. Mercury intake from occupational exposure is of greater significance than that from environmental exposure. Environmental exposure to mercury may involve dietary intake (i.e., from fish) and possibly from dental amalgams, the latter being controversial and under dispute (BEIAS 1993).

Ingestion of mercury metal is usually without effect, while ingestion of inorganic salts may cause severe gastrointestinal irritation, renal failure, and death. Mercury is also known to induce hypersensitivity reactions such as contact dermatitis and acrodynia (pink disease). Inhalation of mercury vapor may cause irritation of the respiratory tract, central nervous system effects characterized by neurobehavioral changes, peripheral nervous system toxicity, renal toxicity, and death. Toxicity resulting from subchronic and chronic exposure to mercury and mercury salts usually involves the kidneys and/or the nervous system. No data are available regarding the carcinogenicity of mercury in humans or animals. The EPA has placed inorganic mercury in weight-of-evidence classification $D$, not classifiable as to human carcinogenicity (BEIAS 1993).

\subsubsection{Molybdenum}

Molybdenum is considered an essential trace element that occurs naturally in various ores, the most important being molybdenite, which is converted to molybdenum trioxide for use in ferro- and manganese alloys, chemicals, catalysts, ceramics, and pigments. Metallic molybdenum is used in electronic parts, induction heating elements, and electrodes (BEIAS 1993).

Data documenting molybdenum toxicity in humans are limited. Mild cases of molybdenosis may be clinically identifiable only by biochemical changes such as increased uric acid levels. Excessive intake of molybdenum causes a physiological copper deficiency, and conversely, in cases of inadequate dietary intake of copper, molybdenum toxicity may occur at lower exposure levels. Oral toxicity data and inhalation toxicity data for molybdenum exposure on humans are unavailable, as is information on the oral or inhalation carcinogenicity of molybdenum compounds in humans (BEIAS 1993).

\subsubsection{Nickel and Nickel Salts}

Nickel is a naturally occurring metal existing in various mineral forms. Nickel may be found throughout the environment including rivers, lakes, oceans, soil, air, drinking water, plants, and animals. Soil and sediment are the primary receptacles for nickel but mobilization may occur depending on physico-chemical characteristics of the soil. Nickel is used in a wide variety of metallurgical processes such as electroplating and alloy production, as well as in nickel-cadmium batteries. Some evidence suggests that nickel may be an essential trace 
element for mammals. As for most metals, the toxicity of nickel is dependent on the route of exposure and the solubility of the nickel compound (BEIAS 1993).

$\therefore$ i'.

Pulmonary absorption is the major route of concern for nickel-induced toxicity. Toxic effects of oral exposure to nickel usually involve the kidneys with some evidence from animal studies showing a possible development/reproductive toxicity effect. Inhalation exposure to some nickel compounds will cause toxic effects in the respiratory tract and immune system. Asthmatic conditions have also been documented for inhalation exposure to nickel. In addition, sensitivity reactions to nickel are well documented and usually involve contact dermatitis reactions resulting from contact with items such as cooking utensils, jewelry, coins, etc., containing nickel. Epidemiologic studies have shown that occupational inhalation exposure to nickel dust (primarily nickel subsulfide) at refineries has resulted in increased incidences of pulmonary and nasal cancer (BELAS 1993).

\subsubsection{Selenium}

Selenium is an essential trace element important in many biochemical and physiological processes including the biosynthesis of coenzyme $\mathrm{Q}$ (a component of mitochondrial electron transport systems), regulation of ion fluxes across membranes, maintenance of the integrity of keratins, stimulation of antibody synthesis, and activation of glutathione peroxidase (an enzyme involved in preventing oxidative damage to cells). Animal studies indicate that deficiencies in selenium can result in damage to the liver, heart, kidneys, skeletal muscle, and testes. The primary dietary sources of selenium are seafoods, kidney and liver meats, and grains and cereals.

In humans, acute oral exposures can result in excessive salivation, garlic odor to the breath, shallow breathing, diarrhea, pulmonary edema, and death. General signs of chronic selenosis in humans include loss of hair and nails, clubbing of the fingers, skin lesions, tooth decay, and nervous system abnormalities attributed to polyneuritis. Human inhalation of selenium or selenium compounds primarily affects the respiratory system. Dusts of elemental selenium and selenium dioxide can cause irritation of the skin and mucous membranes of the nose and throat, coughing, nosebleed, loss of sense of smell, dyspnea, bronchial spasms, bronchitis, and chemical pneumonia. Pertinent data regarding the potential carcinogenicity of selenium by the inhalation route in humans or animals are not available (BEIAS 1993).

\subsubsection{Vanadium}

Vanadium is a metallic element that occurs in six oxidation states and numerous inorganic compounds. The element is used primarily as an alloying agent in steels and nonferrous metals such as copper, aluminum, and titanium. Vanadium compounds are also used as catalysts and in chemical, ceramic, or specialty applications. It may also have applications as an intermetallic compound for superconductor applications. Minor uses include applications as color modifiers in mercury-vapor lamps, as driers in paints and varnish, and as corrosion inhibitors in flue-gas scrubbers (BEIAS 1993).

Vanadium compounds are poorly absorbed through the gastrointestinal system but slightly more readily absorbed through the lungs. Absorbed vanadium is widely distributed in the body, but short-term localization occurs primarily in bone, the kidneys, and the liver. In the body, vanadium can undergo changes in oxidation state and vanadate and can also bind with 
blood protein (transferrin). The toxicity of vanadium depends on its physico-chemical state-particularly on its valence state and solubility. In humans, intestinal cramps and diarrhea may occur following subchronic oral exposures, thereby suggesting that, for subchronic and chronic oral exposures, the primary targets are the digestive system, kidneys, and blood. Inhalation exposures to vanadium and vanadium compounds result primarily in adverse effects to the respiratory system. In studies on workers occupationally exposed to vanadium, the most common reported symptoms were irritation of the respiratory tract, conjunctivitis, dermatitis, cough, bronchospasm, pulmonary congestion, and bronchitis. Little evidence suggests that vanadium or vanadium compounds are carcinogenic; however, few studies have been conducted on the carcinogenicity of vanadium (BEIAS 1993).

\subsubsection{Zinc}

Zinc is an essential element and is used primarily in galvanized metals and metal alloys. In addition, various inorganic zinc salts have numerous commercial uses. Zinc oxide is used in the rubber industry as a vulcanization activator and accelerator and to slow down oxidation, and also as a reinforcing agent, heat conductor, pigment, UV stabilizer, supplement in animal feeds and fertilizers, catalyst, chemical intermediate, and mildew inhibitor. Zinc sulfate is used in rayon manufacture, agriculture, zinc plating, and as a chemical intermediate and mordant. Zinc chloride is used in smoke bombs, in cements for metals, in wood preservatives, in flux for soldering; in manufacture of parchment paper, artificial silk, and glues; as a mordant in printing and dye textiles; and as a deodorant, antiseptic, and astringent. Zinc chromate is used as a pigment in paints, varnishes, and oil colors. In addition, zinc phosphide is used as a rodenticide, and zinc cyanide is used in electroplating. The toxicity of the latter two compounds is caused primarily by their anion component (BEIAS 1993).

Gastrointestinal absorption of zinc is variable (20-80\%) and depends on the chemical compound as well as on zinc levels in the body and dietary concentrations of other nutrients. Zinc is present in all tissues with the highest concentrations in the prostate, kidney, liver, heart, and pancreas. In humans, acutely toxic oral doses of zinc cause nausea, vomiting, diarrhea, and abdominal cramps and in some cases gastric bleeding. Gastrointestinal upset has also been reported in individuals taking dietary zinc supplements for up to 6 weeks. Limited evidence suggests that the human immune system may be impaired by subchronic exposures. Chronic oral exposures to zinc have resulted in hypochromic microcytic anemia associated with hypoceruloplasminemia, hypocupremia, and neutropenia in some individuals. Under occupational exposure conditions, inhalation of zinc compounds (mainly zinc oxide fumes) can result in a condition identified as "metal fume fever," which is characterized by nasal passage irritation, cough, rales, headache, altered taste, fever, weakness, hyperpnea, sweating, pains in the legs and chest, leukocytosis, reduced lung volume, and decreased diffusing capacity of carbon monoxide. "Metal fume fever" is an acute and reversible effect that is unlikely to occur under chronic exposure conditions when zinc air concentrations are less that $8-12 \mathrm{mg} / \mathrm{m}^{3}$. No case studies or epidemiologic evidence has been presented to suggest that zinc is carcinogenic in humans by the oral or inhalation route (BEIAS 1993).

\subsubsection{Radionuclides}

Radionuclides are unstable atoms of elements that will emit charged particles to achieve a more stable state. These charged particles are termed "alpha and beta radiation" and "neutral gamma rays." Interaction of these charged particles (and gamma rays) with matter 
will produce ionization events, or radiation, which may cause living cell tissue damage. Because the deposition of energy by ionizing radiation is a random process, sufficient energy .may be deposited (in a critical volume) within a cell and result in cell modification or death (ICRP 1991). In addition, ionizing radiation has sufficient energy that interactions with matter will produce an ejected electron and a positively charged ion (known as free radicals) that are highly reactive and may combine with other elements, or compounds within a cell, to produce toxins or otherwise disrupt the overall chemical balance of the cell (EPA 1991b). These free radicals can also react with deoxyribonucleic acid (DNA), causing genetic damage, cancer induction, or even cell death.

Radionuclides are characterized by the type and energy level of the radiation emitted. Radiation emissions fall into two major categories: particulate (electrons, alpha particles, beta particles, and protons) or electromagnetic radiation (gamma and x-rays) (ASTDR 1989d). Therefore, all radionuclides are classified by the EPA as Group A carcinogens based on their property of emitting ionizing radiation and on the extensive weight of evidence provided by epidemiological studies of humans with cancers induced by high doses of radiation. Alpha particles are emitted at a characteristic energy level for differing radionuclides. The alpha particle has a charge of +2 and a comparably large size. Alpha particles have the ability to react (and/or ionize) with other molecules, but they have very little penetrating power and lack the ability to pass through a piece of paper or human skin. However, alpha-emitting radionuclides are of concern when there is a potential for inhalation or ingestion of the radionuclide. Alpha particles are directly ionizing and deposit their energy in dense concentrations [termed high linear energy transfer (high LET)], resulting in short paths of highly localized ionization reactions. The probability of cell damage increases as a result of the increase in ionization events occurring in smaller areas; this may also be the reason for increased cancer incidence caused by inhalation of radon gas. In addition, the cancer incidence in smokers may be directly attributed to the naturally occurring alpha emitter, polonium-210, in common tobacco products (Hammonds and Hoffman 1992).

Beta emissions generally refer to beta negative particle emissions. Radionuclides with an excess of neutrons achieve stability by beta decay. Beta radiation, like alpha radiation, is directly ionizing but, unlike alpha activity, beta particles deposit their energy along a longer track length (low-LET), resulting in more space between ionization events (Hammonds and Hoffman 1992). Beta-emitting radionuclides can cause injury to the skin and superficial body tissue but are most destructive when inhaled or ingested. Many beta emitters are similar chemically to naturally occurring essential nutrients and will therefore tend to accumulate in certain specific tissues. For example, strontium-90 is chemically similar to calcium and, as a result, accumulates in the bones, where it causes continuous exposure. The health effects of beta particle emissions depend upon the target organ. Those seeking the bones would cause a prolonged exposure to the bone marrow and affect blood cell formation, possibly resulting in leukemia, other blood disorders, or bone cancers. Those seeking the liver would result in liver diseases or cancer, while those seeking the thyroid would cause thyroid and metabolic disorders. In addition, beta radiation may lead to damage of genetic material (DNA), causing hereditary defects.

Gamma emissions are the energy that has been released from transformations of the atomic nucleus. Gamma emitters and x-rays behave similarly but differ in their origin: gamma emissions originate in nuclear transformations, and x-rays result from changes in the orbiting electron structure. Radionuclides that emit gamma radiation can induce internal and external 
effects. Gamma rays have high penetrating ability in living tissue and are capable of reaching all internal body organs. Without such sufficient shielding as lead, concrete, or steel, gamma radiation can penetrate the body from the outside and does not require ingestion or inhalation to penetrate sensitive organs. Gamma rays are characterized as low-LET radiation, as is beta radiation; however, the behavior of beta radiation differs from that of gamma radiation in that beta particles deposit most of their energy in the medium through which they pass, while gamma rays often escape the medium because of higher energies, thereby creating difficulties in determining actual internal exposure. For this reason, direct whole-body measurements are necessary to detect gamma radiation, while urine/fecal analyses are usually effective in detecting beta radiation (Hammonds and Hoffman 1992).

People receive gamma radiation continuously from naturally occurring radioactive decay processes going on in the earth's surface, from radiation naturally occurring inside their bodies, from the atmosphere as fallout from nuclear testing or explosions, and from space or cosmic sources. Cesium-137 (from nuclear fallout) decays to barium-137, the highest contributor to fallout-induced gamma radiation (NCRP 1977). Beta radiation from the soil is a less penetrating form of radiation but has many contributing sources. Potassium- 40 , cesium-137, lead-214, and bismuth-214 are among the most common environmental beta emitters. Tritium is also a beta emitter but contributes little to the soil beta radiation because of the low energy of its emission and its low concentration in the atmosphere (NCRP 1977). Alpha radiation is also emitted by the soil but is not measurable more than a few centimeters from the ground surface. The majority of alpha emissions are attributable to radon-222 and radon-220 and their decay products (NCRP 1977). This contributes to what is called background exposure to radiation (ATSDR 1989).

The general health effects of radiation can be divided into stochastic (related to dose) and nonstochastic (not related to dose) effects. The risk of development of cancer from exposure to radiation is a stochastic effect. Examples of nonstochastic effects include acute radiation syndrome and cataract formation, which occur only at high levels of exposures (Killough and Eckerman 1983).

Radiation can damage cells in different ways. It can cause damage to DNA within the cell, and the cell either may not be able to recover from this type of damage or may survive but function abnormally. If an abnormally functioning cell divides and reproduces, a tumor or mutation in the tissue may develop. The rapidly dividing cells that line the intestines and stomach and the blood cells in bone marrow are extremely sensitive to this damage. Organ damage results from the damage caused to the individual cells. This type of damage has been reported with doses of 10 to 500 rads ( 0.1 to 5.0 gray, in SI units). Acute radiation sickness is seen only after doses of $>50$ rads ( 0.5 gray) which is a dose rate usually achieved only in a nuclear accident (ATSDR 1989).

When the radiation-damaged cells are reproductive cells, genetic damage can occur in the offspring of the person exposed. The developing fetus is especially sensitive to radiation. The type of malformation that may occur is related to the stage of fetal development and the cells that are differentiating at the time of exposure. Radiation damage to children exposed in the womb is related to the dose the pregnant mother receives. Mental retardation is a possible effect of fetal radiation exposure (ATSDR 1989). 
The most widely studied population that has had known exposure to radiation is the atomic bomb survivors of Hiroshima and Nagasaki, Japan. Data indicate an increase in the rate of leukemia and cancers in this population. However, the rate at which cancer incidence is significantly affected by low radiation exposures, such as results of exposure to natural background and industrially contaminated sites, is still undergoing study and is uncertain (Hammonds and Hoffman 1992). In studies conducted to determine the rate of cancer and leukemia increase, as well as genetic defects, several radionuclides must be considered. A brief physical description, an industrial profile, and radiation emission information pertaining to the primary radionuclides, which are major contributors to background risk (see Sect. 7.6), are given in Sects. 7.5.2.1 through 7.5.2.4.

\subsubsection{Cesium-137}

Cesium occurs in nature as cesium-133 in the aluminosilicates, pollucite (a hydrated silicate of aluminum and cesium) and lepidolite; in the borate, rhodizite; and in other sources (Budavari et al. 1989, Klaassen et al. 1986). Cesium-137 is one of the artificial isotopes of cesium and is one of the principal radionuclides present in reactor effluents under normal operations. Cesium-137 may also be produced in nuclear and thermonuclear explosions, through which it would be a primary contributor to human exposure through fallout radiation, assimilation through the food chain, or beta dose to the skin (Budavari et al. 1989, Klaasen et al. 1986). In addition, cesium-137, along with strontium-90, is one of the most important fission products that was widely distributed in near-surface soils because of historical weapons testing. Measurable concentrations still exist in the soil today, almost exclusively in the upper $15 \mathrm{~cm}$ of soil; these concentrations decrease roughly exponentially with depth.

Cesium-137 may also have important roles in medical treatments (a teletherapy source or intercavitary or interstitial radiation source in treatment of malignancies) and as an encapsulated energy source (Budavari et al. 1989, Casarett 1968). Cesium-137 decays to and reaches radioactive equilibrium with its daughter product, barium-137m (Budavari et al. 1989, Casarett 1968). Barium-137m is a very short-lived gamma emitter that can contribute to external gamma exposure (Budavari et al. 1989).

\subsubsection{Potassium-40}

Potassium is a silvery white, light, very soft, chemically reactive member of the alkali metal family. Potassium is used in manufacturing certain types of soap and glass, and potassium nitrate (saltpeter) is used in matches and explosives. Potassium -40 is a naturally occurring radioisotope of potassium and is found in the earth's crust in measurable quantities. It is a major constituent of both igneous and sedimentary rocks, especially granite ( $>30 \mathrm{pCi} / \mathrm{g})$ and shale $(22 \mathrm{pCi} / \mathrm{g})$, respectively. Potassium -40 has a half-life of 1.3 billion years and is used in radioactive dating of rocks. In addition, potassium- 40 is one of 17 naturally occurring radioisotopes that decay to stable isotopes.

Potassium- 40 is always present in the body; it decays with emission of beta particles and a gamma ray, but the rate of decay is so relatively slow that it requires a whole body count to detect. The rate is considered slow, but potassium-40 expels more than a million beta particles per minute in the average adult. Although potassium- 40 is present in the body, it is not found in fatty tissues. Therefore, a measurement of the total quantity of potassium- 40 
(along with other data) can be used to determine the relative proportions of lean and fatty tissue in the body (Glasstone 1967). The lifetime total cancer risk SF is greater when potassium- 40 is ingested than when it is inhaled. The external exposure is only half as great as the internal risk of ingestion.

\subsubsection{Radium-226}

Radium is a naturally occurring radioactive element that exists in several isotopic forms. The radium isotopes are formed from the decay of uranium and thorium. Radium-226 is formed from uranium-238 and uranium-234, and radium-226 has the longest half-life of the radium isotopes (radium-228, radium-224, and radium-223). In general, the activity concentration of radium-226 measured in most soils and rocks is comparable to those of uranium-238 and uranium-234, suggesting that radium does not tend to migrate from either of its uranium precursors under stable conditions. Radium-226 is primarily an alpha and gamma emitter.

Radium has been used as a component of luminous paints for clock and instrument dials. It has also been used in the treatment of cancer, in radiography, and in research. Radium is released into the environment in coal fly ash and in uranium mining and processing wastes. The background level of radium in industrial regions in soil is about $8.1 \mathrm{pCi} / \mathrm{g}$. Clays and soil components generally retard the movement of radium in the environment, but acidic processing wastes can enhance its movement. Radium may bioaccumulate in plants and animals, and exposure through the food chain is possible.

Many environmental problems can be directly attributed to the decay products or daughters of radium. The primary daughters are isotopes of radon-a colorless, odorless, radioactive gas. Radon gas can infiltrate basements and water systems, resulting in significant exposure via inhalation pathways.

\subsubsection{Thorium-228}

Thorium is a naturally occurring radioactive element commonly found in the earth's crust. It is also produced from monazite, a by-product of mineral sand mined for titanium and zirconium. Much of the thorium mined in the United States is exported. Thorium is used for fuel for nuclear reactors, mantles for camping lanterns, welding electrodes, aerospace alloys, high temperature materials, special lighting fixtures, and nuclear weapons. Thorium is also introduced into the environment from the use of phosphate fertilizers.

Natural thorium is primarily thorium-232, which has a slow decay process. The decay series for thorium-232 proceeds through radium-228 to thorium-228, ending in lead-208, a stable isotope. Thorium-228, as do all thorium isotopes, emits alpha, beta, and/or gamma radiation on decay. However, the major radiation energies of concern from thorium- 228 are alpha and gamma emissions.

\subsubsection{Polynuclear Aromatic Hydrocarbons}

PAHs share a remarkable stability and, because of this stability, they have been found to be quite useful in industry (solvents, lubricants, dyes, etc). Combustion produces a wide variety of aromatic compounds. Ideally, when hydrocarbon (fossil) fuels are burned, carbon 
dioxide and water are the resulting combustion products. However, complete combustion is rare, hence, combustion results in the production of soot and smoke. Soot and smoke contain a number of polycyclic aromatic hydrocarbons (PAHs), some of which are highly toxic and most of which are toxic in large enough doses. Soot from the exhaust of diesel engines contains small PAHs such as benzene, naphthalene, and phenanthrene and larger PAHs such as coronene and ovalene. Soot is believed to be an aggregate of large molecules that have many benzene rings, PAHs included (Aihara 1992).

The degree of carcinogenicity in humans exposed to PAHs, directly corresponds to the size of the PAH molecule. Data prove that many PAHs are carcinogenic, as in the case of benzo(a)pyrene, which is a component in coal tar, soot, and tobacco. Researchers have proven the damage cigarette smoking can cause to the lungs over prolonged periods, and tumors have been discovered in occupational workers such as those who fuel coal-fired furnaces and chimney sweeps (Aihara 1992). However, the acute, chronic and subchronic effects of PAHs on humans is not well documented, and complete data are unavailable. One reason for the lack of valuable information regarding the toxic effects of PAHs is the difficulty in determining the source of such illnesses as lung cancer, liver cancer, skin cancer, and various other ailments. Studies of aromatic compounds show that aromatic compounds also exist naturally in space; carbonaceous chondrite meteorites, for example, are known to contain many kinds of aromatic compounds (Aihara 1973). Therefore, the source of such ailments as lung or liver cancer is difficult to determine because researchers are unsure how large an amount of exposure to aromatics an average person will acquire in a lifetime. However, general ailments such as headaches, dizziness, nausea, and malaise have been attributed to automobile exhaust inhalation (Aihara 1992).

\subsection{RISK CHARACTERIZATION}

The purpose of the risk characterization is to integrate and summarize the information presented in the toxicity and exposure assessments. Potential carcinogenic effects are characterized by estimating the probability that an individual will develop cancer over a lifetime from projected intakes (and exposure) and chemical-specific dose-response data (i.e., SFs). Potential noncarcinogenic (systemic) effects are characterized by comparing projected intakes of contaminants to toxicity values (i.e., RfDs). The SFs and RfDs used in this BSCP study are listed in Tables 7.6 through 7.9. The results of this background risk analysis for the hypothetical on-site residential exposure scenario (discussed in Sect 7.4) are summarized in this section.

Note that the inorganic analytes listed in the tables in this Sect. 7 include chromium VI, mercury salts, and nickel salts. The analytical laboratory reported detected concentrations for the total chromium, mercury, and nickel found. Because (i) the concentrations were reported in this form (i.e., no distinction between valences and speciation); (ii) the percent gastrointestinal (\%GI) absorption toxicity values are known for chromium VI, mercury salts, and nickel salts; and (iii) the RfDs. are known for mercury and nickel, it was necessary to assess all types of these analytes, which included the most toxic form of the metals. The RfDs for mercury and nickel salts were assumed to be the same as those listed for metallic mercury and nickel. The total pathway hazard indices include only one HI value for each pair (i.e., chromium and chromium VI, mercury and mercury salts, and nickel and nickel salts); the most conservative $\mathrm{HI}$ values were included in the total pathway $\mathrm{HI}$ (i.e., HI for chromium VI, 
mercury salts, and nickel salts were included in the pathway totals) to ensure that exposure is not underestimated.

Also note that the CDIs, background risks, and background hazard indices listed in the tables in Sect. 7 are shown with two significant figures. In many cases, SFs, RfDs and/or intake parameters are given with only one significant figure; therefore, only one significant figure should be reported for the calculated risks and HI values. However, for clarity and for comparison (of the calculated values) in this section of the BSCP, two significant figures are given.

\subsubsection{EPA Guidance-Carcinogens}

For carcinogens, risks are estimated as the incremental probability of an individual developing cancer over a lifetime as a result of exposure to the carcinogen (i.e., the term "incremental" refers to excess individual lifetime cancer risk). Cancer risk from exposure to contamination is expressed as excess cancer risk, that is, cancer incurred in addition to normally expected rates of cancer development. An excess cancer risk of 1.0e-06 indicates one person in one million is predicted to incur cancer from exposure to this contamination level, over a 70 year lifetime. Excess cancer risks falling between $1.0 \mathrm{e}-06$ and $1.0 \mathrm{e}-04$ are within the range of concern, and cancer risks above 1.0e-04 are considered unacceptable by the EPA (1989c). The excess cancer risk is determined by the application of an SF, which is a chemical-specific value based on carcinogenic dose-response data. Because the SFs are the upper $95 \%$ confidence limit on the probability of a carcinogenic response, the carcinogenic risk estimate represents an upper confidence bound estimate. Therefore, there is only a 5\% probability that the actual risk will be higher than the estimate presented, and the actual risk may well be less than the estimate.

Slope factors used in the evaluation of risk from exposure to constituents in ORR background soils are listed in Tables 7.6,7.7 and 7.8. Slope factors are not currently available for all background constituents, and several constituents are not indicated by epidemiological studies to be carcinogenic; consequently, these do not have SFs. Furthermore, SFs are not available for several background constituents because their carcinogenicity has not been determined. These constituents may contribute to carcinogenic effects from exposure to the soil, but their effect cannot be quantified at the present time.

\subsubsection{EPA Guidance-Noncarcinogens}

Noncarcinogenic effects are evaluated by comparing an exposure experienced over a specified time period (e.g., 30 years) with an $\mathrm{RfD}$ derived for a similar exposure period. The RfDs available for the constituents present in the background soil are given in Tables 7.7 and 7.9. To evaluate the noncarcinogenic effects of exposure to soil, the hazard quotient (the ratio of the exposure dose to the $\mathrm{RfD}$ ) is calculated for each constituent. This noncarcinogenic hazard index (HI) assumes that, below a given level of exposure (i.e., the $\mathrm{RfD}$ ), even sensitive populations are unlikely to experience adverse health effects. If the exposure level (intake) exceeds this threshold [i.e., if intake/RfD exceeds one (1.0)], there may be concern for potential systemic health effects; the level of concern does not necessarily increase linearly as the hazard index approaches or exceeds unity. In other words, the HI is not a percentage or probability. 
Table 7.6. Toxicity information for carcinogenic potential analytes of concern on the Oak Ridge Reservation

\begin{tabular}{|c|c|c|c|c|c|}
\hline Chemical & $\begin{array}{l}\text { Oral slope } \\
\text { factor }\end{array}$ & $\begin{array}{l}\text { EPA } \\
\text { class }\end{array}$ & $\begin{array}{l}\text { ICRP lung } \\
\text { class }^{c}\end{array}$ & $\begin{array}{l}\text { Type of } \\
\text { cancer }\end{array}$ & $\begin{array}{l}\text { Slope factor basis/ } \\
\text { slope factor source }\end{array}$ \\
\hline \multicolumn{6}{|c|}{ Inorganics (mg/kg-day) $)^{-1}$} \\
\hline Antimony & ND & ND & & ND & IRIS/HEAST \\
\hline Arsenic & ND & $A$ & & Skin & Water/IRIS/HEAST \\
\hline Barium & ND & ND & & ND & IRIS/HEAST \\
\hline \multirow[t]{2}{*}{ Beryllium } & $4.3 \mathrm{E}+00^{d}$ & $\mathrm{~B} 2$ & & Tumors & Intratracheal/IRIS/ \\
\hline & $8.6 \mathrm{E}+01^{e}$ & & & & HEAST \\
\hline Boron & ND & ND & & ND & IRIS/HEAST \\
\hline Chromium & ND & ND & & ND & ND \\
\hline Chromium (VI) & ND & $\mathbf{A}$ & & Tumors & IRIS/HEAST \\
\hline Cyanide & ND & $\mathrm{D}$ & & ND & IRIS/HEAST \\
\hline Manganese (diet) & ND & D & & ND & IRIS/HEAST \\
\hline Mercury & ND & $\mathrm{D}$ & & ND & IRIS/HEAST \\
\hline Mercury (salts) & ND & ND & & ND. & ND \\
\hline Molybdenum & ND & ND & & ND & IRIS/HEAST \\
\hline Nickel & ND & ND & & ND & IRIS/HEAST \\
\hline Nickel (salts) & ND & $\mathrm{ND}$ & & ND & ND \\
\hline Selenium & ND & $\mathrm{D}$ & & ND & IRIS/HEAST \\
\hline Strontium & ND & ND & & ND & IRIS/HEAST \\
\hline Vanadium & ND & $\mathrm{ND}$ & & ND & IRIS/HEAST \\
\hline \multirow[t]{2}{*}{ Zinc } & ND & D & & ND & IRIS/HEAST \\
\hline & \multicolumn{3}{|c|}{ Radionuclides $(p C)^{-1}$} & $\cdot$ & \\
\hline Cesium-137 & $28 \mathrm{E}-11$ & $A$ & D & Various & HEAST \\
\hline Curium-247 & $2.2 \mathrm{E}-10$ & A & W & ND & HEAST \\
\hline Neptunium-237 & $2.2 \mathrm{E}-10$ & A & W & ND & HEAST \\
\hline Plutonium-238 & $2.2 \mathrm{E}-10$ & $\mathbf{A}$ & $\mathbf{Y}$ & ND & HEAST \\
\hline Plutonium-239/240 & $2.3 E-10$ & $A$ & $\mathbf{Y}$ & ND & HEAST \\
\hline Potassium- 40 & $1.1 \mathrm{E}-11$ & $A$ & $\mathrm{D}$ & Various & HEAST \\
\hline Radium-226 & $1.2 \mathrm{E}-10$ & $A$ & $w$ & Various & HEAST \\
\hline Strontium-90 & $3.6 \mathrm{E}-11$ & $A$ & $\mathbf{D}$ & ND & HEAST \\
\hline Technetium-99 & $1.3 \mathrm{E}-12$ & $A$ & w & ND & HEAST \\
\hline Thorium-228 & $5.5 \mathrm{E}-11$ & $\mathbf{A}$ & $\mathbf{Y}$ & Various & HEAST \\
\hline Thorium-230 & $1.3 \mathrm{E}-11$ & $A$ & $\mathbf{Y}$ & Various & HEAST \\
\hline Thorium-232 & $1.2 \mathrm{E}-11$ & $\mathbf{A}$ & $\mathbf{Y}$ & Various & HEAST \\
\hline Thorium-234 & $4.0 \mathrm{E}-12$ & $\mathbf{A}$ & $\mathbf{Y}$ & Various & HEAST \\
\hline Tritium & $5.4 \mathrm{E}-14$ & $\mathbf{A}$ & $\mathbf{G}$ & ND & HEAST \\
\hline Uranium-233/2348 & $1.6 \mathrm{E}-11$ & A & $Y$ & Various & HEAST \\
\hline Uranium-235 & $1.6 \mathrm{E}-11$ & A & $\mathbf{Y}$ & Various & HEAST \\
\hline Uranium-236 & 1.5E-11 & A & $\mathrm{Y}$ & ND & HEAST \\
\hline Uranium-238 & $2.8 \mathrm{E}-11$ & A & $\mathrm{Y}$ & Various & HEAST \\
\hline
\end{tabular}

ND $=$ No data available or data inconclusive.

The radionuclide oral slope factors include contributions from daughter products.

bEPA Weight of Evidence Classification System for Carcinogenicity-used to characterize the extent to which available data indicate that an agent is a human carcinogen: $A=$ human carcinogen; $B 1$ or $B 2=$ probable carcinogen (B1 indicates that limited data on humans are available and B2 indicates sufficient evidence in animals and inadequate or no evidence in humans); - $C$ = possible human carcinogen; $D=$ not classifiable as to human carcinogenicity, $E=$ evidence of noncarcinogenicity for humans. Lung clearance classification recommended by the International Commission on Radiological Protection: $Y=$ year, $W=$ week; $\mathrm{D}=$ day; $\mathrm{G}=$ gas.

Based on Integrated Risk Information System (IRIS) (EPA 1993a) or Health Effects Assessment Summary Tables (HEAST) (Radionuclides - EPA 1992a; Inorganics - EPA 1993b); oral (ingestion) slope factors. The oral SF for beryilium can be found in IRIS (EPA 1993a).

The absorbed slope factor $(8.6 \mathrm{E}+01)$ is used for the dermal contact pathway calculations; the absorbed SF = (SF\%GI); the \% gastrointestinal absorption (\%GI) is $5 \%$ for beryllium (Owen 1990).

fThe most conservative oral slope factor (Pu-239 versus Pu-240) was used for the Pu-239/240 results presented in the BSCP study.

SThe most conservative oral slope factor (U-233 versus U-234) was used for the U-233/234 results presented in the BSCP study. 
Table 7.7. Toxicity information for polycyclic aromatic hydrocarbon analytes of potential concern on the Oak Ridge Reservation

\begin{tabular}{lcccc}
\hline Organic Chemical & $\begin{array}{c}\text { Oral slope } \\
\text { factor } \\
\left(\mathrm{mg} / \mathrm{kg}^{a}-\mathrm{d}\right)^{-1}\end{array}$ & $\mathrm{EPA} \mathrm{class}{ }^{b}$ & $\begin{array}{c}\text { Chronic } \\
\text { oral RfD } \\
(\mathrm{mg} / \mathrm{kg}-\mathrm{d})\end{array}$ & $\begin{array}{c}\text { Subchronic } \\
\text { oral RfD } \\
(\mathrm{mg} / \mathrm{kg}-\mathrm{d})\end{array}$ \\
\hline Acenaphthene & $\mathrm{ND}$ & $\mathrm{ND}$ & $6.0 \mathrm{E}-02^{c}$ & $6.0 \mathrm{E}-01^{d}$ \\
Anthracene & $\mathrm{ND}$ & $\mathrm{D}$ & $3.0 \mathrm{E}-01^{c}$ & $3.0 \mathrm{E}+00^{d}$ \\
Benzo(a)anthracene & $7.3 \mathrm{E}-01$ & $\mathrm{ND}$ & $\mathrm{ND}$ & $\mathrm{ND}$ \\
Benzo(a)pyrene & $7.3 \mathrm{E}+00^{c}$ & $\mathrm{~B} 2$ & $\mathrm{ND}$ & $\mathrm{ND}$ \\
Benzo(b)fluoranthene & $7.3 \mathrm{E}-01$ & $\mathrm{ND}$ & $\mathrm{ND}$ & $\mathrm{ND}$ \\
Benzo(g,h,i)perylene & $7.3 \mathrm{E}+00$ & $\mathrm{ND}$ & $\mathrm{ND}$ & $\mathrm{ND}$ \\
Benzo(k)fluoranthene & $7.3 \mathrm{E}-01$ & $\mathrm{ND}$ & $\mathrm{ND}$ & $\mathrm{ND}$ \\
Chrysene & $7.3 \mathrm{E}-02$ & $\mathrm{ND}$ & $\mathrm{ND}$ & $\mathrm{ND}$ \\
Dibenz(a,h)anthracene & $9.2 \mathrm{E}-02^{c}$ & & $\mathrm{ND}$ & $\mathrm{ND}$ \\
Fluoranthene & $7.3 \mathrm{E}+00$ & $\mathrm{ND}$ & $\mathrm{ND}$ & $4.0 \mathrm{E}-01^{d}$ \\
Fluorene & $\mathrm{ND}$ & $\mathrm{D}$ & $4.0 \mathrm{E}-02^{c}$ & $4.0 \mathrm{E}-01^{d}$ \\
Indeno(1,2,3-cd)pyrene & $\mathrm{ND}$ & $\mathrm{D}$ & $4.0 \mathrm{E}-02^{c}$ & $\mathrm{ND}$ \\
Naphthalene & $7.3 \mathrm{E}-01$ & $\mathrm{ND}$ & $\mathrm{ND}$ & $4.0 \mathrm{E}-02^{d}$ \\
Phenanthrene & $\mathrm{ND}$ & $\mathrm{D}$ & $4.0 \mathrm{E}-02^{d}$ & $\mathrm{ND}$ \\
Pyrene & $7.3 \mathrm{E}+00$ & $\mathrm{ND}$ & $\mathrm{ND}$ & $3.0 \mathrm{E}-01^{d}$ \\
\hline & $\mathrm{ND}$ & $\mathrm{D}$ & $3.0 \mathrm{E}-02^{c}$ & \\
\hline
\end{tabular}

$\mathrm{ND}=$ No data available or data inconclusive.

${ }^{a}$ The oral slope factors (SFs) for these chemicals are derived by multiplying the benzo(a) pyrene oral SF $(7.3 E+00)^{c}$ by the chemical specific toxicity equivalency factor (TEF) (EPA New Interim Region IV Guidance, Feb. 1992). The TEF for benzo(a)pyrene, benzo(g,h,i)perylene, dibenz(a,h)anthracene, and phenanthrene is 1.0 ; the TEF for chrysene is 0.01 ; the TEF for benzo(a)anthracene, benzo(b)fluoranthene, benzo(k)fluoranthene, and indeno(1,2,3-cd)pyrene is 0.1 .

${ }^{b}$ EPA Weight of Evidence Classification System for Carcinogenicity is used to characterize the extent to which available data indicate that an agent is a human carcinogen: $A=$ human carcinogen; $B 1$ or $B 2=$ probable carcinogen (B1 indicates that limited data on humans are available and B2 indicates sufficient evidence in animals and inadequate or no evidence in humans); $C=$ possible human carcinogen; $D=$ not classifiable as to human carcinogenicity; $E=$ evidence of noncarcinogenicity for humans.

'Based on Integrated Risk Information System (IRIS) (EPA 1993a).

${ }^{d}$ Based on Health Effects Assessment Summary Tables (HEAST) (EPA 1993b).

The absorbed SF (9.2E-02) is used for the dermal contact pathway calculations; the absorbed SF = (SF/\%GI); the \% gastrointestinal absorption (\%GD) is 79\% for chrysene (EPA 1982). 
Table 7.8. Toxicity information for external exposure to potential radionuclides of concern on the Oak Ridge Reservation

\begin{tabular}{|c|c|c|c|}
\hline Chemical & $\begin{array}{l}\text { External exposure } \\
\text { slope factor }{ }^{\beta b}\end{array}$ & $\begin{array}{l}\text { ICRP } \\
\text { lung } \\
\text { class }^{c}\end{array}$ & $\begin{array}{c}\text { Type } \\
\text { of } \\
\text { cancer }\end{array}$ \\
\hline \multicolumn{4}{|c|}{ Radionuclides (g/pCi-yr) } \\
\hline Cesium-137 & $2.0 \mathrm{E}-06$ & $\mathrm{D}$ & Various \\
\hline Curium-247 & $9.2 \mathrm{E}-07$ & w & ND \\
\hline Neptunium-237 & 4.3E-07 & w & ND \\
\hline Plutonium-238 & $2.8 \mathrm{E}-11$ & $\mathbf{Y}$ & ND \\
\hline Plutonium-239/240 & 2.7E-11 & $\mathbf{Y}$ & ND \\
\hline Potassium-40 & $5.4 \mathrm{E}-07$ & D & Various \\
\hline Radium-226 & $6.0 \mathrm{E}-06$ & W & Various \\
\hline Strontium-90 & $0.0 \mathrm{E}+00$ & D & ND \\
\hline Technetium-99 & $6.0 \mathrm{E}-13$ & W & ND \\
\hline Thorium-228 & $5.6 \mathrm{E}-06$ & $\mathbf{Y}$ & Various \\
\hline Thorium-230 & $5.4 \mathrm{E}-11$ & $\mathrm{Y}$ & Various \\
\hline Thorium-232 & $2.6 \mathrm{E}-11$ & $\mathbf{Y}$ & Various \\
\hline Thorium-234 & $3.5 \mathrm{E}-09$ & $\mathbf{Y}$ & Various \\
\hline Tritium & $0.0 E+\infty 0$ & G & ND \\
\hline Uranium-233/234e & $4.2 \mathrm{E}-11$ & $\mathbf{Y}$ & Various \\
\hline Uranium-235 & 2.4E-07 & $\mathbf{Y}$ & Various \\
\hline Uranium-236 & $2.4 \mathrm{E}-11$ & $\mathbf{Y}$ & ND \\
\hline Uranium-238 & $3.6 \mathrm{E}-08$ & $\mathbf{Y}$ & Various \\
\hline
\end{tabular}

$\mathrm{ND}=$ No data available or data inconclusive.

${ }^{a}$ Based on Heast Effects Assessment Summary Tables (HEAST) (EPA 1992a).

${ }^{b}$ The radionuclide external exposure slope factors include contributions from daughter products.

'Lung clearance classification recommended by the International Commission on Radiological Protection (ICRP). $\mathrm{Y}=$ year, $\mathrm{W}=$ week; $\mathrm{D}=$ day; $\mathrm{G}=$ gas.

${ }^{d}$ The most conservative external exposure slope factor (Pu-239 versus $\mathrm{Pu}-240$ ) was used for the $\mathrm{Pu}-239 / 240$ results presented in this BSCP study.

The most conservative external exposure slope factor (U-233 versus U-234) was used for the U-233/234 results presented in this BSCP study. 
Table 7.9. Toxicity information for inorganic noncarcinogenic potential analytes of concern on the Oak Ridge Reservation

\begin{tabular}{|c|c|c|c|c|c|c|c|c|c|c|}
\hline Chemical & $\begin{array}{l}\text { Chronic } \\
\text { oral } \\
\mathrm{RfD}^{a, b}\end{array}$ & $\begin{array}{l}\text { Subchronic } \\
\text { oral RfD }\end{array}$ & $\begin{array}{c}\text { Confidence } \\
\text { level }\end{array}$ & $\begin{array}{c}\% \mathrm{GI} \\
\text { absorp. }\end{array}$ & $\begin{array}{l}\% \text { GI } \\
\text { source }\end{array}$ & $\begin{array}{l}\text { Chronic }^{d} \\
\text { oral } \mathrm{RfD} \\
\text { absorbed }\end{array}$ & $\begin{array}{l}\text { Subchronic }^{d} \\
\text { oral RfD } \\
\text { absorbed }\end{array}$ & $\begin{array}{c}\mathrm{RfD} \\
\text { basis } \\
\text { (vehicle) }\end{array}$ & Critical effect & $\begin{array}{l}\text { Uncertain fact.; } \\
\text { Modifying fact. }\end{array}$ \\
\hline \multicolumn{11}{|c|}{ Inorganics (mg/kg-day) } \\
\hline Antimony & $4.0 \mathrm{E}-04^{a}$ & $4.0 \mathrm{E}-04^{b}$ & Low & $\geq 15$ & $\begin{array}{l}\text { Friberg } \\
\text { et al } 1986\end{array}$ & $6.0 \mathrm{E}-05$ & $6.0 \mathrm{E}-05$ & oral & dehydration, death & $\begin{array}{l}\mathrm{UF}=1000 \\
\mathrm{MF}=1^{e}\end{array}$ \\
\hline Arsenic & $3.0 \mathrm{E}-04^{a}$ & $3.0 \mathrm{E}-04^{b}$ & High & $>90$ & ATSDR & $3.0 \mathrm{E}-04$ & $3.0 \mathrm{E}-04$ & oral & $\begin{array}{l}\text { keratosis, } \\
\text { hyperpigmentation, } \\
\text { tumors }\end{array}$ & $\begin{array}{l}\mathrm{UF}=100 \\
\mathrm{MF}=1\end{array}$ \\
\hline Barium & $7.0 \mathrm{E}-02^{a}$ & $7.0 \mathrm{E}-02^{b}$ & ND & 10 & Owen 1990 & $7.0 \mathrm{E}-03$ & $7.0 \mathrm{E}-03$ & $\begin{array}{l}\text { oral } \\
\text { (water) }\end{array}$ & $\begin{array}{l}\text { increased blood } \\
\text { pressure, } \\
\text { fetotoxicity }\end{array}$ & $\mathrm{UF}=3 ; \mathrm{MF}=1$ \\
\hline Beryllium & $5.0 \mathrm{E}-03^{a}$ & $5.0 \mathrm{E}-03^{b}$ & Low & 5 & ND & $2.5 \mathrm{E}-04$ & $2.5 \mathrm{E}-04$ & $\begin{array}{l}\text { intra- } \\
\text { tracheal }\end{array}$ & tumors & $\begin{array}{l}\mathrm{UF}=100 \\
\mathrm{MF}=1\end{array}$ \\
\hline Boron & $9.0 \mathrm{E}-02^{a}$ & $9.0 \mathrm{E}-02^{b}$ & ND & ND & -- & $9.0 \mathrm{E}-02$ & $9.0 \mathrm{E}-02$ & oral & $\begin{array}{l}\text { testicular lesions, } \\
\text { bronchitis }\end{array}$ & $\begin{array}{l}\mathrm{UF}=100 \\
\mathrm{MF}=1\end{array}$ \\
\hline Chromium VI & $5.0 \mathrm{E}-03^{a}$ & $2.0 \mathrm{E}-02^{b}$ & Low & 10.6 & ATSDR & 5.3E-04 & $2.0 \mathrm{E}-03$ & $\begin{array}{l}\text { oral } \\
\text { (water) }\end{array}$ & $\begin{array}{l}\text { hepatotoxicity, } \\
\text { nephrotoxicity, } \\
\text { dermatitis, tumors }\end{array}$ & $\begin{array}{l}\mathrm{UF}=500 \\
\mathrm{MF}=1\end{array}$ \\
\hline Cyanide & $2.0 \mathrm{E}-02^{a}$ & $2.0 \mathrm{E}-02^{b}$ & Medium & 40 & ATSDR & $8.0 \mathrm{E}-03$ & 8.0E-03 & oral & $\begin{array}{l}\text { decreased weight, } \\
\text { thyroid effects, } \\
\text { myelin degeneration }\end{array}$ & $\begin{array}{l}\mathrm{UF}=1000 \\
\mathrm{MF}=1\end{array}$ \\
\hline $\begin{array}{l}\text { Manganese } \\
\text { (diet) }\end{array}$ & $1.4 \mathrm{E}-01^{a}$ & $1.4 \mathrm{E}-01^{b}$ & Medium & 5 & ATSDR & $7.0 \mathrm{E}-03$ & $7.0 \mathrm{E}-03$ & $\begin{array}{l}\text { oral } \\
\text { (water) }\end{array}$ & $\begin{array}{l}\text { neural tissue } \\
\text { damage }\end{array}$ & $\mathrm{UF}=1 ; \mathrm{MF}=1$ \\
\hline Mercury & $3.0 \mathrm{E}-04^{b}$ & $3.0 \mathrm{E}-04^{b}$ & ND & ND & - & 3.0E-04 & $3.0 \mathrm{E}-04$ & oral & $\begin{array}{l}\text { kidney effects, } \\
\text { neurotoxicity }\end{array}$ & $\begin{array}{l}\mathrm{UF}=1000 \\
\mathrm{MF}=1\end{array}$ \\
\hline $\begin{array}{l}\text { Mercury } \\
\text { (salts) }\end{array}$ & $3.0 \mathrm{E}-04^{c}$ & $3.0 \mathrm{E}-04^{c}$ & ND & $<15$ & $\begin{array}{l}\text { Amdur } \\
\text { et al } 1991\end{array}$ & $4.5 \mathrm{E}-05$ & $4.5 \mathrm{E}-05$ & oral & $\begin{array}{l}\text { kidney effects, } \\
\text { neurotoxicity }\end{array}$ & $\begin{array}{l}\mathrm{UF}=1000 \\
\mathrm{MF}=1\end{array}$ \\
\hline
\end{tabular}


Table 7.9 (continued)

\begin{tabular}{|c|c|c|c|c|c|c|c|c|c|c|}
\hline Chemical & $\begin{array}{c}\text { Chronic } \\
\text { oral } \\
\operatorname{RfD}^{a, b} \\
\end{array}$ & $\begin{array}{l}\text { Subchronic } \\
\text { oral } \mathrm{RfD}^{a, b}\end{array}$ & $\begin{array}{c}\text { Confidence } \\
\text { level }\end{array}$ & $\begin{array}{l}\text { \%GI } \\
\text { absorp. }\end{array}$ & $\begin{array}{l}\text { \%GI } \\
\text { source }\end{array}$ & $\begin{array}{l}\text { Chronicd } \\
\text { oral RfD } \\
\text { absorbed }\end{array}$ & $\begin{array}{l}\text { Subchronic } \\
\text { oral RfD } \\
\text { absorbed }\end{array}$ & $\begin{array}{c}\mathrm{RfD} \\
\text { basis } \\
\text { (vehicle) } \\
\end{array}$ & Critical effect & $\begin{array}{l}\text { Uncertain fact.; } \\
\text { Modifying fact. }\end{array}$ \\
\hline \multicolumn{11}{|c|}{ Inorganics (mg/kg-day) } \\
\hline Molybdenum & $5.0 \mathrm{E}-03^{a}$ & $5.0 \mathrm{E}-03^{b}$ & Medium & ND & - & $5.0 \mathrm{E}-03$ & 5.E-03 & oral & $\begin{array}{l}\text { swelling, gout-like } \\
\text { symptoms }\end{array}$ & $\mathrm{UF}=3 ; \mathrm{MF}=0$ \\
\hline Nickel & $2.0 \mathrm{E}-02^{a}$ & $2.0 \mathrm{E}-02^{b}$ & ND & ND & - & $2.0 \mathrm{E}-02$ & $2.0 \mathrm{E}-02$ & oral & reduced weight & $\begin{array}{l}U F=100 ; \\
M F=3\end{array}$ \\
\hline Nickel (salts) & $2.0 \mathrm{E}-02^{c}$ & $2.0 \mathrm{E}-02^{c}$ & ND & 5 & Owen 1990 & $1.0 \mathrm{E}-03$ & $1.0 \mathrm{E}-03$ & oral & reduced weight & $\begin{array}{l}U F=100 \\
M F=3\end{array}$ \\
\hline Selenium & $5.0 \mathrm{E}-03^{a}$ & $5.0 \mathrm{E}-03^{b}$ & ND & 60 & Owen 1990 & $3.0 \mathrm{E}-03$ & $3.0 \mathrm{E}-03$ & oral & selenosis (clinical) & ND \\
\hline Strontium & $6 . \mathrm{E}-01^{a}$ & $6.0 \mathrm{E}-01^{b}$ & Medium & ND & - & $6.0 \mathrm{E}-01$ & $6.0 \mathrm{E}-01$ & $\begin{array}{l}\text { oral } \\
\text { (water) }\end{array}$ & $\begin{array}{l}\text { argyria, rachitic } \\
\text { changes }\end{array}$ & $\mathrm{UF}=2 ; \mathrm{MF}=1$ \\
\hline Vanadium & $7.0 \mathrm{E}-03^{b}$ & $7.0 \mathrm{E}-03^{b}$ & Low & 2.6 & EPA 1987c & $1.8 \mathrm{E}-04$ & $1.8 \mathrm{E}-04$ & $\begin{array}{l}\text { oral } \\
\text { (water) }\end{array}$ & ND & $\begin{array}{l}\mathrm{UF}=100 \\
\mathrm{MF}=1\end{array}$ \\
\hline Zinc & $3.0 \mathrm{E}-01^{a}$ & $3.0 \mathrm{E}-01^{b}$ & Medium & 50 & Owen 1990 & $1.5 \mathrm{E}-01$ & $1.5 \mathrm{E}-01$ & oral & $\begin{array}{l}\text { hyperactivity, } \\
\text { decreased body } \\
\text { weight, death at } \\
\text { high doses }\end{array}$ & $\begin{array}{l}\mathrm{UF}=100 \\
\mathrm{MF}=1\end{array}$ \\
\hline
\end{tabular}

ATSDR $=$ Agency for Taxic. Substances and Disease Registry, Public Healh Services (1987-1990); ND = No data avallable or data inconclustive; $G I=$ Gastrointestinal $(\% G I=$ percent gastrointestinal absorption); RJD = Reference Dose.

${ }^{a}$ Based on Integrated Risk Information System (RRIS) (EPA 1993a).

${ }^{b}$ Based on Health Effecls Assessment Stummary Tables (HEAST) (1993b).

'The chronic and subchronic RDD for mercury and nickel salts were assigned the same RDD value as mercury and nickel metals.

${ }^{d}$ The absorbed RDD = (RDD X \%GI absorption); the absorbed RDD is used for dermal pathway calculations. RJD absorbed $=$ RDD (i.e, \%GI = I00) when the \%GI absorption value is unknown (ND), and when the \%GI is greater than 80 .

${ }^{C}$ BELAS taxicity profiles. 
7.6.3 Background Risk and Hazard Index Comparisons Between the ORR and Anderson and Roane Counties

Background soil samples were collected from soils of the Dismal Gap and Copper Ridge formations in Anderson and Roane counties and on the ORR. In addition, soil samples were collected from the Chickamauga Formation at two different ORR locations only (Bethel Valley and at the K-25 Plant). For detected analytes for which a SF and/or a RfD are available, background risk and/or a $\mathrm{HI}$ were calculated for each analyte for each of the sampling areas. The results of these calculations are summarized in Tables 7.10 and 7.11. A comparison can be made between the calculated human health risk (and/or HI) for each analyte at the three sampling areas (ORR, AND and ROA). This comparison can be used to quantitatively and qualitatively assess the similarities and differences in carcinogenic risk and systemic effects posed by analytes found in background soil on and in the vicinity of $\mathrm{ORR}$. For the purpose of this comparison only, the total background cancer risk and $\mathrm{HI}$ are used [the risk to a child + the risk to an adult (Table 7.10), and the chronic HI for an adult + the subchronic $\mathrm{HI}$ for a child (Table 7.11)]. Adult- or child-specific risks would vary in a similar manner.

\subsubsection{Background risk comparisons between the ORR and Anderson and Roane counties}

From the values shown in Table 7.10, the similarities and differences can be seen between calculated background risk values for Roane County, Anderson County and the ORR, for the Dismal Gap Formation (Table 7.10a) and the Copper Ridge Formation (Table 7.10b). The values shown in Table 7.10c are for comparison of the risk from background constituents at the two ORR sampling locations (ORR-BV and ORR-K25) of the Chickamauga Formation.

From Table 7.10a (Dismal Gap Formation), cesium-137, radium-226, thorium-228, and thorium-234 show slight differences in risks between ORR, AND and ROA. Differences in risk of at least an order of magnitude for the ingestion of soil exposure pathway can be seen for these four analytes; take cesium-137 for example, since $3.9 \mathrm{e}-08>2.0 \mathrm{e}-08$ (where $5.0 \mathrm{e}-08$ minus $1.1 \mathrm{e}-08=3.9 \mathrm{e}-08), 3.9 \mathrm{e}-08$ is greater than two-tenths of $10.0 \mathrm{e}-08$. Beryllium is evaluated for the dermal exposure to soil pathway (Table 7.10a), and no significant differences in risks (between ORR, AND and ROA) are seen. For the external exposure to radionuclides pathway, risks for cesium-137, radium-226, thorium-230 and thorium-232 are slightly different between ORR, AND and ROA. The cumulative background risk, i.e., the sum of the risk from all analytes for all pathways are 6.4e-04, 9.4e-04 and 5.8e-04 for ORR, $A N D$ and $R O A$, respectively. The cumulative risks for ORR and ROA are very similar, while the risk for AND is approximately 1.5 times greater than those for ORR and ROA. The risks from the external exposure to radionuclides pathway are driving the cumulative background risks to be greater than 1.0e-04 (see Sect. 7.6.1 for EPA guidance summary).

From Table 7.10b (Copper Ridge Formation), beryllium, benzo(a)pyrene, chrysene, cesium-137, plutonium-238, plutonium-239/240, potassium-40, thorium-228, thorium-232, uranium-235, and uranium-238 show slight differences in risks between ORR, AND and ROA, for the ingestion of soil pathway. Benzo(a)anthracene, benzo(a)pyrene, benzo(b)fluoranthene, benzo(g,h,i)perylene, chrysene, and dibenz(a,h)anthracene also show slight differences in risks between ORR, AND and ROA, for the dermal exposure to soil pathway (Table 7.10b). The total pathway risks are, however, quite similar between ORR, 
AND and ROA. For the external exposure to radionuclides pathway, slight differences in risk can be seen between ORR, AND and ROA for cesium-137, neptunium-237, plutonium-238, plutonium-239/240, potassium-40, thorium-228, uranium-235, and uranium-238. The total pathway risks between ORR, AND and ROA are very similar.

Despite the differences listed above, the cumulative background risks (i.e., the sum of the risk from all analytes for all pathways) are very similar (7.0e-04, 6.4e-04 and 6.4e-04, for ORR, AND and ROA, respectively). Risks from the ingestion of PAHs in soil and the external exposure to radionuclides pathways are driving the cumulative background risks to be greater than $1.0 \mathrm{e}-04$.

From Table 7.10c (Chickamauga Formation), slight differences in risks between ORR-BV and ORR-K25), can be seen for uranium-235 for the external exposure to radionuclides pathway. The risks for both the ingestion of soil pathway (with the exception of benzo(a)pyrene) and the dermal exposure to soil pathway (with the exception of benzo(k)fluoranthene) are very similar for all of the constituents. The cumulative background risks (i.e., the sum of the risk from all analytes for all pathways) are $1.2 \mathrm{e}-03$ and $1.1 \mathrm{e}-03$ for ORR-BV and ORR-K25, respectively. The risks from the ingestion of PAHs in soil and external exposure to radionuclides are driving the cumulative background risks to be greater than 1.0e-04.

The information in Table 7.10 is illustrated graphically in Figure 7.1. The risk values reported in Table 7.10 were determined using the UCB95 analyte concentrations and are represented in the figure by the top line of each point. The total cumulative background risk (using the UCB95) for the Nolichucky and Chepultepec formations on the ORR are 7.6e-04 and 7.2e-04, respectively, and are also shown in Fig. 7.1.

These background risk estimates should be considered only in the context of comparison with site-related risk. The EPA action level of 1.0e-04 refers to risks related to hazardous waste sites. Therefore, the background risk results are not indicative of concerns or remedial actions that would be identified with similar potential risks from a contaminated site.

\subsection{Background risk comparisons using cesium-137 gamma screening data}

Because of the variation between the cesium-137 concentrations on the ORR and those in Anderson and Roane counties, some uncertainty exists concerning the background risk results for the cesium-137 data in the risk analysis discussed previously (see Sect. 5 for statistical analyses). The gamma scan method was used in this project to screen cesium-137 levels to find appropriate locations for soil sampling sites; data resulting from this method are not commonly used for analysis of radionuclides or for evaluating risk. However, because of the concern stated previously, the cesium-137 gamma screening data ( 0 to $5 \mathrm{~cm}$ depth) were evaluated in terms of background risk and will be discussed below; these screening data were addressed statistically in Sect. 5.8 and qualitatively in Sect. 6.3.

The residential ingestion of soil pathway for the Dismal Gap Formation on the ORR and in Anderson and Roane counties gives background risks (from the cesium-137 gamma screening data) of $6.0 \mathrm{e}-08,4.6 \mathrm{e}-08$, and $3.8 \mathrm{e}-08$, respectively (compare these values with those in Table 7.10a, where cesium-137 gamma spectroscopy data for the A horizon was used); these risks are below the EPA range of concern. The background risks (from the 
cesium-137 gamma screening data) from the residential external exposure pathway for the ORR, Anderson County, and Roane County are 8.2e-05, 6.3e-05, and 5.2e-05, respectively (compare with values in Table 7.10a); these risks are within the EPA range of concern (i.e., 1.0e-06 through 1.0e-04). For both exposure pathways (ingestion and external exposure), the risks from cesium-137 (based on gamma screening data) on the ORR are approximately 1.4 times greater than those for Anderson and Roane counties.

If the cesium-137 risk estimates listed above (i.e., using gamma screening data) were used in the calculation of total cumulative background cancer risks (i.e., in Table 7.10a), instead of the cesium-137 gamma spectroscopy data for horizon A, the background cancer risks for the ORR, Anderson County, and Roane County would be $6.5 \mathrm{e}-04,9.9 \mathrm{e}-04$, and $6.0 \mathrm{e}-04$, respectively. The cumulative risk estimates associated with using the gamma screening data are very similar to those listed in Table 7.10a, which were determined using the cesium-137 gamma spectroscopy data from the $\mathrm{A}$ horizon.

The residential ingestion of soil pathway for the Copper Ridge Formation on the ORR and in Anderson and Roane counties gives background risks (from the cesium-137 gamma screening data) of $4.3 \mathrm{e}-08,3.1 \mathrm{e}-08$, and $4.1 \mathrm{e}-08$, respectively (compare these values with those in Table 7.10b, where cesium-137 gamma spectroscopy data for horizon A was used); these risks are below the EPA range of concern. The background risks (from the cesium-137 gamma screening data) from the residential external exposure pathway for the ORR, Anderson County, and Roane County are 5.9e-05, 4.3e-05, and 5.6e-05, respectively (compare with values in Table 7.10b); these risks are within the EPA range of concern (i.e., 1.0e-06 through 1.0e-04). For both exposure pathways (ingestion and external exposure), the risk from cesium-137 (based on gamma screening data) on the ORR is approximately the same as that seen in Roane County and approximately 1.4 times greater than that seen in Anderson County.

If the cesium-137 risk estimates listed above (i.e. using the gamma screening data) were used in the calculation of total cumulative background cancer risks (i.e., in Table 7.10b) instead of the cesium-137 gamma spectroscopy data for the A horizon, the background cancer risks for the ORR, Anderson County, and Roane County would be 4.5e-04, 3.9e-04, and 4.2e-04, respectively. The cumulative risk estimates associated with using the gamma screening data are slightly lower than those listed in Table $7.10 \mathrm{~b}$, which were determined using the cesium-137 gamma spectroscopy data from the A horizon.

The residential ingestion of soil pathway for the Chickamauga Formation on the ORR, at the Bethel Valley and K-25 Plant sampling locations, gives background risks (using the cesium-137 gamma screening data) of 7.1e-08 and 6.3e-08, respectively (compare these values with those in Table 7.10c, where cesium-137 gamma spectroscopy data for the A horizon was used). The background risks (estimated using the cesium-137 gamma screening data) from the residential external exposure pathway for the CHI-BV and CHI-K25 sampling locations, are 9.7e-05 and 8.6e-05, respectively (compare with Table $7.10 \mathrm{c}$ ). 
Table 7.10a. Comparative background risk estimates (using UCB95 as concentration) ${ }^{a}$ from exposure to soil constituents from the Oak Ridge Reservation, Anderson County, and Roane County-Dismal Gap ${ }^{b}$

\begin{tabular}{lccc}
\hline Analyte & $\begin{array}{c}\text { Oak Ridge } \\
\text { Reservation }\end{array}$ & Anderson & Roane \\
& County & County \\
\hline
\end{tabular}

Exposure pathway: residential ingestion of soil

$\begin{array}{llll} & \text { Inorganics } & & \\ \text { Beryllium } & 6.4 \mathrm{E}-06 & 6.9 \mathrm{E}-06 & 5.3 \mathrm{E}-06\end{array}$

\section{Radionuclides}

Cesium-137

5.0E-08

1.1E-08

2.5E-08

Neptunium-237

$-$

3.1E-08

$-$

Plutonium-238

-

-

4.6E-08

Plutonium-239/240

1.1E-08

1.4E-08

-

Potassium-40

2.7E-07

3.2E-07

1.9E-07

Radium-226

1.7E-07

4.0E-07

$1.8 \mathrm{E}-07$

Strontium-90

6.3E-08

$1.2 \mathrm{E}-08$

Technetium-99

-

1.2E-07

9.8E-08

Thorium-230

7.0E-08

$1.8 \mathrm{E}-08$

1.5E-08

Thorium-232

1.1E-08

1.9E-08

1.7E-08

Thorium-234

1.2E-08

6.2E-09

8.5E-09

Tritium

3.0E-12

Uranium-233/234

2.3E-08

2.3E-08

Uranium-235

1.9E-09

2.3E-08

1.9E-09

Uranium-236

5.5E-10

1.5E-09

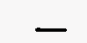

Uranium-238

4.0E-08

3.5E-08

3.9E-08

Total pathway risk

7.2E-06

7.9E-06

6.0E-06

Exposure pathway: residential dermal exposure to soil Inorganics

Beryllium

2.9E-06

3.1E-06

2.4E-06

Total pathway risk

2.9E-06

3.1E-06

2.4E-06 
$7-78$

Table 7.10a (continued)

\begin{tabular}{lccc}
\hline Analyte & $\begin{array}{c}\text { Oak Ridge } \\
\text { Reservation }\end{array}$ & $\begin{array}{c}\text { Anderson } \\
\text { County }\end{array}$ & Roane \\
& County \\
\hline
\end{tabular}

Exposure pathway: residential external exposure to radiation

Cesium-137

Neptunium-237

Plutonium-238

Plutonium-239/240

Potassium -40

Radium-226

Strontium-90

Technetium-99

Thorium-228

Thorium-230

Thorium-232

Thorium-234

Tritium

Uranium-233/234

Uranium-235

Uranium-236

Uranium-238

Total pathway risk

Radionuclides

$\begin{array}{ccc}6.8 \mathrm{E}-05 & 1.5 \mathrm{E}-05 & 3.4 \mathrm{E}-05 \\ - & 1.2 \mathrm{E}-06 & - \\ - & - & 1.1 \mathrm{E}-10 \\ 2.4 \mathrm{E}-11 & 3.1 \mathrm{E}-11 & - \\ 2.6 \mathrm{E}-04 & 3.0 \mathrm{E}-04 & 1.7 \mathrm{E}-04 \\ 1.6 \mathrm{E}-04 & 3.8 \mathrm{E}-04 & 1.7 \mathrm{E}-04 \\ 0.0 \mathrm{E}+00 & - & - \\ - & 1.1 \mathrm{E}-10 & - \\ 1.4 \mathrm{E}-04 & 2.3 \mathrm{E}-04 & 1.9 \mathrm{E}-04 \\ 8.8 \mathrm{E}-10 & 1.4 \mathrm{E}-09 & 1.2 \mathrm{E}-09 \\ 5.0 \mathrm{E}-10 & 7.7 \mathrm{E}-10 & 6.9 \mathrm{E}-10 \\ 1.6 \mathrm{E}-07 & 1.0 \mathrm{E}-07 & 1.4 \mathrm{E}-07 \\ 0.0 \mathrm{E}+00 & - & - \\ 1.1 \mathrm{E}-09 & 1.1 \mathrm{E}-09 & 1.1 \mathrm{E}-09 \\ 5.5 \mathrm{E}-07 & 4.2 \mathrm{E}-07 & 5.3 \mathrm{E}-07 \\ 1.7 \mathrm{E}-11 & - & - \\ 9.9 \mathrm{E}-07 & 8.6 \mathrm{E}-07 & 9.6 \mathrm{E}-07 \\ 6.3 \mathrm{E}-04 & 9.3 \mathrm{E}-04 & 5.7 \mathrm{E}-04\end{array}$

$$
\text { 6.8E-05 }
$$

6.3E-04

6.4E-04

9.4E-04

5.8E-04

${ }^{\circ} U$ CB95 = Upper 95\% confidence bound on the median, used as the representative analyte concentration.

bTotal cancer risk (risk to an adult plus risk to a child).

The sum of the risk from all analytes for all pathways. 
Table 7.10b. Comparative background risk estimates (using UCB95 as concentration) ${ }^{a}$ from exposure to soil constituents from the Oak Ridge Reservation, Anderson County, and Roane County-Copper Ridge ${ }^{b}$

\begin{tabular}{|c|c|c|c|}
\hline Analyte & $\begin{array}{l}\text { Oak Ridge } \\
\text { Reservation }\end{array}$ & $\begin{array}{c}\text { Anderson } \\
\text { County }\end{array}$ & $\begin{array}{l}\text { Roane } \\
\text { County }\end{array}$ \\
\hline \multicolumn{4}{|c|}{ Exposure pathway: residential ingestion of soil } \\
\hline \multicolumn{4}{|c|}{ Inorganics } \\
\hline Beryllium & 4.3E-06 & 6.1E-06 & $3.8 \mathrm{E}-06$ \\
\hline \multicolumn{4}{|c|}{ Organics } \\
\hline Benzo(a)anthracene & 3.1E-06 & 3.3E-06 & $4.9 \mathrm{E}-06$ \\
\hline Benzo(a)pyrene & 4.1E-05 & 2.6E-05 & $1.8 \mathrm{E}-05$ \\
\hline Benzo(b)fluoranthene & $3.6 \mathrm{E}-06$ & 4.3E-06 & $2.8 \mathrm{E}-06$ \\
\hline Benzo(g,h,i)perylene & 4.4E-05 & $3.5 \mathrm{E}-05$ & $2.9 \mathrm{E}-05$ \\
\hline Benzo(k)fluoranthene & 2.1E-06 & 2.1E-06 & $1.4 \mathrm{E}-06$ \\
\hline Chrysene & -6.2E-07 & 1.3E-06 & 3.5E-07 \\
\hline Dibenz(a,h)anthracene & 1.8E-05 & 3.6E-05 & $1.6 \mathrm{E}-05$ \\
\hline Indeno(1,2,3-cd)pyrene & - & $1.5 \mathrm{E}-05$ & 2.3E-05 \\
\hline Phenanthrene & $6.2 E-05$ & $5.5 \mathrm{E}-05$ & $4.8 \mathrm{E}-05$ \\
\hline \multicolumn{4}{|c|}{ Radionuclides } \\
\hline Cesium-137 & 7.0E-08 & 5.3E-08 & 7.9E-08 \\
\hline Neptunium-237 & $3.0 \mathrm{E}-08$ & 2.2E-08 & $1.9 \mathrm{E}-08$ \\
\hline Plutonium-238 & 1.1E-08 & $4.2 \mathrm{E}-08$ & - \\
\hline Plutonium-239/240 & 1.7E-08 & 一 & $4.6 \mathrm{E}-08$ \\
\hline Potassium-40 & $6.9 \mathrm{E}-08$ & 5.7E-08 & $4.6 \mathrm{E}-08$ \\
\hline Radium-226 & 2.7E-07 & $1.3 \mathrm{E}-07$ & 2.0E-07 \\
\hline Technetium-99 & - & $6.3 \mathrm{E}-09$ & - \\
\hline Thorium-228 & $3.4 \mathrm{E}-08$ & 8.3E-08 & $6.1 \mathrm{E}-08$ \\
\hline Thorium-230 & 2.2E-08 & 2.1E-08 & 1.7E-08 \\
\hline Thorium-232 & $1.2 \mathrm{E}-08$ & 1.4E-08 & $9.6 \mathrm{E}-09$ \\
\hline Thorium-234 & 9.3E-09 & - & - \\
\hline Tritium & $1.8 \mathrm{E}-12$ & - & - \\
\hline Uranium-233/234 & $3.5 E-08$ & 2.9E-08 & $3.0 \mathrm{E}-08$ \\
\hline Uranium-235 & 3.6E-09 & 2.1E-09 & $1.0 \mathrm{E}-09$ \\
\hline Uranium-236 & 3.3E-10 & - & - \\
\hline Uranium-238 & 5.4E-08 & 5.4E-08 & 3.3E-08 \\
\hline Total pathway risk & $1.8 \mathrm{E}-04$ & $1.8 \mathrm{E}-04$ & $1.5 \mathrm{E}-04$ \\
\hline
\end{tabular}


Table 7.10b (continued)

\begin{tabular}{lccc}
\hline Analyte & Oak Ridge & Anderson & Roane \\
& Reservation & County & County \\
\hline
\end{tabular}

Exposure pathway: residential dermal exposure to soil

$\begin{array}{lrcc}\text { Beryllium } & \begin{array}{r}\text { Inorganics } \\ 1.9 \mathrm{E}-06\end{array} & 2.7 \mathrm{E}-06 & 1.7 \mathrm{E}-06 \\ & & & \\ & \text { Organics } & & \\ \text { Benzo(a)anthracene } & 6.8 \mathrm{E}-07 & 7.3 \mathrm{E}-07 & 1.1 \mathrm{E}-06 \\ \text { Benzo(a)pyrene } & 9.0 \mathrm{E}-06 & 5.8 \mathrm{E}-06 & 4.0 \mathrm{E}-06 \\ \text { Benzo(b)fluoranthene } & 7.9 \mathrm{E}-07 & 9.6 \mathrm{E}-07 & 6.2 \mathrm{E}-07 \\ \text { Benzo(g,h,i)perylene } & 9.7 \mathrm{E}-06 & 7.8 \mathrm{E}-06 & 6.4 \mathrm{E}-06 \\ \text { Benzo(k)fluoranthene } & 4.6 \mathrm{E}-07 & 4.6 \mathrm{E}-07 & 3.1 \mathrm{E}-07 \\ \text { Chrysene } & 1.7 \mathrm{E}-07 & 3.7 \mathrm{E}-07 & 9.9 \mathrm{E}-08 \\ \text { Dibenz(a,h)anthracene } & 4.1 \mathrm{E}-06 & 8.0 \mathrm{E}-06 & 3.7 \mathrm{E}-06 \\ \text { Indeno(1,2,3-cd)pyrene } & - & 3.2 \mathrm{E}-06 & 5.2 \mathrm{E}-06 \\ \text { Phenanthrene } & 1.4 \mathrm{E}-05 & 1.2 \mathrm{E}-05 & 1.1 \mathrm{E}-05 \\ \text { Total pathway risk } & 4.1 \mathrm{E}-05 & 4.2 \mathrm{E}-05 & 3.4 \mathrm{E}-05\end{array}$

Exposure pathway: residential external exposure to radiation

\begin{tabular}{lccc} 
Cesium-137 & $9.5 \mathrm{E}-05$ & $7.2 \mathrm{E}-05$ & $1.1 \mathrm{E}-04$ \\
Neptunium-237 & $1.1 \mathrm{E}-06$ & $8.2 \mathrm{E}-07$ & $7.0 \mathrm{E}-07$ \\
Plutonium-238 & $2.6 \mathrm{E}-11$ & $1.0 \mathrm{E}-10$ & - \\
Plutonium-239/240 & $3.9 \mathrm{E}-11$ & - & $1.0 \mathrm{E}-10$ \\
Potassium-40 & $6.4 \mathrm{E}-05$ & $5.3 \mathrm{E}-05$ & $4.3 \mathrm{E}-05$ \\
Radium-226 & $2.6 \mathrm{E}-04$ & $1.2 \mathrm{E}-04$ & $1.9 \mathrm{E}-04$ \\
Technetium-99 & & $5.5 \mathrm{E}-11$ & \\
Thorium-228 & $6.5 \mathrm{E}-05$ & $1.6 \mathrm{E}-04$ & $1.2 \mathrm{E}-04$ \\
Thorium-230 & $1.7 \mathrm{E}-09$ & $1.7 \mathrm{E}-09$ & $1.3 \mathrm{E}-09$ \\
Thorium-232 & $4.9 \mathrm{E}-10$ & $5.7 \mathrm{E}-10$ & $3.9 \mathrm{E}-10$ \\
Thorium-234 & $1.5 \mathrm{E}-07$ & - & - \\
Tritium & $0.0 \mathrm{E}+00$ & - & - \\
Uranium-233/234 & $1.8 \mathrm{E}-09$ & $1.4 \mathrm{E}-09$ & $1.5 \mathrm{E}-09$ \\
Uranium-235 & $1.0 \mathrm{E}-06$ & $6.0 \mathrm{E}-07$ & $2.9 \mathrm{E}-07$ \\
Uranium-236 & $1.0 \mathrm{E}-11$ & - & - \\
Uranium-238 & $1.3 \mathrm{E}-06$ & $1.3 \mathrm{E}-06$ & $8.1 \mathrm{E}-07$ \\
Total pathway risk & $4.8 \mathrm{E}-04$ & $4.1 \mathrm{E}-04$ & $4.6 \mathrm{E}-04$ \\
Total Cumululative Risk & $7.0 \mathrm{E}-04$ & $6.4 \mathrm{E}-04$ & $6.4 \mathrm{E}-04$ \\
\hline
\end{tabular}

${ }^{a}$ UCB95 = Upper 95\% confidence bound on the median, used as the representative analyte concentration.

bTotal cancer risk (risk to an adult plus risk to a child).

The sum of the risk from all analytes for all pathways. 


\section{$7-81$}

Table 7.10c. Comparative background risk estimates (using UCB95 as concentration) ${ }^{a}$ from exposure to soil constituents from the Oak Ridge Reservation (Bethel Valley and K-25)-Chickamauga ${ }^{b}$

\begin{tabular}{lll}
\hline Analyte & Bethel & K-25 \\
\hline
\end{tabular}

Exposure pathway: residential ingestion of soil

Inorganics

Beryllium

8.4E-06

7.5E-06

Organics

Benzo(a)anthracene

Benzo(a)pyrene

Benzo(b)fluoranthene

Benzo(g,h,i)perylene

Benzo(k)fluoranthene

Chrysene

Dibenz(a,h)anthracene

Indeno(1,2,3-cd)pyrene

Phenanthrene
7.3E-06

5.6E-05

7.2E-06

5.9E-05

3.3E-06

8.9E-07

$1.6 \mathrm{E}-05$

1.9E-05

1.0E-04
8.6E-06

7.7E-05

7.0E-06

7.0E-05

4.3E-06

9.2E-07

1.8E-05

1.6E-05

1.1E-04

Radionuclides

Cesium-137

Neptunium-237

Plutonium-238

Plutonium-239/240

Potassium- 40

Radium-226

Technetium-99

Thorium-228

Thorium-230

Thorium-232

Tritium

Uranium-233/234

Uranium-235

Uranium-238

Total pathway risk
1.1E-07

-3.5E-08

3.6E-08

2.2E-08

2.5E-07

2.4E-07

3.3E-09

1.3E-07

2.1E-08

2.2E-08

1.1E-11

2.5E-08

2.7E-09

4.2E-08

2.8E-04
9.0E-08

3.3E-08

3.2E-08

1.4E-08

1.6E-07

2.0E-07

2.7E-09

1.1E-07

2.0E-08

1.9E-08

3.0E-08

1.7E-09

4.8E-08

3.2E-04 
Table 7.10c (continued)

\begin{tabular}{lll}
\hline Analyte & $\begin{array}{l}\text { Bethel } \\
\text { Valley }\end{array}$ & K-25 \\
\hline
\end{tabular}

Exposure pathway: residential dermal exposure to soil

Inorganics

Beryllium

Benzo(a)pyrene

Benzo(b)fluoranthene

Benzo(g,h,i)perylene

Benzo(k)fluoranthene

Chrysene

Dibenz(a,h)anthracene

Indeno(1,2,3-cd)pyrene

Phenanthrene

Total pathway risk
Benzo(a)anthracene

3.7E-06

3.4E-06

Organics

\section{Exposure pathway: residential external exposure to radiation}

\section{Radionuclides}

Cesium-137

Neptunium-237

Plutonium-238

Plutonium-239/240

Potassium-40

Radium-226

Technetium-99

Thorium-228

Thorium-230

Thorium-232

Tritium

Uranium-233/234

Uranium-235

Uranium-238

Total pathway risk

Total Cumulative Risk ${ }^{c}$
1.5E-04

1.3E-06

8.7E-11

5.0E-11

2.4E-04

2.3E-04

2.9E-11

2.5E-04

1.6E-09

9.1E-10

$0.0 \mathrm{E}+00$

1.2E-09

7.6E-07

$1.0 \mathrm{E}-06$

8.7E-04

1.2E-03
1.9E-06

1.7E-05

1.5E-06

1.6E-05

9.5E-07

2.6E-07

4.0E-06

3.5E-06

2.4E-05

7.2E-05

\section{}




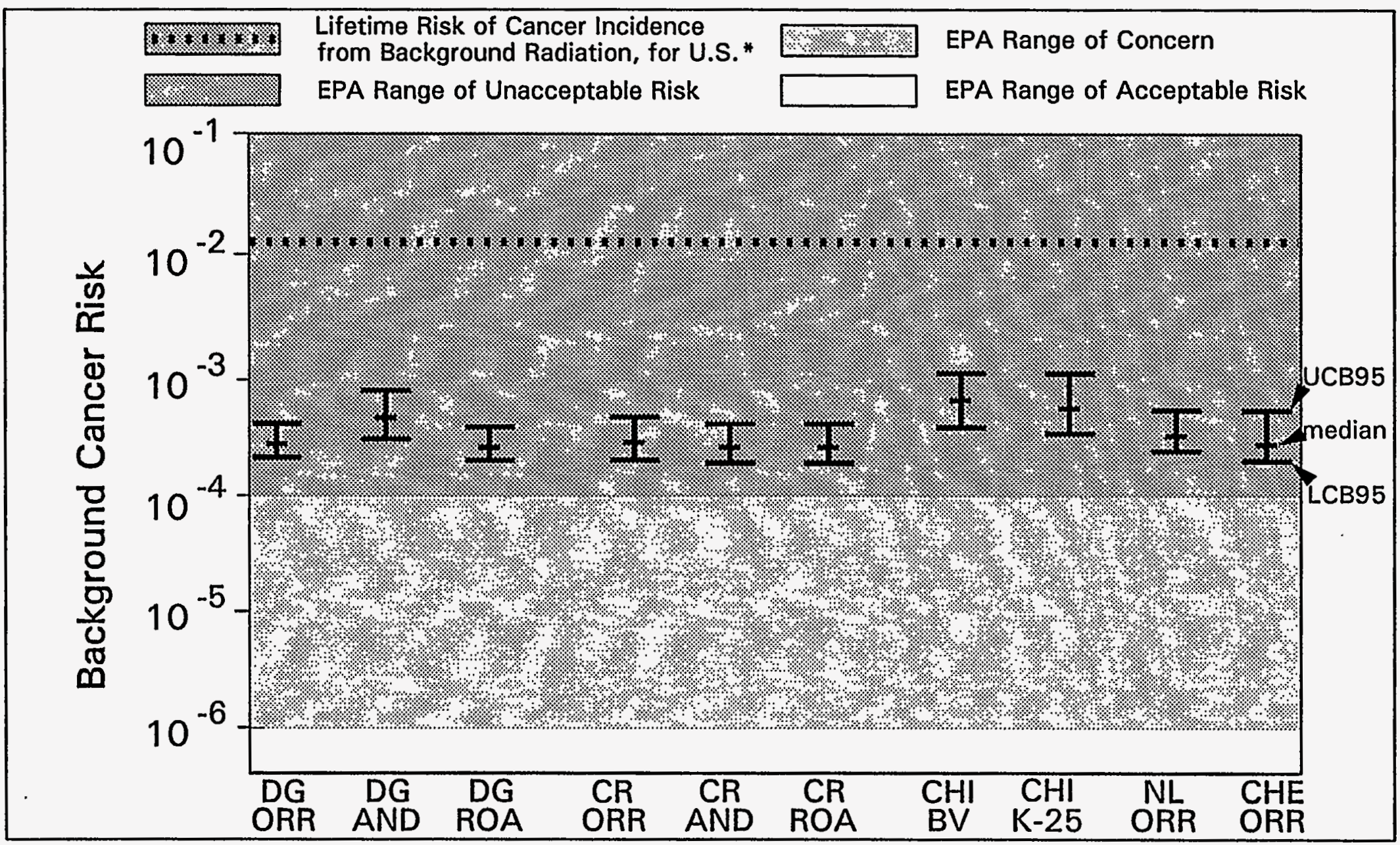

Fig. 7.1. Comparison of total background cancer risks calculated from soil samples from the Dismal Gap Formation in Anderson County, Dismal Gap in Roane County, Dismal Gap on the ORR, and the Nolichucky Formation on the ORR.

* Background Information Document for the Environmental Impact Statement for NESHAPS Radionuclides (EPA 19891). 
If the cesium-137 risk estimates listed above (i.e. using the gamma screening data) were used in the calculation of total cumulative background cancer risks (i.e., in Table 7.10c) instead of the cesium-137 gamma spectroscopy data for the A horizon, the background cancer risks for the CHI-BV and CHI-K25 would be $8.3 \mathrm{e}-04$ and $6.7 \mathrm{e}-04$, respectively. The cumulative risk estimates associated with using the gamma screening data are lower than those listed in Table 7.10b, which were determined using the cesium-137 gamma spectroscopy data from horizon $\mathrm{A}$.

\subsubsection{Background hazard index comparisons between the ORR and Anderson and Roane counties}

Shown in Table 7.11, are the HIs estimated for the background constituents found in Roane and Anderson counties and on the ORR, for the Dismal Gap Formation (Table 7.11a) and the Copper Ridge Formation (Table 7.11b). The HI estimates shown in Table 7.11c are for the background constituents found at the two ORR sampling locations (ORR-BV and ORR-K25) of the Chickamauga Formation. Because the systemic effects are only of concern if the hazard index exceeds a threshold of 1.0 and because the level of concern does not necessarily increase linearly as the hazard index approaches or exceeds unity (i.e., the HI is not a percentage or probability), a direct comparison of the HIs between the sampling areas is not applicable.

The information listed in Table 7.11a (Dismal Gap Formation) illustrates that the HIs for all background constituents are less than 1.0 for ORR, AND, and ROA. From Table 7.11b (Copper Ridge Formation), the HI for arsenic on the ORR (soil ingestion pathway) exceeds 1.0; all other background constituent HIs are less than unity for ORR, AND and ROA. The information listed in Table 7.11c (Chickamauga Formation), illustrates that the HIs for all background constituents are less than 1.0 for ORR-BV and ORR-K25.

In summary, for the Dismal Gap and Chickamauga formations, systemic effects resulting from ingestion of soil are not a concern for the background constituents concentrations. For the Copper Ridge Formation, systemic effects resulting for ingestion of background soil containing arsenic is a concern. For the Dismal Gap, Chickamauga, and Copper Ridge lithologies, systemic effects resulting from dermal contact with the soil are not a concern to human health, for the background constituents concentrations; even sensitive populations are unlikely to experience adverse systemic health effects when exposed to soil constituents at these background concentrations.

In Sects. 7.6.3 through 7.6.3.2, comparisons were made between the calculated risks or HII values (using the UCB95 as the analyte concentration) from background constituents in soils from the Dismal Gap, Copper Ridge and Chickamauga formations from three sampling areas (ORR, Roane County, and Anderson County). In summary, with some exceptions noted above, (i) the background risks (Tables 7.10) determined for individual analytes are quite similar for the three sampling areas, and (ii) all background HIs (Table 7.11), with the exception of the ORR-CR arsenic HI, are less than the systemic effect threshold of 1.0. In Sect. 7.6.4, carcinogenic and systemic effects will be evaluated quantitatively for soil samples that best represent the background analytes found on the ORR only (i.e., the A horizon soil samples taken from the ORR in the DG, NOL, CR, CHE, and CHI formations). 
Table 7.11a. Comparative background hazard index estimates (using UCB95 as concentration) ${ }^{a}$ from exposure to soil constituents from the Oak Ridge Reservation, Anderson County, and Roane County-Dismal Gap ${ }^{b}$

\begin{tabular}{lccl}
\hline Analyte & $\begin{array}{c}\text { Oak Ridge } \\
\text { Reservation }\end{array}$ & $\begin{array}{c}\text { Anderson } \\
\text { County }\end{array}$ & $\begin{array}{l}\text { Roane } \\
\text { County }\end{array}$ \\
\hline
\end{tabular}

Exposure pathway: residential ingestion of soil

Inorganics

$\begin{array}{lccc}\text { Antimony } & - & 3.3 \mathrm{E}-02 & - \\ \text { Arsenic } & 3.8 \mathrm{E}-01 & 2.6 \mathrm{E}-01 & 3.5 \mathrm{E}-01 \\ \text { Barium } & 2.6 \mathrm{E}-02 & 2.1 \mathrm{E}-02 & 2.3 \mathrm{E}-02 \\ \text { Beryllium } & 2.7 \mathrm{E}-03 & 2.9 \mathrm{E}-03 & 2.2 \mathrm{E}-03 \\ \text { Boron } & 3.6 \mathrm{E}-03 & - & 6.0 \mathrm{E}-03 \\ \text { Chromium VI } & 2.7 \mathrm{E}-02 & 3.0 \mathrm{E}-02 & 2.9 \mathrm{E}-02 \\ \text { Cyanide } & 2.0 \mathrm{E}-04 & 1.8 \mathrm{E}-04 & 4.1 \mathrm{E}-04 \\ \text { Manganese } & 1.4 \mathrm{E}-01 & 9.8 \mathrm{E}-02 & 2.4 \mathrm{E}-01 \\ \text { Mercury } & 1.7 \mathrm{E}-02 & 5.6 \mathrm{E}-03 & 8.7 \mathrm{E}-03 \\ \text { Mercury (salts) } & 1.7 \mathrm{E}-02 & 5.6 \mathrm{E}-03 & 8.7 \mathrm{E}-03 \\ \text { Nickel } & 2.1 \mathrm{E}-02 & 1.8 \mathrm{E}-02 & 1.5 \mathrm{E}-02 \\ \text { Nickel (salts) } & 2.1 \mathrm{E}-02 & 1.8 \mathrm{E}-02 & 1.5 \mathrm{E}-02 \\ \text { Selenium } & - & 2.7 \mathrm{E}-03 & 2.8 \mathrm{E}-03 \\ \text { Strontium } & 2.7 \mathrm{E}-04 & 2.0 \mathrm{E}-04 & 1.6 \mathrm{E}-04 \\ \text { Vanadium } & 7.9 \mathrm{E}-02 & 7.0 \mathrm{E}-02 & 7.5 \mathrm{E}-02 \\ \text { Zinc } & 3.0 \mathrm{E}-03 & 2.9 \mathrm{E}-03 & 2.4 \mathrm{E}-03 \\ & & & 7.6 \mathrm{E}-01 \\ \text { Total pathway hazard index } & 6.9 \mathrm{E}-01 & 5.5 \mathrm{E}-01 & \end{array}$

Exposure pathway: residential dermal exposure to soil Inorganics

\begin{tabular}{|c|c|c|c|}
\hline Antimony & - & 2.9E-03 & - \\
\hline Arsenic & $5.0 \mathrm{E}-03$ & $3.5 \mathrm{E}-03$ & 4.7E-03 \\
\hline Barium & $3.5 \mathrm{E}-03$ & $2.8 \mathrm{E}-03$ & $3.1 \mathrm{E}-03$ \\
\hline Beryllium & 7.2E-04 & 7.7E-04 & $6.0 \mathrm{E}-04$ \\
\hline Boron & $4.8 \mathrm{E}-05$ & - & $8.0 \mathrm{E}-05$ \\
\hline Chromium VI & 5.7E-03 & $6.5 \mathrm{E}-03$ & $6.3 \mathrm{E}-03$ \\
\hline
\end{tabular}


Table 7.11a (continued)

\begin{tabular}{lccc}
\hline Analyte & $\begin{array}{c}\text { Oak Ridge } \\
\text { Reservation }\end{array}$ & $\begin{array}{c}\text { Anderson } \\
\text { County }\end{array}$ & $\begin{array}{c}\text { Roane } \\
\text { County }\end{array}$ \\
\hline \multicolumn{4}{c}{ Exposure pathway: residential dermal exposure to soil (continued) } \\
Inorganics (continued) \\
Cyanide \\
Manganese & $6.6 \mathrm{E}-06$ & $6.0 \mathrm{E}-06$ & $1.4 \mathrm{E}-05$ \\
Mercury & $3.7 \mathrm{E}-02$ & $2.6 \mathrm{E}-02$ & $6.4 \mathrm{E}-02$ \\
Mercury (salts) & $2.3 \mathrm{E}-04$ & $7.4 \mathrm{E}-05$ & $1.2 \mathrm{E}-04$ \\
Nickel & $1.6 \mathrm{E}-03$ & $5.0 \mathrm{E}-04$ & $7.7 \mathrm{E}-04$ \\
Nickel (salts) & $2.8 \mathrm{E}-04$ & $2.4 \mathrm{E}-04$ & $2.0 \mathrm{E}-04$ \\
Selenium & $5.5 \mathrm{E}-03$ & $4.9 \mathrm{E}-03$ & $3.9 \mathrm{E}-03$ \\
Strontium & - & $5.9 \mathrm{E}-05$ & $6.3 \mathrm{E}-05$ \\
Vanadium & $3.6 \mathrm{E}-06$ & $2.7 \mathrm{E}-06$ & $2.1 \mathrm{E}-06$ \\
Zinc & $4.1 \mathrm{E}-02$ & $3.6 \mathrm{E}-02$ & $3.9 \mathrm{E}-02$ \\
& $7.9 \mathrm{E}-05$ & $7.7 \mathrm{E}-05$ & $6.3 \mathrm{E}-05$ \\
Total pathway hazard index & $1.0 \mathrm{E}-01$ & $8.5 \mathrm{E}-02$ & $1.2 \mathrm{E}-01$ \\
\hline
\end{tabular}

${ }^{a}$ UCB95 = Upper $95 \%$ confidence bound on the median, used as the representative analyte concentration.

${ }^{b}$ Total hazard index (HI) (HI chronic for an adult plus HI subchronic for a child).

The total pathway HI does not include HI values for mercury and nickel metals. 
Table 7.11b. Comparative background hazard index estimates (using UCB95 as concentration) ${ }^{a}$ from exposure to soil constituents from the Oak Ridge Reservation, Anderson County, and Roane County-Copper Ridge ${ }^{b}$

\begin{tabular}{lccc}
\hline \multirow{2}{*}{ Analyte } & Oak Ridge & Anderson & Roane \\
& Reservation & County & County \\
\hline
\end{tabular}

Exposure pathway: residential ingestion of soil

\section{Inorganics}

\begin{tabular}{|c|c|c|c|}
\hline Arsenic & $1.5 \mathrm{E}+\infty 0$ & 7.3E-01 & $1.6 \mathrm{E}-01$ \\
\hline Barium & $1.9 \mathrm{E}-02$ & $3.0 \mathrm{E}-02$ & $1.6 \mathrm{E}-02$ \\
\hline Beryllium & $1.8 \mathrm{E}-03$ & $2.6 \mathrm{E}-03$ & $1.6 \mathrm{E}-03$ \\
\hline Chromium VI & 1.7E-02 & $2.2 \mathrm{E}-02$ & $1.4 \mathrm{E}-02$ \\
\hline Manganese & $1.5 \mathrm{E}-01$ & 3.1E-01 & 1.2E-01 \\
\hline Mercury & 8.7E-03 & $6.1 \mathrm{E}-03$ & $6.6 \mathrm{E}-03$ \\
\hline Mercury (salts) & 8.7E-03 & $6.1 E-03$ & $6.6 \mathrm{E}-03$ \\
\hline Molybdenum & $5.0 \mathrm{E}-03$ & - & - \\
\hline Nickel & $6.9 \mathrm{E}-03$ & $7.6 \mathrm{E}-03$ & - \\
\hline Nickel (salts) & $6.9 \mathrm{E}-03$ & $7.6 \mathrm{E}-03$ & - \\
\hline Selenium & $2.3 \mathrm{E}-03$ & 3.7E-03 & $1.8 \mathrm{E}-03$ \\
\hline Strontium & 1.1E-04 & $1.8 \mathrm{E}-04$ & 1.2E-04 \\
\hline Vanadium & $6.1 \mathrm{E}-02$ & 8.0E-02 & 5.3E-02 \\
\hline \multirow[t]{2}{*}{ Zinc } & $2.0 \mathrm{E}-03$ & 2.6E-03 & 2.3E-03 \\
\hline & Organics & & \\
\hline Acenaphthene & $8.5 \mathrm{E}-05$ & 7.7E-05 & $6.0 \mathrm{E}-05$ \\
\hline Anthracene & 1.3E-05 & $2.0 \mathrm{E}-05$ & $2.0 \mathrm{E}-05$ \\
\hline Fluoranthene & $5.4 \mathrm{E}-04$ & 2.9E-04 & $4.0 \mathrm{E}-04$ \\
\hline Fluorene & $1.1 E-04$ & 2.7E-04 & 1.1E-04 \\
\hline Naphthalene & $5.8 \mathrm{E}-03$ & - & 一 \\
\hline Pyrene & $6.2 \mathrm{E}-04$ & $3.9 E-04$ & 2.6E-04 \\
\hline Total pathway hazard index & $1.7 \mathrm{E}+00$ & $1.2 \mathrm{E}+00$ & 7.7E-01 \\
\hline
\end{tabular}


Table 7.11b (continued)

\begin{tabular}{|c|c|c|c|}
\hline Analyte & $\begin{array}{l}\text { Oak Ridge } \\
\text { Reservation }\end{array}$ & $\begin{array}{l}\text { Anderson } \\
\text { County }\end{array}$ & $\begin{array}{l}\text { Roane } \\
\text { County }\end{array}$ \\
\hline \multicolumn{4}{|c|}{ Exposure pathway: residential dermal exposure to soil } \\
\hline \multicolumn{4}{|c|}{ Inorganics } \\
\hline Arsenic & $1.9 \mathrm{E}-02$ & 9.7E-03 & $7.4 \mathrm{E}-03$ \\
\hline Barium & $2.5 \mathrm{E}-03$ & 4.1E-03 & 2.1E-03 \\
\hline Beryllium & $4.8 \mathrm{E}-04$ & $6.9 \mathrm{E}-04$ & 4.2E-04 \\
\hline Chromium VI & $3.6 \mathrm{E}-03$ & 4.7E-03 & 2.9E-03 \\
\hline Manganese & $3.9 \mathrm{E}-02$ & 8.3E-02 & 3.2E-02 \\
\hline Mercury & $1.2 \mathrm{E}-04$ & $8.2 \mathrm{E}-05$ & 8.8E-05 \\
\hline Mercury (salts) & 7.7E-04 & $5.4 \mathrm{E}-04$ & 5.8E-04 \\
\hline Molybdenum & $6.6 \mathrm{E}-05$ & - & - \\
\hline Nickel & 9.2E-05 & $1.0 \mathrm{E}-04$ & - \\
\hline Nickel (salts) & $1.8 \mathrm{E}-03$ & $2.0 \mathrm{E}-03$ & - \\
\hline Selenium & $5.1 \mathrm{E}-05$ & $8.2 \mathrm{E}-05$ & $3.9 \mathrm{E}-05$ \\
\hline Strontium & $1.5 \mathrm{E}-06$ & $2.4 \mathrm{E}-06$ & $1.6 \mathrm{E}-06$ \\
\hline Vanadium & 3.2E-02 & 4.1E-02 & $2.8 \mathrm{E}-02$ \\
\hline Zinc & $5.4 \mathrm{E}-05$ & $6.9 \mathrm{E}-05$ & $6.1 E-05$ \\
\hline \multicolumn{4}{|c|}{ Organics } \\
\hline Acenaphthene & 2.7E-05 & $2.4 \mathrm{E}-05$ & $1.9 \mathrm{E}-05$ \\
\hline Anthracene & $4.0 \mathrm{E}-06$ & $6.3 \mathrm{E}-06$ & $6.5 \mathrm{E}-06$ \\
\hline Fluoranthene & 1.7E-04 & $9.3 \mathrm{E}-05$ & 1.3E-04 \\
\hline Fluorene & 3.3E-05 & $8.4 \mathrm{E}-05$ & $3.5 \mathrm{E}-05$ \\
\hline Naphthalene & 7.8E-04 & - & - \\
\hline Pyrene & $2.0 \mathrm{E}-04$ & $1.2 \mathrm{E}-04$ & 8.3E-05 \\
\hline Total pathway hazard index & $1.0 \mathrm{E}-01$ & $1.5 \mathrm{E}-01$ & 7.3E-02 \\
\hline
\end{tabular}

${ }^{\circ} \mathrm{UCB} 95=$ Upper $95 \%$ confidence bound on the median, used as the representative analyte concentration.

${ }^{b}$ Total hazard index (HI) (HI chronic for an adult plus HI subchronic for a child).

The total pathway HI does not include HI values for mercury and nickel metals. 
Table 7.11c. Comparative background hazard index estimates (using UCB95 as concentration) ${ }^{a}$ from exposure to soil constituents from the Oak Ridge Reservation (Bethel Valley and K-25)-Chickamanga ${ }^{b}$

\begin{tabular}{lll}
\hline Analyte & $\begin{array}{c}\text { Bethel } \\
\text { Valley }\end{array}$ & K-25 \\
\hline \multicolumn{2}{c}{ Exposure pathway: residential ingestion of soil } \\
Inorganics & \\
& & \\
Arsenic & $3.8 \mathrm{E}-01$ & $4.6 \mathrm{E}-01$ \\
Barium & $2.1 \mathrm{E}-02$ & $2.0 \mathrm{E}-02$ \\
Beryllium & $3.5 \mathrm{E}-03$ & $3.2 \mathrm{E}-03$ \\
Chromium VI & $3.7 \mathrm{E}-02$ & $3.5 \mathrm{E}-02$ \\
Manganese & $1.5 \mathrm{E}-01$ & $2.3 \mathrm{E}-01$ \\
Mercury & $8.8 \mathrm{E}-03$ & $2.7 \mathrm{E}-02$ \\
Mercury (salts) & $8.8 \mathrm{E}-03$ & $2.7 \mathrm{E}-02$ \\
Nickel & $1.2 \mathrm{E}-02$ & $1.5 \mathrm{E}-02$ \\
Nickel (salts) & $1.2 \mathrm{E}-02$ & $1.5 \mathrm{E}-02$ \\
Selenium & $2.6 \mathrm{E}-03$ & $2.7 \mathrm{E}-03$ \\
Strontium & $2.0 \mathrm{E}-04$ & $3.8 \mathrm{E}-04$ \\
Vanadium & $8.5 \mathrm{E}-02$ & $8.5 \mathrm{E}-02$ \\
Zinc & $2.6 \mathrm{E}-03$ & $2.7 \mathrm{E}-03$ \\
& &
\end{tabular}

Organics

Acenaphthene

Anthracene

Fluoranthene

Fluorene

Naphthalene

Pyrene

Total pathway hazard index
2.6E-04

8.0E-05

1.0E-05

1.7E-05

4.8E-04

3.7E-04

3.9E-03

1.1E-03

6.3E-04

1.4E-04

1.2E-03

1.3E-03

7.0E-01

8.9E-01 
Table 7.11c (continued)

\begin{tabular}{|c|c|c|}
\hline Analyte & $\begin{array}{l}\text { Bethel } \\
\text { Valley }\end{array}$ & $\mathrm{K}-25$ \\
\hline \multicolumn{3}{|c|}{ Exposure pathway: residential dermal exposure to soil } \\
\hline \multicolumn{3}{|c|}{ Inorganics } \\
\hline Arsenic & $5.0 \mathrm{E}-03$ & 6.1E-03 \\
\hline Barium & $2.8 \mathrm{E}-03$ & 2.7E-03 \\
\hline Beryllium & 9.4E-04 & 8.5E-04 \\
\hline Chromium VI & 7.9E-03 & 7.5E-03 \\
\hline Manganese & 3.9E-02 & $6.2 E-02$ \\
\hline Mercury & 1.2E-04 & $3.6 \mathrm{E}-04$ \\
\hline Mercury (salts) & 7.9E-04 & 2.4E-03 \\
\hline Nickel & $1.6 \mathrm{E}-04$ & $2.0 \mathrm{E}-04$ \\
\hline Nickel (salts) & $3.2 \mathrm{E}-03$ & 4.0E-03 \\
\hline Selenium & 5.9E-05 & 6.1E-05 \\
\hline Strontium & 2.7E-06 & 5.0E-06 \\
\hline Vanadium & 4.4E-02 & 4.4E-02 \\
\hline Zinc & 7.0E-05 & 7.2E-05 \\
\hline \multicolumn{3}{|c|}{ Organics } \\
\hline Acenaphthene & 8.4E-05 & $2.5 \mathrm{E}-05$ \\
\hline Anthracene & 3.2E-06 & 5.4E-06 \\
\hline Fluoranthene & $1.5 \mathrm{E}-04$ & $2.0 \mathrm{E}-04$ \\
\hline Fluorene & 1.2E-04 & $4.5 \mathrm{E}-05$ \\
\hline Naphthalene & $5.2 \mathrm{E}-04$ & $1.6 \mathrm{E}-04$ \\
\hline Pyrene & $3.5 \mathrm{E}-04$ & 4.3E-04 \\
\hline Total pathway hazard index & $1.0 \mathrm{E}-01$ & 1.3E-01 \\
\hline
\end{tabular}

${ }^{a}$ UCB95 = Upper $95 \%$ confidence bound on the median, used as the representative analyte concentration.

${ }^{b}$ Total hazard index (HI) (HI chronic for an adult plus HI subchronic for a child).

The total pathway HI does not include $\mathrm{HI}$ values for mercury and nickel metals. 


\subsubsection{Background risk and HI comparisons using the LCB95, median, and UCB95 analyte concentrations}

The following discussion of the range in risk associated with the concentration variability for background soil constituents applies only to this background soil data set. The results associated with the background data set do not necessarily represent the actual variability of constituent concentrations in soils of the $\mathrm{DG}, \mathrm{NL}, \mathrm{CR}, \mathrm{CHE}$ and $\mathrm{CHI}$ formations. Tables 7.12 through 7.15 assess the variability in the risk and $\mathrm{HI}$ estimates for the five sampling areas (ORR, AND, ROA, ORR-K25 and ORR-BV) with respect to the analyte concentrations used in this background evaluation. These tables include risk (Tables 7.12 and 7.13) and hazard indices (Tables 7.14 and 7.15) for three analyte concentrations [i.e., the lower 95\% confidence bound on the median concentration (LCB95), the median concentration, and the upper $95 \%$ confidence bound on the median concentration (UCB95)]. All other tables in Sect. 7 (excluding Tables 7.12 through 7.15) use the UCB95 as the representative analyte concentrations.

The differences between the UCB95 and LCB95 total cumulative (the sum of the risks of all analytes in all pathways) background risk estimates for the ORR, Anderson County, and Roane County for the Dismal Gap Formation (Table 7.12a) are 3.0e-04, 4.3e-04, and 2.7e-04, respectively. Similar information for the Copper Ridge Formation can be found in Table 7.12b. Furthermore, soil data were collected from the Chickamauga, Nolichucky and Chepultepec formations of the ORR only (AND and ROA county soil samples were not collected for these two formations); therefore, the LCB95, median and UCB95 risk values, for ORR-CHI, ORR-NL and ORR-CHE soils only, are illustrated in Table 7.12c and Table 7.13.

This information (Tables 7.12 and 7.13) is also illustrated graphically in Fig. 7.1. The cumulative background risks determined using the UCB95 analyte concentrations are represented by the top line; the risk determined using the median analyte concentrations is shown as the middle line, and when the LCB95 concentration was used to calculate risk, this information is represented by the bottom line. Note, that the variability between the three risk estimates (within each sampling area) is relatively small and, therefore, the overall total background risk to human health does not significantly change by varying the analyte concentration in this manner.

The results tabulated in Tables 7.14 and 7.15 show the variability in the hazard indices for each sampling area using the three analyte concentrations. Again, the differences (i.e., variability between sampling locations) in the HI values are quite small. The results of these comparisons (risk and $\mathrm{HI}$ ) illustrate high confidence in the quantitative validity of this background soil data set (see Sect. 5). However, it should be understood that these conclusions may not necessarily apply to the actual variability of constituent concentrations in soils.

Depending on the application of the background data, either the UCB95 or the LCB95 is more appropriate in terms of human health (refer to Sect. 2.3.4, Data User Guidelines). The Risk Assessment Council is producing guidance which will include specific details concerning the application of this background soil information to site-specific data. 
Table 7.12a. Comparative background risk estimates from exposure to soil constituents from the Oak Ridge Reservation, Anderson County, and Roane County-Dismal Gap ${ }^{a}$

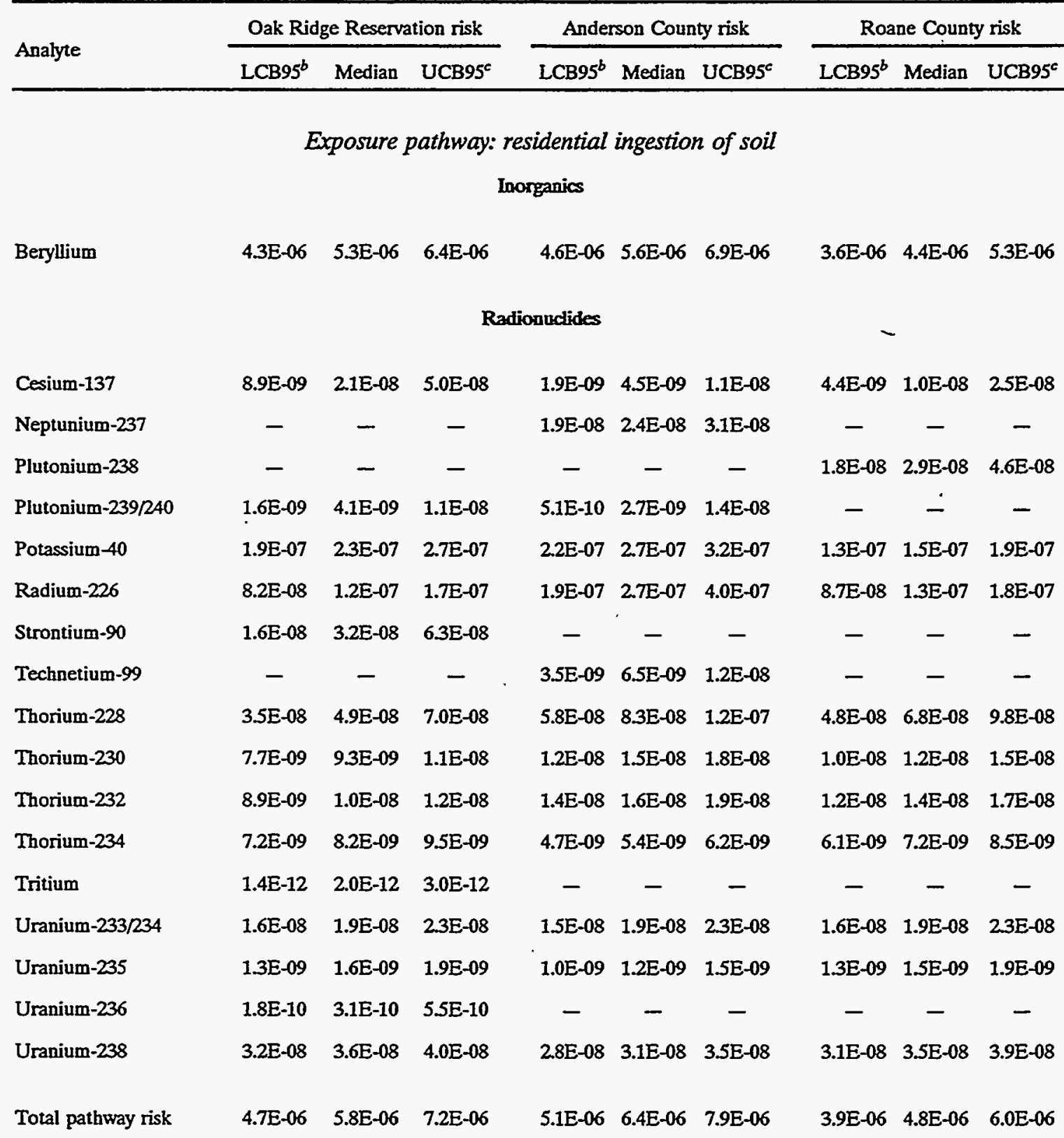

Exposure pathway: residential dermal exposure to soil

Inorganics

$\begin{array}{llllllllll}\text { Beryllium } & 1.9 \mathrm{E}-06 & 2.3 \mathrm{E}-06 & 2.9 \mathrm{E}-06 & 2.0 \mathrm{E}-06 & 2.5 \mathrm{E}-06 & 3.1 \mathrm{E}-06 & 1.6 \mathrm{E}-06 & 1.9 \mathrm{E}-06 & 2.4 \mathrm{E}-06 \\ \text { Total pathway risk } & 1.9 \mathrm{E}-06 & 2.3 \mathrm{E}-06 & 2.9 \mathrm{E}-06 & 2.0 \mathrm{E}-06 & .2 .5 \mathrm{E}-06 & 3.1 \mathrm{E}-06 & 1.6 \mathrm{E}-06 & 1.9 \mathrm{E}-06 & 2.4 \mathrm{E}-06\end{array}$


Table 7.12a (continued)

\begin{tabular}{|c|c|c|c|c|c|c|c|c|c|}
\hline \multirow{2}{*}{ Analyte } & \multicolumn{3}{|c|}{ Oak Ridge Reservation risk } & \multicolumn{3}{|c|}{ Anderson County risk } & \multicolumn{3}{|c|}{ Roane County risk } \\
\hline & LCB9 $^{b}$ & Median & UCB95 ${ }^{c}$ & LCB95 ${ }^{b}$ & Median & UCB95 & $\mathrm{LCB}^{5} 5^{b}$ & Median & UCB95 \\
\hline \multicolumn{10}{|c|}{ Exposure pathway: residential external exposure to radiation } \\
\hline \multicolumn{10}{|c|}{ Radionuclides } \\
\hline Cesium-137 & $1.2 \mathrm{E}-05$ & $2.9 \mathrm{E}-05$ & $6.8 \mathrm{E}-05$ & $2.6 \mathrm{E}-06$ & $6.1 E-06$ & $1.5 \mathrm{E}-05$ & $6.0 \mathrm{E}-06$ & $1.4 E-05$ & 3.4E-05 \\
\hline Neptunium-237 & - & - & - & $7.0 E-07$ & $9.0 \mathrm{E}-07$ & $1.2 \mathrm{E}-06$ & - & - & - \\
\hline Plutonium-238 & - & - & - & - & - & - & $4.4 E-11$ & $7.0 \mathrm{E}-11$ & $1.1 E-10$ \\
\hline Plutonium-239/240 & $3.6 \mathrm{E}-12$ & $9.2 \mathrm{E}-12$ & $2.4 \mathrm{E}-11$ & 1.1E-12 & $5.9 \mathrm{E}-12$ & 3.1E-11 & - & - & - \\
\hline Potassium-40 & $1.7 \mathrm{E}-04$ & 2.1E-04 & $2.6 \mathrm{E}-04$ & 2.1E-04 & $2.5 \mathrm{E}-04$ & $3.0 \mathrm{E}-04$ & $1.2 E-04$ & $1.4 \mathrm{E}-04$ & $1.7 \mathrm{E}-04$ \\
\hline Radium-226 & $7.8 \mathrm{E}-05$ & $1.1 E-04$ & $1.6 \mathrm{E}-04$ & $1.8 \mathrm{E}-04$ & $26 \mathrm{E}-04$ & $3.8 \mathrm{E}-04$ & $8.2 E-05$ & $1.2 E-04$ & 1.7E-04 \\
\hline Strontium-90 & $0.0 \mathrm{E}+00$ & $0.0 \mathrm{E}+00$ & $0.0 \mathrm{E}+00$ & - & - & - & - & - & - \\
\hline Technetium-99 & - & - & - & 3.1E-11 & 5.7E-11 & $1.1 E-10$ & - & - & - \\
\hline Thorium-228 & $6.7 E-05$ & $9.6 \mathrm{E}-05$ & $1.4 E-04$ & $1.1 E-04$ & $1.6 \mathrm{E}-04$ & $2.3 E-04$ & 9.3E-05 & $1.3 E-04$ & $1.9 E-04$ \\
\hline Thorium-230 & $6.1 E-10$ & 7.3E-10 & $8.8 E-10$ & $9.9 \mathrm{E}-10$ & $1.2 \mathrm{E}-09$ & $1.4 \mathrm{E}-09$ & 8.1E-10 & 9.7E-10 & $1.2 \mathrm{E}-09$ \\
\hline Thorium-232 & $3.7 \mathrm{E}-10$ & 4.3E-10 & $5.0 \mathrm{E}-10$ & 5.7E-10 & $6.6 \mathrm{E}-10$ & 7.7E-10 & 5.1E-10 & $5.9 \mathrm{E}-10$ & $6.9 \mathrm{E}-10$ \\
\hline Thorium-234 & $1.2 \mathrm{E}-07$ & $1.4 \mathrm{E}-07$ & $1.6 \mathrm{E}-07$ & $7.8 \mathrm{E}-08$ & $8.9 \mathrm{E}-08$ & $1.0 \mathrm{E}-07$ & $1.0 \mathrm{E}-07$ & $1.2 \mathrm{E}-07$ & $1.4 \mathrm{E}-07$ \\
\hline Tritium & $0.0 \mathrm{E}+00$ & $0.0 \mathrm{E}+00$ & $0.0 \mathrm{E}+00$ & - & - & - & - & - & - \\
\hline Uranium-233/234 & $7.8 \mathrm{E}-10$ & 9.4E-10 & $1.1 E-09$ & 7.7E-10 & 9.3E-10 & 1.1E-09 & $7.8 \mathrm{E}-10$ & 9.4E-10 & $1.1 \mathrm{E}-09$ \\
\hline Uranium-235 & $3.8 \mathrm{E}-07$ & $4.6 \mathrm{E}-07$ & $5.5 \mathrm{E}-07$ & $2.9 E-07$ & $3.5 \mathrm{E}-07$ & $4.2 \mathrm{E}-07$ & 3.7E-07 & $4.4 \mathrm{E}-07$ & $5.3 \mathrm{E}-07$ \\
\hline Uranium-236 & $5.4 \mathrm{E}-12$ & $9.5 \mathrm{E}-12$ & 1.7E-11 & - & - & - & - & - & - \\
\hline Uranium-238 & $7.9 E-07$ & $8.9 \mathrm{E}-07$ & $9.9 \mathrm{E}-07$ & $6.9 \mathrm{E}-07$ & 7.7E-07 & $8.6 \mathrm{E}-07$ & 7.7E-07 & $8.6 \mathrm{E}-07$ & $9.6 \mathrm{E}-07$ \\
\hline Total Pathway Risk & $3.3 E-04$ & $4.5 E-04$ & $6.3 E-04$ & $5.0 \mathrm{E}-04$ & $6.8 \mathrm{E}-04$ & $9.3 E-04$ & $3.0 \mathrm{E}-04$ & 4.1E-0.4 & 5.7E-04 \\
\hline Total Cumulative Risk ${ }^{d}$ & $3.4 \mathrm{E}-0.4$ & $4.6 \mathrm{E}-04$ & $6.4 \mathrm{E}-04$ & 5.1E-04 & $6.9 E-04$ & $9.4 \mathrm{E}-04$ & $3.1 E-04$ & $4.2 E-04$ & $5.8 \mathrm{E}-04$ \\
\hline
\end{tabular}

'The LCB95, median, and UCB95 analyte concentrations are evaluated in terms of total background risk (risk to an adult plus risk to a child).

${ }^{b}$ LCB95 $=$ Lower $95 \%$ confidence bound on the median.

c UCB95 = Upper $95 \%$ confidence bound on the median.

The sum of the risk from all analytes for all pathways. 
Table 7.12b. Comparative background risk estimates from exposure to soil constituents from the Oak Ridge Reservation, Anderson County, and Roane County-Copper Ridge ${ }^{a}$

\begin{tabular}{|c|c|c|c|c|c|c|c|c|c|}
\hline \multirow{2}{*}{ Analyte } & \multicolumn{3}{|c|}{ Oak Ridge Reservation risk } & \multicolumn{3}{|c|}{ Anderson County risk } & \multicolumn{3}{|c|}{ Roane County risk } \\
\hline & LCB95 $5^{b}$ & Median & UCB95 ${ }^{\circ}$ & $\mathrm{LCB}^{b} 5^{b}$ & Median & UCB95 ${ }^{c}$ & $\mathrm{LCB} 95^{b}$ & Median & UCB95 ${ }^{c}$ \\
\hline \multicolumn{10}{|c|}{ Exposure pathway: residential ingestion of soil } \\
\hline \multicolumn{10}{|c|}{ Inorganics } \\
\hline Beryllium & $2.8 \mathrm{E}-06$ & $3.4 \mathrm{E}-06$ & 4.3E-06 & 4.1E-06 & $5.0 \mathrm{E}-06$ & $6.1 E-06$ & $2.5 \mathrm{E}-06$ & $3.1 \mathrm{E}-06$ & $3.8 \mathrm{E}-06$ \\
\hline \multicolumn{10}{|c|}{ Organics } \\
\hline Benzo(a)anthracene & 1.7E-06 & $2.3 E-06$ & $3.1 E-06$ & $1.8 \mathrm{E}-06$ & $2.4 E-06$ & $3.3 E-06$ & $2.8 \mathrm{E}-06$ & 3.7E-06 & 4.9E-06 \\
\hline Benzo(a)pyrene & $2.3 E-05$ & $3.0 \mathrm{E}-05$ & 4.1E-05 & $1.5 E-05$ & 1.9E-05 & $2.6 \mathrm{E}-05$ & 1.1E-05 & $1.4 \mathrm{E}-05$ & $1.8 \mathrm{E}-05$ \\
\hline Benzo(b)fluoranthene & $1.8 \mathrm{E}-06$ & $2.5 \mathrm{E}-06$ & $3.6 \mathrm{E}-06$ & 2.1E-06 & $3.0 \mathrm{E}-06$ & $4.3 E-06$ & $1.5 \mathrm{E}-06$ & $2.0 \mathrm{E}-06$ & $2.8 \mathrm{E}-06$ \\
\hline Benzo(g,h,i)perylene & $2.4 \mathrm{E}-05$ & $3.3 E-05$ & $4.4 \mathrm{E}-05$ & $2.0 E-05$ & $26 \mathrm{E}-05$ & $3.5 \mathrm{E}-05$ & $1.7 \mathrm{E}-05$ & 2.2E-05 & 2.9E-05 \\
\hline Benzo(k)fluoranthene & $1.2 \mathrm{E}-06$ & $1.6 \mathrm{E}-06$ & 2.1E-06 & $1.2 \mathrm{E}-06$ & $1.6 \mathrm{E}-06$ & $2.1 E-06$ & $8.4 \mathrm{E}-07$ & $1.1 \mathrm{E}-06$ & 1.4E-06 \\
\hline Chrysene & $3.2 \mathrm{E}-07$ & 4.5E-07 & $6.2 \mathrm{E}-07$ & $1.9 \mathrm{E}-07$ & $4.9 \mathrm{E}-07$ & $1.3 \mathrm{E}-06$ & 1.7E-07 & $2.4 \mathrm{E}-07$ & $3.5 \mathrm{E}-07$ \\
\hline Dibenz(a,h)anthracene & $7.6 \mathrm{E}-06$ & $1.2 \mathrm{E}-05$ & $1.8 \mathrm{E}-05$ & $6.3 E-06$ & $1.5 \mathrm{E}-05$ & $3.6 \mathrm{E}-05$ & $7.3 \mathrm{E}-06$ & $1.1 \mathrm{E}-05$ & $1.6 \mathrm{E}-05$ \\
\hline Indeno(1,2,3-cd)pyrene & - & - & - & $7.2 \mathrm{E}-06$ & $1.0 \mathrm{E}-05$ & $1.5 \mathrm{E}-05$ & $9.6 \mathrm{E}-06$ & $1.5 \mathrm{E}-05$ & 2.3E-05 \\
\hline Phenanthrene & $3.5 \mathrm{E}-05$ & $4.6 \mathrm{E}-05$ & $6.2 \mathrm{E}-05$ & $3.1 E-05$ & 4.1E-05 & $5.5 \mathrm{E}-05$ & 2.7E-05 & $3.6 \mathrm{E}-05$ & 4.8E-05 \\
\hline
\end{tabular}

Radionuclides

\begin{tabular}{|c|c|c|c|c|c|c|c|c|c|}
\hline Cesium-137 & $1.3 \mathrm{E}-08$ & $3.0 \mathrm{E}-08$ & $7.0 \mathrm{E}-08$ & 9.4E-09 & $2.2 \mathrm{E}-08$ & $5.3 E-08$ & $1.4 \mathrm{E}-08$ & 3.4E-08 & $7.9 \mathrm{E}-08$ \\
\hline Neptunium-237 & $1.8 \mathrm{E}-08$ & $2.3 E-08$ & $3.0 \mathrm{E}-08$ & $1.3 E-08$ & $1.7 \mathrm{E}-08$ & $2.2 \mathrm{E}-08$ & $1.1 \mathrm{E}-08$ & $1.5 \mathrm{E}-08$ & $1.9 \mathrm{E}-08$ \\
\hline Plutonium-238 & $3.9 \mathrm{E}-09$ & $6.4 \mathrm{E}-09$ & 1.1E-08 & $1.4 \mathrm{E}-08$ & $2.4 \mathrm{E}-08$ & $4.2 \mathrm{E}-08$ & - & - & - \\
\hline Plutonium-239/240 & $3.8 \mathrm{E}-09$ & 8.1E-09 & $1.7 \mathrm{E}-08$ & - & - & - & 8.7E-09 & $2.0 \mathrm{E}-08$ & $4.6 \mathrm{E}-08$ \\
\hline Potassium -40 & 4.7E-08 & 5.7E-08 & $6.9 E-08$ & $3.9 \mathrm{E}-08$ & 4.7E-08 & 5.7E-08 & $3.1 E-08$ & $3.8 \mathrm{E}-08$ & $4.6 \mathrm{E}-08$ \\
\hline Radium-226 & $1.3 E-07$ & $1.8 \mathrm{E}-07$ & 2.7E-07 & $5.9 \mathrm{E}-08$ & $8.7 E-08$ & $1.3 E-07$ & $9.5 E-08$ & $1.4 \mathrm{E}-07$ & $2.0 \mathrm{E}-07$ \\
\hline Technetium-99 & - & - & - & $2.2 \mathrm{E}-09$ & 3.7E-09 & $6.3 E-09$ & - & - & - \\
\hline Thorium-228 & $1.6 \mathrm{E}-08$ & $2.3 \mathrm{E}-08$ & $3.4 \mathrm{E}-08$ & 4.1E-08 & $5.9 \mathrm{E}-08$ & $8.3 E-08$ & 3.0E-08 & $4.3 \mathrm{E}-08$ & $6.1 \mathrm{E}-08$ \\
\hline Thorium-230 & $1.5 \mathrm{E}-08$ & $1.8 \mathrm{E}-08$ & $2.2 \mathrm{E}-08$ & $1.5 \mathrm{E}-08$ & $1.8 \mathrm{E}-08$ & 2.1E-08 & $1.2 \mathrm{E}-08$ & $1.4 \mathrm{E}-08$ & 1.7E-08 \\
\hline Thorium-232 & 8.8E-09 & $1.0 \mathrm{E}-08$ & $1.2 \mathrm{E}-08$ & $1.0 \mathrm{E}-08$ & $1.2 \mathrm{E}-08$ & $1.4 \mathrm{E}-08$ & 7.1E-09 & $8.2 \mathrm{E}-09$ & $9.6 \mathrm{E}-09$ \\
\hline Thorium-234 & $6.7 \mathrm{E}-09$ & $7.8 \mathrm{E}-09$ & 9.3E-09 & - & - & - & - & - & - \\
\hline Tritium & $6.6 \mathrm{E}-13$ & 1.1E-12 & $1.8 \mathrm{E}-12$ & - & - & - & - & - & - \\
\hline Uranium-233/234 & 2.4E-08 & 2.9E-08 & $3.5 \mathrm{E}-08$ & $2.0 \mathrm{E}-08$ & 2.4E-08 & $2.9 \mathrm{E}-08$ & $2.1 E-08$ & $2.5 \mathrm{E}-08$ & $3.0 \mathrm{E}-08$ \\
\hline Uranium-235 & $1.8 \mathrm{E}-09$ & $2.5 \mathrm{E}-09$ & $3.6 \mathrm{E}-09$ & 1.1E-09 & $1.5 \mathrm{E}-09$ & 2.1E-09 & $5.0 \mathrm{E}-10$ & 7.1E-10 & $1.0 \mathrm{E}-09$ \\
\hline Uranium-236 & $1.2 \mathrm{E}-10$ & $2.0 \mathrm{E}-10$ & $3.3 E-10$ & - & - & - & - & - & 一 \\
\hline Uranium-238 & 4.4E- -08 & $4.9 \mathrm{E}-08$ & $5.4 \mathrm{E}-08$ & 4.3E- -08 & 4.8E-08 & $5.4 \mathrm{E}-08$ & $2.6 \mathrm{E}-08$ & $3.0 \mathrm{E}-08$ & $3.3 \mathrm{E}-08$ \\
\hline Total pathway risk & $9.8 \mathrm{E}-05$ & $1.3 \mathrm{E}-04$ & $1.8 \mathrm{E}-04$ & $8.9 \mathrm{E}-05$ & $1.3 \mathrm{E}-04$ & $1.8 \mathrm{E}-04$ & $7.9 \mathrm{E}-05$ & $1.1 \mathrm{E}-04$ & $1.5 \mathrm{E}-0.4$ \\
\hline
\end{tabular}

Exposure pathway: residential dermal exposure to soil Inorganics

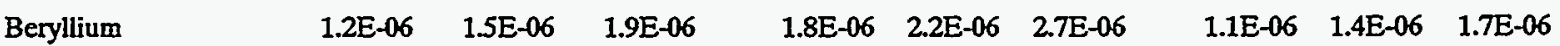


Table 7.12b (continued)

\begin{tabular}{|c|c|c|c|c|c|c|c|c|c|}
\hline \multirow{2}{*}{ Analyte } & \multicolumn{3}{|c|}{ Oak Ridge Reservation risk } & \multicolumn{3}{|c|}{ Anderson County risk } & \multicolumn{3}{|c|}{ Roane County risk } \\
\hline & LCB95 $5^{b}$ & Median & UCB95 ${ }^{c}$ & LCB95 $5^{b}$ & Median & UCB95 & LCB95 $5^{b}$ & Median & UCB95 ${ }^{\circ}$ \\
\hline \multicolumn{10}{|c|}{ Exposure pathway: residential dermal exposure to soil (continued) } \\
\hline \multicolumn{10}{|c|}{ Organics } \\
\hline Benzo(a)anthracene & $3.9 E-07$ & $5.1 E-07$ & $6.8 \mathrm{E}-07$ & 4.0E-07 & $5.4 \mathrm{E}-07$ & 7.3E-07 & $6.2 E-07$ & $8.2 \mathrm{E}-07$ & 1.1E-06 \\
\hline Benzo(a)pyrene & 5.1E-06 & $6.8 \mathrm{E}-06$ & $9.0 \mathrm{E}-06$ & $3.2 \mathrm{E}-06$ & $4.3 \mathrm{E}-06$ & $5.8 \mathrm{E}-06$ & $2.3 \mathrm{E}-06$ & 3.1E-06 & 4.0E-06 \\
\hline Benzo(b)fluoranthene & $3.9 E-07$ & $5.6 \mathrm{E}-07$ & $7.9 \mathrm{E}-07$ & $4.8 \mathrm{E}-07$ & $6.8 \mathrm{E}-07$ & $9.6 \mathrm{E}-07$ & $3.3 \mathrm{E}-07$ & $4.6 \mathrm{E}-07$ & $6.2 \mathrm{E}-07$ \\
\hline $\operatorname{Benzo}(\mathrm{g}, \mathrm{h}, \mathrm{i})$ perylene & $5.4 \mathrm{E}-06$ & $7.3 \mathrm{E}-06$ & 9.7E-06 & 4.4E-06 & $5.9 \mathrm{E}-06$ & $7.8 \mathrm{E}-06$ & $3.7 \mathrm{E}-06$ & $4.8 E-06$ & $6.4 E-06$ \\
\hline Benzo(k)fluoranthene & $2.8 E-07$ & $3.6 \mathrm{E}-07$ & $4.6 \mathrm{E}-07$ & $2.6 \mathrm{E}-07$ & $3.5 \mathrm{E}-07$ & $4.6 \mathrm{E}-07$ & 1.9E-07 & $2.4 \mathrm{E}-07$ & $3.1 E-07$ \\
\hline Chrysene & 9.1E-08 & $1.3 \mathrm{E}-07$ & $1.7 \mathrm{E}-07$ & $5.2 \mathrm{E}-08$ & $1.4 \mathrm{E}-07$ & $3.7 E-07$ & 4.7E-08 & $6.8 \mathrm{E}-08$ & $9.9 \mathrm{E}-08$ \\
\hline Dibenz $(a, h)$ anthracene & 1.7E-06 & $2.6 \mathrm{E}-06$ & 4.1E-06 & $1.4 \mathrm{E}-06$ & $3.3 E-06$ & $8.0 E-06$ & $1.6 \mathrm{E}-06$ & $2.4 \mathrm{E}-06$ & 3.7E-06 \\
\hline Indeno( $(1,2,3-c d)$ pyrene & - & - & - & $1.6 E-06$ & $2.3 E-06$ & $3.2 \mathrm{E}-06$ & 2.1E-06 & 3.3E-06 & $5.2 \mathrm{E}-06$ \\
\hline Phenanthrene & $7.8 \mathrm{E}-06$ & $1.0 \mathrm{E}-05$ & $1.4 \mathrm{E}-05$ & 7.0E-06 & $9.2 \mathrm{E}-06$ & $1.2 \mathrm{E}-05$ & $6.1 \mathrm{E}-06$ & 8.1E-06 & 1.1E-05 \\
\hline Total pathway risk & $2.2 E-05$ & 3.0E-05 & 4.1E-05 & $2.1 E-05$ & $2.9 E-05$ & $4.2 \mathrm{E}-05$ & $1.8 \mathrm{E}-05$ & $2.5 E-05$ & $3.4 \mathrm{E}-05$ \\
\hline
\end{tabular}

Exposure pathway: residential external exposure to radiation

Radionuclides

$\begin{array}{lccccccccc}\text { Cesium-137 } & 1.7 \mathrm{E}-05 & 4.0 \mathrm{E}-05 & 9.5 \mathrm{E}-05 & 1.3 \mathrm{E}-05 & 3.0 \mathrm{E}-05 & 7.2 \mathrm{E}-05 & 1.9 \mathrm{E}-05 & 4.6 \mathrm{E}-05 & 1.1 \mathrm{E}-04 \\ \text { Neptunium-237 } & 6.7 \mathrm{E}-07 & 8.7 \mathrm{E}-07 & 1.1 \mathrm{E}-06 & 4.7 \mathrm{E}-07 & 6.2 \mathrm{E}-07 & 8.2 \mathrm{E}-07 & 4.2 \mathrm{E}-07 & 5.4 \mathrm{E}-07 & 7.0 \mathrm{E}-07 \\ \text { Plutonium-238 } & 9.5 \mathrm{E}-12 & 1.6 \mathrm{E}-11 & 2.6 \mathrm{E}-11 & 3.3 \mathrm{E}-11 & 5.8 \mathrm{E}-11 & 1.0 \mathrm{E}-10 & - & - & - \\ \text { Plutonium-239/240 } & 8.4 \mathrm{E}-12 & 1.8 \mathrm{E}-11 & 3.9 \mathrm{E}-11 & - & - & - & 1.9 \mathrm{E}-11 & 4.5 \mathrm{E}-11 & 1.0 \mathrm{E}-10 \\ \text { Potassium-40 } & 4.4 \mathrm{E}-05 & 5.3 \mathrm{E}-05 & 6.4 \mathrm{E}-05 & 3.6 \mathrm{E}-05 & 4.4 \mathrm{E}-05 & 5.3 \mathrm{E}-05 & 2.9 \mathrm{E}-05 & 3.6 \mathrm{E}-05 & 4.3 \mathrm{E}-05 \\ \text { Radium-226 } & 1.2 \mathrm{E}-04 & 1.8 \mathrm{E}-04 & 2.6 \mathrm{E}-04 & 5.7 \mathrm{E}-05 & 8.2 \mathrm{E}-05 & 1.2 \mathrm{E}-04 & 9.0 \mathrm{E}-05 & 1.3 \mathrm{E}-04 & 1.9 \mathrm{E}-04 \\ \text { Technetium-99 } & - & - & - & 1.9 \mathrm{E}-11 & 3.3 \mathrm{E}-11 & 5.5 \mathrm{E}-11 & - & - & - \\ \text { Thorium-228 } & 3.2 \mathrm{E}-05 & 4.6 \mathrm{E}-05 & 6.5 \mathrm{E}-05 & 8.0 \mathrm{E}-05 & 1.1 \mathrm{E}-04 & 1.6 \mathrm{E}-04 & 5.8 \mathrm{E}-05 & 8.3 \mathrm{E}-05 & 1.2 \mathrm{E}-04 \\ \text { Thorium-230 } & 1.2 \mathrm{E}-09 & 1.4 \mathrm{E}-09 & 1.7 \mathrm{E}-09 & 1.2 \mathrm{E}-09 & 1.4 \mathrm{E}-09 & 1.7 \mathrm{E}-09 & 9.3 \mathrm{E}-10 & 1.1 \mathrm{E}-09 & 1.3 \mathrm{E}-09 \\ \text { Thorium-232 } & 3.6 \mathrm{E}-10 & 4.2 \mathrm{E}-10 & 4.9 \mathrm{E}-10 & 4.2 \mathrm{E}-10 & 4.9 \mathrm{E}-10 & 5.7 \mathrm{E}-10 & 2.9 \mathrm{E}-10 & 3.4 \mathrm{E}-10 & 3.9 \mathrm{E}-10 \\ \text { Thorium-234 } & 1.1 \mathrm{E}-07 & 1.3 \mathrm{E}-07 & 1.5 \mathrm{E}-07 & - & - & - & - & - & - \\ \text { Tritium } & 0.0 \mathrm{E}+00 & 0.0 \mathrm{E}+00 & 0.0 \mathrm{E}+00 & - & - & - & - & - & - \\ \text { Uranium-233/234 } & 1.2 \mathrm{E}-09 & 1.5 \mathrm{E}-09 & 1.8 \mathrm{E}-09 & 9.8 \mathrm{E}-10 & 1.2 \mathrm{E}-09 & 1.4 \mathrm{E}-09 & 1.0 \mathrm{E}-09 & 1.2 \mathrm{E}-09 & 1.5 \mathrm{E}-09 \\ \text { Uranium-235 } & 5.1 \mathrm{E}-07 & 7.2 \mathrm{E}-07 & 1.0 \mathrm{E}-06 & 3.0 \mathrm{E}-07 & 4.3 \mathrm{E}-07 & 6.0 \mathrm{E}-07 & 1.4 \mathrm{E}-07 & 2.0 \mathrm{E}-07 & 2.9 \mathrm{E}-07 \\ \text { Uranium-236 } & 3.8 \mathrm{E}-12 & 6.1 \mathrm{E}-12 & 1.0 \mathrm{E}-11 & - & - & - & - & - & - \\ \text { Uranium-238 } & 1.1 \mathrm{E}-06 & 1.2 \mathrm{E}-06 & 1.3 \mathrm{E}-06 & 1.0 \mathrm{E}-06 & 1.2 \mathrm{E}-06 & 1.3 \mathrm{E}-06 & 6.5 \mathrm{E}-07 & 7.2 \mathrm{E}-07 & 8.1 \mathrm{E}-07 \\ & & & & & & & & & \end{array}$

-The LCB95, median, and UCB95 analyte concentrations are evaluated in terms of total background risk (risk to an adult plus risk to a child).

${ }^{b}$ LCB95 $=$ Lower $95 \%$ confidence bound on the median.

UCB95 = Upper 95\% confidence bound on the median.

${ }^{d}$ The sum of the risk from all analytes for all pathways. 
Table 7.12c Comparative background risk estimates from exposure to soil constituents from the Oak Ridge Reservation (Bethel Valley and K-25)-Chickamauga ${ }^{a}$

\begin{tabular}{|c|c|c|c|c|c|c|}
\hline \multirow{2}{*}{ Analyte } & \multicolumn{3}{|c|}{ Bethel Valley risk } & \multicolumn{3}{|c|}{$\mathrm{K}-25$ risk } \\
\hline & $\mathrm{LCB}^{b} 5^{b}$ & Median & UCB95 ${ }^{c}$ & LCB $95^{b}$ & Median & UCB95 $5^{c}$ \\
\hline \multicolumn{7}{|c|}{ Exposure pathway: residential ingestion of soil } \\
\hline \multicolumn{7}{|c|}{ Inorganics } \\
\hline Beryllium & $5.6 \mathrm{E}-06$ & $6.9 \mathrm{E}-06$ & 8.4E-06 & $5.0 \mathrm{E}-06$ & $6.1 \mathrm{E}-06$ & $7.5 \mathrm{E}-06$ \\
\hline \multicolumn{7}{|c|}{ Organics } \\
\hline Benzo(a)anthracene & 3.3E-06 & 4.9E-06 & 7.3E-06 & $4.9 \mathrm{E}-06$ & $6.5 \mathrm{E}-06$ & $8.6 \mathrm{E}-06$ \\
\hline Benzo(a)pyrene & $3.3 E-05$ & 4.3E-05 & $5.6 \mathrm{E}-05$ & $4.6 \mathrm{E}-05$ & 5.9E-05 & 7.7E-05 \\
\hline Benzo(b)fluoranthene & $3.6 \mathrm{E}-06$ & 5.1E-06 & $7.2 \mathrm{E}-06$ & $3.9 \mathrm{E}-06$ & $5.2 \mathrm{E}-06$ & 7.0E-06 \\
\hline Benzo(g,h,i)perylene & 2.7E-05 & 4.0E-05 & $5.9 \mathrm{E}-05$ & $4.2 \mathrm{E}-05$ & $5.5 \mathrm{E}-05$ & $7.0 \mathrm{E}-05$ \\
\hline Benzo(k)fluoranthene & $2.0 \mathrm{E}-06$ & $2.6 \mathrm{E}-06$ & 3.3E-06 & $2.6 \mathrm{E}-06$ & $3.3 \mathrm{E}-06$ & 4.3E-06 \\
\hline Chrysene & $3.6 \mathrm{E}-07$ & 5.7E-07 & 8.9E-07 & $4.0 \mathrm{E}-07$ & $6.1 \mathrm{E}-07$ & $9.2 \mathrm{E}-07$ \\
\hline Dibenz(a,h)anthracene & $2.9 \mathrm{E}-06$ & $6.8 \mathrm{E}-06$ & $1.6 \mathrm{E}-05$ & 4.3E-06 & 8.7E-06 & $1.8 \mathrm{E}-05$ \\
\hline Indeno(1,2,3-cd)pyrene & $8.9 E-06$ & $1.3 \mathrm{E}-05$ & $1.9 \mathrm{E}-05$ & $7.6 \mathrm{E}-06$ & $1.1 \mathrm{E}-05$ & $1.6 \mathrm{E}-05$ \\
\hline Phenanthrene & $5.7 \mathrm{E}-05$ & $7.6 \mathrm{E}-05$ & $1.0 \mathrm{E}-04$ & $6.2 \mathrm{E}-05$ & 8.2E-05 & 1.1E-04 \\
\hline
\end{tabular}

Radionuclides

Cesium-137

Neptunium-237

Plutonium-238

Plutonium-239/240

Potassium-40

Radium-226

Technetium-99

Thorium-228

Thorium-230

Thorium-232

Tritium

Uranium-233/234

Uranium-235

Uranium-238

Total pathway risk

$\begin{array}{cccccc}2.0 \mathrm{E}-08 & 4.8 \mathrm{E}-08 & 1.1 \mathrm{E}-07 & 1.6 \mathrm{E}-08 & 3.8 \mathrm{E}-08 & 9.0 \mathrm{E}-08 \\ 1.9 \mathrm{E}-08 & 2.6 \mathrm{E}-08 & 3.5 \mathrm{E}-08 & 2.0 \mathrm{E}-08 & 2.6 \mathrm{E}-08 & 3.3 \mathrm{E}-08 \\ 1.2 \mathrm{E}-08 & 2.0 \mathrm{E}-08 & 3.6 \mathrm{E}-08 & 1.3 \mathrm{E}-08 & 2.0 \mathrm{E}-08 & 3.2 \mathrm{E}-08 \\ 4.0 \mathrm{E}-09 & 9.4 \mathrm{E}-09 & 2.2 \mathrm{E}-08 & 3.4 \mathrm{E}-09 & 6.9 \mathrm{E}-09 & 1.4 \mathrm{E}-08 \\ 1.7 \mathrm{E}-07 & 2.1 \mathrm{E}-07 & 2.5 \mathrm{E}-07 & 1.1 \mathrm{E}-07 & 1.3 \mathrm{E}-07 & 1.6 \mathrm{E}-07 \\ 1.1 \mathrm{E}-07 & 1.6 \mathrm{E}-07 & 2.4 \mathrm{E}-07 & 9.7 \mathrm{E}-08 & 1.4 \mathrm{E}-07 & 2.0 \mathrm{E}-07 \\ 1.3 \mathrm{E}-09 & 2.1 \mathrm{E}-09 & 3.3 \mathrm{E}-09 & 1.2 \mathrm{E}-09 & 1.8 \mathrm{E}-09 & 2.7 \mathrm{E}-09 \\ 6.3 \mathrm{E}-08 & 8.9 \mathrm{E}-08 & 1.3 \mathrm{E}-07 & 5.5 \mathrm{E}-08 & 7.8 \mathrm{E}-08 & 1.1 \mathrm{E}-07 \\ 1.4 \mathrm{E}-08 & 1.7 \mathrm{E}-08 & 2.1 \mathrm{E}-08 & 1.4 \mathrm{E}-08 & 1.7 \mathrm{E}-08 & 2.0 \mathrm{E}-08 \\ 1.6 \mathrm{E}-08 & 1.9 \mathrm{E}-08 & 2.2 \mathrm{E}-08 & 1.4 \mathrm{E}-08 & 1.7 \mathrm{E}-08 & 1.9 \mathrm{E}-08 \\ 5.4 \mathrm{E}-12 & 7.7 \mathrm{E}-12 & 1.1 \mathrm{E}-11 & - & - & - \\ 1.7 \mathrm{E}-08 & 2.0 \mathrm{E}-08 & 2.5 \mathrm{E}-08 & 2.0 \mathrm{E}-08 & 2.5 \mathrm{E}-08 & 3.0 \mathrm{E}-08 \\ 1.3 \mathrm{E}-09 & 1.9 \mathrm{E}-09 & 2.7 \mathrm{E}-09 & 8.3 \mathrm{E}-10 & 1.2 \mathrm{E}-09 & 1.7 \mathrm{E}-09 \\ 3.4 \mathrm{E}-08 & 3.7 \mathrm{E}-08 & 4.2 \mathrm{E}-08 & 3.8 \mathrm{E}-08 & 4.3 \mathrm{E}-08 & 4.8 \mathrm{E}-08 \\ & & & & & \\ 1.4 \mathrm{E}-04 & 2.0 \mathrm{E}-04 & 2.8 \mathrm{E}-04 & 1.8 \mathrm{E}-04 & 2.4 \mathrm{E}-04 & 3.2 \mathrm{E}-04\end{array}$

Exposure pathway: residential dermal exposure to soil

\section{Inorganics}

Beryllium 
Table 7.12c (continued)

\begin{tabular}{|c|c|c|c|c|c|c|}
\hline \multirow{2}{*}{ Analyte } & \multicolumn{3}{|c|}{ Bethel Valley risk } & \multicolumn{3}{|c|}{$\mathrm{K}-25$ risk } \\
\hline & $\mathrm{LCB} 5^{b}$ & Median & UCB95 & LCB95 $5^{b}$ & Median & UCB95 $^{c}$ \\
\hline
\end{tabular}

Exposure pathway: residential dermal exposure to soil (continued) Organics

$\begin{array}{lllllll}\text { Benzo(a)anthracene } & 7.3 \mathrm{E}-07 & 1.1 \mathrm{E}-06 & 1.6 \mathrm{E}-06 & 1.1 \mathrm{E}-06 & 1.4 \mathrm{E}-06 & 1.9 \mathrm{E}-06 \\ \text { Benzo(a)pyrene } & 7.4 \mathrm{E}-06 & 9.6 \mathrm{E}-06 & 1.3 \mathrm{E}-05 & 1.0 \mathrm{E}-05 & 1.3 \mathrm{E}-05 & 1.7 \mathrm{E}-05 \\ \text { Benzo(b)fluoranthene } & 8.0 \mathrm{E}-07 & 1.1 \mathrm{E}-06 & 1.6 \mathrm{E}-06 & 8.8 \mathrm{E}-07 & 1.2 \mathrm{E}-06 & 1.5 \mathrm{E}-06 \\ \text { Benzo(g,h,i)perylene } & 5.9 \mathrm{E}-06 & 8.8 \mathrm{E}-06 & 1.3 \mathrm{E}-05 & 9.4 \mathrm{E}-06 & 1.2 \mathrm{E}-05 & 1.6 \mathrm{E}-05 \\ \text { Benzo(k)fluoranthene } & 4.5 \mathrm{E}-07 & 5.8 \mathrm{E}-07 & 7.4 \mathrm{E}-07 & 5.8 \mathrm{E}-07 & 7.4 \mathrm{E}-07 & 9.5 \mathrm{E}-07 \\ \text { Chrysene } & 1.0 \mathrm{E}-07 & 1.6 \mathrm{E}-07 & 2.5 \mathrm{E}-07 & 1.1 \mathrm{E}-07 & 1.7 \mathrm{E}-07 & 2.6 \mathrm{E}-07 \\ \text { Dibenz(a,h)anthracene } & 6.4 \mathrm{E}-07 & 1.5 \mathrm{E}-06 & 3.6 \mathrm{E}-06 & 9.6 \mathrm{E}-07 & 1.9 \mathrm{E}-06 & 4.0 \mathrm{E}-06 \\ \text { Indeno(1,2,3-cd)pyrene } & 2.0 \mathrm{E}-06 & 2.9 \mathrm{E}-06 & 4.1 \mathrm{E}-06 & 1.7 \mathrm{E}-06 & 2.4 \mathrm{E}-06 & 3.5 \mathrm{E}-06 \\ \text { Phenanthrene } & 1.3 \mathrm{E}-05 & 1.7 \mathrm{E}-05 & 2.2 \mathrm{E}-05 & 1.4 \mathrm{E}-05 & 1.8 \mathrm{E}-05 & 2.4 \mathrm{E}-05 \\ & & & & & & \\ \text { Total pathway risk } & 3.3 \mathrm{E}-05 & 4.6 \mathrm{E}-05 & 6.4 \mathrm{E}-05 & 4.1 \mathrm{E}-05 & 5.4 \mathrm{E}-05 & \mathbf{7 . 2 \mathrm { E } - 0 5}\end{array}$

Exposure pathway: residential external exposure to radiation

Radionuclides

\begin{tabular}{|c|c|c|c|c|c|c|}
\hline Cesium-137 & $2.7 \mathrm{E}-05$ & $6.5 \mathrm{E}-05$ & $1.5 \mathrm{E}-04$ & 2.2E-05 & $5.2 \mathrm{E}-05$ & $1.2 \mathrm{E}-04$ \\
\hline Neptunium-237 & 7.2E-07 & 9.6E-07 & $1.3 E-06$ & 7.4E-07 & $9.6 \mathrm{E}-07$ & $1.2 \mathrm{E}-06$ \\
\hline Plutonium-238 & $2.9 \mathrm{E}-11$ & $5.0 \mathrm{E}-11$ & 8.7E-11 & 3.1E-11 & $4.9 \mathrm{E}-11$ & 7.7E-11 \\
\hline Plutonium-239/240 & $8.9 \mathrm{E}-12$ & $2.1 \mathrm{E}-11$ & $5.0 \mathrm{E}-11$ & $7.6 \mathrm{E}-12$ & $1.6 \mathrm{E}-11$ & $3.2 \mathrm{E}-11$ \\
\hline Potassium-40 & $1.6 \mathrm{E}-04$ & $2.0 \mathrm{E}-04$ & $2.4 \mathrm{E}-04$ & $1.0 \mathrm{E}-04$ & $1.3 \mathrm{E}-04$ & $1.5 \mathrm{E}-04$ \\
\hline Radium-226 & $1.1 \mathrm{E}-04$ & $1.6 \mathrm{E}-04$ & 2.3E-04 & 9.2E-05 & $1.3 E-04$ & 1.9E-04 \\
\hline Technetium-99 & $1.1 \mathrm{E}-11$ & $1.8 \mathrm{E}-11$ & $2.9 \mathrm{E}-11$ & $1.1 \mathrm{E}-11$ & $1.6 \mathrm{E}-11$ & 2.4E-11 \\
\hline Thorium-228 & $1.2 \mathrm{E}-04$ & 1.7E-04 & $2.5 \mathrm{E}-04$ & $1.1 \mathrm{E}-04$ & $1.5 \mathrm{E}-04$ & 2.2E-04 \\
\hline Thorium-230 & $1.1 \mathrm{E}-09$ & $1.4 \mathrm{E}-09$ & $1.6 \mathrm{E}-09$ & $1.1 \mathrm{E}-09$ & $1.3 \mathrm{E}-09$ & $1.6 \mathrm{E}-09$ \\
\hline Thorium-232 & $6.7 \mathrm{E}-10$ & $7.8 \mathrm{E}-10$ & 9.1E-10 & $5.9 \mathrm{E}-10$ & $6.9 \mathrm{E}-10$ & 8.0E-10 \\
\hline Tritium & $0.0 \mathrm{E}+00$ & $0.0 \mathrm{E}+00$ & $0.0 \mathrm{E}+00$ & - & - & - \\
\hline Uranium-233/234 & $8.4 \mathrm{E}-10$ & $1.0 \mathrm{E}-09$ & $1.2 E-09$ & $1.0 \mathrm{E}-09$ & $1.2 \mathrm{E}-09$ & $1.5 \mathrm{E}-09$ \\
\hline Uranium-235 & $3.8 \mathrm{E}-07$ & $5.4 \mathrm{E}-07$ & 7.6E-07 & $2.4 \mathrm{E}-07$ & $3.4 \mathrm{E}-07$ & 4.7E-07 \\
\hline Uranium-238 & 8.2E-07 & 9.2E-07 & $1.0 \mathrm{E}-06$ & 9.4E-07 & $1.1 \mathrm{E}-06$ & $1.2 \mathrm{E}-06$ \\
\hline Total pathway risk & 4.2E-04 & $5.9 \mathrm{E}-04$ & 8.7E-04 & $3.3 E-04$ & 4.7E-04 & $6.9 \mathrm{E}-04$ \\
\hline Total Cumulative Risk ${ }^{d}$ & $6.0 \mathrm{E}-04$ & 8.4E-04 & $1.2 \mathrm{E}-03$ & $5.5 \mathrm{E}-04$ & $7.6 \mathrm{E}-04$ & 1.1E-03 \\
\hline
\end{tabular}

a The LCB95, median, and UCB95 analyte concentrations are evaluated in terms of total background risk (risk to an adult plus risk to a child).

${ }^{b}$ LCB95 $=$ Lower $95 \%$ confidence bound on the median.

UCB9S = Upper 95\% confidence bound on the median.

${ }^{d}$ The sum of the risk from all analytes for all pathways. 
Table 7.13a. Comparative background risk estimates from exposure to soil constituents from the Oak Ridge Reservation-Nolichucky"

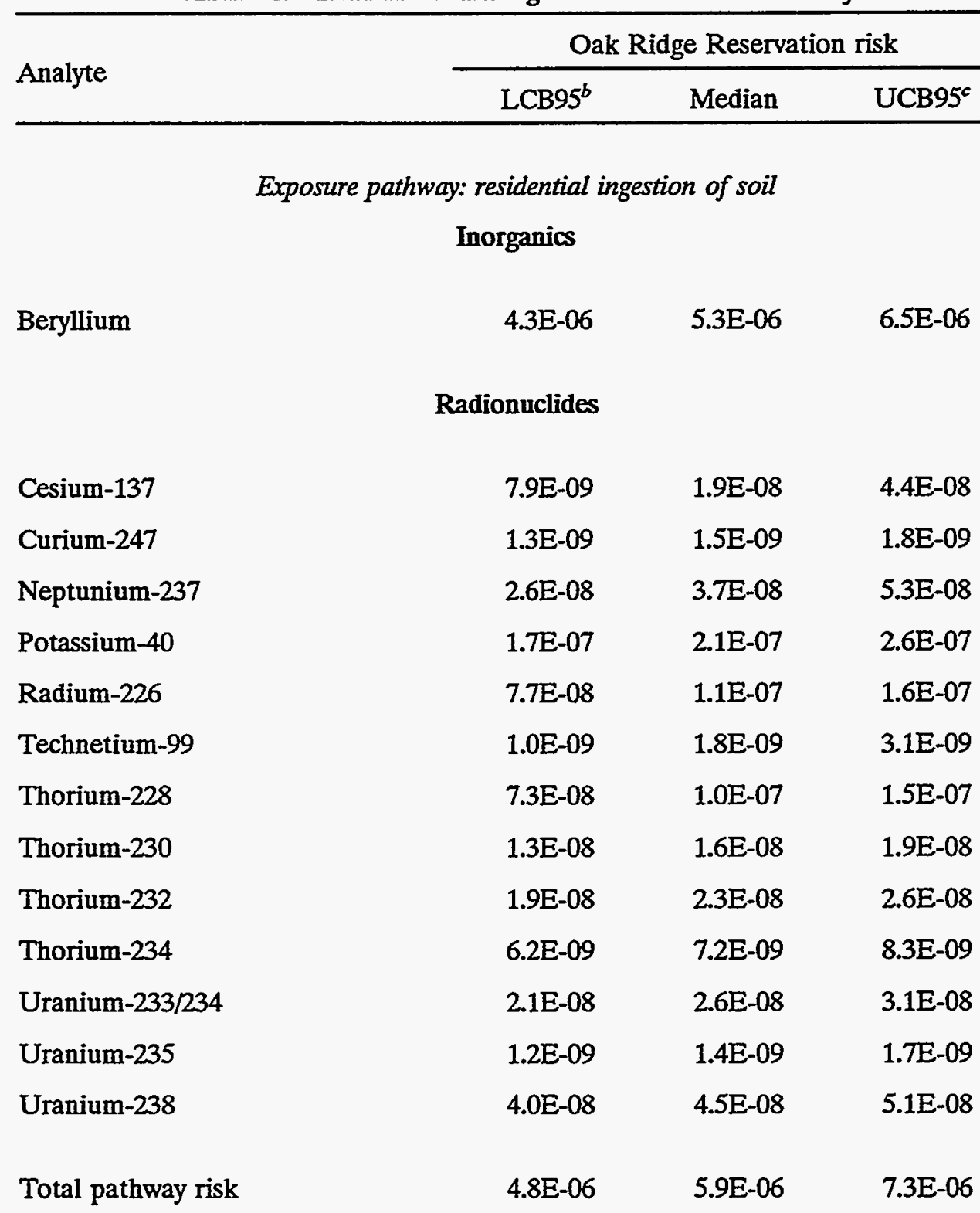

Exposure pathway: residential dermal exposure to soil

Inorganics

$\begin{array}{llll}\text { Beryllium } & 1.9 \mathrm{E}-06 & 2.4 \mathrm{E}-06 & 2.9 \mathrm{E}-06 \\ \text { Total pathway risk } & 1.9 \mathrm{E}-06 & 2.4 \mathrm{E}-06 & 2.9 \mathrm{E}-06\end{array}$


Table 7.13a (continued)

\begin{tabular}{|c|c|c|c|}
\hline \multirow{2}{*}{ Analyte } & \multicolumn{3}{|c|}{ Oak Ridge Reservation risk } \\
\hline & $\mathrm{LCB}^{b} 5^{b}$ & Median & $\mathrm{UCB}^{\circ} 5^{\circ}$ \\
\hline \multicolumn{4}{|c|}{ Exposure pathway: residential external exposure to radiation } \\
\hline & ionuclides & & \\
\hline Cesium-137 & 1.1E-05 & $2.5 \mathrm{E}-05$ & $6.0 \mathrm{E}-05$ \\
\hline Curium-247 & 1.0E-07 & 1.2E-07 & 1.4E-07 \\
\hline Neptunium-237 & 9.6E-07 & 1.4E-06 & 2.0E-06 \\
\hline Potassium-40 & 1.6E-04 & 2.0E-04 & 2.4E-04 \\
\hline Radium-226 & 7.3E-05 & 1.1E-04 & 1.5E-04 \\
\hline Technetium-99 & 9.1E-12 & $1.6 \mathrm{E}-11$ & 2.8E-11 \\
\hline Thorium-228 & 1.4E-04 & $2.0 \mathrm{E}-04$ & 2.9E-04 \\
\hline Thorium-230 & 1.0E-09 & 1.3E-09 & $1.5 \mathrm{E}-09$ \\
\hline Thorium-232 & $8.0 \mathrm{E}-10$ & 9.3E-10 & 1.1E-09 \\
\hline Thorium-234 & $1.0 \mathrm{E}-07$ & 1.2E-07 & 1.4E-07 \\
\hline Uranium-233/234 & 1.1E-09 & 1.3E-09 & $1.6 \mathrm{E}-09$ \\
\hline Uranium-235 & $3.4 \mathrm{E}-07$ & 4.1E-07 & 4.9E-07 \\
\hline Uranium-238 & $9.9 \mathrm{E}-07$ & 1.1E-06 & 1.2E-06 \\
\hline Total pathway risk & 3.9E-04 & 5.3E-04 & 7.5E-04 \\
\hline Total Cumulative Risk ${ }^{d}$ & 4.0E-04 & 5.4E-04 & 7.6E-04 \\
\hline
\end{tabular}

aThe LCB95, median, and UCB95 analyte concentrations are evaluated in terms of total background risk (risk to an adult plus risk to a child).

${ }^{b} \mathrm{LCB} 95=$ Lower $95 \%$ confidence bound on the median.

UCB95 = Upper 95\% confidence bound on the median.

dThe sum of the risk from all analytes for all pathways. 
Table 7.13b. Comparative background risk estimates from exposure to soil constituents from the Oak Ridge Reservation-Chepultepec

\begin{tabular}{|c|c|c|c|}
\hline \multirow{2}{*}{ Analyte } & \multicolumn{3}{|c|}{ Oak Ridge Reservation risk } \\
\hline & $\mathrm{LCB} 95^{b}$ & Median & $\mathrm{UCB}^{c}{ }^{c}$ \\
\hline
\end{tabular}

Exposure pathway: residential ingestion of soil

Inorganics

Beryllium

Benzo(a)anthracene

Benzo(a)pyrene

Benzo(b)fluoranthene

Benzo(g,h,i)perylene

Benzo(k)fluoranthene

Dibenz $(a, h)$ anthracene

Indeno(1,2,3-cd)pyrene

Phenanthrene
$1.8 \mathrm{E}-06$

Organics

1.3E-06

$2.5 \mathrm{E}-05$

$1.9 \mathrm{E}-06$

2.1E-05

1.2E-06

5.9E-06

4.4E-06

$2.5 \mathrm{E}-05$

Radionuclides

Cesium-137

Neptunium-237

Plutonium-238

Potassium-40

Radium-226

Thorium-228

Thorium-230

Thorium-232

Uranium-233/234

Uranium-235

Uranium-238

Total pathway risk
$1.5 \mathrm{E}-08$

$1.4 \mathrm{E}-08$

1.4E-08

3.6E-08

$9.0 \mathrm{E}-08$

2.9E-08

1.1E-08

8.1E-09

$1.8 \mathrm{E}-08$

$1.0 \mathrm{E}-09$

3.5E-08

8.7E-05

2.4E-06

3.1E-06

2.8E-06

$5.6 \mathrm{E}-05$

6.0E-06

4.2E-05

2.6E-06

2.3E-05

1.8E-05

$5.2 \mathrm{E}-05$

8.3E-08

$2.5 \mathrm{E}-08$

3.6E-08

5.3E-08

$1.9 \mathrm{E}-07$

6.0E-08

$1.5 \mathrm{E}-08$

1.1E-08

2.7E-08

2.1E-09

4.4E-08

2.1E-04

Exposure pathway: residential dermal exposure to soil

Inorganics

Beryllium

8.0E-07

$1.0 \mathrm{E}-06$

1.4E-06 
Table 7.13b (continued)

\begin{tabular}{llll}
\hline \multirow{2}{*}{ Analyte ... } & \multicolumn{3}{c}{ Oak Ridge Reservation risk } \\
\cline { 2 - 4 } & $\mathrm{LCB95}^{b}$ & Median & $\mathrm{UCB95}^{c}$ \\
\hline
\end{tabular}

Exposure pathway: residential dermal exposure to soil (continued)

Organics

$\begin{array}{llll}\text { Benzo(a)anthracene } & 3.0 \mathrm{E}-07 & 4.3 \mathrm{E}-07 & 6.3 \mathrm{E}-07 \\ \text { Benzo(a)pyrene } & 5.6 \mathrm{E}-06 & 8.4 \mathrm{E}-06 & 1.3 \mathrm{E}-05 \\ \text { Benzo(b)fluoranthene } & 4.3 \mathrm{E}-07 & 7.6 \mathrm{E}-07 & 1.3 \mathrm{E}-06 \\ \text { Benzo(g,h,i)perylene } & 4.6 \mathrm{E}-06 & 6.5 \mathrm{E}-06 & 9.4 \mathrm{E}-06 \\ \text { Benzo(k)fluoranthene } & 2.7 \mathrm{E}-07 & 4.0 \mathrm{E}-07 & 5.8 \mathrm{E}-07 \\ \text { Dibenz(a,h)anthracene } & 1.3 \mathrm{E}-06 & 2.6 \mathrm{E}-06 & 5.2 \mathrm{E}-06 \\ \text { Indeno(1,2,3-cd)pyrene } & 9.9 \mathrm{E}-07 & 2.0 \mathrm{E}-06 & 4.1 \mathrm{E}-06 \\ \text { Phenanthrene } & 5.5 \mathrm{E}-06 & 7.9 \mathrm{E}-06 & 1.1 \mathrm{E}-05 \\ \text { Total pathway risk } & 2.0 \mathrm{E}-05 & 3.0 \mathrm{E}-05 & 4.7 \mathrm{E}-05\end{array}$

Exposure pathway: residential external exposure to radiation Radionuclides

\begin{tabular}{llll} 
Cesium-137 & $2.0 \mathrm{E}-05$ & $4.8 \mathrm{E}-05$ & $1.1 \mathrm{E}-04$ \\
Neptunium-237 & $5.2 \mathrm{E}-07$ & $6.9 \mathrm{E}-07$ & $9.2 \mathrm{E}-07$ \\
Plutonium-238 & $3.3 \mathrm{E}-11$ & $5.4 \mathrm{E}-11$ & $8.8 \mathrm{E}-11$ \\
Potassium-40 & $3.4 \mathrm{E}-05$ & $4.1 \mathrm{E}-05$ & $5.0 \mathrm{E}-05$ \\
Radium-226 & $8.6 \mathrm{E}-05$ & $1.3 \mathrm{E}-04$ & $1.8 \mathrm{E}-04$ \\
Thorium-228 & $5.7 \mathrm{E}-05$ & $8.1 \mathrm{E}-05$ & $1.2 \mathrm{E}-04$ \\
Thorium-230 & $8.4 \mathrm{E}-10$ & $1.0 \mathrm{E}-09$ & $1.2 \mathrm{E}-09$ \\
Thorium-232 & $3.3 \mathrm{E}-10$ & $3.9 \mathrm{E}-10$ & $4.5 \mathrm{E}-10$ \\
Uranium-233/234 & $9.2 \mathrm{E}-10$ & $1.1 \mathrm{E}-09$ & $1.3 \mathrm{E}-09$ \\
Uranium-235 & $2.9 \mathrm{E}-07$ & $4.2 \mathrm{E}-07$ & $6.0 \mathrm{E}-07$ \\
Uranium-238 & $8.7 \mathrm{E}-07$ & $9.7 \mathrm{E}-07$ & $1.1 \mathrm{E}-06$ \\
Total pathway risk & $2.0 \mathrm{E}-04$ & $3.0 \mathrm{E}-04$ & $4.6 \mathrm{E}-04$ \\
Total Cumulative Risk & & & \\
\hline
\end{tabular}

${ }^{\circ}$ The LCB95, median, and UCB95 analyte concentrations are evaluated in terms of total background risk (risk to an adult plus risk to a child).

${ }^{b}$ LCB95 $=$ Lower $95 \%$ confidence bound on the median.

'UCB95 = Upper 95\% confidence bound on the median.

'The sum of the risk from all analytes for all pathways. 
Table 7.14a. Comparative background hazard index estimates from exposure to soil constituents from the Oak Ridge Reservation, Anderson County, and Roane County-Dismal Gap ${ }^{a}$

\begin{tabular}{|c|c|c|c|c|c|c|c|c|c|}
\hline \multirow{2}{*}{ Analyte } & \multicolumn{3}{|c|}{ Oak Ridge Reservation HI } & \multicolumn{3}{|c|}{ Anderson County HI } & \multicolumn{3}{|c|}{ Roane County HI } \\
\hline & $\mathrm{LCB}^{b} 5^{b}$ & Median & UCB95 ${ }^{c}$ & $\mathrm{LCB}^{5} 5^{b}$ & Median & UCB95 & $\mathrm{LCB}^{\circ} 5^{b}$ & Median & UCB95 ${ }^{c}$ \\
\hline \multicolumn{10}{|c|}{ Exposure pathway: residential ingestion of soil } \\
\hline \multicolumn{10}{|c|}{ Inorganics } \\
\hline Antimony & - & - & - & $3.0 \mathrm{E}-02$ & $3.1 E-02$ & $3.3 \mathrm{E}-02$ & - & - & - \\
\hline Arsenic & 2.3E-01 & $2.9 \mathrm{E}-01$ & $3.8 \mathrm{E}-01$ & $1.6 \mathrm{E}-01$ & 2.1E-01 & $2.6 \mathrm{E}-01$ & $2.2 \mathrm{E}-01$ & $2.8 \mathrm{E}-01$ & $3.5 \mathrm{E}-01$ \\
\hline Barium & $1.5 \mathrm{E}-02$ & $2.0 E-02$ & $26 \mathrm{E}-02$ & $1.3 \mathrm{E}-02$ & $1.6 \mathrm{E}-02$ & $2.1 E-02$ & $1.4 \mathrm{E}-02$ & $1.8 \mathrm{E}-02$ & 2.3E-02 \\
\hline Beryllium & $1.8 \mathrm{E}-03$ & $2.2 \mathrm{E}-03$ & $2.7 \mathrm{E}-03$ & $1.9 E-03$ & $2.4 \mathrm{E}-03$ & $2.9 \mathrm{E}-03$ & $1.5 \mathrm{E}-03$ & $1.8 \mathrm{E}-03$ & $2.2 \mathrm{E}-03$ \\
\hline Boron & $1.3 \mathrm{E}-03$ & $2.2 \mathrm{E}-03$ & $3.6 \mathrm{E}-03$ & - & - & - & $2.8 \mathrm{E}-03$ & 4.1E-03 & $6.0 \mathrm{E}-03$ \\
\hline Chromium VI & $1.9 \mathrm{E}-02$ & 2.3E-02 & $27 \mathrm{E}-02$ & $2.2 \mathrm{E}-02$ & $2.6 \mathrm{E}-02$ & $3.0 \mathrm{E}-02$ & $2.1 E-02$ & $2.5 E-02$ & 2.9E-02 \\
\hline Cyanide & $4.3 \mathrm{E}-05$ & 9.2E-05 & $2.0 \mathrm{E}-04$ & $5.0 \mathrm{E}-05$ & $9.5 \mathrm{E}-05$ & $1.8 \mathrm{E}-04$ & $1.2 \mathrm{E}-04$ & 2.3E-04 & 4.1E-04 \\
\hline Manganese & $7.4 \mathrm{E}-02$ & $1.0 \mathrm{E}-01$ & $1.4 \mathrm{E}-01$ & $5.2 \mathrm{E}-02$ & $7.2 \mathrm{E}-02$ & $9.8 \mathrm{E}-02$ & $1.3 E-01$ & 1.7E-01 & $2.4 \mathrm{E}-01$ \\
\hline Mercury & $1.3 \mathrm{E}-02$ & $1.5 \mathrm{E}-02$ & $1.7 \mathrm{E}-02$ & $3.6 \mathrm{E}-03$ & $4.5 \mathrm{E}-03$ & $5.6 \mathrm{E}-03$ & $6.1 E-03$ & $7.3 E-03$ & 8.7E-03 \\
\hline Mercury (salts) & $1.3 \mathrm{E}-02$ & $1.5 \mathrm{E}-02$ & $1.7 \mathrm{E}-02$ & $3.6 \mathrm{E}-03$ & $4.5 \mathrm{E}-03$ & $5.6 \mathrm{E}-03$ & $6.1 E-03$ & $7.3 E-03$ & 8.7E-03 \\
\hline Nickel & $1.3 \mathrm{E}-02$ & 1.7E-02 & $2.1 E-02$ & $1.2 \mathrm{E}-02$ & $1.5 \mathrm{E}-02$ & $1.8 \mathrm{E}-02$ & $9.6 \mathrm{E}-03$ & $1.2 \mathrm{E}-02$ & $1.5 \mathrm{E}-02$ \\
\hline Nickel (salts) & $1.3 \mathrm{E}-02$ & $1.7 \mathrm{E}-02$ & $2.1 \mathrm{E}-02$ & $1.2 \mathrm{E}-02$ & $1.5 \mathrm{E}-02$ & $1.8 \mathrm{E}-02$ & $9.6 \mathrm{E}-03$ & $1.2 \mathrm{E}-02$ & $1.5 \mathrm{E}-02$ \\
\hline Selenium & - & - & - & 1.7E-03 & 2.1E-03 & 2.7E-03 & $1.5 \mathrm{E}-03$ & $2.0 \mathrm{E}-03$ & $2.8 \mathrm{E}-03$ \\
\hline Strontium & $1.3 \mathrm{E}-04$ & $1.9 E-04$ & $2.7 \mathrm{E}-04$ & $1.1 \mathrm{E}-04$ & $1.5 E-04$ & $2.0 \mathrm{E}-04$ & $8.5 \mathrm{E}-05$ & $1.2 \mathrm{E}-04$ & $1.6 \mathrm{E}-04$ \\
\hline Vanadium & $6.0 \mathrm{E}-02$ & $6.9 E-02$ & $7.9 \mathrm{E}-02$ & $5.4 \mathrm{E}-02$ & $6.1 E-02$ & $7.0 \mathrm{E}-02$ & $5.7 \mathrm{E}-02$ & $6.5 \mathrm{E}-02$ & 7.5E-02 \\
\hline Zinc & $1.9 \mathrm{E}-03$ & $2.4 E-03$ & $3.0 \mathrm{E}-03$ & $1.9 \mathrm{E}-03$ & $2.3 \mathrm{E}-03$ & $29 \mathrm{E}-03$ & $1.6 \mathrm{E}-03$ & $1.9 \mathrm{E}-03$ & $2.4 \mathrm{E}-03$ \\
\hline Total pathway $\mathrm{HI}^{d}$ & $4.3 \mathrm{E}-01$ & $5.5 E-01$ & $6.9 \mathrm{E}-01$ & $3.5 E-01$ & $4.4 \mathrm{E}-01$ & $5.5 E-01$ & $4.6 \mathrm{E}-01$ & $5.9 \mathrm{E}-01$ & $7.6 \mathrm{E}-01$ \\
\hline
\end{tabular}

Exposure pathway: residential dermal exposure to soil

Inorganics

$\begin{array}{lccccccccc}\text { Antimony } & - & - & - & 2.7 \mathrm{E}-03 & 2.8 \mathrm{E}-03 & 2.9 \mathrm{E}-03 & - & - & - \\ \text { Arsenic } & 3.1 \mathrm{E}-03 & 3.9 \mathrm{E}-03 & 5.0 \mathrm{E}-03 & 2.1 \mathrm{E}-03 & 2.7 \mathrm{E}-03 & 3.5 \mathrm{E}-03 & 2.9 \mathrm{E}-03 & 3.7 \mathrm{E}-03 & 4.7 \mathrm{E}-03 \\ \text { Barium } & 2.1 \mathrm{E}-03 & 2.7 \mathrm{E}-03 & 3.5 \mathrm{E}-03 & 1.7 \mathrm{E}-03 & 2.2 \mathrm{E}-03 & 2.8 \mathrm{E}-03 & 1.8 \mathrm{E}-03 & 2.4 \mathrm{E}-03 & 3.1 \mathrm{E}-03 \\ \text { Beryllium } & 4.8 \mathrm{E}-04 & 5.9 \mathrm{E}-04 & 7.2 \mathrm{E}-04 & 5.1 \mathrm{E}-04 & 6.3 \mathrm{E}-04 & 7.7 \mathrm{E}-04 & 4.0 \mathrm{E}-04 & 4.9 \mathrm{E}-04 & 6.0 \mathrm{E}-04 \\ \text { Boron } & 1.7 \mathrm{E}-05 & 2.9 \mathrm{E}-05 & 4.8 \mathrm{E}-05 & - & - & - & 3.7 \mathrm{E}-05 & 5.4 \mathrm{E}-05 & 8.0 \mathrm{E}-05 \\ \text { Chromium VI } & 4.1 \mathrm{E}-03 & 4.8 \mathrm{E}-03 & 5.7 \mathrm{E}-03 & 4.6 \mathrm{E}-03 & 5.5 \mathrm{E}-03 & 6.5 \mathrm{E}-03 & 4.5 \mathrm{E}-03 & 5.3 \mathrm{E}-03 & 6.3 \mathrm{E}-03 \\ \text { Cyanide } & 1.4 \mathrm{E}-06 & 3.1 \mathrm{E}-06 & 6.6 \mathrm{E}-06 & 1.7 \mathrm{E}-06 & 3.2 \mathrm{E}-06 & 6.0 \mathrm{E}-06 & 4.1 \mathrm{E}-06 & 7.5 \mathrm{E}-06 & 1.4 \mathrm{E}-05 \\ \text { Manganese } & 2.0 \mathrm{E}-02 & 2.7 \mathrm{E}-02 & 3.7 \mathrm{E}-02 & 1.4 \mathrm{E}-02 & 1.9 \mathrm{E}-02 & 2.6 \mathrm{E}-02 & 3.4 \mathrm{E}-02 & 4.6 \mathrm{E}-02 & 6.4 \mathrm{E}-02 \\ \text { Mercury } & 1.7 \mathrm{E}-04 & 2.0 \mathrm{E}-04 & 2.3 \mathrm{E}-04 & 4.8 \mathrm{E}-05 & 6.0 \mathrm{E}-05 & 7.4 \mathrm{E}-05 & 8.2 \mathrm{E}-05 & 9.7 \mathrm{E}-05 & 1.2 \mathrm{E}-04 \\ \text { Mercury (salts) } & 1.1 \mathrm{E}-03 & 1.3 \mathrm{E}-03 & 1.6 \mathrm{E}-03 & 3.2 \mathrm{E}-04 & 4.0 \mathrm{E}-04 & 5.0 \mathrm{E}-04 & 5.4 \mathrm{E}-04 & 6.5 \mathrm{E}-04 & 7.7 \mathrm{E}-04 \\ \text { Nickel } & 1.8 \mathrm{E}-04 & 2.2 \mathrm{E}-04 & 2.8 \mathrm{E}-04 & 1.6 \mathrm{E}-04 & 2.0 \mathrm{E}-04 & 2.4 \mathrm{E}-04 & 1.3 \mathrm{E}-04 & 1.6 \mathrm{E}-04 & 2.0 \mathrm{E}-04 \\ \text { Nickel (salts) } & 3.6 \mathrm{E}-03 & 4.4 \mathrm{E}-03 & 5.5 \mathrm{E}-03 & 3.2 \mathrm{E}-03 & 3.9 \mathrm{E}-03 & 4.9 \mathrm{E}-03 & 2.6 \mathrm{E}-03 & 3.2 \mathrm{E}-03 & 3.9 \mathrm{E}-03 \\ \text { Selenium } & - & - & - & 3.7 \mathrm{E}-05 & 4.7 \mathrm{E}-05 & 5.9 \mathrm{E}-05 & 3.3 \mathrm{E}-05 & 4.6 \mathrm{E}-05 & 6.3 \mathrm{E}-05 \\ \text { Strontium } & 1.7 \mathrm{E}-06 & 2.5 \mathrm{E}-06 & 3.6 \mathrm{E}-06 & 1.4 \mathrm{E}-06 & 1.9 \mathrm{E}-06 & 2.7 \mathrm{E}-06 & 1.1 \mathrm{E}-06 & 1.6 \mathrm{E}-06 & 2.1 \mathrm{E}-06 \\ \text { Vanadium } & 3.1 \mathrm{E}-02 & 3.6 \mathrm{E}-02 & 4.1 \mathrm{E}-02 & 2.8 \mathrm{E}-02 & 3.2 \mathrm{E}-02 & 3.6 \mathrm{E}-02 & 3.0 \mathrm{E}-02 & 3.4 \mathrm{E}-02 & 3.9 \mathrm{E}-02 \\ \text { Zinc } & 5.2 \mathrm{E}-05 & 6.4 \mathrm{E}-05 & 7.9 \mathrm{E}-05 & 5.1 \mathrm{E}-05 & 6.3 \mathrm{E}-05 & 7.7 \mathrm{E}-05 & 4.1 \mathrm{E}-05 & 5.1 \mathrm{E}-05 & 6.3 \mathrm{E}-05 \\ & & & & & & & & & \end{array}$

a The LCB95, median, and UCB95 analyte concentrations are evaluated in terms of total hazard index (total HI = HI chronic for an adult plus HI subchronic for a child).

${ }^{b_{L}}$ CB95 $=$ Lower $95 \%$ confidence bound on the median.

UCB95 = Upper 95\% confidence bound on the median.

${ }^{d}$ The total pathway hazard index does not include HI values for mercury and nickel metals. 
Table 7.14b. Comparative background hazard index estimates from exposure to soil constituents from the Oak Ridge Reservation, Anderson County, and Roane County-Copper Ridge ${ }^{a}$

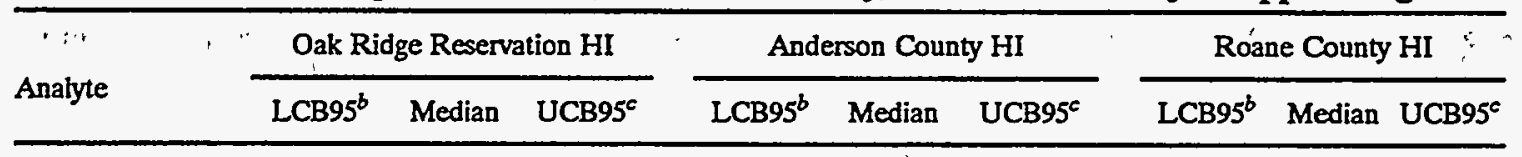

Exposure pathway: residential ingestion of soil

\begin{tabular}{|c|c|c|c|c|c|c|c|c|c|}
\hline \multicolumn{10}{|c|}{ Inorganics } \\
\hline Arsenic & $8.9 \mathrm{E}-01$ & $1.1 E+00$ & $1.5 \mathrm{E}+00$ & $4.5 \mathrm{E}-01$ & $5.7 \mathrm{E}-01$ & 7.3E-01 & $3.4 \mathrm{E}-01$ & $4.4 \mathrm{E}-01$ & $5.6 \mathrm{E}-01$ \\
\hline Barium & $1.1 \mathrm{E}-02$ & $1.5 E-02$ & $1.9 \mathrm{E}-02$ & $1.8 \mathrm{E}-02$ & $2.3 \mathrm{E}-02$ & $3.0 \mathrm{E}-02$ & $9.5 E-03$ & $1.2 E-02$ & $1.6 \mathrm{E}-02$ \\
\hline Beryllium & $1.2 \mathrm{E}-03$ & $1.4 \mathrm{E}-03$ & $1.8 \mathrm{E}-03$ & $1.7 \mathrm{E}-03$ & $2.1 E-03$ & $2.6 \mathrm{E}-03$ & $1.1 \mathrm{E}-03$ & $1.3 \mathrm{E}-03$ & $1.6 \mathrm{E}-03$ \\
\hline Chromium VI & $1.2 E-02$ & $1.4 \mathrm{E}-02$ & $1.7 \mathrm{E}-02$ & $1.6 \mathrm{E}-02$ & $1.8 \mathrm{E}-02$ & $2.2 \mathrm{E}-02$ & $9.8 \mathrm{E}-03$ & $1.2 \mathrm{E}-02$ & $1.4 \mathrm{E}-02$ \\
\hline Manganese & $7.9 E-02$ & $1.1 E-01$ & $1.5 \mathrm{E}-01$ & $1.6 \mathrm{E}-01$ & $2.3 \mathrm{E}-01$ & 3.1E-01 & $6.3 \mathrm{E}-02$ & $8.6 \mathrm{E}-02$ & $1.2 \mathrm{E}-01$ \\
\hline Mercury & $6.3 E-03$ & $7.4 \mathrm{E}-03$ & 8.7E-03 & 4.4E-03 & $5.2 \mathrm{E}-03$ & $6.1 E-03$ & 4.7E-03 & $5.6 \mathrm{E}-03$ & $6.6 \mathrm{E}-03$ \\
\hline Mercury (salts) & $6.3 \mathrm{E}-03$ & $7.4 \mathrm{E}-03$ & 8.7E-03 & 4.4E-03 & $5.2 \mathrm{E}-03$ & $6.1 E-03$ & 4.7E-03 & $5.6 \mathrm{E}-03$ & $6.6 \mathrm{E}-03$ \\
\hline Molybdenum & $3.2 \mathrm{E}-03$ & $4.0 \mathrm{E}-03$ & $5.0 \mathrm{E}-03$ & - & - & - & - & - & - \\
\hline Nickel & $4.3 \mathrm{E}-03$ & $5.4 \mathrm{E}-03$ & $6.9 \mathrm{E}-03$ & $4.9 \mathrm{E}-03$ & $6.1 E-03$ & $7.6 \mathrm{E}-03$ & - & - & - \\
\hline Nickel (salts) & $4.3 \mathrm{E}-03$ & $5.4 \mathrm{E}-03$ & $6.9 \mathrm{E}-03$ & $4.9 \mathrm{E}-03$ & $6.1 \mathrm{E}-03$ & $7.6 \mathrm{E}-03$ & - & - & - \\
\hline Selenium & $1.4 \mathrm{E}-03$ & $1.8 \mathrm{E}-03$ & $2.3 \mathrm{E}-03$ & $23 \mathrm{E}-03$ & $2.9 \mathrm{E}-03$ & $3.7 \mathrm{E}-03$ & $1.1 \mathrm{E}-03$ & $1.4 \mathrm{E}-03$ & $1.8 \mathrm{E}-03$ \\
\hline Strontium & $6.0 \mathrm{E}-05$ & $8.3 E-05$ & $1.1 E-04$ & $9.6 \mathrm{E}-05$ & $1.3 \mathrm{E}-04$ & $1.8 \mathrm{E}-04$ & $5.7 \mathrm{E}-05$ & 8.2E-05 & $1.2 \mathrm{E}-04$ \\
\hline Vanadium & 4.7E-02 & $5.3 E-02$ & $6.1 E-02$ & $6.1 E-02$ & $7.0 \mathrm{E}-02$ & $8.0 \mathrm{E}-02$ & 4.1E-02 & 4.7E-02 & $5.3 E-02$ \\
\hline Zinc & $1.3 E-03$ & $1.6 \mathrm{E}-03$ & $2.0 \mathrm{E}-03$ & $1.7 E-03$ & $2.1 E-03$ & $2.6 \mathrm{E}-03$ & $1.5 E-03$ & $1.9 E-03$ & $2.3 E-03$ \\
\hline \multicolumn{10}{|c|}{ Organics } \\
\hline Acenaphthene & $4.6 \mathrm{E}-05$ & $6.3 E-05$ & $8.5 \mathrm{E}-05$ & $3.6 \mathrm{E}-05$ & $5.3 E-05$ & 7.7E-05 & 2.1E-05 & $3.5 \mathrm{E}-05$ & $6.0 \mathrm{E}-05$ \\
\hline Anthracene & $4.8 \mathrm{E}-0.6$ & $7.8 \mathrm{E}-06$ & $1.3 E-05$ & 7.1E-06 & $1.2 \mathrm{E}-05$ & $2.0 \mathrm{E}-05$ & 7.7E-06 & $1.2 \mathrm{E}-05$ & $2.0 \mathrm{E}-05$ \\
\hline Fluoranthene & $2.9 \mathrm{E}-04$ & $3.9 \mathrm{E}-04$ & $5.4 \mathrm{E}-04$ & $1.2 \mathrm{E}-04$ & $1.9 \mathrm{E}-04$ & $2.9 \mathrm{E}-04$ & $2.1 E-04$ & 2.9E-04 & $4.0 \mathrm{E}-04$ \\
\hline Fluorene & $3.2 \mathrm{E}-05$ & $5.8 \mathrm{E}-05$ & 1.1E-04 & 7.7E-05 & $1.4 \mathrm{E}-04$ & $2.7 \mathrm{E}-04$ & $3.5 \mathrm{E}-05$ & $6.2 \mathrm{E}-05$ & $1.1 \mathrm{E}-04$ \\
\hline Naphthalene & $1.4 \mathrm{E}-03$ & $2.8 \mathrm{E}-03$ & $5.8 \mathrm{E}-03$ & - & - & - & - & - & - \\
\hline Pyrene & $3.2 \mathrm{E}-04$ & 4.4E-04 & $6.2 \mathrm{E}-04$ & $1.9 \mathrm{E}-04$ & $2.7 \mathrm{E}-04$ & $3.9 \mathrm{E}-04$ & $1.3 E-04$ & $1.9 E-04$ & $2.6 \mathrm{E}-04$ \\
\hline Total pathway $\mathrm{HI}^{d}$ & $1.1 E+00$ & $1.4 E+00$ & $1.7 \mathrm{E}+00$ & 7.2E-01 & 9.3E-01 & $1.2 \mathrm{E}+00$ & 4.7E-01 & $6.0 \mathrm{E}-01$ & 7.7E-01 \\
\hline
\end{tabular}

Exposure pathway: residential dermal exposure to soil

\begin{tabular}{lcccccc} 
& & \multicolumn{5}{c}{ Inorganics } \\
Arsenic & $1.2 \mathrm{E}-02$ & $1.5 \mathrm{E}-02$ & $1.9 \mathrm{E}-02$ & $6.0 \mathrm{E}-03$ & $7.6 \mathrm{E}-03$ & $9.7 \mathrm{E}-03$ \\
Barium & $1.5 \mathrm{E}-03$ & $1.9 \mathrm{E}-03$ & $2.5 \mathrm{E}-03$ & $2.4 \mathrm{E}-03$ & $3.1 \mathrm{E}-03$ & $4.1 \mathrm{E}-03$ \\
Beryllium & $3.1 \mathrm{E}-04$ & $3.9 \mathrm{E}-04$ & $4.8 \mathrm{E}-04$ & $4.6 \mathrm{E}-04$ & $5.6 \mathrm{E}-04$ & $6.9 \mathrm{E}-04$ \\
Chromium VI & $2.5 \mathrm{E}-03$ & $3.0 \mathrm{E}-03$ & $3.6 \mathrm{E}-03$ & $3.3 \mathrm{E}-03$ & $3.9 \mathrm{E}-03$ & $4.7 \mathrm{E}-03$ \\
Manganese & $2.1 \mathrm{E}-02$ & $2.9 \mathrm{E}-02$ & $3.9 \mathrm{E}-02$ & $4.4 \mathrm{E}-02$ & $6.0 \mathrm{E}-02$ & $8.3 \mathrm{E}-02$ \\
Mercury & $8.4 \mathrm{E}-05$ & $9.9 \mathrm{E}-05$ & $1.2 \mathrm{E}-04$ & $5.8 \mathrm{E}-05$ & $6.9 \mathrm{E}-05$ & $8.2 \mathrm{E}-05$ \\
Mercury (salts) & $5.6 \mathrm{E}-04$ & $6.6 \mathrm{E}-04$ & $7.7 \mathrm{E}-04$ & $3.9 \mathrm{E}-04$ & $4.6 \mathrm{E}-04$ & $5.4 \mathrm{E}-04$ \\
Molybdenum & $4.3 \mathrm{E}-05$ & $5.3 \mathrm{E}-05$ & $6.6 \mathrm{E}-05$ & - & - & - \\
Nickel. & $5.7 \mathrm{E}-05$ & $7.2 \mathrm{E}-05$ & $9.2 \mathrm{E}-05$ & $6.6 \mathrm{E}-05$ & $8.2 \mathrm{E}-05$ & $1.0 \mathrm{E}-04$ \\
Nickel (salts) & $1.1 \mathrm{E}-03$ & $1.4 \mathrm{E}-03$ & $1.8 \mathrm{E}-03$ & $1.3 \mathrm{E}-03$ & $1.6 \mathrm{E}-03$ & $2.0 \mathrm{E}-03$ \\
Selenium & $3.2 \mathrm{E}-05$ & $4.0 \mathrm{E}-05$ & $5.1 \mathrm{E}-05$ & $5.2 \mathrm{E}-05$ & $6.5 \mathrm{E}-05$ & $8.2 \mathrm{E}-05$ \\
Strontium & $8.1 \mathrm{E}-07$ & $1.1 \mathrm{E}-06$ & $1.5 \mathrm{E}-06$ & $1.3 \mathrm{E}-06$ & $1.8 \mathrm{E}-06$ & $2.4 \mathrm{E}-06$ \\
Vanadium & $2.4 \mathrm{E}-02$ & $2.8 \mathrm{E}-02$ & $3.2 \mathrm{E}-02$ & $3.2 \mathrm{E}-02$ & $3.6 \mathrm{E}-02$ & $4.1 \mathrm{E}-02$ \\
Zinc & $3.6 \mathrm{E}-05$ & $4.4 \mathrm{E}-05$ & $5.4 \mathrm{E}-05$ & $4.5 \mathrm{E}-05$ & $5.5 \mathrm{E}-05$ & $6.9 \mathrm{E}-05$
\end{tabular}

$\begin{array}{ccc}4.5 \mathrm{E}-03 & 5.8 \mathrm{E}-03 & 7.4 \mathrm{E}-03 \\ 1.3 \mathrm{E}-03 & 1.7 \mathrm{E}-03 & 2.1 \mathrm{E}-03 \\ 2.8 \mathrm{E}-04 & 3.4 \mathrm{E}-04 & 4.2 \mathrm{E}-04 \\ 2.1 \mathrm{E}-03 & 2.5 \mathrm{E}-03 & 2.9 \mathrm{E}-03 \\ 1.7 \mathrm{E}-02 & 2.3 \mathrm{E}-02 & 3.2 \mathrm{E}-02 \\ 6.3 \mathrm{E}-05 & 7.4 \mathrm{E}-05 & 8.8 \mathrm{E}-05 \\ 4.2 \mathrm{E}-04 & 5.0 \mathrm{E}-04 & 5.8 \mathrm{E}-04 \\ - & - & - \\ - & - & - \\ - & - & - \\ 2.4 \mathrm{E}-05 & 3.0 \mathrm{E}-05 & 3.9 \mathrm{E}-05 \\ 7.6 \mathrm{E}-07 & 1.1 \mathrm{E}-06 & 1.6 \mathrm{E}-06 \\ 2.1 \mathrm{E}-02 & 2.4 \mathrm{E}-02 & 2.8 \mathrm{E}-02 \\ 4.0 \mathrm{E}-05 & 5.0 \mathrm{E}-05 & 6.1 \mathrm{E}-05\end{array}$ 
Table 7.14b (continued)

\begin{tabular}{|c|c|c|c|c|c|c|c|c|c|}
\hline \multirow[b]{2}{*}{ Analyte } & \multicolumn{3}{|c|}{ Oak Ridge Reservation $\mathrm{HI}$} & \multicolumn{3}{|c|}{ Anderson County $\mathrm{HI}$} & \multicolumn{3}{|c|}{ Roane County HI } \\
\hline & ${\text { LCB } 95^{b}}^{b}$ & Median & $\mathrm{UCB}^{\mathrm{c}}{ }^{\mathrm{c}}$ & $\mathrm{LCB}^{b} 5^{b}$ & Median & UCB95 ${ }^{c}$ & $\mathrm{LCB}^{b} \mathrm{~S}^{b}$ & Median & UCB95 ${ }^{c}$ \\
\hline
\end{tabular}

Exposure pathway: residential dermal exposure to soil (continued)

\begin{tabular}{lccccccccc} 
& \multicolumn{7}{c}{ Organics } \\
Acenaphthene & $1.5 \mathrm{E}-05$ & $2.0 \mathrm{E}-05$ & $2.7 \mathrm{E}-05$ & $1.2 \mathrm{E}-05$ & $1.7 \mathrm{E}-05$ & $2.4 \mathrm{E}-05$ & $6.6 \mathrm{E}-06$ & $1.1 \mathrm{E}-05$ & $1.9 \mathrm{E}-05$ \\
Anthracene & $1.5 \mathrm{E}-06$ & $2.5 \mathrm{E}-06$ & $4.0 \mathrm{E}-06$ & $2.3 \mathrm{E}-06$ & $3.8 \mathrm{E}-06$ & $6.3 \mathrm{E}-06$ & $2.4 \mathrm{E}-06$ & $4.0 \mathrm{E}-06$ & $6.5 \mathrm{E}-06$ \\
Fiuoranthene & $9.2 \mathrm{E}-05$ & $1.3 \mathrm{E}-04$ & $1.7 \mathrm{E}-04$ & $3.9 \mathrm{E}-05$ & $6.0 \mathrm{E}-05$ & $9.3 \mathrm{E}-05$ & $6.8 \mathrm{E}-05$ & $9.2 \mathrm{E}-05$ & $1.3 \mathrm{E}-04$ \\
Fuorene & $1.0 \mathrm{E}-05$ & $1.8 \mathrm{E}-05$ & $3.3 \mathrm{E}-05$ & $2.5 \mathrm{E}-05$ & $4.5 \mathrm{E}-05$ & $8.4 \mathrm{E}-05$ & $1.1 \mathrm{E}-05$ & $2.0 \mathrm{E}-05$ & $3.5 \mathrm{E}-05$ \\
Naphthalene & $1.9 \mathrm{E}-04$ & $3.8 \mathrm{E}-04$ & $7.8 \mathrm{E}-04$ & - & - & - & - & - & - \\
Pyrene & $1.0 \mathrm{E}-04$ & $1.4 \mathrm{E}-04$ & $2.0 \mathrm{E}-04$ & $6.0 \mathrm{E}-05$ & $8.6 \mathrm{E}-05$ & $1.2 \mathrm{E}-04$ & $4.3 \mathrm{E}-05$ & $6.0 \mathrm{E}-05$ & $8.3 \mathrm{E}-05$ \\
& & & & & & & & & \\
Total pathway $\mathrm{HI}^{d}$ & $6.4 \mathrm{E}-02$ & $8.0 \mathrm{E}-02$ & $1.0 \mathrm{E}-01$ & $9.0 \mathrm{E}-02$ & $1.1 \mathrm{E}-01$ & $1.5 \mathrm{E}-01$ & $4.7 \mathrm{E}-02$ & $5.8 \mathrm{E}-02$ & $7.3 \mathrm{E}-02$ \\
\hline
\end{tabular}

The LCB95, median, and UCB95 analyte concentrations are evaluated in terms of total hazard index (total HI = HI chronic for an adult plus HI subchronic for a child).

ILB95 = Lower 95\% confidence bound on the median.

UCB95 = Upper $95 \%$ confidence bound on the median.

The total pathway hazard index does not include HI values for mercury and nickel metals.

Table 7.14c. Comparative background hazard index estimates from exposure to soil constituents from the Oak Ridge Reservation (Bethel Valley and K-25)-Chickamauga ${ }^{a}$

\begin{tabular}{|c|c|c|c|c|c|c|}
\hline \multirow{2}{*}{ Analyte } & \multicolumn{3}{|c|}{ Bethel Valley HI } & \multicolumn{3}{|c|}{ K-25 HI } \\
\hline & $\mathrm{LCB}^{6} 5^{b}$ & Median & UCB95 $5^{c}$ & ${\text { LCB } 95^{b}}^{b}$ & Median & $\mathrm{UCB}^{\circ} 5^{\circ}$ \\
\hline \multicolumn{7}{|c|}{$\begin{array}{c}\text { Exposure pathway: residential ingestion of soil } \\
\text { Inorganies }\end{array}$} \\
\hline Arsenic & 2.3E-01 & $2.9 \mathrm{E}-01$ & $3.8 \mathrm{E}-01$ & $2.8 \mathrm{E}-01$ & $3.6 \mathrm{E}-01$ & 4.6E-01 \\
\hline Barium & $1.2 \mathrm{E}-02$ & $1.6 \mathrm{E}-02$ & $2.1 \mathrm{E}-02$ & $1.2 \mathrm{E}-02$ & $1.6 \mathrm{E}-02$ & $2.0 \mathrm{E}-02$ \\
\hline Beryllium & $2.4 \mathrm{E}-03$ & $2.9 \mathrm{E}-03$ & $3.5 \mathrm{E}-03$ & 2.1E-03 & $2.6 \mathrm{E}-03$ & $3.2 \mathrm{E}-03$ \\
\hline Chromium VI & $2.6 \mathrm{E}-02$ & $3.1 E-02$ & $3.7 \mathrm{E}-02$ & $2.5 \mathrm{E}-02$ & $3.0 \mathrm{E}-02$ & $3.5 \mathrm{E}-02$ \\
\hline Manganese & $7.8 \mathrm{E}-02$ & $1.1 \mathrm{E}-01$ & $1.5 \mathrm{E}-01$ & $1.2 \mathrm{E}-01$ & $1.7 \mathrm{E}-01$ & 2.3E-01 \\
\hline Mercury & $6.4 \mathrm{E}-03$ & $7.5 \mathrm{E}-03$ & $8.8 \mathrm{E}-03$ & $2.0 \mathrm{E}-02$ & 2.3E-02 & 2.7E-02 \\
\hline Mercury (salts) & $6.4 \mathrm{E}-03$ & $7.5 \mathrm{E}-03$ & $8.8 \mathrm{E}-03$ & $2.0 \mathrm{E}-02$ & 2.3E-02 & 2.7E-02 \\
\hline Nickel & 7.7E-03 & $9.5 \mathrm{E}-03$ & $1.2 \mathrm{E}-02$ & $9.8 \mathrm{E}-03$ & $1.2 \mathrm{E}-02$ & $1.5 \mathrm{E}-02$ \\
\hline Nickel (salts) & 7.7E-03 & $9.5 \mathrm{E}-03$ & $1.2 \mathrm{E}-02$ & $9.8 \mathrm{E}-03$ & $1.2 \mathrm{E}-02$ & $1.5 \mathrm{E}-02$ \\
\hline Selenium & $1.7 \mathrm{E}-03$ & $2.1 \mathrm{E}-03$ & $2.6 \mathrm{E}-03$ & $1.7 \mathrm{E}-03$ & $2.2 \mathrm{E}-03$ & $2.7 \mathrm{E}-03$ \\
\hline Strontium & 8.3E-05 & $1.3 \mathrm{E}-04$ & $2.0 \mathrm{E}-04$ & $2.0 \mathrm{E}-04$ & 2.8E-04 & $3.8 \mathrm{E}-04$ \\
\hline Vanadium & $6.5 \mathrm{E}-02$ & $7.4 \mathrm{E}-02$ & $8.5 \mathrm{E}-02$ & $6.5 \mathrm{E}-02$ & 7.4E-02 & $8.5 \mathrm{E}-02$ \\
\hline Zinc & $1.7 \mathrm{E}-03$ & $2.1 \mathrm{E}-03$ & $2.6 \mathrm{E}-03$ & $1.8 \mathrm{E}-03$ & 2.2E-03 & $2.7 \mathrm{E}-03$ \\
\hline
\end{tabular}




\section{$7-105$}

Table 7.14c (continued)

\begin{tabular}{|c|c|c|c|c|c|c|}
\hline \multirow{2}{*}{ Analyte } & \multicolumn{3}{|c|}{ Bethel Valley HI } & \multicolumn{3}{|c|}{$\mathrm{K}-25 \mathrm{HI}$} \\
\hline & $\mathrm{LCB}^{6} 5^{b}$ & Median & $\mathrm{UCB}^{2} 5^{c}$ & $\mathrm{LCB}^{\circ} 5^{b}$ & Median & $\overline{\mathrm{UCB}^{\circ} 5^{\circ}}$ \\
\hline
\end{tabular}

Exposure pathway: residential dermal exposure to soil (continued)

Organies

$\begin{array}{lllllll}\text { Acenaphthene } & 9.1 \mathrm{E}-05 & 1.5 \mathrm{E}-04 & 2.6 \mathrm{E}-04 & 4.3 \mathrm{E}-05 & 5.9 \mathrm{E}-05 & 8.0 \mathrm{E}-05 \\ \text { Anthracene } & 3.0 \mathrm{E}-06 & 5.5 \mathrm{E}-06 & 1.0 \mathrm{E}-05 & 7.1 \mathrm{E}-06 & 1.1 \mathrm{E}-05 & 1.7 \mathrm{E}-05 \\ \text { Fluoranthene } & 2.2 \mathrm{E}-04 & 3.3 \mathrm{E}-04 & 4.8 \mathrm{E}-04 & 3.3 \mathrm{E}-04 & 4.5 \mathrm{E}-04 & 6.3 \mathrm{E}-04 \\ \text { Fluorene } & 8.1 \mathrm{E}-05 & 1.7 \mathrm{E}-04 & 3.7 \mathrm{E}-04 & 6.2 \mathrm{E}-05 & 9.3 \mathrm{E}-05 & 1.4 \mathrm{E}-04 \\ \text { Naphthalene } & 1.2 \mathrm{E}-03 & 2.2 \mathrm{E}-03 & 3.9 \mathrm{E}-03 & 3.6 \mathrm{E}-04 & 6.6 \mathrm{E}-04 & 1.2 \mathrm{E}-03 \\ \text { Pyrene } & 4.3 \mathrm{E}-04 & 6.9 \mathrm{E}-04 & 1.1 \mathrm{E}-03 & 6.9 \mathrm{E}-04 & 9.7 \mathrm{E}-04 & 1.3 \mathrm{E}-03 \\ & & & & & & \\ \text { Total pathway } \mathrm{HI}^{d} & 4.3 \mathrm{E}-01 & 5.5 \mathrm{E}-01 & 7.0 \mathrm{E}-01 & 5.4 \mathrm{E}-01 & 6.9 \mathrm{E}-01 & 8.9 \mathrm{E}-01\end{array}$

Exposure pathway: residential dermal exposure to soil

Inorganics

\begin{tabular}{lllllll} 
Arsenic & $3.1 \mathrm{E}-03$ & $3.9 \mathrm{E}-03$ & $5.0 \mathrm{E}-03$ & $3.8 \mathrm{E}-03$ & $4.8 \mathrm{E}-03$ & $6.1 \mathrm{E}-03$ \\
Barium & $1.7 \mathrm{E}-03$ & $2.1 \mathrm{E}-03$ & $2.8 \mathrm{E}-03$ & $1.6 \mathrm{E}-03$ & $2.1 \mathrm{E}-03$ & $27 \mathrm{E}-03$ \\
Beryllium & $6.3 \mathrm{E}-04$ & $7.7 \mathrm{E}-04$ & $9.4 \mathrm{E}-04$ & $5.6 \mathrm{E}-04$ & $6.9 \mathrm{E}-04$ & $8.5 \mathrm{E}-04$ \\
Chromium VI & $5.6 \mathrm{E}-03$ & $6.6 \mathrm{E}-03$ & $7.9 \mathrm{E}-03$ & $5.4 \mathrm{E}-03$ & $6.3 \mathrm{E}-03$ & $7.5 \mathrm{E}-03$ \\
Manganese & $2.1 \mathrm{E}-02$ & $2.8 \mathrm{E}-02$ & $3.9 \mathrm{E}-02$ & $3.3 \mathrm{E}-02$ & $4.5 \mathrm{E}-02$ & $6.2 \mathrm{E}-02$ \\
Mercury & $8.6 \mathrm{E}-05$ & $1.0 \mathrm{E}-04$ & $1.2 \mathrm{E}-04$ & $2.7 \mathrm{E}-04$ & $3.1 \mathrm{E}-04$ & $3.6 \mathrm{E}-04$ \\
Mercury (salts) & $5.7 \mathrm{E}-04$ & $6.7 \mathrm{E}-04$ & $7.9 \mathrm{E}-04$ & $1.8 \mathrm{E}-03$ & $2.1 \mathrm{E}-03$ & $2.4 \mathrm{E}-03$ \\
Nickel & $1.0 \mathrm{E}-04$ & $1.3 \mathrm{E}-04$ & $1.6 \mathrm{E}-04$ & $1.3 \mathrm{E}-04$ & $1.6 \mathrm{E}-04$ & $2.0 \mathrm{E}-04$ \\
Nickel (salts) & $2.0 \mathrm{E}-03$ & $2.5 \mathrm{E}-03$ & $3.2 \mathrm{E}-03$ & $2.6 \mathrm{E}-03$ & $3.3 \mathrm{E}-03$ & $4.0 \mathrm{E}-03$ \\
Selenium & $3.7 \mathrm{E}-05$ & $4.7 \mathrm{E}-05$ & $5.9 \mathrm{E}-05$ & $3.8 \mathrm{E}-05$ & $4.8 \mathrm{E}-05$ & $6.1 \mathrm{E}-05$ \\
Strontium & $1.1 \mathrm{E}-06$ & $1.7 \mathrm{E}-06$ & $2.7 \mathrm{E}-06$ & $2.7 \mathrm{E}-06$ & $3.7 \mathrm{E}-06$ & $5.0 \mathrm{E}-06$ \\
Vanadium & $3.3 \mathrm{E}-02$ & $3.8 \mathrm{E}-02$ & $4.4 \mathrm{E}-02$ & $3.4 \mathrm{E}-02$ & $3.8 \mathrm{E}-02$ & $4.4 \mathrm{E}-02$ \\
Zinc & $4.6 \mathrm{E}-05$ & $5.7 \mathrm{E}-05$ & $7.0 \mathrm{E}-05$ & $4.7 \mathrm{E}-05$ & $5.8 \mathrm{E}-05$ & $7.2 \mathrm{E}-05$ \\
& & & & & & \\
& & & & & & \\
Acenaphthene & & & & & & \\
Anthracene & $2.9 \mathrm{E}-05$ & $4.9 \mathrm{E}-05$ & $8.4 \mathrm{E}-05$ & $1.4 \mathrm{E}-05$ & $1.9 \mathrm{E}-05$ & $2.5 \mathrm{E}-05$ \\
Fluoranthene & $9.5 \mathrm{E}-07$ & $1.7 \mathrm{E}-06$ & $3.2 \mathrm{E}-06$ & $2.3 \mathrm{E}-06$ & $3.5 \mathrm{E}-06$ & $5.4 \mathrm{E}-06$ \\
Fluorene & $7.1 \mathrm{E}-05$ & $1.0 \mathrm{E}-04$ & $1.5 \mathrm{E}-04$ & $1.0 \mathrm{E}-04$ & $1.4 \mathrm{E}-04$ & $2.0 \mathrm{E}-04$ \\
Naphthalene & $2.6 \mathrm{E}-05$ & $5.5 \mathrm{E}-05$ & $1.2 \mathrm{E}-04$ & $2.0 \mathrm{E}-05$ & $3.0 \mathrm{E}-05$ & $4.5 \mathrm{E}-05$ \\
Pyrene & $1.7 \mathrm{E}-04$ & $2.9 \mathrm{E}-04$ & $5.2 \mathrm{E}-04$ & $4.8 \mathrm{E}-05$ & $8.9 \mathrm{E}-05$ & $1.6 \mathrm{E}-04$ \\
& $1.4 \mathrm{E}-04$ & $2.2 \mathrm{E}-04$ & $3.5 \mathrm{E}-04$ & $2.2 \mathrm{E}-04$ & $3.1 \mathrm{E}-04$ & $4.3 \mathrm{E}-04$ \\
Total pathway $\mathrm{HI}^{d}$ & & & & & & \\
\hline
\end{tabular}

${ }^{a}$ The LCB95, median, and UCB95 analyte concentrations are evaluated in terms of total hazard index (total HI = HI chronic for an adult plus HI subchronic for a child).

${ }^{b}$ LCB95 = Lower $95 \%$ confidence bound on the median.

UCB95 = Upper 95\% confidence bound on the median.

${ }^{d}$ The total pathway hazard index does not include HI values for mercury and nickel metals. 
Table 7.15a. Comparative background hazard index estimates from exposure to soil constituents from the Oak Ridge Reservation-Nolichucky"

\begin{tabular}{|c|c|c|c|}
\hline \multirow[b]{2}{*}{ Analyte } & \multicolumn{3}{|c|}{ Oak Ridge Reservation $\mathrm{HI}$} \\
\hline & $\mathrm{LCB}^{\circ} 5^{b}$ & Median & $\mathrm{UCB}^{\circ}$ \\
\hline \multicolumn{4}{|c|}{ Exposure pathway: residential ingestion of soil } \\
\hline \multicolumn{4}{|c|}{ Inorganics } \\
\hline Antimony & $1.6 \mathrm{E}-02$ & $1.6 \mathrm{E}-02$ & 1.7E-02 \\
\hline Arsenic & $2.2 \mathrm{E}-01$ & $2.9 \mathrm{E}-01$ & $3.9 \mathrm{E}-01$ \\
\hline Barium & $1.2 \mathrm{E}-02$ & $1.5 \mathrm{E}-02$ & $2.0 \mathrm{E}-02$ \\
\hline Beryllium & $1.8 \mathrm{E}-03$ & $2.2 \mathrm{E}-03$ & 2.7E-03 \\
\hline Chromium VI & 2.1E-02 & $2.6 \mathrm{E}-02$ & $3.1 \mathrm{E}-02$ \\
\hline Manganese & $4.8 \mathrm{E}-02$ & $6.6 \mathrm{E}-02$ & $9.0 \mathrm{E}-02$ \\
\hline Mercury & $7.4 \mathrm{E}-03$ & $8.7 \mathrm{E}-03$ & $1.0 \mathrm{E}-02$ \\
\hline Mercury (salts) & 7.4E-03 & 8.7E-03 & $1.0 \mathrm{E}-02$ \\
\hline Nickel & $9.9 \mathrm{E}-03$ & $1.2 \mathrm{E}-02$ & $1.5 \mathrm{E}-02$ \\
\hline Nickel (salts) & $9.9 \mathrm{E}-03$ & $1.2 \mathrm{E}-02$ & $1.5 \mathrm{E}-02$ \\
\hline Selenium & $1.3 E-03$ & $1.6 \mathrm{E}-03$ & $2.0 \mathrm{E}-03$ \\
\hline Strontium & $7.8 \mathrm{E}-05$ & 1.1E-04 & $1.5 \mathrm{E}-04$ \\
\hline Vanadium & 5.7E-02 & $6.6 \mathrm{E}-02$ & $7.5 \mathrm{E}-02$ \\
\hline Zinc & $1.4 \mathrm{E}-03$ & $1.8 \mathrm{E}-03$ & $2.2 \mathrm{E}-03$ \\
\hline Total pathway $\mathbf{H I}^{d}$ & $3.9 \mathrm{E}-01$ & $5.1 \mathrm{E}-01$ & $6.5 \mathrm{E}-01$ \\
\hline \multicolumn{4}{|c|}{ Exposure pathway: residential dermal exposure to soil } \\
\hline \multicolumn{4}{|c|}{ Inorganics } \\
\hline Antimony & $1.4 \mathrm{E}-03$ & $1.5 E-03$ & $1.5 \mathrm{E}-03$ \\
\hline Arsenic & $2.9 \mathrm{E}-03$ & $3.9 \mathrm{E}-03$ & 5.1E-03 \\
\hline Barium & $1.6 \mathrm{E}-03$ & $2.0 \mathrm{E}-03$ & $2.6 \mathrm{E}-03$ \\
\hline Beryllium & $4.8 \mathrm{E}-04$ & 5.9E-04 & 7.3E-04 \\
\hline Chromium VI & $4.5 \mathrm{E}-03$ & $5.5 \mathrm{E}-03$ & $6.6 \mathrm{E}-03$ \\
\hline Manganese & $1.3 \mathrm{E}-02$ & $1.8 \mathrm{E}-02$ & $2.4 \mathrm{E}-02$ \\
\hline Mercury & $9.9 \mathrm{E}-05$ & $1.2 \mathrm{E}-04$ & $1.4 \mathrm{E}-04$ \\
\hline Mercury (salts) & $6.6 \mathrm{E}-04$ & $7.8 \mathrm{E}-04$ & 9.1E-04 \\
\hline Nickel & $1.3 \mathrm{E}-04$ & $1.6 \mathrm{E}-04$ & $2.0 \mathrm{E}-04$ \\
\hline Nickel (salts) & $2.6 \mathrm{E}-03$ & $3.3 \mathrm{E}-03$ & 4.1E-03 \\
\hline Selenium & $2.8 \mathrm{E}-05$ & $3.6 \mathrm{E}-05$ & $4.5 \mathrm{E}-05$ \\
\hline Strontium & $1.0 \mathrm{E}-06$ & $1.4 \mathrm{E}-06$ & $2.0 \mathrm{E}-06$ \\
\hline Vanadium & $3.0 \mathrm{E}-02$ & $3.4 \mathrm{E}-02$ & $3.9 \mathrm{E}-02$ \\
\hline Zinc & $3.9 E-05$ & $4.8 \mathrm{E}-05$ & 5.9E-05 \\
\hline Total pathway $\mathrm{HI}^{d}$ & $5.7 \mathrm{E}-02$ & $6.9 \mathrm{E}-02$ & 8.5E-02 \\
\hline
\end{tabular}

'The LCB95, median, and UCB95 analyte concentrations are evaluated in terms of total hazard index (total $\mathrm{HI}=\mathrm{HI}$ chronic for an adult plus $\mathrm{HI}$ subchronic for a child).

${ }^{b}$ LCB95 $=$ Lower $95 \%$ confidence bound on the median.

UCB95 = Upper $95 \%$ confidence bound on the median.

${ }^{d}$ The total pathway hazard index does not include $\mathrm{HI}$ values for mercury and nickel metals. 
Table 7.15b. Comparative background hazard index estimates from exposure to soil constituents from the Oak Ridge Reservation-Chepultepec

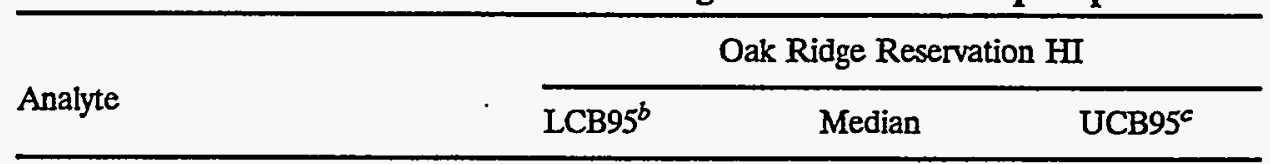

Exposure pathway: residential ingestion of soil

\begin{tabular}{lccc}
\multicolumn{4}{c}{ Inorganics } \\
Arsenic & $4.2 \mathrm{E}-01$ & $5.3 \mathrm{E}-01$ & $6.8 \mathrm{E}-01$ \\
Barium & $8.3 \mathrm{E}-03$ & $1.1 \mathrm{E}-02$ & $1.4 \mathrm{E}-02$ \\
Beryllium & $7.5 \mathrm{E}-04$ & $9.9 \mathrm{E}-04$ & $1.3 \mathrm{E}-03$ \\
Chromium VI & $1.1 \mathrm{E}-02$ & $1.3 \mathrm{E}-02$ & $1.6 \mathrm{E}-02$ \\
Manganese & $6.8 \mathrm{E}-02$ & $9.3 \mathrm{E}-02$ & $1.3 \mathrm{E}-01$ \\
Mercury & $5.1 \mathrm{E}-03$ & $6.1 \mathrm{E}-03$ & $7.2 \mathrm{E}-03$ \\
Mercury (salts) & $5.1 \mathrm{E}-03$ & $6.1 \mathrm{E}-03$ & $7.2 \mathrm{E}-03$ \\
Selenium & $8.8 \mathrm{E}-04$ & $1.2 \mathrm{E}-03$ & $1.8 \mathrm{E}-03$ \\
Strontium & $4.0 \mathrm{E}-05$ & $5.6 \mathrm{E}-05$ & $7.9 \mathrm{E}-05$ \\
Vanadium & $5.3 \mathrm{E}-02$ & $6.1 \mathrm{E}-02$ & $6.9 \mathrm{E}-02$ \\
Zinc & $1.5 \mathrm{E}-03$ & $1.9 \mathrm{E}-03$ & $2.3 \mathrm{E}-03$ \\
& & & \\
& Organics & & \\
Acenaphthene & & & \\
Anthracene & & & $6.0 \mathrm{E}-05$ \\
Fluoranthene & $2.1 \mathrm{E}-05$ & $3.5 \mathrm{E}-05$ & $9.1 \mathrm{E}-06$ \\
Fluorene & $1.4 \mathrm{E}-06$ & $3.5 \mathrm{E}-06$ & $3.1 \mathrm{E}-04$ \\
Naphthalene & $1.4 \mathrm{E}-04$ & $2.0 \mathrm{E}-04$ & $4.8 \mathrm{E}-05$ \\
Pyrene & $1.2 \mathrm{E}-05$ & $2.4 \mathrm{E}-05$ & $7.6 \mathrm{E}-03$ \\
& $1.5 \mathrm{E}-03$ & $3.4 \mathrm{E}-03$ & $4.7 \mathrm{E}-04$ \\
Total pathway $\mathrm{HI}^{d}$ & $2.0 \mathrm{E}-04$ & $3.0 \mathrm{E}-04$ & \\
& & & $9.3 \mathrm{E}-01$
\end{tabular}

Exposure pathway: residential dermal exposure to soil

Inorganics

$\begin{array}{llll}\text { Arsenic } & 5.6 \mathrm{E}-03 & 7.1 \mathrm{E}-03 & 9.1 \mathrm{E}-03 \\ \text { Barium } & 1.1 \mathrm{E}-03 & 1.4 \mathrm{E}-03 & 1.9 \mathrm{E}-03 \\ \text { Beryllium } & 2.0 \mathrm{E}-04 & 2.6 \mathrm{E}-04 & 3.5 \mathrm{E}-04 \\ \text { Chromium VI } & 2.4 \mathrm{E}-03 & 2.9 \mathrm{E}-03 & 3.4 \mathrm{E}-03 \\ \text { Manganese } & 1.8 \mathrm{E}-02 & 2.5 \mathrm{E}-02 & 3.4 \mathrm{E}-02 \\ \text { Mercury } & 6.9 \mathrm{E}-05 & 8.1 \mathrm{E}-05 & 9.6 \mathrm{E}-05 \\ \text { Mercury (salts) } & 4.6 \mathrm{E}-04 & 5.4 \mathrm{E}-04 & 6.4 \mathrm{E}-04 \\ \text { Selenium } & 1.9 \mathrm{E}-05 & 2.8 \mathrm{E}-05 & 3.9 \mathrm{E}-05 \\ \text { Strontium } & 5.3 \mathrm{E}-07 & 7.4 \mathrm{E}-07 & 1.0 \mathrm{E}-06 \\ \text { Vanadium } & 2.7 \mathrm{E}-02 & 3.1 \mathrm{E}-02 & 3.6 \mathrm{E}-02 \\ \text { Zinc } & 4.0 \mathrm{E}-05 & 5.0 \mathrm{E}-05 & 6.1 \mathrm{E}-05\end{array}$


Table 7.15b (continued)

\begin{tabular}{llll}
\hline \multirow{2}{*}{ Analyte } & \multicolumn{3}{c}{ Oak Ridge Reservation HI } \\
\cline { 2 - 4 } & $\mathrm{LCB95}^{b}$ & Median & $\mathrm{UCB95}^{c}$ \\
\hline \multicolumn{3}{c}{ Exposure pathway: residential dermal exposure to soil (continued) } \\
& Organics & & \\
& & & \\
Acenaphthene & $6.6 \mathrm{E}-06$ & $1.1 \mathrm{E}-05$ & $1.9 \mathrm{E}-05$ \\
Anthracene & $4.3 \mathrm{E}-07$ & $1.1 \mathrm{E}-06$ & $2.9 \mathrm{E}-06$ \\
Fluoranthene & $4.3 \mathrm{E}-05$ & $6.5 \mathrm{E}-05$ & $9.8 \mathrm{E}-05$ \\
Fluorene & $3.9 \mathrm{E}-06$ & $7.7 \mathrm{E}-06$ & $1.5 \mathrm{E}-05$ \\
Naphthalene & $2.0 \mathrm{E}-04$ & $4.5 \mathrm{E}-04$ & $1.0 \mathrm{E}-03$ \\
Pyrene & $6.2 \mathrm{E}-05$ & $9.6 \mathrm{E}-05$ & $1.5 \mathrm{E}-04$ \\
& & & \\
Total pathway $\mathrm{HI}^{d}$ & $5.6 \mathrm{E}-02$ & $6.9 \mathrm{E}-02$ & $8.7 \mathrm{E}-02$ \\
\hline
\end{tabular}

'The LCB95, median, and UCB95 analyte concentrations are evaluated in terms of total hazard index (total $\mathrm{HI}=\mathrm{HI}$ chronic for an adult plus $\mathrm{HI}$ subchronic for a child).

${ }^{b}$ LCB95 $=$ Lower $95 \%$ confidence bound on the median.

UCB95 = Upper 95\% confidence bound on the median.

${ }^{d}$ The total pathway hazard index does not include $\mathrm{HI}$ values for mercury and nickel metals.

\subsubsection{Background Risk Characterization for the ORR}

The carcinogenic and systemic health effects are evaluated for elements that have both a SF and a RfD. Some soil constituents, however, have only one (or neither) of the two toxicity values. Each constituent detected in the ORR background soil has been included in the risk or HI calculation, provided it has at least one of the toxicity values. If neither of the toxicity values are available for a constituent, a quantitative CDI can be calculated (Table 7.5), but the carcinogenic and systemic effect can only be evaluated qualitatively (Table 7.2). Such constituents may contribute to carcinogenic and noncarcinogenic effects from exposure to the soil, but their effect can not be quantified at the present time. For constituents that have both a SF and a RfD, both their carcinogenic and systemic health effects are quantified.

\subsubsection{Carcinogenic background risk characterization for the ORR}

As discussed in Sect. 7.4, an on-site resident would be exposed to background soil constituents via ingestion of soil, dermal contact with soil, and external exposure to radionuclides in the soil. Shown in Table 7.16 are (i) the calculated CDIs (and doses), (ii) the calculated background cancer risk for an adult and a child, (iii) the total background cancer risk (adult + child), and (iv) the total pathway risks for the constituents found in the ORR background soils (tables include analytes for which SFs are available).

In general, for beryllium and PAHs (Table 7.16a), the background cancer risk for a child exposed to these constituents is slightly higher than that of an adult for the ingestion pathway, 
and the child's risk is slightly lower than that of an adult for dermal exposure to soil. Note, beryllium is the only inorganic analyte found on the ORR, horizon A, for which an oral SF is available. Exposure to beryllium and PAHs via soil ingestion or dermal contact, for the DG, NOL, CR, CHE, and CHI formations, results in total (adult + child) background cancer risks between 1.7e-07 and 1.1e-04; refer to the far right column in Table 7.16a. The total pathway background, cancer risks from exposure to beryllium and PAHs across these two pathways (ingestion and dermal contact) combined (cumulative background risk) are between 9.3e-06 and $3.9 \mathrm{e}-04$, depending on the formation. Some of these cumulative background cancer risks are within the EPA range of concern (1.0e-06 to 1.0e-04), and most are even above the unacceptable range (i.e, risk $>1.0 \mathrm{e}-04$ ) if these risks were from exposure to contaminated soils.

Included in Table $7.16 \mathrm{~b}$ are the adult and child background cancer risk estimates for ingestion of soil containing radionuclides. In general, the adult resident has a higher cancer risk from ingestion of the soil than does the child resident. The total (adult + child) pathway background cancer risks for ingestion of soil containing radionuclides are less than $1.0 \mathrm{e}-06$ for the DG, NOL, CR, CHE, and CHI formations. These risk values are less than the lower limit of the EPA range of concern, which is considered acceptable for exposure to site-related contaminants.

The adult and child background cancer risk estimates for external exposure to ORR background soils containing radionuclides are summarized in Table 7.16c. Again, in general, the adult resident has a greater background cancer risk than the child resident. The total pathway background cancer risks (adult + child) :for DG, NOL, CR, CHE, and CHI lithologies are greater than 1.0e-04 and fall in the EPA region of unacceptable risk (i.e, risk $>1.0 \mathrm{e}-04$ ) for exposure to contaminated sites.

The total cumulative exposure (ingestion of beryllium, PAHs and radionuclides, dermal contact with beryllium and PAHs, and external exposure to radionuclides) background cancer risks are all greater than $1.0 \mathrm{e}-04$, as shown in Fig. 1 . These relatively high total cumulative background risk results are predominantly from the background risks associated with the external exposure to radiation; of second most importance (to the cumulative background risk estimates) is exposure to these background constituents via ingestion of PAHs. Beryllium levels at BSCP sites are interpreted to be background.

\subsubsection{Noncarcinogenic background risk characterization for the ORR}

The results of the assessment of systemic toxicity of the background inorganic and organic constituents indicate, with one exception, that neither the ingestion of nor dermal contact with these analytes are a concern . Table 7.17 lists the (i) RfDs, (ii) CDIs for a child and an adult, (iii) background hazard indices for a child and an adult, and (iv) the total (adult + child) background hazard indices for systemic toxicants. Background levels of arsenic in the Copper Ridge Formation give a HI greater than 1.0 (i.e., an EPA unacceptable level) for the ingestion pathway (refer to Table 7.17a). Even though arsenic levels in ORR Copper Ridge soils are quite high, these levels are interpreted to be background and not surface contamination. No constituents are identified as having HIs greater than 1.0 for the dermal contact pathway (Table 7.17b). In general (with the exception of some PAHs), the child HI (subchronic) is greater than the adult HI (chronic) for both the ingestion of soil and the 
$7-110$

Table 7.16a. Background cancer risk estimates from exposure

to Oak Ridge Reservation soil constituents

Inorganics and Organics/Ingestion and Dermal Contact

\begin{tabular}{|c|c|c|c|c|c|c|c|}
\hline Analyte & $\begin{array}{l}\text { Soil conc }^{a} \\
(\mathrm{pCi} / \mathrm{g})\end{array}$ & $\begin{array}{l}\text { Adult daily } \\
\text { intake } \\
\text { (mg/kg-day) }\end{array}$ & $\begin{array}{l}\text { Child daily } \\
\text { intake } \\
\text { (mg/kg-day) }\end{array}$ & $\begin{array}{c}\text { Oral slope } \\
\text { factor } \\
\text { (kg-day/mg) }\end{array}$ & $\begin{array}{l}\text { Adult } \\
\text { background } \\
\text { cancer risk }\end{array}$ & $\begin{array}{l}\text { Child } \\
\text { background } \\
\text { cancer risk }\end{array}$ & $\begin{array}{c}\text { Total } \\
\text { background } \\
\text { cancer risk }{ }^{c}\end{array}$ \\
\hline
\end{tabular}

Beryllium

0.9572

4.5E-07 1.0E-06

$4.3 \mathrm{E}+00$

1.9E-06

4.5E-06

6.4E-06

Total pathway risk

DISMAL GAP

Exposure pathway: residential ingestion of soil

Inorganics

Total pathras risk

Beryllium

Total pathway risk

0.9572

$2.4 \mathrm{E}-08$

9.5E-09

$8.6 \mathrm{E}+01^{d, e}$

$2.0 \mathrm{E}-06$

8.2E-07

2.9E-06

Exposure pathway: residential dermal exposure to soil

Inorganics

(1)

Beryllium

Total pathway risk

0.9639

4.5E-07

\title{
NOLICHUCKY
}

Exposure pathway: residential ingestion of soil

Inorganics

\begin{abstract}
Total pathroy risk
\end{abstract}
Beryllium

Total pathway rist

0.9639

2.4E-08

$9.6 \mathrm{E}-09$

$8.6 \mathrm{E}+01^{d e}$

2.1E-06

8.3E-07

2.9E-06

Total pathway rist

Beryllium

0.6337

$3.0 \mathrm{E}-07$

\section{COPPER RIDGE}

Exposure pathway: residential ingestion of soil

Inorganics

Beryllium

Benzo(a)anthracene

Benzo(a)pyrene

Benzo(b)fluoranthene

Benzo(g,h,i)perylene

Benzo(k)fluoranthene

Chrysene

(1)

\begin{tabular}{|c|c|c|c|c|c|c|}
\hline 2.6741 & $1.3 \mathrm{E}-06$ & $2.9 E-06$ & $7.3 E-01$ & $9.2 \mathrm{E}-07$ & $2.1 E-06$ & $3.1 E-06$ \\
\hline 3.5442 & $1.7 \mathrm{E}-06$ & $3.9 \mathrm{E}-06$ & $7.3 \mathrm{E}+00$ & $1.2 \mathrm{E}-05$ & $2.8 E-05$ & 4.1E-05 \\
\hline 3.1076 & $1.5 E-06$ & $3.4 \mathrm{E}-06$ & 7.3E-01 & 1.1E-06 & $2.5 E-06$ & $3.6 \mathrm{E}-06$ \\
\hline 3.8213 & $1.8 \mathrm{E}-06$ & $4.2 \mathrm{E}-06$ & $7.3 E+00$ & $1.3 E-05$ & 3.1E-05 & 4.4E-05 \\
\hline 1.8125 & 8.5E-07 & $2.0 \mathrm{E}-06$ & 7.3E-01 & $6.2 \mathrm{E}-07$ & $1.4 \mathrm{E}-06$ & 2.1E-06 \\
\hline 5.4456 & $2.6 \mathrm{E}-06$ & $6.0 \mathrm{E}-06$ & $7.3 E-02$ & $1.9 \mathrm{E}-07$ & 4.4E-07 & $6.2 \mathrm{E}-07$ \\
\hline 1.5924 & $7.5 \mathrm{E}-07$ & 1.7E-06 & $7.3 \mathrm{E}+00$ & $5.5 E-06$ & $1.3 E-05$ & $1.8 \mathrm{E}-05$ \\
\hline \multirow[t]{2}{*}{5.3883} & $2.5 \mathrm{E}-06$ & $5.9 E-06$ & $7.3 E+00$ & $1.8 \mathrm{E}-05$ & 4.3E-05 & $6.2 \mathrm{E}-05$ \\
\hline & & & & 5.3E-05 & 12E-04 & $1.8 \mathrm{E}-04$ \\
\hline
\end{tabular}

21E-06

8.3E-07

29E-06

Dibenz(a,h)anthracene

Phenanthrene

Total pathway risk 


\section{7-111}

Table 7.16a (continued)

\begin{tabular}{|c|c|c|c|c|c|c|c|}
\hline Anàlyte & $\begin{array}{l}\text { Soil conc. } \\
(\mathrm{pCi} / \mathrm{g})\end{array}$ & $\begin{array}{l}\text { Adult daily } \\
\text { intake } \\
\text { (mg/kg-day) }\end{array}$ & $\begin{array}{l}\text { Child daily } \\
\text { intake } \\
\text { (mg/kg-day) }\end{array}$ & $\begin{array}{l}\text { Oral slope } \\
\text { factor }^{b} \\
\text { (kg-day/mg) }\end{array}$ & $\begin{array}{c}\text { Adult } \\
\text { background } \\
\text { cancer risk }\end{array}$ & $\begin{array}{l}\text { Child } \\
\text { background } \\
\text { cancer risk }\end{array}$ & $\begin{array}{c}\text { Total } \\
\text { background } \\
\text { cancer risk }\end{array}$ \\
\hline \multicolumn{8}{|c|}{ COPPER RIDGE (continued) } \\
\hline \multirow{2}{*}{\multicolumn{8}{|c|}{$\begin{array}{c}\text { Exposure pathway: residential dermal exposure to soil } \\
\text { Inorganics }\end{array}$}} \\
\hline & & & & & & & \\
\hline Beryllium & 0.6337 & $1.6 \mathrm{E}-08$ & $6.3 \mathrm{E}-09$ & 8.6E $+01^{d, e}$ & $1.4 \mathrm{E}-06$ & $5.4 \mathrm{E}-07$ & $1.9 \mathrm{E}-06$ \\
\hline \multicolumn{8}{|c|}{ Organics } \\
\hline Benzo(a)anthracene & 2.6741 & $6.7 \mathrm{E}-07$ & 2.7E-07 & $7.3 E-01$ & $4.9 E-07$ & $1.9 E-07$ & $6.8 \mathrm{E}-07$ \\
\hline Benzo(a)pyrene & 3.5442 & $8.8 \mathrm{E}-07$ & $3.5 \mathrm{E}-07$ & $7.3 E+\infty$ & $6.4 E-06$ & $2.6 \mathrm{E}-06$ & $9.0 E-06$ \\
\hline Benzo(b)fluoranthene & 3.1076 & 7.7E-07 & $3.1 \mathrm{E}-07$ & $7.3 E-01$ & $5.6 \mathrm{E}-07$ & 2.3E-07 & 7.9E-07 \\
\hline $\operatorname{Benzo}(\mathrm{g}, \mathrm{h}, \mathrm{i})$ perylene & 3.8213 & 9.5E-07 & $3.8 \mathrm{E}-07$ & $7.3 E+00$ & $6.9 \mathrm{E}-06$ & $2.8 \mathrm{E}-06$ & 9.7E-06 \\
\hline Benzo(k)fluoranthene & 1.8125 & $4.5 \mathrm{E}-07$ & $1.8 \mathrm{E}-07$ & 7.3E-01 & $3.3 E-07$ & $1.3 \mathrm{E}-07$ & $4.6 \mathrm{E}-07$ \\
\hline Chrysene & 5.4456 & $1.4 \mathrm{E}-06$ & $5.4 \mathrm{E}-07$ & $9.2 \mathrm{E}-02^{\text {de }}$ & $1.2 \mathrm{E}-07$ & $5.0 \mathrm{E}-08$ & $1.7 \mathrm{E}-07$ \\
\hline Dibenz(a,h)anthracene & 1.5924 & $4.0 \mathrm{E}-07$ & $1.6 \mathrm{E}-07$ & $7.3 E+00$ & $2.9 \mathrm{E}-06$ & $1.2 \mathrm{E}-06$ & 4.1E-06 \\
\hline Phenanthrene & 5.3883 & $1.3 \mathrm{E}-06$ & $5.4 \mathrm{E}-07$ & $7.3 E+00$ & $9.8 \mathrm{E}-06$ & $3.9 \mathrm{E}-06$ & $1.4 \mathrm{E}-05$ \\
\hline Total pathway risk & & & & & 29E-05 & 12E-05 & 4.1E-05 \\
\hline \multicolumn{8}{|c|}{ CHEPULTEPEC } \\
\hline \multicolumn{8}{|c|}{ Exposure pathway: residential ingestion of soil } \\
\hline \multicolumn{8}{|c|}{ Inorganics } \\
\hline Beryllium & 0.4597 & $2.2 \mathrm{E}-07$ & $5.0 \mathrm{E}-07$ & $4.3 E+00$ & 9.3E-07 & $2.2 \mathrm{E}-06$ & 3.1E-06 \\
\hline \multicolumn{8}{|c|}{ Organics } \\
\hline Benzo(a)anthracene & 2.4615 & $1.2 \mathrm{E}-06$ & 2.7E-06 & 7.3E-01 & $8.4 \mathrm{E}-07$ & $2.0 \mathrm{E}-06$ & $28 \mathrm{E}-06$ \\
\hline Benzo(a)pyrene & 4.9345 & 2.3E-06 & $5.4 \mathrm{E}-06$ & $7.3 E+00$ & 1.7E-05 & $3.9 \mathrm{E}-05$ & $5.6 \mathrm{E}-05$ \\
\hline Benzo(b)fluoranthene & 5.2792 & $2.5 \mathrm{E}-06$ & $5.8 \mathrm{E}-06$ & $7.3 \mathrm{E}-01$ & $1.8 \mathrm{E}-06$ & $4.2 \mathrm{E}-06$ & $6.0 \mathrm{E}-06$ \\
\hline Benzo(g,h,i)perylene & 3.6832 & $1.7 \mathrm{E}-06$ & $4.0 \mathrm{E}-06$ & $7.3 E+00$ & $1.3 \mathrm{E}-05$ & $29 \mathrm{E}-05$ & $4.2 \mathrm{E}-05$ \\
\hline Benzo(k)fluoranthene & 2.2941 & $1.1 \mathrm{E}-06$ & $25 \mathrm{E}-06$ & 7.3E-01 & $7.9 \mathrm{E}-07$ & $1.8 \mathrm{E}-06$ & $26 \mathrm{E}-06$ \\
\hline Dibenz(a,h)anthracene & 2.0312 & $9.5 \mathrm{E}-07$ & $2.2 \mathrm{E}-06$ & $7.3 E+\infty 0$ & $7.0 \mathrm{E}-06$ & $1.6 \mathrm{E}-05$ & 2.3E-05 \\
\hline Indeno(1,2,3-cd)pyrene & 15.9171 & $7.5 \mathrm{E}-06$ & $1.7 \mathrm{E}-05$ & $7.3 E-01$ & $5.5 \mathrm{E}-06$ & $1.3 E-05$ & $1.8 \mathrm{E}-05$ \\
\hline Phenanthrene & 4.5165 & $2.1 \mathrm{E}-06$ & $4.9 \mathrm{E}-06$ & $7.3 E+00$ & $1.5 \mathrm{E}-05$ & $3.6 \mathrm{E}-05$ & $5.2 \mathrm{E}-05$ \\
\hline Total pathway risk & & & & & 6.2E-05 & $1.4 \mathrm{E}-04$ & 2.1E-04 \\
\hline \multicolumn{8}{|c|}{$\begin{array}{c}\text { Exposure pathway: residential demal exposure to soil } \\
\text { Inorganics }\end{array}$} \\
\hline Beryllium & 0.4597 & $1.1 \mathrm{E}-08$ & $4.6 \mathrm{E}-09$ & $8.6 \mathrm{E}+01^{d e}$ & $9.8 \mathrm{E}-07$ & $3.9 E-07$ & $1.4 \mathrm{E}-06$ \\
\hline \multicolumn{8}{|c|}{ Organics } \\
\hline Benzo(a)anthracene & 2.4615 & $6.1 \mathrm{E}-07$ & $2.5 \mathrm{E}-07$ & $7.3 \mathrm{E}-01$ & $4.5 \mathrm{E}-07$ & $1.8 \mathrm{E}-07$ & $6.3 \mathrm{E}-07$ \\
\hline Benzo(a)pyrene & 4.9345 & $1.2 \mathrm{E}-06$ & $4.9 \mathrm{E}-07$ & $7.3 E+00$ & $9.0 \mathrm{E}-06$ & $3.6 \mathrm{E}-06$ & $1.3 E-05$ \\
\hline
\end{tabular}




\section{$7-112$}

Table 7.16a (continued)

\begin{tabular}{|c|c|c|c|c|c|c|c|}
\hline Analyte & $\begin{array}{l}\text { Soil conc. } \\
\text { (pCi/g) }\end{array}$ & $\begin{array}{l}\text { Adult daily } \\
\text { intake } \\
\text { (mg/kg-day) }\end{array}$ & $\begin{array}{l}\text { Child daily } \\
\text { intake } \\
\text { (mg/kg-day) }\end{array}$ & $\begin{array}{c}\text { Oral slope } \\
\text { factor } \\
\text { (kg-day/mg) }\end{array}$ & $\begin{array}{c}\text { Adult } \\
\text { background } \\
\text { cancer risk }\end{array}$ & $\begin{array}{c}\text { Child } \\
\text { background } \\
\text { cancer risk }\end{array}$ & $\begin{array}{c}\text { Total } \\
\text { background } \\
\text { cancer risk }\end{array}$ \\
\hline
\end{tabular}

CHEPULTEPEC (continued)

Exposure pathway: residential dermal exposure to soil (continued)

Organics (continued)

\begin{tabular}{|c|c|c|c|c|c|c|c|}
\hline Benzo(b)fluoranthene & 5.2792 & $1.3 \mathrm{E}-06$ & $5.3 \mathrm{E}-07$ & $7.3 E-01$ & $9.6 \mathrm{E}-07$ & $3.8 \mathrm{E}-07$ & $1.3 E-06$ \\
\hline $\operatorname{Benzo}(\mathrm{g}, \mathrm{h}, \mathrm{i})$ perylene & 3.6832 & $9.2 \mathrm{E}-07$ & $3.7 \mathrm{E}-07$ & $7.3 \mathrm{E}+00$ & $6.7 \mathrm{E}-06$ & 2.7E-06 & $9.4 \mathrm{E}-06$ \\
\hline Benzo(k)fluoranthene & 2.2941 & $5.7 \mathrm{E}-07$ & $2.3 E-07$ & 7.3E-01 & $4.2 \mathrm{E}-07$ & 1.7E-07 & $5.8 \mathrm{E}-07$ \\
\hline Dibenz $(a, h)$ anthracene & 2.0312 & 5.1E-07 & $2.0 \mathrm{E}-07$ & $7.3 \mathrm{E}+00$ & $3.7 \mathrm{E}-06$ & $1.5 \mathrm{E}-06$ & $5.2 \mathrm{E}-06$ \\
\hline Indeno(1,2,3-cd)pyrene & 15.9171 & $4.0 \mathrm{E}-06$ & $1.6 \mathrm{E}-06$ & 7.3E-01 & $2.9 E-06$ & $1.2 \mathrm{E}-06$ & $4.1 E-06$ \\
\hline Phenanthrene & 4.5165 & $1.1 E-06$ & 4.5E-07 & $7.3 E+00$ & $8.2 E-06$ & $3.3 E-06$ & $1.1 \mathrm{E}-05$ \\
\hline Total pathway risk & & & & & 33E-05 & $1.3 E-05$ & 4.7E-05 \\
\hline
\end{tabular}

CHICKAMAUGA (BETHEL VAIIEY)

Exposure pathway: residential ingestion of soil

Inorganics

Beryllium

1.2480

$5.9 \mathrm{E}-07$

1.4E-06

$4.3 E+00$

2.5E-06

$5.9 \mathrm{E}-06$

8.4E-06

Organies

$\begin{array}{lrllllll}\text { Benzo(a)anthracene } & 6.4199 & 3.0 \mathrm{E}-06 & 7.0 \mathrm{E}-06 & 7.3 \mathrm{E}-01 & 2.2 \mathrm{E}-06 & 5.1 \mathrm{E}-06 & 7.3 \mathrm{E}-06 \\ \text { Benzo(a)pyrene } & 4.9220 & 2.3 \mathrm{E}-06 & 5.4 \mathrm{E}-06 & 7.3 \mathrm{E}+00 & 1.7 \mathrm{E}-05 & 3.9 \mathrm{E}-05 & 5.6 \mathrm{E}-05 \\ \text { Benzo(b)fluoranthene } & 6.2993 & 3.0 \mathrm{E}-06 & 6.9 \mathrm{E}-06 & 7.3 \mathrm{E}-01 & 2.2 \mathrm{E}-06 & 5.0 \mathrm{E}-06 & 7.2 \mathrm{E}-06 \\ \text { Benzo(g,h,i)perylene } & 5.1307 & 2.4 \mathrm{E}-06 & 5.6 \mathrm{E}-06 & 7.3 \mathrm{E}+00 & 1.8 \mathrm{E}-05 & 4.1 \mathrm{E}-05 & 5.9 \mathrm{E}-05 \\ \text { Benzo(k)fluoranthene } & 2.9069 & 1.4 \mathrm{E}-06 & 3.2 \mathrm{E}-06 & 7.3 \mathrm{E}-01 & 1.0 \mathrm{E}-06 & 2.3 \mathrm{E}-06 & 3.3 \mathrm{E}-06 \\ \text { Chrysene } & 7.8215 & 3.7 \mathrm{E}-06 & 8.6 \mathrm{E}-06 & 7.3 \mathrm{E}-02 & 2.7 \mathrm{E}-07 & 6.3 \mathrm{E}-07 & 8.9 \mathrm{E}-07 \\ \text { Dibenz(a,h)anthracene } & 1.4178 & 6.7 \mathrm{E}-07 & 1.6 \mathrm{E}-06 & 7.3 \mathrm{E}+00 & 4.9 \mathrm{E}-06 & 1.1 \mathrm{E}-05 & 1.6 \mathrm{E}-05 \\ \text { Indeno(1,2,3-cd)pyrene } & 16.2448 & 7.6 \mathrm{E}-06 & 1.8 \mathrm{E}-05 & 7.3 \mathrm{E}-01 & 5.6 \mathrm{E}-06 & 1.3 \mathrm{E}-05 & 1.9 \mathrm{E}-05 \\ \text { Phenanthrene } & 8.7940 & 4.1 \mathrm{E}-06 & 9.6 \mathrm{E}-06 & 7.3 \mathrm{E}+00 & 3.0 \mathrm{E}-05 & 7.0 \mathrm{E}-05 & 1.0 \mathrm{E}-04 \\ \text { Total pathway rist } & & & & & 8.3 \mathrm{E}-05 & 1.9 \mathrm{E}-04 & 28 \mathrm{E}-04\end{array}$

Exposure pathway: residential dermal exposure to soil

Inorganics

Beryilium

1.2480

3.1E-08

$1.2 \mathrm{E}-08$

$8.6 \mathrm{E}+01^{\text {de }}$

2.7E-06

1.1E-06

3.7E-06

Organics

Benzo(a)anthracene
Benzo(a)pyrene
Benzo(b)fluoranthene
Benzo(g,h,i)perylene
Benzo(k)fluoranthene
Chrysene
Dibenz(a,h)anthracene
Indeno(1,2,3-cd)pyrene
Phenanthrene

6.4199
4.9220
6.2993
5.1307
2.9069
7.8215
1.4178
16.2448
8.7940

$1.6 \mathrm{E}-06$
$1.2 \mathrm{E}-06$
$1.6 \mathrm{E}-06$
$1.3 \mathrm{E}-06$
$7.2 \mathrm{E}-07$
$1.9 \mathrm{E}-06$
$3.5 \mathrm{E}-07$
$4.0 \mathrm{E}-06$
$2.2 \mathrm{E}-06$

$6.4 \mathrm{E}-07$
$4.9 \mathrm{E}-07$
$6.3 \mathrm{E}-07$
$5.1 \mathrm{E}-07$
$2.9 \mathrm{E}-07$
$7.8 \mathrm{E}-07$
$1.4 \mathrm{E}-07$
$1.6 \mathrm{E}-06$
$8.8 \mathrm{E}-07$

$7.3 E-01$
$7.3 E+00$
$7.3 E-01$
$7.3 E+00$
$7.3 E-01$
$9.2 E-02 d e$
$7.3 E+00$
$7.3 E-01$
$7.3 E+00$

1.2E-06

4.7E- 07

3.6E-06

4.6E-07

3.7E-06

2.1E-07

7.2E-08

1.0E-06

$1.2 \mathrm{E}-06$

$6.4 \mathrm{E}-06$

1.8E-05
1.6E-06

1.3E-05

1.6E-06

1.3E-05

7.4E-07

2.5E-07

3.6E-06

4.1E-06

2.2E-05

6.4E-05 
Table 7.16a (continued)

\begin{tabular}{|c|c|c|c|c|c|c|c|}
\hline Arialyte & $\begin{array}{l}\text { Soil conc } \\
(\mathrm{pCi} / \mathrm{g})\end{array}$ & $\begin{array}{l}\text { Adult daily } \\
\text { intake } \\
\text { (mg/kg-day) }\end{array}$ & $\begin{array}{l}\text { Child daily } \\
\text { intake } \\
\text { (mg/kg-day) }\end{array}$ & $\begin{array}{c}\text { Oral slope } \\
\text { factor }^{b} \\
(\mathrm{~kg} \text {-day/mg) }\end{array}$ & $\begin{array}{c}\text { Adult } \\
\text { background } \\
\text { cancer risk }\end{array}$ & $\begin{array}{c}\text { Child } \\
\text { background } \\
\text { cancer risk }\end{array}$ & $\begin{array}{c}\text { Total } \\
\text { background } \\
\text { cancer risk }\end{array}$ \\
\hline \multicolumn{8}{|c|}{ CHICKAMAUGA (K-25) } \\
\hline \multicolumn{8}{|c|}{ Exposure pathway: residential ingestion of soil } \\
\hline \multicolumn{8}{|c|}{ Inorganics } \\
\hline Beryllium & 1.1188 & $5.3 \mathrm{E}-07$ & $1.2 \mathrm{E}-06$ & $4.3 E+00$ & $23 \mathrm{E}-06$ & $5.3 E-06$ & $7.5 \mathrm{E}-06$ \\
\hline \multicolumn{8}{|c|}{ Organics } \\
\hline Benzo(a)anthracene & 7.5107 & $3.5 \mathrm{E}-06$ & $8.2 E-06$ & 7.3E-01 & $2.6 \mathrm{E}-06$ & $6.0 \mathrm{E}-06$ & $8.6 \mathrm{E}-06$ \\
\hline Benzo(a)pyrene & 6.7506 & $3.2 \mathrm{E}-06$ & $7.4 \mathrm{E}-0.6$ & $7.3 E+00$ & 2.3E-05 & $5.4 E-05$ & 7.7E-05 \\
\hline Benzo(b)fluoranthene & 6.0862 & $2.9 \mathrm{E}-06$ & 6.7E-06 & 7.3E-01 & $2.1 E-06$ & 4.9E-06 & $7.0 \mathrm{E}-06$ \\
\hline Benzo(g,h,i)perylene & 6.1621 & $2.9 \mathrm{E}-06$ & $6.8 \mathrm{E}-06$ & $7.3 E+00$ & 2.1E-05 & $4.9 E-05$ & $7.0 \mathrm{E}-05$ \\
\hline Benzo(k)fluoranthene & 3.7231 & $1.7 \mathrm{E}-06$ & $4.1 \mathrm{E}-06$ & $7.3 \mathrm{E}-01$ & $1.3 \mathrm{E}-06$ & $3.0 \mathrm{E}-06$ & 4.3E-06 \\
\hline Chrysene & 8.0071 & $3.8 \mathrm{E}-06$ & $8.8 E-06$ & $7.3 \mathrm{E}-02$ & $2.7 \mathrm{E}-07$ & $6.4 \mathrm{E}-07$ & $9.2 \mathrm{E}-07$ \\
\hline Dibenz $(a, h)$ anthracene & 1.5579 & 7.3E-07 & $1.7 \mathrm{E}-06$ & $7.3 E+00$ & $5.3 E-06$ & $1.2 \mathrm{E}-05$ & $1.8 \mathrm{E}-05$ \\
\hline Indeno(1,2,3-cd)pyrene & 13.5674 & $6.4 \mathrm{E}-06$ & $1.5 \mathrm{E}-05$ & 7.3E-01 & 4.7E-06 & 1.1E-05 & $1.6 \mathrm{E}-05$ \\
\hline Phenanthrene & 9.5013 & $4.5 \mathrm{E}-06$ & $1.0 \mathrm{E}-05$ & $7.3 \mathrm{E}+00$ & 3.3E-05 & 7.6E-05 & 1.1E-04 \\
\hline Total pathway risk & & & & & 95E-05 - & 22E-04 & $32 \mathrm{E}-04$ \\
\hline
\end{tabular}

Exposure pathway: residential dermal exposure to soil

Inorganics

\begin{tabular}{|c|c|c|c|c|c|c|c|}
\hline Beryllium & 1.1188 & $2.8 \mathrm{E}-08$ & $1.1 E-08$ & 8.6E $+01^{d, e}$ & $2.4 E-06$ & $9.6 \mathrm{E}-07$ & $3.4 \mathrm{E}-06$ \\
\hline \multicolumn{8}{|c|}{ Organics } \\
\hline Benzo(a)anthracene & 7.5107 & $1.9 \mathrm{E}-06$ & $7.5 E-07$ & 7.3E-01 & $1.4 \mathrm{E}-06$ & $5.5 E-07$ & $1.9 \mathrm{E}-06$ \\
\hline Benzo(a)pyrene & 6.7506 & $1.7 \mathrm{E}-06$ & 6.7E-07 & $7.3 E+00$ & $1.2 \mathrm{E}-05$ & $4.9 \mathrm{E}-06$ & 1.7E-05 \\
\hline Benzo(b)fluoranthene & 6.0862 & $1.5 \mathrm{E}-06$ & $6.1 \mathrm{E}-07$ & $7.3 \mathrm{E}-01$ & $1.1 \mathrm{E}-06$ & $4.4 \mathrm{E}-07$ & $1.5 \mathrm{E}-06$ \\
\hline Benzo $(g, h, i)$ perylene & 6.1621 & $1.5 \mathrm{E}-06$ & $6.1 \mathrm{E}-07$ & $7.3 \mathrm{E}+00$ & 1.1E-05 & $4.5 \mathrm{E}-06$ & $1.6 \mathrm{E}-05$ \\
\hline Benzo(k)fluoranthene & 3.7231 & 9.3E-07 & 3.7E-07 & $.7 .3 \mathrm{E}-01$ & $6.8 \mathrm{E}-07$ & $2.7 \mathrm{E}-07$ & $9.5 \mathrm{E}-07$ \\
\hline Chrysene & 8.0071 & $2.0 \mathrm{E}-06$ & $8.0 \mathrm{E}-07$ & $9.2 \mathrm{E}-02^{d \mathrm{e}}$ & $1.8 \mathrm{E}-07$ & 7.3E-08 & $2.6 \mathrm{E}-07$ \\
\hline Dibenz $(\mathrm{a}, \mathrm{h})$ anthracene & 1.5579 & $3.9 E-07$ & $1.6 \mathrm{E}-07$ & $7.3 E+00$ & $2.8 \mathrm{E}-06$ & $1.1 \mathrm{E}-06$ & $4.0 \mathrm{E}-06$ \\
\hline Indeno(1,2,3-cd)pyrene & 13.5674 & $3.4 \mathrm{E}-06$ & $1.4 \mathrm{E}-06$ & 7.3E-01 & $2.5 E-06$ & $9.9 \mathrm{E}-07$ & $3.5 E-06$ \\
\hline Phenanthrene & 9.5013 & $2.4 \mathrm{E}-06$ & 9.5E-07 & $7.3 \mathrm{E}+00$ & $1.7 \mathrm{E}-05$ & $6.9 E-06$ & $2.4 \mathrm{E}-05$ \\
\hline Total pathway rist & & & & & 5.2E-05 & 2.1E-05 & 72E-0S \\
\hline
\end{tabular}

The upper $95 \%$ confidence bound on the median is used as the representative concentration.

${ }^{b}$ Sources: Integrated Risk Information System (IRIS) and Health Effects Assessment Summary Tables (HEAST). Refer to Table 7.7 for sources of organic $(\mathrm{PAH})$ SFs.

The risk for a child plus the risk for an adult.

${ }^{d}$ For dermal exposure to soils, the absorbed oral slope factor was used; the absorbed oral SFs for beryllium and for chrysene are $8.6 \mathrm{E}+01 \mathrm{~kg}$-day/mg and $9.2 \mathrm{e}-02 \mathrm{~kg}$-day/mg, respectively.

${ }^{\text {eOwen }}(1990)$ reports a \%GI efficiency of 0.001 for inorganics and 0.01 for organics. However, based on other unpublished data, a better, more representative \%GI for beryllium is $5 \%$, and it is used here. The \%GI for chrysene is 79\% (EPA 1982). 


\section{$7-114$}

Table 7.16b. Background cancer risk estimates from exposure to Oak Ridge Reservation soil constituents

Radionuclides/Ingestion

\begin{tabular}{|c|c|c|c|c|c|c|c|}
\hline Analyte & $\begin{array}{l}\text { Soil conc.a } \\
\text { (pCi/g) }\end{array}$ & $\begin{array}{l}\text { Adult intake } \\
\text { dose } \\
\text { (pCi) }\end{array}$ & $\begin{array}{l}\text { Child intake } \\
\text { dose } \\
\text { (pCi) }\end{array}$ & $\begin{array}{c}\text { Oral slope } \\
\text { factor }^{b, c} \\
(1 / \mathrm{pCi})\end{array}$ & $\begin{array}{c}\text { Adult } \\
\text { background } \\
\text { cancer risk }\end{array}$ & $\begin{array}{c}\text { Child } \\
\text { background } \\
\text { cancer risk }\end{array}$ & $\begin{array}{c}\text { Total } \\
\text { background } \\
\text { cancer risk }\end{array}$ \\
\hline \multicolumn{8}{|c|}{$\begin{array}{l}\text { DISMAL GAP } \\
\text { Radionuctides }\end{array}$} \\
\hline Cesium-137 & 1.4130 & $1.2 \mathrm{E}+03$ & $5.9 \mathrm{E}+02$ & $2.8 \mathrm{E}-11$ & 3.3E-08 & $1.7 \mathrm{E}-0.8$ & $5.0 \mathrm{E}-08$ \\
\hline Plutonium-239/240 & 0.0366 & $3.1 E+01$ & $1.5 \mathrm{E}+01$ & 23E-10 & $7.1 \mathrm{E}-09$ & $3.5 \mathrm{E}-09$ & $1.1 \mathrm{E}-08$ \\
\hline Potassium -40 & 19.8411 & $1.7 \mathrm{E}+04$ & $8.3 E+03$ & 1.1E-11 & $1.8 \mathrm{E}-07$ & $9.2 \mathrm{E}-0.8$ & 2.7E-07 \\
\hline Radium-226 & 1.1437 & $9.6 \mathrm{E}+02$ & $4.8 \mathrm{E}+02$ & $1.2 \mathrm{E}-10$ & $1.2 E-07$ & $5.8 \mathrm{E}-0.8$ & 1.7E-07 \\
\hline Strontium-90 & 1.3808 & $1.2 \mathrm{E}+03$ & $5.8 \mathrm{E}+02$ & $3.6 \mathrm{E}-11$ & $4.2 \mathrm{E}-08$ & $2.1 E-08$ & $6.3 \mathrm{E}-08$ \\
\hline Thorium-228 & 1.0163 & $8.5 \mathrm{E}+02$ & $4.3 E+02$ & $5.5 \mathrm{E}-11$ & $4.7 \mathrm{E}-08$ & 2.3E-08 & $7.0 \mathrm{E}-0.8$ \\
\hline Thorium-230 & 0.6774 & $5.7 \mathrm{E}+02$ & $2.8 \mathrm{E}+02$ & 1.3E-11 & $7.4 \mathrm{E}-09$ & $3.7 \mathrm{E}-09$ & $1.1 \mathrm{E}-08$ \\
\hline Thorium-232 & 0.7940 & $6.7 \mathrm{E}+02$ & $3.3 E+02$ & 1.2E-11 & $8.0 \mathrm{E}-09$ & $4.0 \mathrm{E}-09$ & $1.2 \mathrm{E}-0.8$ \\
\hline Thorium-234 & 1.8829 & $1.6 \mathrm{E}+03$ & $7.9 \mathrm{E}+02$ & $4.0 \mathrm{E}-12$ & $6.3 E-09$ & $3.2 \mathrm{E}-09$ & $9.5 \mathrm{E}-09$ \\
\hline Tritium & 0.0443 & $3.7 E+01$ & $1.9 \mathrm{E}+01$ & $5.4 \mathrm{E}-14$ & $2.0 \mathrm{E}-12$ & $1.0 \mathrm{E}-12$ & $3.0 \mathrm{E}-12$ \\
\hline Uranium-233/234 & 1.1327 & $9.5 E+02$ & $4.8 \mathrm{E}+02$ & $1.6 \mathrm{E}-11$ & $1.5 \mathrm{E}-08$ & $7.6 \mathrm{E}-09$ & 2.3E-08 \\
\hline Uranium-235 & 0.0950 & $8.0 \mathrm{E}+01$ & $4.0 \mathrm{E}+01$ & $1.6 \mathrm{E}-11$ & $1.3 \mathrm{E}-09$ & $6.4 \mathrm{E}-10$ & 1.9E-09 \\
\hline Uranium-236 & 0.0292 & $2.4 \mathrm{E}+01$ & $1.2 \mathrm{E}+01$ & $1.5 \mathrm{E}-11$ & 3.7E-10 & $1.8 \mathrm{E}-10$ & $5.5 \mathrm{E}-10$ \\
\hline Uranium-238 & 1.1459 & $9.6 \mathrm{E}+02$ & $4.8 \mathrm{E}+02$ & 2.8E-11 & $2.7 \mathrm{E}-08$ & $1.3 \mathrm{E}-08$ & $4.0 \mathrm{E}-08$ \\
\hline Total pathway risk & & & & & 4.9E-07 & 25E-07 & 7.4E-07 \\
\hline \multirow{2}{*}{\multicolumn{8}{|c|}{$\begin{array}{l}\text { NOLICHUCKY } \\
\text { Radionuclides }\end{array}$}} \\
\hline & & & & & & & \\
\hline Cesium-137 & 1.2444 & $1.0 \mathrm{E}+03$ & $5.2 \mathrm{E}+02$ & $2.8 \mathrm{E}-11$ & $2.9 \mathrm{E}-08$ & $1.5 \mathrm{E}-08$ & $4.4 \mathrm{E}-08$ \\
\hline Curium-247 & 0.0065 & $5.5 \mathrm{E}+00$ & $2.7 \mathrm{E}+\infty 0$ & $2.2 E-10$ & $1.2 E-09$ & $6.0 \mathrm{E}-10$ & $1.8 \mathrm{E}-09$ \\
\hline Neptunium-237 & 0.1900 & $1.6 \mathrm{E}+02$ & $8.0 \mathrm{E}+01$ & $2.2 E-10$ & $3.5 \mathrm{E}-08$ & $1.8 \mathrm{E}-08$ & $5.3 \mathrm{E}-08$ \\
\hline Potassium-40 & 18.4437 & $1.5 \mathrm{E}+04$ & $7.7 \mathrm{E}+03$ & 1.1E-11 & 1.7E-07 & $8.5 E-08$ & $2.6 \mathrm{E}-07$ \\
\hline Radium-226 & 1.0763 & $9.0 \mathrm{E}+02$ & $4.5 \mathrm{E}+02$ & $1.2 \mathrm{E}-10$ & $1.1 E-07$ & $5.4 \mathrm{E}-08$ & $1.6 \mathrm{E}-07$ \\
\hline Technetium-99 & 1.9148 & $1.6 \mathrm{E}+03$ & $8.0 \mathrm{E}+02$ & 1.3E-12 & 2.1E-09 & $1.0 \mathrm{E}-09$ & $3.1 \mathrm{E}-09$ \\
\hline Thorium-228 & 2.1491 & $1.8 \mathrm{E}+03$ & $9.0 \mathrm{E}+02$ & $5.5 E-11$ & $9.9 \mathrm{E}-08$ & $5.0 \mathrm{E}-08$ & $1.5 \mathrm{E}-07$ \\
\hline Thorium-230 & 1.1584 & $9.7 \mathrm{E}+02$ & $4.9 E+02$ & $1.3 \mathrm{E}-11$ & $1.3 E-08$ & $6.3 \mathrm{E}-09$ & $1.9 \mathrm{E}-08$ \\
\hline Thorium-232 & 1.7374 & $1.5 \mathrm{E}+03$ & $7.3 \mathrm{E}+02$ & $1.2 \mathrm{E}-11$ & $1.8 \mathrm{E}-08$ & $8.8 \mathrm{E}-09$ & $2.6 \mathrm{E}-08$ \\
\hline Thorium-234 & 1.6385 & $1.4 \mathrm{E}+03$ & $6.9 E+02$ & $4.0 \mathrm{E}-12$ & $5.5 \mathrm{E}-09$ & $2.8 \mathrm{E}-09$ & $8.3 \mathrm{E}-09$ \\
\hline Uranium-233/234 & 1.5507 & $1.3 E+03$ & $6.5 E+02$ & $1.6 \mathrm{E}-11$ & 2.1E-08 & $1.0 \mathrm{E}-08$ & $3.1 \mathrm{E}-08$ \\
\hline Uranium-235 & 0.0855 & $7.2 \mathrm{E}+01$ & $3.6 \mathrm{E}+01$ & $1.6 \mathrm{E}-11$ & $1.1 \mathrm{E}-09$ & $5.7 \mathrm{E}-10$ & $1.7 \mathrm{E}-09$ \\
\hline Uranium-238 & 1.4349 & $1.2 \mathrm{E}+03$ & $6.0 \mathrm{E}+02$ & $2.8 \mathrm{E}-11$ & $3.4 \mathrm{E}-08$ & $1.7 \mathrm{E}-08$ & $5.1 \mathrm{E}-08$ \\
\hline Total pathway risk & & & & & $5.4 \mathrm{E}-07$ & $27 \mathrm{E}-07$ & 8.1E-07 \\
\hline \multicolumn{8}{|c|}{$\begin{array}{l}\text { COPPER RIDGE } \\
\text { Radionuclides }\end{array}$} \\
\hline Cesium-137 & 1.9887 & $1.7 \mathrm{E}+03$ & $8.4 E+02$ & $2.8 \mathrm{E}-11$ & $4.7 \mathrm{E}-08$ & $2.3 E-08$ & $7.0 \mathrm{E}-08$ \\
\hline Neptunium-237 & 0.1082 & $9.1 E+01$ & $4.5 E+01$ & $2.2 \mathrm{E}-10$ & $2.0 \mathrm{E}-08$ & $1.0 \mathrm{E}-08$ & $3.0 \mathrm{E}-08$ \\
\hline Plutonium-238 & 0.0382 & $3.2 \mathrm{E}+01$ & $1.6 \mathrm{E}+01$ & $2.2 E-10$ & $7.1 \mathrm{E}-09$ & $3.5 \mathrm{E}-09$ & $1.1 \mathrm{E}-08$ \\
\hline Plutonium-239/240 & 0.0598 & $5.0 \mathrm{E}+01$ & $2.5 E+01$ & 2.3E-10 & $1.2 \mathrm{E}-08$ & $5.8 \mathrm{E}-09$ & $1.7 \mathrm{E}-08$ \\
\hline Potassium-40 & 4.9722 & $4.2 \mathrm{E}+03$ & $2.1 E+03$ & 1.1E-11 & $4.6 \mathrm{E}-08$ & $2.3 \mathrm{E}-08$ & $6.9 \mathrm{E}-08$ \\
\hline Radium-226 & 1.7758 & $1.5 E+03$ & $7.5 E+02$ & $1.2 \mathrm{E}-10$ & $1.8 \mathrm{E}-07$ & $9.0 \mathrm{E}-08$ & 2.7E-07 \\
\hline Thorium-228 & 0.4836 & $4.1 \mathrm{E}+02$ & $2.0 \mathrm{E}+02$ & $5.5 \mathrm{E}-11$ & $2.2 E-08$ & $1.1 E-08$ & $3.4 \mathrm{E}-08$ \\
\hline Thorium-230 & 1.3274 & $1.1 E+03$ & $5.6 \mathrm{E}+02$ & 1.3E-11 & $1.4 \mathrm{E}-08$ & 7.2E-09 & $2.2 E-08$ \\
\hline
\end{tabular}




\section{7-115}

Table 7.16b (continued)

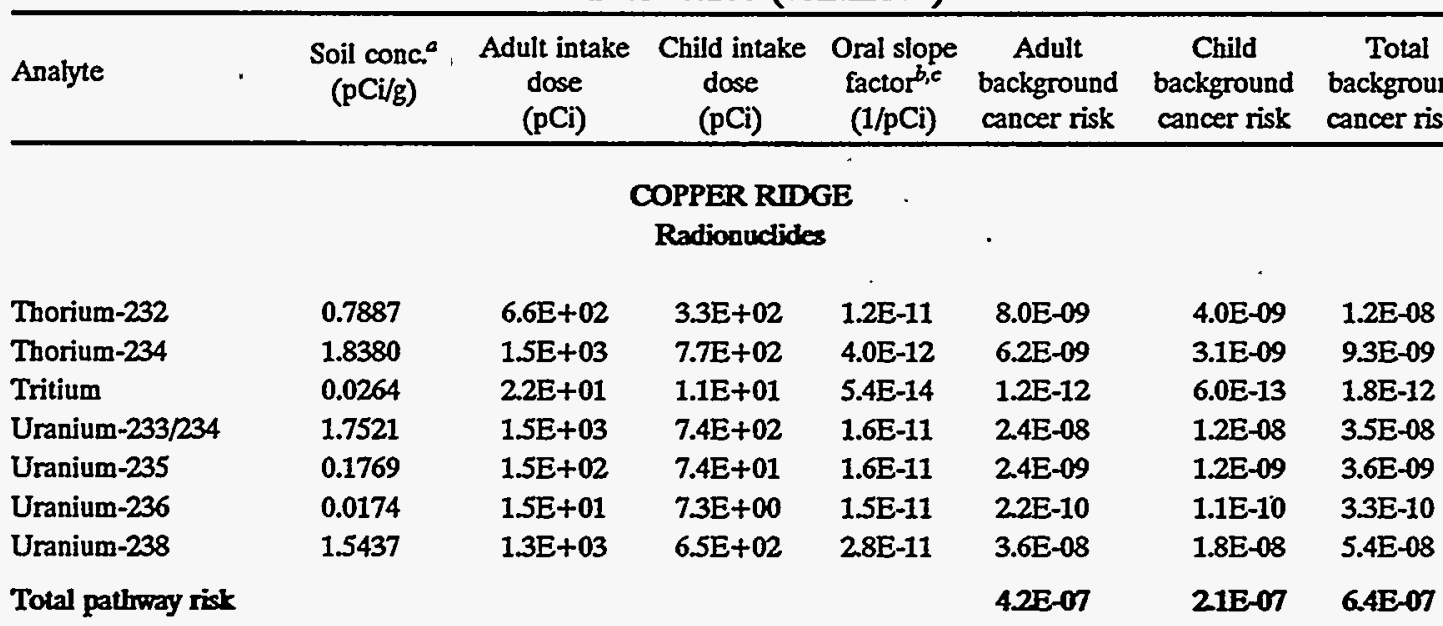

CHEPULTEPEC

Radionuclides

$\begin{array}{ll}\text { Cesium-137 } & 2.3584 \\ \text { Neptunium-237 } & 0.0891 \\ \text { Plutonium-238 } & 0.1305 \\ \text { Potassium-40 } & 3.8195 \\ \text { Radium-226 } & 1.2660 \\ \text { Thorium-228 } & 0.8629 \\ \text { Thorium-230 } & 0.9274 \\ \text { Thorium-232 } & 0.7224 \\ \text { Uranium-233/234 } & 1.3351 \\ \text { Uranium-235 } & 0.1042 \\ \text { Uranium-238 } & 1.2559\end{array}$

Total pathway risk

\section{CHICKAMAUGA (BETHEL VALIEY)}

Radionuclides

$\begin{array}{lr}\text { Cesium-137 } & 3.1908 \\ \text { Neptunium-237 } & 0.1249 \\ \text { Plutonium-238 } & 0.1289 \\ \text { Plutonium-239/240 } & \mathbf{0 . 0 7 7 2} \\ \text { Potassium-40 } & 18.3899 \\ \text { Radium-226 } & 1.5669 \\ \text { Technetium-99 } & 1.9843 \\ \text { Thorium-228 } & 1.8359 \\ \text { Thorium-230 } & 1.2672 \\ \text { Thorium-232 } & 1.4514 \\ \text { Tritium } & 0.1616 \\ \text { Uranium-233/234 } & 1.2233 \\ \text { Uranium-235 } & 0.1315 \\ \text { Uranium-238 } & 1.1879\end{array}$

Total pathway risk

$\begin{array}{llllll}2.0 \mathrm{E}+03 & 9.9 \mathrm{E}+02 & 2.8 \mathrm{E}-11 & 5.5 \mathrm{E}-08 & 2.8 \mathrm{E}-08 & 8.3 \mathrm{E}-08 \\ 7.5 \mathrm{E}+01 & 3.7 \mathrm{E}+01 & 2.2 \mathrm{E}-10 & 1.6 \mathrm{E}-08 & 8.2 \mathrm{E}-09 & 2.5 \mathrm{E}-08 \\ 1.1 \mathrm{E}+02 & 5.5 \mathrm{E}+01 & 2.2 \mathrm{E}-10 & 2.4 \mathrm{E}-08 & 1.2 \mathrm{E}-08 & 3.6 \mathrm{E}-08 \\ 3.2 \mathrm{E}+03 & 1.6 \mathrm{E}+03 & 1.1 \mathrm{E}-11 & 3.5 \mathrm{E}-08 & 1.8 \mathrm{E}-08 & 5.3 \mathrm{E}-08 \\ 1.1 \mathrm{E}+03 & 5.3 \mathrm{E}+02 & 1.2 \mathrm{E}-10 & 1.3 \mathrm{E}-07 & 6.4 \mathrm{E}-08 & 1.9 \mathrm{E}-07 \\ 7.2 \mathrm{E}+02 & 3.6 \mathrm{E}+02 & 5.5 \mathrm{E}-11 & 4.0 \mathrm{E}-08 & 2.0 \mathrm{E}-08 & 6.0 \mathrm{E}-08 \\ 7.8 \mathrm{E}+02 & 3.9 \mathrm{E}+02 & 1.3 \mathrm{E}-11 & 1.0 \mathrm{E}-08 & 5.1 \mathrm{E}-09 & 1.5 \mathrm{E}-08 \\ 6.1 \mathrm{E}+02 & 3.0 \mathrm{E}+02 & 1.2 \mathrm{E}-11 & 7.3 \mathrm{E}-09 & 3.6 \mathrm{E}-09 & 1.1 \mathrm{E}-08 \\ 1.1 \mathrm{E}+03 & 5.6 \mathrm{E}+02 & 1.6 \mathrm{E}-11 & 1.8 \mathrm{E}-08 & 9.0 \mathrm{E}-09 & 2.7 \mathrm{E}-08 \\ 8.8 \mathrm{E}+01 & 4.4 \mathrm{E}+01 & 1.6 \mathrm{E}-11 & 1.4 \mathrm{E}-09 & 7.0 \mathrm{E}-10 & 2.1 \mathrm{E}-09 \\ 1.1 \mathrm{E}+03 & 5.3 \mathrm{E}+02 & 2.8 \mathrm{E}-11 & 3.0 \mathrm{E}-08 & 1.5 \mathrm{E}-08 & 4.4 \mathrm{E}-08 \\ & & & 3.7 \mathrm{E}-07 & 1.8 \mathrm{E}-07 & 5.5 \mathrm{E}-07\end{array}$

$\begin{array}{llllll}2.7 \mathrm{E}+03 & 1.3 \mathrm{E}+03 & 2.8 \mathrm{E}-11 & 7.5 \mathrm{E}-08 & 3.8 \mathrm{E}-08 & 1.1 \mathrm{E}-07 \\ 1.0 \mathrm{E}+02 & 5.2 \mathrm{E}+01 & 2.2 \mathrm{E}-10 & 2.3 \mathrm{E}-08 & 1.2 \mathrm{E}-08 & 3.5 \mathrm{E}-08 \\ 1.1 \mathrm{E}+02 & 5.4 \mathrm{E}+01 & 2.2 \mathrm{E}-10 & 2.4 \mathrm{E}-08 & 1.2 \mathrm{E}-08 & 3.6 \mathrm{E}-08 \\ 6.5 \mathrm{E}+01 & 3.2 \mathrm{E}+01 & 2.3 \mathrm{E}-10 & 1.5 \mathrm{E}-08 & 7.5 \mathrm{E}-09 & 2.2 \mathrm{E}-08 \\ 1.5 \mathrm{E}+04 & 7.7 \mathrm{E}+03 & 1.1 \mathrm{E}-11 & 1.7 \mathrm{E}-07 & 8.5 \mathrm{E}-08 & 2.5 \mathrm{E}-07 \\ 1.3 \mathrm{E}+03 & 6.6 \mathrm{E}+02 & 1.2 \mathrm{E}-10 & 1.6 \mathrm{E}-07 & 7.9 \mathrm{E}-08 & 2.4 \mathrm{E}-07 \\ 1.7 \mathrm{E}+03 & 8.3 \mathrm{E}+02 & 1.3 \mathrm{E}-12 & 2.2 \mathrm{E}-09 & 1.1 \mathrm{E}-09 & 3.3 \mathrm{E}-09 \\ 1.5 \mathrm{E}+03 & 7.7 \mathrm{E}+02 & 5.5 \mathrm{E}-11 & 8.5 \mathrm{E}-08 & 4.2 \mathrm{E}-08 & 1.3 \mathrm{E}-07 \\ 1.1 \mathrm{E}+03 & 5.3 \mathrm{E}+02 & 1.3 \mathrm{E}-11 & 1.4 \mathrm{E}-08 & 6.9 \mathrm{E}-09 & 2.1 \mathrm{E}-08 \\ 1.2 \mathrm{E}+03 & 6.1 \mathrm{E}+02 & 1.2 \mathrm{E}-11 & 1.5 \mathrm{E}-08 & 7.3 \mathrm{E}-09 & 2.2 \mathrm{E}-08 \\ 1.4 \mathrm{E}+02 & 6.8 \mathrm{E}+01 & 5.4 \mathrm{E}-14 & 7.3 \mathrm{E}-12 & 3.7 \mathrm{E}-12 & 1.1 \mathrm{E}-11 \\ 1.0 \mathrm{E}+03 & 5.1 \mathrm{E}+02 & 1.6 \mathrm{E}-11 & 1.6 \mathrm{E}-08 & 8.2 \mathrm{E}-09 & 2.5 \mathrm{E}-08 \\ 1.1 \mathrm{E}+02 & 5.5 \mathrm{E}+01 & 1.6 \mathrm{E}-11 & 1.8 \mathrm{E}-09 & 8.8 \mathrm{E}-10 & 2.7 \mathrm{E}-09 \\ 1.0 \mathrm{E}+03 & 5.0 \mathrm{E}+02 & 2.8 \mathrm{E}-11 & 2.8 \mathrm{E}-08 & 1.4 \mathrm{E}-08 & 4.2 \mathrm{E}-08 \\ & & & 6.3 \mathrm{E}-07 & 3.1 \mathrm{E}-07 & 9.4 \mathrm{E}-07\end{array}$




\section{$7-116$}

Table 7.16b (continued)

\begin{tabular}{|c|c|c|c|c|c|c|c|}
\hline Analyte & $\begin{array}{l}\text { Soil conc. } \\
\text { (pCi/g) }\end{array}$ & $\begin{array}{l}\text { Adult intake } \\
\text { dose } \\
\text { (pCi) }\end{array}$ & $\begin{array}{l}\text { Child intake } \\
\text { dose } \\
\text { (pCi) }\end{array}$ & $\begin{array}{c}\text { Oral slope } \\
\text { factor } b, c \\
(1 / \mathrm{pCi})\end{array}$ & $\begin{array}{c}\text { Adult } \\
\text { background } \\
\text { cancer risk }\end{array}$ & $\begin{array}{c}\text { Child } \\
\text { background } \\
\text { cancer risk }\end{array}$ & $\begin{array}{c}\text { Total } \\
\text { background } \\
\text { cancer risk }\end{array}$ \\
\hline \multirow{2}{*}{\multicolumn{8}{|c|}{$\begin{array}{c}\text { CHICKAMAUGA (K-25) } \\
\text { Radionuclides }\end{array}$}} \\
\hline & & & & & & & \\
\hline Cesium-137 & 2.5633 & $2.2 \mathrm{E}+03$ & $1.1 E+03$ & $2.8 \mathrm{E}-11$ & $6.0 \mathrm{E}-08$ & $3.0 \mathrm{E}-08$ & $9.0 \mathrm{E}-08$ \\
\hline Neptunium-237 & 0.1199 & $1.0 \mathrm{E}+02$ & $5.0 \mathrm{E}+01$ & $2.2 \mathrm{E}-10$ & $2.2 \mathrm{E}-08$ & $1.1 \mathrm{E}-08$ & $3.3 E-08$ \\
\hline Plutonium-238 & 0.1149 & $9.7 E+01$ & $4.8 \mathrm{E}+01$ & $2.2 \mathrm{E}-10$ & 2.1E-08 & $1.1 \mathrm{E}-08$ & $3.2 E-08$ \\
\hline Plutonium-239/240 & 0.0487 & $4.1 E+01$ & $2.0 \mathrm{E}+01$ & $2.3 E-10$ & $9.4 \mathrm{E}-09$ & 4.7E-09 & $1.4 \mathrm{E}-08$ \\
\hline Potassium-40 & 11.7684 & $9.9 E+03$ & $4.9 \mathrm{E}+03$ & $1.1 \mathrm{E}-11$ & $1.1 \mathrm{E}-07$ & $5.4 \mathrm{E}-08$ & $1.6 \mathrm{E}-07$ \\
\hline Radium-226 & 1.3535 & $1.1 E+03$ & $5.7 E+02$ & $1.2 \mathrm{E}-10$ & $1.4 \mathrm{E}-07$ & $6.8 \mathrm{E}-08$ & $2.0 \mathrm{E}-07$ \\
\hline Technetium-99 & 1.6665 & $1.4 E+03$ & $7.0 \mathrm{E}+02$ & $1.3 \mathrm{E}-12$ & $1.8 \mathrm{E}-09$ & $9.1 \mathrm{E}-10$ & 27E-09 \\
\hline Thorium-228 & 1.6072 & $1.4 E+03$ & $6.8 E+02$ & $5.5 \mathrm{E}-11$ & $7.4 \mathrm{E}-0.8$ & $3.7 \mathrm{E}-08$ & 1.1E-07 \\
\hline Thorium-230 & 1.2438 & $1.0 \mathrm{E}+03$ & $5.2 \mathrm{E}+02$ & $1.3 \mathrm{E}-11$ & $1.4 \mathrm{E}-08$ & $6.8 \mathrm{E}-09$ & $2.0 \mathrm{E}-08$ \\
\hline Thorium-232 & 1.2827 & $1.1 E+03$ & $5.4 \mathrm{E}+02$ & $1.2 \mathrm{E}-11$ & $1.3 E-08$ & $6.5 \mathrm{E}-09$ & $1.9 \mathrm{E}-08$ \\
\hline Uranium-233/234 & 1.4726 & $1.2 \mathrm{E}+03$ & $6.2 \mathrm{E}+02$ & $1.6 \mathrm{E}-11$ & $2.0 \mathrm{E}-08$ & $9.9 \mathrm{E}-09$ & $3.0 \mathrm{E}-08$ \\
\hline Uranium-235 & 0.0824 & $6.9 E+01$ & $3.5 \mathrm{E}+01$ & $1.6 \mathrm{E}-11$ & $1.1 \mathrm{E}-09$ & $5.5 \mathrm{E}-10$ & 1.7E-09 \\
\hline Uranium-238 & 1.3596 & $1.1 E+03$ & $5.7 \mathrm{E}+02$ & $2.8 \mathrm{E}-11$ & $3.2 \mathrm{E}-08$ & $1.6 \mathrm{E}-08$ & $4.8 \mathrm{E}-08$ \\
\hline Total pathway risk & & & & & 5.1E-07 & $26 \mathrm{E}-07$ & 7.TE-07 \\
\hline
\end{tabular}

The upper $95 \%$ confidence bound on the median is used as the representative concentration.

${ }^{b}$ Source: Health Effects Assessment Summary Tables (HEAST).

The radionuclide slope factors include contributions from daughter products.

${ }^{d}$ The risk for a child plus the risk for an adult. 


\section{$7-117$}

Table 7.16c. Background cancer risk estimates from exposure

to Oak Ridge Reservation soil constituents

Radionuclides/External Exposure

\begin{tabular}{|c|c|c|c|c|c|c|c|}
\hline Analyte & $\begin{array}{c}\text { Soil } \\
\text { conc. }^{a} \\
\text { (pCi/g) }\end{array}$ & $\begin{array}{c}\text { Adult } \\
\text { intake } \\
\text { dose } \\
\text { (pCi-yr/g) }\end{array}$ & $\begin{array}{c}\text { Child } \\
\text { intake } \\
\text { dose } \\
\text { (pCi-yr/g) }\end{array}$ & $\begin{array}{c}\text { External } \\
\text { Exposure } \\
\text { slope } \\
\text { factor, } \\
\text { (g/pCi-yr) }\end{array}$ & $\begin{array}{l}\text { Adult } \\
\text { background } \\
\text { cancer risk }\end{array}$ & $\begin{array}{l}\text { Child } \\
\text { background } \\
\text { cancer risk }\end{array}$ & $\begin{array}{c}\text { Total } \\
\text { background } \\
\text { cancer risk }\end{array}$ \\
\hline \multicolumn{8}{|c|}{$\begin{array}{l}\text { DISMAL GAP } \\
\text { Radionuclides }\end{array}$} \\
\hline Cesium-137 & 1.4130 & $2.7 E+01$ & $6.8 \mathrm{E}+00$ & $2.0 \mathrm{E}-06$ & $5.4 \mathrm{E}-05$ & $1.4 \mathrm{E}-05$ & $6.8 E-05$ \\
\hline Plutonium-239/240 & 0.0366 & $7.0 \mathrm{E}-01$ & $1.8 \mathrm{E}-01$ & $2.7 \mathrm{E}-11$ & $1.9 E-11$ & 4.7E-12 & $2.4 \mathrm{E}-11$ \\
\hline Potassium-40 & 19.8411 & $3.8 \mathrm{E}+02$ & $9.5 \mathrm{E}+01$ & $5.4 \mathrm{E}-07$ & 2.1E-04 & 5.1E-05 & $2.6 \mathrm{E}-04$ \\
\hline Radium-226 & 1.1437 & $2.2 E+01$ & $5.5 \mathrm{E}+00$ & $6.0 \mathrm{E}-0.0$ & $1.3 E-04$ & 3.3E-05 & $1.6 \mathrm{E}-04$ \\
\hline Strontium-90 & 1.3808 & $27 \mathrm{E}+01$ & $6.6 \mathrm{E}+00$ & $0.0 \mathrm{E}+00$ & $0.0 \mathrm{E}+\infty 0$ & $0.0 \mathrm{E}+00$ & $0.0 \mathrm{E}+00$ \\
\hline Thorium-228 & 1.0163 & $2.0 \mathrm{E}+01$ & $4.9 E+\infty 0$ & $5.6 \mathrm{E}-06$ & 1.1E-04 & 2.7E-05 & $1.4 \mathrm{E}-04$ \\
\hline Thorium-230 & 0.6774 & $1.3 E+01$ & $3.3 E+00$ & $5.4 \mathrm{E}-11$ & 7.0E-10 & $1.8 \mathrm{E}-10$ & $8.8 \mathrm{E}-10$ \\
\hline Thorium-232 & 0.7940 & $1.5 \mathrm{E}+01$ & $3.8 \mathrm{E}+00$ & $2.6 \mathrm{E}-11$ & $4.0 \mathrm{E}-10$ & $9.9 \mathrm{E}-11$ & $5.0 \mathrm{E}-10$ \\
\hline Thorium-234 & 1.8829 & $3.6 \mathrm{E}+01$ & $9.0 \mathrm{E}+00$ & $3.5 E-09$ & $1.3 E-07$ & $3.2 \mathrm{E}-08$ & $1.6 \mathrm{E}-07$ \\
\hline Tritium & 0.0443 & $8.5 \mathrm{E}-01$ & $2.1 E-01$ & $0.0 \mathrm{E}+00$ & $0.0 \mathrm{E}+00$ & $0.0 \mathrm{E}+00$ & $0.0 \mathrm{E}+00$ \\
\hline Uranium-233/234 & 1.1327 & $2.2 \mathrm{E}+01$ & $5.4 \mathrm{E}+00$ & $4.2 \mathrm{E}-11$ & 9.1E-10 & 2.3E-10 & $1.1 E-09$ \\
\hline Uranium-235 & 0.0950 & $1.8 \mathrm{E}+00$ & $4.6 \mathrm{E}-01$ & $2.4 \mathrm{E}-07$ & $4.4 \mathrm{E}-07$ & 1.1E-07 & $5.5 \mathrm{E}-07$ \\
\hline Uranium-236 & 0.0292 & $5.6 \mathrm{E}-01$ & $1.4 \mathrm{E}-01$ & $2.4 \mathrm{E}-11$ & $1.3 \mathrm{E}-11$ & $3.4 \mathrm{E}-12$ & $1.7 \mathrm{E}-11$ \\
\hline Uranium-238 & 1.1459 & $2.2 \mathrm{E}+01$ & $5.5 E+\infty 0$ & $3.6 \mathrm{E}-08$ & $7.9 \mathrm{E}-07$ & $2.0 E-07$ & $9.9 E-07$ \\
\hline Total pathway risk & & & & & 5.0E-04 & 13E-04 & $63 \mathrm{E}-04$ \\
\hline \multicolumn{8}{|c|}{ NOLICHUCKY } \\
\hline \multicolumn{8}{|c|}{ Radionuclides } \\
\hline Cesium-137 & 1.2444 & $2.4 E+01$ & $6.0 \mathrm{E}+00$. & $2.0 \mathrm{E}-06$ & $4.8 \mathrm{E}-05$ & $1.2 \mathrm{E}-05$ & $6.0 \mathrm{E}-05$ \\
\hline Curium-247 & 0.0065 & $1.2 \mathrm{E}-01$ & $3.1 E-02$ & 9.2E-07 & 1.1E-07 & $2.9 \mathrm{E}-08$ & $1.4 \mathrm{E}-07$ \\
\hline Neptunium-237 & 0.1900 & $3.6 \mathrm{E}+00$ & $9.1 E-01$ & 4.3E-07 & $1.6 \mathrm{E}-06$ & $3.9 E-07$ & $2.0 \mathrm{E}-06$ \\
\hline Potassium-40 & 18.4437 & $3.5 \mathrm{E}+02$ & $8.9 E+01$ & $5.4 \mathrm{E}-07$ & $1.9 \mathrm{E}-04$ & $4.8 \mathrm{E}-05$ & $2.4 \mathrm{E}-04$ \\
\hline Radium-226 & 1.0763 & $2.1 E+01$ & $5.2 \mathrm{E}+00$ & $6.0 \mathrm{E}-06$ & $1.2 \mathrm{E}-04$ & $3.1 E-05$ & $1.5 \mathrm{E}-04$ \\
\hline Technetium-99 & 1.9148 & $3.7 \mathrm{E}+01$ & $9.2 \mathrm{E}+00$ & $6.0 \mathrm{E}-13$ & $2.2 \mathrm{E}-11$ & $5.5 \mathrm{E}-12$ & $2.8 E-11$ \\
\hline Thorium-228 & 2.1491 & 4.1E+01 & $1.0 \mathrm{E}+01$ & $5.6 \mathrm{E}-06$ & 2.3E-04 & $5.8 \mathrm{E}-05$ & $2.9 \mathrm{E}-04$ \\
\hline Thorium-230 & 1.1584 & $2.2 \mathrm{E}+01$ & $5.6 \mathrm{E}+00$ & $5.4 \mathrm{E}-11$ & $1.2 \mathrm{E}-09$ & $3.0 \mathrm{E}-10$ & $1.5 \mathrm{E}-09$ \\
\hline Thorium-232 & 1.7374 & $3.3 E+01$ & $8.3 \mathrm{E}+00$ & $2.6 \mathrm{E}-11$ & 8.7E-10 & $2.2 \mathrm{E}-10$ & $1.1 \mathrm{E}-09$ \\
\hline Thorium-234 & 1.6385 & $3.1 \mathrm{E}+01$ & $7.9 \mathrm{E}+00$ & $3.5 \mathrm{E}-09$ & 1.1E-07 & $2.8 \mathrm{E}-08$ & $1.4 \mathrm{E}-07$ \\
\hline Uranium-233/234 & 1.5507 & $3.0 \mathrm{E}+01$ & $7.4 \mathrm{E}+00$ & $4.2 \mathrm{E}-11$ & $1.3 \mathrm{E}-09$ & $3.1 E-10$ & $1.6 \mathrm{E}-09$ \\
\hline Uranium-235 & 0.0855 & $1.6 \mathrm{E}+\infty 0$ & 4.1E-01 & $2.4 \mathrm{E}-07$ & $3.9 \mathrm{E}-07$ & $9.8 \mathrm{E}-08$ & $4.9 \mathrm{E}-07$ \\
\hline Uranium-238 & 1.4349 & $2.8 \mathrm{E}+01$ & $6.9 E+00$ & $3.6 \mathrm{E}-08$ & $9.9 \mathrm{E}-07$ & $25 \mathrm{E}-07$ & $1.2 \mathrm{E}-06$ \\
\hline Total pathway risk & & & & & 6.0E-04 & 1.5E-04 & 75E-04 \\
\hline \multicolumn{8}{|c|}{$\begin{array}{l}\text { COPPER RIDGE } \\
\text { Radionuclides }\end{array}$} \\
\hline Cesium-137 & 1.9887 & $3.8 \mathrm{E}+01$ & $9.5 \mathrm{E}+00$ & $2.0 \mathrm{E}-06$ & $7.6 \mathrm{E}-05$ & $1.9 \mathrm{E}-05$ & $9.5 \mathrm{E}-05$ \\
\hline Neptunium-237 & 0.1082 & $2.1 E+00$ & $5.2 \mathrm{E}-01$ & 4.3E-07 & $8.9 E-07$ & $2.2 E-07$ & $1.1 E-06$ \\
\hline Plutonium-238 & 0.0382 & 7.3E-01 & $1.8 \mathrm{E}-01$ & $2.8 \mathrm{E}-11$ & 2.1E-11 & $5.1 \mathrm{E}-12$ & $2.6 \mathrm{E}-11$ \\
\hline Plutonium-239/240 & 0.0598 & $1.1 \mathrm{E}+00$ & $2.9 \mathrm{E}-01$ & 2.7E-11 & 3.1E-11 & 7.7E-12 & $3.9 \mathrm{E}-11$ \\
\hline
\end{tabular}




\section{7-118}

Table 7.16c (continued)

\begin{tabular}{|c|c|c|c|c|c|c|c|}
\hline Analyte & $\begin{array}{c}\text { Soil } \\
\text { conc }{ }^{a} \\
\text { (pCi/g) }\end{array}$ & $\begin{array}{c}\text { Adult } \\
\text { intake } \\
\text { dose } \\
\text { (pCi-yr/g) }\end{array}$ & $\begin{array}{c}\text { Child } \\
\text { intake } \\
\text { dose } \\
\text { (pCi-yr/g) }\end{array}$ & $\begin{array}{c}\text { External } \\
\text { Exposure } \\
\text { slope } \\
\text { factor }{ }^{b, c} \\
\text { (g/pCi-yr) }\end{array}$ & $\begin{array}{c}\text { Aduit } \\
\text { background } \\
\text { cancer risk }\end{array}$ & $\begin{array}{c}\text { Child } \\
\text { background } \\
\text { cancer risk }\end{array}$ & $\begin{array}{c}\text { Total } \\
\text { background } \\
\text { cancer risk }^{d}\end{array}$ \\
\hline
\end{tabular}

\begin{tabular}{|c|c|c|c|c|c|c|c|}
\hline \multicolumn{8}{|c|}{$\begin{array}{l}\text { COPPER RIDGE (continued) } \\
\text { Radionuclides (continued) }\end{array}$} \\
\hline Potassium -40 & 4.9722 & $9.5 E+01$ & $2.4 \mathrm{E}+01$ & $5.4 \mathrm{E}-07$ & $5.2 \mathrm{E}-0.5$ & $1.3 E-05$ & $6.4 \mathrm{E}-05$ \\
\hline Radium-226 & 1.7758 & $3.4 \mathrm{E}+01$ & $8.5 \mathrm{E}+00$ & $6.0 \mathrm{E}-06$ & $2.0 \mathrm{E}-04$ & 5.1E-05 & $2.6 \mathrm{E}-04$ \\
\hline Thorium-228 & 0.4836 & $9.3 E+00$ & $2.3 E+00$ & $5.6 \mathrm{E}-06$ & $5.2 \mathrm{E}-05$ & 1.3E-05 & $6.5 E-05$ \\
\hline Thorium-230 & 1.3274 & $2.5 \mathrm{E}+01$ & $6.4 \mathrm{E}+00$ & $5.4 \mathrm{E}-11$ & $1.4 \mathrm{E}-09$ & $3.4 \mathrm{E}-10$ & $1.7 \mathrm{E}-09$ \\
\hline Thorium-232 & 0.7887 & $1.5 \mathrm{E}+01$ & $3.8 \mathrm{E}+00$ & $2.6 \mathrm{E}-11$ & $3.9 \mathrm{E}-10$ & 9.8E-11 & $4.9 \mathrm{E}-10$ \\
\hline Thorium-234 & 1.8380 & $3.5 \mathrm{E}+01$ & $8.8 \mathrm{E}+00$ & $3.5 \mathrm{E}-09$ & $1.2 \mathrm{E}-07$ & $3.1 \mathrm{E}-08$ & $1.5 \mathrm{E}-07$ \\
\hline Tritium & 0.0264 & 5.1E-01 & $1.3 \mathrm{E}-01$ & $0.0 \mathrm{E}+00$ & $0.0 \mathrm{E}+00$ & $0.0 \mathrm{E}+00$ & $0.0 \mathrm{E}+00$ \\
\hline Uranium-233/234 & 1.7521 & $3.4 \mathrm{E}+01$ & $8.4 \mathrm{E}+00$ & $4.2 \mathrm{E}-11$ & $1.4 \mathrm{E}-09$ & $3.5 \mathrm{E}-10$ & $1.8 \mathrm{E}-09$ \\
\hline Uranium-235 & 0.1769 & $3.4 \mathrm{E}+00$ & $8.5 E-01$ & $2.4 \mathrm{E}-07$ & 8.1E-07 & $20 \mathrm{E}-07$ & $1.0 \mathrm{E}-06$ \\
\hline Uranium-236 & 0.0174 & 3.3E-01 & 8.3E-02 & $2.4 \mathrm{E}-11$ & 8.0E-12 & $2.0 \mathrm{E}-12$ & $1.0 \mathrm{E}-11$ \\
\hline Uranium-238 & 1.5437 & $3.0 E+01$ & $7.4 \mathrm{E}+00$ & $3.6 \mathrm{E}-08$ & 1.1E-06 & 2.7E-07 & $1.3 \mathrm{E}-06$ \\
\hline \multicolumn{5}{|l|}{ Total pathway risk } & $3.9 \mathrm{E}-04$ & 9.7E-05 & 4.8E-04 \\
\hline \multicolumn{8}{|c|}{$\begin{array}{l}\text { CHEPULTEPEC } \\
\text { Radionuclides }\end{array}$} \\
\hline Cesium-137 & 2.3584 & $4.5 E+01$ & $1.1 E+01$ & $2.0 E-06$ & 9.1E-05 & $2.3 E-05$ & $1.1 \mathrm{E}-04$ \\
\hline Neptunium-237 & 0.0891 & 1.7E+00 & 4.3E-01 & 4.3E-07 & $7.4 \mathrm{E}-07$ & $1.8 \mathrm{E}-07$ & $9.2 \mathrm{E}-07$ \\
\hline Plutonium-238 & 0.1305 & $2.5 \mathrm{E}+00$ & $6.3 \mathrm{E}-01$ & $2.8 \mathrm{E}-11$ & 7.0E-11 & $1.8 \mathrm{E}-11$ & $8.8 \mathrm{E}-11$ \\
\hline Potassium -40 & 3.8195 & $7.3 \mathrm{E}+01$ & $1.8 \mathrm{E}+01$ & $5.4 \mathrm{E}-07$ & $4.0 \mathrm{E}-05$ & $9.9 \mathrm{E}-06$ & $5.0 \mathrm{E}-05$ \\
\hline Radium-226 & 1.2660 & $2.4 E+01$ & $6.1 E+00$ & $6.0 \mathrm{E}-06$ & $1.5 \mathrm{E}-0.4$ & $3.6 \mathrm{E}-05$ & $1.8 \mathrm{E}-04$ \\
\hline Thorium-228 & 0.8629 & $1.7 \mathrm{E}+01$ & $4.1 E+00$ & $5.6 \mathrm{E}-06$ & 9.3E-05 & $2.3 \mathrm{E}-05$ & $1.2 \mathrm{E}-04$ \\
\hline Thorium-230 & 0.9274 & $1.8 \mathrm{E}+01$ & $4.5 E+00$ & $5.4 \mathrm{E}-11$ & 9.6E-10 & $2.4 \mathrm{E}-10$ & $1.2 \mathrm{E}-09$ \\
\hline Thorium-232 & 0.7224 & $1.4 \mathrm{E}+01$ & $3.5 E+00$ & $26 \mathrm{E}-11$ & 3.6E-10 & $9.0 \mathrm{E}-11$ & $4.5 \mathrm{E}-10$ \\
\hline Uranium-233/234 & 1.3351 & $2.6 \mathrm{E}+01$ & $6.4 \mathrm{E}+00$ & 4.2E-11 & 1.1E-09 & $2.7 \mathrm{E}-10$ & $1.3 \mathrm{E}-09$ \\
\hline Uranium-235 & 0.1042 & $2.0 \mathrm{E}+00$ & $5.0 \mathrm{E}-01$ & $24 E-07$ & $4.8 \mathrm{E}-07$ & $1.2 \mathrm{E}-07$ & $6.0 \mathrm{E}-07$ \\
\hline Uranium-238 & 1.2559 & $2.4 \mathrm{E}+01$ & $6.0 \mathrm{E}+00$ & $3.6 \mathrm{E}-08$ & $8.7 \mathrm{E}-07$ & $2.2 \mathrm{E}-07$ & $1.1 \mathrm{E}-06$ \\
\hline Total pathway rist & & & & & 3.TE-04 & 9.3E-05 & $4.6 \mathrm{E}-04$ \\
\hline
\end{tabular}

CHICKAMAUGA (BETHEL VALIEY)

Radionuclides

$\begin{array}{lrllllll}\text { Cesium-137 } & 3.1908 & 6.1 \mathrm{E}+01 & 1.5 \mathrm{E}+01 & 2.0 \mathrm{E}-06 & 1.2 \mathrm{E}-04 & 3.1 \mathrm{E}-05 & 1.5 \mathrm{E}-04 \\ \text { Neptunium-237 } & 0.1249 & 2.4 \mathrm{E}+00 & 6.0 \mathrm{E}-01 & 4.3 \mathrm{E}-07 & 1.0 \mathrm{E}-06 & 2.6 \mathrm{E}-07 & 1.3 \mathrm{E}-06 \\ \text { Plutonium-238 } & 0.1289 & 2.5 \mathrm{E}+00 & 6.2 \mathrm{E}-01 & 2.8 \mathrm{E}-11 & 6.9 \mathrm{E}-11 & 1.7 \mathrm{E}-11 & 8.7 \mathrm{E}-11 \\ \text { Plutonium-239/240 } & 0.0772 & 1.5 \mathrm{E}+00 & 3.7 \mathrm{E}-01 & 2.7 \mathrm{E}-11 & 4.0 \mathrm{E}-11 & 1.0 \mathrm{E}-11 & 5.0 \mathrm{E}-11 \\ \text { Potassium-40 } & 18.3899 & 3.5 \mathrm{E}+02 & 8.8 \mathrm{E}+01 & 5.4 \mathrm{E}-07 & 1.9 \mathrm{E}-04 & 4.8 \mathrm{E}-05 & 2.4 \mathrm{E}-04 \\ \text { Radium-226 } & 1.5669 & 3.0 \mathrm{E}+01 & 7.5 \mathrm{E}+00 & 6.0 \mathrm{E}-06 & 1.8 \mathrm{E}-04 & 4.5 \mathrm{E}-05 & 2.3 \mathrm{E}-04 \\ \text { Technetium-99 } & 1.9843 & 3.8 \mathrm{E}+01 & 9.5 \mathrm{E}+00 & 6.0 \mathrm{E}-13 & 2.3 \mathrm{E}-11 & 5.7 \mathrm{E}-12 & 2.9 \mathrm{E}-11 \\ \text { Thorium-228 } & 1.8359 & 3.5 \mathrm{E}+01 & 8.8 \mathrm{E}+00 & 5.6 \mathrm{E}-06 & 2.0 \mathrm{E}-04 & 4.9 \mathrm{E}-05 & 2.5 \mathrm{E}-04 \\ \text { Thorium-230 } & 1.2672 & 2.4 \mathrm{E}+01 & 6.1 \mathrm{E}+00 & 5.4 \mathrm{E}-11 & 1.3 \mathrm{E}-09 & 3.3 \mathrm{E}-10 & 1.6 \mathrm{E}-09\end{array}$


Table 7.16c (continued)

\begin{tabular}{|c|c|c|c|c|c|c|c|}
\hline Analyte & $\begin{array}{c}\text { Soil } \\
\text { conc }^{a} \\
\text { (pCi/g) }\end{array}$ & $\begin{array}{c}\text { Adult } \\
\text { intake } \\
\text { dose } \\
\text { (pCi-yr/g) }\end{array}$ & $\begin{array}{c}\text { Child } \\
\text { intake } \\
\text { dose } \\
\text { (pCi-yr/g) }\end{array}$ & $\begin{array}{c}\text { External } \\
\text { Exposure } \\
\text { slope } \\
\text { factor } \\
\text { (g/pCi-yr) }\end{array}$ & $\begin{array}{l}\text { Adult } \\
\text { background } \\
\text { cancer risk }\end{array}$ & $\begin{array}{l}\text { Child } \\
\text { background } \\
\text { cancer risk }\end{array}$ & $\begin{array}{l}\text { Total . } \\
\text { background } \\
\text { cancer risk }\end{array}$ \\
\hline
\end{tabular}

\section{CHICKAMAUGA (BETHEL VALLEY) (continued) \\ Radionuciides (continued)}

\begin{tabular}{|c|c|c|c|c|c|c|c|}
\hline Thorium-232 & 1.4514 & $2.8 \mathrm{E}+01$ & $7.0 \mathrm{E}+00$ & $2.6 \mathrm{E}-11$ & $7.2 \mathrm{E}-10$ & $1.8 \mathrm{E}-10$ & 9.1E-10 \\
\hline Tritium & 0.1616 & $3.1 \mathrm{E}+00$ & $7.8 \mathrm{E}-01$ & $0.0 \mathrm{E}+\infty 0$ & $0.0 E+00$ & $0.0 \mathrm{E}+00$ & $0.0 \mathrm{E}+00$ \\
\hline Uranium-233/234 & 1.2233 & $2.3 E+01$ & $5.9 \mathrm{E}+00$ & 4.2E-11 & 9.9E-10 & $2.5 \mathrm{E}-10$ & $1.2 \mathrm{E}-09$ \\
\hline Uranium-235 & 0.1315 & $2.5 \mathrm{E}+00$ & $6.3 E-01$ & $2.4 \mathrm{E}-07$ & $6.1 \mathrm{E}-07$ & $1.5 \mathrm{E}-07$ & $7.6 \mathrm{E}-07$ \\
\hline Uranium-238 & 1.1879 & $2.3 \mathrm{E}+01$ & $5.7 \mathrm{E}+00$ & $3.6 \mathrm{E}-08$ & 8.2E-07 & 2.1E-07 & $1.0 \mathrm{E}-06$ \\
\hline \multirow[t]{2}{*}{ Total pathway risk } & & & & & $6.9 \mathrm{E}-04$ & 1.7E-04 & 8.7E-04 \\
\hline & \multicolumn{5}{|c|}{$\begin{array}{c}\text { CHICKAMAUGA (K-25) } \\
\text { Radionuclides }\end{array}$} & & \\
\hline Cesium-137 & 2.5633 & $4.9 E+01$ & $1.2 \mathrm{E}+01$ & $2.0 \mathrm{E}-06$ & $9.8 \mathrm{E}-05$ & $2.5 \mathrm{E}-05$ & $1.2 E-04$ \\
\hline Neptunium-237 & 0.1199 & $2.3 E+00$ & $5.8 \mathrm{E}-01$ & 4.3E-07 & $9.9 E-07$ & $2.5 \mathrm{E}-07$ & $1.2 \mathrm{E}-06$ \\
\hline Plutonium-238 & 0.1149 & $2.2 \mathrm{E}+00$ & $5.5 \mathrm{E}-01$ & $2.8 \mathrm{E}-11$ & $6.2 \mathrm{E}-11$ & $1.5 \mathrm{E}-11$ & 7.7E-11 \\
\hline Plutonium-239/240 & 0.0487 & $9.3 E-01$ & 2.3E-01 & $2.7 \mathrm{E}-11$ & $25 \mathrm{E}-11$ & $6.3 \mathrm{E}-12$ & $3.2 E-11$ \\
\hline Potassium-40 & 11.7684 & $2.3 \mathrm{E}+02$ & $5.6 E+01$ & $5.4 \mathrm{E}-07$ & $1.2 \mathrm{E}-04$ & 3.1E-05 & $1.5 E-04$ \\
\hline Radium-226 & 1.3535 & $2.6 \mathrm{E}+01$ & $6.5 E+00$ & $6.0 \mathrm{E}-0.6$ & $1.6 \mathrm{E}-04$ & $3.9 \mathrm{E}-05$ & $1.9 \mathrm{E}-04$ \\
\hline Technetium-99 & 1.6665 & $3.2 \mathrm{E}+01$ & $8.0 \mathrm{E}+00$ & $6.0 \mathrm{E}-13$ & $1.9 \mathrm{E}-11$ & $4.8 \mathrm{E}-12$ & $2.4 \mathrm{E}-11$ \\
\hline Thorium-228 & 1.6072 & $3.1 \mathrm{E}+01$ & $7.7 \mathrm{E}+00$ & $5.6 \mathrm{E}-06$ & $1.7 \mathrm{E}-04$ & $4.3 \mathrm{E}-05$ & $2.2 \mathrm{E}-04$ \\
\hline Thorium-230 & 1.2438 & $2.4 E+01$ & $6.0 \mathrm{E}+00$ & $5.4 \mathrm{E}-11$ & $1.3 E-09$ & $3.2 \mathrm{E}-10$ & $1.6 \mathrm{E}-09$ \\
\hline Thorium-232 & 1.2827 & $2.5 E+01$ & $6.2 \mathrm{E}+00$ & $2.6 \mathrm{E}-11$ & $6.4 \mathrm{E}-10$ & $1.6 \mathrm{E}-10$ & $8.0 \mathrm{E}-10$ \\
\hline Uranium-233/234 & 1.4726 & $2.8 \mathrm{E}+01$ & $7.1 \mathrm{E}+00$ & $4.2 \mathrm{E}-11$ & $1.2 E-09$ & $3.0 \mathrm{E}-10$ & $1.5 \mathrm{E}-09$ \\
\hline Uranium-235 & 0.0824 & $1.6 \mathrm{E}+00$ & $4.0 \mathrm{E}-01$ & $2.4 \mathrm{E}-07$ & $3.8 E-07$ & $9.5 \mathrm{E}-08$ & 4.7E-07 \\
\hline Uranium-238 & 1.3596 & $2.6 \mathrm{E}+01$ & $6.5 E+\infty 0$ & $3.6 \mathrm{E}-08$ & 9.4E-07 & 2.3E-07 & $1.2 \mathrm{E}-06$ \\
\hline Total pathway risk & & & & & $55 \mathrm{E}-04$ & $1.4 \mathrm{E}-04$ & 6.9E-04 \\
\hline
\end{tabular}

'The upper $95 \%$ confidence bound on the median is used as the representative concentration.

'Source: Health Effects Assessment Summary Tables (HEAST).

The radionuclide slope factors include contributions from daughter products.

${ }^{d}$ The risk for a child plus the risk for an adult. 
Table 7.17a. Background hazard index estimates for residents exposed to Oak Ridge Reservation soil constituents

Ingestion

\begin{tabular}{|c|c|c|c|c|c|c|c|c|}
\hline Analyte & $\begin{array}{c}\text { Soil } \\
\text { Conc. } \\
(\mathrm{mg} / \mathrm{kg})\end{array}$ & $\begin{array}{c}\text { Adult } \\
\text { daily } \\
\text { intake } \\
\text { (mg/kg-day) }\end{array}$ & $\begin{array}{l}\text { Child } \\
\text { daily } \\
\text { intake } \\
\text { (mg/kg-day) }\end{array}$ & $\begin{array}{c}\text { Chronic } \\
\text { oral RfD } \\
\text { (mg/kg-day) }\end{array}$ & $\begin{array}{l}\text { Subchronic } \\
\text { oral RfD } \\
\text { (mg/kg-day) }\end{array}$ & $\begin{array}{l}\text { Adult } \\
\text { HI } \\
\text { chronic }\end{array}$ & $\begin{array}{c}\text { Child } \\
\text { HI } \\
\text { subchronic }\end{array}$ & $\begin{array}{l}\text { Total } \\
\mathrm{HI}^{c}\end{array}$ \\
\hline
\end{tabular}

\begin{tabular}{|c|c|c|c|c|c|c|c|c|}
\hline \multicolumn{9}{|c|}{$\begin{array}{l}\text { DISMAL GAP } \\
\text { Inorganics }\end{array}$} \\
\hline Arsenic & 7.9709 & 1.1E-05 & $1.0 \mathrm{E}-04$ & $3.0 \mathrm{E}-04$ & $3.0 \mathrm{E}-04$ & $3.6 \mathrm{E}-02$ & $3.4 \mathrm{E}-01$ & $3.8 \mathrm{E}-01$ \\
\hline Barium & 128.5841 & $1.8 \mathrm{E}-04$ & $1.6 \mathrm{E}-03$ & $7.0 \mathrm{E}-02$ & $7.0 \mathrm{E}-02$ & $2.5 \mathrm{E}-03$ & $2.3 E-02$ & $2.6 \mathrm{E}-02$ \\
\hline Beryllium & 0.9572 & $1.3 E-06$ & $1.2 \mathrm{E}-05$ & $5.0 \mathrm{E}-03$ & $5.0 \mathrm{E}-03$ & $2.6 \mathrm{E}-04$ & $2.4 \mathrm{E}-03$ & 2.TE-03 \\
\hline Boron & 22.6907 & $3.1 E-05$ & $2.9 \mathrm{E}-04$ & $9.0 \mathrm{E}-02$ & $9.0 \mathrm{E}-02$ & $3.5 \mathrm{E}-04$ & $3.2 E-03$ & $3.6 \mathrm{E}-03$ \\
\hline Chromium VI & 29.2046 & $4.0 \mathrm{E}-05$ & 3.7E-04 & $5.0 \mathrm{E}-03$ & $2.0 \mathrm{E}-02$ & $8.0 \mathrm{E}-03$ & $1.9 E-02$ & 2.7E-02 \\
\hline Cyanide & 0.2815 & $3.9 E-07$ & $3.6 \mathrm{E}-06$ & $2.0 \mathrm{E}-02$ & $2.0 E-02$ & $1.9 \mathrm{E}-05$ & $1.8 \mathrm{E}-04$ & $2.0 \mathrm{E}-04$ \\
\hline Manganese & 1365.3139 & $1.9 E-03$ & $1.7 \mathrm{E}-02$ & $1.4 \mathrm{E}-01$ & $1.4 \mathrm{E}-01$ & $1.3 E-02$ & $1.2 \mathrm{E}-01$ & $1.4 \mathrm{E}-01$ \\
\hline Mercury & 0.3703 & $5.1 E-07$ & 4.7E-06 & $3.0 \mathrm{E}-04$ & $3.0 \mathrm{E}-04$ & $1.7 \mathrm{E}-03$ & $1.6 \mathrm{E}-02$ & $1.7 \mathrm{E}-02$ \\
\hline Mercury (salts) & 0.3703 & 5.1E-07 & 4.7E-06 & $3.0 \mathrm{E}-04$ & $3.0 \mathrm{E}-04$ & $1.7 \mathrm{E}-03$ & $1.6 \mathrm{E}-02$ & $1.7 \mathrm{E}-02$ \\
\hline Nickel & 29.1185 & $4.0 \mathrm{E}-05$ & 3.7E-04 & $2.0 \mathrm{E}-02$ & $2.0 \mathrm{E}-02$ & $2.0 \mathrm{E}-03$ & $1.9 \mathrm{E}-02$ & $2.1 E-02$ \\
\hline Nickel (salts) & 29.1185 & $4.0 \mathrm{E}-05$ & 3.7E-04 & $2.0 E-02$ & $2.0 \mathrm{E}-02$ & $2.0 \mathrm{E}-03$ & $1.9 \mathrm{E}-02$ & $2.1 E-02$ \\
\hline Strontium & 11.4312 & $1.6 \mathrm{E}-05$ & $1.5 \mathrm{E}-04$ & $6.0 \mathrm{E}-01$ & $6.0 \mathrm{E}-01$ & $2.6 \mathrm{E}-05$ & $2.4 \mathrm{E}-04$ & $2.7 \mathrm{E}-04$ \\
\hline Vanadium & 39.1295 & $5.4 \mathrm{E}-05$ & $5.0 \mathrm{E}-04$ & 7.0E-03 & $7.0 \mathrm{E}-03$ & 7.7E-03 & 7.1E-02 & $7.9 \mathrm{E}-02$ \\
\hline Zinc & 62.6069 & $8.6 \mathrm{E}-05$ & $8.0 \mathrm{E}-04$ & $3.0 \mathrm{E}-01$ & $3.0 \mathrm{E}-01$ & $2.9 \mathrm{E}-04$ & 2.7E-03 & $3.0 \mathrm{E}-03$ \\
\hline Total pathway $\mathrm{HI}^{d}$ & & & & & & $73 E-02$ & $62 \mathrm{E}-01$ & $6.9 \mathrm{E}-01$ \\
\hline \multicolumn{9}{|c|}{$\begin{array}{c}\text { NOLICHUCXY } \\
\text { Inorganics }\end{array}$} \\
\hline Antimony & 0.4848 & $6.6 \mathrm{E}-07$ & $6.2 E-06$ & 4.0E-04 & $4.0 \mathrm{E}-04$ & $1.7 \mathrm{E}-03$ & $1.5 \mathrm{E}-02$ & 1.7E-02 \\
\hline Arsenic & 8.1750 & 1.1E-05 & $1.0 \mathrm{E}-04$ & $3.0 \mathrm{E}-04$ & $3.0 \mathrm{E}-04$ & 3.7E-02 & $3.5 \mathrm{E}-01$ & $3.9 \mathrm{E}-01$ \\
\hline Barium & 97.8229 & $1.3 \mathrm{E}-04$ & $1.3 \mathrm{E}-03$ & $7.0 \mathrm{E}-02$ & $7.0 \mathrm{E}-02$ & $1.9 E-03$ & $1.8 \mathrm{E}-02$ & $2.0 \mathrm{E}-02$ \\
\hline Beryllium & 0.9639 & $1.3 \mathrm{E}-06$ & $1.2 \mathrm{E}-05$ & $5.0 \mathrm{E}-03$ & $5.0 \mathrm{E}-03$ & $26 \mathrm{E}-04$ & $2.5 \mathrm{E}-03$ & $2.7 \mathrm{E}-03$ \\
\hline Chromium VI & 34.0056 & 4.7E-05 & $4.3 \mathrm{E}-04$ & $5.0 \mathrm{E}-03$ & $2.0 \mathrm{E}-02$ & $9.3 \mathrm{E}-03$ & $2.2 \mathrm{E}-02$ & $3.1 E-02$ \\
\hline Manganese & 894.8327 & $1.2 \mathrm{E}-03$ & $1.1 E-02$ & $1.4 \mathrm{E}-01$ & $1.4 \mathrm{E}-01$ & $8.8 \mathrm{E}-03$ & $8.2 \mathrm{E}-02$ & $9.0 \mathrm{E}-02$ \\
\hline Mercury & 0.2168 & $3.0 \mathrm{E}-07$ & $2.8 \mathrm{E}-06$ & $3.0 \mathrm{E}-04$ & $3.0 \mathrm{E}-04$ & $9.9 \mathrm{E}-04$ & $9.2 \mathrm{E}-03$ & $1.0 \mathrm{E}-02$ \\
\hline Mercury (salts) & 0.2168 & $3.0 \mathrm{E}-07$ & $2.8 E-06$ & $3.0 \mathrm{E}-04$ & $3.0 \mathrm{E}-04$ & $9.9 \mathrm{E}-04$ & $9.2 \mathrm{E}-03$ & $1.0 \mathrm{E}-02$ \\
\hline Nickel & 21.4359 & $2.9 \mathrm{E}-05$ & 2.7E-04 & $2.0 \mathrm{E}-02$ & $2.0 \mathrm{E}-02$ & $1.5 \mathrm{E}-03$ & $1.4 \mathrm{E}-02$ & $1.5 \mathrm{E}-02$ \\
\hline Nickel (salts) & 21.4359 & $2.9 \mathrm{E}-05$ & 2.7E-04 & $2.0 \mathrm{E}-02$ & $2.0 \mathrm{E}-02$ & $1.5 E-03$ & $1.4 \mathrm{E}-02$ & $1.5 \mathrm{E}-02$ \\
\hline Selenium & 0.7175 & $9.8 \mathrm{E}-07$ & $9.2 E-06$ & $5.0 \mathrm{E}-03$ & $5.0 \mathrm{E}-03$ & $2.0 \mathrm{E}-04$ & $1.8 E-03$ & $2.0 \mathrm{E}-03$ \\
\hline Strontium & 6.2450 & $8.6 \mathrm{E}-06$ & $8.0 \mathrm{E}-05$ & $6.0 \mathrm{E}-01$ & $6.0 \mathrm{E}-01$ & $1.4 \mathrm{E}-05$ & $1.3 E-04$ & $1.5 \mathrm{E}-04$ \\
\hline Vanadium & 37.1249 & 5.1E-05 & 4.7E-04 & $7.0 \mathrm{E}-03$ & $7.0 \mathrm{E}-03$ & $7.3 E-03$ & $6.8 \mathrm{E}-02$ & $7.5 \mathrm{E}-02$ \\
\hline Zinc & 46.8386 & $6.4 \mathrm{E}-05$ & $6.0 \mathrm{E}-04$ & $3.0 \mathrm{E}-01$ & $3.0 \mathrm{E}-01$ & $2.1 E-04$ & $2.0 \mathrm{E}-03$ & $2.2 \mathrm{E}-03$ \\
\hline Total pathway $\mathbf{H I}^{d}$ & & & & & & $6.9 \mathrm{E}-02$ & $58 \mathrm{E}-01$ & $6.5 \mathrm{E}-01$ \\
\hline \multicolumn{9}{|c|}{$\begin{array}{l}\text { COPPER RIDGE } \\
\text { Inorganics }\end{array}$} \\
\hline Arsenic & 30.7476 & 4.2E-05 & $3.9 \mathrm{E}-04$ & $3.0 \mathrm{E}-04$ & $3.0 \mathrm{E}-04$ & $1.4 \mathrm{E}-01$ & $1.3 E+00$ & $1.5 \mathrm{E}+00$ \\
\hline Barium & 93.1747 & $1.3 \mathrm{E}-04$ & $1.2 \mathrm{E}-03$ & $7.0 \mathrm{E}-02$ & $7.0 \mathrm{E}-02$ & $1.8 \mathrm{E}-03$ & $1.7 \mathrm{E}-02$ & $1.9 \mathrm{E}-02$ \\
\hline Beryllium & 0.6337 & 8.7E-07 & 8.1E-06 & $5.0 \mathrm{E}-03$ & $5.0 \mathrm{E}-03$ & 1.7E-04 & $1.6 \mathrm{E}-03$ & $1.8 \mathrm{E}-03$ \\
\hline
\end{tabular}


Table 7.17a (continued)

\begin{tabular}{lcccccccc}
\hline Ańalyte & $\begin{array}{c}\text { Soil } \\
\text { Conc. } \\
(\mathrm{mg} / \mathrm{kg})\end{array}$ & $\begin{array}{c}\text { Adult } \\
\text { daily } \\
\text { intake } \\
(\mathrm{mg} / \mathrm{kg} \text {-day) }\end{array}$ & $\begin{array}{c}\text { Child } \\
\text { daily } \\
\text { intake } \\
(\mathrm{mg} / \mathrm{kg} \text {-day) }\end{array}$ & $\begin{array}{c}\text { Chronic } \\
\text { oral } \mathrm{RfD}^{b} \\
\left(\mathrm{mg} / \mathrm{kg}^{b}-\mathrm{day}\right)\end{array}$ & $\begin{array}{c}\text { Subchronic } \\
\text { oral RID } \\
(\mathrm{mg} / \mathrm{kg} \text {-day) }\end{array}$ & $\begin{array}{c}\text { Adult } \\
\text { chronic }\end{array}$ & $\begin{array}{c}\text { Child } \\
\text { subchronic }\end{array}$ & $\begin{array}{c}\text { Total } \\
\mathrm{HI}^{c}\end{array}$ \\
\hline
\end{tabular}

COPPER RIDGE (continued)

Inorganics (continued)

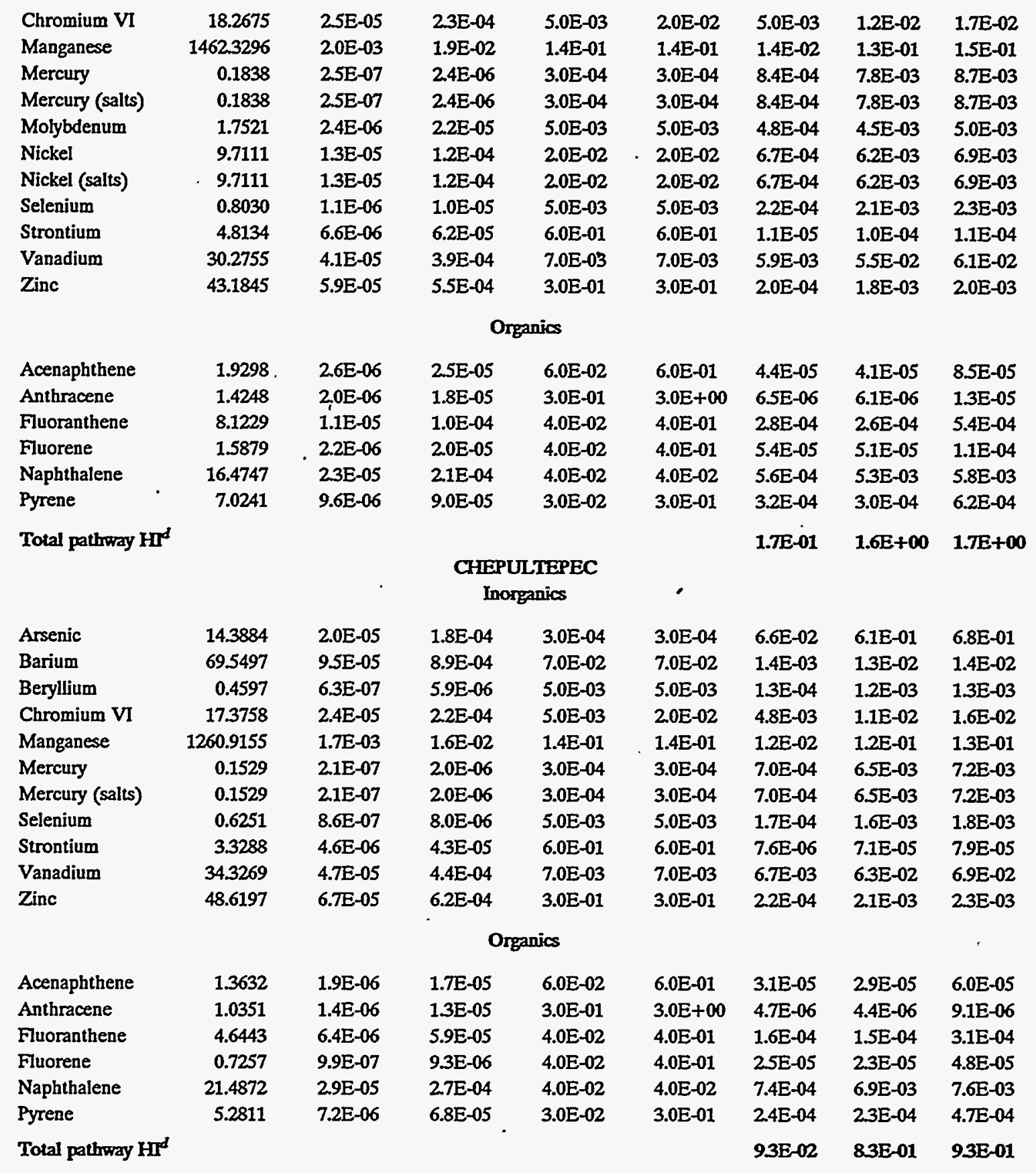


Table 7.17a (continued)

\begin{tabular}{|c|c|c|c|c|c|c|c|c|}
\hline Analyte & $\begin{array}{c}\text { Soil } \\
\text { Conc }^{a} \\
(\mathrm{mg} / \mathrm{kg})\end{array}$ & $\begin{array}{c}\text { Adult } \\
\text { daily } \\
\text { intake } \\
\text { (mg/kg-day) }\end{array}$ & $\begin{array}{c}\text { Child } \\
\text { daily } \\
\text { intake } \\
\text { (mg/kg-day) }\end{array}$ & $\begin{array}{c}\text { Chronic } \\
\text { oral RfD } \\
\text { (mg/kg-day) }\end{array}$ & $\begin{array}{l}\text { Subchronic } \\
\text { oral RED } \\
\text { (mg/kg-day) }\end{array}$ & $\begin{array}{l}\text { Adult } \\
\text { HI } \\
\text { chronic }\end{array}$ & $\begin{array}{c}\text { Child } \\
\text { HI } \\
\text { subchronic }\end{array}$ & $\begin{array}{l}\text { Total } \\
\mathrm{HI}^{c}\end{array}$ \\
\hline
\end{tabular}

CHICKAMAUGA (BETHEL VAUIEY)

\begin{tabular}{|c|c|c|c|c|c|c|c|c|}
\hline \multicolumn{9}{|c|}{ Inorganics } \\
\hline Arsenic & 7.9867 & $1.1 E-05$ & $1.0 \mathrm{E}-04$ & $3.0 \mathrm{E}-04$ & $3.0 \mathrm{E}-04$ & $3.6 \mathrm{E}-02$ & $3.4 \mathrm{E}-01$ & $3.8 \mathrm{E}-01$ \\
\hline Barium & 103.3075 & $1.4 \mathrm{E}-04$ & $1.3 \mathrm{E}-03$ & $7.0 \mathrm{E}-02$ & $7.0 \mathrm{E}-02$ & $20 E-03$ & $1.9 \mathrm{E}-02$ & 2.1E-02 \\
\hline Beryllium & 1.2480 & 1.TE-06 & $1.6 \mathrm{E}-05$ & $5.0 \mathrm{E}-03$ & $5.0 \mathrm{E}-03$ & 3.4E-04 & $3.2 \mathrm{E}-03$ & $3.5 \mathrm{E}-03$ \\
\hline Chromium VI & 40.2327 & $5.5 \mathrm{E}-05$ & $5.1 E-04$ & $5.0 \mathrm{E}-03$ & $2.0 \mathrm{E}-02$ & $1.1 E-02$ & $2.6 \mathrm{E}-02$ & 3.7E-02 \\
\hline Manganese & 1442.6173 & $2.0 \mathrm{E}-03$ & $1.8 \mathrm{E}-02$ & $1.4 \mathrm{E}-01$ & $1.4 \mathrm{E}-01$ & $1.4 \mathrm{E}-02$ & $1.3 \mathrm{E}-01$ & $1.5 E-01$ \\
\hline Mercury & 0.1875 & $26 \mathrm{E}-07$ & $2.4 \mathrm{E}-06$ & $3.0 \mathrm{E}-04$ & $3.0 \mathrm{E}-04$ & 8.6E-04 & $8.0 \mathrm{E}-03$ & $8.8 \mathrm{E}-03$ \\
\hline Mercury (salts) & 0.1875 & $2.6 \mathrm{E}-07$ & $2.4 \mathrm{E}-06$ & $3.0 \mathrm{E}-04$ & $3.0 \mathrm{E}-04$ & $8.6 \mathrm{E}-04$ & $8.0 \mathrm{E}-03$ & $8.8 \mathrm{E}-03$ \\
\hline Nickel & 16.6791 & 2.3E-05 & 2.1E-04 & $2.0 \mathrm{E}-02$ & $2.0 \mathrm{E}-02$ & $1.1 \mathrm{E}-03$ & $1.1 E-02$ & $1.2 E-02$ \\
\hline Nickel (salts) & 16.6791 & 2.3E-05 & 2.1E-04 & $2.0 \mathrm{E}-02$ & $2.0 \mathrm{E}-02$ & $1.1 \mathrm{E}-03$ & $1.1 \mathrm{E}-02$ & $1.2 \mathrm{E}-02$ \\
\hline Selenium & 0.9313 & $1.3 \mathrm{E}-06$ & $1.2 \mathrm{E}-05$ & $5.0 \mathrm{E}-03$ & $5.0 \mathrm{E}-03$ & $2.6 \mathrm{E}-04$ & $2.4 E-03$ & 2.6E-03 \\
\hline Strontium & 8.6393 & $1.2 E-05$ & $1.1 E-04$ & $6.0 \mathrm{E}-01$ & $6.0 \mathrm{E}-01$ & $2.0 \mathrm{E}-0 \mathrm{~S}$ & $1.8 \mathrm{E}-04$ & $2.0 \mathrm{E}-0.4$ \\
\hline Vanadium & 41.8663 & 5.7E-05 & $5.4 \mathrm{E}-04$ & $7.0 E-03$ & $7.0 \mathrm{E}-03$ & $8.2 E-03$ & $7.6 \mathrm{E}-02$ & $8.5 E-02$ \\
\hline Zinc & 55.5213 & $7.6 \mathrm{E}-05$ & 7.1E-04 & $3.0 \mathrm{E}-01$ & $3.0 \mathrm{E}-01$ & $2.5 \mathrm{E}-04$ & $2.4 \mathrm{E}-03$ & $2.6 \mathrm{E}-03$ \\
\hline \multicolumn{9}{|c|}{ Organics } \\
\hline Acenaphthene & 5.9641 & $8.2 \mathrm{E}-06$ & 7.6E-05 & $6.0 \mathrm{E}-02$ & $6.0 \mathrm{E}-01$ & $1.4 \mathrm{E}-04$ & $1.3 E-04$ & $2.6 \mathrm{E}-04$ \\
\hline Anthracene & 1.1459 & $1.6 \mathrm{E}-06$ & $1.5 \mathrm{E}-05$ & $3.0 \mathrm{E}-01$ & $3.0 \mathrm{E}+00$ & $5.2 \mathrm{E}-06$ & $4.9 \mathrm{E}-06$ & $1.0 \mathrm{E}-05$ \\
\hline Fluoranthene & 7.2574 & $9.9 \mathrm{E}-06$ & $9.3 \mathrm{E}-05$ & $4.0 \mathrm{E}-02$ & $4.0 \mathrm{E}-01$ & 2.5E-04 & 2.3E-04 & 4.8E-04 \\
\hline Fluorene & 5.5428 & $7.6 \mathrm{E}-06$ & 7.1E-05 & $4.0 \mathrm{E}-02$ & $4.0 \mathrm{E}-01$ & $1.9 \mathrm{E}-04$ & $1.8 \mathrm{E}-04$ & 3.7E-04 \\
\hline Naphthalene & 10.9247 & $1.5 \mathrm{E}-05$ & $1.4 \mathrm{E}-0.4$ & $4.0 \mathrm{E}-02$ & $4.0 \mathrm{E}-02$ & 3.7E-04 & $3.5 E-03$ & $3.9 \mathrm{E}-03$ \\
\hline Pyrene & 12.5474 & 1.7E-05 & $1.6 \mathrm{E}-04$ & $3.0 E-02$ & $3.0 \mathrm{E}-01$ & $5.7 \mathrm{E}-04$ & $5.3 \mathrm{E}-04$ & $1.1 \mathrm{E}-03$ \\
\hline Total pathway H & & & & & & 7.6E-02 & 6.2F-01 & 7.0E-01 \\
\hline
\end{tabular}

CHICKAMAUGA (K-25)

Inorganics

$\begin{array}{lrlllllll}\text { Arsenic } & 9.7282 & 1.3 \mathrm{E}-05 & 1.2 \mathrm{E}-04 & 3.0 \mathrm{E}-04 & 3.0 \mathrm{E}-04 & 4.4 \mathrm{E}-02 & 4.1 \mathrm{E}-01 & 4.6 \mathrm{E}-01 \\ \text { Barium } & 99.5861 & 1.4 \mathrm{E}-04 & 1.3 \mathrm{E}-03 & 7.0 \mathrm{E}-02 & 7.0 \mathrm{E}-02 & 1.9 \mathrm{E}-03 & 1.8 \mathrm{E}-02 & 2.0 \mathrm{E}-02 \\ \text { Beryllium } & 1.1188 & 1.5 \mathrm{E}-06 & 1.4 \mathrm{E}-05 & 5.0 \mathrm{E}-03 & 5.0 \mathrm{E}-03 & 3.1 \mathrm{E}-04 & 2.9 \mathrm{E}-03 & 3.2 \mathrm{E}-03 \\ \text { Chromium VI } & 38.5109 & 5.3 \mathrm{E}-05 & 4.9 \mathrm{E}-04 & 5.0 \mathrm{E}-03 & 2.0 \mathrm{E}-02 & 1.1 \mathrm{E}-02 & 2.5 \mathrm{E}-02 & 3.5 \mathrm{E}-02 \\ \text { Manganese } & 2288.0077 & 3.1 \mathrm{E}-03 & 2.9 \mathrm{E}-02 & 1.4 \mathrm{E}-01 & 1.4 \mathrm{E}-01 & 2.2 \mathrm{E}-02 & 2.1 \mathrm{E}-01 & 2.3 \mathrm{E}-01 \\ \text { Mercury } & 0.5786 & 7.9 \mathrm{E}-07 & 7.4 \mathrm{E}-06 & 3.0 \mathrm{E}-04 & 3.0 \mathrm{E}-04 & 2.6 \mathrm{E}-03 & 2.5 \mathrm{E}-02 & 2.7 \mathrm{E}-02 \\ \text { Mercury (salts) } & 0.5786 & 7.9 \mathrm{E}-07 & 7.4 \mathrm{E}-06 & 3.0 \mathrm{E}-04 & 3.0 \mathrm{E}-04 & 2.6 \mathrm{E}-03 & 2.5 \mathrm{E}-02 & 2.7 \mathrm{E}-02 \\ \text { Nickel } & 21.3423 & 2.9 \mathrm{E}-05 & 2.7 \mathrm{E}-04 & 2.0 \mathrm{E}-02 & 2.0 \mathrm{E}-02 & 1.5 \mathrm{E}-03 & 1.4 \mathrm{E}-02 & 1.5 \mathrm{E}-02 \\ \text { Nickel (salts) } & 21.3423 & 2.9 \mathrm{E}-05 & 2.7 \mathrm{E}-04 & 2.0 \mathrm{E}-02 & 2.0 \mathrm{E}-02 & 1.5 \mathrm{E}-03 & 1.4 \mathrm{E}-02 & 1.5 \mathrm{E}-02 \\ \text { Selenium } & 0.9617 & 1.3 \mathrm{E}-06 & 1.2 \mathrm{E}-05 & 5.0 \mathrm{E}-03 & 5.0 \mathrm{E}-03 & 2.6 \mathrm{E}-04 & 2.5 \mathrm{E}-03 & 2.7 \mathrm{E}-03 \\ \text { Strontium } & 16.0042 & 2.2 \mathrm{E}-05 & 2.0 \mathrm{E}-04 & 6.0 \mathrm{E}-01 & 6.0 \mathrm{E}-01 & 3.7 \mathrm{E}-05 & 3.4 \mathrm{E}-04 & 3.8 \mathrm{E}-04 \\ \text { Vanadium } & 41.9685 & 5.7 \mathrm{E}-05 & 5.4 \mathrm{E}-04 & 7.0 \mathrm{E}-03 & 7.0 \mathrm{E}-03 & 8.2 \mathrm{E}-03 & 7.7 \mathrm{E}-02 & 8.5 \mathrm{E}-02 \\ \text { Zinc } & 56.9209 & 7.8 \mathrm{E}-05 & 7.3 \mathrm{E}-04 & 3.0 \mathrm{E}-01 & 3.0 \mathrm{E}-01 & 2.6 \mathrm{E}-04 & 2.4 \mathrm{E}-03 & 2.7 \mathrm{E}-03\end{array}$


Table 7.17a (continued)

\begin{tabular}{|c|c|c|c|c|c|c|c|c|}
\hline Analyte & $\begin{array}{c}\text { Soil } \\
\text { Conca } \\
\text { (mg/kg) }\end{array}$ & $\begin{array}{c}\text { Adult } \\
\text { daily } \\
\text { intake } \\
\text { (mg/kg-day) }\end{array}$ & $\begin{array}{c}\text { Child } \\
\text { daily } \\
\text { intake } \\
\text { (mg/kg-day) }\end{array}$ & $\begin{array}{c}\text { Chronic } \\
\text { oral } \mathrm{Rm}^{b} \\
(\mathrm{mg} / \mathrm{kg} \text {-day) }\end{array}$ & $\begin{array}{l}\text { Subchronic } \\
\text { oral } \mathrm{RfD}^{b} \\
\text { (mg/kg-day) }\end{array}$ & $\begin{array}{l}\text { Adult } \\
\text { HI } \\
\text { chronic }\end{array}$ & $\begin{array}{c}\text { Child } \\
\text { HI } \\
\text { subchronic }\end{array}$ & $\begin{array}{l}\text { Total } \\
\mathrm{HI}^{e}\end{array}$ \\
\hline
\end{tabular}

\section{CHICKAMAUGA (K-25) (continued) \\ Organics}

\begin{tabular}{|c|c|c|c|c|c|c|c|c|}
\hline Acenaphthene & 1.8152 & $2.5 E-06$ & $2.3 E-05$ & $6.0 \mathrm{E}-02$ & $6.0 \mathrm{E}-01$ & 4.1E-05 & $3.9 E-05$ & $8.0 \mathrm{E}-05$ \\
\hline Anthracene & 1.9096 & $2.6 \mathrm{E}-06$ & $2.4 \mathrm{E}-05$ & $3.0 \mathrm{E}-01$ & $3.0 \mathrm{E}+00$ & 8.7E-06 & 8.1E-06 & 1.7E-05 \\
\hline Fluoranthene & 9.4479 & $1.3 \mathrm{E}-05$ & $1.2 \mathrm{E}-04$ & $4.0 \mathrm{E}-02$ & $4.0 \mathrm{E}-01$ & 3.2E-0.4 & $3.0 \mathrm{E}-0.4$ & 6.3E-04 \\
\hline Fluorene & 2.1145 & $2.9 \mathrm{E}-06$ & $2.7 \mathrm{E}-05$ & $4.0 \mathrm{E}-02$ & $4.0 \mathrm{E}-01$ & $7.2 \mathrm{E}-05$ & $6.8 \mathrm{E}-05$ & 1.4E-04 \\
\hline Naphthalene & 3.4591 & 4.7E-06 & $4.4 \mathrm{E}-05$ & $4.0 \mathrm{E}-02$ & $4.0 \mathrm{E}-02$ & $1.2 \mathrm{E}-04$ & $1.1 E-03$ & $1.2 E-03$ \\
\hline Pyrene & 15.2652 & 2.1E-05 & $2.0 \mathrm{E}-04$ & $3.0 \mathrm{E}-02$ & $3.0 \mathrm{E}-01$ & $7.0 \mathrm{E}-04$ & $6.5 \mathrm{E}-04$ & $1.3 \mathrm{E}-03$ \\
\hline Total pathway $\mathbf{H I}^{d}$ & & & & & & 9.4E-02 & 7.9E-01 & 8.9E-01 \\
\hline
\end{tabular}

The upper $95 \%$ confidence bound on the median is used as the representative concentration.

${ }^{b}$ Source: Integrated Risk Information System (IRIS) and Health Effects Assessment Summary Tables (HEAST).

'Total HI = Adult HI chronic plus child HI subchronic.

${ }^{d}$ The total pathway hazard index does not include mercury and nickel metals. 
Table 7.17b. Background hazard index estimates for residents exposed to Oak Ridge Reservation soil constituents

Dermal Contact

\begin{tabular}{|c|c|c|c|c|c|c|c|c|}
\hline Analyte & $\begin{array}{c}\text { Soil } \\
\text { Conc. } \\
\text { (mg/kg) }\end{array}$ & $\begin{array}{c}\text { Adult } \\
\text { daily } \\
\text { intake } \\
\text { (mg/kg-day) }\end{array}$ & $\begin{array}{l}\text { Child } \\
\text { daily } \\
\text { intake } \\
\text { (mg/kg-day) }\end{array}$ & $\begin{array}{c}\text { Chronic } \\
\text { oral RfD } \\
\text { absorbed } \\
\text { (mg/kg-day) }\end{array}$ & $\begin{array}{c}\text { Subchronic } \\
\text { oral RfD } \\
\text { absorbed } \\
\text { (mg/kg-day) }\end{array}$ & $\begin{array}{l}\text { Adult } \\
\text { HI } \\
\text { chronic }\end{array}$ & $\begin{array}{c}\text { Child } \\
\text { HI } \\
\text { subchronic }\end{array}$ & $\begin{array}{l}\text { Total } \\
\mathrm{HI}^{d}\end{array}$ \\
\hline
\end{tabular}

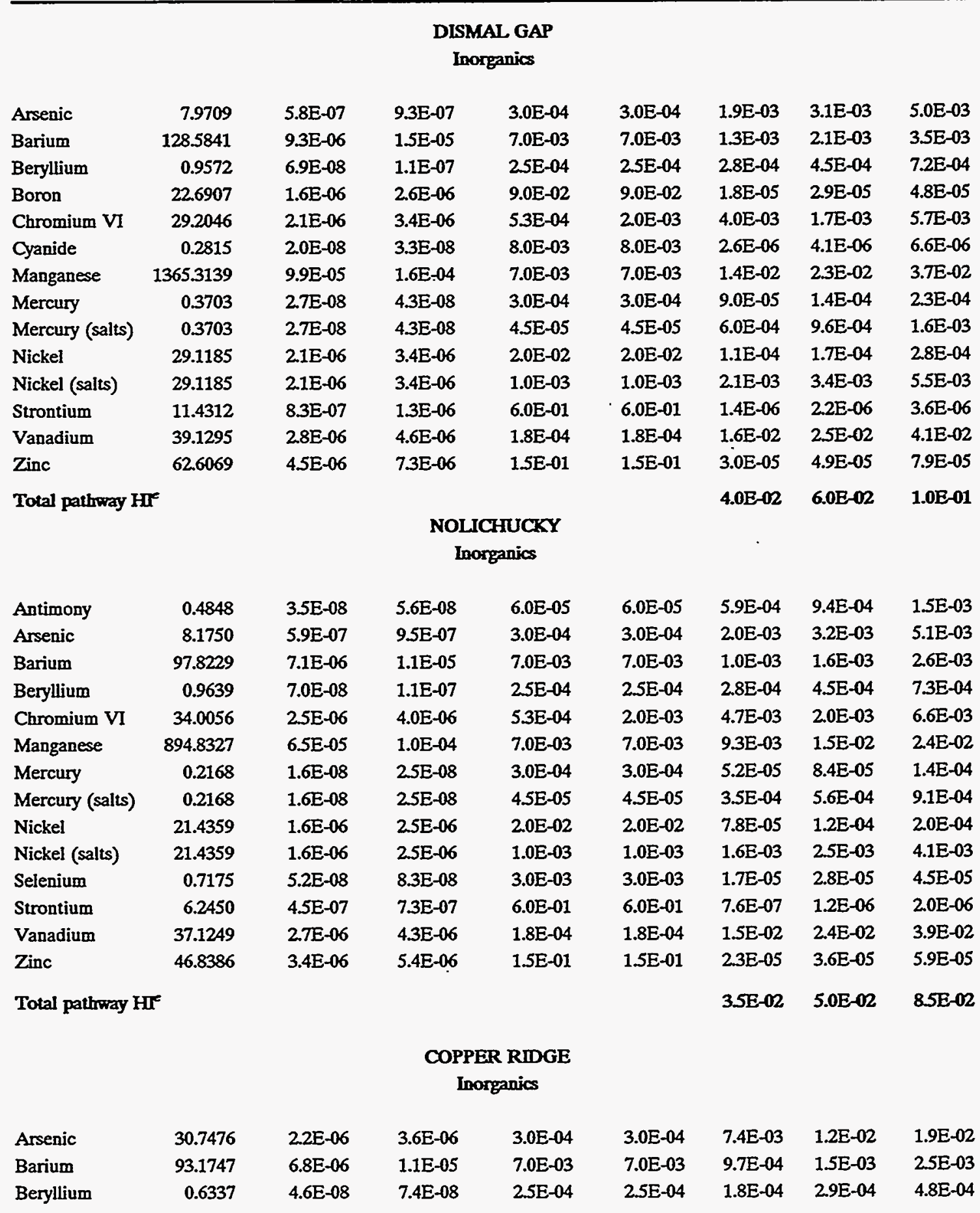


Table 7.17b (continued)

\begin{tabular}{|c|c|c|c|c|c|c|c|c|}
\hline Analyte & $\begin{array}{c}\text { Soil } \\
\text { Conc. } \\
\text { (mg/kg) }\end{array}$ & $\begin{array}{c}\text { Adult } \\
\text { daily } \\
\text { intake } \\
\text { (mg/kg-day) }\end{array}$ & $\begin{array}{c}\text { Child } \\
\text { daily } \\
\text { intake } \\
\text { (mg/kg-day) }\end{array}$ & $\begin{array}{l}\text { Chronic } \\
\text { oral RfD } \\
\text { absorbed } \\
\text { (mg/kg-day) }\end{array}$ & $\begin{array}{c}\text { Subchronic } \\
\text { oral } \mathrm{RfD}^{b, c} \\
\text { absorbed } \\
\text { (mg/kg-day) }\end{array}$ & $\begin{array}{c}\text { Adult } \\
\text { HI } \\
\text { chronic }\end{array}$ & $\begin{array}{l}\text { Child } \\
\text { HI } \\
\text { subchronic }\end{array}$ & $\begin{array}{l}\text { Total } \\
\mathrm{HI}^{d}\end{array}$ \\
\hline
\end{tabular}

COPPER RIDGE (continued)

Inorganics (continued)

$\begin{array}{lrlllllll}\text { Chromium VI } & 18.2675 & 1.3 \mathrm{E}-06 & 2.1 \mathrm{E}-06 & 5.3 \mathrm{E}-04 & 2.0 \mathrm{E}-03 & 2.5 \mathrm{E}-03 & 1.1 \mathrm{E}-03 & -3.6 \mathrm{E}-03 \\ \text { Manganese } & 1462.3296 & 1.1 \mathrm{E}-04 & 1.7 \mathrm{E}-04 & 7.0 \mathrm{E}-03 & 7.0 \mathrm{E}-03 & 1.5 \mathrm{E}-02 & 2.4 \mathrm{E}-02 & 3.9 \mathrm{E}-02 \\ \text { Mercury } & 0.1838 & 1.3 \mathrm{E}-08 & 2.1 \mathrm{E}-08 & 3.0 \mathrm{E}-04 & 3.0 \mathrm{E}-04 & 4.4 \mathrm{E}-05 & 7.1 \mathrm{E}-05 & 1.2 \mathrm{E}-04 \\ \text { Mercury (salts) } & 0.1838 & 1.3 \mathrm{E}-08 & 2.1 \mathrm{E}-08 & 4.5 \mathrm{E}-05 & 4.5 \mathrm{E}-05 & 3.0 \mathrm{E}-04 & 4.8 \mathrm{E}-04 & 7.7 \mathrm{E}-04 \\ \text { Molybdenum } & 1.7521 & 1.3 \mathrm{E}-07 & 2.0 \mathrm{E}-07 & 5.0 \mathrm{E}-03 & 5.0 \mathrm{E}-03 & 2.5 \mathrm{E}-05 & 4.1 \mathrm{E}-05 & 6.6 \mathrm{E}-05 \\ \text { Nickel } & 9.7111 & 7.1 \mathrm{E}-07 & 1.1 \mathrm{E}-06 & 2.0 \mathrm{E}-02 & 2.0 \mathrm{E}-02 & 3.5 \mathrm{E}-05 & 5.6 \mathrm{E}-05 & 9.2 \mathrm{E}-05 \\ \text { Nickel (salts) } & 9.7111 & 7.1 \mathrm{E}-07 & 1.1 \mathrm{E}-06 & 1.0 \mathrm{E}-03 & 1.0 \mathrm{E}-03 & 7.1 \mathrm{E}-04 & 1.1 \mathrm{E}-03 & 1.8 \mathrm{E}-03 \\ \text { Selenium } & 0.8030 & 5.8 \mathrm{E}-08 & 9.3 \mathrm{E}-08 & 3.0 \mathrm{E}-03 & 3.0 \mathrm{E}-03 & 1.9 \mathrm{E}-05 & 3.1 \mathrm{E}-05 & 5.1 \mathrm{E}-05 \\ \text { Strontium } & 4.8134 & 3.5 \mathrm{E}-07 & 5.6 \mathrm{E}-07 & 6.0 \mathrm{E}-01 & 6.0 \mathrm{E}-01 & 5.8 \mathrm{E}-07 & 9.3 \mathrm{E}-07 & 1.5 \mathrm{E}-06 \\ \text { Vanadium } & 30.2755 & 2.2 \mathrm{E}-06 & 3.5 \mathrm{E}-06 & 1.8 \mathrm{E}-04 & 1.8 \mathrm{E}-04 & 1.2 \mathrm{E}-02 & 2.0 \mathrm{E}-02 & 3.2 \mathrm{E}-02 \\ \text { Zinc } & 43.1845 & 3.1 \mathrm{E}-06 & 5.0 \mathrm{E}-06 & 1.5 \mathrm{E}-01 & 1.5 \mathrm{E}-01 & 2.1 \mathrm{E}-05 & 3.3 \mathrm{E}-05 & 5.4 \mathrm{E}-05\end{array}$

Organics

$\begin{array}{lrlllllll}\text { Acenaphthene } & 1.9298 & 1.4 \mathrm{E}-06 & 2.2 \mathrm{E}-06 & 6.0 \mathrm{E}-02 & 6.0 \mathrm{E}-01 & 2.3 \mathrm{E}-05 & 3.7 \mathrm{E}-06 & 2.7 \mathrm{E}-05 \\ \text { Anthracene } & 1.4248 & 1.0 \mathrm{E}-06 & 1.7 \mathrm{E}-06 & 3.0 \mathrm{E}-01 & 3.0 \mathrm{E}+00 & 3.4 \mathrm{E}-06 & 5.5 \mathrm{E}-07 & 4.0 \mathrm{E}-06 \\ \text { Fluoranthene } & 8.1229 & 5.9 \mathrm{E}-06 & 9.5 \mathrm{E}-06 & 4.0 \mathrm{E}-02 & 4.0 \mathrm{E}-01 & 1.5 \mathrm{E}-04 & 2.4 \mathrm{E}-05 & 1.7 \mathrm{E}-04 \\ \text { Fluorene } & 1.5879 & 1.2 \mathrm{E}-06 & 1.8 \mathrm{E}-06 & 4.0 \mathrm{E}-02 & 4.0 \mathrm{E}-01 & 2.9 \mathrm{E}-05 & 4.6 \mathrm{E}-06 & 3.3 \mathrm{E}-05 \\ \text { Naphthalene } & 16.4747 & 1.2 \mathrm{E}-05 & 1.9 \mathrm{E}-05 . & 4.0 \mathrm{E}-02 & 4.0 \mathrm{E}-02 & 3.0 \mathrm{E}-04 & 4.8 \mathrm{E}-04 & 7.8 \mathrm{E}-04 \\ \text { Pyrene } & 7.0241 & 5.1 \mathrm{E}-06 & 8.2 \mathrm{E}-06 & 3.0 \mathrm{E}-02 & 3.0 \mathrm{E}-01 & 1.7 \mathrm{E}-04 & 2.7 \mathrm{E}-05 & 2.0 \mathrm{E}-04 \\ & & & & & & 4.0 \mathrm{E}-02 & 6.1 \mathrm{E}-02 & 1.0 \mathrm{E}-01\end{array}$

CHEPULTEPEC

Inorganics

\begin{tabular}{|c|c|c|c|c|c|c|c|c|}
\hline Arsenic & 14.3884 & $1.0 \mathrm{E}-06$ & $1.7 \mathrm{E}-06$ & $3.0 \mathrm{E}-04$ & $3.0 \mathrm{E}-04$ & $3.5 \mathrm{E}-03$ & $5.6 \mathrm{E}-03$ & $9.1 E-03$ \\
\hline Barium & 69.5497 & $5.0 \mathrm{E}-06$ & $8.1 E-06$ & $7.0 \mathrm{E}-03$ & $7.0 \mathrm{E}-03$ & $7.2 \mathrm{E}-04$ & $1.2 \mathrm{E}-03$ & $1.9 E-03$ \\
\hline Beryllium & 0.4597 & 3.3E-08 & 5.3E-08 & $2.5 \mathrm{E}-04$ & $2.5 \mathrm{E}-04$ & $1.3 \mathrm{E}-04$ & 2.1E-04 & 3.5E-04 \\
\hline Chromium VI & 17.3758 & $1.3 \mathrm{E}-06$ & $2.0 E-06$ & $5.3 E-04$ & $2.0 \mathrm{E}-03$ & $2.4 \mathrm{E}-03$ & $1.0 \mathrm{E}-03$ & $3.4 \mathrm{E}-03$ \\
\hline Manganese & 1260.9155 & $9.2 \mathrm{E}-05$ & $1.5 \mathrm{E}-04$ & $7.0 \mathrm{E}-03$ & $7.0 \mathrm{E}-03$ & $1.3 \mathrm{E}-02$ & $2.1 E-02$ & $3.4 \mathrm{E}-02$ \\
\hline Mercury & 0.1529 & $1.1 \mathrm{E}-08$ & $1.8 \mathrm{E}-08$ & $3.0 \mathrm{E}-04$ & 3.0E-04 & $3.7 \mathrm{E}-05$ & $5.9 \mathrm{E}-05$ & $9.6 \mathrm{E}-05$ \\
\hline Mercury (salts) & 0.1529 & $1.1 \mathrm{E}-08$ & $1.8 \mathrm{E}-08$ & 4.5E-05 & 4.5E-05 & $2.5 E-04$ & $4.0 \mathrm{E}-04$ & $6.4 \mathrm{E}-04$ \\
\hline Selenium & 0.6251 & 4.5E-08 & $7.3 E-08$ & $3.0 \mathrm{E}-03$ & $3.0 \mathrm{E}-03$ & 1.SE-05 & $2.4 E-05$ & 3.9E-05 \\
\hline Strontium & 3.3288 & $2.4 \mathrm{E}-07$ & $3.9 E-07$ & $6.0 \mathrm{E}-01$ & $6.0 \mathrm{E}-01$ & $4.0 \mathrm{E}-07$ & $6.5 \mathrm{E}-07$ & $1.0 \mathrm{E}-06$ \\
\hline Vanadium & 34.3269 & $25 \mathrm{E}-06$ & $4.0 \mathrm{E}-06$ & $1.8 \mathrm{E}-0.4$ & $1.8 \mathrm{E}-04$ & $1.4 \mathrm{E}-02$ & $2.2 \mathrm{E}-02$ & $3.6 \mathrm{E}-02$ \\
\hline Zinc & 48.6197 & $3.5 \mathrm{E}-06$ & $5.7 \mathrm{E}-06$ & $1.5 \mathrm{E}-01$ & $1.5 \mathrm{E}-01$ & 2.4E-05 & $3.8 \mathrm{E}-05$ & $6.1 \mathrm{E}-05$ \\
\hline \multicolumn{9}{|c|}{ Organics } \\
\hline Acenaphthene & 1.3632 & $9.9 E-07$ & $1.6 \mathrm{E}-06$ & $6.0 \mathrm{E}-02$ & $6.0 \mathrm{E}-01$ & $1.6 \mathrm{E}-05$ & $2.6 \mathrm{E}-06$ & $1.9 \mathrm{E}-05$ \\
\hline Anthracene & 1.0351 & $7.5 E-07$ & $1.2 E-06$ & $3.0 \mathrm{E}-01$ & $3.0 E+00$ & $2.5 E-06$ & $4.0 \mathrm{E}-07$ & $2.9 E-06$ \\
\hline Fluoranthene & 4.6443 & $3.4 \mathrm{E}-06$ & $5.4 \mathrm{E}-06$ & 4.0E-02 & $4.0 \mathrm{E}-01$ & $8.4 \mathrm{E}-05$ & $1.4 \mathrm{E}-05$ & $9.8 \mathrm{E}-05$ \\
\hline
\end{tabular}


Table 7.17b (continued)

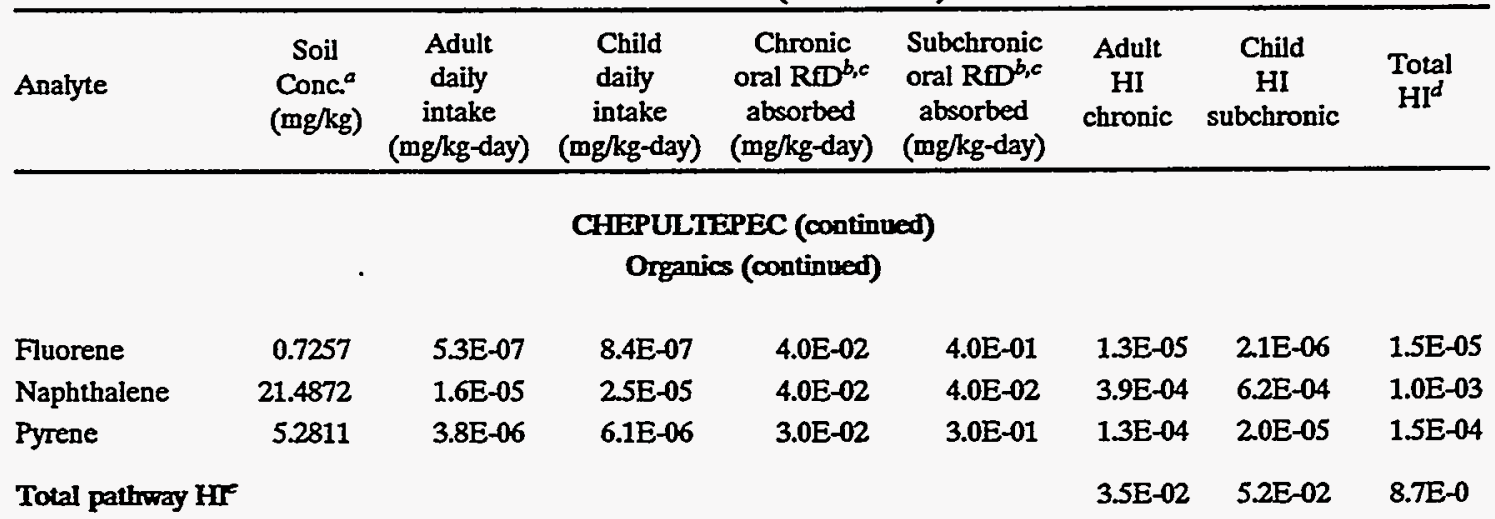

CHICKAMAUGA (BETHEL VALIEY)

Inorganics

$\begin{array}{lrlllllll}\text { Arsenic } & 7.9867 & 5.8 \mathrm{E}-07 & 9.3 \mathrm{E}-07 & 3.0 \mathrm{E}-04 & 3.0 \mathrm{E}-04 & 1.9 \mathrm{E}-03 & 3.1 \mathrm{E}-03 & 5.0 \mathrm{E}-03 \\ \text { Barium } & 103.3075 & 7.5 \mathrm{E}-06 & 1.2 \mathrm{E}-05 & 7.0 \mathrm{E}-03 & 7.0 \mathrm{E}-03 & 1.1 \mathrm{E}-03 & 1.7 \mathrm{E}-03 & 2.8 \mathrm{E}-03 \\ \text { Beryllium } & 1.2480 & 9.1 \mathrm{E}-08 & 1.5 \mathrm{E}-07 & 2.5 \mathrm{E}-04 & 2.5 \mathrm{E}-04 & 3.6 \mathrm{E}-04 & 5.8 \mathrm{E}-04 & 9.4 \mathrm{E}-04 \\ \text { Chromium VI } & 40.2327 & 2.9 \mathrm{E}-06 & 4.7 \mathrm{E}-06 & 5.3 \mathrm{E}-04 & 2.0 \mathrm{E}-03 & 5.5 \mathrm{E}-03 & 2.3 \mathrm{E}-03 & 7.9 \mathrm{E}-03 \\ \text { Manganese } & 1442.6173 & 1.0 \mathrm{E}-04 & 1.7 \mathrm{E}-04 & 7.0 \mathrm{E}-03 & 7.0 \mathrm{E}-03 & 1.5 \mathrm{E}-02 & 2.4 \mathrm{E}-02 & 3.9 \mathrm{E}-02 \\ \text { Mercury } & 0.1875 & 1.4 \mathrm{E}-08 & 2.2 \mathrm{E}-08 & 3.0 \mathrm{E}-04 & 3.0 \mathrm{E}-04 & 4.5 \mathrm{E}-05 & 7.3 \mathrm{E}-05 & 1.2 \mathrm{E}-04 \\ \text { Mercury (salts) } & 0.1875 & 1.4 \mathrm{E}-08 & 2.2 \mathrm{E}-08 & 4.5 \mathrm{E}-05 & 4.5 \mathrm{E}-05 & 3.0 \mathrm{E}-04 & 4.8 \mathrm{E}-04 & 7.9 \mathrm{E}-04 \\ \text { Nickel } & 16.6791 & 1.2 \mathrm{E}-06 & 1.9 \mathrm{E}-06 & 2.0 \mathrm{E}-02 & 2.0 \mathrm{E}-02 & 6.1 \mathrm{E}-05 & 9.7 \mathrm{E}-05 & 1.6 \mathrm{E}-04 \\ \text { Nickel (salts) } & 16.6791 & 1.2 \mathrm{E}-06 & 1.9 \mathrm{E}-06 & 1.0 \mathrm{E}-03 & 1.0 \mathrm{E}-03 & 1.2 \mathrm{E}-03 & 1.9 \mathrm{E}-03 & 3.2 \mathrm{E}-03 \\ \text { Selenium } & 0.9313 & 6.8 \mathrm{E}-08 & 1.1 \mathrm{E}-07 & 3.0 \mathrm{E}-03 & 3.0 \mathrm{E}-03 & 2.3 \mathrm{E}-05 & 3.6 \mathrm{E}-05 & 5.9 \mathrm{E}-05 \\ \text { Strontium } & 8.6393 & 6.3 \mathrm{E}-07 & 1.0 \mathrm{E}-06 & 6.0 \mathrm{E}-01 & 6.0 \mathrm{E}-01 & 1.0 \mathrm{E}-06 & 1.7 \mathrm{E}-06 & 2.7 \mathrm{E}-06 \\ \text { Vanadium } & 41.8663 & 3.0 \mathrm{E}-06 & 4.9 \mathrm{E}-06 & 1.8 \mathrm{E}-04 & 1.8 \mathrm{E}-04 & 1.7 \mathrm{E}-02 & 2.7 \mathrm{E}-02 & 4.4 \mathrm{E}-02 \\ \text { Zinc } & 55.5213 & 4.0 \mathrm{E}-06 & 6.5 \mathrm{E}-06 & 1.5 \mathrm{E}-01 & 1.5 \mathrm{E}-01 & 2.7 \mathrm{E}-05 & 4.3 \mathrm{E}-05 & 7.0 \mathrm{E}-05\end{array}$

Organics

\begin{tabular}{|c|c|c|c|c|c|c|c|c|}
\hline Acenaphthene & 5.9641 & 4.3E-06 & $6.9 \mathrm{E}-06$ & $6.0 \mathrm{E}-02$ & $6.0 \mathrm{E}-01$ & 7.2E-05 & $1.2 \mathrm{E}-05$ & $8.4 \mathrm{E}-05$ \\
\hline Anthracene & 1.1459 & $8.3 E-07$ & $1.3 E-06$ & $3.0 \mathrm{E}-01$ & $3.0 \mathrm{E}+00$ & $2.8 \mathrm{E}-06$ & $4.4 \mathrm{E}-07$ & $3.2 \mathrm{E}-0.6$ \\
\hline Fluoranthene & 7.2574 & $5.3 E-06$ & $8.4 \mathrm{E}-06$ & $4.0 \mathrm{E}-02$ & $4.0 \mathrm{E}-01$ & 1.3E-04 & $2.1 E-05$ & $1.5 E-04$ \\
\hline Fluorene & 5.5428 & $4.0 \mathrm{E}-06$ & $6.4 \mathrm{E}-06$ & $4.0 \mathrm{E}-02$ & $4.0 \mathrm{E}-01$ & $1.0 \mathrm{E}-04$ & $1.6 \mathrm{E}-05$ & $1.2 \mathrm{E}-04$ \\
\hline Naphthalene & 10.9247 & $7.9 \mathrm{E}-06$ & 1.3E-05 & $4.0 \mathrm{E}-02$ & $4.0 \mathrm{E}-02$ & $2.0 \mathrm{E}-04$ & $3.2 \mathrm{E}-04$ & $5.2 \mathrm{E}-04$ \\
\hline Pyrene & 12.5474 & $9.1 \mathrm{E}-06$ & $1.5 \mathrm{E}-05$ & $3.0 \mathrm{E}-02$ & $3.0 \mathrm{E}-01$ & 3.0E-04 & $4.9 E-05$ & $3.5 \mathrm{E}-04$ \\
\hline \multicolumn{6}{|c|}{ Total pathway Hr } & 4.3E-02 & $6.2 \mathrm{E}-02$ & $1.0 \mathrm{E}-01$ \\
\hline
\end{tabular}

CHICKAMAUGA (K-25)

Inorganics

$\begin{array}{lrlllllll}\text { Arsenic } & 9.7282 & 7.1 \mathrm{E}-07 & 1.1 \mathrm{E}-06 & 3.0 \mathrm{E}-04 & 3.0 \mathrm{E}-04 & 2.4 \mathrm{E}-03 & 3.8 \mathrm{E}-03 & 6.1 \mathrm{E}-03 \\ \text { Barium } & 99.5861 & 7.2 \mathrm{E}-06 & 1.2 \mathrm{E}-05 & 7.0 \mathrm{E}-03 & 7.0 \mathrm{E}-03 & 1.0 \mathrm{E}-03 & 1.7 \mathrm{E}-03 & 2.7 \mathrm{E}-03 \\ \text { Beryllium } & 1.1188 & 8.1 \mathrm{E}-08 & 1.3 \mathrm{E}-07 & 2.5 \mathrm{E}-04 & 2.5 \mathrm{E}-04 & 3.2 \mathrm{E}-04 & 5.2 \mathrm{E}-04 & 8.5 \mathrm{E}-04 \\ \text { Chromium VI } & 38.5109 & 2.8 \mathrm{E}-06 & 4.5 \mathrm{E}-06 & 5.3 \mathrm{E}-04 & 2.0 \mathrm{E}-03 & 5.3 \mathrm{E}-03 & 2.2 \mathrm{E}-03 & 7.5 \mathrm{E}-03 \\ \text { Manganese } & 2288.0077 & 1.7 \mathrm{E}-04 & 2.7 \mathrm{E}-04 & 7.0 \mathrm{E}-03 & 7.0 \mathrm{E}-03 & 2.4 \mathrm{E}-02 & 3.8 \mathrm{E}-02 & 6.2 \mathrm{E}-02 \\ \text { Mercury } & 0.5786 & 4.2 \mathrm{E}-08 & 6.7 \mathrm{E}-08 & 3.0 \mathrm{E}-04 & 3.0 \mathrm{E}-04 & 1.4 \mathrm{E}-04 & 2.2 \mathrm{E}-04 & 3.6 \mathrm{E}-04\end{array}$


not natural, because they are widespread they are considered to be background. The radioactive isotopes, with the exception of cesium-137 in the CHI-BV, are all considered background. Several CHI-BV sites had received cesium-137 from local sources. Cesium-137 values from $\mathrm{CHI}-\mathrm{BV}$ are not all at background levels.

The hazard indices estimated for ingestion of inorganics and organics in background soil and for dermal contact with the background soil are below the EPA guideline of 1.0 (with the exception of the arsenic HI for CR); therefore, these pathways pose no expected adverse effects to human health. The total pathway HIs (ingestion plus dermal) for CR, CHE, and CHI-K25 formation samples are slightly above this threshold of 1.0. Arsenic and manganese are the major contributors to the HI for the ingestion pathway; and the main contributors to the HI for the dermal exposure pathway are arsenic, chromium IV, manganese, and vanadium. Note that the risks associated with background soils on the ORR were estimated to provide a frame of reference for interpreting the magnitude and relative importance of risks evaluated at hazardous waste sites on the ORR. Therefore, risks from background soil samples are found to be within or above the EPA region of concern; however, these risks do not indicate concerns or remedial actions that would be identified with similar potential risks from a contaminated site.

\subsection{UNCERTAINTIES AND ASSUMPTIONS}

Risk assessment as a scientific activity is subject to uncertainty (Table 7.18). The methodology used in this background risk evaluation follows EPA guidelines. The risk evaluation in this report is subject to uncertainty pertaining to sampling and analysis, exposure estimation, and toxicological data.

The major assumptions used in risk assessment are (1) that contaminant concentrations detected and reported by the analytical laboratory are representative of true analyte concentrations in soils (i.e., the analyte concentration remains constant over the sampling and analysis time period); (2) that the intake rates and exposure parameters are representative of actual potentially exposed populations; and (3) that all contaminant exposure and intake are from the site-related exposure media (i.e., no other sources contribute to the receptor's health risk). Even if these assumptions are true, other areas of uncertainty may apply. The toxicological data (SFs and RfDs) are frequently updated and revised, which can lead to overor underestimation of risks. These values are often extrapolations from animals to humans, which also induces uncertainties in toxicity values. In addition, as mentioned earlier, in the analytical analyses for metals (total metal only) risks may be overestimated because the metals that are present are conservatively assumed to be in their most toxic forms. Furthermore, not all of the background chemicals reported in Table 7.2 currently have toxicity values; this can lead to an underestimation of total risk because quantitative analysis of such chemicals is currently not possible.

In addition, current analytical methods are limited in their ability to achieve detection limits that are appropriate for use in risk assessment. The risk of increased incidence of cancer from exposure to low-level radiation is estimated by application of a risk factor to either the radiation dose or the radionuclide intake. Regardless of the type of risk factor used, the same basic uncertainties remain. These uncertainties are related to the model used for determining the health effects of radiation exposure. The model most frequently used for 
Table 7.17b (continued)

\begin{tabular}{|c|c|c|c|c|c|c|c|c|}
\hline Analyte & $\begin{array}{c}\text { Soil } \\
\text { Conc }^{a} \\
(\mathrm{mg} / \mathrm{kg})\end{array}$ & $\begin{array}{c}\text { Adult } \\
\text { daily } \\
\text { intake } \\
\text { (mg/kg-day) }\end{array}$ & $\begin{array}{l}\text { Child } \\
\text { daily } \\
\text { intake } \\
\text { (mg/kg-day) }\end{array}$ & $\begin{array}{c}\text { Chronic } \\
\text { oral RfD } \\
\text { absorbed } \\
\text { (mg/kg-day) }\end{array}$ & $\begin{array}{c}\text { Subchronic } \\
\text { oral RfD } \\
\text { absorbed } \\
\text { (mg/kg-day) }\end{array}$ & $\begin{array}{l}\text { Adult } \\
\text { HII } \\
\text { chronic }\end{array}$ & $\begin{array}{l}\text { Child } \\
\text { HI } \\
\text { subchronic }\end{array}$ & $\begin{array}{l}\text { Total } \\
\mathrm{HI}^{d}\end{array}$ \\
\hline
\end{tabular}

\begin{tabular}{|c|c|c|c|c|c|c|c|c|}
\hline \multicolumn{9}{|c|}{ CHICKAMAUGA (K-25) (continued) } \\
\hline \multicolumn{9}{|c|}{ Inorganies (continued) } \\
\hline Mercury (salts) & 0.5786 & $4.2 \mathrm{E}-08$ & $6.7 \mathrm{E}-08$ & $4.5 \mathrm{E}-05$ & 4.5E-05 & 9.3E-04 & $1.5 \mathrm{E}-03$ & 2.4E-03 \\
\hline Nickel & 21.3423 & $1.5 \mathrm{E}-06$ & $2.5 \mathrm{E}-06$ & $2.0 \mathrm{E}-02$ & $2.0 \mathrm{E}-02$ & 7.7E-05 & $1.2 \mathrm{E}-04$ & 2.0E-04 \\
\hline Nickel (salts) & 21.3423 & $1.5 E-06$ & $2.5 E-06$ & $1.0 \mathrm{E}-03$ & $1.0 \mathrm{E}-03$ & $1.5 \mathrm{E}-03$ & $2.5 \mathrm{E}-03$ & $4.0 \mathrm{E}-03$ \\
\hline Selenium & 0.9617 & $7.0 \mathrm{E}-08$ & 1.1E-07 & $3.0 \mathrm{E}-03$ & $3.0 \mathrm{E}-03$ & 2.3E-05 & 3.7E-05 & 6.1E-05 \\
\hline Strontium & 16.0042 & $1.2 \mathrm{E}-06$ & $1.9 E-06$ & $6.0 \mathrm{E}-01$ & $6.0 \mathrm{E}-01$ & $1.9 \mathrm{E}-06$ & $3.1 E-06$ & $5.0 \mathrm{E}-06$ \\
\hline Vanadium & 41.9685 & 3.0E-06 & $4.9 E-06$ & $1.8 \mathrm{E}-04$ & $1.8 \mathrm{E}-04$ & 1.7E-02 & $27 \mathrm{E}-02$ & $4.4 \mathrm{E}-02$ \\
\hline Zinc & 56.9209 & 4.1E-06 & $6.6 \mathrm{E}-06$ & $1.5 \mathrm{E}-01$ & $1.5 \mathrm{E}-01$ & $2.8 \mathrm{E}-05$ & $4.4 \mathrm{E}-05$ & $7.2 \mathrm{E}-05$ \\
\hline \multicolumn{9}{|c|}{ Organics } \\
\hline Acenaphthene & 1.8152 & $1.3 \mathrm{E}-06$ & $2.1 E-06$ & $6.0 \mathrm{E}-02$ & $6.0 \mathrm{E}-01$ & 2.2E-05 & $3.5 \mathrm{E}-06$ & 2.5E-05 \\
\hline Anthracene & 1.9096 & $1.4 \mathrm{E}-06$ & $2.2 \mathrm{E}-06$ & $3.0 \mathrm{E}-01$ & $3.0 \mathrm{E}+00$ & $4.6 E-06$ & 7.4E-07 & $5.4 \mathrm{E}-06$ \\
\hline Fluoranthene & 9.4479 & $6.9 E-06$ & $1.1 \mathrm{E}-05$ & $4.0 \mathrm{E}-02$ & 4.0E-01 & $1.7 \mathrm{E}-04$ & 2.7E-05 & 2.0E-04 \\
\hline Fluorene & 2.1145 & $1.5 \mathrm{E}-06$ & $2.5 \mathrm{E}-06$ & $4.0 \mathrm{E}-02$ & $4.0 \mathrm{E}-01$ & $3.8 \mathrm{E}-05$ & $6.2 \mathrm{E}-06$ & 4.5E-05 \\
\hline Naphthalene & 3.4591 & $2.5 E-06$ & $4.0 \mathrm{E}-06$ & $4.0 \mathrm{E}-02$ & $4.0 \mathrm{E}-02$ & $6.3 \mathrm{E}-05$ & $1.0 \mathrm{E}-04$ & $1.6 \mathrm{E}-04$ \\
\hline Pyrene & 15.2652 & $1.1 E-05$ & $1.8 \mathrm{E}-05$ & $3.0 \mathrm{E}-02$ & $3.0 \mathrm{E}-01$ & 3.7E-04 & $5.9 \mathrm{E}-05$ & $4.3 E-04$ \\
\hline \multicolumn{6}{|c|}{ Total pathway HF } & 5.3E-02 & $7.8 \mathrm{E}-02$ & 1.3E-01 \\
\hline
\end{tabular}

\footnotetext{
The upper $95 \%$ confidence bound on the median is used as the representative concentration.

${ }^{b}$ Source: Integrated Risk Information System (IRIS) and Health Effects Assessment Summary Tables (HEAST).

'The absorbed RfD is equal to the oral RfD $\times$ \% GI (percent gastrointestinal); the absorbed oral RfD is used in the dermal pathway calculations of hazard index (refer to Table 7.7 for organic RfDs and Table 7.9 or inorganic RfDs). For the organics, with the exception of chrysene, the absorbed oral RfDs and the oral RIDs are equivalent (i.e., \%GI = 100).

${ }^{d}$ Total HI = Adult HI chronic plus child HI subchronic.

The total pathway hazard index does not include mercury and nickel metals.
}

dermal contact with soil pathways. The total (adult plus child) cumulative pathway (ingestion plus dermal) background HIs for DG, NOL, CR, CHE, CHI-BV, and CHI-K25 are 0.79, 0.74, 1.8, 1.0, 0.8 and 1.0, respectively. According to EPA guidance for site contamination, for those formations where HIs are above the EPA threshold of 1.0., there is a concern for human health from systemic effects from these natural background constituents.

\subsubsection{Summary of the background risk and hazard index characterization for the ORR}

In summary, the total pathway risk estimates for the carcinogens found in background soil samples taken on the ORR are: (1) between 6.4e-06 and 3.2e-04 for ingestion of inorganics and organics; (2) between $2.9 \mathrm{e}-06$ and 7.2e-05 for dermal contact with inorganics and organics; (3) less than 1.0e-06 for ingestion of radionuclides; and (4) greater than $1.0 \mathrm{e}-04$ for external exposure to radionuclides. The main contributors to the risk for the ingestion and dermal exposure pathways are PAHs. Cesium-137, potassium-40, radium-226, and thorium 228 are the main contributors to risk for the external exposure pathway. Even though PAH's are 
Table 7.18. General uncertainty factors in risk assessment

\begin{tabular}{|c|c|c|}
\hline Uncertainty Factor & Effect of Uncertainty & Comment \\
\hline Use of cancer slope factors & May overestimate risks & $\begin{array}{l}\text { Slopes are upper } 95 \text { th percent confidence limits derived from the linearized model; } \\
\text { considered unlikely to underestimate true risk }\end{array}$ \\
\hline $\begin{array}{l}\text { Risks/doses within an exposure route assumed to } \\
\text { be additive. }\end{array}$ & May over- or underestimate risks & Does not account for synergism or antagonism \\
\hline $\begin{array}{l}\text { Toxicity values derived primarily from animal } \\
\text { studies }\end{array}$ & May over- or underestimate risks & $\begin{array}{l}\text { Extrapolation from animal to humans may induce error due to differences in } \\
\text { pharmacokinetics, target organs, and population variability }\end{array}$ \\
\hline $\begin{array}{l}\text { Toxicity values derived primarily from high doses; } \\
\text { most exposures are at low doses }\end{array}$ & May over- or underestimate risks & Assumes linearity at low doses; tends to have conservative exposure assumptions \\
\hline Toxicity values & May over- or underestimate risks & $\begin{array}{l}\text { Not all values represent the same degree of certainty; all are subject to change as } \\
\text { new evidence becomes available }\end{array}$ \\
\hline Effect of absorption & May over- or underestimate risks & $\begin{array}{l}\text { The assumption that absorption is equivalent across species is implicit in the } \\
\text { derivation of the critical toxicity values; absorption may actually vary with species } \\
\text { and age }\end{array}$ \\
\hline $\begin{array}{l}\text { Effect of applying critical toxicity values to soil } \\
\text { exposures }\end{array}$ & May overestimate risks & $\begin{array}{l}\text { Assumes bioavailability of contaminants sorbed onto soils is the same as detected } \\
\text { in lab studies; contaminants detected in studies may be more bioavailable }\end{array}$ \\
\hline Exposures assumed constant over time & May over- or underestimate risks & $\begin{array}{l}\text { Does not account for environmental fate, transport, or transfer that may alter } \\
\text { concentration }\end{array}$ \\
\hline Metal analysis for total metals only & May overestimate risks & $\begin{array}{l}\text { Did not distinguish between valences or speciation; assumed the metal was present } \\
\text { in its most toxic form }\end{array}$ \\
\hline Not all chemicals at the site have toxicity values & May underestimate risks & These chemicals are not addressed quantitatively \\
\hline Exposure assumptions & May over- or underestimate risks & $\begin{array}{l}\text { Assumptions regarding media intake, population characteristics, and exposure } \\
\text { patterns may not characterize exposures }\end{array}$ \\
\hline
\end{tabular}


determining risk of radiation exposure is the linear nonthreshold model which assumes there is some increased risk for any increment of radiation exposure with no threshold below which effects are not seen. This is the most conservative model for evaluating radiation risk; it uses data from high-dose radiation exposures (such as from the survivors of the atomic bomb) and extrapolates risk from these high exposures to the low-level environment or occupational dose range. The current EPA-recommended radiation risk factors are based on the 1980 National Academy of Sciences Biological Effects of Ionizing Radiation Committee (BEIR III) report. The BEIR III recommendations were increased slightly by EPA to reflect recent information on the health effects of exposure to ionizing radiation. In early 1990, the National Academy of Sciences published the results of the most recent studies of the health effects of ionizing radiation, the BEIR $V$ report, which increases the estimates of cancer risk by a factor of 3 to 5 over the BEIR III report. These increases are based primarily on a reevaluation of the doses received by the atomic bomb victims.

\subsection{PERSPECTIVE}

In order to put the results from the BSCP risk evaluation into perspective, one should consider the probability of an individual's developing cancer from unavoidable exposure to naturally occurring background radiation in general. In the Background Information Document for the Environmental Impact Statement for NESHAPS Radionuclides (EPA 1989d), EPA evaluated risks from exposure to average nationwide levels of background radiation. The risk of fatal cancer for the U.S. population exposed to low-LET radiation over a lifetime (70.7 years) was estimated to be $2.4 \mathrm{e}-03$, which accounts for approximately $1.5 \%$ of U.S. cancer deaths. The average lifetime cancer risk for high-LET radiation exposure is estimated to be $6.5 e-03$ and accounts for approximately $4 \%$ of all U.S. cancer deaths. The total risk of fatal cancer because of background radiation was approximately $8.9 \mathrm{e}-03$. From EPA's risk factors for low-LET radiation, the ratio of cancer incidence to fatal cancers was determined to be 1.6. Therefore, the lifetime risk of cancer incidence in the general population is approximately $1.4 \mathrm{e}-02$ (see Fig. 7.1), which is approximately 100 times greater than the upper bound $(1.0 \mathrm{e}-04)$ of EPA's range of concern and above the levels registered in the vicinity of the ORR in this study.

To understand the background risk information presented in this report, it is important to discern between adverse health effects resulting from unavoidable versus avoidable exposure. The risk of cancer presented in the previous discussion, approximately $1.4 \mathrm{e}-02$, is the result of the unavoidable exposure to natural radiation sources; that is, a risk that we are all subject to because we live on the surface of the planet Earth. The majority of the risks modeled from the exposure to background soil constituents discussed in this section are a subset of the unavoidable risk associated with exposure to natural radiation sources. The EPA has determined that risk from exposure to hazardous waste sites are avoidable sources of exposure. The risk resulting from exposure to such sources is referred to as incremental or excess cancer risk because it is a cancer risk in addition to that which is unavoidable. Therefore, to be protective of human health, the $1 \mathrm{e}-04$ threshold for excess cancer risk was selected to aid risk managers in the evaluation of preventable risks associated with CERCLA sites.

It should be clear that an essential objective for all RIs is to differentiate between risks that are unavoidable (background) and avoidable risks associated with site contamination. To 


\section{$7-131$}

clarify, if unavoidable background risks from exposure to soil on the ORR (6e-04) are not separated from risks resulting from exposure to site contamination, the risk will always be in the EPA's unacceptable range. The information presented in this document should be used to make this differentiation and ensure that risk management decisions are based on excess cancer risk. 


\section{ASSESSMENT OF OVERALL DATA QUALTTY OBJECTIVES}

\subsection{SUMMARY}

Background Soil Characterization Project (BSCP) activities established both field and laboratory data quality objectives at the project planning stage. The BSCP Plan (Energy Systems 1992, Volume 3) discusses training, audits and surveillances, and data management, as well as the establishment of precision, accuracy, representativeness, completeness, and comparability (PARCC) parameters for evaluating field and analytical data.

Training of field sampling crews reduced possible variability related to personnel changes. Sampling procedures were designed to effectively reduce the possibility of cross-contamination throughout sampling activities. Audits and surveillances contributed to improving procedures and practices. Data management activities ensured the organization, consistency, traceability, integrity, and security of the data sets generated.

Representative sampling sites were selected by evaluating soil morphology and vegetation and by testing and screening for volatile organic compounds (VOCs) and radioactive fallout activity. Overall quality of site selection is satisfactory, but several off-site (AND and ROA) locations had either excess loss of surface soils due to erosion, or more than $50 \mathrm{~cm}$ of the upper soil was composed of colluvium or alluvium, such that they could not be considered representative of residual soils. Soil erosion is one of the contributing factors to lower-thanaverage ${ }^{137} \mathrm{Cs}$ values of off-site locations in comparison to ORR sites. Several off-sites were considered to be colluvial soils rather than residual soils and were not considered to be representative. Except for trip blanks, laboratory source waters were used only for washing sampling equipment. Therefore, quality of deionized water was a minor issue.

Analytical data quality was determined by analyzing (1) laboratory blanks to assess contamination levels in the analytical process; (2) laboratory control samples to assess analytical method bias, precision, and comparability; (3) matrix spikes to assess bias of the method for the matrix, as well as precision of the method when performed in duplicate; and (4) duplicates to assess precision of the sampling process and/or the analytical methods.

During the laboratory review process and the independent validation process, the data were evaluated and qualified as discussed in Sects. 4.3 and 4.4, respectively. The majority of the data were usable. Among the organics, however, polynuclear aromatic hydrocarbon (PAH) data were only $75 \%$ usable. Among the radionuclides, $70 \%$ of ${ }^{237} \mathrm{~Np}$ and $43 \%$ of ${ }^{244} \mathrm{Cm}$ were usable (see Table 8.3). The reasons of rejection are discussed in Sect. 8.5.9.2. Lists of sample numbers belonging to each sample delivery group and sample numbers relating to sites, horizons, formations, and analyses are presented in Appendixes $F$ and $G$, respectively.

\subsection{INTRODUCTION}

The purpose of this section is to present and assess the results of field sampling and analytical laboratory quality assurance (QA) and quality control (QC) activities of the BSCP. These QA/QC results are presented to illustrate that the data collected are of sufficient quality to meet project objectives. The QA program was designed to meet the requirements 
of QAMS-005/80 (EPA 1980a), ASME NQA-1 (ASME 1989), and the Environmental Restoration Division Quality Assurance Program Plan (ES/ER/TM-4/R1). The QA objectives were defined in the BSCP Plan (Energy Systems 1992, Volume 3).

\subsection{DATA QUALTTY OBJECTIVES FOR FIELD MEASUREMENT DATA}

The field QA/QC objectives for BSCP data are as follows:

1. Data generated would withstand scientific scrutiny.

2. Data would be gathered using appropriate procedures for site selection, field sampling, chain of custody, laboratory analyses, and data reporting.

3. Data could be used elsewhere on the Oak Ridge Reservation (ORR) for comparison of similar residuum soils or fill from soils from the same geologic formation.

The specific QA objective for all data collected was, therefore, to obtain precise and accurate measurements consistent with the intended use of the data and within the limitations of the relatively few samples, plus errors introduced or inherent in the sampling and analytical procedures used.

These objectives were met through the development and implementation of (1) a QA oversight program of audits and surveillances, (2) standard operating procedures accompanied by a personnel training program, (3) field sampling QC requirements, and (4) data and records management systems.

\subsection{DATA QUALITY OBJECTIVES FOR LABORATORY MEASUREMENT DATA}

The laboratory QA/QC objectives for BSCP data are as follows:

1. Laboratory data generated would withstand scientific scrutiny and be subject to data validation procedures.

2. Data would be generated using appropriate procedures for chain of custody, laboratory analyses, and data reporting.

3. Data would be complete and of known precision and accuracy and will be technically defensible and legally admissible.

These objectives were met through the development of a detailed Analytical Statement of Work to ensure that the laboratories involved understood the requirements of the analytical QC program. Also, the laboratories were to follow approved U.S. Environmental Protection Agency (EPA) procedures for their chemical analyses and HASL-300 (AEC 1972) for radiochemical analyses to ensure that the data generated were from widely accepted methods. Finally, these objectives were met through an extensive data validation process, which evaluated the data packages for their technical and contractual integrity. 


\subsection{ASSESSMENT OF COMPLIANCE WITH DATA QUALITY OBJECTIVES}

\subsubsection{Audits and Surveillances}

Audits and surveillances were performed by personnel of the U.S. Department of Energy (DOE) Oak Ridge Operations Office; Martin Marietta Energy Systems, Inc.; and others who reviewed and evaluated the adequacy of field and laboratory performance and ascertained whether QA/QC as specified in the BSCP Plan (Energy Systems 1992, Volume 3) was adequately and uniformly implemented. Results of these audits and surveillances were documented and reported to project management.

The following field surveillances were conducted for field quality control:

June 12, 1992: Energy Systems Surveillance Report JS-BSCP-92-01.

February 25, 1993: DOE Oak Ridge Report EQA-92-12-10.

February 25, 1993: Energy Systems QA Report JS-BSCP-93-01, Phase I Field Data Validation.

September 15, 1992: Energy Systems Surveillance Report JS-BSCP-92-02, Phase II Field Sampling Activities.

June 4, 1993: Energy Systems QA Report JS-BSCP-93-02, Phase II Field Data Validation.

Corrective actions were initiated after the reports were received.

The following analytical laboratory surveillances were conducted for analytical QC:

September 2, 1992: Environmental Restoration Surveillance Report 92ERTI-9, Data Validation Methods.

October 22-23, 1992: Environmental Restoration Surveillance Report 92ERTI-10, Data Validation Status.

October 27, 1992: Environmental Restoration Surveillance Report 92ERTI-11, Surveillance of Lockheed Analytical Services Laboratory in Las Vegas, Nevada.

April 26, 1993: Environmental Restoration Surveillance Report 93-BSCP-L1, Surveillance of Ecotek LSI in Atlanta, Georgia.

March 1, 1993: Environmental Restoration Surveillance Report 93-BSCP-1, Surveillance of BSCP Project and QA Records.

June 29, 1993: Environmental Restoration Surveillance Report 93-BSCP-3, Surveillance of BSCP Phase II Data Report Subelement Milestones Date Fulfillment.

Written responses and corrective actions were provided after the reports were received. 


\section{8-4}

\subsubsection{Data Quality Indicators for Field Measurement Data}

Both qualitative and quantitative criteria are used as indicators for the overall quality of the field data. In determining whether the data are usable, especially in the decision process, the integrity and authenticity of the data must be evaluated, and the analytical uncertainty must be known. Field indicators generally used to qualitatively assess the data quality are representativeness, comparability, completeness, sensitivity, and whether the data are reasonable in terms of soil morphology, conceptual models of soil genesis, general soil forming processes, and site location criteria specific for each site.

Analysis of field duplicates provided an assessment of the small-scale natural variability of soil samples. Soil Preparation Laboratory (SPL) splits of composited samples provided for some assessment of analytical laboratory variability, the variability introduced by the SPL compositing method, and also natural soil variability. Other quantitative measures of field quality control included proper sample preservation, use of field and source water blanks, equipment rinsates, and suitable precleaned containers.

\subsubsection{Data Quality Indicators for Analytical Laboratory Measurement and Soil Preparation Laboratory Data}

Five qualitative and quantitative parameters are used as data quality indicators. The review of data according to these parameters and the validation of the field and analytical program are used to determine the usability of the data generated. The data quality indicators to be used are precision, accuracy, representativeness, comparability, and completeness. Precision and accuracy are quantitative characteristics, whereas representativeness, comparability, and completeness are qualitative characteristics for evaluating the field and analytical performance.

\subsubsection{Precision}

Precision is the measure of the reproducibility of measurements under a given set of conditions. It is a quantitative measure of the variability of a group of measurements compared to their average values. Precision is usually stated in terms of standard deviation(s) and relative percent difference (RPD). The overall precision of measurement data is a mixture of field sampling and laboratory analytical factors. Analytical precision is much easier to control and quantify than sampling precision. The historical data available to assess method performance depend on the samples received in the laboratory, while sampling precision is unique to each site. Sampling precision was determined by collecting and analyzing field duplicate samples. The results from these measurements provide data on the overall measurement. Analytical precision was determined by the measurement of laboratory replicates. The measurement of the sampling precision is determined by subtracting the analytical precision from the overall measurement precision.

\subsubsection{Accuracy}

Accuracy is a measure of the bias in a measurement system. It is difficult to measure for the entire data collection activity. Sources of error are the sampling process, field contamination, preservation, handling, sample matrix, sample preparation, and analysis 
techniques. Sampling accuracy can be assessed by evaluating the results of field blanks, while the analytical accuracy can be assessed through the use of matrix spike and laboratory control samples.

\subsubsection{Representativeness}

Representativeness is a qualitative parameter that is most concerned with the proper design of the sampling program. It is an expression of how accurately and precisely the data represent a characteristic of a population, the parameter variability at a sampling point, or an environmental condition. Representativeness was addressed in this project by using screening methods for VOCs and radionuclides to determine the acceptability of sampling sites with respect to project objectives.

\subsubsection{Completeness}

Completeness is defined as the percentage of measurements made that are judged to be valid measurements. The completeness goal of a project is satisfied if a sufficient amount of valid data is generated for its intended use. The completeness of the project is assessed by determining the number of measurements judged to be valid from the data validation and evaluation process. For an overview of the completeness of this project, see Table 8.3.

\subsubsection{Comparability}

Comparability is a qualitative parameter expressing the confidence with which one data set can be compared against another data set. The sample data should be comparable with other measurement data for similar samples and sample conditions. Comparability is assessed by determining whether the standard techniques (field and analytical) stated in the plan are used and that the analytical results are reported in the appropriate units. Data sets can only be compared with confidence when the precision and accuracy are known.

\subsubsection{Training of Field and Soil Preparation Laboratory Personnel}

The BSCP training program included actual training in BSCP procedures. Training was completed as required in the appropriate standard operating procedure (SOP), and training records were maintained by the appropriate coordinator for the BSCP. Generally, the extent of field/laboratory training was commensurate with the scope, complexity, and nature of the activity, along with the educational experience and proficiency of the person being trained.

QC measures for field locations, including selection of sampling locations, field data recording, and sample collection, were implemented to meet project objectives. Sampling sites on the ORR were the responsibility of the ORR sampling team leader, while sites in Anderson and Roane counties were the responsibility of The University of Tennessee, Knoxville (UTK) sampling team leader. Discussion of each site is presented in Sect. 3 and Appendix A. Methods for field activities, including record keeping, sample identification, maintenance of sample custody, and laboratory instrument calibration, were specified in SOPs. 


\subsubsection{Field Data and Records Management}

Field data management activities ensured the organization, consistency, traceability, integrity, and security of the data sets generated to enable the project to meet its objectives. A unique identification code was assigned to each sample to ensure internal consistency and compatibility. Sufficient information was recorded at each sampling site to ensure that data were traceable to the sampling task: the location, sample identification, sample depth, and sampling date. The chain-of-custody form listed the laboratory destination.

Records generated by the program that are required (1) to provide a complete and accurate history of sample collection, analysis, and data reporting; (2) to document conduct of project business; and (3) to support any future legal or administrative actions that may be taken are retained in the project files. Similarly, records that furnish documentation or evidence of quality (e.g, project plans and results of QA oversight activities) were designated QA records and added to the project files.

Records identified in sampling and analysis activities included project plans and approvals, field and laboratory notebooks, chain-of-custody forms, request-for-analysis forms, and instrument listings for gamma screening spectroscopy.

All field activities followed standard record keeping and chain-of-custody procedures. These included recording site-specific information in bound notebooks, with routine reviews of the notebooks. Notebooks for ORR activities were divided into field notebooks, in which all field activities were recorded, and lab notebooks, where all laboratory activities were recorded. Sample custody was established by the sampling team upon collection, through the use of standard chain-of-custody forms, and maintained throughout sample processing and delivery to the shipper for transport to the analytical service laboratories. Project field QA/QC procedures included field duplicates, composited splits, equipment-cleaning rinse water samples, and VOC trip water blanks. Specific field QC activities are discussed in Sect. 3.

\subsection{Field Quality Program}

\subsubsection{Selection of sampling sites}

Representative sampling sites were selected that had not been disturbed by recent activities that resulted in surface soil disturbance. These activities included ORR facility activities since 1942 and off-site activities, such as farming operations or recreational uses.

A brief discussion of each site is presented in Sect. 3. Most sites met the minimum qualifications specified in Sect. 3. Most of the Anderson County and Roane County sites had a more varied land use history for the past 50 years than the ORR sites. Some of the off-Reservation sites were still being used for cattle pasture. This showed up in the gamma scanning results, which had a much wider range in variability, an indication of either erosion or sedimentation. The ORR sites were, for the most part, abandoned 50 years ago, although logging has occurred on some ORR sites. This lack of land surface disturbing activity resulted in less variability. Several Anderson and Roane County Copper Ridge sites had soils with a colluvial capping that was more than $50 \mathrm{~cm}$ thick. These particular soils were not considered to be wholly representative of residual soils but were very representative of the associated colluvial soils. 
Any sign of recent (in the past 40 to 50 years) land disturbance, the presence of man-made organic compounds, or the presence of radionuclides above global fallout levels immediately resulted in a site being rejected. Potential sites were initially chosen on the basis of the lack of any recent land disturbance, which, for most sites, was the presence of old-field successional forest. Nearly all of the sites had been cultivated and severely eroded before being abandoned or planted in pines on the ORR or allowed to revert back to forest on private lands. Some ORR sites were located in woods that had never been totally cleared and placed into agriculture.

\subsubsection{Collection of samples}

Representative samples were collected and transferred to temporary refrigerator storage in the SPL (Room 375, Bldg. 1505 at ESD), to the Y-12 Plant Analytical Laboratory, or to the Oak Ridge National Laboratory (ORNL) Shipping Department for transfer to off-site analytical laboratories.

All VOC, organic, and tritium soil samples from $A$ horizons were preserved on ice immediately or within $15 \mathrm{~min}$ after being sampled. Samples collected for compositing usually were not preserved until after they had been partially dried, sieved, mixed, and put into suitable bottles. From that time, composited samples were preserved within $4^{\circ}$ of $4^{\circ} \mathrm{C}$. Observations made during routine sampling and SPL activities indicated that an ice chest and the refrigerator could generally maintain a temperature within $4^{\circ}$ of $4^{\circ} \mathrm{C}$. If a large number of warm samples was placed into the ice chest or in a refrigerator at once, the temperature might exceed $8^{\circ} \mathrm{C}$ for a short time. Temperatures were checked with a maximum/minimum thermometer. Diligent efforts were made to ensure that representative samples were collected. On the ORR, the designated sampling team leader sampled all of the sites except for one absence between April 20 and 23, 1992. All off-ORR sites were sampled by, or activities were monitored by, the UTK sampling team leader.

\subsubsection{Handling of samples}

Efforts were made to prevent cross-contamination at any site and between sites and to maintain a complete chain of custody and detailed records of all field and laboratory compositing activities.

All pit digging equipment was thoroughly cleaned before going from one site to another. All of the SPL-cleaned stainless steel sampling equipment to be used at one site was given a field rinse at the truck, rewrapped in aluminum foil, and carried to the site. One piece of sampling equipment was used for each soil horizon and then placed into a container for used equipment. All dirty equipment was cleaned, rinsed, and wrapped in aluminum foil in the SPL after the day's sampling had been done. The date of cleaning was documented in the BSCP laboratory book. Site and sample descriptions were first recorded in the field log book, from which a unique sample number was assigned. From the field log book, all container labels were filled out and then placed on the sample jar. Field chain-of-custody forms were also filled out from the field log book. Laboratory chain-of-custody forms were filled out in the SPL for samples to be sent to analytical laboratories. Field log books were used to record all field activities. All activities that were done in the SPL were recorded in BSCP laboratory notebooks. The UT sampling crews used only one log book to record both field and SPL activities. 
Field and SPL quality levels ranged from DQ Level II to DQ Level IV. In practice, however, DQ Level IV was adhered to throughout all field sampling activities, including screening samples for VOCs, where samples were placed into precleaned glass containers. SPL work with Environmental Sciences Division (ESD) composite soil samples was done under DQ Level IV documentation requirements.

Field sampling procedures are listed in Sects. 6.6.1.3 to 6.6.1.9 in the BSCP Plan (Energy Systems 1992, Volume 3). The following discussion covers the objectives and methods followed in collecting samples. Before going to the field, all stainless steel sampling equipment was thoroughly washed in the SPL with soap and water, followed by a prescribed number of distilled water rinses. After the final rinse, the wet equipment was immediately wrapped with one or more thicknesses of aluminum foil. The sampling equipment was taken to the field in the back of a pickup truck. At or near the site, the sampling equipment was unwrapped and given a field rinse; it was then immediately rewrapped until it was used. The analysis of source water and field rinse water indicated that the cleaning of sampling equipment did not contribute to any cross-contamination. Some sites were located a considerable distance from the closest point of access. Here the rinsing was done at the truck, and the field-rinsed equipment was wrapped in aluminum foil, placed into a backpack, and carried to the site. A small pit was dug with a steel shovel deep enough to place the sample jar below the soil horizon to be sampled. A sampling tool was unwrapped and used to remove soil from the pit face directly into the jar. At no time were fingers used to place a soil sample into a precleaned glass sample container. Soil pushed by the sampling tool beyond the mouth of the jar was discarded. Placing soil into the ESD gamma poly containers was the only exception to this rule. Placing the entire volume of soil into the gamma poly container required that the soil be packed into the lower restricted space either with the fingers or with a freshly cut stick of a convenient diameter. After each soil horizon was sampled, a new sample tool was used to collect samples from the next soil horizon. All used stainless steel sampling tools were returned to the laboratory for standard cleaning, rinsing, and aluminum foil wrapping. Stainless steel sampling equipment was not given an acid rinse because of potential pitting and etching problems, nor was it given a solvent rinse since it would have been necessary to do this in a radiation-contaminated hood. Shovels used to open and fill pits were thoroughly cleaned between sites to prevent any cross-contamination. In addition, soil removed from pits was placed outside the 3- by 3-m sample area. Data obtained from field duplicates, composited splits, and field rinse water indicated that no cross-contamination was evident.

Each sample was given its own identification number in the field. This number and the description of each sample were first recorded in the field log book. From the field log book, sample container labels were filled out and placed on each glass jar after the jar was filled. Each sample logged into the field log book was then transcribed onto a field chain-of-custody form, which was signed by all personnel involved in the sampling operation. The ORR was initially assigned numbers starting with 1000 and ending with 1999; however, the number of samples exceeded the assigned numbers. The sample after number 1999 was given the number 4000 . ORR samples continued to use 4000 series numbers until the field work was completed.

ESD SPL operations consisted of refrigerating soil samples, compositing operations, preparing laboratory chain-of-custody forms, packing samples into ice chests, and taking them to shipping. Later in the project, preparation of laboratory chain-of-custody forms, new container labels, packing, and shipping were done by personnel from the Measurement, Applications, and Development Group Analytical Projects Office (MAD/APO) according to Procedure BSCP-SOP-02, Rev. 0. 
The compositing operation resulted in the destruction of individual site samples obtained from a given horizon and the creation of new composited samples. All of these activities were recorded in the ESD or UTK soils laboratory log book. New sample numbers were first recorded in the laboratory log book and then transcribed onto container labels and the appropriate chain-of-custody form.

A limited number of field variances [Sect. 6.6.1.9 of the BSCP Plan (Energy Systems 1992)] were needed. These variances were only required in the sampling of Chickamauga sites. One field variance described the partitioning of Chickamauga sites between the Bethel Valley section of the Chickamauga and the K-25 Site section of the Chickamauga. Another field variance described a different grouping of sites for sample compositing purposes. Instead of a random grouping of sites, the Bethel Valley Chickamauga sites were cluster composited because the ESD gamma screening indicated the presence of a local source of ${ }^{137} \mathrm{Cs}$. A decision was made to determine whether other metals, organics, and radionuclides were associated with the ${ }^{137} \mathrm{Cs}$ distribution. All other sampling and compositing of ORR and off-site areas were accomplished by standard procedures.

\subsubsection{Field Data Validation}

As part of the QA/QC effort to satisfy the data quality objectives of this project, validation of the field data is vital to ensure that the field data set is complete with respect to procedure ESP-500, ES/ESH/INT-14, as specified in the project plan. A validation worksheet listing the ESP-500 elements was prepared for each site sampled, and the elements were checked off as they were found. The results of the validation effort revealed that project field records are essentially complete but were distributed among several sources, so a general index of records (and record contents) was needed. This activity identified a lack of complete records on sample preservation and a lack of landowner contact information for sites off the ORR. These areas were addressed by project staff.

Field data validation was easier during the later part of this project for several reasons. In particular, sampling and record-keeping procedures benefitted from earlier surveillances. A major improvement was the adoption of BSCP-SOP-01, Rev. 1, approximately half-way through the project. The standardization of project procedures streamlined the way data could be reported in the field notebooks without loss of information. Such standardization obviated the need to spell out methodology, preservatives, etc., unless unusual conditions caused or demanded a departure from standard operating procedures.

\subsubsection{Assessment of Field Quality Control Methods and Procedures}

Samples and data collected to evaluate QC for field and laboratory activities were outlined in ES/ER/TM-26/R1 (Energy Systems 1992). The frequency and types of QCsamples collected were predetermined in the sampling plan based primarily on cost limitations. The specific QA objectives for all data were to obtain reproducible, precise, and accurate measurements consistent with the intended use of the data and within the limitations of the number of samples, sampling methodology, and analytical procedures used. For this report, field QC includes actions ranging from site selection to sample receipt by the shipper. This includes, but is not limited to, sample collection, custody, processing, preservation, prevention of cross-contamination, and field record keeping. Each of these actions is discussed herein as appropriate. 
Site and sample representativeness is an assessment of how well environmental conditions are represented by the sites sampled and whether contamination of samples occurred between collection and analysis. Representativeness is evaluated relative to field activities through review of site selection rationale, frequency of sampling individual sites, and selection of analytical parameters to be characterized.

Comparability for field activities is the confidence with which data collected at different times from the same site may be compared. Objectives for comparability between samples are met by (1) narrowly defined sampling methodologies, (2) site surveillance and use of standard sampling devices and monitoring devices, (3) training of personnel, and (4) documentation of sampling locations.

Cross-contamination is a possible problem during field sampling and composite sample preparation. To minimize such a possibility, this project practiced the following procedures: (1) Each sample container was precleaned and had a certified rinsate water analysis. (2) Sampling equipment was used only once before being cleaned and then rinsed on-site before sampling. (3) Contact with distilled rinse water and stainless steel was a possible source of contamination, but the possible influence on data quality was negligible (see water analysis results). (4) The soil sampling procedure was designed to effectively reduce possible cross-contamination among samples from different horizons within a soil profile. (5) Laboratory analytical procedures were developed to ensure no cross-contamination among the soil samples.

\subsubsection{Soil}

All samples were collected in accordance with the BSCP Plan (Energy Systems 1992, Volume 3) regarding sample collection procedures, sampling devices, sample container compatibility, preservation, custody, and preanalytical SPL processing. Soil variability was evaluated through the collection of field duplicates.

The major purpose for obtaining field duplicates was to assess small-scale soil variability. Field duplicate samples for volatile organic analysis (VOA) and organic analysis were sampled in two corners of the sampling square, or about $3 \mathrm{~m}$ apart. If the primary sample, for example, contained a VOC and the field duplicate did not, then the primary sample with the VOC was rejected. Field duplicate samples for compositing purposes were collected from different faces of the soil pit, or from opposite ends of the primary sampling face, or a distance between 100 and $120 \mathrm{~cm}$. Data from composited sample splits allowed for an initial look at SPL variability in compositing and at whether the analytical laboratory made a serious error. At least one notable laboratory error was found when comparing primary and duplicate data for the $A$ horizon (ORR 5028 and 5037), where the problem occurred, and the B and C horizons (ORR 5031, 5034, 5040, 5043), which had very comparable values. A laboratory reference soil was also used to assess analytical laboratory variability. One soil reference sample was submitted near the start of the project, and another was submitted at the close of the project. Comparison of the results indicates that there were no important departures in the data (more than two orders of magnitude difference).

\subsubsection{Water}

Water QC samples were treated identically to soil samples in terms of sample identification, custody, request for analytical services, and data processing. The only major 
difference in handling was strict adherence to preservation, which involved refrigeration, acidification, or other prescribed methods. Results from water QC samples were not used to adjust the results obtained for primary or duplicate soil samples. Water QC samples included VOC trip water blanks, rinse water collected from field sampling equipment, and source water used to rinse sampling equipment in the laboratory and in the field.

Trip blank A sealed container of organic-free source water was used to identify contamination contributed to VOA soil samples during transport from the field to the Y-12 Plant Analytical Laboratory. Trip blanks were transported to and from the field and preserved in the same manner as primary soil samples. Information from trip blanks can be relevant to the interpretation of VOCs in soil samples and in VOC field rinsates.

Rinse water. Field rinse water is obtained by rinsing sample collection tools after arriving as close as possible to the sampling site. Analysis and comparison of the rinsate with the source water determined whether the cleaning procedures were adequate to avoid carry-over of contamination from one site to another and whether the sampling equipment had been thoroughly cleaned in the SPL.

Comparison results from all rinse water samples from field and laboratory equipment cleaning operations with source water are presented in Tables 8.1 and 8.2. Sample identification numbers and analytes for which there were no differences are not presented.

All of these values, except for strontium in the rinse water, are either below detection limits or are estimates. The rest of the data are nearly the same for both field and laboratory samples of source water. The data generally indicate that (1) the laboratory detection limits varied from day to day (Note: if field blanks were available, they would be expected to exhibit the same variability) and (2) the ORR field rinse water was removing ions from the stainless steel field sampling equipment. The comparison of the ORR source and metals field rinses indicates that the rinse water had increased amounts of $\mathrm{Fe}, \mathrm{Mn}$, and $\mathrm{Al}$. The increase in silicon is probably from water storage in 1-gal glass jugs carried to the field. Because of detection limit changes and other problems, there were no detects or estimated values for PAHs in the Phase I source water and rinsate samples, but there were several in the Phase II source water and rinsate samples. Again, a review of these data indicates problems with laboratory analytical equipment, including instrument contamination.

No tritium or ${ }^{99} \mathrm{Tc}$ was detected in any of the field rinses or source water samples. Europium-155 and potassium-40 were detected in the radionuclides' ORR rinse water but were not detected in the ORR source water. However, the high values shown are not reasonable, and the data should not be considered valid. No pesticides or herbicides were detected in the ORR source water or field rinse water samples. Some trip blanks and field rinse water samples for the ORR VOC analysis were estimated to contain ( $\mathrm{J}$ qualifier) acetone and 2-butanone. In addition, four VOA trip blank water samples contained trichloroethene along with one VOA field rinse sample. Trichloroethene was not detected in any soil sample. This compound is highly suspected to be the result of instrument contamination. In conclusion, comparisons of rinse water with source water do not indicate any sampling contamination problems; rather, most of the listed differences are the result of laboratory contamination or problems with instrument calibration and/or lower limits of detection. 
Most of the values are either below detection limits or are estimates. The rest of the data are the same and are not listed. Of interest is that some numbers are higher in the source water than in the rinse water. This is most likely because of instrument variability and sensitivity from day to day.

Table 8.1. Comparison of rinse water and source water for metals on the ORR [Inductively coupled plasma (ICP) method; units are micrograms per liter]

\begin{tabular}{|c|c|c|c|c|c|c|}
\hline $\begin{array}{l}\text { Element } \\
\text { rinsate }\end{array}$ & $\begin{array}{l}\text { Phase I } \\
\text { source }\end{array}$ & $\begin{array}{l}\text { Phase II } \\
\text { source }\end{array}$ & $\begin{array}{c}\text { Nol-DG } \\
\text { rinsate }\end{array}$ & $\begin{array}{c}\mathrm{CR}^{\mathrm{b}} \\
\text { rinsate }\end{array}$ & $\begin{array}{c}\mathrm{CH}^{c} \\
\text { rinsate }\end{array}$ & $\begin{array}{l}\text { Chick. }^{d} \\
\text { rinsate }\end{array}$ \\
\hline $\mathrm{Al}$ & $18.0 \mathrm{U}^{e}$ & $19.0 \mathrm{~B}^{f}$ & $54.6 \mathrm{~B}$ & $60.5 \mathrm{~B}$ & $83.0 \mathrm{~B}$ & $12.4 \mathrm{~B}$ \\
\hline $\mathrm{Cr}$ & & $2.0 \mathrm{U}$ & & $12.5 \mathrm{U}$ & $5.2 \mathrm{~B}$ & $2.0 \mathrm{U}$ \\
\hline $\mathrm{Cu}$ & $3.7 \mathrm{~B}$ & $9.0 \mathrm{U}$ & $7.9 \mathrm{~B}$ & $5.0 \mathrm{U}$ & $9.5 \mathrm{~B}$ & 9.0 \\
\hline $\mathrm{Fe}$ & $5.0 \mathrm{U}$ & $30.8 \mathrm{~B}$ & $65.5 \mathrm{~B}$ & $60.5 \mathrm{~B}$ & $83.0 \mathrm{~B}$ & $19.0 \mathrm{~B}$ \\
\hline $\mathrm{Mn}$ & $1.0 \mathrm{U}$ & $1.4 \mathrm{~B}$ & $3.7 \mathrm{~B}$ & $2.5 \mathrm{U}$ & $1.0 \mathrm{U}$ & $1.0 \mathrm{U}$ \\
\hline $\mathrm{Sr}$ & $1.4 \mathrm{~B}$ & $1.0 \mathrm{U}$ & 5.1 & $2.5 \mathrm{U}$ & $1.0 \mathrm{U}$ & $1.0 \mathrm{U}$ \\
\hline Si & & 102.0 & & 558.0 & 298.0 & 150.0 \\
\hline Sulfate & & $1000.0 \mathrm{U}$ & & 4000.0 & $1000.0 \mathrm{U}$ & $1000.0 \mathrm{U}$ \\
\hline $\mathrm{Zn}$ & $6.1 \mathrm{~B}$ & $7.0 \mathrm{U}$ & $11.6 \mathrm{~B}$ & $14.2 \mathrm{~B}$ & $9.1 \mathrm{~B}$ & $7.0 \mathrm{U}$ \\
\hline${ }^{20} \mathrm{Ra}$ & $D^{g}$ & $\mathrm{D}$ & 9.85 & D & $\mathrm{D}$ & $D$ \\
\hline${ }^{40} \mathrm{~K}$ & $\mathrm{D}$ & D & 9.7 & $\mathrm{D}$ & $D$ & 1040.0 \\
\hline Compound & $\begin{array}{c}\text { Phase II } \\
\text { source }\end{array}$ & $\begin{array}{c}\mathrm{CR} \\
\text { rinse }\end{array}$ & $\begin{array}{c}\mathrm{CH} \\
\text { rinse }\end{array}$ & $\begin{array}{c}\text { Chi-BV }^{\mathrm{h}} \\
\text { rinse }\end{array}$ & \multicolumn{2}{|c|}{ Chic. $\mathrm{K}-25^{\mathrm{i}}$ rinse } \\
\hline $\begin{array}{l}\text { Benzo[a]- } \\
\text { anthrene }\end{array}$ & $0.01 \mathrm{U}$ & 0.02 & $0.05 \mathrm{U}$ & $0.01 \mathrm{~J}^{c}$ & \multicolumn{2}{|c|}{$0.08 \mathrm{U}$} \\
\hline Benzo[a]pyrene & $0.01 \mathrm{U}$ & 0.02 & $0.05 U$ & $0.05 \mathrm{U}$ & & \\
\hline Fluoranthene & 0.02 & & $0.05 \mathrm{U}$ & $0.01 \mathrm{~J}$ & & \\
\hline $\begin{array}{l}\text { Benzo[ghi]- } \\
\text { perylene }\end{array}$ & $0.01 \mathrm{U}$ & 0.03 & $0.05 \mathrm{U}$ & $0.05 \mathrm{U}$ & & \\
\hline Phenanthrene & $0.01 \mathrm{U}$ & $0.02 \mathrm{U}$ & $0.03 \mathrm{~J}$ & $0.01 \mathrm{~J}$ & \multicolumn{2}{|c|}{$0.01 \mathrm{U}$} \\
\hline
\end{tabular}

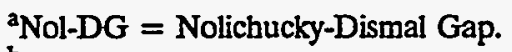

${ }^{\mathrm{b}} \mathrm{CR}=$ Copper Ridge.

${ }^{\mathrm{C}} \mathrm{CH}=$ Chepultepec.

${ }^{\mathrm{d} C h i c k}$. $=$ Chickamauga.

$\mathcal{U}=$ nondetect.

$f_{\mathrm{B}}=$ estimated.

$\mathrm{BD}=$ Identifies all compounds indicated at a secondary dilution factor.

${ }^{\text {h }}$ Chi-BV = Chickamauga-Bethel Valley.

${ }^{\mathrm{i}}$ Chic. $\mathrm{K}-25=$ Chickamauga-K-25.

jJ = estimated.

Note: no qualifier letter is a detect. 
The source water for Anderson County herbicides or pesticides analyses did not contain any detects, but the Roane source water and field rinsate samples did, but in very small amounts. Indeed, from looking at the data above, one cannot be certain that there are any PAHs at all in these water samples.

Table 8.2 Comparison of source water and rinse water for Anderson and Roane counties

(Units are micrograms per liter)

\begin{tabular}{|c|c|c|c|c|}
\hline \multirow[b]{2}{*}{ Element } & \multicolumn{2}{|c|}{ Anderson County } & \multicolumn{2}{|c|}{ Roane County } \\
\hline & Source & Rinse & Source & Rinse \\
\hline $\mathrm{Al}$ & $72.0 \mathrm{U}^{a}$ & $72.0 \mathrm{U}$ & 261.0 & $88.5 \mathrm{~B}^{b}$ \\
\hline B & 170.0 & 209.0 & $24.0 \mathrm{U}$ & $24.0 \mathrm{U}$ \\
\hline $\mathrm{Cu}$ & $7.0 \mathrm{U}$ & $7.0 \mathrm{U}$ & 78.5 & $9.0 \mathrm{U}$ \\
\hline $\mathrm{Fe}$ & $61.0 \mathrm{U}$ & $61.0 \mathrm{U}$ & 202.0 & 107.0 \\
\hline $\mathrm{Mn}$ & $8.0 \mathrm{U}$ & $8.0 \mathrm{U}$ & $3.6 \mathrm{~B}$ & $2.2 \mathrm{~B}$ \\
\hline $\mathrm{Pb}$ & $1.8 \mathrm{~B}$ & $1.8 \mathrm{~B}$ & $2.0 \mathrm{U}$ & $2.0 \mathrm{U}$ \\
\hline $\mathrm{Si}$ & 419.0 & 398.0 & 423.0 & 665.0 \\
\hline $\mathrm{Zn}$ & $6.0 \mathrm{~B}$ & $5.4 \mathrm{~B}$ & 58.5 & $19.4 \mathrm{~B}$ \\
\hline Acenapthylene & $\mathrm{A}^{c}$ & A & $0.18 \mathrm{~J}^{d}$ & $0.04 \mathrm{~J}$ \\
\hline $\begin{array}{l}\text { Benzo }[a]- \\
\text { anthrene }\end{array}$ & A & A & $0.01 \mathrm{U}$ & $0.01 \mathrm{~J}$ \\
\hline Napthalene & A & A & $0.01 \mathrm{~J}$ & $0.02 \mathrm{~J}$ \\
\hline Phenanthrene & A & A & $0.01 \mathrm{~J}^{\circ}$ & $0.01 \mathrm{U}$ \\
\hline Aldrin & $0.05 \mathrm{U}$ & $0.05 \mathrm{U}$ & $0.064 P^{e}$ & $0.063 \mathrm{P}$ \\
\hline $\begin{aligned}{ }^{a} \mathrm{U}= & \text { nondetect. } \\
{ }^{b} \mathrm{~B}= & \text { estimated. } \\
{ }^{c} \mathrm{~A}= & \text { PAHs were } \\
{ }^{d_{\mathrm{J}}}= & \text { estimated. } \\
{ }^{\mathrm{P}}= & \text { used for pes } \\
& \text { concentratio } \\
& \text { and flagged. }\end{aligned}$ & $\begin{array}{l}\text { zed in the } \\
\text { cior target a } \\
\text { en the two } g\end{array}$ & $\begin{array}{l}\text { source wat } \\
\text { ton there i } \\
\text { tograph co }\end{array}$ & $\begin{array}{l}\text { rinse water } \\
\text { lifference for } \\
\text { he lower of th }\end{array}$ & reported \\
\hline
\end{tabular}

The Anderson County rinse water for radionuclide analysis contained ${ }^{40} \mathrm{~K}$, but Roane County rinse water for radionuclides did not contain any detects for tritium. Neither the Anderson nor Roane source water samples contained any radiation detects.

Some of the Roane County trip blanks and rinse water samples for VOC analysis contained estimated $\mathrm{J}$ detects for acetone and 2-butanone. These are considered to be due to instrument contamination. Of note was the presence of carbon disulfide and 1,2-dichloropropane in the following VOC trip blanks: ROA $(3042,3043),(3068,3069)$, and $(3095,3096)$. Each of these is a pair. The accompanying VOC soil samples for each trip blank pair were all resampled because of contamination from sealing the bottle lid with a particular brand of masking tape used by the UTK sampling crews. This practice was promptly 
discontinued upon discovery of the problem. Chloroform was detected (14 $\mu \mathrm{g} / \mathrm{L})$ in sample 2024. This is a trip blank and is most likely laboratory contamination because no associated soil samples contained this compound.

\subsubsection{Analytical Data Quality Assessment}

The laboratory QC program was designed to ensure that all data generated and reported are scientifically valid, consistent with accepted methods, and of known accuracy. All inorganics and organics were analyzed by Lockheed Analytical Services Laboratory (Las Vegas, Nevada), while all radiological samples were analyzed by EcoTek, LSI (Atlanta, Georgia). The laboratories analyzed the following QC samples:

- Laboratory blanks to assess the contamination levels in the analytical process.

- Laboratory control samples to assess method bias, precision, and comparability.

- Matrix spikes to assess the bias of the method for the matrix, as well as the precision of the method when performed in duplicate.

- Duplicates to assess the precision of the sampling process and/or the analytical methods.

\subsubsection{Data validation}

Section 4.4 of this document details the data validation program followed for the BSCP. The criteria for the BSCP were prepared specific to the methods defined for this project. The results of the data validation with respect to the methods used for this project are provided in Sect. 4.4. This section will detail the results of the data validation with respect to formation and will provide an overall assessment of the data. Two sets of data qualifiers were used for this project. During the laboratory review process, the data were qualified by the laboratory generating the data. These qualifiers are defined in Sect. 4.3 of this document. The data were also qualified during the data validation process. These qualifiers are defined in Sect. 4.4 of this document.

Qualification of the data. A total of 94 data packages was provided by the laboratories. There were 18 inorganic, 17 pesticide/polychlorinated biphenyl (PCB), 11 chlorinated herbicide, 18 polynuclear aromatic hydrocarbon, and 30 radiological data packages. This section will provide an overall summary of the QC problems found during the data validation process. The distribution of usable data by method is presented in Table 8.3. A compilation of sample delivery group (SDG) numbers to sample numbers can be found in Appendix $F$.

Pesticides/PCBs. A total of 17 data packages was provided for pesticide/PCB analysis. The data were found to be $99 \%$ usable; only one sample was qualified unusable (R). The QC problems found during the data validation that qualified the data J or UJ (Table 4.1) were

- that two SDGs were extracted outside of holding times,

- there were problems observed in the gas chromatograph/electron capture detector (GC/ECD) instrument performance, and

- there were calibration concerns, and surrogate recoveries were outside QC limits.

Chlorinated herbicides. A total of 11 data packages was provided by the laboratory for chlorinated herbicide analysis. The data were found to be $88 \%$ usable. Eighteen samples were analyzed for Dalapon and six samples of the other reported herbicides, which were rejected because surrogate recoveries were below $10 \%$ and/or because the holding times were 
exceeded by two times the limit. Some data were qualified J or UJ because of calibration problems and surrogate recoveries that were outside of $Q C$ limits.

Polynuclear aromatic hydrocarbons. There were 18 data packages provided by the laboratory for polynuclear aromatic hydrocarbon analysis. PAH data were found to be $75 \%$ usable. The $\mathrm{QC}$ problems found during the data validation process that rejected the data were

- very poor surrogate recoveries,

- laboratory control sample (LCS) and matrix spike/matrix spike duplicate (MS/MSD) recoveries outside $\mathrm{QC}$ limits, and

- surrogate coelution problems.

Table 8.3. Distribution of data usability

\begin{tabular}{|c|c|c|}
\hline Analysis type & Method & $\%$ Usable \\
\hline $\begin{array}{c}\text { Radiochemical } \\
\text {. }\end{array}$ & $\begin{array}{l}\text { Gamma }^{a} \\
\text { Isotopic thorium } \\
\text { Isotopic uranium } \\
\text { Total uranium } \\
\text { Isotopic neptunium } \\
\text { Isotopic plutonium } \\
\text { Strontium-90 } \\
\text { Technetium-99 } \\
\text { Tritium } \\
\text { Curium-244 }\end{array}$ & $\begin{array}{r}100 \\
100 \\
100 \\
100 \\
70 \\
96 \\
100 \\
100 \\
93 \\
43\end{array}$ \\
\hline Organic & $\begin{array}{l}\text { Pesticides/PCBs } \\
\text { Chlorinated herbicides } \\
\text { PAHs }\end{array}$ & $\begin{array}{l}99 \\
88 \\
75\end{array}$ \\
\hline Inorganic & $\begin{array}{l}\text { Metals } \\
\text { Cyanide } \\
\text { Sulfate } \\
\text { ICP/MS metals } \\
\text { NAA metals }\end{array}$ & $\begin{array}{r}95 \\
92 \\
92 \\
100 \\
87\end{array}$ \\
\hline
\end{tabular}

${ }^{a}$ Europium-155 was qualified unusable (148 samples) because the laboratory misidentified the energy line.

${ }^{b}$ ICP/MS = inductively coupled plasma/mass spectroscopy.

TAA $=$ neutron activation analysis.

In addition to the rejected data, the data were also qualified J/UJ and JN/UJN/RN (Table 4.1). The data were qualified J/UJ because of missed holding times (one SDG), coelution problems, calibration problems, laboratory blank contamination (two SDGs), surrogate recoveries, and LCS recoveries outside QC limits. The data were qualified JN/UJN/RN because of problems with the laboratory's method of identifying peaks within the retention time windows. 
Inorganics. Eighteen data packages were provided by the laboratory for the analysis of inorganic analytes. The data were found to be $95 \%$ usable for the metals, $92 \%$ usable for cyanide and sulfate, $100 \%$ usable for ICP/MS metals, and $87 \%$ usable for NAA. The rejected metals data were for osmium, resulting from predigestion recoveries being outside QC limits. The lead data were rejected because the samples were diluted, but the dilution was not taken into consideration when recalculating the dry concentration. The potassium results in some of the data were qualified unusable because the interference check sample was outside the criteria. The data also had some analytes qualified as $\mathrm{J}$ or UJ. The reasons for this qualification were

- there were calibration problems,

- the cyanide middle standard or initial calibration verification (ICV) was not properly distilled,

- the cyanide holding time was exceeded,

- there was laboratory blank contamination,

- duplicate percent RPD was outside criteria,

- MS and analytical spike recoveries were outside QC limits.

Six data packages for NAA were submitted by the laboratory. The NAA analytes that were rejected were $\mathrm{Cd}, \mathrm{Sm}, \mathrm{Se}, \mathrm{W}$, and $\mathrm{Zn}$. These were rejected because of calibration concerns and MS and LCS recoveries outside QC criteria. The data also had some analytes qualified as $\mathrm{J}$ or UJ. The reasons for this qualification were

- continuing calibration outside criteria,

- MS and LCS outside criteria,

- laboratory blank contamination.

Radiochemical analyses. A total of 30 data packages was submitted by the laboratory. The usability of the radiochemical data generated for this project was broken down by method and/or isotope. The data for all of the gamma-emitting isotopes were $100 \%$ usable with the exception of ${ }^{155} \mathrm{Eu}$, which was qualified unusable because of the laboratory misidentifying the ${ }^{155} \mathrm{Eu}$ line. The data for ${ }^{90} \mathrm{Sr},{ }^{99} \mathrm{Tc}$, isotopic thorium, isotopic uranium, and total uranium were found to be $100 \%$ usable. The remaining isotopes had percent usability values ranging from 43 to $96 \%$. Isotopic neptunium was found to be $30 \%$ unusable because of calibration problems and an inability to assess the chemical separation. The isotopic plutonium was found to have $4 \%$ of the data unusable because of calibration problems and the inability to assess the chemical separation. Seven percent of the tritium data were found to be unusable because of poor matrix spike recoveries and the laboratory reporting points outside of the quench curve. The ${ }^{244} \mathrm{Cm}$ results were found to be only $43 \%$ usable because the laboratory did not recover the tracer from spike and duplicate samples in some of the samples.

The other isotopes may have been qualified as $\mathrm{J}$ or UJ for various reasons. Some of the reasons for this qualification were

- blank spike and matrix spike recoveries outside QC limits,

- inability to determine chemical separation specificity,

- no daily instrument performance check,

- calibration problems, 
- laboratory performance or method accuracy could not be determined,

- inability to assess activity, error, or minimum detectable activities in samples.

\subsubsection{Analytical Data Gaps}

The occurrences of rejected analytical data for organics, inorganics, and radionuclides are tabulated in Appendix $\mathrm{H}$. Most rejects are in PAHs and radionuclides. The rejected PAHs include a variety of compounds (as discussed in Sect. 4), whereas five inorganic analytes (cyanide, $\mathrm{Pb}, \mathrm{Os}, \mathrm{K}$, and sulfate) were affected. Rejection of radionuclides can be ascribed to ${ }^{237} \mathrm{~Np}$, isotopic plutonium, ${ }^{3} \mathrm{He}$, and ${ }^{244} \mathrm{Cm}$.

In addition to data qualified unusable because of quality control concerns, there were problems with samples not being analyzed as well as other laboratory problems. Five PAH samples did not get analyzed because of a laboratory oversight. The inorganic and gamma analyte lists from the laboratories were not always consistent, thus creating holes in the data set for some of the analytes. Finally, the radiochemical laboratory misidentified the ${ }^{155} \mathrm{Eu}$, so all of those data were qualified unusable.

\subsection{LESSONS LEARNED AND RECOMMENDATIONS}

The BSCP as implemented worked extremely well in the field. The following are presented as particular examples of this.

- Site selection based on matching soil taxonomy with geologic formations in potentially contaminated areas.

- Statistical methods applied for scoping and design of the field sampling program.

- Application of a random site selection process within geologic formations.

- Utilization of a randomized technique for the grouping of sites within a formation into threes for sample compositing purposes.

The following represent project successes associated with analytical results from this project:

- Prequalification of commercial analytical laboratories and competitive final selection.

- Basing final analyte lists on risk assessment requirements.

- Developing NAA laboratory procedures in-house to provide supporting data for inorganics.

- Developing data validation procedures geared toward providing real-time feedback to the laboratories.

- Developing computerized data validation procedures applicable across Environmental Restoration projects.

"Lessons Learned" from this project indicating what could work better in future projects can be grouped into the following areas.

The major area requiring more emphasis and improvement in a future project of this type is the area of interactive coordination and real-time feedback between the respective project technical and analytical coordinators and the laboratories well before data are officially received and processed through the validation phase. The primary reason for this suggested 
requirement is to facilitate early detection and correction of data anomalies and inconsistencies that may be the result of variable interpretation of standard EPA procedures by laboratories or idiosyncrasies of analytical instrumentation calibration or the operation/interpretation of automated system outputs.

The most advantageous approach would be to utilize a phased approach to data collection in the field in future projects of this nature. It is suggested that a two-week to onemonth cessation in sample collection be established to allow sufficient time for interaction with the laboratory to resolve data concerns and issues.

Other areas requiring improvement include the following:

- Need more planning up front to meet evolving QA/QC requirements and data quality objective process needs.

- Do not assume that CLP-qualified laboratories will meet your project-specific requirements, even with EPA standard analytical methods.

- Conduct project-specific preaudits

- Conduct extensive, detailed, on-site reviews of the laboratory's operating procedures and QA implementation procedures.

- Provide project-specific performance evaluation samples to evaluate laboratory performance and data deliverables.

In negotiations with commercial analytical laboratories supporting future projects, it is recommended that provisions be made to

- Conduct preaudit surveillances including facilities, instrumentation, procedures, training, and record keeping with laboratory management and staff members.

- Revise commercial laboratory statements of work, as appropriate, to include required detail beyond CLP.

The following additional specifics are offered for future work in this area:

1. Laboratory data need to be made available as early as possible to the field sampling team for the following reasons:

- Correlation/connection of sites to specific data packages.

- Determination if data are reasonable and related. A, B, and C horizon data for residual soils should always be related.

2. Application of the concept of cluster compositing would allow for more detailed field interpretation of composited results and could be used to generate additional statistics. Random compositing as used herein does not allow for such detailed field interpretations.

Most of the composited data for metals and radionuclides cannot be partitioned into sources of origin because of naturally occurring and local anthropogenic sources. Cluster compositing would allow for trends to be observed and whether any of the ORR facilities had an effect on the data for a particular cluster. 
3. Procedure ESP-500 should be altered to fit the needs and requirements of a follow-on project. Field sampling crews in this project tried to adapt existing Clinch River chain-ofcustody (COC) forms. New COC forms specific to the BSCP were developed for this reason. An entirely new form for composited samples had to be developed also.

4. For statistical purposes, data flagged as U or UJ should not be used without due regard for the qualifiers.

5. If certain temperature preservative standards are to be strictly adhered to, then the equipment to do this must be in place before work is started. This comment refers to the $4^{\circ} \mathrm{C}$ criterion listed as a common sample preservative technique. Using refrigerators and "blue" icepacks to keep samples cold results in an actual measured temperature range of $4^{\circ} \pm 2^{\circ} \mathrm{C}$, by EPA standard. 


\section{REFERENCES}

AEC (U.S. Atomic Energy Commission). 1972. Health and Safety Laboratory Procedures Manual. HASL-300. New York.

Aihara, Jun-ichi. 1992. "Why Aromatic Compounds are Stable." Scientific American. New York. March.

Amdur, M. O., Doull, J., and Klassan, C. D. (eds.). 1991. Casarett and Doull's: Toxicology, The Basic Science of Poisons. 4th ed. Pergamon Press. New York.

ANSI/ASTM (American Society for Testing and Materials). 1980. Soil Investigation and Sampling by Auger Borings. ANSI ASTM D 1452-80. Philadelphia.

ASME (American Society of Mechanical Engineers). 1989. Quality Assurance Program Requirements for Nuclear Facilities. ANSI/ASME NQA-1. New York.

ATSDR (Agency for Toxic Substances and Disease Registry). 1988. Toxicological Profile for Chromium. U.S. Department of Health and Human Services, Public Health Service. Atlanta.

ATSDR (Agency for Toxic Substances and Disease Registry). 1989. Draft Toxicological Profile for Plutonium. U.S. Department of Health and Human Services, Public Health Service. Atlanta.

BELAS (Biomedical and Environmental Information Analysis Section). 1993. Toxicity Profiles for Contaminants of Concern on the Oak Ridge Reservation. ES/ER/TM-77. Oak Ridge, Tennessee.

Brookins, D. G. 1989. "Aqueous Geochemistry of Rare Earth Elements," in Geochemistry amd Minerology of Rare Earth Elements. B. R. Lipin and G. A. McKay (eds.). Mineralogical Society of America. Washington, D.C.

Budavari, S., M. J. O'Neill, A. Smith, P. E. Heckelman, ed. 1989. The Merck Index: An Encyclopedia of Chemicals, Drugs, and Biologicals, 11th ed. Merck and Co., Inc. Rahway, New Jersey.

Casarett, A. P. 1968. Radiation Biology. Prentice-Hall, Inc. Englewood Cliffs, New Jersey.

DOE (U.S. Department of Energy). 1993. Annual Report on the Background Soil Characterization Project on the Oak Ridge Reservation, Oak Ridge, Tennessee-Results of Phase IInvestigation. DOE/OR/01-1136, ES/ER/TM-43. Environmental Restoration Division, Oak Ridge, Tennessee.

Eckkerman, K. E. and M. W. Young. 1980. A Method for Calculating Residual Radioactivity Levels Following Decommissioning. INTEGRATED-0707. U. S. Nuclear Regulatory Commission. Office of Standards Development. Washington, D.C. 
Energy Systems (Martin Marietta Energy Systems, Inc.). 1992. Project Plan for the Background Soil Characterization Project on the Oak Ridge Reservation, Oak Ridge, Tennessee. ES/ER/TM-26/R1. Environmental Restoration Division. Oak Ridge, Tennessee.

Energy Systems (Martin Marietta Energy Systems, Inc.). 1993. Obtaining Access to Data in OREIS. ER Division Procedure ER/C-P2702, Rev. 0. Environmental Restoration Division. Oak Ridge, Tennessee.

EPA (U. S. Environmental Protection Agency). 1980. Samplers and Sampling Procedures for Hazardous Waste Streams. EPA/600/2-80/018. Washington, D.C.

EPA (U. S. Environmental Protection Agency). 1980a. Interim Guidelines and Specifications for Preparing Quality Assurance Project Plans. QAMS-005/80. Office of Monitoring Systems and Quality Assurance, Office of Research and Development. Washington, D.C.

EPA (U. S. Environmental Protection Agency). 1982. An Exposure and Risk Assessment for benzo (a)pyrene and other polyaromatic hydrocarbons. Office of Water Regulations and Standards (OWRS). Vol. I-III., October 1982. Washington, D.C.

EPA (U. S. Environmental Protection Agency). 1983. Preparation of Soil Sampling Protocol, Techniques, and Strategies. PB83-206979. University of Nevada-Las Vegas. Las Vegas.

EPA (U. S. Environmental Protection Agency). 1987a. A Compendium of Superfund Field Operations Methods. EPA/540/P-87/001. Washington, D.C.

EPA (U. S. Environmental Protection Agency). 1987b. Data Quality Objectives for Remedial Response Activities. EPA/540/G-87/003. Washington, D.C.

EPA (U. S. Environmental Protection Agency). 1987c. Health Assessment Document for Vanadium and Compounds. Office of Health and Environmental Assessment, Environmental Criteria and Assessment Office. ECAO-CINN-H108. Cincinnati.

EPA (U. S. Environmental Protection Agency). 1989a. RCRA Facility Investigation (RFI) Guidance. PB89-200299, (EPA 530/SW-89-031). Waste Management Division, Office of Solid Waste. Washington, D.C.

EPA (U. S. Environmental Protection Agency). 1989b. Federal Register (54 FR 48184). Washington, D.C.

EPA (U. S. Environmental Protection Agency). 1989c. Risk Assessment Guidance for Superfund Volume I: Human Health Evaluation Manual (Part A). EPA/540/1-89/002. Washington, D.C.

EPA (U. S. Environmental Protection Agency). 1989d. Risk Assessments Methodology; Environmental Impact Statement. NESHAPS (National Emission Standards for Hazardous Air Pollutants) for Radionuclides. Background Information Document. Volume 1 EPA/520/1-89/005 and Volume 2 EPA/520/1-89/006-1. Washington, D.C. 
EPA (U. S. Environmental Protection Agency). 1990. Guidance for Data Useability in Risk Assessment. Interim Final, EPA/540/G-90/008, Directive 9285.7-05, Office of Emergency and Remedial Response. Washington, D.C.

EPA (U. S. Environmental Protection Agency). 1990a. Contract. Laboratory Program Statement of Work for Organics. Las Vegas.

EPA (U. S. Environmental Protection Agency). 1990b. Contract Laboratory Program Statement of Work for Inorganics. Las Vegas.

EPA (U. S. Environmental Protection Agency). 1991a. Engineering Support Branch Standard Operating Procedures and Quality Assurance Manual. Region IV. Athens, Georgia.

EPA (U. S. Environmental Protection Agency). 1991b. Test Methods for Evaluating Solid Waste. SW-846, 3rd Edition. Washington, D.C.

EPA (U. S. Environmental Protection Agency). 1991c. Laboratory Data Validation Functional Guidelines for Evaluating Organic Analyses. Hazardous Site Control Division. Latest Edition. Alexandria, Virginia.

EPA (U. S. Environmental Protection Agency). 1991d. Laboratory Data Validation Functional Guidelines for Evaluating Inorganic Analyses. Hazardous Site Control Division. Latest Edition. Alexandria, Virginia.

EPA (U. S. Environmental Protection Agency). 1991e. Human Health Evaluation Manual, Supplement Guidance. "Standard Default Exposure Factors." OSWER Directive 9285.6-03. Office of Solid Waste and Emergency Response. Washington, D.C.

EPA (U. S. Environmental Protection Agency). 1992a. Health Effects Assessment Summary Tables. OERR 9200.6-3303(92-8). Office of Research and Development and Office of Emergency and Remedial Response. Washington, D.C.

EPA (U. S. Environmental Protection Agency). 1992b. Dermal Exposure Assessment: Principles and Applications. Interim report EPA/600/8-91/011B. Washington, D.C.

EPA (U. S. Environmental Protection Agency). 1993a. Integrated Risk Information System Database. Office of Research and Development. Washington, D.C.

EPA (U. S. Environmental Protection Agency). 1993b. Health Effects Assessment Summary Tables. Office of Research and Development and Office of Emergency and Remedial Response. OHEA ECAO-CIN-909. March 1993. Washington, D.C.

Friberg, L., Nordberg, G., and Vouk, V. (eds.) 1986. Handbook on the Toxicology of Metals. 2nd. ed. Elsevier Science Publishers. Amsterdam.

Glasstone, S. 1967. Sourcebook on Atomic Energy. Division of Technical Information, U.S. Atomic Energy Commission. D. Van Nostrand Co., Inc., New York.

Hammonds, J. A, and F. O. Hoffman. 1992. Toxicity Profiles for Radionuclides. SENES Oak Ridge Inc., Center for Risk Analysis. Oak Ridge, Tennessee. 
ICRP (International Commission on Radiological Protection). 1991. 1990 Recommendations of the International Commission on Radiological Protection. ICRP Publication No. 60. Pergamon Press, Inc. New York.

Kabata-Pendias, A, and H. Pendias. 1984. Trace Elements in Soils and Plants. CRC Press. Boca Raton, Florida.

Killough, G. G., and K. F. Eckerman. 1983. "Internal Dosimetry." In Radiological Assessment, NUREG/CR-3332, ORNL-5966, pp. 7-1-7-98. Eds. J. E. Till and H. R. Meyer. United States Nuclear Regulatory Commission. Washington, D.C.

Kimbrough, C. W., L. W. Long, and L. W. McMahon (eds.). 1988. Environmental Surveillance Procedures Quality Control Program. ESH/Sub/87-21706/1. Martin Marietta Energy Systems, Inc., Oak Ridge, Tennessee.

Klaassen, C. D., M. O. Amdur, J. Doull, eds. 1986. Casarett and Doull's Toxicology: The Basic Science of Poisons. 3rd ed. Macmillan Publishing Co. New York.

Lawless, J. F. 1982. Statistical Models and Methods for Lifetime Data. John Wiley \& Sons, New York.

Lehmann, E. I. 1975. Nonparametrics: Statistical Methods Based on Ranks. John Wiley \& Sons. New York.

NCRP (National Council on Radiation Protection). 1977. Environmental Radiation Measurements. NCRP Report No. 50. Washington, D.C.

Owen, B. A. 1990. "Literature-Derived Absorption Coefficients for 39 Chemicals via Oral and Inhalation Routes of Exposure." Regulatory Toxicology and Pharmacology, Volume 11. San Diego.

Owens, D. B. 1962. Handbook of Statistical Tables. Addison-Wesley Publishing Co. Reading, Massachusetts.

Page, A. L., R. H. Miller and D. R. Keeney (eds). 1982. Methods of Soil Analysis, Part 2 -Chemical and Microbiological Properties. Agronomy Monograph No. 9, Part 2, 2nd ed. American Society of Agronomy, Soil Science Society of America. Madison, Wisconsin.

Perkins, W. R., and C. W. Thomas. 1980. "Worldwide Fallout," in Transurancic Elements in the Environment. W. C. Hanson (ed.). Technical Information Center/U. S. Department of Energy. Washington, D.C.

Rankama, K. and T. G. Sahama. 1950. Geochemistry. The University of Chicago Press. Chicago.

Rupp, G. L. and R. R. Jones. 1991. Characterizing Heterogeneous Wastes: Methods and Recommendations. EPA 800/R-92/033. Harry Reid Center for Environmental Studies. University of Nevada-Las Vegas. Las Vegas. 
SAS. 1990. SAS/STAT Users Guide, Volume 2, GLM-Varcomp. SAS Institute, Inc. Cary, North Carolina.

Sax, N. I. and R. J. Lewis, Sr. 1987. Hazardous Chemicals Desk Reference. Van Nostrand Reinhold Co., Inc. New York.

Searle, S. R. 1971. Linear Models. John Wiley \& Sons. New York.

Sehmel, G. A. 1984. Deposition and Resuspension in Atmospheric Science and Power Production. DOE/TIC-27601. Edited by D. R. Anderson. Technical Information Center Office of Scientific and Technical Information. U. S. Department of Energy. Oak Ridge, Tennessee.

Seiler, H. G., H. Sigel, and A Sigel. 1988. Handbook on Toxicity of Inorganic Compounds. Marcel Dekker, Inc. New York.

Wilks, S. S. 1962. Mathematical Statistics. John Wiley \& Sons. New York. 


\section{DISTRIBUTION}

1. R. O. Barnett (PORTS)

2. F. P. Baxter

3. D. T. Bell

4. H. L. Boston

5. V. J. Brumback

6. R. B. Cook

7. T. O. Early

8. C. W. Francis

9. P. L. Goddard

10. P. A. Gourieux (PGDP)

11. T. L. Hatmaker

12. L. A. Hook

13. R. H. Ketelle

14. C. W. Kimbrough

15. B. L. Kimmel

16. A. J. Kuhaida

17. S. Y. Lee
18-20. D. M. Matteo

21. C. W. McGinn

22. S. A. Meacham

23. - M. J. Norris

24. B. D. Nourse

25-26. P. T. Owen

27. R. L. Schmoyer

28. S. H. Stow

29. R. R. Turner

30-32. D. R. Watkins

33. P. S. Wood

34. Central Research Library

35-37. ESD Library

38. Laboratory Records Department

39. ORNL Patent Section

40-42. Central ER Doc. Mgmt. Center

43-44. ORNL ER Doc. Mgmt. Center

45. Office of Assistant Manager for Energy Research and Development, DOE Oak Ridge Operations Office, P.O. Box 2001, Oak Ridge, TN 37831-8600

46. J. T. Ammons, Department of Plant and Soil Science, University of Tennessee, Knoxville, TN 37916

47. G. W. Bodenstein, DOE Oak Ridge Operations Office, P.O. Box 2001, Oak Ridge, TN 37831-8541

48. D. M. Carden, DOE Oak Ridge Operations Office, P.O. Box 2001, Oak Ridge, TN 37831-8541

49. R. N. Farvolden, Department of Earth Sciences, University of Waterloo, Waterloo, Ontario N21 3G1 Canada

50. M. S. Ferre, DOE Oak Ridge Operations Office, P.O. Box 2001, Oak Ridge, TN $37831-8541$

51. C. S. Gist, DOE Oak Ridge Operations Office, P.O. Box 2001, Oak Ridge, TN 37831-8541

52. D. A. Lietzke, Lietzke Soil Services, Route No. 3, Box 607, Rutledge, TN 37861

53. W. N. Lingle, DOE Oak Ridge Operations Office, P.O. Box 2001, Oak Ridge, TN 37831-8541

54. S. P. Riddle, DOE Oak Ridge Operations Office, P.O. Box 2001, Oak Ridge, TN 37831-8541

55. R. C. Sleeman, DOE Oak Ridge Operations Office, P.O. Box 2001, Oak Ridge, TN 37831-8541

56. J. T. Sweeney, DOE Oak Ridge Operations Office, P.O. Box 2001, Oak Ridge, TN 37831-8541

57-58. Office of Scientific and Technical Information, P.O. Box 62, Oak Ridge, TN 37831 